JEFERSON TEODOROVICZ

\title{
A AFIRMAÇÃO HISTÓRICA DA DOUTRINA DO DIREITO TRIBUTÁRIO BRASILEIRO
}

Tese de Doutorado

Orientador: Professor Doutor Paulo Celso Bergstrom Bonilha

Universidade de São Paulo

Faculdade de Direito

São Paulo-SP 
JEFERSON TEODOROVICZ.

\section{A AFIRMAÇÃO HISTÓRICA DA DOUTRINA DO DIREITO TRIBUTÁRIO BRASILEIRO}

TESE DE DOUTORADO apresentada à Banca Examinadora do Programa de PósGraduação em Direito da Faculdade de Direito da Universidade de São Paulo, como exigência parcial para obtenção do título de Doutor em Direito, na área de concentração Direito Econômico, Financeiro e Tributário, sob orientação do Professor Doutor Paulo Celso Bergstrom Bonilha.

Universidade de São Paulo

Faculdade de Direito

São Paulo-SP 
TEODOROVICZ, Jeferson. 2015. A Afirmação Histórica da Doutrina do Direito Tributário Brasileiro. 570 p. Tese de Doutorado. Faculdade de Direito, Universidade de São Paulo, 2015. Versão final corrigida e depositada no dia 25 de maio de 2015, de acordo com os termos da Deliberação CPG n.01, de 06 de abril de 2011, bem como da Resolução COGR n. 5890, de 20 de dezembro de 2010. 
TERMO DE AVALIAÇÃO

\section{A AFIRMAÇÃO HISTÓRICA DA DOUTRINA DO DIREITO TRIBUTÁRIO BRASILEIRO}

JEFERSON TEODOROVICZ

APROVADO EM:

Orientador: Professor Doutor Paulo Celso Bergstrom Bonilha

\begin{tabular}{c}
\hline Professor \\
\hline Professor \\
\hline Professor \\
\hline Professor
\end{tabular}

Universidade de São Paulo

Faculdade de Direito

São Paulo-SP 
À Clara e Dany, por quem tudo vale a pena. Aos meus amados familiares, pelo apoio de sempre. 


\section{Agradecimentos:}

Agradeço ao meu orientador Professor Doutor Paulo Celso Bergstrom Bonilha, mestre da academia e da vida, pela orientação, pela amizade construída, assim como pelo apoio irrestrito em minhas pesquisas.

Agradeço aos Professores James Marins, Roberto Ferraz, Luís Eduardo Schoueri e José Roberto Vieira, pois cada um contribuiu, à sua própria maneira, para instigar minhas reflexões ao estudo do direito tributário brasileiro.

Agradeço aos membros da Diretoria do Instituto Brasileiro de Direito Tributário - IBDT, pela rica e inesquecível oportunidade de atuar como pesquisador no Instituto durante meus estudos em São Paulo.

Agradeço às queridas amigas Eloíza, bibliotecária do IBDT, e Maria Helena, secretária do IBDT, pela amizade e convívio fraternal.

Agradeço aos amigos que fiz nessa etapa "doutoral" e, em especial, à minha amiga Sarah Maria Linhares de Araújo, pelo companheirismo acadêmico e lealdade.

Agradeço aos amigos Marco Antonio Villatore, Martinho Martins Botelho e Francielli Morêz Gusso pelo valioso auxílio na revisão dos resumos em inglês e italiano.

Agradeço ao Núcleo de Estudos de Direito Internacional (NEADI) da PUC-PR, sob a liderança do Prof. Luís Alexandre Carta Winter, por impulsionar meus primeiros passos na pesquisa acadêmica.

Por fim, agradeço aos ilustres tributaristas que generosamente aceitaram participar das entrevistas durante as pesquisas de elaboração dessa Tese (em ordem alfabética): Alcides Jorge Costa, Fernando Aurelio Zilveti, Gerd Willi Rothmann, Hamilton Dias de Souza, Hiromi Higuchi, Hugo de Brito Machado, Ives Gandra da Silva Martins, Paulo de Barros Carvalho, Paulo Celso Bergstrom Bonilha, Ricardo Mariz de Oliveira, Salvador Cândido Brandão e Tércio Sampaio Ferraz Júnior. 


\section{RESUMO}

A presente Tese defende que o processo de construção histórica da disciplina hodiernamente conhecida como Direito Tributário no Brasil pode ser visualizada sob diferentes formatações ou reformulações históricas, decorrentes diretamente de fatores internos e externos ao processo de construção jurídica da disciplina, identificados em etapas ou configurações mais ou menos definidas, mas nem por isso impermeáveis. Ao mesmo tempo, fundamentado em sólida investigação sobre a formação histórica da disciplina, defende também que o processo histórico disciplinar do Direito Tributário Brasileiro liga-se ao processo identificado na epistemologia (e pedagogia) denominado "especialização disciplinar", caracterizado pela prevalência da especialização disciplinar pautada na sucessiva redução do objeto de estudo e na tendência ao isolamento disciplinar, o que se confirma também pelo histórico tratamento concedido entre o Direito Tributário e a Ciência das Finanças, bem como pela natural elevação da autonomia. Contudo, o reconhecimento preliminar da autonomia do Direito Tributário também revela importância estratégia ao presente estudo, pois concentrado na premissa de diferentes aspectos dessa autonomia, e que levam a diferentes modos de enxergar o processo histórico-disciplinar do Direito Tributário no Brasil. Em qualquer perspectiva analisada, e observando eventual predomínio epistemológico da especialização disciplinar, chega-se à conclusão de que o processo histórico disciplinar do Direito Tributário Brasileiro não assume plenamente essa tendência, pois fatores históricos peculiares da disciplina favorecem uma adoção ponderada, ainda que determinadas linhas de estudo sejam favorecidas por esse contexto epistemológico prevalecente nas ciências do século XX. No mesmo passo, a prevalência, ainda que com ponderações, do processo de especialização disciplinar pode ser comprovada pelo tímido tratamento tradicionalmente concedido pela doutrina ao que se convencionou denominar por "interdisciplinaridade" (que não é simplesmente a busca de conhecimentos extraídos de outras disciplinas para simples aplicação ao Direito Tributário, e nem se identifica com o diálogo entre disciplinas jurídicas constantemente operadas no âmbito disciplinar da Ciência do Direito). Tais reflexões oportunizam também a elaboração de breves observações orientadas ao passado recente, ao presente e ao futuro da disciplina, seja pela consideração de fatores contemporâneos (internos e externos) que influenciam a construção recente do direito tributário (e a disciplina dedicada a estudá-la), seja pela perspectiva de estudos interdisciplinares do qual o Direito Tributário, enquanto disciplina jurídica, pode tomar parte.

Palavras-chave: História do Direito Tributário; Disciplinaridade; Interdisciplinaridade; Doutrina, Direito Tributário Brasileiro; Afirmação Histórica 


\begin{abstract}
This Thesis argues that the historical process of construction of the nowadays known as Tax Law discipline in Brazil can be viewed under different formats or historical restatements, arising directly from internal and external factors to the legal construction process of this discipline, identified in different steps or more or less defined settings - but not so incommunicables. At the same time, also based on solid research on the historical development of the discipline, this Thesis also argues that the disciplinary historical process of Brazilian Tax Law binds to the process identified in epistemology (and pedagogy) as "disciplinary specialization", characterized by the prevalence of disciplinary expertise guided on the successive reduction of the research matter and on tendency to disciplinary isolation, which is confirmed also by the historical treatment accorded between the Tax Law and the Science of Finance, as well as the natural elevation of its autonomy. However, the preliminary recognition of the autonomy of Tax Law also reveals the strategic importance to this research, because it's concentrated on the premise of different aspects of autonomy, that lead to different ways of seeing the historical and disciplinary procedures of the Tax Law in Brazil. In any analyzed perspective, and observing any epistemological dominance of disciplinary specialization, one comes to the conclusion that the disciplinary historical process of Brazilian Tax Law does not fully take this trend, because peculiar historical factors of discipline favor a weighted adoption, though certain lines study are favored by this epistemological context prevailing in the sciences of the twentieth century. In this perspective, the prevalence of the disciplinary specialization process can be proven by the timid treatment traditionally given by the doctrine to what is conventionally called as "interdisciplinary" (which is not simply the pursuit of knowledge drawn from other disciplines for simple application to the Tax Law, and that not identifies with the dialogue between legal constraints constantly operated in the disciplinary scope of the Law Science). Such reflections also allow the development of brief remarks directed to the recent past, the present and the future of the discipline, by the consideration of contemporary factors (internal and external) that influence the recent construction of the Tax Law (and the discipline dedicated to studying it), or by the perspective of interdisciplinary studies which the Tax Law, as a legal discipline, can take part.
\end{abstract}

Keywords: History of Tax Law; Disciplinarity; Interdisciplinarity; Doctrine; Brazilian Tax Law; Historical Statement. 


\section{RIASSUNTO}

Questa Tesi sostiene che il processo della costruzione storica della disciplina conociusta come Diritto Tributario in Brasile può essere visualizzato in diversi formati o correzioni storici derivanti diretamente da fattori interni ed esterni al processo di costruzione legale della disciplina. Questi fattori sono identificati a passi o a configurazioni più o meno definite, ma non così impermeabile. Allo stesso tempo, sulla base di una solida ricerca sul sviluppo storico della disiclina, può tenere anche che il processo storico de trattamento del Diritto Tributario brasiliano è associato con un processo identificado nella epistemologia (e nella pedagogia), chiamato "specializzazione disciplinare", caratterizzata dalla prevalenza di specializzazione della disciplina tributaria guidata dalla successiva riduzione della materia e della tendenza all'isolamento scientifiche, che è confermato anche dal trattamento storico accodato tra il Diritto Tributario e la Scienza delle Finanze, nonchè l'elevazione naturale di autonomia. Tuttavia, il riconoscimento preliminare dell'autonomia di Diritto Tributario rivale anche un'importanza strategica per questo studio, perché è concentrato sulla premissa di diversi aspetti di autonomia, e che portano a differenti modi di vedere le procedure storiche e disciplinari del Diritto Tributario in Brasile. In ogni prospettiva analizzato, e osservando qualsiasi dominio epistemologico della specializzazione disciplinare, si giunge alla conclusione che il processo storico disciplinare di legislazione fiscale brasiliana non assume pienamente questa tendenza come peculiari fattori storici della disciplina, perché peculiari fattori storici della disciplina favoriscono un'adozione ponderata, sebbene alcune linee di studio sono favorite da questo contesto epistemologico prevalente nelle scienze nel XX secolo. In concomitanza, la prevalenza del processo di specializzazione disciplinare può essere dimostrata dal trattamento timido dato dalla dottrina di quelo che viene convencionalmente detto "interdisciplinarità". Questo tratamento non è semplicemente la ricerca della conoscenza tratte da altre discipline ad una semplice applicazione al Diritto Tributario, e non identificasi con il dialogo tra i vincoli giuridici costantemente operato nell'ambito disciplinare della Scienza Giuridica. Queste riflessioni alimentano anche lo sviluppo di brevi osservazioni dirette al passato, presente e futuro della disciplina, o la considerazione di fattori contemporanei (interni ed esterni) che influenzano la recente costruzione del Diritto Tributario, o la dal punto di vista degli studi interdisciplinari che il Diritto Tributario, como disciplina legale, può partecipare.

Parole chiave: Storia del Diritto Tributario; Disciplinarità; Interdisciplinarità; Dottrina; Diritto Tributario brasiliano; la legge fiscale brasiliano; Dichiarazione storica. 


\section{GLOSSÁRIO}

ALALC $=$ Associação Latino-americana de Livre Comércio

$\mathrm{BID}=$ Banco Interamericano de Desenvolvimento

$\mathrm{CPC}=$ Comitê de Pronunciamentos Contábeis

CVM = Comissão de Valores Mobiliários

RAO = Reichsabgabenordnung (Código Tributário Alemão)

CTN = Código Tributário Nacional

CTM = Código Tributário Mexicano

$\mathrm{CF}=$ Constituição Federal

DTI = Direito Tributário Internacional

$\mathrm{EC}=$ Emenda Constitucional

LAF = SteuerAnpassungsGesetz (Lei de Adaptação Fiscal Alemã)

MP = Medida Provisória

OEA = Organização dos Estados Americanos

OCDE = Organização para Cooperação e Desenvolvimento Econômico

ONU = Organização das Nações Unidas

RFB $=$ Receita Federal do Brasil

STF $=$ Supremo Tribunal Federal

STJ = Superior Tribunal de Justiça

TIT $=$ Tribunal de Impostos e Taxas

$\mathrm{TJ}=$ Tribunal de Justiça

$\mathrm{UE}=$ União Europeia 


\section{SUMÁRIO}

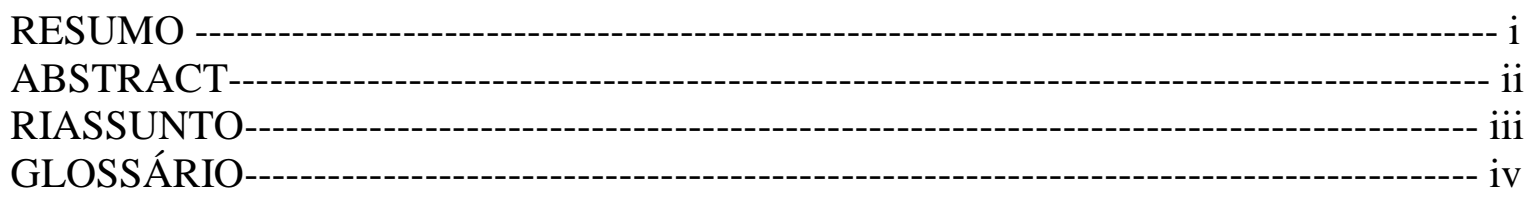

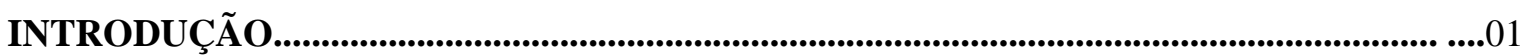

Por que, afinal, "Afirmação Histórica da Doutrina Tributária"? .......................................................04

O processo epistemológico de especialização disciplinar e a dúvida elementar sobre sua plena aplicabilidade ao processo histórico-disciplinar do Direito Tributário Brasileiro................................09

O processo disciplinar e os diferentes sentidos da autonomia do Direito Tributário......................15

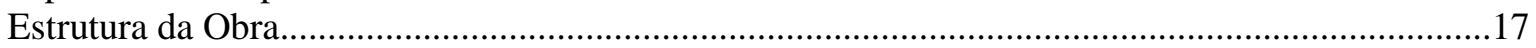

\section{CAPÍTULO 1 - OS ANTECEDENTES E A CONSOLIDAÇÃO DO PROCESSO DISCIPLINAR DO DIREITO TRIBUTÁRIO BRASILEIRO.}

1. Os antecedentes estrangeiros no período pré-disciplinar do Direito Tributário

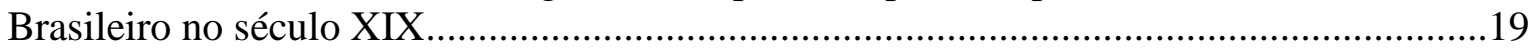

1.1. Aspectos preliminares...........................................................................19

1.2. A preferência histórica da Ciência das finanças no estudo do fenômeno

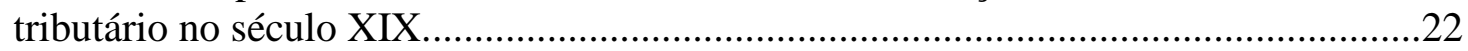

1.3. O surgimento do Direito Público Europeu e sua contribuição inicial à

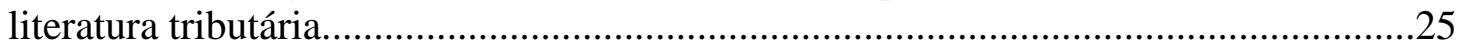

2. O lastro histórico do formalismo jurídico e do positivismo jurídico no século XIX e suas consequências ao Direito Público Europeu....................................................................32

2.1. Brevíssima síntese das tendências hermenêuticas no século XIX: a base elementar para o positivismo e formalismo jurídicos....................................................32

2.2. O formalismo jurídico e positivismo jurídico no século XIX e a tendência ao afastamento de influências externas ao "método jurídico"............................................. 37

2.3. A estratégia (política e científica) do formalismo e do positivismo jurídico

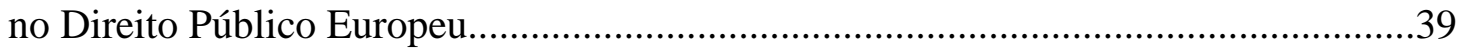

2.3.1. Os esforços científicos (e políticos) de Gerber e Laband..............................39

2.3.2. A contribuição de Otto Mayer perante o Poder Tributário no Direito

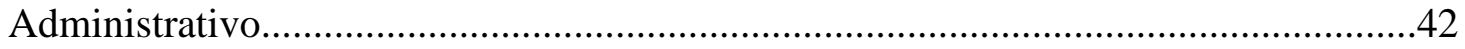

2.3.3. Franz Von Myrbach-Rheinfeld e a sistematização jurídica do Direito

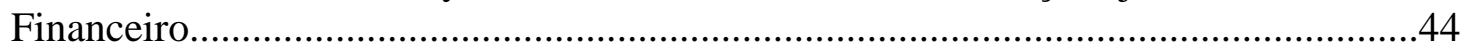

3. A "Pré-história" da doutrina tributária brasileira: o período pré-disciplinar do

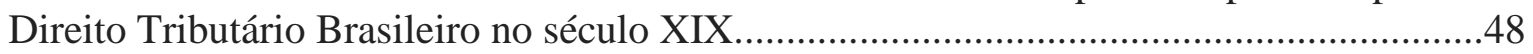

3.1. As repercussões das produções teóricas europeias nos estudos "brasileiros"

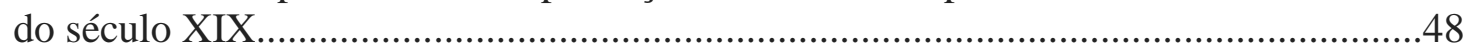

3.2. Os estudos tributários na Monarquia brasileira.........................................54

3.3. A contribuição de Rui Barbosa e as transformações vivenciadas nos anos

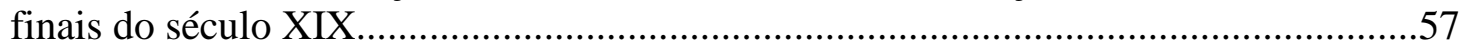

4. Primeiras décadas do século XX e os estudos fiscais..............................................59

5. Constitucionalismo tributário pré-disciplinar (da Monarquia ao Estado Novo)......65

6. As tentativas iniciais disciplinares (autonomistas) na fase pré-disciplinar do Direito

Tributário Brasileiro: o período de transição................................................................... 71

7. Os obstáculos ao processo disciplinar (autonomia teórica e autonomia de ensino) do

Direito Tributário no Brasil nas primeiras décadas do século XX...................................75 
8. Fatores Externos que impulsionaram o processo disciplinar do Direito Tributário no

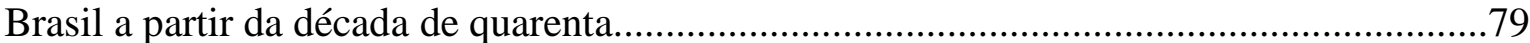

8.1. Crises políticas e econômicas do período e reflexos tributários................... 79

8.2. A Política Fiscal Anticíclica Keynesiana e a elevação da carga tributária no

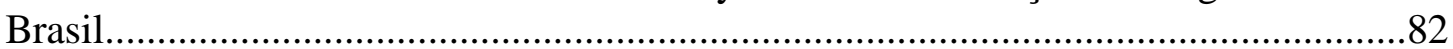

8.3. A "Crise do Supremo" e a luta pela criação de um Tribunal Fiscal (judicial)

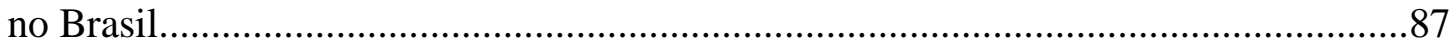

8.4. A contribuição histórica do emergente contencioso fiscal..........................92

8.5. A contribuição europeia posterior à Primeira Guerra Mundial....................95

8.6. A crescente divulgação de estudos tributários através de periódicos especializados. 108

8.7. A Contribuição da Constituição de 1946 e as normas gerais em matéria de direito financeiro.

8.8. A influência de Tullio Ascarelli no processo disciplinar (autonomia teórica e autonomia de ensino) do Direito Tributário Brasileiro. 116

8.9. A contribuição de Rubens Gomes de Sousa no processo disciplinar do Direito Tributário entre os anos 40 e 50.

9. A difusão da literatura tributária a partir da década de cinquenta: a consolidação da especialização disciplinar (autonomia teórica).

10. As tendências positivistas no período da consolidação disciplinar inicial do Direito Tributário Brasileiro: as ponderações entre o positivismo formal conceitualista e o positivismo historicista ou sociológico.

11. A institucionalização disciplinar do ensino: a consagração da autonomia do ensino do Direito Tributário frente à Ciência das Finanças e ao Direito Financeiro no Brasil.....133

\section{CAPÍtULO 2 - A POSITIVAÇÃO PERANTE O PROCESSO DE ESPECIALIZAÇÃO DISCIPLINAR DO DIREITO TRIBUTÁRIO BRASILEIRO: CODIFICAÇÃO, CONSTITUCIONALIZAÇÃO E SISTEMATIZAÇÃO.}

1. Os "Constitucionalismos Tributários" no limiar do século XIX para o século XX e a abertura (involuntária) para a codificação do Direito Tributário

2. A contribuição histórica da codificação para o direito tributário estrangeiro.........150

3. Traços diferenciais da autonomia legislativa do direito tributário brasileiro perante a experiência estrangeira: direito tributário positivo centrado na constitucionalização e na codificação.

4. As influências estrangeiras ao constitucionalismo tributário brasileiro: o novo ambiente constitucional democrático europeu pós-guerra, e suas consequências na literatura tributária europeia.....

5. As peculiaridades históricas do direito constitucional tributário brasileiro pós-

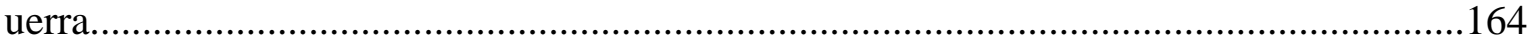

6. Constitucionalismo tributário brasileiro a partir da Constituição de 1946..............166

7. A autonomia legislativa através da codificação do direito tributário brasileiro a partir da década de cinquenta.

7.1. Os bastidores da codificação tributária no Brasil 169

7.2. Antecedentes nacionais e as influências do Anteprojeto e do Projeto de Código Tributário Nacional.

7.3. O Anteprojeto, o Projeto e a versão final do Código Tributário Nacional: a consolidação da codificação tributária no Brasil entre as décadas de cinquenta e sessenta. 
8. As mutações constitucionais brasileiras da década de sessenta e a constitucionalização do "sistema tributário nacional".....................................................179

9. Os reflexos do direito constitucional tributário na literatura tributária brasileira na década de sessenta e a tendência histórica à extensão e rigidez do sistema.

10. Reflexos históricos da sistematização constitucional tributária no Brasil: entre o

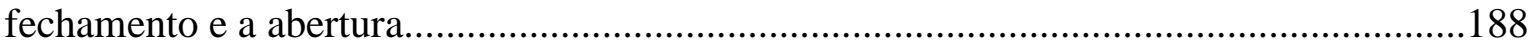

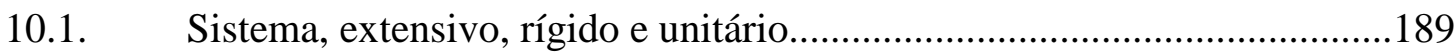

10.2. Sistema extensivo, plural e aberto

11. Por que os aspectos elementares do constitucionalismo democrático europeu pósguerra (neoconstitucionalismo europeu) não foram eficientemente absorvidos na literatura constitucional tributária brasileira no período ditatorial?.

12. A contribuição histórica dos tributaristas para a Constituição de 1988 na década de oitenta.

12.1. A tentativa de criação de justiça tributária especializada na Constituição de

1988 (autonomia do contencioso judicial tributário): o esforço de Miguel Reale......204

13. A elevação normativa dos princípios no sistema constitucional tributário brasileiro

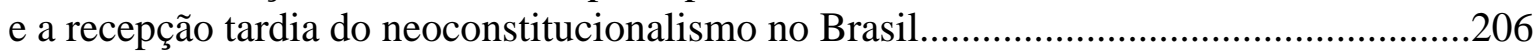

13.1. O neoconstitucionalismo tardio na Constituição de 1988..........................206

13.2. Anotações históricas: a principiologia constitucional tributária no processo disciplinar do direito tributário brasileiro.

13.3. Das concepções jurídicas de princípios na literatura do Direito Tributário no Brasil 222

14. O processo disciplinar do Direito Tributário Brasileiro e o ambiente sistemático principiológico na égide da Constituição de 1988. .227

\section{CAPÍtUlO 3 - ESTRATÉGIA(S) DE ESTUdO (E ENSINO) NO PROCESSO DISCIPLINAR DO DIREITO TRIBUTÁRIO BRASILEIRO}

1. A estratégia de investigação e os antecedentes teóricos necessários à consolidação da pesquisa e ensino do Direito Tributário no Brasil.

2. Brevíssimo retrospecto sobre a autonomia teórica (e de ensino) na literatura tributária estrangeira fundacional.

3. A contribuição histórica das Escolas italianas de Pávia e de Nápoles para o debate sobre as relações entre Direito Financeiro e Ciência das Finanças....

4. A contribuição fundamental de Alfredo Augusto Becker (e seus reflexos) para o afastamento das relações entre Direito Tributário e Ciência das Finanças.......

5. A interpretação do direito tributário e sua contribuição ao processo disciplinar do Direito Tributário

5.1. Os antecedentes hermenêuticos ao processo disciplinar do Direito Tributário. 251

5.2. A consideração econômica e o combate ao abuso de formas do Direito

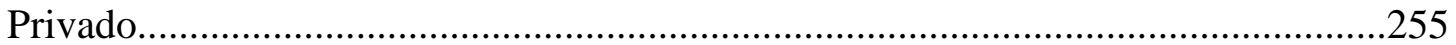

5.3. A recepção da literatura tributária estrangeira sobre a consideração econômica...... .257

6. Antecedentes da formação das estratégias de estudo e ensino do Direito Tributário Brasileiro.

6.1. Década de quarenta à década de cinquenta.

6.2. A primeira posição sobre o problema autonomista no Brasil: autonomia científica do Direito Tributário Brasileiro. 
6.2.1. A tentativa inicial de inclusão da interpretação econômica na codificação tributária brasileira.

6.2.2. A recepção favorável da autonomia científica à interpretação econômica na década de cinquenta.

6.3. Década de sessenta e os antecedentes teóricos (e políticos) da formação das estratégias de estudo e ensino do Direito Tributário no Brasil..... 278

6.4. A consolidação da segunda posição sobre a autonomia disciplinar do Direito Tributário no Brasil: a autonomia didática. 280

6.4.1. Os primeiros passos para a autonomia didática: a oposição à interpretação econômica em Alfredo Augusto Becker. 280

6.4.2. A difusão da autonomia didática a partir da década de sessenta no Brasil..... .283

7. A estruturação histórica das estratégias de estudo e ensino do Direito Tributário: o exemplo estrangeiro e as dificuldades de enquadramento da experiência brasileira 286

8. As estratégias de estudo e ensino do Direito Tributário em São Paulo no ambiente pré-democrático.

9. A contribuição da Faculdade de Direito do Largo São Francisco (USP) para o estudo e ensino do Direito Tributário no Brasil. 298

10. A contribuição da Faculdade Paulista de Direito da Pontifícia Universidade Católica de São Paulo para a consolidação do ensino do Direito Tributário no Brasil.......307

10.1. O intercâmbio teórico e a difusão do método jurídico da PUC-SP.............311

10.2. O esforço na harmonização de premissas jurídicas aplicáveis ao Direito Tributário e as características da Faculdade de Direito da PUC-SP.....

11. As contribuições teóricas além do "Eixo USP x PUCSP" no período. 319

12. O diálogo (ponderado) entre Direito Tributário e outros ramos do conhecimento (e notadamente a Ciência das Finanças) na doutrina brasileira na década de oitenta e a resistência ao método da Escola da PUC-SP...

13. Tendências históricas consolidadas pela gradual preferência ao formalismo jurídico no estudo e no ensino do Direito Tributário Brasileiro. 328

13.1. A gradual preferência histórica da interpretação a partir do dogmatismo normativo nos estudos tributários brasileiros. .328

13.1. Repercussões do estudo do Direito Tributário sob a perspectiva da norma jurídica.

13.1.1. A refração à consideração econômica na perspectiva normativista............337

13.1.2. A atividade interpretativa sob a perspectiva do dogmatismo normativo....340

14. A formação das estratégias de estudo (e ensino) entre a década de oitenta e a década de noventa. .343

14.1. A influência de fatores históricos na consolidação dos estudos na década de noventa... 344

14.2. O Construtivismo Lógico-semântico aplicado ao Direito Tributário: a contribuição de Paulo de Barros Carvalho. 347

14.3. O Pós-positivismo Neoconstitucional aplicado ao Direito Tributário: a contribuição de Ricardo Lobo Torres no Rio de

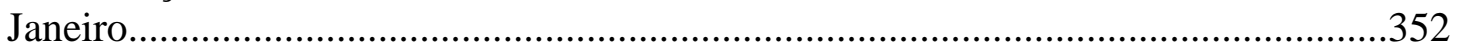
14.4. A construção da Hermenêutica Histórica enquanto estratégia complementar ao Dogmatismo Normativo no Direito Tributário: a contribuição de José Souto Maior Borges. 
15. Balanço do período: a impossibilidade de se conceber o processo disciplinar do Direito Tributário Brasileiro por uma rota única.

\section{CAPÍTULO IV - DESDOBRAMENTOS RECENTES E A QUESTÃO DA "INTERDISCIPLINARIDADE" NO PROCESSO DISCIPLINAR DO DIREITO TRIBUTÁRIO BRASILEIRO CONTEMPORÂNEO}

1. O Processo histórico-disciplinar do Direito Tributário Brasileiro contemporâneo e as recentes "mudanças paradigmáticas".... 363

2. Os fatores externos recentes que impulsionam a consolidação (e atualização) disciplinar do Direito Tributário contemporâneo (o limiar do século XX para o século XXI) 368

2.1. O Estado Fiscal contemporâneo e a tributação....................................................368

2.2. Globalização, sociedade de riscos e seus reflexos na tributação..................373

2.3. As novas Gerações de Direitos Fundamentais e os reflexos no Direito Tributário Contemporâneo................................................................................... 380

3. Desdobramentos recentes no processo disciplinar do Direito Tributário Brasileiro

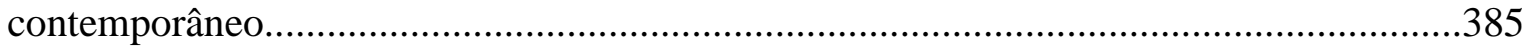

3.1. O processo disciplinar do Direito Tributário Brasileiro contemporâneo e o diálogo com a Ordem Econômica...............................................................................388

3.2. O processo disciplinar do Direito Tributário Brasileiro e o diálogo com a

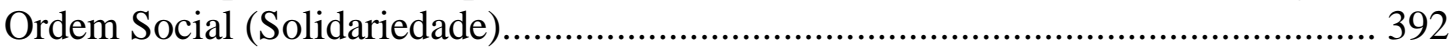

3.3. O processo disciplinar do Direito Tributário Brasileiro contemporâneo e o

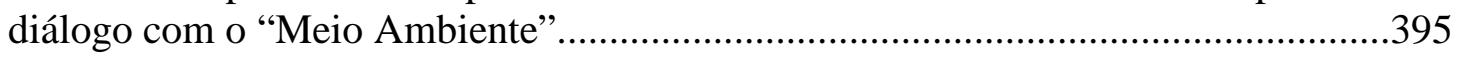

3.4. O processo disciplinar do Direito Tributário Brasileiro contemporâneo e o

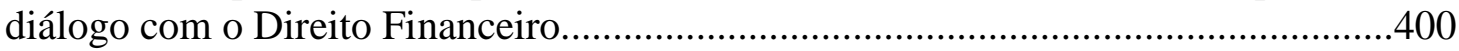

3.5. O processo disciplinar do Direito Tributário Brasileiro contemporâneo e o progressivo reforço da tributação internacional.........................................................405

3.6. O processo disciplinar do Direito Tributário Brasileiro contemporâneo e o progressivo desenvolvimento tecnológico (tecnologia e internet).....

3.7. O processo disciplinar do Direito Tributário Brasileiro contemporâneo e o

"Direito Contábil" (reflexos da "nova contabilidade")...............................................416

3.8. O processo disciplinar do Direito Tributário Brasileiro contemporâneo e o acesso à informação: a questão da transparência fiscal.

4. Direito Tributário Brasileiro contemporâneo, legalidade tributária, a segurança jurídica.

4.1. A questão da rediscussão dos tipos no Direito Tributário Brasileiro..........435

5. Recentes ponderações (hermenêuticas) sobre as funções da Ciência do Direito Tributário frente ao Direito Tributário Positivo...............................................................440

6. A dimensão pragmática da norma tributária, a indução normativa e a consideração econômica. 446

7 - O processo disciplinar do direito tributário brasileiro diante do desafio interdisciplinar. 454

7.1. Considerações iniciais sobre a "interdisciplinaridade" praticada no processo histórico-disciplinar do Direito Tributário Brasileiro no século

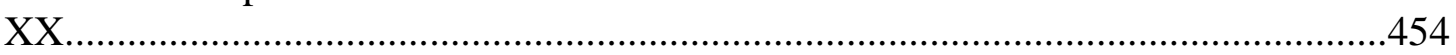

7.2. Recentes esforços pela elevação da interdisciplinaridade no Direito Tributário Brasileiro. 
7.3. As premissas epistemológicas (e pedagógicas) para a delimitação do tema: especialização disciplinar, complexidade e transdisciplinaridade. .466

7.3.1. O verdadeiro sentido da interdisciplinaridade na epistemologia e pedagogia: a alternativa ao processo desenfreado de especialização disciplinar. 471

7.3.2. Interdisciplinaridade como proposta substitutiva ou complementar ao processo disciplinar?. 475

7.4. Os riscos e desafios da verdadeira interdisciplinaridade na Ciência Jurídica Brasileira. 479

8. O progressivo reflexo da epistemologia da complexidade e a elevação da interdisciplinaridade na doutrina do Direito Tributário Brasileiro contemporâneo............481

9. Interdisciplinaridade e a função prospectiva (normativa) do tributarista...............487 9.1. Perspectivas de Diálogo Recíproco entre Filosofia e Tributação: a Filosofia Tributária e a Ciência do Direito Tributário Brasileiro contemporâneo 489

9.2. Perspectivas do diálogo recíproco entre Análise Econômica do Direito e Ciência do Direito Tributário contemporâneo..............................................................496 9.3. Perspectivas de diálogo recíproco entre Política Tributária e Ciência do Direito Tributário contemporâneo.......................................................................503

9.3.1. O desafio interdisciplinar da Política Jurídico-Tributária perante o processo disciplinar do Direito Tributário Brasileiro contemporâneo. 507

10. O nível de cooperação "interdisciplinar" no processo disciplinar do Direito

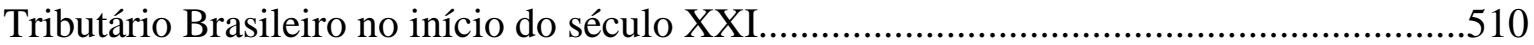

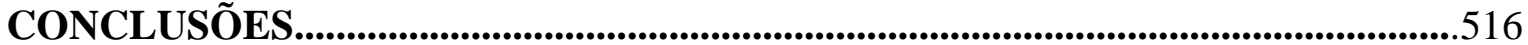

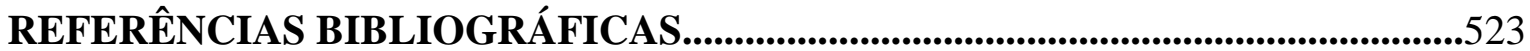




\section{INTRODUÇÃ̃o}

O presente estudo pretende demonstrar que a investigação histórica (contextual) é de grande importância para o Direito Tributário Brasileiro e, especialmente, para melhor compreensão da literatura contemporânea sobre as origens históricas de sua própria disciplina.

A tônica histórica, naturalmente, serve como pano de fundo para a presente investigação. Busca-se, nesse sentido, trazer elementos no passado jurídico da disciplina, no intuito de utilizá-los com vistas à reflexão do patamar de estudos contemporâneos da disciplina do Direito Tributário no Brasil. Almeja-se o diálogo entre o passado e o presente da disciplina.

Mas deve-se reconhecer preliminarmente que estudos históricos sobre a tributação não são necessariamente novidades na doutrina jurídica tributária. A relevância da investigação histórica pode ser observada na obra coordenada por Nicola D'Amati e Andrea Amatucci, contando com estudos históricos jurídicos sobre as doutrinas europeias, sobretudo italianas do Direito Tributário, do Direito Financeiro e das Finanças Públicas ${ }^{1}$.

No Brasil também se identificam alguns exemplos de estudos históricos vinculados à tributação. Cite-se, por exemplo, o histórico curso ministrado no Instituto Histórico e Geográfico sobre a História Tributária no Brasil, por Augusto Olympio Viveiros de Castro, em $1915^{2}$. Nesse contexto também se recorde a relevante obra de Ubaldo Cezar Balthazar, intitulada "História do tributo no Brasil", que tem como objetivo descrever o desenvolvimento histórico da legislação tributária no Brasil ${ }^{3}$. Tencionando o mesmo objeto, merece menção o panorama elaborado por Benedito Ferreira, na obra "História da

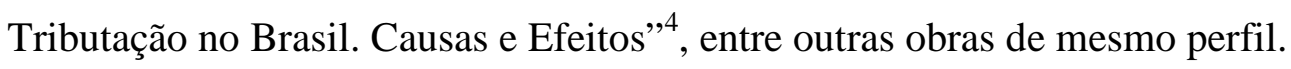

\footnotetext{
${ }^{1}$ D’AMATI, Nicola. AMATUCCI, Andrea (Organiz). Historia del Derecho de la Hacienda Pública y del Derecho Tributario en Italia. E aporte del pensamento juridico financiero de la Italia Meridional. Derecho de la Hacienda Pública. Obras Fundamentales 1. Bogotá-Colombia: Temis, 2004.

${ }^{2}$ CASTRO, Augusto Olympio Viveiros de. Historia Tributária do Brasil. Curso promovido no Instituto Histórico e Geográfico Brasileiro. In: Coleção Memória Fazendária. Volume 2. Brasília-DF : ESAF, Escola de Administração Fazendária, 1989.

${ }^{3}$ BALTAZAR, Ubaldo Cezar. História do tributo no Brasil. Florianópolis: Ed. Boiteux, 2005.

${ }^{4}$ FERREIRA, Benedito. A História da Tributação no Brasil. Causas e Efeitos. Brasília, 1986.
} 
Além disso, também merece referência o celebrado estudo de Alcides Jorge Costa, publicado em dois artigos, intitulados "História da Tributação no Brasil", , assim como a pesquisa produzida por Fernando José Amed e Plínio José Labriola de Campos Negreiros, denominada "História dos Tributos no Brasil", publicada sob o patrocínio do Sindicado dos Agentes Fiscais de Rendas do Estado de São Paulo ${ }^{6}$, bem como a obra de José Eduardo Pimentel de Godoy ${ }^{7}$ e o relevante estudo de José Eduardo Monteiro de Barros, sobre os aspectos históricos do processo de codificação tributária no Brasil ${ }^{8}$. Esses relevantes trabalhos, porém, concentram-se prioritariamente na construção histórica da legislação tributária e, eventualmente, seus elementos econômicos, sociais e políticos atinentes.

Investigam especialmente as fontes legislativas tributárias do passado, mas em menor grau as doutrinas a elas envoltas. Evidentemente, não se trata de uma crítica às supramencionadas obras, que cumprem com grande êxito a proposta de estudo tencionada, isto é, a de revelar a evolução histórica da tributação no Brasil. A premissa geral escolhida pela presente investigação, contudo, diferencia-se das propostas supracitadas, pois se volta ao direito tributário em sua perspectiva eminentemente disciplinar. Inspira-se, portanto, no caminho trilhado pelos estudos históricos publicados por Brandão Machado ${ }^{9}$, Alcides Jorge Costa $^{10}$, Ruy Barbosa Nogueira ${ }^{11}$, dentre outros renomados tributaristas devidamente lembrados no decorrer deste trabalho.

Da mesma forma, também não é o objetivo central desse estudo analisar com profundidade os pressupostos filosóficos ou epistemológicos que embasam ou influenciam a construção do pensamento jurídico-tributário no decorrer de sua formação histórica

\footnotetext{
${ }^{5}$ COSTA, Alcides Jorge. História da Tributação no Brasil. In: FERRAZ, Roberto (Coord.). Princípios e Limites da Tributação. Volume 1. Quartier Latin: São Paulo.

${ }^{6}$ AMED, Fernando José; NEGREIROS, Plínio José Labriola de Campos. História dos Tributos no Brasil. $2^{\mathrm{a}}$ Ed. São Paulo: Sindicato dos Agentes Fiscais de Rendas do Estado de São Paulo - Sinafresp.

${ }^{7}$ GODOY, José Eduardo Pimentel de. Dicionário de história tributária do Brasil. Brasília, ESAF, 2002.

${ }^{8}$ BARROS, José Eduardo Monteiro de. Notas sobre a História Externa do Código Tributário Nacional. In: Revista AFRESP de Tributação. Ano II. n.4. Outubro/Dezembro de 1998. São Paulo: Afresp, 1998, p. 3345.

${ }^{9}$ MACHADO, Brandão. Prefácio do Tradutor. In: HARTZ, Wilhelm. Interpretação da Lei Tributária. Conteúdo e Limites do Critério Econômico. Tradução, Prefácio e Notas de Brandão Machado. Rio de Janeiro: Resenha Tributária, 1993, p. 05-31.

${ }^{10}$ COSTA, Alcides Jorge. A doutrina italiana e sua influência no Direito Tributário Brasileiro. In: Princípios do Direito Tributário Comparado. Homenagem a Gilberto Ulhôa Canto. Org: Agostinho Toffoli Tavolaro, Brandão Machado e Ives Gandra Martins. Forense: Rio de Janeiro, 1998, p. 24-25. COSTA, Alcides Jorge. Algumas Notas sobre a Relação Jurídico Tributária. In: Direito Tributário. Estudos em Homenagem a Brandão Machado. Coordenadores: Luís Eduardo Shoueri; Fernando Aurelio Zilveti. São Paulo: Dialética, 1998, p. 21-35.

${ }^{11}$ NOGUEIRA, Ruy Barbosa. Prefácio. In: Souza Diniz. Códigos Tributários. Alemão. Mexicano. Brasileiro. $1^{\circ}$ edição. Tradução de Souza Diniz. São Paulo: Edições Financeiras S.A., 1965, p. ix.
} 
disciplinar, perspectiva que já foi enfrentada com salutar competência, ainda que sob premisas e objetivos específicos, por exemplo, nas obras de André Folloni ${ }^{12}$ (ao apontar as premissas epistemológicas, filosóficas e metodológicas que embasam a construção doutrinária brasileira, sobretudo, a partir da elementar obra de José Souto Maior Borges), José Maria Arruda de $\operatorname{Andrade}^{13}$ (ao traçar as correntes filosófico-jurídicas e epistemológicas que contribuíram à construção das teorias hermenêuticas aplicadas ao Direito Tributário), Paulo Caliendo (ao delinear as correntes filosófico-jurídicas prevalecentes na doutrina tributária em sua particular relação com a progressiva construção sistêmica do direito tributário) ${ }^{14}$ e Renato Lopes Becho (ao analisar as influências filosóficas e epistemológicas identificáveis no Direito Tributário Brasileiro, buscando citérios de identificação doutrinária para uma (ou várias) Filosofia(s) do (ou no) Direito Tributário) ${ }^{15}$.

Não se assume, portanto, como um estudo de conotação "fillosófico-jurídica tributária", de modo que é importante ressaltar, ainda no início do presente trabalho. A finalidade deste é, afinal, mostrar como o processo histórico do direito tributário brasileiro levou à sua construção disciplinar. Naturalmente, a construção histórica do Direito Tributário é inspirada pelas peculiaridades do contexto histórico em que se consolidou.

O Direito Tributário buscou emancipar-se cientificamente, seja pela influência de outros ramos jurídicos (direito administrativo, financeiro e privado), seja pela influência de outros ramos ou fenômenos extrajurídicos.

Nesse contexto, nenhum outro campo do conhecimento extrajurídico exerceu tanta influência na formação do Direito Tributário como a Ciência das Finanças. Essa influência, naturalmente, passa a ser pano de fundo para a própria intensificação dos esforços autonomistas, buscando elevar os estudos jurídicos tributários ao patamar de uma autêntica disciplina. Contudo, a discussão sobre a viabilidade (e pertinência) dessa influência extrajurídica, e, sobretudo, no campo das ciências econômicas, pairou sobre o desenvolvimento do direito tributário enquanto disciplina desde sua formação disciplinar

\footnotetext{
${ }^{12}$ FOLLONI, André. Ciência do Direito Tributário no Brasil: críticas e perspectivas a partir de José Souto Maior Borges. São Paulo: Saraiva, 2013.

${ }^{13}$ ANDRADE, José Maria Arruda de. Interpretação da Norma Tributária. São Paulo: MP Editora, 2006.

${ }^{14}$ CALIENDO, Paulo. Três modos de pensar a tributação. Elementos para uma teoria sistemática do Direito Tributário. Porto Alegre: Livraria do Advogado, 2009.

${ }^{15}$ BECHO, Renado Lopes. Filosofia do Direito Tributário. São Paulo: Saraiva, 2009.
} 
inicial, servindo de pano de fundo para debate interdisciplinar (Direito Tributário e Ciência das Finanças) que influenciaria fortemente a construção histórica do direito tributário brasileiro.

Até mesmo a construção de linhas de estudo e Escolas do Direito Tributário se orienta pela consideração, ponderação ou rejeição a esses elementos.

As razões pelas quais os reflexos desses debates (positivos ou negativos, dependendo do ponto de vista) foram sentidos, e ainda o são, nos dias atuais, serão compreendidos nos capítulos seguintes.

\section{Por que, afinal, “Afirmação Histórica da Doutrina Tributária”?}

A escolha do título apresenta conotação assumidamente simbólica, estilística e estratégica. Inspira-se no título da celebrada obra "A Afirmação Histórica dos Direitos Humanos", de Fabio Konder Comparato, ${ }^{16}$ embora tal inspiração não signifique a necessária transposição das ideias dessa notável obra para os estudos empreendidos na presente Tese.

Talvez não fizesse tanta diferença denominar a presente obra como "História disciplinar (ou doutrinária) do Direito Tributário" ${ }^{17}{ }_{-}^{18}$, como aplicação de estudos direcionados ao direito tributário do passado ${ }^{19}{ }_{-}^{20}$, ainda que o último capítulo apresente

\footnotetext{
16 “(...) este livro procura mostrar como se foram criando e estendendo progressivamente, a todos os povos da Terra, as instituições jurídicas de defesa da dignidade humana contra a violência, o aviltamento, a exploração e a miséria". COMPARATO, Fabio Konder. A Afirmação Histórica dos Direitos Humanos. Op.cit., 2015, pp.13 e ss; 541-568.

17 Ademais, merece relevo também a posição de Luis Carlos de Azevedo, ao ponderar que a História do Direito é “(...) tanto uma ciência histórica, quanto jurídica; em face desta dualidade, sua área de atuação não se restringe a limites rígidos ou previamente direcionados; já que não se conforma com a mera descrição dos fenômenos jurídicos, deve compreendê-los e explicá-los desde o momento em que sucederam, como na sequência temporal na qual persistiram sobrevivendo ou deixando de existir". AZEVEDO, Luiz Carlos de. História do Direito, Ciência e Disciplina. OPVSCVLA IV. Osasco: FIEO, 1998, p. 01-22.

${ }^{18}$ Para os objetivos do presente estudo entende-se que a História do Direito pode ser definida de dois modos distintos, conforme a lição de Ricardo Marcelo Fonseca, de acordo com o próprio sentido dúplice que a palavra "história" encerra. De um lado, a História do Direito é o ramo do saber que se ocupa do passado jurídico (como na expressão "a história do direito aborda prioritariamente o período moderno"). De outro lado, História do Direito é o objeto deste mesmo saber, aquilo que é objeto de estudo (como, por exemplo, na expressão "a história do direito demonstra que a emergência da propriedade foi um processo descontínuo e complexo"). FONSECA, Ricardo Marcelo. Introdução Teórica à História do Direito. Biblioteca de História do Direito. FONSECA, Ricardo Marcelo (Coord.). Instituto Brasileiro de História do Direito. Curitiba: Juruá, 2011, p. 33.

${ }^{19}$ Nesse sentido, as primeiras propostas de definições sobre o direito tributário na doutrina brasileira foram elaboradas enfocando em maior ou menor grau tanto a disciplina que estuda o fenômeno jus-tributário,
} 
reflexões voltadas ao passado recente, presente e perspectivas futuras da disciplina, não se vinculando, portanto, a uma perspectiva unicamente histórica de investigação.

Afinal, como bem salientou John Gillissen, a “(...) história do direito visa fazer compreender como é que o direito actual se formou e desenvolveu, bem como de que maneira evoluiu no decurso dos séculos" 21.

quanto ao próprio fenômeno jurídico-tributário. Nesse sentido, apenas pinçando algumas das célebres definições apresentadas pela doutrina brasileira, recorda-se a definição clássica de Ruy Barbosa Nogueira, para quem Direito Tributário seria a (...) "disciplina da relação entre fisco e contribuinte, resultante da imposição, arrecadação e fiscalização dos impostos, taxas e contribuições”. Já o celebrado tributarista Hugo de Brito Machado conceituou o Direito Tributário como o “(...) ramo do Direito que se ocupa das relações entre o fisco e as pessoas sujeitas a imposições tributárias de qualquer espécie, limitando o poder de tributar e protegendo o cidadão contra abusos desse poder (...)".Por sua vez, o autor do Anteprojeto de Código Tributário Nacional, Rubens Gomes de Sousa, acentuou que o “(...) Direito Tributário é o ramo do direito público que rege as relações jurídicas entre o Estado e os particulares, decorrentes das atividades financeiras do Estado, o que se refere à obtenção de receitas que correspondam ao conceito de Tributos". A doutrina jurídico-tributária contemporânea tende a delimitar o Direito Tributário em dois sentidos: primeiramente, enquanto conjunto de normas jurídicas que regem os tributos; em segundo lugar, quanto à disciplina que investiga essas normas. Segue esse caminho Paulo de Barros Carvalho, para quem o Direito Tributário Positivo é o “(...) ramo didaticamente autônomo do Direito formado pelo conjunto das proposições jurídicas (normativas e não-normativas), que correspondam, direta ou indiretamente, à instituição, arrecadação e fiscalização dos tributos”. Já a disciplina que estuda o Direito Tributário Positivo é compreendida da seguinte forma: “(...) Desse modo caberá à ciência do Direito Tributário descrever esse objeto, na sua estrutura estática e na sua atuação dinâmica, extraindo todas as relações lógicas que possa conter”. NOGUEIRA, Ruy Barbosa. Curso de Direito Tributário. Editora Saraiva. 14. ${ }^{a}$ Edição. 1995. São Paulo, p. 30. SOUSA, Rubens Gomes de. Compêndio de Legislação Tributária. Edição Póstuma. São Paulo: Editora Resenha Tributária, 1975, p. 35. CARVALHO, Paulo de Barros. Teoria da Norma Tributária. Max Limonad. 1998. São Paulo, p. 82; CARVALHO, Paulo de Barros Curso de Direito Tributário. 16 ${ }^{\text {a }}$ Edição. Editora Saraiva. 2004. São Paulo, 15-17. Nesse sentido também: ATALIBA, Geraldo. Hipótese de Incidência Tributária. $5^{\text {a }}$ Edição. Coleção Estudos de Direito Tributário. Malheiros Editores. 1992. São Paulo, p. 35.

${ }^{20}$ Se a História do Direito pode ser definida em dois sentidos distintos, isto é, em primeiro lugar, como ramo do conhecimento dedicado ao estudo do passado jurídico, e, em segundo lugar, quanto ao objeto do mesmo ramo do conhecimento, pode-se tomar emprestadas as supracitadas definições de direito tributário para apresentar breve esboço da denominação "História do Direito Tributário". Na delimitação dúplice da História do Direito anteriormente esboçada, e agora adaptada ao contexto jurídico-tributário, pode-se entender o seguinte: a História do Direito Tributário pode ser compreendida preliminarmente como o ramo do conhecimento dedicado ao passado jurídico-tributário, tomado enquanto disciplina jurídico-histórica que investiga o fenômeno histórico-jurídico tributário, e, num segundo momento, enquanto o próprio direito tributário do passado, objeto de investigação do historiador do direito tributário. Mas, recorde-se que o objeto do tributarista que almeje realizar estudo sobre a história do direito tributário não se limita exclusivamente a buscar as fontes "legislativas", ou "jurisprudenciais" do passado, mas também abarca a própria construção do pensamento jurídico-tributário, da ciência ou da disciplina jurídica que foi construída através daquelas fontes do passado, e, por extensão, a possibilidade de buscar o passado jurídico de institutos jurídico-tributários. Ao mesmo tempo, deve-se antever que a investigação do passado jurídico-tributário sob as premissas da História do Direito não é tema facilmente encontrado na literatura histórico-jurídica especializada, que não possui tradição na investigação do passado jurídico da realidade tributária. De todo modo, o presente estudo, ainda que imperfeito e incompleto, poderá ser utilizado, ainda que para a crítica, refutação ou aperfeiçoamento, por historiadores do direito para investigações pautadas em pressupostos metodológicos e epistemológicos construídos naquela ciência histórico-jurídica.

${ }^{21}$ GILLISSEN, John. Introdução Histórica ao Direito. Lisboa: Fundação Calouste Gulbenkian, p. 1986, p. 13. 
Mas, ao mesmo tempo, parece oportuno denominá-la como "afirmação histórica" para enfatizar seu caráter reflexivo direcionado às reflexões sobre o passado recente, o presente e um vislumbre do futuro da disciplina no Brasil.

Nesse sentido, a presente Tese assume uma posição essencialmente otimista sobre o futuro disciplinar do direito tributário. Não porque o direito tributário de amanhã será necessariamente melhor do que o de ontem, ou do presente. Mas porque o processo disciplinar se reformula constantemente, fruto da influência inequívoca de fatores (internos e externos) determinantes a esse processo.

Em cada contexto histórico, os fatores mudam, e com isso muda-se a formatação disciplinar do Direito Tributário. O que se pode antecipar, portanto é que a adoção da expressão "afirmação histórica" enfatiza a reformulação ou reconstrução disciplinar, que tem se mantido até agora (o que não significa presumir uma continuidade absoluta a esse processo no futuro) em movimento de sucessivas adaptações ou reformulações disciplinares diante da influência de fatores internos ou externos (diferenciados de acordo com cada contexto histórico peculiar). Quanto maior a atenção a esses fatores, maiores as chances de compreensão sobre o papel que o direito tributário, seja enquanto ramo do direito, seja enquanto objeto de estudo, deve exercer perante o contexto histórico em que se insere.

O passado jurídico-tributário da disciplina no Brasil é desbravado com a perspectiva de que sobre ele se lancem reflexões, seja para compreender certas abordagens contemporâneas proeminentes no direito tributário brasileiro, seja para visualizar com maior clareza (na medida do possível) o emaranhado teórico que se consubstancia a disciplina do Direito Tributário Brasileiro, que nada tem de linear, mas se configura muito mais como uma árvore dotada de grandes ramificações, por vezes convergentes ou não, não raramente assumindo referências metodológicas e filosóficas completamente diferentes. Foca-se o passado jurídico disciplinar do direito tributário no presente trabalho com feição expressamente instrumental, portanto.

Porém, deve-se reconhecer que, ao mesmo tempo, é inevitável a inspiração nas notáveis contribuições recentes à História do Direito, sobretudo pela elevação de viés crítico-problemático vislumbrado nas melhores doutrinas estrangeiras e brasileiras, especialmente pela reflexão crítica, questionadora, desmistificadora e problematizadora 
sobre o passado jurídico, que é uma característica da História do Direito atual ${ }^{22}{ }_{-}^{23}{ }_{-}{ }^{24}$, que, de certa forma, não se afasta também da Hermenêutica Histórica, de José Souto Maior Borges $^{25}$.

A construção do método de investigação ${ }^{26}$, e das estratégias aplicadas no presente trabalho ao Direito Tributário do passado, por sinal, inspira-se em algumas opções trazidas pela História do Direito ${ }^{27}$.

${ }^{22}$ Não por acaso é a lição de Paolo Grossi, abaixo reproduzida, refletindo sobre o papel do historiador do direito frente ao cientista do direito: "Acredito piamente - e escrevi muitas vezes nos últimos tempos, tornando-me quase monótono - que um dos papéis, e certamente não o último, do historiador do direito junto ao operador do direito positivo seja o de servir como sua consciência crítica, revelando como complexo o que na sua visão unilinear poderia parecer simples, rompendo as suas convicções acríticas, relativizando certezas consideradas absolutas, insinuando dúvidas sobre lugares comuns recebidos sem uma adequada confirmação cultural. O historiador também pode esconder-se no outro papel, o de erudito conhecedor do passado próximo e remoto. Papel que não hesito em considerar - em relação ao primeiro - nobre mas menor e, no fundo, ao qual se pode renunciar".GROSSI, Paolo. Mitologias Jurídicas da Modernidade. $2^{\circ}$ Ed. Florianópolis: Editora Fundação Boiteux, 2007, p.13.

${ }^{23}$ Vale lembrar também o lúcido conselho do historiador do direito José Geraldo de Lima Lopes, para quem o método de investigação jus-histórico deve sempre "levantar suas próprias suspeitas", lição que se reproduz em quatro principais "suspeitas”, ou conselhos: “(...) Em primeiro lugar, suspeita do poder: seu objeto é sempre um elemento do poder, o exercício da autoridade formalizada pelo direito (...)"; “(...) Em segundo lugar, suspeita do romantismo: a história do direito que se fez antes foi uma história romântica. Tomemos apenas o exemplo da escola história de Savigny. Ela não foi seguramente uma história econômica e social e não foi tampouco sociológica ou jusnaturalista. Ela foi antes de mais nada nacionalista e tradicional"; “(...) Em terceiro lugar, suspeita das continuidades: 'O tempo verdadeiro é por sua própria natureza um contínuo. É também uma mudança perpétua', dizia Marc Bloch. Para escapar de uma história legitimadora status quo, é indispensável pensar que fomos precedidos por gerações diferentes de nós e seremos sucedidos por gerações diferentes de nós". Uma história crítica mostra que as coisas foram diferentes do que são e podem ser no futuro também muito diferentes (...)"; “(...) e em quarto lugar, suspeita da ideia de progresso e evolução: cuidado diante das concepções organicistas e evolucionistas. O futuro é contingente e aberto (...)"LOPES, José Reinaldo de Lima. O Direito na História. Lições Introdutórias. $3^{\circ}$ Ed. São Paulo: Atlas, 2011, p. 0407.

${ }^{24}$ Essa salutar reflexão de Antonio Carlos Wolkner sintetiza com clareza as tendências contemporâneas da História do Direito: "Desde até pouco tempo, viveu-se o pouco interesse por discussões, envolvendo temas de historicidade no Direito, em razão deste campo de estudo estar marcado por uma historiografia sobejamente identificada a textos legislativos, à interpretação firmada na autoridade de notáveis juristas e às contruções dogmáticas desvinculadas da realidade social, consagrando, por consequência, uma cultura histórica idealista, erudita, elitista e marginalizada frente à concretude do real. Nas últimas décadas do século XX, esta tradição linear e conservadora desencadeou, como reação, o esforço e a persistência em trazer para o mundo acadêmico aportes recriadores, problematizantes, transgressores de História para o mundo específico e complexo do Direito. Com isso, viabilizou-se alcançar novos referenciais teórico-metodológicos, apropriados para transmitir alternativas não convencionais de investigação e de interpretação histórica. Assim, pautar pela renovação da História do Direito foi ter em conta não só a perspectiva interdisciplinar, mas, sobretudo, direcionar-se por uma historicidade, nascida e articulada na dialética da produção da vida material e das relações concretas". WOLKNER, Antonio Carlos. Prefácio. In: História do Direito Brasileiro. BITTAR, Eduardo C.B. (Organizador). São Paulo: Atlas, 2012, s/p.

${ }^{25}$ BORGES, José Souto Maior. Hermenêutica Histórica no Direito Tributário. In: Revista Tributária e de Finanças Públicas. n. 31, São Paulo: Rt, 2000, p. 112 e seguintes.

${ }^{26}$ Para uma análise preliminar sobre as diferentes concepções do método no estudo jurídico, conferir: CARNELUTTI, Francesco. Metodologia do Direito. Traduzido por Frederico A. Pascoal. $3^{\circ}$ Edição. Campinas - SP: Bookseller, 2005, p. 21. DEL VECCHIO, Giorgio. Filosofia del Derecho. Novena Edición Española Corregida y Aumentada. Barcelona: Bosch, Casa Editorial, p. 290. FERRAZ JÚNIOR, Tércio Sampaio. A Ciência do Direito. São Paulo: Editora Atlas S.A., 1977, p.11. DINIZ, Maria Helena. Compêndio de Introdução à Ciência do Direito. $1^{\circ}$ edição. São Paulo: Saraiva, 2000, p. 18. COELHO, Luiz Fernando. Teoria da Ciência do Direito. São Paulo: Saraiva, 1974, p. 72-79. REALE, Miguel. Lições 
Na realidade, esse mesmo desafio tem sido enfrentado na História do Direito, em considerar e isolar qual evento histórico é realmente digno de nota e apto à construção do "quebra-cabeça" histórico-jurídico que remonte com maior fidelidade (na medida do possível, naturalmente) o passado jurídico objeto de investigação.

Não é suficiente a análise das "leis" promulgadas e outorgadas pelo Estado, para o reconhecimento de um passado jurídico. O passado é muito mais rico do que isso. E nem sempre (ou quase nunca) "fontes oficiais" representam o que de fato ocorreu naquela realidade histórica do passado. A máxima "a história é contada pelos vencedores" assume aqui uma posição de destaque a ser enfrentada.

É inafastável a verificação de "outras versões" desses passados, e para isso, é preciso considerar, antes da elevação das "fontes oficiais do direito" (lei ou texto constitucional, por exemplo), elementos que favoreceram diretamente a construção da disciplina jurídica objeto deste estudo.

Para a construção fidedigna (na medida do possível, e reconhecendo os limites inerentes ao empreendimento) do passado jurídico-disciplinar do Direito Tributário, é preciso assumir outra perspectiva, portanto, considerando os fatores jurídicos e extrajurídicos que influenciam essa construção (ou desconstrução), assim como averiguar, na medida do possível, como as distintas realidades (e complexas) históricas, seja do ponto de vista político, econômico, social ou cultural, assim como os elementos de diferenciação perante realidades históricas anteriores, facilitaram e favoreceram a construção (ou desconstrução) disciplinar do direito tributário no Brasil. Todo esse esforço permitirá uma melhor compreensão dos rumos recentes, atuais e futuros da disciplina ora denominada "Direito Tributário Brasileiro".

Preliminares de Direito. 20 Edição. São Paulo: Saraiva, 1993, p. 07. COELHO, Luiz Fernando. Op.cit., p. 72. LARENZ, Karl. Metodologia da Ciência do Direito. $3^{\circ}$ Edição. Tradução de José Lamego. Lisboa Portugal: Editora Fundação Calouste Gulbenkian, 1997, p. 01. VILANOVA, Lourival. As Estruturas Lógicas e o Sistema de Direito Positivo. São Paulo: RT, 1977, p. 37.

27 Sobre o problema e os desafios da eleição do método na historiografia jurídica, conferir: FONSECA, Ricardo Marcelo. Introdução Teórica à História do Direito. Biblioteca de História do Direito. FONSECA, Ricardo Marcelo (Coord.). Instituto Brasileiro de História do Direito. Curitiba: Juruá, 2011 , p. 32-33; 39-66; 67-88. HESPANHA, António Manuel. A história do direito na história social. Lisboa: Livros Horizonte, 1978, p.16-17. NASCIMENTO, Walter Vieira do. Lições de História do Direito. Rio de Janeiro: Forense, 2006, p. 03-05. COSTA, Pietro. Soberania, Representação, Democracia. Ensaios de História do Pensamento Jurídico. Biblioteca de História do Direito. Coordenada por Ricardo Marcelo Fonseca. Curitiba: Juruá, 2010, p. 17-81. FONSECA, Ricardo Marcelo. O deserto e o vulcão: reflexões e avaliações sobre a história do direito no Brasil. In: História do Direito Brasileiro. BITTAR, Eduardo C.B. (Organizador). São Paulo: Atlas, 2012, p. 01-19. WOLKNER, Antonio Carlos. Prefácio. In: História do Direito Brasileiro. BITTAR, Eduardo C.B. (Organizador). São Paulo: Atlas, 2012, s/p. 
É nesse sentido, muito mais estilístico e estratégico, que deve ser compreendida a escolha pelo título "a afirmação histórica da doutrina tributária" (embora também pudesse ser denominada “A afirmação histórica disciplinar do direito tributário"), em preferência à expressão "História Disciplinar (ou doutrinária) do Direito Tributário".

O processo epistemológico de especialização disciplinar e a dúvida elementar sobre sua plena aplicabilidade ao processo histórico-disciplinar do Direito Tributário Brasileiro.

Para seguir a investigação histórica pretendida nesse trabalho é preciso identificar preliminarmente o ponto de vista pelo qual se iniciará essa pesquisa.

O ponto de vista particular preliminarmente definido para a investigação desse trabalho refere-se ao processo denominado na epistemologia e pedagogia como "especialização disciplinar", que se refere inevitavelmente ao processo de construção e especialização das disciplinas científicas, uma característica do conhecimento científico do século XIX e XX.

É sobre essa particular perspectiva que seguirá o presente estudo, objetivando relacionar esse processo identificável no campo da epistemologia e aplicado na pedagogia, ao processo histórico-disciplinar do Direito Tributário, sobretudo para fins comparativos e, naturalmente, para verificar no que se aproxima (e se afasta) o processo históricodisciplinar do Direito Tributário Brasileiro perante essas tendências (epistemológicas e pedagógicas) construídas na história das ciências a partir do século XIX.

Em verdade, no âmbito das ciências naturais o desenvolvimento disciplinar e a perspectiva de que, quanto mais especializado o objeto, mais aprofundado é o seu estudo, e mais precisos são seus resultados, dominou a teoria do conhecimento no último século XX. Perspectiva essa que Descartes, no estudo da Geometria, apontou os passos para se alcançar o conhecimento com maior precisão: "O primeiro era o de jamais aceitar algo como verdadeiro sem saber com evidência que seja tal; isto é, evitar com cuidado a precipitação e a prevenção, e nada mais incluir em meus juízos além do que se apresente tão clara e tão distintamente ao meu espírito que eu não tenha nenhuma ocasião de pô-lo 
em dúvida. O segundo, o de dividir cada dificuldade examinada em tantas partes quantas puder e for necessário para melhor resolvê-las. O terceiro, conduzir pela ordem os meus pensamentos, começando pelos objetos mais simples e mais fáceis de se conhecer, para subir aos poucos, como por degraus, até o conhecimento dos mais compostos e supondo até haver certa ordem entre os que não se precedem naturalmente uns aos outros. E o último, fazer em toda parte enumerações tão completas e revisões tão gerais, que me assegure de nada omitir,"28.

A separação e redução passam a traços característicos do desenvolvimento científico no século XX. Quanto mais especializado é o estudo, o método e a redução do objeto, mais precisos os resultados. Essa constante válida para as ciências naturais levou à especialização disciplinar, como ocorreu na medicina, na biologia, na matemática e na física (todas progressivamente divididas em respectivas especialidades). A cada especialização o objeto é reduzido e, assim, maiores as chances de uma investigação cada vez mais aprofundada sobre aquele objeto (já reduzido). E a cada especialização surge uma nova redução ao objeto, que passa a ser estudado cada vez mais aprofundadamente.

A epistemóloga portuguesa Olga Pombo, nesse sentido, contextualiza muito bem a tendência à especialização da ciência: "Ora, o que é a especialização? Uma tendência da ciência moderna, exponencial a partir do século XIX. Sabemos que a ciência moderna se constitui pela adopção da metodologia analítica proposta por Galileu e Descartes. Isto é, se constituiu justamente no momento em que adoptou uma metodologia que lhe permitia "esquartejar" cada totalidade, cindir o todo em pequenas partes por intermédio de uma análise cada vez mais fina. Ao dividir o todo nas suas partes constitutivas, ao subdividir cada uma dessas partes até aos seus mais ínfimos elementos, a ciência parte do princípio de que, mais tarde, poderá recompor o todo, reconstituir a totalidade. A idéia subjacente é a de que o todo é igual à soma das partes",29.

28 DECARTES, René. Discurso do Método. Meditações. Tradução. Roberto Leal Ferreira. São Paulo: Martin Monet, 2008, p. 25-26.

29 "O procedimento científico é este. Sempre foi este. É assim que a ciência tem funcionado. Já os gregos haviam chegado à concepção do átomo, a tomos, ou seja, daquilo que, justamente, é sem partes. E o átomo, limite para que tendeu a ciência moderna, foi também ele descoberto na sua estruturação interna. Continua a sê-lo. Ou seja, sob os nossos olhos, a ciência continua esse movimento em direcção a uma cada vez mais profunda especialização. Especialização que tem produzido resultados notáveis, magníficos. Não podemos recusar, nem menosprezar, nem esquecer, que foi este procedimento analítico da ciência moderna que deu origem a todos os conhecimentos e a todo o bem-estar que lhe devemos. Talvez não valha a pena reforçar aqui os seus aspectos positivos. Todos os conhecemos. A nossa vida depende deles a cada instante. Porém, se 
Evidentemente, o caminho seguido pela ciência contemporânea legou ao século XX grandes conquistas. Sem a especialização jamais existiriam as conquistas da microbiologia, ou da física quântica, das viagens espaciais, entre tantos outros avanços científicos e tecnológicos registrados no século XX.

Contudo, alerta Edgar Morin: “o desenvolvimento disciplinar das ciências não traz unicamente as vantagens da divisão do trabalho (isto é, a contribuição das partes especializadas para a coerência de um todo organizador), mas também os inconvenientes da superespecialização: enclausuramento ou fragmentação do saber" ${ }^{30}$.

A fragmentação do saber é um risco que se submete o cientista ao proceder a seguidas especializações. Partindo-se do geral (ou do todo), e passando a especializar o objeto sucessivas vezes, corre-se o risco de perder a conexão entre o todo e o específico, ocasionando a trituração ou dilaceramento de conceitos, a fragmentação do conhecimento, sem a consciência de que o objeto especializado é parte e deve dialogar "com o todo", e esse é um risco que Morin reconhece especialmente nas "ciências antropossociais", que "adquirem todos os vícios da especialização sem nenhuma de suas vantagens". Assim: “(...) os conceitos de homem, de indivíduo, de sociedade, que perpassam várias disciplinas, são de fato triturados ou dilacerados entre elas, sem poder ser reconstruídos pelas tentativas interdisciplinares",31.

A reflexão acima do celebrado epistemólogo francês não se limita, naturalmente, às tendências científicas trazidas pela literatura jurídica contemporânea, notadamente à doutrina tributária brasileira atual.

A ciência jurídica contemporânea talvez seja culpada e merecedora de tais críticas, pois a influência do método investigativo, e das técnicas de pesquisa das "ciências duras", foi absorvida nas ciências sociais. As ciências sociais passaram o século XIX com forte sentimento de "cachorro vira-lata" frente às ciências duras, que renegavam a elas o status

não podemos esquecer, diminuir, negar os benefícios da ciência moderna, tanto em termos de compreensão do mundo como de melhoria das nossas próprias vidas, isso não pode ser impeditivo do reconhecimento dos custos que a especialização trouxe consigo". POMBO, Olga. Texto apresentado no Congresso LusoBrasileiro sobre Epistemologia e Interdisciplinaridade na Pós-Graduação, realizado em Porto Alegre, Brasil, na Pontifícia Universidade Católica do Rio Grande do Sul, nos dias 21, 22 e 23 de Junho de 2004. Disponível em: http://revista.ibict.br/liinc/index.php/liinc/article/view/186/103 (último acesso em 17.11.2014)

${ }^{30}$ MORIN, Edgar. Ciência com Consciência. São Paulo: Bertrand Brasil, 2010, p. 16.

${ }^{31}$ Idem, p. 16-17. 
da cientificidade, motivados, sobretudo, pela falta de "estabilidade" em seus respectivos objetos de estudo.

No caso da ciência do direito o problema resta ainda mais forte justamente porque existiria suposta "instabilidade" nas leis, que poderiam ser revogadas a qualquer momento, a contento do legislador. Tal argumento privou à ciência jurídica durante muito tempo o status científico que tanto almejava.

Logo, a ciência jurídica percebeu que, para ser reconhecida como ciência por aqueles cientistas das "ciências duras", deveria ao menos aproximar o máximo possível da rigidez do método investigativo ao praticado por aquelas ciências. Mas isso não era o suficiente.

Deveria também afastar-se de influências negativas ao progresso da Ciência do Direito, notadamente de elementos externos ao objeto de estudo. Se as leis são o objeto de estudo, tão somente elas interessam, e nada mais. Mas tal tarefa era dificílima. Como conseguir alcançar a tão sonhada precisão que permitia aos estudiosos da física e da matemática lograrem resultados tão primorosos?

Nas ciências sociais, o dilema se perpetuava, especialmente entre o século XIX e o início do século XX. O sincretismo metodológico prevalecia. As dificuldades para alcançar o êxito do trabalho científico no direito não passou despercebida por Friedrich Karl Von Savigny que, em meados do século XIX, questionava: "Como podemos, pois, alcançar o ideal de uma ciência? Um meio auxiliar geral é a história da literatura, pois dela surge o estudo literário, e com ele um método geral e um juízo sobre o indivíduo”.

Savigny compreendia a importância do método para a afiguração da ciência jurídica, a ponto de reconhecer que a história da ciência jurídica, para Savigny, seria a história do método. A confusão entre ciência do direito e técnica legislativa já mostrava que na época ainda não se havia clarificado o trabalho do "cientista do direito". ${ }^{32}$

Assim, ainda naquele momento histórico oitocentista residia a questão epistemológica elementar: como afastar a influência de fatores externos ao estudo da

\footnotetext{
${ }^{32}$ SAVIGNY, Friedrich Karl Von. Metodologia Jurídica. Traducción de J.J. Santa-Pinter. Buenos Aires: Depalma, 1994, p. 01-03.
} 
ciência do direito, permitindo-a aprimorar seu método de estudo a partir da tradição das ciências duras?

Essa foi uma pergunta que se manteve perene na mente dos estudiosos do direito até meados do século XX, quando Hans Kelsen, tendente a elevar o estudo jurídico ao patamar que lhe cabia, publicou, em 1934, a obra "Teoria Pura do Direito".

No seu prefácio à primeira edição, de 1934, transpôs o seu objetivo: "Há mais de duas décadas que empreendi desenvolver uma teoria jurídica pura, isto é, purificada de toda a ideologia política e de todos os elementos de ciência natural, uma teoria jurídica consciente da sua especificidade porque consciente da legalidade específica do seu objeto. Logo, desde o começo foi meu intento elevar a Jurisprudência que - aberta ou veladamente - se esgotava quase por completo em raciocínios de política jurídica, à altura de uma genuína ciência, de uma ciência do espírito. Importava explicar, não as suas tendências endereçadas à formação do Direito, mas as suas tendências exclusivamente dirigidas ao conhecimento do Direito, e aproximar tanto quanto possível os seus resultados do ideal de toda ciência: objetividade e exatidão",33

Ao esforço da especialização disciplinar, próprio das tendências científicas desde o século XIX, segue-se ao recorte e redução do objeto de estudo em frações, para melhor analisá-lo. Essa é uma tendência que dominou a teoria do conhecimento científico durante todo o século, e de certa forma, impregnou invariavelmente a "Ciência do Direito", assim como as demais ciências sociais.

Mas, será mesmo que esse processo de especialização disciplinar identificado pela epistemologia segue tendência incessante e absolutória na disciplina jurídica hodiernamente conhecida como Direito Tributário (em toda sua complexidade e riqueza)?

Essa é a pergunta central que motiva a presente Tese.

Com base na busca por respostas palatáveis a essa pergunta, a construção históricodisciplinar do Direito Tributário Brasileiro passa a ser tecida como uma teia de aranha, onde diferentes linhas de pesquisa e estratégias de ensino (e estudo) surgem permeadas por diferentes influências, historicamente identificáveis, e tendentes a relacionar-se

\footnotetext{
${ }^{33}$ KELSEN, Hans. Teoria Pura do Direito. São Paulo: Matin Fontes, 1999, p. 01 e seguintes.
} 
distintamente com determinados elementos, a exemplo da influência da Ciência das Finanças.

Nesse sentido, propõe-se inicialmente separar os períodos históricos (diacrônicos, fluídos e permeáveis), em quatro momentos historicamente distintos (mas não necessariamente estanques reciprocamente) entre o século XIX e o século XX: a) período pré-disciplinar, quando ainda não há consciência do desenvolvimento do Direito Tributário enquanto ciência jurídica (autonomia teórica); b) período de formação disciplinar: quando os estudos tributários começam a repercutir a necessidade de autonomia (teórica) disciplinar; c) período de institucionalização disciplinar (autonomia do ensino); d) período de formação de linhas de ensino e pesquisa no Direito Tributário Brasileiro.

É evidente que as peculiaridades do contexto histórico brasileiro servem de pano de fundo para o aperfeiçoamento disciplinar do Direito Tributário no Brasil, já que aspectos sociais, políticos e econômicos influenciam a construção doutrinária, assim como a estruturação histórica do direito tributário positivo.

Reconhece-se, portanto, que a legislação tributária, aliada à jurisprudência tributária, contribuiu para esse desenvolvimento doutrinário. Mas deve-se assumir a dificuldade de abordar adequadamente a complexidade de tantos fenômenos que interferem nesse processo histórico. Por esse motivo, por expressa conveniência investigativa, não se priorizará o contexto histórico legislativo ou mesmo jurisprudencial atinente ao direito tributário, mas tão somente seu substrato doutrinário, ainda que se reconheça que, em muitos aspectos, esses se revelam essenciais para a compreensão do fenômeno histórico jurídico-tributário.

Não obstante, no âmbito legislativo (autonomia legislativa), dois processos fundamentais para a formação disciplinar do direito tributário brasileiro devem ser examinados: a codificação tributária e a constitucionalização. Ambos levam ao peculiar processo de positivação e à subsequente sistematização do direito tributário brasileiro, garantindo perfil próprio e diferenciado frente às experiências tributárias estrangeiras, e influenciando diretamente as linhas de pesquisa e ensino no Brasil.

Sob o aspecto temático é evidente que muitos assuntos peculiares ao direito tributário marcaram o desenvolvimento histórico do Direito Tributário Brasileiro, como é o 
caso da relação (obrigacional) tributária, da interpretação da lei tributária, do fato gerador da obrigação tributária, das espécies tributárias, etc. Porém, não se pretende analisá-los em detalhes, pois tal compromisso incorreria no afastamento das premissas gerais desse estudo, que se concentra na análise geral dos rumos historicamente definidos travados pela literatura tributária brasileira, em distintos momentos históricos, no intuito de responder à pergunta central já levantada, confirmando ou não a hipótese apresentada.

Note-se também que o presente trabalho não almeja reconhecer-se necessariamente como estudo "histórico-evolutivo", e nem pretende apresentar o marco histórico de forma linear, como se a doutrina caminhasse por uma "linha reta" 34 . A realidade teórica tributária brasileira não segue uma lógica linear. Portanto, mais adequado para compreendê-la é averiguar diferentes (mas essenciais) aspectos dessa construção (ou desconstrução) histórica. Muitos momentos históricos situados em períodos semelhantes serão analisados por capítulos diferentes, já que cada capítulo explorará aquele determinado período histórico a partir de particular ponto de vista.

\section{O processo disciplinar e os diferentes sentidos da autonomia do Direito Tributário.}

O processo de especialização científica disciplinar pode ser compreendido como o processo epistemológico refletido a partir dos anos finais do século XIX, e que tem como consequência a busca pela constante especialização de distintos ramos do conhecimento, cada vez mais especializados na busca pela profunda e exata investigação do seu objeto de estudo. É claro que, enquanto fenômeno identificado na epistemologia e, aprofundado na pedagogia, não se pode assegurar que o processo de especialização disciplinar se manifeste com plenitude e em igual intensidade em todos os ramos do conhecimento, jurídicos ou não.

Da mesma forma, os reflexos identificáveis em ramos do conhecimento jurídico não caminham rumo à completa especialização disciplinar, como se posse possível separálas totalmente.

Por outro lado, o processo de construção disciplinar caminha lado a lado da concepção, no âmbito da Ciência do Direito, do que se convencionou denominar por

\footnotetext{
${ }^{34}$ FONSECA, Ricardo Marcelo. Introdução Teórica à História do Direito. Biblioteca de História do Direito. FONSECA, Ricardo Marcelo (Coord.). Instituto Brasileiro de História do Direito. Curitiba: Juruá, 2011, p. 32 e seguintes.
} 
"autonomia do direito", tema que ainda hoje, no direito tributário, arregimente incessantes debates acerca da autonomia "científica" ou "didática" da disciplina perante outros campos do conhecimento, cuja distinção depende mais das premissas adotadas do que das consequências jurídicas ao processo disciplinar na realidade tributária brasileira.

A autonomia do direito tributário ligada à disciplina do Direito Tributário no Brasil apresenta, segundo o presente estudo, três sentidos possíveis, a serem explorados neste trabalho: autonomia legislativa (criação de leis próprias, ou seja, do objeto de estudo da ciência do direito); autonomia do ensino (criação de cadeiras próprias); autonomia teórica (ciência jurídica própria). A Autonomia aqui investigada compõe-se desses três sentidos, complementares, mas que não necessariamente precisam atuar conjuntamente e simultaneamente para o progresso da Ciência do Direito Tributário ${ }^{35}$.

Assim, a classificação aqui proposta considera que a noção de autonomia do direito tributário pode levar a três sentidos específicos de autonomia: a) autonomia legislativa (direito positivado): que significa a criação de corpos legislativos próprios e específicos à

${ }^{35}$ Existem, ainda, posições ligeiramente distintas quanto à consideração das expressões "autonomia didática" ou "autonomia científica". Por exemplo, para Fernando Aurelio Zilveti, a autonomia legislativa "(...) resulta do fato de o Direito Tributário contar com leis específicas decorre da necessidade de determinar hipóteses de interesse exclusivamente fiscal, a ponto de identificar as riquezas passíveis de tributação". Já a autonomia didática, por sua vez, “(...) emerge da relevância prática do ensino de determinada matéria no âmbito curricular das faculdades de Direito". Note-se aqui, que a noção de autonomia didática localiza-se em ambiente distinto do debate teórico sobre a questão da autonomia meramente "didática" ou "científica". O sentido de autonomia didática trazida pelo autor identifica-se com a autonomia do ensino, na criação de cadeiras próprias e separadas de outros ramos do conhecimento (a exemplo do Direito Financeiro, do Direito Administrativo ou mesmo da Ciência das Finanças). Por outro lado, para Zilveti, a autonomia científica “(...) é defendida por parcela da doutrina que considera o Direito Tributário mais que mero setor normativo do Direito Público, verdadeiro ramo do Direito subordinado a princípios próprios e homogêneos, capaz de tratamento sistêmico autônomo em face às demais disciplinas jurídicas". Para fins didáticos, que se acredita servir bem à problemática histórica brasileira, sobretudo porque as expressões "autonomia didática" (no sentido de autonomia do ensino) e "autonomia científica" (no sentido de autonomia teórica), embora muito utilizadas na literatura estrangeira, como se pode observar nos estudos de Gonzalez, Amatucci e D' Amatti, adiante citados, são corriqueiramente ligadas a outros contextos do debate na realidade brasileira, onde a autonomia científica e a autonomia didática digladiam-se dentro do que se convencionou denominar neste estudo como autonomia teórica. Sobre o assunto: ZILVETI, Fernando Aurelio. Obrigação Tributária Fato Gerador e Tipo. São Paulo: Quartier Latin, 2009, p. 24 e seguintes. ZILVETI, Fernando Aurelio. A Evolução da Teoria da Incidência - Análise Histórica das Estruturas Socioeconômicas na Formação do Sistema Tributário. Tese de Livre Docência. São Paulo: USP, 2010, s/np (introdução e cap.1). D’AMATI, Nicola. La Formación del Derecho Tributario en Italia. In: Historia del Derecho de La Hacienda Pública y del Derecho Tributario en Italia. El aporte del pensamiento jurídico financiero de La Italia Meridional. AMATUCCI, Andrea; D’ AMATI, Nicola. Bogotá - Colômbia: Temis, 2004, p. 139 e ss. 'D’AMATI, Nicola. L'Insegnamento del Diritto Tributario. In: L'Evoluzione dell'Ordinamento Tributario Italiano. UCKMAR, Victor (Coord.) CEDAM: Milani, 2000, p. 135 e ss. AMATUCCI, Andrea. Historia de La Enseñanza del Derecho Financiero Público en Italia. Op.cit., p. 100 e ss. D’AMATI, Nicola. La Formación del Derecho Tributario en Italia. In: Historia del Derecho de La Hacienda Pública y del Derecho Tributario en Italia. In: Historia del Derecho de La Hacienda Pública y del Derecho Tributario en Italia. El aporte del pensamiento jurídico financiero de La Italia Meridional. AMATUCCI, Andrea; D’AMATI, Nicola. Bogotá - Colômbia: Temis, 2004, p. 140 e ss. GONZALEZ, Eusebio. La Enseñanza del derecho Tributario. In: L'Evoluzione dell'Ordinamento Tributario Italiano. UCKMAR, Victor (Coord.) CEDAM: Milani, 2000, p. 163 e ss. 
determinado matéria do direito, que passa a ser regida primordialmente por esses instrumentos, ganhando emancipação (ainda que por vezes relativa) de outros ramos do direito positivado; b) autonomia teórica: quando os estudiosos de determinado ramo do conhecimento passam a construir institutos próprios, sem necessariamente remeter-se às construções trazidas por outros campos do conhecimento jurídico. Nesse sentido, a literatura diverge, por fundamentos distintos e tomando como pressuposto perspectivas distintas de enxergar a autonomia, na elevação da "autonomia científica" e na "autonomia didática", que serão melhores compreendidos nas próximas linhas; c) autonomia do ensino: manifesta-se quando se criam cadeiras específicas para lecionar a disciplina. Ocorre quando se cria a cátedra específica da disciplina "Direito Tributário", apartada de outras disciplinas conexas, como o "Direito Financeiro", ou a "Ciência das Finanças".

Talvez pudesse ser incluída a ideia de autonomia do contencioso fiscal ou tributário como outro possível reflexo da autonomia (autonomia do contencioso fiscal), haja vista que, como acertadamente expôs Hensel, a criação da Corte Financeira do Reich (Reichsfinanzhof-RFH), ao lado da consolidação da administração financeira do Reich, e da consequente emanação do ordenamento tributário do Reich (Reichsabgabenordnung), que por sua vez viabilizou a unificação das normas jurídicas gerais válidas para aquele ramo do direito ${ }^{36}$. Além disso, na realidade brasileira, verdadeiro foco dessa investigação, a autonomia do contencioso fiscal (pelo menos judicialmente) ainda não se institucionalizou, o que não impede, naturalmente, o frutífero desenvolvimento legislativo, teórico e do ensino do Direito Tributário Brasileiro.

Assim, ainda que a criação de tribunais especializados em matéria fiscal sempre tenha favorecido o desenvolvimento da legislação e do estudo e ensino a ele envoltas, optase, por manter a consolidação da autonomia apenas nessas três vertentes (legislativa, de ensino, e teórica), pois servem bem aos objetivos deste estudo.

\section{Estrutura da Obra}

Este trabalho apresenta divisão em quatro capítulos, estruturados de acordo com a separação de aspectos históricos (para fins didáticos, naturalmente) não necessariamente lineares, mas muitas vezes convergentes e permeáveis entre si, embora seja possível

\footnotetext{
${ }^{36}$ HENSEL, Albert. Diritto Tributario. Traduzione di Dino Jarach. Milano: Dott. A. Giufrrè Editore, 1956, p.03-04.
} 
identificar determinadas etapas na construção teórica do Direito Tributário Brasileiro, conforme visto acima. São muito mais pontos de vista particulares sobre o processo disciplinar do direito tributário Brasileiro do que "etapas evolutivas", portanto.

Assim, o Capítulo 1 enfoca o período da consolidação histórica disciplinar do Direito Tributário Brasileiro, desde seus primeiros indícios históricos até alcançar a institucionalização do ensino do Direito Tributário no Brasil (autonomia do ensino). Também se busca identificar o momento em que a autonomia teórica apresenta seus primeiros passos efetivos na literatura brasileira, considerando-se, nesse momento, o passo inical para o período disciplinar do Direito Tributário Brasileiro.

O Capítulo 2 trata do processo de positivação (autonomia legislativa) do Direito Tributário Brasileiro, focando no processo de codificação, constitucionalização e subsequente sistematização (teórica) do direito tributário, bem como suas consequências ao processo disciplinar do direito tributário brasileiro.

O Capítulo 3 aborda discussões relativas à especialização (autonomia) teórica do Direito Tributário Brasileiro e as subsequentes linhas de pesquisa e ensino construídas no Brasil no século XX formadas a partir desse debate. Nesse contexto, apresenta as estratégias de estudo adotadas no processo histórico disciplinar do Direito Tributário Brasileiro, baseadas na interpretação do direito tributário, no debate autonomista e nas relações do Direito Tributário perante a Ciência das Finanças.

Por fim, o Capítulo 4 foge da investigação histórica para desaguar na análise reflexiva e prospectiva. Discorre sobre a influência de determinados fenômenos contemporâneos no processo histórico disciplinar do direito tributário brasileiro, nos anos finais do século XX e no início do século XXI, demonstrando a existência de novas perspectivas (jurídicas) de estudo, que não necessariamente se harmonizam com as perspectivas prevalecentes na maior parte do século $\mathrm{XX}$, e que viabilizam o diálogo entre outros ramos do direito. Essas perspectivas diferenciadas são reflexos das peculiaridades históricas próprias do pós-modernismo, da complexidade epistemológica e da sociedade de risco pós-industrial.

Mostra-se, portanto, nesse capítulo, o patamar e o grau de influência de determinadas questões extrajurídicas no processo disciplinar do Direito Tributário 
Brasileiro, que não assume integralmente, mas apenas ponderadamente, o processo de especialização disciplinar delimitado na epistemologia, permitindo-se, portanto, o diálogo com outros campos do conhecimento.

\section{CAPÍTULO 1 - OS ANTECEDENTES E A CONSOLIDAÇÃO DO PROCESSO DISCIPLINAR DO DIREITO TRIBUTÁRIO BRASILEIRO.}

\section{Os antecedentes estrangeiros no período pré-disciplinar do Direito Tributário Brasileiro no século XIX}

\subsection{Aspectos preliminares}

Antes de checar o processo histórico disciplinar do Direito Tributário Brasileiro é preciso, ainda que superficialmente e sem pretensão de apresentar qualquer profundidade histórica, apresentar algumas linhas basilares sobre o processo histórico do direito público europeu, sobretudo oitocentista, já que muitas características identificáveis naquele período seriam ulteriormente absorvidas na literatura tributária.

O processo histórico de formação do direito público europeu oitocentista contribuiu enormemente para o posterior desenvolvimento do Direito Tributário. Nomes como Schimidt, Paul Laband, Von Gerber, Ranelleti, Jellinek, Mayer, Santi Romano, Orlando, entre outros, figuraram entre aquelas fontes necessárias para a investigação do direito público europeu oitocentista, já que contribuíram para o aperfeiçoamento da literatura do direito público (notadamente, da Teoria do Estado, do direito constitucional, administrativo e financeiro).

Contudo, as peculiaridades históricas trazidas pelas diversidades políticas vivenciadas na Europa do século XIX denunciavam as variantes estruturais entre cada país, que seguia influenciado por peculiaridades políticas, sociais, econômicas, culturais e filosóficas próprias.

Naquele contexto histórico europeu, o Estado Absolutista (Estado de Polícia), já em sua segunda fase (impulsionado pelo iluminismo e pelo absolutismo esclarecido) começa a 
perder espaço para o Estado Estado Representativo ou Estado de Direito, na transição entre o século XVIII e o século XIX, influenciado pela Revolução Francesa, e, naturalmente, na Independência norte-americana, sucedidas pelo constitucionalismo, a partir do qual ganha espaço gradativamente o Estado Liberal ou Burguês, no século XIX, sobretudo na França e Inglaterra, consubstanciado, nas palavras de Jorge Miranda, na "ideia de liberdade e, em nome dela, empenhado em limitar o poder político tanto internamente (pela sua divisão) como externamente (pela redução ao mínimo das suas funções perante a sociedade"37.

Segundo ensina Fioravanti ${ }^{38}$, nas diferentes formatações históricas do Estado Moderno $^{39}$, identifica-se inicialmente uma formação de Estado Jurisdicional (século XVI ao limiar entre o século XVIII e XIV), passando para o Estado de Direito (legislativo e administrativo, a partir do século XIX até a primeira metade do século XX) e, posteriormente, chegando ao Estado Constitucional (da segunda metade do século XX em diante).

Há, portanto, diferenciadas formatações históricas identificáveis na construção dos "Estados europeus", e que refletem diretamente na formação histórica disciplinar do Direito Público (e do Direito Tributário) nesse contexto ${ }^{40}$.

Da mesma forma, esse processo histórico não aflora com a mesma intensidade, e harmonicamente, em todos os países europeus, já que tal processo depende também de fatores políticos, sociais, ideológicos, culturais e econômicos próprios de cada realidade estatal.

Por exemplo, a Alemanha, diferente da França e da Inglaterra, onde o Liberalismo apareceu com força no período, concentrou-se fortemente no século XIX na progressiva centralização política (unificação), e pela reestruturação estatal (Estado Federal Alemão). ${ }^{41}$

Consequentemente, com a restauração e a afirmação da consolidação dos grandes regimes políticos liberais nacionais na Europa continentais até o fim do século (Alemanha e Itália), instauram-se novas perspectivas para os estudos de direito público naqueles países. A construção do Estado de Direito Alemão, no período do século XIX, manifestouse diferentemente de outros países, como a França e a Inglaterra.

\footnotetext{
${ }^{37}$ MIRANDA, Jorge. Teoria do Estado e da Constituição. Rio de Janeiro: Forense, 2007, Op.cit., p. 44-47.

${ }^{38}$ FIORAVANTI, Maurizio. Stato e Costituzione. In: Lo Stato Moderno in Europa. Istiuzioni e Diritto. A cura di Maurizio Fioravanti. Roma-Bari: Laterza, 2010, p. 03-35.

${ }^{39}$ Sobre o assunto, também: WOLKNER, Antonio Carlos. Síntese de uma História das Ideias Jurídicas. Da Antiguidade Clássica à Modernidade. Florianópolis: Boiteux, 2006, p. 99 e ss.

${ }^{40}$ FIORAVANTI, Maurizio. Stato e Costituzione. Op.cit., p. 03-35.

${ }^{41}$ STOLLEIS, Michael. The History of Public Law in Germany. 1914-1945. Oxford, p. 06 e ss.
} 
Por isso, impulsionado pelo processo de unificação política germânica, Paul Laband, segundo Fiovaranti, afirmava que o Reich deveria ser considerado "um fato imutável" ${ }^{42}$. Logo, a Constituição do Império Alemão (1871), promulgada na égide da unificação do império alemão, fortaleceu o interesse ao direito público na época, conforme é possível observar em Paul Laband, que procedeu a um notável esforço sistematizador do direito público na época, a partir do novo cume constitucional do Estado Federal Alemão ${ }^{43}$.

É a partir desse momento em que os juristas podem dedicar-se à análise e à sistematização do direito positivo do Estado, sobre o pressuposto de que este último não seria mais o "político" da revolução incessantemente submetida às reformas dos equilíbrios sociais, mas uma subjetividade já mais pacificada, segundo o dogmatismo, na visão de Fioravanti. Por isso, a “(...) célebre formulação dogmática da personalidade jurídica passou a neutralizar antigos princípios políticos opostos, como a soberania do monarca e a soberania do povo",44.

Por outro lado, certas tendências do Estado Absolutista, e a própria dificuldade do dimensionamento do Direito Público Europeu, levava a certas características hoje questionáveis. Nela, segundo Mayer, o Poder de Polícia aparecia com semelhantes características concedidas ao Poder Financeiro ${ }^{45}$.

Mas a realidade é que o processo histórico do Direito Público Europeu no século XIX foi permeado por diferentes facetas que colaboram para a visualização de uma complexa e intrincada realidade, onde interagem elementos do liberalismo econômico, filosófico e político, do utilitarismo, do absolutismo tardio, sem mencionar importantes resquícios patrimonialistas. A ideia de direito público, naturalmente, distanciava-se do que se entende hodiernamente.

Mas também na história do Direito Público Europeu transparece a dúvida elementar sobre a prevalência (ou afastamento) do elemento político sobre o elemento jurídico, e nesse quadro, por exemplo, Carl Schimidt e Hans Kelsen, na realidade germânica, travaram importantes debates, já no início do século XX. A própria visão diferenciada através do constitucionalismo alemão sob a ideia de "Constituição", seja ela como

\footnotetext{
${ }^{42}$ A obra extraída por Fiovaranti foi: LABAND, Paul. Das Staatsrecht des Deutschen Reiches, Tübingen, 1911, p. V. FIORAVANTI, Maurizio. La Scienza del Diritto Publico. Dotrinne dello Stato e della Costituzione tra Otto e Novecento. Per La storia del pensiero giuridico moderno. 58/59 Tomo II. Milano: Giuffrè Editore Milano, 2001, p. 588.

${ }^{43}$ LABAnd, Paul. Le Droit Publique de l' Empire Allemand. Tome V. La force armée de l'Empire Allemand.. Traduction de Savinien Souissy. Paris: V. Giard \& Briere, 1903, p. 01-02.

${ }^{44}$ FIORAVANTI, Maurizio. Op.cit., p. 588.

${ }^{45}$ MAYER, Otto. Derecho Administrativo Alemán. Tomo II. Parte Especial. Poder de Policia y Poder Tributário. Depalma: Buenos Aires, 1950, p. 195.
} 
"suprema norma jurídica de garantia" (Kelsen) ou "princípio basilar da unidade da ordem política" (Schimidt), segundo Fioravanti ${ }^{46}$, denunciava esse intento.

Por outro lado, o formalismo jurídico e o positivismo jurídico oitocentista favorecem o afastamento de elementos exteriores ao direito, a busca pela aplicação da lógica às normas jurídicas e tendência conceitualista. A estabilidade do direito, fortalecida pela codificação, simboliza a máxima positivista. É claro que essas características, sob diferentes premissas e contextos históricos, no século $\mathrm{XX}$, apareceram engendradas na própria literatura tributária europeia (e, posteriormente, na literatura brasileira).

Assim, o positivismo e o formalismo jurídico no direito público europeu fornecia maior afastamento da política perante o direito público, ainda que, na órbita do Direito Tributário, essa realidade necessitasse de inequívocas ponderações.

O Direito Público oitocentista é permeado também por certas tendências hermenêuticas construídas na filosofia do direito (aplicadas ao direito privado), como a jurisprudência dos conceitos que, ao elevar a lógica jurídica aplicada à consolidação de conceitos jurídicos, favoreceu também a elevação posterior do positivismo jurídico ${ }^{47}$.

Portanto, nesse diferenciado e complexo contexto jurídico (e político) é que o Direito Público Europeu se instala, nas últimas décadas do século XIX, trazendo importantes contribuições ao posterior surgimento do Direito Tributário, conforme se observará.

Contudo, em meados do século XIX, ainda o fenômeno tributário recebia pouca atenção nos estudos jurídicos, cabendo à Ciência das Finanças suas mais importantes contribuições.

\subsection{A preferência histórica da Ciência das finanças no estudo do fenômeno tributário no século XIX.}

No século XIX o estudo sobre o fenômeno tributário no âmbito jurídico era severamente limitado já que o próprio direito administrativo somente daria seus passos

\footnotetext{
${ }^{46}$ FIORAVANTI, Maurizio. Op.cit., p. 576 e ss.

${ }^{47}$ Em outras palavras: "Conforme já exposto, a jurisprudência dos conceitos abriu o caminho para o domínio do formalismo jurídico. Ao se privilegiar um tratamento sistemático e dogmático, o jurista, por meio de um arsenal lógico, passa a deduzir novos conceitos, o que permite a clausura e completude do ordenamento. Essa criação de novos conceitos não seria uma tarefa arbitrária, ela estaria, ao contrário, presa a um "método jurídico", não precisando, portanto, contaminar-se com o campo das contingências e vicissitudes políticas ou mesmo em considerações éticas". ANDRADE, José Maria Arruda de. Interpretação da Norma Tributária. São Paulo: MP Editora, 2006, p. 98 e ss.
} 
iniciais enquanto disciplina jurídica nos últimos anos do século XIX. Assim, o fator efetivamente determinante para o estudo do fenômeno tributário naquele período vinculouse ao florescimento do interesse para os estudos econômico-financeiros no final do século XIX, na órbita da "Ciência das Finanças". A influência dessa disciplina na análise do fenômeno tributário foi tamanha que muitas obras de célebres estudiosos dessa época não raramente incluíam a temática da "Legislação Financeira" como capítulo obrigatório de suas obras (considerando a raridade ou inexistência de estudos sobre o assunto, do ponto de vista jurídico). ${ }^{48}$

Na realidade, o avanço das "Finanças Públicas" sobre assuntos que deveriam ser estudados por juristas não pode resultar em surpresa para o leitor. Comparando a evolução dos estudos jurídico-tributários e os estudos econômico-financeiros, vê-se que estes últimos estavam na época muito mais preparados para analisar os aspectos financeiros e tributários do aparelho estatal que os próprios juristas (sobretudo os administrativistas) ${ }^{49}$. Essa confusão epistemológica no estudo do fenômeno tributário no século XIX foi muito bem ponderada por Berliri: "De outro lado, seja na economia política, onde a jovem Ciência das Finanças não limitou suas indagações somente ao campo estritamente econômico e financeiro, mas examinaram, mais ou menos profundamente, também o lado jurídico do fenômeno tributário e, portanto, também nos tratados de economia e ciência das Finanças, larga parte reservou ao Direito Tributário. Realmente a contaminação e a confusão entre a Ciência Das Finanças, a Economia e o Direito Tributário é tal que algumas vezes pôde ser difícil dizer qual estudo devia ser abordado adequadamente frente à outra disciplina",50.

\footnotetext{
${ }^{48}$ Nesse sentido, recorde-se que a doutrina financeira francesa não raramente utilizava-se de elementos de "legislação financeira" em obras dedicadas originalmente à Ciência das Finanças, como se observa em Edgard Allix e Gastón Jèze, por exemplo. JÈZE, Gastón. Cours de Science des Finanzes et de Legislatión Financière Française. Sixième Editión. Paris: Marcel Giárd, 1922, p. 01-02; ALLIX, Edgard. Traité Élémentaire de Science des Finances et de Législation Financière Française. Quatrième Édition. Paris: Rousseau et Cie Éditeurs, 1921, p. 01-03.

${ }^{49}$ VILLEGAS. Héctor. Curso de Finanzas, Derecho financiero y tributario. Autor: $5^{\circ}$ Edición. Tomo único. Buenos Aires: Depalma Ediciones, 1993, p. 25-27; BALEEIRO, Aliomar Uma Introdução à Ciência das Finanças. $15^{\circ}$ Edição. Atualizador: CAMPOS, Dejalma Rio de Janeiro: Forense, 2000. p. 13-14; D’AURIA, Francisco. Ciência das Finanças (Teoria e Prática). $2^{\circ}$ Edição.São Paulo: Companhia Editora Nacional, 1946, p.16-17; FANNO, Marco. Elementi di Scienza delle Finanze. Anno VII. E.F. Torino: S.Lattes\& C.,Editori, 1929, p.66 e seguintes. NITTI, Francesco. Princípios da Ciência das Finanças. Tradução de C. Machado. Primeiro Volume. Rio de Janeiro: Atena Editora, 1937, p. 55 e seguintes.

${ }^{50}$ Para a verificação das principais obras sobre o tema (cursos ou monografias sobre temas específicos da realidade financeira), sugere-se a leitura de Berliri, que realizou copioso levantamento bibliográfico do período, buscando demonstrar a existência pretérita de estudos relacionados ao direito tributário naquele período (ainda que não tenham demonstrado emancipação do direito administrativo ou da Ciência das
} 
A dúvida explicitada na reflexão de Berliri não era sem motivo, afinal, naquele período os estudiosos da ciência das finanças detinham muito mais experiência no trato do fenômeno tributário que os próprios juristas, ainda em seus primeiros passos na busca do desenvolvimento do Direito Público (e, para o que interessa, do Direito Administrativo). Por isso não é surpresa que as mais avançadas contribuições teóricas ao estudo do fenômeno tributário, no século XIX, tenham sido construídas pela leitura dos financistas, e não pelos juristas.

Essa observação é confirmada na medida em que os próprios estudiosos do Direito Administrativo, quando tratavam de assuntos tributários, não titubeavam a tomar como referências as construções teóricas e reflexões elaboradas no seio da Ciência das Finanças.

Exemplo maior dessa influência financista pode ser observada na obra de Otto Mayer, na qual muitas de suas contribuições teóricas ao fenômeno tributário, e que posteriormente seriam severamente refletidas pelos juristas do século $\mathrm{XX}$, eram em verdade contribuições já largamente debatidas na órbita da Ciência das Finanças. É o caso das espécies tributárias e suas classificações (tripartida, quadripartida, quinquipartida, etc). A classificação exposta por Mayer ${ }^{51}$ (tripartida) entre impostos (Steuer), taxas (Gebühr) e contribuições (Beiträge) nada mais era do que uma das várias propostas da ciência das finanças que detinha maior adesão entre os financistas e, provavelmente, a de maior adesão na doutrina financista na época, como se pode observar em Adolph Wagner ${ }^{52}$. Mayer, nesse caso, teve o mérito de levar à atenção dos juristas uma construção que havia se sedimentado entre os financistas ${ }^{53}$.

De qualquer forma, feitas essas ponderações iniciais, em síntese, tais circunstâncias supramencionadas viabilizaram o seguinte panorama dos estudos tributários europeus no final do século XIX: 1) nítido avanço dos estudiosos da Ciência das Finanças no campo dos estudos tributários, chegando a inclusive inserir em suas obras de Ciência das Finanças o capítulo "Legislação Financeira"; 2) confusão dos estudos jurídicos tributários e a

Finanças). BERLIRI, Antonio. Principi di Diritto Tributario. Volume 1. Milano: Dott.A.Giuffrè - Editore, 1952, p. 206 e seguintes.

${ }^{51}$ MAYER, Otto. Derecho Administrativo Alemán. Tomo II. Parte Especial. Poder de Policía y Poder Tributário. Buenos Aires: Depalma, 1950, p. 185 e seguintes.

${ }^{52}$ WAGNER, Adolph. Traité des Science des Finances. Théorie de l'Impositión, Théorie des Taxes et Théorie Générale des Impôts. Traduction par Jules Ronjat. Deuxième Editión. Paris: V. Giard \& E. Brière, 1909 , p.155 e seguintes.

${ }^{53}$ MAYER, Otto. Op.cit., p.196 e seguintes. 
dificuldade propagada pela ausência de autonomia frente ao Direito Administrativo, já que o substrato jurídico da atividade tributária era observado pela lente dos administrativistas; 3) grandes dificuldades marcadas pela própria distinção teórica (e legislativa) entre Direito Público e Privado, sobretudo no que respeita ao contencioso fiscal ainda incipiente e à fragmentação legislativa na matéria. Essa dificuldade epistemológica de desconsiderar a visão privatista do direito também foi responsável pela grande dificuldade de emancipação do futuro Direito Tributário frente ao uso de institutos ou conceitos oriundos do Direito Privado.

Não é surpresa que, afinal, a própria Ciência das Finanças tenha ensinado tanto sobre o fenômeno tributário, antes mesmo do Direito Administrativo considerá-lo como objeto de estudo relevante ao Direito Público. Mas, gradualmente, o Direito Público, ainda que não tratando com elevada atenção à matéria tributária (e nem reconhecendo o direito financeiro enquanto disciplina jurídica, quando mais o direito tributário), passa a demonstrar importantes contribuições ao tema. Não obstante, a consolidação histórica do Direito Público Europeu, no século XIX, apresenta algumas opções metodológicas e epistemológicas que influenciarão fortemente a construção disciplinar do Direito Tributário Europeu e, posteriormente, na realidade brasileira. Por isso é conveniente trazer algumas linhas gerais sobre esse processo.

\subsection{O surgimento do Direito Público Europeu e sua contribuição inicial à literatura tributária}

O surgimento do Direito Público Europeu foi severamente influenciado pelo ambiente oitocentista, conforme se observa em Berliri, que produziu relevante síntese da produção acadêmica europeia (sobretudo italiana) no século XIX, no que diz respeito ao Direito Público (e, especialmente no que tange ao Direito Administrativo, Financeiro e Tributário), assinalando que a evolução ainda incipiente daquele ramo do Direito (Público) ganhou maior impulso após a Revolução Francesa, pois foi justamente a partir desse acontecimento político que o Direito Administrativo inicia sua especialização disciplinar na realidade francesa.

Já no âmbito jurídico inicia-se a concepção relacionada à separação entre o Fisco e o Estado, a distinção entre o Patrimônio Público, que não pertenceria mais ao Príncipe, 
mas ao Fisco (Estado). Por outro lado, ocorre a revalorização do Direito Privado, impulsionada pela codificação francesa e, com a Revolução Francesa, a criação dos primeiros tribunais administrativos. Ainda, a ciência jurídica passou a separar as duas pessoas jurídicas - Estado e Fisco, muito embora ainda fosse severa a influência do Direito Romano neste período ${ }^{54}$.

A importância do Direito Privado na época é elevada pela consideração de que ela garantiria a justiça no tratamento do próprio patrimônio do Estado e do Fisco. A noção de Direito Privado envolve ideia de bilateralidade, paridade, permeada pela perspectiva liberal individualista do período, ao passo que a visão de Direito Público (e de Direito Administrativo) parte essencialmente de uma perspectiva unilateral de relação entre governante e governado, de emanação do poder público sobre o governado, e muitos autores viam até com naturalidade a relação de Direito Público como uma relação de submissão fática. Obviamente, para preservar os interesses individuais, muito melhor seria aplicar a lógica prevalecente no Direito Privado. Esse foi um dos motivos para a difícil aceitação do tratamento diferenciado do fenômeno tributário pela lógica do Direito Público (e Administrativo).

Por outro lado, essas concepções vão fortalecer a dicotomia entre o Direito Público e o Direito Privado e, notadamente, em primeiro momento, entre o Direito Civil e o Direito Administrativo. Na dissociação entre o Direito Privado e o Direito Público destacou-se o estudo de Otto Mayer, versando sobre a relação entre contribuinte e Estado. A Noção de fisco com personalidade jurídica própria desaparece, e o conceito de unidade da personalidade jurídica do Estado domina o período, substituindo o termo "fisco", que possui a partir desse período, diferente conotação ${ }^{55}$.

Nicola D'Amati também destacou a separação feita pelos administrativistas alemães entre a disciplina dos direitos patrimoniais do ente público e o presumido poder financeiro. A dicotomia entre o "Patrimônio Público" e o "Patrimônio Privado" apresentou essencial importância para o desenvolvimento do Direito Administrativo, e,

\footnotetext{
${ }^{54}$ BobBIO, Norberto. O positivismo jurídico. Lições de filosofia do direito. Coleção Elementos de direito, São Paulo: Ícone, 1995, p. 15 e seguintes.

${ }^{55}$ D'AMATI, Nicola. La Formación del Derecho Tributário en Itália. In: D’AMATI, Nicola. AMATUCCI, Andrea (Organiz). Historia del Derecho de la Hacienda Pública y del Derecho Tributario en Italia. E aporte del pensamento jurídico financiero de la Italia Meridional. Derecho de la Hacienda Pública. Obras Fundamentales 1. Bogotá-Colombia: Temis, 2004, p. 139-190.
} 
posteriormente, ao Direito Financeiro, encontrando respaldo na doutrina enfatizada por Otto Mayer, conforme destaca Nicola D'Amati ${ }^{56}$.

Na realidade, como asseverou Fritz Fleiner, o Direito Administrativo alemão se desenvolveu com força autônoma em meados do século XIX, quando os tribunais judiciários, nos julgamentos de litígios entre administração pública e cidadãos, partiam por considerações de relações jurídicas (em que figurava a administração pública), mas continuavam a tecer considerações à luz do Direito Civil, por sua vez permeado por aquela visão liberal individualista ${ }^{57}$.

Já em 1863 foram instalados os tribunais administrativos especiais dos Estados Alemães e, especialmente, o Supremo Tribunal Administrativo prussiano (Preussisches Oberverwaltungsgericht), no ano de 1875.

O surgimento desse contencioso administrativo foi o passo decisivo para o desenvolvimento da elaboração de um direito especial da administração pública, necessário para a orientação e aplicação do direito pelos tribunais. Paralelamente a esse evento, na administração do Estado ocorreu a construção da autonomia da administração, consistente na administração comunal. Ainda, a estrutura federal do Estado alemão obrigou a coexistência de um direito administrativo do Império e dos "direitos administrativos" dos Estados particulares ${ }^{58}$.

Mas foi lenta a consolidação do Direito Administrativo no século XIX, ganhando corpo apenas a partir do último quarto daquele século. Isso porque foi justamente naquele período que dois outros fenômenos políticos ocorreram em países que futuramente seriam conhecidos como berços do Direito Administrativo, ao lado da França. Dentre esses

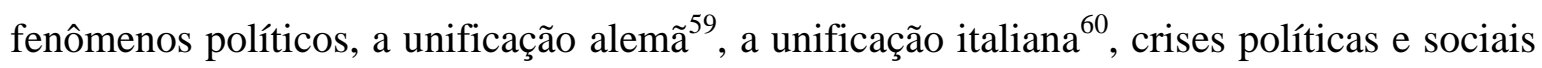
na França, na Inglaterra, dentre outros países, e que tiveram como consequência a

\footnotetext{
${ }^{56}$ D’AMATI, Nicola. La Formación del Derecho Tributário en Itália. Op.cit., p. 139-190.

57 FLEINER, Fritz. Les Principes Généraux Du Droit Administratif Allemand. Traduction de Ch. Eisemann. Paris: Libraire Delagrave, 1933, p. 252-266.

${ }^{58}$ Idem, p. 22 e seguintes.

${ }^{59}$ Sobre a unificação alemã, também se sugere a leitura do seguinte trabalho: STOLLEIS, Michael. Storia Del Diritto Pubblico in Germania. Per La storia Del Pensiero giuridico moderno. n.79. Milano: Giuffrè Editore, 2008, p.530 e seguintes.

${ }^{60}$ Sobre a unificação italiana, sugere-se a leitura dos seguintes trabalhos: BERLIRI, Antonio. Principi di Diritto Tributario. Op.cit., p. 206 e seguintes; ROMANO, Santi. Princípios de Direito Constitucional Geral. Maria Helena Diniz (Trad). São Paulo: Rt, 1977, p. 59 e seguintes.
} 
gradativa centralização política estatal, a necessidade de um corpo de normas mais adequado a abarcar aquelas novas realidades políticas, a criação de tribunais administrativos e, consequentemente, um novo impulso à produção jurídica decorrente dessa centralização ${ }^{61}$. É claro que, no exemplo germânico, a unificação política e a reestruturação federal consolidada na Constituição de 1871, inaugurando o Estado de Direito do Império Alemão, fortaleceu ainda mais a tendência europeia aos estudos de direito público na época.

Por outro lado, havia clara preferência ao estudo de outros ramos do Direito já consolidados, conforme se observa em Friedrich Karl Von Savigny que, em meados do século XIX, demonstrava clara dificuldade de reconhecer o Direito Público com o mesmo status de Ciência do Direito ao qual reservava ao Direito Penal e ao Direito Privado ${ }^{62}$.

Noutro passo, junto da contribuição bibliográfica de Berliri, com idêntica relevância, cumpre registrar a opinião de Brandão Machado, que reforçou a sensação lacunar sobre o assunto, pois o que se tinha escrito anteriormente ao século XX sobre tributos não tinha o caráter de especialização, e nem apresentava sistemas de princípios. Assim: “(...) Os numerosos tratados catalogados, como bibliografia, por Pomini e Berliri na Itália, e por Von Lang e Riess, na Alemanha, não têm essa especialização e versam temas tributários de permeio com instituições típicas do direito privado" ${ }^{\text {.63. }}$.

No século XIX, portanto, emergiu a necessidade de separação do Direito Privado e do Direito Público, e a subsequente emancipação teórica do Direito Administrativo, e seus respectivos ramos, que foi uma característica imediatamente ulterior àquelas crises político-sociais, conforme acertadamente aponta Berliri, em consulta às obras de Romagnosi e Manna ${ }^{64}$.

É justamente nesse contexto que se visualiza o tratamento jurídico dedicado inicialmente ao fenômeno tributário, que, nas obras de Direito Administrativo Europeu, era sempre exposto, mas como mero tópico da disciplina geral do Direito Administrativo (e submetido às regras e princípios desse).

\footnotetext{
${ }^{61}$ ROMANO, Santi. Op.cit., p. 379 e seguintes.

${ }^{62}$ SAVIGNY, Friedrich Karl Von. Op.cit., p.05-06.

${ }^{63}$ MACHADO, Brandão. Apresentação. In: MORAES, Oswaldo de. Curso de Legislação Tributária. São Paulo: Saraiva, 1974, p. vii.

${ }^{64}$ BERLIRI, Antonio. Principi di Diritto Tributario. Op.cit., p. 206 e seguintes.
} 
Conforme aponta acertadamente Brandão Machado, até os últimos 25 anos do século XIX, o Direito Tributário constituía simples apêndice do Direito Administrativo, e parte integrante da Ciência das Finanças ${ }^{65}$. Mas isso não impediu que os primeiros administrativistas da época analisassem o substrato tributário, pois Otto Mayer, especialmente, dedicou todo um longo capítulo ao estudo do poder financeiro, ao passo que Fleiner ${ }^{66}$, em 1911, em minuciosa análise sobre as instituições do Direito Administrativo Alemão, também não se esqueceu dos tributos, embora o analisasse sobre a perspectiva do Direito Administrativo. Os célebres publicistas da época Santi Romano, Meucci e Georg Meyer também seguiram essa tendência ${ }^{67}$.

De qualquer forma pode-se antecipar que, nas obras de Direito Administrativo do século XIX, sempre a tributação esteve presente, ainda que não contando com sistematização científica organizada, acompanhada do reconhecimento científicodisciplinar que poderia ser relegado à matéria, pelo menos da maneira como é concebido o Direito Tributário atual, pois ainda pautados naquela particular visão de administrativistas aplicados ao tratamento dos tributos ${ }^{68}$.

Além disso, na doutrina de língua alemã o termo Direito Financeiro já apresentava antiga tradição, especialmente por influência direta da Constituição do Império Alemão de 1871 (que trouxe toda uma seção específica sobre as finanças públicas do Império Alemão e, notadamente, sobre o direito orçamentário), pois Von Stein se referia a ele em 1871, ao passo que, em 1873, Paul Laband escreve sua obra Das Finanzrecht des Deutschen Reichs. Por outro lado, Wagner, em seu Finanzwissenschaft, de 1883, determinava seu conteúdo e ressaltava a sua vinculação a disposições constitucionais. Não é demais lembrar da importancia à expressão trazida pelo "Grundriss des Finanzrechts", de Myrbach-Rheinfeld, de 1906, assim, como no mesmo ano, por Heinrich Konrad, no Konstitutionelles Finanzrecht. Além disso, já em 1912, apresenta-se a obra de Lippert (Das Internationale Finanzrecht), e, em 1917, a obra de Waldecker (Finanz- und Steuerrecht, além das obras de Lassar (Der Erstattungsanspruch im Verwaltunggsrecht und Finanzrecht), Otto Mayer

\footnotetext{
${ }^{65}$ MACHADO, Brandão. Apresentação. In: MORAES, OSWALDO de. Op.cit., p.vii-xiii.

${ }^{66}$ FLEINER, Fritz. Op.cit., p. 252-266.

${ }^{67}$ MACHADO, Brandão. Apresentação, In: MORAES, OSWALDO de. Op.cit., p.vii-xiii.

${ }^{68}$ Nesse sentido, dentre várias obras citadas, Berliri destacou as seguintes: "O Direito Administrativo das Duas Sicílias", de Manna, aparecido em 1840; "Instituições de Direito Administrativo", de 1879, de Meucci; o "Direito Administrativo dos Estudantes" (Pisa, 1866); "Curso de Direito público administrativo" de De Giovanninis (1877); "Curso de Direito Administrativo", de Rocco; "Curso de Direito Administrativo", de Persico. BERLIRI, Antonio. Principi di Diritto Tributario. Volume 1. Op.cit., p. 209 e seguintes.
} 
(Finanzwirtschaft und Finanzrecht, de 1927), Wittschieben (Das österreichische Finanzrecht, de 1926), Popitz (Finazrecht und Finanzwissenschaft) de 1928; e Stier-Somlo, (voz Finanzrecht) de 1927, Handwörterbuch der Rechtswissenchaft ${ }^{69}$.

Mas não somente a doutrina juspublicista alemã e francesa manifestou obras de relevo para o florescimento do Direito Administrativo. Nesse aspecto, é preciso destacar a importância da doutrina financeira italiana para o desenvolvimento do Direito Tributário.

De forte tradição econômica, os estudiosos italianos logo viram-se envoltos à polêmica do tratamento diferenciado no âmbito do Direito Administrativo e do Direito Financeiro, destinado a regular a atividade financeira ${ }^{70}$.

Nesse aspecto, o século XIX foi muito profícuo na Itália para o resguardo dos estudos de Direito Público, dentre os quais poder-se-iam citar, previamente, Luigi Cossa, Giuseppe Ricca Salerno, Oreste Ranelleti, V.E.Orlando, Graziani, e outros ${ }^{71}$. Por outro lado, a Itália foi sobretudo reconhecida enquanto pólo oitocentista para estudos financeiros sob a perspectiva econômica (Ciência das Finanças). A larga tradição econômicofinanceira da produção italiana gerou grande influência na produção teórica brasileira, ao lado da produção de língua inglesa, potuguesa e francesa.

Em anos posteriores, o surgimento de autores dedicados aos aspectos jurídicos do fenômeno financeiro gerou uma produção acadêmica essencialmente multidisciplinar ${ }^{72}$, e tal característica trouxe importantes consequências para a literatura tributária italiana (assim como a latino-americana) no século XIX até meados do século XX.

Mas, efetivamente, as duas grandes contribuições aos estudos "jurídico-tributários" na época deram-se através das obras de Otto Mayer e Franz Von Myrbach-Rheinfeld.

\footnotetext{
${ }^{69}$ MARTUL-ORTEGA, Perfecto Yebra. Prologo a La Edición Española. In: KRUSE, Heinrich Wilhelm. Derecho Tributario. Op.cit., p. 12.

${ }^{70}$ D’AMATI, Nicola. La Formación del Derecho Tributário en Itália. Op.cit., p. 139-143.

71 AMATUCCI, Andrea. Las Raíces de la Concepción Sustancial del Derecho Financiero Público en Nápoles y en la Italia Meridional. In: D’AMATI, Nicola. AMATUCCI, Andrea (Organiz). Historia del Derecho de la Hacienda Pública y del Derecho Tributario en Italia. E aporte del pensamento jurídico financiero de la Italia Meridional. Op.cit., p. 89 e seguintes.

72 D'AMATI, Nicola. Historia de La Enseñanza del Derecho Financiero Público en Italia. In: In: D'AMATI, Nicola. AMATUCCI, Andrea (Organiz). Historia del Derecho de la Hacienda Pública y del Derecho Tributario en Italia. E aporte del pensamento jurídico financiero de la Italia Meridional. Derecho de la Hacienda Pública. Op.cit., p. 99 e seguintes.
} 
Otto Mayer, eminente publicista, no século XIX, escreveu o célebre trabalho "O Direito Administrativo Alemão"73, com extenso capítulo dedicado aos aspectos jurídicos das finanças estatais, trazendo muitas importantes contribuições que seriam posteriormente absorvidas e aprimoradas pela literatura jurídica tributária no século XX, como é o caso das espécies tributárias, da relação tributária, da legalidade tributária e, especialmente, do conceito de tributo ${ }^{74}$.

Porém, a estrutura de "curso", "manual" ou "compêndio" didático que reunisse sistematicamente a matéria financeira foi trabalhado minuciosamente por Franz Von Myrbach-Rheinfeld, cujo pioneirismo pode ser observado na sua tentativa expressa de separar os estudos de Direito Financeiro dos estudos econômicos e, assim, elevar o Direito Financeiro enquanto disciplina jurídica. O trabalho original foi publicado em 1906, porém teve maior repercussão em outros países a partir da tradução francesa da mesma obra, no ano de 1910. Não é por outro motivo que Gastón Jèze, no prefácio da tradução francesa da obra de Myrbach-Rheinfeld, assinalou expressamente tratar-se de livro de pura técnica jurídico-financeira, que inaugurava um novo gênero de pesquisas ${ }^{75}$.

As motivações de Myrbach-Rheinfeld justificam-se porque, na época, eram os financistas que estudavam mais arduamente as leis financeiras, e não os juristas, mais apegados aos ramos privatistas. Curiosamente, Myrbach-Rheinfeld dedicou mais da metade de sua obra ao chamado "Direito dos Impostos" em preferência a outros temas financeiros ${ }^{76}$.

\footnotetext{
${ }^{73} \mathrm{O}$ "Direito Administrativo Alemão", com três volumes, é reconhecidamente um clássico para a literatura do Direito Público, versando sobre variados temas que envolviam o Direito Administrativo da época. Curiosamente, Otto Mayer dedicou também espaço em sua obra para retratar o "Direito da Imposição" da época. Como a obra foi anterior ao próprio livro de Myrbach-Rheinfeld, não havia ainda grandes esforços para separar o Direito Financeiro do Direito Administrativo e, portanto, tudo que se referia ao atual Direito Financeiro (inclusive o Direito Tributário) estava incluído como matéria objeto de estudo do Direito Administrativo. Logo, não é por acaso que Mayer tenha dedicado pelo menos metade do seu segundo volume (referente ao Poder de Polícia e ao Poder Tributário). A obra de Otto Mayer foi traduzida para a língua francesa em 1904, que traduziu a versão alemã de 1895-1896, que possuía dois volumes. Na versão espanhola, porém, a obra de Mayer foi dividida em três volumes (tomos). MAYER, Otto. Op.cit., p. 185 e seguintes.

74 “(...) o imposto é um pagamento em dinheiro que o poder tributário impõe ao sujeito em virtude de uma regra permanente". MAYER, Otto. Op.cit., p. 197 e seguintes.

${ }^{75}$ JÈZE, Gastón Avertissement au Lecteur Français. In: MYRBACH-RHEINFELD, Franz Von. Précis de Droit Financier. Traductión Française par É. Bouché-Leclercq. Paris: V. Giard \& Briere, 1910, p. v-vi.

${ }^{76}$ Fundamenta-se tal posição pelo simples motivo de que, na leitura do "Précis de Droit Financier", que possui cerca de seiscentas páginas, apresentar pelo menos 450 páginas dedicadas à discussão do "direito do imposto". O Direito Financeiro, que não se incluía no Direito do Imposto, era tratado somente nas 100 páginas iniciais, concedendo as páginas restantes ao tratamento exclusivo da matéria tributária. Na realidade,
} 
Os fenômenos estrangeiros identificados no âmbito da literatura publicista e financista europeia servem de arcabouço teórico que irá influenciar a formação da literatura tributária brasileira, ainda que essa, conforme se observará, tenha seguido caminhos distintos.

Por outro lado, o Direito Público Europeu oitocentista também legará importantes características que serão herdadas pela doutrina do direito tributário no século $\mathrm{XX}$, e muitas dessas devidas à influência do formalismo e do positivismo jurídico no Direito Público daquele período.

2. O lastro histórico do formalismo jurídico e do positivismo jurídico no século XIX e suas consequências ao Direito Público Europeu.

\subsection{Brevíssima síntese das tendências hermenêuticas no século XIX: a base elementar para o positivismo e formalismo jurídicos.}

Historicamente, certas estratégias da filosofia do direito (construídas na órbita do direito privado) adotadas no século XIX, como o formalismo jurídico e o positivismo jurídico e, sobretudo, algumas de suas características, afloraram na Alemanha e na Itália com grande intensidade, favorecendo a defesa do afastamento do elemento político em face do elemento jurídico, que passa a ser perseguido no âmbito do Direito Público Europeu.

É claro que, no âmbito do Direito Tributário, salvo quando analisado na órbita do sistema financeiro estatal ou dos dispositivos constitucionais alinhados à tributação, pouco havia sido acrescido, muito embora, conforme já se observou, por exemplo, em Mayer, a base essencial para o posterior desenvolvimento do Direito Tributário já apresentasse ali suas premissas.

Note-se que o positivismo jurídico, aliando-se a características do formalismo jurídico, sobretudo por influência da jurisprudência dos conceitos (e do formalismo jurídico praticado no direito privado) favoreceu gradativamente na França e na Alemanha (não necessariamente na mesma velocidade) a própria codificação do direito, símbolo da

a obra do autor austríaco, na opinião desse estudo, poderia muito bem ser denominada "Direito Financeiro e Direito Tributário". MYRBACH-RHEINFELD, Franz Von. Précis de Droit Financier. Traductión Française par É. Bouché-Leclercq. Paris: V. Giard \& Briere, 1910, p. 20 e seguintes. 
vitória do positivismo jurídico perante outras tendências filosóficas (como o jusnaturalismo) $)^{77}$.

O debate fundamental entre o jusnaturalismo e o juspositivismo (e, sobretudo, sobre o direito natural e o direito positivo $)^{78}$, entre o final do século XVIII até meados do século XIX na Europa (e especialmente na Alemanha) forneceu indícios fortes das tendências históricas (e metodológicas) aplicadas à ciência do direito (incluindo o direito público) no século XIX (e também no século XX).

Embora não se possa afirmar que o jusnaturalismo tenha sido completamente extirpado no progresso das ciências jurídicas a partir do século XIX (para Bobbio, a utilização de critérios jusnaturalistas para resolver o problema da lacuna do direito, não bem desenvolvida pelo positivismo jurídico, mostraria sinais de sobrevivência do jusnaturalismo naquele específico contexto) ${ }^{79}$, essa corrente, inicialmente deduzida do iluminismo racionalista (direito natural enquanto direito universal e imutável deduzido pela razão), foi fortemente combatida pelo historicismo jurídico, que teve entre seus grandes representantes, Carl Friedrich Von Savigny ${ }^{80}$, que elevou o direito consuetudinário perante o direito natural (dedutível do raciocínio iluminista da época) ${ }^{81}$.

Ao contrapor-se expressamente ao jusnaturalismo, segundo Bobbio, o historicismo jurídico influenciaria o posterior surgimento do positivismo jurídico ${ }^{82}$.

Mas também é verdade que, em meados do século XIX, no entanto, outras tendências hermenêuticas favoreceram a ulterior consolidação do positivismo jurídico e do formalismo jurídico.

A experiência francesa, a partir do Código Napoleônico (1804), favorece o desenvolvimento da Escola de Exegese, que, segundo Bobbio, teria as seguintes características: a) "inversão das relações tradicionais entre direito natural e direito positivo; b) “concepção rigidamente estatal do direito; c) "interpretação da lei fundada na intenção

77 CORDEIRO, Antonio Menezes. Introdução à Edição Portuguesa. In: CANARIS, Claus Wilhelm. Pensamento Sistemático e Conceito de Sistema na Ciência do Direito. Op.cit., p. xi e ss.

${ }^{78}$ BOBBIO, Norberto. O Positivismo Jurídico. Lições de Filosofia do Direito. São Paulo: Ícone, 1995, p. 22-23.

${ }^{79}$ Idem, p.42-44.

${ }^{80}$ Segundo Bobbio, o Historicismo Jurídico, que, enquanto crítica radical ao Direito Natural, também contribui para o positivismo jurídico. As características dessa corrente seriam as seguintes: a) individualidade e variedade do homem; b) irracionalidade das forças históricas; c)pessimismo antropológico; d) amor pelo passado; e) sentido de tradição. Contrapõe-se ao direito natural derivado do racionalismo iluminista, que via o direito como dedutível da razão, e que fundamentou o movimento codificador no final do século XVIII e início do século XIX. Ibidem, p. 51-53.

${ }^{81}$ WOLKNER, Antonio Carlos. Ideologia, Estado e Direito. $2^{\text {a }}$ Ed. São Paulo: RT, 1989, p.17-91.

${ }^{82}$ BOBBIO, Norberto. O Positivismo Jurídico. Lições de Filosofia do Direito. Op.cit., p. 54. 
do legislador"; d) identificação do direito como a lei escrita (culto do texto da lei); e) o respeito pelo princípio da autoridade" ${ }^{\wedge 3}$.

Note-se que essas características defendidas no positivismo jurídico francês enaltecem pontos que depois seriam aperfeiçoados (ou ponderados) pelo positivismo e o formalismo jurídico. A própria codificação do direito, afinal, é o ponto de apoio para o surgimento de positivismos, e surge impulsionada por essas tendências, conforme se observa na realidade germânica, ainda que com posteridade.

Por isso também a jurisprudência dos conceitos (também conhecida como pandectística) ganhou força na Alemanha nos anos finais do século XIX, impulsionando também a codificação do direito privado alemão. ${ }^{84}$

Mas o processo codificador na Alemanha foi recebido com certo atraso perante a experiência francesa. Porém, conforme relata Bobbio, o debate entre Tibhaut (favorável à codificação do direito civil na Alemanha no século XIX) e Savigny (desfavorável à codificação do direito civil na Alemanha, por entender que o país não se encontrava em condições culturais aptas à codificação), não impediu que a codificação chegasse ao Direito Civil Alemão, pois, conforme Tibhaut, com a codificação, haveria maior perfeição formal e substancial na legislação ${ }^{85}$.

Noutro aspecto, as duas tendências hermenêuticas que, ao lado do historicismo jurídico, serviriam de base para a consolidação do formalismo jurídico e do positivismo jurídico europeu foram a jurisprudência dos conceitos e a jurisprudência dos interesses.

A primeira consolida-se em meados do século XIX, na Europa, sobretudo na Alemanha.

A jurisprudência dos conceitos, também denominada "pandectistica", teve entre seus representantes Puchta ${ }^{86}$. Savigny, ainda como representante da "Escola Histórica", também apresentou as bases para a jurisprudência dos conceitos.

A Jurisprudência dos Conceitos foi ramo da hermenêutica jurídica notabilizado pela contribuição sistematizadora das fontes do Direito, e pautadas em conceitos abstratos (construídos pela lógica formal), onde o sistema de conceitos, segundo Larenz, apareceria como uma pirâmide, em que o conceito supremo, ocupante do vértice da pirâmide, paira

\footnotetext{
${ }^{83}$ Ibidem, p. 84 e ss.

84 CORDEIRO, Antonio Menezes. Introdução à Edição Portuguesa. In: CANARIS, Claus Wilhelm. Pensamento Sistemático e Conceito de Sistema na Ciência do Direito. Op.cit., p. xi e ss.

${ }^{85}$ BOBBIO, Norberto. O Positivismo Jurídico. Lições de Filosofia do Direito. São Paulo: Ícone, 1995, p. 57 e ss.

${ }^{8686}$ CALIENDO, Paulo. Direito Tributário. Três Modos de Pensar a Tributação. Elementos para uma teoria sistemática do Direito Tributário. Op.cit., p. 85-87.
} 
sobre os demais por cima da base. Em outras palavras, quanto maior a altura da pirâmide, menor sua largura ${ }^{87}$.

Puchta defendeu que a ciência jurídica do seu tempo deveria tomar o caminho de um sistema lógico no estilo de uma "pirâmide de conceitos", buscando a elevação de uma "jurisprudência de conceitos formal"

O método conceitualista formal, pautado na compreensão de conceitos abstratos interligados a um sistema conceitual dedutível por operações lógicas, é a característica essencial da jurisprudência dos conceitos. A ideia de sistema como nexo orgânico de "proposições jurídicas", já aparece nessa corrente hermenêutica. A genealogia dos conceitos, de Puchta, seria, para Larenz, “(...) a pirâmide de conceitos do sistema construído segundo as regras da lógica formal" $" 89$.

Nesse contexto, eleva-se a ideia do "conceito supremo" (no ápice da pirâmide), do qual se deduziriam todos os conceitos inferiores. O conceito inferior, por sua vez, somente seria válido se fosse subsumido ao conceito superior (valendo obrigatoriamente todas as afirmações feitas sobre o conceito superior ao inferior). Assim, a genealogia dos conceitos de Puchta parte do pressuposto de que o conceito supremo, do qual se deduzem todos os outros, codetermina os restantes através de seu conteúdo" 90 .

Em outras palavras, o modelo conceitual abstrato, construído sob a perspectiva de um sistema piramidal (do conceito superior no ápice que codeterminaria e coautorizaria a existência e validade de conceitos inferiores), dedutível por operações da lógica formal, e a própria subsunção lógica da matéria de fato nos conceitos jurídicos, apresenta como base histórica a jurisprudência dos conceitos, que posteriormente influenciaria o formalismo jurídico e o próprio positivismo jurídico, no século $\mathrm{XX}^{91}$.

Por outro lado, além da jurisprudência dos conceitos, emanou-se no final do século XIX e início do século XX, a jurisprudência dos interesses, que teve entre seus grandes

\footnotetext{
${ }^{87}$ Segundo Larenz, observando a jurisprudência dos conceitos, “(...) o ideal do sistema lógico é atingido quando no vértice se coloca o conceito mais geral possível, em que se venham a subsumir, como espécies e subespécies, todos os outros conceitos, de sorte a que de cada ponto da base possamos subir até ele, através de uma série de termos médios e sempre pelo caminho da eliminação particular". LARENZ, Karl. Metodologia da Ciência do Direito. 5 Ed. Lisboa: Fundação Calouste Gulbenkian, 2009, p. 21 e ss.

${ }^{88}$ LARENZ, Karl. Op.cit., p. 21 e ss.

${ }^{89}$ LARENZ, Karl. Op.cit., p. 24 e ss.

${ }^{90}$ LARENZ, Karl. Op.cit., p. 27 e ss.

${ }^{91}$ Conforme bem salienta Caliendo: "Como legado, a pandecística irá formatar um pensamento conceitualista onde o direito passa a ser entendido como um sistema fechado e dedutivo de conceitos, ocorrendo um apassagem da diversidade de leis e casos para a unidade de um sistema conceitual ordenado e conhecido pela ciência dogmática do dirieto. A verdadeira fonte do direito passa dos dispositivos e textos legais para o estudo lógico dedutivo de conceitos jurídicos". CALIENDO, Paulo. Direito Tributário. Três modos de pensar a tributação. Elementos para uma teoria sistemática do direito tributário. Op.cit., p. 87.
} 
representantes Rudolf Von Jhering (em segunda fase de seu pensamento), Phlipp Heck, Heinrich Stoll e Rudolf Müeller-Erzbach ${ }^{92}$. Jhering, sobretudo, foi notabilizado pela difusão dessa tendência, sobretudo no ambiente jus-publicista.

Basicamente, a jurisprudência dos interesses, contrapondo-se à jurisprudência dos conceitos, apresenta como tendência o “(...) primado da indagação da vida e da valoração da vida" $" 93$.

A Jurisprudência dos Interesses consideraria o Direito como "tutela de interesses", ou seja, que os preceitos legislativos visam não apenas delimitar interesses, mas são produtos desses mesmos interesses. Para compreender adequadamente o Direito é preciso investigar os interesses que o legislador buscou tutelar através do Direito ${ }^{94}$.

Diferentemente da genealogia dos conceitos, a busca pela causa dos interesses (que Heck via como fatos, reconhecidos cientificamente, tal como na física, na biologia, e não como meras abstrações) que o legislador buscou tutelar, aparece com força na elevação da jurisprudência dos interesses (busca-se a causalidade dos conceitos jurídicos). Note-se que a interpretação do direito, na jurisprudência dos interesses, também se vinculava à busca da causa (enquanto fatos) do preceito legal, para se entender corretamente os preceitos, já que seriam efeitos diretos dessas mesmas causas ${ }^{95}$.

Mas também, gradualmente, representantes da jurisprudência dos interesses passam a admitir a valoração dos interesses adotada pelo próprio legislador. Assim, seria necessário compreender o juízo de valor do legislador sobre os interesses em causa para aplicar corretamente a lei.

Uma das grandes contribuições da jurisprudência dos interesses, nesse contexto, conforme lembra Larenz, seria no preenchimento das lacunas, ao abrir a possibilidade do juiz de “(...) desenvolver o direito não apenas na fidelidade à lei, mas de harmonia com as exigências da vida" $" 96$.

\footnotetext{
92 LARENZ, Karl. Op.cit., p. 63.

${ }^{93}$ LARENZ, Karl. Op.cit., p. 63.

${ }^{94}$ A visão de Heck, segundo Larenz, parte da consideração de que as leis são resultantes de interesses de ordem geral, seja de ordem material, nacional, religiosa, ética, e que nas comunidades jurídicas, contrapõemse uns aos outros, na luta pelo seu próprio reconhecimento. Em outras palavras, a interpretação, para Heck, deve remontar, “(...) por sobre as concepções do legislador, aos interesses que foram causas para a lei”. Dessa constatação, deriva a ideia de que certos interesses seriam causais para a norma jurídica, já que determinam no legislador “(...) representações, ideias do dever-ser, que se transformam em comandos (teoria dos interesses). LARENZ, Karl. Op.cit., p. 65 e ss.

${ }^{95}$ LARENZ, Karl. Op.cit., p. 65 e ss.

96 “À jurisprudência dos interesses estava destinado, na prática jurídica alemã, um sucesso invulgar. Com o decurso do tempo, revolucionou efetivamente a aplicação do direito, pois veio a substituir progressivamente o método de uma subsunção nos rígidos conceitos legislativos, fundamentada tão somente em termos lógicos-formais, pelo de um juízo de ponderação de uma situação de fato complexa, bem como de uma
} 
Ainda que não se possa afirmar a prevalência absoluta de uma das correntes hermenêuticas sucintamente analisadas acima, no progresso da ciência do direito, é preciso reconhecer que todas, em suas próprias peculiaridades, permitiram o fortalecimento de tendências formalistas e positivistas aplicadas à ciência do direito (inicialmente sob as premissas do direito privado), que posteriormente seriam expandidas para o estudo (e ensino) do direito público europeu.

Não há como negar, portanto, que a progressiva busca pelo "método jurídico" por excelência, pautas elementares do chamado positivismo e formalismo, tenha influenciado soberbamente o processo histórico disciplinar do Direito Público Europeu, e consequentemente, o próprio processo disciplinar do Direito Tributário Europeu (e, posteriormente, ao próprio processo disciplinar do Direito Tributário Brasileiro).

\subsection{O formalismo jurídico e positivismo jurídico no século XIX e a tendência ao} afastamento de influências externas ao "método jurídico".

Historicamente, a busca pelo método jurídico por excelência, aliado ao reconhecimento da própria ciência do direito enquanto efetiva "ciência", anseio característico do século XIX, e essencial ao processo disciplinar do Direito Tributário, foi impulsionado por determinados ramos oitocentistas da filosofia do direito (como a jurisprudência dos conceitos e a jurisprudência dos interesses, construídos por sua vez nas investigações próprias do direito privado) e, que foram, paulatinamente, aplicados ao Direito Público, nem sempre com as devidas ponderações.

As duas grandes influências desse raciocínio excludente podem ser identificadas no positivismo jurídico e no formalismo jurídico, tendências metodológicas construídas em meados do século XIX, e que forneceram grande influência no desenvolvimento do direito público, sobretudo no início do século XX.

Construídos sob o predomínio de estruturas gnoseológicas neokantianas, possuem em comum a característica elementar da “(...) recusa, na Ciência do Direito, de considerações não estritamente jurídico-positivas" $" 97$.

avaliação dos interesses em jogo, de harmonia com os critérios de valoração próprios da ordem jurídica. Deste modo, deu aos juízes uma consciência são, tornando frequentemente supérfluas as pseudo-motivações. LARENZ, p. 76-77.

${ }_{97}$ CORDEIRO, Antonio Menezes. Introdução à Edição Portuguesa. In: CANARIS, Claus Wilhelm. Pensamento Sistemático e Conceito de Sistema na Ciência do Direito. Op.cit., p. xi e ss. 
O formalismo jurídico oitocentista apresentava as seguintes características: a) separação entre ser e dever-ser; base de cortes sucessivos e convictos com as realidades transportadas pelos "seres normativos"; b) a contraposição entre Direito e Moral; c) isolamento das proposições jurídicas na sua própria estrutura; d) desinteresse pelo plano teleológico das normas.

A forte adesão posterior, na difusão de construções jurídicas firmadas por definições abstratas e de conexões amparadas, apenas nos conceitos definidores de que provém, seriam, na visão de Menezes Cordeiro, a prova da profunda influência do formalismo jurídico no pensamento jurídico contemporâneo ${ }^{98}{ }_{-9}^{99}$.

Por outro lado, o positivismo jurídico, ou melhor, os "positivismos jurídicos", trariam em comum a característica fundamental da recusa de qualquer "referência metafísica”, afastando-se referências filosóficas, religiosas e políticas, privando a Ciência do Direito, segundo Menezes Cordeiro, de "vários de seus planos", o que significou, em uma veia mais radical, à exegese literal dos textos (como ocorreu na realidade francesa, após a codificação).

É claro que tais tendências metodológicas aplicadas ao direito não passaram sem grandes críticas.

Nesse contexto, extraem-se duas insuficiências fundamentais ao formalismo jurídico. A primeira deficiência resultaria na inviabilidade da aplicação de método apriorístico a um objeto de conhecimento que possui inerente natureza histórico-cultural (complexa e mutável com o tempo) ${ }^{100}$. Por outro lado, a segunda insuficiência do formalismo jurídico residiria na incapacidade do formalismo perante a riqueza dos casos concretos $^{101}$.

${ }^{98}$ CORDEIRO, Antonio Menezes. Introdução à Edição Portuguesa. In: CANARIS, Claus Wilhelm. Pensamento Sistemático e Conceito de Sistema na Ciência do Direito. Op.cit., p. xiii

${ }_{99}$ Em idêntico sentido, ANDRADE, José Maria Arruda de. Interpretação da Norma Tributária. São Paulo: MP Editora, 2006, Op.cit., p. 97 e ss.

${ }^{100100}$ Assim, o Direito pertence a categoria de realidades construídas pela evolução da sociedade, e portanto, sua configuração apriorística restaria impossibilitada, já que o direito é produto de uma “(...) inabarcável complexidade causal que impossibilita, por completo, explicações integralmente lógicas e racionais". A riqueza da realidade jurídica, produto da própria complexidade da sociedade a qual busca regular, impediria a aplicação de um método apriorístico (único e imutável) a este objeto de conhecimento. Para Cordeiro, o direito deve ser conhecido de modo direto, “(...) tal como se apresenta". CORDEIRO, Antonio Menezes. Introdução à Edição Portuguesa. In: CANARIS, Claus Wilhelm. Pensamento Sistemático e Conceito de Sistema na Ciência do Direito. Op.cit., p. xiii

${ }^{101} \mathrm{Em}$ outras palavras: "Na verdade, todas as construções formais assentam num discurso de grande abstração e, como tal, marcado pela extrema redução das suas proposições. Quando invocadas para resolver casos concretos, tais proposições mostram-se insuficientes: elas não comportam os elementos que lhes facultem acompanhar a diversidade das ocorrências e, daí, de soluções diferenciadas". CORDEIRO, Antonio Menezes. 
Porém, ao lado do formalismo jurídico, o positivismo jurídico também legou importantes características à ciência do direito contemporânea.

Em primeiro lugar, o positivismo refere-se à “(...) recusa, pela ciência do direito, de considerações que não sejam estritamente jurídicas, sobretudo pelo afastamento de abordagens metafísicas. Considera-se o direito antes um fato do que um valor" ${ }^{\prime 102}$.

Porém, as tendências positivistas acabaram sofrendo também reservas na ciência do direito, sobretudo através de quatro "insuficiências fundamentais": a) o positivismo jurídico não admite a presença de lacunas (e, quando as admite, não apresenta qualquer solução material para resolvê-las); b) ausência de meios para lidar com conceitos indeterminados; normas em branco e, em geral, proposições carentes de preenchimento, com valorações; c) incapacidade em resolver situações caracterizadas pelas contradições entre princípios; d) dificuldade para lidar com as chamadas "normas injustas" (faltando ao positivismo a capacidade de, diante de injustiças ou inconveniências grave ao direito vigente, apontar soluções alternativas) ${ }^{103}$.

Portanto, nem o formalismo jurídico nem o positivismo jurídico escaparam de críticas consideráveis no âmbito da Ciência do Direito.

De qualquer forma, independentemente de eventuais insuficiências metodológicas e epistemológicas identificáveis pela literatura especializada no decorrer do século XIX ${ }^{104}$, é fato de que a literatura tributária brasileira, posteriormente, assumiria muitas características caras ao positivismo formalista conceitual, herdando características historicamente construídas no século anterior.

\subsection{A estratégia (política e científica) do formalismo e do positivismo jurídico no Direito Público Europeu.}

\subsubsection{Os esforços científicos (e políticos) de Gerber e Laband.}

Introdução à Edição Portuguesa. In: CANARIS, Claus Wilhelm. Pensamento Sistemático e Conceito de Sistema na Ciência do Direito. Op.cit., p. xi e ss.

${ }^{102}$ Idem.

103 CORDEIRO, Antonio Menezes. Introdução à Edição Portuguesa. In: CANARIS, Claus Wilhelm. Pensamento Sistemático e Conceito de Sistema na Ciência do Direito. Op.cit., p. xi e ss.

104 Segundo José Maria Arruda de Andrade, consultando Menezes Cordeiro, o formalismo teria duas insuficiências metodológicas “(...) i) a natureza histórico-cultural do direito e a complexidade causal; e (ii) a incapacidade de analisar soluções diferenciadas para casos concretos semelhantes". Já quanto às insuficiências do positivismo jurídico, apontam-se quatro insuficiências fundamentais: "dificuldade em aceitar ou explicar lacunas; ii) soluções materiais à margem do discurso científico; iii) conceitos indefinidos e conflitos entre princípios; iv) injustiça em normas regularmente produzidas”. ANDRADE, José Maria Arruda de. Interpretação da Norma Tributária. São Paulo: MP Editora, 2006, p. 93 e ss. 
As características gerais construídas pelos ramos da Filosofia do Direito acima vislumbrados causaram forte impacto no processo disciplinar do Direito Público Europeu.

Contudo, o paulatino reconhecimento científico do Direito Público Europeu, sobretudo ocorrido nas últimas décadas do século XIX, levava também à inevitabilidade do recurso às construções teóricas elaboradas em outros ramos do conhecimento e, nesse caso, especificamente, do direito privado, e das correntes hermenêuticas e propostas metodológicas elaboradas para compreendê-la.

Isso significa que, o formalismo jurídico e o positivismo jurídico aplicado ao Direito Privado, e resultante das tendências hermenêuticas como a jurisprudência dos conceitos e a jurisprudência dos interesses, gradativamente favoreceu a consolidação de determinadas opções metodológicas compreensíveis, no limiar do século XIX e o início do século XX, para o processo disciplinar do Direito Público Europeu.

Não é por acaso que entre os principais representantes do Direito Público do século XIX, a adoção desse "arsenal metodológico", construído na seara do direito privado, foi autêntico caminho para a progressiva elevação científica do Direito Público.

Mas também guardou inequívocas motivações políticas, identificáveis sobretudo nas construções de Carl Friedrich Von Gerber e Paul Laband, especialmente na órbita do Direito do Estado, na realidade germânica.

Para esses autores, segundo José Maria Arruda de Andrade, “(...) a utilização do arsenal metodológico, desenvolvido pelo direito privado, de cunho formalista na formulação do direito público (...)" acabou também sendo identificado como um autêntico projeto político e metodológico aplicado à ciência do Direito Público Europeu ${ }^{105}$.

Existia uma compreensiva tendência de Von Gerber, conforme acertadamente expõe Andrade, na órbita do Direito do Estado, de defender a aplicação das construções jurídicas do direito privado como ponto de partida para uma elaboração segura do direito público, pois aquele seria campo do direito de maior amadurecimento (e sistematização científica, sobretudo sob a perspectiva formalista e positivista).

Mas acrescente-se que a importância concedida por Von Gerber ao direito privado poderia ser compreendida também pela familiaridade que o autor possuía sobre aquele ramo do direito (já que na época havia publicado importantes estudos sistemáticos na órbita do direito privado) ${ }^{106}$, perante o ainda recente direito público (nesse caso o Direito

\footnotetext{
${ }^{105}$ GERBER, Carl Friedrich Von. Grundzüge des Deutschen Staatsrechts. Leipzig: Verlag Von Bernhard. Tauchnitz, 1880, p. 03-19.

${ }^{106}$ GERBER, Carl Friedrich Von. System des Deutschen Privatenrechts. G. Fischer, 1895, p. 01 e ss.
} 
do Estado). Por isso fazia sentido para Von Gerber defender o direito privado como ponto de partida seguro para a construção disciplinar do direito público (sobretudo buscando uma compreensão dogmática do direito privado).

A tendência ao formalismo e ao positivismo pode ser acentuada, segundo José Maria Arruda de Andrade, pelo fato de que Gerber não buscou empreender investigações históricas aos institutos do direito público, tendência repetida nos estudos de Paul Laband, priorizando sistematicamente o substrato (formal e jurídico) do Direito Público, mas que ignora “(...) o nexo entre as formulações dogmáticas e a realidade social”"107.

Laband, ao tratar das forças armadas imperiais, em seu clássico estudo sobre o Direito Público Alemão, mostra claramente a tendência a elevar a forma jurídica do direito público, mas sem se prender a elementos históricos anteriores à Constituição de 1871. Buscava assim, o exame dogmático do direito público vigente, em suas diferentes peculiaridades. ${ }^{108}{ }_{-} 109$

Note-se que Laband foi fortemente influenciado pelo método jurídico de Gerber, e foi considerado “(...) o chefe da dogmática do direito público do Segundo Reich"110.

Para Arruda de Andrade, a intenção de Gerber e Laband era política, pois “(...) a eliminação de elementos valorativos e não-dogmáticos da análise do direito público alemão estava comprometida com a intenção politicamente conservadora, tendente a manter estático o direito público/constitucional e perpetuar a ideia de um Estado de castas"111_112.

Não por acaso, a obra de Otto Mayer, influenciado também pela estratégia metodológica de Laband, buscou uma análise formalmente jurídica aplicada ao direito

${ }^{107}$ ANDRADE, José Maria Arruda de. Op.cit., p. 100 e ss.

${ }^{108}$ LABAND, Paul. Le Droit Publique de l' Empire Allemand. Tome V. La force armée de l'Empire Allemand.. Traduction de Savinien Souissy. Paris: V. Giard \& Briere, 1903, p. 03.

${ }^{109}$ LABAND, Paul. Staatsrecht des Deutschen Reiches. Freiburg: Mör, 1895, p. 01 e ss.

${ }^{110}$ ANDRADE, José Maria Arruda de. Op.cit., p. 100 e ss.

111 "Dessa forma, se de um lado tem-se o rigor científico proporcionado pelo formalismo e pelo positivismo, de outro, todos os problemas práticos e concretos (banidos como metafísicos e não jurídicos) foram ofuscados, o que, se levado a sério, geraria uma teoria do Estado sem Estado, nos dizeres de Heller" (Bercovici). Idem, p. 100-101.

${ }^{112}$ Para Andrade, deslocando-se do direito constitucional e da teoria do Estado para o direito financeiro, a (...) a adoção do método jurídico formalista teve uma importância política e metodológica muito grande. Do ponto de vista político, a disputa entre o Parlamento e a Coroa prussianos (1861-1866), em torno da desaprovação do orçamento da Coroa por parte das Câmaras legislativas, motivou, já do ponto de vista dogmático, o desenvolvimento da concepção dualista da lei (lei em sentido formal e material). No período que vai do século XIX ao início do século XX, a ênfase no estudo do fenômeno tributário, no bojo do direito administrativo, recaía sobre a relação de poder existente entre o Estado e o indivíduo. Nesse contexto, o Estado seria titular de um poder derivado da soberania de impor a tributação sobre uma parcela do patrimônio, bastando, par isso apenas de um alei formalmente posta autorizadora". Ibidem. 
administrativo alemão, ainda que sob as peculiaridades daquele específico contexto histórico e territorial. $^{113}$

\subsubsection{A contribuição de Otto Mayer perante o Poder Tributário no Direito Administrativo}

Otto Mayer, seguindo os pressupostos jurídicos assumidos pela literatura do direito público alemão (sobretudo Laband), também legou ao direito público importante contribuição, dedicando em seu grande clássico (direito administrativo alemão), reflexões sobre o Poder de Polícia e o Poder Tributário (Poder Financeiro). ${ }^{114}$

Evidentemente, Mayer mostrava uma mentalidade jurídica que estava ainda apresentando seus primeiros passos, sobretudo na transposição do Estado de Polícia para o Estado de Direito, ao buscar demonstrar a submissão do poder público ao Direito.

Mas célebre foi sua contribuição ao Poder Tributário, para quem é a "força pública dirigida para as rendas do Estado", que não deveria ser confundida com as atividades econômicas privadas que o Estado usa para alcançar vantagens pecuniárias (tuteladas pelo direito civil) ou todas as outras relações de direito público que tenham semelhante resultado, como as multas, expropriações, pagamentos por concessões outorgadas, e direitos de restituição dos fundos públicos confiados aos distintos arrecadadores.

O Poder Tributário encontra sua razão de existência em uma "noção superior", que reúne toda uma série de instituições jurídicas, incluindo-o junto em situação análoga ao poder de polícia. Não é por outro motivo que Mayer reconhecia a grande afinidade entre o poder de polícia e o poder tributário. ${ }^{115}$

No entanto, Mayer, no mesmo passo, apresentou algumas diferenças substanciais entre os dois "poderes", já que o Poder de Polícia derivaria do direito natural de não

\footnotetext{
${ }^{113}$ Ibidem, p. 101-102.

${ }^{114}$ MAYER, Otto. Derecho Administrativo Alemán. Tomo II. Parte Especial. Poder de Policía y Poder Tributário. Buenos Aires: Depalma, 1950, p. 185 e ss.

115 "Em um e outro caso, os dois poderes apresentam, desde o princípio, uma diferença importante. Traz o poder de polícia temos encontrado um princípio de direito natural que ajuda a interpretar e completar o poder de polícia: o dever geral de não perturbar a ordem pública. O exercício do poder tributário não tem como base o direito natural: o dever geral do sujeito de pagar impostos é uma fórmula carente de sentido e de valor jurídico. De outra forma, dentro da organização do Estado Constitucional, colocou-se por cima de todo movimento relativo à fazenda e, especialmente, por cima de toda manifestação mais importante do poder tributário - a percepção dos impostos - outro regulador supremo. É o orçamento do Estado; o qual, por sua vez, está determinado pelo direito do pressuposto que pertence à representação nacional; se manifesta na lei do pressuposto". MAYER, Otto. Derecho Administrativo Alemán. Tomo II. Parte Especial. Poder de Policia y Poder Tributário. Depalma: Buenos Aires, 1950, p. 195 e ss.
} 
perturbar a ordem pública, ao passo que o Poder Tributário careceria de conteúdo e sentido jurídico a priori, somente sendo compreensível dentro do Estado Constitucional onde o imposto seria a principal manifestação do Poder Tributário, pressupondo um orçamento (este, por sua vez, regulado pelo direito orçamentário, também amplamente tratado na obra de Mayer, que já mostrava afinidade ao direito financeiro) previsto em lei, e aprovado pela representação nacional.

Para Mayer, portanto, a principal manifestação do Poder Tributário é a instituição dos impostos, estas criadas por lei e previstas em orçamento. A partir daí, Otto Mayer oferece uma conceituação de extrema importância para o desenvolvimento do Direito Tributário Contemporâneo: "o imposto é um pagamento em dinheiro que o poder tributário impõe ao sujeito em virtude de uma regra permanente".

É necessário que o imposto, que é uma obrigação (de direito público, salienta), seja criado por uma manifestação de poder público, ou, em melhores termos, trazendo consigo a característica de ser "uma obrigação de direito público". ${ }^{116}$

Para Mayer, o imposto, sem o adequado tratamento de uma regra permanente, afastada por lei especial ou autorização do poder público, perderia sua característica de imposto. Aqui, são esboçados por Mayer, dois princípios fundamentais para as relações tributárias, a legalidade tributária (criação do imposto por regra) e a segurança jurídica (pois a regra permanente afasta a possibilidade de criação de imposto por outros atos).

Mayer também trabalhou com os conceitos de taxas e contribuições, adotando uma classificação tripartida de tributos. ${ }^{117}$

\footnotetext{
116 No entanto, Mayer destaca a necessidade de uma "regra permanente" para que se possa considerar a obrigação como de direito público e, portanto, um imposto: "Mas também pertence à essência do imposto que a imposição se faça segundo uma regra permanente, ou seja, que se determine por fatos fixados de antemão e que apresentem certa regularidade". O poder público poderia prescindir das regras deste gênero em algum caso particular, mediante lei especial ou em virtude de autorizações concedidas ao governo. Em realidade, não o fará, se assim suceder, o imposto de pagamentos isolados desta natureza não seria um imposto". Mayer também é enfático em afastar a possibilidade de o poder público prescindir de regras desta natureza em algum caso específico, através de lei especial ou de autorizações mediante o governo. MAYER, Otto. Derecho Administrativo Alemán. Tomo II. Parte Especial. Poder de Policia y Poder Tributário. Depalma: Buenos Aires, 1950, p. 197-199.

${ }^{117}$ Mayer também elaborou seu conceito de Taxa: "a taxa (Gebühr) é o equivalente das vantagens que o indivíduo obtém pessoalmente da utilidade que os serviços públicos oferecem ao público; a causa e a medida da obrigação de pagar reside no ato mediante o qual o indivíduo faz uso destes serviços". Por fim, completando sua classificação, traz a noção de contribuições sociais: "Já as contribuições sociais (Beiträge) são pagamentos em dinheiro que o indivíduo deve efetuar com destino a empresas ou estabelecimentos públicos, porque se supõe que tem particular interesse na existência deles e em seu funcionamento em geral; são as vantagens que se obtém não de atos ou usos isolados, mas de uma situação criada, vantagens a cuja consecução o indivíduo contribui pela sua parte".MAYER, Otto. Derecho Administrativo Alemán. Tomo II. Parte Especial. Poder de Policia y Poder Tributário. Depalma: Buenos Aires, 1950, p. 197-199.
} 
Essa tríplice classificação de tributos foi de essencial importância e influência para o direito tributário contemporâneo. Otto Mayer, baseado na classificação tripartida de grande popularidade no século XIX, entre os Financistas da época, inclusive em Adolph Wagner, delineou traços jurídicos a esta, estabelecendo as três espécies especializadas no direito tributário contemporâneo ${ }^{118}$.

Não obstante, apesar da grande contribuição de Mayer para a tributação, esta ainda era feita no âmbito do direito administrativo, sem qualquer tratamento específico e sistematizado referente ao aspecto jurídico do fenômeno financeiro, o que limitava por demais a evolução do pensamento jurídico tributário, por óbvio. Essa situação permaneceu estática no final do século XIX e nos primeiros anos do século XX, com poucas obras de relevo que pudessem contribuir para a mudança dessa situação.

\subsubsection{Franz Von Myrbach-Rheinfeld e a sistematização jurídica do Direito Financeiro}

Com a introdução, em 1893, da disciplina "Direito Financeiro", como disciplina autônoma - e paralela à Ciência das Finanças, na Áustria (onde emergia a histórica tradição cameralista no estudo do fenômeno financeiro), não surpreende que, no início do século XX, com o avanço dos estudos de financistas para o aspecto jurídico do fenômeno financeiro, a criação de cátedra de "Direito Financeiro" na Áustria, e a progressiva tendência ao formalismo jurídico aplicado ao estudo do direito público, parecesse inevitável que naquele país surgisse a primeira obra de teor claramente sistemático dedicada exclusivamente à matéria.

Logicamente, conforme já observado, o direito financeiro já era trabalhado por importantes autores europeus, a exemplo de Mayer e Laband (sobretudo na órbita do direito orçamentário), mas foi realmente em 1906 que surge efetivamente a primeira publicação de uma obra sistemática dedicada à matéria, de autoria de Franz Von MyrbachRheinfeld $^{119}$.

\footnotetext{
${ }^{118}$ WAGNER, Adolph. Traité des Science des Finances. Théorie de l'Impositión, Théorie des Taxes et Théorie Générale des Impôts. Traduction par Jules Ronjat. Deuxième Editión. Paris: V. Giard \& E. Brière, 1909.

${ }^{119}$ MYRBACH-RHEINFELD. Franz Von. Précis de Droit Financier: Paris: V. Giard \& Brière". "Grundriss der Finanzrecht”, publicado em 1906, e trazido para o francês em 1910. MYRBACH-RHEINFELD, Franz Von. Précis de Droit Financier. Traductión Française par É. Bouché-Leclercq. Paris: V. Giard \& Briere, 1910.
} 
Gastón Jèze, no prefácio da tradução francesa da obra de Myrbach-Rheinfeld, assinalou expressamente tratar-se de livro de "pura técnica jurídico-financeira, que inaugurava um novo gênero de pesquisas". De fato, tinha razão Jèze ao atribuir tal qualificação jurídica à obra do autor.

É extremamente arriscado apontar determinado período histórico como ponto de partida para o processo disciplinar do direito tributário, já que esse surge, conforme se demonstrará (na realidade brasileira) motivado por uma série de fatores.

Porém, no âmbito europeu, talvez não fosse tão exagerado atribuir a MyrbachRheinfeld, em conjunto com Otto Mayer, a paternidade histórica do Direito Tributário, enquanto disciplina (teórica) jurídica, ainda que esses o estudassem sob a órbita do direito administrativo (Mayer) ou do direito financeiro (Myrbach-Rheinfeld), como parece também apontar Heinrich Wilhelm Kruse ${ }^{120}$.

Myrbach-Rheinfeld expressamente buscava extirpar a influência da Ciência das Finanças perante o Direito Financeiro, elabora o "Précis de Droit Financier", que possuía cerca de seiscentas páginas, mas apresentava, por outro lado, pelo menos 450 páginas dedicadas à discussão jurídica do "direito do imposto". Veja-se, o direito financeiro (incluindo o direito orçamentário), que não se incluía no direito do imposto, era tratado somente nas 100 páginas iniciais, concedendo as páginas restantes ao tratamento exclusivo da matéria tributária.

A obra de Myrbach-Rheinfeld, na realidade, acompanhou tendência geral atribuída ao Direito Público (por influência do formalismo e do positivismo jurídico praticado no direito privado e recepcionado no Direito Público), embora, para muitos autores, tenha sido o primeiro a publicar obra de conteúdo assumidamente jurídico (buscando a autonomia teórica do direito financeiro perante a ciência das finanças), como destacou Gastón Jèze no "Aviso ao Leitor Francês". ${ }^{121}{ }_{-}{ }^{122}$

\footnotetext{
${ }^{120}$ KRUSE, Heinrich Wilhelm. Steuerrecht. I. Allgemeiner Teil. 3. Auflage. München: Verlag CH Beck, 1973, p. 01-05.

${ }^{121}$ JÉZE, Gastón. Avertissement au lecteur Français. In: MYRBACH-RHEINFELD, Franz Von. Précis de Droit Financier. Traductión Française par É. Bouché-Leclercq. Paris: V. Giard \& Briere, 1910.

${ }_{122}$ MYRBACH-RHEINFELD, Franz Von. Précis de Droit Financier. Traductión Française par É. BouchéLeclercq. Paris: V. Giard \& Briere, 1910.
} 
Para o autor, parecia-lhe claro que somente uma obra de conteúdo e estrutura diferenciada e absolutamente nova (sistemática), poderia fazer frente às obras publicadas na área ${ }^{123}$.

E curiosamente, deixou transparecer profunda crítica aos juristas da época, sobretudo no que diz respeito à histórica timidez demonstrada pelos juristas da época no trato jurídico do fenômeno financeiro. A essa peculiaridade, Myrbach-Rheinfeld oferece uma hipótese: "Parece que não queremos confronto frente ao economista que tem se aventurado no campo da pura lei”. ${ }^{124}$

Uma preocupação elementar no estudo de Myrbach-Rheinfeld é justamente a de sistematizar adequadamente o direito financeiro (do ponto de vista jurídico), e dos institutos jurídicos que comporiam a disciplina (sobretudo dos impostos), chegando também a tecer considerações sobre sub-ramos do direito financeiro como (o direito constitucional financeiro e o direito penal financeiro) ${ }^{125}$.

Existe, portanto, clara tendência metodológica à aplicação do formalismo jurídico ao Direito Financeiro em Myrbach-Rheinfeld e, ainda que não tenha logrado êxito integral em seu objetivo essencial, buscou claramente a autonomia do direito financeiro perante a ciência das finanças, o direito administrativo e o próprio direito privado.

Ainda, a tendência ideológica não escapa às investigações de Myrbach-Rheinfeld, que demonstra preferência claramente liberal (no sentido de odiosidade do imposto, mas, sobretudo pelo sentido deduzido por ele na característica elementar da Política Financeira). ${ }^{126}$

Partindo de simplificada divisão da Economia Pública (entre nós, chamada de Ciência das Finanças, Finanças Públicas, ou simplesmente, Finanças), revelou que as concepções político-econômicas prevalecentes na época (sobretudo as liberais individualistas) inspiravam também a doutrina jurídico-financeira, ofereceu análise preliminar do Direito Financeiro, “(...) que era considerada, em geral, uma parte do direito administrativo". 127

\footnotetext{
${ }^{123}$ MYRBACH-RHEINFELD, Franz Von. Op.cit.,p. XII-X.

${ }^{124}$. Idem, p. 10 e ss.

${ }^{125}$ MYRBACH-RHEINFELD, Franz Von. Ibidem,, p. XII a X.

126 Ibidem, p. 14.

${ }^{127}$ MYRBACH-RHEINFELD, Franz Von. Op.cit., p. 01.
} 
Mas Myrbach-Rheinfeld tencionava desenvolver muito mais essa noção rudimentar de que o Direito Financeiro era apenas parte do direito administrativo. E para valorizar sua estruturação sistemática, estabeleceu um ponto de partida, que vai permitir o desenlace dos capítulos e tópicos da sua obra. ${ }^{128}$

Myrbach-Rheinfeld também tratou das fontes do direito financeiro (leis, regulamentos e jurisprudência) ${ }^{129}$, além de estabelecer definições jurídicas sobre as espécies tributárias, no âmbito do "direito do imposto", a exemplo do imposto público, além de lançar mãos de noções elementares ${ }^{130}$, como é o caso do lançamento (atribuindo-a caráter declaratório, por sinal), e da necessidade de lei para o estabelecimento de uma obrigação de direito financeiro ${ }^{131}$. Nesse contexto, também discorre sobre a diferenciação fundamental entre direito financeiro e direito privado, do qual decorrem as características próprias da obrigação de direito financeiro (que é obrigação de direito público). ${ }^{132}$

Não obstante, a obra de Myrbach-Rheinfeld está preocupada em apresentar um caminho para a sistematização jurídica da matéria financeira, em separado de outros ramos do conhecimento, influenciado substancialmente pelo formalismo e positivismo do direito público na sua época, o que não o privou, contudo, de eventuais mergulhos às contribuições da "Ciência das Finanças", sobre o Direito Financeiro.

Assim, a tendência ao formalismo e ao positivismo no processo disciplinar do Direito Público Europeu, que tem origens históricas nos autores supramencionados,

\footnotetext{
${ }^{128}$ Prestes a "circunscrever o conceito de direito financeiro", esclarece que o direito financeiro é o ramo do direito positivo público cujo objetivo é a regulação das finanças públicas, bem como de outros organismos próprios da administração estatal ínsita. E compreende o direito financeiro positivo: a) normas de direito público, que se afastam do direito civil comum; b) regras relativas às instituições financeiras. Por outro lado, incluem-se nesse bojo as leis financeiras pertencentes ao direito constitucional (direito constitucional financeiro), e as leis pertencentes às regras do direito administrativo. MYRBACH-RHEINFELD, Franz Von. Op.cit. p. 16-17.

${ }^{129}$ Idem, p. 20.

${ }^{130}$ Nesse contexto, estabelece o conceito de impostos públicos, núcleo central para o chamado "direito do imposto", que apresenta enorme importância para Myrbach-Rheinfeld, como veremos a seguir. Para o autor, os “(...) impostos públicos são, do ponto de vista jurídico, as prestações pecuniárias para pessoas públicas, que a lei impõe em face de certas hipóteses determinadas, sem a necessidade de um outro título para dar origem a uma obrigação".Ibidem, 1910. p. 115.

131 Ibidem, p.137.

132 Outro ponto trabalhado pelo autor também merece lembrança, que é a diferenciação entre o Direito Financeiro e o Direito Privado: "Cada vez que o direito financeiro cria relações jurídicas (em especial, direito e obrigações), ou instituições jurídicas, que não podem ser associarem ao direito privado, ou seja, que não estão relacionadas ao direito privado, diz-se que é incompatível e com o direito privado". E por isso, "(...) não podemos de forma alguma aplicar a esses objetos os princípios das normas de direito privado". Para Myrbach-Rheinfeld, as normas provenientes do direito privado devem servir à concretização das idéias legais, com base em necessidades específicas e em alguns casos, e devem ser adaptadas exatamente às necessidades e relações de natureza financeira.MYRBACH-RHEINFELD, Franz Von. Op.cit., p. 18.
} 
posteriormente, em meados do século XX, favoreceram interessantes tendências históricas aplicadas ao estudo do Direito Tributário, primeiramente na Europa e, em menor intensidade, na realidade brasileira.

Feitas essas considerações iniciais, chega-se o momento de analisar a realidade brasileira e os efeitos (ainda que tardios) que a tradição estrangeira legou ao processo disciplinar do Direito Tributário no Brasil.

\section{A "Pré-história" da doutrina tributária brasileira: o período pré-disciplinar do Direito Tributário Brasileiro no século XIX.}

\subsection{As repercussões das produções teóricas europeias nos estudos “brasileiros" do século XIX.}

A produção teórica brasileira em meados do século XIX nada mais era do que mero resquício da produção europeia dedicada aos estudos econômicos financeiros. Aqui, não há ainda que se falar em autonomia teórica do Direito Tributário. Mas já houve quem defendeu a antecedência do Direito Financeiro no Brasil, já manifestado no primeiro quinquênio do século XIX, frente ao Direito Financeiro europeu surgido com Franz Myrbach-Rheinfeld, no início do século XX (1906).

Em verdade, a produção do que se chamou "Direito Financeiro" no século XIX no Brasil nada mais era do que um conjunto de estudos técnicos, estruturados por economistas, "guarda-livros", e técnicos da fazenda, de forma a facilitar a compreensão das leis relativas aos aspectos financeiros do Império.

Naturalmente que a temática tributária ou fiscal acabava sendo tocada. Mas ainda assim, a influência efetiva para esses estudos se resguardava no campo das Finanças Públicas e da Economia Política. Ainda que a Constituição Imperial de 1824, e algumas leis infraconstitucionais, tocassem a matéria tributária, não representava incentivo forte o suficiente para fazer brotar o interesse pelo fenômeno jurídico da tributação.

Mas essa dificuldade inicial é compreensível, na realidade, pois mesmo na Europa, o Direito Público (leia-se Direito Administrativo), enquanto disciplina jurídica, só se 
manifestou com maior força nas últimas décadas do século XIX. Assim, a verdadeira fonte de investigação na época concentrava-se nos estudos econômico-financeiros, e por isso a tendência oitocentista na produção brasileira recebia sólida formação financista.

No âmbito do Direito Constitucional e Administrativo no Brasil Imperial, por exemplo, pode-se mencionar a clássica contribuição de José Antonio Pimenta Bueno, na histórica obra sobre Direto Público e Direito Administrativo na Constituição Imperial, de 1857, que já apresentava lineamentos sobre o Direito Financeiro, ainda sob a específica perspectiva do "direito público", e sobre a clara influência do liberalismo, no qual se inseriam o Direito Constitucional e Administrativo. Entre os elementos de direito financeiro identificados nessa obra, pode-se destacar o próprio princípio da anualidade, reflexões referentes ao orçamento, e a necessidade de consentimento prévio (legalidade) para fixar as despesas públicas do Império. ${ }^{133}$ Também tratava das "contribuições diretas" e "contribuições indiretas" (artigo 171), assim como dos "empréstimos públicos"134, da iniciativa especial das Câmaras para a criação de impostos ${ }^{135}$, comentando-as perante as previsões da Constituição de 1824, sobretudo ao vinculá-las à necessidade de prévia previsão orçamentária (estabelecida exclusivamente pelo Poder Legislativo). A legalidade tributária já aparecia na obra desse juspublicista: "Em todo caso, os Brazileiros não são obrigados a pagar contribuições senão em virtude de lei, e nem por mais tempo que aquelle que esta marcar"136.

Também se preocupou expressamente de que a fixação anual de contribuições fosse menos onerosa quanto possível aos cidadãos (mínimo sacrifício). A visão liberal característica daquele período expressa-se na seguinte passagem: “o imposto é reconhecido como um mal; posto que necessário"137.

\footnotetext{
${ }^{133}$ BUENO, José Antonio Pimenta. Direito Publico Brazileiro e Analyse da Constituição do Imperio. Parte 1 e 2. Rio de Janeiro : Typographia Imp. e Const. de J. Villeneuve \& C., 1857, p.85 e ss.

${ }^{134}$ Idem, p. 99 e ss.

${ }^{135}$ Ibidem, p. 109 e ss.

${ }^{136}$ Ibidem, p. 88 e ss

137 "É de mister que esse mal se limite a sua própria natureza e que não seja aggravado por outros accessorios remediaveis, que não prejudique o trabalho, que não embarece a producção, que guarde justiça pesando com igualdade, não excedendo as faculdades dos contribuintes, não aniquilando os capitães". "É também a ocasião de examinar os regulamentos fiscaes do governo e de cohibir seus abusos para que os impostos sejão arrecadados sem vexame, nas épocas e formas devidas, segundo o modo de percepção legal, com economia e equidade; enfim nos precisos termos da lei, sem que sejam distentidos ou aggravados pelo pensamento sempre dominante do fisco". Note-se pensamento claramente liberal na contribuição de Pimenta Bueno, lançando já alguns princípios relacionados aos grandes monumentos de Economia Política, como os princípios da tributação de Adam Smith, já conhecidos da literatura brasileira na época. Ibidem, p. 89-90.
} 
Concede, também, grande importância aos direitos individuais e políticos (primeira geração), tratando, inclusive da igualdade de contribuições, no qual defendia que ricos e pobres devem contribuir para as despesas gerais do governo, proporcionalmente ${ }^{138}$.

Mas os estudos tributários no período foram efetivamente iniciados no âmbito da Ciência das Finanças. No contexto financista brasileiro, Pontes de Miranda ${ }^{139}$ considerou que o primeiro trabalho expressamente desse teor teria sido provavelmente a obra "Princípios de Sintetologia", do autor português José Ferreira Borges, publicado em 1831, em Portugal, mas que teve grande adesão dos estudiosos brasileiros da época. Recorde-se que, na época, a Sintetologia queria significar "Ciência das Finanças"140, e não Direito Financeiro, sendo uma obra claramente voltada às ciências econômicas da época.

Embora destinado diretamente à realidade financeira portuguesa, ganhou enorme atenção em terras brasileiras por apresentar remissões expressas à realidade brasileira, como o próprio título sugere: "Princípios de Sintelologia: compreendendo em geral a Teoria do Tributo e em particular observações sobre a Administração, e Despesas de Portugal, em grande parte applicaveis ao Brasil".

Conhecido pela adesão expressa ao liberalismo, o autor foi influenciado por grandes nomes da época como Adam Smith, J. B. Say e Henri Storch.

\footnotetext{
138 "Todas as classes da socidade, todas as espécies de bens, toda as fortunas, devem contribuir proporcionalmente para as necessidades e serviços sociaes, pois que são de interesse comum e aproveitarão a todos". O governo, mediante luzes econômicas, deve trabalhar para que não exija dos povos contribuições que excedão suas faculdades, nem que sejam na desproporção dos haveres de cada um; nessa proporção está a justiça e a igualdade, e em uma bem entendida economia a sabedoria e previsão". BUENO, José Antonio Pimenta. Op.cit., p. 424.

${ }^{139}$ Segundo Pontes de Miranda, "Os estadistas do Império liam muito o Compêndio de Direito Financeiro do Conselheiro José Antônio da Silva Maia, publicado em 1841, a introdução da Science dês Finances de Ganth e os Princípios de Sintetologia de Ferreira Borges. Em 1855, publicou José Maurício Fernandes Pereira de Barros os seus Apontamentos de Direito Financeiro Brasileiro. Fora certas incursões em revistas francesas (e.g., Journal dês Économies) e, raramente, inglesas, esse foi o lastro do direito financeiro do Brasil-Império e da República”. MIRANDA, Francisco Cavalcanti Pontes de. Comentários à Constituição de 1946. Vol. I (arts 1-36). Rio de Janeiro: Livraria Boffoni, 1946, p.297.

${ }^{140}$ Sintetologia, para o autor, seria: "ciência que ensina os meios de prover às necessidades do Estado social, até hoje chamada - Ciência da Fazenda, ou Finanças. Esta ciência é nova: nasceu da Economia Política; e se é pouco generalizada, é ainda menos compreendida. Ela abrange as combinações mais vastas, e pode prestar à sociedade os mais relevantes serviços; dependendo dela a averiguação exacta das necessidades, e dos recursos de uma nação, e a sua combinação em forma, que se não ofenda as prosperidades dos povos, e se alcance a necessária força dos governos". BORGES, José Ferreira. Princípios de Syntelologia: coprehendendo em geral a Theoria do Tributo, e em particular Observaçoens sobre a Administração, e Despezas de Portugal, em grande parte applicaveis ao Brazil. Londres: Impresso por Bingham, 1831, p.03.
} 
É interessante notar que, adepto do liberalismo, Ferreira Borges buscou normatizar as receitas e as despesas, sempre enfatizando que os tributos (receita) penalizariam a riqueza (fruto do trabalho) ${ }^{141}$, angariando uma função restritiva, na medida do possível, da utilização do tributo como meio de obtenção de receitas públicas. Essa perspectiva liberal restrita da tributação proveniente de Ferreira Borges influenciaria fortemente a realidade brasileira da época.

Mas, nesse ponto, Aliomar Baleeiro, por sua vez, apontando o mesmo autor (Ferreira Borges) como o precursor da matéria em solo brasileiro, concluiu que as primeiras obras escritas no Brasil sobre o assunto, em contraste com a orientação econômica europeia, assumiram caráter "jurídico", contrariando a tendência europeia voltada às elaborações de obras versadas em Ciência das Finanças (e Legislação Financeira).

Nesse aspecto reside uma importante distinção entre a produção jurídica europeia do Direito Público e a produção brasileira, mostrando que, embora a influência europeia se perpetuasse nas obras da época, a cultura jurídico-financeira brasileira iniciou-se de forma ligeiramente distinta.

Mas note-se que essas obras mostravam uma estrutura muito mais assemelhada às obras de técnica fiscal com sólida base econômico-financeira, e com extensa parcela de suas obras dedicadas à consolidação legislativa, isto é, das leis fiscais da época, com comentários sobre os dispositivos mais relevantes.

Em muito pouco se assemelhavam à tradição jurídico-financeira europeia consolidada por Franz Myrbach-Rheinfeld, em seu Compêndio publicado em 1906 na

\footnotetext{
${ }^{141}$ Segundo António Almodóvar, Ferreira Borges via o tributo como mal necessário, um desfalque na riqueza apenas justificado para ser única e exclusivamente limitado à sua configuração como "o preço da segurança". Por esse motivo a opinião restritiva do autor quanto à tributação insistia na busca por maiores cuidados para a forma como esse ataque à riqueza particular procederia. Por isso, Ferreira Borges insistia no estudo da sintetologia como uma forma de que o estudo sobre a ciência das finanças viabilizasse o conhecimento da sociedade sobre como ela gera, adquire, distribui e consome riquezas, para evitar que o tributo ocasione mais estragos do que os estritamente necessários. Trata-se, portanto, de uma visão claramente liberal e restritiva da atividade tributária, que se refletiu na produção doutrinária brasileira da época, pois a obra não apenas influenciou financistas brasileiros, mas aqueles estudiosos, técnicos ou políticos que trabalhavam pelo aspecto jurídico do tributo. ALMODOVAR, António. José Ferreira Borges. In: CARDOSO, José Luís (coordenador). Dicionário Histórico de Economistas Portugueses. Lisboa: Temas e Debates, 2001, p.60 e seguintes. Também: BORGES, José Ferreira. Princípios de Syntelologia: coprehendendo em geral a Theoria do Tributo, e em particular Observaçoens sobre a Administração, e Despezas de Portugal, em grande parte applicaveis ao Brazil. Op.cit., p. 03 e seguintes.
} 
Áustria, essa sim, uma obra com aspirações assumidamente jurídico-financeiras, cuja meta maior seria separar os estudos de direito financeiro dos estudos econômico-financeiros, prevalecentes à época. Buscava, portanto, sistematizar, juridicamente, o Direito Financeiro Austríaco.

Outras obras brasileiras conhecidas da época seguiram a mesma tendência acima mencionada, dentre as quais: "Compêndio de Direito Financeiro", de José Antônio da Silva Maia (1841); "Apontamentos do Direito Financeiro Brasileiro", de José Maurício Fernandes Pereira de Barros (1855) e "Considerações sobre a Situação Financeira do Brasil acompanhadas da Indicação dos Meios para Occorrer ao Deficit do Thesouro", publicado pelo mesmo autor, em $1867^{142}$; "Sistema Financial do Brasil”, por Candido Batista Oliveira $(1842)^{143}$; "Elementos das Finanças", de Amaro Cavalcanti (que escreveu diversos trabalhos financeiros).

Por sua vez, esses trabalhos impulsionaram posteriormente, no início do século XX, a publicação do "Manual de Sciencia das Finanças", de João Pedro da Veiga Filho, bem como o "Tratado dos Impostos", de A.O.Viveiros de Castro (1867-1927), e os "Ensaios de Sciencia das Finanças" de Dídimo da Veiga ${ }^{144}$.

Nesses estudos, naturalmente a temática tributária era abordada, como é o caso dos direitos de importação e direitos de exportação, o tratamento das alíquotas (taxas), dentre outros assuntos que tocavam o tema, mas nada que indicasse maior precisão jurídica relativa ao Direito Tributário.

Destaque-se a interessante contribuição de José Antonio da Silva Maia, que esboçou, segundo João Martins de Oliveira, a primeira e mais antiga definição de Direito Financeiro construída na literatura jurídica brasileira, no livro "Compendio de Direito Financeiro", editado na Tipografia nacional, em 1841. Para esse autor: "Entenderemos por Direito Financeiro aquele, que compreende as regras, por que se deve dirigir a Administração geral da Fazenda Nacional, no que é relativo à Receita e Despesa do

${ }^{142}$ BARROS, J.M.F. Pereira de. Considerações sobre a Situação Financeira do Brasil acompanhadas da Indicação dos Meios para Occorrer ao Deficit do Thesouro. Rio de Janeiro: Typographia Universal de Laemmert, 1867, p. 01-29.

143 Essa obra foi publicada em São Petersburgo. Baleeiro apontou que essa obra teria sido publicada originalmente em 1882, mas a presente pesquisa encontrou edição anterior, do ano de 1842. BALEEIRO, Aliomar. Uma Introdução à Ciência das Finanças. Op.cit, p.19-20. OLIVEIRA, Candido Baptista de. Sistema Financial do Brasil. São Petersburgo: Typographia Privilegiada de Fischer, 1842, p. 01-30.

${ }^{144}$ BALEEIRO, Aliomar. Uma Introdução à Ciência das Finanças. Op.cit., p.19-20. 
Império, â Arrecadação, Fiscalização, e Distribuição das Rendas Públicas; ao desempenho das atribuições de todos os encarregados da guarda, e aplicação dos dinheiros nacionais, à tomada de suas contas; e a maneira de se lhes fazer efetiva a responsabilidade".

Essa concepção, segundo conta João Martins de Oliveira, foi adotada por J.M.F. Pereira de Barros no seu clássico livro "Apontamentos de Direito Financeiro Brasileiro", editado em 1855. Não obstante, Oliveira acrescentou que, em meados da década de quarenta do século XX, “(...) os publicistas modernos, ainda usam dos mesmos conceitos dos antigos tratadistas brasileiros, quando se dedicam ao trabalho de definir o direito financeiro" 145

Veja-se que já havia uma noção delineada de Direito Financeiro Brasileiro. E o mais curioso é que, se comparada à consolidação do Direito Administrativo Europeu, que somente ganhou força nas últimas décadas do século XIX, o Brasil já dava ancestrais esforços para sua consolidação enquanto disciplina jurídica, por expressa influência portuguesa.

Contudo, é importante mencionar que a produção teórica europeia oitocentista já vislumbrava conceitualmente o Direito Financeiro, embora o preferisse estudar sob a óptica do Direito Administrativo, como subtópico deste, e a própria Ciência das Finanças da época, que já delineava importantes avanços à Legislação Financeira, o que provavelmente influenciou aqueles estudiosos oitocentistas no Brasil.

Em verdade, a tendência oitocentista brasileira era severamente focada na elaboração de leis fiscais infraconstitucionais (além de decretos e instruções) para facilitar a atuação da "Fazenda Imperial" e os próprios cursos e manuais relacionados ao tema, e que continham brevíssimas remissões ao "Direito Fiscal", eram geralmente direcionados à atuação dos "agentes fiscais" (ou técnicos fiscais) da época, que se dividiam em uma parcela de aspectos "doutrinários" e consolidação de leis financeiras (e fiscais).

A publicação de obras denominadas "Direito Financeiro" na realidade brasileira, cuja construção mantivera-se anterior até mesmo à lenta solidificação do Direito Administrativo no período (e à própria consolidação do Direito Financeiro Europeu), era

\footnotetext{
${ }^{145}$ OLIVEIRA, João Martins. Direito Fiscal (Estudos doutrinários e anotações ao decreto-lei n.960, de 17 de dezembro de 1938). Rio de Janeiro: Livraria Jacinto, 1943, Nota de rodapé n.13, p.14.
} 
mais uma consolidação de leis financeiras e fiscais, cumulada com alguns comentários técnicos, do que produção de cunho acadêmico, como demonstram as obras analisadas acima.

Na realidade, essa tendência às doutrinas econômico-financeiras se manterá perene até meados da década de trinta no século $\mathrm{XX}$, quando alguns fenômenos importantes impulsionam o maior interesse pelo trato jurídico da matéria.

Isso significa que, durante pelo menos 100 anos no Brasil, o fenômeno tributário foi estudado quase que exclusivamente sob a óptica da Ciência das Finanças. Não é por acaso a larga influência que a produção de origem econômica financeira deteve - e ainda detém nas obras de Direito Tributário prevalecentes no século XX.

\subsection{Os estudos tributários na Monarquia brasileira}

Em meados do século XIX, vislumbrava-se uma Monarquia brasileira essencialmente liberal, inspirada no liberalismo econômico europeu, e ávido pela consolidação do Brasil independente enquanto potência exportadora de matérias-primas, onde as tarifas aduaneiras recebiam toda a atenção, em detrimento de outras espécies tributárias.

Por outro lado, as leis infraconstitucionais, assim como a própria Constituição de 1824, traziam elementos tributários, mas de forma pouco organizada para viabilizar qualquer estudo jurídico de relevo sobre o assunto.

Tais suposições foram reforçadas a partir da leitura da obra oitocentista produzida ainda no regime monárquico, intitulada "Novo Manual do Procurador dos Feitos da Fazenda", publicada em 1888, de autoria de Antonio Herculano de Souza Bandeira, na época Primeiro Procurador dos Feitos da Fazenda Nacional da Côrte (espécie de chefe da "Procuradoria da Fazenda Nacional") ${ }^{146}$.

Esse autor, cuja obra tencionava suplantar lacuna teórica deixada pelas obras de caráter técnico destinadas ao ofício do Procurador dos Feitos, teve como antecedentes as

\footnotetext{
${ }^{146}$ BANDEIRA, Antonio Herculano de Souza. Novo Manual do Procurador dos Feitos da Fazenda. Rio de Janeiro: Lemmert \& C - Livreiros Editores, 1888.
} 
obras de Agostinho Marques Perdigão Malheiro, ("Manual do Procurador dos Feitos da Fazenda Nacional", de 1859), primeira obra específica sobre o tema, lembrando também da influência dos estudos publicados por José Antonio da Silva Maia, mas que nos anos finais do Império jaziam desatualizados e lacunosos em suas propostas iniciais ${ }^{147}{ }_{-}{ }^{148}{ }^{149}$ 150

No que tange à obra de Antonio Herculano de Souza Bandeira, merece destaque especial o conteúdo contido no Título VI relativo aos "Princípios de Direito Fiscal de Immediata Applicação ao Foro". Nesse título ${ }^{151}$, o autor traz uma definição de direito fiscal que se confundia com direito financeiro: "entende-se por direito fiscal ou financeiro a parte do direito administrativo que comprehende as regras por que se deve dirigir a Administração Geral da Fazenda Pública no que é relativo à receita e despeza do Império, á arrecadação, fiscalização e distribuição das rendas publicas, ao desempenho das

147 "Mais feliz que o meu benemérito antecessor eu achei, para auxiliar-me no estudo da complicada legislação da Fazenda, aquelle livro notável, um dos florões da nossa litteratura jurídica. Succedeu, porém, que a evolução da legislação causou ao Manual do Procurador dos Feitos do Dr. Perdigão Malheiro o mesmo prejuízo que anteriormente havia causado aos Apontamentos do Conselheiro Silva Maia. Apezar do grande merecimento do livro, elle já não corresponde às necessidades actuaes, ou porque ficaram excluídas matérias que hoje devem ser constantemente tratadas pelo Procurador dos Feitos, ou porque estão radicalmente alteradas quase todas as disposições que serviram de base á primitiva compilação, sem embargo do trabalho de reconstrucção, datado de 1870, e ao qual seu autor deu o título de "Supplemento ao Manual do Procurador dos Feitos". Idem, p. 06 e seguintes.

$148 \mathrm{O}$ autor, que aparentemente analisou atentamente os estudos anteriormente publicados por seus antecessores, buscou acompanhar a evolução legislativa que se iniciou em 1870 em diante, período não abarcado pelas obras anteriores. De grande curiosidade histórica revela-se uma passagem do prefácio do autor, alertando o leitor de que a editora (Srs. Laemmert \& C.) insistia na publicação urgente da obra, “(...) os quais allegavam urgência de uma publicação sobre os regulamentos fiscaes vigentes, attenta a falta sensível de qualquer trabalho systematico sobre elles". Idem, p. 07 e seguintes.

${ }^{149}$ Idem.

${ }^{150}$ A estrutura da obra do autor foi concebida em algumas partes. A) Parte Geral: que tratava especificamente das atribuições do Cargo de Procurador Judicial da Fazenda Nacional, cujos capítulos tratavam, respectivamente da nomeação, função, obrigações e deveres e atribuições do cargo; B) Primeira Parte - que tratava da organização do Juízo dos Feitos; das regras no Juízo dos Feitos; das diligências diversas dos feitos, a exemplo da desapropriação, da incorporação de bens nos próprios nacionais arrematação de objetos depositados nos cofres públicos, dos herdeiros e cessionários de credores do Estado, de acidentes ocorridos em repartições fiscais, da nobreza da perda de títulos de dívida pública, de sonegação de impostos, da insolubilidade da dívida fiscal, dentre outros temas; b) Segunda Parte - nessa parte tratava-se de diligências a cargo do procurador da Fazenda nos diversos Juízos de $1^{\text {a }}$ Instância, a exemplo de inventários, falências, habilitação de herdeiros, juízos criminais, juízos diversos e, por fim, dos "princípios de direito fiscal de immediata aplicação ao foro", que se dividiam em dois tópicos (Contribuições e Propriedade Nacional). Por fim, no "Appendice" (Legislação usual da Fazenda) mencionam-se as principais inovações normativas do século XIX no que tange à matéria objeto de atuação do Procurador de Feitos, matérias que incluíam Direito Privado, Direito Administrativo, Financeiro, Penal e Fiscal. BANDEIRA, Antonio Herculano de Souza. Op.cit., p. 263 e seguintes.

${ }^{151}$ Idem. 
contribuições dos encarregados da guarda e applicação dos dinheiros nacionaes, à tomada de suas contas, e á maneira de se lhes fazer effetiva a responsabilidade"152.

Na verdade, esse conceito não era novo, mas foi uma síntese da definição de Direito Financeiro (ou Fiscal) nas mais importantes obras publicadas sobre Direito Financeiro até aquele período, que foram as obras de Silva Maia (o autor se referia à obra de José Antonio da Silva Maia. Compendio do direito financeiro. Imprensa: Rio de Janeiro, Typ. Nacional, 1841, título 1, Capítulo 1, 108p) ${ }^{153}$ e de Pereira de Barros (o autor se referia à obra de José Mauricio Fernandes Pereira de Barros, Apontamentos de Direito Financeiro, título 1, Capítulo 1, Editores E. \& H. Laemmert, 1855, 431p), bem como a publicação oficial que acompanhou o Relatório do Ministério da Fazenda de 1884, cujo título era "Exposição contendo os principaes disposições sobre os artigos da receita do império"154.

Em síntese, a obra de Bandeira, embora muito esclarecedora sobre o perfil geral dos estudos, da produção legislativa e dos trabalhos publicados sobre a matéria tributária no século XIX, apresentava nítida função de servir apenas de referência técnica e legislativa para a atuação do Procurador dos Feitos, não apresentando qualquer tendência de aprofundamento nas investigações de natureza tributária, que, à época, sob a denominação de "Direito Fiscal" (que, como visto, era identificado como Direito Financeiro, e não como "parte" dele), era apenas uma pequena parte do Direito Administrativo ${ }^{155}$.

Portanto, pode-se afirmar que, com base nos estudos acima fornecidos, às vésperas da Revolução Republicana, em 1889, que o Direito Tributário ainda inexistia como disciplina no Brasil, e não era objeto de estudo de juristas, mas apenas de financistas, geralmente alinhados a técnicos e políticos fiscais, e não raramente funcionários públicos com algum contato com a matéria.

\subsection{A contribuição de Rui Barbosa e as transformações vivenciadas nos anos finais do século XIX}

\footnotetext{
${ }^{152}$ Ibidem, p. 264.

${ }^{153} \mathrm{O}$ autor referiu-se a um brevíssimo compêndio publicado pelo então por José Antonio da Silva Maia, em 1841. MAIA, José Antonio da Silva. Compendio do direito financeiro. Imprensa: Rio de Janeiro, Typ. Nacional, 1841, 108p. Idem, p. 264 e seguintes.

154 Idem.

${ }^{155}$ BANDEIRA, Antonio Herculano de Souza. Op.cit., p. 264 e seguintes.
} 
Merece menção expressa também a contribuição de Rui Barbosa no período, ainda que não versada em Direito Tributário, mas em Ciência das Finanças e Política Fiscal.

Porém, adiante-se que nesse momento ainda não há que se falar em Direito Tributário (autonomia teórica), no que se inclui a obra de Rui Barbosa.

Jurista, Rui Barbosa teve seus pareceres (dentre os produzidos até a data de 1899) reunidos em um único livro, intitulado "Trabalhos Jurídicos", como parte da coletânea destinada a homenageá-lo (“Obras Completas de Rui Barbosa”, de 1949) ${ }^{156}$.

Nessa coletânea foi publicado brevíssimo Parecer de Rui Barbosa a uma consulta sobre a tributação sobre dividendos de sociedades anônimas ${ }^{157}$, com fundamento na Lei n.490 de 1897, no art. $1^{\text {a }}$, número 40, que foi respondida em 2 de janeiro de 1899, às vésperas do século XX. Observa-se, entretanto, que Rui não havia consultado qualquer obra relativa ao "Direito Fiscal" ou Financeiro, e mesmo de Finanças Públicas, mas apenas obras francesas relativas ao direito comercial das sociedades anônimas ${ }^{158}$.

Além de contribuir decisivamente para a organização da discriminação de rendas tributárias da Constituição Republicana de 1891, Rui Barbosa teve grande contribuição à tributação através do Relatório do Ministro da Fazenda, publicado em 1891, durante o governo provisório para auxiliar e orientar a reforma do sistema financeiro e tributário na passagem da Monarquia para a República, buscando apresentar elementos técnicos (de Ciência das Finanças e Política Fiscal) para proceder com uma reforma no sistema financeiro e tributário condizentes com a realidade brasileira. ${ }^{159}$

Nota-se que, através da leitura do Relatório, a ampla e criteriosa pesquisa desempenhada por Rui Barbosa, considerando as lições dos principais autores estrangeiros da época, mergulhava profundamente nas áreas da Ciência das Finanças e da Política Fiscal, áreas de pesquisa onde o fenômeno tributário era melhor estudado até aquele

\footnotetext{
${ }^{156}$ BARBOSA, Rui. Trabalhos Jurídicos. Vol. XXVL. 1891. Tomo I. In: Obras Completas de Rui Barbosa. Ministério da Educação e Saúde. Rio de Janeiro, 1949.

${ }^{157}$ O questionamento era o seguinte: "se as companhias ou sociedades anônimas com sede e foro jurídico nos Estados onde pagam o imposto de 2 1/2/\% sôbre os seus dividendos estão sujeitos ao impôsto Federal de 2 $1 / 2 \%$. Quando assim fôr, se o impôsto compreende as quotas distribuídas como bônus e lançadas em lucros suspensos e fundo de reserva?" Respondeu Rui, com base no art.1, n.40 e no art.4 da Lei i n.490 de 1897, que "livres estão, portanto, do impôsto em questão todos os benefícios da sociedade anônima, que não constituírem dividendos rigorosamente falando, se não forem como tais destinados à distribuição entre os sócios. Idem, p.219.

${ }^{158}$ As obras citadas no parecer foram: "VAVASSEUR: sociétés, v.I, n.608 e 609, p.411-412" e "SIVILLE: Traité dês sociétés anonymes belges, 1898, v.II., n.1318, p.45-6". Ibidem, p.213-223.

${ }^{159}$ BARBOSA, Rui. Relatório do Ministro da Fazenda. In: Obras Completas de Rui Barbosa. Vol. XVIII 1891. Tomo III. Ministério da Educação e Saúde. Rio de Janeiro: Imprensa Nacional, 1949, p. 01 e seguintes.
} 
momento, não se identificando no trabalho remissões a publicações de conotação propriamente jurídica (ou pelo menos, com o título do trabalho remetendo-se à expressão "Direito Financeiro", "Direito Fiscal”, "Legislação Financeira”, etc.). As influências do relatório passam por obras de língua inglesa, francesa, italiana, portuguesa, espanhola e alemã, existindo uma prevalência quase absoluta de consultas às obras escritas nas duas primeiras línguas citadas (francesas e inglesas), bem como o relato de experiências legislativas naquelas realidades sobre a criação e aplicação de impostos análogos aos propostos no relatório.

Cita-se, como exemplo, o Imposto de Renda, cuja ausência no país era criticada por Rui Barbosa, sendo o tributo que deteve as maiores atenções no Relatório ${ }^{160}$. Essa ausência poderia ser compreendida porque na época havia certo preconceito no Brasil para a adoção de tributos diretos, pois, Rui Barbosa, analisando Thiers, viu que aquele defendia que o imposto indireto “(...) seria o dos povos mais adiantados em civilização, ao passo que o impôsto direto o dos povos mais atrasados (...)". A opinião de Rui Barbosa era diametralmente diversa, pois o imposto de renda teria sua importância majorada através de ideais democráticos, onde a importância de tributos diretos, entendidos como elementos civilizadores, seria “(...) exigência do princípio de justiça nas sociedades de mais amplo desenvolvimento moral" 161 .

Por isso, a contribuição de Rui Barbosa, ainda que relevante, passou pelo campo da Ciência das Finanças e da Política Fiscal, mas não tocou, naturalmente, o Direito Tributário.

A literatura brasileira na virada do século XIX para o século XX não se afastou da pecha de que quem estudava na época a tributação eram os financistas, e não os juristas.

Em decorrência da situação financeira um tanto quanto caótica daquele contexto histórico, essa situação tardou a mudar, mantendo-se estável em grande parte nos primeiros anos da República Velha, ainda que sob fundamentos constitucionais, políticos, sociais e econômicos distintos do período monárquico.

\footnotetext{
${ }^{160}$ Idem, p. 11-69.

${ }^{161}$ BARBOSA, Rui. Relatório do Ministro da Fazenda. Op.cit., p. 11-69.
} 
E não foram poucas as modificações trazidas pelo contexto extrajurídico no período. Dentre os principais fatores de natureza econômica, social ou política do período (meados do século XIX até o início do século XX), citam-se: a) mudança da Monarquia para a República; b) instauração do Pacto Federativo e a consequente distribuição de rendas entre União e Estados (e secundariamente aos Municípios); c) grande importância dos tributos aduaneiros, especialmente das tarifas aduaneiras; d) aumento exponencial do comércio exterior, e a abertura dos portos; e) crises financeiras decorrentes da transformação da Monarquia para a República; f) a transição do trabalho escravo para a mão-de-obra assalariada; g) os primeiros passos da indústria brasileira em um país essencialmente extrativista.

\section{Primeiras décadas do século XX e os estudos fiscais}

$\mathrm{O}$ início do século $\mathrm{XX}$ foi marcado rapidamente pelo crescimento do papel brasileiro na exportação de matérias-primas. Os tributos aduaneiros recebiam enorme atenção pela importância financeira que constituíam para a União. Contudo, crises econômicas e políticas da época (não necessariamente internas) geraram importantes modificações na estrutura tributária do período, a exemplo da $1^{\text {a }}$ Guerra Mundial e da “Crise de 1929” (Quebra da Bolsa de Nova York) e suas consequências na economia brasileira (como a Crise do Café).

O perfil das obras de Direito Tributário naquela época, entre o final do século XIX e as primeiras décadas do século XX, demonstra bem a ausência de estudos propriamente jurídicos vinculados à disciplina. Logo, não se identifica, nesse período, a consciência do estudo autônomo do Direito Tributário.

Quem realmente estudava a tributação eram os estudiosos das Finanças Públicas, contabilistas, técnicos e políticos fiscais preocupados com as transformações financeiras da época.

Nessa fase, especialmente até a década de 40, os magistrados detinham formação solidamente focada no Direito Privado (de influência do Direito Romano), e os tributos eram matéria de "guarda-livros" (hoje conhecidos como contadores ou contabilistas). Na 
época, a matéria tributária somente era tratada com alguma dignidade nos conselhos e tribunais administrativos fiscais.

De qualquer forma, ainda que com as dificuldades acima vislumbradas, as transformações políticas, sociais, econômicas e jurídicas de suas primeiras décadas constituíram importante chamariz para que novos estudiosos se debruçassem sobre tempestuoso assunto, especialmente aqueles afeitos ao fenômeno econômico-financeiro e técnico-contábil.

Assim, nos primeiros anos do século $\mathrm{XX}$ foram publicados alguns importantes "manuais" de Ciência das Finanças, claramente inspirados no exemplo estrangeiro e nas construções oitocentistas sobre o Direito Financeiro no Brasil, a exemplo do "Manual de Sciência das Finanças" (1 ${ }^{a}$ edição de 1906), de João Pedro da Veiga Filho, onde imposto e suas espécies eram tratados brevemente em alguns poucos capítulos ${ }^{162}$. De qualquer forma essa obra revela uma inicial influência estrangeira, quando esboçou noção de Direito Financeiro $^{163}$.

Outra obra de relevo no início do século XX foi elaborada por Viveiros de Castro ("Tratado dos Impostos"), que trilhou caminho distinto de seus contemporâneos afeitos ao estudo das Ciências das Finanças, cuja primeira edição foi publicada em 1901 e, a segunda, em 1910. Esse estudo pretendia preencher uma lacuna nos estudos financeiros na realidade brasileira, pois, segundo o próprio autor, a maioria das obras publicadas por seus conterrâneos estruturavam-se como "manuais" ou "compêndios" de Ciência das Finanças (como cursos gerais), e apenas incidentalmente tratavam dos impostos (ou tributos em

\footnotetext{
${ }^{162}$ FILHO, João Pedro da Veiga. Manual da Sciencia das Finanças. Quarta Edição. São Paulo: Monteiro Lobato \& C, 1923, p.57-185.

163 "O direito financeiro, também chamado financial ou fiscal, é o complexo das leis segundo as quais são reguladas as finanças do Estado. Muito se distingue da Sciencia das finanças, a qual é essencialmente theorica ou especulativa e estuda os princípios geraes, as condições de uma boa organização financeira. $\mathrm{O}$ direito financeiro tem por objectivo a applicação d'esses princípios, a parte pratica da sciencia, os direitos e deveres que nascem das relações creadas pela atividade financeira. $O$ direito financeiro comprehende todas as regras, por que se deve dirigir a administração geral da fazenda nacional no que é relativo á despeza, receita, orçamento e credito publico; á arrecadação, fiscalização e distribuição das rendas publicas; ao desempenho das attribuições de todos os encarregados da guarda e applicação dos dinheiros nacionaes; á tomada de suas contas; e á maneira de se lhes fazer effectiva a responsabilidade". As referências do autor foram: "GRAZIANI, Augusto, Instituzioni di Scienza delle Finanze (p.8), GARELLI, Alexandre, "Il Diritto Internazionale Tributario", 1899, e Pereira de Barros, "Apontamentos de Direito Financeiro Brazileiro", p. 1 (1855). FILHO, João Pedro da Veiga. Manual da Sciencia das Finanças. Quarta Edição. Op.cit., p.21-22.
} 
geral). É o exemplo, na época, do "Manual da Sciência das Finanças", de Veiga Filho, e Amaro Cavalcanti (Elementos de Finanças), como relata o próprio autor ${ }^{164}$.

Naturalmente, nas primeiras quatro décadas do século XX, já havia a divulgação de alguns autores renomados no campo da Ciência das Finanças, a exemplo dos aportes de Dídimo Veiga ${ }^{165}$, Veiga Filho, ${ }^{166}$ De Plácido e Silva ${ }^{167}$, Carvalho Pinto ${ }^{168}$, Amaro Cavalcanti, Francisco D'Auria, Teotônio Monteiro de Barros Filho ${ }^{169}$ e as traduções muito repercutidas de Francesco Nitti ${ }^{170}$ e Paul Hugon ${ }^{171}$, além de outros trabalhos acadêmicos ou técnicos específicos sobre determinado tema fiscal ${ }^{172}{ }_{-}^{173}$, muito embora alinhados aos aspectos econômicos e contábeis, e pouco harmonizados à ideia de Direito Tributário que foi posteriormente adotada pela doutrina brasileira.

Também se registra nessa época os primeiros trabalhos publicados por Aliomar Baleeiro, no âmbito da Ciência das Finanças, intitulados “O Imposto sôbre a Renda”, em 1938, e “A Tributação e a Imunidade da Dívida Pública”, em 1939, na Bahia ${ }^{174}$.

Naturalmente, em ambos os estudos a temática tributária é levada sob o aspecto econômico-financeiro, e não prioritariamente sob a perspectiva do Direito Tributário.

Ademais, registra-se que alguns estudiosos da época arriscaram publicar estudos versados sobre o Direito Tributário. É o exemplo de Epitácio Pessoa, que publicou alguns

\footnotetext{
${ }^{164}$ CASTRO, Augusto Olympio Viveiros de. Prefácio à Primeira Edição. In: Tratado dos Impostos (Estudo Theorico e Pratico). Segunda Edição. Rio de Janeiro: Industria Nacional, 1910, p. IX-XIII.

${ }^{165}$ VEIGA, Dídimo Agapito da. Ensaios de Sciencia das Finanças e de Economia Publica. Rio de Janeiro: Jacintho Ribeiro dos Santos, 1927, p. 173.

${ }^{166}$ VEIGA FILHO, João Pedro da. Manual da Sciencia das Finanças. Terc. Ed. São Paulo: Secção de obras do Estado, 1917, p. 82-83.

${ }^{167}$ DE PLÁCIDO E SILVA. Noções de Finanças e Direito Fiscal. São Paulo: Guairá Editora, 1941, p 151153.

${ }^{168}$ CARVAlHO PINTO, Carlos Alberto A. Discriminação de Rendas. Prefeitura de São Paulo, 1941, p. 145 e seguintes.

${ }^{169}$ FILHO, Teotônio Monteiro de Barros. As Taxas e seus Principais Problemas Teóricos. São Paulo: Editora Revista dos Tribunais, 1941, p. 10-15.

${ }^{170}$ NITTI, Francesco. Princípios da Ciência das Finanças. 2 Volumes. Rio de Janeiro: Atena Editora, 1937, p. 09 e seguintes.

${ }^{171}$ HUGON, O Imposto. Teoria Moderna e Principais Sistemas. São Paulo: Editora Renascença, 1945, p. 13 e seguintes.

${ }^{172}$ VIEIRA, Enilton. Fisco versus Fisco, Rio de Janeiro: 1950, p.35-40; 71-90.

${ }^{173}$ Interessante mencionar a publicação de uma "ação" julgada pelo Tribunal Federal de Recursos em seu inteiro teor, sobre “Anistia Fiscal”. Ação Rescisória n.7. São Paulo. Autora: Alonso, Calcerrada \& Cia. Ltda. Ré: Fazenda Nacional; Relator: Exmo. Snr. Ministro Afrânio Antônio da Costa. Revisor: Exmo. Snr. Ministro Edmundo de Macedo Ludolf. Rio de Janeiro: Tribunal Federal de Recursos, 1948.

${ }^{174}$ É clara a maior vinculação das obras citadas à Ciência das Finanças: BALEEIRO, Aliomar. Imposto sobre a Renda. Bahia: Editora Bahiana, 1938, p. 09 e seguintes. BALEEIRO, Aliomar. A Tributação e a Imunidade da Dívida Pública. Baía: Livraria Editora Baiana, 1939, p. 111 e seguintes.
} 
pareceres relativos ao Direito Fiscal. Nesse contexto, citam-se os seguintes: "Taxas portuárias - sua inconstitucionalidade" "175; "Taxas de portos - vencimentos dos empregados de docas e armazéns para cargas, etc. ${ }^{176}$; "Extensão dos favores concedidos a empresas de navegação durante a guerra, no Brasil"; "Imposto de renda sobre renda garantida em contrato" "177; "Impôsto de renda sôbre renda garantida em contrato" "178; "Ágio de ações novas destinado ao fundo de reserva não está sujeito ao impôsto de renda" "179; "Os impostos de indústrias e profissões, territorial e predial distinguem-se do atual impôsto de renda - A inconstitucionalidade do impôsto sobre a renda de certos títulos de dívidas públicas"180; "Autonomia do Distrito Federal - Direito de lançar o impôsto de indústrias e profissões e outros reservados à União"181; "Privilégio da "Western Telegraph"182; "Impôsto de dividendos"183, entre outros. ${ }^{184}$

Até os primeiros anos da década de quarenta, Epitácio Pessoa já havia publicado obras relacionadas ao Direito Público ${ }^{185}$ e ao "Direito Fiscal", destacando-se a obra "Elementos de Direito Fiscal”, em 1943 (já em sua segunda edição) ${ }^{186}$, voltada aos estudantes de contabilidade. Este trabalho, apesar de apresentar algumas noções jurídicas,

${ }^{175}$ Publicado em Petrópolis, em fevereiro de 1913. PESSOA, Epitácio. Pareceres Jurídicos. Tomo I. Rio de Janeiro: INL, 1959, p. 85-87.

${ }^{176}$ Idem, p. 155-162.

${ }^{177}$ Publicado no Rio de Janeiro, em 10 de outubro de 1916. Ibidem, p. 155-162.

${ }^{178}$ Publicado no Rio de Janeiro, em 12 de março de 1925. Ibidem, p. 282-285

${ }^{179}$ Publicado no Rio de Janeiro, em 1 de março de 1926. Ibidem, p.289-293.

${ }^{180}$ O parecer foi publicado em "O Jornal", de 24-12-1926. Ibidem, p.293-304

${ }^{181}$ Publicado em Petrópolis, em 5 de Março de 1927. Ibidem, p. 311-321.

${ }^{182}$ Parecer publicado em Rio de Janeiro, 1 de maio de 1928. Ibidem, p.366-370.

${ }^{183}$ Nesse trabalho, Epitacio Pessoa já mostra alguma familiaridade com importantes autores do Direito Administrativo e da Ciência das Finanças. Buscando a caracterização do imposto sobre dividendos, pesquisa as obras de Otto Mayer, no âmbito do direito administrativo alemão, e de alguns financistas, como Adolph Wagner (Traité dês Finances, trad. De Ronjat, vol. II, par.172) e Visconde de Ouro Preto ("que publicou artigo sobre "A incidência do impôsto", na Revista "O Direito, vol.88, p.172"). Nesse estudo, Epitacio Pessoa defendeu que a incidência do imposto seria a renda auferida pelos membros de tais associações e provenientes dos lucros que elas realizaram. Basicamente, buscava delimitar o campo de incidência do imposto, que havia sido ampliado seguidamente por Decretos, incidindo sobre a renda ou lucros distribuídos aos acionistas. Publicado em Petrópolis, em 15 de abril de 1916. PESSOA, Epitácio. Pareceres Jurídicos. Tomo I. Op.cit., p. 150-155.

${ }^{184}$ Com cartas publicadas nas datas: 01/06/1932; 19/10/1933, 15/04/1935; 16/01/1936. PESSOA, Epitácio. Pareceres Jurídicos. Tomo II. Rio de Janeiro: INL, 1959, p.365-415.

185 Outras obras são mencionadas que, embora não consultadas na presente pesquisa, mostram a atenção específica a temas fiscais na pesquisa do autor: PESSOA, Epitacio M. Lições da Cadeira de Direito Constitucional. Rio de Janeiro: Papelaria Muniz, 1931; PESSOA, Epitacio M. Lições da Cadeira de Legislação Fiscal. . Rio de Janeiro: Papelaria Muniz, 1931; PESSOA, Epitacio M. Elementos de Direito Fiscal. $1^{a}$ Edição. Rio de Janeiro: Papelaria Muniz, 1932. In: PESSOA, Epitacio Monteiro. Elementos de Direito Fiscal (contendo as matérias exigidas no Programa de Legislação Fiscal, aprovado pela Divisão do Ensino Comercial para a Escola de Comércio do Rio de Janeiro e nos das congêneres, bem como elementos subsidiários importantes para exatores federais e tomadores de suas contas). Segunda Edição. Volume I. Rio de Janeiro: Livraria Freitas Bastos, 1943, p. 01 e seguintes.

${ }^{186}$ PESSOA, Epitacio Monteiro. Elementos de Direito Fiscal. Op.cit., p. 12-23. 
era claramente voltado aos aspectos contábil, econômico e legislativo do fenômeno fiscal $^{187}$.

Aliás, nessa época, já começam a surgir alguns manuais voltados a estudantes de direito, contabilidade (os "guarda-livros") e economia, a exemplo do Manual de De Plácio e Silva, intitulado "Noções de Finanças e de Direito Fiscal" publicado em 1941, com a mesma característica esboçada nos estudos de Epitacio Pessoa.

O Prefácio de De Plácido e Silva denunciava seu intento, pois o objetivo era oferecer conhecimentos básicos sobre a matéria em face da “(...) carência de um livro destinado ao estudo do Direito Fiscal, constituído, como se sabe, por esse emaranhado de leis e regulamentos baixados como regras e princípios à arrecadação de impostos", complementando, criticamente, que "os regulamentos em si, cheios de confusões e mesmo afastados de qualquer sentido elucidativo, não podiam fornecer elementos de divulgação aos fundamentos de um direito de tal relevância, desde que se mostra matéria substancial às atividades financeiras do próprio estado" ${ }^{188}$.

Na década de quarenta as obras de alguns publicistas europeus e cientistas das finanças (estrangeiros ou nacionais) já tinham se disseminado em estudos fiscais brasileiros. Por isso não é surpresa que obras de caráter técnico como a de De Plácido e Silva, apresentassem noções "jurídicas”, a exemplo da noção de Direito Fiscal extraída da análise do Poder Financeiro da obra do administrativista Otto Mayer.

Mas distinguia o Direito Financeiro (que estabelece os impostos, e mais amplo), do Direito Fiscal (que traça as regras de cobrar). Para o autor, o "Direito Financeiro" “(...) indica as pessoas sobre quem deve recair a tributação (...)", ao passo que o Direito Fiscal "vai convocá-las a quem cumpram o encargo, que lhe é exigido pelo Estado".

\footnotetext{
${ }^{187}$ Não havia ali ainda clara a noção de direito fiscal (no sentido de direito tributário contemporâneo), prova disso é a noção esboçada pelo autor, por sua vez baseado em Trotabas: "direito fiscal é o ramo do direito público que regula os direitos do fisco e suas prerrogativas do exercício. Nesta definição vamos encontrar três elementos: a sujeição do Direito Fiscal ao Direito Público, a ideia dos direitos do fisco e as das prerrogativas do exercício". Trata-se, é verdade, de uma noção bastante incipiente de direito fiscal, que, para o autor era definível apenas se transportados para o terreno fiscal os elementos do direito administrativo. Portanto, sequer considerava o trato da matéria apartado do direito administrativo. PESSÔA, Epitácio M. Op.cit., p.25-26.

${ }^{188}$ DE PLÁCIDO E SILVA. Op.cit., p.11-21.
} 
Em interessante passagem, De Plácido e Silva também observa a ausência de um regulamento fiscal geral (não havia ainda, na visão do autor, a percepção de uma codificação tributária), pois “(...) cada modalidade de imposto ou tributo traz o seu regulamento com as condições próprias para a sua exigência ou incidência e para a sua arrecadação", cuja discriminação, decretação e arrecadação de cada um seria previsto nesse regulamento, e, de cada um desses regulamentos, retira o Direito Fiscal os princípios que lhe são próprios, “(...) para construir seu corpo de regras e preceitos ${ }^{189}$.

Na mesma época, outros estudos técnicos foram publicados e disseminados entre os estudiosos e profissionais da área, como é o caso dos estudos técnicos defendidos pela Delegação do Estado de São Paulo durante o Congresso Nacional de Legislação Tributária, que ocorreu no Rio de Janeiro em 19 de maio de 1941.

Dentre esses estudos destacaram-se os seguintes: a) "discriminação de rendas" (versado em técnica legislativa fiscal, e publicado na vigência da Constituição de 1937), apresentado por Carvalho Pinto ${ }^{190}$; "Hermenêutica das Leis Fiscais", também de Carvalho Pinto (onde buscou delinear a necessidade de aplicar a hermenêutica das leis - em geral ao direito fiscal, severamente influenciado pelo clássico estudo de Ezio Vanoni) ${ }^{191}{ }^{192}$; c) "Crédito Fiscal", de autoria de Paulo Barbosa Campos Filho, subdividido em dívida ativa (definição, caracterização e cobrança); prestação; preferência (já demonstrando clara referência às doutrinas francesas e italianas, a exemplo do clássico de Giannini (Il raporto giuridico della Imposta), além de teóricos da Economia como Adam Smith. ${ }^{193}{ }^{194}$.

Apesar de já tocarem em pontos importantes que seriam disseminados entre estudos jurídico-tributários, os três estudos elaborados no seio do Congresso de Legislação Fiscal, demonstram os perfis essencialmente técnicos, ainda sedimentados em "Ciência das Finanças", amplamente estruturados em conceitos econômicos e contábeis, com aporte

\footnotetext{
${ }^{189}$ Idem, p. 121-403

${ }^{190}$ CARVAlHO PINTO, Carlos Alberto A. Discriminação de Rendas. Prefeitura de São Paulo, 1941, p. 145 e seguintes. Sobre o assunto também: JÚNIOR, Goffredo Telles. O Sistema Brasileiro de Discriminação de Rendas. Tese de Livre Docência defendida na Faculdade de Direito de São Paulo. São Paulo: Imprensa Nacional, 1946, p 03-33.

${ }^{191}$ CARVALHO PINTO, Carlos Alberto A. Hermenêutica das Leis Fiscais. Prefeitura de São Paulo, 1941, p.20 e seguintes.

${ }^{192}$ Idem, p.36.

${ }^{193}$ FILHO, Paulo Barbosa de Campos. Crédito Fiscal. I - Dívida Ativa; II - Prescrição; III - Preferência. São Paulo: Prefeitura do Município de São Paulo, s/d, p.01-27; 51-52.

${ }^{194}$ Idem, p.62-63.
} 
inicial às doutrinas jurídicas estrangeiras, até então pouco conhecidas no contexto brasileiro.

Naturalmente, esse contexto, de priorização de elementos de Ciência das Finanças, influenciou diretamente as raras incursões à perspectiva jurídico-tributária no Brasil.

No tópico subsequente, será analisado breve retrospecto do constitucionalismo tributário brasileiro, especialmente porque, de certa forma, a previsão constitucional da matéria tributária no Brasil, que apresentou graus crescentes, favoreceu o desenvolvimento da literatura tributária brasileira, especialmente a partir da Constituição de 1946. Contudo, não se pode desprezar o fato de que as constituições anteriores a ela prepararam o terreno para que a posterior evolução se manifestasse.

\section{Constitucionalismo tributário pré-disciplinar (da Monarquia ao Estado Novo)}

Naturalmente, o início do percurso constitucional tributário brasileiro foi marcado pela parca previsão da matéria tributária. A Carta Constitucional de 1824, outorgada em pleno período imperial, e sob ampla influência do iluminismo e liberalismo nãointerventor, detinha poucos dispositivos referentes à matéria fiscal ${ }^{195}$. Assim, na Constituição de 1824, não se poderia afirmar a identificação clara de princípios da tributação, mas tão somente esboços do que poderiam vincular-se à especialização tributária, como é o caso da anualidade (Art. 15. inc. X); iniciativa privativa da câmara dos deputados para impostos (Art. 36. I), além da legalidade e igualdade (legal), ambos previstos nos art.179 (I e XIII).

Na Constituição Republicana de 1891, com maior atenção à discriminação de competências tributárias ${ }^{196}$, inaugurando a república federativa, fixou tributos de competência da União (art. $7^{\mathrm{a}}$ e art. $8^{\mathrm{a}}$ ), trazendo também competência dos Estados para a tributação (art.9 - através do "federalismo centrífugo", na lição de Antonio Roberto Sampaio Dória) ${ }^{197}$, ainda que não trouxesse competência municipal, que ficaria atrelada

\footnotetext{
${ }^{195}$ BALTHAZAR, Ubaldo Cesar. História do Tributo no Brasil. Op.cit., p. 69-84.

${ }^{196}$ Idem, p. 103 e ss.

197 DÓRIA, Antonio Roberto Sampaio. Discriminação de Competência Impositiva (Sua evolução na federação brasileira). Tese de Concurso à Cátedra de Direito Financeiro da Faculdade de Direito da Universidade de São Paulo: USP, São Paulo, 1972, p. 48 e seguintes.
} 
aos Estados, a quem competia legislar sobre o tema ${ }^{198}$, destacando-se também o art. $10^{\text {a }}$, que fixava pela primeira vez no Brasil a chamada "imunidade recíproca", amplamente inspirada na orientação jurisprudencial norte-americana ("Maryland Versus MacCulloch") ${ }^{199}$.

O processo de amadurecimento federalista no Brasil favoreceu a evolução na organização estrutural do direito tributário brasileiro, de forma que o estudo das discriminações de rendas tributárias sempre se manifestaram perenes entre estudiosos brasileiros (a exemplo do próprio Rui Barbosa).

Mas apesar de esforçar-se para garantir melhor distribuição de receitas tributárias entre Estados e União, o acúmulo de competências tributárias concorrentes prejudicou a nova formação federal, especialmente por força do art. 12, que autorizou o acúmulo de competências entre a União e os Estados ${ }^{200}$.

$\mathrm{O}$ art.11 realmente exerceu papel de destaque no campo das limitações ao poder tributário, já que trouxe dispositivo que reuniu algumas importantes limitações à União e aos Estados, que ficaram proibidos de: a) "criar impostos de trânsito pelo território de um Estado, ou na passagem de um para outro, sobre produtos de outros Estados da República ou estrangeiros, e, bem assim, sobre os veículos de terra e água que os transportarem"; b) estabelecer, subvencionar ou embaraçar o exercício de cultos religiosos; c) "prescrever leis retroativas".

Em outras palavras, o art.11 já reunia dispositivo claramente vinculado aos direitos e garantias fundamentais, que traziam importantes imunidades (a exemplo da religiosa) e o princípio da irretroatividade.

\footnotetext{
${ }^{198}$ Sobre o assunto, conferir: TORRES, David. Revelando o sistema tributário brasileiro. Sinafresp: São Paulo, 2003, p.51-52.

${ }^{199}$ No Brasil, Alcides Jorge Costa relembra o problema relativo aos municípios, no caso de Santos, quando a União operava o Porto através da Companhia das Docas (uma empresa particular) e o Município não podia cobrar imposto durante o contrato de concessão. Depois do fim da concessão, retornando ao domínio da União os municípios não poderiam cobrar tributos em face do art.10. A situação era extremamente curiosa, pois o Município investia em infraestrutura para beneficiar as Docas, mas não recebia "um centavo" em contrapartida. COSTA, Alcides Jorge. A História da Tributação no Brasil. Op.cit., p. 71-75.

${ }^{200}$ Veja-se o teor do art. 12, na Constituição de 1891: “Além das fontes de receita discriminadas nos arts. $7^{\circ} \mathrm{e}$ $9^{\circ}$, é licito à União como aos Estados, cumulativamente ou não, criar outras quaisquer, não contravindo, o disposto nos arts. $7^{\circ}, 9^{\circ}$ e $11, n^{\circ} 1^{\prime}$.
} 
As mudanças políticas, econômicas e sociais do Velho Regime viabilizaram, depois do Estado Novo, nova configuração constitucional, consolidada pela promulgação da Constituição de 1934, que, à época, trouxe como novidade a divisão de competências tributárias entre União (art. $\left.6^{\mathbf{a}}\right)$, Estados $\left(\operatorname{art} .8^{\mathbf{a}}\right)$ e Municípios ${ }^{201}$, estabelecendo, no artigo 17, as seguintes vedações: "I - criar distinções entre brasileiros natos ou preferências em favor de uns contra outros Estados"; "VII - cobrar quaisquer tributos sem lei especial que os autorize, ou fazê-lo incidir sobre efeitos já produzidos por atos jurídicos perfeitos"; "VIII - tributar os combustíveis produzidos no País para motores de explosão"; "IX cobrar, sob qualquer denominação, impostos interestaduais, intermunicipais de viação ou de transporte, ou quaisquer tributos que, no território nacional, gravem ou perturbem a livre circulação de bens ou pessoas e dos veículos que os transportarem"; "X - tributar bens, rendas e serviços uns dos outros, estendendo-se a mesma proibição às concessões de serviços públicos, quanto aos próprios serviços concedidos e ao respectivo aparelhamento instalado e utilizado exclusivamente para o objeto da concessão (...)", embora o parágrafo único tenha mencionado a possibilidade, a despeito da imunidade recíproca prevista no item $\mathrm{X}$, da cobrança de taxas remuneratórias devidas pelos concessionários de serviços públicos. Esse artigo (17) é importante porque avança na delimitação das limitações constitucionais ao poder de tributar, tanto no que diz respeito às imunidades como aos chamados "princípios constitucionais tributários".

No mesmo passo, o artigo 18 estabeleceu vedação específica à União, que posteriormente significaria o princípio da uniformidade geográfica: “Art. 18 - É vedado à União decretar impostos que não sejam uniformes em todo o território nacional, ou que importem distinção em favor dos portos de uns contra os de outros Estados”.

Já o artigo 19, inc.IV, estabeleceu vedação expressa aos Estados, Distrito Federal e Municípios, dispondo que estes não poderiam estabelecer “(...) qualquer diferença

\footnotetext{
${ }^{201}$ E, assim, a Constituição de 1934 trouxe aos Municípios a seguinte competência tributária: a) Imposto de licenças; b) imposto predial e territorial urbano, o primeiro sendo cobrado sob a forma de décima ou de cédula de renda; c) imposto sobre diversões públicas; d) imposto cedular sobre a renda de imóveis rurais; e) taxas. Conforme salienta Alcides Jorge Costa “(...) pela primeira vez na história, os Municípios apareceram com o seu campo tributário exclusivo e derivado diretamente da Constituição. E aquela total ausência de autonomia municipal, tão acentuada durante o Império, que se restringiu um pouco durante a República, foi desaparecendo, e a Constituição de 1934 foi um grande passo a esse respeito". COSTA, Alcides Jorge. História da Tributação no Brasil. Op.cit., p. 76-77. Sobre o assunto também: BALTHAZAR, Ubaldo Cesar. Op.cit., p. 114-121.
} 
tributária, em razão da procedência, entre bens de qualquer natureza; (...)", fixando o princípio da não diferenciação tributária.

Situados ao final da Constituição, os direitos e garantias individuais foram previstos no art. 113, que, além de estabelecer a igualdade e a legalidade (genérica), no que tange aos direitos e garantias fundamentais, trouxe imunidade tributária no inciso 36: "Nenhum imposto gravará diretamente a profissão de escritor, jornalista ou professor”.

É importante notar que, segundo Antonio Roberto Sampaio Dória, verifica-se processo progressivo a partir da Constituição de 1934, influenciado pela Constituição de Weimar, o chamado "federalismo financeiro centrípeto", onde o poder político torna a residir, de jure, no vértice da pirâmide federativa, ao invés de se fragmentar dela. Mantémse a autonomia estadual, embora restringida. E libera-se o status político e financeiro dos Municípios perante os Estados e a União ${ }^{202}{ }_{-}^{203}$.

Três anos depois, com o "Estado Novo", outorgou-se, em 1937, nova Constituição, de caráter fortemente autoritário e centralizador, embora Bernardo Ribeiro de Moraes tenha opinado que a "Polaca" até tentou aperfeiçoar a discriminação constitucional de rendas tributárias ${ }^{204}$.

Note-se que a Constituição de 1937 trouxe importantes diferenciações com a Constituição de 1934, reforçando, por exemplo, o princípio da uniformidade geográfica, direcionado à União, mas observado também pelos Estados e Municípios, estipulando a vedação de impostos que não fossem uniformes, ou que implicassem discriminação de um ou de outros Estados.

A Constituição de 1937, sensível à experiência da bitributação que prevalecia entre União e Estados nas Constituições anteriores, deu especial ênfase ao fenômeno, e estabeleceu, no art.24, que prevaleceria o imposto decretado pela União em casos de competência concorrente. Atribuiu-se também competência ao Conselho Federal (por

\footnotetext{
202 DÓRIA, Antonio Roberto Sampaio. A Discriminação de Competência Impositiva. Op.cit., p. 72 e seguintes.

${ }^{203}$ AMED, Fernando José; NEGREIROS, Plínio José Labriola de Campos. Op.cit., p. 260.

${ }^{204}$ MORAES, Bernardo Ribeiro de. Compêndio de Direito Tributário. Primeiro Volume. $3^{\text {a }}$ Ed. Forense: Rio de Janeiro, 1995, p. 100-189; 126-127.
} 
iniciativa própria ou através de representação dos contribuintes) para declarar a existência da bitributação, que suspenderia a cobrança do imposto estadual ${ }^{205}$.

Note-se esforço claramente centralizador estabelecido na Constituição de 1937, que buscou avançar nas limitações ao exercício do poder tributário até então exercido pelos demais entes tributantes em prol da União. ${ }^{206}$

Curiosamente, o art.122 ("dos direitos e garantias do cidadão"), que seguiu a tendência já incorporada nas Constituições anteriores estabelecendo o princípio da igualdade e legalidade, não apresentou qualquer dispositivo expressamente tributário, ao contrário de sua antecessora.

A Constituição de 1937, em sua tendência centralizadora, enfrentou o problema da competência outorgada aos Estados para impostos sobre a exportação, excluindo a possibilidade de exigência desse imposto entre os Estados, e restringiu essa competência apenas relacionada às mercadorias destinadas ao exterior ${ }^{207}$. Em suma, a discriminação constitucional de rendas tributárias na Constituição de $1937^{208}$ manteve praticamente igual a discriminação de rendas da Constituição de 1934, com algumas diferenciações.

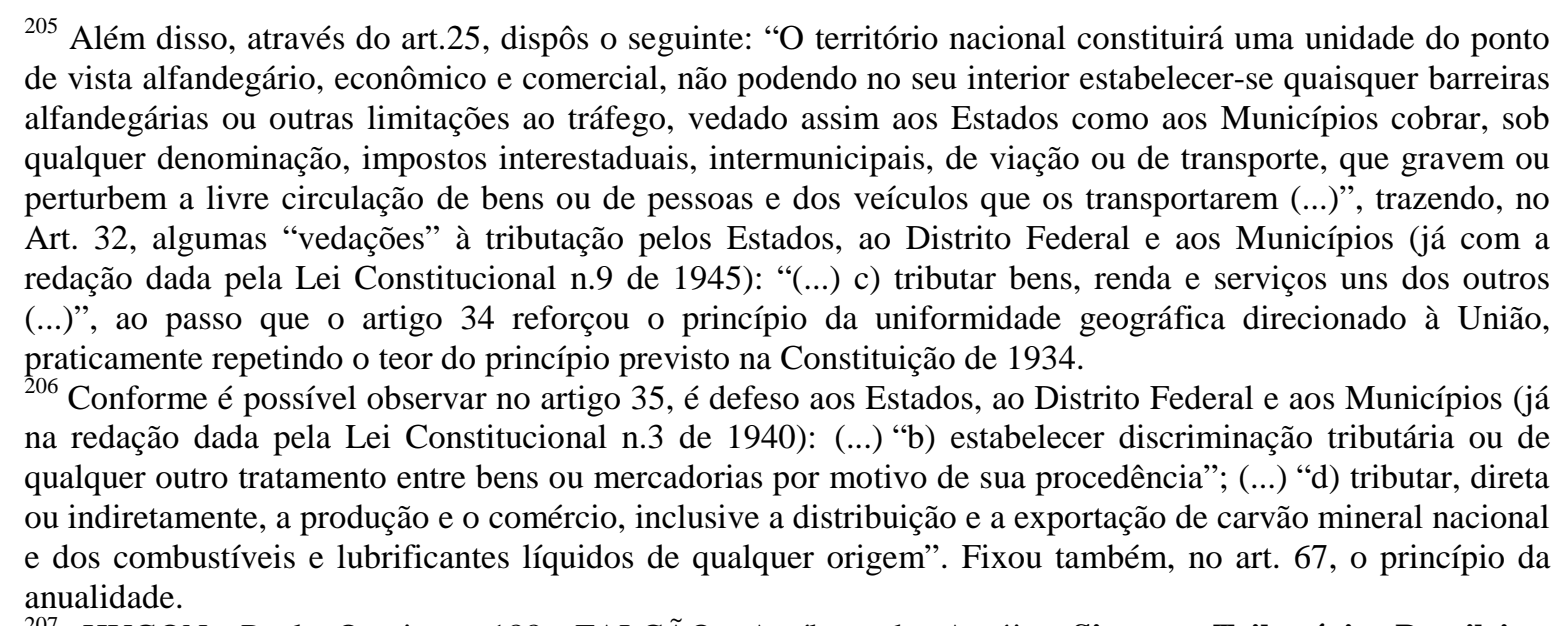

${ }^{207}$ HUGON, Paul. Op.cit., p.188. FALCÃO, Amílcar de Araújo. Sistema Tributário Brasileiro. Discriminação de Rendas. Rio de Janeiro: Edições Financeiras, 1965, p. 35.

${ }^{208}$ Conforme o artigo 20 da Constituição de 1937 estabeleceu-se a competência da União para impostos sobre: importação de mercadorias de procedência estrangeira; consumo e quaisquer mercadorias; de renda e proventos de qualquer natureza; de transferência de fundos para o exterior; sobre atos emanados do seu governo, negócios da sua economia e instrumentos ou contratos regulados por lei federal. Já os Estadosmembros ficaram reservados aos seguintes impostos: sobre propriedade territorial, exceto a urbana; transmissão de propriedade causa mortis; transmissão de propriedade imóvel intervivos, inclusive a sua incorporação ao capital e sociedade; vendas e consignações efetuadas por comerciantes e produtores, mantendo-se isenta a primeira operação do pequeno produtor (conforme seria definido em lei estadual); exportação de mercadorias de sua produção até o máximo de $10 \%$ ad valorem, vedando-se quaisquer adicionais; industrias e profissões, atos emanados de seu governo e negócio de sua economia, ou regulados 
Mas sobre a efetividade da Carta de 1937, vale ressaltar a importante opinião de Alcides Jorge Costa: “A Constituição de 1937 nunca chegou a ser praticada. Foi outorgada por Getúlio Vargas”209. No mesmo sentido, apontou Ubaldo Cesar Balthazar, em face da ditadura implantada no país, na época ${ }^{210}$.

Apesar disso, Amílcar de Araújo Falcão analisou que, a partir da Carta de 1934, dois novos critérios importantes foram introduzidos na discriminação de rendas: "o da limitação da concorrência concorrente pelo óbice da bitributação e o da definição da competência dos Municípios para decretar impostos privativos". E, ainda, acrescenta-se o reforço da competência privativa federal, incluindo-se impostos sobre o consumo de mercadorias, sobre a renda, e sobre a transferência de fundos para o exterior, também fixando competência privativa estadual para o imposto de vendas e consignações ${ }^{211}{ }_{-}^{212}$.

Mas, de fato, o papel reservado aos princípios constitucionais tributários ainda permanecia severamente restrito, praticamente repetindo os teores dos artigos da Constituição de 1934, e as chamadas vedações aplicadas aos entes tributantes ainda não apresentavam estruturação organizada. Sequer havia a compreensão de um "sistema tributário" naquelas cartas constitucionais, o que certamente prejudicava a compreensão conjuntural do fenômeno.

As crises financeiras decorrentes das transformações políticas (Monarquia para República), aliadas a crises mundiais (como a Primeira Guerra Mundial e o Crack de 1929), forneceram importantes substratos para a revisão (e expansão) do papel da atividade tributária no Estado. No âmbito teórico (econômico), as ideias de Keynes passaram a

por lei estadual. Finalmente, aos Municípios competiu a instituição dos seguintes impostos: sobre licenças; sobre propriedade predial e territorial urbana; sobre diversões públicas.

${ }^{209}$ COSTA, Alcides Jorge. A História da Tributação no Brasil. Op.cit., p. 78-79.

${ }^{210}$ Contudo, salienta Balthazar: “(...) foi uma carta relativamente observada mais pelos interesses de Estados e Municípios do que por atuação do contribuinte brasileiro”. BALTHAZAR, Ubaldo Cesar. Op.cit., p. 121 e ss.

${ }^{211}$ FALCÃO, Amílcar de Araújo. Sistema Tributário Brasileiro. Discriminação de Rendas. Op.cit., p. 3536.

${ }^{212}$ Em síntese, a Constituição de 1937 modificou pouco o sistema já estabelecido na Constituição anterior, registrando-se que os Estados perderam competência privativa para tributar sobre o consumo de combustíveis de motor a explosão, e foi retirada a competência outrora municipal para tributar a renda das propriedades rurais. O campo de competência residual passou à esfera privativa dos Estados, sem qualquer repartição. No ano de 1940, a Lei Constitucional n.3 proibiu aos Estados o lançamento de tributos sobre carvão mineral e sobre combustíveis e lubrificantes líquidos e o Ato Constitucional n.4 incluiu na competência da União o imposto único sobre a produção, comércio e distribuição, o consumo, a importação e exportação de carvão mineral e dos combustíveis e lubrificantes líquidos de qualquer origem. VARSANO, Ricardo. A Evolução do Sistema Tributário Brasileiro ao longo do Século: Anotações e Reflexões para Futuras Reformas. Texto para Discussão no 405, Rio de Janeiro: IPEA, 1996, p. 03-06. 
serem repercutidas no final da década de trinta no Brasil (até porque a obra de Keynes foi publicada em 1936). Mas o elemento teórico (econômico) ainda não era o bastante para significar o aumento progressivo da atividade tributária ${ }^{213}$.

Nesse quadro, com importantes modificações surgidas na década de quarenta, especialmente impulsionadas pela Segunda Guerra Mundial (1941-1945), o Brasil experimentou nova reorganização política, que ficou simbolizada pela promulgação de Constituição Federal, de 1946, essa que se notabilizou pelo esforço na organização da temática tributária, o que favoreceu diretamente o seu disciplinamento infraconstitucional e, consequentemente, a melhor atenção pela doutrina ${ }^{214}$.

\section{As tentativas iniciais disciplinares (autonomistas) na fase pré-disciplinar do Direito Tributário Brasileiro: o período de transição.}

A realidade tributária brasileira, conforme já observado, até as primeiras décadas do século XX, manteve clara inclinação à Ciência das Finanças, e, especialmente a partir dos últimos anos da década de trinta, maior aproximação com a experiência francesa e italiana do Direito Tributário (possivelmente pela proximidade linguística) que, naquele período, estava florescendo naquelas nações. Naturalmente, o fato de a literatura francesa e a italiana na época também apresentarem sólida influência da Ciência das Finanças reforçava ainda mais a influência dessa disciplina nas produções jurídicas tributárias nacionais.

Mesmo nas primeiras décadas do século XX identifica-se a prevalência quase absoluta de estudos técnicos de caráter prático (esses nunca faltaram, na realidade), a exemplo de estudos e comentários dos autores Paulo Barbosa de Campos Filho, Otto Gil (“Lições de Direito Fiscal”, publicado em 1937), o estudo profissional de Clóvis Ribeiro (Revista dos Tribunais, 1924, 49/127), e o "Comentário", de Melo Rocha, que, segundo lembra Brandão Machado, mostrava o erro na invocação do Direito Civil para a regulação da repetição de indébito tributário. Este trabalho destacou-se frente aos demais pela sólida

\footnotetext{
${ }^{213}$ Sobre o assunto, ver tópico 6.2 deste Capítulo.

${ }^{214}$ Sobre o assunto, ver tópico n. 6.7 deste Capítulo.
} 
pesquisa na doutrina estrangeira (publicado em Revista de Crítica Judiciária, 1928, 7/541 a $570)^{215}$.

Contudo, em análise da coletânea de pareceres publicados por Otto Gil (em sua maioria) e Vizeu Gil, publicados a partir de 1937, por sua vez denominada "Direito Fiscal", e, evidentemente, focada em pareceres sobre o assunto, pode-se confirmar que, de fato, ainda que de elevado valor, não ultrapassavam o caráter de produção técnica, sem remissões às produções teóricas estrangeiras (já avançadas na época), onde a principal referência teórica identificável era Tito Rezende (e seus pareceres técnicos sobre imposto sobre consumo e sobre a renda) na Revista Fiscal ${ }^{216}$, e, ocasionalmente, pareceres ou obras de autores nacionais.

Já os trabalhos técnicos publicados a partir da década de cinquenta, apresentavam remissões aos trabalhos de Rubens Gomes de Sousa ${ }^{217}$, Vanoni ${ }^{218}$, Carlos Maximiliano, Pontes de Miranda e Francisco Campos. Destaque-se, no entanto, Parecer publicado em 1952, em que Otto Gil defende, baseado em Albert Hensel, Buhler, Damervalle, Puglièse, Tesoro, Thomas Cooley, Jèze, Ezio Vanoni e Adam Smih, a determinação exata da incidência na lei (determinando os primeiros passos para a legalidade estrita na estrutura dos tributos), para quem “(...) não se cria incidência por analogia"219_220_221.

Também merece menção a coletânea de pareceres de F.Sá Filho no Rio de Janeiro, denominada "Estudos de Direito Fiscal", publicada em 1942, que reuniu estudos publicados entre 1933 e 1939. Em Parecer publicado em 1933, chegou a elevar a autonomia do Direito Fiscal frente ao Direito Privado, baseado no célebre debate entre Geny e Trotabas, assim como nas lições de Myrbach-Rheinfeld, Enno Becker,

\footnotetext{
${ }^{215}$ Sobre a dificuldade do período para identificar obras de Direito Tributário, consulte-se o excelente estudo de Brandão Machado, cujos estudos supramencionados foram analisados: MACHADO, Brandão. Apresentação, In: MORAES, OSWALDO de. Op.cit., p.vii-xiii.

${ }^{216}$ GIL, Otto; GIL, Vizeu. Direito Fiscal. Pareceres e Memoriais. Rio de Janeiro: Associação Comercial do Rio de Janeiro e Associação Bancaria do Rio de Janeiro, s/d, p. 13 e ss.

${ }^{217}$ Idem, p. 11.

${ }^{218}$ Idem, p. 05.

${ }^{219}$ Idem, p. 23 e seguintes.

220 Destaque-se também Parecer da Comissão Especial constituída por Vizeu Gil, Aliomar Baleeiro e Gilberto Ulhôa Canto, em 1957, sobre o imposto de renda, que mostra já atualizados estudos refletidos pela doutrina tributária europeia da época. GIL, Otto; GIL, Vizeu. Direito Fiscal. Op.cit., p. 29 e ss.

${ }^{221}$ Outro estudo que mostra considerações sobre o Direito Fiscal pode ser observado no estudo de GIL, Otto. La Preuve en Droit Fiscal. Trabalho publicado no XIIème Congrés International de Droit Financier et Fiscal (Bruxelles, Septembre,1958). In: GIL,Otto; GIL, Vizeu. Op.cit., p. 01 e ss.
} 
Blumenstein, Vaononi, e Griziotti. Mostrava-se, portanto, bastante atualizado com a moderna literatura tributária da época ${ }^{222}$.

Ademais, em muitos aspectos, seus pareceres não raramente buscavam refúgio em estudos elaborados no âmbito da Ciência das Finanças, como é o caso de parecer destinado a distinguir impostos de taxas, ao considerar as lições de Francisco Campos. Por outro lado, em outro parecer (publicado em 1940), sobre a interpretação da lei tributária, faz interessantes considerações sobre as antigas interpretações "in dubio contra fiscum", tomando como base as referências históricas de Vanoni e seu celebrado estudo ${ }^{223}$. Por fim, apresentou interessante parecer (publicado em 1933) sobre a reforma dos Conselhos de contribuintes, buscando a unificação do processo fiscal administrativo, defendendo a igualdade de direitos do fisco e do contribuinte, em face das normas processuais ${ }^{224}$, além de ter mencionado outros estudiosos da época, como Tesoro e Otto Mayer.

Mas, de fato, o autor que realmente diferenciou-se dos demais no sentido de viabilizar o desenvolvimento do Direito Tributário no Brasil, na mesma época, foi João Martins de Oliveira, magistrado em Minas Gerais que, dentre outros estudos, publicou importante obra claramente destinada a impulsionar os estudos jurídicos tributários no Brasil. Ou seja, tencionava elevar a autonomia do Direito Tributário, enquanto disciplina jurídica, distinta do Direito Privado e da Ciência das Finanças.

Em livro pioneiro sobre o Direito Tributário (em sua perspectiva "jurídica") 225 , publicado em $1943^{226}$, no Rio de Janeiro, criticou duramente a realidade da cultura jurídica

\footnotetext{
${ }^{222}$ FILHO, F. Sá. Estudos de Direito Fiscal. Imposto de selo sobre conhecimentos de carga - Falta de assinatura - Requisitos - Tributabilidade pelos caracteres aparentes do ato - autonomia do direito financeiro - (Recurso n.478 R, de 1933). Parecer publicado em 29 de novembro de 1933. In: Estudos de Direito Fiscal. Rio de Janeiro: Imprensa Nacional, 1942, p. 01-05.

${ }^{223}$ FILHO, F.Sá. Interpretação da lei tributária, “in dúbio contra fiscum”? - Processo n.5877/40. In: FILHO, F. Sá. Estudos de Direito Fiscal. Op.cit., p.35-38.

${ }^{224}$ FILHO, F.Sá. Reforma dos Conselhos de Contribuintes, suas diretrizes - Codificação do processo fiscal - Ofício n.50 de 1933. In: Idem, p. 501-504.

${ }^{225}$ OLIVEIRA, João Martins. Direito Fiscal (Estudos doutrinários e anotações ao decreto-lei n.960, de 17 de dezembro de 1938). Rio de Janeiro: Livraria Jacinto, 1943, p.08 e seguintes.

${ }^{226}$ Essas interessantíssimas passagens foram extraídas da obra "Direito Fiscal", publicada no ano de 1943, que se divide em duas partes: a) a primeira essencialmente doutrinária e que reúne conceitos e definições relativas ao Direito Fiscal mais avançadas na doutrina jurídica europeia (e algumas remissões à doutrina brasileira); b) anotações sobre o decreto-lei n.960, de 17 de dezembro de 1938, com jurisprudência atinente. Mostrava conhecer as obras de autores europeus como Trotabas, Vanoni, Puglièse, Griziotti, Gannini, Otto Mayer, Myrbach-Rheinfeld, Fritz Fleiner, dentre outros, demonstrando esforço diferenciado de seus antecessores. Entretanto, apesar de seus indiscutíveis méritos, essa obra teve somente uma única edição e são desconhecidas da presente pesquisa as razões para tal fato, e nem teve grande difusão entre os estudos da
} 
brasileira naquele período (início da década de quarenta), que, para ele, era de um grande descaso e quase aversão pelo estudo dos problemas jurídicos resultantes da atividade financeira estatal.

Note-se que a obra de João Martins de Oliveira apresentava semelhante aspiração vislumbrada em Myrbach-Rheinfeld, tentando trazer um raciocínio eminentemente jurídico (e consequentemente formal e positivista) ao direito tributário.

Essa característica pode ser explicada também pela sólida influência do formalismo e positivismo jurídico da Escola de Nápoles (sobretudo Giannini), embora também se identifiquem claras ponderações causalistas (por influência de Griziotti), na obra do autor.

De qualquer forma, essa obra destacou-se das demais na época, embora Brandão Machado considere que mesmo este estudo, a exemplo dos demais, foi incapaz de inspirar o desenvolvimento do estudo e o aumento do interesse sobre a disciplina no Brasil ${ }^{227}$.

Somente a partir da década de quarenta é que se vislumbra maior interesse aos estudos jurídicos tributários no Brasil, e o estudo do Direito Tributário começa a ganhar corpo na doutrina brasileira, ainda que em passos lentos, e claramente refletidos pela influência europeia. Esses, notadamente oriundos da Itália, França e Alemanha (cujas lições foram repercutidas pelas duas primeiras), acabaram progressivamente absorvidos pela doutrina brasileira.

Tal influência chegou a gerar até mesmo a absorção de institutos, conceitos construídos naqueles ambientes teóricos, que acabaram adaptados à realidade tributária brasileira, como é o caso da autonomia, da interpretação das leis fiscais, da relação tributária, e, evidentemente, do fato gerador.

Mas realmente muito pouco pode ser observado como doutrina de produção legitimamente brasileira, e por esse motivo é dificultosa qualquer afirmação de que o período vislumbrado entre o século XIX (a partir de Ferreira Borges) e as três primeiras décadas do século XX indicaria efetivamente a consolidação disciplinar do Direito Tributário Brasileiro.

época, especialmente em São Paulo, cujos primeiros trabalhos sequer o mencionavam. OLIVEIRA, João Martins de. Op.cit., p.01-26.

${ }^{227}$ MACHADO, Brandão. Apresentação, In: MORAES, OSWALDO de. Op.cit., p.vii-xiii. 
Abaixo foram listados os obstáculos para a consolidação da disciplina no período, com base nos relatos de João Martins de Oliveira, cumulados com as restrições de Brandão Machado.

\section{Os obstáculos ao processo disciplinar (autonomia teórica e autonomia de ensino) do Direito Tributário no Brasil nas primeiras décadas do século XX.}

Conforme já observado, João Martins de Oliveira foi um dos primeiros autores a efetivamente debater a tributação sobre a perspectiva jurídica (com tendência claramente formalista e positivista) da investigação no Direito Tributário Brasileiro.

Para Oliveira, a dificuldade para a consolidação disciplinar do Direito Tributário no Brasil passava por alguns obstáculos pontuais, e era caracterizada pela ampla dependência do influxo científico proveniente de outras nações (especialmente de países europeus).

Naturalmente, na visão do autor, o problema crônico que envolvia a matéria passava pelo completo desconhecimento do assunto pela população da época, problema que também assolava os teóricos da época, cujos mais corajosos dedicavam-se ao estudo do fenômeno financeiro em seu substrato econômico. Oliveira entendia que a dedicação de estudiosos brasileiros ao fenômeno tributário pela perspectiva da Ciência das Finanças era resultado de secular descaso com o trato da matéria, o que evidenciava “(...) pobreza de nossa literatura jurídica em matéria fiscal"228.

Para o autor, três motivos concorriam para ocasionar essa lacuna: a) a formação civilista dos juristas brasileiros; b) a falta de atração da matéria, motivada pela antiga “odiosidade" do imposto; c) e as flutuações da legislação tributária ${ }^{229}$.

Em primeiro lugar, a cultura civilista (o chamado "Direito Comum") floresceu no momento em que doutrinas individualistas e liberais atingiam seus ápices, ou seja, em meados do século XIX. Porém, com os caracteres prevalecentes da "socialização" do Direito (aparentemente, Oliveira referia-se ao Estado Social de Direito e à Política

${ }^{228}$ OLIVEIRA, João Martins de. Op.cit., p. 08.

229 "O civilismo tem constituído obstáculo ao desenvolvimento do direito financeiro, não porque dê origem à pigrizia mental, de que falou Vanoni, nem por impregnar misoneismo á vivaz mentalidade dos juristas, mas porque as modernas concepções do direito são incompatíveis com os seus cânones e tendências". Idem. 
Keynesiana), chegava o momento de o publicismo tomar sua posição de direito no mundo jurídico, livrando-se das amarras do civilismo. Em verdade, atribuía às predileções pelo Direito Civil, o verdadeiro óbice ao desenvolvimento do Direito Administrativo e, por extensão, ao Direito Tributário, em todos os países.

O segundo motivo refere-se à tendência histórica de aversão a questões do imposto, já que “(...) as velhas concepções dos tributos e os seus pesados processos de arrecadação fizeram sofrer muitas gerações de modo que, na atualidade, se torna difícil imprimir na consciência pública a verdadeira noção do impôsto como obrigação jurídica"230.

E o último motivo lembrado por João Martins de Oliveira foi o abandono do estudo das leis fiscais devido à sua “(...) contínua flutuação”. A complexidade, a alteração e a inovação constante de leis fiscais, provocavam contrariedades entre contribuintes que “(...) veem sempre aumentados seus deveres fiscais" ${ }^{231}$.

Mas o argumento relativo ao maior apego aos estudos civilistas aos estudiosos brasileiros (e o consequente descaso aos estudos fiscais) não foi aceito plenamente pela doutrina. Brandão Machado, discordando de João Martins de Oliveira, defendeu a improcedência do argumento de que o atraso dos estudiosos brasileiros seria decorrente do maior apego ao Direito Privado, o que incorreria em resistência ao reconhecimento de uma nova disciplina publicista ${ }^{232}$.

Segundo Brandão Machado, esse argumento deve ser desconsiderado pelo simples fato de que na Alemanha, conhecida pelos seus grandes civilistas, não deixou de lado o interesse pelo Direito Tributário (já que muitos dos grandes tratadistas do Direito Tributário eram originários do Direito Civil, a exemplo de Nawiasky). O próprio Klaus Tipke (em Finanz-Rundschau, 1968, p.5), lembrado por Brandão Machado, reconhecia a

\footnotetext{
230 "Hoje, é preciso esclarecer que o tributo tem a sua causa e não é consequência do arbítrio de quem governa. Também é preciso pôr em evidencia que não póde ser odioso o que é necessário à existência do Estado". OLIVEIRA, João Martins de. Op.cit., p. 08.

231 "E o erro maior está nas inovações, pois é sabido que impôsto velho é pago sem relutância, porque está previsto no orçamento de cada cidadão. Verdadeira fonte de receita é o estímulo à produção, ao comercio e à industria que levam florescimento à fortuna particular. Também a despesa pública deve ser prevista sob critério que a faça legitima e estritamente necessária. Tributar e tributar sempre não faz a riqueza do Estado e aumenta o custo de vida dos cidadãos". Idem, p.08 e seguintes.

${ }^{232}$ MACHADO, Brandão. Apresentação. In: MORAES, OSWALDO de. Op.cit., p.vii-xiii.
} 
participação de estudiosos do Direito Civil na formação do Direito Tributário Alemão, não diminuindo em nada o interesse pela nova ciência ${ }^{233}$.

Em verdade, o fator primordial para o desenvolvimento da disciplina somente a partir da década de quarenta no Brasil refere-se à influência francesa e italiana (e sua preferência pela ciência econômico-financeira), que influenciou decisivamente a cultura jurídica brasileira, de forma que noções próprias de Ciência das Finanças eram tomadas como conceitos típicos da ciência "jurídica" tributária.

Diferença importante deve ser lembrada sobre as perspectivas de estudo propriamente analisadas nas doutrinas de língua alemã, onde o fenômeno jurídico da tributação constituía-se objeto de tratamento científico cada vez mais rigoroso, ao passo que em outros países, o fenômeno tributário ganhava predileção pela sua abordagem econômico-financeira, como foi o caso da Itália e da França ${ }^{234}$.

Isso não significa inferioridade da produção italiana e francesa relacionada ao fenômeno da tributação, conforme bem salienta Brandão Machado, mas efetivamente deve-se reconhecer que, na Itália, o Direito Tributário, enquanto ciência jurídica, recebeu desenvolvimento tardio, ao passo que na França prevaleceu a orientação pelo tratamento peculiar da legislação fiscal (também misturando elementos de Direito Tributário e Ciência das Finanças) ${ }^{235}$.

Portanto, fato histórico que deve ser reconhecido de antemão foi a prevalência da influência das produções teóricas de língua francesa e italiana no Brasil.

Por esse motivo não é surpresa que o Brasil, conforme ensina Brandão Machado, experimentaria “(...) os mesmos inconvenientes”.

Não é coincidência que somente com a efetiva consolidação italiana do Direito Tributário, a partir de Ranelleti, Vanoni, Puglièse e Giannini (entre a década de trinta e

\footnotetext{
${ }^{233}$ Idem.

${ }^{234}$ MACHADO, Brandão. Apresentação. In: MORAES, OSWALDO de. Op.cit., p.vii-xiii.

${ }^{235}$ Idem.
} 
quarenta), entre outros, é que o Direito Tributário Brasileiro realmente se consolidou como uma literatura jurídico-tributária. ${ }^{236}{ }^{237}$

Note-se também que, embora João Martins de Oliveira criticasse acidamente essa dependência à cultura civilista, o alicerce fundamental para suas construções teóricas embasavam-se (quando não utilizava de elemento de Ciência das Finanças e Legislação Financeira, bem como das doutrinas do "Direito do Imposto", de matriz germânica, e do Direito Financeiro ou Tributário Italiano), não raras vezes, aos institutos do Direito Privado para suplantar a lacuna evidente que a falta de uma legislação coesa e estruturada em matéria fiscal acarretava, o que denunciava ainda restrito desenvolvimento da disciplina no Brasil, ainda em meados da década de quarenta.

Assim, ironicamente, a própria estrutura da obra de João Martins de Oliveira acabava favorecendo a argumentação de Brandão Machado, sobre a influência civilista, que, embora importante, não seria o verdadeiro óbice ao desenvolvimento do Direito Tributário no Brasil.

Por outro lado, não se pode deixar de lado também que as peculiaridades históricas da doutrina brasileira (em sua adoção, ponderada ou não, da doutrina do direito privado) devem ser analisadas à luz da particular experiência nacional (já que produto direto de fatores jurídicos e extrajurídicos não necessariamente identificáveis na experiência estrangeira alemã ou italiana).

Essa situação, contudo, iria apresentar sinais de mudança nos anos seguintes, motivada por importantes fatores jurídicos, econômicos e políticos do período.

\section{Fatores Externos que impulsionaram o processo disciplinar do Direito Tributário no Brasil a partir da década de quarenta}

\footnotetext{
${ }^{236}$ Ibidem.

${ }^{237}$ Tome-se como exemplo a obra de João Martins de Oliveira, pois a própria estrutura do manual elaborado pelo autor muito se assemelhava à estrutura dos principais cursos ou manuais didáticos de direito financeiro e de legislação fiscal escritos (ou traduzidos) em língua italiana ou francesa da época. GIANNINI, Achille Donato. Il Rapporto Giuridico D'Imposta. Milano: Giuffrè Edittore, 1937, p.v-vii. OLIVEIRA, João Martins de. Op.cit., p.01 e seguintes.
} 


\subsection{Crises políticas e econômicas do período e reflexos tributários.}

O desenvolvimento crescente da doutrina (autonomia teórica) do Direito Tributário Brasileiro a partir da década de quarenta não é resultado único e exclusivamente da produção doutrinária emergente do período. Injustiça seria desconsiderar importantes elementos econômicos, políticos e sociais que contribuíram diretamente para a elevação do interesse sobre a matéria, direcionando o rápido desenvolvimento da disciplina nesse período.

Com a economia brasileira passando por importantes reformulações na última metade do século XIX, verificou-se a urgente necessidade de uma mudança estrutural em todo o sistema econômico brasileiro tendente à melhor formação de capital e atração de investimentos. Essa mudança dependia do processo de industrialização, que teve início no Brasil nos últimos anos do século XIX, por sua vez impulsionado por fatores econômicos, políticos, e sociais da realidade brasileira. Passados os problemas crônicos mundiais decorrentes das primeiras décadas do século XX, sobretudo pela eclosão da Primeira Guerra Mundial (1914-1918), bem como a "Crise do Café", no contexto brasileiro e, no âmbito global, pela Crise de 29, o impulso industrial definitivo no Brasil ocorreu a partir da década de 30 do século XX. Isso porque segundo Antonio Correia de Lacerda “(...) de modo geral, até a década de 1930, o desenvolvimento capitalista do país tivera um caráter esporádico dado as condições de domínio do latifúndio semifeudal e as formas de capitalismo inferiores". ${ }^{238}$

Com a revolução de 30, ocorrida em 3 de outubro de 1930 inicia-se a Segunda Fase do período republicano brasileiro, com a tomada do poder por Getúlio Vargas, na condição de chefe da Junta Provisória.

Essa circunstância gerou ampla reformulação nas estruturas políticas do período, através, sobretudo, do Decreto n.19.398 de 11 de novembro de 1930, quando foram dissolvidos o Congresso nacional, as Assembleias Legislativas Estaduais e as Câmaras Municipais. Nesse contexto, os Governadores de Estados foram substituídos por interventores nomeados pelo Presidente da República. Apesar da Revolução de 1930,

${ }^{238}$ LACERDA, Antonio Correia de. et al. Economia Brasileira. 3.ed. - São Paulo: Saraiva, 2006, p.60. 
praticamente toda a legislação anterior (inclusive tributária) mantinha-se em vigor, desde que não contrariasse as disposições emanadas pelos novos governantes.

Politicamente, tratava-se de um período marcado pela grande instabilidade política, especialmente em decorrência de eventos como a Revolução Constitucionalista no ano de 1932 em São Paulo. A esse momento de instabilidade política somaram-se também os efeitos que a Quebra da Bolsa de Valores de Nova York teve na produção e comércio do café no Brasil. E a própria estrutura tributária brasileira viu-se afetada por tal crise, já que o Brasil dependia fortemente do imposto de importação, sua mais relevante receita tributária na época, e que foi sensivelmente afetada pela queda do volume do comércio internacional provocada pelo Crack da Bolsa.

Na realidade, a sensível diminuição do comércio internacional não afetara apenas o Brasil, mas todo o mundo. Paul Hugon, na obra "O Imposto", relata que naquele período, mais precisamente em 1928, o comércio internacional elevava-se ao valor de 38,5 bilhões de dólares para as importações e a 32,6 bilhões de dólares para as exportações. Já depois da crise, em 1935, as importações reduzem-se a 21 bilhões e as exportações em 19 bilhões.

No ano de 1938 registrou-se tímida elevação comercial, motivada, sobretudo, pelo comércio originário dos preparativos bélicos de alguns países às vésperas da Segunda Guerra Mundial, quando as importações sobem para 24 bilhões e meio e as exportações elevam-se para 22 bilhões. De qualquer forma, pode-se dizer que não foi fácil ou rápida a recuperação da balança comercial internacional ${ }^{239}$.

Aliás, entre 1891 e 1930, foram criados dois importantes impostos para a estrutura econômica do país: a) criou-se em 1922 um Imposto de Vendas Mercantis; b) criou-se, no mesmo ano, o Imposto de Renda (artigo 31 da Lei de Orçamento n.4.625, de 31 de dezembro de 1922, emendada pela Lei 4783 de 31 de dezembro de 1923 e alterações posteriores, mas somente aplicado em 1926) ${ }^{240}$. Note-se, todavia, que não estavam previstos expressamente na Constituição, mas foram estabelecidos conforme o campo residual autorizado à criação desses tributos. A Constituição de 1891 durou até o ano de 1930.

\footnotetext{
${ }^{239}$ HUGON, Paul. Op.cit., p.180-181.

${ }^{240}$ AMED, Fernando José; NEGREIROS, Plínio José Labriola de Campos. Op.cit., p. 246-254.
} 
De 1930 até 1934, o Brasil foi governado por Decretos, até a Constituição de 1934, muito bem estudada e discutida, segundo Alcides Jorge Costa, no âmbito da partilha das receitas entre os entes federais. Ocorreu maior preocupação dos efeitos econômicos dos impostos $^{241}{ }_{-}^{242}$.

Ainda que nesse período deflagrassem esses importantes acontecimentos na órbita nacional e internacional, no Brasil, entre a Revolução de 1930 e a aprovação da Constituição da República de 16 de julho de 1934, conforme assinalou Bernardo Ribeiro de Moraes, muito pouco foi acrescentado à matéria tributária, não existindo espaço na época para suscitar reformas tributárias relevantes ${ }^{243}$.

No Brasil, naturalmente, não se poderia deixar de mencionar a importância da "Era Vargas" (1930-1945), período onde a industrialização impulsiona-se, sobretudo também favorecido pelo ciclo da Borracha, trazendo novas mudanças na política tributária ${ }^{244}$.

Esses acontecimentos tiveram importância histórica salutar para o desenvolvimento do Direito Tributário no Brasil, pois tais crises promoveram o "racha" com a política econômica de tradição liberal clássica, prevalecente nos países europeus e nos Estados Unidos durante praticamente todo o século XIX (e início do século XX), quando a atividade tributária encontrava papel severamente restrito em ambiente político de limitação à atividade estatal na economia e na sociedade.

\subsection{A Política Fiscal Anticíclica Keynesiana e a elevação da carga tributária no Brasil}

\footnotetext{
${ }^{241}$ COSTA, Alcides Jorge. História da Tributação no Brasil. Op.cit., p.76-77.

${ }^{242}$ Recomenda-se também a leitura das seguintes obras acerca das principais alterações na legislação tributária experimentadas no período: FERREIRA, Benedito. Legislação Tributária (História da Tributação no Brasil). 1986, p.73-100; AMED, Fernando José; NEGREIROS, Plínio José Labriola de Campos. Op.cit., p. 231-254.

${ }^{243}$ As principais inovações tributárias do período foram as seguintes: criação da taxa de educação e saúde, pelo Decreto n.21.335, de 29 de abril de 1932, que incidia sobre qualquer documento submetido ao selo federal, estadual ou municipal; criação da taxa especial de benefício (Decreto n.21.390, de 11 de maio de 1932), que possuía “(...) conceito de contribuição de melhoria”; criação do imposto proporcional sobre capitais empregados em hipotecas (Decreto n.21.949 de 12 de outubro de 1932. Em suma, foram poucas as alterações daquele período, mas causaram, por outro lado, elevação da receita pública, em comparação aos decênios anteriores. MORAES, Bernardo Ribeiro de. Compêndio de Legislação Tributária. Volume 1. Op.cit., p.134.

${ }^{244}$ AMED, Fernando José; NEGREIROS, Plínio José Labriola de Campos. Op.cit., p. 254 e seguintes.
} 
Com o racha impulsionado pela Primeira Guerra e pelo Crack da Bolsa, surge a necessidade de novos ares aos estudos econômicos. Ganha destaque a contribuição de John Maynard Keynes, assim como sua proposta de política econômica interventora, e, especificamente, a importância relegada pelo autor aos tributos que, a partir desse momento, teriam importância severamente majorada enquanto veículos viabilizadores das políticas econômicas e sociais ${ }^{245}$.

Evidentemente, embora tais considerações teóricas sobre a utilização de instrumentos financeiros pelo Estado já fossem discussões antigas nas doutrinas financistas, contudo, somente na década de trinta do século XX a expressão "Política Fiscal" ${ }^{246}$ passou a ser veiculada com significado específico, passando a significar a aplicação de determinadas teorias econômicas, através de mecanismos financeiros, "à política anticíclica"247. Essa ideia fundamenta a adoção da Política Fiscal enquanto instrumento de intervenção de estruturas econômico-sociais, e essa passou a ser identificada como corretivo das depressões econômicas, bem como de processos inflacionários $^{248}$.

Embora a obra de Keynes buscasse reformular a teoria econômica da época, rejeitando o liberalismo clássico individualista (prevalecente no século XIX e início do século XX na Europa), o viés de sua intervenção era marcado notadamente pela influência de fenômenos externos. Buscava responder às crises econômicas e sociais originárias daquele período, notadamente a Primeira Guerra Mundial e o Crack de 1929, em Nova York. Tencionava oferecer resposta que não foi alcançada pelos pressupostos do liberalismo econômico clássico, cujos postulados eram severamente criticados por Keynes,

\footnotetext{
${ }^{245}$ Sobre o assunto: KEYNES, John Maynard. El camino hacia La prosperidad. In: La Politica Fiscal em Accion. In: DEL BRIO, Francisco Dominguez. Madrid: Instituto de Estudios Fiscales, 1971, p.81-119. Também: DEL BRIO, Francisco Dominguez. Estudio Preliminar. In: La Politica Fiscal em Accion. In: DEL BRIO, Francisco Dominguez. Madrid: Instituto de Estudios Fiscales, 1971, p.07-49.

${ }^{246} \mathrm{~A}$ ideia de política fiscal contemporânea teve forte reformulação no trabalho de Keynes, que, no ano de 1936, publicou estudo intitulado "Teoria Geral do Emprego, do Juro e da Moeda" (cujo título foi encurtado para Teoria Geral), revolucionando a Teoria Econômica da época, determinado o marco inicial para a macroeconomia, e concedendo caráter de elevada importância aos instrumentos financeiros. KEYNES, John Maynard. A Teoria Geral do Emprego, do Juro e da Moeda. Tradução de Mário R. da Cruz. São Paulo: Editora Atlas S.A., 1992, p. 23.

${ }^{247}$ BALEEIRO, Aliomar. Cinco aulas de finanças e política fiscal. $2^{\mathbf{o}}$ edição. São Paulo: José Bushatsky, 1975, p.29.

${ }^{248}$ Idem.
} 
especialmente no que tange às ideias prevalecentes sobre o trabalho, a produção e a possibilidade do mercado orientar as relações de emprego. ${ }^{249}{ }_{-}^{250}$

No que tange especificamente à tributação, Keynes defende o papel dos gastos públicos como complemento ao dispêndio privado, ${ }^{251}{ }_{-}^{252}$ consagrando a necessidade de que o papel do Estado alterasse sua feição, de índole restritivista e "neutra", no período liberal, para assumir papel intervencionista na economia e na sociedade. Embora assevere Bernard Pajiste que a temática tributária não ocupe grande extensão e desenvolvimento naquele trabalho de Keynes, ${ }^{253}$ a importância da tributação ficou evidenciada “(...) nas conclusões e notas finais redigidas por Keynes sôbre a filosofia social da Teoria Geral”." 254

Nesse aspecto, verifica Pajiste que a concepção de Keynes parte da constatação da existência de dois grandes vícios marcantes no mundo econômico. Por um lado, passa pelo reconhecimento da ineficiência da busca pelo pleno emprego (emprego digno). Por outro, passa pela noção de distribuição da fortuna e da renda, absolutamente arbitrária e carente de qualquer noção de igualdade, para Keynes. Assim, a instrumentalização da atividade tributária para satisfazer esses dois objetivos (alcançar o pleno emprego e a distribuição de renda) - seria proporcionada “(...) sobretudo através de uma mecânica fiscal, que pretende remedia-los" 255 .

A nova orientação da atividade tributária identificada por Keynes, fundamentado em necessidades da época, passa a representar, estruturalmente, uma atividade tributária ativa no combate às grandes depressões. Não é por outro motivo que, a partir dessas ideias de Keynes, a Política Fiscal passa a guardar grande aproximação terminológica à chamada "Política Fiscal Anticíclica" (de combate a depressões).

O direito tributário positivo, enquanto instrumento formalizador de políticas públicas, começa a ganhar maior importância, deixando de lado o papel restrito que era

\footnotetext{
${ }^{249}$ A Teoria Geral do Emprego (1937). John Maynard Keynes. Economia. Organizador: Tamás Szmrecsányi. $2^{\circ}$ edição. São Paulo: Editora Ética, 1984, p. 170.

${ }^{250}$ CONTADOR, Cláudio R. A Importância da Teoria Geral do Emprego, do Juro e da Moeda. Apresentação da Edição Brasileira. In: KEYNES, John Maynard. A Teoria Geral do Emprego, do Juro e da Moeda. Tradução de Mário R. da Cruz. São Paulo: Editora Atlas S.A., 1992, p. 11-12.

${ }^{251}$ KEYNES, John Maynard. A Teoria Geral do Emprego, do Juro e da Moeda. Op.cit, p. 24-27.

${ }^{252}$ KEYNES, Johm Maynard. A Teoria Geral do Emprego (1937). Op.cit, p. 175.

${ }^{253}$ PAJISTE, Bernard. Introdução à Política Fiscal. Rio de Janeiro: Edições Financeiras S.A., s/d, p. 26.

${ }^{254}$ Idem, p. 26

${ }^{255}$ PAJISTE, Bernard. Introdução à Política Fiscal. Op.cit., p. 24
} 
relegado pelas culturas econômicas liberais, e passando a se tornar instrumento de indiscutível importância para a intervenção na economia e na sociedade.

Nesse quadro, a experiência do direito tributário positivo no Brasil passava por gradativa alteração, especialmente entre a Constituição de 1891, liberal (com evidente restrição à matéria tributária), e as constituições posteriores que, em ambientes históricos propícios, passavam a conceder maior atenção à temática tributária.

As mudanças do período podem ser sentidas especialmente através do súbito aumento da carga tributária a partir da década de quarenta no Brasil, conforme o estudo elaborado por Gerson Augusto da Silva, em 1948 (em sua segunda edição) ${ }^{256}$, assim como em estudos elaborados pelo IPEA sobre a evolução da carga tributária no Brasil durante o século XX. Na realidade, a pesquisa enfocou o impacto tributário das discriminações previstas na Constituição de 1934 , e que foi praticamente reproduzida em $1937^{257}$.

Além disso, era o período em que se começou a sentir os efeitos da Segunda Guerra Mundial sobre a situação econômica e financeira do país. Conforme informa o Gerson Augusto da Silva, no ano de 1940 o conjunto de impostos brasileiros representava 65,5\% da receita total, que foi elevada para $76,6 \% \mathrm{em} 1946^{258}$.

Percebe-se que os impostos federais tiveram um grande salto representativo na receita da União. Gerson Augusto da Silva ponderou também que esse crescimento foi atribuído se a duas questões principais: a) crescimento considerável dos impostos (devido

\footnotetext{
256 Trata-se de estudo técnico de índole econômica, mas que representa grande utilidade para as considerações que se pretende remeter. Intitulado "Sistema Tributário Brasileiro" (possivelmente a primeira obra brasileira com esse título, expressamente remetida à noção de "sistema tributário"), traçava, inicialmente, a evolução do sistema, e depois sua composição (pacto federativo e discriminação de rendas tributárias entre os entes políticos). Vale ressaltar que a $1^{\text {a }}$ edição (cuja data não foi descoberta) era publicação oficial do Ministério da Fazenda, que gerou grande interesse nas áreas administrativas e legislativas, impulsionando a publicação de uma segunda edição. A $2^{a}$ edição teve seu acesso mais facilitado, pois se direcionava não somente aos membros dos poderes, mas ao público em geral. Foi esta edição (1948) a consultada, embora se remeta ao período ligeiramente anterior à entrada em vigor da Constituição de 1946. SILVA, Gerson Augusto da. Sistema Tributário Brasileiro. 2 2a Edição. Prefácio de Valentim F. Bouças. Rio de Janeiro: Ministério da Fazenda, 1948, p. 01 e seguintes.

${ }^{257} \mathrm{Na}$ época o autor não tinha acesso a dados resultantes da arrecadação decorrente do pacto federativo de 1946. Assim, comparou estatisticamente o período entre 1940 e 1946 . O autor afirma que escolheu principiar pelo ano de 1940 porque era o ano em que se efetuou a padronização dos orçamentos e balanços dos Estados e Municípios (Decreto n. 2416 de 17-7-1940, que uniformizou a nomenclatura dos tributos estaduais e municipais, facilitando estudos técnicos destinados a levantar dados tributários globais), permitindo o levantamento de estatísticas até então praticamente impossíveis. SILVA, Gerson Augusto da. Op.cit., p. 0205.

${ }^{258}$ Idem, p. 22.
} 
às alterações introduzidas na legislação de consumo); b) desincorporação do orçamento geral da renda de vários serviços industriais transformados em autarquias (até aquele período a segunda maior fonte de receita da União, atrás dos impostos, eram os serviços industriais fornecidos pelo governo). ${ }^{259}$

Recorde-se também que foi publicada pelo IPEA, com base nos dados do IBGE, a progressão da carga tributária (em média) entre 1930-1945. Assim, entre 1930-1935, a carga tributária correspondeu a 10,23\% do PIB, ao passo que entre 1936-1940, correspondeu aproximadamente a 12,5\%. Entre 1941 e 1945 elevou-se para $12,71 \%{ }^{260}$.

De modo geral, a evolução da renda geral dos impostos pode ser facilmente observada na década de quarenta, já que a arrecadação dos impostos em apenas sete anos (de 1940 para 1946) elevou-se de 4,9 Bilhões de cruzeiros para 16,4 Bilhões de Cruzeiros.

Em outras palavras, a arrecadação tributária, apesar de manter um ritmo mais ou menos perene até 1942, acelerou bruscamente a partir de 1943, e quase se quadruplicou em apenas curto período de tempo (1940-1946). Mas por que essa substancial elevação da carga tributária global no Brasil naquele contexto?

Gerson Augusto da Silva aponta algumas razões que poderiam explicar tal súbito crescimento: 1) alterações na legislação de determinados tributos, a exemplo do imposto de consumo e de vendas e consignações que teve suas alíquotas fortemente elevadas; 2) $\mathrm{O}$ aumento efetivo da renda nacional, já que a produção nacional e, especialmente, a produção industrial, experimentou nos sete anos analisados “(...) um aumento bem apreciável"; 3) a elevação considerável do nível dos preços, gerada pela inflação e cuja fase mais aguda corresponde exatamente ao biênio $1945-1946^{261}$.

A partir do ano de 1947 foi instaurado o sistema de contas nacionais do Brasil, alterando a sistemática de verificação da carga tributária geral, o que facilitou sobremaneira a análise e apuração de dados para se chegar à carga tributária nacional frente ao PIB.

\footnotetext{
${ }^{259}$ Ibidem.

${ }^{260}$ OLIVEIRA, Fabrício Augusto de. A evolução da estrutura tributária e do fisco brasileiro: 1889-2009. Texto para discussão n. 1469 Brasília: IPEA, 2010, p.01-31.

${ }^{261}$ SILVA, Gerson Augusto da. Op.cit, p. 23-24.
} 
Com base nessa mudança metodológica, em pesquisa patrocinada pelo IPEA, e com base nos dados fornecidos pelo IBGE, constatou-se que a carga tributária a partir de 1947 alcançou o percentual de 13,87\% global do PIB, ao passo que, no ano de 1948, a carga tributária global elevou-se para 14,03\% e, em 1949, manteve o crescimento para 14,39\% e, em 1950, a carga tributária global representava $14,42 \%$ do PIB. ${ }^{262}{ }_{-}^{263}$.

Já em 1946, o imposto de consumo era responsável por $40 \%$ da receita tributária da União, e o Imposto de Renda também assumia elevada importância, pois chegou, em 1944, a superar o imposto de consumo e, em 1946, representava $27 \%$ da receita tributária total da União.

O Brasil ingressa na etapa em que a tributação finca bases domésticas ao passo que consolida o crescimento industrial sustentado. Nesse contexto, a Constituição de 1946 trouxe poucas modificações, mas adiciona à competência municipal o imposto de selo e o imposto de indústrias e profissões (originalmente pertencentes aos Estados).

Os Estados tiveram alíquota máxima de imposto de exportação limitada a 5\%, e a competência residual voltou a ser exercida pela União e Estados. A partilha da União na competência residual significava ao Estado entregar 20\% à União e 40\% aos Municípios. A Constituição de 1946 prosseguiu na discriminação de rendas entre as esferas de governo, institucionalizando um sistema de transferência de impostos. ${ }^{264}$

\footnotetext{
${ }^{262}$ É importante salientar que os resultados distintos apurados pelas pesquisas investigadas não deve significar a equivocidade de uma ou outra proposta investigativa, mas apenas denunciam as diferentes formas de abordagem que cada trabalho procurou executar. De qualquer forma, o que realmente importa é visualizar o salto progressivo da carga tributária naqueles anos, dado que foi apontado unanimemente nas pesquisas consultadas. Este trabalho foi elaborado conjuntamente pela Diretoria de Pesquisa do IPEA e pela Secretaria de Assuntos Fiscais do BNDES. VARSANO, Ricardo; PESSOA, Elisa de Paula; SILVA, Napoleão Luiz Costa da; AFONSO, José Roberto Rodrigues. ARAUJO, Erika Amorim; RAMUNDO, Julio Cesar Maciel. Uma Análise da Carga Tributária do Brasil.Texto para Discussão n. ${ }^{\circ}$ 583, Rio de janeiro: IPEA, 1998, p. 39.

263 "Em 1947, quando teve início o registro sistemático das contas nacionais do Brasil, a carga tributária brasileira era de 13,8\% do PIB, como registra o Gráfico 1.1 Desde então, apresentou um crescimento lento até atingir 18,7\% do PIB em 1958. A partir daquele ano, iniciou uma trajetória de queda, chegando em 1962, em meio à crise institucional, a 15,8\% do PIB. Nos anos seguintes, marcados pela mais profunda reforma tributária por que passou o país, recuperou sua tendência ascendente. A reforma da década de 60 criou um sistema tributário que, a despeito de pecar contra a equidade e o grau de centralização, era tecnicamente avançado para a época". VARSANO, Ricardo; PESSOA, Elisa de Paula; SILVA, Napoleão Luiz Costa da; AFONSO, José Roberto Rodrigues. ARAUJO, Erika Amorim; RAMUNDO, Julio Cesar Maciel. Op.cit., p. 03.

${ }^{264}$ Naquele contexto histórico, com a restrição do imposto de exportação estadual, o imposto de vendas e consignações rapidamente ocupou o lugar de principal fonte de receita estadual, equivalendo à cerca de $45 \%$ da receita tributária dos Estados, ao passo que a participação do imposto de exportação decaiu para pouco
} 
Até o final da década de trinta, o imposto de importação, até a época o mais importante, acabou superado pelo imposto de consumo. Tal fato se deve também aos fatores externos, pois com a Segunda Guerra Mundial a participação na receita federal foi bruscamente reduzida em 1942, deixando de ser uma fonte primordial de arrecadação da União, e tal fato facilitou a opção governamental de torná-lo instrumento de política econômica (imposto regulador) a partir da década de $50^{265}{ }_{-}^{266}$.

A brusca elevação da carga tributária, decorrente dos motivos elencados por Gerson Augusto da Silva, e as profundas transformações na estrutura tributária da época, acabaram gerando progressivo interesse não somente dos técnico-fiscais e contabilistas, mas também dos juristas e contribuintes da época, que viam dia a dia crescer em importância aquele ramo do direito positivo.

Não é por outro motivo que se adianta a direta relação entre a elevação da carga tributária brasileira com o aumento do interesse dos estudos de Direito Tributário, sob a perspectiva essencialmente jurídica. Mas somente esses dois fatores não seriam capazes de desaguar tamanho processo disciplinar. Seriam necessários mais alguns ingredientes, que serão apresentados nas linhas seguintes.

\subsection{A "Crise do Supremo" e a luta pela criação de um Tribunal Fiscal (judicial) no Brasil}

No mesmo passo, com a elevação da carga tributária, aumenta-se a quantidade de lides envolvendo a matéria de Direito Público, provocando na década de quarenta a "Crise do Supremo", ocasionada pelo afogamento do Supremo Tribunal Federal em face do abrupto aumento dessas "lides", o que motivou diversos estudiosos, advogados, técnicos e

mais de $10 \%$. Essa tendência foi crescente e o imposto sobre vendas e consignações já ocupava, em 1946, $60 \%$ da receita tributária estadual. Já nos municípios o imposto sobre indústrias e profissões e o predial mantinham-se como os mais relevantes, correspondendo cada qual a um percentual variando entre $40 \%$ e 30\% da receita tributária.VARSANO, Ricardo. A Evolução do Sistema Tributário Brasileiro ao longo do Século: Anotações e Reflexões para Futuras Reformas. Texto para Discussão n ${ }^{\circ} 405$, Rio de Janeiro: IPEA, 1996, p. 03-06.

${ }^{265}$ Idem, p. 03-06.

${ }^{266}$ OLIVEIRA, Fabrício Augusto de. A evolução da estrutura tributária e do fisco brasileiro: 1889-2009. Texto para discussão n. 1469 Brasília: IPEA, 2010, p.01-31. 
profissionais a se manifestarem favoravelmente à consolidação de um Tribunal especializado para julgar lides fiscais, tentando seguir a experiência alemã.

Note-se que, no entanto, a existência de Tribunal destinado a julgar o contencioso administrativo fiscal já aparecia com antecedência a esses esforços, conforme se pode observar no Tribunal de Impostos e Taxas do Estado de São Paulo - TIT-SP, criado pelo Decreto n.7.184/1935, cuja criação, conforme assinala José Eduardo Monteiro de Barros, buscou “(...) precisamente o aperfeiçoamento da distribuição da justiça em matéria fiscal" 267 .

Mas a criação de Tribunais Administrativos não afastava a preocupação com o aperfeiçoamento da jurisprudência fiscal no âmbito judicial, conforme pode ser observado em Baleeiro, acerca do "relativismo jurídico" manifestado nos tribunais na aplicação do Direito Fiscal até a década de cinquenta, para quem “(...) não se alimentem ilusão sobre o conteúdo ontológico da "ciência jurídica do direito". Se ela existisse, - já foi dito, - seria possível profetizar-se como os tribunais decidiriam determinadas causas. As perplexidades de todos os tribunais do mundo provam aquele 'relativismo jurídico",268.

Diversos congressos foram realizados enfocando esse assunto, resultando na produção de algumas das primeiras obras sobre o Direito Tributário, sob a perspectiva jurídica.

É o exemplo dos estudos de Bilac Pinto, publicados entre a década de trinta e quarenta $^{269}$, que defendia expressamente a conveniência da criação do tribunal fiscal e a aplicação de um sistema de interpretação e aplicação da lei específica ao Direito

\footnotetext{
${ }^{267}$ BARROS, José Eduardo Monteiro de. Momento Histórico. Tit - 70 anos de Justiça Fiscal. In: Repertório Histórico - 1935-2005. Edição Comemorativa 70 anos de Justiça Fiscal, Secretaria da Fazenda do Estado de São Paulo, 2005, p. 23.

${ }^{268}$ BALEEIRO, Aliomar. Prefácio. In: Clínica Fiscal. Bahia: Editora Progresso, 1958, s/p.

${ }^{269}$ Bilac Pinto enfocou expressamente a necessidade de construção de um contencioso administrativo (e fiscal) mais adaptado às peculiaridades da matéria. Tal tendência administrativa não poderia causar surpresa, haja vista que foi justamente a criação do contencioso administrativo francês, no século anterior, que concedeu o passo efetivo para o desenvolvimento da disciplina, assim como ocorreu em países de língua germânica. Da leitura do prefácio do autor, nota-se preocupação pela emancipação do Direito Administrativo frente ao Direito Privado, sobretudo na pena dos juízes que, "salvo raras exceções, vinham decidindo as questões relativas ao direito administrativo à luz dos seus conhecimentos de direito privado (...)" e, naturalmente, essa preocupação se estendia ao Direito Tributário. PINTO, Bilac. Estudos de Direito Público. Edição comemorativa do cinquentenário da fundação da "Revista Forense". Rio de Janeiro: Revista Forense, 1953, p.01-03.
} 
Tributário, o que resultaria também na sugestão (observando a experiência estrangeira) da melhor organização legislativa sobre o assunto.

Foi claro defensor da autonomia do Direito Público (Administrativo e Fiscal) frente à influência do Direito Privado, e dessa linha defendida pelo autor, decorreriam duas consequências práticas: 1) “(...) No que tange à determinação do fato gerador, o direito fiscal não é obrigado a respeitar as qualificações do direito privado e do direito administrativo (...)”; 2) “(...) os princípios das disciplinas jurídicas afins nunca se aplicam como tais ao direito fiscal. O direito fiscal se rege por normas que lhe são próprias é a este respeito que se pode falar de verdadeira autonomia". ${ }^{270}{ }_{-}^{271}$.

Também nessa época foram realizados diversos eventos reunindo os profissionais da área para discutir e influenciar a criação desses tribunais fiscais, bem como estudos de relevo também foram elaborados, angariando importantes contribuições ao Direito Tributário na época, a exemplo do trabalho de Mozart da Gama que, em 1941, chegou a defender a conveniência (seguindo exemplo estrangeiro) da criação de uma codificação das normas tributárias no país. Em outras palavras: "Quando a nossa nação possuir o seu direito tributário, devidamente codificado e os seus Tribunais fiscais em pleno funcionamento, terá dado um "admirável passo à frente" para resolver o magno problema do sistema tributário perfeito". ${ }^{272}{ }^{273}$

Argumento absolutamente coerente com as tendências europeias voltadas ao desenvolvimento da disciplina, que geralmente eram diretamente posteriores à criação dos tribunais fiscais e à codificação da matéria fiscal. Nesse contexto, outra contribuição de Mozart da Gama pode ser identificada no trabalho intitulado "Direito Tributário e Justiça Fiscal" 274 , publicado no ano de 1941, quando buscou expressamente a criação de uma

\footnotetext{
${ }^{270}$ Idem, p.213-219.

${ }^{271}$ Possivelmente, um dos primeiros (e talvez o primeiro parecer publicado em temática fiscal por Bilac Pinto) foi o trabalho intitulado "Transmissão Causa Mortis - Instrumentos de Dívida não Registrados Impugnação do Fisco Estadual - O Direito Fiscal e a Figura Jurídica do "Terceiro" - Competência do Judiciário em face das Impugnações da Fazenda Estadual". Outros dois estudos relativos ao "Direito Fiscal" publicados naquele período foram: parecer publicado no ano de 1943 intitulado "Dívida Fiscal - Certidão da sua Inscrição - Emenda ou Substituição da Certidão - Lançamento Fiscal Retroativo"; Parecer intitulado "Desapropriação por Zona - Revenda Parcial de Imóveis Desapropriados - Financiamento de Obras Públicas - "Excess Condenation" - Contribuição de Melhoria", publicada também em 1943. Idem, p. 225-233; 357371.

${ }^{272}$ PINTO, Bilac. Op.cit., p. 63 e ss.

${ }^{273}$ Idem, p. 05-721,

${ }^{274}$ Para o autor, "É necessária e urgente a criação de uma Justiça Fiscal como órgão independente, porque ela muito poderá facilitar e colaborar na simplificação do sistema tributário, tornando mais fáceis e certas as
} 
Justiça Fiscal especializada, cuja estrutura apresenta realmente relevantes considerações jurídicas. $^{275}$

Ainda, observando o mesmo problema (das leis), e buscando reunir mais juristas para debater soluções para a "Crise no Supremo", organizaram-se algumas Conferências centralizadas na temática, a exemplo de evento organizado pelo Instituto de Advogados de São Paulo em 1943, que contou com a apresentação de alguns estudos sobre o tema ${ }^{276}$.

Foi justamente esse o caminho seguido por Rubens Gomes de Sousa, em sua obra inaugural na seara do "Direito Fiscal", intitulada "A Distribuição da Justiça em Matéria Fiscal no Brasil”, publicada no ano de 1943, onde propôs uma nova regulamentação no âmbito de criação de um tribunal especializado em matéria fiscal, organizado através de hierarquia própria, e tendo como órgão superior o próprio Supremo Tribunal Federal, como proposta de solução para o desembaraço do poder judiciário na época ${ }^{277}{ }_{-} 278$

Segundo Rubens Gomes de Sousa, os estudos publicados sobre o caso concordavam que o problema teria como principal origem o aumento das questões de

relações de direitos e deveres dos contribuintes e dos empregados do fisco. Essa Justiça terá ainda a extraordinária vantagem de assumir o encargo do julgamento para melhor aplicá-lo na sua função. Na sua função mais característica e mais própria que é, e deverá ser só, de lançar, fiscalizar a boa arrecadação e orientar os contribuintes no mister de bem compreender os textos regulamentares. Penso, assim, que o Direito Tributário deve constituir-se como uma disciplina especial, devidamente codificado, com órgão próprios, afim de acompanhar as evoluções do mundo moderno". Trata-se de um trabalho doutrinário voltado a elencar argumentos políticos e legislativos na área fiscal para justificar a criação da "Justiça Fiscal" e até encaminhava um "esboço" da organização dessa justiça especializada. GAMA, Mozart da. Direito Tributário e Justiça Fiscal - Único Livro que contém a mais moderna jurisprudência em vigor sobre: imposto de consumo, imposto de renda, vendas e mercadorias, selo e tarifas de alfândega. São Paulo: Livraria Freitas Bastos, 1941, p. 05-06.

${ }^{275}$ Idem, p. 05 e seguintes.

${ }^{276}$ No mesmo ano, foi organizado o Congresso Jurídico Nacional, no Rio de Janeiro, além da Segunda Conferência Interamericana de Advogados, na mesma cidade que, afinal, apresentou uma resolução bastante exemplificativa sobre aquele contexto: "Que a Comissão de Impostos da Federação Interamericana de Advogados estude e proponha a instituição, em cada país americano, de uma justiça fiscal autônoma, cujos membros possuam as condições técnicas e gozem das garantias adequadas ao bom desempenho do cargo, cabendo, das decisões finais dessa justiça, revisão pelo Poder Judiciário ùnicamente em casos especialmente previstos". Essa passagem encontra-se reproduzida na obra de SOUSA, Rubens Gomes de. A Distribuição da Justiça em Matéria Fiscal no Brasil. São Paulo: Livraria Martins Editora, 1943, p.01-08.

${ }^{277}$ Para o autor, o próprio governo na época demonstrava preocupação com o problema do congestionamento dos tribunais, não somente quanto ao Supremo, mas também quanto aos tribunais estaduais, o que era demonstrado também através de algumas publicações elaboradas por integrantes do governo expressando essa preocupação. SOUSA, Rubens Gomes de. A Distribuição da Justiça em Matéria Fiscal no Brasil. Op.cit, p.07-08.

${ }^{278}$ Rubens Gomes de Sousa refere-se aos estudos de Ministro Filadelfo Azevedo ("A crise no Supremo Tribunal Federal”, em "Arquivos do Ministério da Justiça”, vol.1, junho de 1943, p.7), Dr. Levi Carneiro ("Ainda a crise do Supremo Tribunal Federal", em "Arquivos", cit.,vol.2, agosto de 1943, p.01) e do Professor Noé Azevedo (“A crise dos Tribunais de Apelação”, em “Arquivos”, cit, vol.2., agosto de 1943, p.27'). Idem. 
direito público, mas apenas procuravam soluções baseadas na redistribuição de competências para os órgãos do poder judiciário, não questionando a possibilidade de uma “(...) regulamentação harmônica e sistemática do procedimento administrativo e do processo judicial" 279 .

Essa obra representa certamente um dos primeiros estudos assumidamente focados na disciplina "Direito Fiscal", diferenciando-se fortemente da maioria de suas antecessoras no Brasil. ${ }^{280}$ Pensava Rubens Gomes de Sousa que tais circunstâncias deveriam ser consideradas primordiais para o reconhecimento de um "novo direito", no Brasil. Mas é interessante notar que a origem de sua preocupação era essencialmente prática, pois buscava alternativas para solucionar o problema das lides fiscais que cada vez mais ganhavam espaço nos tribunais, consequência lógica do aumento da incidência e da generalidade da imposição aos contribuintes.

Em verdade, a solução do problema das lides fiscais não poderia ser resolvida apenas com a criação de um Tribunal (fiscal) especializado na matéria. Era preciso, pensava Rubens Gomes de Sousa, a consolidação de normas ou princípios gerais que facilitassem o julgamento da matéria por aqueles mesmos tribunais, já que havia considerável emaranhado legislativo fiscal que dificultava sobremaneira a interpretação e a aplicação da matéria (aqui se encontra possivelmente a gênese das ideias que o levariam à construção do Anteprojeto de Código Tributário Brasileiro, adiante analisado).

\footnotetext{
${ }^{279}$ Ibidem.

280 Essa consciência disciplinar que tomava corpo através do crescimento de lides fiscais no Brasil (consequência também do caos tributário imanente àquele período) foi fortemente abraçada pelo autor, quando apontou o problema da distribuição da justiça em matéria fiscal, no que importa à individualização prática dos princípios teóricos e das normas legais genéricas do direito tributário, que na época vinha assumindo importância crescente. Isso ocorreu, após a Primeira Guerra Mundial, por dois motivos principais, conforme assinalou o próprio autor: “(...) intervencionismo cada vez mais acentuado do Poder Público, no que antes era campo exclusivamente reservado às atividades privadas, intervencionismo esse que traz consigo a necessidade da criação de novos órgãos e serviços administrativos, e, por conseguinte a exigência de novos recursos orçamentários; segundo, o abandono de antigas noções civilistas e liberais quanto à natureza do imposto e à sua justificação, e a substituição de tais noções pelo conceito da sujeição do indivíduo ao poder impositivo do Estado entendido como ato de império, bem como pela ideia da generalização da participação individual nos encargos coletivos da nacionalidade. Isto nos traz ao segundo aspecto geral do problema, ou seja, ao ponto de vista do contribuinte. Hoje em dia cada vez mais cidadãos pagam impostos, e impostos cada vez mais onerosos". E consequência direta e imediata do crescimento e da difusão do fenômeno tributário, foi o estudo dos problemas fiscais, que “(...) deixou o terreno das especulações teóricas e mais ou menos herméticas dos juristas e economistas de gabinete, e veio ocupar posição de destaque na lista das principais questões da arte de governar. Do aumento do peso dos tributos, e da ampliação dos seus campos de incidência, com a consequente multiplicação dos conflitos entre o particular e o poder tributante, originou-se uma consciência, não só jurídica, mas também popular, de que um novo direito estava criado”. Ibidem, p.07-
} 11. 
Some-se a isso a tradição civilista brasileira, que repercutia na consideração dos conceitos jurídicos a partir daquela lógica do Direito Civil (ainda que sob a crítica de Brandão Machado, já mencionada), que, na maioria das vezes, não se adaptavam bem na órbita do "Direito Fiscal", ramo do Direito Público.

Na realidade, Gomes de Sousa culpava a persistência dos conceitos de Direito Civil pelo retardamento da constituição de uma base doutrinária própria do Direito Fiscal, enquanto ramo do Direito Público, no Brasil, na mesma linha que João Martins de Oliveira, embora este não tenha sido incluído entre as obras consultadas por Sousa naquele momento. Para Sousa, a solução seria a busca pela consolidação de uma doutrina do Direito Fiscal, autônoma e emancipada do Direito Civil, cujos conceitos haviam por acomodar os juristas, advogados e magistrados até então ${ }^{281}$.

\subsection{A contribuição histórica do emergente contencioso fiscal.}

Historicamente, as decisões emanadas do contencioso fiscal, seja administrativo ou judicial, apresentam inequívoca vinculação ao processo disciplinar do Direito Tributário Brasileiro. A jurisprudência tem papel histórico representativo nesse processo e reflete (assim como é refletida) pela doutrina especializada ${ }^{282}$, mesmo antes do período republicano.

Conforme se observa na leitura de Paulo Celso Bergstrom Bonilha, a tutela jurídica do contribuinte possui raízes históricas que remontam ao período colonial, passando pelo período imperial, para desabrochar no período republicano ${ }^{283}$. Não é, portanto, novidade trazida com o período disciplinar do Direito Tributário Brasileiro.

Também não se olvida a importância de que os próprios juízes construíram doutrina. A história disciplinar do Direito Tributário Brasileiro tem mantido importantes exemplos de estudiosos participativos como julgadores, seja no âmbito administrativo, seja

\footnotetext{
${ }^{281}$ SOUSA, Rubens Gomes de. A Distribuição da Justiça em Matéria Fiscal no Brasil. Op.cit., p.08-13. ${ }^{282}$ MARINS, James. Direito Processual Tributário Brasileiro (Administrativo e Judicial). $7^{\text {a }}$ Ed. São Paulo: Dialética, 2014, p. 445 e seguintes.

${ }^{283}$ Para um histórico da tutela jurídica do contribuinte, desde o período colonial até o período republicano (democrático), conferir: BONILHA, Paulo Celso Bergstrom. Da Prova no Processo Administrativo Tributário. $2^{a}$ Ed. São Paulo: Dialética, 1992, p. 15-28.
} 
no âmbito judicial. Especialmente no contencioso administrativo, a especialidade temática aliada à competência dos julgadores, entre membros do fisco e representantes dos contribuintes, favorece a impulsão aos estudos tributários, especialmente em ambiente histórico desejoso de ver um dia o sonho da criação de um Tribunal (judicial) Fiscal no Brasil, conforme se observa já no estudo inaugural de Rubens Gomes de Sousa ${ }^{284}$.

Chegou-se, inclusive, a buscar, posteriormente, com Gilberto Ulhôa Canto, a proposição de um Anteprojeto de Lei Orgânica do Processo Tributário, em 1965 e 1966, posteriormente revisto por Comissão de especialistas, onde, relata Bonilha, estariam previstos, na composição do Poder Judiciário, três tribunais federais, denominados Tribunais Federais Tributários, dotados de competência para processar e julgar, originalmente, mandados de segurança, "habeas corpus" e conflitos de jurisdição em matéria fiscal da União e, nos casos previstos em lei, as ações de revisão dos atos decisórios administrativos. Também se propôs, no segundo texto, lei orgânica de processo tributário, a instituição de processo administrativo tributário contraditório, desdobrado em duas instâncias. No entanto, o Anteprojeto de Gilberto Ulhôa Canto não obteve o sucesso almejado $^{285}$.

Esse empreendimento, não obstante, foi pelo menos alcançado com sucesso no âmbito administrativo. Exemplificativamente, na construção histórica do Tribunal de Impostos e Taxas de São Paulo, criado em 1935, tem tradicionalmente incluído entre seus juízes reconhecidos tributaristas, dentre os quais Alcides Jorge Costa, Rubens Gomes de Sousa, Ruy Barbosa Nogueira, José Eduardo Soares de Melo, Luiz Mélega, Paulo Celso Bergstrom Bonilha, Yonne Dolacio de Oliveira, e muitos outros ${ }^{286}{ }_{-}^{287}$.

Evidentemente, o papel do contencioso administrativo fiscal federal representa passo importante para o impulso inicial dos estudos do Direito Tributário brasileiro. Em verdade, a estruturação histórica do contencioso administrativo fiscal federal variou substancialmente na história da disciplina.

\footnotetext{
${ }^{284}$ SOUSA, Rubens Gomes de. A Distribuição da Justiça em matéria fiscal. Op.cit., p. 20 e seguintes.

285 BONILHA, Paulo Celso Bergstrom. Da Prova no Processo Administrativo Tributário. Op.cit., p. 3132.

${ }^{286}$ BARROS, José Eduardo Monteiro de. Momento Histórico. Tit - 70 anos de Justiça Fiscal. Op.cit., p. 23 e seguintes.

287 BONILHA, Paulo Celso Bergstrom. Da Prova no Processo Administrativo Tributário. Op.cit., p. 2930 .
} 
O primeiro Conselho de Contribuintes do Imposto de Renda foi criado pelo Decreto n.16.580, de 1924 (iniciando funcionamento em 14 de setembro de 1925), instituindo um Conselho em cada Estado e no Distrito Federal com competência para julgar recursos fiscais em matéria de imposto de renda, e já naquela época havia composição paritária entre representantes do fisco e dos contribuintes, escolhidos pelos setores do comércio, indústria, profissões liberais e funcionários públicos, especialistas na área.

Posteriormente foi criado, pelo Decreto n.5.157, de 1927, o Conselho de Contribuintes para Impostos de Consumo, seguindo semelhante estrutura do anterior, posteriormente modificado pelo Decreto n.20.350/1931. Contudo, ambos foram extintos pelo Decreto n.24.036/1934, que substituiu os Conselhos anteriores pelo $1^{\mathrm{a}}$ e $2^{\mathrm{o}}$ Conselhos de Contribuintes e o Conselho Superior de Tarifa. Ressalte-se, ainda, a participação fundamental de Tito Rezende nos trabalhos do $1^{\mathrm{a}}$ e $2^{\mathrm{a}}$ Conselho.

A partir desse momento, ao $1^{\circ}$ Conselho foi atribuída competência para julgar, em $2^{\mathrm{a}}$ instância, questões sobre imposto de renda, imposto do selo e imposto sobre vendas mercantis; ao passo que, ao $2^{\text {a }}$ Conselho coube o imposto de consumo, a taxa de viação e os demais impostos, taxas e contribuições internas, etc $^{288}{ }_{-}^{289}$.

Por outro lado, não se poderia deixar de mencionar, no âmbito do contencioso judicial, a histórica participação de Aliomar Baleeiro ${ }^{290}$ que, enquanto ministro do Supremo Tribunal Federal (1965-1975), foi o primeiro tributarista a integrar a cadeira do STF. Contribuiu, assim, enormemente, para o aperfeiçoamento das decisões em matéria

${ }^{288}$ Em 1964, com o Decreto n.54.767/64, cria-se o $3^{\text {a }}$ Conselho de Contribuintes, desmembrando-se do $2^{\circ}$ Conselho, e, em 1972, criou-se o $4^{\text {a }}$ Conselho, através do Decreto n.70.235, redistribuindo a competência sobre o julgamento em segunda instância de matéria tributária entre os 4 conselhos. Por outro lado, com o Decreto n.79.630 de 1977, redistribui-se a competência entre os Conselhos, que passam a ser apenas 3, por sua vez organizados em Câmaras. Posteriormente, recebe nova modificação em sua estrutura com a Lei 11.457/2007 com a criação da Receita Federal do Brasil. Ademais, note-se que a Câmara Superior de Recursos Fiscais (CSRF) foi criada pelo Decreto 83.304/1979. Finalmente, com a Medida Provisória n.449/2008 (posteriormente convertida na Lei n.11941 de 2009), cria-se o Conselho Administrativo de Recursos Fiscais, competente para recursos administrativos fiscais federais, e atualmente vigente. Conselho Administrativo de Recursos Fiscais. Origens do Conselho Administrativo de Recursos Fiscais: Histórico dos Conselhos de Contribuintes do Ministério da Fazenda. Disponível em: http://carf.fazenda.gov.br/sincon/public/pages/ConsultarInstitucional/Historico/HistoricoPopup.jsf (último acesso em 06/12/2004). BOTALLO, Eduardo Domingos. Curso de Processo Administrativo Tributário. São Paulo: Malheiros, 2009, p. 199 e seguintes.

${ }^{289}$ BONILHA, Paulo Celso Bergstrom. Da Prova no Processo Administrativo Tributário. Op.cit., p. $27-$ 28.

${ }^{290}$ A biografia jurisprudencial de Aliomar Baleeiro, enquanto ministro do STF, foi recentemente organizada em publicação destinada a homenagear sua memória: AMARAL JÚNIOR, José Levi Mello do. Memória jurisprudencial: Ministro Aliomar Baleeiro. (Série memória jurisprudencial) Brasília: Supremo Tribunal Federal, 2006. 
tributária, imprimindo até mesmo posições sobre hermenêutica jurídica aplicável ao direito tributário, contra os "farisaísmos hermenêuticos", 291 e o apego à literalidade do texto de lei (“interpretação judaica”, segundo Baleeiro). Chegou até mesmo a lançar olhares sobre a relação entre Direito e Economia, reconhecendo a perspectiva instrumental ao primeiro ${ }^{292}$, e elevando interpretação finalista do direito, visando identificar os interesses econômicos ou políticos por detrás da legislação. Também manifestava posição firme na compreensão de que o juiz não poderia fazer substituir-se à lei ou à autoridade competente definida por lei, para dar decisão final atribuível àquela outra autoridade 293.

Entre as posições jurisprudenciais memoráveis de Aliomar Baleeiro destacam-se a defesa perene dos direitos e garantias fundamentais ${ }^{294}$, inclusive adotando posições firmes no controle de constitucionalidade face ao decreto-lei, quando instituído para criar ou majorar tributos. Por ocasião da Emenda Constitucional n.1 de 1967, atribuía-se a possibilidade do Decreto-lei dispor sobre "finanças públicas" (art. 58, II). Dois anos após, com a Emenda Constitucional n.1 de 1969, incluiu-se, no campo material do Decreto-lei, dispor sobre "normas tributárias"(art. 55, II), mas Baleeiro indispôs-se veementemente acerca dessa possibilidade ${ }^{295}$.

Para Baleeiro: "Decreto-lei não é lei. É uma ferramenta da Constituição brasileira, um instrumento de um regime diferente, instituído, a princípio, pela ditadura de 1937; em segundo lugar, pelo regime parlamentar de 1961, restabelecido dentro de uma Constituição presidencialista. Tem as mais nefastas conseqüências para a evolução do Direito brasileiro, para a perfeição do regime, porque mistura instrumentos de regimes políticos diversos e

\footnotetext{
${ }^{291}$ RE n. 29.990/GB, Relator o Ministro Victor Nunes, julgado em 20 de junho de 1966, STF. In: AMARAL JÚNIOR, José Levi Mello do. Op.cit., p.26 e seguintes.

292 "Para mim, o Direito tem uma função puramente ancilar, é mero auxiliar de outros interesses humanos. Esses interesses são de várias ordens, sobretudo a ordem econômica e política. Então, não se pode afastar da interpretação de uma lei o seu conteúdo econômico ou político. Que o legislador quis proteger, qual foi o fim que ele visou a amparar? Para mim, o que ele quis, na sua expressão literal e gramatical, não é o precípuo. Para mim importa muito mais o que a lei quis, em que circunstâncias a lei quis isso, para que algo se atingisse. 'Por que disse' e não 'como disse'." RE n. 65.733/GB, Relator para o acórdão o Ministro Themistocles Cavalcanti, julgado em 9 de dezembro de 1968. Idem.

${ }^{293}$ RE n. 60.385/GB, Relator o Ministro Aliomar Baleeiro, julgado em 3 de maio de 1966. Ibidem.

${ }^{294}$ RE n. 72.021/CE, Relator o Ministro Barros Monteiro, julgado em 14 de março de 1973; RE n. 64.333/PR, Relator o Ministro Aliomar Baleeiro, julgado em 29 de outubro de 1968; RE n. 69.528/PR, Relator o Ministro Amaral Santos, julgado em 24 de novembro de 1970; RMS n. 18.534/SP, Relator o Ministro Themistocles Cavalcanti, julgado em $1^{\text {o }}$ de outubro de 1968; RE n. 73.895/MG; RE n. 67.653/GB, Relator o Ministro Aliomar Baleeiro, julgado em 20 de maio de 1970. AMARAL JÚNIOR, José Levi Mello do. Op.cit., p. 26 e seguintes.

${ }^{295}$ RE n. 75.935/SP, julgado em 9 de outubro de 1973. Idem.
} 
opostos.”296 Sedimentou, portanto, importante contribuição para o aperfeiçoamento do direito tributário, enquanto ministro do STF. ${ }^{297}$

Assim, a posição de Baleeiro permanece atemporal, especialmente por revelar que a participação da jurisprudência na consolidação do Direito Tributário, que ganhou progressivamente importância, sobretudo, no ambiente contemporâneo.

\subsection{A contribuição europeia posterior à Primeira Guerra Mundial.}

O desenvolvimento teórico do Direito Tributário Brasileiro passa pela inevitável análise histórica dos suportes objetivos que viabilizaram essa construção. A relevância de tal descrição serve para reforçar que o Direito Tributário encontra suportes históricos que se diferenciam do desenvolvimento encontrado no percurso científico da disciplina jurídica em outros países.

Mas, por outro lado, a história disciplinar do Direito Tributário Brasileiro passa também pela consideração da experiência estrangeira, inevitavelmente.

Se não fosse a experiência preliminar estrangeira, atenta aos contornos jurídicos do fenômeno tributário, dificilmente a disciplina hoje especializada do Direito Tributário Brasileiro teria as feições teóricas que possui hoje.

A influência do pensamento jurídico-tributário estrangeiro não se limitou apenas à literatura, mas também avançou, sobretudo, no campo da política legislativa, e até mesmo nas tentativas de implantação de tribunais especializados (administrativos ou judiciais) em matéria fiscal, à imagem dos tribunais fiscais europeus.

Assim, tal influência no desenvolvimento disciplinar do Direito Tributário não poderia ser facilmente contada em um pequeno tópico, mas permeia paralelamente toda a história do pensamento jurídico-tributário brasileiro.

\footnotetext{
${ }^{296}$ RE n. 75.972/SP, Relator o Ministro Thompson Flores, julgado em 10 de outubro de 1973. Ibidem.

${ }^{297}$ Os principais acórdãos sobre matéria fiscal, relatados por Aliomar Baleeiro, foram sintetizados na mesma coletânea. Dentre inúmeras decisões, citam-se, exemplificativamente: voto que afirma a natureza tributária das contribuições parafiscais (RE n. 59.415/GB, Relator o Ministro Vilas Boas, julgado em 17 de maio de 1966). Ibidem, p. 116-187 e seguintes.
} 
Diante de tais considerações, resta ao presente estudo reconhecer as influências históricas estrangeiras do Direito Tributário Brasileiro, em sua emancipação disciplinar, ainda que sinteticamente.

O Código Tributário Alemão (Reichsabgabenordnung - RAO), que entrou em vigor no dia 23 de dezembro de 1919, é considerado, por muitos, como o fator principal para o desenvolvimento da doutrina do Direito Tributário, cuja criação é devida a Enno Becker $^{298}{ }_{-}^{299} 300$.

Não é por outro motivo que Sainz de Bujanda, diante das evidentes dificuldades manifestadas na tentativa de indicação de um momento exato para o nascimento de qualquer disciplina científica, preferiu sustentar que a entrada em vigor da RAO (Reichsabgabenordnung) ${ }^{301}$, foi o fator decisivo e impulsionador da construção científica e efetivamente sistematizada dos estudos versados em Direito Tributário ${ }^{302}$, muito embora Kruse, como visto, aponte, com toda razão, a antecedência de Otto Mayer e Franz Von Myrbach-Rheinfeld no disciplinamento teórico do Direito Tributário ${ }^{303}$.

Nesse aspecto, os primeiros estudos ligeiramente anteriores à entrada em vigor da RAO apresentavam feições tímidas, carentes de sistematização e organicidade, a exemplo dos estudos "tímidos", como dizia Vanoni, de Waldecker e Schneider, ainda que o último, em período posterior à promulgação do RAO, segundo Vanoni, tenha apresentado importantes contribuições para o desenvolvimento da matéria ${ }^{304}$.

Mas ainda nesses autores era visível a dificuldade encontrada para alcançar determinada sistematização científica, o que pode ser explicada pela própria complexidade legal do sistema jurídico tributário alemão pré-codificação, bem como também pela falta

\footnotetext{
${ }^{298}$ VANONI, Ezio. L'Esperienza della Codificazione Tributaria In Germania. In: Opere Giuridiche. A cura di Francesco Forte e Cesare Longobardi. II. Elementi di Diritto tributario. Altri saggi di diritto finanziario. Milano - Dott.A. Giuffrè Editore, 1962, p. 383 e seguintes.

${ }^{299}$ DINIZ, Souza. Códigos Tributários. Alemão. Mexicano. Brasileiro. $1^{\text {o }}$ edição. Tradução de Souza Diniz. São Paulo: Edições Financeiras S.A., 1965, p. 01 e seguintes.

${ }^{300}$ BÜHLER, Ottmar. La Importanza di Enno Becker per Lo Sviluppo del Diritto Tributario Tedesco dal 1918. In: Rivista di Diritto Finanziario e Scienza della Finanze.Volume IV. XVIII, Parte I. Padova: Cedam - Casa Editrice Dott. Antonio milani, 1940, p.43-46.

${ }^{301}$ DINIZ, Souza. Op.cit, p. 01 e seguintes.

${ }^{302}$ BUJANDA, Fernando Sainz de. Hacienda Y Derecho. I. Madrid: Instituto de Estudios Politicos. Madrid, 1975 , p. 58 e seguintes.

${ }^{303}$ KRUSE, Heinrich Wilhelm. Steuerrecht. I. Allgemeiner Teil. 3. Auflage. München: Verlag CH Beck, 1973, p. 01-05.

${ }^{304}$ VANONI, Ezio. L'Esperienza della Codificazione Tributaria In Germania. Op.cit., p. 383 e seguintes.
} 
de apoio constitucional à sistematização e organicidade da disciplina, afinal, tanto a Constituição do Império Alemão, de 1871, como a Constituição de Weimar, de 1919, não apresentavam teor sistemático e organizado à matéria tributária, pouco contribuindo para o incentivo ao estudo sistemático do aspecto constitucional do direito tributário (embora incentivasse o estudo das Finanças Públicas) naquele primeiro momento ${ }^{305}$.

Conforme recorda Ruy Barbosa Nogueira, o Código Tributário Alemão impulsionou a literatura de língua germânica da época, já que reuniu em um único texto as normas gerais em torno dos tributos, facilitando enormemente seu estudo: "A sistematização imposta pela lei excitou os espíritos críticos, que atacaram os fundamentos: às observações destes, opuseram-se os que aderiram ao sistema proposto pelo Código. Surgiu assim um reboliço de discussões, de pesquisas, de construções a que, de um lado, o novo Código oferecia material e de outro constituía um limite contra os riscos de excessivas abstrações e de inúteis divagações" ${ }^{306}$.

A RAO era, sem dúvida, um instrumento de limitação ao exercício do poder tributário. Mas era, com maior ênfase, um instrumento viabilizador da atividade tributária, em todas as etapas da relação jurídica tributária, isto é, destinado a viabilizar a tributação e arrecadação aos cofres públicos, peculiaridades da própria situação europeia posterior à Primeira Guerra, na época carente de recursos (mais uma vez, é importante destacar que a Alemanha vivia em sucessivo "Estado de Emergência", o que repercutiu nas reformas financeiras da época).

Diante dessas peculiaridades, a literatura tributária estrangeira manifestou importantes contribuições ao tema, no qual se destacaram os estudos sobre as fontes do direito tributário, a interpretação das leis tributárias, a diferenciação da obrigação tributária (obrigação ex lege) da obrigação de direito privado, a vinculação da relação tributária enquanto relação de Direito, pautada na lei, e também esboços iniciais referentes à amplitude da legalidade tributária, que culminaria na elaboração posterior da tipicidade tributária, do Tabestand, dentre muitos outros temas.

\footnotetext{
${ }^{305}$ VANONI, Ezio. Opere Giuridiche. A cura di Francesco Forte e Cesare Longobardi. II. Elementi di Diritto tributario. Altri saggi di diritto finanziario. Milano - Dott.A. Giuffrè Editore, 1962, p. 393.

306 NOGUEIRA, Ruy Barbosa. Prefácio. In: DINIZ, Souza. Códigos Tributários. Alemão, Mexicano, Brasileiro. Rio de Janeiro: Edições Financeiras S.A., 1965, p. viii.
} 
Assim, a doutrina tributária de língua germânica passa a se desenvolver em torno dessas polêmicas, impulsionadas diretamente pela entrada em vigor do Código Tributário Alemão e seus dispositivos. Conforme sintetiza Ruy Barbosa Nogueira, os seguintes estudiosos se destacaram na época: "Aos primeiros estudos tímidos de Direito Tributário de Waldecker e de Schneider, que precederam à promulgação do Código, surgem as obras sistemáticas de Hensel, de Bühler, de Merkl, de Mirbt, de Ball, de Von Pistorius; as críticas agudas de Nawiasky, de Strutz, de Schranil; os comentários de Becker, Beker, Mrozek, Nierbel; as monografias sobre este ou aquele problema; os comentários sobre leis particulares de cada imposto entre os quais os magistrais comentários de Popitz sobre o imposto de vendas e os de Strutz sobre o Imposto de Renda; os artigos de revistas sobre Direito Tributário, entre cujas revistas pela importância estão a "Steuern und Wirtschfat" e a "Vierteljahresschrift für Steuer und Finanzrecht" $" 307$.

Note-se que Nogueira não se afasta das considerações de Kruse, que apontou, sinteticamente, algumas das principais obras (e autores) daquele período inicial: Schneiders (“Das Abgabengewaltverhältnis", Tübingen, 1918), Lassars (Erstattungsanspruch im Verwaltungsund Finanzrecht", Berlin, 1921), bem como as obras sistemáticas de Kurt Ball, Waldecker, Strutz, Hensel, Friedrichs, Mirbt, Merk, Bühler, Jahn e Crisolli ${ }^{308}$.

O próprio Enno Becker foi influenciado por importantes doutrinadores na elaboração de seu Projeto de Código Tributário Alemão, conforme informa Kruse. Becker levou em consideração as exposições de Otto Mayer, Fritz Fleiner, bem como a obra "System der Rechsgeschäftlichen Staatsakte (Berlim, 1910), de Karl Kormanns. Apesar da importância da obra austríaca de Franz Von Myrbach-Rheinfeld, Enno Becker não havia sido inspirado por essa obra, já que o Código Tributário Alemão, na opinião de Kruse, seria claramente inspirado nas obras de Mayer e Kormanns. ${ }^{309}{ }_{-} 310$

307 NOGUEIRA, Ruy Barbosa. Prefácio. In: Souza Diniz. Códigos Tributários. Alemão. Mexicano. Brasileiro. Op.cit., p. viii-ix. KRUSE, Heinrich Wilhelm. Steuerrecht. I. Allgemeiner Teil. 3. Auflage. München: Verlag CH Beck, 1973, p. 01-05.

${ }^{308}$ KRUSE, Heinrich Wilhelm. Steuerrecht. I. Allgemeiner Teil. 3. Auflage. München: Verlag CH Beck, 1973, p. 01-05.

309 KRUSE, Heinrich Wilhelm. Derecho Tributario. Parte General. $3^{\circ}$ edición. Editorial de Derecho Financiero. Editorial de Derecho Reunidas. Madrid, 1978, p. 36-38. Também: KRUSE, Heinrich Wilhelm.

Steuerrecht. I. Allgemeiner Teil. 3. Auflage. München: Verlag CH Beck, 1973, p. 01-05.

${ }^{310}$ KRUSE, Heinrich Wilhelm. Steuerrecht. I. Allgemeiner Teil. 3. Auflage. München: Verlag CH Beck, 1973, p. 01-05. 
Em $1920^{311}$ foi implantado o Direito Financeiro e Tributário como disciplina jurídica nos planos de ensino das universidades alemãs, embora no início do semestre do verão na Universidade de Berlim, em $1915^{312}$, Ludwig Waldecker ministrou um curso particular de quatro horas sobre o Direito Financeiro e Tributário. ${ }^{313}$

Note-se também que, na Áustria, a matéria tributária já era também ensinada e estudada na órbita do Direito Financeiro (Finanzrecht), por Tezner, em Viena, na Áustria, assim como por Myrbach-Rheinfeld ${ }^{314}$.

O Direito Tributário se destaca, assim, nitidamente, do Direito Administrativo, sob a égide do qual, com as elaborações de Mayer, “(...) havida dado os primeiros passos”. ${ }^{315}$ 316

Mas, de fato, embora na década de vinte e trinta a literatura tributária alemã fosse reconhecidamente a mais avançada na época, em primeiro estágio da literatura tributária brasileira, a influência direta das obras germânicas ainda não se fazia sentir (pelo menos aquelas versadas somente em língua alemã), especialmente pela dificuldade do acesso ao idioma.

\footnotetext{
${ }^{311}$ ZILVETI, Fernando Aurelio. Obrigação Tributária - Fato Gerador e Tipo. Op.cit.,p. 24-25. D’AMATI, Nicola. L'Insegnamento del Diritto Tributario. In: L'Evoluzione dell'Ordinamento Tributario Italiano. UCKMAR, Victor (Coord.) CEDAM: Milani, 2000, p. 127 e ss. AMATUCCI, Andrea. Historia de La Enseñanza del Derecho FinancieroPúblico en Italia. Op.cit., p. 101-102. Sobre o assunto, também: D’AMATI, Nicola. La Formación del Derecho Tributario en Italia. In: Historia del Derecho de La Hacienda Pública y del Derecho Tributario en Italia. El aporte del pensamiento jurídico financiero de La Italia Meridional. AMATUCCI, Andrea; D'AMATI, Nicola. Bogotá - Colômbia: Temis, 2004, p. 139 e ss.

${ }^{312}$ KRUSE, Heinrich Wilhelm. Steuerrecht. I. Allgemeiner Teil. 3. Auflage. München: Verlag CH Beck, 1973, p. 01-05.

313 "Um outro autor não alemão, o Professor norte americano da Colúmbia University, Robert Murray Haig, escrevendo um estudo sobre os sistemas tributários, conclui comparativamente que o sistema alemão é o mais desenvolvido do mundo (The academic influence has been perhaps greater in Germany than in any of the countries mencioned above, and Germany possesses the most highly developed and well rounded system of all. Giuliani Fonrouge, um dos maiores mestres do Direito tributário na América Latina, em recente e magnífico escorço sob o título de "Realidad y Perspectivas de la Codificación Tributaria", aos mostrar que à semelhança da AO "codificar importa, en esencia, crear un cuerpo orgânico y homogêneo de principios generales regulatorios de la materia tributaria en el aspecto sustancial, en lo ordinario y en lo sancionatorio, inspirado en la specificidad de los conceptos y que debe servir de base para la aplicación e interpretación de las normas" declara que "la reseña debe comenzar necessariamente por la codificación alemana, no sólo por haber constituido el primer cuerpo legal en la materia, sino principalmente por su influencia en el desarrollo del derecho tributário". Sugere-se a leitura do excelente prefácio de Ruy Barbosa Nogueira, contextualizando a importância da codificação alemã. NOGUEIRA, Ruy Barbosa. Prefácio. In: Souza Diniz. Códigos Tributários. Alemão. Mexicano. p. viii e seguintes.

${ }^{314}$ KRUSE, Heinrich Wilhelm. Steuerrecht. I. Allgemeiner Teil. 3. Auflage. München: Verlag CH Beck, 1973, p. 01-05.

${ }^{315}$ NOGUEIRA, Ruy Barbosa. Prefácio. In: DINIZ, Souza. Op.cit., p. viii-ix.

${ }^{316}$ VANONI, Ezio. Opere Giuridiche. II. Op.cit., p. 393.
} 
A influência efetiva do pensamento alemão na formação disciplinar inicial do Direito Tributário no Brasil se fez indiretamente, graças à influência da primeira nas produções doutrinárias versadas em línguas da família latina (notadamente Itália e França).

Naturalmente, a exceção pode ser identificada em obras de autores alemães (Hensel ${ }^{317}$, Mayer), suíços (Blumenstein, Bühler ${ }^{318}$ ) e austríacos (Myrbach-Rheinfeld, Nawiasky ${ }^{319}$ ) que tiveram suas obras traduzidas para o francês e italiano, facilitando o conhecimento daquelas doutrinas. Assim, as lições tributárias germânicas passaram a ser repercutidas indiretamente, através de autores italianos e franceses, na literatura tributária brasileira, como é possível observar em João Martins de Oliveira (com prevalência à língua italiana), Rubens Gomes de Sousa (que demonstra predomínio influência da literatura francesa e inglesa), e Tullio Ascarelli (que mesclou ambas as influências, inclusive difundindo traduções italianas e francesas de obras germânicas).

Assim, como acertadamente já expôs Brandão Machado, como influência determinante no momento de especialização disciplinar inicial do Direito Tributário Brasileiro predominavam obras versadas em língua italiana e francesa e, indiretamente, as lições da língua alemã repercutidas pelas primeiras. Tal informação é importante, pois características próprias dessa formação podem ser identificadas mesmo em algumas tendências acadêmicas vislumbradas naqueles países europeus, e que depois seriam reproduzidas com grande semelhança no Brasil.

O predomínio de estudos versados em "Ciência das Finanças e Legislação Financeira" (era de costume na literatura francesa e italiana juntar ambos os assuntos nos manuais da época) na produção literária italiana e francesa acabou influenciando severamente a produção literária brasileira, que repercutiu essa tendência durante praticamente toda a primeira metade do século XX.

\footnotetext{
317 A primeira edição da obra de Albert Hensel, data de 1924, e a terceira (e última) de 1933. HENSEL, Albert. Diritto Tributario. Traduzione di Dino Jarach. Milano: Dott. A. Giufrrè Editore, 1956, p.03-04.

318 Obras "Schweizerisches Steuerrecht" - Il Diritto delle Imposte Svizzero - O Direito do Imposto Suíço (dois volumes, 1926 e 1929). A obra "Sistema di Diritto delle Imposte", traduzida para o Italiano em 1954, teve duas edições, a primeira, em 1944 e a segunda em 1951, na versão suíça. BLUMENSTEIN, Ernst. Sistema di Diritto delle Imposte. Traduzione: FORTE, Francesco. Milano: Dott A. Giuffrè, 1954, p.11-12. 319 NAWIASKY, Hans. Cuestiones Fundamentales de Derecho Tributário. Obras Básicas de Hacienda Pública. Madrid: Instituto de Estúdios Fiscales, 1982, p. 68-71. Esta é uma compilação de artigos publicados no ano de 1926, e que foram reunidos em uma mesma coletânea pelo jurista germânico Klaus Vogel, na obra supracitada. VOGEL, Klaus. Prefacio. In: NAWIASKY, Hans. Cuestiones Fundamentales de Derecho Tributário. Obras Básicas de Hacienda Pública. Madrid: Instituto de Estúdios Fiscales, 1982, s/p.
} 
Raras exceções podiam ser observadas na literatura tributária brasileira (no que diz respeito à atenção à literatura de língua germânica), como é o caso de Amílcar de Araújo Falcão $^{320}$, que foi um dos primeiros notórios interlocutores das obras tributárias de língua germânica no Brasil, a partir da década de cinquenta. Essa tendência ao germanismo foi impulsionada, especialmente a partir da década de sessenta, por outros autores, a exemplo de Ruy Barbosa Nogueira ${ }^{321}$.

Posteriormente, será possível identificar na literatura tributária brasileira maior atenção às construções germânicas de estudo, mas de fato, a influência prevalecente, em absoluto, deveu-se à produção literária italiana e francesa.

A literatura francesa da época, com forte tradição financista, tinha prevalência pela elaboração de obras que misturavam elementos de Direito Tributário e Ciência das Finanças, característica dos estudos fiscais na França durante a primeira metade do século XX.

Mas deve-se reconhecer a importância da contribuição francesa, seja pelas obras oitocentistas de Edgard Allix, Emile Worms, entre diversos outros, e, sobretudo, pela impulsão dos estudos fiscais de Gastón Jèze, seja pela tradução em língua francesa de importantes tratados sobre direito administrativo, financeiro e ciência das finanças, a exemplo de Otto Mayer, Franz Von Myrbach-Rheinfeld, Adolph Wagner, Edwin A. Seligman $^{322}$, facilitando a divulgação desses autores em outros países como o Brasil, assim como os debates sobre a autonomia e sobre a interpretação do direito fiscal protagonizados por Louis Trotabas e François Geny ${ }^{323}$, cujas traduções em revistas brasileiras também

\footnotetext{
${ }^{320}$ Amílcar de Araújo Falcão, em seu primeiro livro, publicado em 1959, "Introdução ao Direito Tributário", mostrava conhecimento de diversas obras versadas em língua alemã, dentre as quais: Wilhelm Merk, "Steuerschuldrecht, 1926, Philipp Zorn, Das Staatsrecht des deutschen Reiches, 1895, 1ª vol., p 444; JOHANNES, Hein, Die Zuzammenhäange zwischen steuerrecht und Handelsrecht und ihro Entwicklung, 1928, p.17-20, BLUMENSTEIN, Ernst. Gegenseitige Beziehungen zwischen Zivillrecht und Steuerrecht, in Zeitschrift für Schweizerisches Recht, Band 52, Heft 4, 1938, p.146-147, entre outros. FALCÃO, Amílcar. Introdução ao direito tributário. Rio de Janeiro: Editora Rio, 1976, p. 73 e seguintes.

${ }^{321}$ Ruy Barbosa Nogueira, já em 1964, em suas primeiras obras, "Direito Financeiro (Curso de Direito Tributário", e "Da Interpretação e da Aplicação das Leis Tributárias" (1964) já mostrava conhecimento de obras e comentários ao Código Tributário Alemão, além dos principais doutrinadores germânicos da época, como Hensel (Steuerrecht, Berlim, 3 Ed., 1933) NOGUEIRA, Ruy Barbosa. Direito Financeiro (Curso de Direito Tributário). São Paulo: José Bushatsky, 1964, p. 03. BARBOSA, Ruy Barbosa. Da Interpretação e Aplicação das Leis Tributárias. $2^{a}$ Ed. São Paulo: Rt, 1965, p. 05 e seguintes.

${ }^{322}$ SELIGMAN, Edwin R. A. Essais sur L'Impôt. Traductión française d'après de 1' $8^{\circ}$ edictión américaine par Louis Suret. Tome Second. Paris: V. Girard \& E.Brière, 1914, p. 01 e seguintes.

${ }^{323}$ O ensaio de Geny foi publicado na língua francesa em 1931, e posteriormente traduzido na Revista de Direito Administrativo. GENY, François. O Particularismo do Direito Fiscal. Guilherme Augusto dos
} 
foram importantes elementos de reflexão para a literatura nacional, na década de quarenta, assim como o clássico estudo de Jèze sobre o fato gerador, publicado originalmente em francês em 1937, e traduzido na Revista de Direito Administrativo em $1945^{324}$.

Naturalmente, obras versadas em outras línguas (a exemplo da inglesa, da portuguesa e da espanhola) também mantiveram importante fonte de investigação na literatura tributária brasileira, mas de fato, se fosse possível escolher entre o país que mais influenciou a literatura tributária brasileira, esse país seria a Itália. Não somente por trazer diretamente as lições da literatura germânica (e da codificação), mas também por semear muitas características (originárias da literatura tributária italiana) e que acabavam se repetindo, de certa forma, na literatura tributária brasileira.

A Itália, desde os séculos anteriores, já apresentava contribuições teóricas à tributação. E a tradição seguiu-se nos estudos de Direito Público e, sobretudo, no Direito Administrativo do século XIX. No aspecto econômico-financeiro, contudo, a contribuição italiana à teoria financeira tinha alcançado importância com a doutrina de Mazzola e De Viti de Marco, Graziani ${ }^{325}$, Benvenuto Griziotti e Luigi Einaudi ${ }^{326}$, mantendo-se durante as três primeiras décadas do século XX. O perfil essencialmente econômico-financeiro das obras italianas acabou repercutindo no perfil das obras brasileiras, que seguiram aquelas estruturas.

Nesse aspecto, pode-se afirmar que, a priori, o Direito Financeiro nasce por filiação e separa-se do corpo da Ciência Econômica (Finanças Públicas), em primeiro momento,

Anjos (Trad). Revista de Direito Administrativo n.20. São Paulo: FGV, 1950, p. 06-31; Por outro lado, o ensaio de Trotabas, publicado na França, em 1928, também seguiu mesmo destino. TROTABAS, Louis. Ensaio sobre o Direito Fiscal. Guilherme Augusto dos Anjos (Trad.). Revista Forense. Doutrina, s/d, p. 5368.

${ }^{324}$ JÈZE, Gastòn. O Fato Gerador do Imposto (Contribuição à Teoria do Crédito do Imposto). Trad. Paulo da Mata Machado. Revista de Direito Administrativo. Vol. II - Fase I. Julho -1945, p. 50-63.

${ }^{325}$ Sobre o assunto, a doutrina pátria interessou-se pelo assunto já que a vinculação entre a produção jurídicotributária italiana e a experiência brasileira apresenta estreita conexão. COSTA, Alcides Jorge. A doutrina italiana e sua influência no Direito Tributário Brasileiro. In: Princípios do Direito Tributário Comparado. Homenagem a Gilberto Ulhôa Canto. Org: Agostinho Toffoli Tavolaro, Brandão Machado e Ives Gandra Martins. Forense: Rio de Janeiro, 1998, p.23 e seguintes. TORRES, Heleno Taveira. Contribuições da Doutrina Italiana para a Formação do Direito Tributário Brasileiro. Direito Tributário. Vol. II. Homenagem a Alcides Jorge Costa. Coordenação: SCHOUERI, Luís Eduardo. São Paulo: Quartier Latin, p. 1146-1167. TORRES, Ricardo Lobo. As Influências Italianas no Direito Tributário Brasileiro. Revista de Direito Renovar, Rio de Janeiro, n.4, 1996 p. 45-60.

326 AMATUCCI, Andrea. Las Raíces de la Concepción Sustancial del Derecho Financiero Público en Nápoles y en la Italia Meridional. In: D’AMATI, Nicola. AMATUCCI, Andrea (Organiz). Historia del Derecho de la Hacienda Pública y del Derecho Tributario en Italia. E aporte del pensamento jurídico financiero de la Italia Meridional. Op.cit., p. 89 e seguintes. 
para trilhar caminho diferenciado em face da perspectiva econômica do fenômeno financeiro, em momento ligeiramente posterior, de forma muito semelhante ao ocorrido com a especialização disciplinar no Brasil, em meados dos anos sessenta ${ }^{327}$.

Este fato explica o interesse de financistas do porte de Griziotti, Einaudi, e outros, a unirem-se aos juristas Mario Puglièse, Ezio Vanoni, Dino Jarach, entre outros no mesmo Instituto Financeiro na Escola de Pávia, para, juntos, dedicarem-se à análise do fenômeno financeiro, muito embora Luigi Cossa já defendesse o estudo apartado entre as duas disciplinas $^{328}$, caminho que também foi partilhado por Oreste Ranelleti e Emílio Giardina, segundo informa Gaspare Falsitta ${ }^{329}$, cujas contribuições, não somente ao Direito Financeiro, mas ao Direito Tributário, também favoreceram os impulsos iniciais de estudiosos lançados ao Direito Tributário Brasileiro naquele período.

Nesse sentido, Ranelleti ${ }^{330}$, líder da chamada Escola de Nápoles, defendeu o estudo apartado entre Direito Financeiro e Ciência das Finanças, tendência que foi seguida e aperfeiçoada pelo seu discípulo Achille Donato Giannini, ${ }^{331}$ ainda que negasse autonomia disciplinar do Direito Tributário frente ao Direito Administrativo ${ }^{332}$.

\footnotetext{
${ }^{327} \mathrm{Na}$ Itália, o ensino da legislação financeira (sob a perspectiva da Ciência das Finanças) teve início em 1859, com a construção do departamento de economia pública e territorial. Luigi Cossa, naquele ano, iniciou os estudos de Economia Política na Universidade de Pávia, com o ensino de Teoria das Finanças. No ano de 1878 foi conferida a primeira cátedra italiana sobre a matéria a Giuseppe Rica Salerno. Já em 1886-1887 foi por lei introduzida no ordenamento universitário a Cátedra de Ciência das Finanças e Direito Financeiro, sob os auspícios de Antonio De Viti de Marco e Ugo Mazzola. D’AMATI, Nicola. La Formación del Derecho Tributário en Itália. Op.cit., p. 139-143.

${ }^{328}$ AMATUCCI, Andrea. Historia de La Enseñanza del Derecho Financiero Público en Italia. In: In: D’AMATI, Nicola. AMATUCCI, Andrea (Organiz). Historia del Derecho de la Hacienda Pública y del Derecho Tributario en Italia. E aporte del pensamento jurídico financiero de la Italia Meridional. Derecho de la Hacienda Pública. Op.cit., 2004, p. 99 e seguintes.

${ }^{329}$ Conforme destaca FALSITTA, Gaspare. Osservazioni sulla nascita e lo sviluppo scientifico dei Diritto Tributário in Itália. In: L'Evoluzione dell'Ordinamento Tributário Italiano. Atti del Convegno "I settanta anni di "Diritto e Pratica Tributaria". Il Diritto Tributário. Antonio e Victor Uckmar (Coords.) Serie I. Volume LXXXIX. Padova: CEDAM, 2000, p. 87-89.

${ }^{330}$ AMATUCCI, Andrea. Las Raíces de la Concepción Sustancial del Derecho Financiero Público en Nápoles y en la Italia Meridional. Op.cit, p. 89 e ss.

331 Sobre a importância de Ranelleti, sugere-se a leitura de: AMATUCCI, Andrea. L'Insegnamento del Diritto Finanziario. In: L'Evoluzione dell'Ordinamento Tributário Italiano. Atti del Convegno "I settanta anni di "Diritto e Pratica Tributaria". Op.cit., p. 102 e ss.

${ }^{332}$ Como se observa em seu estudo intitulado "Ciência da Finança e Direito Financeiro", em "Direito Financeiro e Ciência das Finanças”, "L’insegnamento Del diritto Finanziario, in Dr. Prat. Tribu.,1954,I, 299”. D’AMATI, Nicola. La Formación del Derecho Tributário en Itália. Op.cit., p. 139-143..
} 
Mas a tendência aos estudos conjuntos ainda se fazia forte, pois, na época, Luigi Einaudi, eminente financista, lançou alguns aportes de grande relevância ao Direito Financeiro, em seus cursos de Ciência das Finanças (e Legislação Financeira). ${ }^{333}$

A literatura tributária italiana passou as três primeiras décadas do século $\mathrm{XX}$ permeada por essas influências, elevando-se nessa época, as teses autonomistas de Gustavo Ingrosso $^{334}$, Francesco D’Alessio, Vincenzo Romanelli-Grimaldi ${ }^{335}$, Vincenzo Sica e Giuseppe Abbamonte ${ }^{336}$, Giorgio Tesoro, entre outros ${ }^{337}$, e, naturalmente, Griziotti ${ }^{338}$, que exerceu função de liderança na Escola de Pávia, lançando diversos estudiosos.

Naturalmente, nem todos manifestaram adesão expressa à teoria do fenômeno financeiro de Griziotti. Sem sombra de dúvida, o principal antagonista de Griziotti foi Giannnini $^{339}$, que, discípulo de Ranelleti, selou a separação epistemológica entre o Direito Tributário e a Ciência das Finanças. Por outro lado, a influência germânica na Itália perdurou também com a manifestação de um espírito reformulador do direito tributário, que se refletia mais adiantado em Ezio Vanoni, cujos estudos tiveram grande repercussão

\footnotetext{
${ }^{333}$ FALSITTA, Gaspare. Osservazioni sulla nascita e lo sviluppo scientifico dei Diritto Tributário in Itália. Op.cit., p. 87. Também: EINAUDI, Luigi. Corso di Scienza della Finanza. Quarta Edizione. Torino: Edizione della Rivista "La Riforma Sociale", 1926, p.03.

${ }^{334}$ INGROSSO, Gustavo. Istituzioni di Diritto Finanziario. Volume II. Le entrate dello Stato. Imposte e Tasse. Ed altri entrate patrimoniali. Napoli: Dott. Eugenio Jovene Editore, 1937, p. 06-08.

${ }^{335}$ Sobre a importância de Gustavo Ingrosso, Francesco D’Alessio, e Romanelli-Grimaldi, sugere-se a leitura de: AMATUCCI, Andrea. L'Insegnamento del Diritto Finanziario. Op.cit., p. 110 e seguintes.

336 AMATUCCI, Andrea. Historia de la Enseñanza del Derecho Financiero Público en Italia. Op.cit., p. 99-107.

${ }^{337}$ Para uma contextualização da situação financeira italiana - e da sua atividade tributária - no período referente à Primeira Guerra Mundial, além de doutrinas correlatas, sugere-se a leitura do seguinte estudo: MARONGIU, Gianni. L'Ordinamento Tributário Italiano Tra La Prima Guerra Mondiale e Il Consolidamento del Regime Fascista. In: L’Evoluzione dell'Ordinamento Tributário Italiano. Atti del Convegno "I settanta anni di "Diritto e Pratica Tributaria". Op.cit., p.13-77.

${ }^{338}$ Griziotti também estabeleceu o elo entre o estudo do direito tributário italiano e o estudo do direito tributário germânico coordenando diversas traduções para a língua italiana, como a obra de Ernst Blumenstein (Sistema di Diritto delle Imposte), em 1954, com prefácio de Irene Blumenstein e Benvenuto Griziotti, além de nota introdutória de Francesco Forte. Também coordenou a tradução da obra de Albert Hensel, "Diritto Tributário", na sua última edição, publicada na Itália no ano de 1956. Chefiou também diversas revistas de Direito Financeiro e Tributário, incentivando seus estudiosos na Escola de Pávia e investigarem as minúcias do Direito Tributário tedesco. Não foi por outro motivo que Ezio Vanoni partiu para a Alemanha com o objetivo de investigar a codificação tributária alemã de 1919 e a doutrina germânica que emergiu dessa criação legislativa. Poder-se-ia afirmar que, se em primeiro momento, a doutrina tributária italiana mantinha-se ligada à Ciência das Finanças e à cátedra de Direito Financeiro, com o apoio de Griziotti, com o largo intercâmbio com autores tedescos, os estudos italianos viram-se influenciados enormemente pelo Direito Tributário fundacional germânico. GRIZIOTTI, Benvenuto. Princípios de Política, Derecho y Ciência de la Hacienda. Trad: Enrique R. Mata. Segunda Edición. Madrid: Instituto Editorial Réus, 1958. p.316 e seguintes.

339 BUJANDA, Fernando Sainz de. Achille Donato Giannini. In Memorian. In: Hacienda y Derecho. Madrid: Instituto de Estudios Políticos, 1967, p.631-639.
} 
no Brasil, a exemplo da tradução de sua obra "Natureza e Interpretação da Lei Tributária", por Rubens Gomes de Sousa, em $1952^{340}$.

No campo do Direito Processual Tributário, pode-se destacar os autores Enrico Allorio $^{341}$, com seus "Princípios de Direito Processual Tributário", ao lado do estudo de Francesco Carnelutti, denominado "Introdução ao Estudo do Direito Processual Tributário" 342 , além de Mario Puglièse, com a obra relativa à "Prova no Direito Processual Tributário"343.

Também nos anos posteriores à Segunda Guerra Mundial outros autores se destacaram na doutrina Italiana, a exemplo de Antonio Berliri, ${ }^{344}$ com a obra "Princípios de Direito Tributário". Por outro lado, a doutrina da relação jurídica tributária encontrou também sólidas contribuições, que inclusive causaram uma evolução e autoquestionamento da estrutura da relação jurídica tributária, posteriormente ${ }^{345}$.

A literatura italiana repercutiu severamente não somente no Brasil, mas também na América Latina, como é possível observar na doutrina de Mario Puglièse, que, através da tradução castelhana de seu "Istituzioni di Diritto Finanziario",346, que influenciou diretamente a elaboração e a interpretação da Lei de Justiça Fiscal de 1936 e do Código Fiscal Mexicano de 1938, o primeiro código tributário da América Latina, além de Dino Jarach que, no período da Segunda Guerra, desembarcou na Argentina, formando forte escola tributária, e influenciando toda a América latina, notabilizando-se pelo estudo (e de grande repercussão na literatura brasileira) sobre "El Hecho Imponible" (publicado originalmente em 1943), além do contributo de Tullio Ascarelli (cuja influência na

\footnotetext{
${ }^{340}$ VANONI, Ezio. Opere giuridiche. II. Elementi di diritto tributário. Altri saggi di diritto finanziario. Milano: Dottt. A.Giuffrè, 1963. p. 37-49; VANONI, Ezio. Natureza e interpretação da legislação tributária. Trad. Rubens Gomes de Sousa. Rio de Janeiro: Edições Financeiras S.A., 1952, p. 16 e seguintes.

341 ALLORIO, Enrico. Diritto Processuale Tributário. Quarta Edizione. Unione Tipográfico Editrice Torinese, 1942, p. 36 e seguintes.

342 CARNELUTTI, Francesco. Introduzione al Diritto Processuale Tributario. In Rivista di Diritto Processuale Civile. Direttori: Chiovenda; Carnelutti. Cooeditori: Calamandrei. Volume IV - Parte $1-\mathrm{X}$. Padova: CEDAM, 1932, p.112.

${ }^{343}$ PUGLIÈSE, Mario. La prueba en el Processo Tributario. Jus: México, 1949, p. 08-17.

${ }^{344}$ BERLIRI, Antonio. Principi di Diritto Tributario. Volume I. Milano: Dott. A. Giuffrè - Editore, 1952; BERLIRI, Antonio. Principi di Diritto Tributario. Tomo I. Volume II. Milano: Dott. A. Giuffrè - Editore, 1957.

${ }^{345}$ Ademais, sobre o ensino do Direito Financeiro e Direito Tributário na Itália, sugere-se também a leitura de D’AMATI, Nicola. L'Insegnamento del Diritto Tributário. Op.cit., p.126 e seguintes.

${ }^{346}$ PUGLIÊSE, Mario. Instituciones de Derecho Financiero. Alfonso Cortina.México, 1939, p. 05.
} 
literatura tributária brasileira merecerá tópico à parte), dentre muitos outros autores após a Segunda Guerra Mundial ${ }^{347}$.

Note-se que toda essa movimentação da literatura tributária italiana se procedeu durante as primeiras quatro décadas do século XX, onde a influência da Ciência das Finanças se fez prevalecente, até que, com as obras de Giannini, Vanoni e Puglièse, o Direito Tributário passa a ser estudado separadamente do fenômeno econômico financeiro.

Esse dado é importante para o Brasil, pois é possível identificar clara influência da estrutura das obras italianas (notadamente Vanoni e Giannini) na estrutura do trabalho de João Martins de Oliveira, publicado originalmente em 1943, e considerado pelo presente estudo o primeiro "manual" ou "curso" de Direito Tributário no Brasil. A estrutura desse manual didático segue fielmente a estrutura tradicional das obras italianas versadas em Direito Tributário.

Alguns resultados positivos vivenciados na Europa, contudo, não conseguiram lograr o mesmo intento no Brasil. Por exemplo, infelizmente, até o presente momento não se chegou a criar Tribunal Fiscal (judicial), aos moldes do modelo alemão, por exemplo, mas tal fato não impediu a consolidação de célebres tribunais administrativos. ${ }^{348}$

Nesse mesmo passo, os estudos brasileiros de Direito Tributário, refletindo as dificuldades de emancipação disciplinar entre o Direito Tributário e a Ciência das Finanças na Itália, registram semelhantes características, situação que perdura até o começo da década de sessenta.

Portanto, o processo disciplinar do Direito Tributário Europeu (notadamente de idiomas alemão, francês e, especialmente, italiano) arregimentou grandes contribuições que foram absorvidas em sua maioria para facilitar a especialização disciplinar do Direito Tributário Brasileiro, já que, a partir da década de cinquenta, as principais obras versadas nas línguas francesa e italiana (incluindo-se as traduções italianas e francesas de obras de língua germânica) já tinham sido repercutidas na doutrina nacional.

\footnotetext{
${ }^{347}$ D’AMATI, Nicola. La Formación del Derecho Tributário en Itália. In: Op.cit., p. 139-143.

${ }^{348}$ BONILHA, Paulo Celso Bergstrom. Da Prova no Processo Administrativo Tributário. São Paulo: Dialética, 1997, p. 15-65.
} 


\subsection{A crescente divulgação de estudos tributários através de periódicos especializados}

O surgimento de publicações específicas relativas ao Direito Público (e Tributário) favoreceu a divulgação de estudos (nacionais ou estrangeiros) dedicados ao tema, além de facilitar o acesso à legislação, às decisões administrativas e judiciais da época, assim como às doutrinas especializadas.

Contudo, ainda que o espaço à temática fosse reduzido nas primeiras revistas jurídicas da época, os primeiros trabalhos publicados na temática tributária não apresentavam o caráter doutrinário, mas geralmente constituíam-se de pareceres e acórdãos, já que, em uma época de acesso restrito a informações de caráter fiscal ${ }^{349}$, as revistas mantinham importante função divulgadora da práxis jurídica, como é o caso da Revista Jurídica, de $1906^{350}$, que, já em seus primeiros números, incluía (poucos) acórdãos de natureza tributária.

Nesse contexto, na primeira edição da Revista Forense, em 1904, foi publicado no Volume I o Parecer de Joaquim da Costa Barradas, sobre a possibilidade dos Estados cobrarem tributos em território exclusivo da União Federal ${ }^{351}$. Já no Volume II do mesmo número da Revista Forense, foram publicados pareceres sobre três temas: a) imposto sobre transmissão de propriedade ${ }^{352}$; b) imposto sobre o valor das transacções comerciais ${ }^{353}$; c)

\footnotetext{
${ }^{349}$ Por exemplo, foi publicado o Decreto n.1678 (que "approva o regulamento para o Imposto Territorial", de 1904). Legislação. In: Revista Forense. Doutrina, Legislação e Jurisprudência. Volume I; Fascículo $1^{\text {a. }}$. Bello Horizonte: Imprensa Official do Estado de Minas Geraes, 1904, p. 323 e seguintes.

${ }^{350}$ Exemplificativamente, a Revista de Direito, iniciada em 1906, dedicada ao Direito Civil, Comercial e Criminal, não apresentava remissões diretas ao direito tributário em seu Volume 1, a exceção de acórdão sobre a não incidência de contratos de honorários advocatícios sobre o "sello". Revista de Direito. Civil Commercial e Criminal. Doutrina, Jurisprudencia e Legislação. Antonio Bento de Faria (Dir.). Volume I. Julho. Fasc.I. Rio de Janeiro: 1906, p. 618 e seguintes. Já no Volume 2, apresentou acórdãos sobre a temática fiscal: a) taxa sanitária que não seja instituída por lei não poderia ser cobrada pelo Governo; b) a definição e a possibilidade de sua cobrança (nesse acórdão publicado pelo Juízo Federal da Segunda Vara do Districto Federal, definiu-se que por imposto "se entende todas as contribuições exigíveis dos habitantes de paz, qualquer que seja o destino ou denominação que se lhes dê: imposto, direitos, sellos, taxas"; c) as hipóteses em que o Estado pode cobrar impostos sobre mercadorias. Revista de Direito. Civil Commercial e Criminal. Doutrina, Jurisprudencia e Legislação. Antonio Bento de Faria (Dir.). Volume II. Outubro. Fasc.I. 1906. Op.cit., p. 133 e seguintes; p. 353 e seguintes.

${ }^{351}$ BARRADAS, Joaquim da Costa. Parecer. In: Revista Forense. Doutrina, Legislação e Jurisprudência. Volume I; Fascículo 1a. Bello Horizonte: Imprensa Official do Estado de Minas Geraes, 1904, p. 114-128.

${ }^{352}$ Pareceres de Visconde de Ouro Preto e Lafayete Rodrigues Pereira. Revista Forense. Doutrina, Legislação e Jurisprudência. Volume II; Fascículo 1 ${ }^{\mathrm{a}}$. Bello Horizonte: Imprensa Official do Estado de Minas Geraes, 1904, p. 229 e seguintes.

${ }^{353}$ Pareceres de Visconde de Ouro Preto. Revista Forense. Volume II; Fascículo 1ª Op.cit., p. 233 e seguintes.
} 
imposto sobre dividendos ${ }^{354}$ (que os pareceristas da época identificavam com o imposto de indústrias e profissões do direito comparado com base nos ensinamentos da Ciência das Finanças) ${ }^{355}$.

Mas o interessante é que nesse volume foi publicada a primeira "doutrina" em revista especializada: "Imposto sobre dividendos", de José da Silva Costa, ${ }^{356}$ além de acórdãos sobre execução fiscal ${ }^{357}$. Note-se que os perfis dos estudos sobre o tema mantinham forte vinculação à doutrina econômico-financeira, como reconhece o próprio José da Silva Costa: “A estreita alliança do direito e da sciencia econômica é postulado lustral" 358 .

A Revista dos Tribunais, iniciada em 1912, também manteve semelhante tendência à Revista Forense, dedicando-se a publicação de pareceres, estudos técnicos e acórdãos na área $^{359}$, que foi seguida pela Revista da Crítica Judiciária ${ }^{360}$, dedicada à elaboração de comentários críticos às decisões judiciais da época. Nesse sentido, incluiu comentário de Frederico da Silva Ferreira à decisão sobre "Imposto Inconstitucional”, de $1925^{361}$, assim

${ }^{354}$ Pareceres de Visconde de Ouro Preto. Revista Forense. Volume II; Fascículo 1ª Op.cit., p. 355 e seguintes.

${ }^{355}$ Publicou-se Parecer de Ruy Barbosa sobre imposto de indústrias e profissões. Nesse trabalho, alinhado às contribuições da Ciência das Finanças da época, mostra-se avançada pesquisa sobre o direito constitucional comparado (sobretudo norte-americano) para distinguir a estrutura do imposto de indústrias e profissões do imposto sobre a importação "de procedência estrangeira”. BARBOSA, Ruy. Parecer. In: Revista Forense. Volume II; Fascículo 1 ${ }^{\text {a }}$. Op.cit., p. 234-238. Sobre o mesmo tema foram publicados Pareceres de Baptista Martins (este denominado "Artigo"), Veiga Filho, Mendes Pimentel e Carlos de Carvalho. Revista Forense. Volume II; Fascículo 1'. Op.cit., p.239-249.

${ }^{356}$ COSTA, José da Silva. Imposto sobre Dividendos. Revista Forense. Volume II; Fascículo $1^{\text {a }}$. Op.cit., p. 325 e seguintes.

${ }^{357}$ Idem, p. 261 e seguintes.

${ }^{358}$ Ibidem, p. 325.

${ }^{359} \mathrm{Na}$ Revista dos Tribunais, dedicada à divulgação dos trabalhos do Tribunal de Justiça de São Paulo, poucos acórdãos foram publicados sobre a temática fiscal em seus primeiros volumes. Cita-se, exemplicativamente, acórdãos sobre a taxa de heranças, legados e doações causa mortis, devida aos Estados. Revista dos Tribunais (Publicação Official dos trabalhos do Tribunal de Justiça de São Paulo). Anno I. Fasciculo n.1. Volume I. São Paulo: s/e, 1912, p. 366-367; 467 e seguintes. Já no Fascículo n.7, foram publicados acórdão sobre imposto sobre subrogações (inconstitucionalidade do Decreto Estadual de 1896). Revista dos Tribunais. Anno I. Fasciculo n.7. Op.cit., p. 179 e seguintes. Também no Fascículo n. 9, Volume II, foram publicadas acórdãos sobre imposto sobre o capital, definindo que empréstimos anteriores a 1904 não estariam sujeitos ao imposto. Ainda no fascículo 9, Volume II, publicou-se acórdãos sobre a competência para decretar os impostos, assim como impostos sobre consumo (infração e formalidades, decidindo a necessidade de auto de infração para imposição de multa). Revista dos Tribunais. Anno I. Fasciculo n. 9. Volume II. Op.cit., p. 179 e seguintes; p.237 e seguintes; p. 346 e seguintes.

${ }^{360}$ Revista de Critica Judiciária. Ano II. Rio de Janeiro: s/e, 1925, p. 147 e seguintes; p. 221 e seguintes.

${ }^{361}$ Veja-se a crítica atemporal do autor: "E' irrecusável que no afan de majorarem os recursos orçamentários e até por motivos nada plausíveis, ás vezes por mero interesse de política estreita, as nossas edilidades, sinão mesmo as corporações legislativas estadoaes, engendram tributações aberrantes de qualquer systema scientifico de imposto, sem subordinação ao mais elementar requisito de ordem econômica e menos ainda ás exigências da justiça. São casos, como diz a sentença, de taxação puramente empírica". FERREIRA, 
como os comentários e estudos técnicos já citados por Brandão Machado, seguindo o mesmo perfil ${ }^{362}$.

Não obstante, ainda que a divulgação de trabalhos e jurisprudência sobre o tema já se manifestasse nas revistas jurídicas da época, a primeira revista especializada em tributação foi publicada originalmente em 1930, a cargo de Tito Rezende, que à época era funcionário do Tesouro Nacional no Rio de Janeiro. Sensibilizado com a necessidade de maior divulgação com o estudo do direito tributário, criou a "Revista Fiscal", que teve o primeiro número organizado em dois "tomos". Nos dois volumes, a revista publicava pareceres de Tito Rezende sobre os tributos vigentes na época, bem como de alguns especialistas na matéria ${ }^{363}$.

É importante que se diga que a leitura dos artigos e pareceres reproduzidos denunciava domínio dos autores sobre temas tributários. Contudo, a perspectiva de estudo e as opiniões esboçadas pelos autores evidenciava um predomínio do conteúdo econômicofinanceiro sobre o legislativo, privilegiando a "técnica tributária" a serviço dos funcionários da Fazenda. Também não fugia daquela perspectiva de estudo recorrente a elementos de Ciência das Finanças e Legislação Financeira. Por outro lado, consagrou Tito Rezende, elevando seu nome como um dos principais especialistas nacionais sobre temas fiscais na época, sobretudo pela qualidade de seus trabalhos reproduzidos na revista na temática do imposto de renda e imposto sobre o consumo ${ }^{364}$.

Frederico da Silva. Comentário. In: Revista de Critica Judiciária. Ano II. Rio de Janeiro: s/e, 1925, p. 151153. Outro comentário, sobre decisão do Supremo Tribunal Federal, no tema "Executivo Fiscal por differença de imposto de consumo", e que teve comentários de Antonio Magarinos Torres. TORRES, Antonio Magarinos. Revista de Critica Judiciária. Ano II. Op.cit., p. 221-226.

${ }^{362}$ MACHADO, Brandão. Apresentação. In: MORAES, OSWALDO de. Op.cit., p.vii-xiii

${ }^{363}$ Assim, a edição número 1 teve os seguintes estudos publicados: "Revista Fiscal - Imposto de Consumo Assuntos Aduaneiros - Outros Assuntos - Tito Rezende - Número 1 - 1930: a) Imposto de Consumo - Tito Rezende (p. 1 -164); b) Classificação de Mercadorias - J. Rezende Silva (p. 165); c) Assumptos Aduaneiros (p. 65); c) Revista Fiscal e de Legislação da Fazenda - Tito Rezende. O segundo tomo da Revista Fiscal, por sua vez, contou com as seguintes publicações: Revista Fiscal - Imposto de Renda - Contabilidade Pública Despesa Pública - Consultório - Venda de Mercadorias - Pequenos Impostos - Tito Rezende - Número 1 1930: a) Imposto de Renda - Tito Rezende - p. 01; b) Imposto do Selo - Tito Rezende - p. 01; c) Contabilidade Pública- Tito Rezende - p. 01; d) Despesa Pública - Tito Rezende - p. 01; e) Consultório Industrial e Comercial - O. Pupo Nogueira; f) Imposto de Venda Mercantis - Tito Rezende; g) Pequenos Impostos - Tito Rezende. Revista Fiscal. Imposto de Consumo - Assuntos Aduaneiros - Outros Assuntos. REZENDE, Tito. (Coord). Número 1. Rio de Janeiro: s/e, 1930.

${ }^{364}$ Por exemplo, recorde-se obra didática (de cunho técnico) em matéria de imposto de renda elaborada pelo mesmo autor: REZENDE,Tito. Manual Pratico do Imposto de Renda $2^{\text {a }}$ Ed Rio De Janeiro: Sfreddo \& Gravina Ltda, s/d, p. 09 e seguintes. 
Mas, apesar dessas peculiaridades, a Revista manteve-se publicada regularmente durante muitos anos e foi a única inteiramente dedicada a temas tributários durante mais de vinte anos, desde sua fundação. Essa, pelo menos, é a opinião de Ruy Barbosa Nogueira, referindo-se ao início da década de quarenta, quando “(...) na ocasião, praticamente só havia o repertório da Revista Fiscal e de legislação da Fazenda, dirigida por Tito Rezende, na qual eu colaborava". 365

Durante muitos anos a única revista tributária seria a coordenada por Tito Rezende, que consolidava trabalhos técnicos e teóricos, cumuladas com a normatização atualizada da época. Por isso era um importante referencial para os operadores da atividade tributária, seja no seu aspecto econômico-contábil, seja no aspecto jurídico ${ }^{366}$.

Mas no ano de 1945, outra importante revista, embora não dedicada exclusivamente a temas tributários, foi criada no Brasil ${ }^{367}$ : a Revista de Direito Administrativo. Esse periódico era parte da Revista de Serviço Público (e, portanto, uma publicação oficial patrocinada pela Fundação Getúlio Vargas), e trazia estudos, pareceres e jurisprudência mais atualizada sobre Direito Público, sobretudo em matéria de Direito Administrativo, Constitucional, Penal, Financeiro e Tributário, e contribuiu enormemente para a difusão de estudos de autores estrangeiros dedicados à problemática fiscal.

$\mathrm{O}$ traço marcante dessa revista foi a qualidade propriamente jurídica dos estudos e pareceres publicados, bem como da organização destinada à atualização sobre os principais temas (técnicos, teóricos, legislativos ou jurisprudenciais) atinentes ao Direito Público.

Sem dúvida, analisando as edições das primeiras décadas de sua criação, pode-se perceber que a contribuição primacial dessa revista para o Direito Tributário foi o de ajudar a disseminar importantes estudos estrangeiros versados em Direito Tributário, através de suas traduções para a língua portuguesa, além de importantes estudos nacionais. A revista

\footnotetext{
${ }^{365}$ NOGUEIRA, Ruy Barbosa. A Contribuição de Tullio Ascarelli para a formação da doutrina jurídicotributária no Brasil. Direito Tributário Atual. Vol.10. São Paulo: Co-edição. Instituto Brasileiro de Direito Tributário. Resenha Tributária, 1990, p.21 e seguintes.

${ }^{366}$ Revista Fiscal. "Imposto da Renda. Selo. Despesas. Contribuições Públicas. Vendas Mercantis e Pequenos Impostos". REZENDE, Tito. (Coord). Rio de Janeiro: RBN, 1931. REVISTA FISCAL. "Consumo. Assuntos Aduaneiros. Outros Assuntos". REZENDE, Tito. Rio de Janeiro: RBN, 1931. Revista fiscal. "Consumo. Vendas Mercantis. Outros Assuntos Aduaneiros". REZENDE, Tito. Rio de Janeiro: RBN, 1932.

${ }^{367}$ LOPES, Luiz Simões. Apresentação. In: Revista de Direito Administrativo. Seção II da Revista do Serviço Público. Carlos Medeiros Silva (Diretor), São Paulo: 1945, s/p.
} 
notabilizou-se pela divulgação de importantes estudos estrangeiros traduzidos para a língua portuguesa (especialmente oriundos da França), a exemplo dos trabalhos de Louis Trotabas $^{368}$, André Hariou ${ }^{369}$, assim como pela divulgação de importantes estudos brasileiros sobre o tema, como os trabalhos de Castro Nunes ${ }^{370}$, entre outros.

Nos volumes seguintes, a Revista de Direito Administrativo dedicou-se a publicar estudos claramente tencionados a divulgar a imperiosidade de estudos jurídicos tributários distintos da influência de outros ramos do direito, como é possível observar na publicação dos estudos Gastón Jèze, sobre o "Fato Gerador do Imposto",371, e sobre a "Natureza e Regime Jurídico do Crédito Fiscal ${ }^{372}$. Publicou também o interessante trabalho de Paulo Barbosa de Campos Filho, tratando do tema "Codificação do Direito Tributário Brasileiro" 373 , claramente dedicado a defender a necessidade de se instaurar o processo de codificação do direito tributário brasileiro, à exemplo da experiência alemã, além de outros trabalhos específicos, como "Observações sobre a Tributação Municipal" (Româo Côrtes de Lacerda) ${ }^{374}$, e o artigo de Rubens Gomes de Sousa, intitulado "A coisa Julgada no Direito Tributário" 375 .

Nesse quadro, vale destacar também o relato de Rubens Gomes de Sousa, que mostra que a importância dos periódicos para informação e divulgação de legislação, jurisprudência e doutrina no Brasil não se limitou às duas supracitadas, mas também

368 TROTABAS, Louis. Interpretação das Leis Fiscais. Vol.I. Fasc. I. In: Revista de Direito Administrativo, Rio de Janeiro: Seção II da Revista do Serviço Público - Departamento Administrativo do Serviço Público - Fundação Getúlio Vargas, abril de 1945, p.30-47.

${ }^{369}$ HAURIOU, André. A Utilização em Direito Privado das Regras e Princípios do Direito Privado. Vol.I. Fasc. II. In: Revista de Direito Administrativo, Rio de Janeiro: Seção II da Revista do Serviço Público - Departamento Administrativo do Serviço Público - Fundação Getúlio Vargas, abril de 1945, p.465-475.

${ }^{370}$ NUNES, Castro. Problemas de Partilha Tributária. In: Revista de Direito Administrativo, Vol.I. Fasc. I, Rio de Janeiro: Seção II da Revista do Serviço Público - Departamento Administrativo do Serviço Público - Fundação Getúlio Vargas, abril de 1945, p.01-16.

371 JÈZE, Gastón. O Fato Gerador do Impôsto. Revista de Direito Administrativo, Rio de Janeiro: Seção II da Revista do Serviço Público - Departamento Administrativo do Serviço Público - Fundação Getúlio Vargas, junho de 1945, p.50-65.

372 JĖZE, Gastón. Natureza e Regime Jurídico do Crédito Fiscal, Revista de Direito Administrativo, Vol.III. Rio de Janeiro: Seção II da Revista do Serviço Público - Departamento Administrativo do Serviço Público - Fundação Getúlio Vargas, janeiro de 1946, p.59-69.

${ }^{373}$ FILHO, Paulo Barbosa de Campos. Codificação do Direito Tributário Brasileiro. In: Revista de Direito Administrativo, Vol.III. Rio de Janeiro: Seção II da Revista do Serviço Público - Departamento Administrativo do Serviço Público - Fundação Getúlio Vargas, janeiro de 1946, p.44-59.

${ }^{374}$ LACERDA, Româo Côrtes de. Observações sobre a Tributação Municipal. In: Revista de Direito Administrativo, Vol. IV, Rio de Janeiro: Seção II da Revista do Serviço Público - Departamento Administrativo do Serviço Público - Fundação Getúlio Vargas, julho de 1946, p.88 e seguintes.

${ }^{375}$ SOUSA, Rubens Gomes de. A coisa Julgada no Direito Tributário. In: Revista de Direito Administrativo, Vol. 5, Rio de Janeiro: Seção II da Revista do Serviço Público - Departamento Administrativo do Serviço Público - Fundação Getúlio Vargas, julho de 1946, p.48-77. 
passou por outras, de análoga importância: "Do ponto de vista prático, para acompanhar a legislação, a jurisprudência e as decisões administrativas, é indispensável a Revista Fiscal e de Legislação da Fazenda, editada quinzenalmente no Rio de Janeiro, desde 1930, e dedicada aos tributos federais. Nos anos de 1950 e 1952, esta revista publicou uma edição em São Paulo, sob o título Revista Fiscal de São Paulo, dedicada aos tributos estaduais e do Município da Capital: embora tenha, infelizmente, cessado sua publicação, a coleção daqueles anos é muito útil. É também recomendável a Revista de Estudos Fiscais, editada mensalmente em São Paulo, desde 1947, pelo Centro de Estudos dos Agentes Fiscais do Imposto de Consumo: trata de todos os tributos federais, exceto o imposto de renda, e publica alguma matéria doutrinária. Semelhante a esta, mas dedicada aos impostos de renda e de lucros extraordinários, é a revista "CEFIR", publicada em São Paulo desde 1956, pelo Centro de Estudos de Fiscalização do Imposto de Renda”, lembrando também da Revista de Direito Administrativo, assim como da Revista de Finanças Públicas, editada bimestralmente no Rio de Janeiro pelo Conselho Técnico de Economia e Finanças do Ministério da Fazenda (com o título atual a partir de 1952, pois anteriormente denominavase "Boletim do CTEF")". 376

Essas revistas, também elevadas por Aliomar Baleeiro ${ }^{377}$, foram sucedidas por outras de análoga relevância, cada vez mais especializadas em matéria tributária ${ }^{378}$, traduzindo-se em fortes aliados para a divulgação de estudos sobre o ambiente do Direito Tributário brasileiro, em uma época carente de publicações de relevo no tema.

\subsection{A Contribuição da Constituição de 1946 e as normas gerais em matéria de direito financeiro}

Um dos fatores primordiais para o desenvolvimento efetivo do Direito Tributário Brasileiro enquanto disciplina foi semelhante ao que já indicava eficiência no direito

\footnotetext{
${ }^{376}$ SOUSA, Rubens Gomes de. Compêndio de Legislação Tributária. Edição Póstuma. IBET - Resenha Tributária, 1975, p. 46.

${ }^{377}$ BALEEIRO, Aliomar. Prefácio. In: FALCÃO, Amílcar de Araújo. Introdução ao Direito Tributário. Rio de Janeiro: Editora Rio - Faculdades Integradas Estácio de Sá, 1976, p.12-14.

${ }^{378}$ É o exemplo da Revista de Direito Tributário, publicada a partir de 1977, sob os auspícios do IDEPE Instituto Internacional de Direito Público e Empresarial e do IBET - Instituto Brasileiro de Estudos Tributários, que, conforme recorda Geraldo Ataliba, foi inspirada nos trabalhos de Rubens Gomes de Sousa. ATALIBA, Geraldo. Editorial. Revista de Direito Tributário. n.1. julho/setembro, IDEPE - IBET. São Paulo: Malheiros, 1977, p. 07-09.
} 
estrangeiro. Trata-se do fenômeno codificador, que somente se consolidaria a partir da década de sessenta no Brasil, embora os esforços para sua consolidação já datassem da década de quarenta. Não é por acaso que, a partir da Constituição de 1946, por expressa influência de Aliomar Baleeiro, foi inserido o art.5 $5^{\mathrm{a}}$, inc.I, b, que autorizaria à União a criação de normas gerais em matéria de direito financeiro.

Tal autorização foi celebrada pelos estudiosos da área, pois significaria abertura constitucional para o mesmo fenômeno que impulsionou o rápido desenvolvimento do direito tributário em outros países, a exemplo da Alemanha e seu Código Tributário.

A grande preocupação relativa aos estudos constitucionais do Direito Tributário é devida aos esforços de Aliomar Baleeiro ${ }^{379}$, na época, já reconhecido como um dos grandes incentivadores do desenvolvimento dos estudos sobre a matéria, e buscou incentivá-la não somente no campo político-legislativo, mas também acadêmico, e, assim, foi um dos grandes articuladores, no âmbito constitucional, de um dispositivo específico na Constituição de 1946 que forneceu o impulso que faltava para o progresso do direito tributário brasileiro. Nesse sentido, a Constituição de 1946, em seu artigo $5^{\circ}$ prescreveu: “Art $5^{\circ}$ - Compete à União: (...) XV - legislar sobre: (...) b) normas gerais de direito financeiro; $(\ldots)^{380}$.

O testemunho de Amílcar de Araújo Falcão comprova o débito do Direito Tributário para Baleeiro: "Como se sabe, deve-se a Aliomar Baleeiro a introdução desse dispositivo (art.5, inc.XV) no texto da Constituição, o que se logrou após amplos debates em que figurava como grande opositor Mário Mazagão"381.

A Constituição de 1946 representou, em matéria tributária, um marco legislativo, pois efetivamente demonstrou uma organização muito mais clarificada quanto às demarcações de competências e às limitações ao poder de tributar. Também restabeleceu princípios democráticos trazidos na Constituição de 1934, na opinião de Ubaldo Cesar Balthazar $^{382}$. Por isso, conforme atesta Antônio Roberto Sampaio Dória: a “(...) Liberalização da vida política, relativa descentralização financeira e propósitos de

\footnotetext{
${ }^{379}$ BALEEIRO, Aliomar. Nota Prévia. In: BALEEIRO, Aliomar. Direito Tributário Brasileiro. $11^{\circ}$ edição. Atualizada e com notas de Mizabel Derzi. Forense: Rio de Janeiro, 2000, s/p.

${ }^{380}$ Idem.

${ }^{381}$ FALCÃO, Amílcar de Araújo. Sistema Tributário Brasileiro. Discriminação de Rendas. Op.cit., p. 5152.

${ }^{382}$ BALTHAZAR, Ubaldo Cesar. Op.cit., p. 125 e ss.
} 
valorização do Município brasileiro foram a pedra de toque da Constituição Federal de 1946,383

Também reaproximou os direitos e garantias individuais e a matéria tributária, relação que se mantinha perene, porém tímida nas Constituições anteriores. A Constituição de 1946 concedia maior importância à matéria tributária que suas antecessoras, e incluía algumas novidades importantes. Contudo, apesar desse fato, ainda não havia uma estrutura harmônica e coordenada da matéria na estrutura constitucional.

De qualquer forma, a Constituição de 1946 conservou as limitações já previstas nas suas antecessoras e consagrou princípios gerais, já universalmente aceitos, mas que não haviam sido expressamente previstos nas Constituições anteriores ${ }^{384 \_}{ }^{385}$. É o caso do princípio da capacidade contributiva. Esse princípio aparece pela primeira vez nas cartas constitucionais brasileiras, embora já conhecido no ambiente jurídico pátrio. ${ }^{386}{ }^{387} \_388$

Conforme assinala Alcides Jorge Costa, o pacto federativo direcionado à discriminação de receitas tributárias deu um passo adiante na melhor distribuição de competências tributárias, ampliando a competência municipal ${ }^{389}$ e aprimorando as limitações ao poder de tributar, graças à atuação de Aliomar Baleeiro, que, enquanto parlamentar, teve destacada atuação para a melhor organização da matéria tributária na Constituição de 1946.

\footnotetext{
${ }^{383}$ DÓRIA, Antônio Roberto Sampaio. Discriminação de Competência Impositiva. Op.cit., p. 102.

${ }^{384}$ Conforme sintetizou Aliomar Baleeiro, o rol de princípios disciplinadores da tributação (as chamadas "limitações ao poder de tributar") foi severamente majorado desde a Constituição de 1824 até a Constituição de 1946, já que o convívio de três competências fiscais simultâneas sobre o mesmo campo econômico, graças ao federalismo, "(...) explica, em grande parte, a presença dessas regras, algumas das quais, expressas no Direito Constitucional brasileiro, encontram origem na construction de tribunais americanos". BALEEIRO, Aliomar. Limitações Constitucionais ao Poder de Tributar. $2^{\mathrm{a}}$ Edição, Rio de Janeiro: Forense, 1959, p. 12.

${ }^{385}$ LIMA, Ruy Cirne. Princípios de Direito Administrativo Brasileiro. 3 Ed. Porto Alegre: Livraria Sulina, p. 104 e seguintes.

${ }^{386}$ BALEEIRO, Aliomar. Limitações Constitucionais ao Poder de Tributar. $2^{\text {a }}$ Edição. Op.cit., p. 12-15.

387 MAXIMILIANO, Carlos. Comentários à Constituição Brasileira. Quarta edição. Volume II. Rio de Janeiro: Livraria Freitas Bastos, 1948, p. 166 e seguintess; p. 265 e seguintes. MIRANDA, Francisco Cavalcanti Pontes de. Comentários à Constituição de 1946. Vol. II (arts 37-48), Rio de Janeiro: Livraria Boffoni, 1946, p.365 e seguintes.

${ }^{388}$ FALCÃO, Amílcar de Araújo. Sistema Tributário Brasileiro. Discriminação de Rendas. Op.cit., p. 3672.

${ }^{389}$ COSTA, Alcides Jorge. História da Tributação no Brasil. Op.cit., p. 79-80.
} 


\subsection{A influência de Tullio Ascarelli no processo disciplinar (autonomia teórica e autonomia de ensino) do Direito Tributário Brasileiro}

A elevação da carga tributária, o constitucionalismo tributário reforçado pela Constituição de 1946 e os francos debates envolvendo a criação de tribunais fiscais já eram assuntos consolidados nos estudos da década de quarenta no Brasil.

Mas é um erro afirmar que somente aqueles fatores viabilizariam o processo disciplinar do Direito Tributário Brasileiro, pois outros também contribuíram para a consolidação da disciplina no Brasil.

A partir da autorização constitucional para a elaboração federal de normas gerais sobre matéria financeira trazida pela Constituição de 1946, ao que parece, a doutrina do direito tributário brasileiro começa a se desenvolver largamente inspirada nos estudos europeus. Apesar de, na década de quarenta, já se registrarem as primeiras obras sobre o tema (a exemplo de João Martins de Oliveira), foi com o italiano Tullio Ascarelli que o estudo - e o ensino - do Direito Tributário alcançou seus mais fortes impulsos iniciais, pelo menos em São Paulo ${ }^{390}$.

O autor italiano desembarcou em São Paulo, e passou a desenvolver profícua produção jurídica, inclusive elaborando importantes estudos que depois seriam repercutidos na doutrina brasileira. Dentre os esforços (e estudos) elaborados pelo autor na época destacam-se: a) “A quota-parte dos funcionários nas multas e os princípios de justiça fiscal" ${ }^{391}$, que, embora não tenha sido publicada com a identificação, pois publicada na sede da Federação das Indústrias, no ano de 1941, na comunidade jurídica da época, era conhecida a verdadeira autoria da obra ${ }^{392}$; b) Ascarelli elaborou trabalho enviado ao

\footnotetext{
390 A importância de Tullio Ascarelli pode ser compreendida a partir do testemunho de Ruy Barbosa Nogueira, que decidiu homenagear o mestre italiano pelos seguintes motivos: "Por eu ter sido seu aluno na primeira das turmas curriculares de Direito Comercial, das que lecionou nesta faculdade, e particularmente; por ter trabalhado vários anos a seu lado, nos serviços jurídicos da Federação das Indústrias; Ter, desde solicitador acadêmico sido seu companheiro de escritório por vários anos, e ainda; depois de formado, ter sido seu aluno em curso monográfico de Direito Tributário que prelecionou na Escola Livre de Sociologia e Política de São Paulo, Divisão de Estudos Pós-Graduados, em 1947”. A influência fundamental de Tullio Ascarelli para o desenvolvimento da doutrina brasileira pode ser verificada no artigo: NOGUEIRA, Ruy Barbosa. A Contribuição de Tullio Ascarelli para a formação da Doutrina Jurídico-Tributária do Brasil. Direito Tributário Atual. Vol.10. São Paulo: Co-edição. Instituto Brasileiro de Direito Tributário. Resenha Tributária, 1990, p. 05 e seguintes.

${ }^{391}$ Idem.

${ }^{392}$ Com Ascarelli, já Advogado-Chefe do Centro e Federação das Indústrias, dez anos mais tarde, esse estudo foi estendido, com o acréscimo de uma introdução e quatro capítulos, e um adendo com comentário da
} 
Ministério da Fazenda como colaboração da Federação de Indústrias, e que jamais foi editado, referente ao conceito de rendimento para os efeitos da tributação, intitulado: "O conceito de rendimento tributável e o projeto do Novo Regulamento de Imposto de Renda"; ${ }^{393}$ c) a realização, em 1947, do curso de "Princípios Básicos do Imposto de Renda e o Sistema Brasileiro", sendo provavelmente o primeiro curso monográfico de natureza “científica” (segundo a opinião de Ruy Barbosa Nogueira ${ }^{394}$ ) publicado no Brasil ${ }^{395}$; d) exerceu larga influência em muitos estudiosos que posteriormente viriam a exercer papel de grande destaque no desenvolvimento da doutrina brasileira, como é o caso de Rubens Gomes de Sousa ${ }^{396}{ }_{-}^{397}$; e) colaboração entre Rubens Gomes de Sousa e Tullio Ascarelli ${ }^{398}$, pois entre Rubens Gomes de Sousa e Tullio Ascarelli já havia anterior colaboração

Revista do Serviço Público do DASP. Tal acréscimo teve a colaboração do próprio Prof. Ruy Barbosa Nogueira. O estudo estendido foi publicado sob o título "Multas Fiscais" (edição do Centro e Federação das Indústrias do Estado de São Paulo, São Paulo, 1951). NOGUEIRA, Ruy Barbosa. A Contribuição de Tullio Ascarelli para a formação da Doutrina Jurídico-Tributária do Brasil. Op.cit., p.05-10.

${ }^{393}$ Nesse trabalho, já se visualizava contribuições estrangeiras para o assunto (do direito e da economia). Segundo Ascarelli “(...) a renda passa a ser tributável quando atinge a condição de circulação econômica, tratando também dos conceitos de separação da renda (a distinção entre bens e frutos só é, entretanto, possível, quando estes sejam separados daqueles; o que se pode esclarecer informando que essa separação tem lugar quando os frutos se tornam suscetíveis de circulação econômica”. E também relacionou aquele conceito à realização da renda, ao afirmar que “(...) o rendimento também deve ser realizado": “(...) não somente é necessária a sua separação física, mas também a sua separação econômica. Por sua vez, a realização verifica-se com o consumo direto do fruto pelo possuidor do bem que o produz, ou com a sua alienação". Passagens extraídas das páginas 07 e 08 do trabalho, que foi reproduzido por Ruy Barbosa Nogueira. Idem, p.27-26

394 Além disso, Ascarelli incentivou a primeira publicação de Ruy Barbosa Nogueira, quando ainda bacharelando, estudava a ação declaratória com o Prof. Enrico Tulio Liebman. Naquele contexto, ainda inexperiente em matéria fiscal, segundo ele próprio dizia, propôs-se a elaborar paralelo entre a ação declaratória e a consulta fiscal e respectivos efeitos declaratórios. Ruy levou o trabalho a Ascarelli, que discutiu o trabalho com ele e incentivou-o a publicá-lo. O trabalho foi publicado sob o título "A Consulta como Meio de Harmonia Fiscal” (Revista Industrial de São Paulo, dezembro de 1944, páginas 66/67). Também foi importante difusor do debate entre o "formalismo jurídico e o conteúdo econômico", tema que se relacionava à consideração econômica frente ao direito tributário. Ibidem.

${ }^{395}$ Ibidem.

${ }^{396}$ ASCARELLI, Tullio. Imposto sobre a Renda e Sociedades Comerciais Vol. VII. Janeiro-Março de 1947. In: Revista de Direito Administrativo, Rio de Janeiro: Seção II da Revista deo Serviço Público Departamento Administrativo do Serviço Público - Fundação Getúlio Vargas, p.19-33.

${ }^{397}$ E a influência de Ascarelli na obra de Rubens Gomes de Sousa foi assumida pelo mesmo, referindo-se ao período em que ainda era aluno do mestre italiano: "Embora naquela época eu já tivesse dez anos de prática especializada em matéria tributária, foi de Ascarelli que recebi a base científica, sobre a qual pude, em seguida, modestamente, construir a minha própria elaboração. Dele tive, desde a indicação de bibliografia antes desconhecida no Brasil, até a orientação doutrinária e o alargamento de horizontes, muito além do campo estritamente tributário, que me permitiram fazer algo mais que o simples trato espírito de problemas fiscais em arrazoados forenses” SOUSA, Rubens Gomes de. Compêndio de Legislação Tributária. Edição Póstuma: IBET - Resenha Tributária, 1975, p. 42 e seguintes.

${ }^{398}$ Segundo relato do próprio Ruy Barbosa Nogueira, “(...) entre os poucos alunos contavam-se mesmo aqueles que mais tarde iriam ser os primeiros professores da matéria ou codificadores nesse campo. Assim, entre os advogados, já mais experiente, estava Rubens Gomes de Sousa que foi sem dúvida aluno "primus inter pares". Basta ler-se a dissertação por ele feita dentro desse curso - "O fato gerador do imposto de Renda" - o que Rubens, mais tarde, publicou de páginas 162 a 206 em seu livro "Estudos de Direito Tributário”, edição Saraiva, 1950”. NOGUEIRA, Ruy Barbosa. A Contribuição de Túllio Ascarelli para a formação da Doutrina Jurídico-Tributária do Brasil. Op.cit., p.15. 
científica de relevo, na publicação do estudo "Lucros Extraordinários e Imposto de Renda”, em 1944, fruto de colaboração entre Ascarelli e dois de seus futuros alunos naquele curso de pós-graduação, Rubens Gomes de Sousa e João Batista Pereira Almeida Filho, porém focado como estudo propriamente de Ciência das finanças e não necessariamente Direito Tributário; f) grande esforço para divulgar as doutrinas europeias do Direito Tributário, ajudando a difundir no Brasil nomes como Albert Hensel, Ernst Blumenstein, Franz Von Myrbach-Rheinfeld, Ezio Vanoni, Mario Puglèse, Benvenuto Griziotti, Giannini, Louis Trotabas, François Geny, Henry Laufemburger e Seligman ${ }^{399}$; g) também buscou divulgar as primeiras obras brasileiras dedicadas à matéria, a exemplo do “Curso" de João Martins de Oliveira, além da obra de Seabra Fagundes ( $1^{\text {a }}$ edição publicada em 1941), intitulada "O Controle dos Atos Administrativos pelo Judiciário" que, muito embora não tratasse diretamente do Direito Tributário, foi muito bem recebida pelos primeiros tributaristas da época.

Aliás, peculiaridade importante na obra de Ascarelli, lembrado por Ruy Barbosa Nogueira, foi justamente seu esforço em demonstrar que o substrato econômico serve para esclarecer o alcance do conceito jurídico. Mas, para Ascarelli, o reconhecimento da consideração econômica não deveria levar a conclusões apressadas no sentido de que o Direito Tributário observaria tão somente o aspecto econômico - mas não o jurídico - das relações tributárias. Ascarelli reconhecia que nenhuma disciplina jurídica deve descuidar do aspecto econômico, mas também afirmava a necessidade de o Direito Tributário, assim como qualquer outra disciplina jurídica, assentar-se em conceitos jurídicos. No caso do Direito Tributário, esse pode pautar-se apenas em conceitos jurídicos, embora eventualmente possa ancorar-se em conceitos de Direito Privado, utilizando-os em um sentido diverso. Em síntese, reconhecia Ascarelli que o Direito Tributário, angariando cada vez maior importância, passava a oferecer seus próprios contributos perante a ciência jurídica, não dependendo necessariamente de conceitos de Direito Privado ${ }^{401}$.

Assim, a clara visão aberta ao diálogo entre Economia e Direito vislumbrada por Ascarelli, cumulada à sua percepção (orientado pela doutrina estrangeira) sobre a

\footnotetext{
399 NOGUEIRA, Ruy Barbosa. A Contribuição de Tullio Ascarelli para a formação da Doutrina Jurídico-Tributária do Brasil. Op.cit., p.27 e seguintes.

${ }^{400}$ FAGUNDES, M. Seabra. O Controle dos Atos Administrativos pelo Poder Judiciário, $4^{\circ}$ Ed., Rio, 1967, p.16 e seguintes.

401 NOGUEIRA, Ruy Barbosa. A Contribuição de Túllio Ascarelli para a formação da Doutrina Jurídico-Tributária do Brasil. Op.cit., p. 32.
} 
necessidade de maior autonomia da disciplina frente a conceitos oriundos de outros ramos do Direito, influenciou decisivamente os primeiros anos da doutrina brasileira, especialmente até a década de sessenta ${ }^{402}$.

Retornando para a Itália em 1949, deixou grande legado aos estudos de Direito Tributário $^{403}$. Por isso, Heleno Taveira Tôrres identificou-o como “(...) o fundador, no Brasil, dos estudos de Teoria Geral de Direito Tributário, cuja sequência dada pelo gênio de Rubens Gomes de Sousa fez prosperar, no campo legislativo, a criação de um Código Tributário Nacional, e no palco acadêmico, a constituição do Instituto Brasileiro de Estudos Tributários - IBET, em 1971”404.

Contudo, ressalta-se que já havia o expressivo trabalho de João Martins de Oliveira com sólida obra publicada no Rio de Janeiro, e que não poderia ser ignorada.

Assim, sinais inaugurais da construção disciplinar (teórica) do Direito Tributário já existiam, mas encontrou em Ascarelli um direcionamento científico propriamente jurídico, além da divulgação das principais obras estrangeiras sobre o tema. Nesse ponto, reside o maior mérito de Ascarelli, qual seja atrair e direcionar a doutrina do Direito Tributário para o rumo da ciência propriamente jurídica (ainda que não signifique um impulso ao formalismo jurídico excludente entre o Direito e a Economia).

Além disso, os estudos estrangeiros mais avançados em matéria de Direito Tributário foram propagados para os estudos do Direito Tributário Brasileiro, e graças à Ascarelli. Porém, não se diga que alguns desses autores já não fossem conhecidos do público brasileiro. Nomes como Otto Mayer, Geny, Jèze, Trotabas, Myrbach-Rheinfeld, Giannini, entre outros, já haviam sido mencionados em estudos anteriores à disseminação doutrinária europeia antes mesmo da chegada do mestre italiano no Brasil. Contudo, é com Tullio Ascarelli que se visualiza melhor seleção, divulgação e incentivo desses estudos jurídico tributários na época, o que favoreceu enormemente o processo disciplinar do Direito Tributário Brasileiro, sobretudo em São Paulo.

\footnotetext{
402 NOGUEIRA, Ruy Barbosa. A Contribuição de Tullio Ascarelli para a formação da Doutrina Jurídico-Tributária do Brasil. Op.cit. p. 32.

${ }^{403}$ Recomenda-se as considerações de Norberto Bobbio sobre a obra de Ascarelli: BOBBIO, Norberto. Da Estrutura à Função. Novos studos de Teoria do Direito. São Paulo: Manole, 2007, p. 211-271.

${ }^{404}$ TORRES, Heleno Taveira. Contribuição da Doutrina Italiana para a Formação do Direito Tributário Brasileiro. Op.cit., p.1159.
} 


\subsection{A contribuição de Rubens Gomes de Sousa no processo disciplinar do Direito Tributário entre os anos 40 e 50}

A contribuição de Rubens Gomes de Sousa não poderia deixar de ser lembrada, já que possui papel essencial para o desenvolvimento dos estudos tributários a partir da década de quarenta.

A primeira obra do autor, já mencionada nos tópicos anteriores, foi publicada no ano de 1943, intitulada “A Distribuição da Justiça em Matéria Fiscal”, visando defender a criação de um tribunal fiscal especializado em matéria tributária, e desafogar o Supremo Tribunal Federal do excesso de lides de Direito Público (e Fiscal). Também nessa obra era clara a defesa, pelo autor, da autonomia do Direito Tributário perante outros ramos do conhecimento jurídico.

De fato, a influência de Tullio Ascarelli não pode ser esquecida na visão do autor, que foi seu aluno "primus inter pares" (conforme expôs Ruy Barbosa Nogueira) e chegou a publicar obra em coautoria com o mestre italiano, em 1944, quando publicou, junto com João Batista Pereira de Almeida Filho, por sua vez intitulada "Lucros extraordinários e imposto de renda", que buscava analisar o Decreto 15.028/1944, em relação à doutrina e ao imposto de renda, contendo larga análise comparativa do tratamento do imposto sobre lucros extraordinários em sistemas jurídicos estrangeiros, alcançando boa atualização relativa à estrutura e ao tratamento legal do imposto sobre lucros extraordinários ${ }^{405}$, temática que também acabou abordada por José Luiz de Almeida Nogueira Porto. ${ }^{406}$ Ambas as obras, no aspecto doutrinário, aproximaram-se muito mais da produção doutrinária da Ciência das Finanças, ao passo que no aspecto legislativo, teceram comentários à luz dessas mesmas contribuições.

\footnotetext{
${ }^{405}$ ASCARELLI, Tullio; SOUSA, Rubens Gomes de; FILHO, João Batista Pereira de Almeida. Lucros Extraordinários e Imposto de Renda. Comentários ao Decreto n.15028 de 13 de março de 1944, em relação com a doutrina e a legislação do imposto de renda. São Paulo: Livraria Martins Editora, 1944, p.56-85 e p.200-202.

${ }^{406}$ PORTO, José Luiz de Almeida Nogueira Porto. Lucros Extraordinários. Teoria e Prática. São Paulo: Editora Comercial, 1944, p.11-52. Outro trabalho do mesmo autor, que aparentemente segue semelhante proposta: PORTO, José Luiz de Almeida Nogueira Porto. Imposto do Sêlo Federal - Comentário à Nova Lei (em colaboração com Marcello Ulysses Rodrigues) - São Paulo - 1942, p.93 e seguintes.
} 
Em 1946, Gomes de Sousa, já conhecendo as obras de Jèze e Jarach, em estudo denominado "A coisa julgada em matéria tributária", apresentou efetivo conhecimento dos institutos caros ao Direito Tributário Europeu, como é o caso do "fato gerador do imposto" (até porque o clássico "O Fato Gerador do Imposto", de autoria de Gastón Jèze, já havia sido traduzido ao português em 1945, pela RDA), para quem esse seria “(...) o fato material que demonstra a criação, a posse, ou a transmissão de uma riqueza, e do qual, nesse pressuposto, a lei faz depender a incidência, identificando o fato gerador do imposto como causa próxima da obrigação tributária, ou a "causa próxima que a lei faz derivar a incidência"407.

Mas papel de difusão da importância do Direito Tributário foi traçado por Rubens Gomes de Sousa em monografia dedicada aos alunos do curso oferecido na Escola de Sociologia e Política, em 1947, (Introdução ao Direito Tributário - Parte Especial) ${ }^{408}$, no qual vinculava, no trato da teoria da relação jurídica tributária, os temas mais caros à literatura tributária da época, conforme é possível observar em Ademar Ferreira ${ }^{409}$. Tomese como exemplo o esforço do autor na divulgação da teoria do objeto da relação tributária, que seria, nas palavras do autor, "a teoria do fato gerador".

A teoria da relação jurídica tributária seria elemento central em torno do qual se constrói o sistema do direito tributário, e sendo o direito tributário essencialmente obrigacional, ou seja, um direito que disciplina o poder jurídico pelo qual uma das partes (sujeito ativo ou credor) possa exigir da outra parte (sujeito passivo ou devedor, ou contribuinte) o cumprimento de uma prestação pessoal de fazer traduzida pelo pagamento de uma soma em dinheiro. Elevou, portanto, a importância basilar do estudo da relação tributária estabelecida entre as partes para o correto entendimento do sistema tributário. E enquadra a importância fundamental do fato gerador no âmbito da relação tributária: “(...) Por outro lado, ao estudar os elementos da relação jurídica tributária os Srs verão que um desses elementos, o objeto, é de capital importância, porquanto dá oportunidade ao estudo do fato gerador do tributo; o fato gerador é o fato, simples ou complexo (isto é, fato único ou conjunto de fatos correlatos) de cuja ocorrência a lei faz depender o direito do Estado ao

\footnotetext{
${ }^{407}$ SOUSA, Rubens Gomes de. A Coisa Julgada no Direito Tributário. Op.cit., p.58-63.

${ }^{408}$ SOUSA, Rubens Gomes De. Introdução ao Direito Tributário. Parte Especial, São Paulo: s/e, 1947, p. 01.

409 É interessante notar que a influência dos cursos oferecidos por Rubens Gomes de Sousa na Escola de Sociologia e Política de São Paulo (1949) foi expressamente lembrada por Ademar Ferreira. FERREIRA, Ademar. Direito Fiscal. Aspectos Doutrinários e Práticos. São Paulo: Saraiva, 1961, p. v.
} 
lançamento do tributo em cada caso concreto; o fato gerador, portanto, é, por assim dizer, a mola que põe em movimento todo o sistema" ${ }^{\text {410. }}$.

Além disso, segundo Rubens Gomes de Sousa, no estudo particularizado de cada tributo, a classificação desses segundo as suas características jurídicas somente poderia ser feita através da pesquisa de seu fato gerador: “(...), portanto, o estudo do fato gerador adquire também importância imediata para este curso sob este aspecto prático"411.

Note-se, portanto, que, no curso de extensão proferido na Escola de Sociologia e Política de São Paulo, Rubens Gomes de Sousa já apresentava intimidade com temas complexos da literatura tributária especializada, experiência que seguiu compartilhando através de notáveis estudos, como a coletânea publicada em 1950, que reuniu pareceres e estudos monográficos do autor, publicada pela editora Saraiva, e intitulada "Estudos de Direito Tributário", destacando-se, dentre outros estudos, a monografia do autor no curso ministrado por Tullio Ascarelli, intitulada "O Fato Gerador do Imposto de Renda" ${ }^{412}$. Mas Rubens Gomes de Sousa também seria credor de outra importante conquista do Direito Tributário: a codificação do direito tributário brasileiro, a ser analisada com maior atenção no Segundo Capítulo.

\section{A difusão da literatura tributária a partir da década de cinquenta: a consolidação da especialização disciplinar (autonomia teórica)}

A difusão aos estudos tributários, através de figuras históricas como Tullio Ascarelli, Rubens Gomes de Sousa, João Martins de Oliveira, Aliomar Baleeiro, entre outros na década de quarenta, incentivou maior preocupação com o trato da matéria a partir desse período.

\footnotetext{
${ }^{410}$ SOUSA, Rubens Gomes De. Introdução ao Direito Tributário. Parte Especial. Op.cit., p. 01.

${ }^{411}$ Esta apostila foi analisada graças à generosidade do Prof. Alcides Jorge Costa, aluno do curso na época, e que conseguiu conservar em sua biblioteca particular uma das apostilas do curso (entre várias que acabaram perdidas no tempo...). SOUSA, Rubens Gomes De. Introdução ao Direito Tributário. Parte Especial, São Paulo: s/e, 1947, p. 01.

412“"Seria talvez procedente uma objeção de caráter terminológico contra a expressão "fato gerador", porquanto esta dá a ideia de que tal fato é necessário e suficiente para gerar a obrigação quando acabarmos de ver que ele é necessário, porém não suficiente (Jèze sentiu esta objeção). Talvez por isto outras terminologias foram propostas: fato tributável (Jarach), situação - base fiscal (Allorio). Todavia, eventualmente, em razão da maior influência, entre nós, da doutrina, e da maior familiaridade da língua francesa, a expressão "fato gerador" (Jèze) já penetrou na terminologia". SOUSA, Rubens Gomes de. Estudos de Direito Tributário, Ed. Saraiva, 1950, p.167, 12-B
} 
Essa também é a posição de Brandão Machado ${ }^{413}$, sobretudo porque a partir da década de quarenta, com o apoio das influências acima citadas, o Direito Tributário passa a experimentar produção teórica própria, com ampla publicação e divulgação de artigos, comentários, pareceres, não se incluindo trabalhos de interesse prático, que segundo Brandão Machado, nunca faltaram, dentre alguns poucos ensaios, lembrando ainda que o tratamento científico dos assuntos tributários, já inicialmente manifestado nos autores acima lembrados, começa a ganhar maior volume na literatura, sem considerar os pareceres e estudos práticos sobre o tema, que sempre existiram, em maior ou menor grau.

Assim, a literatura tributária brasileira chega à década de cinquenta já estruturada por essas peculiaridades, reforçando-se nas décadas seguintes.

Nesse momento histórico, grande participação na divulgação e difusão de estudos versados em Direito Tributário deteve a Fundação Getúlio Vargas, que, a partir da década de cinquenta, inicia esforços para instigar o interesse dos estudos sobre a matéria, promovendo cursos, organizando coletâneas e eventos, e patrocinando a divulgação de textos de interesse acadêmico.

Dentre os inúmeros estudos publicados sob o patrocínio da FGV, destacou-se a aula de Carlos da Rocha Guimarães, no Curso proferido em 1953 na Fundação Getúlio Vargas, cuja apresentação "Introdução ao Direito Fiscal” foi publicada em coletânea. ${ }^{414}$

Outro esforço teórico que merece lembrança foi o estudo produzido pelo publicista Bilac Pinto, que também não se furtou de apresentar, em 1950, em Parecer Jurídico, profunda análise sobre o fato gerador, demonstrando, já à época, que a doutrina brasileira encontrava-se atenta às lições da realidade literária estrangeira, especialmente no fato gerador (Jèze) ou fato imponível (Jarach) relacionando-o à isenção fiscal. É interessante notar que Bilac Pinto estava, como poucos, atento às principais pendências doutrinárias relativas ao Direito Tributário Europeu, já recorrendo a autores do porte de Jarach, Giannini, Tesoro, Vanoni, Jèze, Damervalle ${ }^{415}$, Ingrosso, e Myrbach-Rheinfeld. ${ }^{416} 417$

\footnotetext{
${ }^{413}$ MACHADO, Brandão. Apresentação, In: MORAES, OSWALDO de. Op.cit., p.vii-xiii.

${ }^{414}$ GUIMARÃES, Carlos da Rocha. Introdução ao Direito Fiscal. In: Elementos de Direito Tributário. Curso proferido em 1953 na Fundação Getúlio Vargas. Rio de Janeiro: Edições Financeiras S.A., s/d, p. 11.

${ }^{415}$ Idem, p. 14.

${ }^{416}$ Ibidem, p.63.
} 
Nessa época, também Gilberto de Ulhôa Canto passou a publicar importantes estudos, e, já em 1958, participou ativamente da difusão dos estudos tributários através de conferências sobre o tema ${ }^{418}{ }_{-}^{419}$, além de publicar coletânea de pareceres e estudos monográficos (“Temas de Direito Tributário”, em 1955).

Não é por outro motivo que o Rio de Janeiro concorreu com São Paulo pela hegemonia na difusão de estudos tributários naquele período inicial, contando com a experiência de financistas do porte de Gerson Augusto da Silva, Tito Rezende, e Aliomar Baleeiro $^{420}$, que também produziram clássicos estudos em Direito Tributário, seguido por Amílcar de Araújo Falcão, Gilberto Ulhôa Canto, e o grande papel difusor de estudos tributários que deteve a Fundação Getúlio Vargas, à época sediada no Rio.

Acrescente-se também a importante contribuição do Instituto Brasileiro de Direito Financeiro - IBDF, criado em 1948, sob a liderança de Gilberto Ulhôa Canto, e reconhecida impulsionadora de estudos jurídicos tributários nesse período.

Mas, por outro lado, não menos verdade é que, em meados da década de cinquenta, ainda havia poucos estudos efetivamente dedicados ao Direito Tributário.

Essa perspectiva pode ser facilmente percebida no registro bibliográfico feito por Rubens Gomes de Sousa, em momento posterior, ao citar como referência os estudos de Viveiros de Castro (Tratado dos impostos, Rio, Imprensa Nacional, 2 ed. 1910), lembrando também (entre as principais referências da época) do estudo de João Martins de Oliveira (Direito Fiscal, Rio, Livraria Jacinto, 1943) e de Amílcar de Araújo Falcão (Introdução ao Direito Tributário, Parte Geral, Rio, Edições Financeiras, S.A., 1959), além da coletânea "Elementos de Direito Tributário" (Rio, Edições Financeiras, S.A., 1954), que reuniu

\footnotetext{
${ }^{417}$ PINTO, Bilac. "Isenção Fiscal - Fato Gerador do Imposto - Isenções Pessoais e Reais - Realidade Econômica contra a Forma Jurídica - Evasão Fiscal”. In: Estudos de Direito Público. Forense: Rio de Janeiro, 1953, p. 55-66.

${ }^{418}$ CANTO, Gilberto Ulhôa. Obrigação Tributária, seus pressupostos e elementos. (Conferencia da Série. $1^{\text {a }}$ Conferência do Prof. Gilberto de Ulhôa Canto, realizada no dia 22 de maio de 1956, às 18:00, sobre o tema "Obrigação Tributária, seus pressupostos e elementos"). In: Instituto Brasileiro de Direito Financeiro (Filiado à I.F.A.). Publicação n.6. In: Curso de Direito Financeiro. 1958. Rio de Janeiro: FGB, 1958, p.108-110. ${ }^{419}$ Idem, p.111-112.

${ }^{420} \mathrm{Na}$ Bahia, em 1951, Baleeiro publicou as "Limitações Constitucionais ao Poder de Tributar”, e, em 1955 publica "Uma Introdução à Ciência das Finanças", com parte de sua obra dedicada à tributação. BALEEIRO, Aliomar Uma Introdução à Ciência das Finanças. $15^{\circ}$ Edição. Atualizador: CAMPOS, Dejalma Rio de Janeiro: Forense, 2000, p. 06 e seguintes. BALEEIRO, Aliomar. Limitações Constitucionais ao Poder de

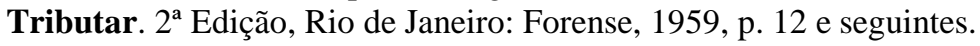


lições dos professores e estudiosos da matéria na época, proferidas em um curso prático realizado em 1953 pela Fundação Getúlio Vargas ${ }^{421}$.

Menção importante também foi feita à publicação intitulada "Trabalhos da Comissão Especial do Código Tributário Nacional”, editado pelo Ministério da Fazenda, no Rio de Janeiro, em 1954, contendo o Relatório da Comissão nomeada pelo Governo Federal em 1953 para elaborar o Código Tributário Nacional (a temática da codificação será abordada no capítulo seguinte).

Rubens Gomes de Sousa também elencou as monografias e pareceres jurídicos versados em questões concretas - e controvertidas na época, a exemplo de: Sá Filho (Estudos de Direito Fiscal, Rio, Imprensa Nacional, 1942); Rubens Gomes de Sousa (Estudos de Direito Tributário, São Paulo, Editora Saraiva, 1950); Raul Loureiro (Questões Fiscais, São Paulo, Editora Saraiva, 1953); Gilberto Ulhôa Canto (Temas de Direito Tributário, Rio, Edições Financeiras, 1955); Aliomar Baleeiro (Clínica Fiscal, Salvador, Livraria Progresso Editora, 1958); e Amílcar de Araújo Falcão (Direito Tributário Brasileiro, Rio, Edições Financeiras, 1960) ${ }^{422}$.

Em rápida análise, pode-se atestar que existe um conflito na identificação da gênese histórica em que a disciplina foi criada (quando surge efetivamente a consciência de autonomia teórica da disciplina), por dois motivos: a) foi São Paulo o berço da formação teórica efetiva do Direito Tributário, com a contribuição de Tullio Ascarelli e Rubens Gomes de Sousa, na década de quarenta, e que acabou gerando os primeiros cursos (de extensão ou extracurriculares) sobre a disciplina no Brasil, e, consequentemente, a futura criação das cadeiras de direito tributário na USP e na PUC-SP, pela influência de Ruy Barbosa Nogueira, na década de sessenta; b) contudo, em 1943, João Martins de Oliveira, magistrado em Minas Gerais, já havia publicado importante obra sobre o tema no Rio de Janeiro, seguido na década de cinquenta por alguns estudiosos renomados no período, a exemplo de Aliomar Baleeiro e Amílcar de Araújo Falcão.

Infelizmente, na época em que foi publicado, o "Curso" de João Martins de Oliveira praticamente não teve forte repercussão nas obras do mesmo período em São Paulo (muito embora Tullio Ascarelli o recomendasse, segundo lembra Ruy Barbosa

\footnotetext{
${ }^{421}$ SOUSA, Rubens Gomes de. Compêndio de Legislação Tributária. Op.cit., p. $42-43$. 
Nogueira) ${ }^{423}$, como a que deteve o trabalho de Rubens Gomes de Sousa, publicado no mesmo ano (embora já no Compêndio, publicado na década de cinquenta, a obra de João Martins de Oliveira fosse lembrada por Sousa, ao lado do trabalho de Amílcar de Araújo Falcão $\left.^{424}\right)$.

Ainda sob a égide da Constituição de 1946, e fortemente influenciada pela literatura produzida naquele período, a exemplo de Tito Rezende, João Martins de Oliveira, Tullio Ascarelli, Gilberto de Ulhôa Canto ${ }^{425}$, Aliomar Baleeiro ${ }^{426}$, Carlos da Rocha Guimarães, Amílcar de Araújo Falcão ${ }^{427}$, e do próprio Rubens Gomes de Sousa, emerge a doutrina jurídica tributária brasileira, ganhando seus primeiros passos na década de quarenta e fortemente divulgada na década de cinquenta em diante (a exemplo dos valiosos esforços da Fundação Getúlio Vargas e suas diversas publicações sobre o tema a partir da década de cinquenta), recebendo importantes contribuições na década de sessenta de Alfredo Augusto Becker e Antonio Roberto Sampaio Dória ${ }^{428}$, além dos primeiros trabalhos de Geraldo Ataliba $^{429}$, José Souto Maior Borges e Ruy Barbosa Nogueira ${ }^{430}$, entre outros, na mesma década.

${ }^{423}$ NOGUEIRA, Ruy Barbosa. A Contribuição de Tullio Ascarelli para a formação da doutrina Jurídico-Tributária do Brasil. Op.cit., p. 20.

${ }^{424}$ SOUSA, Rubens Gomes de. Compêndio de Legislação Tributária. Op.cit., p. $42-43$.

${ }^{425}$ Citam-se, apenas a título exemplificativo, algumas de suas principais obras já publicadas na época, já em edições posteriores: CANTO, Gilberto de Ulhôa. Temas de direito tributário. Ed. Alba, 1964. v.1. CANTO, Gilberto de Ulhôa. Estudos e Pareceres de Direito Tributário. São Paulo, Ed. Revista dos Tribunais, 1975.

${ }^{426}$ Citam-se, apenas a título exemplificativo, algumas de suas principais obras publicadas na época, já com edições posteriores: BALEEIRO, Aliomar. Direito Tributário Brasileiro, Rio de Janeiro : Forense, 1987. BALEEIRO, Aliomar. Limitações Constitucionais ao Poder de Tributar. 7. ed. revista e atualizada pela Dra. Misabel Derzi. Rio de Janeiro, Editora Forense, 1997.

${ }^{427}$ Citam-se, apenas a título exemplificativo, sua principal obra publicada na época (já em edição posterior): FALCÃO, Amílcar de Araújo. Introdução ao Direito Tributário. Rio de Janeiro: Editora Rio, 1976.

${ }^{428} \mathrm{Citam}$-se, apenas a título exemplificativo, algumas de suas principais obras publicadas na época: DÓRIA, Antônio Roberto Sampaio. Princípios Constitucionais Tributários e a Cláusula Due Process of Law. São Paulo, 1964. DÓRIA, Antonio Roberto Sampaio. Da lei tributária no tempo. São Paulo, Ed. Obelisco, 1968. DÓRIA, Antônio Roberto Sampaio Dória. Elisão e Evasão Fiscal. 2. ed. São Paulo, Bushatsky, 1977.

${ }^{429}$ ATALIBA NOGUEIRA, José Geraldo. Natureza Jurídica da contribuição de melhoria. São Paulo, Revista dos Tribunais, 1964, p.13 e seguintes.

${ }^{430430}$ O primeiro manual didático publicado por Ruy Barbosa Nogueira foi publicado pelo Centro Onze de Agosto, e que se originou do curso de direito tributário (extracurricular) ministrado pelo professor nas Arcadas, em 1957, por iniciativa do Centro Onze de Agosto, naquela Faculdade: NOGUEIRA, Ruy Barbosa. Curso de Direito Tributário. Ensaio de uma sistemática para facilitar didaticamente a apreensão e a compreensão do Direito Tributário Brasileiro. São Paulo, Centro Acadêmico Onze de Agosto. Edição mimeografada, 1957. In: RAMOS, José Nabaltino; CORRÊA, Walter Barbosa; COSTA, Alcides Jorge. Sesquicentenário Onze de Agosto. In: NOGUEIRA, Ruy Barbosa. Curso de Direito Tributário. São Paulo: Instituto Brasileiro de Direito Tributário - Saraiva, 1999, p. xii. 
Esse, em síntese, foi o quadro histórico da produção literária tributária entre a década de quarenta e a década de cinquenta no Brasil, com publicações de relevo que não passavam do eixo "São Paulo-Rio", com raras exceções (nas quais podem se incluir De Plácido e Silva, no Sul do Brasil, ainda que o seu "manual" não tivesse conotação ou ambição jurídica, e Aliomar Baleeiro, na Bahia, ainda que o mesmo autor atuasse no Rio de Janeiro e Brasília).

Em verdade, outro elemento facilitaria o reconhecimento do Direito Tributário como verdadeira disciplina jurídica autônoma (especializada) de outros ramos do conhecimento: o processo de institucionalização disciplinar (autonomia do ensino) do Direito Tributário, iniciado na década de cinquenta, e que se consolidou em meados dos anos sessenta, com Ruy Barbosa Nogueira (em São Paulo) e com Amílcar de Araújo Falcão (no Rio de Janeiro, sob o apoio de Aliomar Baleeiro).

\section{As tendências positivistas no período da consolidação disciplinar inicial do Direito Tributário Brasileiro: as ponderações entre o positivismo formal conceitualista e o positivismo historicista ou sociológico.}

A consolidação disciplinar do Direito Tributário Brasileiro, iniciada a partir da década de quarenta, e, sobretudo, na década de cinquenta, denuncia algumas tendências verificáveis na produção teórica do período. A tendência ao formalismo e ao positivismo (ou positivismos) jurídico(s), inspirados na jurisprudência dos conceitos e (ou) na jurisprudência dos interesses, no século XIX, registra fortes tendências que seriam absorvidas pela produção teórica (e legislativa) no Direito Tributário Brasileiro no século $\mathrm{XX}$.

O positivismo jurídico formal, que herda muitas características da jurisprudência dos conceitos, traz também ao Direito Tributário forte tendência conceitualista, voltada à determinação conceitual em atendimento à lei.

Em verdade, o próprio esforço codificador, levantado por vezes na doutrina brasileira (mesmo no início da década de quarenta, quando ainda sequer era imaginável a construção de um Código Tributário Nacional) ${ }^{431}$ denuncia tendência ao positivismo, em busca constante da estabilidade e organização do objeto de estudo. Note-se que a tendência da determinação de conceitos legais (como o conceito de tributo, posteriormente previsto

\footnotetext{
${ }^{431}$ Sobre o assunto, ver capítulo 2.
} 
no artigo $3^{\text {a }}$ do Código Tributário Nacional), reforçava essa característica, ainda que criticável do ponto de vista teórico ${ }^{432}{ }_{-}^{433}{ }_{-}^{434}$.

Mas ao mesmo tempo, a literatura alemã dividia espaço entre tendências oriundas da jurisprudência dos conceitos (é exemplo elementar o parágrafo único que busca conceituar o imposto, bem como outras modalidades tributárias), com tendências oriundas da jurisprudência dos interesses (como é o caso do causalismo no direito tributário, defendido com força por muitos financistas e tributaristas europeus até a metade do século XX, bem como da própria consideração econômica, introduzida pelo Código Tributário Alemão, que por sua vez denunciava clara influência de Jhering, sobretudo em sua perspectiva teleológica ou finalística da lei tributária) ${ }^{435}{ }_{-}^{436}{ }_{-} 437$.

A literatura italiana também contribuiu para esse contexto, já que o causalismo e o formalismo jurídico foram, respectivamente, atribuídos a duas Escolas Italianas: a Escola de Nápoles (conceitualista, anticausalista e formalista), que teve entre seus representantes Giannini e Ranneleti; e de Pávia (causalista e teleológica), que teve entre seus representantes Griziotti (na Itália) e Jarach (na Argentina) ${ }^{438}$. No âmbito da legalidade,

${ }^{432}$ Conforme ensina Ricardo Lobo Torres: "O positivismo formalista e conceitualista, apegados à possibilidade de uma legalidade estrita ou absoluta, com seus corolários representados pela superioridade do discursos do legislador, pela exacerbação da segurança jurídica e pela ingênua crença na possibilidade de fechamento dos conceitos jurídicos. Do ponto de vista idológico serve ao fortalecimento do Estado Liberal Clássico, inclusive na sua vertente rousseauniana, com o ódio ao imposto. Seus representantes mais importantes são A.D. Giannini, Cocivera, Werner Flume, Kruse e, entre nós, os autores do Código Tributário Nacional". TORRES, Ricardo Lobo. Legalidade Tributária e Riscos Sociais. Op.cit., p. 178 e ss.

${ }^{433}$ SOUSA, Rubens Gomes de. Relatório. In: Trabalhos da Comissão Especial do Código Tributário Nacional. Rio de Janeiro, 1954, p. 79 e ss.

${ }^{434}$ FONROUGE, Giuliani. Conceitos de Direito Tributário. São Paulo: Lael, 1973, p. 19 e ss.

${ }^{435}$ Sobre a consideração econômica e sua previsão legislativa na codificação alemã, ver capítulo 2 deste trabalho.

${ }^{436}$ Por outro lado, os positivismos historicistas ou sociológicos passam a defender o “(...) exagero oposto", de uma "(...) legalidade flácida e aberta, fundada na superioridade do papel do juiz, na possibilidade da permanente consideração econômica do fato gerador e na defesa intransigente de uma justiça fiscal surgida magicamente da realidade social. A sua base ideológica está ligada ao Estado de Bem-estar Social ou, para utilizar a expressão de Forsthoff, ao Estado da Sociedade Industrial, cada vez mais voraz nos recursos financeiros da sociedade para financiar as políticas desenvolvimentistas e pleno emprego. E. Becker na Alemanha, Griziotti na Itália, D.Jarach na Argentina e A.Baleeiro no Brasil foram alguns dos seus grandes nomes. TORRES, Ricardo Lobo. Legalidade Tributária e Riscos Sociais. Op.cit., p. 178-179.

${ }^{437}$ DÓRIA, Antonio Roberto Sampaio. Elisão e Evasão Fiscal. São Paulo: Lael, 1971, p. 55 e ss.

${ }^{438}$ A causa da obrigação tributária frente à tendência normativista (anticausal) dividiu tributaristas na primeira metade do século XX, recebendo diferentes posicionamentos, de acordo com a maior ou menor adesão ao formalismo jurídico. Nesse sentido, “(...) o estudo da causa dos atos jurídicos e, especialmente, das obrigações jurídicas, constitui um dos mais complexos problemas, de quantos percorrem o campo do direito, cujas fronteiras em muitos aspectos tende a transpor, para invadir o plano filosófico". Com essas palavras, Gilberto Ulhôa Canto sintetizou a dificuldade que a teoria da causa ou fundamento da obrigação tributária, que passou de uma concepção muitas vezes autoritária, com fundamento na relação de poder, para lentamente uma obrigação fundada na lei, conforme apregoava a doutrina jurídico-tributária posterior (anticausal). Assim, a Escola de Pávia utilizava como elemento a causa jurídica em seu caráter de fundamento da obrigação, que apresentaria aspectos característicos em cada um dos tributos. Por outro lado, Dino Jarach e Ezio Vanoni delimitaram o critério como sendo a capacidade contributiva, a contraprestação e 
essas tendências manifestaram-se entre uma legalidade estrita (não admitindo a analogia no direito tributário, por exemplo) ou uma legalidade flexível (admitindo, ainda que com ponderações, o recurso à analogia, por exemplo).

Logo, tais perspectivas também influenciaram a produção jurídica tributária brasileira, especialmente nas primeiras décadas de sua formação, já inicialmente centradas no positivismo (seja aquele formalista conceitualista, seja aquele voltado ao causalismo, ao legalismo flexível e à consideração da interpretação funcional ou da consideração econômica).

Do ponto de vista ideológico, ambas eram salutarmente influenciadas por resquícios do Estado Liberal Clássico (enxergando o tributo como algo odioso), ou do Estado Social de Direito (enxergando o tributo como veículo para viabilizar o desenvolvimento econômico, o pleno emprego ou a redistribuição de riquezas, caracteristicamente keynesiano) $^{439}$.

Aliomar Baleeiro, Amílcar de Araújo Falcão e Ruy Barbosa Nogueira apresentaram, naquele período, fortes traços do positivismo historicista ou sociológico (ainda que com ponderações, pois nem todos manifestavam idêntico apoio à causa ou à analogia no direito tributário, por exemplo) ${ }^{440}$, que também era característica identificável em Enno Becker, Benvenuto Griziotti e Dino Jarach (cada qual com suas próprias peculiaridades e segundo premissas próprias) ${ }^{441}{ }_{-}^{442}$.

o benefício, para os impostos, taxas e contribuições, respectivamente. Porém, a doutrina anticausal procurou buscar nos elementos incorporados efetivamente na lei tributária e especialmente nos elementos definidos dos pressupostos de fato. Contribuíram para o tema também Giannini, cuja introdução ao elemento "finalidade" como essencial para classificação e Tesoro, pela sua opinião pessoal no que respeita à assimilação da noção de causa com o de pressuposto de fato. Blumenstein, apresentou uma posição intermediária para quem haveria tributos com causa: taxas e contribuições, e os tributos sem causa: impostos. Gradativamente prevaleceu a teoria anticausal, fundada na "causa legal" (norma tributária) para a obrigação tributária. Sobre o assunto, conferir: BLUMENSTEIN, Ernst. Sistema di Diritto Delle Imposte. Op.cit., p. 01-04. HENSEL, Albert. Op.cit., p. 71 e ss. JARACH, Dino. Finanzas Públicas y Derecho Tributario. Tercera Edición. Buenos Aires: Abeledo-Perrot, p. 232-252.VANONI, Ezio. Opera Giuridiche. Tomo II. P.50 TESORO, Giorgio. Pricipii di diritto tributario, Bari, 1938, p. 172. GIANNINI, A. D. Istituzioni di Diritto Tributario. Op.cit., p.51-61.GIANNINI, A.D. I Concetti fondamentali del Diritto Tributario. Op.cit., p. 54 e ss. TIPKE, Klaus; LANG, Joachin. Direito Tributário. $18^{\circ}$ edição. Tradução de Luiz Dória Furquim. Volume I. Porto Alegre: Sergio Antonio Fabris Editor, 2008, p. 133 e ss. INGROSSO, Diritto Finanziario. Op.cit., p. 98. Para uma contextualização sobre a problemática da teoria da causa ou fundamento do tributo, e suas variadas concepções, conferir: CANTO, Gilberto de Ulhôa. A Causa da Obrigação Tributária. Temas de Direito Tributário. Pareceres e Estudos. Rio de Janeiro: Edições Financeiras S.A, 1955 , p. 330 e ss.

${ }^{439}$ TORRES, Ricardo Lobo. Legalidade Tributária e Riscos Sociais. Op.cit., p. 178-179.

${ }^{440}$ Nesse sentido, é a posição de Ruy Barbosa Nogueira: "Em conclusão, pois, em face do nosso sistema tributário constitucional e de Direito Positivo, é inadmissível qualquer processo de interpretação por analogia ou abando no da forma jurídica legítima, para impor, alterar ou extinguir as obrigações tributárias". NOGUEIRA, Ruy Barbosa. Direito Financeiro. São Paulo: José Bushatsky, 1964, p. 57.

${ }^{441}$ Idem, p. 47-57. 
Por outro lado, no mesmo período, ainda que com ponderações, outros autores como Rubens Gomes de Sousa, Gilberto Ulhôa Canto ${ }^{443}$, João Martins de Oliveira, apresentavam maiores características ligadas ao positivismo conceitualista (ainda que com ponderações causalistas, como se observa em João Martins de Oliveira e Gilberto Ulhôa Canto $\left.^{444}\right)$.

Porém, ao mesmo tempo, não se pode deixar de admitir a prevalência gradual do anticausalismo na doutrina brasileira. Note-se que na obra inaugural de Rubens Gomes de Sousa, já havia a afirmação expressa nesse sentido: “(...) o fundamento jurídico, ou causa, do crédito fiscal, reside, pois, exclusivamente na lei; a necessidade de obter os meios econômicos para enfrentar as despesas dos serviços públicos indivisíveis constitue o motivo pré-jurídico da imposição, não a causa jurídica do imposto"445.

O próprio esforço e a elevação da codificação como caminho para o progresso jurídico da matéria denunciava esse intento. Naturalmente, a elevação à codificação também era identificável em outros autores não necessariamente ligados a essa linha (como Baleeiro que, por sinal, foi o grande responsável pela autorização constitucional que levou à posterior codificação, conforme já observado) ${ }^{446}$.

Por outro lado, Rubens Gomes de Sousa, por exemplo, ainda que identificado como positivista, apresentava clara defesa da consideração econômica no direito tributário (no intuito de elevá-lo como disciplina autônoma frente ao direito privado), pelo menos em seus estudos iniciais ${ }^{447}$.

Não há, portanto, posições estanques ou extremistas entre o positivismo formal conceitualista e o positivismo historicista ou sociológico na doutrina tributária brasileira, naquele contexto histórico (década de quarenta até início da década de sessenta).

Da mesma forma, não se pode ainda afirmar, entre a década de quarenta e o início da década de sessenta, a existência de um positivismo dogmático normativo formal de matriz kelseniana prevalecente na doutrina tributária brasileira, pois, afinal, como lembra Nelson Saldanha, “(...) No Brasil, apesar de ter sido publicada em 1934 a obra mais característica de Kelsen, e de a partir da década de 60 seu influxo ter decaído em todo o

${ }^{442}$ FALCÃO, Amílcar de Araújo. Introdução ao Direito Tributário. Rio de Janeiro: Editora Rio, 1976, p. 69-93.

${ }^{443}$ Não obstante, Gilberto Ulhôa Canto pontua: "Admitimos a pesquisa da causa na obrigação tributária, e consideramo-la como um problema jurídico, snedo apenas necessário estabelecer algumas definições básicas a respeito". CANTO, Gilberto de Ulhôa. A Causa da Obrigação Tributária. Op.cit., p. 378.

${ }^{444}$ OLIVEIRA, João Martins de. Op.cit., p. 45 e ss.

${ }^{445}$ SOUSA, Rubens Gomes de. A Distribuição da Justiça em matéria fiscal. Op.cit., p. 16.

${ }^{446}$ BALEEIRO, Aliomar. Direito Tributário Brasileiro. Forense: Rio de Janeiro, 1973, p. 15-60.

${ }^{447}$ SOUSA, Rubens Gomes de. Compêndio de Legislação Tributária. Op.cit., p. 15 e ss. 
mundo, a presença do kelsenismo acentuou-se depois do Golpe de 1964, provavelmente porque o formalismo metodológico eximia os professores de pronunciamentos politicamente comprometedores" 448 .

Ainda que em Alfredo Augusto Becker, em 1963, já aparecesse considerações favoráveis ao kelsenianismo, de fato, a difusão efetiva da Teoria Pura do Direito no Direito Tributário fortaleceu-se rapidamente após o Golpe de 1964, por motivos que serão compreendidos no capítulo seguinte ${ }^{449}$.

Eram, portanto, tendências positivistas anteriores à influência de Kelsen, e influenciadas diretamente pelo positivismo europeu oitocentista que prevalecia entre o século XIX e início do século XX. Sobre essas tendências é que se funda o chamado "Tempos heroicos do Direito Tributário", conforme denominou Rubens Gomes de Sousa, ao se referir ao período ${ }^{450}$.

O positivismo se alastrará no Direito Tributário Brasileiro a partir da década de sessenta, mas sobretudo impulsionado a partir da década de setenta, especialmente com a consolidação de específicas estratégias de estudo e ensino bem-sucedidas nas Faculdades de Direito brasileiras. Mesmo autores com tendências jusnaturalistas apresentarão fortes resquícios do positivismo conceitualista ${ }^{451}$, o que demonstra a força dessa tendência no processo disciplinar do Direito Tributário Brasileiro.

Essas tendências positivistas serão sucedidas, a partir da década de sessenta e, sobretudo, a partir do Golpe de 1964, por reforçada característica, sobretudo caracterizada pela intensificação do formalismo jurídico positivista de matriz dogmática normativa kelseniana, que ganhará grande relevância nas décadas posteriores, ainda que convivendo com o positivismo historicista e sociológico ou mesmo o positivismo conceitualista, que ainda sobreviverão nas décadas posteriores ${ }^{452}$.

\footnotetext{
${ }^{448} \mathrm{Na}$ realidade, segundo conta Saldanha, como um contraste doutrinário em relação ao normativismo, o pensamento de Carl Schmitt aportou no Brasil antes de 1950, porquanto alguns teóricos do Estado Novo (como Francisco Campos) tiveram conhecimento de sua obra desde a década de 40. Como também da dos grandes publicistas alemães das décadas de 20 e 30 (Anschütz, Koellreuter, Smend e outros). Em contrapartida, como uma espécie de versão mitigada do kelsenianismo, penetraria no Brasil, cremos que nas alturas da década de 60, a obra de Bobbio, por sinal mais conhecido entre nós como cientista político, do que como jusfilósofo". SALDANHA, Nelson. Filosofia do Direito. Rio de Janeiro: Renovar, 1998, p. 08.

${ }^{449}$ BECKER, Alfredo Augusto. Teoria Geral do Direito Tributário. São Paulo: Saraiva, 1963, p. 54-55.

${ }^{450}$ SOUSA, Rubens Gomes de. Prefácio à Primeira Edição. In: FANUCCHI, Fábio. Op.cit., p. xix.

${ }^{451}$ MARTINS, Ives Gandra da Silva. A missão do jurista e o Direito Natural. In: Direito Econômico e Tributário. Comentários e Pareceres. Co-Edição - FIEO - Fundação Instituto de Ensino para Osasco. São Paulo: Resenha Tributária, 1982, p. xv-xx. MARTINS, Ives Gandra da Silva. Os princípios da legalidade e da tipicidade. In: Curso de Direito Tributário. Org: MARTINS, Ives Gandra da Silva. São Paulo, 1982, p. 49 e ss.

${ }^{452}$ Sobre o assunto, confira-se capítulo 3.
} 
De qualquer forma, para compreender o percurso histórico a partir desse período é preciso identificar, não obstante, o marco inicial da autonomia do ensino no Direito Tributário Brasileiro, que somente se efetivará (institucionalmente) no final da década de sessenta, consolidando a institucionalização do ensino do Direito Tributário no processo disciplinar do Direito Tributário Brasileiro, conforme se observará nas linhas seguintes.

\section{A institucionalização disciplinar do ensino: a consagração da autonomia do ensino do Direito Tributário frente à Ciência das Finanças e ao Direito Financeiro no Brasil.}

O ensino do fenômeno tributário, até meados da década de sessenta do século XX, era realizado sob a égide da Cátedra de "Ciência das Finanças", que, embora já institucionalizado pelo Decreto Executivo n.7247, de 1879, que já autorizava o ensino nos cursos jurídicos de "Ciência das Finanças e Contabilidade do Estado" no Brasil, como assevera Rui Barbosa, lembrado por Aliomar Baleeiro ${ }^{453}$, só teve institucionalização efetiva a partir da década de trinta do século XX no Brasil, com gritante atraso. Só então a Ciência das Finanças recebeu efetiva autonomia institucional do curso de Economia Política.

E era no quadro da Ciência das Finanças que o estudo dos aspectos jurídicos do fenômeno financeiro era exercido, geralmente sob a denominação "Legislação Financeira", influência expressa da literatura italiana e francesa, que publicaram muitos cursos denominados "Ciência das Finanças e Legislação Financeira" (França) ou "Ciência das Finanças e Direito Financeiro" (Itália) ${ }^{454}$.

Na década de cinquenta, Aliomar Baleeiro já lecionava a Cátedra de Ciência das Finanças na Universidade do Estado do Rio de Janeiro (na época denominada Universidade do Distrito Federal), cátedra que foi sucedida por Amilcar de Araújo Falcão, em 1958, quando, anos mais tarde, originou, por especialização, a Cátedra de Direito

\footnotetext{
453 "Rui Barbosa, no Parecer do ensino superior, já reconhecia essencial a instituição da cadeira autônoma de Finanças, mas só se realizou essa sugestão depois de 1930. Até então, o curso abrangia a Economia Política e a Ciência das Finanças, e como o tempo era escasso para o programa daquela primeira disciplina, nada ou quase nada se ensinava da última". BALEEIRO, Aliomar. Uma Introdução à Ciência das Finanças. Op.cit., p. 10.

${ }^{454}$ BALEEIRO, Aliomar. Uma Introdução à Ciência das Finanças. Op.cit., p. 11.
} 
Financeiro na mesma instituição (a primeira no Rio de Janeiro, e segundo Baleeiro, a primeira no Brasil). ${ }^{455}$

Em 1943, o programa de Ciência das Finanças consagrava algumas aulas relativas ao Direito Tributário, na então Faculdade da Bahia, local onde já emergia propostas na defesa da autonomia do Direito Financeiro (e respectiva proposta de codificação), em congressos jurídicos da época ${ }^{456}$.

Por outro lado, ainda que São Paulo não tenha sido o local onde os primeiros estudos com genuína perspectiva jurídica tributária tenham sido produzidos, podem-se apontar fortes indícios para identificá-lo como o local em que se deu o impulso inicial efetivo para a consolidação disciplinar e consequente difusão nas demais regiões do Brasil.

Essa verificação pode ser atestada no testemunho de Ruy Barbosa Nogueira, grande responsável pela implantação dos cursos de Direito Tributário em dois dos mais influentes cursos jurídicos no Brasil: a USP e a PUC-SP.

Não é demais lembrar que a USP já apresentava, através de Tullio Ascarelli, os primeiros cursos monográficos, que também foram impulsionados por Rubens Gomes de Sousa, quando ministrou curso de extensão universitária sobre o tema na Escola de

\footnotetext{
${ }^{455}$ Veja-se o testemunho de Baleeiro sobre Amílcar: "Por minha fortuna, venho contemplando seu esforço fecundo e já premiado por belos frutos em plena primavera. Observei a seriedade com que fez o curso de doutorado na Faculdade de Direito da U.D.F. Gozei de sua companhia em jornadas universitárias no estrangeiro. Por esses títulos e pela produção intelectual nas revistas especializadas, indiquei seu nome para meu assistente na cátedra de Finanças daquela Universidade, assim como lhe confiei o primeiro curso de Direito Tributário em estabelecimento de ensino jurídico no Brasil. Galhardamente desempenha ambas as missões". Recorde-se que a Universidade do Distrito Federal citada por Aliomar Baleeiro não é aquela mesma Universidade do Distrito Federal, à época situada no Rio de Janeiro, e criada em 1935, e que foi posteriormente incorporada à Universidade do Brasil, nome atribuído à atual Universidade Federal do Rio de Janeiro (ou Universidade do Rio de Janeiro) durante a era Vargas. A Universidade do Distrito Federal mencionada por Baleeiro (UDF) foi criada em 1950, rebatizada de Universidade do Rio de Janeiro, até chamar-se Universidade de Guanabara, e, a partir de 1975, de Universidade do Estado do Rio de Janeiro (UERJ). Em outras palavras, registrou-se dúvida se a autonomia institucional do Direito Tributário procedeuse na Universidade de São Paulo (Ruy Barbosa Nogueira), ou na Universidade do Distrito Federal (posteriormente denominada UERJ), com Amílcar de Araújo Falcão. BALEEIRO, Aliomar. Prefácio. In: FALCÃO, Amílcar de Araújo. Introdução ao Direito Tributário. Op.cit., p. 13-14. Mas a verdade é que a cátedra "Direito Financeiro", já instituída na década de sessenta na UERJ, manteve-se no currículo acadêmico seguinte (1978), deixando o Direito Tributário como disciplina eletiva, e repetindo-se a mesma situação no currículo de 2002 (ainda vigente). A presente pesquisa obteve acesso aos currículos acadêmicos do curso de Direito da Faculdade de Direito da UERJ.

${ }^{456}$ BALEEIRO, Aliomar. Prefácio. In: FALCÃO, Amílcar de Araújo. O Fato Gerador da Obrigação Tributária. $2^{\mathrm{a}}$ Ed. São Paulo: Rt, 1971, p. 11-15.
} 
Sociologia e Política, entre 1947 e 1948, cujas aulas foram publicadas na Revista Estudos Fiscais volumes 2 e 3 sob o título "Curso de Introdução ao Direito Tributário" 457 _ 458.

As lições de Rubens Gomes de Sousa tiveram sequência no ano seguinte, quando o mesmo professor assumiu, em 1949, a cátedra de "Legislação Tributária" (criada no mesmo ano), que passou a ser ministrada na Faculdade de Ciências Econômicas e Administrativas da Universidade de São Paulo.

O próprio Rubens Gomes de Sousa já testemunhava a relevância inicial do trato da matéria sob a égide da Faculdade de Ciências Econômicas e Administrativas da USP: "A Lei n.1401 de 31.7.51 modificou a denominação da cátedra no Curso de Ciências Contábeis e Autuariais, para "Elementos de Finanças e Legislação Tributária e Fiscal". Com isto, o nosso país terá querido seguir o exemplo da França e da Itália, onde a cadeira se intitula, nas Faculdades de Direito, "Ciência e Legislação Financeira". 459

Mais uma vez, é possível visualizar a influência francesa e italiana na consolidação do ensino jurídico-tributário no Brasil. Mas, como bem advertiu Rubens Gomes de Sousa, não era fácil encontrar um especialista em Ciência das Finanças e em Direito Financeiro, simultaneamente, de modo que, na própria experiência europeia, a cátedra foi dividida em duas disciplinas, a primeira ensinada por financista e a segunda por um jurista.

De qualquer forma, ainda que com esses louváveis antecedentes, a institucionalização disciplinar do Direito Tributário Brasileiro em São Paulo coube efetivamente a Ruy Barbosa Nogueira.

Na Faculdade Paulista de Direito, da PUC-SP, desde sua criação, em 1946, já se incluía na grade a disciplina Ciência das Finanças, mas a primeira vez que a disciplina

\footnotetext{
${ }^{457}$ SOUSA, Rubens Gomes de. Compêndio de Legislação Tributária. Op.cit., p.42.

${ }^{458} \mathrm{Na}$ época as aulas foram datilografadas por um aluno e organizadas na forma de apostilas, que foram distribuídas aos demais alunos da época. A pesquisa teve acesso a uma pequena parcela dessas apostilas que constavam as aulas do Prof. Rubens Gomes de Sousa. É possível perceber que o mesmo desde então já manifestava conhecimento da experiência estrangeira (possivelmente também por influência de Tullio Ascarelli), e grande preocupação na divulgação desses estudos no Brasil. SOUSA, Rubens Gomes de. Introdução ao Direito Tributário. Op.cit., p. 01 e seguintes.

${ }^{459}$ Mas advertiu Rubens Gomes de Sousa: "A iniciativa é sem dúvida louvável, enquanto vise evitar uma excessiva dissociação didática entre os princípios e instituições financeiras de um lado, e de outro os instrumentos jurídicos adequados ao funcionamento prático daqueles princípios e instituições; mas não é possível ignorar a dificuldade de encontrar um professor igualmente versado em matéria financeira e em matéria jurídica, que terá levado os países a que me referi a dividirem a cátedra em duas disciplinas regidas, a primeira por um financista, a segunda por um jurista". SOUSA, Rubens Gomes de. Advertência à $\mathbf{1}^{\mathbf{a}}$ Edição. In: Compêndio de Legislação Tributária. Op.cit., p. 21.
} 
passou a ser ensinada foi em 1949, com o Prof. Carvalho Pinto, que lecionou a disciplina até 1954, quando o Professor Ruy Barbosa Nogueira, na condição de professor contratado, assumiu a disciplina, com o propósito de desenvolver, ao lado da Ciência das Finanças, pela primeira vez no currículo de uma Faculdade de Direito no Brasil, a disciplina Direito Tributário, conforme confessa, em seu "Curso de Direito Tributário". ${ }^{460} 461$

Por isso, segundo o próprio Ruy Barbosa Nogueira, foi possível alterar a denominação da Cátedra, em 1958, priorizando o Direito Financeiro e, especialmente, o Direito Tributário, onde lecionou a disciplina até $1968^{462}$, quando assume a Cadeira o Professor Geraldo Ataliba.

Mas, naquela Instituição, somente em 1973, com uma grande reforma curricular no Curso de Direito (inclusive alterando a denominação da Faculdade Paulista de Direito para Faculdade de Direito da PUC-SP) e, graças à influência de Geraldo Ataliba, é que a disciplina passa a ser efetivamente denominada "Direito Tributário"463.

De qualquer forma, para Alcides Jorge Costa, José Nabaltino Ramos e Walter Barbosa Corrêa, o período em que Ruy Barbosa Nogueira assumiu a disciplina naquela Faculdade seria o momento em que se inaugurou “(...) o primeiro curso curricular de Direito Tributário em Faculdade de Direito no Brasil"464.

Mas, note-se que, inicialmente, a temática era ministrada em cursos de Ciência das Finanças, para, em segundo momento, com a separação das cadeiras universitárias de Ciência das Finanças e de Direito Financeiro, passar a ser ensinada no âmbito dessa última.

Logo, não havia ainda naquele momento institucionalização disciplinar do Direito Tributário (ainda que fosse já ensinado no programa de ensino da Ciência das Finanças).

\footnotetext{
${ }^{460}$ BARBOSA NOGUEIRA, Ruy. Curso de Direito Tributário. $15^{\circ}$ edição. São Paulo: Saraiva, 1999, p. 1718.

${ }^{461}$ BARbOSA NOGUEIRA, Ruy. Ensino Pesquisas e Serviços à Comunidade. Direito Tributário Atual. Volumes 7/8. São Paulo: Resenha Tributária- IBDT, 1987-1988, p. 1687-1689.

462 NOGUEIRA, Ruy Barbosa. Rubens Gomes de Sousa, 30 anos amigo e companheiro. Estudos Tributários. São Paulo; Resenha Tributária, s/d, p. 03.

${ }^{463}$ Registra-se expresso agradecimento aos Professores Paulo de Barros Carvalho e Roque Antonio Carrazza, Titulares da disciplina na Faculdade de Direito da PUC-SP, pelas informações históricas gentilmente prestadas, que foram generosamente reunidas e encaminhadas, mediante correio eletrônico, pelo Prof. Fábio Ulhoa Coelho, Chefe do Departamento de Direito Tributário, Comercial, Econômico e Internacional daquela Faculdade de Direito da PUC-SP.

${ }^{464}$ RAMOS, José Nabaltino; CORRÊA, Walter Barbosa; COSTA, Alcides Jorge. Sesquicentenário Onze de Agosto, 1976. In: NOGUEIRA, Ruy Barbosa. Curso de Direito Tributário. São Paulo: Instituto Brasileiro de Direito Tributário - Saraiva, 1999, p. xii.
} 
Mas Ruy Barbosa Nogueira, já em 1960, demonstrava inequívoca ambição de criar, oficialmente, a disciplina "Direito Tributário", ao destacar que: "O primeiro problema jurídico-tributário que se apresenta em nosso país é exatamente o da escassez do ensino e consequentemente da elaboração, quer doutrinária, quer jurisprudencial do Direito Tributário. Enquanto a realidade econômica e o fenômeno da tributação se agigantam em nosso país, até hoje as Faculdades de Direito não criaram, no currículo acadêmico, a cadeira de Direito Tributário" 465.

Dessa forma ocorreu na Faculdade de Direito do Largo São Francisco, na década de sessenta, assim como na Pontifícia Universidade Católica de São Paulo.

Mas mesmo diante da autonomia institucionalizada, a Ciência das Finanças, nesse momento, ainda não era ignorada, pois: “(...) Ao nosso ver este é o melhor critério, eis que o estudo de ciência das finanças é pressuposto, é base, ou melhor, é a preparação fundamental para o estudo propriamente jurídico da atividade financeira do Estado, a qual também é objeto de estudo do Direito Financeiro". 466

$\mathrm{Na}$ realidade, tais modificações curriculares foram viabilizadas graças à promulgação da Lei de Diretrizes e Bases, pela Comissão de Ensino Superior do Conselho Federal de Educação, em 1962, que fixou um currículo mínimo a ser dado nas Faculdades de Direito, incluindo-se nesse currículo a disciplina do Direito Financeiro, justificando a necessidade do ensino separado entre Ciência das Finanças e Direito Financeiro, nos seguintes termos, como lembra Ruy Barbosa Nogueira: "A autonomia da cadeira de Direito Financeiro resulta de um exame detido dos atuais desdobramentos da profissão de advogado, prestando assistência a empresas e orientando-as quanto a regulamentos financeiros e imposições fiscais (Parecer $\mathrm{n}^{\circ} 215$ )", onde, no currículo mínimo apontado por tal lei, nenhuma faculdade de Direito no Brasil poderia deixar de incluir, a partir de então, a disciplina " 12 - Direito Financeiro e Finanças"467.

\footnotetext{
${ }^{465}$ NOGUEIRA, Ruy Barbosa. A Problemática do Direito Tributário no Brasil. In: Revista dos Tribunais, vol.305, 1960, p.18e seguintes.

${ }^{466}$ NOGUEIRA, Ruy Barbosa. Direito Financeiro (Curso de Direito Tributário). São Paulo: José Bushatsky, 1964, p. XVI-XV.

${ }_{467}$ "Em 1962, pelo parecer n.215, o Conselho Federal de Educação, afinal resolve incluir de modo genérico o Direito Financeiro pela necessidade "dos atuais desdobramentos da profissão de advogado, prestando assistência a empresas e orientando-as quanto a regulamentos financeiros e imposições fiscais". NOGUEIRA, Ruy Barbosa. O Direito Tributário. Monografia publicada na Revista Jurídica LEMI n.06 Dezembro de 1977, p. 1-12.
} 
Evidentemente, no campo da legislação, tal especialização também se fundamentou no dispositivo constitucional previsto no art.5, inc.XV, alínea "b", que concedia competência à União para legislar sobre "normas gerais de direito financeiro", assim como também na tramitação do Projeto de Lei 4.834 de 1954, que visava criar um Código Tributário Nacional ${ }^{468}$.

Assim, a Cadeira de Ciência das Finanças origina, na década de sessenta, o primeiro processo de especialização disciplinar, qual seja a separação do Direito Financeiro (1963), e quase automaticamente, esse cede especialização, posteriormente, ao Direito Tributário, conforme é o testemunho do insigne professor: "Sobrevindo a reforma do ensino, foi incluído nos currículos das faculdades de direito, o estudo genérico Direito Financeiro e logo em 1963 a Faculdade de Direito da USP, oficialmente, pela primeira vez no Brasil, a disciplina Direito Tributário para a qual prestamos concursos de títulos e provas, tanto para livre docência, como para cátedra" (Ruy Barbosa Nogueira, em 1965, concorreu à cátedra de Direito Financeiro, com a tese "Teoria do Lançamento Tributário", na Faculdade de Direito do Largo São Francisco). ${ }^{469}$

Reforçam a tese de que efetivamente foi a Faculdade de Direito do Largo São Francisco a primeira a institucionalizar a disciplina o testemunho de José Nabaltino Ramos, Walter Barbosa Corrêa e Alcides Jorge Costa, para quem o curso sistemático de Direito Tributário de Ruy Barbosa Nogueira (e seus cursos extracurriculares) influenciariam decisivamente “(...) a criação oficial da disciplina, ocorrida em 1963, nesta Faculdade, e agora já desdobrada em Direito Tributário, Direito Tributário Aplicado e Direito Tributário Comparado" 470 . Porém, note-se que embora a disciplina tenha sido criada em 1963, o concurso para a Cátedra de Direito Financeiro só ocorreu em 1965, conquistada por Ruy Barbosa Nogueira, passando a ocupar Cátedra de Direito Financeiro.

\footnotetext{
${ }^{468}$ NOGUEIRA, Ruy Barbosa. Direito Financeiro (Curso de Direito Tributário), Op.cit., p. xv.

469 "Compreendendo sempre a importância da matéria e de conformidade com a reforma, a Congregação da Faculdade de Direito do Largo São Francisco foi ampliando os currículos e hoje temos, sob nossa regência, as disciplinas Direito Tributário na área profissionalizante, Direito Tributário Aplicado na área de especialização e Direito Tributário Comparado na área de pós-graduação (nos níveis de Mestrado e Doutorado)". NOGUEIRA, Ruy Barbosa. Estudos Tributários. In: Debates Tributários. Ruy Barbosa Nogueira e Colegas. Co-edição. Instituto Brasileiro de Direito Tributário. Editora Resenha Tributária. São Paulo, 1975, p. 118 e seguintes.

${ }^{470}$ RAMOS, José Nabaltino; CORRÊA, Walter Barbosa; COSTA, Alcides Jorge. Sesquicentenário Onze de Agosto, 1976. Op.cit., p. xiii.
} 
Mas assevera-se que há certa divergência sobre a data precisa dessa institucionalização ${ }^{471}$, segundo pontua Fabio Fanucchi: "Nas Faculdades de Direito das Universidades de São Paulo e Mackenzie, a segunda cadeira interligada do programa perdeu a denominação de "Direito Financeiro". Isto aconteceu em 1971 e à altura em que terminamos a primeira edição deste "Curso" apenas a escola do Largo de São Francisco mudara a denominação da matéria, adaptando-a ao conteúdo dos ensinamentos ministrados". A segunda disciplina que Fanucchi se referia era "Direito Tributário".

Essa informação de certa forma contrasta com as ponderações de outros autores supra-analisados, a respeito da criação da disciplina na década de sessenta. A $1^{\mathrm{a}}$ edição da obra de Fanucchi foi publicada em 1971, de forma que, se o curso de Direito da Mackenzie ainda não tinha institucionalizado a matéria até então, reforça-se a tese de que foi de fato a Faculdade de Direito do Largo São Francisco a primeira a concebê-la enquanto denominação "Direito Tributário".

Mas a verdade é que a Cátedra de Direito Tributário, de Ruy Barbosa Nogueira, somente em 1969 passou a ser denominada dessa forma. Nesse contexto, Nogueira assumiu oficialmente a cadeira de Direito Tributário em $1970^{472}$. Na época, existindo a disciplina "Ciência das Finanças" (cuja cátedra pertencia a Theotônio Monteiro de Barros Filho, e da qual se dissociou a disciplina ministrada por Ruy Barbosa) passou a ser denominada "Direito Financeiro", em 1971, cuja cátedra foi exercida por Antonio Roberto Sampaio Dória, a partir de 1972.

Aparentemente, oficializa-se institucionalmente, neste momento, a autonomia do ensino do Direito Tributário, ainda que o Direito Tributário já fosse ensinado no âmbito da Ciência das Finanças e do próprio Direito Financeiro, com anterioridade.

Também se acrescenta que em Curitiba, no Paraná, na Universidade Federal do Paraná, o Professor J. Petrelli Gastaldi ministrou cursos de extensão sobre o Direito Tributário na década de sessenta no curso de Direito, que culminariam na publicação da

${ }^{471}$ FANUCCHI, Fabio. Curso de Direito Tributário. Curso de Direito Tributário Brasileiro. Volume I. $4^{\mathrm{a}}$ Edição. São Paulo: Co-edição - IBET - Instituto Brasileiro de Estudos Tributários - Editora Resenha Tributária, 1976, p. 18.

${ }^{472}$ MACHADO JR, Armando Marcondes. "Cátedras e Catedráticos". Curso de Bacharelado. Faculdade de Direito. Universidade de São Paulo. 1827-2009. Associação dos Antigos Alunos da Faculdade de Direito de São Paulo (1931), p. 39-44. Essa informação também foi confirmada pela análise das Atas das Sessões da Congregação, mais precisamente, a de número 25 (1968-1969) e a de número 26 (1969-1970). As Atas foram examinadas mediante autorização do Diretor da Faculdade de Direito da USP, mediante requerimento formal. 
obra: "Iniciação ao Curso de Direito Tributário", publicado em 1965, e direcionado a estudantes interessados no tema, porém sem vinculação institucional à disciplina ${ }^{473}$.

Note-se que, portanto, há certa dúvida inicial sobre a originalidade da autonomia de ensino institucional da disciplina. Foi São Paulo (com Ruy Barbosa Nogueira) ou Rio de Janeiro (com Amílcar de Araújo Falcão) o local onde a autonomia do ensino do Direito Tributário (como disciplina autônoma da Ciência das Finanças e do Direito Financeiro) se consagrou institucionalmente?

Essa dúvida é reforçada pelo próprio testemunho de Baleeiro, sobre Amílcar de Araújo Falcão: "Por esses títulos e pela produção intelectual nas revistas especializadas, indiquei seu nome para meu assistente na cátedra de Finanças daquela Universidade, assim como lhe confiei o primeiro curso de Direito Tributário em estabelecimento de ensino jurídico no Brasil." O testemunho de Baleeiro foi publicado em 1958, por ocasião da primeira edição do celebrado livro de Amílcar, intitulado "Introdução ao Direito Tributário", publicado como manual didático daquele curso (mencionado por Baleeiro), no ano de $1959^{474}$.

Na década de cinquenta, a Faculdade de Direito da Universidade do Estado de Guanabara criou um curso opcional de Direito Tributário, anexo à Cátedra de Ciência das Finanças, que, após grande procura, gerou posteriormente a cátedra de Direito Financeiro, que seria conquistada por Amílcar Falcão, em concurso para Livre Docente, e depois para a cátedra, vindo a conquistar também concurso para a mesma disciplina na Universidade Federal do Rio $^{475}$.

No mesmo ano em que a cadeira de Direito Financeiro foi criada na USP, conforme relata Baleeiro, em 1963, a cadeira de Direito Financeiro foi criada na Universidade do Estado do Rio de Janeiro, influenciada pelo mesmo plano de reforma do ensino ${ }^{476}$, que, foi

\footnotetext{
${ }^{473}$ GASTALDI, J.Petrelli. Apresentação. In: Iniciação ao Curso de Direito Tributário. São Paulo: Edições Saraiva, 1965, s/p.

474 BALEEIRO, Aliomar. Prefácio. In: FALCÃO, Amílcar de Araújo. Introdução ao Direito Tributário. Op.cit., p. 09-14.

${ }^{475}$ BALEEIRO, Aliomar. Prefácio. In: FALCÃO, Amílcar de Araújo. O Fato Gerador da Obrigação Tributária. Op.cit., p. 12.

${ }^{476}$ BALEEIRO, Aliomar. Uma Introdução à Ciência das Finanças. Nota de rodapé n.14. Op.cit., p.11.
} 
exercida por Falcão, enquanto titular da cátedra, até 1967, quando veio a falecer, e foi sucedido por Flávio Bauer Novelli ${ }^{477}$.

Porém, deve-se ressaltar que, em 1957, por iniciativa dos estudantes do Largo São Francisco, o Centro acadêmico XI de agosto procurou Ruy Barbosa Nogueira para ministrar Curso de Direito Tributário ${ }^{478}$. Este curso ocorreu nas Arcadas, e teve edição mimeografada, e, portanto, 1 (um) ano antes do curso ministrado por Amílcar de Araújo Falcão.

De qualquer forma, tais divergências não afastam a conclusão de que ambas as regiões (São Paulo e Rio de Janeiro) foram os locais onde o Direito Tributário ascendeu como disciplina institucionalmente autônoma da Ciência das Finanças e do Direito Financeiro, especialmente a partir da década de sessenta.

É realmente curioso que a especialização disciplinar que levaria à institucionalização da cadeira de Direito Tributário nas universidades tenha se originado de disciplina própria das ciências econômicas, e não das ciências jurídicas, contrariando, $a$ priori, a lógica da especialização disciplinar (do jurídico-geral para o jurídico-específico).

Assim, a partir da institucionalização disciplinar do Direito Financeiro, ensinado separadamente da Ciência das Finanças (mas guardando evidentemente estreitas relações), passa-se a elevar a importância do Direito Tributário, na época já considerado “(...) o ramo mais desenvolvido e mais importante capítulo (...)"479 do Direito Financeiro, e, sucessivamente, a própria autonomia do ensino institucional do Direito Tributário perante as duas primeiras.

\footnotetext{
${ }^{477}$ NOVELLI, Flavio Bauer. Depoimento. In: Setenta Anos de História \& Memória - 1935-2005. Coord. Carlos Kessel. Faculdade de Direito da Universidade Estadual do Rio de Janeiro. Rio de Janeiro: Universidade do Estado do Rio de Janeiro. Disponível em: http://www.direitouerj.org.br/2005/fdir70/index.htm (último acesso em 04.12.2014).

${ }^{478}$ RAMOS, José Nabaltino; CORRÊA, Walter Barbosa; COSTA, Alcides Jorge. Sesquicentenário Onze de Agosto, 1976. In: Op.cit., p. xii.

${ }^{479}$ NOGUEIRA, Ruy Barbosa. Direito Financeiro (Curso de Direito Tributário), Op.cit., p. xv.
} 


\section{CAPÍtulo 2 - A POSITIVAÇÃo PERANTE O PROCESSO DE ESPECIALIZAÇÃO DISCIPLINAR DO DIREITO TRIBUTÁRIO BRASILEIRO: CODIFICAÇÃO, CONSTITUCIONALIZAÇÃO E SISTEMATIZAÇÃO.}

\section{Os "Constitucionalismos Tributários" no limiar do século XIX para o século} XX e a abertura (involuntária) para a codificação do Direito Tributário.

Antes de seguir à análise do processo de positivação do Direito Tributário, revelase útil, ainda que preliminarmente, e sem qualquer pretensão de aprofundar a temática, lançar mão de algumas ideias gerais sobre o processo histórico de construção do Estado de Direito, esse que se consolida na Europa a partir do século XIX, substancialmente influenciada pela Revolução Francesa e independência norte-americana, que, por sua vez, levam à criação da Constituição francesa e norte-americana. Mas o Estado de Direito e o próprio constitucionalismo do século XIX ("constitucionalismo moderno"480) apresentam substanciais diferenças perante o Estado Constitucional de Direito contemporâneo.

Em verdade, o período histórico antecedente à configuração moderna de Estado, especialmente trazida a partir do século XIX, foi marcado pela pluralidade de fontes normativas, fortemente influenciadas pela produção jurídica inspirada na tradição do direito romano, e pela sólida influencia jusnaturalista em sua fundamentação. Em outras palavras, segundo Barroso, doutrina e jurisprudência desempenhariam um papel "(...) criativo do Direito e, como consequência, também normativo" ${ }^{481}$.

Por outro lado, o século XIX foi caracterizado especialmente após a revolução francesa e a independência norte-americana pelo chamado "Estado Legislativo de Direito", que prevaleceu até meados do século XX. Entre suas características o monopólio estatal da produção jurídica, bem como sobre o próprio princípio da legalidade. A norma legislada consolida-se como fator de unidade e estabilidade jurídica, e a justificativa central “(...) passa a ser de natureza positivista (...) ${ }^{\natural 482}$. A doutrina e a jurisprudência desse período passam por transformações, já que a primeira assume papel eminentemente descritivo das

\footnotetext{
480، Sinteticamente, tem-se que o constitucionalismo moderno revela-se na ideia básica de registrar por escrito o documento fundamental do povo". TAVARES, André Ramos. Curso de Direito Constitucional. São Paulo: Saraiva, 2007, p. 10 e ss.

481 BARROSO, Luís Roberto. Curso de Direito Constitucional Contemporâneo. Os conceitos fundamentais e a Construção do Novo Modelo. 3 Ed. São Paulo: Saraiva, 2012, p.265-267.

${ }^{482}$ Idem.
} 
normas em vigor, ao passo que a jurisprudência absorve uma função meramente “(...) técnica de conhecimento, e não de produção do Direito"483.

Note-se, portanto que o constitucionalismo emanado nesse período assume substancial diferenciação perante o constitucionalismo consolidado a partir da segunda metade do século XX, pois diretamente causa e efeito dessa configuração histórica jusestatal. As Constituições, nesse contexto histórico, assumem muito mais uma feição de cartas políticas, do que portadoras de normatividade vinculante perante as leis ${ }^{484}$. Mesmo Constituições "democráticas" como a Constituição de Weimar, de 1919, não conseguiram escapar dessa formatação.

Essa configuração só mudará com o surgimento do chamado "Estado Constitucional de Direito", que somente aparece efetivamente a partir da segunda metade do século XX. Entre suas características estão: a) subordinação da legalidade a uma Constituição rígida (e, portanto, a validade das leis deve ser cotejada perante a Constituição, não sendo mais suficiente apenas o cotejo de sua produção formal, mas sobretudo da compatibilidade dessas com as normas constitucionais), onde a Constituição impõe limites ao legislador e ao administrador, impondo-lhes deveres de atuação; b) feição crítica à ciência do direito (pós-positivismo); c) o desempenho de novas tarefas pela jurisprudência (competência para invalidar atos legislativos ou administrativos, bem como “(...) interpretar criativamente as normas jurídicas à luz da Constituição”) ${ }^{485}$.

Portanto, o "constitucionalismo tributário" deve ser obrigatoriamente observado à luz dessas distintas peculiaridades históricas. Ademais, historicamente, é possível observar que a gradual autonomia legislativa do direito tributário se fortaleceu na medida em que os “constitucionalismos" "486_487 cedem espaço à matéria tributária (notadamente aos limites

\footnotetext{
${ }^{483}$ Ibidem.

${ }^{484}$ Não por acaso, Fioravanti identifica três formatações históricas das constituições no Estado Moderno: a) as constituições "cetuales"; b) as constituições liberais e; c) as constituições democráticas. Sobre o assunto, conferir: FIORAVANTI, Maurizio. Stato e Costituzione. Op.cit., p. 21 e ss.

485 BARROSO, Luís Roberto. Curso de Direito Constitucional Contemporâneo. Os conceitos fundamentais e a Construção do Novo Modelo. Op.cit., p. 265-267.

${ }^{486}$ Para os propósitos do presente estudo, adota-se a noção de Canotilho: "Constitucionalismo é a teoria (ou a ideologia) que ergue o princípio do governo limitado indispensável à garantia dos direitos em dimensão estruturante da organização político-social de uma comunidade. Neste sentido, o constitucionalismo moderno representará uma técnica específica de limitação do poder com fins garantísticos. O conceito de constitucionalismo transporta, assim, um claro juízo de valor. É, no fundo, uma teoria normativa da política, tal como a teoria da democracia ou a teoria do liberalismo". Já numa acepção histórico-descritiva, “(...) falase em constitucionalismo moderno para designar o movimento político, filosófico e jurídico que, sobretudo a partir de meados do século XVIII, questiona nos planos político, filosófico e jurídico os esquemas tradicionais de domínio político, sugerindo, ao mesmo tempo, a invenção de uma nova forma de ordenação e fundamentação do poder político. Este constitucionalismo, como o próprio nome indica, pretende opor-se ao
} 
constitucionais à tributação exercida pelo Estado). Mas esse processo não é simples, e apresentará nuances históricos onde se oportunizará diferenciadas estratégias para a consolidação do direito tributário, seja brasileiro ou estrangeiro.

Interessa, nesse momento, o aspecto histórico-constitucional da tributação.

Mas, inicialmente, assevere-se, com Canotilho, que “(...) o movimento constitucional gerador da constituição em sentido moderno tem várias raízes localizadas em horizontes temporais diacrônicos e em espaços históricos geográficos diferenciados. Em termos rigorosos, não há um constitucionalismo mas vários constitucionalismos (o constitucionalismo inglês, o constitucionalismo americano, o constitucionalismo francês)" ${ }^{488}$.

Não há apenas um constitucionalismo, portanto, mas vários, e que refletem a própria realidade histórica e social a que se referem essas respectivas normas constitucionais. Não é por acaso que Konrad Hesse assim determinou: "Toda Constituição é Constituição no tempo; a realidade social, a que são referidas suas normas, está submetida à mudança histórica e esta, em nenhum caso, deixa incólume o conteúdo da Constituição"489.

Os movimentos constitucionais são, portanto, frutos de seus próprios contextos históricos, e o tratamento à matéria tributária (em maior ou menor extensão) é também reflexo sobre o próprio perfil daquela realidade social, política, cultural e econômica e, sua própria particular visão sobre a tributação. Se a tendência política e filosófica da época pauta-se na restrição da atividade estatal à esfera individual, conforme se obseva no Estado

chamado constitucionalismo antigo, isto é, o conjunto de princípios escritos ou consuetudinários alicerçadores da existência de direitos estamentais perante o monarca e simultaneamente limitadores do seu poder. Estes princípios ter-se-iam sedimentado num tempo longo - desde os fins da Idade Média até o século XVIII”. CANOtIlho, J.J. Gomes. Direito Constitucional e Teoria da Constituição. 5 Ed. Coimbra: Almedina, s/d, p. 51-52.

487 "Pode-se identificar pelo menos quatro sentidos para o constitucionalismo. Numa primeira acepção, emprega-se a referência ao movimento político-social de origens históricas bastante remotas que pretende, em especial, limitar o poder arbitrário. Numa segunda acepção, é identificado com a imposição de que haja cartas constitucionais escritas. Tem-se utilizado, numa terceira concepção possível, para indicar os propósitos mais latentes e atuais da função e posição das constituições nas diversas sociedades. Numa vertente mais restrita, o constitucionalismo é reduzido à evolução histórico-constitucional de um determinado Estado". TAVARES, André Ramos. Curso de Direito Constitucional. São Paulo: Saraiva, 2007, p. 01 e ss.

${ }^{488}$ Idem, p. 51.

${ }^{489}$ HESSE, Konrad. Constituição e Direito Constitucional. In: HESSE, Konrad. Temas Fundamentais do Direito Constitucional. Textos selecionados e traduzidos por Carlos de Santos Almeida, Gilmar Ferreira Mendes e Inocêncio Mártires Coelho. São Paulo: Saraiva, 2009, p. 13. 
Liberal (Estado Guarda-Noturno) ${ }^{490}$, é óbvio que tal desfecho também se repercutirá na configuração tributária concedida pelos Estados da época.

Não é mero acaso que, embora as cartas constitucionais apresentem elementos centrais para o reconhecimento (e dos limites) ao poder de tributar do Estado, os processos históricos constitucionais, em matéria tributária, sobretudo até a primeira metade do século XX, possuíam previsão esparsa e pouco organizada no âmbito da tributação, limitando-se, não raramente, à eleição de alguns princípios (já reconhecidos historicamente, ou elevados pela filosofia política e economia política), a discriminação das "competências impositivas", e algumas hipóteses de não incidência constitucionalmente qualificadas (imunidades).

Tome-se, por exemplo, a Constituição norte-americana de $1787^{491}$, bem como a Carta Constitucional Francesa de $1791^{492}$, reflexos diretos das declarações de direitos oriundas da independência norte-americana e da revolução francesa ${ }^{493}$, respectivamente, e que igualmente refletiam apresentavam como norte a ideia de Estado Liberal Burguês, assente na ideia de liberdade e, em nome dela, empenhado em limitar o poder político tanto internamente como externamente ${ }^{494}{ }_{-}^{495}$.

\footnotetext{
${ }^{490}$ TORRES, Ricardo Lobo. Curso de Direito Financeiro e Tributário. Op.cit., p. 08-10.

${ }^{491} \mathrm{Na}$ Constituição norte-americana de 1787, por exemplo, além de estabelecer, na Seção III, item 1, a competência dos Estados de fixar impostos diretos em seus territórios, na Seção VIII, item 1, ficou estabelecido o seguinte: "Será da competência do Congresso: Lançar e arrecadar taxas, direitos, impostos e tributos, pagar dívidas e prover a defesa comum e o bem-estar geral dos Estados Unidos; mas todos os direitos, impostos e tributos serão uniformes em todos os Estados Unidos; (...)".

${ }^{492} \mathrm{Na}$ Constituição Francesa de 1791, era possível observar alguns dispositivos esparsos constitucionais, consubstanciando princípios construídos historicamente e politicamente: " ${ }^{\circ}$ Todas as contribuições serão igualmente repartidas entre todos os cidadãos proporcionalmente aos seus recursos (...)" Assim como no capítulo III, seção 1 , conceder à Assembleia Nacional Constituinte, (...) $2^{\circ}$ fixar as despesas públicas; $3^{\circ}$ estabelecer as contribuições públicas, determinando sua natureza, sua quota, a duração e o modo de sua arrecadação; $4^{\circ}$ fazer a repartição da contribuição direta entre os departamentos do reino, fiscalizar o emprego de todas as rendas públicas e fazê-los prestarem contas; $5^{\circ}$ decretar a criação ou supressão de cargos públicos; (...)". Evidentemente, as Constituições subsequentes refletiam ambientes históricos (e políticos) diferenciados naquele contexto, como a Constituição Francesa de 1814, que apresentou substanciais alterações perante a constituição posterior, levando também à elevação das despesas (e consequentemente das receitas públicas). Não por acaso, a Constituição francesa de 1848 apresentava em seu preâmbulo o compromisso da diminuição dos encargos públicos (sobretudo impostos), consagrando, naquele ambiente histórico, uma conjunção entre o liberalismo político e ideais sociais democráticos. COMPARATO, Fabio Konder. A Afirmação Histórica dos Direitos Humanos. Op.cit., p.

${ }^{493}$ COMPARATO, Fabio Konder. A Afirmação Histórica dos Direitos Humanos. São Paulo: Saraiva, 2015 , p. 62 e ss.

${ }^{494}$ MIRANDA, Jorge. Op.cit., p. 47.

${ }^{495}$ SILVA, José Afonso da. Curso de Direito Constitucional Positivo. São Paulo: Malheiros, 2015, p. 151192.
} 
Por isso também a elevação da liberdade individual, da liberdade contratual, da elevação absoluta da propriedade privada, da recursa da liberdade de associação e, afinal, dos desvios aos princípios democráticos (ainda que existindo proclamação formal), sobretudo através da “(...) restrição do direito ao voto aos possuidores de certos bens ou rendimentos, únicos que, tendo responsabilidades sociais, deveriam ter responsabilidades políticas (sufrágio censitário)"496.

Porém, com salutares críticas sofridas aos movimentos constitucionais daquele período elevam-se, também, as "liberdades políticas", ao mesmo tempo entendida como "liberdade autonomia e liberdade-participação", sendo acrescida à já conquistada liberdade civil individualista, conforme expõe Jorge Miranda ${ }^{497}$.

Contudo, no constitucionalismo liberal oitocentista era possível contar nos dedos o número de dispositivos constitucionais tendentes à tributação, e essa tendência se manteve perene até o final da Segunda Guerra Mundial.

Por outro lado, os "constitucionalismos" europeus fornecem indícios de que seria equivocado padronizar os diferentes movimentos constitucionais consolidados naquele período, cada qual com características derivadas de específico contexto político e territorial $^{498}$.

Nesse sentido, as Constituições Francesa e Norte-americana, emanadas, pontualmente, por um movimento de independência, ou de um movimento revolucionário, mas ambas consolidando o chamado Estado Liberal (e que leva ao Estado Fiscal minimalista) ${ }^{499}$ apresentavam também importantes diferenciações históricas perante o processo político que levou à consagração da Constituição do Império Alemão (motivado pela consagração do "princípio da nacionalidade" ${ }^{500}$, diretamente ligado à unificação do Império Alemão), de 1871.

\footnotetext{
${ }^{496}$ MIRANDA, Jorge. Op.cit., p. 47-48.

${ }^{497}$ Idem, p.49.

${ }^{498}$ CANOTILHO, J.J. Gomes. Direito Constitucional e Teoria da Constituição.Op.cit., p. 51.

499 "O Estado de Polícia, com o seu absolutismo político e a sua economia mercantilista ou comercial, foi historicamente substituído pelo Estado Fiscal, com a sua estrutura econômica capitalista e o seu liberalismo político e financeiro". TORRES, Ricardo Lobo. A Ideia de Liberdade no Estado Patrimonial e no Estado Fiscal. Op.cit., p. 97 e ss.

${ }^{500}$ MIRANDA, Jorge. Op.cit., p. 48.
} 
Em primeiro lugar, na Constituição Imperial, a elevação “cidadania alemã” no artigo $3^{\text {a }}$ é emblemática, e reflete-se, de certa forma, nos artigos 33 a 40 daquela Constituição (e que consolida a união aduaneira e comercial e respectivos efeitos nos impostos do Império Alemão).

Concedendo espaço específico às Finanças do Império Alemão (artigos 69 e seguintes), forneceu importantes bases para o direito financeiro alemão, sobretudo pela elevação da legalidade e anualidade das leis financeiras. A elaboração de uma seção própria dedicada às finanças do império forneceu suporte também para o maior interesse da matéria pelos estudiosos do direito público da época.

Não por acaso que a atenção ao direito orçamentário pôde ser observada em Mayer, Fleiner e, posteriormente, em Myrbach-Rheinfeld, entre os anos finais do século XIX e início do século $\mathrm{XX}^{501}$.

Posteriormente, a Constituição de Weimar, situada em ambiente político ulterior à Primeira Guerra Mundial, apresenta também dispositivos tributários (a exemplo do artigo 8), seja nas relações aduaneiras (artigo 82) e na própria legislação financeira (ligando a legalidade à anualidade financeira, conforme se observa nos artigos 84 e seguintes).

Identifica-se aqui uma tendência histórica, desde a Constituição de 1871, mas também observada em Weimar, na "mistura" entre dispositivos tributários, aduaneiros e financeiros em um único dispositivo, o que também facilitava a identificação pelos autores da época do tratamento do tema prioritariamente em matéria financeira.

Evidentemente, a Constituição de Weimar, ao lado da Constituição Mexicana de $1917^{502}$, representou forte passo para a consagração do chamado Estado Social de Direito (consagrando direitos econômicos e sociais), consolidando exigências dos movimentos sociais do século XIX e $\mathrm{XX}^{503}$. Conforme destaca Comparato: "O reconhecimento dos direitos humanos de caráter econômico e social foi o principal benefício que a humanidade

\footnotetext{
${ }^{501}$ Mayer, Otto. Op.cit., p. 84-95. FLEINER, Fritz. Op.cit., p. 252 e ss. MARTUL-ORTEGA, Perfecto Yebra. Op.cit., p. 12. MYRBACH-RHEINFELD, Franz Von. Op.cit., p. 20 e seguintes.

${ }^{502} \mathrm{Na}$ Constituição Mexicana, por exemplo, destacou-se o artigo 31, ao estabelecer que “(...) são obrigações de todos os mexicanos: contribuir para os gastos públicos, notadamente da federação, assim como do Estado e Município em que residam, de maneira proporcional e equitativa conforme disposições das leis".

${ }^{503}$ ALEXY, Robert. Teoria dos Direitos Fundamentais. Trad: Virgílio Afonso da Silva. 2 Ed. São Paulo: Malheiros, 2009, p. 27 e ss.
} 
recolheu do movimento socialista, iniciado na primeira metade do século XIX. O titular desses direitos, com efeito, não é o ser humano abstrato, com o qual o capitalismo sempre conviveu maravilhosamente. É o conjunto dos grupos sociais esmagados pela miséria, a doença, a fome e a marginalização" ${ }^{, 504}$.

Porém, apesar de aperfeiçoar a legislação tributária, conforme se observa no artigo $134^{505}$, não apresentava fortes diferenciações frente a essa tendência histórica, mantendo a legislação tributária em dispositivos esparsos, quase sempre previstos juntos da legislação financeira do Reich.

O limitado e pouco coeso tratamento constitucional à matéria tributária, aliás, dificultava sobremaneira a compreensão de um direito tributário organizado e sistematizado.

Na Alemanha, a ausência de uma legislação racional, harmônica e extensiva sobre a matéria tributária trazia enormes dificuldades para a própria interpretação e aplicação do direito tributário perante os Tribunais Financeiros, notadamente aqueles criados na Reforma Administrativo-Financeira do Reich, em 1918, voltada à reconstrução financeira e estrutural da Alemanha, bem como a busca pelos pesados encargos financeiros legados pela Primeira Guerra.

Assim, se no constitucionalismo tributário alemão daquele período não era possível encontrar as respostas para o problema financeiro do país (e nem força normativa suficiente para tanto), era preciso buscar soluções alternativas que fornecessem melhor suporte ao intérprete e aplicador da legislação tributária.

A resposta, afinal, encontrava-se no plano infraconstitucional.

\footnotetext{
504 “A Constituição Francesa de 1848, retomando o espírito de certas normas das Constituições de 1791 a 1793, reconheceu algumas exigências econômicas e sociais. Mas a plena afirmação desses novos direitos humanos só veio a ocorrer no século XX, com a Constituição mexicana de 1917 e a Constituição de Weimar de 1919". COMPARATO, Fabio Konder. A Afirmação histórica dos direitos humanos. São Paulo: Saraiva, 2015, p. 115 e ss

505 Constituição de Weimar (1919): “Artigo 134 - Todos os cidadãos, sem discriminação contribuem em relação aos seus meios para o encargo público, em conformidade com as leis.”
} 
Nesse quadro, emana-se a codificação do Direito Tributário, que por sinal, apresenta aspectos de semelhança ao processo de codificação do direito que já ocorreu em outros campos do direito.

Geralmente, o processo de organização e consolidação de dispositivos em um único corpo de normas gerais serve para melhor organizar a interpretação e a aplicação daquele ramo do direito, facilitar a racionalização dos estudos relativos àquele conteúdo e, consequentemente, no século XIX, alcançar maior estabilidade no objeto de estudo do jurista $^{506}$, pois viabilizaria maior sistematização e organização do seu próprio objeto de conhecimento.

A codificação é processo legislativo que se vincula diretamente ao fenômeno do positivismo jurídico, e é consequência dos eventos atinentes ao Estado Moderno, caracteristicamente centralizador da organização administrativa estatal e monopolizador do $\operatorname{direito}^{507}$.

Na prática, a codificação também antevia maior impulso ao desenvolvimento de estudos sobre aquele corpo de regras codificado. Os códigos napoleônicos, por exemplo, impulsionaram rapidamente o desenvolvimento de diversos ramos do direito privado na França, incluindo-se até a codificação penal. O positivismo jurídico francês, impulsionado pelo fenômeno codificador, chegou ao extremismo exegético, no qual só importaria o exato conteúdo das leis, e nada mais ${ }^{508}$.

Na cultura germânica oitocentista, por outro lado, a recepção da codificação foi atrasada especialmente pela prevalência de outros pontos de vista não necessariamente harmônicos com o positivismo jurídico codificador do direito privado francês.

Cite-se como exemplo o próprio historicismo jurídico, ramo jus-filosófico da Filosofia do Direito, por sua vez desenvolvido por Savigny (para quem a ciência legislativa deveria ser histórica e filosófica $)^{509}$, e que favoreceu o atraso da codificação germânica.

\footnotetext{
${ }^{506}$ GIL, Antonio Hernández. Problemas Epistemológicos de la Ciencia Jurídica. Madrid: Civitas, 1981, p. 17-31.

${ }^{507}$ Sobre o assunto, sob a perspectiva da história do direito, conferir: GROSSI, Paolo. Mitologias Jurídicas da Modernidade. $2^{\mathrm{a}}$ Ed. Florianópolis: Fundação Boiteux, 2007, p. 87-114.

${ }^{508}$ BOBBIO, Norberto. O Positivismo Jurídico. Lições de Filosofia do Direito. Coleção Elementos de Direito. São Paulo: Ícone Editora, 1995, p.45-57, 78-83, 119-122.

${ }^{509}$ SAVIGNY, Karl Von Friedrich. Op.cit., p. 06 e seguintes.
} 
Mesmo Puchta apresentava reservas à aplicação da codificação do direito privado naquele contexto histórico $^{510}$.

A codificação germânica, portanto, passando também por elementos culturais, econômicos, sociais e políticos da região, atrasou-se em relação ao exemplo francês, e somente nas décadas finais do século XIX logrou êxito pela codificação do direito penal (1871), seguida pela codificação do direito civil $(\mathrm{BgB})$, em $1901^{511}$, no início do século XX. Em outras palavras, a codificação germânica ocorreu de forma distinta do que na realidade francesa ${ }^{512}{ }^{513}$.

No processo de codificação tributária germânica, contudo, a situação se fez de forma diferente do fenômeno análogo ocorrido nos outros ramos do direito, conforme se observará abaixo.

A importância histórica fundamental da codificação tributária para o processo disciplinar do Direito Tributário justifica a elaboração de tópico próprio para a problemática, abaixo vislumbrada.

\section{A contribuição histórica da codificação para o direito tributário estrangeiro.}

O primeiro código tributário entrou em vigor em 23 de dezembro de 1919, na Alemanha. A Ordenação Tributária do Reich (Reichsabgabenordnung) foi consolidada como parte do conjunto de medidas que compôs o Plano de Reforma Financeira estabelecida pelo Reich, incumbindo o jurista Enno Becker da tarefa de elaborá-la.

Note-se que esse era o ambiente histórico onde começava a prevalecer, com a Constituição de Weimar (que já consagrava os Direitos Fundamentais de $2^{\mathrm{a}}$ Geração, ou Direitos Sociais ${ }^{514}$, em contraposição aos direitos negativos ou de Primeira Geração,

\footnotetext{
${ }^{510}$ BOBBIO, Norberto. O Positivismo Jurídico. Lições de Filosofia do Direito. Op.cit., p.45-57, 78-83, 119-122.

${ }^{511}$ LARENZ, Karl. Metodologia da Ciência do Direito. $3^{\circ}$ Edição. Tradução de José Lamego. Lisboa Portugal: Editora Fundação Calouste Gulbenkian, 1997, p.10 e seguintes.

${ }_{512}$ BOBBIO, Norberto. O Positivismo Jurídico. Lições de Filosofia do Direito. Coleção Elementos de Direito. São Paulo: Ícone Editora, 1995, p.45-57, 78-83, 119-122.

${ }^{513}$ LARENZ, Karl. Op.cit., p.10 e seguintes.

${ }^{514}$ Os Direitos de Segunda Geração são os direitos sociais, econômicos e culturais. BONAVIDES, Paulo. Curso de Direito Constitucional. 19ª Edição, São Paulo: Editora Malheiros, 2006, p. 517.
} 
próprios do Liberalismo ${ }^{515}$ ), elevando-se o Estado Social Fiscal, referente ao aspecto financeiro do Estado Social de Direito (ou "Estado de Bem-estar Social"), florescendo no Ocidente no século XX, especialmente a partir da Primeira Guerra, onde passa a ganhar força a expressão "Estado Fiscal". 516

A Alemanha, vencida em guerra, encontrava-se em flagrante situação de escassez econômica, política e social. Era preciso, no entanto, seja para reconstruir o país, seja para atender aos pesados compromissos financeiros firmados pelo Pacto de Versalhes, restabelecer-se financeiramente, e enfrentar os diversos problemas que contribuíram para a desestruturação de uma organização tributária, dentre os quais: a) a complexidade e a desorganização da legislação infraconstitucional tributária; b) a confusão decorrente da existência de diversas organizações administrativas destinadas à fiscalização e à arrecadação dos tributos; c) a dificuldade de reprimir abusos e fraudes fiscais; d) a crescente pressão fiscal; e) a incerteza de princípios tributários aplicáveis aos tributos alemães; f) a divergência entre a aplicação da lei por parte dos órgãos dos vários Estados; g) abusos, arbitrariedades e injustiças derivadas dessa confusão; h) e a impossibilidade de julgar adequadamente a matéria tributária sem um instrumento-base para interpretação e aplicação da lei ${ }^{517}$.

Estes problemas contribuíram enormemente para as medidas radicais adotadas pelo Ministério do Tesouro do Reich, que, no verão de 1918, iniciou seus trabalhos para alcançar uma profunda reforma na organização formal do sistema tributário através da codificação dos princípios que regeriam a administração tributária ${ }^{518}$. Nesse contexto, Enno Becker é incumbido de elaborar um projeto de codificação tributária, destinado a suprir tais dificuldades, que, após alguns meses de elaboração, foi convertido em lei e

\footnotetext{
515 Os direitos fundamentais de primeira geração, segundo Paulo Bonavides, seriam os direitos civis e políticos. Idem, p 500 e seguintes.

${ }^{516}$ TORRES, Ricardo Lobo. Curso de Direito Financeiro e Tributário. $12^{\circ}$ Ed. Rio de Janeiro: Renovar, 2005, p. 8-9. TORRES, Ricardo Lobo. A ideia de liberdade no Estado Patrimonial e no Estado Fiscal. Rio de Janeiro: Renovar, 1991, p. 127 e seguintes. Sobre o "Estado Fiscal" também se sugere a leitura de: NABAIS, José Casalta. O Dever Fundamental de Pagar Impostos. Coimbra: Livraria Almedina, 1998, p. 191-192.

${ }^{517}$ HENSEL, Albert. Op.cit., p. 10 e seguintes.

${ }^{518}$ Dessa forma, podem ser elencadas como causas determinantes para o desenvolvimento efetivo do direito tributário alemão (Steuerrecht) a Reforma da Administração Financeira do Reich, promovida logo após o final da Primeira Guerra, e que originou no mesmo ano a criação do Tribunal Financeiro do Reich (Reichsfinanzhof-RFH), dedicado às lides financeiras, além de incutir a necessidade de que os juízes e fiscais tivessem uma fonte adequada de interpretação e aplicação da lei tributária. Idem.
} 
publicado em 13 de dezembro de 1919, entrando em vigor em 23 de dezembro do mesmo ano.

Criava-se oficialmente o Código Tributário Alemão, ${ }^{519}$ cuja estrutura buscava alcançar todas as etapas da relação tributária, e corporificava instrumento viabilizador da atividade tributária estatal, buscando também evitar onerações injustas aos cidadãos. Era, afinal, instrumento de segurança jurídica nas relações tributárias ${ }^{520}$, além de construir eficiente instrumento legislativo próprio à interpretação e aplicação da lei pelos juízes fiscais, na tentativa de escapar da influência do direito civil ${ }^{521}{ }_{-}^{522}{ }_{-}^{523}$. Não se pode esquecer que a Alemanha Pós-Guerra era um país em "Estado de Emergência" e, portanto, altamente necessitado de recursos financeiros urgentes ${ }^{524}$.

Nesse aspecto, pode afirmar-se a RAO constituiu uma estrutura de codificação geral $^{525}$, já que esse tratamento jurídico unitário de relação tributária foi possibilitado através de um ordenamento de princípios gerais sobre tributação, comuns a toda classe de impostos, e que constituiriam o embasamento jurídico do sistema fiscal, contribuindo para a centralização administrativa no que tange também à fiscalização, administração, cobrança e à arrecadação dos tributos ${ }^{526}{ }_{-}^{527}$. Por outro lado, também favoreceu ao surgimento da literatura tributária especializada, sobretudo em países de língua alemã, e, por extensão, em outros países europeus, como a Itália. Por isso, Sainz de Bujanda afirmava que restava ali a "gênese" da literatura tributária. ${ }^{528}$

Posteriormente, em 1934, entrou em vigor a Lei de Adaptação Fiscal (SteuerAnpassungsGesetz), com o objetivo de esclarecer, especificar ou mesmo afastar

\footnotetext{
${ }^{519}$ BUJANDA, Fernando Sainz de. Hacienda Y Derecho. I. Op.cit., p. 58-59.

${ }^{520}$ VANONI, Ezio. L'Esperienza della Codificazione Tributaria In Germania. In: Opere Giuridiche. A cura di Francesco Forte e Cesare Longobardi. II. Elementi di Diritto tributario. Altri saggi di diritto finanziario. Milano - Dott.A. Giuffrè Editore, 1962, p. 383 e seguintes.

${ }^{521}$ Idem.

${ }^{522}$ BÜHLER, Ottmar. La Importanza di Enno Becker per Lo Sviluppo del Diritto Tributario Tedesco dal 1918. In: Rivista di Diritto Finanziario e Scienza della Finanze.Volume IV. XVIII, Parte I. Padova: 1940 CEDAM - CASA EDITRICE DOTT. ANTONIO MILANI, 1940, p.43-46

${ }^{523}$ MACHADO, Brandão. Prefácio do Tradutor. In: HARTZ, Wilhelm. Interpretação da Lei Tributária. Conteúdo e Limites do Critério Econômico. Tradução, Prefácio e Notas de Brandão Machado. Rio de Janeiro: Resenha Tributária, 1993, p. 05-31.

${ }_{524524}$ HENSEL, Albert. Op.cit., p. 16-25.

525 DINIZ, Souza. Códigos Tributários. Alemão. Mexicano. Brasileiro. $1^{\circ}$ edição. Tradução de Souza Diniz. São Paulo: Edições Financeiras S.A., 1965, p. 03 e seguintes.

${ }^{526}$ BUJANDA, Fernando Sainz de. Hacienda Y Derecho. I. Op.cit., p. 58-59.

${ }^{527}$ VANONI, Ezio. L'Esperienza della Codificazione Tributaria In Germania. Op.cit., p. 383 e ss.

${ }^{528}$ BUJANDA, Fernando Sainz de. Hacienda Y Derecho. I. Op.cit., p. 58-59.
} 
determinados dispositivos considerados "problemáticos" pela doutrina e jurisprudência alemã ${ }^{529}$.

Na experiência europeia também se pode mencionar a codificação francesa, que originalmente organizou-se por códigos tributários parciais, a partir de 1934, que, posteriormente reunidos, levaram à promulgação do "Código Geral dos Impostos", em 1950, assim como a Lei Geral Tributária na Espanha, de $1963 .{ }^{530}$

Mas deve-se asseverar que tanto a RAO como a Lei de Adaptação Fiscal, que modificou a primeira, influenciaram severamente o fenômeno codificador em outros países, seja na Europa ou na América Latina, que seguiram a estrutura metodológica daquelas Leis, chegando, em muitos casos, a repetir dispositivos de forma praticamente idêntica aos dispostos originalmente naquelas codificações. Além disso, os debates doutrinários e jurisprudenciais sobre determinados assuntos versados sobre a RAO e a Lei de Adaptação Fiscal também repercutiram fortemente no desenvolvimento da doutrina tributária posterior. ${ }^{531}$

$\mathrm{Na}$ América Latina, o fenômeno codificador seguiu caminhos ligeiramente distintos, ainda que a influência europeia fosse expressa. Isso porque o efetivo elemento difusor do processo codificador pode ser identificado em duas vertentes: a) a regionalização, ou política de integração econômica regional, organizada pela Associação Latino-Americana de Livre Comércio, a BID - Banco Interamericano de Desenvolvimento, OEA - Organização dos Estados Americanos, e CEPAL - Comissão Econômica para a América Latina e Caribe, especialmente a partir da Segunda Guerra Mundial; b) a influência doutrinária europeia na literatura tributária emergente na América Latina.

${ }^{529}$ Lei de Adaptação Fiscal de 1934, traduzida em língua portuguesa por DINIZ, Souza. Códigos Tributários. Alemão. Mexicano. Brasileiro. $1^{\circ}$ edição. Tradução de Souza Diniz. São Paulo: Edições Financeiras S.A., 1965, p. 220 e seguintes.

${ }_{530}$ BALEEIRO, Aliomar. Parecer sobre o Projeto do C.T.N. In: BALEEIRO, Direito Tributário Brasileiro. Rio de Janeiro: Forense, 1973, p. 29-30.

${ }^{531}$ Posteriormente, o Código Tributário Alemão de 1919 foi retirado do ordenamento jurídico e, substituído pelo Código Tributário Alemão (AbgabenOrdnung), em 1977, que apresentava redação melhor ordenada e sistematizada. A codificação alemã influenciou o movimento codificador em países europeus, sobretudo, mas também impulsionou semelhante efeito na América Latina. Novo Código Tributário Alemão (AO - 1977). Tradução de Alfred J. Schimid, Brandão Machado, Eduardo Frederico de A.Carvalho, Gerd W. Rothmann, Henry Tilvery, Ruy Barbosa Nogueira. São Paulo: Co-edição: Companhia Editora Forense \& Instituto Brasileiro de Direito Tributário, 1978, p. 01-158. 
Mas assevera-se que o movimento codificador dos sistemas tributários latinoamericanos e a integração econômica regional inspiram-se na experiência codificadora europeia $^{532}$, que influenciou largamente as primeiras tentativas de codificação na América Latina. Nesse sentido, o primeiro Código latino-americano foi o Código Tributário Mexicano, de $1938^{533}$, profundamente influenciado pela codificação germânica (praticamente apresentando a mesma estrutura legislativa), assim como pela elaboração doutrinária de Mario Puglièse, que, à época, havia difundido fortemente sua obra "Instituições de Direito Financeiro" 534 naquele país.

Segue-se na Argentina a elaboração doutrinária de Giuliani Fonrouge que, encantado com a repercussão do Código Tributário Alemão, resolve elaborar de próprio punho o Anteprojeto de Código Fiscal Argentino ${ }^{535}$, cujo objetivo central, entre outros, voltava-se à criação de um Tribunal Fiscal Especializado na Argentina. Ainda que não obtendo o sucesso esperado, a obra, inspirada na codificação germânica e mexicana, acabou servindo como referência doutrinária de alto valor. Aquele país acaba adotando, em primeiro momento, com a colaboração de Dino Jarach, a codificação tributária provincial, e a posterior Lei nacional (de caráter nacional) n.11.683, com a colaboração de Jorge Tejerina. ${ }^{536}$

No Uruguai, Ramón Valdés Costa, em 1958, liderou comissão destinada à construção de Código Tributário, ainda que também tenha, inicialmente, seguido o mesmo destino do Anteprojeto de Fonrouge ${ }^{537}$.

Esses esforços, naturalmente, caminhavam pela perspectiva da influência europeia na literatura latino-americana. Contudo, a regionalização também apresentaria sua própria contribuição à codificação tributária, já que a ALALC, em parceria com a OEA e o BID,

\footnotetext{
${ }^{532}$ VALDÉS COSTA, Ramón. A Codificação Tributária na América Latina. Direito Tributário: estudos em homenagem ao Prof. Ruy Barbosa Nogueira. COORDENADOR: MACHADO, Brandão. São Paulo: Saraiva, 1984, p. 241-242.

${ }_{533}$ O Código Tributário Mexicano de 1938 foi traduzido na língua portuguesa por DINIZ, Souza. Códigos Tributários. Alemão. Mexicano. Brasileiro. Op.cit., p. 343 e seguintes.

${ }^{534}$ PUGLIÈSE, Mario. Instituciones de Derecho Financiero. Tradución Española de México: 1939, p. 09 e seguintes.

${ }^{535}$ FONROUGE, C. M. Giuliani. Anteproyecto de Código Fiscal. Facultad del Derecho y Ciências Sociales. Investigaciones del Seminário de Ciências Jurídicas y Sociales. XXXVIII. Buenos Aires: Seccion publicaciones del seminário de ciências jurídicas y sociales, 1942, p. 363 e seguintes.

${ }_{536}^{53}$ VALDÉS COSTA, Ramón. A Codificação Tributária na América Latina. Op.cit., p. 241-243.

${ }^{537}$ Idem, p. 241-243.
} 
lançariam o Programa Conjunto de Tributação (cuja meta principal seria obter a harmonização legislativa tributária entre países latino-americanos).

Dentre as medidas do Programa cita-se a elaboração de Modelo de Código Tributário para a América Latina, que foi coordenado por Giuliani Fonrouge, Ramón Valdés Costa e Rubens Gomes de Sousa, em 1967 ${ }^{538}$, buscando servir de referência enquanto norma geral tributária para os países latino-americanos, facilitando assim a maior harmonização dos sistemas tributários nacionais.

A estratégia codificadora integrativa também aliava o estudo comparativo entre as legislações tributárias latino-americanas, no intuito de verificar sua compatibilidade com os dispositivos do Modelo539_540_541. Infelizmente, o Programa (e o Modelo) acabou esquecido, ainda que apresente elevada importância histórica para a compreensão do processo codificador do direito tributário latino-americano. De qualquer forma, as experiências europeias e latino-americanas contribuíram positivamente para criar, na realidade brasileira, o ambiente propício para a codificação tributária.

Mas deve-se reconhecer que a autonomia legislativa do Direito Tributário brasileiro apareceu de forma diferenciada, ainda que tenha absorvido importantes reflexos da experiência codificadora e constitucional estrangeira, notadamente europeia.

\section{Traços diferenciais da autonomia legislativa do direito tributário brasileiro perante a experiência estrangeira: direito tributário positivo centrado na constitucionalização e na codificação.}

É imprescindível, para a adequada compreensão das diferenças vivenciadas entre a literatura estrangeira (notadamente europeia) e a literatura tributária brasileira, de que a

\footnotetext{
${ }^{538}$ Ibidem, p. 241-242.

${ }^{539}$ TILBERY, Henry. Tributação e Integração da América Latina. São Paulo: José Bushatshky, 1971, p. 145.

${ }^{540}$ Análise Comparativa das Normas Substantivas do Modelo de Código Tributário com a dos Códigos Vigentes nos Países-Membros da ALALC. Associação Latino-Americana de Livre Comércio. Secretaria Geral da Organização dos Estados Americanos. Programa Conjunto de Tributação OEA/BID. Washington D.C., 1970. A tradução integral do trabalho foi publicada como anexo na obra: In: NOGUEIRA, Ruy Barbosa. Direito Tributário Comparado. São Paulo: Edição Saraiva, 1971, p. 244-245.

${ }^{541}$ Idem, p. 237-330.
} 
literatura tributária estrangeira no período fundacional (sobretudo de língua germânica), impressionou-se pelo fenômeno legislativo infraconstitucional e, mais precisamente, pelo fenômeno codificador. A parca efetividade da Constituição de Weimar fortalecia essa tendência.

Seja pela crítica ou pela elevação do Código Tributário Alemão, a literatura passou a se desenvolver e se especializar com fundamento nesta. A parca previsão constitucional em matéria tributária na Constituição de Weimar facilitou a concentração da literatura da época nas disposições do Código, ainda que autores como Blumenstein ${ }^{542}$, e notadamente, Albert Hensel $^{543}$ já tivessem tratado do que viria a ser desenvolvido na doutrina como Direito Constitucional Tributário.

A realidade tributária brasileira, no que tange à consolidação da codificação e sua relação com a doutrina, é muito diferente. Isso porque não foi a partir do Código Tributário que se poderia reconhecer a autonomia disciplinar do direito tributário brasileiro. Nem teve o Brasil criação do tribunal fiscal especializado, como aconteceu na Alemanha. Foi na verdade, o próprio Código - e o processo de codificação - fruto de esforço doutrinário que o levou à sua criação, apoiado pela sociedade civil e levada ao Congresso com o apoio do Poder Público, com fundamento na própria Constituição de 1946, e com a perspectiva de viabilizar melhor harmonia entre as legislações tributárias dos entes tributantes em um país federado de dimensões continentais.

Note-se que o Código Tributário Nacional foi promulgado em 25 de outubro de 1966, antes da entrada em vigor da Reforma Constitucional promovida pela E.C 18/65, que entrou em vigor em primeiro de janeiro de $1967^{544}$.

Existiam motivos maiores para sua entrada em vigor, que abaixo são listados: a) criação de normas gerais em matéria tributária para aumentar a coesão e harmonia entre as competências legislativas tributárias dos entes políticos de um país federado com dimensões continentais; b) fornecer impulso à autonomia disciplinar - e científica - do direito tributário nacional, que teria seu próprio instrumento de interpretação e aplicação do direto tributário, à semelhança do direito civil e do direito penal; c) organizar a

\footnotetext{
${ }^{542}$ BLUMENSTEIN, Ernst. Op.cit., p. 15 e ss.

${ }^{543}$ HENSEL, Albert. Op.cit., p. 10 e ss.

${ }^{544}$ AMED, Fernando José; NEGREIROS, Plínio José Labriola de Campos. Op.cit., p. 284 e seguintes.
} 
legislação tributária infraconstitucional (consequência inerente do primeiro item) facilitando assim a interpretação e aplicação do direito tributário pelas autoridades administrativas e judiciais, assim como fornecer instrumento de suporte aos direitos e garantias dos contribuintes e responsáveis pela relação tributária; d) sedimentar conceitos e institutos tributários oriundos da literatura estrangeira, mas adaptados à realidade tributária brasileira (ex: art. $3^{\mathrm{a}}$, sobre o conceito de tributo), assim como a obrigação tributária, seus elementos e o crédito tributário; e) estabelecer com nitidez as normas gerais relativas às atribuições, garantias e privilégios do fisco; f) marcar posição oficial da legislação tributária brasileira sobre determinados temas controversos na literatura (e legislação estrangeira), como é o caso da noção e efeitos do lançamento, por exemplo, ou da interpretação e integração da lei tributária; g) trazer normas gerais sobre as espécies tributárias, assim como da administração tributária e, f) naturalmente, a partir de corpo mais organizado de normas tributárias, maximizando a arrecadação, especialmente em momento de profunda mudança política estrutural (trazida pelo Golpe de 1964); g) facilitar a organização tributária alterada pela Emenda Constitucional n.18 de 1965, que transformou substancialmente o direito constitucional tributário da época, complementando o sistema tributário nacional.

A literatura tributária brasileira, surgida em meados dos anos quarenta, recebe influências da realidade tributária estrangeira, notadamente europeia, mas naquele momento, a literatura europeia já passava por profundas transformações, especialmente porque a partir da década de vinte essa literatura era centrada notadamente na legislação codificadora infraconstitucional. Somente a partir da Segunda Guerra, é que a literatura tributária europeia passa a estruturar-se com intensidade no âmbito constitucional (por motivos que serão compreendidos nos próximos tópicos).

Por isso parece adequada a ponderação de Ricardo Lobo Torres no sentido de que os doutrinadores que contribuíram par o processo de codificação do Direito Tributário apresentavam também características positivistas, como é o caso de Aliomar Baleeiro, Gilberto Ulhôa Canto e Rubens Gomes de Sousa. Afinal, a elevação da codificação é, e sempre foi, o trunfo dos positivismos ${ }^{545}$.

\footnotetext{
${ }^{545}$ TORRES, Ricardo Lobo. Legalidade Tributária e Riscos Sociais. Op.cit., p. 108 e ss.
} 
A literatura tributária brasileira, diferentemente, seja pela ausência de um tribunal fiscal (que nunca se concretizou, a não ser no âmbito administrativo), seja pela ausência de um código de normas gerais (que só ocorreria em 1966), forçou-se à adaptação, recorrendo ao extensivo rol de normas tributárias, que até então dificultavam sobremaneira a interpretação e aplicação do direito tributário positivo.

Por outro lado, as Constituições brasileiras sempre geraram reflexões por parte da literatura da época, que se manteve desde o início com especial atenção às estruturas de discriminação de rendas em matéria tributária ${ }^{546}$.

Pode-se antecipar, assim, que o processo disciplinar da literatura tributária brasileira manteve também maior atenção inicial aos aspectos constitucionais tributários da matéria (especialmente a partir de 1946), diferentemente da literatura europeia que se inicia centrada na codificação, e passa a conservar maior atenção constitucional a partir da Segunda Guerra.

Sob o contexto temporal, conforme será observado nas linhas posteriores, será praticamente contemporânea a preocupação constitucional do direito tributário na Europa, e o surgimento das primeiras doutrinas brasileiras (ambas em meados da década de quarenta).

A literatura tributária brasileira, especialmente a partir da década de cinquenta (período em que se inicia a efetiva difusão dos estudos tributários), concentra maior atenção ao chamado "Direito Tributário Constitucional", no mesmo passo em que a literatura europeia passa a elevá-la, em momento posterior à priorização codificadora.

Portanto, pode-se afirmar que a literatura tributária brasileira, por constituir-se com posteridade à europeia, acabou absorvendo ambos os períodos de formação da literatura tributária europeia (codificada e constitucionalizada), em sua formação inicial, que se fundiram na literatura tributária brasileira a partir da década de cinquenta, quando surgem as primeiras obras sobre direito tributário constitucional no Brasil, e o esforço codificador tem início (através do Anteprojeto de Gomes de Sousa). Note-se que a particular atenção à constituição não significava já o mergulho em movimentos "neoconstitucionalistas"

\footnotetext{
${ }^{546}$ Como é o exemplo do clássico estudo de Aliomar Baleeiro, já com primeira edição em 1951. BALEERO, Aliomar. Limitações Constitucionais ao Poder de Tributar. Op.cit., p.12 e seguintes
} 
oriundos a partir da década de cinquenta na Europa, tendências que só seriam sentidas com maior clareza nas décadas posteriores do século XX (especialmente com a Constituição de 1988).

De qualquer forma, quando ocorre a efetiva institucionalização do ensino do Direito Tributário Brasileiro (com a criação das primeiras cadeiras sobre a disciplina em São Paulo e no Rio), a literatura tributária já está suficientemente voltada à codificação e à constitucionalização do direito tributário positivo brasileiro, acompanhando com atraso a tendência codificadora, mas com velocidade à tendência constitucional do Direito Tributário Europeu, e, naturalmente, adaptando ambas às peculiaridades do Direito Tributário Brasileiro.

\section{As influências estrangeiras ao constitucionalismo tributário brasileiro: o novo ambiente constitucional democrático europeu pós-guerra, e suas consequências na literatura tributária europeia.}

Após o novo período de suspensão de estudos jurídico-tributários durante a Segunda Guerra Mundial, entram em pauta novos fenômenos nas relações internacionais, diretamente impulsionados a evitar novos abusos e violações aos direitos humanos perpetuados naquela.

Nesse contexto, a recém-nascida Organização das Nações Unidas (1945) elabora Declaração de elevada carga simbólica para o período: A Declaração Fundamental dos Direitos Humanos $(1948)^{547}$, cujo conteúdo buscava afastar o risco de que atrocidades cometidas no período bélico voltassem a ocorrer. Retoma-se a defesa dos direitos e garantias fundamentais, sobretudo reforçando os direitos de Primeira Geração (direitos individuais e políticos) para alcançar os direitos de Segunda Geração (Direitos Econômicos e Sociais). ${ }^{548}$

Para Jorge Miranda, o século XX, marcado por guerras, crises econômicas, mudanças sociais e culturais e progresso técnico sem precedentes é a era das ideologias e

\footnotetext{
${ }^{547}$ COMPARATO, Fabio Konder. A Afirmação Histórica dos Direitos Humanos. São Paulo: Saraiva, 2015 , p. 237 e ss.

${ }^{548}$ BONAVIDES, Paulo. Curso de Direito Constitucional. Op.cit., p. 563.
} 
revoluções, desembocando nele todas as correntes filosóficas, acelerando o ritmo de eventos políticos. Nesse quadro de profundas transformações, expõe acertadamente o autor quatro linhas de forças dominantes emergentes do cenário posterior à Segunda Guerra Mundial: a) "transformações do Estado num sentido democrático, intervencionista, social, bem contraposto ao laissez faire liberal"; b) "o aparecimento e, depois, o desaparecimento de regimes autoritários e totalitários de diversas inspirações"; c) "a emancipação dos povos coloniais, com a distribuição agora de toda a Humanidade por Estados - por Estados moldados pelo tipo europeu, embora com sistema político-constitucionais bem diferentes;" c) "a organização da comunidade internacional e a proteção internacional dos direitos do homem". 549

O ambiente pós-guerra impulsiona renovação dos movimentos democráticos na Europa, iniciando-se nova constitucionalização (cujas aspirações históricas retomam simbolicamente a Constituição de Weimar e a do México), que, naturalmente, reforçam ainda mais a defesa dos direitos e garantias fundamentais ${ }^{550}$, passando pela Alemanha, com a Lei Fundamental de Bonn, em 1949, a Itália, em 1947 (um ano antes da Declaração da ONU, mas apresentando semelhantes aspirações) ${ }^{551}$, França, em 1958, Espanha, em 1978, da Venezuela em 1961, Portugal, em 1976 e, com atraso, no Brasil, em 1988. Todas as Constituições citadas com clara tendência à elevação do Estado Social de Direito, buscando, ao mesmo tempo, dar efetividade à tutela de direitos fundamentais, reforçando os mecanismos de garantia da Constituição ${ }^{552}{ }_{-} 53$

Emerge nesse período novo movimento entre os constitucionalistas dedicados à elevação e à efetividade desses direitos fundamentais, vinculando-os ao novo Estado Democrático de Direito. Passa-se a falar em "neoconstitucionalismo" "554, enquanto

\footnotetext{
${ }^{549}$ MIRANDA, Jorge. Op.cit., p. 49-50.

${ }^{550}$ ALEXY, Robert. Teoria dos Direitos Fundamentais. Trad. Virgílio Afonso da Silva. São Paulo: Malheiros, s/d, p. 65 e seguintes.

551 Exemplificativamente, na Constituição italiana de 1947 já transparecia com clareza o princípio da legalidade tributária, bem como da capacidade contributiva: "Art. 23 - Nenhuma prestação pessoal ou patrimonial pode ser imposta, a não ser com base na lei”. Art. 53 - Todos têm a abrigação de contribuir para as despesas públicas na medida de sua capacidade contributiva.O sistema tributário é inspirado nos critérios de progressividade.

552 MIRANDA, Jorge. Op.cit., p. 53.

${ }^{553}$ COMPARATO, Fabio Konder. A Afirmação Histórica dos Direitos Humanos. Op.cit., 2015, p. 68 e ss

${ }^{554}$ BARROSO, Luís Roberto. Direito Constitucional Contemporâneo. Op.cit., p. 288-289.
} 
movimento constitucional proeminente na defesa de que o Estado Constitucional deve buscar a realização dos “(...) direitos de primeira, segunda e terceira geração”"555_ 556 .

Assim, a Constituição, enquanto ordem jurídica fundamental do Estado $^{557}$, apresenta, portanto, nexo inerente aos direitos fundamentais que, aliás, passam a ter cada vez mais significativa participação constitucional, graças também à Declaração das Nações Unidas de $1948^{558}$.

Por isso, nesse ambiente imediatamente ulterior às duas grandes guerras mundiais fortalecesse o Estado Social de Direito que, para Jorge Miranda, não seria outro senão uma segunda fase do Estado Constitucional ou representativo ${ }^{559}$ de direito (que sucede o Estado Liberal). Passa-se a falar, efetivamente, em "força normativa da Constituição". 560

As repercussões ao fenômeno tributário, nesse ambiente histórico, são severas. Isso porque o direito tributário, anteriormente estudado principalmente a partir da codificação (germânica), passa, por influência da própria literatura germânica, a dedicar-se ao exame do direito constitucional tributário positivo, graças à Lei Fundamental de Bonn, que, em 1949, apresenta extensão inédita na Europa à matéria tributária. Consequentemente, começa-se a desenhar diferenciado perfil aos estudos tributários, agora focados no constitucionalismo tributário.

A Constituição Alemã inicia uma modificação estrutural, através do seu Capítulo $\mathrm{X}$, que forneceu ampla e minuciosa regulação à Fazenda Pública Alemã, de forma mais estruturada e harmônica do que sua antecessora, acrescentando ao direito financeiro - e ao direito tributário, dois vórtices fundamentais: a) tratamento minucioso da Fazenda Pública,

\footnotetext{
${ }^{555}$ CALIENDO, Paulo. Direito Tributário. Três modos de pensar a tributação. Op.cit., p. 24-25.

${ }^{556}$ Sobre o neoconstitucionalismo, conferir, nesse capítulo, o item 10, onde o tema é explorado com maior atenção, já em ambiente histórico favorável à inserção do fenômeno no contexto brasileiro.

${ }^{557}$ HESSE, Konrad. Conceito e peculiaridade da Constituição. In: HESSE, Konrad. Temas Fundamentais de Direito Constitucional. Op.cit., p.86 e ss.

${ }^{558}$ HESSE, Konrad. Significado dos Direitos Fundamentais. In: HESSE, Konrad. Temas Fundamentais de Direito Constitucional. Op.cit., p.24 e ss.

559 Para Miranda, a identificação do Estado Social de Direito como uma segunda fase do Estado Constitucional representativo apresenta duas justificativas fundamentais: "1a) porque, para lá das fundamentações que se mantêm ou se superam (iluminismo, jus-racionalismo, liberalismo filosófico) e do individualismo que se afasta, a liberdade - pública e privada - das pessoas continua a ser o valor básico da vida coletiva e a limitação do poder político um objetivo permanente; $2^{a}$ ) porque continua a ser (ou vem a ser) o povo como unidade e totalidade dos cidadãos, conforme proclamara a Revolução francesa, o titular do poder político". MIRANDA, Jorge. Op.cit., p. 53.

${ }^{560}$ HESSE, Konrad. A força normativa da Constituição. In: HESSE, Konrad. Temas Fundamentais de Direito Constitucional. Op.cit., p. 123 e ss.
} 
com melhor clarificação da previsão financeira aos poderes e entes da Federação, a denominada "Constituição Financeira"; b) a vinculação e elevação dos direitos e garantias fundamentais do cidadão ${ }^{561}{ }_{-} 562563$.

A principal tônica claramente vislumbrada no processo de constitucionalização tributária europeia pode ser sintetizada em dois pontos fundamentais: a) expansão da matéria tributária na Constituição (princípios, imunidades e distribuição de rendas); b) elevação expressa dos direitos e garantias fundamentais do cidadão (expressamente ou implicitamente vinculados ao direito constitucional tributário). Passa-se a falar em um "novo perfil do direito financeiro", conforme assevera Sainz de Bujanda ${ }^{564}$. Por outro lado, na égide constitucional, passa-se a falar em Estado constitucional democrático ${ }^{565}$.

Essa expansão da matéria tributária na Constituição também apresenta forte vinculação ao neoconstitucionalismo, já que os meios para se garantir e proteger os direitos fundamentais devem, nesse ambiente, serem custeados através da tributação. ${ }^{566}$

Porém, deve-se ressaltar que, embora aparecesse finalmente ambiente histórico propício à elevação do direito constitucional tributário europeu, no campo doutrinário, esse já era elevado por parcela da literatura, mas, principalmente, em Albert Hensel. Este último autor foi o principal responsável pelo estudo do "Direito Tributário Constitucional", no período anterior à Segunda Guerra. Porém, por motivos políticos (e sua ascendência judaica), seu prestígio acabou diminuído em sua própria terra natal, ainda que tenha dedicado considerável parcela de sua obra ao estudo dessa parte do direito tributário ${ }^{567}{ }_{2} 568$.

\footnotetext{
${ }^{561}$ MARTUL-ORTEGA, Perfecto Yebra. Prólogo. In: KRUSE, Heinrich Wilhelm. Derecho Tributario. Parte General. Op.cit., p. 15.

${ }^{562}$ Note-se que a maioria dos processos constitucionais (democráticos) do período teve como antecedentes a ruptura com anteriores regimes antidemocráticos (ditatoriais). Essa tendência será vislumbrada em semelhante intensidade na América Latina e, com certo atraso, na realidade brasileira.

563 Assinala Hesse que a garantia dos direitos fundamentais no Direito positivo alemão possuem diversas bases, seja pela Lei Fundamental, seja pela maioria das constituições dos Länder. HESSE, Konrad. Significado dos Direitos Fundamentais. Op.cit., p. 29.

${ }^{564}$ Fernando Sainz de Bujanda fala sobre a então "nova organização política", ou "novo direito financeiro" (constitucionalizado), recordando sobre a profunda transformação política, social e econômica ocorridas no período pós-guerra, marcado pelo reconhecimento dos direitos individuais e pela convivência coletiva, destinando-se a melhorar a economia e a vida da população, assegurando o emprego da totalidade dos recursos de cada país, além de uma justa distribuição de renda, dentre outros objetivos. BUJANDA, Fernando Sainz de. Hacienda y derecho. I. Op.cit.. p. 423-429.

${ }^{565}$ CANOTILHO, J.J. Gomes. Direito Constitucional e Teoria da Constituição. Op.cit., p. 97-100.

${ }^{566}$ CALIENDO, Paulo. Direito Tributário. Três modos de pensar a tributação. Op.cit., p. 25.

${ }^{567}$ HENSEL, Albert. Op.cit., p. 27-50.
} 
Contudo, com a literatura posterior à Segunda Guerra, lentamente os estudos de Hensel são resgatados, e passam, junto com o espírito garantista trazido por aquele ambiente histórico (e pela Constituição de Bonn), à retomada do direito tributário constitucional, fundamentado nos direitos e garantias fundamentais ${ }^{569}$, no que concorda Henrich Wilhelm Kruse ${ }^{570}$ : “Quase todo o tratamento fundamentado de direito tributário recente parte do direito constitucional e tem como objeto os distintos aspectos dos vínculos jurídico-constitucionais do direito tributário (...)", fixando com maior clareza a principiologia constitucional financeira ${ }^{571}$, limitando o abuso de poder e viabilizando a formulação de princípios gerais da tributação ${ }^{572}$.

Assim, a partir do constitucionalismo democrático pós-guerra, a literatura tributária europeia passa também por importante reformulação, dedicando-se intensamente ao "Direito Constitucional Tributário" ou "Direto Tributário Constitucional".

Por outro lado, conforme observado, o processo histórico disciplinar do Direito Tributário Brasileiro consolida-se a partir da década de quarenta, e impulsiona-se na década de cinquenta, justamente no período em que a literatura tributária europeia já se encontrava no estágio de transição histórica entre a priorização infralegal (sobretudo codificadora) para o período constitucional democrático. Tais peculiaridades serão sentidas no processo histórico disciplinar do Direito Tributário Brasileiro.

Por outro lado, conforme será observado, o neoconstitucionalismo será recebido com certo atraso na realidade constitucional brasileira, somente sendo expressamente apoiado a partir da Constituição de 1988. As razões pelos quais o neoconstitucionalismo (e

\footnotetext{
${ }^{568}$ Segundo Hensel: "O direito tributário constitucional se ocupa menos do poder tributário em si que de suas limitações, com a finalidade de constituir um metódico sistema tributário complexivo". Idem, p. 32.

${ }^{569}$ BUJANDA. Fernando Sainz de. Sistema de Derecho Financiero Tomo I. Volumen Segundo. Análisis Estructural del Derecho Financiero. Ramos del Derecho público con sectores proyectados sobre la materia financiera. Madrid. Facultad de Derecho de La Universidad Complutense, 1985, p.47-48.

${ }^{570}$ A propósito, a influência de Hensel no constitucionalismo tributário germânico é muito bem retratada em Kruse, no seu prefácio à $1^{\circ}$ edição: "Albert Hensel, a cuja memória está dedicada este livro, foi um dos mais consequentes defensores do direito tributário constitucional. Foi também um dos poucos que lutou contra a separação do direito tributário das outras disciplinas jurídicas e que sempre novamente supôs expor nas conexões existentes. Em 1923, Hensel chegou a Catedrático extraordinário na Universidade de Bonn, em 1929, a Catedrático numerário na Universidade de Kônigsberg. Já na primavera de 1933 não quiseram deixálo ensinar mais em uma universidade fronteiriça. Foi suspenso e consequentemente marchou para o Instituto Financeiro de Pávia. Em Pávia morreu em 18 de outubro de 1933, aos 38 anos de idade. Na Alemanha foi pouco conhecido o nome e a obra magistral de Hensel. A universidade de Pávia restou reservada a edição, agora faz dez anos da obra mestra de Hensel, com o título Direito Tributário em língua italiana". KRUSE, Heinrich Wilhelm. Derecho Tributario. Op.cit., p. 36-38.

${ }^{571}$ MARTUL-ORTEGA, Perfecto Yebra. Op.cit., p. 15

${ }^{572}$ KRUSE, Heinrich Wilhelm. Derecho Tributario. Op.cit., p. 92-94.
} 
a proteção expressa dos direitos fundamentais) atrasou-se em relação à experiência europeia fundamentam-se, sobretudo, no regime de exceção (1964-1985) que perpetuou-se com certa perenidade na realidade constitucional brasileira, a partir da Segunda Guerra Mundial até a redemocratização (1985-1987).

De qualquer forma, é imperioso reconhecer que mesmo com essas peculiaridades, o constitucionalismo tributário brasileiro apresentou interessantes características que merecem ser apontadas (inclusive com diferenciações perante a experiência estrangeira), pela sua importância histórica ao processo disciplinar do Direito Tributário Brasileiro.

\section{As peculiaridades históricas do direito constitucional tributário brasileiro pós- guerra.}

Evidentemente, o desenvolvimento histórico doutrinário do Direito Tributário Brasileiro não poderia ser comparado ao início dos estudos europeus, pois efetivamente, nos primórdios, na década de 1940, conforme já observado, é que surgem as primeiras obras capitulares ao tratamento específico da disciplina, e o período disciplinar somente se institucionaliza, efetivamente, a partir da década de sessenta.

Nesse aspecto, no âmbito legislativo, sob o ponto de vista constitucional, a matéria tributária apresentava alguma preocupação, muito embora absolutamente destituída de organicidade ou resquícios que denunciassem a formação de uma sistematização constitucional.

Isso porque as Constituições de 1824 e 1891 apresentavam poucos dispositivos em matéria tributária, essa que ganhou evolução gradativa com as Constituições e 1934 e 1937, culminando maior aperfeiçoamento com a Constituição de 1946, em termos tributários, especialmente com a previsão da expressão "Limitações Ao Poder de Tributar".

Não que as limitações já não fossem previstas no constitucionalismo anterior. A luta pela organização tributária federal em um país de dimensões continentais como o Brasil sempre foi alvo de preocupação e curiosidade dos estudiosos da época. 
Prova de tal atenção pode ser observada no clássico estudo Rui Barbosa (Relatório do Ministro das Finanças, de 1889), já mencionado, assim como o estudo posterior de Carvalho Pinto no ano de $1941^{573}$ sobre as "Discriminações de Rendas Tributárias" (ainda que sob a peculiar óptica da Ciência das Finanças, e observando o teor da Constituição de 1937), além dos celebrados "comentários" ao direito constitucional positivo da época publicados por destacados juristas, sempre atentando também à matéria tributária prevista na Constituição.

Mas, de fato, o período disciplinar do Direito Tributário brasileiro, diferentemente de outros contextos, manifesta-se com atenção ao constitucionalismo tributário, assim como à codificação tributária. Essa atenção reflete-se na produção doutrinária da época, e nas influências teóricas (sobretudo da Teoria Geral do Direito e da Filosofia do Direito), que acabam permeando o desenvolvimento, dentro do período disciplinar, que também foi favorecido pelo contexto político-econômico da época.

Com o fim da Era Vargas, na República Populista (1945-1964), em face do considerável déficit público (em 1961 a receita do Governo Federal foi calculada em 317,5 Bilhões de cruzeiros, contra 420 bilhões de cruzeiros de déficit público) não se afastou a percepção, na década de sessenta, de que era necessária uma profunda reforma tributária $^{574}$, sobretudo para acompanhar as novas alterações estruturais da economia nacional, onde a industrialização avançava apoiada em investimentos estrangeiros e benefícios fiscais. Alterações essas que seriam provocadas por substancial alteração constitucional, logo após a Segunda Guerra Mundial, destinada a atender a essas novas demandas políticas e econômicas.

Portanto, pode-se dizer que, do ponto de vista teórico, ainda que estudos voltados aos aspectos constitucionais da matéria já fossem identificados anteriormente à década de quarenta do século XX, esses realmente amadureceram substancialmente a partir da década de cinquenta (impulsionada pelo melhor tratamento à temática do direito tributário positivo na Constituição de 1946) e, decididamente, através das reformas constitucionais trazidas na

\footnotetext{
${ }^{573}$ No entanto, a obra de Carvalho Pinto, como era de se esperar, na ausência de estudos jurídico-tributários, foi severamente influenciada pela bibliografia da Ciência das Finanças e Direito Financeiro da época (sobretudo autores franceses e italianos). Mas já apresentava sólidas referências à doutrina jurídica (no âmbito da Teoria Geral do Direito e da Hermenêutica, por exemplo). CARVALHO PINTO, Carlos Alberto A. Discriminação de Rendas. Prefeitura de São Paulo, 1941, p. 145 e seguintes.

${ }^{574}$ AMED, Fernando José; NEGREIROS, Plínio José Labriola de Campos. Op.cit., p. 267 e seguintes.
} 
década de sessenta, quando se destacou a Emenda Constitucional n.18/65, reorganizando o sistema tributário brasileiro, e fornecendo o suporte constitucional para a consolidação da codificação (1966). Essa Emenda Constitucional foi substituída, na mesma década, pela Emenda n.1/1967 e, dois anos mais tarde, pela Emenda n.1/1969.

A literatura tributária brasileira, portanto, desde seus primeiros passos disciplinares, volta-se com semelhante intensidade teórica à codificação e à constitucionalização do Direito Tributário (o que não significa afirmar, naturalmente, que a literatura já mergulhava no chamado "neoconstitucionalismo", ligado à democracia e aos direitos fundamentais, que só receberia maior atenção nas décadas posteriores), o que lhe permite reconhecer característica levemente diferenciada perante o processo de autonomia legislativa do Direito Tributário europeu.

\section{Constitucionalismo tributário brasileiro a partir da Constituição de 1946}

Conforme observado, o direito constitucional tributário sempre teve importância destacada entre os tributaristas nacionais, característica peculiar da produção jurídica brasileira.

Mas, de fato, foi a partir da Constituição de 1946 que realmente o interesse pelo direito tributário constitucional ganhou efetivo impulso, inclusive com a inédita inclusão de importantes princípios. Embora não apresentasse elevada diferenciação das cartas anteriores $^{575}$, trouxe alguns acréscimos essenciais para o posterior desenvolvimento do direito tributário positivo e, naturalmente, da própria literatura especializada, demonstrando uma organização mais clarificada quanto às demarcações de competências e às limitações ao poder de tributar. ${ }^{576}$

Também reaproximou os direitos e garantias individuais e a matéria tributária, relação que se mantinha perene, porém tímida nas Constituições anteriores, chegando a ser obliterada na Carta de 1937, mas encontrando novamente amparo expresso na Constituição de 1946.

\footnotetext{
${ }^{575}$ BALTHAZAR, Ubaldo Cesar. Op.cit., p. 125 e ss.

${ }^{576}$ DÓRIA, Antônio Roberto Sampaio. Discriminação de Competência Impositiva. Op.cit., p. 102.
} 
Mas, assevera-se que a estrutura da discriminação de rendas, apesar de menos centralizada que a Carta de 1937 , seguiu a tradição de suas antecessoras ${ }^{577}$, como é possível observar nos artigos 20, 21 e 22, que trouxeram algumas regras de organização discriminatória de rendas entre os entes tributantes, reforçando inclusive a autonomia municipal $^{578}$, ao passo que o artigo $31^{579}$ acrescentou maior organização das limitações constitucionais aplicadas aos entes tributantes, assim como os artigos 32 e 33, que dispuseram sobre a não diferenciação tributária entre Estados, Distrito Federal e Municípios, entre bens de qualquer natureza, em razão da procedência ${ }^{580}$.

Conforme já mencionado, a Constituição de 1946 promoveu reaproximação expressa entre as vedações tributárias e os direitos e garantias individuais, conforme é possível observar no Título IV, referente à Declaração de Direitos, onde, no Capítulo II (Dos Direitos e Garantias Individuais), o artigo 141 garantiu o direito à vida, à liberdade, à segurança individual e à propriedade (caput), bem como assegurou os princípios da igualdade $\left(\S 1^{\circ}\right)$, legalidade $\left(\S 2^{\circ}\right)$, segurança jurídica $\left(\S 3^{\circ}\right)$, garantia jurisdicional $\left(\S^{\circ}\right)$, entre outros, que já haviam sido esboçados nas constituições anteriores, mas também

\footnotetext{
577 É o que se observa na leitura do art. 15 que fixou competência privativa da União para decretar determinados impostos (I) e taxas (II). Aqui também estabeleceu no parágrafo $1^{\circ}$ dispositivo interessante, ao determinar a "isenção" (imunidade), no $\S 1^{\circ}$, do imposto de consumo sobre os artigos que a lei classificar como o mínimo indispensável à habitação, vestuário, alimentação e tratamento médico das pessoas de restrita capacidade econômica, emanando medida de caráter extrafiscal. Os demais parágrafos ( $\$ \S 3$ a 5) também se referem à matéria tributária, sobretudo à fixação da competência extraordinária para decretar impostos extraordinários pela União (§6), competindo também à União decretar impostos a serem cobrados nos territórios (art.16). Já o art. 17 estipulava a regra da uniformidade tributária federal em todos os Estados, repetindo dispositivo das constituições anteriores, e consagrando a necessidade de um sistema tributário coeso e harmônico entre os entes federados. Por outro lado, ainda no espírito federativo, o artigo 18 estabeleceu competência legislativa aos Estados, ao passo que o artigo 19 fixou a competência tributária estadual para impostos determinados, bem como dispositivos pertinentes.

${ }^{578} \mathrm{O}$ artigo 28 prescreveu expressamente a autonomia municipal, viabilizando que o município se estruturasse através da decretação e arrecadação dos tributos de sua competência e à aplicação das suas rendas. Além disso, complementando a autonomia municipal, o art.29 também fixou a competência municipal para determinados impostos. Por sua vez, o art. 30 estabeleceu inovação com a competência concorrente dos entes tributantes para cobrar: "I - contribuição de melhoria, quando se verificar valorização do imóvel, em consequência de obras públicas; II - taxas; III - quaisquer outras rendas que possam provir do exercício de suas atribuições e da utilização de seus bens e serviços".

$579 \mathrm{O}$ art.31 apresentou as seguintes vedações: "V - lançar impostos sobre: a) bens, rendas e serviços uns dos outros, sem prejuízo da tributação dos serviços públicos concedidos, observado o disposto no parágrafo único deste artigo; b) templos de qualquer culto; c) bens e serviços de Partidos Políticos, instituições de educação e de assistência social, desde que as suas rendas sejam aplicadas integralmente no País para os respectivos fins; d) papel destinado exclusivamente à impressão de jornais, periódicos e livros". E o parágrafo único também dispôs que os serviços públicos não gozariam de "isenção tributária", salvo disposição em contrário estabelecida pelo Poder competente ou quando a União a instituisse, e pelo Poder Competente ou estipulada pela União, em lei especial, relativamente aos próprios serviços, tendo em vista o interesse comum.

${ }^{580}$ Mas no capítulo referente ao Poder legislativo, na Seção IV, o art.65 atribuiu competência ao Congresso Nacional, para: "II - votar os tributos próprios da União e regular a arrecadação e a distribuição das suas rendas". Já a Seção VI trata das disposições orçamentárias.
} 
dispondo expressamente o seguinte: “\$34 - Nenhum tributo será exigido ou aumentado sem que a lei o estabeleça; nenhum será cobrado em cada exercício sem prévia autorização orçamentária, ressalvada, porém, a tarifa aduaneira e o imposto lançado por motivo de guerra (...)”, que, naturalmente, refere-se ao princípio da legalidade em matéria tributária, cumulado com o princípio da anualidade, em uma feição primária. Como é de costume, o art.144 estabeleceu a não exclusão de outros direitos e garantias que não estivessem previstos no artigo anterior ${ }^{581}$.

Grande destaque merece a previsão do art.202, que consagra expressamente, pela primeira vez no direito constitucional tributário brasileiro, o princípio da capacidade contributiva: "os tributos terão caráter pessoal, sempre que isso for possível, e serão graduados conforme a capacidade econômica do contribuinte." ${ }^{, 52}$

Nota-se que a Constituição de 1946 concedia maior importância à matéria tributária que suas antecessoras ${ }^{583}$ e incluía algumas novidades importantes na matéria (assim como a autorização da União para criar normas gerais sobre direito financeiro, como já observado no capítulo anterior).

Contudo, apesar desse fato, ainda não havia uma estrutura harmônica e coordenada da matéria na estrutura constitucional. Em outras palavras, a Constituição de 1946 conservou as limitações já previstas nas suas antecessoras e consagrou alguns princípios gerais, já universalmente aceitos, mas que não haviam sido expressamente previstos nas Constituições anteriores ${ }^{584}$, como é o caso do princípio da capacidade contributiva. ${ }^{585}{ }_{-}^{586}{ }_{-}$ 587

${ }^{581}$ No Título IV (Disposições Gerais), foram previstos diversos dispositivos em matéria tributária, dentre os
quais, o art. 198 (que trata do plano de defesa contra a seca no nordeste e sua distribuição da renda tributária
na região), além do art. 203, que repetiu dispositivo já expresso em constituição anterior, determinando que:
"nenhum imposto gravará diretamente os direitos de autor, nem a remuneração de professores e jornalistas".
582 Para Pontes de Miranda, por outro lado, esse artigo apenas envolve advertência, uma diretriz, mas não
uma regra peremptória intangível, até porque o uso da expressão "sempre que isso for possível”, bem como
do fato da própria norma suprema, ao distribuir a competência tributária, instituir impostos reais. E cita as
obras de François Questay, Bastable, Gastón Jéze, Paul Leroy, Beaulieu e Seligman (enfim, a doutrina
essencialmente econômica) e, principalmente, Adam Smith, de quem tomou emprestados os quatro princípios
que regem fundamentalmente a matéria tributária MIRANDA, Francisco Cavalcanti Pontes de. Comentários
à Constituição de 1946. Vol. I (arts 1-36). Rio de Janeiro: Livraria Boffoni, 1946, p $267-268$.
583 AMED, Fernando José; NEGREIROS, Plínio José Labriola de Campos. Op.cit., p. 268 e ss.
584 Conforme sintetizou Aliomar Baleeiro, o rol de princípios disciplinadores da tributação (as chamadas
"limitações ao poder de tributar") foi severamente majorado desde a Constituição de 1824 até a Constituição
de 1946, já que o convívio de três competências fiscais simultâneas sobre o mesmo campo econômico, graças
ao federalismo, “(...) explica, em grande parte, a presença dessas regras, algumas das quais, expressas no 
Sintetizando as conquistas daquela Carta Constitucional, o pacto federativo direcionado à discriminação de receitas tributárias deu um passo adiante na melhor distribuição de competências tributárias, ampliando a competência municipal ${ }^{588}$, aprimorando também as limitações ao poder de tributar, graças à Aliomar Baleeiro que, enquanto parlamentar, teve destacada atuação para a melhor organização da matéria tributária na Constituição de 1946.

Mas, como visto, a Constituição de 1946 abriu portas também para outro fenômeno, que atuando em patamar infraconstitucional, mas complementando o sistema tributário nacional, elevaria o patamar do direito tributário positivo brasileiro: a codificação.

\section{A autonomia legislativa através da codificação do direito tributário brasileiro a partir da década de cinquenta.}

\subsection{Os bastidores da codificação tributária no Brasil}

Em 1953, Rubens Gomes de Sousa, no Brasil, elaborou, de próprio punho, o Anteprojeto de Código Tributário Nacional, que foi encaminhado e aprovado enquanto Projeto de Código Tributário Nacional em $1954^{589}$, por influência de Aliomar Baleeiro,

Direito Constitucional brasileiro, encontram origem na construction de tribunais americanos". BALEEIRO, Aliomar. Limitações Constitucionais ao Poder de Tributar. Op.cit., p. 12.

${ }^{585}$ Idem, p. 12-15.

${ }^{586}$ Note-se que os constitucionalistas ao versarem sobre matéria tributária na Constituição de 1946 quase sempre recorriam aos princípios de Adam Smith, demonstrando a nítida influência das teorias econômicas da tributação. Mesmo entre renomados juristas, o conhecimento da matéria era claramente voltado à aspectos econômicos, pelo menos em primeiro contato. Essa tendência é vislumbrada nas seguintes obras: MAXIMILIANO, Carlos. Comentários à Constituição Brasileira. Quarta edição. Volume II. Rio de Janeiro: Livraria Freitas Bastos, 1948, p. 166 e seguintes; 265 e seguintes. MIRANDA, Francisco Cavalcanti Pontes de. Comentários à Constituição de 1946. Vol. II (arts 37-48), Rio de Janeiro: Livraria Boffoni, 1946 , p.365 e seguintes.

587 Sobre a discriminação de rendas prevista na Constituição de 1946, sugere-se a leitura da seguinte obra: FALCÃO, Amílcar de Araújo. Sistema Tributário Brasileiro. Discriminação de Rendas. Op.cit., p. 36-72

588 "Em 1946, houve um outro avanço dos Municípios. Ficou com a União a competência para decretar impostos sobre importação, consumo de mercadorias e - aqui parece - "produção, comércio, distribuição e consumo, bem assim importação e exportação de lubrificantes e de combustíveis líquidos ou gases de qualquer origem ou natureza" - e acrescentou "estendendo-se esse regime, no que for aplicável, aos minerais do País e à energia elétrica”. COSTA, Alcides Jorge. História da Tributação no Brasil. Op.cit., p. 79-80.

${ }^{589}$ O Projeto de Código Tributário Nacional de 1954 foi publicado por DINIZ, Souza. Códigos Tributários. Alemão. Mexicano. Brasileiro. $1^{\circ}$ edição. Tradução de Souza Diniz. São Paulo: Edições Financeiras S.A., 1965, p. 469 e seguintes. 
que, recebendo notícia de que Rubens havia escrito um Anteprojeto, pediu-o para apresentá-lo à votação do Congresso ${ }^{590}$.

O Anteprojeto torna-se Projeto de Código Tributário Nacional, sendo encaminhado à Câmara dos Deputados pela Mensagem n.373/54 do Poder Executivo (Diário do Congresso Nacional, seção I, de 7-9-54, página 6071), com clara perspectiva de constituirse na emanação das normas gerais tão almejadas em matéria tributária, e cuja abertura constitucional já havia sido fornecida pela Constituição de 1946, no art. 5º n. XV, alínea "b", ao atribuir competência da União para legislar sobre "normas gerais de direito financeiro".

Em agosto de 1953, ocorreu a designação do Ministro da Fazenda (Oswaldo Aranha), e de Comissão Especial ${ }^{591}$ formada por funcionários e técnicos da fazenda, para elaborar o Código Tributário Nacional a partir do Anteprojeto.

Os integrantes da Comissão Especial tiveram a missão de, a partir do Anteprojeto de Rubens Gomes de Sousa, do mesmo ano, e aproveitando a colaboração de entidades e pessoas que não pertenciam aos quadros da administração pública, elaborar um Projeto de Código Tributário Nacional, encaminhado em 1954 para ser debatido pelo Plenário do Congresso Nacional. ${ }^{592}{ }_{-}^{593}$

Recorda-se também que a revisão do Anteprojeto de Código Tributário Nacional teve como característica ser democrática no sentido de aceitar apontamentos oriundos dos diversos setores da sociedade, e absorvendo complementos produzidos por especialistas na época, como é o caso do notável Parecer elaborado pela Comissão Especial do Instituto Brasileiro de Direito Financeiro, composta por Tito Rezende (Presidente), Carlos da Rocha

\footnotetext{
${ }^{590}$ BARROS, José Eduardo Monteiro de. Notas sobre a História Externa do Código Tributário Nacional. In: Revista AFRESP de Tributação. Ano II. n.4. Outubro/Dezembro de 1998. São Paulo: Afresp, 1998, p. 3345.

${ }^{591}$ Essa Comissão Especial foi composta pelos seguintes nomes: Afonso Almiro Ribeiro da Costa, Pedro Teixeira Soares Júnior, Gerson Augusto da Silva e Romeu Gibson. A Presidência da Comissão Especial foi atribuída ao Ministro de Estado dos Negócios da Fazenda, simbolizando a conscientização e o esforço governamental para viabilizar a codificação de normas gerais de direito tributário, em face das relevantes razões que motivavam a sua elaboração. Trabalhos da Comissão Especial do Código Tributário Nacional. Ministério da Fazenda, Rio de Janeiro, 1954, p.30 e seguintes.

${ }^{592}$ SOUSA, Rubens Gomes de. Relatório. (apresentado pelo prof. Rubens Gomes de Sousa, relator geral, e aprovado pela Comissão Especial nomeada pelo Ministro da Fazenda para elaborar o Projeto de Código Tributário Nacional). In: Trabalhos da Comissão Especial do Código Tributário Nacional. Ministério da Fazenda, Rio de Janeiro, 1954, p.81-86.

${ }^{593}$ Idem, p. 89.
} 
Guimarães, Eduardo Lopes Rodrigues, Jayme Péricles e Gilberto Ulhôa Canto, sobre o Anteprojeto de Código Tributário Nacional.

A Comissão Especial recebeu os apontamentos desses especialistas e deliberou, uma a uma, todas as sugestões, o que resultou em importantes alterações já na composição do Projeto de Código Tributário Nacional.

Esse esforço, conforme já esboçado por Oswaldo Aranha, no que tange à conceituação dos impostos específicos, seguiu à risca a regra geral de estruturá-los, definilos e diferenciá-los exclusivamente a partir de seus respectivos fatos geradores, com eventual e restrita menção a outros elementos ("ùnicamente quando essenciais ao conceito ou necessários para impedir sua descaracterização"), como a base de cálculo e a pessoa do contribuinte ${ }^{594}$.

O Projeto Código Tributário Brasileiro (1954) ${ }^{595}$ foi severamente modificado no que tange ao conteúdo já delineado no Anteprojeto de Código Tributário Brasileiro, de 1953, acrescido das sugestões e alterações promovidas pela Comissão Especial, bem como pelos debates do Congresso, e a recepção de sugestões enviadas por diversos especialistas na matéria. ${ }^{596}{ }^{597}$ As alterações ao Anteprojeto foram feitas em duas fases, que levou aproximadamente 8 meses de discussões ${ }^{598}$.

\subsection{Antecedentes nacionais e as influências do Anteprojeto e do Projeto de} Código Tributário Nacional.

\footnotetext{
${ }^{594}$ SOUSA, Rubens Gomes de. Relatório. (apresentado pelo prof. Rubens Gomes de Sousa, relator geral, e aprovado pela Comissão Especial nomeada pelo Ministro da Fazenda para elaborar o Projeto de Código Tributário Nacional). In: Trabalhos da Comissão Especial do Código Tributário Nacional. Ministério da Fazenda. Op.cit., p.115.

595 Projeto de Código Tributário Nacional. (Projeto de lei n.4834, de 1954, publicado no Diário do Congresso de 7-9-1954). In: Trabalhos da Comissão Especial do Código Tributário Nacional. Ministério da Fazenda. Op.cit., p.17-79

596 Idem.

${ }^{597}$ Ibidem.

598 ARANHA, Oswaldo. Exposição de Motivos do Ministro da Fazenda, Dr. Oswaldo Aranha, encaminhado ao Sr. Presidente da República, o Projeto de Código Tributário Nacional (Exposição n.1250, de 21-7-1954. Projeto de Código Tributário Nacional). In: Trabalhos da Comissão Especial do Código Tributário Nacional. Ministério da Fazenda, Rio de Janeiro, 1954, p.1-17. p. 14-15.
} 
Na Exposição de motivos do então Ministro da Fazenda Oswaldo Aranha, ${ }^{599}$, a influência do Anteprojeto e do Projeto de Código Tributário Brasileiro remete-se indiscutivelmente ao Código Tributário Alemão, em seu texto original de 1919 (e, portanto, anterior às alterações promovidas pela influência de ideologias políticas). Em semelhante patamar Oswaldo Aranha colocou também o Código Fiscal Mexicano, de 1938, e o Código Fiscal da Província de Buenos Aires, de 1948, de autoria de Dino $\operatorname{Jarach}^{600}$.

Outros ordenamentos (ainda que com caráter apenas parcial de códigos), mas que consolidaram a legislação vigente, contendo por vezes princípios gerais e, em outros casos, restrições a aspectos específicos das leis tributárias, foram lembrados: a) o Código Geral de Impostos da França, de 1949; b) o Código de Rendas Internas dos Estados Unidos da América; c) e a lei federal argentina de 1949 sobre normas gerais de arrecadação dos impostos internos.

Naturalmente, o Anteprojeto de Código Fiscal da Argentina, de 1942, embora não vertido em lei, pelo alto valor doutrinário inserido por Giuliani Fonrouge, também serviu de inspiração às modificações do Anteprojeto, além do projeto de codificação do direito fiscal federal suíço, de autoria de Ernst Blumenstein, que permaneceu inédito com o falecimento deste autor $^{601}$, dos trabalhos da Comissão encarregada de codificar e consolidar a legislação sobre o imposto de renda na Grã-Bretanha, publicados em 1936 e em 1951, bem como dois trabalhos brasileiros: a) Anteprojeto de Código Tributário e Fiscal para os Municípios, elaborado pela Diretoria das Prefeituras Municipais do Estado do Rio Grande do Sul e; b) o Anteprojeto de Código Tributário do mesmo Estado, de autoria de Gervásio da Luz (Porto Alegre, 1952). ${ }^{602}$

Conforme lembra Rubens Gomes de Sousa, foi também expressiva a influência da doutrina italiana sobre o imposto de renda, a exemplo de Quarta, além do notável estudo

\footnotetext{
${ }^{599}$ Idem, p.1-17.

${ }^{600}$ SOUSA, Rubens Gomes de. Relatório - apresentado pelo prof. Rubens Gomes de Sousa, relator geral, e aprovado pela Comissão Especial nomeada pelo Ministro da Fazenda para elaborar o Projeto de Código Tributário Nacional. In: Trabalhos da Comissão Especial do Código Tributário Nacional. Ministério da Fazenda. Op.cit., p.99.

${ }^{601}$ SOUSA, Rubens Gomes de. Relatório (apresentado pelo prof. Rubens Gomes de Sousa, relator geral, e aprovado pela Comissão Especial nomeada pelo Ministro da Fazenda para elaborar o Projeto de Código Tributário Nacional). In: Trabalhos da Comissão Especial do Código Tributário Nacional. Ministério da Fazenda. Op.cit., p.99.

${ }^{602}$ Idem.
} 
elaborado pelo próprio Rubens Gomes de Sousa em coautoria com Tullio Ascarelli e Pereira de Almeida ${ }^{603}$, sobre o imposto sobre lucros extraordinários e sobre o Imposto de Renda $^{604}{ }^{605}$ nessa revisão do Anteprojeto.

Interessante mencionar que, embora o esforço codificador tivesse nascimento a partir do hercúleo trabalho de Rubens Gomes de Sousa, a inspiração codificadora já alçava seus primeiros passos na doutrina brasileira ${ }^{606}$.

Nessa época os trabalhos favoráveis à codificação tributária já apareciam nas revistas especializadas. É o exemplo do trabalho de Paulo Barbosa de Campos Filho (“Codificação do Direito Tributário Brasileiro, Revista de Direito Administrativo, n.3/44, Revista Forense, 108/5), que já antevia a necessidade de um Código que conseguisse se harmonizar enquanto código unitário e a diversidade de códigos locais, que seria inconciliável com a necessidade de estruturação de princípios comuns. Para esse autor, segundo relata Rubens Gomes de Sousa, "Tratar-se-ia, assim, de uma lei orgânica fiscal, aplicável por igual aos três níveis de governo, que continuaria a legislar sobre os seus próprios tributos, cada qual, porém, com estrita observância daqueles princípios comuns por eles traçados, que imprimiriam ao conjunto a desejada uniformidade"607.

Com o feliz advento da alínea "b" do inciso XV do art. 5ª da Constituição de 1946, atribuiu-se à União a competência para legislar normas gerais de direito financeiro, restando ali, segundo reconhece o próprio Rubens Gomes de Sousa, a gênese da futura codificação do direito financeiro e tributário ${ }^{608}$, gerando o sentimento da necessidade de

\footnotetext{
${ }^{603}$ Ibidem, p.81.

${ }^{604}$ Ibidem, p.192-193.

${ }^{605}$ Ibidem.

${ }^{606}$ Sobre o histórico da codificação no Brasil (e seus incentivadores) recomenda-se a leitura do Relatório de Rubens Gomes de Sousa, que mencionou entre seus antecessores, Aristides Milton, Barbalho, Rui Barbosa, Amaro Cavalcanti, ao projeto de codificação financeira elaborado em 1902 por Alfredo Varela, seguindo-se, cronologicamente, ao Código de Contabilidade Pública de Dídimo da Veiga, decretado em 1922, ainda que esses se limitassem a aspectos técnicos e administrativos da atividade financeira estatal. Os problemas gerados de natureza tributária foram levantados pela Segunda Conferência de Técnicos em Contabilidade Pública e Assuntos Fazendários, em 1940, que se harmonizou no sentido da necessidade da criação de um conjunto sistemático de normas gerais, (segundo Rubens Gomes Sousa, a primeira vez em que essa expressão foi utilizada em documento oficial - Anais, p.485). SOUSA, Rubens Gomes de. Relatório (apresentado pelo prof. Rubens Gomes de Sousa, relator geral, e aprovado pela Comissão Especial nomeada pelo Ministro da Fazenda para elaborar o Projeto de Código Tributário Nacional). In: Trabalhos da Comissão Especial do Código Tributário Nacional. Ministério da Fazenda. Op.cit., p. 82-85.

${ }^{607}$ Ibidem, p.192-193.

${ }^{608}$ Ibidem.
} 
uma futura organização da legislação tributária, ao nível de um corpo de regras e princípios nacionais $^{609}$.

\subsection{O Anteprojeto, o Projeto e a versão final do Código Tributário Nacional: a consolidação da codificação tributária no Brasil entre as décadas de cinquenta e sessenta.}

O Anteprojeto elaborado por Rubens Gomes de Sousa apresentava lista de artigos muito mais extensa que o Projeto que surgiu de sua revisão ${ }^{610}$. Possuindo 454 artigos (mais que o dobro da versão final do Código Tributário Nacional), expressava nítidas influências das experiências codificadoras estrangeiras, lembrando que a estrutura do Anteprojeto demonstrava bastante fidelidade à estrutura do Código Tributário Alemão (1919) ${ }^{611}$.

A preocupação com a previsão legislativa das etapas da relação tributária aparece já clarificada no Anteprojeto, assim como de seus conceitos gerais (Livro I), a exemplo do conceito de tributo e suas espécies ${ }^{612}$, o tratamento das fontes legislativas (Livro II), da interpretação e integração do direito tributário (Título III) ${ }^{613}$ e, naturalmente, dos elementos componentes da obrigação tributária (incluindo o fato gerador), seus sujeitos, o

\footnotetext{
${ }^{609}$ Sentimento esse que já se fazia sentir antes mesmo de 1946, como revela Rubens Gomes de Sousa: "Os apelos ao Governo para sua efetivação, já implícitos, antes mesmo de 1946, nas conclusões da Primeira Conferência Nacional das Classes Produtoras (Therezópolis 1945), multiplicam-se depois da inclusão do seu fundamento constitucional; merecem, por suas origens, especial menção o apresentado pela Segunda Conferência Nacional das Classes Produtoras (Araxá, 1949) e os incluídos nas reivindicações formuladas pelo Primeiro e pelo Segundo Congresso Nacionais dos Municípios Brasileiros (Petrópolis 1950 e São Vicente, 1952), sem esquecer os trabalhos da Associação Brasileira de Municípios (Afonso Almiro, "A Constituição e o Código Tributário Nacional”, Revista do serviço público, n.3 de 1946)”. Ibidem.

${ }^{610} \mathrm{O}$ texto integral do Anteprojeto analisado neste estudo pode ser consultado em: SOUSA, Rubens Gomes de. Anteprojeto de Código Tributário Nacional. 1953. In: Trabalhos da Comissão Especial do Código Tributário Nacional. Op.cit., p.265-405.

611 Assim, o artigo $1^{\mathrm{a}}$ incluiu a disposição preliminar que explicava o fundamento constitucional do Anteprojeto (art.5, VI, b, CF/46). Não é por acaso que o primeiro Livro (Livro I) dispôs no Título I sobre a competência tributária (at. $2^{\mathrm{a}}$ ), a indelegabilidade e suas exceções (art. $3^{\mathrm{a}}$ ), ao passo que o Título II tratou das limitações da competência tributária (a exemplo dos princípios e das imunidades, previstos nos arts. $4^{\circ}$ a 15), e o Título III, previu as "participações na arrecadação" (art.16 a 22), apresentando as discriminações de rendas tributárias entre os entes tributantes.

${ }^{612}$ Já os livros seguintes buscaram seguir o delineamento dos conceitos jurídicos tributários fundamentais, a exemplo do conceito e classificação de tributos (e suas espécies, como é o caso do Livro II, nos seus títulos I (disposições gerais) e II, ao tratar dos impostos e outras espécies tributárias).

${ }^{613} \mathrm{Com}$ semelhante atenção ao exemplo exterior, a preocupação com os métodos de interpretação e integração das leis tributárias acabou objeto do Título III, que trouxe os dispositivos atinentes à interpretação e integração da legislação tributária (art.128 a 138), e naturalmente, o art.129 acabou remetido ao chamado "abuso de formas" e seu combate através da interpretação econômica, ainda que não o previsse expressamente, ideia reforçada pelo parágrafo único do art.131. Esse tema será retomado no Capítulo 3.
} 
lançamento e seus efeitos, e as peculiaridades decorrentes da constituição do crédito tributário, até sua extinção (Livros IV e V).

Aliás, até aqui o Anteprojeto de Rubens Gomes de Sousa guardou muitas semelhanças com a versão final do Projeto que seria convertida em Código Tributário Nacional $^{614}$. A estrutura segue praticamente idêntica entre o Anteprojeto e Projeto, apenas variando na numeração dos dispositivos e na redação (mais sintética e simplificada), pois, como alertou Ives Gandra Martins, sobre o Anteprojeto: "A linguagem, todavia, foi revisada, visto que a genialidade de Rubens levava-o, muitas vezes, a um discurso legislativo mais prolixo e menos técnico, na busca de esclarecimentos para o maior número possível de problema que a realidade pudesse suscitar". ${ }^{615}$

As grandes modificações trazidas ao Anteprojeto pelos debates da Comissão (e, sobretudo, a retirada de dispositivos da versão final do Projeto) ocorreram com os artigos referentes ao Livro VII (que trazia verdadeira codificação do direito penal tributário), assim como o Livro VIII (que, por sua vez, trouxe, à semelhança do anterior, a proposta de codificação do direito tributário administrativo) e o Livro IX, que simbolizava desejo antigo de Rubens Gomes de Sousa, ao ver criada no Brasil autêntica justiça tributária (embora não tenha incluído proposta de criação de Tribunal Judicial Fiscal nesses dispositivos), inclusive prevendo exaustivamente o rito do processo de execução fiscal.

É importante lembrar que Rubens Gomes de Sousa chegou a propor, ao final de seu Anteprojeto, "Texto Alternativo" ao Livro VIII e ao Livro IX, visando, provavelmente, aumentar as chances da aprovação de uma das alternativas.

$\mathrm{Na}$ época nenhuma delas foi incorporada ao Projeto, que não manteve os citados Livros sobre "Direito Tributário Administrativo" (incluindo-se "Processo Administrativo Tributário"), "Direito Tributário Penal", e "Direito Tributário Processual Judicial".

Abstraindo tais peculiaridades, a estrutura do Projeto de Código Tributário Nacional, de $1954,{ }^{616}$ apresentou semelhanças (relativas) ao Anteprojeto, mantendo a

\footnotetext{
${ }^{614}$ BARROS, José Eduardo Monteiro de. Notas sobre a História Externa do Código Tributário Nacional. Op.cit., p. 33-45.

${ }^{615}$ MARTINS, Ives Gandra da Silva. Sistema Tributário na Constituição de 1988. São Paulo: Saraiva, 1990, p. 25-29.

${ }^{616}$ DINIZ, Souza. Códigos Tributários. Alemão. Mexicano. Brasileiro. $1^{\circ}$ edição. Tradução de Souza Diniz. São Paulo: Edições Financeiras S.A., 1965, p. 469-530.
} 
posição sobre os conceitos de tributo e espécies tributárias, sobre a discriminação de rendas (competências, princípios e imunidades) ${ }^{617}$, assim como a previsão das fontes do direito tributário (Livro III), respectivamente, assim como regras de interpretação e integração da Lei Tributária (Título V), ${ }^{618}$ seguindo caminho semelhante ao trilhado no Anteprojeto, ao prever, no Livro IV, as regras relativas à obrigação tributária, e, no Livro V, os dispositivos referentes ao crédito tributário.

Note-se que o Livro VI restringiu severamente a previsão original de Rubens Gomes de Sousa, pois referidos especificamente ao direito administrativo fiscal, dispondo tão somente sobre a administração tributária ${ }^{619}$.

Restrição que não impediu que Aliomar Baleeiro, em Parecer sobre o Projeto do CTN acima descrito, apontasse o seguinte: "Pela excelência da notável obra o Prof. Rubens Gomes de Sousa, reputamos valioso e inestimável serviço ao progresso do direito positivo brasileiro e a aprovação do Projeto de Código Tributário Nacional. Ele honrará a cultura jurídica do país e o dotará de um Código Fiscal que não teme confronto com qualquer dos que vigoram nas mais civilizadas nações. Em conclusão, somos do parecer que: $1^{\mathrm{a}} \mathrm{o}$ projeto é constitucional; 2. Observa os melhores princípios e estilos de técnica legislativa; 3. Deve ser recomendado à aprovação do plenário com as emendas anexas, que submetemos à consideração da douta Comissão de Justiça"620.

De qualquer forma, frente aos elogios de Baleeiro, entre o Anteprojeto e o Projeto pode-se perceber nítida tendência a afastar a necessidade de uma codificação exaustiva sobre a matéria tributária, ao contrário do que acontecera no Código Tributário Alemão.

\footnotetext{
${ }^{617}$ Dessa forma, à semelhança do Anteprojeto, o Livro I manteve-se tratado das disposições relativas ao direito constitucional tributário (competências, princípios, imunidades e distribuição de rendas tributárias), ao passo que o Livro II tratou dos tributos e demais espécies tributárias. No Título I (disposições gerais) tem-se o conceito de tributo: "art.17 - tributo é toda prestação pecuniária instituída por lei com caráter compulsório pela União, pelos Estados, pelo Distrito Federal ou pelos Municípios, no uso de competência constitucional inerente à sua condição de pessoa jurídica de direito público”. Note-se já maior proximidade conceitual com a versão final atualmente em vigor no art. $3^{\mathrm{a}}$ do CTN.

${ }^{618}$ Além das regras de interpretação (e integração) da lei tributária (arts.73-78), polêmico dispositivo previsto através do artigo 74, que representava expressamente a influência da interpretação econômica e o combate ao abuso de formas, que tantas discussões trouxeram ao direito tributário europeu. Esse dispositivo será analisado no Capítulo 3.

${ }^{619}$ Nesse aspecto, o título I apresenta os procedimentos de fiscalização (arts.175-183), ao passo que o Título II dispõe sobre o processo administrativo (arts.184-190). Por fim, originalmente, no Anteprojeto, os dispositivos relaivos à dívida ativa e às certidões mantinham-se previstas no Livro correspondente ao crédito tributário (Livro V). No Projeto, por outro lado, tais dispositivos acabaram incluídos no Livro da administração tributária.

${ }^{620}$ BALEEIRO, Aliomar. Parecer sobre o Projeto do CTN. Op.cit., p. 41.
} 
Porém, após as sucessivas revisões e edições ao texto do Anteprojeto, e subsequentemente ao texto do Projeto, a partir de 1954, este permaneceu suspenso durante quase doze anos, quando, com o regime militar, e impulsionado também pela Emenda Constitucional n.18 de 1965, o Projeto acaba aprovado no Congresso, convertendo-se na Lei n.5172 de 1966, mais conhecida como Código Tributário Nacional, buscando estabelecer as normas gerais de direito tributário aplicáveis à União, Estados, Distrito Federal e Municípios $\left(\operatorname{art} .1^{\circ}\right)$.

Observa-se que a estrutura do Código Tributário Nacional difere substancialmente da estrutura original do Anteprojeto de Código Tributário Brasileiro (1953), na forma como foi originalmente apresentado, este mais prolixo e guardando maior identidade com sua influência germânica (cuja estrutura era adotada com maior fidelidade).

Ao invés do Anteprojeto e do Projeto, o CTN previu em seus primeiros artigos as disposições gerais do Sistema Tributário Nacional (art. $2^{\mathrm{a}}$ a $5^{\mathrm{a}}$ ), trazendo, no art. $3^{\mathrm{a}}$, o conceito de tributo $^{621}$, definindo a natureza jurídica do mesmo (art. $\left.4^{\mathrm{a}}\right)^{622}$, assim como suas espécies (art. $\left.5^{\mathrm{a} 623}\right)$, para só então trazer, no título II, os dispositivos atinentes ao direito constitucional tributário, a exemplo da competência tributária, dos princípios e imunidades ${ }^{624}$. Já o Livro Segundo dispõe sobre as "normas gerais de direito tributário", contendo importantes dispositivos sobre fontes do direito tributário ${ }^{625}$, normas de interpretação e integração ${ }^{626}$, e dispositivos relativos à relação jurídica tributária e seus componentes, especialmente relativas (Título II) à obrigação tributária, e seus desdobramentos, incluindo-se dispositivos atinentes à criação, exigibilidade, suspensão e

621 “Art. $3^{\circ}$ Tributo é toda prestação pecuniária compulsória, em moeda ou cujo valor nela se possa exprimir, que não constitua sanção de ato ilícito, instituída em lei e cobrada mediante atividade administrativa plenamente vinculada".

622 "Art. $4^{\circ}$ A natureza jurídica específica do tributo é determinada pelo fato gerador da respectiva obrigação, sendo irrelevantes para qualificá-la: I - a denominação e demais características formais adotadas pela lei;II - a destinação legal do produto da sua arrecadação"

${ }^{623}$ Mantém-se, portanto, a estrutura original do artigo 21 do Projeto: “Art. $5^{\circ}$ Os tributos são impostos, taxas e contribuições de melhoria".

${ }^{624}$ Note-se que, dissociado das disposições gerais (diferente do que ocorria no Anteprojeto e Projeto), as espécies tributárias acabaram previstas nos títulos III (impostos), IV(taxas) e V(contribuições de melhoria), incluindo-se apenas no Título VI as regras de distribuição de receitas tributárias entre entes tributantes (diferente do que ocorria no Anteprojeto e no Projeto), nos artigos 83 a 95, encerrando o primeiro livro do CTN.

${ }^{625}$ No Título I (legislação tributária) encontra-se o Capítulo I, onde estão previstas disposições gerais sobre o uso da expressão "legislação tributária" (art.96), e as fontes identificadas como tais (Seção II - Leis, Tratados e Convenções Internacionais e Decretos), nos arts. 97 a 99, bem como normas complementares (art.100).

${ }^{626}$ No capítulo II - tem-se as regras atinentes à vigência e à aplicação da legislação tributária (arts.101 a 106), e sobre a interpretação e integração das leis tributárias (art.107-112), de essencial importância para o labor do intérprete. 
extinção do crédito tributário ${ }^{627}$, além de disposições sobre a administração tributária, fiscalização, dívida ativa e disposições transitórias, totalizando $218 \operatorname{artigos}^{628}$, menos que a metade do número original de artigos previstos no Anteprojeto.

Por questão de política legislativa, entendeu-se ser mais adequado levar a expressão "normas gerais" a sério, quando se dispôs de um código de normas gerais (mas não exaustivo) destinado a organizar e harmonizar a legislação tributária dos entes tributantes da federação brasileira ${ }^{629}$.

Para Ives Gandra Martins, dentre os muitos méritos inseridos no Código, este permitiu que os “(...) princípios da estrita legalidade, tipicidade fechada e reserva absoluta da lei formal, fossem consagrados pela doutrina e jurisprudência, transformando-se muito mais em um estatuto do contribuinte que em manual de exigência impositiva"630.

Naturalmente, o Código Tributário Nacional sofreu sucessivas modificações e revisões, frutos da necessidade de adaptação legislativa a diferentes contextos históricos ${ }^{631}$.

De qualquer forma, praticamente a integralidade dos dispositivos do CTN ainda se mantém em vigor, demonstrando sua qualidade inequívoca para o estudo do Direito Tributário brasileiro.

Por outro lado, a codificação tributária brasileira se consolidou não apenas por interesses acadêmicos, mas sobretudo, por anseios políticos voltados à complementar o "sistema tributário nacional" previsto na Emenda Constitucional n. 18/65, buscando adaptar o sistema tributário às necessidades econômicas e sociais da época. Tal realidade constitucional, que evidentemente suporta a codificação, em sua etapa final, dá a

\footnotetext{
${ }^{627}$ O Título II do Livro II apresenta as regras relativas à obrigação tributária, ou, em melhores termos, sobre a relação jurídica tributária obrigacional e seus desdobramentos, ao passo que o título III prevê as regras acerca do "crédito tributário", que decorre da obrigação principal e com a mesma natureza desta (art.139), com previsão do procedimento de constituição do crédito (lançamento), da exigibilidade deste e formas de suspensão, exclusão e extinção, dispondo ainda, sobre as garantias e privilégios (incluindo preferência) atribuídos ao crédito tributário.

${ }^{628}$ Por fim, o Código Tributário Nacional trouxe disposições gerais (no Título IV), trazendo regras aplicáveis ao funcionamento da Administração Tributária e sua atividade de fiscalização, constituição da dívida ativa, bem como sobre as certidões negativas e positivas (arts.194-208), para, finalmente, trazer as disposições finais e transitórias, nos arts. 209 a 218 do CTN.

629 “(...) É, portanto, o Código elemento de estabilização do Direito Tributário, posto que serve de "colchão legislativo" entre a Constituição e a legislação ordinária". MARTINS, Ives Gandra. Sistema Tributário Brasileiro na Constituição de 1988. Op.cit., p. 28.

${ }^{630}$ Idem, p. 34-35.

631 BALEEIRO, Aliomar. Direto Tributário Brasileiro. Op.cit., p. 57 e seguintes.
} 
característica essencial do direito tributário positivo: codificado a partir da Constituição. Contudo, os mesmos interesses políticos que levaram à rápida aprovação do Código (após doze longos anos de espera no Congresso) também proporcionaram importantes (e rápidas) reestruturações no direito constitucional tributário brasileiro, sobretudo na década de sessenta. Considerar esse período histórico não democrático, portanto, é elemento fundamental para a compreensão do perfil disciplinar do direito tributário contemporâneo. É o que se verá a seguir.

\section{As mutações constitucionais brasileiras da década de sessenta e a constitucionalização do "sistema tributário nacional"}

É verdade que a Constituição de 1946 trouxe importantes acréscimos à organização constitucional tributária, mas realmente não apresentava, no aspecto organizacional, efetiva reformulação do tratamento constitucional à matéria tributária. O reconhecimento dessa situação ficou evidenciado através do novo regime ditatorial trazido pelo Golpe de 1964, que imediatamente procedeu à reforma do sistema tributário (1965) previsto na Constituição $^{632}$, com expressiva busca pelo aumento de receitas tributárias e melhor adaptação do sistema tributário vigente às necessidades econômicas do país ${ }^{633}$, tencionando elevar o afluxo de investimentos estruturais no Brasil, sobretudo na esperança de alcançar o "Milagre Brasileiro". 634

Contudo, em outro passo, conforme refletiu na época o Ministro Octavio G. Bulhões, na Exposição de Motivos enviada ao Presidente Castelo Branco sobre a Reforma de 1965, “(...) a multiplicação e a acumulação de incidências tributárias, a despeito da separação formal dos impostos, dificultam e oneram a produção. Os empecilhos ao progresso estão se tornando alarmantes" $" 635$.

\footnotetext{
632 Sobre a distribuição dos tributos frente à estrutura federativa até a década de sessenta, consulte-se: AMED, Fernando José; NEGREIROS, Plínio José Labriola de Campos. Op.cit., p. 273-275.

${ }^{633}$ Sobre as conjunturas históricas da formação do sistema tributário, também conferir: ZILVETI, Fernando Aurelio. A Evolução da Teoria da Incidência - Análise Histórica das Estruturas Socioeconômicas na Formação do Sistema Tributário. Op.cit., s/np (cap. II, item 9).

${ }^{634}$ AMED, Fernando José; NEGREIROS, Plínio José Labriola de Campos. Op.cit., p. 276 e seguintes.

635 BULHÕES, Otávio G. Exposição de Motivos n.910 ao Presidente Castelo Branco. In: BALEEIRO, Aliomar. Direito Tributário Brasileiro. Op.cit., p. 43-53.
} 
Existia necessidade de adaptar a realidade tributária brasileira aos anseios econômicos daquele "novo contexto" $" 636$ e, com essa perspectiva ${ }^{637}$, iniciaram-se os primeiros estudos para a reforma tributária brasileira, que foi estruturada especialmente a partir de trabalhos promovidos pelo Ministério da Fazenda, através de comissão formada por especialistas no assunto, como Rubens Gomes de Sousa, Gerson Augusto da Silva, Luiz Simões Lopes, Sebastião Santana e Silva, Gilberto Ulhôa Canto e Mario Henrique Simonsen ${ }^{638}$, que formularam dois importantes relatórios destinados à revisão dos projetos de reforma constitucional tributária (1965).

Não é por acaso também a criação da Secretaria da Receita Federal com a perspectiva de aprimorar o controle da fiscalização tributária (Decreto 63.659/1968), substituindo a Direção-Geral da Fazenda Nacional ${ }^{639}$.

Dentre as críticas fundamentais apresentadas pelo Primeiro Relatório da Comissão, em 18 de junho de 1965, a mais elevada centrava-se na conviç̧ão de que a causa principal dos defeitos do sistema tributário até então vigente (Constituição de 1946), “(...) por demais conhecidos para serem aqui lembrados pormenorizadamente, de que padece a atual discriminação de rendas é o fato de o assunto ser tratado como problema jurídico e não econômico" "640_641.

\footnotetext{
${ }^{636}$ A estratégia para reestruturação tributária que culminou na Emenda Constitucional número 18 de 1965 do Brasil estruturou-se em três etapas (a primeira, com a tomada de medidas de emergência, a segunda, com a revisão dos impostos federais e a terceira, onde se procedeu a reforma constitucional propriamente dita), e pode ser observada com mais detalhes nas obras: MORAES, Bernardo Ribeiro de. Compêndio de Legislação Tributária. Volume 1. Op.cit., p. 91-95. AMED, Fernando José; NEGREIROS, Plínio José Labriola de Campos. Op.cit., p. 280-283.

${ }^{637}$ BALTHAZAR, Ubaldo Cesar. Op.cit., p. 132 e ss.

${ }^{638}$ O Segundo Relatório foi assinado pelos seguintes especialistas: Rubens Gomes de Sousa, Gerson Augusto da Silva, Luiz Simões Lopes, Sebastião Santana e Silva, Gilberto Ulhôa Canto e Mario Henrique Simonsen, muito embora outros fizessem parte da Comissão, como Antonio Roberto Sampaio Dória, que não teve tempo hábil para analisar o Projeto, ficando de fora do Segundo Relatório. Segundo Relatório da Comissão. In: Reforma Tributária Nacional. Rio de Janeiro: FGV, 1965, p. 85-86.

${ }^{639}$ AMED, Fernando José; NEGREIROS, Plínio José Labriola de Campos. Op.cit., p. 284 e ss.

${ }^{640}$ Primeiro Relatório da Comissão do Ministério da Fazenda. In: Reforma Tributária Nacional. Rio de Janeiro: FGV, 1965, p. 29.

641 "Por outro lado, a Constituição, em seus artigos 15, 19 e 29, assenta a partilha tributária na conferência à União, aos Estados e aos Municípios, de impostos privativos, colocados em três campos supostamente estanques e insuscetíveis de confusão. Entretanto, imperativos econômicos bem conhecidos, cuja atuação é possibilitada por distinções jurídicas igualmente notórias, solaparam aquela premissa básica do sistema, e a interpenetração dos campos privativos é hoje um fato que dispensa demonstração. Para esse resultado concorreu decididamente o critério formal e nominalista da discriminação de rendas, ensejando a deformação conceitual, tanto dos impostos previstos, como dos que legitimamente caberiam no campo residual, imperfeitamente regulado no art.21, como ainda das taxas, mencionadas de forma necessariamente genérica
} 
Assim, buscando superar as dificuldades identificadas nos regimes constitucionais tributários anteriores, o Primeiro Relatório da Comissão do Ministério da Fazenda partiu das seguintes premissas: a) “(...) a consolidação dos impostos de idênticas naturezas em figuras unitárias, definidas por via de referência às suas bases econômicas, antes que a uma das modalidades jurídicas que pudessem revestir; b) “(...) a concepção do sistema tributário como integrado no plano econômico e jurídico nacional, em substituição ao critério atual e histórico, de origem essencialmente política, da coexistência de três sistemas tributários autônomos, federal, estadual e municipal"642.

Dessa forma, como os próprios estudiosos afirmaram, no Segundo Relatório buscou-se “(...) organizar em sistema o direito tributário constitucional, e não meramente reformular a discriminação de rendas (...)" ${ }^{643}$

Esses estudiosos revisaram o anteprojeto que viria a ser introduzido, na década de sessenta, pela Emenda Constitucional no 18 de 1965, que reformou o "Sistema Tributário Nacional", concedendo atenção inédita ao termo.

É justamente a partir desse período que a literatura especializada passa a usar com mais intensidade a expressão "sistema tributário nacional", ou mesmo "sistema constitucional tributário", já que a partir da Emenda 18 de 1965, o direito tributário constitucional recebe capítulo próprio, consolidado em 27 artigos.

Esses artigos consolidaram as limitações ao poder de tributar, isto é, as competências tributárias, as imunidades e os princípios constitucionais tributários aplicáveis aos impostos, taxas e contribuições (art. $1^{\mathrm{a}}$ ), estabelecendo expressamente as

no art.30”. Primeiro Relatório da Comissão do Ministério da Fazenda. In: Reforma Tributária Nacional. Rio de Janeiro: FGV, 1965, p. 29-30.

${ }^{642}$ Naturalmente, essa premissa também se relacionava com o ideal de unidade nacional perseguido no Projeto, buscando elevar a unidade econômica, política e jurídica do país, contra eventuais medidas discriminatórias e entraves fiscais às atividades interestaduais e intermunicipais, buscando impedir também "pontos de atrito" entre diferentes níveis de governo, exemplificando o imposto sobre a circulação mercantil, em substituição ao antigo imposto sobre vendas e consignações, “(...) que sabidamente funcionam hoje, principalmente o segundo, como armas de uma verdadeira guerra tributária entre Estados produtores e Estados consumidores". Além disso, o Relatório também foi favorável à priorização da realidade econômica, estabelecendo quatro campos econômicos distintos de tributação: a)impostos sobre o comércio exterior; b) impostos sobre o patrimônio e a renda; c) impostos sobre a produção e a circulação de bens e; d) finalmente, os imposto especiais, que transcenderiam, por características especiais, os limites de cada um dos três grupos acima. A ideia era de que toda a matéria econômica suscetível à tributação estivesse estabelecida nesses quatro grupos. Idem, p. 30-31.

${ }^{643}$ Segundo Relatório da Comissão do Ministério da Fazenda. In: Reforma Tributária Nacional. Op.cit., p. 84-85. 
limitações ao poder de tributar (União, Estados, Municípios e Distrito Federal), nos artigos $\mathbf{2}^{\mathbf{a} 644}$ e $\mathbf{3}^{\mathbf{a} 645}$, que ampliam e organizam com maior clareza o rol de princípios constitucionais tributários.

Ainda, a E.C, através do art. $4^{\circ}$, autorizou expressamente a União a criar empréstimos compulsórios (em casos excepcionais definidos em lei complementar), além de organizar as competências dos entes tributantes relativas aos impostos (arts. $5^{\mathrm{a}}$ a 17), taxas (art.18), contribuições de melhoria (art.19), distribuição das receitas tributárias (art.20 a 24), e disposições tributárias transitórias (25 a 27).

O grande mérito da Emenda Constitucional n.18 de 1965 foi efetivamente reorganizar e reestruturar o sistema tributário nacional (mais atento às necessidades econômicas do país). Essa reestruturação, embora recebesse alterações posteriores, manteve em essência a mesma estrutura trazida em 1965, complementada, naturalmente, com a entrada em vigor do Código Tributário Nacional, em 1966, cujas peculiaridades já foram assinaladas.

Contudo, as rápidas modificações políticas do período repercutiram no regime constitucional, acabou viabilizando duas reorganizações constitucionais, em período de apenas quatro anos após a Emenda n.18/65.

Em primeiro lugar, dois anos depois da Emenda número 18 de 1965, com a Constituição de 1967 (Emenda Constitucional n.1 de 1967), no qual o sistema tributário

\footnotetext{
${ }^{644}$ Art. 2 ${ }^{\text {o: }}$ "É vedado à União, aos Estados, ao Distrito Federal e aos Municípios": "I - Instituir ou majorar tributo sem que a lei o estabeleça, ressalvados os casos previstos nesta Emenda" (princípio da legalidade tributária); "II - cobrar impôsto sôbre o patrimônio e a renda, com base em lei posterior à data inicial do exercício financeiro a que corresponda" (princípio da anterioridade tributária); "III - estabelecer limitações ao tráfego, no território nacional, de pessoas ou mercadorias, por meio de tributos interestaduais ou intermunicipais" (princípio da liberdade de tráfego); "IV - cobrar impostos sôbre: a) o patrimônio, a renda ou os serviços uns dos outros; b) templos de qualquer culto; c) o patrimônio, a renda ou serviços de Partidos Políticos e de instituições de educação ou de assistência social, observados os requisitos fixados em lei complementar; d) o papel destinado exclusivamente à impressão de jornais, periódicos e livros.(...)"

${ }^{645} \mathrm{O}$ art. $3^{\mathrm{a}}$ vedou também: "I - à União, instituir tributo que não seja uniforme em todo o território nacional, ou que importe distinção ou preferência em favor de determinado Estado ou Município" (princípio da uniformidade geográfica); "II - aos Estados, ao Distrito Federal e aos Municípios, estabelecer diferença tributária entre bens de qualquer natureza, em razão da sua procedência ou do seu destino" (princípio da nãodiscriminação).
} 
passou a ser previsto expressamente entre os artigos 18 e 28 da Constituição ${ }^{646}$, entre outros importantes dispositivos ${ }^{647}$.

Exemplificativamente, o artigo 20 trouxe as limitações (ou vedações) à União, Estados, Municípios e distrito federal, que estabelece o princípio da legalidade tributária (art.20, inc.I), liberdade de tráfego (art.20, inc.II), a imunidade recíproca (inc.III, a), templos de qualquer culto (inciso III, b), partidos políticos, entidades de educação e assistência social (inc.III, c), livros, jornais e periódicos, e material destinado à impressão (inc.III, d), assim como outros princípios, como a uniformidade geográfica, não diferenciação tributária, entre outros (art. 21), e a discriminação de competências tributárias entre União, Estados, Municípios e Distrito Federal (art.22 a 28) ${ }^{648}$.

No que tange aos direitos e garantias individuais, previstos no art.150, a Constituição de 1967 manteve dispositivo já consagrado na Constituição de 1946: "§ 29 Nenhum tributo será exigido ou aumentado sem que a lei o estabeleça; nenhum será cobrado em cada exercício sem prévia autorização orçamentária, ressalvados a tarifa aduaneira e o imposto lançado por motivo de guerra".

Conforme já mencionado, a década de sessenta, no entanto, foi agitada do ponto de vista constitucional. Assim, em menos de dois anos após a Constituição de 1967, emergiu a Emenda Constitucional número 1 de 1969, alterando novamente o Sistema Constitucional Tributário, a partir dos artigos 18 a 26 (Sistema Tributário Nacional). ${ }^{649}$

\footnotetext{
646 Esses dispositivos regularam a competência dos entes tributantes para criarem impostos, taxas e contribuições de melhoria (art.18) e seus limites $\left(\S 3^{\circ}\right.$, art.19), as normas gerais em direito tributário $\left(\S 1^{\circ}\right.$, art.19), proibição de taxas terem base de cálculo iguais aos de impostos ( $\$ 2^{\circ}$, art.19) e empréstimos compulsórios ( $\$ 4^{\circ}$, art.19).

647 A Emenda Constitucional também estabeleceu competência ao Distrito Federal e aos Estados não divididos em Municípios, cumulativamente, os impostos estaduais e municipais atribuídos aos Estados e Municípios, e à União, nos Territórios Federais, os impostos estaduais e, se o Território não for dividido em Município, os impostos municipais (par.5, art.19), e competência residual da União (par.6a art.19), admitindo a possibilidade de convênios entre entes tributantes (par. $7^{a}$ ), assim como incentivos fiscais à industrialização de produtos do solo e subsolo realizados no imóvel de origem $\left(\S 8^{\circ}\right.$, art.19).

648 Acrescenta-se que o art.21 trouxe novamente o princípio da uniformidade geográfica, aplicado à União, assim como à vedação da União tributar a renda das obrigações da dívida pública estadual ou municipal e os proventos dos agentes dos Estados e Municípios, em níveis superiores aos que fixar para as suas próprias obrigações e para os proventos dos seus próprios agentes (inc.II), além do princípio da não diferenciação tributária, aplicável aos Estados, ao Distrito Federal e aos Municípios. Os demais artigos prescrevem a competência para criação de impostos pela União (art.22), que também poderia criar impostos extraordinários (art.23), aos Estados e Distrito Federal (art.24), e aos Municípios (art.25). Nesse contexto, os art.26 a 28 trataram da distribuição de receitas tributárias entre os entes federados.

${ }^{649}$ Exemplificativamente, o artigo 18 estabeleceu os tributos reconhecidos na Constituição (taxas, impostos e contribuições de melhoria), além do empréstimo compulsório $\left(\$ 3^{\mathrm{a}}\right)$, as normas gerais em direito tributário
} 
Praticamente repetindo o teor da Emenda Constitucional $n^{\circ} .18$ de 1965, e da Constituição de 1967, a Emenda nº.1 de 1969, no artigo 19, estabeleceu as vedações à União, Estados, Municípios e Distrito Federal ${ }^{650}$, assim como a possibilidade da União (assim como em constituições anteriores), no $\S 2^{\circ}$, estabelecer as chamadas "isenções heterônomas", e o art.20, que praticamente repetiu as vedações estabelecidas aos entes tributantes ${ }^{651}$.

$\mathrm{Na}$ discriminação das competências tributárias, a União recebeu, no art. 21, a competência para criar determinados impostos, além da competência residual da União, ao passo que o parágrafo $2^{\mathrm{a}}$, autorizou-a, sob certas condições, a criar empréstimos compulsórios (inc.II) e contribuições (inc.I), além da imunidade de pequenas glebas rurais $\left(\S 6^{\circ}\right)$, e da possibilidade de impostos extraordinários de guerra (art.22). A competência dos Estados foi fixada no artigo 23, ao passo que a dos Municípios no artigo 24. Finalmente, os artigos 25 e 26 trataram da discriminação de receitas tributárias entre os entes tributantes ${ }^{652}$.

Em breve reflexão sobre as modificações constitucionais trazidas a partir de 1965, pode-se perceber que foi efetivamente a E.C n.18/65 que promoveu as verdadeiras

$\left(\S 1^{\text {a }}\right)$, a vedação, no $\S 2^{\text {o }}$, de que as taxas tenham base de cálculo dos impostos. O mesmo dispositivo também acrescentou a competência residual da União $\left(\$ 5^{\mathrm{a}}\right)$ : “5 $5^{\circ}$ A União poderá, desde que não tenham base de cálculo e fato gerador idênticos aos dos previstos nesta Constituição instituir outros impostos, além dos mencionados nos artigos 21 e 22 e que não sejam da competência tributária privativa dos Estados, do Distrito Federal ou dos Municípios, assim como transferir-lhes o exercício da competência residual em relação a impostos, cuja incidência seja definida em lei federal".

${ }^{650}$ Nesse sentido, o art.19 apresentou as seguintes vedações: "I - instituir ou aumentar tributo sem que a lei o estabeleça, ressalvados os casos previstos nesta Constituição; II - estabelecer limitações ao tráfego de pessoas ou mercadorias, por meio de tributos interestaduais ou intermunicipais; e III - instituir impôsto sôbre: a) o patrimônio, a renda ou os serviços uns dos outros; b) os templos de qualquer culto; c) o patrimônio, a renda ou os serviços dos partidos políticos e de instituições de educação ou de assistência social, observados os requisitos da lei; e d) o livro, o jornal e os periódicos, assim como o papel destinado à sua impressão. $\S 1^{\circ} \mathrm{O}$ disposto na alínea a do item III é extensivo às autarquias, no que se refere ao patrimônio, à renda e aos serviços vinculados às suas finalidades essenciais ou delas decorrentes; mas não se estende aos serviços públicos concedidos, nem exonera o promitente comprador da obrigação de pagar impôsto que incidir sôbre imóvel objeto de promessa de compra e venda".

${ }^{651}$ Art. 20. "É vedado: I - à União instituir tributo que não seja uniforme em todo o território nacional ou implique distinção ou preferência em relação a qualquer Estado ou Município em prejuízo de outro; II - à União tributar a renda das obrigações da dívida pública estadual ou municipal e os proventos dos agentes dos Estados e municípios, em níveis superiores aos que fixar para as suas próprias obrigações e para os proventos dos seus próprios agentes; e III - aos Estados, ao Distrito Federal e aos Municípios estabelecer diferença tributária entre bens de qualquer natureza, em razão da sua procedência ou destino".

${ }^{652}$ Finalmente, ressalte-se que, no capítulo dedicado aos direitos e garantias fundamentais, o artigo 153 fixou o seguinte princípio, já previsto nas constituições anteriores, embora com expressa restrição a determinados impostos (reguladores): “\$ 29. Nenhum tributo será exigido ou aumentado sem que a lei o estabeleça, nem cobrado, em cada exercício, sem que a lei o houver instituído ou aumentado esteja em vigor antes do início do exercício financeiro, ressalvados a tarifa alfandegária e a de transporte, o impôsto sôbre produtos industrializados e o imposto lançado por motivo de guerra e demais casos previstos nesta Constituição". 
modificações históricas à estrutura constitucional tributária, ao passo que a E.C. n.1/67 e E.C. n.1/69 praticamente mantiveram, em maior parte, os acréscimos trazidos pela primeira $^{653}$.

Evidentemente, a despeito dos muitos méritos da Emenda Constitucional n.18/1965, o grande problema trazido com as modificações constitucionais daquele período circulava sobre a insegurança jurídica, já que em período de quatro anos (1965 a 1969) o sistema constitucional tributário foi destruído e reconstruído três vezes.

Além disso, as constantes transformações constitucionais na década de sessenta também apresentavam característica centralizadora (política e financeiramente) no Brasil $^{654}$, seja reconhecendo o direito constitucional tributário em sua vertente instrumental (de políticas fiscais) seja para promover a expansão econômica (e o desenvolvimento econômico do país) naquele período.

\section{Os reflexos do direito constitucional tributário na literatura tributária brasileira na década de sessenta e a tendência histórica à extensão e rigidez do sistema.}

A partir da Constituição de 1946 o direito tributário constitucional passa a ser efetivamente estruturado, especialmente pela atuação de Aliomar Baleeiro, que defendeu que o conjunto daqueles princípios e regras das quais se realiza a discriminação das rendas no sistema de 1946 formariam o que “(...) alguns financistas e juristas já apartam do Direito em geral para formação de ramo dogmaticamente autônomo - o Direito Tributário Constitucional". Em outras palavras, na visão de Baleeiro, seriam normas de grau superior à lei, e assim de particular importância, onde a Constituição é a “(...) primeira e uma das mais opulentas fontes do Direito Tributário Substantivo"655.

Nota-se também, na construção do autor, a influência de Dino Jarach, na obra "O Fato Imponível”, quando tratou do que seria o Direito Tributário Substantivo e, sobretudo,

\footnotetext{
${ }^{653}$ BALTHAZAR, Ubaldo. Op.cit., p. 159-177.

${ }^{654}$ DÓRIA, Antonio Roberto Sampaio. A Discriminação da Competência Impositiva. Op.cit., p. 156 e seguintes.

${ }_{655}$ BALEEIRO, Aliomar. Limitações Constitucionais ao Poder de Tributar. Op.cit., p. 15-16.
} 
pela definição trazida pelo autor sobre Direito Tributário Constitucional, como “(...) conjunto de normas que disciplinam as soberanias fiscais dentro do Estado e as delimitam entre elas" $" 656$.

Para Baleeiro, seguindo a linha de Hensel e Kruse, na Alemanha, o Direito Tributário Constitucional seria um indício proeminente da "autonomia" da disciplina.

Aliás, o próprio Aliomar Baleeiro brindou a produção teórica brasileira, na década de 50, com o clássico "Limitações Constitucionais ao Poder de Tributar" (cuja primeira edição foi publicada em 1951$)^{657}{ }_{-}^{658}$ que, inclusive, já defendia a rigidez da discriminação de rendas contida no direito constitucional tributário brasileiro ${ }^{659}$.

A rigidez da discriminação de rendas tributárias também foi refletida por Amílcar de Araújo Falcão (analisando sistemas rígidos e flexíveis), caminhando no sentido de reconhecer discriminação de rendas rígidas na Constituição de $1946^{660}$.

Naturalmente, as preocupações com o direito tributário constitucional, demonstradas por Baleeiro, acabaram sendo igualmente perseguidas na literatura ${ }^{661}{ }_{-}^{662} 663$.

Tal espírito constitucionalista, já elevado por Baleeiro, também pôde ser observado na época pela publicação do clássico estudo de Antonio Roberto Sampaio Dória, denominado "Princípios Constitucionais Tributários e a Cláusula Due Process of Law", cuja primeira edição apareceu em 1964, ainda sob a égide da Constituição de 1946, que, influenciado por Baleeiro e Uckmar, reconheceu a importância histórica das limitações

\footnotetext{
${ }^{656}$ JARACH, Dino. O Fato Imponível. $2^{\text {a} E d . ~ T r a d . ~ D e j a l m a ~ C a m p o s . ~ S a ̃ o ~ P a u l o: ~ R t, ~ 2004, ~ p . ~} 54$.

657 BALEEIRO, Aliomar. Limitações Constitucionais ao Poder de Tributar. Atualizada por Mizabel Derzi. Rio de Janeiro: Forense, 1999, p. 14 e seguintes.

${ }^{658}$ ATALIBA, Geraldo. Prefácio. In: BALEEIRO, Aliomar. Limitações Constitucionais ao Poder de Tributar. Atualizada por Mizabel Derzi. Op.cit., 1999.

${ }^{659}$ BALEEIRO, Aliomar. Discriminação de Rendas. Rio de Janeiro: IBDF, s/d, p. 30.

660 "Essas qualificações - rígido e flexível, plástico, ou fluído - foram propostas por James Bryce e são usadas pelos constitucionalistas para distinguir as constituições segundo o processo adotado para sua revisão, reforma ou emenda (...)". FALCÃO, Amílcar de Araújo. Sistema Tributário Brasileiro. Discriminação de Rendas. Op.cit., p. 25-48.

661 Sobre o assunto também se recomenda a leitura de: MIRANDA, Francisco Cavalcanti Pontes de. Comentários à Constituição de 1946. Vol. I (arts 1-36). Op.cit., p.297.

${ }^{662}$ BALEEIRO, Aliomar. Limitações Constitucionais ao Poder de Tributar. Atualizada por Mizabel Derzi. Op.cit., p. 15 e seguintes.

${ }^{663}$ Sobre o assunto, conferir o testemunho de Geraldo Ataliba, sobre a importância desta obra para o Direito Tributário Brasileiro: ATALIBA, Geraldo. Prefácio. In: BALEEIRO, Aliomar. Limitações Constitucionais ao Poder de Tributar. Atualizada por Mizabel Derzi. Op.cit., s/p.
} 
constitucionais ao poder de tributar ${ }^{664}$, concedendo especial atenção aos princípios tributários $^{665}$.

Nesse período, imediatamente anterior à Emenda Constitucional número 18 de 1965, que traria profundas reformas ao sistema constitucional tributário, também se inclui o já citado estudo de Amílcar de Araújo Falcão, publicado um ano antes, sobre "Sistema Tributário Brasileiro", com o objetivo expresso de analisar a discriminação de rendas tributárias sob a égide daquela Carta Constitucional de $1946^{666}$.

Foi inequívoca também, na mesma época, a posição de Ruy Barbosa Nogueira, para quem, “(...) a imposição tributária (como as demais manifestações de vontade do poder público), no Estado de Direito, está, em primeiro plano, vinculada à Constituição"667, assim como, de forma análoga, o estudo de Bernardo Ribeiro de Moraes ${ }^{668}$.

Nesse período, especialmente posterior à Emenda Constitucional n.18/1965, impulsiona-se fortemente a atenção ao direito constitucional tributário, conforme se observa também nos estudos de José Souto Maior Borges, que já se preocupava com os aspectos constitucionais da tributação em "Isenções Tributárias"669.

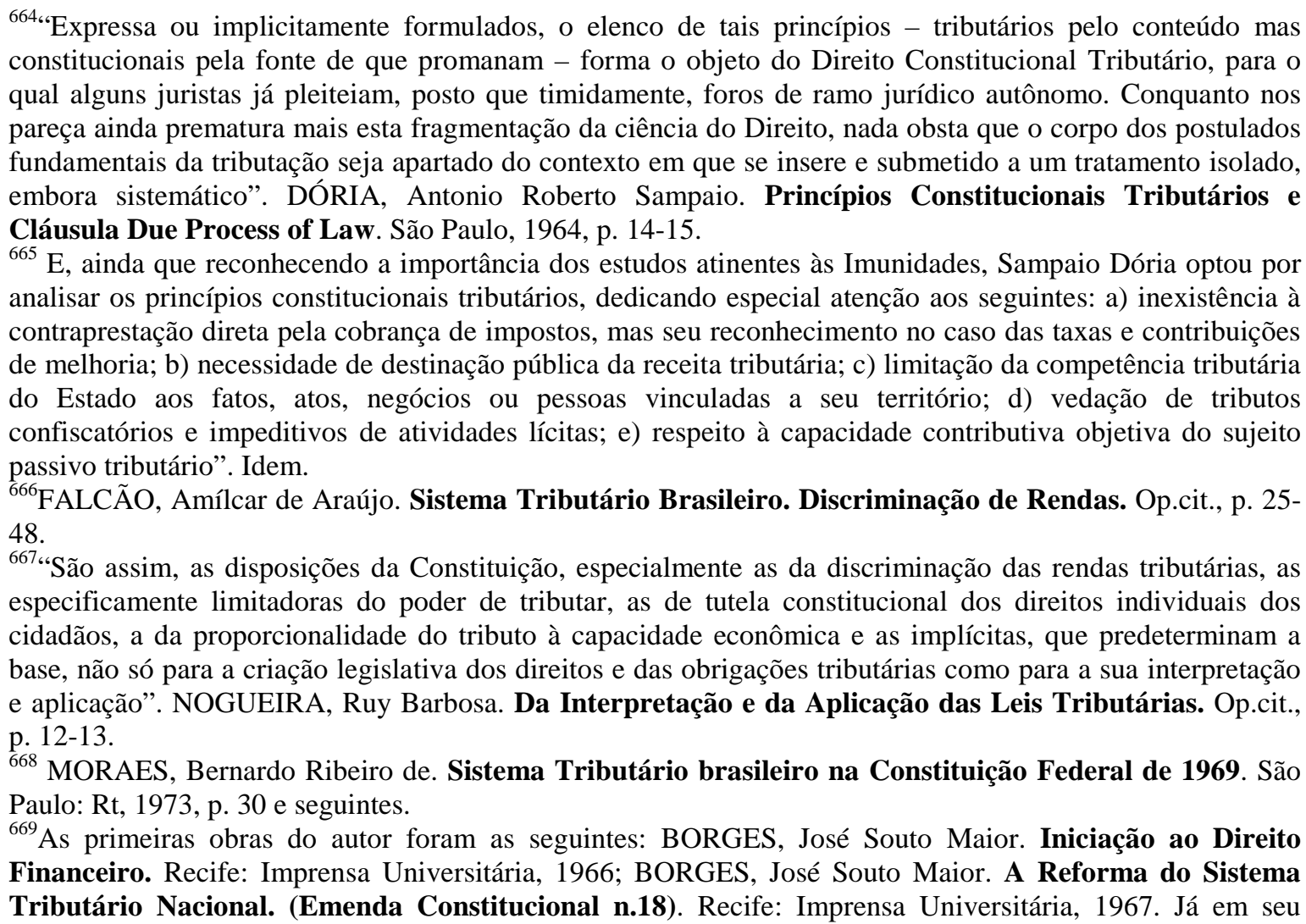


Mas, realmente, na década de sessenta, a obra que mais traria influências à literatura tributária posterior foi publicada por Geraldo Ataliba, por sua vez denominada "Sistema Constitucional Tributário Brasileiro" (com a $1^{\text {a }}$ publicação em 1966), com reedição em $1968^{670}$, mas destinando-se a atacar as mutações constitucionais promovidas pela EC n.18/1965 (e depois, também a E.C. nº.1 de 1967).

De fato, a instabilidade constitucional em matéria tributária naquela época demandava protestos por parte da literatura especializada. Nesse contexto, a obra de Ataliba era a que mais claramente se indispôs corajosamente sobre o tema, já que, para o autor, a constituição brasileira seria rigidíssima ${ }^{671}$ no tratamento ao direito tributário positivo (extensivo e super-rígido no Brasil, diferente de outros sistemas estrangeiros, mais restritos e flexíveis), e não poderia ser alterada com tanta facilidade (como ocorreu com as Emendas n.18/65, n.1/67 e n.1/69), já que a Constituição Tributária apresentaria tratamento mais extensivo à matéria em comparação com as experiências constitucionais estrangeiras.

\section{Reflexos históricos da sistematização constitucional tributária no Brasil: entre o fechamento e a abertura}

\subsection{Sistema, extensivo, rígido e unitário.}

A constitucionalização do direito tributário positivo - e sua codificação - leva à sistematização (dogmática). Mas, em verdade, é a própria constitucionalização, complementada pela codificação e pela legislação infraconstitucional, que viabiliza a compreensão sistemática do Direto Tributário Brasileiro.

clássico estudo sobre isenções é possível observar a forte preocupação do autor com a veiculação do direito tributário constitucional: BORGES, José Souto Maior. Isenções Tributárias. $1^{a}$ Edição. São Paulo: Sugestões Literárias S.A., 1969, p. 15 e seguintes.

${ }^{670}$ ATALIBA, Geraldo. Sistema Constitucional Tributário Brasileiro. $2^{\circ}$ Edição. São Paulo: Editora Revista dos Tribunais, 1968, p. 01 e seguintes.

${ }^{671}$ Ataliba, elencando a rigidez jurídica da constituição, destaca que "é que os princípios constitucionais tributários, por isso que constitucionais, se erigem em "normas de grau superior à lei e, por isso mesmo, assumem particular importância nos países de Constituição rígida e de controle da constitucionalidade por parte dos órgãos jurisdicionais". ATALIBA, Geraldo. Sistema Constitucional Tributário Brasileiro. Op.cit., p.31. 
É claro que, no âmbito do Direito Público, conforme já observado no capítulo 1, a sistematização é também consequência do positivismo e do formalismo jurídico ${ }^{672}$. Da mesma forma, torna-se evidente que rapidamente a compreensão do direito tributário a partir de uma apreensão sistemática apareceria, sob o argumento de racionalização, organização e harmonia entre as normas tributárias daquele mesmo ordenamento jurídico.

Contudo, no início do processo disciplinar do Direito Tributário Brasileiro, a noção dogmático-jurídica atrelada ao sistema tributário parecia guardar poucas semelhanças com as condepções sistêmicas atribuídas ao direito tributário brasileiro contemporâneo.

De qualquer forma, historicamente, a noção de sistema tributário já aparecia com maior atenção desde a década de quarenta, mas com feições muito distintas das preconizadas a partir do dogmatismo jurídico.

Nesse sentido, Gerson Augusto da Silva já denominava, com anterioridade, a expressão sistema tributário nacional: "como sistema tributário nacional designamos, aqui, o conjunto de todos os impostos cobrados no país, sem distinguir os de competência federal, estadual ou municipal (...)"673.

Naturalmente, era uma definição ampla que, de certa forma, também aparecia em Rubens Gomes de Sousa, que defendia a existência do sistema tributário nacional (mas não somente federal, estadual, municipal), onde “(...) nele se conjugam os três sistemas individuais de cada um dos três níveis de governo, não apenas como mecanismos autônomos, embora concorrentes, mas como partes integrantes de um mesmo todo"674.

Amílcar de Araújo Falcão, por sua vez, definia, sob a égide da Constituição de 1946, o sistema tributário como o “(...) conjunto dos tributos existentes em um Estado, considerados seja nas suas recíprocas relações, seja quanto aos efeitos globalmente

\footnotetext{
${ }^{672}$ BONAVIDES, Paulo. Curso de Direito Constitucional. Op.cit., p. 93 e ss. CANOTILHO, J.J.Gomes. Direito Constitucional e Teoria da Constituição. Op.cit., p. 1143 e ss.

${ }^{673}$ SILVA, Gerson Augusto da. Sistema Tributário Brasileiro. Op.cit., p. 45 e seguintes.

${ }^{674}$ SOUSA, Rubens Gomes de. O sistema tributário federal. In: Revista de Direito Administrativo, volume 72 , p. 05 e seguintes.
} 
produzidos sobre a vida econômica e social". ${ }^{675}$ Note-se também que, em Ruy Barbosa Nogueira, a defesa de sistemas científicos inspirada na literatura germânica já aparecia ${ }^{676}$.

A visão sistemática do direito infere-se necessariamente à ideia de ordem e totalidade, conforme é possível observar na opinião de um dos principais expositores do tema na seara tributária, Geraldo Ataliba. Para o autor, o "sistema" partiria necessariamente da composição coerente e harmônica de diversos elementos integrados em uma realidade maior, formando um "todo unitário"677.

O princípio unitário, na leitura de Ataliba, possui importância fundamental na composição do sistema, assinalando que os elementos que compõe o sistema não lhes constituem através de uma mera "soma", mas da coordenação harmônica desses em função do "todo (sistema)". ${ }^{678} 679$

Para Ataliba, o sistema constitucional tributário brasileiro seria o mais rígido entre os sistemas conhecidos, que o teria entregado "pronto e acabado" ao legislador ordinário, a quem somente caberia a tarefa de obedecê-lo ${ }^{680}$, chegando a considerar a rigidez um princípio constitucional implícito, “(...) que deve se inscrever ao lado dos demais princípios constitucionais tributários" ${ }^{\text {681 }}$.

\footnotetext{
${ }^{675}$ FALCÃO, Amílcar de Araújo. Sistema Tributário Brasileiro. Discriminação de Rendas. Op.cit., p. 2548.

676 “(...) cada sistema científico deve adaptar-se à sua matéria, ao seu objeto material, de tal modo que faça ressaltar com clareza as características. Esta finalidade ou síntese deve ser conseguida pela formulação dos conceitos e relações fundamentais (características comuns, princípios, categorias, institutos)". NOGUEIRA, Ruy Barbosa. Direito Financeiro. Op.cit., p. 09-10.

${ }^{677}$ Ainda, segundo Ataliba: "sistema é o conjunto unitário e ordenado de elementos, em função de princípios coerentes e harmônicos". Já o sistema normativo seria “(...) o conjunto unitário e ordenado de normas, em função de uns tantos princípios fundamentais, reciprocamente harmônicos, coordenados em torno de um fundamento comum". ATALIBA, Geraldo. Sistema Constitucional Tributário Brasileiro. Op.cit., p. 04$05 ; 19-21$.

${ }^{678}$ Idem, p.07.

${ }^{679}$ De grande repercussão, aliás, foi sua definição de Sistema Constitucional Tributário: "Por sistema constitucional tributário entende-se o conjunto de princípios constitucionais que informa o quadro orgânico de normas fundamentais e gerais do direito tributário vigentes em determinado país. Se "Sistema é um conjunto ordenado de elementos segundo uma perspectiva unitária", o sistema constitucional tributário brasileiro é o conjunto ordenado das normas constitucionais que tratam da matéria tributária, matéria esta tomada como princípio de relação que as unifica". O sistema visto como conjunto de normas jurídicas já era adotado por Ataliba, amplamente influenciado pela literatura de Hans Kelsen. Não é por outro motivo que Ataliba entendia que o "(...) conjunto de normas constitucionais forma o sistema constitucional" ao passo que "o conjunto de normas na Constituição que versa matéria tributária forma o sistema (parcial) constitucional tributário". Ibidem, p. 08; p. 19-21.

${ }_{680}$ Ibidem, p. 21.

${ }^{681}$ Ibidem, p.37.
} 
Nesse sentido, a lição de Ataliba seguiu reproduzida - e até mesmo aperfeiçoada na literatura tributária da época, como também é possível observar na opinião de Paulo de Barros Carvalho ${ }^{682}$, definindo o sistema de direito como o conjunto de normas jurídicas dispostas de maneira que apresentem entre si relações horizontais - coordenação - e verticais - hierarquização - formando o que denominamos de ordenamento jurídico. Essa posição está atrelada à verificação de que as normas - enquanto elementos formadores do ordenamento - convergem em um único ponto, como asseverou Paulo de Barros: a Norma Fundamental (Grundnorm) de Kelsen ${ }^{683}{ }^{684}$.

Entendimento que seguiu expresso também em Roque Antônio Carrazza, para quem o Sistema é a “(...) reunião ordenada das várias partes que formam um todo, de tal sorte que elas se sustentam mutuamente e as últimas explicam-se pelas primeiras. As que dão razão às outras chamam-se princípios, e o sistema é tanto mais perfeito quanto em menor número existam (...) ${ }^{\text {,685 }}$, posição que se manteve semelhante, exemplificativamente, nas obras de Sacha Calmon Navarro Coêlho ${ }^{686}$ e José Eduardo Soares de Melo ${ }^{687}$, para quem o Sistema Tributário Nacional apresenta extensivo tratamento constitucional fundamentado pelo Subsistema Constitucional Tributário Brasileiro, esse que rege o quadro orgânico de normas, regras e princípios que tratam da matéria tributária em nível constitucional.

No rastro dessas célebres concepções teóricas atinentes ao sistema constitucional tributário, recorda-se a lição de Tércio Sampaio Ferraz Júnior. Este autor trouxe definição de sistema que alcançou grande difusão na literatura jurídica tributária, especialmente a partir da década de setenta, ao conceituá-lo como complexo composto de uma estrutura conjunto de regras de relacionamento e das relações por elas estabelecidas, aliando-se ao repertório, que é o conjunto de seus elementos. ${ }^{688}{ }_{-}^{689}$

${ }^{682}$ CARVALHO, Paulo de Barros. Curso de Direito Tributário. $17^{\circ}$ Edição. São Paulo: Saraiva, 2005, p. 136-137.

${ }^{683}$ KELSEN, Hans. Teoria Pura do Direito. Op.cit., p. 135 e seguintes.

${ }^{684}$ CARVALHO, Paulo de Barros. Curso de Direito Tributário. Op.cit., p. 190-191.

${ }^{685}$ CARRAZZA, Roque Antonio. Curso de Direito Constitucional Tributário. 24 ed. São Paulo, 2008, p. 37.

${ }^{686}$ NAVARro COÊLHO, Sacha Calmon. Curso de Direito Tributário Brasileiro. $8^{\circ}$ Edição. Rio de Janeiro: Forense, 2005, p. 48.

${ }^{687}$ MELO, José Eduardo Soares de. Curso de Direito Tributário. $6^{\circ}$ Edição. São Paulo: Dialética, p. 12-13.

688 "O sistema é um complexo que se compõe de uma estrutura e um repertório. Nesse sentido, ordenamento

é sistema". JÚNIOR, Tércio Sampaio Ferraz. Introdução ao Estudo do Direito. Técnica, Decisão, Dominação. $4^{a}$ Ed. São Paulo: Atlas, 2003, p. 175-176. 
Já em 1985, em pleno processo histórico de democratização, Geraldo Ataliba apresenta ensaio que simbolizaria - e amadureceria - suas principais ideias acerca do sistema constitucional tributário: "República e Constituição". Esse trabalho, embora não propriamente referente ao "Direito Tributário", teve grande difusão entre o meio, elevando o princípio federativo e a democracia ${ }^{690}$, em momento de grandes transformações políticas no país.

Assim, o dogmatismo jurídico kelseniano, caracterizado pela visão de que o sistema jurídico seria organizado por normas dispostas em relação de coordenação e hierarquia, apreensíveis por processos de dedução ${ }^{691}$, teve forte repercussão na compreensão do sistema constitucional tributário na literatura brasileira a partir da década de sessenta.

\subsection{Sistema extensivo, plural e aberto.}

Ricardo Lobo Torres, amplamente influenciado pela literatura germânica "póspositivista”, levantou a existência de vários sistemas, alguns abertos à influência externa.

Aliás, se fosse possível apresentar duas obras como máximas representantes de ambas as teorias sistemáticas no período histórico anterior à Constituição de 1988, elas seriam respectivamente representadas pela obra de Geraldo Ataliba, publicada em 1966, e, vinte anos depois, em 1986, pela obra de Ricardo Lobo Torres, quando escreveu Tomo do Tratado de Direito Tributário Brasileiro dedicado aos Sistemas Constitucionais Tributários.

É claro que seria injusto compará-las, pois produzidas em ambientes históricos totalmente distintos: a primeira (de Geraldo Ataliba), consolidada em ambiente onde a ditatura se fortalecia, e a instabilidade política (e constitucional) eram marca registrada do período; a segunda (Ricardo Lobo Torres), consolida-se no período de redemocratização, e portanto, quando estudiosos do direito constitucional (e do próprio direito tributário)

\footnotetext{
${ }^{689}$ MIRANDA, Francisco Cavalcanti Pontes de. Tratado de Direito Privado. Tomo I. $2{ }^{a}$ Edição. Parte Geral. Introdução. Pessoas Físicas e Jurídicas. Campinas-SP:Bookseller, 2000, p. 13.

${ }^{690}$ A primeira edição da obra foi publicada em 1985: ATALIBA, Geraldo. República e Constituição. São Paulo: Rt, 1985. ATALIBA, Geraldo. República e Constituição. São Paulo: Malheiros, 2001, p. 122-126.

${ }^{691}$ É compreensível que, para Mario G. Losano, a ideia de sistema tradicionalmente é ligada à ideia de ordem e composição harmônica. Para o autor, no fundo, a concepção de sistema poderia ser traduzida por "estrutura". LOSANO, Mario G. Sistema e Estrutura no Direito. Volume 1. Das origens à Escola Histórica. Trad. Carlo Alberto Dastoli. São Paulo: Martins Fontes, 2008, p. 04-06.
} 
passam a deter maior atenção ao fenômeno do "neoconstitucionalismo" e do "póspositivismo" pós-guerra, relativizando certas tendências dogmáticas kelsenianas.

São produtos de seus próprios contextos históricos, que devem ser compreendidos e elevados nos seus próprios termos.

De qualquer forma, a obra de Ricardo Lobo Torres simboliza posterior etapa à sistematização do direito constitucional tributário, ainda que a tendência ao dogmatismo kelseniano tenha se mantido forte nas últimas décadas do século XX. Nesse sentido, para o autor $^{692}$, o sistema pode ser conceituado como o “(...) o conjunto de elementos dotado de unidade interna, coerência lógica, ordem, ausência de contradições e independência do todo com relação às partes. Mas essa definição, por se confundir com a totalidade, não permitiria o exame científico do conceito de sistema".

Ademais, traço marcante nas reflexões do autor revela-se na defesa do pluralismo de sistemas. Nesse contexto, o sistema tributário também se apresenta como plural ${ }^{693}$, pois “(...) a ideia de único sistema jurídico é inaceitável, porquanto se confundiria com todo o fenômeno do Direito, em suas dimensões espaciais e temporais, objetivas e ideais e com a própria vida humana, que se desenrola sub specie juris" ${ }^{\circ 94}$.

Tanto o sistema científico e o sistema objetivo possuem o pluralismo que, por sua vez, apresenta repercussões distintas às respectivas modalidades sistemáticas.

Em primeiro lugar, o pluralismo do sistema objetivo implica na possibilidade de identificação dos sistemas de Direito Público e de Direito Privado, assim como dos sistemas de Direito Constitucional, do sistema de Direito Administrativo, etc. Assim, o sistema jurídico objetivo, para Torres, revela-se como ordem parcial no plural das relações

\footnotetext{
${ }^{692}$ Sobre as diversas teorias dos sistemas jurídicos aplicados ao direito tributário, sugere-se a contextualização feita por: TORRES, Ricardo Lobo. Sistemas Constitucionais Tributários. Tratado de Direito Tributário Brasileiro. V. II. Rio de Janeiro: Forense, 1986, p. 03 e seguintes.

${ }^{693}$ TORRES, Ricardo Lobo. Curso de Direito Financeiro e Tributário. Rio de Janeiro: Renovar, 2005, p. 355-357.

694 "A ideia de sistema contém a sua validade, desde que se aplique aos diferentes campos do conhecimento, a perquirir sobre realidades distintas. Recusa-se o sistema total, fechado e completo, suscetível de apreensão por um único método ou ciência. Mas o pluralismo de sistemas, que abrange a gama variadíssima da realidade física, orgânica e social, desdobrando-se esta última por sua vez em sistemas jurídicos, éticos, econômicos, financeiros, históricos, estéticos, linguísticos, etc., tem consequências valiosas. Ao mesmo tempo as ciências que estudam aqueles objetos também refletem o pluralismo metodológico e se auxiliam na pesquisa multidisciplinar". TORRES, Ricardo Lobo. Sistemas Constitucionais Tributários. Op.cit., p.0305.
} 
humanas, pluralizando-se na juridicização dos fatos sociais. A visualização dessas peculiaridades sob a perspectiva do pluralismo permite melhor observância e identificação de outros subsistemas em que esses sistemas eventualmente se fracionem. É o caso do Sistema Constitucional, do qual se fraciona o Subsistema Constitucional Tributário.

Ao mesmo tempo, o pluralismo dos sistemas científicos, igualmente, não apresenta unidade fechada, ainda que o sistema de conhecimentos científicos apresente-se conexo e coerente ${ }^{695}{ }_{-}^{696}$.

Mas verdade seja dita: a concepção de sistemas fechados, pautados na premissa da unidade e na super-rigidez do ordenamento, foi prevalecente na literatura tributária nacional a partir da década de setenta (influenciada pelos fenômenos da década anterior) e seguiu-se firmemente nos anos oitenta e noventa do século XX. A configuração da Constituição de 1988, ampliando o tratamento tributário frente às suas antecessoras, reforçou ainda mais essa tendência, mas, por outro lado, promoveu fundamentos para a defesa da abertura sistêmica, notadamente graças à maior vinculação aos direitos e garantias fundamentais.

695 “Os sistemas constitucionais tributários, no plano objetivo, ou seja, os sistemas genéricos da Constituição Tributária e do Estado Fiscal se dividem da seguinte forma: a) sobre-sistemas constitucionais tributários, que abrangem os sobre-sistemas da tributação da riqueza nacional e da distribuição do poder tributário; b) o cosistema internacional tributário, que se compõe das relações internacionais em matéria fiscal imbricadas na Constituição; c) os subsistemas constitucionais quase-fiscais, isto é, os outros subsistemas da Constituição que se encontram na zona fronteiriça com o subsistema tributário; d) o subsistema das limitações constitucionais ao poder de tributar, que é o conjunto das garantias da liberdade individual e dos direitos fundamentais do cidadão frente ao poder do Estado; e) o susbsistema dos princípios constitucionais tributários, representado pelos princípios derivados das ideias de justiça fiscal, segurança, utilidade e técnica; f) subsistema do processo constitucional tributário, compreendendo o processo jurisdicional, legislativo e administrativo, coextensivo à ideia do Estado moderno, que pressupõe o status ativus processualis; g) o subsistema da interpretação da Constituição Tributária, que, embora se subordine a princípios gerais, não pode olvidar os elementos e a dinâmica do sistema que lhe compete compreender, pelo que se pode falar em um sistema de interpretação com metodologia própria, que se não confunde com o método de interpretação sistemática e não conflita nem contrasta com a tópica”. E finalmente, “(...) o pluralismo científico encontra os seus pressupostos na Teoria da Constituição Tributária, que se divide nas teorias correspondentes a cada qual dos sobre-sistemas ou subsistemas objetivos". TORRES, Ricardo Lobo. Sistemas Constitucionais Tributários. Op.cit., p. 08-11.

${ }^{696}$ Em outras palavras: “(...) A unidade do Sistema Científico do Direito se desfaz, por conseguinte, em razão da descontinuidade do sistema global do saber científico em que se insere e em virtude do seu fraccionamento interno". Idem. 
11. Por que os aspectos elementares do constitucionalismo democrático europeu pósguerra (neoconstitucionalismo europeu) não foram eficientemente absorvidos na literatura constitucional tributária brasileira no período ditatorial?

O movimento constitucional democrático europeu pós-guerra (neoconstitucionalismo) trouxe à baila questões fundamentais como a necessidade de extensão e rigidez do sistema constitucional, a elevação da dignidade da pessoa humana e a defesa dos direitos e garantias fundamentais em um ambiente democrático.

Essas características fundamentais do neoconstitucionalismo, contudo, serão dificilmente sentidas no ambiente tributário brasileiro daquele período, já que sequer se apresentava, naquelas Constituições, o princípio da dignidade da pessoa humana, que somente apareceria na Constituição de 1988.

O ambiente não-democrático do período também dificultava a absorção das características elementares ao neoconstitucionalismo, ainda que algumas fossem absorvidas (convenientemente) pela literatura tributária brasileira (como a extensão e a rigidez do sistema constitucional, que já aparecia no neoconstitucionalismo, como busca ao reforço normativo constitucional, e como superação ao constitucionalismo anterior à Segunda Guerra).

Mas note-se que a rigidez e a extensão apontada por alguns autores da época pouco tinha relação com o neoconstitucionalismo europeu voltado à defesa dos direitos e garantias fundamentais, à democracia e ao que se convencionou chamar de "póspositivismo" ${ }^{697}$.

Geraldo Ataliba, conforme já observado, elevava a rigidez e a extensão do sistema constitucional tributário pela sólida influência da Teoria Pura do Direito e da Teoria Geral do Direito e do Estado, de Hans Kelsen ${ }^{698}$. Era, portanto, também um projeto de aspiração política, já que buscava proteger o direito constitucional tributário da instabilidade política do período.

Note-se que o positivismo (e sobretudo o formalismo dogmático kelseniano) teve influência maciça justamente no período nazi-facista, onde o positivismo jurídico formal apolítico (separando o direito, a política e a moral, ligando o direito tão somente à sua

\footnotetext{
697 BARROSO, Luís Roberto. Fundamentos Teóricos e Filosóficos do novo direito constitucional brasileiro (pós-modernidade, teoria crítica e pós-positivismo). Op.cit., p.18-26.

${ }^{698}$ ATALIBA, Geraldo. Sistema Constitucional Tributário Brasileiro. Op.cit., p. 04-05; 19-21.

KELSEN, Hans. Teoria Pura do Direito. Op.cit., p. 135 e seguintes.

ATAliBA, Geraldo. República e Constituição. São Paulo: Rt, 1985. ATALIBA, Geraldo. República e Constituição. São Paulo: Malheiros, 2001, p. 122-126.
} 
forma) de Hans Kelsen serviu muito bem aos regimes totalitários europeus ${ }^{699}$, caindo em desuso após o fim desses regimes ${ }^{700}$. De qualquer forma, adotar Kelsen para proteger o sistema constitucional de mudanças arbitrárias e repentinas trazidas pelo totalitarismo, não deixava de ser bastante curioso, e denotava tendência que iria se perpetuar anacrônicamente no Brasil, a partir daquele período ${ }^{701}{ }^{702}$.

Assim, o ambiente histórico político (e jurídico) brasileiro prevalecente entre a década de sessenta e oitenta não comportou a recepção plena do neoconstitucionalismo, senão meros resquícios, geralmente traduzidos indiretamente por tributaristas europeus (como Victor Uckmar, Kruse e Jarach, por exemplo), conforme se observa em Baleeiro, Sampaio Dória e Ruy Barbosa Nogueira ${ }^{703}$.

Por outro lado, constitucionalismo tributário presente naquele período tendia muito mais à elevação de princípios historicamente consolidados, aliando-se à exigência de extensão e, eventualmente, ao fechamento do sistema tributário (características que, embora identificáveis no neoconstitucionalismo, apresentavam fundamento histórico totalmente diverso).

Em síntese, a influência tardia do dogmatismo normativo kelseniano favoreceu a disseminação de uma compreensão distinta acerca da sistemática constitucional tributária prevalecente na Europa Pós-Guerra, que somente trará sinais de flexibilização a partir do início do período de redemocratização (1985), ainda que o dogmatismo normativo kelseniano aplicado ao direito constitucional tributário tenha se mantido forte na realidade brasileira no século XX (inclusive em ambiente posterior à Constituição de 1988).

De qualquer forma, do ponto de vista da autonomia legislativa (constitucional), os tributaristas ativos no período de redemocratização exerceram papel proeminente na reformulação constitucional tributária, conforme se observará nas linhas seguintes.

\section{A contribuição histórica dos tributaristas para a Constituição de 1988 na} década de oitenta.

\footnotetext{
${ }^{699}$ SALDANHA, Nelson. Filosofia do Direito. Op.cit., p. 08-09.

${ }^{700}$ KAUFMANN, Arthur. Filosofia do Direito. Lisboa: Fundação Calouste Gulbekian, p.39 e ss.

${ }^{701}$ BARROSO, Luís Roberto. Curso de Direito Constitucional Contemporâneo. Op.cit., p. 269 e ss.

702 BARROSO, Luís Roberto. Fundamentos Teóricos e Filosóficos do novo direito constitucional brasileiro (pós-modernidade, teoria crítica e pós-positivismo). Op.cit., p.18-26.

${ }^{703}$ FALC ̃̃O, Amílcar de Araújo. Sistema Tributário Brasileiro. Discriminação de Rendas. Op.cit., p. 2548. NOGUEIRA, Ruy Barbosa. Direito Financeiro. Op.cit., p. 09-10. BALEEIRO, Aliomar. Limitações Constitucionais ao Poder de Tributar. Atualizada por Mizabel Derzi. Op.cit., p. 15 e seguintes. DÓRIA, Antonio Roberto Sampaio. Princípios Constitucionais Tributários e Cláusula Due Process of Law. São Paulo, 1964, p. 14-15.
} 
A década de setenta foi período de grandes modificações políticas trazidas pela ditadura militar, contexto que, no âmbito da tributação, pôde ser visualizado sob a perspectiva da aplicação do Código Tributário Nacional que, naquele período, já aparecia alterado por sucessivas normativas emanadas pelo Poder Executivo.

Afinal, o Código Tributário Nacional, não obstante os avanços proporcionados, também era alvo de críticas, em grande parte, decorrentes do desequilíbrio financeiro frente à carência de recursos e respectiva disponibilidade, assim como pelo aumento de despesas e receitas, a má-administração de alguns impostos, o grande número de leis tributárias, ordinárias e regulamentares, mudando excessivamento o sistema tributário no decorrer do período ditatorial ${ }^{704}$, comprometendo a própria eficiência do mesmo, assim como a impontualidade da União na entrega de receitas financeiras aos outros entes $\operatorname{políticos}^{705}$.

Assim, na década de oitenta já se somava a esse panorama financeiro considerável salto inflacionário, gerando novas alterações no Código Tributário Nacional, notadamente por outras Emendas Constitucionais em vigor naquele período, buscando sempre aumentar a arrecadação, sobretudo pela criação de novos impostos, ou mesmo pela alteração da participação financeira dos outros entes políticos ${ }^{706}$.

Com o final do regime militar, em 1985, o Brasil encontrava-se em verdadeiro "espiral inflacionário", criando, novamente, clima favorável a novas alterações na legislação tributária brasileira, sobretudo no CTN. Nesse ambiente político e economicamente diferenciado, emerge o neoliberalismo, e o modelo econômico adotado no regime militar começa a dar sinais de esgotamento.

Com a democratização do país, novamente surge a necessidade da consolidação do Estado Democrático de Direito e, com ele, a iminência de novas reformas tributárias destinadas à eliminação do déficit público ${ }^{707}$.

\footnotetext{
${ }^{704}$ BALTHAZAR, Ubaldo Cesar. Op.cit., p. 176-177.

705 MORAES, Bernardo Ribeiro de. Compêndio de Legislação Tributária. Volume I. Op.cit., p. 169 e seguintes.

706 AMED, Fernando José; NEGREIROS, Plínio José Labriola de Campos. Op.cit., p. 286 e seguintes.

${ }^{707}$ Eleito Tancredo Neves o primeiro presidente posterior ao final o regime militar, faleceu 37 dias depois de tomar posse, sendo substituído pelo então vice-presidente José Sarney, cujo governo caracterizou-se por três planos econômicos (Plano Cruzado, Plano Bresser e Plano Verão), tendo por consequência o congelamento e
} 
Em meio à forte crise econômica, na década de oitenta, as discussões mais intensas sobre a tributação focavam-se na perspectiva da nova assembleia constituinte, necessária para aquela diferenciada realidade política, econômica e social.

Através do Projeto de Emenda Constitucional n.43 de 1985, o então Presidente da República convocou a Assembleia Nacional Constituinte, a ser realizada na sede do Congresso Nacional em 01 de janeiro de 1987, posteriormente convertida em Emenda Constitucional n.26/1985, em 27 de novembro de 1985, pela Mesa da Câmara dos Deputados e do Senado Federal. A partir desse período, iniciam-se os trabalhos preparatórios que levariam à ulterior Constituição.

Em 18 de Julho de 1985, foi instituída Comissão Provisória de Estudos Constitucionais (Decreto n.91.450/1985), com o objetivo de redigir o Anteprojeto Constitucional que, depois de aproximadamente 14 meses, foi publicado em 1986 no Diário Oficial, conhecido na época como “Anteprojeto Afonso Arinos de Melo Franco", foi debatido e elaborado por Comissão Provisória de Estudos Constitucionais, do qual participaram, entre outros, Gilberto Ulhôa Canto e Miguel Reale ${ }^{708}$.

Essa informação pode ser comprovada já em trabalhos antecedentes à Constituinte, pois nota-se que, na elaboração do Anteprojeto Afonso Arinos, graças à participação de Gilberto Ulhôa Canto, e aos esforços de tributaristas capitaneados por Ives Gandra Martins, a participação da doutrina tributária nacional foi essencial. ${ }^{709}$

preços e salários, reforma monetária, entre outros dispositivos heterodoxos, mas fracassando no controle inflacionário. Idem.

${ }^{708}$ ANTEPROJETO CONSTITUCIONAL, elaborado pela Comissão Provisória de Estudos Constitucionais, instituída pelo Decreto $\mathrm{n}^{\circ}$ 91.450, de 18 de julho de 1985. Diário Oficial. Suplemento Especial ao n.185. Sexta-Feira, 26 de setembro de 1986, Brasília - DF, p. 03 e seguintes.

${ }^{709}$ No substrato tributário, o Anteprojeto contou com a participação ativa dos tributaristas mais destacados do período, conforme testemunha Ives Gandra Martins. Chegou-se, no Instituto de Advogados de São Paulo, a elaborar proposta de Anteprojeto (tributário), que iniciou seus trabalhos paralelamente à Constituição Afonso Arinos, organizando Comissão do qual participaram membros do Instituto de Advogados de São Paulo e da Associação Brasileira de Direito Financeiro, através de Gilberto Ulhôa Canto. Participaram por São Paulo Geraldo Ataliba, Ruy Barbosa Nogueira, Hamilton Dias de Souza, Alcides Jorge Costa, Marco Aurélio Greco, Ives Gandra Martins, e o economista Carlos Alberto Nobre; pelo Rio de Janeiro participaram Gilberto Ulhôa Canto, Carlos da Rocha Guimarães, Mairo Caldeira de Andrade e Gustavo Muniz de Melo. Esse Anteprojeto foi levado à Comissão Afonso Arinos pelo Prof. Gilberto Ulhôa Canto, recebendo, segundo Ives Gandra Martins, cerca de $80 \%$ a $90 \%$ de aprovação. Posteriormente, o Anteprojeto também contou com a colaboração de Celso Ribeiro Bastos, Hely Lopes Meirelles, Cláudio Mesquita Pereira e Cássio Mesquita de Barros Junior e, após, foi reapresentado pelo próprio Ives Gandra Martins por ocasião da Assembleia Nacional Constituinte à Subcomissão de Tributos. MARTINS, Ives Gandra. O Sistema Federativo e a Organização Tributária. In: ANEXO À ATA DA $6^{a}$ REUNIÃO, REALIZADA EM 29-4-87 E PUBLICADA NO SUPLEMENTO AO DANC $\mathrm{N}^{\circ}$ 53, DE 19-5-87, p. 99. In: ANAIS DO SENADO 
O Sistema Tributário, previsto naquele Anteprojeto entre os artigos 133 e 149, embora mais sintético, já guardava muitas características a serem consagradas na versão final promulgada, antevendo as principais metas almejadas com a reforma constitucional: “Art. 133 - A política tributária tem por objetivo: I - prover o Estado dos recursos necessários ao financiamento de suas atividades; II - realizar a correção de desigualdades sócio-econômicas entre Estados, Municípios, regiões e grupos sociais; III - incentivar o desenvolvimento nacional (...)" ${ }^{, 710}$, preocupando-se em garantir melhor distribuição de rendas entre a União (artigo 137), Estados, Distrito Federal (artigo 138) e Municípios (artigo 139), assim como aos princípios e imunidades (artigos 135 e 136), e da participação e distribuição de receitas entre os entes (art.141 a 147). Note-se que a capacidade contributiva, curiosamente, constava prevista nas disposições finais e transitórias, no último artigo $(149)^{711}$.

Na versão final promulgada pela Constituição de 1988, dentre inúmeros dispositivos que diretamente ou indiretamente se referiram à matéria tributária, a temática tributária foi incluída no Título IV (Tributação e do Orçamento), no Capítulo I (Do Sistema Tributário Nacional), e notadamente, elevaram-se os princípios constitucionais e as imunidades tributárias (artigos 150 e 151$)^{712}$.

FEDERAL (ATAS DE COMISSÕES). Subcomissão de Tributos, participação e distribuições de receitas. Disponível em: www.senado.gov.br. (último acesso em 28.11.2014)

${ }^{710}$ ANTEPROJETO CONSTITUCIONAL, elaborado pela Comissão Provisória de Estudos Constitucionais, instituída pelo Decreto ${ }^{\circ}$ 91.450, de 18 de julho de 1985. In: ANAIS DO SENADO FEDERAL (ATAS DE COMISSÕES). Subcomissão de Tributos, participação e distribuições de receitas. Disponível em: www.senado.gov.br. (último acesso em 28.11.2014), p. 22.

711 "Art. 149 - Os tributos terão caráter pessoal, sempre que isso for possível, e serão graduados pela capacidade econômica do contribuinte segundo critérios fixados em lei complementar, que assegurará às pequenas e microempresas tratamento tributário compatível com a sua receita bruta". Idem.

712 Por isso, o art.150 da Constituição de 1988 estabelece as limitações ao poder de tributar à União, aos Estados, ao Distrito Federal e aos Municípios, como o princípio da legalidade tributária (I), igualdade (II), bem como no inc. III, a irretroatividade (a), anterioridade (b), anterioridade nonagesimal (c) (atualmente acrescentado pela EC n.42 de 2003), vedação do efeito confisco (IV), limitação ao tráfego de pessoas ou bens por tributos interestaduais ou intermunicipais, com exceção do pedágio, incluindo-se no inciso VI a previsão expressa de algumas imunidades sobre impostos, dentre as quais, a imunidade recíproca (a), imunidade de templos (b), imunidade do patrimônio, renda ou serviços (vinculados às suas finalidades essenciais) dos partidos políticos - e suas fundações-, entidades sindicais, instituições de educação e assistência social sem fins lucrativos (imunidade condicionada), imunidade de jornais, livros, periódicos e do papel destinado à sua impressão, entre outras especificações nos parágrafos $1^{\circ}$ a $7^{\circ}$. Por outro lado, o art.151 estabelece princípios a serem cumpridos pela União, dentre os quais, o princípio da uniformidade territorial, bem como a vedação de “(...) tributar a renda das obrigações da dívida pública dos Estados, do Distrito Federal e dos Municípios, bem como a remuneração e os proventos dos respectivos agentes públicos, em níveis superiores aos que fixar para suas obrigações e para seus agentes", assim como "III - instituir isenções de tributos da competência dos Estados, do Distrito Federal ou dos Municípios". 
Note-se que o art. 145 já consagrava tradicionalmente a competência dos entes tributantes sobre a instituição de impostos (I), taxas (II) e contribuições de melhoria (III), ainda que não tenha incluído, como no Anteprojeto Afonso Arinos, as contribuições sociais entre suas modalidades no mesmo dispositivo. Além disso, o destaque aparece já no seu $\S$ $1^{\circ}$, ao estabelecer o respeito da atividade tributária à pessoalidade e à capacidade econômica do contribuinte, ${ }^{713}$ princípio que já havia sido colocado entre os primeiros dispositivos do Capítulo, mas afastando, por outro lado, no $\S 2^{\circ}$, a identidade de bases de cálculo entre taxas e impostos, objetivo largamente perseguido nos debates dos Anais da Comissão de Tributos da Assembleia Nacional Constituinte.

No peculiar ambiente ligeiramente anterior à Constituição de 1988, a necessidade de reformas tributárias buscava atender, como relata Bernardo Ribeiro de Moraes, maior descentralização e fortalecimento da autonomia dos Estados e Municípios, atenuação dos desequilíbrios regionais do país, maior justiça fiscal e melhor proteção ao contribuinte, simplificação da tributação e adaptação às mudanças do sistema produtivo, maior garantia de uniformidade nacional ao sistema tributário, maior respeito aos seus princípios básicos, sobretudo na preservação da lei complementar em matéria tributária, a crescente progressividade dos impostos sobre produtos industrializados e a criação de novos impostos, no intuito de elevar a arrecadação ${ }^{714}$.

O produto dessas preocupações pode ser observado no texto final da Constituição de 1988, já que, conforme o art. 146 estabelecem-se as funções da Lei Complementar em matéria tributária, reforçando a polêmica acerca das normas gerais em matéria tributária no sistema tributário brasileiro ${ }^{715}$.

Historicamente, segundo relata Francisco Dornelles, em conformidade com a Emenda Constitucional n.26/1985, os trabalhos da Assembleia Nacional Constituinte iniciaram-se no ano de 1987 e foram distribuídos em subcomissões temáticas. Nesse

\footnotetext{
713 “\$ $1^{\circ}$ - Sempre que possível, os impostos terão caráter pessoal e serão graduados segundo a capacidade econômica do contribuinte, facultado à administração tributária, especialmente para conferir efetividade a esses objetivos, identificar, respeitados os direitos individuais e nos termos da lei, o patrimônio, os rendimentos e as atividades econômicas do contribuinte".

${ }_{714}^{714}$ MORAES, Bernardo Ribeiro de. Compêndio de Legislação Tributária. Op.cit., p. 169-171.

${ }^{715}$ Assim, o art. 146 fixa: "Cabe à lei complementar: I - dispor sobre conflitos de competência, em matéria tributária, entre a União, os Estados, o Distrito Federal e os Municípios; II - regular as limitações constitucionais ao poder de tributar; III - estabelecer normas gerais em matéria de legislação tributária (...). Posteriormente a doutrina tributária divide-se quanto às funções da lei complementar (e das normas gerais) no direito tributário brasileiro. Para uma contextualização histórica do assunto, conferir: AMARO, Luciano. Direito Tributário Brasileiro. $11^{\text {a }}$ Edição. São Paulo: Editora Saraiva, 2005, p. 168-170.
} 
contexto, a temática tributária foi objeto de análise liderada por Benito Gama e Fernando Bezerra Coelho, e o Anteprojeto acabou aprovado em 25 de maio de 1987, cuja proposta acabou consolidada com a de outras duas subcomissões, que por sua vez analisaram os orçamentos e o sistema financeiro, dentro da Comissão temática (que possuía 62 participantes).

O Anteprojeto de Constituição Tributária e Financeira foi objeto dos trabalhos da Comissão do Sistema Tributário, Orçamento e Finanças ${ }^{716}$ que, por sua vez, incluiu a Subcomissão de Tributos, Participação e Distribuição de Receitas, a Subcomissão de Orçamento e Fiscalização Financeira e a Subcomissão do Sistema Financeiro.

Na Subcomissão de Tributos nota-se preocupação em ouvir os principais expoentes doutrinários da época, no intuito de oferecer trabalhos harmônicos com a doutrina nacional. $^{717}$.

E prossegue: "Depois de ouvirmos os Professores Fernando Rezende, Geraldo Ataliba, Alcides Jorge da Costa e Carlos Alberto Longo, ouviríamos um bloco de tributaristas regionais." Nesse contexto, além de Alcides Jorge Costa e Geraldo Ataliba ${ }^{718}$, foram lembrados, entre possíveis expositores, os tributaristas Hugo de Brito Machado, José

\footnotetext{
${ }^{716}$ Membros da Comissão: Presidente Jutahy Magalhães, Affonso Camargo, Jutany Magalhães, Airton Sandoval, Domingos Juvenil, Fernando Bezerra Coelho, Geraldo Fleming, Iraja Rodrigues, lvo Vanderlinde, Nion Albernaz, Osmundo Rebouças, Gerson Camata, Benito Gama, Jesus Tajra, José Tinoco, Mussa Demes, Simão Sessim, Carlos Virgilio, João Castelo, Adhemar de Barros filho, Virgilio Guimarães e José Maria Eymael, e o suplente Júlio Costamilan. In: ANAIS DO SENADO FEDERAL (ATAS DE COMISSÕES). Subcomissão de Tributos, participação e distribuições de receitas. Disponível em: www.senado.gov.br. (último acesso em 28.11.2014)

717 É o que se conclui da leitura do seguinte trecho do Constituinte Benito Gama, na Ata da Subcomissão: "Quanto às convocações extraordinárias, o Plenário irá decidir, de acordo com sua necessidade. Na parte da manhã, ouviríamos o Prof. Fernando Rezende; à tarde, às 17h, convidaríamos o Prof. Geraldo Ataliba para fazer uma exposição e apresentar seus pontos de vista perante o Plenário. Seria uma convocação da Subcomissão, utilizando o plenário da Comissão Temática. No dia 23, quinta-feira, pela manhã para completar nossa visão crítica, estudarmos e debatermos, poderíamos convidar o Prof. Alcides Jorge da Costa, da Universidade de São Paulo, tributarista emérito, tido como um dos mais brilhantes no setor, que apresentaria também suas idéias sobre o sistema tributário do Brasil, tanto no que se refere à experiência do atual como o que ele pensa deve existir no futuro. No mesmo dia, para a parte da tarde, convidaríamos o Prof. Carlos Alberto Longo, também da USP, pessoa de alta qualificação no setor, advogado brilhante". Ata da Subcomissão de Tributos, participação e distribuição de receitas. In: ANAIS DO SENADO FEDERAL (ATAS DE COMISSÕES). Subcomissão de Tributos, participação e distribuições de receitas. Op.cit., p. 11.

${ }^{718}$ A Conferência proferida por Geraldo Ataliba, intitulada "Dispositivos Constitucionais Pertinentes aos Tribunais de Contas - Proposta para Discussão do Tribunal de Contas - Proposta para Discussão do Tribunal de Contas do Estado de São Paulo", e sugestões podem ser observadas Ata da Quarta Reunião ordinária, com audiência pública, realizada em 24-4-87. In: ANAIS DO SENADO FEDERAL (ATAS DE COMISSÕES). Op.cit., p. 49-59.
} 
Souto Maior Borges, Ives Gandra Martins, Edvaldo Brito ${ }^{719}$, Osiris de Azevedo Lopes Filho, entre muitos outros conferencistas ${ }^{720}$, para proferir exposições destinadas ao aperfeiçoamento do Projeto.

A Subcomissão buscou aperfeiçoar seus estudos relativos ao projeto contando com a colaboração dos mais destacados tributaristas da época. ${ }^{721}{ }_{-}^{722} \mathrm{O}$ Anteprojeto da Subcomissão de Tributos, distribuição e participação contou com 25 artigos, já com estrutura bastante assemelhada ao texto final da Constituição, que, naturalmente, foi submetida a alterações e emendas posteriores ${ }^{723}$, resultantes no texto final da Constituição de 1988, já acima descrita.

Assim como Bernardo Ribeiro de Moraes, Dornelles parece concordar que os temas que mais detiveram atenção nos debates da reforma tributária constitucional foram a

\footnotetext{
${ }^{719}$ As atas das conferências realizadas por Ives Gandra Martins, José Souto Maior Borges e Edvaldo Brito podem ser observadas no anexo à Ata da $6^{\mathrm{a}}$ reunião, realizada em 29-4-87 e publicada no suplemento ao DANC N ${ }^{\circ}$ 53, DE 19-5-87. In: ANAIS DO SENADO FEDERAL (ATAS DE COMISSÕES). Subcomissão de Tributos, participação e distribuições de receitas. Disponível em: www.senado.gov.br. (último acesso em 28.11.2014), p. 99 e seguintes.

720 ANEXO A ATA DA $8^{\mathrm{a}}$ REUNIÃO REALIZADA EM 5-5-87, Às 10h20m E PUBLICADA NO SUPLEMENTO AO DANC $\mathrm{N}^{\circ}$ 56, de 8-5-87. In: ANAIS DO SENADO FEDERAL (ATAS DE COMISSÕES). Subcomissão de Tributos, participação e distribuições de receitas. Op.cit., p. 149 e ss.

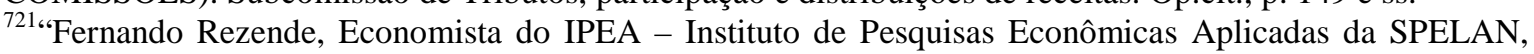
que apresentou o trabalho "A Reforma Tributaria e a Constituinte" e o Dr. Alcides Jorge Costa, Professor de Direito Tributário da Faculdade de Direito da USP, que apresentou os trabalhos "Alguns Princípios para um Sistema Tributário Nacional" e "Algumas Considerações sobre a Reforma Tributária". ATA DA TERCEIRA REUNIÃO, ORDINÁRIA, COM AUDIÊNCIA PÚBLICA, REALIZADA EM 22-4-87. In: ANAIS DO SENADO FEDERAL (ATAS DE COMISSÕES). Subcomissão de Tributos, participação e distribuições de receitas. Op.cit., p. 11-13.

722 “(...) Uma Constituição - e agora me refiro especificamente ao sistema tributário - não é um programa de governo. Por esta razão, não pode ser excessivamente pormenorizada. Caso contrário, ela se transforma num programa de governo. Ela vai atender às exigências de determinada conjuntura, mas vai envelhecer com uma rapidez muito grande. Com este fundamento em vista, isto é, o de construir um arcabouço que permita que o sistema constitucional - o sistema tributário constituído por leis ordinárias, regulamentos etc. - possa moverse". COSTA, Alcides Jorge. In: ATA DA TERCEIRA REUNIÃO, ORDINÁRIA, COM AUDIÊNCIA PÚBLICA, REALIZADA EM 22-4-87. In: ANAIS DO SENADO FEDERAL (ATAS DE COMISSÕES), $p$ 36-47. Em verdade, a participação de Alcides Jorge Costa, conforme revela Dornelles, não se limitou apenas à realização das conferências, mas também aconselhou por diversas vezes os constituintes na redação do projeto, sendo até considerado por Dornelles "membro" da Constituinte. O Prof. Alcides Jorge Costa foi citado como integrante do Assessoramento Técnico requisitado fora dos quadros do Congresso. Essa situação mostra que a Comissão contou com o apoio e sugestões de renomados tributaristas. DORNELLES, Francisco. In: ATA DA TERCEIRA REUNIÃO, ORDINÁRIA, COM AUDIÊNCIA PÚBLICA, REALIZADA EM 22-4-87, In: ANAIS DO SENADO FEDERAL (ATAS DE COMISSÕES). Op.cit., p. 3647.
}

${ }^{723}$ Anteprojeto da Subcomissão de Tributos, Distribuição e Participação. In: ANAIS DO SENADO FEDERAL (ATAS DE COMISSÕES). Subcomissão de Tributos, participação e distribuições de receitas. Op.cit.,p. 199-201. 
descentralização, o fortalecimento dos Estados e Municípios e a atenuação de desequilíbrios regionais ${ }^{724}$.

Naturalmente, ainda que a descentralização financeira seja aprimorada na Constituição de 1988, o amplo alcance da Competência da União Federal segue preservado, conforme se observa no art.147, que fixa a competência da União em Território Federal, assim como no art. 148, que estabelece competência da União para instituir, por lei complementar, empréstimos compulsórios. As Contribuições Sociais, ainda que não mencionadas expressamente no artigo 145, são incluídas majoritariamente na competência da União (artigo 149). ${ }^{725}$

A busca pelo equilíbrio na distribuição de competências tributárias entre União, Estados, Distrito Federal e Municípios pode ser observada nos artigos 153 a $156^{726}$, assim como na repartição de receitas tributárias (artigos 157 a 162), equilíbrio que se vislumbra também no art.152, ao estabelecer o já antigo princípio da não-diferenciação tributária pelos Estados, ao Distrito Federal e aos Municípios entre bens e serviços, de qualquer natureza, em razão de sua procedência ou destino.

Fora do capítulo dedicado ao Sistema Tributário Nacional também se encontram importantes dispositivos tributários ${ }^{727}$, a exemplo da previsão expressa sobre contribuições previdenciárias (art.195), assim como disposições conexas sobre matéria financeira no Capítulo II (Finanças Públicas) ${ }^{728}$.

Sobre as principais alterações tributárias trazidas pela Constituição de 1988 frente às anteriores,
recomenda-se: DORNELLES, Francisco. O Sistema Tributário da Constituição de 1988. Disponível em:
www.dornelles.com.br (último acesso em $22 / 10 / 2014$ ), p. 06-08. Também confira-se: AMED, Fernando
José; NEGREIROS, Plínio José Labriola de Campos. Op.cit., p. 294 e ss.
${ }_{725}$ Mas ressalve-se que o $\S 1^{\circ}$, posteriormente incorporado, autorizou aos Estados, o Distrito Federal e os
Municípios instituirão contribuição, cobrada de seus servidores, para o custeio, em benefício destes, do
regime previdenciário. Posteriormente também foi criado o art.149-A concedendo possibilidade dos
Municípios e Distritos Federais instituírem contribuição de iluminação pública.
${ }_{726}$ Já no art.153 há a previsão expressa da competência da União para a instituição de determinados impostos.
Nesse aspecto também se destaca o art.154, que estabelece a competência da União para instituir novos
impostos, desde que cumprindo determinados requisitos (I), e impostos extraordinários (II). O art. 155 trata
da competência para a instituição de determinados impostos pelos Estados e Distrito Federal.
${ }_{727}$ No art. 170 incluem-se também os princípios gerais da atividade econômica. Também se destaca, no art.
182 , a progressividade do IPTU, como instrumento de política urbana (II), e no art.184 (política agrícola e
fundiária e da reforma agrária), a seguinte imunidade: “(...) § $5^{\circ}$ - São isentas de impostos federais, estaduais
e municipais as operações de transferência de imóveis desapropriados para fins de reforma agrária”.
728 No Capítulo II, a Constituição trata das regras atinentes às Finanças Públicas, estabelecendo no art. 163
que a Lei complementar deverá dispor sobre essa matéria, além de outras pertinentes, como a competência da
União para emissão de moeda, exercida pelo Banco Central (art. 164). Finalmente, nos arts.165 a 169 , tem- 
Note-se, portanto, que há maior preocupação ao equilíbrio orçamentário para viabilizar a autonomia municipal, distrital e estadual, frente à União, ainda que a esta última tenha sido atribuída a competência residual (a novos impostos e novas contribuições sociais).

\subsection{A tentativa de criação de justiça tributária especializada no período de redemocratização (autonomia do contencioso judicial tributário).}

Finalmente, é importante ressaltar que, nos debates que antecederam à Constituição de 1988, foi levantada por Miguel Reale a proposta de criação de um Tribunal especializado em julgar dissídios judiciais tributários.

Miguel Reale, reconhecendo a crise do poder judiciário ${ }^{729}$ (aquela mesma já mencionada por Rubens Gomes de Sousa no capítulo 1), buscou alternativas à luz do exemplo francês, italiano e norte-americano, para desafogar o judiciário considerando, pragmaticamente, as matérias que possuíam maior número de lides no poder judiciário.

se as regras disciplinadoras do Orçamento, além dos dispositivos tributários previstos nas disposições constitucionais transitórias.

${ }^{729}$ Pede-se licença para reproduzir, na íntegra, a síntese do pensamento de Reale sobre a crise do poder judiciário na época, e a importância da criação de justiças especializadas administrativas e tributárias: "Bom, tem se falado muito na crise do poder judiciário e é um problema extremamente complexo. Eu daria três razões para, talvez, poder resolver a crise. Em primeiro lugar, a crise do judiciário decorre da contradição que existe na nossa legislação, sobretudo a processual civil e processual penal. Nós somos muito zelosos das chamadas garantias de privilégio individuais. E, em razão dessas garantias e privilégios, criamos recursos de tudo quanto é espécie, incidentes processuais de toda ordem, de maneira que um bom advogado faz com que dure anos uma ação que, na realidade, deveria durar pouco se os nossos tribunais tivessem organização americana, mais popular e menos tribunícia. Esse é o primeiro fato que eu trago como razão da crise. O segundo é a própria estrutura do nosso poder judiciário que deveria passar por uma modificação, não que eu seja, por exemplo, a favor da extinção da Justiça Trabalhista, mas a Justiça Trabalhista não deve ser corporativa, não deve ter representação de classe, nem na primeira e muito menos na segunda ou terceira instância. Então, outras reformas tinham que ser feitas... Sobretudo uma reforma de distribuição de competência, o que quer dizer isso? Nós devemos olhar a situação judicial no país e fazer a pergunta: qual é o maior número de ações que estão entupindo os tribunais? São as ações administrativas e fiscais. São ações movidas contra a União, os estados e os municípios, então, são ações de natureza administrativa ou tributária. Sendo assim, nós devíamos olhar para esse aspecto e criar aquilo que eu chamo de Justiça Tributária. Durante muitos anos, eu lutei para que se fosse criado o contencioso administrativo. Por que não criou o contencioso administrativo, como na França ou Itália, para julgar as questões em que o interesse público era interesse administrativo, que está entulhando a Justiça comum? Mas imediatamente surge o abstratismo jurídico que declara: "nenhuma lesão de direito deve ser subtraída ao conhecimento do poder judiciário". E nós vivemos com essas fórmulas que podiam ser contemporizadas, bastaria criar a Justiça Administrativa, já que não se quer que haja sempre justiça. É um exemplo que eu estava dizendo.” REALE, Miguel. Entrevista concedida ao programa Roda Viva. Disponível em: http://www.rodaviva.fapesp.br/materia/727/entrevistados/miguel_reale_2000.htm (último acesso em $11 / 05 / 2015$. 
Constatando que as matérias de ordem administrativa e tributária figuravam entre as de maior incidência de apreciação do poder judiciário na época, propôs imediatamente a criação de justiça administrativa especializada (à luz do exemplo francês), e justiça tributária especializada, levando-as à Assembleia Nacional Constituinte encarregada da criação da Constituição de 1988.

Em outras palavras, tencionava-se a criação de uma justiça tributária especializada, à luz da justiça do trabalho e da justiça eleitoral, destinada à concentração de lides fiscais em um único sistema judicial. A premissa, absolutamente compreensível, tanto pela relevância temática como pela possibilidade de julgamentos mais técnicos e céleres no âmbito do direito tributário, inspirava-se em exemplos estrangeiros do contencioso tributário, a exemplo do Tribunal Fiscal Alemão.

Por outro lado, a proposta levantada por Miguel Reale não foi adiante, sobretudo pelos pesados compromissos políticos condicionados à aprovação do Projeto, especialmente do setor dos representantes das grandes propriedades rurais no Congresso na Comissão de Reforma Agrária ${ }^{730}$.

Esse momento histórico no Brasil foi o mais significativo para a possibilidade da criação de um contencioso judicial tributário próprio (pela expectativa da autonomia do contencioso judicial tributário perante outras justiças - ordinária e especializadas).

Como a proposta não foi adiante nos debates que antecederam à Constituição de 1988, a proposta acabou "esquecida".

De qualquer forma, tal "derrota" não impediu que a matéria tributária (e o equilíbrio entre distribuição de rendas tributárias) alcançasse grande atenção nos debates que antecederam ao texto final da Constituição de 1988.

13. A elevação normativa dos princípios no sistema constitucional tributário brasileiro e a recepção tardia do neoconstitucionalismo no Brasil.

\footnotetext{
${ }^{730}$ É curioso notar que, embora notoriamente lembrado e difundido pela doutrina nacional da época, a questão da criação do contencioso tributário judicial especializado sequer foi objeto de efetiva atenção na versão final das Atas da Assembleia Nacional Constituinte.
} 


\subsection{O neoconstitucionalismo tardio na Constituição de 1988.}

$\mathrm{O}$ neoconstitucionalismo ${ }^{731}$ europeu chegou tardiamente à realidade brasileira. Fruto das profundas transformações políticas e sociais vivenciadas após o final da Segunda Guerra Mundial consolidou-se especialmente pela elevação do movimento constitucional democrático pautado na extensão e rigidez da Constituição, que passa a adquirir "força normativa", assim como na defesa dos direitos e garantias fundamentais (sobretudo na elevação das "gerações de direitos fundamentais"), declaradas na Declaração dos Direitos Fundamentais da ONU (1948), e absorvidas pela constitucionalização posterior à derrocada de regimes antidemocráticos vislumbrados na Europa. A dignidade da pessoa humana passa a exercer núcleo central na investigação dos estudos constitucionais europeus.

O novo processo constitucionalista que resulta dessas substanciais transformações históricas pauta-se em três perspectivas: a) histórica; b) filosófica e; c) teórica ${ }^{732}$.

O marco histórico liga-se ao período pós-guerra e ao processo de redemocratização pelo qual a Europa passou naquele período. Evidentemente, conforme já observado, a Lei Fundamental de Bonn (1949) e a criação do Tribunal Constitucional Federal Alemão (1951), impulsionou rica produção teórica e jurisprudência, sendo diretamente responsável pela “(...) ascensão científica do direito constitucional no âmbito dos países de tradição romano-germânica" ${ }^{, 733}$. Ao mesmo tempo, também se registra a Constituição italiana de 1947, assim como a subsequente criação da Corte Constitucional italiana (1956). A esse processo segue-se ao constitucionalismo democrático decorrente do final de regimes totalitários, como em Portugal (1976) e Espanha (1978). Em outras palavras, busca-se

\footnotetext{
731 "O novo direito constitucional, fruto das transformações narradas neste capítulo, tem sido referido, por diversos autores, pela designação de neoconstitucionalismo. O termo identifica, em linhas gerais, o constitucionalismo democrático do pós-guerra, desenvolvido em uma cultura filosófica pós-positivista, marcado pela força normativa da Constituição, pela expansão da jurisdição constitucional e por uma nova hermenêutica. Dentro dessas balizas gerais, existem múltiplas vertentes neoconstitucionalistas. Há quem questiona e efetiva novidade dessas ideias, assim como seus postulados teóricos e ideológicos. Mas a verdade é que, independentemente dos rótulos, não é possível ignorar a revolução profunda e silenciosa ocorrida no direito contemporâneo, que já não s assenta apenas em um modelo de regras e de subsunção, nem na tentativa de ocultar o papel criativo dos juízes e tribunais. Tão intenso foi o ímpeto dessas transformações que tem sido necessário reavivar as virtudes da moderação e da mediania, em busca de equilíbrio entre valores tradicionais e novas concepções”. BARROSO, Luís Roberto. Direito Constitucional Contemporâneo. Op.cit., p. 288-289. Para uma crítica ao neoconstitucionalismo, conferir: ÁVILA, Humberto. Neoconstitucionalismo: entre a ciência do Direito e o Direito da ciência. In: NETO, Cláudio Pereira de Souza; BINENBOJM, Gustavo (Coordenação). Vinte anos da Constituição Federal de 1988. São Paulo: 2009, p. 187 e ss.

732 Idem, p. 267-288.

${ }^{733}$ BARROSO, Luís Roberto. Curso de Direito Constitucional Contemporâneo. Op.cit., p. 269 e ss.
} 
efetivar a força normativa da Constituição, diferentemente do que ocorria até o período anterior à Segunda Guerra. ${ }^{734}$

É perspicaz a lição de Konrad Hesse, adiantando o novo "perfil constitucional": “(...) a Constituição jurídica está condicionada pela realidade histórica. Ela não pode ser separada da realidade concreta de seu tempo. A pretensão de eficácia da Constituição somente pode ser realizada se se levar em conta essa realidade" ${ }^{, 735}$.

Evidentemente, o marco filosófico refere-se à construção do que se denominou "pós-positivismo", que se constrói através das insuficiências das duas grandes correntes de pensamento da época: jusnaturalismo e juspositivismo. Da superação (ou sublimação) desses modelos puros, surge um “(...) conjunto difuso e abrangente de ideias, agrupadas sobre o rótulo genérico de pós-positivismo" ${ }^{\text {736_ }}{ }^{737}$.

Situado no limiar entre o juspositivismo e o jusnaturalismo ${ }^{738}$, mas diferenciando-se de ambos, o pós-positivismo identifica-se como uma terceira via entre as concepções positivistas e naturalistas, não ignorando a importância da clareza, certeza e objetividade do direito, mas não desconsiderando também a necessidade de uma filosofia moral e de uma filosofia política, contestando o postulado positivista de separação entre direito e moral e política ${ }^{739}$. Nomes como Alexy ${ }^{740}$, Dworkin ${ }^{741}$, Hart, Habermas, Rawls, entre muitos outros, surgem como representantes ilustres dessas tendências, apresentando inerente vinculação aos direitos fundamentais ${ }^{742}{ }_{-}{ }_{73}$.

\footnotetext{
${ }^{734}$ HESSE, Konrad. A Força Normativa da Constituição. In: HESSE, Konrad. Temas Fundamentais de Direito Constitucional. Op.cit., p.125 e ss.

${ }^{735}$ Idem, p. 136-137.

${ }^{736}$ BARROSO, Luís Roberto. Curso de Direito Constitucional Contemporâneo. Op.cit., p. 269 e ss.

${ }^{737}$ Assim, a inspiração do pós-positivismo inspira-se na revalorização da razão prática, na teoria da justiça e na legitimação democrática, buscando ir além da legalidade estrita, embora não despreze o direito posto; e ainda que busque observar uma investigação jurídica (sem distanciar-se da moral) na Constituição e nas leis, recorre ainda assim a categorias metafísicas. BARROSO, Luís Roberto. Fundamentos Teóricos e Filosóficos do novo direito constitucional brasileiro (pós-modernidade, teoria crítica e pós-positivismo). Op.cit., p.27 e ss.

${ }^{738}$ Sobre o confronto entre "direito positivo" e "direito natural", suas ligações ao legalismo e ao Estado Moderno, conferir: SALDANHA, Nelson. Teoria do Direito e Crítica Histórica. Rio de Janeiro: Freitas Bastos, 1987, p. 153.

739 BARROSO, Luís Roberto. Fundamentos Teóricos e Filosóficos do novo direito constitucional brasileiro (pós-modernidade, teoria crítica e pós-positivismo). Op.cit., p.18-26.

${ }_{740}$ ALEXY, Robert. Teoria dos Direitos Fundamentais. Op.cit., p. 10 e ss.

${ }^{741}$ DWORKIN, Ronald. Levando os Direitos a sério. São Paulo: Martins Fontes, 2010, p. 205-315.

${ }^{742}$ Idem.

743 Sobre o assunto, também conferir: CALIENDO, Paulo. Direito Tributário. Três modos de pensar a tributação. Op.cit., p. 25- 27.
} 
Não é surpreendente que nesse período o estudo da justiça e da ética no Direito volta a ser impulsionado e o neokantismo passa a se fortalecer na literatura nacional, especialmente pela influência da obra de John Rawls ${ }^{744}$.

Na própria legalidade chega a ser desenvolvida a ideia de que “(...) a legalidade pode, exclusivamente, receber a sua legitimidade, de uma racionalidade de procedimento de grande valor moral" ${ }^{745}$. Passa-se a buscar o entrelaçamento entre direito, política e moral $^{746}$, como resposta ao afastamento entre os três prevalecentes no positivismo jurídico, como se observa em Habermas.

Logo, a legalidade (inclusive a tributária) não pode prescindir da sua conexão com a segurança e a justiça ${ }^{747}$.

Por outro lado, há aqueles que preferem manter, no pós-positivismo, um "positivismo moderado", conforme se autodenominou Herbert Hart, ao referir-se à crítica de Dworkin de que sua teoria caminharia por um "positivismo fático" (positivismo factual, na tradução portuguesa). De qualquer forma, mesmo Hart (à luz das tendências póspositivistas) apresentou importantes reflexões ligadas à discussão dos "juízos morais" frente ao direito ${ }^{748}$.

Entre as características identificáveis desse contexto histórico, podem-se citar: a) revalorização de normatividade aos princípios e de sua diferença qualitativa em relação às regras; b) reabilitação da razão prática e da argumentação jurídica; c) formação de uma nova hermenêutica; d) desenvolvimento de uma teoria de direitos fundamentais construída sobre a dignidade da pessoa humana ${ }^{749}$.

Note-se, portanto, uma reaproximação entre direito e ética no pós-positivismo, o que permite também maior atenção a determinados princípios que não haviam sido bem desenvolvidos até o período, como é o caso da própria dignidade da pessoa humana, da

\footnotetext{
${ }^{744}$ RAWLS, John. Uma Teoria da Justiça. São Paulo: Martins Fontes, 2002, p. 03 e ss.

${ }^{745}$ HABERMAS, Jürgen. Direito e Moral. Lisboa: Instituto Piaget, 1992, p. 15.

${ }^{746}$ HABERMAS, Jürgen. Direito e Moral. Lisboa: Instituto Piaget, 1992, p. 87 e ss.

${ }^{747}$ "Hoje, com o refluxo dos positivismos de diferentes matizes, a questão da legalidade tributária passa a se colocar de outra forma. O novo relacionamento entre Estado e Sociedade e a reaproximação entre direito e ética conduzem a que a legalidade seja vista no contexto mais amplo do equilíbrio entre segurança e justiça, da ponderação com os demais princípios constitucionais, da emergência dos conceitos indeterminados e da interação entre os Poderes do Estado, já pela concretização normativa por parte do poder regulamentar do Executivo, já pela judicialização das políticas públicas, inclusive fiscais e parafiscais". TORRES, Ricardo Lobo. Legalidade Tributária e Riscos Sociais. Op.cit., p.179. Sobre a "expulsão da lógica formal no campo prático do direito", conferir: SICHES, Luis Recasens. Nueva Filosofia de La Interpretación del Derecho. Mexico: Editorial Porrúa, 1980, p. 278-280.

${ }_{748}$ HART, Herbert. O conceito de Direito. 2. Ed. Lisboa: Fundação Calouste Gulbekian, 1994, p. 314-316.

${ }^{749}$ BARROSO, Luís Roberto. Curso de Direito Constitucional Contemporâneo. Op.cit., p. 269 e ss.
} 
proporcionalidade e da razoabilidade, que passam a ser objeto de estudos no âmbito do direito público ${ }^{750}{ }_{-}^{751}{ }_{-}^{752}$.

Naturalmente, a força do positivismo dogmático de matriz kelseniana na realidade do direito público brasileiro, conforme já observado, manteve-se firme e impulsionado pelo constitucionalismo de 1988. Porém, ao mesmo tempo, foi possível observar claras ponderações teóricas sobre as estruturas fundamentais do sistema constitucional tributário brasileiro.

Assim, deve-se reconhecer que a influência do neoconstitucionalismo, por sua vez fundada no reforço da defesa dos direitos fundamentais, chegou ao Brasil com certo atraso, e consolidou-se efetivamente somente a partir da Constituição de 1988, sobretudo através dos próprios direitos fundamentais estaria consolidada a abertura sistêmica à Constituição ${ }^{753}{ }_{-}^{754}$.

No âmbito sistemático constitucional tributário, a abertura passa a ser justificada pela elevação de caros princípios tributários progressivamente inseridos na Constituição Brasileira. Essa elevação apresenta motivações históricas, que merecem ser refletidas, pois interferem diretamente na forma de compreensão do processo histórico-disciplinar do Direito Tributário Brasileiro.

\subsection{Anotações históricas: a principiologia constitucional tributária no processo disciplinar do direito tributário brasileiro}

\footnotetext{
${ }^{750}$ Por fim, Barroso aponta que o marco teórico inerente ao neoconstitucionalismo é influenciado por três mudanças de paradigma: a) o reconhecimento da força normativa da Constituição: supera-se o modelo prevalecente até meados do século XX, onde a Constituição era vista apenas como documento essencialmente político, “(...) um convite à atuação do administrador”. Para Barroso, o debate da força normativa da Constituição só chegou de forma consistente na realidade brasileira na década de 80, o que não passou sem resistências; b) “(...) a expansão da jurisdição constitucional”: sobretudo inspirada na experiência americana da supremacia constitucional, expande-se a tendência da constitucionalização dos direitos fundamentais, a serem protegidos pelo próprio poder judiciário, através do controle de constitucionalidade das leis e dos atos administrativos; c) “(...) o desenvolvimento de uma nova dogmática da interpretação constitucional”: que, impulsionado pelo constitucionalismo democrático e normativo, pela expansão da jurisdição constitucional, assim como pela influência do pós-positivismo, segue-se à grandes modificações na hermenêutica jurídica, sobretudo na interpretação da Constituição. BARROSO, Luís Roberto. Curso de Direito Constitucional Contemporâneo. Op.cit., p. 273 e ss.

${ }^{751}$ BARROSO, Luís Roberto. Curso de Direito Constitucional Contemporâneo. Op.cit., p. 273 e ss.

752 BARROSO, Luís Roberto. Fundamentos Teóricos e Filosóficos do novo direito constitucional brasileiro (pós-modernidade, teoria crítica e pós-positivismo). In: A Nova Interpretação Constitucional. Ponderação, direitos fundamentais e relações privadas. BARROSO, Luís Roberto. (Organizador). 2 Ed. Rio de Janeiro: Renovar, 2006, p. 01-49.

${ }^{753}$ CANOTILHO, J.J. Gomes. Direito Constitucional e Teoria da Constituição. Op.cit., p. 1143.

${ }^{754}$ HESSE, Konrad. O Significado dos Direitos Fundamentais. Op.cit., p. 26 e ss.
} 
Inicialmente, o processo histórico do reconhecimento dos princípios tributários notabiliza-se pela inicial atenção ao caráter histórico dos princípios estabelecidos nas constituições de 1824 a 1946, e, não raramente, elaborando considerações à luz das contribuições trazidas pela Ciência das Finanças, Economia Política, Filosofia Política e pela literatura estrangeira fundacional. Pode ser caracterizada pela ausência de uma concepção sistemática jurídica dogmática clara frente ao direito tributário, o que se evidencia pela preferência da literatura na época ao delineamento das limitações constitucionais ao poder de tributar, ou à própria discriminação de rendas estabelecidas na constituição, amparados na sólida experiência estrangeira. Ainda que aparecesse em alguns autores da época, os princípios, ainda que reconhecidos juridicamente, ainda não são identificados claramente como espécies normativas que deveriam se interligar às regras de direito para compor o sistema jurídico normativo.

É claro que a transposição histórica para o Estado Fiscal ${ }^{755}$, onde já aparece a elevação do Estado de Direito, colabora para o desenvolvimento principiológico no direito tributário, ao passo que as "fases", "etapas" ou "gerações" de direitos fundamentais apresentam importância inequívoca nessa consolidação histórica ${ }^{756}$.

Nesse contexto, os princípios apareciam como nortes orientadores consagrados historicamente, ou mesmo construídos por outros campos do conhecimento onde a tributação encontrava espaço para reflexão, como na filosofia política e na Economia Política. Tome-se como exemplo o princípio da legalidade tributária, cuja origem remonta a Magna Charta, de 1215, mantendo-se firme em Cartas ou Declarações de Direitos, elevada por filósofos políticos e economistas da Idade Moderna, e consagrada gradualmente nas Constituições modernas no limiar do século $\mathrm{XIX}^{757}{ }_{-}^{758}{ }_{-}^{759}$.

A própria capacidade contributiva, princípio já identificável entre os primeiros estudiosos da Economia Política, como Willian Petty ${ }^{760}$, e, consagrado entre os princípios da tributação de Adam Smith ${ }^{761}$, Stuart Mill $^{762}$, e outros financistas, mostram que os

\footnotetext{
${ }^{755}$ TORRES, Ricardo Lobo. A Ideia de Liberdade no Estado Patrimonial e no Estado Fiscal. Op.cit., p. 97 e ss.

${ }^{756}$ Sobre as gerações de direitos fundamentais relativos à tributação, veja-se o Capítulo IV deste trabalho.

${ }^{757}$ BALEEIRO, Aliomar. Limitações Constitucionais ao Poder de Tributar. Op.cit., p. 01-02.

${ }^{758}$ MORAES, Bernardo Ribeiro de. Compêndio de Direito Tributário. Segundo Volume. $3^{\circ} \mathrm{Ed}$. Rio de Janeiro: Forense, 1995, p. 91-99.

${ }_{759}$ COMPARATO, Fabio Konder. A Afirmação Histórica dos Direitos Humanos. São Paulo: Saraiva, 2015 , p. 83 e ss

${ }^{760}$ PETTY, Willian. Tratado de Impostos e Contribuições. Trad. João Guilherme Vargas Neto. Os Economistas. São Paulo: Nova Cultural, 1996, p. 47 e ss.

${ }^{761}$ SMITH, Adam. A Riqueza das Nações. Investigação Sobre sua Natureza e suas Causas. Vol.II. Trad. Luiz João Baraúna. Os Economistas. São Paulo: Nova Cultural, 1996, p. 282-285.
} 
princípios da tributação apresentam origens históricas extrajurídicas e que somente depois seriam consagrados em ordenamentos jurídicos. A elevação dos princípios como limitadores à tributação aparece com bastante ênfase na literatura econômica, como se observa em Pietro Verri, Broggia, Von Justi, Lorde Kames e, contemporaneamente, Michel Bouvier, Marie-Christine Esclassan, Jean-Pierre Lassale ${ }^{763}$, Fritz Neumark ${ }^{764}$, Benvenuto Griziotti $^{765}$, Adolph Wagner ${ }^{766}$, Luigi Einaudi ${ }^{767}$, e outros financistas ${ }^{768}$. É claro que a tributação aparece como objeto de preocupação dos filósofos políticos modernistas, como Rousseau $^{769}$, Montesquieu ${ }^{770}$, John Locke ${ }^{771}$, entre muitos outros. A preocupação com limites previamente estabelecidos para proteger o cidadão nas relações tributárias aparece com ênfase nas obras acima mencionadas.

A principiologia constitucional tributária no Brasil naquele período foi também influenciada pela própria literatura jurídica europeia do direito público, antes mesmo de qualquer sinal de que o Direito Tributário seria autonomamente reconhecido, a partir da codificação tributária germânica, como se observa em Otto Mayer ${ }^{772}$ e MyrbachRheinfeld $^{773}$, seguindo-se reforçada na literatura tributária europeia posterior à codificação tributária germânica, onde se emanam Blumenstein ${ }^{774}$, Nawiasky ${ }^{775}$, Bühler ${ }^{776}$ ou mesmo Hensel $^{777}$.

\footnotetext{
${ }^{762}$ MILL, Stuart. Princípios de Economia Política. Com Algumas de suas Aplicações à Filosofia Social. Volume II. Trad. Luiz João Baraúna. Os Economistas. São Paulo: Nova Cultural, 1996, p. 375 e ss.

${ }^{763}$ BOUVIER, Michel; ESCLASSAN, Marie-Christine; LASSALE, Jean-Pierre. Op.cit., p. 576-583.

${ }^{764}$ NEUMARK, Fritz. Op.cit., 1974, p.71-72.

${ }^{765}$ GRIZIOTTI, Benvennuto. Principios de Política, Derecho y Ciencia de La Hacienda. Op.cit., p. 185 e SS.

${ }^{766}$ WAGNER, Adolph. Op.cit., p. 150 e 155-157.

${ }^{767}$ EINAUDI, Luigi. Corso di Scienza della Finanza. Quarta Edizione. Torino: Edizione della Rivista "La Riforma Sociale", 1926, p.03 e ss.

768 JARACH, Dino. Finanzas Públicas y Derecho Tributario. Tercera Edición. Buenos Aires: AbeledoPerrot, 1996, p.297-299.

${ }^{769}$ ROUSSEAU, Jean-Jacques. Do Contrato Social. Trad. Pietro Nassetti. $3^{\circ}$ Edição. São Paulo: Martin Claret, p. 48.

${ }^{770}$ MONTESQUIEU, Do Espírito das Leis. Trad. Jean Meville. São Paulo: Martin Claret, p.221-234.

${ }^{771}$ LOCKE, John. Segundo Tratado sobre o Governo. Os Pensadores. Trad. Anoar Aiex e E.Jacy Ribeiro. São Paulo: Abril Cultural, 1978, p. 90.

${ }_{772}$ MYRBACH-RHEINFELD, Franz Von. Op.cit., p. 115-123.

${ }^{773}$ Idem, p. 116 e ss.

${ }^{774}$ BLUMENSTEIN, Ernst. Op.cit., p. 09.

${ }^{775}$ NAWIASKY, Hans. Op.cit., p. 68-138

${ }^{776}$ BÜHLER, Ottmar. Op.cit., p.15-16.

${ }^{777}$ HENSEL, Albert. Op.cit., p. 71-72.
} 
Na Itália, a percepção era semelhante, mesmo em ambiente pretérito à Constituição de 1947, a exemplo de Vanoni ${ }^{778}$ e Giannini, que, ao considerar a principiologia tributária, não deixou de vinculá-la à contribuição de Adam Smith ${ }^{779}$.

A principiologia constitucional tributária, sobretudo no estudo da capacidade contributiva, encontra em Griziotti ${ }^{780}{ }^{781}$ um de seus maiores defensores na realidade teórica europeia, sendo, porém, reconhecida também em estudiosos cujas análises sobre os princípios constitucionais tributários tornaram-se célebres, como é o caso de Antonio Berliri $^{782}$ e Benedeto Cocivera ${ }^{783}$.

No Brasil, assim, no período pré-disciplinar até o período de consolidação incial disciplinar (até meados da década de cinquenta do século XX), apesar de alguns princípios serem facilmente identificáveis nas primeiras constituições, os estudiosos da época quase sempre os remetiam à construção extrajurídica. Se na realidade estrangeira, o panorama era esse, não havia porque esperar situação distinta da realidade brasileira, onde inexistia a noção de princípios constitucionais tributários enquanto espécies normativas componentes de um sistema jurídico dogmaticamente hierarquizado.

Essa percepção é extraída dos Comentários à Constituição de 1946, de Pontes de Miranda, onde, ao referir-se a determinados princípios constitucionais tributários, pautavase não raras vezes a elementos das Ciências Econômicas, como é o caso do princípio da capacidade contributiva, imediatamente ligada por Pontes de Miranda à contribuição histórica de Adam Smith ${ }^{784}$, tendência seguida por Carlos Maximiliano nos seus Comentários à Constituição de $1946^{785}$.

Não é surpresa, afinal, que a década de cinquenta registre como ápice as primeiras obras expressamente dedicadas ao Direito Constitucional Tributário na realidade tributária brasileira.

Esse contexto de fortes contribuições na senda do direito constitucional tributário e na visão principiológica como melhor exposição dos limites ao exercício do poder

\footnotetext{
${ }^{778}$ VANONI, . Op.cit., p. 110 e ss. Posteriormente reproduzida em VANONI, Ezio. Opere Giuridiche. II. Elementi di diritto Tributário. Op.cit., p. 52-70.

${ }_{779}$ GIANNINI, A.D. Il Rapporto Giuridico D'Imposta. Op.cit., p. 02-25.

${ }^{780}$ GRIZIOTTI, Benvennuto. Op.cit., p. 176 e ss.

${ }^{781}$ Idem, p. 185 e ss.

${ }^{782}$ BERLIRI, Antonio. Principi di Diritto Tributário. Volume I. Op.cit, p. 27-53.

${ }^{783}$ COCIVERA, Benedetto. Principî di Diritto Tributário. Volume I. Milano: Dott. A. Giuffrè - Editore, 1959, p.01-05.

${ }^{784}$ MIRANDA, Francisco Cavalcanti Pontes de. Comentários à Constituição de 1946. Vol. I (arts 1-36). Rio de Janeiro: Livraria Boffoni, 1946, p 267-268.

${ }^{785}$ MAXIMILIANO, Carlos. Comentários à Constituição Brasileira. Quarta edição. Volume II. Rio de Janeiro: Livraria Freitas Bastos, 1948, p. 166 e seguintes; 265 e seguintes.
} 
tributário, logo repercute na realidade tributária brasileira, como se observa nas obras de Carvalho Pinto ${ }^{786}$, ainda que com fortes influências da Ciência das Finanças, mas identificando-se com força na notável contribuição de Aliomar Baleeiro ${ }^{787}$, elegendo os princípios constitucionais tributários enquanto verdadeiras limitações ao poder de tributar.

Para Baleeiro “(...) o poder de tributar, na Constituição, é regulado segundo rígidos princípios que deitam raízes nas próprias origens históricas e políticas do regime democrático por ela adotado. Vários desses princípios abrigam limitações ao exercício daquele poder e não apenas à competência tributária. (...)"788.

Essa tendência segue reforçada nas obras alinhadas ao direito constitucional tributário em meados da década de sessenta, a exemplo de Amílcar de Araújo Falcão ${ }^{789}{ }^{790}$, Ruy Barbosa Nogueira ${ }^{791}$, Antonio Roberto Sampaio Dória ${ }^{792}$, entre outros.

Mas note-se que, na época, a tendência teórica ao estudo dos princípios constitucionais tributários facilitava que estudiosos do período elevassem os princípios com forte conteúdo axiológico, e vinculando-os não raramente a considerações extrajurídicas ou provenientes de realidades estrangeiras.

A década de sessenta, porém, é caracterizada pelo progressivo reforço do dogmatismo normativo sistemático aplicado ao direito constitucional tributário, seja pelos delineamentos de Alfredo Augusto Becker $^{793}$, seja pela elevação dos princípios constitucionais tributários nas obras de Antonio Roberto Sampaio Dória ${ }^{794}$, que, junto da obra de Aliomar Baleeiro, foi sempre lembrada por esses doutrinadores, ou a perspectiva

\footnotetext{
${ }^{786}$ CARVALHO PINTO, Carlos Alberto A. Op.cit., p. 145 e ss.

787 "As constituições brasileiras do período republicano, em contraste com a velha Carta monárquica outorgada em 1824, inscreveram, em suas disposições, vários princípios disciplinadores da tributação. O convívio de três competências fiscais simultâneas obre o mesmo campo econômico, por efeito do regime federal, explica, em grande parte, a presença dessas regras, algumas das quais, expressas no Direito Constitucional brasileiro, encontram origem na construction de tribunais americanos". BALEEIRO, Aliomar. Limitações Constitucionais ao Poder de Tributar. Op.cit., p. 11 e seguintes.

${ }^{788}$ BALEEIRO, Aliomar. Direito Tributário Brasileiro. $11^{\circ}$ Ed. Rev. e Atual. por Misabel Derzi. Rio de Janeiro: Forense, 2000, p. 90.

${ }^{789}$ FALCÃO, Amílcar de Araújo. Introdução ao Direito Tributário. Rio de Janeiro: Editora Rio, 1976, p. 39-44.

${ }^{790}$ FALCÃO, Amílcar de Araújo. Sistema Tributário Brasileiro. Discriminação de Rendas. Op.cit., p. 2548.

${ }^{791}$ NOGUEIRA, Ruy Barbosa. Da Interpretação e da Aplicação das Leis Tributárias. Op.cit., p. 12-13.

792 Sampaio Dória optou por analisar os princípios constitucionais tributários, dedicando especial atenção aos seguintes: a) inexistência à contraprestação direta pela cobrança de impostos, mas seu reconhecimento no caso das taxas e contribuições de melhoria; b) necessidade de destinação pública da receita tributária; c) limitação da competência tributária do Estado aos fatos, atos, negócios ou pessoas vinculadas a seu território; d) vedação de tributos confiscatórios e impeditivos de atividades lícitas; e) respeito à capacidade contributiva objetiva do sujeito passivo tributário". DÓRIA, Antonio Roberto Sampaio. Princípios Constitucionais Tributários e Cláusula Due Process of Law. São Paulo, 1964, p. 14-15.

${ }^{793}$ BECKER, Alfredo Augusto. Teoria Geral do Direito Tributário. São Paulo: Saraiva, 1963, p. 01-05.

${ }^{794}$ DÓRIA, Antônio Roberto Sampaio. Op.cit., p.11-16
} 
constitucional tributária concedida por José Souto Maior Borges ao estudo das isenções tributárias $^{795}$, mas, sobretudo, através do estudo sistêmico de Geraldo Ataliba ${ }^{796}$, promovendo princípios estruturais necessários à construção do sistema constitucional tributário brasileiro, no qual se elevaria o princípio da rigidez do sistema constitucional tributário, peculiar ao direito tributário brasileiro, na visão de Ataliba.

Com o empreendimento do dogmatismo jurídico normativo, e a visão dos princípios sob esse específico prisma sistemático, passa-se a enxergar os princípios não apenas como baluartes históricos da liberdade, mas como espécies normativas de grande importância estrutural para a construção sistêmica do ordenamento jurídico positivo.

Note-se que a elevação desses princípios na realidade tributária brasileira também passava por importantes justificativas políticas, especialmente a partir da década de sessenta, com o Golpe Militar de 1964.

É claro que aquele período político, comprometendo a segurança jurídica, logo chama a atenção de tributaristas de escol, a exemplo de Geraldo Ataliba, que passam a desenvolver com maior intensidade as normas jurídicas que buscassem reforçá-la, o que significa dizer que a elevação teórica dos princípios constitucionais vinculados à segurança jurídica apareceria com maior força naquele momento ${ }^{797}$.

O dogmatismo normativo kelseniano e a noção de Grundnorm pareciam reforçar essa tendência. Não é por acaso que Alfredo Augusto Becker, já proferindo apoio à teoria normativa kelseniana ${ }^{798}$, manteve reservas quanto o princípio da capacidade contributiva, de cuja previsão constitucional expressa (na Constituição de 1946) que, para o autor,

\footnotetext{
795 "Os princípios constitucionais da tributação e as regras pelas quais se realiza a discriminação de rendas estão integradas no sistema tributário constitucional, formando ramo científico que se pretende caracterizar como dogmaticamente autônomo - direito tributário constitucional, ou direito constitucional tributário, como prefere Victor Uckmar”. BORGES, José Souto Maior. Isenções Tributárias. Op.cit., p. 18 e ss.

${ }^{796}$ ATALIBA, Geraldo. Sistema Constitucional Tributário Brasileiro. São Paulo: RT, 1968, p. 31.

${ }^{797}$ Veja-se, por exemplo, o testemunho de Geraldo Ataliba, em nota prévia à sua célebre obra Sistema Constitucional Tributário Brasileiro, que expõe com clareza as aspirações não somente jurídicas, mas profundamente políticas, pela elevação de um sistema constitucional tributário rígido e protegido de súbitas alterações: "Fomos animados a escrever este trabalho - apologético do nosso sistema constitucional tributário - pela profunda frustração que de nós se apossou com a promulgação da Emenda Constitucional n. 18. Em gesto precipitado, verdadeiramente inconsciente - e inconsequente - o Congresso derrubou por terra um sistema cuidado, quase perfeito, funcional e - o que é de muita importância em matéria de direito constitucional - tradicional já, para substituí-lo empiricamente por um amontoado de regras tão estético quão distante da nossa realidade, das nossas tradições e das exigências da nossa ordenação federal e municipal. É, felizmente, possível, ainda, voltar atrás. Ninguém censuraria o parlamento, se este souber recuar - atendendo, aliás, aos reclamos da opinião pública, dos administradores conscientes, dos financistas prudentes e juristas de rol, como Amílcar Falcão - repondo as coisas no estado atual. Não é tarde para tanto (...)”. ATALIBA, Geraldo. Nota Prévia. In: Sistema Constitucional Tributário Brasileiro. Op.cit., p. xi.

${ }^{798}$ BECKER, Alfredo Augusto Becker. Teoria Geral do Direito Tributário. São Paulo: Saraiva, 1963, p. $54-55$.
} 
significou a "constitucionalização do equívoco", já que a capacidade contributiva, apareceria, na visão do autor, como regra de direito natural ${ }^{799}$.

Não é surpresa também que Geraldo Ataliba, inspirado em Kelsen (mas não sem ponderações), elevasse o princípio da rigidez do sistema constitucional tributário, em ambiente ligeiramente posterior às transformações constitucionais trazidas pela Emenda Constitucional n.18/65. Para Ataliba, “(...) dentre os princípios constitucionais tributários brasileiros dos mais importantes, o mais característico e o mais peculiar ao Brasil é o da "rigidez do sistema tributário" 800 .

Na mesma linha, Paulo de Barros Carvalho, em Tese de Livre-docência defendida em 1981, igualmente caminhou no sentido de considerar o sistema constitucional tributário como rígido e exaustivo, seguindo tendência maciça da literatura pátria da época ${ }^{801}$.

Não se pode, contudo, afirmar a prevalência absoluta de uma linha de estudos relativa aos princípios constitucionais tributários, já que, mesmo no apogeu dessas tendências, apareciam obras que lhes faziam oposição, como é o caso do estudo de Ives Gandra da Silva Martins, que, sem desconsiderar o caráter sistemático do direito tributário, caminha pela consideração axiológica da justiça ${ }^{802}$ no direito tributário, assim como no reconhecimento de princípios econômicos alinhados ao direito tributário ${ }^{803}$.

A segurança jurídica em matéria tributária passa a ser desenvolvida em todas as etapas da relação jurídica tributária, de seu nascimento à extinção. O dogmatismo kelseniano representa, nesse contexto, importante veículo para reforçar a busca pela maior segurança jurídica em ambiente político de profunda insegurança. Não que estudos voltados a temas fundamentais da justiça tributária fossem necessariamente obliterados na época, como já se observou em Ives Gandra Martins ${ }^{804}$. Mas não se pode deixar de reconhecer a clara e evidente preferência pelos temas ligados à segurança jurídica tributária, o que foi fruto de um contexto jurídico e político plenamente justificado, e mantendo-se com força a partir de sessenta e até os dias atuais.

\footnotetext{
${ }^{799}$ Idem, p. 447 e seguintes.

${ }^{800}$ ATALIBA, Geraldo. Sistema Constitucional Tributário Brasileiro. Op.cit., p. 22.

801 CARVAlHO, Paulo de Barros. A Regra Matriz do ICM. Tese de Livre-Docência. Pontifícia Universidade Católica de São Paulo. São Paulo, 1981, p. 22.

${ }^{802}$ MARTINS, Ives Gandra da Silva. Teoria da Imposição Tributária. São Paulo: Rt, 1988, p. 50 e ss.

${ }^{803}$ Nesse sentido: “(...) os princípios meramente formais (legalidade e tipicidade da tributação) são insuficientes para abrigar essa realidade, sendo necessário chamar, invocar outros princípios inerentes à espinha dorsal do fenômeno econômico, em sua faceta de incorporação do Estado”. Idem, p. 73.

${ }^{804}$ MARTINS, Ives Gandra da Silva. Teoria da Imposição Tributária. Op.cit., p. 50 e ss.
} 
Mas novamente, a experiência estrangeira e as peculiaridades históricas da realidade brasileira fornecem ambiente propício para consolidação de uma etapa ulterior da Principiologia Constitucional Tributária no Brasil.

Essa experiência estrangeira é fornecida pelo movimento constitucional democrático europeu, a partir da década de cinquenta, elevado a partir das constituições europeias democráticas pós-guerra, e suas doutrinas a elas envoltas, como se observa nas contribuições de Klaus Tipke, Joachim Lang e Fritz Neumark, e Itália, com Antonio Berliri $^{805}$, Victor Uckmar $^{806}$ e outros, passa a representar grande oportunidade para o aperfeiçoamento de outros aspectos da principiologia constitucional tributária brasileira, equilibrando a atenção entre segurança jurídica fiscal e a justiça em matéria fiscal, historicamente desprestigiada na literatura pátria até então.

O ambiente político propício trazido pela redemocratização constitucional (assim como pelo neoconstitucionalismo tardio e o pós-positivismo próprio do período) elevada a partir de 1985, e consolidada em 1988, caminha pela necessidade do reconhecimento da dignidade da pessoa humana (art.5 $5^{a}$ e suas consequências nos estudos principiológicos tributários, e que perdura até os dias atuais, onde convivem segurança jurídica em matéria fiscal e justiça em matéria fiscal, ainda que na década de noventa do século XX tenham sido ainda proeminentes estudos dedicados a esmiuçar a primeira, e a justiça em matéria fiscal apareça com maior intensidade no limiar daquele século.

Assim, parcela da literatura, inspirada nesse posterior ambiente políticoconstitucional, passa a conceder maior atenção à carga axiológica dos princípios na construção do sistema jurídico e, nesse contexto, aumenta a influência de obras refratárias ao dogmatismo normativo kelseniano, ou mesmo adotando as premissas fundamentais com ponderações axiológicas, que passam a conviver com outras tendências principiológicas. Exemplificativamente, a importância dessa carga axiológica ou teleológica aplicada aos princípios pode ser observada na leitura de Larenz ${ }^{807}$ e Canaris. Este último autor considera o ordenamento (a partir da noção de justiça) axiologicamente e teleologicamente (focado

\footnotetext{
${ }^{805}$ BERLIRI, Antonio. Principi di Diritto Tributario. Volume 1. Milano: Dott.A.Giuffrè - Editore, 1952, p. 206 e ss.

${ }^{806}$ UCKMAR, Victor. Princípios Comuns de Direito Constitucional Tributário. Trad. Marco Aurélio Greco. São Paulo: Malheiros, 2001, p. 21-39.

807“Enquanto princípios não são regras imediatamente aplicáveis aos casos concretos, mas ideias directrizes, cuja transformação em regras que possibilitem uma resolução tem lugar em parte pela legislação, em parte pela jurisprudência, segundo o processo anteriormente descrito da concretização e do aperfeiçoamento de princípios mais especiais mediante a formação de grupos de casos” (...). Larenz também se refere aos princípios jurídicos que, (...) enquanto critérios teleológicos-objetivos, são coadjuvantes para a interpretação, bem como para a integração de lacunas. (...)”. Idem, p. 599 e seguintes.
} 
nos fins à concretização dos valores) ${ }^{808}$, geralmente vinculando-os aos valores no sistema jurídico ${ }^{809}{ }^{810}$. Ambos possuem grande influência nos estudos principiológicos constitucionais na realidade tributária europeia, como se observa em Kruse ${ }^{811}{ }^{812}$, Tipke ${ }^{813}$, e na obra conjunta de Tipke e Lang. Na realidade tributária brasileira essa influência também se manifestou, conforme se observa em Ricardo Lobo Torres ${ }^{814}$, ainda que seja exagero dizer que haveria prevalência clara dessa tendência perante as anteriormente analisadas.

Klaus Tipke e Joachim $\mathrm{Lang}^{815}$, enaltecendo a principiologia constitucional financeira prevista na ordem jurídica tributária, também apontaram a importância do reconhecimento dos princípios inerentes ao Estado de Direito - representados pelos direitos e garantias fundamentais - como orientadores do sistema jurídico tributário

${ }^{808}$ CANARIS, Claus Wilhelm. Pensamento Sistemático e Conceito de Sistema na Ciência do Direito. $2^{\circ}$ Ed. Trad. A. Menezes Cordeiro. Lisboa: Serviço de Educação Fundação Calouste Gulbenkian, 1996, p. 66 e ss.

${ }^{809}$ Canaris chega a identificar os princípios gerais do direito como os “(...) valores mais profundos da ordem jurídica", definindo o sistema como “(...) ordem axiológica ou teleológica de princípios gerais de direito, no qual o elemento de adequação valorativa se dirige à característica de ordem telológica e o da unidade interna à característica dos princípios gerais". CANARIS, Claus-Wilhelm. Op.cit., p. 76 e ss. Para Canaris, o princípio ocuparia o ponto intermédio entre o valor, por um lado, e o conceito, por outro. Idem, p. 87.

${ }^{810}$ Ainda sobre os princípios, segundo Canaris, esses podem estar em oposição entre si, já que não tem a pretensão de exclusividade; “(...) ostentam o seu sentido próprio apenas numa combinação de complementação e restrição recíprocas”, necessitando, “(...) para sua realização, da concretização através de subprincípios e de valorações singulares com conteúdo material próprio”. Idem, p. 88-100.

${ }^{811}$ Ainda no campo da elevação dos princípios constitucionais tributários, Kruse, no contexto alemão, destacou a importância de vínculos jurídico-constitucionais que limitam e permeiam o exercício da soberania tributária, dentre os quais, a legalidade e tipificação da tributação, a proporcionalidade, a igualdade da tributação, o mandamento da igualdade de direitos e o direito fundamental da proteção da família, a liberdade de eleição profissional e do exercício profissional, a garantia da propriedade, entre outros valores, mas sobretudo, os elementos concretos do Estado de Direito, destinados a viabilizar a justiça objetivada pela Lei de Bonn. Mas Kruse destaca também a existência dos princípios jurídicos gerais, que são também no direito tributário a "causa de conhecimento" para alguma coisa, assim como para o direito em geral. KRUSE, Heinrich Wilhelm. Derecho Tributário. Op.cit., 88-113.

${ }^{812}$ Ao lado dos princípios gerais, Kruse destacou também a importância dos princípios especiais: "São fontes de direito igual que os princípios jurídicos gerais. Sem embargo, se distinguem destes já que não são deduzidos imediatamente da idéia de justiça e ademais em que estão sujeitas às mudanças pelos ordenamentos que os motivam e a disposição dos interesses particulares. (...) Os princípios especiais, em suma seriam variáveis conforme o ordenamento tributário respectivo, ao contrário dos princípios gerais, inerentes a todo e qualquer ordenamento tributário. Idem, p. 143.

${ }^{813}$ A importância dos direitos e garantias fundamentais do indivíduo impressos na Lei Fundamental de Bonn também foi objeto de outro jurista de destaque no período pós-Segunda Guerra Mundial, Klaus Tipke, que denominou os princípios constitucionais enquanto "princípios sistemáticos sustentadores do direito tributário", em que a maioria foi expressamente prevista, segundo a interpretação do jurista alemão, na Lei Fundamental, dentre os quais: a) ordenamento jurídico enquanto ordenamento de justiça; b) capacidade contributiva; c) princípio do Estado social; d) princípio do Estado de Direito; e) proibição de prejudicar o matrimônio e a família; f) o princípio da livre eleição e exercício profissional. Também a evolução doutrinária encontrou forte recepção na jurisprudência constitucional, embasada, por sua vez nos princípios previstos na Lei Fundamental. MARTUL-ORTEGA, Perfecto Yebra. Op.cit., p.15 e seguintes.

${ }_{814}^{814}$ TORRES, Ricardo Lobo. Curso de Direito Financeiro e Tributário. Op.cit., p. 88 e seguintes.

${ }^{815}$ TIPKE, Klaus; LANG, Joachim. Direito Tributário. Tradução da $18^{\circ}$ edição alemã. Tradutor Luiz Dória Furquim. Volume 1. Porto Alegre: Sergio Antonio Fabris Editor, 2008, p. 165 e seguintes. 
interno, como a uniformidade de imposição, a capacidade contributiva, a legalidade, a segurança jurídica. Naturalmente, parte-se do pressuposto de que o Sistema Jurídico é divisível em sistema apreensível quanto ao conteúdo ou interno (sistema interno) ${ }^{816}$, no qual emanam diversos princípios, e, de outro lado, o sistema externo. ${ }^{817}$

Mas, ressalve-se, a interpretação acerca dos princípios constitucionais tributários é variável de acordo com a linha de estudo assumida e, logo, pode condensar elementos valorativos ou mesmo afastá-los amplamente. Ambas as tendências (que abraçam o elemento axiológico, ponderam ou o refutam) aparecem engendradas na literatura tributária brasileira, por expressa influência estrangeira.

Dado histórico importante refere-se ao fato de que a constitucionalização democrática do direito tributário, aliada à sistematização das normas jurídicas e à elevação de princípios jurídicos orientadores desse sistema, permitiu que a doutrina brasileira sentisse semelhante preocupação, especialmente com a entrada em vigor da Constituição de 1988, que avança na racionalização de uma principiologia constitucional que interferiria na organização e na abertura dos sistemas tributários, escapando, a priori, do fechamento hermético dos sistemas jurídicos (ainda que na prática, esse fechamento fosse impossível).

Esse raciocínio é igualmente extraído da contextualização de Sacha Calmon Navarro Coelho, sobre a tendência à principiologia constitucional tributária. Para Sacha Calmon Navarro Coêlho, a “(..) tributação ou o poder de tributar limitados pelos valores positivados da igualdade, liberdade, propriedade, proporcionalidade e razoabilidade acima da relação jurídico-tributária" ${ }^{818} 819$.

Mas é forte a percepção de que a segurança jurídica deve manter-se reforçada diante das experiências de instabilidade constitucional vivenciadas no período ditatorial, já em pleno processo de redemocratização, com primeira edição publicada em 1985, Geraldo Ataliba, lança sua obra "República e Constituição", onde reforça ainda mais a necessidade de um sistema super-rígido, pautado na intocabilidade dos princípios constitucionais

\footnotetext{
816 "O sistema de conteúdo ou interno do ordenamento jurídico é extraído de princípios como valorações fundantes da ordem institucional (Ordnungsstiftende Grundwertungen); eles são critérios diretivos que permitem, através de consenso ético-jurídico, justificar decisões jurídicas". TIPKE, Klaus. LANG, Joachim. Op.cit., p. 180 e seguintes.

${ }^{817}$ "O sistema externo diz respeito ao modo da ordenação formal da matéria, a articulação técnica e ordem da matéria, que deve ser o quanto possível sumária. Elementos do sistema externo são os conceitos de ordenamento da lei, a construção da lei e a posição da norma jurídica singela na estrutura da lei. $\mathrm{O}$ assim chamado método sistemático da interpretação da lei opera com esses elementos. O conhecimento jurídico desse sistema externo depende do grau de maturidade da lei a ser aplicada". Idem, p. 168-169.

${ }^{818}$ NAVARRO COÊLHO, Sacha Calmon Curso de Direito Tributário. Op.cit., p. 48.

${ }^{819}$ BuChanAN, James. La Hacienda Publica en un Proceso Democrático. Trad. Jose R. Alvarez Rendueles. Madrid: Aguilar, 1973, p. 298 e seguintes.
} 
fundamentais da federação e da república, e cujas consequências inevitáveis da superrigidez constitucional das primeiras estaria na impossibilidade de o órgão constituinte derivado sequer discutir projeto "tendente a anular competências estaduais, reduzindo as entidades federadas a meras setrapias" ${ }^{\prime 820}$. Essa tendência ganha reforço na vigência da Constituição de 1988, quando da leitura do artigo 60, parágrafo $4^{\text {a }}$, a república e a federação, dentre os próprios direitos fundamentais previstos no artigo $5^{\mathrm{a}}$ da Constituição, passam a ser defendidos como cláusulas pétreas.

Perspectiva essa que segue reforçada por sólida e respeitável parcela da doutrina tributária pátria, sobretudo visando proteger o sistema constitucional tributário, e seus elementos estruturantes, de eventuais abusos ou alterações bruscas, como ocorria no período ditatorial (1964-1985), e que ainda hodiernamente são sentidas.

Sem pretender, naturalmente, esgotar o tema, toma-se como exemplo o clássico estudo de Roque Antônio Carrazza, sobre o Direito Constitucional Tributário ${ }^{821}$, em que se eleva a vinculação estreita entre a tributação e princípios constitucionais, a exemplo do princípio republicano, que se vincula fortemente ao princípio da capacidade contributiva; do não-confisco (não-confiscatoriedade) e da igualdade; o princípio federativo; o princípio da autonomia municipal; o princípio da anterioridade; o princípio da legalidade, o princípio da irretroatividade, e o princípio da segurança jurídica, que também se vincularia ao princípio da tipicidade fechada, do exclusivismo, da vinculação do lançamento à lei, da interpretação estrita da lei, da igualdade, da confiança na lei fiscal e da boa fé do contribuinte.

No mesmo passo, um ano depois da consagração da Constituição de 1988, Hugo de Brito Machado lança obra dedicada ao enaltecimento dos princípios jurídicos da tributação na Constituição de 1988, elevando os seguintes princípios: legalidade; isonomia; capacidade contributiva; a irretroatividade; a anterioridade; a vedação do confisco e a liberdade de tráfego ${ }^{822}$.

Naturalmente, os referenciais teóricos que viabilizaram a construção do Sistema Jurídico sob esse ou aquele fundamento jurídico favoreceram diferenciadas posições a

\footnotetext{
${ }^{820}$ ATALIBA, Geraldo. República e Constituição. Op.cit., p. 32 e ss.

${ }^{821}$ CARRAZZA, Roque Antonio. Curso de Direito Constitucional Tributário. Op.cit., p. 55-459

${ }^{822}$ MACHADO, Hugo de Brito. Os Princípios Jurídicos da Tributação na Constituição de 1988. $2^{\mathrm{a}}$ Ed. São Paulo: Rt, p. 14 e seguintes.
} 
respeito da compreensão do papel do sistema jurídico (seu fechamento ou abertura) e a relação dos elementos que os compõem (a exemplo dos princípios) ${ }^{823}$.

Logo, no período de redemocratização constitucional decorrente a partir de 1985 em diante, é previsível que cada vez mais estudos passem a abordar o assunto, ganhando novo impulso com a entrada em vigor da Constituição de 1988, período que segue influenciado mais fortemente pelo neoconstitucionalismo europeu (e de tendências póspositivistas), e que perdura até os dias atuais, consubstanciada na progressiva construção "Estatuto do Contribuinte", expressão cunhada por Louis Trotabas, e que recebeu grande adesão na doutrina pátria, quando se destacam os estudos constitucionais de Geraldo Ataliba, Sacha Calmon Navarro Coêlho ${ }^{824}$, Misabel Derzi ${ }^{825}$, Roque Antônio Carrazza ${ }^{826}$, Ruy Barbosa Nogueira ${ }^{827}$, Paulo de Barros Carvalho ${ }^{828}$, Ricardo Lobo Torres ${ }^{829}$, Hugo de Brito Machado ${ }^{830}$, Ives Gandra da Silva Martins ${ }^{831}$, Humberto Ávila ${ }^{832}{ }^{833}$, dentre outros ${ }^{834}$. Conforme bem sintetiza Ávila, “(...) a expressão "Estatuto do Contribuinte” denota um conjunto de normas que regula a relação entre o contribuinte e o ente tributante. Sua utilização possui conotação tanto garantista dos direitos dos contribuintes quanto

\footnotetext{
${ }^{823}$ Naturalmente, não se ignora as importantes contribuições às teorias sistêmicas contemporâneas, a exemplo de Gunter Teubner e Niklas Luhmann, (na perspectiva das teorias dos sistemas sociais, da qual o sistema jurídico seria parte, comunicando-se inevitavelmente com os demais "subsistemas" que compõe o sistema social), sobretudo ao enxergar o sistema jurídico como autopoiético, mas reconhece-se que a ideia de sistemas fechados e abertos é ainda prevalecente na literatura tributária brasileira contemporânea. TEUBNER, Gunter. O direito como sistema autopoiético. Trad. José Engrácia Antunes. Lisboa: Fundação Calouste Gulbenkian, 1996, p. 27 e seguintes. LUHMANN, Niklas. Introdução à Teoria dos Sistemas. Petrópolis: Editora Vozes, 2010, p. 79.

${ }^{824}$ NAVARRO COÊLHO, Sacha Calmon. Comentários à Constituição de 1988: Sistema Tributário. 3. ed. Rio de Janeiro: Forense, 1991, p. 01 e ss. NAVARRO.COÊLHO, Sacha Calmon. Op.cit., p. 37 e ss.

${ }^{825}$ DERZI, Misabel. Nota. In: BALEEIRO, Aliomar. Limitações Constitucionais ao Poder de Tributar. Op.cit., p. 03 e seguintes.

${ }^{826}$ CARRAZZA, Roque Antonio. Op.cit., p. 238-387.

${ }^{827}$ NOGUEIRA, Ruy Barbosa. Curso de Direito Tributário. São Paulo: Saraiva, 1999, p.124-125.

${ }^{828}$ CARVALHO, Paulo de Barros. Estatuto do Contribuinte, direitos, garantias individuais em matéria tributária e limitações constitucionais nas relações entre fisco e contribuinte. Revista de Direito Tributário (7/8):138, 1979.

${ }^{829829}$ TORRES, Ricardo Lobo. Os Direitos Humanos e a Tributação. In: Tratado de Direito Constitucional Financeiro e Tributário, V. 3 Rio de Janeiro: Renovar, 1998, p. 27 e ss.

${ }^{830830}$ MACHADO Hugo de Brito, Os princípios constitucionais na Constituição de 1988. São Paulo: RT, 1989, p. 20 e ss. MACHADO, Hugo de Brito. Curso de Direito Tributário. $27^{\circ}$ Ed. São Paulo: Malheiros, 2007, p. 288.

${ }^{831}$ MARTINS, Ives Gandra da Silva. Sistema Tributário na Constituição de 1988. 2 Ed. São Paulo: Saraiva, 1990, p. 61 e ss.

832 ÁVILA, Humberto Bérgmann. Estatuto do Contribuinte: Conteúdo e Alcance. In: Revista Diálogo Jurídico. Ano I - vol. I - n ${ }^{\circ} .3$ - junho de 2001 - Salvador - Bahia - Brasil. Disponível em: www.direitopublico.net - último acesso em 11 de março de 2011, p.04 e ss.

${ }^{833}$ ÁVILA, Humberto Bérgmann. Sistema Constitucional Tributário. Op.cit.,p. 308-309.

${ }^{834}$ VIEIRA, José Roberto. Fundamentos Republicano-democráticos da Legalidade Tributária: Óbvios Ululantes e Não Ululantes. In: Tributação e Direitos Fundamentais. Coord. FOLMANN, Melissa. Curitiba: Juruá, 2006. P. 183-215.
} 
limitativa do poder de tributar" ${ }^{\natural 35}$, não por acaso, os princípios da razoabilidade e da proporcionalidade passam a receber maior atenção a partir desse contexto histórico.

Note-se, portanto, essa diferenciada perspectiva garantista no estudo dos princípios constitucionais tributários, característica do ambiente democrático posterior à Constituição de 1988, e que influencia o reforço dos princípios constitucionais tributários na realidade brasileira.

É claro que, como visto, a visão dos princípios e seu papel a ser exercido no sistema constitucional tributário dependerá das premissas teóricas adotadas, seja pela proposta sistemática de Geraldo Ataliba, cuja concepção sistêmica manteve-se alinhada ao dogmatismo normativo sistemático kelseniano aplicado ao direito constitucional tributário, mas permitindo-se gradualmente elevar os princípios jurídicos como alicerces estruturantes para a construção do edifício sistemático jurídico constitucional tributário, seja pela proposta de Ricardo Lobo Torres, caminhando nas propostas sistemáticas pós-positivistas, como em Larenz e Canaris, e elevando a importância da abertura sistêmica aos valores.

De qualquer forma, ambas as propostas são abraçadas e ponderadas nesse contexto constitucional democrático no Brasil, refletindo-se sobre as premissas principiológicas, agora já construídas na órbita de sistemas jurídicos, e não necessariamente vinculados às contribuições históricas das Cartas de Direitos ou às teorias econômicas no ambiente sistemático (jurídico) do direito tributário contemporâneo.

Adiante, a título complementar, veja-se como a literatura tributária contemporânea enxerga os princípios, já amparados nas contemporâneas teorias jurídicas principiológicas provenientes de diferentes linhas de estudos oriundas da Teoria Geral do Direito e da Filosofia do Direito.

\subsection{Das concepções jurídicas de princípios na literatura do Direito Tributário no Brasil.}

A partir das décadas de sessenta e setenta, a literatura do direito público começa a esboçar ideias sobre os princípios jurídicos, ainda que sob a influência da Teoria Geral do

\footnotetext{
${ }^{835}$ ÁVILA, Humberto Bérgmann. Estatuto do Contribuinte: Conteúdo e Alcance. In: Revista Diálogo Jurídico. Ano I - vol. I - n o. 3 - junho de 2001 - Salvador - Bahia - Brasil. Disponível em: www.direitopublico.net - último acesso em 11 de março de 2011, p.04 e ss.
} 
Direito e do dogmatismo kelseniano (e, portanto, enxergando-a do ponto de vista "formal" ou "estrutural").

As mais difundidas, no entanto, vinculam-se à ideia de princípios como "linhasmestras" (Geraldo Ataliba) ${ }^{836}$ ou "mandamento nuclear do sistema", (Celso Antonio Bandeira de Mello ${ }^{837}$ e José Afonso da Silva ${ }^{838}$ ), como "núcleos de condensações" (Canotilho) $)^{839}$, seja pelos caminhos da lógica jurídica, como enunciado lógico de grande generalidade (Roque Carrazza) ${ }^{840}$ ou mesmo como a "pedra de fecho do sistema ao qual pertence ${ }^{\nexists 41}$, como linha diretiva (Paulo de Barros Carvalho) ${ }^{842}$, ou, afastando-se com maior intensidade do dogmatismo kelseniano, ter o condão de atribuir indiscutível carga axiológica aos princípios (Paulo Bonavides) ${ }^{843}$, que, enquanto valores, seriam a pedra de toque do sistema jurídico.

\footnotetext{
${ }^{836}$ ATALIBA, Geraldo. República e Constituição. Op.cit., p.34 e seguintes.

837 "Princípio é, por definição, mandamento nuclear de um sistema, verdadeiro alicerce dele, disposição fundamental que se irradia sobre diferentes normas, compondo-lhes o espírito e servindo de critério para a sua compreensão e inteligência, exatamente por definir a lógica e a racionalidade do sistema Normativo, no que lhe confere a tônica e sentido harmônico. É o conhecimento dos princípios que preside a intelecção das diferentes partes componentes do todo unitário que há por nome sistema jurídico positivo.” MELLO, Celso Antônio Bandeira de. Elementos do Direito Administrativo. Editora RT, São Paulo. 1981, p. 230.

${ }^{838}$ SILVA, José Afonso da. Curso de Direito Constitucional Positivo. Malheiros: São Paulo, 2006, p.91-92.

${ }^{839}$ CANOTILHO, J.J. Gomes. Direito Constitucional e Teoria da Constituição. $3^{\circ}$ Edição. Almedina: Coimbra, 2003, p. 1144-1146

840 "Princípio é um enunciado lógico, implícito ou explícito, que, por sua grande generalidade, ocupa posição de preeminência nos vastos quadrantes do Direito e, por isso mesmo, vincula, de modo inexorável, o entendimento e a aplicação das normas jurídicas que com ele se conectam". CARRAZZA, Roque Antônio. Curso de Direito Constitucional Tributário. Op.cit., p.29.

${ }^{841}$ CARRAZZA, Roque Antonio. Princípios Constitucionais Tributários e Competência Tributária. São Paulo: Saraiva, 1986, p. 06.

${ }^{842}$ Paulo de Barros Carvalho aponta quatro possíveis sentidos de "princípio": "a) como norma jurídica de posição privilegiada e portadora de valor expressivo; b) como norma jurídica de posição privilegiada que estipula limites objetivos; c) como os valores insertos em regras jurídicas de posição privilegiada, mas considerados independentemente das estruturas normativas; e d) como o limite objetivo estipulado em regra de forte hierarquia, tomado, porém, sem levar em conta a estrutura da norma. Nos dois primeiros, temos "princípio" como "norma"; enquanto nos dois últimos, "princípio" como "valor" ou como "critério objetivo". Para Paulo de Barros, os princípios "(...) aparecem como linhas diretivas que iluminam a compreensão de setores normativos, imprimindo-lhes caráter de unidade relativa e servindo de fator de agregação num dado feixe de normas". CARVALHO, Paulo de Barros. Curso de Direito Tributário. São Paulo: Saraiva, 2011, p. $148-149$

${ }^{843 ،(. . .)}$ os princípios são, por conseguinte, enquanto valores, a pedra de toque ou o critério com que se aferem os conteúdos constitucionais em sua dimensão normativa mais elevada". BONAVIDES, Paulo Bonavides. Curso de Direito Constitucional. Op.cit., p. 282-294.
} 
Como é possível observar também em Eros $\mathrm{Grau}^{844}$, grande preocupação também encontra a doutrina em revelar o papel dos princípios e suas distinções com outras espécies normativas, dividindo-as em princípios e regras.

Para Dworkin ${ }^{845}{ }_{-}^{846}$ e Alexy $^{847}$, a distinção entre princípios e regras estaria na estruturação normativa e não no caráter de fundamentalidade, possuindo assim, neutralidade (e afastando concepções valorativas). Haveria a diferenciação qualitativa entre regras e princípios, indicando a existência de um caráter lógico na distinção.

Noutro sentido, há que se mencionar também outra tentativa de distinção, que focaria no critério de grau das normas, onde as normas se diferenciariam através da abstração, grau, generalidade e fundamentalidade ${ }^{848}$.

844 “(...) Pois bem, quanto aos princípios positivos do Direito, evidentemente reproduzem a estrutura peculiar das normas jurídicas", dividindo as normas jurídicas em princípios (mais gerais) e regras. GRAU, Eros Roberto. A Ordem Econômica na Constituição de 1988 - Interpretação e Crítica. Malheiros: São Paulo, 2012, p. 125 e seguintes. No mesmo sentido também: GRAU, Eros Roberto. O Direito Posto e o Direito Pressuposto. São Paulo: Malheiros, 2002, p. 21 e seguintes. Note-se que em estudos posteriores, Eros Grau apresenta linha de estudos convergente com os estudos de Humberto Ávila. GRAU, Eros Roberto. Por que tenho medo dos juízes (a interpretação/ aplicação do direito e os princípios). $6^{\mathrm{a}}$ Edição, São Paulo, Malheiros, 2013, p. 18 e seguintes.

${ }^{845}$ Dworkin baseia sua posição teórica criticando o positivismo jurídico, especialmente o positivismo jurídico desenvolvido por Herbert Hart. Dessa maneira, para Dworkin, existem, além de regras, os chamados Princípios, que, ao contrário das regras, que possuiriam apenas a dimensão da validade, possuem a validade, acrescida de outra dimensão, o peso. Para Dworkin, as regras, ou valem, ou não valem, não haveria o meiotermo. Assim, se uma regra vale, será aplicável, e se não for válida, não há que se falar em aplicabilidade. No entanto, para os princípios, não importariam, no caso de choque entre princípios, se seriam válidos ou não. Na realidade, o que importaria seria a análise do peso de cada um dos princípios, em caso de "colisão". Assim, aquele que possuir maior peso prevaleceria perante outro. DWORKIN, Ronald. Levando os direitos a sério. Trad. Nelson Boeira. São Paulo: Martins Fontes, 2002, p.17-31. SILVA, Virgílio Afonso da. Princípios e Regras: Mitos e Equívocos acerca de uma Distinção. Revista Latino-Americana de Estudos Constitucionais 1. 2003, p. 607-630. Sobre o assunto também: HART, Herbert. O conceito de direito. Lisboa, Fundação Calouste Gulbekian, s/d, p. 324.

${ }^{846}$ DWORKIN, Ronald. Op.cit., p.17-31.

${ }^{847}$ Robert Alexy parte de ideia semelhante à de Dworkin, defendendo a distinção qualitativa entre regras e princípios. Sua contribuição decorre da determinação de algumas premissas básicas, desenvolvendo os princípios como mandamentos de otimização. Assim, os princípios seriam normas que estabelecem algo que deve ser realizado na maior medida possível, diante das possibilidades fáticas e jurídicas presentes. Ainda, a realização total de um princípio poderia ser obstada por outro princípio, a colisão de princípios, onde haveria um sopesamento, para que se chegue a um resultado ótimo, onde, muitas vezes, vê-se necessário limitar a realização de um ou de ambos. Para Alexy, princípios expressam direitos e deveres prima facie, que terão possibilidade de se revelar menos amplos após o sopesamento com outros princípios. Assim, para Alexy, se uma regra é válida, que expressa deveres e direitos definitivos, deve se realizar exatamente naquilo que ela prescreve, e, em caso de conflito de regras, só poderia ser solucionada se em uma das regras fosse incluída cláusula de exceção, ou da declaração de invalidade de uma delas. Já os princípios, terão seu grau de realização variável (máxima da proporcionalidade). ALEXY, Robert. Teoria dos Direitos Fundamentais. Trad. Virgílio Afonso da Silva. São Paulo: Malheiros, s/d, Op.cit., p. 91 e ss. SILVA, Virgílio Afonso da. Op.cit., p. 610.

${ }^{848}$ CANOTILHO, J.J. Gomes. Op.cit., p. 1144-1147. 
Assim, os princípios vinculam-se à ideia de normas fundamentais do sistema, enquanto regras são definidas como a concretização desses princípios, possuindo, portanto, caráter instrumental e menos fundamental. Percebe-se que, para a classificação entre princípios e regras, há que se partir de uma determinada teoria sobre o conceito e distinção de princípios e regras, conforme expõe Canotilho ${ }^{849}$.

Portanto, as contribuições de Alexy e Dwerkin à distinção entre princípios e regras foi - e continua - a mais difundida e celebrada pelos tributaristas brasileiros contemporâneos.

Contudo, isso não significa a ausência de discordâncias ou ponderações perante as propostas prevalecentes, como se pode observar nos estudos de Humberto Ávila ${ }^{850}$ que, diferenciando princípios e regras, fixa que as regras referem-se às normas imediatamente descritivas, primariamente retrospectivas e com pretensão de decidibilidade e abrangência, para cuja aplicação se exige a avaliação da correspondência, sempre centrada na finalidade que lhes dá suporte ou nos princípios que lhes são axiologicamente sobrejacentes, entre a construção conceitual da descrição normativa e a construção conceitual dos fatos ${ }^{851}$, ao passo que os princípios seriam normas “(...) imediatamente finalísticas, primariamente prospectivas e com pretensão de complementaridade e de parcialidade, para cuja aplicação se demanda uma avaliação da correlação entre o estado de coisas a ser promovido e os efeitos decorrentes da conduta havida como necessária à sua promoção" ${ }^{\text {852_ }} 853$.

\footnotetext{
${ }^{849}$ Idem.

850 ÁVILA, Humberto. Teoria dos Princípios. Da definição à aplicação dos princípios jurídicos. 14 ed, São Paulo, Malheiros, 2013, p. 64-85.

${ }^{851}$ ÁVILA, Humberto.Teoria dos Princípios. da Definição à aplicação dos Princípios Jurídicos. $2^{\circ}$ Edição. Editora Malheiros. São Paulo -SP. 2004, p.70.

${ }^{852}$ Idem.

${ }^{853}$ Para Ávila, a diferença entre regras e princípios é uma mera diferença no grau de abstração, sendo os princípios mais abstratos do que as regras, argumentando que as regras não são aplicadas em modelo "tudo ou nada", já que deveriam passar por um processo interpretativo, tanto quanto os princípios. Rejeita também a ideia de mandamentos de otimização, já que o princípio deve ser aplicado em sua máxima medida: “(...) a distinção entre princípios e regras não pode ser baseada no suposto método "tudo ou nada" de aplicação das regras, pois também elas precisam, para que sejam implementadas as suas consequências, de um processo prévio - e por vezes longo e complexo como o dos princípios - de interpretação que demonstre quais as consequências que serão implementadas. E, ainda assim, só a aplicação diante do caso concreto é que irá corroborar as hipóteses anteriormente havidas como automáticas. Nesse sentido, após a interpretação diante de circunstâncias específicas (ato de aplicação), tanto as regras quanto os princípios, em vez de se extremarem, se aproximam. A única diferença constatável continua sendo o grau de abstração anterior à interpretação". ÁVILA, Humberto Bérgmann. A Distinção entre Princípios e Regras e a Redefinição do Dever de Proporcionalidade. Revista de Direito Administrativo 215. São Paulo: s/e, 1999, p. 161.
} 
Ademais, Humberto Ávila inclui também o "Postulado Normativo", localizado em um segundo grau na hierarquia normativa que, por sua vez, estabelece a estrutura de aplicação das outras normas, quais sejam princípios e regras, permitindo a verificação de casos em que há a violação de normas cuja aplicação estruturam ${ }^{854}$.

Conforme também contextualiza James Marins, apoiado em Ávila, os postulados se situam em um plano distinto das normas cuja aplicação estruturam (seriam metanormas), e a violação deles consiste na não-interpretação de acordo com sua estruturação, sendo, portanto, metanormas, ou normas de segundo grau ${ }^{855}$.

Mas como se disse, entre aqueles que afastam os elementos valorativos na diferenciação entre princípios e regras, há aqueles que também os abraçam, como é o caso de Paulo Bonavides, dividindo-os em normas primárias, que seriam os princípios, e normas secundárias, aquelas baseadas nos princípios, costumes e convenções ${ }^{856}$.

É claro que a consideração dos princípios (e suas relações com as regras e postulados normativos) e seu papel na construção do Sistema Jurídico Tributário dependem da linha de pesquisa assumida.

Se a compreendida sob a perspectiva dogmático jurídica, é evidente que os esforços caminharão no sentido das contribuições de Dworkin e Alexy, não se desconsiderando propostas alternativas ou complementares, ainda que hodiernamente minoritárias, mas apresentadas por outros estudiosos, a exemplo de Ávila, ou mesmo Bonavides.

\footnotetext{
${ }^{854}$ Os Postulados Normativos estariam em um nível diverso dos princípios e regras, pois aqueles não impõem a promoção de um fim, mas em vez disso, estruturam a aplicação do dever de promover esse fim, e não são confundíveis com os princípios. Também não são regras, pois os Postulados, distintamente, não descrevem comportamentos, mas apenas estruturam a aplicação de normas que as descrevem. Dentre os exemplos de Postulados Normativos Aplicativos, citam-se a Proporcionalidade e Razoabilidade. Dentre os Postulados Normativos Hermenêuticos, cita-se o postulado da coerência, aplicável quando algo deve conter consistência e completude. ÁVILA. Humberto. Teoria dos Princípios. da Definição à aplicação dos Princípios Jurídicos. 14 ed. Op.cit.,p. 81-82; p. 148-149.

${ }^{855}$ MARINS, James. Direito Processual Tributário Brasileiro (Administrativo e Judicial). $7^{\text {a }}$ Ed. Op.cit., p. 163 e seguintes.

${ }^{856}$ Nesse contexto, Bonavides esclarece que a teoria dos princípios chega a presente fase pós-positivismo com os seguintes resultados já consolidados: "a passagem dos princípios da especulação metafísica abstrata para o campo concreto e positivo do Direito, com baixíssimo teor de densidade normativa; a transição crucial da ordem jusprivatista (sua antiga inserção nos Códigos) para a órbita juspublicística (seu ingresso nas Constituições); a suspensão da distinção clássica entre princípios e normas; o deslocamento dos princípios da esfera jusfilosófica para o domínio da Ciência Jurídica; a proclamação de sua normatividade; a perda de seu caráter de normas programáticas; o reconhecimento definitivo de sua positividade e concretude por obra sobretudo das Constituições; a distinção entre regras e princípios, como espécies diversificadas do gênero norma, e, finalmente, por expressão máxima de todo esse desdobramento doutrinário, o mais significativo de seus efeitos: a total hegemonia e preeminência dos princípios". BONAVIDES, Paulo. Op.cit., p. 294.
} 
Contudo, se o elemento valorativo for considerado, não há como negar a influência registrada pelo "pós-positivismo", como designou Bonavides, e a reaproximação entre valores e direito, característica intensificada com o neoconstitucionalismo tardio no direito constitucional brasileiro. Ambas as perspectivas contribuem para o aperfeiçoamento disciplinar do Direito Tributário Brasileiro, atuando em frentes distintas, que, embora pautadas em premissas epistemológicas e metodológicas diferentes, podem se complementar mutuamente.

Contemporâneamente, porém, parece que, mesmo no Direito Constitucional, a concepção de sistema constitucional aberto tem se fortalecido, conforme assinala Canotilho, sobre o Sistema Constitucional: “(1) é um sistema jurídico porque é um sistema dinâmico de normas; (2) é um sistema aberto porque tem uma estrutura dialógica (Caliess), traduzida na disponibilidade e "capacidade de aprendizagemn" das normas constitucionais para captarem a mudança da realidade e estarem abertas às concepções cambiantes da "verdade" e da "justiça"; (3) é um sistema normativo, porque a esruturação das expectativas referentes a valores, programas, funções e pessoas, é feita através de normas; (4) é um sistema de regras e princípios, pois as normas do sistema tanto podem revelar-se sob a forma de princípios como sob a forma de regras" ${ }^{\$ 57}$.

Por isso, conforme se verá a seguir, maior tendência há atualmente em compreender o Sistema Constitucional tributário, enquanto sistema normativo rígido, extensivo, porém aberto, pois permeado por princípios e regras jurídicas tributárias. ${ }^{858}$

\section{O processo disciplinar do Direito Tributário Brasileiro e o ambiente sistemático principiológico na égide da Constituição de 1988.}

A Constituição de 1988 inicia-se pautada primordialmente por seus princípios fundamentais previstos nos artigos $1^{\mathrm{a}}$ a $4^{\mathrm{a}}$, além do art. $5^{\mathrm{a}}$, que consagra os Direitos e

\footnotetext{
${ }^{857}$ CANOTILHO, J.J. Gomes. Direito Constitucional e Teoria da Constituição. Op.cit., p. 1143.

${ }^{858}$ Exemplo recente que promove esse diálogo pode ser observado na última edição do curso de Direito Processual Tributário, de James Marins, que, embora voltado à sistematização dogmática do Direito Processual, acaba por aplicar a Teoria de Humberto Ávila (ainda que mantenha a construção principiológica publicada em edições anteriores), o que simboliza nova guinada na compreensão do papel dos princípios no direito processual tributário brasileiro. MARINS, James. Processo Tributário Brasileiro (Administrativo e Judicial). $7^{a}$ Ed. Op.cit., p. 166-169.
} 
Garantias Individuais, com a diferença de que não apresentou dispositivos expressamente tributários, como suas antecessoras ${ }^{859}$.

Os chamados Direitos Fundamentais de Terceira Geração, voltados à fraternidade e à solidariedade, começam a serem efetivamente sentidos na realidade constitucional tributária brasileira ${ }^{860}$.

$\mathrm{Na}$ literatura tributária nacional, de modo geral, a nova reformulação constitucional não afastou antigas controvérsias doutrinárias, que, por fundamentos distintos, acabaram se intensificando, frente à extensa previsão constitucional da matéria tributária.

De todo modo, a discordância fundamental entre Geraldo Ataliba e Ricardo Lobo Torres seguiu influência na literatura, angariando vozes, ainda que, sob fundamentos teóricos distintos, favoráveis ou contrários à abertura (ou fechamento) do sistema, já na égide da Constituição de 1988, como pode ser observado no celebrado trabalho de Humberto Ávila, denominado "Sistema Constitucional Tributário", que prenuncia como características do Sistema Tributário Nacional a delimitação exaustiva na Constituição, mas também a abertura do sistema, a exemplo da consideração os direitos e garantias fundamentais $^{861}$.

Nesse rastro também segue, por exemplo, a contribuição recente de Paulo Caliendo à compreensão sistemática do Direito Tributário, por sua vez embasado na atual comprensão dos direitos fundamentais, na teoria da justiça e na teoria da $\operatorname{argumentação~}{ }^{862}$.

De forma análoga, pode-se mencionar Paulo de Barros Carvalho, em posicionamento posterior sobre o "Subsistema Constitucional Tributário", que de certa forma não se afasta da compreensão original de Ataliba ${ }^{863}{ }_{-}^{864}$.

${ }^{859}$ DORNELLES, Francisco. Ata das Comissões. In: Anais da Assembleia Nacional Constituinte de $1987, \mathrm{p}$.
184 . Disponível em: www.senado.gov.br
${ }^{860}$ Exemplificativamente, direito ao meio ambiente, à autodeterminação dos povos, direito à paz, direitos
transindividuais, direitos coletivos, etc. BONAVIDES, Paulo. Op.cit., p. 563 .
${ }^{861}$ ÁVILA, Humberto. Sistema Constitucional Tributário. Op.cit., p. 107 e seguintes.
862 CALIENDO, Paulo. Direito Tributário. Três modos de pensar a tributação. Op.cit., p. $77-267$.
863 "Os conceitos até aqui introduzidos permitem ver a ordem jurídica brasileira como um sistema de normas,
algumas de comportamento, outras de estrutura, concebido pelo homem para motivar e alterar a conduta no
seio da sociedade. É composto por subsistemas que se entrecruzam em múltiplas direções, mas que se
afunilam na busca de seu fundamento último de validade semântica que é a Constituição do Brasil. E esta,
por sua vez, constitui também um subsistema, o mais importante, que paira, sobranceiro, sobre todos os
demais, em virtude de sua privilegiada posição hierárquica, ocupando o tópico superior do ordenamento e 
Ataliba, aliás, em seu estudo "República e Constituição", em edições posteriores, e já com fundamento no art.60, $\S 4^{\mathrm{a}}$, da Constituição de 1988, elevou, dentre as chamadas cláusulas pétreas, o princípio federativo e os direitos e garantias fundamentais, livres de qualquer alteração constitucional posterior (o que reforçaria a tese da super-rigidez constitucional) ${ }^{865}$, posições que seguiram mantidas por muitos estudiosos contemporâneos.

Assim, duas tônicas gerais (mas que não afastam ponderações entre ambas) se instalaram na compreensão do Sistema Constitucional Tributário brasileiro a partir da Constituição de 1988: a) a primeira, com maior difusão, compreende o sistema constitucional tributário, uno, extensivo, dogmático, fechado e rigidíssimo (como forma de protegê-lo da insegurança jurídica); b) de outro lado, permeou-se progressivamente a ideia de que o sistema constitucional tributário seria formado por diversos subsistemas, e, portanto plural, aberto à influência externa, e inclusive ao diálogo como outros sistemas de conhecimento.

Se a noção de sistema jurídico para Geraldo Ataliba, Roque Carazza, Paulo de Barros Carvalho, passa (ainda que ponderadamente) por Hans Kelsen ${ }^{866}$, por outro lado, Ricardo Lobo Torres, assim como Klaus Tipke e Joachim Lang ${ }^{867}$, passa por autores como Karl Larenz e Claus Canaris. ${ }^{868}$ As visões distintas dos supracitados referenciais teóricos, acabam inevitavelmente contribuindo para visões dissonantes acerca da sistemática constitucional tributária no Brasil, assim como na composição estrutural das espécies normativas tributárias.

hospedando as diretrizes substanciais que regem a totalidade do sistema jurídico nacional". CARVALHO, Paulo de Barros. Curso de Direito Tributário. 27 Ed. Op.cit., p. 188-189.

${ }^{864}$ Idem, p. 190.

${ }^{865}$ ATALIBA, Geraldo. República e Constituição. Op.cit., p. 122-126.

${ }^{866}$ KELSEN, Hans. Teoria Pura do Direito. Op.cit., p. 20. Sobre o assunto, também: HABERMAS, Jünger.

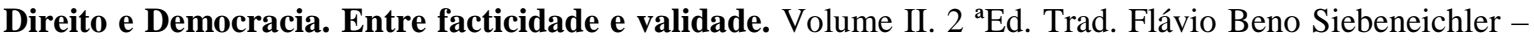
UGF. Rio de Janeiro: Tempo Brasileiro, 2003, p. 222 e seguintes.

${ }^{867 ،}$ “Um direito tributário sistematizado não é absolutamente uma questão de estética ou coesmética jurídicas. Ele tem frente a um Direito Tributário não sistematizado não apenas a vantagem de maior harmonia, também boa disposição, clareza, transparência, inteligibilidade, praticabilidade, didática e apreensibilidade, comprovabilidade e interpretabilidade. Faltando ao sistema interno a disciplina de princípios ético-jurídicos, então o Direito tributário não é também nenhum ordenamento de justiça (Gerechtigkeitsordnung). Pensamento sistemático, uma concepção sistemática é, portanto, indispensável pressuposto para uma boa legislação tributária. TIPKE, Klaus; LANG, Joachim. Op.cit., p.179-180.

${ }^{868}$ CANARIS, Claus Wilhelm. Pensamento Sistemático e Conceito de Sistema na Ciência do Direito. $2^{\circ}$ Ed. Trad. A. Menezes Cordeiro. Lisboa: Serviço de Educação Fundação Calouste Gulbenkian, 1996, p. 2545; LARENZ, Karl. Metodologia da Ciência do Direito. $5^{\circ}$ Ed.. Trad. José Lamego. Lisboa: Serviço de Educação Fundação Calouste Gulbenkian, 2009, p. 621-701. 
Nesse sentido, veja-se que a técnica da previsão extensiva dos dispositivos de matéria tributária na Constituição contribuiu para a formulação do "princípio da rigidez do Subsistema tributário". ${ }^{869}{ }_{-}^{870}$.

Em síntese, duas consequências importantes da sistematização (dogmática) do direito constitucional tributário devem ser lembradas: a) a maior atenção à normatização do direito tributário (consequência inerente ao dogmatismo essencialmente normativo prevalecente na literatura brasileira) ${ }^{871}$; b) a elevação dos princípios jurídicos tributários, como "vigas-mestras" ${ }^{872}$, para a construção do sistema jurídico tributário brasileiro que, pelo seu conteúdo ético inerente, favoreceu também o discurso de abertura sistêmica, pois os princípios, para muitos autores, além de apresentar importância estrutural à composição do sistema jurídico, inevitavelmente apresentam forte carga axiológica.

Por outro lado, deve-se reconhecer que a elevação excessiva dos princípios não pode levar ao que já se denominou por “caos de princípios”, pois a elevação dessas espécies normativas (pela sua generalidade e indeterminação inerente) aos quatro ventos poderia levar também à insegurança jurídica ${ }^{873}$. Daí a necessidade de compreendê-los adequadamente, no intuito de melhor aplicá-los em benefício da abertura do Sistema Constitucional Tributário Brasileiro.

\footnotetext{
${ }^{869}$ CARRAZZA, Roque Antônio. Curso de Direito Constitucional Tributário. Op.cit., p. 38.

${ }^{870}$ Ademais, “(...) apesar de esse ordenamento constitucional formulado especificamente para um âmbito material (VOGEL: "Sachbereichsspezifish Formulierte Steurrechtsordnung") ser qualificado pela extensão e intensidade com que trata a relação tributária, ele é caracterizado pela sua abertura. Aberto não apenas no sentido de um sistema capaz de desenvolvimento, como o são os sistemas vertidos em linguagem, mas no sentido de um sistema que expressamente reenvia a outras normas não expressamente previstas no Sistema Tributário Nacional, mas em outras partes da Constituição". ÁVILA, Humberto. Sistema Constitucional Tributário. Op.cit., p. 107 e seguintes.

${ }^{871}$ Os efeitos do normativismo jurídico no direito tributário serão analisados no Capítulo 3.

${ }^{872}$ CARRAZZA, Roque Antônio. Curso de Direito Constitucional Tributário. Op.cit., p. 38.

${ }^{873}$ Para Roberto Ferraz “(...) são princípios em matéria tributária: a igualdade, a universalidade, a generalidade, a legalidade, a irretroatividade, a capacidade contributiva e a transparência". Busca o autor afastar os "falsos princípios", considerando apenas aqueles que não encontram exceções no direito tributário brasileiro. FERRAZ, Roberto. Princípios são Universais e não comportam Exceções. $10^{\circ}$ Volume. Grandes questões do direito tributário. Valdir de Oliveira Rocha. São Paulo: Dialética, p.398.
} 


\section{CAPÍtUlO 3 - ESTRATÉGiA(S) DE ESTUdO (E ENSINO) NO PROCESSO DISCIPLINAR DO DIREITO TRIBUTÁRIO BRASILEIRO}

\section{A estratégia de investigação e os antecedentes teóricos necessários à consolidação da pesquisa e ensino do Direito Tributário no Brasil}

A consolidação histórico-disciplinar do Direito Tributário Brasileiro envolve necessariamente a consideração da autonomia diante de outros ramos do conhecimento (jurídicos ou não). A ideia de autonomia (teórica), para muitos estudiosos, vincula-se à estruturação sistemática ligada à construção de institutos e princípios próprios a essa mesma disciplina, e que não se encontrariam em nenhuma outra. Daí a necessidade do estudo particularizado. Mas não basta apenas a estruturação teórica em princípios e institutos próprios afeitos ao Direito Tributário. É preciso identificar e elevar o instrumento ou veículo pelo qual esses princípios e institutos serão construídos. E o instrumento próprio para a construção disciplinar do direito tributário, enquanto disciplina jurídica, é a própria interpretação.

Nesse sentido, o processo disciplinar do Direito Tributário guarda peculiaridades não identificáveis em outros ramos do Direito, especialmente no estudo dos métodos interpretativos. A hermenêutica jurídica ${ }^{874}$, tradicionalmente identificada como parcela da dogmática jurídica dedicada aos processos interpretativos do direito, recebe diferente formatação na história do Direito Tributário, especialmente pela elevação da chamada “interpretação econômica”, considerada um dos argumentos elementares para a defesa da autonomia do Direito Tributário perante outros ramos do conhecimento jurídico (sobretudo o Direito Privado) em determinado contexto histórico.

É claro que o elemento político mantém aspecto crucial para a consolidação disciplinar do Direito Tributário. Quando se constrói o Código Tributário Alemão, o objetivo não era outro senão viabilizar receitas tributárias para impulsionar a reconstrução

\footnotetext{
${ }^{874}$ STRECK, Lenio Luiz. Hermenêutica Jurídica e(m) Crise. Uma exploração hermenêutica da Construção do Direito. $2^{\circ}$ Edição. Porto Alegre: Livraria do Advogado, 2000, p. 176-177. SCHNAID, David. Filosofia do Direito e Interpretação. $2^{\circ}$ Edição. São Paulo: Revista dos Tribunais, 2004, p. 268. COELHO. Luiz Fernando. Lógica Jurídica e Interpretação das Leis. $2^{\circ}$ Edição. Rio de Janeiro: Forense, 1981, p. 177-179.
} 
daquele país. Era, afinal, uma situação de extrema emergência. E diversos dispositivos insertos no Código comprovam tal argumentação. Não é surpresa que tal circunstância tenha impulsionado a rápida aprovação do Código, fazendo repercutir seus cruciais efeitos no desenvolvimento disciplinar do Direito Tributário (não somente germânico, naturalmente).

Mas seguramente também, do ponto de vista teórico, legislativo e pedagógico, a codificação tributária apresentou imperdível oportunidade para a elevação do que se convencionou denominar, na Alemanha, de autonomia do Direito Tributário, fortalecida pela perspectiva de veículo hermenêutico próprio e, em tese, mais apto à compreensão das particularidades do Direito Tributário, já que partia da análise da inerente vinculação econômica ao patrimônio do indivíduo, em detrimento das técnicas hermenêuticas tradicionalmente aplicadas até então, e construídas, em muitos aspectos, sob a sólida influência do direito privado.

Consequentemente, no estudo da interpretação do direito tributário, veículo teórico para a elevação da autonomia (em suas diferentes perspectivas), emana-se a construção das linhas de pesquisa e ensino coletivas do Direito Tributário, as chamadas "Escolas", que possuem importância crucial ao processo disciplinar do direito tributário brasileiro.

Ao mesmo tempo, a consolidação disciplinar do Direito Tributário busca construir seu próprio método de estudo, sob diferentes premissas epistemológicas, seja assumindo como pressuposto a possibilidade do diálogo entre o Direito Tributário e a Ciência das Finanças (ainda que com ponderações) seja pela integral refutação a essa aproximação, no século XX. Esse caminho colabora diretamente para determinados posicionamentos estratégicos que viabilizam o reconhecimento de diferentes linhas de estudo desenvolvidas no processo disciplinar do Direito Tributário Brasileiro.

Assim, o reconhecimento disciplinar da formação das diferentes linhas de estudo e de pesquisa do Direito Tributário Brasileiro pode ser analisado sob esse tríplice vértice: a) teorias sobre a autonomia teórica do direito tributário; b) teorias relacionadas ao diálogo entre Direito Tributário e a Ciência das Finanças; c) teorias sobre a interpretação do Direito Tributário. 
Os três diferentes (mas curiosamente complementares) aspectos selecionados para investigação histórica do processo disciplinar do Direito Tributário Brasileiro servirão estrategicamente como pano de fundo para a averiguação de elementos-chave da consolidação ulterior das chamadas "Escolas do Direito Tributário no Brasil", e as respectivas linhas de estudo assumidas no processo disciplinar do Direito Tributário Brasileiro.

\section{Brevíssimo retrospecto sobre a autonomia teórica (e de ensino) na literatura tributária estrangeira fundacional}

O debate da autonomia teórica (científica ou didática), como o próprio nome adianta, compreende substrato teórico fundamental para o processo de especialização disciplinar do Direito Tributário. É claro que esse processo não guarda apenas elementos acadêmicos. Como observado no capítulo 2, o processo de codificação do direito tributário alemão guarda inequívocas características políticas, já que amplamente necessitado de recursos financeiros. A positivação do direito tributário (autonomia legislativa) nasce com essa forte tendência arrecadatória.

Por outro lado, a autonomia legislativa leva também à autonomia do ensino e à autonomia teórica, já que simbolizam a busca pela emancipação frente às disciplinas (jurídicas ou não) que exerciam influência teórica nos estudos jurídicos sobre o fenômeno tributário.

No que diz respeito à autonomia do ensino no direito tributário alemão, conforme informa Kruse, Ludwig Waldecker, em 1915, na Universidade de Berlim, inicia suas aulas no curso de Verão de Direito Financeiro e Direito Tributário, consolidando-a como disciplina jurídica autônoma em 1920, na mesma universidade ${ }^{875}$. Na mesma época, Albert Hensel viabiliza o primeiro curso de Direito Tributário da Universidade de Bonn ${ }^{876}$.

\footnotetext{
${ }^{875}$ KRUSE, Heinrich Wilhelm. Steuerrecht. I. Allgemeiner Teil. 3. Auflage. München: Verlag CH Beck, 1973, p. 01-05.

${ }^{876}$ NOGUEIRA, Ruy Barbosa. Prefácio. In: Souza Diniz. Códigos Tributários. Alemão. Mexicano. Brasileiro. Op.cit., p. viii-ix.
} 
Por isso faz sentido a afirmação de Fernando Aurelio Zilveti, para quem “(...) o Direito Tributário pôde, portanto, ser considerado disciplina autônoma da Ciência do Direito, a partir do início da época de Weimar, após integrar as disciplinas da Ciência das Finanças e do Direito Administrativo" ${ }^{, 77}$. E, claro, a entrada em vigor da Ordenação Tributária do Reich, em $1919^{878}$, impulsionou fortemente esse processo ${ }^{879}$.

Eram, para Amatucci “(...) os anos de ouro da Ciência do Direito Tributário na Alemanha", contando com nomes como Enno Becker; L.Waldecker; assim como das influências dos publicistas Jellinek; Otto Mayer; Fleiner, Fritz Reinhardt, Blumenstein, entre outros ${ }^{880-881}$.

Da mesma forma, conforme já informado, segundo Kruse, também contribuíram para o fortalecimento disciplinar do Direito Tributário na época Schneiders, Lassars, bem como Kurt Ball, Waldecker, Strutz, Hensel, Friedrichs, Mirbt, Merk, Bühler, Jahn e Crisolli, na Alemanha, assim como Nawiasky, na Áustria ${ }^{882}$.

Na Áustria, o ensino do Direito Tributário, ainda que vinculado em muitos aspectos ao Direito Financeiro, aparece em 1886, na Universidade de Viena, sob a cátedra de Tezner, e, na Universidade de Insbruck, sob a tutela de Franz Von Myrbach-Rheinfeld ${ }^{883}$ ${ }^{884}$, grande responsável também por viabilizar a autonomia teórica entre Direito Financeiro (e Direito Tributário) e Ciência das Finanças ${ }^{885}$.

Na Itália, os processos aparecem quase simultaneamente ${ }^{886}$. Naturalmente, como já visto, pelas próprias peculiaridades históricas da realidade italiana, pode-se dizer que as disciplinas financeiras surgem no campo de ensino da Economia Política, com Luigi

${ }^{877}$ ZILVETI, Fernando Aurelio. Obrigação Tributária - Fato Gerador e Tipo. Op.cit.,p. 24-25.

${ }^{878}$ D'AMATI, Nicola. L'Insegnamento del Diritto Tributario. In: L'Evoluzione dell'Ordinamento Tributario Italiano. UCKMAR, Victor (Coord.) CEDAM: Milani, 2000, p. 127 e ss.

${ }^{879}$ BUJANDA, Fernando Sainz de. Sistema de Derecho Financiero. I. Introduccion. Volumen Segundo. Madrid: Universidad Complutense, 1985, p. 25 e ss.

${ }_{880}$ Recomenda-se a leitura da nota de rodapé n.7. AMATUCCI, Andrea. Historia de La Enseñanza del Derecho FinancieroPúblico en Italia. Op.cit., p. 101-102.

${ }^{881}$ KRUSE, Heinrich Wilhelm. Steuerrecht. I. Allgemeiner Teil. 3. Auflage. München: Verlag CH Beck, 1973, p. 01-05.

${ }^{882}$ KRUSE, Heinrich Wilhelm. Steuerrecht. I. Allgemeiner Teil. 3. Auflage. München: Verlag CH Beck, 1973, p. 01-05.

883 Idem.

${ }^{884}$ AMATUCCI, Andrea. Historia de La Enseñanza del Derecho FinancieroPúblico en Italia. Op.cit., p. 101-102.

${ }^{885}$ MYRBACH-RHEINFELD, Franz Von. Op.cit., p. 10-12; p.107-108.

${ }^{886}$ Sobre o assunto, também: D’AMATI, Nicola. La Formación del Derecho Tributario en Italia. In: Historia del Derecho de La Hacienda Pública y del Derecho Tributario en Italia. El aporte del pensamiento jurídico financiero de La Italia Meridional. AMATUCCI, Andrea; D'AMATI, Nicola. Bogotá - Colômbia: Temis, 2004, p. 139 e ss 
Cossa ${ }^{887}$, em 1859, em Pávia, e se efetivam com a criação oficial da disciplina, em 1878, por Giuseppe Ricca Salerno. A autonomia do ensino leva à autonomia teórica que leva à autonomia legislativa, ainda que tardia, quando se cria, em 1924, por Raneletti a cátedra de Direito Financeiro e Ciência das Finanças na Faculdade de Direito da Universidade Frederico II de Nápoles e, posteriormente, a mesma cadeira na Faculdade de Direito da Universidade de Milão ${ }^{888}$.

Raneletti buscava a autonomia do direito financeiro, sobretudo da influência econômica, embora não a refutasse em absoluto. Influenciado pela literatura germânica (Waldecker), defendeu que o fenômeno jurídico-financeiro e o fenômeno econômicofinanceiro tratavam de fenômenos distintos e, portanto, mais adequado para estudá-los seria a separação das cátedras, mas com fortes conexões com o Direito Administrativo.

Reconhecia que o estudo do direito financeiro e da ciência das finanças, ainda que analisando o mesmo fenômeno, o faziam de dois particulares pontos de vistas diferentes. Muitos discípulos de Ranelleti apareceriam buscando manter essa visão, como Tesoro, Giannini e D'amatti ${ }^{889}$.

No mesmo período, em 1920, Benvenuto Griziotti ${ }^{890}$, aluno de Adolph Wagner, P.Leroy-Beaulieu, V.Pareto, M. Pantaleoni, Antonio de Viti de Marco, R.Benini e Luigi Einaudi $^{891}$, assume a cátedra de Ciência das Finanças e Direito Financeiro da Universidade de Pávia, universidade onde já havia lecionado Antonio de Viti de Marco. Forma-se, a Escola de Pávia, segundo a qual a Ciência das Finanças e o Direito Financeiro estudam o mesmo fenômeno ${ }^{892}$. Entre seus alunos, destacaram-se juristas e financistas, como Ezio Vanoni, Mario Puglièse e Jarach.

No âmbito teórico, contudo, a Itália manteve posicionamentos distintos acerca de uma teoria autonomista ou antiautonomista do direito tributário perante outros ramos do

\footnotetext{
887 D'AMATI, Nicola. L'Insegnamento del Diritto Tributario. In: L'Evoluzione dell'Ordinamento Tributario Italiano. UCKMAR, Victor (Coord.) CEDAM: Milani, 2000, p. 135 e ss.

${ }^{888}$ ZILVETI, Fernando Aurelio. Obrigação Tributária - Fato Gerador e Tipo. Op.cit.,p. 26.

${ }^{889}$ AMATUCCI, Andrea. Historia de La Enseñanza del Derecho Financiero Público en Italia. Op.cit., p. 100 e ss.

${ }^{890}$ Mas em 1914, Griziotti já apresentava uma introdução ao Curso de Ciência das Finanças e Direito Financeiro, lecionado na Universidade de Catania. D’AMATI, Nicola. La Formación del Derecho Tributario en Italia. In: Historia del Derecho de La Hacienda Pública y del Derecho Tributario en Italia. In: Historia del Derecho de La Hacienda Pública y del Derecho Tributario en Italia. El aporte del pensamiento jurídico financiero de La Italia Meridional. AMATUCCI, Andrea; D’AMATI, Nicola. Bogotá - Colômbia: Temis, 2004, p. 140 e ss

${ }^{891}$ AMATUCCI, Andrea. Historia de La Enseñanza del Derecho Financiero Público en Italia. Op.cit., p. 100 e ss.

${ }^{892}$ AMATUCCI, Andrea. Historia de La Enseñanza del Derecho Financiero Público en Italia. Op.cit., p. 100 e ss.
} 
conhecimento, seja sobre a Ciência das Finanças, seja frente ao Direito Financeiro, conforme reconhece Berliri ${ }^{893}$, divergência que se manifesta também na literatura europeia de modo geral ${ }^{894}$.

$\mathrm{Na}$ literatura italiana, a autonomia teórica (e de ensino) do direito financeiro passa a se fortalecer com os esforços de Nicola D’Alessio e Gustavo Ingrosso, e, posteriormente, com Romanelli Grimaldi, na Universidade de Nápoles, assim como de Vincenzo Sica, e Giuseppe Abamonte, na principiologia constitucional aplicada ao estudo do fenômeno financeiro.

Historicamente, as duas Escolas, a de Nápoles e a de Pávia, apresentaram posicionamentos distintos sobre o método de estudo e ensino do Direito Financeiro. Ambos apresentaram como líderes Ranelleti e Griziotti, respectivamente. Com seus discípulos assumindo cátedras de outras universidades italianas, a polêmica se manteve. Mas como esperado, o processo de autonomia teórica e de ensino, decorrente do próprio processo de especialização disciplinar, caminhou pela prevalência do método de estudo da Escola de Nápoles, ainda que com ponderações à Ciência das Finanças. ${ }^{895}$

Na Espanha, a influência de Fernando Sainz de Bujanda nas cátedras universitárias de Direito Financeiro foi determinante ${ }^{896}$, sobretudo enquanto catedrático da Universidade Complutense de Madrid, trazendo ensinamentos de Griziotti, Carnelutti, Giannini, e influenciando importantes estudiosos latino-americanos como Calvo Ortega e Pérez de Ayala, assim como Ramón Valdés Costa, no Uruguai ${ }^{897}$.

De qualquer forma, observando a experiência estrangeira acima, é possível identificar três facetas fundamentais do debate autonomista, não necessariamente sucessivas e nem excludentes: a) em primeiro lugar, os estudiosos buscam a autonomia teórica do Direito Tributário para afastá-lo da influência dos estudos econômicos sobre o fenômeno tributário (especialmente exercidos pela Ciência das Finanças); b) em segundo lugar, os estudiosos buscam autonomia teórica (reconhecendo-a como disciplina

\footnotetext{
${ }^{893}$ BERLIRI, Antonio. Principii di Diritto Tributario. Volume I. Op.cit., p. 03 e ss.

${ }^{894}$ TESORO, Giorgio. Principii di diritto tributario, Bari: Dott. Luigi Macri Editore, XVI, 1938, p. 09 e ss. BLUMENSTEIN, Ernst. Sistema di Diritto delle Imposte. Traduzione: FORTE, Francesco. Milano: Dott A. Giuffrè, 1954, p. 22 e ss. GENY, François. Le Particularisme du Droit Fiscal. Revue Trimestrielle de Droit Civil, 30 vol., Recueil Sirey, Paris, 1931, p. 36. TROTABAS, Louis. Ensaio sobre o Direito Fiscal. Revista Forense. Doutrina, p. 53-68.

${ }^{895}$ AMATUCCI, Andrea. Historia de La Enseñanza del Derecho FinancieroPúblico en Italia. Op.cit., p. 135-136.

${ }^{896}$ GONZALEZ, Eusebio. La Enseñanza del derecho Tributario. In: L'Evoluzione dell'Ordinamento Tributario Italiano. UCKMAR, Victor (Coord.) CEDAM: Milani, 2000, p. 163 e ss.

${ }^{897}$ AMATUCCI, Andrea. L'Insegnamento del Diritto Finanziario. In: L'Evoluzione dell'Ordinamento Tributario Italiano. UCKMAR, Victor (Coord.) CEDAM: Milani, 2000, p. 113 e ss.
} 
autônoma) perante disciplinas conexas, como o Direito Administrativo e o Direito Financeiro, por entender que o Direito Tributário apresentaria princípios e temas próprios que não seriam necessariamente permeáveis pelas lógicas aplicadas às duas disciplinas (mais amplas); c) em terceiro lugar, os estudiosos buscam a autonomia do Direito Tributário (e de seus conceitos) da influência do Direito Privado (e seus conceitos), por entender que, diante do processo de amadurecimento disciplinar do primeiro, este não necessitaria recorrer ao historicamente bem consolidado Direito Civil (e seus conceitos).

Sobre a primeira perspectiva, a autonomia teórica do Direito Tributário revela-se nos esforços de Franz Von Myrbach-Rheinfeld, que, a propósito de seu Compêndio de Direito Financeiro (que deveria se chamar Compêndio de Direito Tributário e Direito Financeiro, por dedicar a maior parte de sua obra ao primeiro campo), tencionava emancipar juridicamente a disciplina da influência da Política Fiscal e da Ciência das Finanças (que, na época, já lançava aportes sobre a Legislação Financeira, substituindo os afazeres dos juristas) ${ }^{898}{ }_{-}^{899}$.

Para Myrbach-Rheinfeld, separar os estudos de Direito Financeiro (e Tributário) da influência econômica era o caminho para a emancipação disciplinar, especialmente em ambiente histórico em que a Ciência das Finanças prevalecia em importância sobre os juristas ao fenômeno financeiro.

O fenômeno tributário na época (século XIX e início do século XX) era ainda estudado na órbita do Direito Administrativo e Financeiro, passando a ser estudado com efetiva intensidade enquanto ramo legislativamente, didaticamente (ensino) e teoricamente autônomo a partir da entrada em vigor do Código Tributário Alemão ${ }^{900}{ }^{901}$.

Este, aliás, tinha entre seus objetivos fundamentais a própria autonomia (legislativa, que por sua vez levou à teórica) dos conceitos de Direito Tributário daqueles sedimentados no Direito Civil, e, mais precisamente, a separação do Direito Tributário de outros ramos

\footnotetext{
${ }^{898}$ MYRBACH-RHEINFELD, Franz Von. Op.cit., p. 20 e seguintes.

899 JÈZE, Gastón. Cours de Science des Finanzes et de Legislatión Financière Française. Op.cit., p. 0102; ALLIX, Edgard. Traité Élémentaire de Science des Finances et de Législation Financière Française. Op.cit., p. 01-02.

${ }^{900}$ HENSEL, Albert. Op.cit., p. 03-04.

901 NOGUEIRA, Ruy Barbosa. Prefácio. In: Souza Diniz. Códigos Tributários. Alemão. Mexicano. Brasileiro. Op.cit., p. iv e seguintes.
} 
do conhecimento (notadamente do Direito Civil). Mas não afastava expressamente as contribuições da Ciência das Finanças.

Mas a tese da autonomia teórica do Direito Tributário não foi recebida sem críticas imediatas de doutrinadores da época, como é possível observar em Giorgio Tesoro, que preferiu apontar o particularismo próprio ao Direito Tributário, ao mesmo tempo em que reconheceu o Direito Tributário como parte do Direito Financeiro, já que o primeiro não escapava da influência do segundo, ainda que mantivesse as próprias particularidades. ${ }^{902}$

A síntese do debate teórico da autonomia (especialmente divulgada na literatura de língua latina) pode ser simbolizada, no ponto de vista teórico, entre François Geny (antiautonomista) $^{903}$ e Louis Trotabas (autonomista) ${ }^{904}$, que utilizaram a polêmica do uso de conceitos de Direito Privado no Direito Tributário para catapultar a tese da autonomia, ou refutá-la, no desenvolvimento da Ciência do Direito Tributário.

Nesse sentido, basicamente tais debates autonomistas proporcionaram as seguintes questões: $1^{\text {a }}$ ) divergência doutrinária sobre a subordinação - ou não subordinação - do Direito Tributário a conceitos e institutos do Direito Privado; $2^{\mathrm{a}}$ ) a consideração europeia sobre a possibilidade de haver: a) uma recepção expressa dos conceitos de Direito Privado pelo Direito Tributário; b) uma recepção implícita de conceitos de Direito Privado no Direito Tributário; c) uma alteração explícita de conceitos do Direito Civil no Direito Tributário e; d) finalmente, uma aplicação analógica das normas de Direito Civil no Direito Tributário $^{905}$.

\footnotetext{
902 TESORO, Giorgio. Op.cit., p. 09 e seguintes.

903 Segundo o próprio Geny: "Este último (o direito civil e comercial) tirou e tira ainda ensinamentos preciosos do direito fiscal. Todo civilista prudente sabe o quanto as teorias, mais essenciais, do direito privado obtiveram de revelações fecundas e de desenvolvimentos ricos e novos, pela penetração das teorias fiscais, que, graças à própria sutileza, exigida por sua adaptação, levam a descobrir pontos de vista que esclarecem melhor os conflitos dos interesses privados e sugerem os meios de solucioná-los". GENY, François. O Particularismo do Direito Fiscal. Op.cit., p. 06-09.

${ }^{904}$ Mas a linha defendida por Louis Trotabas era diametralmente oposta, já que assumia como necessidade a autonomia científica do Direito Tributário perante os demais ramos do Direito. Essa defesa era fundamentada no aparente "descaso" com que era tratado o Direito Tributário na época (início do século XX), revestindo o papel de verdadeira, segundo as palavras do autor, “(...) parente pobre, a cinderela, de quem ninguém se ocupa". Trotabas compreendia que o desenvolvimento disciplinar do Direito Tributário seria viabilizado pelo reconhecimento autonômo do Direito Tributário, sem necessitar recorrer aos conceitos de outros ramos do direito, em especial ao Direito Privado. TROTABAS, Louis. Ensaio sobre o Direito Fiscal. Revista Forense. Doutrina. 145, s/d, p. 53-68.

905 Sobre o assunto: TESORO, Giorgio. Pincippi di Diritto Tributario. Op.cit., p. 10 e seguintes; BLUMENSTEIN, Ernst. Sistema di Diritto delle Imposte. Op.cit.,p. 23-25. Na literatura brasileira,
} 
A consolidação do debate pode ser visualizada através de seus reflexos na própria autonomia legislativa, como se observa na literatura e na legislação latino-americana, a exemplo do Código Mexicano, de 1938, a primeira codificação latino-americana em matéria tributária, ao prever, no art.11, que “(...) o direito comum só se poderá aplicar subsidiàriamente a propósito deste Código e das demais disposições fiscais, quando expressamente esteja (isso) previsto, ou quando não exista norma expressa e a aplicação subsidiária não esteja em contradição com a própria natureza do direito tributário definido nessas leis. As normas de direito tributário que estabeleçam encargos à particulares serão de aplicação estrita. Para as demais, observar-se-ão os princípios gerais do direito"906.

Tencionava alcançar, o art.11, maior equilíbrio na relação entre Direito Tributário e o Direito Privado, ou, em melhores termos, no uso de conceitos e princípios do Direito Privado frente ao Direito Tributário, naturalmente concedendo preferência ao último em detrimento do primeiro, que só seria utilizado em caráter subsidiário, isto é, sem comprometer a prevalência do instituto tributário.

Essa tendência também foi visualizada nas Primeiras Jornadas Latino-Americanas de Direito Tributário, realizadas em Montevidéu, no ano de 1956, quando foram aprovadas as seguintes recomendações em relação à autonomia teórica e legislativa do Direito Tributário: “1") O Direito Tributário tem autonomia dentro da unidade geral do Direito, porquanto se rege por princípios próprios e possui institutos, conceitos e objetos também próprios; $2^{\mathrm{a}}$ ) Por conseguinte, a norma tributária deve precisar seus conceitos próprios, assinalando os elementos de fato contidos nelas; e, quando utilize os de outras disciplinas, deve precisar o alcance que atribua os mesmos. $3^{\text {a }}$ ) - As normas jurídicas tributárias substantivas, formais e processuais, devem ser agrupadas sistematicamente em corpos jurídicos orgânicos (...)"907.

Sucessivamente, o tema catapultou a atenção dos primeiros estudiosos do Direito Tributário no Brasil, que logo foram permeados por semelhantes sintomas no processo de especialização disciplinar.

recomenda-se o panorama histórico levantado por Alcides Jorge Costa: COSTA, Alcides Jorge. Direito Tributário e Direito Privado. Op.cit., p. 221 e ss.

${ }^{906}$ Código Tributário Mexicano. In: Souza Diniz. Códigos Tributários. Alemão. Mexicano. Brasileiro. $1^{\circ}$ edição. Tradução de Souza Diniz. São Paulo: Edições Financeiras S.A., 1965, p.343-447.

${ }^{907}$ Revista de Derecho Financiero y de Hacienda Publica, Editorial Derecho Financiero, Madrid, 1956, p.759 e ss). Citado por NOGUEIRA, Ruy Barbosa. Direito Financeiro (Curso de Direito Tributário). Op.cit., p. 09. 
Mas para compreender a importância do debate autonomista (teórico e de ensino) para o processo histórico disciplinar do Direito Tributário brasileiro, é preciso entender, ainda que superficialmente, dois alicerces fundamentais da questão: as teorias sobre o diálogo entre o Direito Tributário e outros ramos do conhecimento (e sobretudo, entre o Direito Tributário e a Ciência das Finanças) e a construção histórica da interpretação do Direito Tributário. Ambos contribuem diretamente para a melhor compreensão das opções teóricas que influenciaram o florescimento disciplinar do Direito Tributário Brasileiro, sobretudo perante a experiência europeia.

\section{A contribuição histórica das Escolas italianas de Pávia e de Nápoles para o debate sobre as relações entre Direito Financeiro e Ciência das Finanças.}

A consideração de fenômenos "extrajurídicos" na doutrina financeira (e tributária) nunca foi novidade, restando sempre presente entre os estudiosos do fenômeno tributário a elementar questão do diálogo entre o Direito Tributário e outros ramos do conhecimento (sobretudo, a Ciência das Finanças) ${ }^{908}$. Contudo, o diálogo com outros ramos do conhecimento, embora expressamente defendido no início do processo disciplinar do Direito Tributário, acabou afastado, pelos motivos abaixo compreendidos. Os protagonistas principais do debate europeu pela consideração de fenômenos exteriores no estudo do Direito Tributário frente a outros campos do conhecimento foram Griziotti e Giannini, na doutrina italiana, na primeira metade do século XX.

A primeira teoria foi construída originalmente por Benvenuto Griziotti ${ }^{909}$, que, como líder da Escola de Pávia, expôs a teoria da complexidade do fenômeno financeiro (global). Para ele, a Ciência da Fazenda (Financeira) seria formada pelo "conjunto": jurídico, econômico, político e técnico. Porém, nada impediria a análise sob um "aspecto"

\footnotetext{
${ }^{908}$ Mas é importante que se ressalte que, sob o ponto de vista das atuais teorias interdisciplinares, o diálogo entre disciplinas só pode se manifestar através de disciplinas bem consolidadas. Na época, o estudo do fenômeno financeiro, especialmente na sua perspectiva jurídica, na literatura italiana, ainda trilhava seus primeiros passos, motivo pelo qual é absolutamente temerário considerar o debate na época ligado à ideia de interdisciplinaridade (epistemologicamente compreendida) contemporânea, o que não impede a identificação de semelhanças com o fenômeno. $\mathrm{O}$ estudo do fenômeno financeiro ainda buscava a definição de seu objeto e método de estudo apropriado, e nesse contexto, é que as teorias monista ou dualista se afirmaram.

${ }^{909}$ Considerado líder da famosa Escola de Pávia, promoveu o aperfeiçoamento dos estudos financeiros, seja através do apoio de juristas, seja pelo apoio de financistas (dentre eles, Ezio Vanoni, Mario Puglièse, Dino Jarach). GRIZIOTTI; Benvenuto. Princípios de Política, Derecho y Ciência de la Hacienda. Traducción: Enrique R. Mata .Segunda Edición. Madrid: Instituto Editorial Réus, 1958.
} 
apenas, desde que não se deixasse de considerar o aspecto "global" inerente à Ciência da Fazenda. ${ }^{910}$

Nesse contexto, Griziotti afirmava a impossibilidade absoluta de "estudos apartados" entre a Ciência das Finanças e o Direito Financeiro, já que ambos seriam componentes da mesma realidade, incindível, que só admitiria o estudo separado de ambas se, ao final de cada estudo, fosse expresso o teor unitário ínsito ao Direito Financeiro e à Ciência das Finanças ${ }^{911}$. Todos esses elementos, embora permitissem estudos separados, não escapariam à necessidade de reconhecimento do caráter unitário do fenômeno financeiro $^{912}$.

A relevância da doutrina (e da codificação) germânica pode ser identificada como marco teórico na vida acadêmica de Griziotti, e, especialmente, ao seu convívio com Albert Hensel. Pelo menos essa é a opinião de Fonrouge, e que parece acertada. De fato, a influência do pensamento de Hensel foi marcante para Griziotti. Tanto é que, no período que se sucedeu ao falecimento de Hensel (1934), foi a doutrina italiana muito mais influenciada pelo autor alemão que a própria doutrina germânica e, isso, em grande parte, graças ao apoio de Griziotti. Nesse sentido, Griziotti desenvolveu e aprofundou um apontamento formulado por Albert Hensel, em seu "Direito do Imposto", no qual ele defendia que “(...) o Direito Tributário sem a fecundação da Ciência das Finanças termina

\footnotetext{
${ }^{910}$ Para o autor, não se poderia prescindir do reconhecimento de que o melhor método de conhecimento de um objeto como o fenômeno financeiro (unitário e inseparável) seria a análise sob todas as perspectivas em seu conjunto. Para Griziotti, a atividade financeira mantinha uma complexidade tal que não se poderia tratar de seus aspectos absolutamente separados uns dos outros, sob pena de não ser possível compreender a riqueza do fenômeno em sua completude. Em outros termos: "Na atividade financeira são inseparáveis, ainda que nitidamente distintos e distinguíveis, os elementos políticos, jurídicos e económicos. Por conseguinte, estimo insuficiente e indeterminado um estudo que não considere a orientação política, o fundamento jurídico, o conteúdo econômico e a ordenação científica dos institutos financeiros (tradução livre)". GRIZIOTTI, Benvenuto. Introdución. In: GRIZIOTTI; Benvenuto. Princípios de Política, Derecho y Ciência de la Hacienda. Op.cit., p. 05.

${ }^{911}$ GRIZIOTTI, Benvenuto. Introdución. In: GRIZIOTTI, Benvenuto. Princípios de Política, Derecho y Ciência de la Hacienda. Op.cit., p. 05 e seguintes.

${ }^{912}$ Desta forma, conforme assinalam Valdés Costa e Giuliani Fonrouge, a visão de Griziotti passava pelos seguintes elementos: a) o elemento político, que se refere aos critérios determinantes da eleição financeira de despesas e receitas que o Estado realiza; b) o elemento econômico-social que, por sua vez indica a função econômico-social, assinalando o fim, a causa e a razão daquela eleição; c) o elemento jurídico, por sua vez, referido à natureza unilateral ou bilateral da relação; d) o elemento técnico que se relaciona às operações técnicas que se manifestam no desenrolar da atividade tributária.VALDÉS COSTA, Ramón. Curso de Derecho Tributário. Buenos Aires - Santa Fé de Bogotá - Madrid: Depalma - Themis - Marcial Pons, 1996, p. 03. FONROUGE, Carlos M. Giuliani. Derecho Financiero. Volumen I. $2^{\circ}$ Edición. Buenos Aires: Depalma, 1970, p. 112-114.
} 
em um simples trabalho técnico; a ciência das finanças sem o controle do direito positivo, não sai da estipulação abstrata (...)" ${ }^{, 913}$.

Por expressa influência de Hensel, Griziotti afirmou que somente a investigação econômica, desprovida de adequadas orientações políticas e jurídicas conduziria a resultados insustentáveis. Desta forma, somente a investigação jurídica - que não tenha o apoio dos conceitos e institutos formulados pelas Ciências das Finanças sobre a natureza e as funções dos tributos - é insegura e conduziria a conclusões errôneas ${ }^{914}$. É por isso também que Griziotti recebeu sem maiores traumas a doutrina da interpretação econômica da lei tributária, da qual foi um de seus principais artífices, em terras italianas.

Em síntese, o líder da Escola de Pávia elaborou uma concepção unitária, global ou monista do fenômeno financeiro, reconhecendo e elevando expressamente sua complexidade ínsita. Essa concepção serviu de fundamento para todos os seus trabalhos doutrinários, seja no âmbito da Ciência das Finanças ou do Direito Financeiro.

Porém, embora a doutrina de Griziotti fosse muito respeitada na época, mesmo na Itália, as ideias sobre a complexidade e o caráter unitário do fenômeno financeiro - e, sobretudo, sua impossibilidade de análise "em apartado" -, não encontraram aceitação pacífica na doutrina italiana que emergia do Direito Tributário, já mais condicionada ao ideal de autonomia (e especialização) jurídica da disciplina. Enquanto contraposto à ideia de Griziotti, surge corrente antagônica, defendendo a completa impossibilidade - do ponto de vista teórico e pragmático - de fundir em uma única ciência o Direito Financeiro e a Economia.

Essa doutrina, aqui denominada de corrente dualista ou separatista, teve como principal representante Achille Donato Gianinni, um dos principais expoentes da Escola de

\footnotetext{
${ }^{913}$ Cita-se na íntegra o desenvolvimento do raciocínio de Hensel, que inspirou Griziotti a elaborar sua tese acerca do caráter unitário do fenômeno financeiro: "Se o trabalho da ciência do direito tributário fosse aquele de formar expertos funcionários de finanças, o fim prático da Ciência das Finanças, seria a preparação de políticos de finanças instruídos cientificamente. Esta fórmula indica, portanto, as disciplinas, não obstante as suas separações na teoria e no estudo científico, serem em substância muito afins. O direito tributário sem a fecundação da ciência das finanças permanece um simples trabalho técnico, e a ciência das finanças sem o controle do direito positivo não sairia da especulação abstrata" (tradução livre). HENSEL, Albert. Op.cit., p. 04-05.

914 Por esse motivo Griziotti também afirmou que, “(...) os fatos financeiros se apresentam homogêneos em sua constituição, unitários, bem caracterizados, mas complexos em seus elementos constitutivos, que são essenciais e, portanto, vinculados por inter-relações funcionais". GRIZIOTTI, Benvenuto. Studi di Scienza delle Finanze e Diritto Finanziario. Milano: Giuffrè, 1956, p. 51.
} 
Nápoles, embora não seja correto afirmar que essa tese fosse criação desse autor, pois já era defendida por seu mestre da Escola Napolitana, Orestes Ranelleti e, posteriormente, essa posição foi assumida por Romaneli-Grimaldi, na mesma Escola.

Em síntese, Giannini defendeu que, sobre a possibilidade de estudos conjuntos entre a Ciência das Finanças e o Direito Tributário, tal tentativa equivaleria à probabilidade infrutífera de “(...) combinar quimicamente a madeira com o ferro". 915

Para Giannini, não obstante a atividade financeira ter em sua orientação objetivos políticos, econômicos ou sociais e deva levar em consideração aspectos econômicos, através de instrumentos técnicos, isso não significaria de forma alguma que se tivesse de considerar os antecedentes de natureza econômica, utilizando determinados meios técnicos, e não significaria que devesse existir uma fusão entre esses elementos e o elemento jurídico como se fosse um todo unitário ${ }^{916}$.

Giannini reconhecia a existência de relações entre as duas ciências, provenientes das "identidades de pressupostos de fato". Porém, nem isso seria “(...) suficientemente certo para legitimar a unificação das duas disciplinas, porque, por outro lado, todo o conhecimento humano deveria ser transportado para as ciências jurídicas, não havendo algum ramo em que não ocorra tal retorno a cognição para a exata inteligência e a correta aplicação desta ou daquela norma jurídica (...)”.

Giannini não acreditava que a contraposição do critério econômico ao formalismo jurídico poderia resultar numa mais poderosa “(...) síntese entre a ciência das finanças e o direito financeiro". Pelo contrário, na opinião de Giannini, o risco de se operar com instrumentos da Ciência das Finanças e do Direito Financeiro se manifestaria na produção de respostas aberrantes, servindo apenas a atrapalharem-se reciprocamente quanto aos seus

\footnotetext{
${ }^{915}$ GIANINNI, Achile Donato. I Concetti Fondamentali di Diritto Tributário. Op.cit., p. 11 e seguintes.

916 Para a melhor compreensão do leitor acerca do embate epistemológico referido, menciona-se expressamente a passagem da obra de Giannini, quando contrariou a doutrina de Griziotti: "No nosso regulamento universitário o ensino do direito financeiro é atrelado àquele da Ciência das Finanças, não faltando cultores desta última disciplina os quais negam a possibilidade lógica ou a oportunidade prática de uma distinção entre as duas ciências. Mas que se trata de uma opinião evidentemente errônea resulta do simples relevo que o direito financeiro pertence, como se clarificou, ao grupo das ciências jurídicas, enquanto a ciência das finanças remanesce no quadro das ciências econômicas. Ambas as disciplinas movem-se sobre a consideração de um mesmo fato, a arrecadação e o emprego dos meios econômicos ocorridos na vida dos entes públicos, mas o consideram, e é isto que interessa para a classificação das ciências, de dois diversos pontos de vista" (tradução livre). GIANNINI, A. D. Istituzioni di Diritto Tributario. Op.cit., p.09-11.
} 
objetivos e métodos. Por isso: “(...) este é, como efeito, que mais se teme, da fusão do direito financeiro com a Ciência das Finanças". 917

Mas, historicamente, ainda que não prevalecentes, mesmo na literatura tributária latino-americana, foi possível identificar a elaboração de estudos jurídicos com aportes da Ciência das Finanças. ${ }^{918}$ Ainda que a necessidade de separação entre as duas disciplinas possuidoras de princípios e métodos próprios, acabasse prevalecendo ${ }^{919}$, figurou-se extensa gama de autores que apontaram pela conveniência do estudo apartado - porém sem negar a existência de estreitas conexões entre ambas, e mesmo recebendo contribuições desses outros ramos do conhecimento (notadamente da Ciência das Finanças), como Louis Trotabas $^{920}$, Ernst Blumenstein ${ }^{921}$, Gustavo Ingrosso ${ }^{922}$, Ezio Vanoni ${ }^{923}$, Antonio Berliri ${ }^{924}$, Dino Jarach ${ }^{925}$, Valdés Costa ${ }^{926}$, Mario Puglièse ${ }^{927}$, Fonrouge ${ }^{928}$ e Fernando Sainz de Bujanda $^{929}$.

${ }^{917}$ Idem.

918 Giuliani Fonrouge didaticamente apontou uma importante característica diferenciadora entra as duas correntes: a unitária ou monista (Griziotti) concebia os distintos elementos do fenômeno financeiro como simultâneos, ao passo que a corrente dualista ou separatista (Giannini) aceitava a presença de momentos sucessivos, sendo que o primeiro momento, primeiramente de caráter econômico-social, pertenceria à Ciência das Finanças e a Política Financeira, e o segundo, posteriormente, constituiria na manifestação do fenômeno financeiro enquanto ato jurídico, estando, portanto, na presença de duas disciplinas distintas: as ciências econômicas e as ciências jurídicas. FONROUGE, Carlos M. Giuliani. Derecho Financiero. Op.cit., p. 13-14.

${ }^{919}$ Em ponderação separatista mais enérgica, por outro lado, menciona-se Giorgio Tesoro, que, criticando expressamente a opinião de Griziotti, valeu-se da lição de Carnelutti: "é melhor - assim escreve Carnelutti estudar o fenômeno financeiro profundamente de um só lado, do que por todos os lados superficialmente, como se pode fazer com uma meia cultura; nem há necessidade de acrescentar que quando o fenômeno financeiro é estudado pelo jurista, este deve estudá-lo, pois, com seus métodos e com seus princípios". TESORO, Giorgio. Pricipii di diritto tributário. Op.cit., p. 09 e seguintes.

${ }^{920}$ TROTABAS, Louis. Droit Fiscal. $2^{\circ}$ édition. Paris: Dalloz, 1975, p.16-17.

${ }^{921}$ BLUMENSTEIN, Ernst. Op.cit., p.14-16.

${ }^{922}$ INGROSSO, Gustavo. Diritto Finanziario. Op.cit., p. 06-17.

${ }^{923}$ VANONI, Ezio. Opere Giuridiche. A cura di Francesco Forte e Cesare Longobardi. II. Elementi di Diritto tributario. Altri saggi di diritto finanziario. Milano - Dott.A. Giuffrè Editore, 1962, p. 10-17

${ }_{924}^{92}$ BERLIRI, Antonio. Principi di Diritto Tributario. Volume I. Op.cit., p. 15 e seguintes.

925 JARACH, Dino. El Hecho Imponible. Teoria General del Derecho Tributario Sustantivo. Tercera Edición. Buenos Aires: Abeledo-Perrot, 1971, p. IX-XXXII; 1-15.

${ }^{926}$ VALDÉS COSTA, Ramón. Curso de Derecho Tributário. Op.cit., p. 03 e seguintes.

${ }^{927}$ PUGLIÈSE, Mario. Instituciones de Derecho Financiero. Op.cit., p. 25-26.

${ }^{928}$ Nesse retrospecto histórico, identificam-se algumas opiniões interessantes a respeito do método de estudo aplicado ao Direito Tributário, em suas conexões com a Ciência das Finanças. Nesse sentido, Giuliani Fonrouge firmou posição peculiar frente ao debate do direito financeiro: “(...) concebemos de um ponto de vista jurídico, sem entender por ele atentarmos a um conceito formalista de origem germânica - que é uma apreciação de Griziotti controvertida - e sem omitir referências aos aspectos econômicos, políticos e técnicos enquanto sirvam de base de sustentação ao jurídico". FONROUGE, Carlos M. Giuliani. Derecho Financiero. Op.cit., p. 13-14.

${ }^{929}$ Fernando Sainz de Bujanda, mesmo afirmando a separação entre os estudos de Direito Financeiro e de Ciência das Finanças, reconheceu a complexidade do fenômeno financeiro, cujo estudo em apartado estaria atrelado às dificuldades de sua investigação. Por isso, Sainz de Bujanda referendou a pertinência da 
Hoje em dia é fácil supor que a doutrina de Giannini foi de fato a prevalecente, ao ensaiar a prevalência do estudo propriamente jurídico do fenômeno financeiro (e tributário), buscando afastá-lo da influência da Ciência das Finanças.

Essa linha serviu bem ao debate autonomista iniciado na realidade europeia, a partir do início do século XX, repercutindo-se com maior intensidade na literatura latinoamericana, e que, sob a perspectiva brasileira, caminhava também para um peculiar debate próprio no âmbito da autonomia teórica do Direito Tributário Brasileiro (a contraposição entre a chamada "autonomia científica" e a "autonomia didática"), sobretudo após progressivo reconhecimento do caráter unitário do ordenamento jurídico e da autonomia meramente didática das disciplinas que se dedicam a estudá-lo, no contex to brasileiro.

Ainda, a crescente formalização e generalização dos estudos jurídico-tributários, e exclusão (ou sua tentativa) de aspectos "extrajurídicos", favoreceu a linha defendida por Giannini e Ranneleti, perante a construção monista, unitária ou complexa de Griziotti.

\section{A contribuição fundamental de Alfredo Augusto Becker (e seus reflexos) para o afastamento das relações entre Direito Tributário e Ciência das Finanças.}

O processo de especialização disciplinar do Direito Tributário Brasileiro, no século XX, além de valorizar gradualmente a tese autonomista (teórica), registra clara tendência ao dualismo de Giannini, e já podia ser observada na literatura do pioneiro João Martins de Oliveira.

Porém, o processo de especialização disciplinar do Direito Tributário não segue uma lógica linear. Prova disso é que, entre os primeiros estudiosos do Direito Tributário Brasileiro, era comum elevar o "conteúdo patrimonial essencialmente econômico" do direito tributário para considerá-lo autônomo (teoricamente) de outros ramos do Direito (e notadamente do direito civil), tendência trazida pela experiência estrangeira, conforme se

investigação das parcelas do fenômeno financeiro, enquanto fenômeno jurídico, econômico, histórico, sociológico, etc., muito embora não deixando de ressaltar o caráter complexo da atividade financeira. Note-se que Giuliani Fonrouge apontou Sainz de Bujanda enquanto autor afiliado à doutrina representada por Giannini. FONROUGE, Carlos M. Giuliani. Derecho Financiero. Op.cit., p. 13. Porém, como visto no presente estudo, este também reconheceu a complexidade do fenômeno financeiro, e a conveniência do estudo "em apartado". BUJANDA, Fernando Sainz de. Hacienda y Derecho. Estudios de Derecho Financiero.I. Op.cit., p. 52 e seguintes. 
observa nas primeiras contribuições de Rubens Gomes de Sousa ${ }^{930}$ e Carlos da Rocha Guimarães $^{931}$, e era até mesmo possível verificar aproximações expressas à teoria de Griziotti, conforme se observa em Aliomar Baleeiro. ${ }^{932}{ }_{-}^{933}$

Assim, a literatura tributária prevalecente até a década de sessenta no Brasil tratava das relações entre o Direito Tributário e outros ramos do conhecimento (notadamente a Economia, através da Ciência das Finanças) com poucas reticências.

Contudo, no Brasil, em 1963 (vinte anos depois do primeiro "manual" de Direito Fiscal, de João Martins de Oliveira e do estudo de Rubens Gomes de Sousa), emerge o paradigmático estudo de Alfredo Augusto Becker, intitulado “Teoria Geral do Direito Tributário".

Esse notável trabalho, seguindo os passos de João Martins de Oliveira (embora não o tenha consultado), mas adotando pressuposto epistemológico e metodológico totalmente distinto, particularmente atento à Filosofia do Direito e à Teoria Geral do Direito, foi efetiva força difusora inicial do pensamento separatista ou dualista no Brasil, em 1963, influenciado, por um lado, pelos pressupostos alicerçados por Pontes de Miranda ${ }^{934}$ e, por outro, pela escola dualista de Giannini, destacando o Direito Tributário enquanto disciplina jurídica com princípios e métodos próprios (no âmbito do ordenamento único), sendo calorosamente abraçado pela doutrina nacional. Becker apresentou separação

\footnotetext{
${ }^{930}$ SOUSA, Rubens Gomes de. Compêndio de Legislação Tributária. Op.cit., p. 59.

${ }^{931}$ GUIMARÃES, Carlos da Rocha. Introdução ao Direito Fiscal. Op.cit., p. 08.

932 "Giannini falou da "deletéria fusão e confusão do Direito com a Ciência das Finanças", ou da "estrutura jurídica com a essência econômica”. Nem fusão, nem confusão, mas vinculação íntima e originária, como Gangemi acentuou em réplica à afirmativa do Prof. Romanelli, em 1959, de que "Ciência das Finanças e Direito Financeiro tem por objeto ordens de fato completamente distintos". Já o contestara, no Brasil, há mais de meio século, C.Maximiliano". Baleeiro refere-se à seguinte lição de Maximiliano: "Em verdade não se presume inteligência dos textos positivos contrária aos princípios científicos; estes abrem o caminho para o exegeta. Se assim é de concluir a respeito das ciências em geral, com abundância mais de razão, do mesmo modo se há de afirmar em se tratando da Ciência das Finanças, matéria intimamente conexa com o Direito. (...). MAXIMILIANO, Carlos. Comentários à Constituição Brasileira, Rio de Janeiro, Freitas Bastos, n.219, vol.I, p. 331. Essa passagem também foi mencionada por BALEEIRO, Aliomar. Uma Introdução à Ciência das Finanças. Op.cit., p. 37-38.

${ }_{933}$ BALEEIRO, Aliomar. Uma Introdução à Ciência das Finanças. Op.cit., p. 38-39.

${ }^{934}$ Pontes de Miranda já antevia expressa necessidade de discernimento entre o mundo jurídico e o nãojurídico, pois “(...) Ao passo que o mundo é composto por fatos, o mundo jurídico é composto por fatos jurídicos (fatos que interessam ao direito, e entram no mundo jurídico, pela incidência das regras jurídicas que a assinalam)". MIRANDA, Francisco Cavalcanti Pontes de. Tratado de Direito Privado. Op.cit., p. 02 e seguintes.
} 
epistemológica entre os momentos pré-jurídico, jurídico e pós-jurídico, rechaçando expressamente a doutrina de Griziotti, mas assemelhando-se às lições de Giannini. ${ }^{935}$

Para Becker, a evolução dos estudos na área do Direito Tributário e na Ciência das Finanças desencadeou a separação epistemológica dos dois ramos do conhecimento, já que “(...) o conúbio do Direito Tributário com a Ciência das Finanças (...)” “(...) provoca a gestação de um ser híbrido e teratológico: o Direito Tributário invertebrado". 936

A posição do celebrado autor guardava harmonia com o processo de especialização disciplinar do Direito Tributário, buscando melhor recortar o objeto de estudos, através métodos de estudo propiamente jurídicos, no intuito de vê-la emancipada como verdadeira “disciplina jurídica", reforçando os pontos de apoio para o posterior amadurecimento dos estudos jurídico-tributários no Brasil, gerando (pela sua defesa ${ }^{937}$ ou sua crítica ${ }^{938}$ ) a formação de "Escolas" voltadas ao Direito Tributário no Brasil, a partir daquele período.

Mas, ainda que a posição de Alfredo Augusto Becker defendesse a necessidade de estudos apartados entre juristas e economistas (cientistas das finanças), na década de sessenta, prevalecia na literatura o estudo que reconhecia (ainda que ponderadamente) as utilidades dos elementos econômicos nos estudos jurídicos. Portanto, o que havia era um

\footnotetext{
${ }^{935}$ Na opinião de Becker, na busca pela conceituação do Direito, devemos nos ater a três momentos: "Momento Pré-Jurídico: O fim do Direito não é atingir a verdade (a realidade); a busca da verdade (a realidade) é o objeto das Ciências. A Ciência faz a colheita e a análise dos fatos (a realidade) físicos, biológicos, psicológicos, financeiros, sociais e morais. Momento Jurídico: Com o auxílio ou contra aquêles fatos, colhidos e analisados pelas Ciências pré-jurídicas, o Estado age, utilizando como instrumento o Direito.(...) Momento Post-Jurídico: A atividade desenvolvida neste terceiro momento é de natureza essencialmente filosófica e consiste no trabalho desenvolvido pelo filósofo para responder as seguintes perguntas: O Bem Comum de um determinado Estado, é autêntico ou falso? O que é Justiça? O instrumento (determinada regra jurídica) é justo ou injusto? A ciência do momento post-jurídico (que procura responder estas perguntas) é a Filosofia do Direito." (grifo nosso). BECKER, Alfredo Augusto. Teoria Geral do Direito Tributário. Op.cit., p. 19-20.

${ }^{936}$ Idem, p. 20 e seguintes.

${ }^{937} \mathrm{O}$ caminho apontado por Becker para a doutrina posterior à sua obra poderia ser sintetizado na seguinte passagem: “(...) hoje, a principal preocupação dos juristas é a juridicização do Direito Tributário. Retirá-lo da zona da ciência econômica e fazê-lo voltar para o plano da ciência jurídica. Só assim poderão ser sanados os extensos malefícios da infeliz teoria de Enno Becker". Ainda: "O primeiro grande sintoma dessa reação é que, hoje, tanto os juristas quanto os financistas estão de pleno acordo em recomendar a rigorosa e nítida separação entre a Ciência das Finanças Públicas e o Direito Tributário e isto quer no plano didático, quer no plano científico. Os melhores e mais completos estudos nesse sentido foram feitos, em 1959, por RomanelliGrimaldi (Catedrático da Universidade de Nápoles) e, em 1962 e 1963, por Fernando Sáinz de Bujanda (Catedrático da Universidade de Madrid). BECKER, Alfredo Augusto. Teoria Geral do Direito Tributário. Op.cit., p. 20 e seguintes.

${ }^{938}$ Mas complementa: "Muitos autores têm se pronunciado contra a teoria hermenêutica ora analisada, porém ainda o fazem com maiores ou menores ressalvas, procurando conciliar o inconciliável, por saudosismo, por fidelidade aos clássicos e por injustificável modéstia que os inibe de declarar cruamente a sua "ripugnanza" a teoria hermenêutica que lhes ofende a sensibilidade e vocação jurídica”. Idem, p. 149-151.
} 
dualismo ponderado no estudo do direito tributário, entre as décadas de cinquenta e sessenta. Em outras palavras, enquanto ramo do direito autônomo, pelas suas próprias peculiaridades (que o distanciaria do Direito Privado, por exemplo), permitiria, sob certas condições, considerações econômicas, ou a atenção às lições da Ciência das Finanças.

Tanto pela influência de Ruy Barbosa Nogueira ${ }^{939}{ }^{940}$, em seus primeiros estudos (ainda que com reservas) e, notadamente, com Amílcar de Araújo Falcão (no Rio de Janeiro $)^{941}$, havia ainda reconhecimento das vantagens ao diálogo entre direito e outros ramos do conhecimento. A visão de Ruy Barbosa Nogueira ${ }^{942}$ manteve-se indiscutivelmente aberta ao diálogo com a Ciência das Finanças, mostrando influência de Tullio Ascarelli e Rubens Gomes de Sousa (em primeira fase de seu pensamento), assim como de Miguel Reale ${ }^{943}$.

Contudo, na década de sessenta em diante, especialmente por impulso dos célebres representantes da Escola de Direito Tributário da PUC-SP, as lições de Alfredo Augusto Becker se impulsionam e acabam por reforçar a expressa linha kelseniana (mas com ponderações) defendida nessa Escola, como se pode observar em Geraldo Ataliba ${ }^{944}$, cuja influência remonta os ensinamentos de Alfredo Augusto Becker, Lourival Vilanova e Hans Kelsen $^{945}$.

\footnotetext{
${ }^{939}$ NOGUEIRA, Ruy Barbosa. Direito Financeiro (Curso de Direito Tributário). Op.cit., p. 07.

${ }^{940}$ Idem, p. 54.

${ }^{941}$ FALCÃO, Amílcar de Araújo. Introdução ao Direito Tributário. Op.cit., p. 27-33.
}

${ }^{942}$ Essa abertura pode ser observada nos trabalhos de Ruy Barbosa Nogueira, e especialmente, na seguinte passagem de seu celebrado Curso de Direito Tributário: "Com esta explicação queremos ressaltar aos estudantes de Direito que a Ciência das Finanças, dada a sua forma de estudo especulativo de toda a atividade financeira, é informativa para os estudos e elaborações dogmáticas do Direito Financeiro, posto que esse tem a missão de disciplinar, por meio de normas jurídicas, a mesma atividade financeira do Estado. Quer no momento da elaboração da doutrina, quer da legislação ou da jurisprudência, o jurista especializado em direito financeiro não pode deixar de estar informado dos dados e conclusões teóricas da Ciência das Finanças”. NOGUEIRA, Ruy Barbosa. Curso de Direito Tributário. Op.cit., p. 04-05.

${ }^{943}$ Em síntese, Ruy Barbosa Nogueira, defendeu que “(...) a mesma realidade pode ser objeto de estudo de mais de uma ciência e cada uma a estudará sob feições diferentes, empregando por isso mesmo sistemas ou métodos diferentes", e por isso, "(...) cada sistema científico deve adaptar-se à sua matéria, ao seu objeto material, de tal modo que faça ressaltar com clareza as características. Esta finalidade ou síntese deve ser conseguida pela formulação dos conceitos e relações fundamentais (características comuns, princípios, categorias, institutos)". NOGUEIRA, Ruy Barbosa. Direito Financeiro (Curso de Direito Tributário). Op.cit., p. 09-10.

${ }^{944}$ Geraldo Ataliba entendia que os institutos e categorias jurídicas só seriam válidos e operantes nos âmbito do Direito, e assim, “(...) Daí o terrível engano dos que pensam que a economia e o direito podem estudar um mesmo objeto, o tributo por exemplo, intercambiando informações, princípios e técnicas de compreensão, operação e aplicação. O conceito de tributo, para o direito, nasce e esgota-se no universo jurídico". ATALIBA, Geraldo. Hipótese de Incidência Tributária. Op.cit., p. 24 e seguintes.

${ }^{945}$ Geraldo Ataliba, em seu clássico estudo, assinala: "O conceito de tributo para o direito é um conceito jurídico privativo, que não se pode confundir com o conceito financeiro, ou econômico de outro objeto, de outros setores científicos, como é o tributo ontologicamente considerado. Tributo, para o direito, é coisa 
No mesmo caminho seguiu Paulo de Barros Carvalho que, no Preâmbulo da primeira edição de seu clássico estudo "Teoria da Norma Jurídica Tributária”, acentuava, em 1974: "Vive a ciência do Direito Tributário dias de grande perplexidade. Havendo-se desvencilhado, parcialmente, da negativa influência da Ciência das Finanças, encontra-se em condições de postular sua própria afirmação como matéria jurídica. Muitos autores, todavia, como que tolhidos pelos antigos preconceitos que detiveram o progresso científico daquela disciplina e preocupados com a farta e desordenada produção legislativa, parecem entender possível o desdobramento sistemático da matérias em qualquer atinência àquelas noções isagógicas que inspiram e iluminam todo ramo do saber jurídico, mais atentos que estão aos efeitos práticos e tangíveis que ladeiam a instituição do tributo. A presença do cuidado metodológico, como necessidade preemente no desenvolvimento de trabalhos de cunho científico, não é frequente nas obras brasileiras sobre Direito Tributário, situação que informa um ramo jurídico quase que totalmente divorciado de suas origens, implica dizer, da Teoria Geral do Direito". 946 -947_948

A posição de Geraldo Ataliba e Paulo de Barros Carvalho naquele período segue também referendada por outros estudiosos daquela mesma Escola, partindo de semelhantes pressupostos, como Roque Antonio Carrazza ${ }^{949}$ e Aires Fernandino Barreto ${ }^{950}$, seguindo as lições de Ciência de Direito trazidas pelos citados autores, e adotando posicionamento alinhado aos pressupostos de estudo de Hans Kelsen (ainda que com eventuais

diversa de tributo como conceito de outras ciências". "O direito constrói suas próprias realidades, com especificidade, característica e naturezas próprias”. Idem, p. 23 e seguintes.

946 "A ciência do Direito Tributário nada mais representa que uma especialização da ciência do Direito, pelo que suas raízes haverão de ser pesquisadas no plano dos conceitos fundamentais, aplicáveis em os seguimentos do universo jurídico. Queremos crer que nenhuma solução jurídico-tributária haverá de prosperar, se não estiver devidamente esteiada naquelas noções propedêuticas que desenham o campo de estudo da Teoria Geral do Direito. A verificação das premissas comuns ao setor do conhecimento humano em que se labora, não é imperativo a que se devem submeter apenas os tributaristas, mas recomendação geral a que estão sujeitos todos os que pretenderem fazer ciência”. CARVALHO, Paulo de Barros. Preâmbulo. In: Teoria da Norma Tributária. ${ }^{a}$ Edição. São Paulo: Edições Lael, 1974, p. 09-11.

${ }^{947}$ ATALIBA, Geraldo. Prefácio. In: CARVALHO, Paulo de Barros. Teoria da Norma Tributária. Op.cit., p. 14.

${ }^{948}$ No mesmo passo, Paulo de Barros Carvalho complementa, criticando a expressão "fatos jurídicos de conteúdo econômico": "O direito não toma por empréstimo entidades de outro campo, para os fins de que necessita. Sua grande virtude é construir as próprias realidades. Por isso mesmo, as construções jurídicas não deformam as leis econômicas ou políticas, como amiúde se afirma. (...) A ciência do direito não pode construir outra realidade que não aquela de descrever seu objeto específico. O mesmo acontece com a Física ou com a Economia que haverão de cingir-se à tarefa de descrever, respectivamente, as leis físicas e as leis econômicas" CARVALHO, Paulo de Barros. Teoria da Norma Jurídica. 1974. Op.cit., p.131-133.

${ }_{949}$ CARRAZZA, Roque Antonio. Curso de Direito Constitucional Tributário. Op.cit., p.27 e seguintes.

950 BARRETO, Aires Fernandino. Base de Cálculo, Alíquota e Princípios Constitucionais. Op.cit., p.15 e seguintes. 
ponderações, a exemplo da elevação principiológica constitucional no Direito Tributário Brasileiro).

Característica marcante nessa linha de estudo também a viabilizar segurança jurídica e a certeza do direito, preocupação constante na obra de Geraldo Ataliba ${ }^{951}$ (além da defesa da Constituição super-rígida), o que de certa forma favoreceu o repúdio ao diálogo dos juristas com outros ramos do conhecimento, sobretudo no âmbito da Ciência das Finanças ${ }^{952}$.

Mas é interessante notar que a doutrina tributária brasileira, ainda que construída em ambiente histórico irradiado pelo dogmatismo jurídico kelseniano, revelou posições teóricas interessantes sobre o debate, mesmo entre estudiosos com grandes conexões àquelas premissas.

É o caso de José Souto Maior Borges que, no decorrer do transcorrer histórico do Direito Tributário Brasileiro, sempre manteve importante vinculação acadêmica às produções teóricas originárias da Faculdade de Direito da PUC-SP. Contudo, ainda assim, Souto Maior Borges enxergava a problemática epistemológica da complexidade do fenômeno financeiro com lentes diferenciadas, conforme é possível observar em suas primeiras publicações. Prova disso é que em sua primeira obra, "Iniciação ao Direito Financeiro" (e depois publicada como "Introdução ao Direito Financeiro") tratou de transcrever interessantes considerações à teoria monista de Griziotti, que não repudiava absolutamente ${ }^{953}$, mas considerava adequada e conveniente, do ponto de vista metodológico, a separação disciplinar entre Direito Tributário e Ciência das Finanças.

A posição assumida por Souto Maior Borges, em primeiro momento, assemelhouse às adotadas por Puglièse e Jarach, discípulos de Griziotti ${ }^{954}$, com o diferencial que,

951 ATALIBA, Geraldo. República e Constituição. Op.cit., p.179 e seguintes.
952 Idem, p. 40 e seguintes.
953 José Souto Maior Borges, em seu primeiro estudo, pautou-se a analisar a estrutura do fenômeno financeiro
refletindo sobre a teoria monista e integradora de Griziotti, isto é, reconhecendo a complexidade do
fenômeno financeiro, embora tenha assinalado: “As ideias de Griziotti sobre o estudo da atividade financeira
não tiveram consagração no âmbito doutrinário", lembrando a literatura tributária italiana prevalecente (a
exemplo de Tesoro e de Giannini) que “(...) separou o Direito Tributário da Ciência das Finanças”. E
contextualiza sobre a polêmica: "Essa orientação separatista - triunfante no âmbito doutrinário - não
importa, ao nosso ver, em negar a complexidade estrutural do fato financeiro. Imposto, isso sim, na
afirmação da necessidade de metodologia científica própria para cada disciplina particular que tenha por
objeto o estudo dos fenômenos financeiros". BORGES, José Souto Maior. Introdução ao Direito
Financeiro. Op.cit., p. 80 .
954 Naturalmente, não significa que José Souto Maior Borges advogou a teoria monista naquela época. Assim
como alguns discípulos de Griziotti, como Puglièse, Jarach, entre outros, entendeu que o reconhecimento do 
situado em ambiente histórico-jurídico distinto daquele ambiente italiano, apontar a conveniência dos estudos apartados aproximava-se inevitavelmente aos estudos promovidos na Escola da PUC-SP, sobretudo na elevação do dogmatismo normativo kelseniano e à separação epistemológica dos estudos sobre o fenômeno tributário (e naturalmente, da separação entre Direito Tributário e Ciência das Finanças).

Em seus estudos posteriores, ainda no século $\mathrm{XX}$, aprofundou-se no reconhecimento de que a investigação científica adequada deveria permear-se pelo purismo metodológico, afastando-se de sincretismos, e, assim, aproximando-se das obras de Geraldo Ataliba, Alfredo Augusto Becker e Paulo de Barros Carvalho que, embora possuindo conteúdos e posições distintas, apresentavam esse traço comum ${ }^{955}$.

No século XX, portanto, José Souto Maior Borges mostra-se mais inclinado à posição de dualista, ainda que tenha acrescentado importantes considerações acerca da interdisciplinaridade jurídica (tratando do diálogo de saberes jurídicos somente) ${ }^{956}$, em seu notável estudo sobre o Direito Comunitário ${ }^{957}$.

Contudo, ainda que o processo disciplinar do Direito Tributário Brasileiro tenha caminhado para o dualismo de Giannini, não se pode deixar de reconhecer que esse não prevaleceu sem fortes resistências.

\section{A interpretação do direito tributário e sua contribuição ao processo disciplinar do Direito Tributário.}

fenômeno financeiro em sua complexidade não afasta a conveniência de que cada parcela do fenômeno seja analisada por disciplina específica. BORGES, José Souto Maior. Isenções Tributárias. Op.cit., p. 129-130.

${ }^{955}$ BORGES, José Souto Maior. Obrigação Tributária. Uma introdução metodológica. Op.cit., p. 101-103.

${ }^{956}$ Fora do âmbito do direito tributário, em notável estudo sobre o Direito Comunitário, fez alguns apontamentos sobre a noção de interdisciplinaridade (no seu substrato jurídico), especialmente considerando o ordenamento comunitário, que, para o autor, constituiria um “(...) ponto de convergência de várias disciplinas normativas (...)" (a exemplo do Direito Tributário Comunitário, do Direito do Consumidor Comunitário, etc.,), observados, naturalmente, “(...) os limites de cada ciência jurídica especializada que dele se ocupa". Consequentemente, entendeu que o estudo do direito comunitário demanda esforço interdisciplinar, porém, “(...) sem o abandono ou afastamento do campo jurídico-dogmático e seus limites”. E prossegue: "Mas o caráter interdisciplinar dos estudos jurídicos, antes de infirmá-la, confirma a necessidade de preservação da demarcação do objeto nessas disciplinas jurídicas especializadas. Impossível a interdisciplinaridade onde se mesclam, em insólita confusão, as várias disciplinas jurídicas com saberes extradogmáticos”. BORGES, José Souto Maior. Curso de Direito Comunitário. Op.cit., p.XXXVII.

${ }^{957}$ Idem, p. XXXIX; p. 106-108. 


\subsection{Os antecedentes hermenêuticos ao processo disciplinar do Direito Tributário}

A atividade interpretativa das leis tributárias sempre apresentou peculiar tendência de produzir seus próprios mecanismos.

Como bem observa Vanoni: "é pacificamente aceito pela doutrina que as regras a serem interpretadas na interpretação da lei não se podem considerar inteiramente idênticas em todos os campos do direito". 958

Mesmo em Roma Antiga já se desenvolviam correntes interpretativas relacionadas à compreensão e à aplicação das leis tributárias, a exemplo das técnicas de interpretação pro fiscum ${ }^{959}$ e contra fiscum ${ }^{960}$. As justificativas, naturalmente, passavam pelo poder supremo do Imperador (pro fiscum) e pela hipossuficiência do contribuinte (contra fiscum).

A interpretação extensiva (quando a lei diz menos, e o intérprete amplia o seu campo de aplicabilidade), literal (quando o intérprete mantém-se preso aos limites aplicativos do conteúdo da lei, não a restringindo nem a estendendo) e restritiva (quando a lei “diz mais do que deveria”, impondo ao intérprete restrição aplicativa de seu conteúdo) também já eram debatidas nesse período. Mas, de fato, a tendência histórica ulterior na interpretação da lei tributária caminhou para a interpretação restritiva. ${ }^{961}$

Porém, com o desenvolvimento da Ciência do Direito, notadamente a partir do século XIX, os processos interpretativos passam a apresentar suporte embasado nas construções teóricas do Direito Civil (na época o ramo do direito mais desenvolvido, e por isso, com grande influência teórica perante os demais).

\footnotetext{
${ }^{958}$ Mas “(...) Existem, com efeito, de um lado regras de interpretação ditadas pelo legislador ou elaboradas pela doutrina, que possuem uma validade universal porque decorrem de caracteres gerais da norma jurídica, encontrando portanto aplicação em todos os campos do direito". VANONI, Ezio. Natureza e Interpretação das Leis Tributárias. Op.cit., p.11.

${ }_{959}$ Essa corrente declara que "(...) a lei tributária deve ser aplicada de modo a favorecer a entidade que cobra o tributo". Ibidem, p.13

${ }^{960}$ Essa corrente declara que "(...) a lei tributária, quando o seu significado não seja evidente, deve sempre estar entendida no seu sentido mais favorável àquele que esteja subordinado ao tributo”. Idem, p. 16 e seguintes.

961 "Colocada em têrmo médio entre as duas primeiras, a terceira escola, que é também a mais recente no tempo, e que se pode dizer atualmente dominante, ensina que não se deve favorecer, segundo regras apriorísticas, nem aquele que percebe o tributo, nem tão pouco o contribuinte, mas que a lei tributária, em virtude de sua própria natureza, deve ser entendida de maneira rígida, e, em caso de dúvida, restritivamente". VANONI, Ezio. Natureza e Interpretação das Leis Tributárias. Op.cit., p.13.
} 
Emergem, nesse período, as famosas Escolas europeias de Interpretação, que forneceram forte influência no desenvolvimento posterior ao Direito Tributário, como a Escola de Exegese (L'École de L'Exégèse), a Escola Histórica do Direito, a Jurisprudência dos Conceitos (Begriffsjurisprudenz) ou Pandectistica (Pandektenwissenschaft) e a Jurisprudência dos Interesses (Interessenjurisprudenz) ${ }^{962}$.

Destacou-se, nesse contexto, o labor de Friedrich Karl Von Savigny, que ofereceu aperfeiçoamento ao tema, afastando determinadas tendências hermenêuticas consideradas ultrapassadas para a época, e consolidando a hermenêutica jurídica do período em três modalidades: interpretação histórica, interpretação gramatical e interpretação lógica. ${ }^{963}$

Para Savigny, "toda lei deve expressar um pensamento em forma tal que valha como norma. Quem interprete, pois, uma lei, deve analisar o pensamento contido na lei, deve investigar o conteúdo da lei”. Assim, o sentido da interpretação seria primeiramente, a reconstrução do conteúdo da lei, onde o intérprete se colocaria sob o ponto de vista do legislador e produzir assim artificialmente seu pensamento. Esse processo interpretativo somente seria possível por uma tarefa (interpretativa) composta triplamente da lógica, da gramática e da história ${ }^{964}$.

Mas não somente desses aspectos Savigny se reportava. Na análise dos "princípios fundamentais para a interpretação em geral", Savigny referiu-se a dois princípios. O primeiro (individual), deveria proceder a uma análise individualizada das partes da lei (aprofundada), e o segundo (universal) deveria viabilizar a compreensão da lei como parte

\footnotetext{
${ }^{962}$ Conforme já observado no capítulo 1 , não é o objetivo deste trabalho apresentar os meandros históricos e teóricos que circundam as citadas Escolas, seus representantes e suas respectivas influências no processo de interpretação do direito tributário. Contudo, para melhor compreensão da influência dessas escolas oitocentistas na consolidação das técnicas de interpretação da norma tributária no Brasil, consulte-se: ANDRADE, José Maria de Arruda. Interpretação da Norma Tributária. São Paulo: MP editora, 2006, p. 33 e ss.

${ }^{963}$ SAVIGNY, Friedrich Karl Von. Op.cit., p. 41-45.

${ }^{964}$ Cada tarefa interpretativa deveria apresentar essa estrutura (tripla): "uma parte lógica que consiste na representação do conteúdo da lei em sua origem e representa a relação das partes entre si. É também a genética representação do pensamento na lei. Mas o pensamento deve ser expressado, pelo qual é preciso também que existam normas de linguagem, e dele surge; 2) a parte gramática, uma condição necessária da lógica. Também se relaciona com a parte lógica; 3) a parte histórica. A lei é dada em um momento determinado, a um povo determinado; é preciso conhecer estas condições históricas para captar o pensamento da lei. A representação da lei é somente possível pela representação do momento em que a lei existe" (tradução livre). Idem, p. 12-13.
} 
de um todo (sistema). Portanto, Savigny também esboçava a interpretação sistemática, ainda que de forma incipiente. ${ }^{965}$

Na época, Savigny, representante da chamada "Escola Histórica", apresentava contraponto às tendências teóricas de alinhamento exegético na Europa, especialmente frutos do processo codificador ocorrido na França, que, por sua vez, leva à construção de outras correntes hermenêuticas, como a "Escola de Livre Pesquisa e do Direito Livre", conforme contextualiza Miguel Reale ${ }^{966}$.

Assim, a despeito das históricas correntes de interpretação no Direito Tributário, deve-se reconhecer que essas acabaram perdendo espaço, para o progresso da Ciência do Direito, no século XIX e início do século XX (o que não significa, naturalmente, que contribuições teóricas construídas nessas Escolas não tenham sido repercutidas nesse processo) $)^{967}$, que expandiu sua própria influência aos estudos das leis tributárias, especialmente em período pré-codificação tributária. Para Savigny, interpretação é “(...) reconstrução do pensamento (claro ou obscuro, é igual) expressado na lei enquanto seja cognoscível na lei (...)", afastando-se da concepção usual: "interpretação como esclarecimento de uma lei obscura" ${ }^{968}$.

A Hermenêutica Jurídica passa a, gradativamente, fornecer substrato metodológico para a interpretação do Direito. Nesse sentido, a elaboração de métodos dos mais variados geraram inclusive controvérsias quanto à real efetividade na construção do conteúdo da norma jurídica. Isso porque com o desenvolvimento da hermenêutica aparecem diversas classificações elaboradas para precisar as espécies ou tipos de métodos interpretativos ${ }^{969}$.

Tradicionalmente, na Hermenêutica Jurídica, sedimentou-se a difusão de cinco métodos principais de interpretação: a) método gramatical ou filológico: ${ }^{970}$, que considera as palavras do texto legal, ou o entendimento "vernacular", em sua literalidade, a construção gramatical ou o significado semântico, mantendo íntima conotação com o

\footnotetext{
965 Ibidem, p. 18-21.

${ }^{966}$ REALE, Miguel. Lições Preliminares de Direito. $25^{\text {a }}$ Ed. São Paulo: Saraiva, p. 260-270.

${ }^{967}$ ANDRADE, José Maria Arruda de. Interpretação da Norma Tributária. Op.cit., p. 58 e ss.

${ }^{968}$ REALE, Miguel. Lições Preliminares de Direito. Op.cit., p.14.

${ }^{969}$ FRANÇA, Limongi. Hermenêutica Jurídica. $7^{\circ}$ Edição. São Paulo: Saraiva, 1999, p. 5-13.

${ }^{970}$ MAXIMILIANO, Carlos. Hermenêutica e Aplicação do Direito. $19^{\circ}$ Edição. São Paulo: Forense, p. 88.
} 
método literal (apego ao texto da lei) ${ }^{971}$; b) método lógico: que significaria descobrir, ou melhor, construir o sentido da lei, mergulhando nos princípios científicos da lógica ${ }^{972}$, ou seja, utilizando os instrumentos metodológicos originários dessa ciência do saber $^{973}$; c) método histórico ou histórico evolutivo: no qual o interprete busca esclarecer o sentido da lei através de investigações históricas, buscando evidenciar a mens legislatoris, e mesmo através do contexto histórico em que a lei foi editada ${ }^{974}$; d) método finalístico ou teleológico: enfatiza a finalidade buscada pelo legislador ao elaborar aquela norma, o resultado buscado pelo legislador ${ }^{975}$; e) método sistemático: que significa interpretar o dispositivo como parte do sistema jurídico ${ }^{976}{ }_{-}^{977}{ }_{-}^{978}$, envolvendo a própria concepção da norma como elemento inserido em um sistema de normas que implicam influência sobre ela e, simultaneamente, esse mesmo sistema sofre a pressão exercida pela inserção daquela norma em seu quadro normativo ${ }^{979}$.

A Hermenêutica Jurídica consolida-se como disciplina jurídica para construir o sentido da norma, estruturar seu verdadeiro conteúdo, viabilizado através de métodos científicos de interpretação, integração e aplicação capazes de auxiliar na construção do direito $^{980}{ }^{981}$.

Porém, os métodos tradicionais de interpretação do Direito, por terem sido construídos no âmbito do Direito Privado (na época, chamado de "Direito Comum"), em meados do século XIX, passaram a favorecer o amplo desenvolvimento desse ramo do direito, que ganha contornos propriamente jurídicos. Mas, por outro lado, gerou

\footnotetext{
${ }^{971}$ MELO, José Eduardo Soares de. Interpretação e Integração da Legislação Tributária. Curso de Direito Tributário. Volume 1. Coordenador: MARTINS, Ives Gandra. $4^{\circ}$ Edição. São Paulo: CEJUP, 1995, p. 164.

${ }^{972}$ COELHO. Luiz Fernando. Lógica Jurídica e Interpretação das Leis. Op.cit., p. 210-214.

${ }^{973}$ VILANOVA, Lourival. Lógica Jurídica. São Paulo: José Bshatsky, 1976, p.15-17.

${ }^{974}$ COELHO, Luiz Fernando. Lógica Jurídica e Interpretação das Leis. Op.cit., p. 216.

${ }^{975}$ CARVALHO, Paulo de Barros. Hermenêutica do Direito Tributário. Elementos de Direito Tributário. III Curso de Especialização em Direito Tributário realizado na PUC-SP. Coordenação: ATALIBA, Geraldo. São Paulo: Revista dos Tribunais, 1978, p. 228-229.

${ }^{976}$ Segundo Carlos Maximiliano, “(...) consiste em comparar o dispositivo sujeito à exegese, com outros do mesmo repertório ou de leis diversas, mas referentes ao mesmo objeto". MAXIMILIANO, Carlos. Hermenêutica e Aplicação do Direito. Op.cit., p. 104.

${ }_{977}^{9}$ Luiz Fernando Coelho, por sua vez, conceitua que a interpretação sistemática consiste “(...) simplesmente em considerar o preceito jurídico interpretando como parte do sistema normativo mais amplo que o envolve". COELHO, Luiz Fernando. Lógica Jurídica e Interpretação das Leis. Op.cit.,p. 215.

978 Já Paulo de Barros Carvalho assevera que, “(...) no desenvolvimento dessa etapa de interpretação, o intérprete volta-se para o próprio sistema, procurando analisar as influências, as pressões, as deformações que aquele comando sofreu ao ingressar na ordem jurídica”. CARVALHO, Paulo de Barros. Hermenêutica no Direito Tributário. Op.cit., p. 231.

${ }_{979}$ COELHO, Luiz Fernando. Lógica Jurídica e Interpretação das Leis. Op.cit., p. 215.

${ }^{980}$ REALE, Miguel. Lições Preliminares de Direito. Op.cit., p. 260-272.

${ }^{981}$ FRANÇA, Limongi. Hermenêutica Jurídica. Op.cit., p. 13-19.
} 
interessante tendência refratária no Direito Tributário: a criação de métodos interpretativos próprios como sinônimo da autonomia do Direito Tributário frente ao "Direito Comum".

\subsection{A consideração econômica e o combate ao abuso de formas do Direito Privado.}

O combate ao abuso de formas do direito privado no direito tributário foi uma das tônicas que impulsionaram a criação do Código Tributário Alemão, que respondia a aquele através da interpretação econômica da lei tributária (ou interpretação funcional). A interpretação funcional, por outro lado, angariava mais do que simplesmente combater o abuso de formas, mas serviu de principal ponto de apoio das teses autonomistas do Direito Tributário frente à influência do Direito Civil.

A Ordenação Tributária Alemã, como informa Brandão Machado, ${ }^{982}$ denuncia claramente essa preocupação. A resposta positivada pela RAO para alcançar essa emancipação passou diretamente pela criação de mecanismo hermenêutico próprio do direito tributário, mas que, por outro lado, utilizaria como pressuposto a realidade econômica dos fatos, em detrimento do formalismo jurídico (do Direito Privado).

Assim, cria-se o critério econômico ou funcional da interpretação das leis tributárias $^{983}$, justamente porque na época o Tribunal do Reich e o Superior Tribunal Administrativo da Prússia ordinariamente admitiam como válidos os negócios jurídicos que visavam alcançar a economia de impostos, entendendo que o combate à evasão fiscal não seria tarefa dos juízes, mas sim dos legisladores ${ }^{984}$.

A visão de Becker (além de evidentemente política, já que se fundamentava também na necessidade de arrecadação tributária pelo Reich) também caminhava pela emancipação da legislação tributária (e dos tribunais) frente à influência da jurisprudência dos conceitos, fortalecendo as premissas finalísticas da jurisprudência dos interesses, de

${ }^{982}$ MACHADO, Brandão. Prefácio do Tradutor. In: HARTZ, Wilhelm: Interpretação da Lei Tributária. Conteúdo e Limites do Critério Econômico. Tradução, prefácio e notas de Brandão Machado. São Paulo: Resenha Tributária, 1993, p. 5-27.

${ }^{983}$ Idem, p 7-8.

${ }^{984} \mathrm{O}$ abuso de formas do direito privado inspirou Becker, sobretudo por casos emblemáticos como o MITROPA, a elaborar mecanismo que viabilizasse suporte (legislativo) para a interpretação e aplicação do direito tributário, afastando o abuso de formas. Autorizou-se, assim, a utilização da interpretação econômica, priorizando a realidade econômica em detrimento do formalismo jurídico. Sobre o caso MITROPA, conferir: Ibidem, p.8-9 
Rudolf Von Ihering, para quem: “O direito é uma ideia prática, isto é, designa um fim, e, como toda ideia e tendência, é essencialmente dupla, porque contém em si uma antítese, o fim e o meio. Não é suficiente investigar o fim, deve-se também saber o caminho que a ele conduz" $" 985$.

O primeiro enunciado trazido no Código Tributário Alemão que catalisou essa vertente hermenêutica foi previsto no parágrafo $4^{\mathrm{a}}$ : " $\delta$ 4. $\mathrm{Na}$ interpretação das leis tributárias devem ser considerados a sua finalidade, o seu significado econômico e o desenvolvimento das circunstâncias".

Mas este enunciado ainda deveria ser complementado pelo preceito subsequente: " $\delta$ 5. A obrigação tributária não pode ser eludida ou reduzida mediante o emprego abusivo de formas e formulações de direito civil. Haverá abuso no sentido do inciso 1, 1: Quando, nos casos em que a lei submete a um imposto fenômenos, fatos e relações econômicas em sua forma jurídica correspondente, as partes contratantes escolhem formas ou negócios jurídicos inusitados para eludir o imposto, e 2: Quando, segundo as circunstâncias e a forma como é ou deve ser processado, obtêm as partes contratantes, em substância, o mesmo resultado econômico que seria obtido, se escolhida fosse a forma jurídica correspondente aos fenômenos, fatos e relações econômicas."

A finalidade de Becker, ao trazer a interpretação econômica ao Direito Tributário, centrava-se na consagração de mecanismo hermenêutico próprio que não dependesse das construções hermenêuticas do Direito Privado, e, obviamente, impulsionasse a arrecadação tributária.

Afinal, as tradicionais técnicas interpretativas, difundidas por Savigny ${ }^{986}$ (que era afiliado à Escola Histórica, mas apresentou fortes contribuições à construção da jurisprudência dos conceitos $)^{987}$, eram as pedras de toque da interpretação jurídica da

\footnotetext{
${ }^{985}$ IHERING, Rudolf Von. A Luta pelo Direito. $2^{\text {a }}$ Ed. Trad. Ricardo Rodrigues Gama. São Paulo: Russel, 2005 , p. 07.

986 Savigny, na elaboração sistemática da jurisprudência, vinculava-se à chamada "jurisprudência dos conceitos": "Se deve conhecer um princípio particular de direito, ou seja, se deve desenvolver os conceitos contidos nele, o qual equivale a dar definições e fazer distinções (o segundo pode-se reduzir ao primeiro).Trata-se, pois, de recorrer ao mesmo caminho das leis - fidelidade genética - demonstrando especialmente os contrastes. 1) Muito natural que no sistema não deva tratar-se nenhum conceito sem referilo a um princípio de direito; cada qual deve ter uma realidade jurídica. (...) 2) Os conceitos determinam ao sistema; a conceitos falsos seguem interpretações falsas". SAVIGNY, Friedrich Karl Von. Op.cit., p. 36-39.

${ }^{987}$ ANDRADE, José Maria Arruda de. Interpretação da Norma Tributária. Op.cit., p. 42.
} 
época. Para afastar a influência desses mecanismos a alternativa era clara: construir mecanismo próprio de interpretação para o direito tributário, que se traduziu, nas palavras de Brandão Machado, na própria “(...) consagração da interpretação teleológica do direito tributário, como tem sido chamada por muitos autores alemães" 988 .

Em outras palavras, o verdadeiro "empecilho" declarado pelo Código Tributário Alemão não era necessariamente a Ciência das Finanças, mas sim a prevalência do direito civil sobre o direito tributário, que inviabilizaria a sua emancipação disciplinar (embora na verdade o fundamento fosse o combate ao abuso de formas do direito privado e não o direito privado propriamente dito), e, sobretudo, a arrecadação de tributos pelo Reich, já que os juízes fiscais necessitavam de instrumento interpretativo (e legislativo) expresso e próprio para combater com maior eficácia o abuso de formas e, assim, viabilizar a arrecadação.

\subsection{A recepção da literatura tributária estrangeira sobre a consideração econômica.}

Se o método é pressuposto para o reconhecimento científico de determinado ramo do conhecimento, é natural que aqueles que busquem esse status partam em busca de método mais adequado para apreender e compreender esse objeto de estudo. Se o labor do jurista parte da interpretação do direito, é razoável supor que, na época, o melhor mecanismo para viabilizar a emancipação disciplinar de um ramo do conhecimento fosse a elaboração de seus próprios métodos de interpretar o objeto de estudo.

A literatura tributária da época logo se posiciona diante da questão. Alguns estudiosos opuseram-se, como Hans Nawiasky ${ }^{989}$. Por outro lado, o mecanismo hermenêutico angariou defensores, como Kurt Ball, para quem a defesa da interpretação funcional simbolizaria a independência científica do Direito Tributário enquanto ramo jurídico. Mais uma vez, a interpretação econômica reforçava a percepção de alguns estudiosos pela chamada "autonomia científica".

\footnotetext{
${ }^{988}$ MACHADO, Brandão. Prefácio do Tradutor. In: HARTZ, Wilhelm Op.cit.., p.11.

${ }^{989}$ NAWIASKY, Hans. Op.cit., p. 26-27.
} 
As ideias de Ball, sintetizadas por Giannini (que as refutou), partiam do fato de que, na análise das funções exercidas pelas normas de direito privado e as de direito tributário relativas a uma mesma relação econômica, deveria se excluir a ideia de que, em primeira análise, para a determinação concreta do fato gerador, referir-se necessariamente às normas de direito privado. Ball defendia a separação entre as regras de direito privado e as de direito tributário, portanto ${ }^{990}{ }^{991}$, para assegurar a independência do Direito Tributário, apoiando plenamente a interpretação econômica de Becker ${ }^{992}$.

Ora, evidentemente que tais mecanismos hermenêuticos traziam em seu âmago grande poder de arbítrio estatal na aplicação da norma tributária, conforme relata Brandão Machado, “(...) a ponto de converter a relação jurídica do tributo em verdadeira relação de força, dado que o Código não fixava nenhum critério para definir o conceito de econômico, nem para distinguir entre o que seria forma jurídica adequada e forma jurídica abusiva, tudo dependendo, portanto, do critério subjetivo do aplicador da lei" ${ }^{993}$.

Mas a polêmica sobre essa interpretação econômica mostrava posicionamentos ponderados até mesmo por Albert Hensel, que se manifestou sobre a aplicação do então $\S$ $9^{\circ}$ (que, com a reforma fiscal de 1931, substituiu o $\$ 4^{\circ}$, mas manteve o mesmo conteúdo), destacando a relevância da necessidade de interpretação justa da lei tributária, mas também admitindo a interpretação econômica ${ }^{994}$.

Mas Hensel, diferente de Ball, não refutou as críticas para as dificuldades frente aos magistrados na interpretação e aplicação dos dispositivos interpretativos. O risco de abuso ou arbítrio na aplicação desses dispositivos era inevitável, e por isso Hensel ponderou:

\footnotetext{
${ }^{990}$ Essa disparidade de opiniões também foi lembrada por COSTA, Alcides Jorge. Algumas notas sobre a Relação Jurídico Tributária. Op.cit., p. 222-224.

${ }^{991}$ Essa linha de pensamento de Ball foi principalmente exposta no seguinte estudo: BALL, Kurt. Steuerrecht und Privatrecht, Theorie dês Selbständigen Steuerrechtssystems, 1924. A obra de Ball foi também citada por TIPKE, Klaus. Steuerrecht. Ein Systematischer Grundriß. 4. Völlig überarbeitete Auflage. Verlag Dr. Otto Schmidt KG. Köln, 1977, p. 08-09.

992 A obra consultada por Giannini foi: BALL, Kurt. Steuerrecht und Privatrecht, 1924, p.121 e seguintes. GIANNINI, A. D. I Concetti Fondamentali del Diritto Tributario. Torino: Unione Tipografico - Editrice Torinese, 1956, p. 163-166.

${ }^{993}$ MACHADO, Brandão. Prefácio do Tradutor. In: HARTZ, Wilhelm Op.cit.., p.11.

${ }^{994}$ HENSEL, Albert. Op.cit., p. 63-69.
} 
"Somente uma inteligente combinação e cooperação entre a legislação, a interpretação e a aplicação da lei, podem acrescentar ao ideal (inalcançável) de uma justa imposição", 995

Mas novas reformas sucederam ao Código Tributário Alemão, ${ }^{996}$ que culminariam na denominada Lei de Adaptação Tributária (SteuerAnpassungsGesetz), do ano de 1934.

Esta Lei estabeleceu em seu parágrafo $1^{\circ}$ regras de interpretação, praticamente reproduzindo o preceito do parágrafo 4 do Código Tributário Alemão de 1919, de modo que os preceitos da Lei de Adaptação Tributária de 1934 ( $\delta \delta 1$ e 6$)^{997}$ não apresentariam grandes mudanças nos polêmicos dispositivos legais, mas pelo menos afastaram, como destacou Brandão Machado, o "espúrio ingrediente do nacional-socialismo”, aprimorando, conforme lembra Griziotti, a interpretação funcional, ${ }^{998}$ o que não impediu o prosseguimento de críticas à essa prática interpretativa, a exemplo de Wilhelm Hartz. ${ }^{999}$

Contudo, de importância capitular é o teor do $\S 1^{\circ}$ da Lei de Adaptação Fiscal: “(Interpretação) (1) Revogado; (2) Para isso devem ser tomadas em considerações as concepções do povo, a finalidade e o significado econômico das leis fiscais e o desenvolvimento das relações. (3) O mesmo se dá com a apreciação dos estados de fato". 1000

Em outras palavras, a sombra nacional-socialista ainda se fazia constante naquele dispositivo legal, somente apagando-se por reformas fiscais ulteriores, que acabariam ocasionando a entrada em vigor do então "novo" Código Tributário Alemão (Abgabenordnung), de 1977, e que retirou o dispositivo relacionado à interpretação econômica $^{1001}$.

\footnotetext{
${ }^{995}$ Idem. Para um contexto histórico da doutrina da interpretação das leis tributárias, sugere-se também: BLUMENSTEIN, Ernst. Op.cit., p. 16 e seguintes.

${ }_{996}$ Já em 1931, o Código Tributário Alemão sofre uma reformulação, quando o parágrafo 4 passou a ser o parágrafo 9 , e o parágrafo 5 converteu-se no parágrafo 10 , entre outras modificações significativas. MACHADO, Brandão. Prefácio do Tradutor. In: HARTZ, Wilhelm Op.cit.., p.11 e seguintes.

${ }_{997}$ Lei de Adaptação Fiscal (1934). In: DINIZ, Souza. Códigos Tributários. Alemão. Mexicano. Brasileiro. $1^{\circ}$ edição. Tradução de Souza Diniz. São Paulo: Edições Financeiras S.A., 1965, p. 225-226.

${ }^{998}$ GRIZIOTTI, Benvenuto. Princípios de Política, Derecho y Ciência de la Hacienda. Op.cit., p.316 e seguintes.

${ }^{999}$ HARTZ, Hilhelm. Interpretação da Lei Tributária. Conteúdo e Limites do Critério Econômico. Op.cit., p. 101.

${ }^{1000}$ Lei de Adaptação Fiscal de 1934, traduzida em língua portuguesa por DINIZ, Souza. Códigos Tributários. Alemão. Mexicano. Brasileiro. $1^{\circ}$ edição. Tradução de Souza Diniz. São Paulo: Edições Financeiras S.A., 1965, p.220-235.

${ }^{1001}$ Novo Código Tributário Alemão (AO - 1977). Op.cit., p. 03 e seguintes.
} 
É interessante destacar que o processo de especialização disciplinar do Direito Tributário gerou (motivado também por outras questões) a interpretação econômica da lei tributária, ou seja, a criação de método próprio para o desenvolvimento desse ramo do conhecimento jurídico (ainda que utilizasse de mecanismos econômicos). Favoreceu, assim, a repulsa inicial a conceitos ou métodos do Direito Privado, para, em momento posterior, aceitar-se, e até incentivar-se, a utilização desses.

Naturalmente, cada linha de estudo recebeu em intensidades diferentes a repulsa e/ou aceitação da utilização de conceitos de Direito Privado ou de Direito Tributário na Europa. Na Alemanha, conforme acentuam Klaus Tipke e Joachim Lang ${ }^{1002}$, a evolução das doutrinas (e mesmo da jurisprudência alemã) sobre o uso de conceitos de Direito Privado no Direito Tributário manteve-se perene mesmo com a supressão legislativa da interpretação econômica ou teleológica, no que concorda também Brandão Machado. ${ }^{1003}$

Naturalmente, a interpretação econômica também foi repercutida da mesma forma a países de língua latina, como se pode observar na Itália, onde o financista Benvenuto Griziotti $^{1004}$ foi considerado o precursor ${ }^{1005}$ da doutrina da interpretação funcional (teleológica ou econômica) italiana, conquistando imediatamente opiniões favoráveis e

1002 Nesse sentido, interessante aporte sobre a discussão da interpretação econômica foi elaborado pelos supracitados autores germânicos. "Nem um flutuante 'ponto de vista econômico' nem uma interpretação civilística apaixonada das leis tributárias conduzem a resultados corretos. Na interpretação de conceitos legais tributários deve-se em primeiro lugar partir do princípio de que não existe nenhuma prevalência teleológica do Direito Civil. Pelo contrário, deve-se examinar com fundamento na teleologia da lei tributária, se e em que proporção um conteúdo de regramento civilístico também codetermina a conseqüência jurídica da lei tributária. Assim deve-se uma situação de fato civilisticamente configurada em primeiro lugar qualificar civilisticamente e só então examinar, se ela deve adscrever-se econômico-teleologicamente ao tipo legal da lei tributária. Coincidindo a qualificação de Direito Civil com a finalidade da lei tributária, então o Direito Civil é preponderante (Massgebend) (s.K.Tipke, StRO III, 1295). Conduzindo entretanto a interpretação teleológica da lei a um conceito jurídico-derrogante do Direito Civil, assim deve esse interpretar-se econômico-teleológicamente". TIPKE, Klaus; LANG, Joachim. Op.cit., p. 323-324.

${ }^{1003}$ É nesse sentido a pontuação de Brandão Machado: “(...) em primeiro momento, durante a implantação da nova hermenêutica na Alemanha, a partir dos anos vinte e até pouco depois da morte de Enno Becker, os conceitos e institutos do direito privado utilizados na legislação tributária eram tomados, como se disse, no seu conteúdo próprio. “(...) havia até um lema, segundo o qual o intérprete devia ficar longe do direito civil: Weg vom BGB [longe do Código Civil]. Porém, em segundo momento, no começo dos anos cinquenta, as coisas começaram a mudar. O direito privado, como veículo de fatos tributáveis, passou a ser encarado não mais como simples forma vazia de significado tributário, mas como elemento capaz de influir na interpretação dos fatos. Foi quando, como disse H. Wilhem Kruse, o lema passou a ser o inverso do outro: Hin zum BGB [Vamos ao Código Civil]”. MACHADO, Brandão. Prefácio do Tradutor. In: HARTZ, Wilhelm Op.cit., p. 05 e seguintes.

1004 GRIZIOTTI, Benvenuto. Princípios de Política, Derecho y Ciência de la Hacienda. Op.cit.,p. 316-333. 1005 FALSITTA, Gaspare. Obsservazioni sulla nascita e lo sviluppo scientifico del diritto tributario in Itália. In: UCKMAR, Victor. (coordenação). L'Evoluzione dell'Ordinamento Tributario Italiano. Atti del Convegno. I settanta anni di "Diritto e pratica tributaria" (Genova 2-3 Iuglio 1999). Il Diritto Tributario. Serie I. Volume LXXXIX. MILANO: CEDAM, 2000. p. 80-83. 
contrárias a esse entendimento, inclusive com manifestações diretas de autores italianos a exemplo de Giannini ${ }^{1006}$, Tesoro ${ }^{1007}$, Berliri ${ }^{1008}$, Mario Puglièse ${ }^{1009}$, Ezio Vanoni ${ }^{1010} \mathrm{e}$ também Dino Jarach ${ }^{1011}$ na Argentina, que manifestou posição favorável à interpretação econômica. Para Jarach, a interpretação econômica está ligada ao princípio da capacidade contributiva $^{1012}$.

Aliás, Tullio Ascarelli também era um grande exemplo dessa tendência, pois era conhecida sua visão da lei como consubstanciada na utilização da chamada interpretação econômica (vinculando-a ao direito) frente à tradicional "interpretação jurídica do direito" (relacionando-a às tradicionais concepções construídas na órbita do direito privado) ${ }^{1013}$ 1014

Por outro lado, Giuliani Fonrouge, influenciado por Enno Becker, introduziu em seu Anteprojeto de Código Fiscal da Argentina, de 1942, no art. 2º o seguinte teor: "Os atos, fatos ou circunstâncias sujeitos à tributação, se interpretam conforme a sua significação econômico-financeira, prescindindo de sua aparência formal, ainda que esta corresponda a figuras ou instituições de direito comum"1015.

É por isso que a polêmica europeia sobre a interpretação das leis tributárias decorrente do Código Tributário Alemão, e o próprio debate autonomista, atravessou o continente europeu e desembarcou na América Latina, tendo como artífices, Giuliani Fonrouge $^{1016}$, Dino Jarach ${ }^{1017}$, Rafael Bielsa ${ }^{1018}$ e Ramón Valdés Costa ${ }^{1019}$.

\footnotetext{
${ }^{1006}$.GIANNINI, Achille Donato. I Concetti del Diritto Tributario. Op.cit., p. 37-47.

1007 TESORO, Giorgio. Op.cit., p. 09 e seguintes.

${ }^{1008}$ BERLIRI, Antonio. Principi di Diritto Tributario. Tomo I. Volume II. Op.cit., p.03 e seguintes.

${ }^{1009}$ PUGLIÈSE, Mario. Instituciones de Derecho Financiero. Op.cit., p. 122-127.

1010 Sugere-se, nesse sentido, a classificação de métodos interpretativos apresentados por Vanoni e que influenciaram Puglièse. VANONI, Ezio. Opere Giuridiche. II. Op.cit., p. 85-111.

${ }^{1011}$ JARACH, Dino. Hermenêutica no Direito Tributário. In: Interpretação no Direito Tributário. Coord. Geraldo Ataliba. São Paulo: EDUC, 1975, p. 83 e seguintes.

1012 “(...) A consideração econômica, nesta matéria, resulta não do caráter pecuniário da obrigação, mas do princípio de ordem superior, que é de nível constitucional em quase todos os países - o princípio da capacidade contributiva. (...) A chamada interpretação econômica não é outra coisa que o propósito próprio do legislador de gravar fatos que manifestem capacidade contributiva”. Idem, p. 99-100.

${ }^{1013}$ Sobre a visão de Ascarelli sobre a relação entre economia e direito, e especialmente, sobre a interpretação econômica no direito, recomenda-se a leitura de: NOGUEIRA, Ruy Barbosa. A Contribuição de Túllio Ascarelli para a formação da Doutrina Jurídico-Tributária do Brasil. Op.cit., p.05 e ss.

${ }^{1014}$ Para Eros Grau, a interpretação de Ascarelli já diferenciava texto e norma, considerando que o autor não se limitaria à interpretação dos textos, mas da realidade. GRAU, Eros Roberto. Por que tenho medo dos juízes (a interpretação/aplicação do direito e os princípios). Op.cit., p. 39-40.

${ }_{1015}$ FONROUGE, C. M. Giuliani. Anteproyecto de Código Fiscal. Op.cit., p. 366 e seguintes.

${ }^{1016}$ Idem.
} 
Tais caminhos naturalmente repercutiram-se diretamente no processo de especialização disciplinar do Direito Tributário Brasileiro, conforme se verá a seguir.

\section{Antecedentes da formação das estratégias de estudo e ensino do Direito Tributário Brasileiro}

\subsection{Década de quarenta à década de cinquenta.}

Como já ressaltado, a especialização disciplinar do Direito Tributário no Brasil apresenta como foco dois locais estratégicos iniciais: São Paulo e Rio de Janeiro.

Com a influência de Tullio Ascarelli na USP, que passou a incutir em alunos da Faculdade de Direito a importância do estudo do Direito Tributário, forma-se a primeira linha de pesquisa e ensino no Direito Tributário Brasileiro, do qual saíram nomes como Rubens Gomes de Sousa ${ }^{1020}$ e Ruy Barbosa Nogueira ${ }^{1021}$.

Mas assevera-se que, embora reunidos e orientados por Tullio Ascarelli, não havia necessariamente unidade de premissas metodológicas e epistemológicas aplicadas ao Direito Tributário.

De fato, a realização de cursos sobre a temática tributária contribuiu enormemente para aproximar a literatura tributária brasileira dos grandes monumentos teóricos europeus, incutindo-lhes a influência estrangeira na construção do Direito Tributário. Tanto os cursos ministrados por Tullio Ascarelli (1947), como os ministrados por Rubens Gomes de Sousa

1017 JARACH, Dino. Curso de Derecho Tributario. Tercera Edición. Buenos Aires: Cima, 1980, p. 205214. JARACH, Dino. O Fato Imponível. Teoria Geral do Direito Substantivo. Traduzido por Dejalma Campos. $2^{\circ}$ edição, 2004, p. 09 e seguintes.

1018 BIELSA, Rafael. Estudios de Derecho Público. II. Derecho Fiscal. Buenos Aires: Depalma, 1951, p. 71-94.

1019 VALDÉS COSTA, Ramón. Interpretación de las Normas Tributarias. In: Estudios de Derecho Tributario Latinoamericano.Montevideu, 1982, p.61 e seguintes. Sobre o assunto também: VALDÉS COSTA, Ramón. A Codificação Tributária na América Latina. Direito Tributário: estudos em homenagem ao Prof. Ruy Barbosa Nogueira. COORDENADOR: MACHADO, Brandão. São Paulo: Saraiva, 1984, p. 241-242.

${ }^{1020}$ NOGUEIRA, Ruy Barbosa. Rubens Gomes de Sousa, trinta anos amigo e companheiro. In: Estudos Tributários. Direção e Colaboração. Prof. Ruy Barbosa Nogueira. São Paulo: Resenha Tributária, s/d, p. 0113.

${ }^{1021}$ Sobre o assunto ver Capítulo 1. 
(1947, 1948 e especialmente 1949) ${ }^{1022}$, apresentavam essa característica (quase introdutória ao Direito Tributário) ${ }^{1023}$.

A verdade é que, nesse período (década de quarenta e cinquenta), as linhas de estudo se mantiveram harmônicas com as construções teóricas estrangeiras do período fundacional do Direito Tributário europeu, sobretudo na pena da emergente doutrina tributária brasileira dos chamados "tempos heroicos do direito tributário" (conforme se referiu Rubens Gomes de Sousa) ${ }^{1024}$.

E mesmo com o esforço de divulgação do estudo do direito tributário, seja pela doutrina, seja por institutos de pesquisa, como o antigo IBDF (com Gilberto Ulhôa Canto) e a Fundação Getúlio Vargas, esses impulsionados também pelo processo de codificação tributária, oficialmente encaminhado em 1954 (Projeto), não mudava a característica proeminente no Brasil ${ }^{1025}$.

Mas de fato, nesse período já se lançavam os alicerces para o futuro aperfeiçoamento dos estudos relacionados ao Direito Tributário, que desaguariam na participação determinante de Ruy Barbosa Nogueira na consolidação de dois dos principais cursos jurídico-tributários do Brasil (USP e PUCSP), iniciando-se na década de cinquenta e consolidando-se na década de sessenta, assim como a contribuição de Amílcar de Araújo Falcão (impulsionado por Aliomar Baleeiro), na mesma época, na UERJ ${ }^{1026}$, que depois foi aperfeiçoada por Flávio Bauer Novelli, sucessor de Amílcar de Araújo Falcão.

\subsection{A primeira posição sobre o problema autonomista no Brasil: autonomia científica do Direito Tributário Brasileiro}

A literatura tributária brasileira, especialmente entre as décadas de quarenta e sessenta, recebeu de braços abertos às repercussões que o debate autonomista apresentava

${ }^{1022}$ NOGUEIRA, Ruy Barbosa. Rubens Gomes de Sousa, trinta anos amigo e companheiro. Op.cit., p. $01-13$.

${ }^{1023}$ SOUSA, Rubens Gomes de. Apresentação. In: FANUCCHI, Fabio. Curso de Direito Tributário. Op.cit., p. xiii-xviii.

${ }^{1024}$ SOUSA, Rubens Gomes de. Prefácio. In: FANUCCHI, Fabio. Op.cit., p. xix.

${ }^{1025}$ BALEEIRO, Aliomar. Uma Introdução à Ciência das Finanças. Op.cit., p.19 e seguintes.

1026 Sobre o assunto ver capítulo 1. 
na literatura estrangeira, caminhando para elevar a chamada "autonomia científica" do Direito Tributário.

Na década de quarenta, já era possível observar atenção ao tema em João Martins de Oliveira, que, semelhante à Myrbach-Rheinfeld, também registrava preocupação com a influência dos estudos econômico-financeiros, contribuindo diretamente para a “(...) pobreza de nossa literatura jurídica em matéria fiscal (...)”, incutindo também tradição civilista na cultura jurídica brasileira (o que prejudicava o avanço da literatura tributária, na época). Note-se que Oliveira apresentava já as duas facetas fundamentais da defesa autonomista: preocupação com a influência econômica; preocupação com a influência dos conceitos de Direito Civil, ainda predominantes na literatura da época. ${ }^{1027}$.

Posição análoga também registrou Rubens de Sousa que, em seu trabalho inaugural (1943), já defendia a autonomia do "Direito Fiscal" e, já atento à temática da autonomia em seus primeiros estudos ${ }^{1028}$, reconhecia que o Direito Tributário, “(...) para atingir suas finalidades, elabora conceitos e institutos jurídicos específicos que lhe são próprios, porque não interessam às finalidades dos outros ramos do direito: o estudo de tais conceitos institutos próprios do direito tributário constitui justamente a matéria de nosso programa. Podemos, portanto, concluir no sentido de que o direito tributário é um ramo jurídico autônomo (...). ${ }^{1029}$

Contudo, deve-se considerar importante aspecto elementar ao debate autonomista visualizado em Sousa: a elevação da autonomia jurídica do Direito Tributário (distanciando-se do Direito Privado) seria justificada porque o primeiro encararia o fato “(...) quanto os seus efeitos econômicos”, já que “(...) O direito tributário tem um conteúdo essencialmente patrimonial ou econômico “(...)"1030.

Note-se que a posição de Sousa caminhava em semelhante aspecto à ideia-base esboçada por Enno Becker: elevar a autonomia do Direito Tributário através de sua particular atenção à realidade econômica dos fatos. E muitos estudiosos da época pareciam

\footnotetext{
1027 OLIVEIRA, João Martins. Op.cit., p. 08.

1028 Assim, “(...) é indiscutível, pois, que a sistematização das regras de aplicação de um princípio por tal forma especial constitui, necessariamente um ramo autônomo do direito. A natureza específica do crédito fiscal, noção básica e central do direito tributário, basta para conferir a todo esse direito o caráter de autonomia". SOUSA, Rubens Gomes de. A distribuição da justiça fiscal. Op.cit., p. 20 e seguintes.

${ }^{1029}$ SOUSA, Rubens Gomes de. Compêndio de Legislação Tributária. Op.cit., p. 59.

${ }^{1030}$ Idem, p. 63.
} 
seguir esse caminho, especialmente na década de cinquenta, a exemplo de Carlos da Rocha Guimarães negando-lhe a alcunha de "direito de sobreposição" ${ }^{1031}$, e elevando sua autonomia científica perante o Direito Privado, baseado igualmente em Sousa, já que “(...) ao direito fiscal interessam os fenômenos econômicos subjacentes nos atos de direito privado".

Naturalmente, no processo codificador do direito tributário brasileiro, os debates autonomistas também influenciaram a literatura, e favoreceram a Rubens Gomes de Sousa impulsionar o próprio processo codificador, fundamentado na autorização constitucional para a elaboração, pela União, de normas gerais em direito financeiro ${ }^{1032}$.

Essa posição, contudo, prevalecente na década de quarenta e cinquenta (vinculando a autonomia do Direito Tributário à sua particular atenção ao fenômeno econômico), receberia diferentes percepções na literatura da época.

Por exemplo, Aliomar Baleeiro reconheceu o Direito Tributário enquanto sub-ramo mais desenvolvido do Direito Financeiro (reconhecia a autonomia didática e dogmática do Direito Financeiro, mas não frente ao Direito Tributário). ${ }^{1033}$

Logo, a noção de autonomia passa a ser identificada como autonomia jurídica ou científica, isto é, quando o Direito Tributário passa a reunir princípios e institutos próprios que o diferenciaria de outros ramos jurídicos, exigindo assim tratamento autônomo.

Essa perspectiva pode também ser observada em Amílcar de Araújo Falcão, que, ainda na década de cinquenta, ponderou: "Ocorre a autonomia jurídica de uma disciplina quando ela preenche duas condições: a) cria um número de institutos e instrumentos próprios e entre si aproximados - autonomia estrutural; b) cria um certo número de princípios e regras que lhe são peculiares - autonomia dogmática". ${ }^{1034}$

\footnotetext{
${ }^{1031}$ GUIMARÃES, Carlos da Rocha. Introdução ao Direito Fiscal. Op.cit., p. 08.

1032 Sobre o assunto, ver Capítulos 1 e 2 deste trabalho.

1033 GUIMARÃES, Carlos da Rocha. Introdução ao Direito Fiscal, p. 38-39.

${ }^{1034}$ E complementa; "Que o direito tributário pode ser estudado, para fins didáticos, como uma disciplina autônoma, ou de modo unitário, é evidente e ninguém o contesta. O punctum dolens está em saber se, cientificamente, ou dentro de um ponto de vista sistemático, o direito tributário possui autonomia jurídica. $\mathrm{O}$ problema tem que ser encarado em face do direito privado, do direito administrativo e financeiro e do direito em geral (...)", concluindo pela autonomia dogmática e estrutural do direito tributário, o que justificaria não somente o seu tratamento unitário, “(...) como a configuração daquela chamada autonomia jurídica ou científica”. FALCÃO, Amílcar de Araújo. Introdução ao Direito Tributário. Op.cit., p. 27-33.
} 
Outros estudiosos de renome também advogaram a autonomia "científica" do Direito Tributário, a exemplo de Ruy Barbosa Nogueira, para quem o Direito Tributário possuiria princípios e institutos próprios, apresentando corpo próprio de regras orientadas por vários princípios específicos e, assim, reconhecendo o Direito Tributário como ramo científico e metodologicamente autônomo do Direito. ${ }^{1035}$

Para Nogueira “(...) a separação por motivo puramente didático não pode ser considerada verdadeira autonomia, porque ela não é feita em razão de princípios específicos. Assim, por exemplo, a divisão do Direito Civil em Direito de Família, Direito das Coisas, é feita apenas por motivo prático, metodológico ou didático, pois são todos eles regidos pelos princípios do Direito Civil. Cientificamente autônomo é o Direito Civil”" ${ }^{1036}$.

Note-se que a conclusão de Ruy Barbosa Nogueira apresentava-se menos extremada que a posição de Amílcar de Araújo Falcão. A autonomia "científica" para Ruy Barbosa Nogueira justifica-se pela consolidação de institutos e princípios próprios de estudo: “(...) Toda vez que uma parte do Direito passa a ser estudada autonomamente, por necessidade científica, por diferenciação de princípios, é que podemos realmente falar de um ramo novo, porque existe uma matéria a ser estudada por métodos próprios, constituindo então um sistema de normas jurídicas regidas por princípios diferentes dos princípios que regulam outros ramos jurídicos. Este é o caso do Direito Constitucional, do Direito Administrativo; do Direito Financeiro e do Direito Tributário”.

A autonomia "científica" (e não independência) é esboçada em um sentido diferente do que afirmar que o Direito Tributário não poderia ser permeado por outros ramos do conhecimento, e nem tecer influências sobre eles. A unidade do ordenamento jurídico já aparecia como pedra de toque na construção de Ruy Barbosa Nogueira, e não parecia escapar à vista dos demais doutrinadores acima citados. Mas efetivamente, a posição manifestada por Ruy Barbosa Nogueira, apresentaria importantes repercussões ao processo disciplinar do Direito Tributário.

\footnotetext{
${ }^{1035}$ E prossegue: "Esta questão da autonomia não deve ser entendida de modo extremado; a autonomia é no sentido de ramo autônomo. O Direito é uno, uma só árvore. O que é necessário ressaltar e é relevante na prática, é que o Direito Tributário tem muitos princípios e institutos próprios, não devendo o jurista procurar resolver as questões tributarias por princípios ou institutos de outros ramos, inadequados à natureza e finalidades de Direito Tributário". NOGUEIRA, Ruy Barbosa. Direito Financeiro (Curso de Direito Tributário). Op.cit., p. 07. ${ }^{1036}$ NOGUEIRA, Ruy Barbosa. Curso de Direito Tributário. Op.cit., p. 34.
} 
Curiosamente, no âmbito da defesa da autonomia científica do Direito Tributário aparecia com menores resistências a adoção da interpretação econômica do Direito Tributário, justamente por ser o elemento central para justificar a emancipação disciplinar dessa perante outros ramos do conhecimento jurídico (notadamente o Direito Civil). Nesse ponto, parece conveniente esboçar algumas linhas históricas sobre as tentativas de inclusão do dispositivo no direito tributário positivo brasileiro.

\subsubsection{A tentativa inicial de inclusão da interpretação econômica na codificação tributária brasileira}

O processo codificador do direito tributário brasileiro passou por semelhantes experiências vivenciadas na codificação alemã e na latino-americana, e, naturalmente, não se afastou das peculiaridades da interpretação econômica. Mas, por outro lado, apresentava detalhes que o diferenciou, ligeiramente, das demais.

Nesse sentido, no Anteprojeto de Código Tributário Nacional (1953), de Rubens Gomes de Sousa, não havia a expressa menção à interpretação econômica ou funcional, ainda que não a refutasse expressamente: "Art.128. Na aplicação da legislação tributária, são admissíveis quaisquer métodos ou processos de interpretação, observado o disposto neste Título”.

Isso porque, provavelmente por influência do Código Tributário Mexicano (e seu artigo 11), Sousa preferiu não importar mecanismo tão polêmico na realidade tributária, muito embora seja possível, em tese, extraí-la de alguns dispositivos, como é o caso do Art.129: "Salvo em se tratando de tributos incidentes sobre atos jurídicos formais e de taxas, a interpretação da legislação tributária, no que se refere à conceituação de um determinado ato, fato ou situação jurídica como configurando ou não o fato gerador, e também no que se refere à determinação da alíquota aplicável, terá diretamente em vista os resultados quando tais resultados não correspondam aos normais, com o objetivo de que a resultados idênticos ou equivalentes coresponda tratamento tributário igual”.

Em outras palavras, existia abertura à interpretação finalista na lei tributária, perspectiva que também fica transparecida nos artigos 134 a 138, que tratam das regras de 
interpretação da lei tributária, ainda que a menção à "realidade econômica dos fatos" não seja utilizada expressamente em qualquer desses dispositivos.

Essa também foi a posição de Gilberto Ulhôa Canto, da mesma forma que Tito Rezende $^{1037}$, sobre a remissão inequívoca à interpretação econômica proporcionada pelo art.129 $9^{1038}$, de forma que esse dispositivo acabou suprimido.

Mas, ainda que tenha recebido ressalvas dos integrantes da Comissão Especial, o próprio Anteprojeto de Código Tributário Nacional forneceu suporte para o Projeto de Código Tributário Brasileiro reproduzir expressamente o preceito da interpretação econômica no art.74: “A interpretação da legislação tributária visará à sua aplicação não só aos atos ou situações jurídicas nela nominalmente referidos como também àqueles que produzam ou sejam suscetíveis de produzir resultados equivalentes" ${ }^{1039}{ }_{-}^{1040}$.

Naturalmente, tal fato poderia ter sido motivado pelo próprio Parecer da Comissão Especial, para quem “(...) o direito fiscal deve ter bastante mobilidade para poder se adaptar à evolução rápida dos fenômenos econômicos (...)"1041.

O mesmo título ainda trazia o art.75, que inseriu as técnicas de integração da lei tributária, que incluía a adoção da analogia, princípios gerais de direito tributário,

1037 “Artigos 129 e 130 e parágrafo único do artigo 131 - Eis aí um conjunto de princípios doutrinários que inegàvelmente traduzem com felicidade os rumos da evolução do direito tributário - , embora, como sempre sucede no campo jurídico, possam merecer tais ou quais ressalvas ou aditamentos. Entendemos, todavia, que tais princípios possam servir de orientação ao legislador, não ao aplicador da lei. (...) Não cremos que esses dispositivos, especialmente o primeiro, sequer se conciliem com a norma constitucional que diz que ninguém é obrigado a fazer ou deixar de fazer alguma coisa senão em virtude de lei”. Voto de Tito Rezende. In: Instituto Brasileiro de Direito Financeiro. A Codificação do Direito Tributário. Rio de Janeiro: s/e, 1954, p. 182.

1038 “Art.129 - Não nos parece que a norma, tal como se encontra redigida, possa prevalecer. Percebe-se que visa a consagrar a prevalência do conteúdo econômico sobre a apresentação formal, preocupação que vem dominando a doutrina tributária moderna, desde a adoção expressa da regra pela legislação alemã ("Reichsabgabenordnung" e "Steueranpassungsgesetz"), até a elaboração contemporânea, na Itália, da qual são férteis em exemplos os últimos volumes da "Rivista di Diritto Finanziario ed Scienza delle Finanze". Mas, como está redigido o texto, cremos que ensejaria constantes problemas de constitucionalidade, em vista do princípio inserto no art.141, $\S 2^{\mathrm{a}}$ da Constituição Federal. O que poderia subsistir, por ser uma simples regra de interpretação sem subversão do princípio da legalidade estrita, é a regra do $\S$ único ao art.131, seguinte, a propósito do qual voltaremos ao ponto". Voto de Gilberto Ulhôa Canto, sobre o art.129 do Anteprojeto de Código Tributário Nacional. In: Instituto Brasileiro de Direito Financeiro. A Codificação do Direito Tributário. Op.cit., p.183.

${ }^{1039}$ Projeto de Código Tributário Nacional. In: Instituto Brasileiro de Direito Financeiro. A Codificação do Direito Tributário. Op.cit., p.341-342.

${ }^{1040}$ BALEEIRO, Aliomar. Direito Tributário Brasileiro. Op.cit., p.688-689.

${ }^{1041}$ Parecer da Comissão Especial, composta por Tito Rezende (Presidente), Carlos da Rocha Guimarães, Eduardo Lopes Rodrigues, Jayme Péricles e Gilberto Ulhôa Canto, sobre o Ante-Projeto de Código Tributário Nacional. In: Instituto Brasileiro de Direito Financeiro. A Codificação do Direito Tributário. Op.cit., p. 103- 110. 
princípios gerais de direito público e a equidade, com suas respectivas restrições, no caso da analogia, para não ocasionar instituição de tributo previsto em lei e, no caso da equidade, para não dispensar pagamento do imposto devido.

Ora, evidentemente, a introdução de dispositivo relativo à interpretação das leis tributárias que fosse distinto daqueles mecanismos interpretativos secularmente construídos na raiz do Direito Privado, representava, de igual forma, a consagração de pensamento crescente entre estudiosos que começavam a se reunir em torno daquela matéria que agora possuiria sua própria fonte legislativa autêntica de interpretação.

Mas o artigo 74 (relativo à interpretação econômica) foi revogado antes mesmo de se tornar vigente no ordenamento jurídico, motivando Baleeiro a deduzir que a interpretação econômica foi inserida de forma muito tímida no Código Tributário Nacional, limitada por aqueles conceitos de direito privado previstos previamente na Constituição Federal, nas Constituições Estaduais, nas Leis Orgânicas Municipais e do DF. Porém, fora da prévia limitação prevista naqueles dispositivos, asseverou Baleeiro: “(...) tal primado não existe se aquelas definições, conceitos e formas promanam de outras leis ordinárias (...)"1042.

Mas, complementando a opinião de Baleeiro, o art.73, no Título IV do mesmo Projeto, previu que, na aplicação da legislação tributária, seriam admissíveis quaisquer métodos ou processos de interpretação, desde que respeitado o conteúdo do presente Título IV $^{1043}$.

Em outras palavras, fora daquelas limitações, abrir-se-ia campo de atuação para que a interpretação econômica fosse adotada. Baleeiro tocou em ponto central que determinou a consagração das regras de direito privado no ordenamento jurídico brasileiro na interpretação das leis tributárias, pois o próprio Projeto de Código Tributário Nacional, no art.76, introduziu uma técnica não visualizada no Código Fiscal Mexicano, buscando equilibrar ou botar panos frios na dificuldade da utilização de conceitos de direito privado em matéria tributária, ao determinar que “(...) os princípios gerais de direito privado constituem método ou processo supletivo de interpretação da legislação tributária

\footnotetext{
1042 BALEEIRO, Aliomar. Direito Tributário Brasileiro. Op.cit., p. 15-42.

1043 Projeto de Código Tributário Brasileiro. In: Souza Diniz. Códigos Tributários. Alemão. Mexicano. Brasileiro. $1^{\circ}$ edição. Tradução de Souza Diniz. São Paulo: Edições Financeiras S.A., 1965, p.469-530.
} 
ùnicamente para pesquisa da definição, conteúdo e alcance próprios dos institutos, conceitos e formas de direito privado a que faça referência aquela legislação, mas não para a definição de seus efeitos tributários".

E o parágrafo único determinava que a “(...) lei tributária poderá modificar expressamente a definição, conteúdo e alcance próprios dos institutos, conceitos e formas a que se refere êste artigo, salvo quando expressa ou implicitamente utilizados, na Constituição Federal, nas Constituições dos Estados, ou nas Leis Orgânicas dos Municípios, para definir competência tributária”.

Assim, se o conceito ou instituto construído na senda do direito privado fosse previsto ou tratado expressa ou implicitamente em matéria constitucional, haveria restrição ao uso ou modificação desse instituto relativo ao Direito Tributário, não podendo ser objeto de restrição, transformação ou extensão em sua estrutura (e efeitos) no direito tributário positivo.

Tal enunciado, ao tentar resolver ou colocar um obstáculo constitucional ao uso (e desvirtuamento) de conceitos civis em matéria tributária, tinha seus fundamentos, pois o desenvolvimento histórico da atividade tributária sempre demonstrou tendência inequívoca ao desvirtuamento de conceitos de direito privado visando facilitar ou potencializar a arrecadação tributária, trazendo riscos à segurança jurídica, ao patrimônio e à liberdade do cidadão.

Colocar um "freio constitucional" a impulsos modificadores abusivos do Estado parecia ser um justo e adequado mecanismo que evitaria tais transtornos legais, e parecia se harmonizar com o espírito constitucionalista protetor dos direitos e garantias individuais, notadamente a legalidade tributária.

$\mathrm{Na}$ relação entre os dispositivos já previstos no Projeto de Código Tributário Nacional (assim como no Anteprojeto), vale destacar a opinião de Alcides Jorge Costa, que apontou, sob a égide da Emenda Constitucional n. 1/69, que “(...) inexiste entre nós sequer a possibilidade de discutir se os conceitos e institutos de direito privado mencionados na Constituição Federal devem ou não ser recebidos como tais pelo Direito Tributário". 1044

${ }^{1044}$ COSTA, Alcides Jorge. Direito Tributário e Direito Privado. Op.cit., p. 225. 
E, naturalmente, aqueles originários dispositivos previstos nos artigos 75 e 76 do Projeto de Código Tributário Nacional, foram incorporados ao ordenamento jurídico tributário na figura dos artigos 109 e 110 do Decreto-Lei n. 5172/66, praticamente repetindo seus respectivos enunciados ${ }^{1045}$.

Em outras palavras, prevaleceu o uso de conceitos de direito privado constitucionalmente previstos à margem da possibilidade da alteração de efeitos tributários respectivos, e com a tentativa aparentemente frustrada de inserção do dispositivo da interpretação funcional no ordenamento jurídico brasileiro (artigo 74 do Projeto), através do Anteprojeto de Rubens Gomes de Sousa (art.129 a 138), e das preocupações de Aliomar Baleeiro, que reconheceu a possibilidade, ainda que restrita, de utilização desse recurso no direito tributário ${ }^{1046}$.

Sobre o mesmo assunto pontuou Alcides Jorge Costa, para quem: “(...) se há conceitos, institutos e formas de direito privado não utilizados pela Constituição nem pela lei complementar, parece-me que podem ser alterados explicitamente pela lei ordinária, desde que a alteração não constitua maneira oblíqua de ofender a discriminação constitucional das fontes de receita tributária". ${ }^{1047}$

Note-se que a interpretação econômica foi também ligada a alguns dispositivos que compõe os métodos de interpretação e integração no direito tributário brasileiro ${ }^{1048}$, e, mais especificamente, no campo da utilização da analogia.

1045 Dispõem os artigos 109 e 110 do Código Tributário Nacional: “Art. 109. Os princípios gerais de direito privado utilizam-se para pesquisa da definição, do conteúdo e do alcance de seus institutos, conceitos e formas, mas não para definição dos respectivos efeitos tributários"; "Art. 110. A lei tributária não pode alterar a definição, o conteúdo e o alcance de institutos, conceitos e formas de direito privado, utilizados, expressa ou implicitamente, pela Constituição Federal, pelas Constituições dos Estados, ou pelas Leis Orgânicas do Distrito Federal ou dos Municípios, para definir ou limitar competências tributárias".

${ }^{1046}$ BALEEIRO, Aliomar. Direito Tributário Brasileiro. Op.cit, p.688-689.

${ }^{1047}$ Mas pondera: “Alterações implícitas ou aplicações que considerem o substrato econômico sem levar em conta a forma não são compatíveis com o sistema constitucional brasileiro. É claro que esta última afirmação não elimina a existência de problemas relativos à simulação, nem ao que se conhece por fraude à lei ou abuso de formas". COSTA, Alcides Jorge. Direito Tributário e Direito Privado. Op.cit., p.225-226.

${ }^{1048}$ No CTN foi incluído o Capítulo IV "Interpretação e Integração da Legislação Tributária”, que trata dos elementos de integração da lei tributária (art. 108), incluindo a analogia; os princípios gerais de direito tributário; os princípios gerais de direito público; a equidade, mas vedando o emprego da analogia para exigir tributo não previsto em lei, ou, em outro passo, para proibir o emprego da equidade para dispensar o pagamento do tributo devido. Além do artigo 108, e dos já citados artigos 109 e 110, incluiu-se também o artigo 111 (interpretação literal ou estrita), e a interpretação favorável ao réu (artigo 112). 
Essa pode ser entendida como “(...) uma semelhança de relações (...)”, consistindo em “(...) aplicar a uma hipótese não prevista em lei a disposição relativa a um caso semelhante" 1049 .

Mas a analogia encontra severa restrição no campo do direito, isso porque, conforme adverte Miguel Reale “(...) ela não tem emprego em todos os domínios do Direito, sendo inadmissível, em princípio, quando se tratar de regras de caráter penal, ou se as normas forem restritivas de direitos ou abrirem exceções" ${ }^{\prime 1050}$.

Não é por outro motivo que o próprio Código Tributário Nacional restringiu seu campo de atuação: “§ $1^{\circ} \mathrm{O}$ emprego da analogia não poderá resultar na exigência de tributo não previsto em lei”. Restrição que acabou majoritariamente defendida pela literatura tributária, o que não impediu a literatura de manifestar posicionamentos divergentes sobre o tema, como se pode ver em Amílcar de Araújo Falcão ${ }^{1051}$ e Rubens Gomes de Sousa. ${ }^{1052}$

Portanto, o processo de especialização disciplinar do Direito Tributário Brasileiro apresenta, nesse ínterim, prevalência relativa aos conceitos de direito privado, ainda que seja explícito que a legislação tributária possa atribuir efeitos tributários próprios a conceitos de direito privado. Sob essa possibilidade, o legislador nacional atribuiu proteção constitucional a conceitos ou institutos previstos - expressamente ou implicitamente - na Constituição, como uma forma de apresentar um sistema de freios e contrapesos a eventuais abusos cometidos pelo legislador tributário, refutando, ou pelo menos restringindo amplamente o espaço para a interpretação econômica, tendência que se coaduna com a prevalente tendência de especialização disciplinar no século XX.

\footnotetext{
1049 “(...) Por outro lado, não se deve confundir a analogia com a interpretação extensiva, apesar de, como já assinalamos, esta representar, até certo ponto, uma forma de integração. A doutrina tem vacilado na exposição dos critérios distintivos entre uma e outra. Parece-nos que assiste razão àqueles que não apontam entre elas uma diferença qualitativa, mas de grau, ou de momento no processo de integração sistemática". REALE, Miguel. Lições Preliminares de Direito. Op.cit., p. 279.

${ }^{1050}$ Idem, p. 280.

${ }^{1051}$ FALCÃO, Amílcar de Araújo. Introdução ao Direito Tributário. Op.cit, p. 90-91.

${ }^{1052}$ Este autor esforçou-se para diferenciar a interpretação extensiva da analogia, afastando a primeira do direito tributário, mas aceitando a segunda, sob certas condições: “(..) é preciso distinguir entre interpretação extensiva e interpretação analógica: a primeira é a que, partindo de um texto de lei, cria uma norma jurídica nova e a aplica a uma situação diferente da prevista na lei; a segunda é a que, partindo de um texto de lei, faz incluir as situações análogas, embora não expressamente referidas no texto. Por conseguinte, a interpretação extensiva não é admissível no direito tributário, porque implica em criar tributos sem lei, o que, como já vimos, é proibido até mesmo pela Constituição. Ao contrário, a interpretação analógica é admissível, porque não cria direito novo mas apenas completa o alcance do direito existente: aliás, se rejeitássemos essa forma de interpretação, voltaríamos a exigir que a lei tributária enumerasse expressamente todos os casos". SOUSA, Rubens Gomes de. Compêndio de Legislação Tributária. Op.cit., p. 81.
} 


\subsubsection{A recepção favorável da autonomia científica à interpretação econômica na década de cinquenta}

A recepção da interpretação das leis tributárias chegou ao Brasil com rapidez, especialmente também pela tradução de importantes estudos sobre o tema no Brasil.

É o caso, por exemplo, da tradução do trabalho de Ezio Vanoni, por Rubens Gomes de Sousa. Na opinião de Ezio Vanoni, dever-se-ia considerar mecanismos hermenêuticos próprios ao Direito Tributário: “O problema da interpretação das leis tributárias tem-se apresentado muitas vezes, também sob um ponto de vista teórico, aos estudiosos do direito. A tendência doutrinária mais autorizada, que ainda hoje encontra fácil acolhida, nega à interpretação das leis financeiras o uso dos meios que comumente se aplicam à explicação das leis. Considera-se que a natureza particular das leis tributárias impede a aplicabilidade das regras de hermenêutica formuladas para as leis em geral. Sustenta-se que as leis tributárias são leis de natureza particular, que devem ser entendidas e aplicadas segundo sistemas particulares" $" 1053$.

A obra de Vanoni teve grande repercussão na literatura tributária brasileira na época. Mas a tradução de estudos voltados à temática da interpretação já não era novidade no Brasil, pois, com antecedência, foi publicado em 1945 importante estudo de Louis Trotabas, versando sobre a "A Hermenêutica das Leis Fiscais", que criticava o uso quase absoluto da "interpretação literal" na realidade francesa (profundamente influenciada pela Escola da Exegese), utilizando-se das características próprias do Direito Tributário para justificar outros mecanismos hermenêuticos (como a interpretação extensiva) e até mesmo a defender o recurso da analogia (enquanto reconhecia, à diferença de François Geny, que a refutava) como poder criador dos tribunais fiscais ${ }^{1054}$.

\footnotetext{
${ }^{1053}$ VANONI, Ezio. Natureza e interpretação da legislação tributária. Op.cit., p. 13.

1054، CCreio desde logo poder legitimamente, concluir que o pretendido princípio da interpretação literal, das leis fiscais já não se funda no estado atual das fórmulas jurídicas e das condições políticas e sociais da legalidade moderna. E, para terminar, não poderei melhor apontar os defeitos da fórmula, estreita e árida, da interpretação literal das leis fiscais, do que lhe opondo, com o comentador avisado de uma decisão fiscal bem recente, os méritos da interpretação "que apanha o espírito da legislação inteira, acima das prescrições rígidas da lei escrita, palavra por palavra, de um texto", e que, só ela se revela, por si mesma, "à altura da dignidade das instituições". TROTABAS, Louis. A interpretação das Leis Fiscais. Paulo da Mata Machado (Trad.) In: Revista de Direito Administrativo. 1. Rio de Janeiro: FGV, 1945, p.49.
} 
Assim, o reconhecimento de um método (ou métodos) peculiar de interpretação ao direito tributário logo chegou em terras brasileiras. E naturalmente, os defensores da autonomia do Direito Tributário rapidamente passaram a defender também a necessidade de método próprio de interpretação, como se oberva em João Martins de Oliveira $^{1055}$, Rubens Gomes de Sousa ${ }^{1056}$, Carlos da Rocha Guimarães ${ }^{1057}$ e Amílcar de Araújo Falcão ${ }^{1058}$.

Note-se que, até meados da década de cinquenta, era extremamente comum aos adeptos da autonomia científica do Direito Tributário (especialmente para justificar a autonomia de conceitos entre Direito Tributário e Direito Privado) a recorrência a elementos econômicos.

Naturalmente, a remissão a esses elementos econômicos ocasionava indiscutível vinculação às contribuições teóricas dos cientistas das finanças. Nessa época, com exceção de João Martins de Oliveira, nem mesmo Rubens Gomes de Sousa preocupava-se em separar dos estudos jurídicos tributários os elementos de Economia. Pelo contrário, utilizavam-nos como principal justificativa para elevar o Direito Tributário perante outros ramos do direito já consagrados (como o Direito Privado, naturalmente).

Nesse contexto, Rubens Gomes de Sousa, em seu "Compêndio de Legislação Tributária”, entendia que o aplicador da lei “(...) pode e deve utilizar todos os métodos ou processos de raciocínio que conduzam à realização prática integral das finalidades que a lei se destina a alcançar. Nesse sentido se diz que a interpretação deve ser teleológica, isto é, deve visar a realização das finalidades ou objetivo da lei (...)", seguindo, nesse raciocínio, à eleição de alguns "princípios de interpretação" 1059 .

${ }^{1055}$ OLIVEIRA, João Martins. Op.cit., p. 08.

1056 Idem, p. 63.

1057 GUIMARÃES, Carlos da Rocha. Introdução ao Direito Fiscal. Op.cit., p. 08.

1058 FALCÃO, Amílcar de Araújo. Introdução ao Direito Tributário. Op.cit., p. 72-91.

1059 Para Gomes de Sousa, a interpretação deve alcançar a realização integral das finalidades da lei, e deve considerar a possibilidade da interpretação econômica (os atos fatos ou contratos devem ser previstos na lei tributária e devem ser interpretados de acordo com seus efeitos econômicos e não de acordo com a forma jurídica), a vedação da alteração dos efeitos tributários dos atos, negócios e contratos decorrentes da lei tributária pela vontade das partes, que atos ou negócios idênticos tenham idênticos efeitos tributários, ainda que as partes lhes tenham atribuído formas jurídicas diferentes (no intuito de combater o abuso de formas do Direito Privado), assim como o fato de que o ato nulo ou ilícito possa ser tributado, desde que tenha produzido efeitos econômicos. SOUSA, Rubens Gomes de. Compêndio de Legislação Tributária. Op.cit., p. $78-81$. 
$\mathrm{Na}$ época, Amílcar de Araújo Falcão foi considerado um dos grandes difusores (embora não tenha sido o primeiro a ressaltá-lo) da interpretação econômica: "A interpretação moderna da lei tributária, pois, admite todos os meios e processos consentidos pelos demais ramos do direito. A peculiaridade, no caso do direito tributário, está apenas em que certas considerações de ordem política e econômico-financeira devem ser feitas para alcançar - alcançar, não alterar ou corrigir - a determinação da lei, do mesmo modo como se lança mão de noções de medicina legal ou de ciência autuarial e contábil, muitas vezes, para penetrar o sentido, respectivamente, da lei penal ou da legislação sobre seguros (...)", ${ }^{1060}$ posição mantida pelo autor em outros trabalhos de relevo, na década de sessenta, sobre o tema ${ }^{1061}$.

Não por acaso, a literatura tributária brasileira inspirou-se nas lições estrangeiras para refletir sobre a consideração econômica, essa que, para Heinrich Beisse, significaria uma interpretação “(...) mais livre de conceitos jurídicos, principalmente daqueles que têm significado flexível, para abranger estruturações "iguais"1062.

A consideração econômica relaciona-se, segundo Beisse, ao princípio da uniformidade da tributação, salientando que a consideração econômica não deve ser confundida com a apreciação das ciências econômicas, embora reconheça que tais aspectos podem ser relevantes quando o fim específico de determinada lei tributária exija a sua utilização (embora não seja isso consideração econômica $)^{1063}$.

\footnotetext{
${ }^{1060}$ FALCÃO, Amílcar de Araújo. Introdução ao Direito Tributário. Op.cit., p. 73-84.

1061 "Existirá, em direito tributário, um método de interpretação que discrepe ou difira dos métodos e sistemas consagrados nos outros ramos do direito? Certamente não. O que há, em direito tributário, é uma ótica, uma visão ou um ponto de vista diferentes daqueles comumente adotados nos demais ramos do direito, e, em especial, no direito privado; daí a propriedade terminológica com que os juristas germânicos se referem às considerações econômicas (Wirtschaftliche Betrachtungsweise) que comportam a interpretação em direito tributário". Assim: "Em direito tributário, autoriza-se o intérprete, quando o contribuinte comete um abuso de forma jurídica ("Missbrauch Von Formen und Gestaltungsmöglichkeiten des Bürgerlichen Rechts"), a desenvolver considerações econômicas para a interpretação da lei tributária e o enquadramento do caso concreto em face do comando resultante não só da literalidade do texto legislativo, mas também do seu espírito, da mens ou ratio legis." FALCÃO, Amílcar de Araújo. O Fato Gerador da Obrigação Tributária. Op.cit., p.70-71.

${ }^{1062}$ Para Heinrich Beisse, a consideração econômica seria uma modalidade de método teleológico característica do Direito Tributário (material), onde no então §1, inc.2 da StAnpG o prevê como princípio de interpretação legal. Por outro lado, a consideração econômica também se liga como princípio de avaliação da situação de fato ( $\left(1^{\mathrm{a}}\right.$, inc. $3^{\mathrm{a}}$, StAnpG), decorrente do primeiro. BEISSE, Heinrich. O critério econômico na interpretação das leis tributárias segundo a mais recente jurisprudência alemã. In: Direito Tributário: Estudos em Homenagem à Ruy Barbosa Nogueira. Coord: Brandão Machado. São Paulo: Saraiva, 1984, p. 39-43.

${ }^{1063}$ Idem, p. 44-57.
} 
Da mesma forma Lis Loli Cabral Nogueira ${ }^{1064}$, para quem, “(...) a consideração econômica, por basear-se em princípios superiores de igualdade, uniformidade e capacidade contributiva, deve ser atribuída ao legislador, sob pena de contrariar os mesmos princípios, em nome de uma autonomia exagerada do direito tributário (...)", mas limitou a interpretação econômica à sua aplicação aos conceitos autônomos e mistos “(...) quando compatível com o princípio da estrita legalidade". ${ }^{1065}$

Caminho análogo foi apontado pelo tributarista alemão Klaus Tipke, a respeito da relação entre a Legislação do Imposto e o Direito Privado, reconhecendo que, muitas vezes, não há como fugir da legislação do Direito Privado, especialmente, quando determinado instituto não possui origem no Direito Tributário. Porém, para Tipke, que analisou as obras de Kurt Ball e Liebsch, clássicos do assunto, também é verdade que existem conceitos ou noções que não necessariamente se remetem em outros ramos do direito, ou, especialmente, no Direito Privado, isto é, são próprios do Direito Tributário. ${ }^{1066}$

Embora a temática da consideração econômica tenha sido progressivamente afastada dos estudos tributários direcionados ao dogmatismo normativo de perfil kelseniano, especialmente no século $\mathrm{XX}$, não se pode dizer que a literatura tributária brasileira afastou-se totalmente da reflexão à interpretação econômica, como indicam os estudos de Alcides Jorge Costa sobre a relação entre os conceitos de Direito Tributário e de Direito Privado na história do desenvolvimento teórico do Direito Tributário ${ }^{1067}$, além dos trabalhos anteriores de Rubens Gomes de Sousa ${ }^{1068}$, Ricardo Lobo Torres ${ }^{1069}$, Ruy Barbosa

\footnotetext{
${ }^{1064}$ Para a autora, a interpretação econômica nada mais seria do que um método de interpretação jurídico de caráter teleológico, finalístico. E reforça que tal método hermenêutico não é peculiaridade exclusiva do direito tributário, já que a “(...) perquirição da realidade fática subjacente à formulação jurídica correspondente existe nos demais ramos do direito". NOGUEIRA, Lis Loli Cabral. A consideração econômica no direito tributário. In: Estudos Tributários. Ruy Barbosa Nogueira (Edição e Colaboração). São Paulo: Resenha Tributaria, s/d, p. 381 e seguintes.

${ }^{1065}$ Idem, p. 382.

${ }^{1066}$ É o exemplo da renda para fins tributários, e, naturalmente, abriu-se espaço para que conceitos que detinham origem em outros ramos do direito, como o próprio Direito Privado, alcançassem efeitos ou consequências específicas quando inseridas ou tratadas pelo Direito Tributário. As obras consultadas por Klaus Tipke foram: BALL, Kurt. Steuerrecht und Privatrecht, Theorie dês selbständigen Steuerrechtssystems, 1924; Liebisch, Steuerrecht und Privatrecht, 1933; Tipke, Steuerrecht und büngerliches Rechts, JuS 1970, 149, m.w.N. In: TIPKE, Klaus. Steuerrecht. Ein systematischer Grundriß. 4. Völlig überarbeitete Auflage. Verlag Dr. Otto Schmidt KG. Köln, 1977, p. 08-09.

${ }^{1067}$ COSTA, Alcides Jorge. Direito Tributário e Direito Privado. Op.cit., p. 225-226.

${ }^{1068}$ SOUSA, Rubens Gomes de. Normas de Interpretação no Código Tributário Nacional. In: Interpretação no Direito Tributário. MORAES, Bernardo Ribeiro de (Org). São Paulo: EDUC/Saraiva, 1975, p. 99 e seguintes.

${ }^{1069}$ TÔRRES, Ricardo Lobo. Normas de Interpretação e Integração do Direito Tributário. Op.cit., p. 175 e seguintes.
} 
Nogueira ${ }^{1070}$, Antonio Roberto Sampaio Dória ${ }^{1071}$, Lis Loli Cabral Nogueira ${ }^{1072}$ e Heinrich Beisse $^{1073}$.

\subsection{Década de sessenta e os antecedentes teóricos (e políticos) da formação das estratégias de estudo e ensino do Direito Tributário no Brasil}

A década de sessenta já apresentava traços importantes de diferenciação, produzidos tanto por fenômenos legislativos como também oriundos de outros campos do conhecimento, como na Teoria Geral do Direito e Filosofia Jurídica.

Foi período de grandes transformações para o direito tributário, seja porque o chamado "direito constitucional tributário" se transmuta com substanciais diferenças frente ao regime anterior, sobrevindo três "emendas constitucionais" destinadas a reestruturar o sistema tributário brasileiro na época: a Emenda n.18/65, a Emenda n.1/67 e a Emenda n.1/69. Além disso, some-se fato de que a codificação finalmente se consolida em 1966, depois de doze longos anos de espera ${ }^{1074}$.

O positivismo kelseniano passa a influenciar o pensamento jurídico tributário, especialmente a partir da tradução portuguesa da obra de Kelsen, "Teoria Pura do Direito",

${ }^{1070}$ NOGUEIRA, Ruy Barbosa. Da Interpretação e Aplicação das Leis Tributárias. Op.cit., p. 88 e ss.

1071 A importância da consideração econômica no fenômeno da elisão fiscal e da evasão fiscal pode ser observada no grande clássico brasileiro da matéria: DÓRIA, Antonio Roberto Sampaio. Elisão e Evasão Fiscal. São Paulo: Edições Lael, s/d, p. 54 e seguintes.

${ }^{1072}$ Segundo os estudos de Liz Loli Cabral Nogueira, baseando-se em Heinrich Beisse e Marcel Wurlod, sobre a utilização de conceitos puramente de Direito Privado, conceitos mistos e autônomos e suas relações ao Direito Tributário, essa resposta seria condicionada à espécie de conceitos utilizados no Direito Tributário. Nos conceitos puros de Direito Privado, as formas de Direito privado seriam vinculantes para o Direito Tributário, e seria inadmissível, a princípio, a interpretação econômica. Já os conceitos mistos ocorreriam quando o conceito de Direito Privado seria "acomodado" ao direito tributário. Assim, o Direito Tributário referir-se-ia ao Direito Privado ao tratar daquele conceito, mas visa “(...) indiretamente apreender e disciplinar uma situação econômica". Já os conceitos autônomos ocorreriam quando o Direito Tributário, “(...) para atingir a subjacência econômica, não encontra uma configuração jurídica correspondente ou, se a encontra, ela não se presta aos objetivos tributários. Surgem então os conceitos cuja estrutura jurídica é privativa do Direito Tributário: os chamados conceitos autônomos de Direito Tributário". De qualquer forma, na visão da autora, a interpretação econômica encontraria maior espaço nos chamados "conceitos autônomos". NOGUEIRA, Lis Loli Cabral. Op.cit., p.349 e seguintes.

1073 BEISSE, Heinrich. Op.cit., p. 05 e seguintes.

${ }^{1074}$ Sobre o assunto ver capítulos 2. 
a desembarcar no Brasil na década de sessenta, causando enorme impacto na literatura jurídica pátria ${ }^{1075}{ }^{1076}$.

Ao mesmo tempo, estudiosos passam a considerar com maior atenção o chamado "direito constitucional tributário", fruto também da percepção da necessária hierarquia constitucional, conforme se pode observar na contribuição inicial de Geraldo Ataliba, e sua predileção pelo estudo do sistema constitucional tributário brasileiro ${ }^{1077}$.

No Rio de Janeiro, o desaparecimento precoce de Amílcar de Araújo Falcão (em 1967) ${ }^{1078}$, reconhecida linha de pesquisa individual na década de sessenta no Rio de Janeiro, compromete temporariamente a consolidação de novas linhas de pesquisa e ensino na região, especialmente porque o autor era um dos estudiosos mais atentos às novidades do Direito Tributário estrangeiro (notadamente alemão), e sua juventude ao assumir a cátedra de Direito Financeiro gerava inequivocamente a presunção de que então nova linha de pesquisa e ensino poderia surgir no Rio de Janeiro.

Dessa forma, no Rio de Janeiro, ainda que contasse com importantes doutrinadores do porte de Gilberto Ulhôa Canto, Tito Rezende, Flávio Bauer Novelli e Aliomar Baleeiro $^{1079}$, não se logrou nesse período a consolidação de uma linha de pesquisa e ensino que pudesse ser considerada uma "Escola" própria e definida, cada qual apresentando suas próprias peculiaridades e premissas investigativas.

Por outro lado, se o aspecto constitucional tributário da década de sessenta era marcado pela instabilidade política decorrente daquele período ditatorial, verificam-se estudos cada vez mais dedicados a defender o ideal de segurança jurídica que deveria orientar as relações tributárias.

Não é por acaso que, na década de sessenta, o dogmatismo kelseniano passe a ser estudado com afinco nos cursos jurídicos do Brasil, com especial atenção às obras "Teoria Pura do Direito" (que defendia a separação entre os estudos jurídicos e os estudos de

1075 KELSEN, Hans. CAMPAGNOLO. Umberto Direito Internacional e Estado Soberano. Organ.Mario G. Losano. São Paulo: Martin Fontes, 2002, p.01-77. A primeira edição em língua portuguesa da obra de Kelsen foi publicada no ano de 1960. KELSEN, Hans. Teoria Pura do Direito. São Paulo: Martins Fontes, 2000, p. 01 e seguintes.

${ }^{1076}$ SALDANHA, Nelson. Filosofia do Direito. Op.cit., p. 08 e ss.

1077 Também ver capítulo 2.

1078 Ver capítulo 1.

${ }^{1079}$ Ver capítulo 1. 
outros ramos do conhecimento), e "Teoria Geral do Estado" (que reforçou a ideia de pirâmide kelseniana, assim como os alicerces de sua teoria da federação nos estudos constitucionais), de Hans Kelsen ${ }^{1080}$.

É curioso notar que, a partir da década de sessenta, claramente influenciada por esse contexto político (marcado pela instabilidade constitucional), e por outro lado, pela predominância de estudos jurídico-tributários por sua vez alinhados a obras de Ciência das Finanças (e, portanto, mantendo a relevância de estudos econômicos nas considerações dos trabalhos jurídicos tributários) emerge clara tendência à aplicação de postulados kelsenianos ao Direito Tributário, ou pelo menos oriundos de representantes do formalismo jurídico (que em grande parte se identificavam com as ideias básicas de Kelsen).

Esta perspectiva jurídico-doutrinária pode ser vista com originalidade na obra capitular de Alfredo Augusto Becker, claramente influenciada pelo formalismo jurídico europeu (assim como pelo positivismo normativo de Pontes de Miranda), em $1963^{1081}$.

Na verdade, a tradução da elementar obra de Hans Kelsen, na década de sessenta, sob o ponto de vista da segurança jurídica, trazia contribuição extremamente oportuna para os estudos tributários daquele período, convergindo sobre o ponto de vista de Becker, inclusive na consideração da regra jurídica (influenciado por Pontes de Miranda) ${ }^{1082}$, harmonizada na elevação da norma jurídica de Kelsen.

Diante desse interessante panorama, nos anos finais da década de sessenta em diante, consolidam-se as chamadas "Escolas do Direito tributário", isto é, linhas de pesquisa e ensino coletivamente estudadas e ensinadas no Brasil, diretamente refletidas seja pela aceitação ou pela crítica - sobre o panorama acima lembrado. Nesse ambiente histórico também se emana a segunda posição teórica sobre o debate autonomista no Direito Tributário Brasileiro: a autonomia didática.

\subsection{A consolidação da segunda posição sobre a autonomia disciplinar do Direito} Tributário no Brasil: a autonomia didática

\footnotetext{
${ }^{1080}$ KELSEN, Hans. Teoria Geral do Direito e do Estado. Op.cit., p. 450-452.

1081 BECKER, Alfredo Augusto. Teoria Geral do Direito Tributário. $1^{\circ}$ edição. São Paulo: Saraiva, 1963, p. 01 e seguintes. ${ }^{1082}$ Idem.
} 


\subsubsection{Os primeiros passos para a autonomia didática: a oposição à interpretação econômica em Alfredo Augusto Becker}

A interpretação econômica do direito tributário, mesmo antes da conclusão do processo codificador, já encontrava oposição de Alfredo Augusto Becker, que, na época, foi categórico ao apontar os resultados supostamente negativos que a adoção à doutrina favorável da interpretação econômica apresentaria: “(...) a) Incorre no maior equívoco do Direito Tributário; b) Destrói a certeza e praticabilidade do Direito Tributário; c) Importa na inversão da própria fenomenologia Jurídica; d) Nega utilidade precisamente àquilo que é jurídico". 1083

Em anos posteriores, Alfredo Augusto Becker seguiu firmemente em sua posição, inclusive reproduzindo alguns capítulos de seu celebrado estudo semibiográfico, "Carnaval Tributário", onde se dedicou a atacar o que denominou de "maior equívoco na história do Direito Tributário". ${ }^{1084}$

Aquele mecanismo de interpretação teria, nas palavras de Becker, baseado em Vanoni e Bühler, profundas relações com o nazismo (na Alemanha) ${ }^{1085}$ e o fascismo (na Itália), sendo progressivamente adotado na medida em que os regimes ganhavam força naqueles países ${ }^{1086}$.

O próprio Alfredo Augusto Becker elaborou, a pedido de Rubens Gomes de Sousa (que aparentemente teria alterado a própria posição anterior sobre interpretação econômica), estudo dedicado a demonstrar as eventuais incoerências daquela doutrina hermenêutica de Enno Becker: "Em dezembro de 1965, eu recebi uma carta do Rubens Gomes de Sousa, falando em seu próprio nome e na qualidade de Presidente da Comissão de Assessoramento do Ministério da Fazenda e do Ministério do Planejamento, durante a tramitação do Projeto do Código Tributário Nacional no Congresso Nacional. Nessa carta,

\footnotetext{
${ }^{1083}$ BECKER, Alfredo Augusto. Teoria Geral do Direito Tributário. Op.cit., p.126 e seguintes.

1084 BECKER, Alfredo Augusto. Carnaval Tributário. 2a Edição. São Paulo: Lejus, 1999, p. 129 e seguintes.

${ }^{1085}$ Sobre o assunto, ver a crítica de Fernando Aurelio Zilveti, que condenou a acusação da doutrina à Becker - e a interpretação econômica - de vincular-se ao nazismo e ao totalitarismo. ZILVETI, Fernando Aurelio. Obrigação Tributária. Fato Gerador e Tipo. São Paulo: Quartier Latin, 2009, Op.cit., p. 88.

${ }^{1086}$ BECKER, Alfredo Augusto. Carnaval Tributário. Op.cit., p. 136-137; p.139 e seguintes.
} 
Rubens me pedia um parecer demonstrando que a "Teoria do Abuso das Formas Jurídicas e a Interpretação Econômica das Leis Fiscais" era um absurdo jurídico que deixava o contribuinte ao arbítrio subjetivo do Ministério da Fazenda e não ao julgamento objetivo dos tribunais." $1087 \_1088$

A reação (dogmático-jurídica) contemporânea, inspirada por Alfredo Augusto Becker, reconhece que, “(...) hoje, a principal preocupação dos juristas é a juridicização do Direito Tributário. Retirá-lo da zona da ciência econômica e fazê-lo voltar para o plano da ciência jurídica. Só assim poderão ser sanados os extensos malefícios da infeliz teoria de Enno Becker" $1089 \_1090$.

Assim, a grande resistência, na década de sessenta, aos estudos que reuniam elementos jurídicos e econômicos em uma mesma disciplina, foi oferecida graças a

1087،Era uma teoria introduzida no Código Tributário Alemão pelo Nazismo e que autorizou a morte financeira dos contribuintes alemães de forma igual à morte física dos judeus. O pedido de Rubens era justificado em sua carta pela decisão do Ministério da Fazenda de introduzir aquela teoria nazista do capítulo da interpretação das leis fiscais. Escrevi o parecer solicitado, que resultou em 30 páginas. Em janeiro de 1966, enviei ao Rubens o parecer, que produziu o efeito desejado, uma vez que o Código Tributário Nacional não converteu em lei aquela teoria nazista. Essa é a origem do meu ensaio "A Interpretação Econômica das Leis Tributárias e a Teoria do Abuso das Formas Jurídicas", que o Gilberto Ulhôa Canto dizia ser uma briga em família, porque eu "tacava o porrete" na cabeça do Enno Becker". Idem, p. 30 e seguintes.

${ }^{1088}$ Segundo Becker, na época também havia grande tendência da migração dos juristas para a economia, sobretudo motivados pelos seguintes fatores: “a) autonomia": "O adolescente anseio pela autonomia do Direito Tributário fez com que se procurasse, com urgência, um fundamento para tão sagrada qualidade"; b) "sistema dos fundamentos óbvios": "O direito tributário está em desgraça e a razão deve buscar-se não na superestrutura, mas precisamente naqueles seus fundamentos que costumam ser aceitos como demasiado "óbvios" para merecerem a análise crítica"; c) "rebelião do fato contra o jurídico": "Em todos os ramos do direito e principalmente no Direito Tributário, o fato está em rebelião contra o jurídico e o linguajar jurídico atual multicoloriu-se de expressões que denunciam a homenagem que os juristas, hoje, rendem ao fato: fato gerador, contribuinte de fato, domicílio de fato, tutela de fato, separação de fato, sociedade de fato, filiação de fato, etc". Segundo Becker, as três causas para a rebelião do fato contra o jurídico são: “a) o desejo por uma simplificação do direito positivo; b) o progresso das ciências pré-jurídicas e o envelhecimento das estruturas jurídicas; c) o realismo degenerado em mística"; d) "abuso do direito": "Aqueles que negam a liceidade da evasão fiscal (elusão ou evasão legal) e, na sua ocorrência, entendem que se deva fazer abstração da estrutura jurídica (o que significa recomendar o abandono da realidade jurídica, aceitando-se apenas a realidade econômica), nada mais fazem do que implantar dentro do Direito Tributário, empírica e quase sempre inconscientemente, a teoria do abuso do direito e todas as confusões e erros jurídicos que a ela costuma gerar"; e) "esquecimento de que o jurídico também é realidade": "Muitos estudiosos do Direito Tributário esqueceram (ou, pelas circunstâncias acima apontadas, não quiseram admitir) que o fato jurídico é uma realidade distinta do fato econômico subjacente e que aquela específica realidade jurídica é um excelente signo presuntivo de uma específica capacidade contributiva”. BECKER, Alfredo Augusto. Carnaval Tributário. Op.cit., p. 144-147.

${ }^{1089}$ Idem, p. 147-149.

${ }^{1090}$ E complementa: "Muitos autores têm se pronunciado contra a teoria hermenêutica ora analisada, porém ainda o fazem com maiores ou menores ressalvas, procurando conciliar o inconciliável, por saudosismo, por fidelidade aos clássicos e por injustificável modéstia que os inibe de declarar cruamente a sua "ripugnanza" à teoria hermenêutica que lhes ofende a sensibilidade e vocação jurídica”. Ibidem, p. 149-151. 
Alfredo Augusto Becker, especialmente com sua obra "Teoria Geral do Direito Tributário".

Mas o mais importante é que os estudos de Becker no Brasil redirecionam a literatura tributária que passa, majoritariamente, a buscar, ao invés da "autonomia" através de interpretação econômica, a elevação da dignidade científica do Direito Tributário através das premissas do dogmatismo jurídico normativo, configurando alicerce fundamental para a defesa da autonomia didática (mas não científica, conforme se desenvolveu na literatura europeia, sobretudo germânica, e no Brasil na década de cinquenta e sessenta) no Direito Tributário, o que, de certa forma, mostra uma certa visão peculiar (mas não exclusiva) da literatura tributária brasileira sob o debate autonomista.

\subsubsection{A difusão da autonomia didática a partir da década de sessenta no Brasil}

Com o amadurecimento da ciência jurídica durante o século $\mathrm{XX}$, e a expansão da importância do dogmatismo jurídico de viés kelseniano, especialmente, a partir da década de 60 em diante, na Europa e na América Latina, a percepção de um ordenamento jurídico formado por normas jurídicas dispostas em relação de hierarquia e coordenação passou a ser corolário para muitos estudiosos do direito.

Nesse contexto, a compreensão da autonomia do Direito Tributário (científica ou disciplinar) em sentidos semelhantes aos preconizados por Amílcar de Araújo Falcão, Ruy Barbosa Nogueira e Rubens Gomes de Sousa, em primeiro momento, foi sopesada pela interpretação jurídica consagrada pela então nova perspectiva de estudo dogmáticonormativa $^{1091}$.

Isso ocorreu porque a expressão "autonomia científica" repercutia a sólida construção disciplinar europeia (e sobretudo germânica), e aparecia, de certa forma, deslocada, no período histórico em que passou a prevalecer o dogmatismo normativo kelseniano, impulsionado pelo dogma da unidade do ordenamento jurídico, no Brasil. Em outras palavras, a prevalência dogmática normativa kelseniana impulsionou parcela progressiva da doutrina pátria (ainda que a perspectiva da autonomia científica não refutasse esse dogma) a compreender o debate autonomista sob particulares premissas

${ }^{1091}$ KELSEN, Hans. Teoria Pura do Direito. São Paulo: Martis Fontes, 1999, p. 01 e seguintes. 
teóricas, ainda que na prática, os resultados fossem semelhantes. Ou seja, sob a peculiar lente do dogmatismo normativo de matriz kelseniana, fazia mais sentido olhar o direito tributário enquanto didaticamente autônomo, sobretudo à luz da unidade do ordenamento, o que não significa, naturalmente, que a defesa da autonomia (científica ou dogmática) herdada do direito tributário germânico chegasse à conclusões distintas (sob diferentes premissas) sobre a unidade do ordenamento.

Nessa linha (autonomia meramente didática) seguiu Alfredo Augusto Becker, para quem, apoiado por Geraldo Ataliba, ${ }^{1092}$ a autonomia do Direito Tributário seria falsa, assim como falsa seria também a autonomia de qualquer ramo positivo ${ }^{1093}$.

A própria visão de Geraldo Ataliba, ao conceber o sistema constitucional tributário partindo do princípio unitário, denuncia essa tendência ${ }^{1094}$. Obviamente, a compreensão sistemática preconizada por Geraldo Ataliba (por influência kelseniana) organizando o sistema constitucional tributário composto por elementos integrantes que deveriam interagir harmonicamente "em função do todo"1095, inevitavelmente compreenderia todo o ordenamento jurídico através de um grande sistema (cuja ápice seria a Constituição), e que pode ser observado também em Roque Carrazza ${ }^{1096}$, Paulo de Barros Carvalho ${ }^{1097}$ e, naturalmente, através da concepção sistemática de Tércio Sampaio Ferraz Júnior ${ }^{1098}$ e Pontes de Miranda ${ }^{1099}$. O dogmatismo normativo kelseniano, essencialmente sistemático e unitarista, facilitou a compreensão de que a autonomia do Direito Tributário seria tão somente didática perante outros ramos do (mesmo) ordenamento jurídico.

Paulo de Barros Carvalho, por exemplo, fundamentando a unidade e indivisibilidade do ordenamento jurídico, seguiu a tendência maciça da doutrina jurídica contemporânea. Seus elementos, as unidades normativas, estariam irremediavelmente

${ }^{1092}$ CARVAlHO, Paulo de Barros. Curso de Direito Tributário. $17^{\circ}$ Edição. Op.cit., p.99 e seguintes. CARVAlHO, Paulo de Barros. Hermenêutica do Direito Tributário. Elementos de Direito Tributário. III Curso de Especialização em Direito Tributário realizado na PUC-SP. Coordenação: ATALIBA, Geraldo. São Paulo: Revista dos Tribunais, 1978, p. 233 e seguintes. ATALIBA, Geraldo. Hipótese de Incidência Tributária. 6. ed. São Paulo: Malheiros, 2009, p.24. BECKER, Alfredo Augusto. Teoria Geral do Direito Tributário. Op.cit., 126 e seguintes.

${ }^{1093}$ BECKER, Alfredo Augusto. Teoria Geral do Direito Tributário. Op.cit., p. 23 e seguintes.

1094 ATALIBA, Geraldo. Sistema Constitucional Tributário Brasileiro. Op.cit., p. 04-05. P.19-21.

1095 Idem, p.07.

${ }^{1096}$ CARRAZZA, Roque Antônio. Curso de Direito Constitucional Tributário. Op.cit., p. 33.

1097 CARVALHO, Paulo de Barros. Curso de Direito Tributário, $17^{\text {a }}$ Ed. Op.cit., p. 136-137.

1098 FERRAZ JÚNIOR, Tércio Sampaio. Introdução ao Estudo do Direito. Op.cit., p. 175-176.

${ }^{1099}$ MIRANDA, Francisco Cavalcanti Pontes de. Tratado de Direito Privado. Op.cit., p. 13. 
entrelaçados pelos vínculos de hierarquia e pelas relações de coordenação, mas admitindo o Direito Tributário como ramo didaticamente autônomo do Direito, recusando a autonomia científica $^{1100}$.

Pode-se observar que a autonomia didática prevaleceu na literatura tributária, recebendo posicionamentos favoráveis de Sacha Calmon Navarro Côelho ${ }^{1101}$, Hugo de Brito Machado ${ }^{1102}$, Paulo de Barros Carvalho ${ }^{1103}$, e a parcela majoritária da literatura contemporânea.

Em todo caso, permanece ainda atual a lição de Alfredo Augusto Becker, para quem a "autonomia" (no sentido de independência relativa) "(...) de qualquer ramo do direito positivo é sempre e unicamente didática para, investigando-se os efeitos resultantes da incidência de determinado número de regras jurídicas, descobrir a concatenação lógica do sistema jurídico" ${ }^{\prime 104}$.

De certa forma, a defesa pela autonomia didática ou científica, no fundo, não se afasta de conclusões semelhantes manifestadas por Zilveti, harmônico com a posição de Ruy Barbosa Nogueira: "a autonomia científica de qualquer ramo do Direito é relativa, diante da unidade do sistema jurídico em seu conjunto" $" 1105$.

Assim, o processo disciplinar se consolida, e o Direito Tributário, ainda que diagliando-se sobre a ideia de autonomia didática ou sobre a autonomia científica perante outros ramos jurídicos, passa a construir institutos caros ao seu próprio campo do conhecimento jurídico. Torna-se ramo (teoricamente) autônomo do Direito (que compreende a própria noção de autonomia didática e científica).

A verdade é que o debate autonomista mostra-se hodiernamente um pouco datado, pois se a defesa da autonomia didática é que o direito tributário é parte do ordenamento jurídico, assim como o direito penal, o direito administrativo e o direito civil, também é verdade que o direito tributário também constrói institutos próprios e princípios próprios

\footnotetext{
${ }^{1100}$ CARVAlHO, Paulo de Barros. Curso de Direito Tributário. 17 Ed. Op.cit., p. 45 e seguintes.

${ }^{1101}$ COÊLHO, Sacha Calmon Navarro. Curso de Direito Tributário Brasileiro. Op.cit., p. 33.

${ }^{1102}$ MACHADO, Hugo de Brito. Curso de Direito Tributário. 34 Ed. São Paulo: Malheiros, 2013, p. 53-54.

${ }^{1103}$ CARVALHO, Paulo de Barros. Curso de Direito Tributário. 17 Ed. Op.cit., p. 45-48.

${ }^{1104}$ BECKER, Alfredo Augusto. Teoria Geral do Direito Tributário. Op.cit., p. 27-32.

1105 Sobre o assunto, também consultar: ZILVETI, Fernando Aurelio. Obrigação Tributária. Fato Gerador e Tipo. Op.cit., p.24-38.
} 
que não são aplicáveis a outros ramos do conhecimento. Há, portanto, autonomia científica (observando-se a construção de institutos, princípios e conceitos próprios não necessariamente aplicáveis a outros ramos do conhecimento jurídico) e autonomia didática (na observância ao princípio da unidade do ordenamento jurídico). São duas faces da mesma moeda, construídas por análises que consideravam aspectos (parcelas) do fenômeno jurídico tributário. Hodiernamente, faz mais sentido falar, portanto, em autonomia teórica (que compreenderia a noção de autonomia didática e científica).

De qualquer forma, voltando ao cerne histórico da questão, aspecto elementar identificável no debate autonomista, e que favoreceria a construção posterior das Escolas de Direito Tributário, reside no tratamento teórico dado pelos estudiosos frente ao relacionamento deste com outros ramos do conhecimento (notadamente, sobre os aspectos econômicos da tributação).

Se para os estudiosos que elevaram a autonomia científica, essa relação não apareceria absolutamente refratária, para os estudiosos da autonomia didática (pelo próprio dogmatismo normativo) a refração do Direito Tributário (como disciplina jurídica) perante outros ramos do conhecimento "extrajurídicos" apareceria com maior intensidade.

As duas posições (autonomia didática ou científica) servirão de substrato teórico (aliada à recepção favorável ou não à interpretação econômica) para a consolidação das duas primeiras Escolas de Direito Tributário no Brasil, cada qual apresentando fundamentação distinta sobre os dois temas acima mencionados.

\section{A estruturação histórica das estratégias de estudo e ensino do Direito} Tributário: o exemplo estrangeiro e as dificuldades de enquadramento da experiência brasileira.

A consolidação das autonomias teórica, legislativa e de ensino do direito tributário é pressuposto para a consolidação do processo de especialização disciplinar do Direito Tributário perante outros ramos do conhecimento. Evidentemente, a autonomia legislativa, diferentemente da autonomia teórica e da autonomia de ensino, não se vincula diretamente 
ao processo disciplinar, embora seja causa e efeito deste último. O avanço histórico disciplinar do direito tributário brasileiro é, seguramente, a história da ciência do direito tributário. Mas também é, igualmente, a história do ensino do direito tributário. Ambos se complementam na consolidação histórica da disciplina.

É nesse contexto, onde emana a autonomia legislativa (direito tributário codificado e constitucionalizado, favorecendo sua sistematização), a autonomia teórica (manifestada pelo reconhecimento da autonomia do direito tributário perante outros ramos do direito e, logo após, pela discussão entre autonomia científica ou didática), e a autonomia do ensino (com a institucionalização formal das cátedras de Direito Tributário, separadas de outros ramos do conhecimento), que se formam as estratégias dedicadas à difusão do estudo e ao ensino do Direito Tributário Brasileiro.

Esse processo, ainda que proeminente, guarda ponderações, expressamente identificáveis no processo de construção disciplinar do Direito Tributário Brasileiro, mas que não necessariamente se identificam plenamente com a experiência estrangeira.

Nesse processo também não se pode ignorar a influência de fatores extrajurídicos na consolidação da disciplina no Brasil, pois o anseio político, nessa construção, caminha lado a lado do anseio acadêmico, e, por vezes, chega a superar o segundo em importância. A formação histórica do direito tributário, e a ciência jurídica que busca estudá-la, não surgem de maneira desinteressada, mas consequências de provocações que não raramente fogem da alçada jurídica, desaguando, por vezes, na revelação de interesses políticos, que nem sempre guardam harmonia com o interesse da coletividade. A ideologia por detrás da positivação do direito tributário é causa a ser sempre investigada em estudos históricos ${ }^{1106}$ 1107.

Mas as dificuldades ao empreendimento de identificar as chamadas "Escolas" são, naturalmente, sobressalientes. Mesmo os pouquíssimos estudos levados ao empreendimento de discorrer ou investigar o processo histórico da disciplina denominada

\footnotetext{
${ }^{1106}$ A ciência do Direito Tributário que busca estudá-la, se quiser aproximar-se da verdade por trás da positivação do direito tributário, não pode prescindir dessa compreensão, deixando de lado, por exemplo, o contexto histórico, filosófico, político, social, econômico, cultural que irradiam nas normas tributárias. Como bem destaca Andrea Amatucci, “(...) a elaboração didática que se desenvolveu nas universidades no decorrer do século XIX, inspirando-se conjuntamente na ciência, na cultura e política, favoreceu, no início do século XX, a manifestação de evidentes sintomas de interesse pela busca de uma metodologia de ensino do Direito Financeiro, plena de modificações político-econômicas”. AMATUCCI, Andrea. Historia de La Enseñanza del Derecho FinancieroPúblico en Italia. In: Historia del Derecho de La Hacienda Pública y del Derecho Tributario en Italia. El aporte del pensamiento jurídico financiero de La Italia Meridional. AMATUCCI, Andrea; D’AMATI, Nicola. Bogotá - Colômbia: Temis, 2004, p. 100 e ss.

${ }^{1107}$ AMATUCCI, Andrea. L'Insegnamento del Diritto Finanziario. In: L'Evoluzione dell'Ordinamento Tributario Italiano. UCKMAR, Victor (Coord.) CEDAM: Milani, 2000, p. 97 e ss.
} 
Direito Tributário são reticentes na amplitude e no sucesso da tarefa ${ }^{1108}$. Isso porque não existe método ou fórmula segura para a determinação das variadas correntes científicas e pedagógicas que compõem essa disciplina. Os riscos de cair no subjetivismo opinativo são alarmantes. Mas nem por isso não devem ser enfrentados.

Se elas contribuem para esse empreendimento, a elaboração de alguns (poucos) critérios identificados em pesquisas estrangeiras, sobretudo italianas, para, pelo menos, aumentar as chances do reconhecimento desses centros, seja a existência de linha de estudo ou pesquisa própria, a identificação de um mestre fundador, ou a respectiva contribuição ao estudo do Direito, como se observa no panorama fornecido por Gaspare Falsitta ${ }^{1109}$.

Além disso, alguns autores, como Eusebio González, vinculam-nas a peculiaridades próprias de cada ordenamento jurídico. Em outras palavras, para cada específico ordenamento jurídico (objeto de estudo do estudioso de direito), haveria critérios próprios para identificação desses centros de estudo e ensino que lhes circundam.

Por outro lado, da leitura de Gonzalez pode-se deduzir que o método ou a escolha de uma fórmula jurídica para a investigação do direito tributário pode ser determinante para a identificação de centros de estudo e ensino do Direito Tributário ${ }^{1110}$. A tradição europeia, nesse contexto, apresenta, historicamente, importantes exemplos de Escolas voltadas ao estudo e ensino do Direito Tributário.

Na Alemanha, o processo histórico de consolidação desses centros, conforme registra Amatucci, apresenta-se diferenciado perante a experiência italiana e espanhola, já que se identificam maiores dificuldades para a individualização dessas na experiência alemã, sobretudo porque os estudiosos alemães tradicionalmente se dividem pelas suas

${ }^{1108}$ FALSITTA, Gaspare. Osservazioni sulla Nascita e lo sviluppo scientifico del Diritto Tributario in Italia. In: L'Evoluzione dell'Ordinamento Tributario Italiano. UCKMAR, Victor (Coord.) CEDAM: Milani, 2000 , p. 77 e ss.

1109 Idem, p. 78.

${ }^{1110}$ Conforme contextualiza Eusebio Gonzalez, o “(...) método de investigação, método de interpretação e método de ensino do Direito, no pensamento de quem o escreve, são outros tantos meios ou menos de aproximar-se ao conhecimento, aplicação e explicação do Direito, que pela própria natureza das coisas devem responder a uma mesma e única concepção de Direito, em nosso caso, o Direito Tributário. Daqui que se falar em ensino do Direito tributário, não pode prescindir-se, em nossa opinião, da localização da nossa disciplina no marco do ordenamento jurídico geral, nem seja possível marginar os problemas atinentes à aplicação do Direito (interpretação das normas e qualificação dos fatos), porque todas essas operações são a consequência lógica de uma finalidade, a adequação do ordenamento tributário aos princípios da legalidade e da justiça, e devem apresentar-se de forma ordenada e coerente, que é o que denominamos "sistema tributário". Na realidade, todo o problema do método nesta disciplina se baseia naquela aptidão metodológica que proclama a necessidade de fórmulas jurídicas quando se trata de penetrar no conhecimento do fenômeno jurídico. Seria suficiente considerar, pelo menos fora brevemente, o desenvolvimento histórico do pensamento jurídico-tributário através, por exemplo, das obras destinadas a este propósito por Vanoni, Berliri e D'Amati, para chegar por caminhos distintos à mesma conclusão”. GONZALEZ, Eusebio. La Enseñanza del Derecho Tributario. In: L'Evoluzione dell'Ordinamento Tributario Italiano. UCKMAR, Victor (Coord.) CEDAM: Milani, 2000, p. 153e ss. 
respectivas bases científicas, seja no direito civil seja no direito público. Para Amatucci, os estudiosos de Direito Tributário na Alemanha cultivam ao mesmo tempo outro ramo de investigação, seja o direito privado ou o direito público. Assim, considerando tais características, embora seja possível distinguir, ainda que não claramente, elementos comuns que “(...) fazem entender a presença de escolas entendidas como áreas comuns de investigação no sentido já definido" ${ }^{1111}$. Esses elementos comuns de investigação, ou áreas de interesse, seriam os indícios para a identificação das chamadas "Escolas alemãs", na leitura de Amatucci. ${ }^{1112}{ }^{1113}$.

De fato, o surgimento de "Escolas" dedicadas ao estudo e ao ensino do Direito Tributário, com fórmulas, métodos ou estratégias expressamente assumidas com

${ }^{1111}$ AMATUCCI, Andrea. Historia de La Enseñanza del Derecho Financiero Público en Italia. Op.cit., p. 100 e ss.

${ }^{1112}$ Considerando o período posterior à Segunda Guerra, destaca-se a Escola de Klaus Tipke, da Universidade de Colônia, cujo conjunto da obra, e as premissas sistemático-estruturais ao estudo do Direito Tributário Alemão apresentam influência sobre todos os tributaristas alemães contemporâneos, tendo como sucessor Joachim Lang. Tipke também escreveu comentários sobre o Código Tributário Alemão, junto de Heinrich Wilhelm Kruse, professor da Universidade de Bochum. Conforme reconhece Amatucci, todos os professores alemães são partidários, ainda que não expressamente, das lições de Tipke, ainda que mantenham suas próprias posições em determinados temas. Para Amatucci, “(...) a Universidade de Colônia, privilegiando a construção sistemática, presta-se mais do que as outras a expressar uma escola da que foram parte predecessores como Ottmar Bühler e Armin Spitaler, que não alcançaram o brilho de um mestre como é Klaus Tipke". Outra Escola, lembrada por Amatucci, é a Escola de Münster, que estaria voltada, entre seus temas de interesse, às relações entre Direito Tributário, Direito Constitucional e Direito Administrativo, onde lecionaram Ottmar Bühler, Klaus Vogel, Paul Kirchof e Dieter Birk. As relações com o direito privado são analisadas na Escola de Bonn, a qual integram Werner Flume, Wolfang Schon e Brigitte Knobbe-keuk. Idem. ${ }^{1113}$ Poder-se-ia supor também que a continuidade temporal da Escola através de líderes sucessivos seria sinal inequívoco da existência de uma "Escola", ou seja, quando o discípulo assume a cadeira que um dia foi de seu mestre, esse seria um sinal inequívoco da consolidação de uma "Escola". Na experiência alemã, especialmente através da Escola de Colônia, essa experiência se fez de modo muito claro, já que o emérito tributarista alemão Klaus Tipke foi sucedido na Cátedra por seu discípulo, Joachim Lang, que, inclusive é o grande responsável pela atualização de seu celebrado curso de direito tributário. Mas a fidelidade acadêmica quanto aos métodos ou pressupostos de investigação e ensino passados do mestre ao aluno são pressupostos, nesse contexto de continuidade temporal, para o reconhecimento de uma Escola?

Acredita-se que esses critérios são importantes, e favorecem a continuidade temporal da Escola. Porém, não pode ser considerado elemento absoluto a sucessão na Escola entre discípulo e mestre para o reconhecimento de uma Escola, nem a plena identidade de ideias entre mestre e discípulo, uma vez que tal fator seria extremamente negativo para a evolução histórica do pensamento jurídico-tributário, sem mencionar o atentado à autonomia necessária ao exercício da cátedra. Na experiência italiana, Benvenuto Griziotti, líder da Escola de Pávia, apresentava método integracionista ou unitário para o estudo do fenômeno financeiro. Um particular ponto de vista sobre o Direito Financeiro, portanto. Dentre seus discípulos, como Puglièse ou Jarach, nenhum dos dois assumiu e aplicou expressamente o método unitário, ainda que reconhecessem, com Griziotti, a complexidade do fenômeno financeiro. Caminharam, inclusive, com maior aproximação às ideias autonomistas de Ranelleti, adepto do formalismo jurídico, e que levou discípulos que partilhavam de ideias comuns dando continuidade em suas premissas, como Giannini e Tesoro. Mas ambas, a Escola de Pávia e a Escola de Nápoles, foram consideradas genuínas Escolas (pelos critérios italianos), pelo grau de influência e pelas contribuições ao estudo e ao ensino do Direito Financeiro (e Tributário) italiano. Nota de rodapé n. 60. AMATUCCI, Andrea. Historia de La Enseñanza del Derecho Financiero Público en Italia. Op.cit., p. $135-136$. 
estabilidade para investigar o ordenamento jurídico tributário, simbolizam fase de amadurecimento no processo disciplinar do Direito Tributário, nacional ou estrangeiro.

Mas algumas ressalvas devem ser apresentadas no contexto brasileiro. Em primeiro lugar, é tradicional identificar uma "Escola", do ponto de vista científico ou filosófico ("Escola de Pensamento" ou "Corrente de Pensamento"), como uma grande corrente teórica com particular visão estrutural (teoria estrutural própria, pautada em premissas epistemológicas, metodológicas e finalísticas particulares) sobre determinado objeto de estudo, geralmente alinhado às construções de um ou mais mestres, cujo conjunto da obra fornece as estruturas teóricas basilares para sua construção histórica.

Mas, na experiência histórica da formação disciplinar do Direito Tributário, essa visão, corrente na filosofia e na evolução das ciências, nem sempre apresenta plena identificação. Por isso, talvez seja mais adequado, do ponto de vista didático-pedagógico, propor uma pequena diferenciação terminológica, contextualizando as "Escolas" do Direito Tributário nos respectivos contextos históricos em que se consolidam.

Nesse sentido, identificam-se três contextos históricos específicos das estratégias de difusão do ensino no Direito Tributário Brasileiro.

Primeiramente, identifica-se o período introdutório do ensino autônomo do Direito Tributário Brasileiro (década de cinquenta a setenta), quando as instituições de ensino, na realidade, são instituições dedicadas à divulgação do estudo e do ensino do Direito Tributário, sem método expressamente e previamente adotado (formalismo), mas aplicados caso a caso, sem pressupostos filosóficos ou epistemológicos expressamente assumidos com estabilidade. A disseminação do ensino institucionalizado ainda encontrase em seus primeiros passos na realidade jurídica brasileira. Há também maior influência da experiência estrangeira (em face da escassez teórica nacional sobre o tema). Conforme observado no capítulo 1, a origem (esforço inicial) da autonomia do ensino do Direito Tributário pode ser verificada tanto em São Paulo (com Tullio Ascarelli, Rubens Gomes de Sousa e, posteriormente, Ruy Barbosa Nogueira), como no Rio de Janeiro, com Amílcar de Araújo Falcão (impulsionado por Aliomar Baleeiro). Contudo, por motivos que já foram expostos, o núcleo desse contexto histórico tende historicamente a centrar-se em São Paulo.

Os estudiosos brasileiros, como autodidatas, buscam aplicar a experiência estrangeira, adaptando-a à realidade brasileira. O objetivo, portanto, é disseminar o estudo e ensino institucionalizado do Direito Tributário no Brasil. Nesse quadro encontra-se a 
Faculdade de Direito da USP, sob a tutela inicial de Ruy Barbosa Nogueira, a partir da década de sessenta.

Trata-se de um período substancial, com maior atenção ao conteúdo e estruturação pedagógico-disciplinar do direito tributário, iniciada com as primeiras aulas sobre a matéria e consolidada com a criação oficial da disciplina na grade curricular dos cursos de Direito.

A grande preocupação da "Escola da USP", nesse contexto histórico, é a construção de Programa de Ensino adequado à disseminação da disciplina entre as Faculdades de Direito, selecionando as matérias que seriam estudadas e ensinadas no âmbito do Direito Tributário, e menor preocupação às correntes da Teoria Geral do Direito (sobretudo formalistas) que poderiam influenciar essa construção. A influência estrangeira (sobretudo alemã), nessa missão, é fundamental. Também nesse contexto a Escola da USP aparece preocupada com as relações entre o direito e a realidade, e ainda em período onde não há absoluto afastamento entre Direito e Economia (ciência das finanças).

Praticamente no mesmo período pode-se identificar também o surgimento de uma segunda estratégia de estudo e ensino do Direito Tributário no Brasil, capitaneada pela Faculdade Paulista de Direito da Pontifícia Universidade Católica de São Paulo, quando se identifica o período de difusão inicial formalismo jurídico no ensino autônomo do Direito Tributário (década de setenta em diante). Esse período é iniciado quando determinadas instituições de ensino, já institucionalizadas, e influenciadas pela teoria geral do direito e o dogmatismo normativo de matriz kelseniana, começam a defender a busca por método jurídico por excelência, livres da influência da "ciência das finanças".

Nesse período determinadas referências filosóficas e epistemológicas tornam-se expressas e constantes, como pressupostos formais à ciência do direito, e a busca por um método jurídico próprio aparece com maior intensidade.

O positivismo dogmático-kelseniano aparece com força nesse contexto, pela facilidade de acesso à doutrina, e pelo contexto histórico-político altamente favorável à influência de doutrinas pautadas no formalismo epistemológico.

Inicia-se o período do formalismo jurídico no ensino e pesquisa do direito tributário no Brasil.

É baluarte desse contexto, a Faculdade de Direito da PUC-SP, sobretudo sob a regência de Geraldo Ataliba. Já, nessa fase, o ensino do Direito Tributário foi disseminado, mas buscam-se alternativas metodológicas e epistemológicas (formalistas) ao ensino 
disseminado no período imediatamente anterior (substanciais). Na realidade o período de consolidação da primeira etapa praticamente coincide temporalmente com os esforços iniciais da segunda (início da década de setenta).

Ademais, entre a década de setenta e oitenta também aparecem importantes posicionamentos distintos às tendências formalistas, sem necessariamente vincular-se à Faculdade de Direito da USP, conforme se observa nos esforços de Ives Gandra da Silva Martins, na Faculdade de Direito da Universidade Presbiteriana Mackenzie, que, embora mantendo traços formalistas, caminha para o substancialismo influenciado por tendências jusnaturalistas aplicadas ao Direito Tributário, e igualmente mantendo atenção às relações entre Direito Tributário e os aspectos econômicos, sociais e éticos da tributação.

Os debates travados entre as citadas Faculdades de Direito acima mencionadas constroem o ambiente histórico imediatamente ulterior favorável ao período de formação das Escolas Metodológicas do Direito Tributário (com início na década de oitenta e consolidação efetiva na década de noventa) no Brasil.

Nesse período, o ensino e o estudo do direito tributário começam a passar pelo reforço na busca do cientificismo acadêmico, especialmente nos quadrantes da PUC-SP. A busca por método jurídico científico e o reforço das premissas filosóficas jurídicas são centrais para a consolidação desse contexto.

Contudo, não significa o apego ao purismo epistemológico pleno, já que a consideração da Filosofia do Direito aplicada ao Direito Tributário, e a elevação de princípios da tributação própria do constitucionalismo tributário elevado naquele período denuncia também inevitável camada ética ao raciocínio jurídico-tributário daqueles estudiosos.

Essa ponderação gradual, por exemplo, pode ser observada em Geraldo Ataliba, especialmente na ponderação dos princípios da república e da federação, assim como na construção principiológica aplicada ao direito constitucional tributário, em Roque Antonio Carrazza e Paulo de Barros Carvalho. O grande impecilho, na realidade, centrava-se no afastamento ou no diálogo (ponderado) entre Direito Tributário e Ciência das Finanças.

Nesse ambiente histórico, tem-se início os primeiros esforços acadêmicos que seriam responsáveis pela posterior consolidação da "Escola de Paulo de Barros Carvalho" (Construtivismo Lógico-Semântico aplicado ao Direito Tributário) e, alternativamente, na "Escola de Ricardo Lobo Torres" (pós-positivismo neoconstitucional aplicado ao Direito Tributário), no Rio de Janeiro. Também se idenificam propostas complementares às 
tendências já consolidadas de estudos dogmáticos, a exemplo da Hermenêutica Histórica, de José Souto Maior Borges.

De qualquer forma, as linhas de pesquisa assumidas pelos dois primeiros estudiosos, naquele período histórico, são diametralmente distintas, pois aliadas a métodos jurídicos rígidos ou adaptáveis a cada caso concreto, assumindo expressamente referenciais filosóficos específicos (seja por influência da virada linguística ou da virada kantiana), que se consolidam pelo conjunto de obra dos respectivos autores, referenciais teóricos elementares de estudo e de ensino entre seus discípulos e demais adeptos, ainda que com ponderações, de suas premissas.

São reflexos diretos dos debates travados nos períodos anteriores (seja pela aceitação, complementação e aperfeiçoamento de um ponto de vista defendido nesse ambiente histórico, seja pela refutação do mesmo, e a apresentação de determinada proposta alternativa aos debates). Esse período consolida-se efetivamente a partir da década de noventa em diante, mantendo-se contemporaneamente. Ao considerar o processo histórico da autonomia do ensino do Direito Tributário, torna-se razoável considerar que a classificação de estratégias de ensino e estudo no Direito Tributário (eventualmente identificadas como "Escolas") deva ser realizada tomando como base a própria realidade histórica brasileira, sem necessariamente deixar-se influenciar por modelos construídos no ambiente estrangeiro. É claro que, como visto, a experiência estrangeira fornece importantes instrumentos auxiliadores nesse processo.

Mas, a contextualização histórica demonstra a conveniência da adaptação de métodos próprios aplicáveis ao processo disciplinar do Direito Tributário Brasileiro, que não se identifica plenamente com qualquer outro processo disciplinar observável em outros países.

Por esse motivo, considerando especificamente a realidade brasileira (o que não exclui os critérios adotados para identificação de Escolas no Direito Tributário Comparado), denominar-se-á Escola, o centro onde se concentra o estudo e ensino do Direito Tributário, ou seja, aquele grupo formado por dois ou mais estudiosos, pautados em premissas epistemológicas ou metodológicas harmônicas (se expressamente assumidas), contendo um ou mais líderes (fundador ou sucessor), e vinculados à determinada instituição (ou instituições) de ensino e pesquisa, geralmente uma universidade. Na identificação das Escolas de Direito Tributário o caráter pedagógicodidático apresenta grande importância, independentemente das premissas teóricas (se 
facilmente identificáveis), e sempre voltadas às estratégias de disseminação do conteúdo ali apreendido.

É claro que a existência de pontos de vista estruturais sobre o direito tributário fortalece o embasamento científico das chamadas "Escolas". Mas deve-se ponderar historicamente (e contextualmente) a viabilidade dessa construção. Em primeiro momento, a difusão inicial de método de estudo e ensino do Direito Tributário é a prioridade (seja sob aspectos substanciais ou formais).

É nesse sentido que se sobressaem as "Escolas" da USP e da PUC-SP, e assim, com suas próprias contribuições, pode-se entendê-las como Escolas, historicamente contextualizadas, com aperfeiçoamento de técnicas de estudo e ensino sob particulares premissas epistemológicas. A contribuição ao Direito Tributário, nesse sentido, das citadas Escolas, é indubitável, e fornece as bases para o aperfeiçoamento posterior do estudo e do ensino do Direito Tributário no Brasil, assim como as propostas alternativas a elas envoltas, como os estudos promovidos por Ives Gandra da Silva Martins na Faculdade de Direito da Mackenzie.

Com o percurso histórico do Direito Tributário Brasileiro, fortalecem-se os alicerces teóricos (sobretudo metodológicos) e pedagógicos, favorecendo a construção de teorias estruturais que impulsionariam determinadas Escolas.

As Faculdades de Direito supracitadas possuem importância particular ao direito tributário brasileiro, sendo as grandes responsáveis pela disseminação do ensino e estudo na realidade tributária brasileira, especialmente em seus primeiros anos de formação. São, naturalmente, as bases históricas sobre as quais se finca e se desenvolve o estudo e ensino coletivo do Direito Tributário Brasileiro. Embora a experiência estrangeira, como registra Amatucci, sobretudo italiana, em determinado momento histórico tendencialmente as apresente como "Escolas" (já que apresenta uma classificação mais flexível) ${ }^{1114}$ vinculadas

1114 Nesse ambiente teórico, várias escolas surgem no ensino e pesquisa italianos: Escola Napolitana: atualmente formada por Andrea Amatucci, Gaetano Liccardo, Rafaelle Perrone Capano, Manlio Ingrosso, Enrico Potitto, Franco Fichera e Nicola D’Amati; Escola siciliana: Andrea Parlato, Salvatore Sammartino, Luigi Ferlazzo Natoli e Salvatore Múscarà; Escola de Bolonha: criada por Antonio Berliri, hoje é representada por Adriano di Pietro e Furio Bosello; Escola de Génova: criada por Victor Uckmar, e pelos professores Corrado Magnani, Gianni Maronglu e Piera Filippe; A Escola de Florença, formada por Pasquale Russo e Marco Miccinesi; A Escola de Veneza, formada por Francesco Moschetti e Loris Tosi. Em Turin encontram-se Claudio Sacchetto, Rafaelo Braccini, em Cerdenha, o Professor Mario Giovani Polano. Em Pisa, leciona Franco Batistoni Ferrara, segundo Amatucci, “(...) expressão de autonomia plena ante às demais escolas". Note-se que, no relato de Amatucci, a vinculação institucional a uma cadeira universitária é elemento essencial para o reconhecimento de uma Escola. Há aí maior flexibilidade na identificação das Escolas, que aparentemente apresentariam características próprias mais ligadas à temas de interesse para estudo e ensino, do que propostas epistemológicas absolutamente refratárias ou alternativas entre si. Sobre as 
institucionalmente à determinada instituição de ensino superior, e apresentando diferentes mestres, opta-se por adotá-la, ainda que com adaptações, na realidade brasileira, pelos fundamentos acima apresentados.

Assim, naquele contexto histórico, diferentemente de uma Escola Filosófica ou Científica do Direito, a Escola do Direito Tributário, ou Centro de Ensino e Estudo dedicado ao Direito Tributário Brasileiro, para os propósitos didáticos e investigativos desse estudo, não significa necessariamente corrente teórica, filosófica ou científica que apresente uma teoria estrutural sobre a forma de enxergar determinado objeto de conhecimento (o fenômeno jurídico tributário) ${ }^{1115}$. Também não se prioriza a ideia de Centro de Ensino e Estudo centralizado necessariamente na averiguação do conjunto da obra de seus líderes teóricos, pois, naturalmente, essa visão se aproximaria da ideia de Escola Científica ou Filosófica. Nada obsta que um Centro de Estudo e Ensino do Direito Tributário aproxime-se gradualmente dessas premissas, apresentando uma visão estrutural própria do estudo do Direito Tributário. Nesse sentido, se aproximaria da noção de Escola Científica ou Filosófica do Direito Tributário. Mas essa visão estrutural teórica particular depende de uma série de fatores, que se vinculam ao ambiente histórico-cultural favorável a esse tipo de construção, o que somente se daria nas últimas duas décadas do século XX.

Somente a partir de determinado momento na realidade brasileira é que se cria o ambiente teórico apropriado a essa construção. Assim, a realidade brasileira, detentora de suas próprias particularidades, deve ser analisada e ponderada, se quiser realmente compreender o momento histórico em que uma Escola Científica ou Filosófica do Direito Tributário (que se identifica muito mais como uma teoria estrutural ou corrente teórica) pode efetivamente ser consolidada.

\section{As estratégias de estudo e ensino do Direito Tributário em São Paulo no ambiente pré-democrático.}

Escolas Europeias, recomenda-se a leitura da nota de rodapé n. 60. AMATUCCI, Andrea. Historia de La Enseñanza del Derecho Financiero Público en Italia. Op.cit., p. 135-136.

${ }^{1115} \mathrm{O}$ centro de estudos e ensino geralmente vincula-se a um professor responsável pela condução e orientação dos trabalhos que se realizam em torno dessa Escola. Mas não poderia ser vinculada a mais de um professor? É condição sine qua non a existência de apenas um líder para a consolidação de determinada Escola? A experiência estrangeira aponta em dois caminhos: na Alemanha, parece clara a identificação inicial de um líder principal, ao passo que na Itália, ainda que em primeiro momento histórico o mesmo caminho fosse seguido (Griziotti e Ranelleti e, posteriormente, Giannini), a consolidação de Escolas contemporâneas guardaria a presença de dois ou mais "mestres", situados em uma mesma "Escola". AMATUCCI, Andrea. Historia de La Enseñanza del Derecho Financiero Público en Italia. Op.cit., p. 135-136. 
Conforme já visto, o processo disciplinar do Direito Tributário Brasileiro não poderia ser realizado sem a consolidação de estretégias de estudo e ensino peculiares, que favoreceram a difusão de seus próprios métodos de estudo e ensino. Essas, consolidadas em ambiente histórico que lhes era favorável, conservam características próprias que não permitem acolher grandes semelhanças entre elas.

A consciência do Direito Tributário como disciplina teoricamente autônoma (cientificamente ou didaticamente, conforme a linha) é inerente pressuposto para o "passo adiante", e a consolidação de linhas de pesquisa e ensino que eventualmente configurem a autonomia do ensino que reforça o empreendimento disciplinar.

Afinal, parte importante dessa autonomia é também a consolidação de métodos de ensino e pesquisa próprios da matéria. Mas como ciência social (e jurídica), o Direito Tributário passa a refletir influências exteriores, seja no campo político, seja por diferentes referências filosóficas jurídicas, que acabam influenciando determinantemente as respectivas construções estruturais. Todas as premissas de estudo e de ensino apresentam pano de fundo comum, isto é, a consolidação da autonomia teórica do Direito Tributário.

Contudo, somente a libertação teórica não basta, é preciso que se instituam programas de ensino adequadamente aptos a ensinar a disciplina. E mais do que isso, é preciso apresentar os alicerces estruturais que consolidarão esse ensino.

Já nos primeiros anos do período disciplinar do Direito Tributário essa tendência dedicada à divulgação do ensino já se manifesta, com Tullio Ascarelli e Rubens Gomes de Sousa, em São Paulo. O primeiro curso monográfico foi elaborado por Ascarelli, denominado "Curso de Princípios Básicos do Imposto sobre a Renda e o Sistema Brasileiro", em 1947, na Escola de Sociologia e Política. Participaram do curso, entre outros, Rubens Gomes e Sousa e Ruy Barbosa Nogueira.

Rubens Gomes de Sousa, assim, foi convidado por Theotônio Monteiro de Barros Filho que, à época, lecionava Ciência das Finanças na Faculdade de Direito e na Faculdade de Ciências Econômicas e Administrativas na USP, para ministrar a disciplina "Legislação Tributária" para economistas, autuários e contabilistas. Contudo, para poder ser contratado pela Faculdade precisaria provar que já apresentava experiência acadêmica (o que não possuía na época). 
O primeiro curso de Rubens Gomes de Sousa foi viabilizado graças aos esforços de Ruy Barbosa Nogueira e Cyro Berlinck, que organizaram o curso na Escola de Sociologia e Política que, ministrado na primavera de 1947, foi denominado "Curso de Introdução ao Direito Tributário", sendo finalizado em $1948^{1116}$. Já em 1949, Sousa assumiu a cadeira de Legislação Tributária, na Faculdade de Ciências Econômicas da USP ${ }^{1117}$.

Note-se, que, conforme já salientado, Nogueira iniciou carreira acadêmica na Cátedra de Ciência das Finanças (substituindo o Prof. Carvalho Pinto), em 1954, quando incluiu pela primeira vez o estudo sistematizado do Direito Tributário, através de programa aprovado pela Congregação da Faculdade de Direito da PUC-SP, lecionando a disciplina até o ano de $1968^{1118}$, quando assume seu lugar o Prof. Geraldo Ataliba.

Com a Reforma do ensino, em 1962, incluiu-se nos currículos das faculdades de Direito o estudo genérico do Direito Financeiro ${ }^{1119}$, que leva à criação da disciplina "Direito Financeiro" (1963) na USP, e a posterior criação da Cátedra de "Direito Tributário", em 1969.

Ruy Barbosa Nogueira, prestando concurso para a Cátedra de Direito Financeiro, em 1965, (posteriormente convertida em Direito Tributário, ainda que na prática, Nogueira já se dedicasse ao ensino dessa disciplina no âmbito do Direito Financeiro), torna-se o

\footnotetext{
${ }^{1116}$ Segundo o relato do próprio Rubens Gomes de Sousa, "Em 1948, dei na Escola de Sociologia, um primeiro curso de direito tributário (dito pós-graduado", um tanto esdruxulamente, se era o primeiro): nele procurei apenas despertar a consciência do fato de existir um direito tributário, traduzindo em português o que lá fora já era moeda corrente”. (...) SOUSA, Rubens Gomes de. Prefácio da 1Edição. In: FANUCCHI, Fabio. Curso de Direito Tributário.Volume I. $4^{a}$ Ed. São Paulo: IBET- Resenha Tributária, 1976, p. xiii-xx. ${ }^{1117}$ Sobre o assunto, ver capítulo 1.

${ }^{1118}$ Segundo Ruy Barbosa: "Se em 1954, a convite da Congregação da Faculdade de Direito da PUC, criamos o primeiro curso curricular de Direito Tributário em nosso país e o regemos de 1954 a 1968, muito antes, já vínhamos ministrando cursos extracurriculares na São Francisco, cujo Centro XI de Agosto lançou a $1^{\text {a }}$ edição mimeografada de nosso Curso de Direito Tributário". Já em 1946, Ruy Barbosa Nogueira apresentava cursos extracurriculares e palestras sobre Direito Tributário, inclusive na USP. NOGUEIRA, Ruy Barbosa. O Direito Tributário. Op.cit., p.14.

${ }^{1119}$ Conforme salienta Nogueira: "Na verdade, do ponto de vista formal ainda não tivemos a obrigatoriedade da inclusão curricular autônoma da disciplina Direito Tributário, quando todo um capítulo da Constituição trata especificadamente do "Sistema Tributário" e há dez anos temos um Código Tributário Nacional, além da constante torrente de leis fiscais. Todavia, graças à reforma universitária da USP que tanto se deveu ao Reitor Miguel Reale, no currículo desta faculdade temos as disciplinas específicas Direito Tributário no VI semestre, Direito Tributário Aplicado nos dois últimos semestres da área de especialização, dentro do Direito de Empresa. No pós-graduação, Direito Tributário Comparado, além de cursos de extensão universitária como este dedicado à comunidade. Idem, p.10-11.
} 
primeiro catedrático da matéria naquela tradicional Faculdade, assumindo-a em $1970 .{ }^{1120}$ _

\section{A contribuição da Faculdade de Direito do Largo São Francisco (USP) para o estudo e ensino do Direito Tributário no Brasil}

Não seria exagerado afirmar que a gênese histórica da formação do ensino do Direito Tributário no Brasil estaria nos cursos introdutórios de Tullio Ascarelli e Rubens Gomes de Sousa nos anos finais da década de quarenta. Mas, efetivamente, a mola propulsora para a consolidação da divulgação do estudo e ensino do Direito Tributário na USP foi capitaneada por Ruy Barbosa Nogueira, o primeiro catedrático da disciplina naquela Faculdade.

Nogueira possuía particular preocupação pela difusão e divulgação da pesquisa e do ensino do Direito Tributário no Brasil, que o fez participar da criação da primeira cadeira de Direito Financeiro na Pontifícia Universidade Católica de São Paulo, e, também, na Universidade de São Paulo.

Mas a estratégia de Ruy Barbosa Nogueira, em ambiente onde não se restava sedimentado qualquer método de ensino e pesquisa propriamente aplicado ao direito tributário brasileiro, era arrojado. Buscou inspiração nas lições do país que possuía maior sucesso no desenvolvimento dos estudos tributários, a Alemanha. Com esse objetivo, aprendeu a língua de Goethe e prosseguiu a perene intercâmbio acadêmico de ideias e experiências com muitos destacados tributaristas germânicos. Vários foram os esforços engendrados por Ruy Barbosa no intuito de absorver e aprender com o exemplo germânico $^{1122}$, visando fortalecer o desenvolvimento dos estudos (e do ensino) da matéria no Brasil ${ }^{1123}$.

\footnotetext{
${ }^{1120}$ NOGUEIRA, Ruy Barbosa. Rubens Gomes de Sousa, trinta anos amigo e companheiro. Op.cit., p. 112.

${ }^{1121}$ FANUCCHI, Fábio. Curso de Direito Tributário. Op.cit., p. 17-18.

${ }^{1122}$ Pode-se observar claramente o conhecimento do autor sobre a literatura germânica da época, na apresentação da tradução dos Códigos Tributários Alemão, Mexicano e do Projeto de Código Tributário
} 
Com a missão de estruturar o plano de ensino de Direito Tributário na Faculdade da USP, procurou inspiração na experiência europeia (e notadamente alemã), para maximizar as chances de sucesso. Não é por acaso que chegou a divulgar amplamente Planos de Ensino da disciplina lecionada em tradicionais instituições daquele país. Também não é por acaso a elevação, pelo autor, da importância da observação da experiência estrangeira, assim como das raízes históricas da disciplina ${ }^{1124}$.

Por isso, nas décadas de sessenta e setenta, a Faculdade do Largo São Francisco já mantinha equipe de estudiosos, seja como alunos, ex-alunos ou professores ${ }^{1125}$, não necessariamente vinculados à grade de professores Faculdade de Direito do Largo São Francisco, mas familiares pelo estudo do Direito Tributário Brasileiro e Estrangeiro ${ }^{1126}$, seja no estudo teórico e prático ${ }^{127}$, seja nos estudos voltados ao Direito Tributário Comparado ${ }^{1128}$.

Nacional, os dois primeiros traduzidos por Souza Diniz, em 1965, a quem Ruy Barbosa Nogueira prefaciou: "Trabalhando com o Direito Tributário desde o tempo dos bancos acadêmicos, ouvimos logo falar do Código Tributário da Alemanha. Tivemos então a ventura de conhecer o Dr. Heinrich Reinach que viera morar em nosso país e fora o fundador e diretor da "Steuer und Wirtschaft", uma das mais importantes revistas jurídicotributárias da Alemanha, editada até hoje em München, onde tem sede a Suprema Corte Financeira da Alemanha (hoje Bundesfinanzof) e em cuja revista colaborara ativamente o grande Senatspräsident daquela Corte, Enno Becker, autor do projeto que se convertera no celebrado Código Tributário (Reichsabgabenordnung hoje Abgabenordnung, citado abreviadamente pelas iniciais AO). Foi exatamente o desejo e o interesse profissional de conhecer esse Código que nos levou a estudar a língua de Goethe". NOGUEIRA, Ruy Barbosa. Prefácio. In: DINIZ, Souza. Códigos Tributários. Alemão, Mexicano, Brasileiro. Op.cit., p. v.

${ }^{1123}$ NOGUEIRA, Ruy Barbosa. Programas e Compêndios de Direito Tributário. Excerto da Seção Imposto de Renda - Comentário, n.34/85. São Paulo: Resenha Tributária, 1985, p. 721 e seguintes.

${ }_{1124}$ NOGUEIRA, Ruy Barbosa. Estudos Tributários. In: Debates Tributários. Ruy Barbosa Nogueira e Colegas. São Paulo: IBDT - Resenha Tributária, 1975, p. 117 e seguintes.

${ }^{1125}$ A última edição do célebre "Curso" foi publicada em 1999, quatro anos antes do falecimento de Ruy Barbosa Nogueira, no ano de 2003. NOGUEIRA, Ruy Barbosa. Curso de Direito Tributário. $15^{\circ}$ edição. São Paulo: Saraiva, 1999, p. 17-18.

${ }^{1126}$ MACHADO, Brandão. "Ruy Barbosa Nogueira". Direito Tributário. Estudos em Homenagem ao Prof. Ruy Barbosa Nogueira. São Paulo: Saraiva, 1984.

${ }^{1127}$ No intuito de alcançar esse objetivo, Ruy Barbosa Nogueira organizou, no âmbito do IBDT, curso de extensão promovido aos sábados, e contando com diversos professores da época: Ruy Barbosa Nogueira, José Nabaltino Ramos, José Afonso da Silva, Alcides Jorge Costa, Ministro Rodrigues Alckmin, Aliomar Baleeiro, Walter Barbosa Correa, Hely Lopes Meirelles, José Frederico Marques e Dínio de Santis Garcia. NOGUEIRA, Ruy Barbosa. O Estudo Teórico e Prático do Direito Tributário. São Paulo: Resenha Tributária, 1975, p.V-VII.

${ }^{1128}$ Neste Plano de Trabalho apresentado à Reitoria da USP em 1972, pode-se observar a formação da equipe de Direito Tributário da Faculdade de Direito do Largo São Francisco naquele período: Professor Catedrático: Ruy Barbosa Nogueira; Livre-Docentes: Walter Barbosa Côrrea; Antonio Roberto Sampaio Dória; José Nabantino Ramos; Auxiliares de Ensino: Gerd W. Rothmann; Paulo Roberto Cabral Nogueira; Monitores Voluntários: Eduardo Frederico de Andrade Carvalho; Walter Piva Rodrigues; Maria Lucia Lencastre Ursaia; José Nicola Jannuzzi; Luis Antonio Vasconcellos Boselli; Victor Brandão Teixeira; Pesquisador Voluntário: Henry Tilbery. NOGUEIRA, Ruy Barbosa. Direito Tributário e Direito Tributário Comparado. Cursos de Graduação, Mestrado, Doutorado, Extensão Universitária e Mesa de 
Note-se que, entre os objetivos da Mesa de Debates promovidos pelos estudiosos vinculados à USP e dedicados ao ensino e à pesquisa no âmbito do Plano de Ensino das disciplinas de Direito Tributário e Direito Tributário Comparado, seriam os seguintes: "Os estudos e pesquisas, desses grupos, de que participam também vários juristas do Curso de pós-graduação, tem não só objetivo de esclarecer problemas da atualidade, colaborar de lege ferenda e na crítica construtiva, mas também o consagramento dos estudiosos de Direito Tributário e a formação de escola.’(grifo nosso). ${ }^{129}$

Na realidade, os objetivos das atividades de ensino e extensão promovidos pela equipe de tributaristas da USP, liderados por Ruy Barbosa Nogueira, tinham como meta primordial consolidar o ensino da disciplina do Direito Tributário no Brasil (sequer inclusa na maioria dos cursos de direito no Brasil na época) e, para alcançar tal objetivo, não poupavam esforços na observância de exemplos estrangeiros de sucesso. É o que se pode observar na leitura de diversos estudos publicados por Ruy Barbosa Nogueira e integrantes da equipe da USP, onde o ânimo de difundir a disciplina do Direito Tributário no Brasil (e consequentemente, seu amadurecimento científico) era a maior prioridade, especialmente no contexto em que a disciplina começava a aparecer nos currículos dos cursos de Direito no Brasil ${ }^{1130}{ }_{-}^{1131}$.

Note-se que o próprio Ruy reconhecia a influência germânica na estruturação de seu Curso de Direito Tributário, assim como também a importância da harmonização do ensino na Faculdade de Direito do Largo São Francisco, às diretrizes (sobretudo germânicas) aplicáveis à disciplina ${ }^{1132}{ }^{1133}$.

Debates. Plano de Trabalho e Pesquisas para 1972 (apresentado à Faculdade de Direito e Reitoria da Universidade de São Paulo), p. 05-06.

${ }^{1129}$ Idem, p. 07.

${ }^{1130}$ A importância da experiência e dos programas de ensino estrangeiros em Direito Tributário pode ser observada com facilidade na publicação: NOGUEIRA, Ruy Barbosa. Ensino, Pesquisas e Serviços à Comunidade. Separata do Vol.7 da Coleção Direito Tributário Atual. São Paulo: IBDT/Resenha Tributária, 1987, p. 1685 e seguintes.

${ }^{1131}$ Por ocasião da obra de Klaus Tipke (Steuerrecht - Ein Systematischer Grundriss, 10. Völlig überarbeitete Auflage, Verlag, Dr. Otto Schimidt Kg Köln, 1985, 710 pp), verifica a publicação de um acordo de diretrizes buscando maior harmonização e uniformização da matéria tributária que deve ser objeto de ensino nas cadeiras de Direito Tributário. Tais Diretrizes, não somente aplicáveis ao Direito Alemão, e com aspirações de padronização mundial do ensino do Direito Tributário, levaram Ruy Barbosa Nogueira a traduzi-la (o autor preferiu o termo "adaptação"), dos trechos mais relevantes para o ensino do Direito Tributário no Brasil. NOGUEIRA, Ruy Barbosa. Programas e Compêndios de Direito Tributário. Op.cit., p. 724-727.

${ }^{1132}$ É realmente notável a dedicação do autor à divulgação das grandes obras científicas produzidas na literatura germânica, buscando maior intercâmbio científico entre estudiosos germânicos e nacionais, como pode ser observado na apresentação do autor do Dicionário Expositivo do Direito Tributário e das Ciências 
Não se limitou à análise doutrinária, mas chegou a publicar estudo comparando as estruturas do Direito Tributário brasileiro frente às elaborações legislativas germânicas ${ }^{1134}$, em 1961, antes mesmo de assumir a Cátedra de Direito Tributário naquela faculdade.

Nogueira também patrocinou, através do Instituto Brasileiro de Direito Tributário, a tradução do Novo Código Tributário Alemão (Abgabenordnung - 1977), apenas um ano após sua entrada em vigor na Alemanha, cuja tradução ficou a cargo de Alfred J. Schmid, Brandão Machado, Eduardo Frederico de A. Carvalho, Gerd W. Rothmann, Henry Tilbery e do próprio Ruy Barbosa Nogueira ${ }^{1135}$. Não por acaso, publicou o trabalho "O Novo Código Tributário da Alemanha: Como se deve legislar", no intuito de divulgar as conquistas do Novo Código Tributário Alemão (AO-1977) em terras brasileiras ${ }^{1136}$.

Embora não se possa afirmar a prevalência de uma referência jurídico-filosófica basilar e harmônica para os estudos enfrentados na Faculdade de Direito da USP, deve-se lembrar que Ruy Barbosa Nogueira apresentava expressa simpatia à obra de Miguel Reale $^{1137}$, conforme testemunha o próprio Ruy Barbosa Nogueira: “Ao descobrirmos Reale em 1945, não só ficamos encantados com o Direito como Experiência, mas com o início do que viria a ser na tridimensionalidade "La formula Reale" e as suas citações sobre as elaborações germânicas. Desde então tivemos a ideia de, em homenagem ao nosso inexcedível Mestre e Amigo, escrever, o que agora estamos tentando. Pesquisar o

Fiscais (Handwörterbuch des Steuerrechts und der Steuerwissenschaften), o qual demonstra “(...) o alto grau de elaboração que o Direito Tributário já alcançou e é precisamente esta novidade que desejamos divulgar, não só para conhecimento dos interessados, mas também para demonstrar a sua utilidade entre nós, em razão de a legislação da Alemanha ter sido uma das mais importantes fontes do nosso Código Tributário”. Idem, p. 727-728.

${ }^{1133}$ Conforme o testemunho do próprio autor: "Com recomendação e apresentação do nosso saudoso amigo e companheiro de estudos Dr. Heinrich Reinach, fundador de uma das melhores revistas que até hoje se publica na Alemanha, Steuer und Wirtschaft - tivemos a ventura de ir estudar em München, sede da Corte Tributária, lá voltando várias vezes para discutir e aprender com mestres notáveis, dentre os quais Ottmar Bühler, Carl Boettcher, Hugo Von Wallis, Hans Spanner e tantos outros". NOGUEIRA, Ruy Barbosa. Apresentação do Dicionário Expositivo do Direito Tributário e das Ciências Fiscais. Publicação da Cadeira de Direito Tributário Comparado. São Paulo: Faculdade de Direito do Largo São Francisco, 1972, p. 04.

1134 NOGUEIRA, Ruy Barbosa. Panorama do Direito Tributário Brasileiro e as Elaborações Germânicas. Separata da Revista dos Tribunais. Volume 303. Janeiro de 1961. São Paulo: RT, 1961, p. 3440.

${ }^{1135}$ Novo Código Tributário Alemão. Trad. SCHMID, Alfred J, MACHADO, Brandão; CARVALHO, Eduardo Frederico de A.; ROTHMANN, Gerd W; TILBERY, Henry; NOGUEIRA, Ruy Barbosa. São Paulo: IBDT - Editora Forense, 1978, s/p.

1136 NOGUEIRA, Ruy Barbosa. O Novo Código Tributário da Alemanha: como se deve legislar. São Paulo, LTr, Sup.Trib.n96, p. 455-458.

1137 REALE, Miguel. Lições Preliminares de Direito.Op.cit., p. 200-201. 
tridimensionalismo na Ciência e Filosofia do Direito tributário tedesco, com a qual, sinteticamente, desejamos encerar este breve escrito." ${ }^{1138}{ }_{-} 1139$

E vai adiante: "Se no Brasil somente em 1954 foi fundada a primeira disciplina curricular da Ciência do Direito Tributário e em 1963 sua livre docência e em seguida a primeira cátedra, a especialização e a pós-graduação, parece que está faltando a formação de uma plêiade de Filósofos do Direito Tributário dentro da Escola Reale, como já dissemos, para humanizar a tributação e o fisco brasileiros"1140_ ${ }^{1141}$.

Ruy Barbosa Nogueira, a despeito do positivismo dogmático kelseniano, preferiu seguir (assim como a maioria de seus interlocutores) o caminho da investigação aberta ao direito tributário, compreendendo-o como fenômeno cultural, considerando-o a partir da premissa jurídica, mas permeada por valores, e jamais distraído com a importância da observação da realidade fática nos estudos de Direito Tributário ${ }^{1142}$.

De qualquer forma, a consolidação de Ruy Barbosa Nogueira ${ }^{1143}$ enquanto fundador da disciplina institucionalizada do Direito Tributário no Brasil, pode ser

\footnotetext{
${ }^{1138} \mathrm{~A}$ influência e a importância de Miguel Reale na construção teórica de Ruy Barbosa Nogueira podem ser observadas com maior clareza no estudo: NOGUEIRA, Ruy Barbosa. Miguel Reale e o Direito Tributário. In: Imunidades. Contra Impostos na Constituição Anterior e sua disciplina mais completa na Constituição de 1988. $2^{a}$ Ed. São Paulo: Saraiva, 1992, p.191 e seguintes.

${ }^{1139}$ Nessa notável obra, para o jusfilósofo “(...) o direito não é só experiência, mas só pode ser compreendido como experiência". E, nesse sentido, defende a necessidade de reaproximação do jurista à experiência jurídica, além de analisar criticamente posições fundamentais da dogmática jurídica. Para o autor: "O essencial é reconhecer que a experiência jurídica é uma forma dessa experiência universal, e que a Jurisprudência, sendo, ao mesmo tempo, expressão de ordem e de progresso, de certeza e de justiça, é "exigência de sistema" e de "validades dogmáticas", sem prejuízo de sua intrínseca problematicidade". Notese também que o mesmo autor apontou a crise do normativismo e a exigência de uma normatividade concreta, afastando-se do normativismo kelseniano e vinculando o "nexo fático-axiológico" na norma jurídica, por sua vez sempre inserida em um "processo histórico-cultural". REALE, Miguel. O Direito Como Experiência (Introdução à Epistemologia Jurídica). São Paulo: Saraiva, 1968, p 01-07; p. 142 e seguintes; p.187 e seguintes; p. 201 e seguintes.

${ }_{1140}$ NOGUEIRA, Ruy Barbosa. Imunidades. Contra Impostos na Constituição Anterior e sua disciplina mais completa na Constituição de 1988. Op.cit., p.191 e seguintes.

${ }^{1141}$ A teoria tridimensional do direito, construída por Reale, influenciou fortemente a Faculdade de Direito da USP, especialmente por apresentar a experiência jurídica (e o próprio normativismo jurídico) à luz da implicação polar "fato-valor": "considero a experiência jurídica uma "experiência tridimensional de caráter normativo bilateral atributivo", com os termos fato, valor e norma indicando os fatores ou momentos de uma realidade em si mesma dialética, como é o mundo do direito". E complementa: "Em suma, o termo "tridimensional" só pode ser rigorosamente como traduzindo um processo dialético, no qual o elemento normativo integra em si e supera a correlação fático-axiológica, podendo a norma, por sua vez, converter-se em fato, em um ulterior momento do processo, mas somente com referência e em função de uma nova integração normativa determinada por novas exigências axiológicas e novas intercorrências fáticas". REALE, Miguel. Teoria Tridimensional do Direito. Situação Atual. 5ª Ed. São Paulo: Saraiva, 1994, p. 74-77.

${ }^{1142}$ NOGUEIRA, Ruy Barbosa. Imunidades. Contra Impostos na Constituição Anterior e sua disciplina mais completa na Constituição de 1988. Op.cit., p.191 e seguintes.

${ }^{1143}$ NOGUEIRA, Ruy Barbosa. Curso de Direito Tributário. Op.cit., p. 04-05.
} 
observada no testemunho de Ives Gandra Martins, por ocasião de obra desenvolvida em homenagem à Ruy Barbosa Nogueira, e organizada por Brandão Machado: "A equipe mais íntima de seus colaboradores no Instituto Brasileiro de Direito Tributário, entidade complementar da USP, que fundou e preside, desde sua instituição, na qual se destacam os eminentes juristas Alcides Jorge Costa, Luis Mélega, Walter Barbosa Côrrea e Henry Tilbery, sob a coordenação de Brandão Machado, iniciaram o projeto, há 3 anos e meio, objetivando a edição de um livro que, pelo seu próprio conteúdo, representasse o melhor elogio ao preclaro mestre da Escola do Largo de São Francisco" ${ }^{\prime 144}$.

Em verdade, a equipe de tributaristas colaboradores do Instituto Brasileiro de Direito Tributário em grande parte confundia-se com os integrantes da Faculdade de Direito do Largo São Francisco, já que o IBDT, oficialmente criado em 1974, constituía instituto vinculado aos trabalhos do Departamento de Direito Econômico e Financeiro da USP, ainda que suas reuniões já ocorressem com vários anos de antecedência, tendo como presidentes Ruy Barbosa Nogueira, Alcides Jorge Costa, Paulo Celso Bergstrom Bonilha e Ricardo Mariz de Oliveira, sucessivamente. ${ }^{1145}$

Da mesma forma, pode-se observar a influência e a intensa participação de Alcides Jorge Costa na manutenção do histórico prestígio da Faculdade de Direito da USP. Este autor manteve atenção expressa aos estudos voltados ao Direito Tributário Brasileiro, no entanto, sem ignorar a experiência trazida pelo direito estrangeiro ou pela história do Direito Tributário Brasileiro. Seus estudos também jamais ignoraram a contribuição dos estudos financeiros à compreensão do fenômeno tributário ${ }^{1146}$.

\footnotetext{
${ }^{1144}$ MARTINS, Ives Gandra da Silva. Do Direito Tributário. Excerto da Seção Imposto sobre a Renda Comentário - n.31/84. São Paulo: Resenha Tributária, p.715-717.

1145 O IBDT foi criado oficialmente em 24 de outubro de 1974 (muito embora extraoficialmente já fosse ativo há anos), sob a presidência do Prof. Ruy Barbosa Nogueira, originalmente como entidade vinculada institucionalmente ao departamento de Direito Econômico e Financeiro da Faculdade de Direito do Largo São Francisco, da Universidade de São Paulo. Ainda hoje ativa, o Instituto é responsável por manter (e atualizar) as estratégias de ensino e pesquisa desenvolvidas originalmente no seio da Faculdade de Direito da USP, sobretudo pelo esforço de Ruy Barbosa Nogueira. NOGUEIRA, Ruy Barbosa. Teoria, Experiência e Trabalho a Serviço do Ensino e do Desenvolvimento. Melhoria da Legislação Tributária. In: Direito Tributário Atual. Vol.1. São Paulo: IBDT - Resenha Tributária, 1982, p. 13-20.

${ }^{1146}$ Essas características são observáveis nas seguintes obras do renomado professor: COSTA, Alcides Jorge. A História da Tributação no Brasil. Op.cit., p. 71-75. COSTA, Alcides Jorge. A doutrina italiana e sua influência no Direito Tributário Brasileiro. Op.cit., p.23 e seguintes; COSTA, Alcides Jorge. Algumas Notas sobre a Relação Jurídico Tributária. Op.cit., p. 21-35. COSTA, Alcides Jorge. Contribuição ao Estudo da Obrigação Tributária. 1972. Instituto Brasileiro de Direito Tributário. Edição especial para a Jornada de Direito Tributário. São Paulo: IBDT, 2003, p.07-61. No mesmo sentido verifica-se a sólida
} 
Tornou-se sucessor de Ruy Barbosa Nogueira na cátedra de Direito Tributário pela mesma Universidade, no que se poderia considerar uma segunda fase na Faculdade de Direito da USP, na década de noventa, dando continuidade às atividades exercidas na Tradicional Faculdade de Direito da USP ${ }^{147}$, bem como ao Instituto Brasileiro de Direito Tributário, já que lá também Alcides Jorge Costa sucedeu o Prof. Ruy Barbosa Nogueira enquanto presidente do Instituto (o que mostra também grande carga simbólica e alinhamento entre as estratégias de ensino e pesquisa adotada no Instituto Brasileiro de Direito Tributário perante a estratégia praticada na Faculdade de Direito da USP) ${ }^{1148}$.

Contudo, não se pode afirmar que Alcides Jorge Costa, fosse necessariamente discípulo de Ruy Barbosa Nogueira, pois apresentou clara autonomia de ideias e pressupostos de investigação, perante as obras de Ruy Barbosa Nogueira. A afinidade entre os dois mestres da USP dava-se na busca incessante ao aperfeiçoamento do estudo e do ensino do Direito Tributário no Brasil, na evolução legislativa da matéria, no repúdio ao positivismo dogmático kelseniano aplicado como pressuposto elementar dos estudos tributários, assim como a particular atenção à investigação histórica e à experiência estrangeira e suas respectivas utilidades para a resolução (com as devidas adaptações) de determinados problemas na realidade tributária brasileira.

Assim, a Faculdade de Direito da USP merece essa menção honrosa por ter sido a primeira instituição de ensino a reunir diversos estudiosos, a partir de Ruy Barbosa

investigação histórica sobre a tributação sobre o consumo (estrangeira e nacional): COSTA, Alcides Jorge. ICM na Constituição e na Lei Complementar. São Paulo: Resenha Tributária, 1978, p. 13 e seguintes.

1147 Outro ponto importante é que, naturalmente, a Faculdade de Direito da USP (pela sua própria abertura institucional) não significava que todos os professores da Universidade de São Paulo seguiam essas mesmas características, existindo, naturalmente, professores da mesma instituição que acabaram seguindo linhas próprias de pesquisa, ou mesmo maior afinidade com outras linhas de pesquisa e ensino.

${ }^{1148}$ Na prática, embora o programa de ensino da Faculdade de Direito fosse elaborado por Ruy Barbosa Nogueira, e mantido por seu sucessor na cátedra Alcides Jorge Costa, a estratégia de ensino e pesquisa adotada pelos professores foi mantida posteriormente com maior força através dos esforços desenvolvidos no Instituto Brasileiro de Direito Tributário (IBDT), que, em muitos aspectos, pode ser considerado um dos grandes legados de Ruy Barbosa Nogueira ao Direito Tributário Brasileiro. Isso porque o Instituto, originalmente concebido como entidade complementar à Faculdade, na década de setenta, absorveu as mesmas estratégias de ensino e pesquisa praticadas na Faculdade, e manteve-se alinhada em muitos aspectos àquelas premissas construídas por Ruy Barbosa Nogueira, sendo também aplicadas por professores da Faculdade de Direito integrantes do Instituto, a exemplo de Gerd Willi Rothmann e Paulo Celso Bergstrom Bonilha. Note-se que a sucessão de Nogueira na cátedra de Direito Tributário por Alcides Jorge Costa, não alterou, mas fortaleceu essa característica, já que Alcides Jorge Costa sucedeu também Nogueira na presidência do Instituto Brasileiro de Direito Tributário. Com a sucessão de Alcides Jorge Costa por Paulo de Barros Carvalho, essa tendência à aplicação das estratégias de estudo e ensino de Ruy Barbosa Nogueira, centram-se com maior força nos professores da Faculdade de Direito e integrantes do Instituto Brasileiro de Direito Tributário, período em que inaugura nova fase na estratégia de ensino e pesquisa da Faculdade de Direito da USP. 
Nogueira (e tendo por antecedentes Tullio Ascarelli e Rubens Gomes de Sousa), a exemplo de Alcides Jorge Costa, José Nabantino Ramos, Walter Barbosa Côrrea, Gerd Willi Rothmann $^{1149}$, Hamilton Dias de Souza, Paulo Celso Bergstrom Bonilha ${ }^{150}$, dentre muitos outros, e por encontrar a maior parte de seus mestres e alunos vinculados a essa instituição, assim como seus interlocutores (sejam alunos, ex-alunos, professores ou colaboradores) $)^{1151}$.

As principais características comuns identificáveis no estudo e ensino da Faculdade de Direito da USP seriam as seguintes: a) estudos sempre atentos às peculiaridades históricas da disciplina; b) estudos sempre atentos ao direito comparado e à literatura estrangeira especializada (inclusive alemã); c) estudos que não desprezavam, em sua maioria, as contribuições da Ciência das Finanças ou a consideração econômica (o que não significa necessariamente a aceitação, por exemplo, da interpretação econômica no direito tributário brasileiro, rejeitada por importantes membros da Escola; d) estudo do direito tributário aberto à realidade (direito como norma-fato-valor); e) maior preocupação com a substância (conteúdo do direito tributário) em detrimento ao formalismo jurídico.

Observam-se também menores restrições aos estudos que consideram, por exemplo, a consideração econômica, bem como a contribuição da "Ciência das Finanças", na obra do professor. Para Ruy Barbosa Nogueira, a experiência estrangeira não deveria ser

1149 ROTHMANN, Gerd Willi. O Princípio da Legalidade Tributária. In: NOGUEIRA, R. B. (Org.). Direito Tributário - Estudos de Casos e Problemas. São Paulo: José Bushatsky, 1974, p. 137-180. ROTHMANN, Gerd Willi; NOGUEIRA, Ruy Barbosa. Tradução do verbete Auslegung (Interpretação, de Heinrich Beisse, do Handwörterbuch des Steuerrechts und der Steuerwissenschaften). In: Resenha Tributária. (Org.). Estudos Tributários. São Paulo: Resenha Tributária, 1974, p. 33-56.

${ }^{1150}$ BONILHA, Paulo Celso Bergstrom. IPI e ICM Fundamentos da Técnica Não-Cumulativa. São Paulo: Editora Resenha Tributária Ltda., 1979. BONILHA, Paulo Celso Bergstrom. Da Prova no Processo Administrativo Tributário. Op.cit., p. 15 e seguintes. BONILHA, Paulo Celso Bergstrom. Da educação tributária como fator de desenvolvimento econômico e social. $2^{\text {a }}$ Congresso Interamericano de Direito Tributário, São Paulo: Co-Edição. Sociedade Interamericana de La tributación, Centro de Estudos de Extensão Universitária - Editora Resenha Tributaria, 1975, p. 01-51.

${ }^{1151}$ A Cátedra de titularidade em Direito Tributário foi mantida por Alcides Jorge Costa, até o final da década de noventa, tempo de sua aposentadoria, sendo posteriormente sucedido por Paulo de Barros Carvalho, em 1997, quando se inicia uma terceira fase na Faculdade de Direito da USP, a ser abordada em tópico específico, e, no ano de 2014, a titularidade da cátedra passou a ser exercida por Humberto Bérgmann Ávila, que por não ser discípulo direto de seus antecessores, tende a estabelecer uma quarta fase na Faculdade de Direito. Importante lembrar também que a titularidade da cátedra de Legislação Tributária, originalmente exercida por Rubens Gomes de Sousa, e depois por Fabio Nusdeo, hodiernamente, é exercida por Luís Eduardo Schoueri, que, mantendo fortes vínculos com Ruy Barbosa Nogueira, Alcides Jorge Costa e o Instituto Brasileiro de Direito Tributário, tende a manter firme a tradição e as estratégias de estudo e ensino disseminados pelos citados mestres da "Tradicional Escola da USP", mas não sem atualizações ou aperfeiçoamentos inerentes ao progresso da disciplina no século XXI. 
ignorada, mas, na medida do possível, apreendida e adaptada à realidade tributária nacional. ${ }^{1152}{ }_{-}^{1153}$

Ressalvas devem ser levantadas, assim, à caracterização do ensino e pesquisa promovidos sob o patrocínio da Faculdade de Direito da USP como autêntica "Escola Científica". Em primeiro lugar, não se assumia a adoção expressa de um pressuposto epistemológico ou metodológico comum aplicado ao estudo do Direito Tributário. Além disso, não havia a introdução de uma teoria estrutural do direito tributário, que a enxergasse sob particular ponto de vista. $\mathrm{O}$ que havia era a busca pela disseminação das estruturas de ensino e pesquisa construídas na experiência estrangeira (sobretudo germânicas, italianas e francesas), assim como a reflexão e adaptação de institutos materiais fundamentais ao direito tributário, notadamente já construídos naquelas realidades, inclusive perante a realidade econômica dos fatos. O pragmatismo e a atenção à realidade tributária brasileira era o pano de fundo para os debates voltados à reflexão e aprimoramento das estruturas teóricas, legislativas e de ensino do direito tributário brasileiro. Também não se observa plena harmonia entre ideias fundamentais entre os integrantes da Faculdade de Direito da USP, não sendo possível identificar, também, Alcides Jorge Costa como discípulo de Ruy Barbosa Nogueira, ainda que se apresentassem familiaridades entre as construções de ensino e pesquisa dos dois mestres da USP.

Contudo, justiça seja feita. O contexto histórico em que se consolida o esforço na divulgação do estudo e ensino no seio da Faculdade de Direito do Largo São Francisco foi consolidado em período de inexistência de qualquer proposta anterior ou alternativa a apresentada nos quadros da renomada Faculdade. Foi, portanto, a primeira a apresentar esforço inequívoco na divulgação de estudos e do ensino do direito tributário brasileiro.

Foi de fato introdutora do ensino e da pesquisa do Direito Tributário no Brasil, ainda que não apresentasse intensidade critérios determinantes para o reconhecimento de uma Escola Científica ou Acadêmica. Além disso, apresentou influência acadêmica nesses esforços, chegando a influenciar propostas contrárias ao estudo e ensino praticado no seio da USP. Talvez na identificação de propostas expressamente contrárias às apresentadas nessa Faculdade é que assiste razão denominá-la como uma "Escola do Direito Tributário".

\footnotetext{
${ }^{1152}$ NOGUEIRA, Ruy Barbosa; NOGUEIRA, Paulo Roberto Cabral. Prefácio à 2a Edição. In: Direito Tributário Aplicado e Comparado. Volumes I e II. Forense: Rio de Janeiro, 1977, s/p.

${ }^{1153}$ Idem, p. 331-388.
} 
De qualquer forma, reconhecendo a importância inequívoca aos estudos e ao modelo de ensino divulgado pela Faculdade de Direito da USP, é que garante historicamente seu lugar como verdadeira introdutora e difusora do ensino e pesquisa do Direito Tribuário Brasileiro.

Mas, não obstante os méritos trazidos por essa Faculdade de Direito, conforme já observado, tal empreendimento gera esforços contrários, que serão melhores analisados em tópico apartado.

\section{A contribuição da Faculdade Paulista de Direito da Pontifícia Universidade Católica de São Paulo para a consolidação do ensino do Direito Tributário no Brasil.}

O início da divulgação do ensino e estudo do Direito Tributário na PUC-SP confunde-se com o início da trajetória acadêmica José Geraldo Ataliba Nogueira, mais conhecido por Geraldo Ataliba.

Nas décadas sessenta e setenta, Geraldo Ataliba, filho do catedrático da USP José Carlos de Ataliba Nogueira, notabilizou-se por obras como "Natureza Jurídica das Contribuições de Melhoria", de $1964^{1154}$, "Sistema Constitucional Tributário Brasileiro" (1966), “O Decreto-lei na Constituição de 1967” (1968), "Lei Complementar na Constituição de 1967" (1971) ${ }^{1155}$ e "Hipótese de Incidência Tributária", de $1973^{1156}$.

Chegou também, já como Livre-docente, e por indicação de José Carlos de Ataliba Nogueira (indicação que foi aprovada unanimemente pela Congregação da mesma Faculdade, na época presidida por Miguel Reale), a ser aceito para ministrar a disciplina Ciência das Finanças, no final da década de sessenta, na Faculdade de Direito da Universidade de São Paulo ${ }^{1157}$.

Mas seus primeiros passos rumo à Cátedra de Direito Tributário na PUC-SP consolidam-se pela conquista da Livre-Docência em Direito Financeiro pela Universidade

\footnotetext{
${ }^{1154}$ NOGUEIRA, José Geraldo Ataliba. Natureza Jurídica das Contribuições de Melhoria. Revista dos Tribunais, São Paulo, 1964, p. 32 e seguintes.

1155 BORGES, José Souto Maior. À Guisa do Prefácio. In: ATALIBA, Geraldo. Hipótese de Incidência

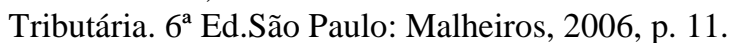

${ }^{1156}$ Idem.

${ }^{1157}$ Essa informação consta registrada nas Atas das Sessões da Congregação da Faculdade de Direito da USP, especialmente nas Atas de número 25(1968-1969) e 26 (1969-1970).
} 
de São Paulo, na década de sessenta, assumindo o lugar de Ruy Barbosa Nogueira na Faculdade de Direito da Pontifícia Universidade Católica de São Paulo, em 1968.

Ao mesmo tempo, naquela mesma Instituição, emergiu novo grupo de estudiosos, muitos deles originados do Direito Público, cujas reflexões passaram a refletir-se sobre o direito tributário, mas também profundamente influenciados por aquele particular ambiente político, marcado pelo Golpe Militar de 1964, e passam a desenvolver reflexões em pleno regime ditatorial, especialmente originárias entre a década de sessenta e setenta ${ }^{1158}$.

Além disso, fenômenos políticos (e jurídicos) ocorridos na década de sessenta influenciaram profundamente a linha de estudo defendida pelo notável professor nos estudos promovidos pela Faculdade de Direito da PUC-SP, de forma que, pode-se dizer, sinteticamente, que os seguintes aspectos influenciaram o Prof. Geraldo Ataliba na construção da Escola Paulista de Direito Tributário da PUC-SP, como foi tradicionalmente denominada: a) as transformações constitucionais perpetuadas pelas alterações à Constituição de 1946 (E.C. 18/1965, E.C.1/1967 e E.C.1/1969), e o sentimento de instabilidade constitucional; b) a repercussão do estudo de Alfredo Augusto Becker ${ }^{1159}$, a advogar o estudo (e o ensino) separado entre Direito Tributário e Ciência das finanças, amparado em Giannini, Pontes de Miranda, e outros teóricos da Teoria Geral do Direito e da Filosofia do Direito; c) a busca por método de estudo e ensino distinto do já praticado nos estudos de Direito Tributário na época, e notadamente à USP (e Ruy Barbosa Nogueira), além do esforço na divulgação deste mesmo método como substituto ao método da Escola da USP; d) o diálogo com outros interlocutores que compartilhavam ânimos semelhantes, a exemplo de José Souto Maior Borges e Paulo de Barros Carvalho; e) a influência e o diálogo com a renomados estudiosos de Direito Público da PUC-SP (notadamente no campo do Direito Constitucional, do Direito Administrativo e na Filosofia do Direito da Escola Paulista de Direito da PUC-SP), cujos estudos tinham grande predileção ao dogmatismo normativo kelseniano, a exemplo de Celso Antonio Bandeira de Mello, Adilson Dallari, no Direito Administrativo ${ }^{1160}$, Michel Temer, no Direito Constitucional, Tercio Sampaio Ferraz Júnior, na Teoria Geral do Direito, e Maria Helena

\footnotetext{
${ }^{1158}$ Para estudo histórico das circunstâncias que levaram ao desenvolvimento desta Escola, recomenda-se a leitura de: SUNDFELD, Carlos Ari. Os Publicistas da Geração de 60, a Turma de Perdizes e o Direito Tributário. In: Curso de Direito Tributário e Finanças Públicas. Do fato à norma, da realidade ao conceito jurídico. SANTI, Eurico Diniz de (Coord.). São Paulo: Saraiva-FGV, 2008, p.312-321.

${ }_{1159}$ BECKER, Alfredo Augusto. Teoria Geral do Direito Tributário. Op.cit., p. 19-20.

${ }^{1160}$ BANDEIRA DE MELLO, Celso Antônio. Teoria Geral do Direito. Op.cit., p. 04.
} 
Diniz. Note-se que o diálogo entre o Direito Tributário como disciplina do Direito Público favorecia o diálogo entre Direito Tributário, Direito Administrativo e Direito Constitucional entre seus estudiosos.

Por esses motivos, nas palavras de Carlos Ari Sundfeld, aspecto diferencial entre a "Turma de Perdizes", e seus publicistas, frente a outras linhas (notadamente a Faculdade de Direito do Largo São Francisco), residiria no seguinte: "Outra característica marcante da Geração de 1960 é de haver iniciado o seu trabalho no magistério quando surgiram os Cursos de Pós-graduação em Direito. Este fato criará uma importante diferença para com as gerações anteriores de publicistas, formadas por autodidatas, mais tendentes a misturar petição com doutrina e a usar argumentos que mais tarde viriam a ser criticados como políticos ou econômicos (por isso, "não jurídicos"). O grande paradigma para os publicistas da nova geração será o do "cientista". O positivismo de inspiração kelseniana servirá como o instrumento ideal para a afirmação da identidade do cientista jurídico". ${ }^{1161}$

Mas não se pode negar que as estratégias de estudo e ensino do Direito Tributário divulgadas na Faculdade de Direito da PUC-SP é também fruto de seu próprio ambiente político, profundamente marcado pela insegurança jurídica trazida pelo autoritarismo político reinante no período, favorecendo a necessidade de se encontrar justificativas teóricas destinadas a afastar considerações políticas, econômicas, sociológicas, tudo que pudesse contribuir para essa insegurança, sobretudo no aspecto constitucional ${ }^{1162}$.

O dogmatismo kelseniano, nesse contexto, é abraçado pela Faculdade de Direito da PUC-SP por atender a esses anseios, e a perspectiva do Direito Tributário analisado sob as premissas de uma ciência jurídica (e igualmente componente do ordenamento jurídico) passa a consolidar linha de argumentação crítica aos excessos autoritários, notadamente no âmbito das modificações constitucionais. ${ }^{1163}$

De grande importância para a consolidação da "Escola da PUC-SP" foi o intercâmbio com especialistas da época. Nesse sentido, conforme o testemunho de Geraldo Ataliba e Paulo de Barros Carvalho, o Curso de Especialização em Direito Tributário,

\footnotetext{
${ }^{1161}$ SUNDFELD, Carlos Ari. Op.cit., p. 316.

1162 Sobre o ambiente político no qual emergiu a influência de Hans Kelsen nas Faculdades de Direito, confira-se: CAMPILONGO, Celso Fernandes. KELSEN, o positivismo e o ensino do Direito nos anos 70. In: Curso de Direito Tributário e Finanças Públicas. Do fato à norma, da realidade ao conceito jurídico. SANTI, Eurico Diniz de (Coord.). São Paulo: Saraiva-FGV, 2008, p.329-344.

${ }^{1163}$ SUNDFELD, Carlos Ari. Op.cit., p. 320-321.
} 
promovido pela PUC-SP ${ }^{1164}$, recebeu a colaboração dos seguintes autores: Rubens Gomes de Sousa, Dino Jarach, Ramon Valdés Costa, Gilberto Ulhôa Canto, Aliomar Baleeiro, Antonio Roberto Sampaio Dória, Celso Antônio Bandeira de Mello, Josaphat Marinho, Fábio Fanucchi, José Eduardo Monteiro de Barros, Fernando Schneider e Fábio Monteiro de Barros $^{1165}{ }^{1166}$.

Note-se que a "Escola da PUC-SP" se voltava à colaboração com alguns dos grandes nomes da matéria na época (nacionais e estrangeiros) promovendo intercâmbio de ideias (incluindo-se autores com fortes laços com a Faculdade de Direito da USP, como Alcides Jorge Costa) que seria aprimorado pelo método de estudo e ensino praticado naqueles cursos de pós-graduação, e que, por sinal, refletia a tônica por excelência da Escola de Perdizes, buscando a instituição de uma “(...) filosofia de magistério inteiramente nova, na plataforma de sistemas já desgastados pela erosão dos tempos, (...)”. Tencionavam captar a elaboração de um “(...) raciocínio jurídico por excelência”"1167.

A oposição de Geraldo Ataliba às linhas de estudo e ensino que não compartilhavam seus ensinamentos poderia ser resumida na seguinte passagem: "Os pobres tributaristas - formados na escola da autonomia do direito tributário - souberam inventar sutilezas técnicas ridículas, com a distinção entre "fatos geradores" (linguagem equivocada e simplória, acientífica e denunciadora do primarismo da nossa literatura) instantâneos e complexivos (para horror do cientista Paulo de Barros Carvalho), mas não

\footnotetext{
${ }^{1164}$ Já a pós-graduação stricto sensu (mestrado e doutorado) foi implantada em 1973, e, portanto, dois anos depois da implantação do curso na Universidade de São Paulo. ATALIBA, Geraldo. Prefácio para esta Edição. In: MICHELI, Gian Antonio. Curso de Direito Tributário. Trad. Marco Aurélio Greco; Pedro Luciano Marrey Jr. São Paulo: RT, 1978, p. xiii-xvii.

${ }^{1165}$ É interessante notar que alguns estudiosos dos tempos heroicos do Direito Tributário (dentre eles Rubens Gomes de Sousa e Gilberto Ulhôa Canto), em seus últimos estudos, aparentaram apresentar maior proximidade com a metodologia de ensino e pesquisa promovida pela PUC-SP, prova de que Geraldo Ataliba tencionava reunir grandes mestres para elaborar contraproposta teórica ao ensino do Direito Tributário praticado no Brasil (e, sobretudo, na Faculdade de Direito da USP). ATALIBA, Geraldo; CARVALHO, Paulo de Barros. Apresentação. In: VI Curso de Especialização em Direito Tributário (Aulas e Debates). Volume I. São Paulo: Editora Resenha Tributária, 1978, p.xi.

${ }^{1166}$ No segundo semestre de 1975 foi promovido o VI Curso de Especialização em Direito Tributário na PUC-SP, que contou com a participação dos seguintes tributaristas (nacionais e estrangeiros): Alberto Xavier, Antonio Roberto Sampaio Dória, Fábio Fanucchi, Fernando J. Schneider, Geraldo Ataliba, Gian Antonio Micheli, Hector Villegas, José Juan Perez de Ayala, José Souto Maior Borges, Paulo de Barros Carvalho e Victor Uckmar. ATALIBA, Geraldo; CARVALHO, Paulo de Barros. Apresentação. Op.cit., p. xi-xii.

${ }^{1167}$ ATALIBA, Geraldo; CARVALHO, Paulo de Barros. Apresentação. VI Curso de Especialização em Direito Tributário (Aulas e Debates). Op.cit., p. xi-xii.
} 
foram capazes de sacar (na terminologia de Lourival Vilanova) o sentido de alcance do princípio da autorização orçamentária ou anualidade dos tributos" ${ }^{\prime 168}$.

\subsection{O intercâmbio teórico e a difusão do método jurídico da PUC-SP}

Consolidando histórica tradição dogmático-normativa de matriz kelseniana, a "Escola Paulista de Direito da Pontifícia Universidade Católica de São Paulo" foi responsável por construir uma das mais importantes linhas de pesquisa e ensino do Direito Tributário, emergente do panorama acima relatado, que, sob a liderança de Geraldo Ataliba $^{1169}$, lançou também importantes representantes, tendo por expressa influência as obras de Hans Kelsen ${ }^{1170}$, Alfredo Augusto Becker, Tércio Sampaio Ferraz Júnior ${ }^{1171}$, Eduardo Garcia Maynez ${ }^{1172}$, Edmund Husserl, Lourival Vilanova ${ }^{173}$, Norberto Bobbio ${ }^{1174}$, Carlos Cossio ${ }^{1175}$, Pontes de Miranda ${ }^{1176}$, entre outros, contando, inclusive, com a colaboração esporádica de autores estrangeiros, como Giuliani Fonrouge ${ }^{1177}$, Héctor Villegas $^{1178}$, e dos italianos Dino Jarach ${ }^{1179}$, Victor Uckmar e Gian Antonio Micheli ${ }^{1180}$,

${ }^{1168}$ ATALIBA, Geraldo. Prefácio. In: DERZI, Misabel Abreu Machado. Direito Penal, Direito Tributário e Tipo. Op.cit., p. 10.

${ }^{1169}$ ATALIBA, Geraldo. Hipótese de Incidência Tributária. $1^{\circ}$ Edição. São Paulo: Malheiros Editores, 1973.

${ }^{1170}$ KELSEN, Hans. Teoria Pura do Direito. $6^{\circ}$ Edição. Tradução: MACHADO, João Baptista. São Paulo: Martin Fontes, 1999, p. 01 e seguintes. A obra italiana foi traduzida como "La dottrina pura Del diritto. Traduzione di Renato Treves, Einaudi, Torino, 1952.

${ }^{1171}$ JÚNIOR, Tércio Sampaio Ferraz. A Ciência do Direito. São Paulo: Atlas, 1977, p.50-52.

1172 MAYNEZ, Eduardo García. Introducción a La lógica jurídica. Fondo de cultura econômica. México, s/e, 1951, p. 233. MAYNEZ, Eduardo García. Introducción al Estudio Del Derecho. México: Ed.cit., p.195 e seguintes.

${ }^{1173}$ VILANOVA, Lourival. Lógica Jurídica. São Paulo: José Bushatsky, 1976, p. 113-115; VILANOVA, Lourival. As Estruturas Lógicas e o Sistema de Direito Positivo. São Paulo: RT, 1977, p. 05 e seguintes.

${ }^{1174}$ BOBBIO, Norberto. Teoria da Norma Jurídica. Tradução: BAPTISTA, Fernando Pavan; SAUDATTI, Ariani. Bueno. São Paulo: EDIPRO, 2001, p. 01 e seguintes. BOBBIO, Norberto. Teoria do Ordenamento Jurídico. $10^{\text {a }}$ Ed. Brasília: Editora UNB, 1999, p. 32 e seguintes.

${ }_{1175}$ COSSIO, Carlos. La Valoración Jurídica y La Ciência Del Derecho, Buenos Ayres: Ed. Arayú, 1954, p.61 e seguintes.

${ }_{1176}$ MIRANDA, Francisco Cavalcanti Pontes de. Tratado de Direito Privado. Op.cit., p. 16 e seguintes.

${ }^{1177}$ Parte do livro "Derecho Financiero" de Fonrouge foi traduzido para o português por Geraldo Ataliba e Marco Aurélio Greco. FONROUGE, Giuliani. Conceitos de Direito Tributário. São Paulo: LAEL, 1973, p. 23 e seguintes.

1178 Roque Antonio Carrazza traduziu o livro de Héctor Villegas para a língua portuguesa. Outro livro traduzido pela equipe de professores da PUC-SP foi "Direito Penal Tributário". ATALIBA, Geraldo. Prefácio. In: VILLEGAS, Héctor B. Curso de Direito Tributário. São Paulo: RT, 1980, p. 01-02.

${ }^{1179}$ A influência do pensamento de Jarach na Escola da PUC-SP pode ser visualizada na seguinte passagem do prefácio de Ataliba, sobre a tradução do clássico estudo de Jarach traduzido por Dejalma Campos: "Vou 
além da forte colaboração do português Alberto Xavier, que, passando a residir no Brasil nesse período, a partir da década de setenta, contribui ativamente com a Escola, destacando-se por seus estudos relativos ao lançamento tributário, ao princípio da legalidade e tipicidade e, com grande notoriedade, no campo do Direito Tributário Internacional $^{1181}$.

Aliás, Lourival Vilanova, na Faculdade de Recife, apresenta importante influência na consolidação dos pilares da "Escola da PUC-SP", conforme reconhece o próprio Geraldo Ataliba: "Dentre os cientistas do direito tributário brasileiro, são exceções os discípulos de Lourival Vilanova, que aplicam suas lições com argúcia e oportunidade, como Paulo de Barros Carvalho e Souto Maior Borges (...)", assim como a influência de Alfredo Augusto Becker nessa Escola: “(...) Antes deles, e preocupado com igual linha de elevação científica e rigor técnico, Alfredo Augusto Becker" ${ }^{\text {1182. }}$

Além dos mencionados, essa renomada instituição reuniu diversos estudiosos, conforme o próprio Ataliba reconhece: "São nítidas vocações para o estudo teórico do direto, com excelentes resultados, Francisco Otávio de Almeida Prado, Cléber Giardino, Marco Aurélio Greco e Sacha Calmon Navarro Coêlho"1183. Notabilizaram-se também nomes como Roque Antônio Carrazza ${ }^{1184}$, Aires Barreto ${ }^{1185}$, Paulo de Barros Carvalho ${ }^{1186}$,

adotar esta tradução como texto obrigatório no meu curso de pós-graduação: o mesmo farão os profs. Paulo de Barros Carvalho, Souto Maior Borges, Misabel Derzi, Sacha Calmon e Ozíris Azevedo Lopes Filho. em: ATALIBA, Geraldo. Prefácio. In: JARACH, Dino. O Fato Imponível. $2^{\mathrm{a} E d}$. Trad. Dejalma de Campos. São Paulo: Rt, 2004, p. p. 05-07.

${ }^{1180}$ A obra de Gian Antonio Micheli foi traduzida por Marco Aurélio Greco e Pedro Luciano Marrey Jr. MICHELI, Gian Antonio. Curso de Direito Tributário. São Paulo: RT, 1978.

${ }^{1181}$ Dentre algumas importantes obras publicadas pelo autor português no Brasil citam-se: XAVIER, Alberto. Do lançamento no Direito Tributário Brasileiro, São Paulo, 1977; XAVIER, Alberto. Os Princípios da Legalidade e da Tipicidade da Tributação. São Paulo: Editora RT, 1978. XAVIER, Alberto. Conceito e natureza do acto tributario. Coimbra, Livr. Almedina, 1972. Cap.1. Tipicidade da Tributação, Simulação e Norma Antielisiva. São Paulo, Dialética, 2001, entre outros a seguir citados.

${ }^{1182}$ ATALIBA, Geraldo. Prefácio. In: DERZI, Misabel Abreu Machado. Direito Tributário, 1. ed. São Paulo: Revista dos Tribunais, 1988, p. 12.

${ }^{1183}$ Idem.

${ }^{1184}$ Em seus primeiros trabalhos, Carrazza mostra alinhamento às premissas kelsenianas (ponderado), que pressupôs "correta e apta a explicar a maioria dos fenômenos jurídicos". CARRAZZA, Roque Antonio. O Sujeito Ativo da Obrigação Tributária. São Paulo: Resenha Tributária, 1977, p 25 e ss. Contudo, em estudos posteriores o mesmo autor admitiu importantes ressalvas à doutrina kelseniana: "Embora adeptos de Hans Kelsen, queremos, desde logo, consignar que, neste trabalho, não levamos sua teoria às últimas consequências. Tanto é assim que, em mais de uma passagem admitimos: a) a existência do direito subjetivo; b) a distinção entre nulidade e anulabilidade; c) a inconstitucionalidade das normas jurídicas; d) a função axiológica dos princípios jurídicos no sistema do Direito; e, e) que só a interpretação sistemática é válida": CARrAZZA, Roque Antonio. Princípios Constitucionais Tributários e Competência Tributária. Op.cit., p. 01 e seguintes.

${ }^{1185}$ BARRETO, Aires. Base de Cálculo, Alíquota e Princípios Constitucionais. São Paulo: RT, 1986, p. 09 e seguintes. 
Elizabeth Nazar Carrazza ${ }^{1187}$, Américo Masset Lacombe ${ }^{1188}$, José Eduardo Soares de Melo $^{1189}$, Diva Malerbi ${ }^{1190}$, Marçal Justen Filho (antes de migrar para o estudo do direito administrativo) $^{1191}$, além de difundir estudos estrangeiros (a exemplo dos trabalhos de Uckmar $^{1192}$, Villegas ${ }^{1193}$, Jarach $^{1194}$, Micheli ${ }^{1195}$, e Fonrouge ${ }^{1196}$ ), no Direito Tributário Brasileiro.

Da mesma forma, renomados estudiosos de outras regiões do Brasil foram estudar na "Escola Paulista de Direito Tributário da PUC-SP", apresentando harmonização com seus pressupostos, a exemplo de Misabel Derzi ${ }^{197}$ e Sacha Calmôn Navarro Coêlho ${ }^{1198}$.

Agregue-se também a esse grupo a interlocução com estudiosos de outras regiões, e principalmente, com o intercâmbio intelectual de José Souto Maior Borges, em Recife.

O intercâmbio inicial com José Souto Maior Borges e a Escola da PUC-SP também merece expressa menção, já que o Professor da Faculdade de Recife apresentava importantes características assemelhadas à linha de pesquisa da PUC-SP, tendência já identificável em seus primeiros estudos. A proximidade com esses pressupostos levou-o a alçar forte vínculo com os principais representantes daquela "Escola", como Geraldo

1186 CarValhO, Paulo de Barros. Teoria da Norma Tributária. São Paulo: Saraiva, 1974, p. 03 e seguintes.

1187 CARRAZZA, Elizabeth Nazar. Progressividade e IPTU. Curitiba: Editora Juruá, 1992, p. 18 e seguintes.

${ }^{1188}$ LACOMBE, Américo Masset. Obrigação tributária. São Paulo, Revista dos Tribunais, 1977, p.13 e seguintes.

${ }^{1189}$ MELO, José Eduardo Soares de. Curso de Direito Tributário. São Paulo, Dialética, 2006, p. 12 e seguintes.

${ }^{1190}$ MALERBI, Diva Preste Marcondes. Elisão Tributária. São Paulo: Revista dos Tribunais, 1984, p. 09 e seguintes.

${ }^{1191}$ Neste trabalho, o autor, adota como premissas epistemológicas gerais a construção de Hans Kelsen (com ponderações). FILHO, Marçal Justen. Sujeição Passiva Tributária. Belém: CEJUP, 1986, p. 01 e seguintes.

${ }^{1192}$ UCKMAR, Victor. Princípios Comuns de Direito Constitucional Tributário. Trad. Marco Aurélio Greco. São Paulo: Malheiros, 2001, p. 10 e seguintes.

1193 VILLEGAS, Héctor. Curso de Direito Tributário. Op.cit., p.100-101.

1194 ATALIBA, Geraldo. In: Prefácio. JARACH, Dino. O Fato Imponível. 2 edição. Tradução de Dejalma Campos. São Paulo: LTr, 2004, p. 96.

1195 MICHELI, Gian Antonio. Curso de Direito Tributário. Op.cit., p. 17 e ss.

${ }^{1196}$ FONROUGE, Giuliani. Conceitos de Direito Tributário. Trad. Geraldo Ataliba e Marco Aurélio Greco. São Paulo: LAEL, 1973, p.87.

${ }^{1197}$ DERZI, Misabel. Direito Tributário, Direito Penal e Tipo. 1. ed. São Paulo: Revista dos Tribunais, 1988 , p. 17 e seguintes.

${ }^{1198}$ COÊLHO, Sacha Calmon Navarro. Convênios competência isencional. 1. ed. Belo Horizonte: Instituto de Técnica Tributária, 1974, p. 13 e seguintes. COÊLHO, Sacha Calmon Navarro. Curso de Direito Tributário Brasileiro. $3^{a}$. ed. Rio de Janeiro: Companhia Editora Forense, 1999, p. 115 e seguintes. 
Ataliba e Paulo de Barros Carvalho, motivando-o a participar ativamente da construção das premissas epistemológicas e metodológicas fundamentais daquela Escola ${ }^{1199}$.

Conforme o amadurecimento dos estudos de Souto Maior Borges, esse passa a empreender esforços em busca de afastar o chamado "sincretismo metodológico” “(...) que mescla o método jurídico, com investigações extrajurídicas, a dogmática e as investigações extradogmáticas". ${ }^{1200}$ Esse ponto de vista foi amadurecido em seu estudo "Obrigação Tributária: uma introdução metodológica", onde a necessidade da unidade metodológica deveria ser considerada elemento fulcral aos estudos do Direito Tributário ${ }^{1201}$.

Além de intercâmbios teóricos com importantes estudiosos de renome nacional, a divulgação dos estudos dessa Escola foi favorecida pela criação, em 1967, da Revista de Direito Público - RDP (sob os cuidados da Editora Revista dos Tribunais) que, na época, foi dirigida por Geraldo Ataliba e Celso Antonio Bandeira de Mello, muito embora inicialmente tenha sido identificada como publicação da Universidade de São Paulo. ${ }^{1202}$ 1203 Além disso, o IDEPE, Instituto Internacional de Direito Público e Empresarial, fundado em 1975, posteriormente renomeado como Instituto Geraldo Ataliba - IGAIDEPE,consolidou-se como importante veículo para divulgação e desenvolvimento dos trabalhos viabilizados por estudiosos familiarizados com os ensinamentos da Escola de Perdizes $^{1204}$.

${ }^{1199}$ A proximidade acadêmica e pessoal de Souto Maior Borges especialmente com Lourival Vilanova, Geraldo Ataliba e Alfredo Augusto Becker pode ser observada em BORGES, José Souto Maior. Ciência Feliz, $2^{\circ}$ Edição. São Paulo: Max Limonad, 2000, p. 151 e seguintes.

${ }^{1200}$ Para o autor, mantendo convergência com os ensinamentos da PUCSP, “(...) O sincretismo é um atentado contra a pureza metodológica e ao mesmo tempo contra o monismo que deve caracterizar as ciências modernas, como o seu critério de demarcação. Misturam-se por essa via, antes um desvio epistemológico, saberes regidos por campos científicos diversos. A matéria-prima do direito é convertida numa colcha de retalhos (...)". BORGES, José Souto Maior. Curso de Direito Comunitário. Op.cit., p. 09 e seguintes.

${ }^{1201}$ Sobre a vinculação das premissas da teoria geral do direito na obra do autor, conferir: BORGES, José Souto Maior. Obrigação Tributária (uma introdução metodológica). 2ª̃d. São Paulo: Malheiros, 1999, p. $19-46$.

${ }^{1202}$ Sundfeld destaca que a sede dos paulistas na Geração de 60 não seria a Escola da Universidade de São Paulo, mas a Escola da PUC-SP, fator favorecido por Oswaldo Aranha Bandeira de Mello ter assumido na década de setenta a Reitoria da Universidade, acatando as iniciativas de Celso Antonio Bandeira de Mello e Geraldo Ataliba, no intuito de divulgar os estudos daquela. Mais tarde, na entre 1973 e 1976, Ataliba e Celso Antonio assumem a Reitoria e a Vice-reitoria respectivamente, instigando ainda mais a formação de novos estudiosos, a partir da década de setenta. SUNDFELD, Carlos Ari. Op.cit., p.316-317.

${ }^{1203} \mathrm{Na}$ época também houve a criação da Revista de Direito Tributário - RDT, sob a iniciativa de Ataliba, o que favoreceu a divulgação de estudos sob aquelas premissas teóricas, especialmente no particular método de investigação jurídica aplicada ao direito tributário assim como congressos e institutos posteriormente criados com esse intuito, o de divulgar o método de investigação da Escola da PUC-SP. Idem, p. 317.

${ }_{1204}$ Tal entendimento é comprovado pelo testemunho Eurico Diniz de Santi, ao identificar as quatro linhas de estudo atuantes naquele Instituto: “(i) o modelo teórico constitucional de Geraldo Ataliba, de vocação 
Através desses inúmeros esforços, consolida-se a chamada "Escola da PUC-SP", que passou a dividir em influência com a "Escola da USP" o plantel de principal centro de estudo e ensino do Direito Tributário, chegando, em muitos aspectos também pela inteligente estratégia difusora e divulgadora de Geraldo Ataliba (dedicado a divulgá-la em outras regiões do Brasil, bem como em outros países), assim como pelo ambiente histórico favorável à elevação do dogmatismo jurídico normativo kelseniano, a superar a última em influência, naquele período em diante, especialmente em outras regiões do Brasil ${ }^{1205}$.

\subsection{O esforço na harmonização de premissas jurídicas aplicáveis ao Direito} Tributário e as características da Faculdade de Direito da PUC-SP.

Por outro lado, a necessidade de identificação das mesmas premissas epistemológicas e metodológicas defendidas pela "Escola da PUCSP" (método científicojurídico por excelência), leva ao afastamento de estudiosos originalmente inseridos nesse quadro que passam a aplicar linhas epistemológicas e metodológicas distintas daquela ensinada por Geraldo Ataliba, como foi o caso de Marco Aurélio Greco, introdutor da Teoria Funcional do Direito Tributário, que concede outra visão à tradicional relação jurídica obrigacional no Direito Tributário ${ }^{1206}$, criticando fundamentalmente o entendimento tradicional de Direito Público (para quem tal concepção estaria em crise).

publicista e matriz kelseniana, valorando as noções de república, democracia, legalidade, sistema e princípios; (ii) o arcabouço e o rigor de Celso Antonio Bandeira de Mello, dando concretude, sentido e controle aos mesmos valores de Ataliba, no plano da aplicação do direito; (iii) a hermenêutica histórica, também inspirada em Kelsen e Pontes, que marca a inquietante trajetória do incansável pensador José Souto Maior Borges, cuidando da autorreflexão necessária para a saudável epistemologia de uma ciência feliz do direito tributário; e, enfim, (iv) o constructivismo lógico-semântico de Paulo de Barros Carvalho, outorgando coerência e didática aos conceitos fundantes dessa Escola, no plano normativo com a poderosa regra-matriz de incidência, e no plano dos fatos com a importante distinção evento/fato, revolucionária na reflexão sobre os limites da prova no direito". Note-se, portanto, que as quatro linhas de estudo identificadas pelo autor nos trabalhos do IDEPE-IGA apresentam como pano de fundo o fato de terem sido construídas sob os auspícios da Escola da PUC-SP ou harmonizadas com suas premissas fundamentais. SANTI, Eurico Diniz de. Direito tributário em rede e desenvolvimento: Prefácio em Homenagem ao Prof. Aires Barreto. In: Transparência Fiscal e Desenvolvimento. Homenagem ao Professor Isaias Coelho. Coordenação: Eurico Marcos Diniz de Santi, Basile Georges Christopoulos, Daniel Leib Zugman, Frederico Silva Bastos. São Paulo: Fiscosoft, 2013, p. 04.

${ }^{1205}$ Primeiro Titular da Cadeira de Direito Tributário da PUC-SP, Geraldo Ataliba desapareceu precocemente, aos 58 anos de idade, em 1995. Tamanha perda, no entanto, não interrompeu o progresso dos estudos promovidos pela "Escola Paulista de Direito Tributário", que continuou se desenvolvendo através de seus sucessores. Nesse sentido, a Cátedra de Direito Tributário foi assumida pelos seguintes titulares: Paulo de Barros Carvalho (1984), Roque Antônio Carrazza (1989) e José Eduardo Soares de Melo (2012).

1206 GRECO, Marco Aurélio. Dinâmica da tributação e procedimento. 1. ed. São Paulo: Revista dos Tribunais, 1979, p. 06-13. 
O estudioso, apresentando posteriormente maior contato com a literatura italiana, começa a desenvolver estudos aproximados à chamada "Escola Funcionalista" ou "Escola Dinâmica" ou "Procedimentalista" do Direito Tributário ${ }^{1207}$, que basicamente negava a existência de uma relação jurídico-tributária obrigacional, um dos principais pontos de apoio do Direito Tributário (não somente no Brasil), cuja visão influenciou predominantemente o Direito Tributário brasileiro (artigo 113 do CTN), e plenamente adotada pelos estudiosos adeptos dos ensinamentos daPUCSP. ${ }^{1208}$

Por representar posicionamentos distintos das premissas fundamentais do estudo do Direito Tributário exercido pela PUCSP, Marco Aurélio Greco perdeu espaço nos quadrantes daquela Escola, passando a exercer seus estudos individualmente, sem o apoio de Geraldo Ataliba e dos demais integrantes da PUCSP, o que não impediu, naturalmente, assim como outros autores, a investigar o direito tributário positivo a partir de suas próprias premissas investigativas.

Essa circunstância peculiar, contudo, sob o ponto de vista do processo disciplinar, e da autonomia do ensino, representa importante indício histórico do esforço na construção de uma harmonização de premissas epistemológicas e metodológicas entre os integrantes de determinada Escola, característica que na experiência estrangeira favorece $o$ reconhecimento de uma Escola do Direito Tributário. Essa característica, particularmente presente nos quadrantes da Escola da PUC-SP, se aperfeiçoará no ambiente acadêmico posterior.

\footnotetext{
${ }^{1207}$ Para essa linha de pesquisa não haveria uma relação tributária obrigacional, mas um conjunto de atos e procedimentos destinados a harmonizar duas situações jurídicas (Poder de Império e Dever do Contribuinte). Assim, a compreensão da relação tributária como relação procedimental, formada pelo conjunto de procedimentos que levaria à criação, fiscalização, cobrança e arrecadação do tributo, fundamentada no Poder de Império, de um lado, e do Dever do Contribuinte de pagar o imposto, demonstra o reconhecimento do poder de imposição inserto na relação entre Fisco e Contribuinte. Reconhecer a natureza dessa função seria a melhor forma de equilibrar os interesses entre contribuinte e Poder Público, o que não seria verdadeiramente proporcionado pela visão tradicional da relação jurídica tributária obrigacional da doutrina majoritária. MAFFEZZONI, Frederico. Profili di una Teoria Giuridica Generale Dell'Imposta. Milano: Giuffrè, 1969, p. 61. MICHELI, Gian Antonio. Corso di Diritto Tributário, $4^{\circ}$ ed. Ver. Aum. Torino: Utet, 1978, p. 161 e seguintes. FANTOZZI, Augusto. Diritto Tributário. UTET, 1991, p. 16-18. AYALA, José Luiz Perez de; e GONZALEZ, Eusébio. Curso de Derecho Tributário. Madrid: EDERSA, 1975, p. 10 e seguintes.

${ }^{1208}$ Marco Aurélio Greco enxerga que a tradicional visão aplicada ao Direito Tributário mantinha o sujeito passivo em clara posição de subserviência e passividade do contribuinte perante o Poder Público. A visão dinâmica buscaria ultrapassar a visão do tributo como expressão de um poder tributário, mas compreender que o “(...) núcleo do fenômeno tributário está em conceber a tributação como exercício de uma atividade no desempenho de uma função, pois isto implicará deslocar a sociedade de mera destinatária e submetida ao poder formal, para assumir o papel de protagonista positiva do direcionamento a imprimir esta função". GRECO, Marco Aurélio. Do Poder à Função Tributária. In: FERRAZ, Roberto. Limites e Princípios da Tributação 2. São Paulo: Quartier Latin, 2009, p. 165-176.
} 
Diante desse panorama, as características da linha de pesquisa e ensino defendida por Geraldo Ataliba na Escola da PUC-SP podem se subsumir nos seguintes aspectos: a) o estudo do direito tributário positivo a partir de seu cume constitucional, para daí, em escala decrescente, analisar o tema de estudo proposto: em outras palavras, foi um dos principais defensores (senão o maior) da estabilidade, da rigidez e do fechamento sistemático da Constituição Tributária no Brasil; b) o dualismo epistemológico (negação do diálogo entre Direito Tributário e Ciência das Finanças): o Direito deve ser estudado em separado aos demais ramos do conhecimento e alheio à influencias econômicas, cujos fundamentos teóricos remontam aos ensinamentos de Hans Kelsen, Pontes de Miranda e Alfredo Augusto Becker; c) a elevação dos pressupostos de estudo da Ciência do Direito, da Lógica Jurídica e da Teoria Geral do Direito, como alicerces teóricos para os estudos de Direito Tributário; d) a preferência à doutrina tributária nacional, sobretudo para elevar o autêntico "Direito Tributário Brasileiro", e suas especificidades, naturalmente distintas de outros países: busca-se a consolidação de uma doutrina autenticamente brasileira, em detrimento das doutrinas "alienígenas" ${ }^{1209}$; e) o intercâmbio acadêmico, através de cursos de aperfeiçoamento, jornadas, congressos, que reuniram estudiosos de vários cantos do país, e até alguns renomados estudiosos de língua espanhola e italiana, onde o mais célebre de todos foi o tradicional Curso de Especialização em Direito Tributário (cuja primeira edição ocorreu em 1971) ${ }^{1210}$, cujos estudos, largamente repercutidos na literatura tributária brasileira a partir da década de setenta, mostravam as pretensões pedagógicas daqueles que dali participavam e também incentivavam os métodos de pesquisa e ensino consolidados nessa Escola ${ }^{1211}$.

\footnotetext{
${ }^{1209}$ ATALIBA, Geraldo. Prefácio. In: DERZI, Misabel Abreu Machado. Op.cit., p. 07-16.

${ }^{1210}$ VI Curso de Especialização em Direito Tributário (Aulas e Debates). Volume I. São Paulo: Editora Resenha Tributária, 1978, p. xi-xiv.

${ }^{1211}$ É particularmente interessante a crítica formulada por Geraldo Ataliba, que sintetiza a plêiade de suas oposições à "Escola da autonomia do Direito Tributário" (referindo-se à Escola da USP): "O preconceito da autonomia do direito tributário foi tão solidamente implantado entre nós - graças exatamente à generalizada ignorância e deficiente formação cultural - que se entendeu que estudar direito tributário não era preocupação dos juristas, mas sim de economistas e contabilistas voltados para normas jurídicas de escalão inferior, porque práticas e de aplicação imediata. (...) É preciso que constitucionalistas, como os juristas em geral, saibam que nenhuma peculiaridade maior apresenta o direito tributário que o afaste do universo geral do direito e, ainda, é preciso que saibam que a unidade fundamental do direito não perdoa nem justifica a desconsideração com que tem sido visto o direito tributário pelos juristas em geral (por culpa dos tributaristas, que aos olhos de terceiros passam por conhecedores do direito, quando não são mais que contabilistas dos regulamentos). É preciso resgatar a elaboração exegética das normas tributárias, para reintegrá-la no universo jurídico. É imperioso repor o direito tributário no mundo do direito e subordinado ao direito constitucional". Idem, p. 11.
} 
A Faculdade de Direito da PUC-SP, embora não apresente uma teoria estrutural própria baseada no conjunto da obra de um líder (Geraldo Ataliba) ou líderes nos quais a estratégia de estudo e ensino se pautariam, apresenta características que aproximam-a mais da ideia de "Escola Científica ou Filosófica", sobretudo perante os esforços introdutórios identificados na Faculdade de Direito da USP.

A Escola Paulista de Direito Tributário, enquanto introdutora do estudo e do ensino sob a perspectiva do formalismo jurídico no direito tributário brasileiro, dá um passo importante à construção posterior das Escolas Científicas ou Filosóficas do Direito Tributário no Brasil (segundo as premissas previamente adotadas neste estudo).

Note-se que a Faculdade de Direito da PUC-SP tinha como expressa motivação apresentar-se como proposta alternativa à praticada na USP, naquele período inicial.

Não por acaso, inicia, com ela, o período de formalismo jurídico no ensino e pesquisa do Direito Tributário na realidade brasileira. Por outro lado, embora aplicasse o positivismo normativo kelseniano (ainda que com ponderações), e defendesse a necessidade do estudo da teoria geral do direito e da lógica jurídica aplicada ao estudo e ao ensino do direito tributário, não apresentava, através de seu líder, uma teoria estrutural própria aplicável ao Direito Tributário, mas a aplicação de teorias estruturais construídas por outros autores (Geraldo Ataliba foi substancialmente influenciado pelas teorias estruturais de Hans Kelsen, Alfredo Augusto Becker, Dino Jarach, etc).

Também se posicionou politicamente, já que apresentava, em muitas de suas construções, verdadeira peça de resistência perante os desmandos da ditadura militar naquele período, posição que não se identificava com tanta expressão na Faculdade de Direito da USP. O raciocínio jurídico por excelência, era, na visão desses renomados estudiosos, o raciocínio positivista kelseniano por excelência (ainda que com evidentes ponderações, como a atenção à principiologia constitucional tributária).

Apresenta, portanto, maior aproximação à ideia de Escola Acadêmica ou Científica do que a Escola da USP, o que pode ser observada tanto pelo ambiente acadêmico histórico mais favorável (pois já existia uma proposta anterior a ser refletida e, eventualmente, criticada), seja pelas influências, naquele contexto histórico, do dogmatismo kelseniano e da refração à instabilidade política marcante naquele período. 
Contudo, a influência daquelas Faculdades de Direito, naqueles específicos e particulares contextos históricos não foi suficientemente forte para intimidar outras propostas de estudo ou teorias, nem sempre harmônicas com as propostas anteriores.

\section{As contribuições teóricas além do "Eixo USP x PUCSP" no período.}

Naturalmente, a consolidação das citadas Faculdades de Direito no período da década de setenta e oitenta não afastou a possibilidade do desenvolvimento de outros estudiosos não necessariamente alinhados aos pressupostos de estudo e ensino daquelas Escolas já mencionadas.

Nesse sentido, pode-se mencionar a contribuição de Ives Gandra da Silva Martins $^{1212}$ e Fábio Fanucchi ${ }^{1213}$, à frente da tradicional faculdade de Direito da Universidade Presbiteriana Mackenzie, instituição do qual fizeram parte, seja como alunos ou professores, estudiosos do porte de Henry Tilbery ${ }^{1214}$ (ainda que este autor tivesse forte

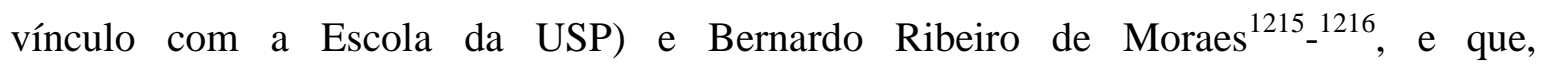
posteriormente, foram somados às contribuições de Edvaldo Pereira de Brito (UFBA e Mackenzie) ${ }^{1217}$, Eduardo Marcial Ferreira Jardim (Mackenzie e PUC-SP) ${ }^{1218}$ e Luciano Amaro (Mackenzie) ${ }^{1219}$. Note-se, contudo, que a maioria destes autores teve formação

\footnotetext{
${ }^{1212}$ MARTINS, Ives Gandra da Silva. Teoria da Imposição Tributária. São Paulo: Saraiva, 1983, p.27 e seguintess; MARTINS, Ives Gandra da Silva. Direito Constitucional Tributário. Pareceres. BELÉM: CEJUP, 1985, p. 17 e seguintes.

${ }^{1213}$ FANUCCHI, Fábio. Curso de direito tributário. 4.ed. Resenha Tributária, 1976, p.16 e seguintes. FANUCCHI, Fábio A decadência e a prescrição no direito tributário. Resenha Tributária, 1976, p. 11 e seguintes.

${ }^{1214}$ TILBERY, Henry. Tributação e Integração da América Latina. São Paulo: José Bushatshky, 1971, p. 11 e seguintes. TILBERY, Henry. A tributação dos ganhos de capital. São Paulo: Resenha Tributária, 1977 , p. 25 e seguintes.

${ }^{1215}$ MORAES, Bernardo Ribeiro de. Compêndio de Direito Tributário. Primeiro e Segundo Volumes. $3^{\text {a }}$ Ed. Forense: Rio de Janeiro, 1995, p.xv.

${ }^{1216}$ Sobre o Compêndio de Direito Tributário (escrito por Bernardo Ribeiro de Moraes em dois volumes), Ives Gandra da Silva opinou: "Creio que os dois compêndios clássicos do nosso direito são os de Rubens Gomes de Sousa e de Bernardo, muito embora excelentes cursos de Direito Tributário tenham surgido, destacandose, entre outros, os escritos de Celso Bastos, Ruy Barbosa Nogueira, Roque Carrazza, Paulo de Barros Carvalho, Zelmo Denari e Hugo de Brito Machado". MARTINS, Ives Gandra da Silva. Prefácio. MORAES, Bernardo Ribeiro de. Compêndio de Direito Tributário. Volume I. Rio de Janeiro: Forense, 1993, s/p.

${ }_{1217}$ BRITO, Edvaldo Pereira de. IPI: Fato Gerador da Importação. Revista Tributaria e de Finanças Públicas, v. 45, São Paulo: Rt, 2002, p. 204-242.

${ }^{1218}$ JARDIM, Eduardo Marcial Ferreira. Manual de Direito Financeiro e Tributário. 1ª ed. São Paulo: Editora Saraiva, 1993, p. 43 e seguintes.

${ }^{1219}$ AMARO, Luciano. Direito Tributário Brasileiro. 11 Ed. São Paulo: Saraiva, 2005, p. 10 e seguintes.
} 
oriunda da USP ou da PUC-SP, motivo pelo qual é possível observar alinhamentos teóricos a uma dessas Faculdades, ainda que com reservas.

Não obstante, o progresso disciplinar do Direito Tributário registra, mesmo entre estudiosos institucionalmente vinculados às Faculdades de Direito da USP e da PUCSP, estudos autônomos, isto é, sem guardar as características primordiais inerentes àquelas Escolas, como é possível observar em Bernardo Ribeiro de Moraes que, na década de setenta, foi também assistente do Prof. Geraldo Ataliba na Disciplina Direito Tributário, na PUC-SP, ou mesmo sem necessariamente se vincular institucionalmente a uma das citadas entidades, como se observa em Kioshi Harada ${ }^{1220}$, Yoshiaki Ichihara ${ }^{1221}$, entre muitos outros.

Contudo, a autonomia de pensamento frente às Faculdades de Direito da PUC e USP pode ser demonstrada no manifesto de Ives Gandra Martins: "No país, duas linhas de ensino são bem detectáveis, na propedêutica do direito tributário: aquela corrente dos que reduzem sua fenomenologia, pelo prisma jurídico, a objeto de uma ciência instrumental, desnecessário se fazendo o conhecimento da economia, contabilidade, finanças públicas e ciências que o influenciam, e a corrente dos que universalizam o fenômeno tributário, interpretando a instrumentalidade do direito à luz de todas as ciências que o impactam. À evidência, a produção literária, tanto dos formalistas como quanto dos estruturalistas, termina por veicular a pessoal visão de seus autores, com o que não poucas vezes a divergência doutrinária ultrapassa os limites da investigação científica, adentrando o campo das preferências e antipatias temáticas. Embora fecunda a polêmica travada pelas duas correntes, a zona fronteiriça entre a pesquisa científica e a mera preferência dogmática inúmeras vezes distorce os objetivos, dificultando aos estudiosos a percepção nítida do que representa, na veiculação doutrinária, convicção científica e opção ideológica",1222_ ${ }^{1223}{ }^{1224}$.

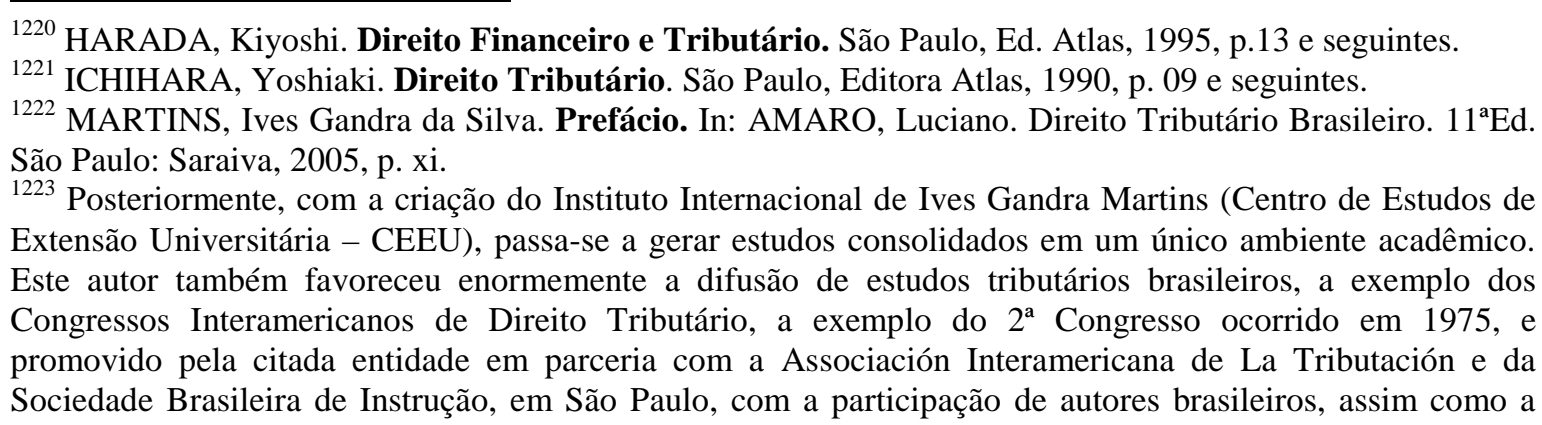


Ademais, a contribuição acadêmica de Hugo de Brito Machado, em Fortaleza, também poderia ser classificada como esforço intelectual individual, consolidado na grande contribuição acadêmica do professor, cujo manual didático intitulado "Curso de Direito Tributário", com primeira edição em 1979, consagra trajetória na pesquisa do direito tributário. Mas, por outro lado, Hugo de Brito nunca se alinhou plenamente às perspectivas de estudo acima citadas, criando linha de estudo e de ensino próprio de investigação do direito tributário, ainda hoje ininterrupta ${ }^{1225}$.

Além disso, deve-se lembrar da histórica contribuição de Brandão Machado, um dos fundadores do Instituto Brasileiro de Direito Tributário, que influenciou fortemente os estudos jurídico-tributários no quadrante da Faculdade de Direito da USP, tendo inclusive incentivado Ruy Barbosa Nogueira no desafio da institucionalização da disciplina na Faculdade de Direito da USP, e reconhecido como exímio pesquisador, jurista e filólogo.

Embora não vinculado a qualquer instituição de ensino, e mantendo plena autonomia de pensamento perante os principais autores da época, a linha de investigação atenta às contribuições estrangeiras (notadamente germânicas, inclusive dedicando-se à tradução de importantes obras e artigos estrangeiros, além de ter elaborado preciosos

organização do próprio Ives Gandra Martins (enquanto coordenador), Cândido Mendes, Miguel Colasuonno, Manuel de Juano, Américo Masset Lacombe, Hamilton Dias de Souza e Edgard Neves da Silva. Aliás, na época, os estudos do argentino Manuel de Juano, também foram bem recebidos pela doutrina nacional. JUANO, Manuel de. Curso de Finanzas y Derecho Tributario, $2^{\mathrm{a}}$ ed., Rosario, Ediciones Molachino, 1969, p. 23 e seguintes. MARTINS, Ives Gandra da Silva. Apresentação. In: In: BONILHA, Paulo Celso Bergstrom. Da Educação Tributária como fator de desenvolvimento econômico e social. Op.cit., s/p. Da mesma forma, no Centro de Extensão Universitária foi elaborada coletânea de artigos organizada por Americo Masset Lacombe e Ives Gandra Martins, sob o título "Noções de Direito Tributário", publicada em São Paulo: LTR, sintetizando as aulas sobre direito tributário ministradas no centro de estudos de extensão universitária, em 1973, contando com a colaboração de Américo Masset Lacombe, Arthur Carlos A. Pereira Gomes, Hamilton Dias de Souza, Ives Gandra da Silva Martins, José Carlos Graça Wagner, Rubens Approbato Machado, Silvio Feliciano Soares, Walter Barbosa Correa e Ilves José de Miranda Guimarães. MARTINS, Ives Gandra da Silva. LACOMBE, Américo Masset. Noções de Direito Tributário. São Paulo: Ltr, 1973, p. 09 e ss.

${ }^{1224}$ Além dos institutos já mencionados, vale citar também a ABDF - Academia Brasileira de Direito Financeiro, que sucedeu o IBDF (1949) no Rio de Janeiro, liderada originalmente por Tito Rezende e, depois por Gilberto Ulhôa Canto, na época; a ABDT, Academia Brasileira de Direito Tributário, fundada em 1987, em São Paulo, às vésperas da Constituição de 1988.

${ }^{1225}$ A primeira edição do curso do autor foi publicada em 1979: MACHADO, Hugo de Brito. Curso de Direito Tributário. $1^{a}$. ed. Resenha Tributária: São Paulo, 1979. Sobre a obra, Ives Gandra Martins ponderou: "Hugo Machado, professor da Univesidade de Fortaleza e Juiz Federal da 2a Vara no Ceará, temse revelado estudioso profundo e cultor dedicado do direito tributário. Seu nome, hoje conhecido nacionalmente, é sempre lembrado pela seriedade da doutrina, que desvenda e realiza, assim como pela variedade dos temas, que aborda, sobre as mais diversas áreas impositivas do país”. MARTINS, Ives Gandra da Silva. Apresentação (da $1^{a}$ Edição) In: MACHADO, Hugo de Brito. Curso de Direito Tributário. 27 Ed. São Paulo: Malheiros, 2006, s/p. 
prefácios a obras nacionais e estrangeiras ${ }^{1226}$ ) e ao estudo histórico do direito tributário foi severamente intensificada com as lições desse mestre. Foi também um dos grandes responsáveis pela tradição do chamado "Festschrift" no Direito Tributário Brasileiro (coletânea de estudos organizadas para homenagear determinado estudioso ou professor renomado) ${ }^{1227}$. Seus estudos ${ }^{1228}$ exerceram grande influência na literatura tributária brasileira, e, sobretudo, entre estudiosos e alunos que participavam da mesa de debates do Instituto Brasileiro de Direito Tributário, do qual foi um dos fundadores, na época entidade complementar à Faculdade de Direito da USP ${ }^{1229}{ }_{-}^{1230}$.

Note-se, portanto, que embora as estratégias de ensino e pesquisa das Faculdades de Direito da USP e da PUCSP apresentassem forte influência acadêmica no período, ao mesmo tempo foi possível compreender a existência de estudiosos que procuraram manter e desenvolver linhas de pesquisa até certo ponto autônomas, ainda que isso significasse a eventual colaboração com os estudos produzidos naquelas instituições, e ainda que, na maioria das vezes, esses mesmos autores apresentassem fortes vinculações (ainda que de formação) àquelas supracitadas Escolas.

\footnotetext{
${ }^{1226}$ MACHADO, Brandão. Prefácio do Tradutor. In: HARTZ, Wilhelm. Interpretação da Lei Tributária. São Paulo: 1993, p. 05-27; MACHADO, Brandão. Prefácio. In: MORAES, Oswaldo de. Curso de Legislação Tributária. São Paulo, 1974, p. VII-XV, entre outros.

${ }^{1227}$ Direito Tributário - Estudos em Homenagem ao Prof. Ruy Barbosa Nogueira, Brandão Machado (Coord.). São Paulo: Saraiva, 1984.

${ }^{1228}$ MACHADO, Brandão. Ainda a substituição tributária. In: Revista Direito Tributário Atual. São Paulo: Dialética, v.19, 2005, p.12-15; MACHADO, Brandão. São Tributos as Contribuições Sociais? Revista Direito Tributário Atual, São Paulo: Resenha Tributária, v.7/8, 1987-1988, p. 1815-1872. MACHADO, Brandão. Fato Gerador Complexivo. Uma Questão Terminológica. In: ltr, 1982 N. 7/82, P. 273-275. MACHADO, Brandão. Repetição do Indébito no Direito Tributário. In: Direito Tributário - Estudos em Homenagem ao Prof. Ruy Barbosa Nogueira, Brandão Machado (Coord.). São Paulo: Saraiva, 1984, p. 61106; MACHADO, Brandão. Decadência e Prescrição no Direito Tributário. In: Revista Direito Tributário Atual n.6. são Paulo: 1986, p. 1309-1378, entre outros.

${ }^{1229} \mathrm{~A}$ influência de Brandão Machado pode ser visualizada com maior clareza nos estudos em homenagem organizados por discípulos, colegas, amigos e professores a exemplo de Luís Eduardo Schoueri, Alcides Jorge Costa e Fernando Aurelio Zilveti: Estudos em Homenagem a Brandão Machado. SCHOUERI, Luís Eduardo; ZILVETI, Fernando Aurelio; COSTA, Alcides Jorge. São Paulo: Dialética, 1998.

${ }^{1230}$ SCHOUERI, Luís Eduardo. Brandão Machado - Uma Amizade. In: Estudos em Homenagem a Brandão Machado. SCHOUERI, Luís Eduardo; ZILVETI, Fernando Aurelio; COSTA, Alcides Jorge. São Paulo: Dialética, 1998, p. 09-11; ZILVETI, Fernando Aurelio. Um Perfil de Brandão Machado. In: Estudos em Homenagem a Brandão Machado. SCHOUERI, Luís Eduardo; ZILVETI, Fernando Aurelio; COSTA, Alcides Jorge. São Paulo: Dialética, 1998, p.13-15.
} 


\section{O diálogo (ponderado) entre Direito Tributário e outros ramos do conhecimento (e notadamente a Ciência das Finanças) na doutrina brasileira na década de oitenta e a resistência ao método da Escola da PUC-SP.}

Não se pode afirmar que a teoria dualista foi unanimemente acatada pela doutrina brasileira, existindo importantes representantes a advogarem linhas de investigação jurídicas diversas das pretendidas pelo peculiar dogmatismo jurídico-normativo prevalecente naquele contexto histórico, especialmente no período da década de oitenta, período analisado nesse tópico.

Entre alguns relevantes exemplos dessa tendência favorável ao diálogo com a Ciência das Finanças, a resistência foi promovida por autores do porte de Ives Gandra da Silva Martins, conforme é possível observar em seu estudo "Teoria da Imposição Tributária". Nesse trabalho, assume como referência as normas jurídicas, para consideralas sob a perspectiva de elementos sociológicos (e até psicológicos) aduzindo que “(...) o direito à vida seria uma norma de aceitação social (...)”, ao passo que a norma tributária seria norma de rejeição social, já que sem sanção, poucos a cumpririam ${ }^{1231}$. Logo, já se antevia estudo expressamente ancorado na pragmática da norma tributária, antecendo estudos que aperfeiçoariam esse vislumbre da norma tributária nas décadas seguintes.

Na realidade, a contribuição de Ives Gandra da Silva Martins também se estendeu ao diálogo entre o Direito Tributário e a Economia, mas, sobretudo, ao Direito Econômico, disciplina ministrada pelo autor na Faculdade de Direito da Universidade Presbiteriana Mackenzie. A particular atenção ao diálogo entre Direito Tributário e Direito Econômico pode ser observada na obra "Direito Econômico e Tributário. Comentários e Pareceres", de $1982^{1232}$, que demonstra a particular atenção do autor à Economia e ao Direito Econômico e conexões com a tributação.

\footnotetext{
1231 Note-se que neste estudo, Ives Gandra aplica a estrutura da norma jurídica, embora a relacione à realidade social. Assumindo como base a aceitação social, as normas de sanção (sancionatórias) seriam secundárias e as normas de comportamento seriam primárias. Na perspectiva das normas de rejeição social, as sanções seriam caracterizadas como normas primárias, ao passo que as normas de conduta seriam consideradas normas secundárias. Portanto, não se afasta do dogmatismo normativo tendencial naquele período, muito embora se distancie na perspectiva das considerações de outros campos do direito tributário. MARTINS, Ives Gandra. Teoria da Imposição Tributária. Op.cit., p. 01-03.

${ }^{1232}$ MARTINS, Ives Gandra da Silva. Direito Econômico e Tributário. Comentários e Pareceres. Co-Edição - FIEO - Fundação Instituto de Ensino para Osasco. São Paulo: Resenha Tributária, 1982, p. xv-Xx.
} 
Nesse quadro, emana-se com clareza o posicionamento que seria característico de sua obra, seja no âmbito da filosofia do direito, seja no âmbito do direito tributário: “A maléfica influência do positivismo, que filosoficamente endeusou o vazio das utopias perecíveis, tentando perpetuar, como ideal, a insuficiência notória da relação do objeto conhecido com a inteligência conhecedora, amesquinhando a universalidade do ser humano, em galbar alturas incomensuráveis, aos estritos limites do conhecimento racional, incapaz de por si só responder qualquer indagação sobre a vida, sobre o homem e sobre o mundo, fez-se notar também na configuração jurídica, na medida em que a genialidade de Kelsen reduziu a grandeza do conteúdo ético e moral do Direito, único a justificá-lo, à frieza da norma pura, da norma com força capaz de se fazer cumprida, seja por monstros, como Hitler, seja por Santos, como Luiz da França"1233.

Não é por acaso a posição expressa do autor, vislumbrada na sua concepção de Direito: "o Direito é a mais perfeita de todas as ciências, sempre que suas normas sejam alicerçadas nas normas imutáveis do Direito Natural, estas pré-existentes ao ser humano".

E denomina o "direito em crise" como aquele que esteja fora da concepção de "direito natural" defendida pelo autor. Nesse sentido emana-se importante linha apresentada pelo autor, na contramão expressa da tendência majoritária da doutrina tributária da época, e, sobretudo perante a Escola da PUC-SP ${ }^{1234}$.

De certa forma, em trabalho recente, intitulado "Uma Teoria do Tributo",1235, retoma essas premissas investigativas, assinalando que “(...) a ciência jurídica, não diferentemente das demais ciências, tem como finalidade a apreensão das leis naturais de convivência social, para otimizá-las a favor da sociedade, que por suas leis será conduzida

\footnotetext{
${ }^{1233}$ MARTINS, Ives Gandra da Silva. A missão do jurista e o Direito Natural. In: Direito Econômico e Tributário. Comentários e Pareceres. Co-Edição - FIEO - Fundação Instituto de Ensino para Osasco. São Paulo: Resenha Tributária, 1982, p. xv-xx. ${ }^{1234}$ Idem.

${ }^{1235} \mathrm{Na}$ visão do autor, o conhecimento do fato, a ponderação que receberá para “(...) o complemento normativo e sua formulação impositiva compõem uma única realidade, sendo, todos os três elementos, objeto de estudo da Ciência do Direito". Mas a formação clássica fato-valor-norma (Miguel Reale), na visão de Ives Gandra Martins, só teria sentido na medida em que a valoração do fato seja feita em coerência com a lei natural, não sendo suficiente apenas o ato de valorar, mas o do valorar corretamente, único caminho para a identificação entre o direito natural e o direito positivo. Para Ives Gandra Martins, por regular todos os fatos e situações da convivência social, a Ciência do Direito exige cientistas com vocação universal, pois a interligação de todas as ciências, no plano normativo positivo, só pode ser, em nível de imposição, axiologicamente equilibrado pelo jurista. MARTINS, Ives Gandra. Uma Teoria do Tributo. São Paulo: Quartier Latin, 2005, p.436.
} 
(...)", ao passo que o “(...) direito positivo e o direito natural devem sempre formar a mesma realidade, para que fluam, verazmente, as leis que regulam o convívio social" ${ }^{1236}$.

Contudo, não se pode afirmar categoricamente que o referido autor não apresentasse tendências positivistas, especialmente na análise da interpretação do autor acerca do princípio da tipicidade cerrada, do qual foi um dos seus mais importantes defensores naquele período, sobretudo aceitando a teoria de Alberto Xavier.

Por outro lado, Ives Gandra Martins, conforme mostra a obra anteriormente citada, apresenta uma particular tendência ao jusnaturalismo (em contraposição expressa ao positivismo jurídico dogmático de matriz kelseniana praticado na Escola da PUC-SP).

Embora a consideração aos aspectos econômicos da tributação aparecesse já em autores do porte de Ruy Barbosa Nogueira e Amílcar de Araújo Falcão, os estudos de Ives Gandra da Silva Martins mostram particular sensibilidade sobre a política tributária, seja voltada ao desenvolvimento econômico ou a finalidades fiscais.

Note-se que, apesar de exercer a titularidade da cátedra de Direito Econômico, os estudos voltados ao Direito Tributário foram intensificados através dos trabalhos promovidos no âmbito do CEU - Centro de Extensão Universitária - Instituto Internacional de Ciências Sociais, formado em 1972, e criado por Ives Gandra Martins, que favoreceu a divulgação de estudos não necessariamente alinhados àquelas premissas construídas nas linhas de estudo já mencionadas, e particularmente atentas aos diálogos entre direito e economia.

Ademais, no trabalho "Tributos, Justiça Fiscal e Desenvolvimento", mostra atenção às finalidades do tributo (que, segundo o autor, estariam vinculadas às duas grandes tendências: aquela política tributária voltada ao desenvolvimento nacional; aquela política tributária voltada à obtenção dos meios necessários ao exercício do poder em um Estado constituído, onde se entrelaçam a alocação de recursos, a justiça fiscal, a coordenação

${ }^{1236}$ A visão de Ives Gandra Martins “(...) pressupõe o exame do fato por ele regulado e do elemento axiológico que permite a eleição da norma incindível (...)", apoiando assim expressamente o estudo de matérias que se refiram à imposição tributária, a exemplo da Economia. MARTINS, Ives Gandra da Silva. Uma Teoria do Tributo. Op.cit., p. 433 e seguintes. 
fiscal intergovernamental e as finalidades política, jurídica e administrativa" ${ }^{\text {1237 }}$. Por outro lado, mostra também atenção aos reflexos do comércio internacional frente à tributação, apresentando já interessantes considerações sobre os efeitos "da aldeia global" na tributação mundial $^{1238}$, ou mesmo sobre a relação entre a política tributária e a inflação ${ }^{1239}$.

Note-se, portanto, que Ives Gandra Martins, em meados da década de oitenta, já apresentava posição ponderada ao diálogo entre o Direito e outros ramos do conhecimento, seja na Universidade Presbiteriana Mackenzie, seja no Centro de Estudos de Extensão Universitária, apresentando expressamente tendências jusnaturalistas em ambiente disciplinar notoriamente caracterizado pelo positivismo dogmático normativo kelseniano.

Na década de oitenta, o diálogo entre o Direito Tributário e outros campos do conhecimento (e naturalmente, à Ciência das Finanças) foi também defendido por outros autores, conforme se observa em Raimundo Bezerra Falcão, que, a seu turno, teve o mérito de corajosamente aplicar - expressamente - o reconhecimento da necessidade do estudo segundo as premissas metodológicas de Benvenuto Griziotti, em sua obra "Tributação e Mudança Social", publicada em 1981, fruto de sua tese de doutoramento. Curiosamente, esse trabalho também apresenta claro vislumbre sobre o aspecto pragmático da norma tributária.

Este trabalho realmente busca, com as premissas metodológicas construídas a partir da investigação dos métodos aplicados nas ciências sociais, analisar a extrafiscalidade voltada à viabilização de mudanças sociais. Reconhecendo que críticas não faltaram à tese unitarista de Griziotti, especialmente aos seus critérios de investigação, Bezerra Falcão classificou-as como “(...) ranços imobilistas, responsáveis por tantos males que se hão causado às potencialidades das ciências sociais e, por via de consequência, à sociedade mesma". E foi ainda mais explícito no que tange à interdisciplinaridade em Griziotti: "A visão interdisciplinar sugerida pelo grande financista assemelha-se-nos a única capaz de

\footnotetext{
${ }^{1237}$ MARTINS, Ives Gandra da Silva. Tributos, Justiça Social e Desenvolvimento. In: Direito Econômico e Tributário. Comentários e Pareceres. Co-Edição - FIEO - Fundação Instituto de Ensino para Osasco. São Paulo: Resenha Tributária, 1982, p. 1-7.

${ }^{1238}$ MARTINS, Ives Gandra da Silva. O Comércio Internacional e o Retorno às Teorias Protecionistas. In: Direito Econômico e Tributário. Comentários e Pareceres. Co-Edição - FIEO - Fundação Instituto de Ensino para Osasco. São Paulo: Resenha Tributária, 1982, p.10-27.

${ }^{1239}$ MARTINS, Ives Gandra da Silva. Inflação e Política Tributária. In: Direito Econômico e Tributário. Comentários e Pareceres. Co-Edição - FIEO - Fundação Instituto de Ensino para Osasco. São Paulo: Resenha Tributária, 1982, p. 29-38.
} 
levar a tributação e, numa postura mais ampla, as finanças públicas, ao seu verdadeiro e efetivo papel mudancista",1240_ ${ }^{1241}$.

O trabalho de Bezerra Falcão provavelmente foi o primeiro a defender (e aplicar) expressamente Griziotti no Brasil, em ambiente histórico no qual a defesa de Giannini (e notadamente de Alfredo Augusto Becker) era quase absoluta ${ }^{1242}$, guardando inequívocas semelhanças entre essa abordagem de estudo e a teoria "unitarista" de Griziotti. ${ }^{1243}{ }^{1244}$

Mas, sem dúvida, a defesa do diálogo entre o Direito Tributário e a Ciência das Finanças também pôde ser vista claramente na obra de Ricardo Lobo Torres. Este autor, amplamente influenciado pela literatura germânica, levantou a existência de vários sistemas, alguns abertos às influências externas ${ }^{1245}{ }_{-}^{1246}{ }_{-} 247$.

${ }^{1240}$ FALCÃO, Raimundo Bezerra. Tributação e Mudança Social. Rio de Janeiro: Forense, 1981, p. 16.

${ }^{1241}$ Para o autor, tal visão interdisciplinar pode ser justificada pelo fato de que o tema objeto de investigação não foi criado isoladamente em um departamento científico apenas, mas “(...) envolveu economistas, cientistas políticos, juristas e filósofos, num complexo de ideias e teorias que, amalgamadas, terminaram por debuxar a configuração e o embasamento da tributação mudancista, bem como de outros conceitos mais amplos, como o de finanças ordinatórias e o de intervencionismo estatal"'. Idem, p.325.

${ }^{1242}$ Analisou a extrafiscalidade e a mudança social a partir da perspectiva econômica (Teoria Econômica), da Teoria Política, da Teoria Jusfilosófica (Çiência do Direito e Filosofia do Direito), e da Função Social da Propriedade (onde explora aspectos sociológicos úteis à pesquisa), para defender o potencial finalístico da tributação voltado à promoção da intervenção na sociedade sem comprometer a "superestrutura jurídica" do direito. Em outras palavras, analisa o fenômeno da extrafiscalidade e a mudança social a partir de quatro pontos de vista: a) econômico; b) jurídico (científico e filosófico); c) político; e) social. FALCÃO, Raimundo Bezerra. Op.cit., p. 200 e seguintes.

${ }^{1243}$ Demonstrando ciência expressa com as dificuldades da abordagem pretendida, preocupa-se desde o início do trabalho com a delimitação de um método (e técnicas) adequado para alcançar os resultados desejados por sua pesquisa. Nesse sentido, recorda Griziotti, para quem “(...) o cientista italiano põe de manifesto a relevância de se ter em conta, nos estudos financeiros e tributários, os fatores de cunho econômico, ético e sociais, (...)". Idem, p. 15.

1244 A visão de Raimundo Bezerra Falcão é expressiva na consideração do Direito, da Sociologia, da Economia e da Política, com suas respectivas implicações na tributação extrafiscal. Idem.

${ }^{1245}$ Nesse sentido, Ricardo Lobo Torres relacionou a noção de sistema à multidisciplinaridade: “A visão multidisciplinar do sistema científico do Direito, que abrange simultaneamente as disciplinas voltadas para os aspectos fáticos e as que se preocupam com os valores e o dever ser, de modo integrado (História do Direito, Sociologia do Direito, Dogmática Jurídica, Teoria do Direito, Política do Direito, Filosofia do Direito, etc.) vem sendo defendida por número crescente de juristas”. TORRES, Ricardo Lobo. Sistemas Constitucionais Tributários. Op.cit., p. 03 e seguintess.

${ }^{1246}$ Idem, p. 08-11.

${ }^{1247}$ Essa tendência pode ser observada em trabalhos posteriores do autor, como no estudo "Interpretação e Integração das Leis Tributárias", assim como em seu "Curso de Direito Financeiro e Tributário". Nessa obra, trabalha com a interdisciplinaridade, isto é, com o diálogo entre os saberes, mostrando detalhadamente que o Direito Financeiro (e o Direito Tributário) registra íntimas relações com diversos campos do conhecimento. TORRES, Ricardo Lobo. Curso de Direito Financeiro e Tributário. 2005. Op.cit., p.23-25. 
$\mathrm{Na}$ defesa do diálogo entre Direito Financeiro e a Filosofia ${ }^{1248}$, a Política, a Sociologia, a Economia e a Ciência das Finanças, é possível observar a abertura ao diálogo com outros ramos do conhecimento ${ }^{1249}$.

Mas de fato, o ponto de relevo na argumentação de Ricardo Lobo Torres encontra-se no enfrentamento das relações entre Direito Financeiro e Ciência das Finanças. $^{1250}$

$\mathrm{Na}$ visão do autor, com a superação progressiva de posições positivistas, “(...) o Direito Financeiro e a Ciência das Finanças retornam, de modo integrado, ao estudo dos grandes temas da tributação, pelo coeficiente axiológico de que são dotados (...)"1251, posicionando-se à favor da interdisciplinaridade frente ao Direito Financeiro (e, por extensão, ao Direito Tributário).

Mas deve-se ressaltar que, não obstante pudessem ser identificados autores dissonantes da posição dualista predominante na doutrina tributária brasileira, o século XX, especialmente a partir dos anos finais da década de sessenta até meados da década de noventa, caminhou para o separatismo/reducionismo epistemológico do Direito Tributário perante a Ciência das Finanças.

\section{Tendências históricas consolidadas pela gradual preferência ao formalismo jurídico no estudo e no ensino do Direito Tributário Brasileiro}

\footnotetext{
${ }^{1248}$ Idem, p. 26.

${ }^{1249}$ Considerou também da maior relevância as relações entre a Economia e o Direito Financeiro, especialmente porque na Economia, com o posterior predomínio do positivismo e do utilitarismo, em primeiro momento, rejeitou os julgamentos de valor, para, em segundo momento, readmiti-los, aproximandoa como ciência voltada à ética, com a emissão de juízos de valor. Assim, para Torres, as relações entre Direito e Economia apresentam-se em diversos temas de estudo, como a extrafiscalidade (economia política), o desenvolvimento dos impostos, a construção do sistema tributário nacional, o federalismo financeiro, o equilíbrio orçamentário, entre outros. Ibidem, p.27-28.

${ }^{1250}$ A Ciência das Finanças, que ostenta a característica de ciência normativa e valorativa, teria íntima ligação com o Direito Financeiro. E acrescenta: "A tese da incomunicabilidade ou do reducionismo entre Ciência do Direito Tributário e Ciência das Finanças, defendida com tanto ardor pelos positivismos, que negavam à ciência jurídica a função valorativa reservada às Finanças, ficou prejudicada pelo coeficiente de normatividade em ambas presente". Ibidem, p.28-29.

1251 “Assuntos como o da redistribuição de rendas pela via de imposto ou da tributação ótima reingressam nas suas cogitações, posto que não se prendem exclusivamente à abordagem empírica ou científica, transitando antes pelo campo da ética e da filosofia social. Também são objeto da pesquisa interdisciplinar os sistemas de tributação e de discriminação de rendas, bem como os princípios gerais decorrentes da ideia de justiça, segurança ou utilidade". TORRES, Ricardo Lobo. Curso de Direito Financeiro e Tributário. 2005. Op.cit., p. 30 .
} 


\subsection{A gradual preferência histórica da interpretação a partir do dogmatismo normativo nos estudos tributários brasileiros}

A partir da década de setenta do século XX, já na consolidação teórica do constitucionalismo (e da sistematização) do direito tributário, os pressupostos teóricos construídos pela dogmática jurídica passam a ser fortemente refletidos pela literatura tributária brasileira.

O formalismo jurídico disseminado no ambiente teórico da Faculdade de Direito da PUC-SP favorece enormemente a difusão e prevalência do dogmatismo normativo aplicado ao Direito Tributário no Brasil (notadamente de matriz kelseniana, ainda que com ponderações).

Mas mais do que isso, a própria Hermenêutica Jurídica (seus métodos e resultados) começa a ser refletida sob as premissas do dogmatismo jurídico normativo.

Não se pode negar que os mecanismos difundidos pelas diversas correntes hermenêuticas que se desenvolveram na Alemanha e França, ou mesmo através da jurisprudência dos conceitos, ao defender a interpretação gramatical, lógica e histórica, especialmente com o desenvolvimento do dogmatismo normativo (e notadamente, em Kelsen, a partir da década de trinta do século XX), traziam certa margem de insegurança $^{1252}$.

A Teoria Pura do Direito, por excelência, visava alcançar a expurgação de qualquer elemento estranho que pudesse atrapalhar o raciocínio puramente jurídico do intérprete do Direito. Não é por outro motivo que Kelsen repudiou expressamente a jurisprudência dos conceitos, ainda que o positivismo kelseniano tivesse herdado algumas características comuns ligadas à secular Escola Hermenêutica. Naturalmente, a interpretação jurídica realizada na Ciência do Direito deveria se separar da interpretação "autêntica" feita pelos “órgãos jurídicos”.

Para Kelsen: "A interpretação científica é pura determinação cognoscitiva do sentido das normas jurídicas. Diferentemente da interpretação feita pelos órgãos jurídicos,

${ }^{1252}$ KELSEN, Hans. Teoria Pura do Direito. Op.cit., p.01 e seguintes. 
ela não é criação jurídica"1253. Kelsen defende forte rigidez no labor interpretativo do jurista, para quem a interpretação jurídico-científica só pode estabelecer as possíveis significações de uma norma jurídica.

Inicia-se assim momento em que a atividade interpretativa exercida pelo cientista do direito começa a ser considerada no intuito de torná-la a mais exata possível. Mas mesmo Kelsen reconheceu a dificuldade dessa missão: “A interpretação jurídico-científica tem de evitar, com o máximo cuidado, a ficção de que uma norma jurídica apenas permite, sempre e em todos os casos, uma só interpretação: a interpretação "correta". Isto é uma ficção de que se serve a jurisprudência tradicional para consolidar o ideal da segurança jurídica. Em vista da plurissignificação da maioria das normas jurídicas, este ideal somente é realizável aproximativamente" ${ }^{, 254}$.

Mesmo assim, para obter maior segurança jurídica, Kelsen buscava alcançar, através da interpretação, a formulação de normas jurídicas de forma mais inequívoca possível, ou “(...) pelo menos, de uma formulação feita de tal maneira que a inevitável pluralidade de significações seja reduzida a um mínimo e, assim, se obtenha o maior grau possível de segurança". ${ }^{1255}$

A atividade interpretativa das leis passa a ser a atividade interpretativa da norma jurídica (componente do sistema jurídico), objeto de estudo do intérprete, pois Kelsen compreendia o estudo da norma jurídica como de vital importância para a compreensão do ordenamento jurídico ${ }^{1256}{ }^{1257}$. Sendo o direito uma ordem normativa, é também um sistema de normas que regula o comportamento humano (norma de conduta) ${ }^{1258}$.

\footnotetext{
${ }^{1253}$ E prossegue: "A ideia de que é possível, através de uma interpretação simplesmente cognoscitiva, obter Direito Novo, é o fundamento da chamada jurisprudência dos conceitos, que é repudiada pela Teoria Pura do Direito. A interpretação simplesmente cognoscitiva da ciência jurídica também é, portanto, incapaz de colmatar as pretensas lacunas do Direito. O preenchimento da chamada lacuna do Direito é uma função criadora do Direito que somente pode ser realizada por um órgão aplicador do mesmo; e esta função não é realizada pela via da interpretação do Direito vigente". Idem, p.395.

${ }^{1254}$ Ibidem, p. 396.

${ }_{1255}^{1255}$ KELSEN, Hans. Teoria Pura do Direito. Op.cit., p.01 e seguintes, p. 396-397.

${ }^{1256}$ O Direito (Recht), segundo Kelsen, é uma ordem, e mais precisamente um sistema de normas caracterizadas pelo fato de que todas elas possuem o mesmo fundamento de validade. $\mathrm{O}$ fundamento de validade de uma ordem normativa é uma norma fundamental da qual se retira a validade de todas as normas que pertencem a essa ordem. As normas caracterizadas como normas jurídicas conferem a determinados fatos o caráter de atos jurídicos ou antijurídicos. Idem, p. 33-35

${ }^{1257}$ Ibidem. p. 35

${ }^{1258}$ BORGES, José Souto Maior. Obrigação Tributária. Op.cit., p. 376-382. BOBBIO, Norberto. Teoria do Ordenamento Jurídico. 10ª Ed. Brasília: Editora UNB, 1999, p. 32 e seguintes.
} 
O dogmatismo normativo leva à compreensão do ordenamento jurídico enquanto sua estrutura formal. Passa-se a compreendê-lo como sistema de linguagem. Assim, segundo Kelsen, uma norma estabelece (prescreve) uma conduta, ao passo que uma segunda norma (sancionadora) estabelece a sanção, para o caso de não cumprimento dessa conduta prevista na primeira norma ${ }^{1259}$.

Para Norberto Bobbio, o melhor modo de estudar o Direito seria compreendê-lo como um conjunto de Normas, ou Regras de Conduta, pois “(...) a nossa vida se desenvolve em um mundo de normas. Acreditamos ser livres, mas, na realidade, estamos envoltos em uma rede muito espessa de regras de conduta que, desde o nascimento até a morte, dirigem nesta ou naquela direção nossas ações" 1260 .

A concepção normativa do direito segue compartilhada em considerável parcela da literatura tributária no Brasil na década de sessenta, mas, especialmente, a partir da década de setenta, como Celso Antônio Bandeira de Mello ${ }^{1261}$, Geraldo Ataliba ${ }^{1262}$, Alfredo Augusto Becker ${ }^{1263}$, José Souto Maior Borges ${ }^{1264}$ e Paulo de Barros Carvalho, que abraçaram a concepção do direito tributário enquanto ordenamento formado por conjunto de normas jurídicas tributárias (sistema normativo).

É claro que a compreensão do Direito Tributário a partir da norma jurídica tributária não é exclusividade de uma linha de estudo apenas, mas da generalidade da literatura tributária nacional, conforme se observa também em Alcides Jorge Costa: “A norma tributária é norma jurídica, como jurídicas e não de simples poder, são as relações tributárias que se estabelecem entre Estado e contribuinte" ${ }^{1265}$.

O dogmatismo normativo passa a elevar a importância da função do intérprete, buscando alcançar a maior objetividade possível da atividade hermenêutica (livrando-lhe na medida do possível - de eventuais subjetivismos). Inicia-se assim, nova fase na

\footnotetext{
${ }^{1259}$ KELSEN, Hans. Teoria Pura do Direito. Op.cit., p.60-61.

${ }^{1260}$ BOBBIO, Norberto. Teoria da Norma Jurídica, p. 23-24.

${ }^{1261}$ BANDEIRA DE MELLO, Celso Antônio. Teoria Geral do Direito. Op.cit., p. 04.

${ }^{1262}$ ATALIBA, Geraldo. Hipótese de Incidência Tributária. Op.cit., p. 32.

1263 BECKER, Alfredo Augusto. Teoria Geral do Direito Tributário. Op.cit., p. 20 e seguintes.

1264 BORGES, José Souto Maior. Lançamento Tributário. Tratado de Direito Tributário Brasileiro. Volume IV. Rio de Janeiro: Forense, 1981, p.05-06.

1265 Note-se que, contudo, o autor não compartilha dos pressupostos investigativos trazidos por Kelsen (e pelos tributaristas nacionais que adotam suas premissas) sobre a Ciência do Direito, já que o último priorizou a análise do Direito sob as premissas da Teoria Geral (e Formal) do Direito. COSTA, Alcides Jorge. Contribuição ao Estudo da Obrigação Tributária. Op.cit., p. 11.
} 
interpretação do Direito Tributário no Brasil, permeada por esse importante contexto histórico.

\subsection{Repercussões do estudo do Direito Tributário sob a perspectiva da norma jurídica.}

$\mathrm{A}(\mathrm{s})$ teoria(s) da norma jurídica basicamente se estrutura(m) sob a premissa de que a ordem jurídica é uma ordem normativa, formada por normas que regulam a conduta humana. Dessa assertiva geral inicia-se a preocupação pela estrutura jurídica (lógica) das normas e seu papel (e efeitos) na conduta individual, onde o sistema normativo seria conjunto de normas que teriam o mesmo fundamento de validade.

A norma dirige-se intencionalmente a regular a conduta de outrem, prescrevendo (comandando) determinada conduta, permitindo ao indivíduo realizar determinado ato ou proibindo-o, sob a ameaça de sanção. Emerge dessa noção preliminar a ideia de "dever", vinculada ao conteúdo da norma, que condiciona o comportamento humano dirigido a outrem $^{1266}{ }^{1267}$. Estruturalmente dissemina-se a ideia da norma completa de Kelsen, prelecionando a existência de uma norma que regula o comportamento e outra sancionadora (que agiria na inocorrência do comportamento dentro da previsão do primeiro).

Norma é uma proposição (que, segundo Bobbio, nada mais é do que um conjunto de palavras que apresenta conteúdo em sua unidade), e logo, deve apresentar estrutura lógico-linguística que poderá ser preenchida com diversos conteúdos. Compreendida a norma jurídica como figura proposicional (Bobbio, Kelsen e Carlos Cossio ${ }^{1268}$ ), emana-se a oportunidade de vislumbrá-la sob os alicerces da lógica jurídica.

A valência aplicável às proposições científicas (verdade/falsidade) passa a ser diferenciada da valência das proposições normativas (válida/inválida). Nesse sentido, eleva-se também a consideração das diferenças linguísticas entre a proposição da ciência do direito (descritiva e formulada pelo cientista do direito - descrição objetiva) e a

\footnotetext{
${ }^{1266}$ KELSEN, Hans. Teoria Pura do Direito. Op.cit., p. 05.

${ }^{1267}$ MIRANDA, Francisco Cavalcanti Pontes de. Tratado de Direito Privado. Op.cit., p. 12-49.

${ }^{1268}$ VILANOVA, Lourival. Lógica Jurídica. Op.cit., p. 113-115.
} 
proposição normativa (Sollsätze - formulada pela autoridade legislativa - prescritiva) $^{1269}$, diferenciando expressamente a proposição jurídica (descritiva) da norma jurídica (prescritiva) ${ }^{1270}$, perspectiva que acabou acatada pela maior parte da literatura dogmáticonormativa da época, ainda que contivesse diferenciadas terminologias ${ }^{1271}$.

A teoria de Kelsen acabou se identificando com a teoria anti-imperativa, especialmente por considerar a norma como um juízo hipotético (prescritivo) ${ }^{1272}$, e não como comando. É por isso que, para Bobbio, a teoria do juízo hipotético não renega que a norma jurídica seja prescrição, já que o juízo expressado pela norma será um juízo hipotético prescritivo, e não descritivo ${ }^{1273}$.

Essa diferenciação é importante porque simboliza expressamente a importância da lógica na composição estrutural da norma jurídica identificada como juízo hipotético prescritivo. Elas afirmam um dever-ser (Sollen) condicionado através da "hipótese legal", onde, se preenchidos determinados pressupostos, deve ser realizada determinada consequência (nesse aspecto emerge a importância da composição estática da norma jurídica face à sua estrutura dinâmica, ligando a subsunção à incidência normativa) ${ }^{1274}$ _ 1275

O vínculo que ligaria a hipótese à consequência foi denominado por Kelsen como “cópula dever-ser”, cujas denominações variaram na literatura, mas não se afastaram de sua ideia-base ${ }^{1276}{ }^{1277}$. Kelsen ainda trabalha com a ideia de imputação jurídica (contraposta à lógica da causalidade nas ciências), que ligaria pressuposto e consequência ao fato concreto, através da subsunção.

Com a estrutura bimembre da norma jurídica enquanto juízo hipotético proposicional prescritivo expresso pela formulação "Se F é, C deve ser", reconhecendo a

\footnotetext{
${ }^{1269}$ KELSEN, Hans. Teoria Pura do Direito. Op.cit., p.88-89.

${ }^{1270}$ Idem.

${ }^{1271}$ MAYNEZ, Eduardo Garcia. Introducción al estudio del Derecho. Op.cit., p. 04.

${ }^{1272}$ Naturalmente, a teoria da norma como juízo hipotético encontrou aprimoramento, conforme observado em Carlos Cossio (enxergando a norma como juízo disjuntivo), ou mesmo aperfeiçoamentos ulteriores adicionados pelo próprio Kelsen. COSSIO, Carlos. La Norma y el Imperativo. In: Anuario de Filosofia Del Derecho de Madrid, s/d, p. 13 e seguintes.

1273 BOBBIO, Norberto. Teoria da Norma Jurídica. Op.cit., p. 01-05.

${ }^{1274}$ ENGISH, Karl. Introdução ao Pensamento Jurídico. $6^{a}$ Edição. Tradução de João Baptista Machado. Lisboa: Fundação Calouste Gulbenkian, 1983, p.36.

${ }^{1275}$ NETO, A.L. Machado. Teoria Geral do Direito. Rio de Janeiro: Edições tempo brasileiro, 1966, p.36.

${ }^{1276}$ VILANOVA, Lourival. Lógica Jurídica. Op.cit., p.87-88.

${ }^{1277}$ ENGISH, Karl. Introdução ao Pensamento Jurídico. Op.cit., p. 34.
} 
imputação jurídica e o vínculo entre o pressuposto e a consequência (cópula do dever-ser de Kelsen), visualizada através da subsunção e respectiva incidência, estão lançadas as bases para os estudos do direito tributário sob a perspectiva da Teoria Geral (Formal) do Direito e, notadamente, pela Lógica Jurídica, ${ }^{1278 \_}{ }^{1279}{ }_{-}{ }^{1280}$, esta consubstanciada na lógica do dever ser (dado A deve ser B), que pressupõe a imputação, frente à tradicional lógica aristotélica (lógica do ser) pautada na causalidade. ${ }^{1281}$

De qualquer forma, Kelsen deu o passo inicial para expressar a norma jurídica através de sua estrutura lógico-linguística, sendo esta aperfeiçoada pela literatura posterior, seja no âmbito da Teoria Geral do Direito ou da Lógica Jurídica e, ainda que posteriormente aperfeiçoadas pela literatura especializada, passa a exercer severa influência na literatura tributária brasileira, entre a década de sessenta e a década de setenta $^{1282}$, ainda que alguns estudiosos brasileiros optem pela estrutura normativa formada por hipótese, mandamento e sanção ${ }^{1283}{ }_{-}^{1284}$, lembrando que a literatura especializada dividiu-se em dois grupos: sancionistas e não-sancionistas (para quem a sanção não seria elemento integrante para que a norma jurídica alcance sua completude) ${ }^{1285}{ }^{1286}$.

Essa concepção (normativa) significa também que temas caros à doutrina jurídica tributária passem a ser estudados sob aquela específica óptica.

Exemplificativamente, a própria relação jurídica tributária, observada pela perspectiva normativista, passa a concentrar atenções no estudo do pressuposto de fato ou fato gerador da obrigação tributária (artigo 114 do CTN) que, a partir daí, passa a exercer papel fundamental nos estudos tributários desse período, reconstruída em sua estrutura lógico-formal, impulsionando a literatura a analisá-la sob a perspectiva da "teoria da norma

\footnotetext{
${ }^{1278}$ REALE, Miguel. Lições Preliminares de Direito. Op.cit., p. 93-104.

${ }^{1279}$ MAYNEZ, Eduardo Garcia. Introducción al estudio del Derecho. Op.cit., p. 13.

${ }^{1280}$ VILANOVA, Lourival. Lógica Jurídica. Op.cit., p.86-87.

${ }^{1281}$ Muito interessante é a reflexão de Eros Grau, analisando relato de Carlos Cossio, que até os anos setenta do século XX, período em que Kelsen e Merkl aplicaram pela primeira vez a relação lógica existente entre o momento legislativo e o momento judicial do direito. Nesse sentido: "o juiz não pode criar normas gerais, mas cria direito ao criar normas individualizadas". O juiz, ao aplicar a lei cria dentro da própria lei uma norma jurídica individualizada, e por isso sentenças, resoluções administrativas, enre outros não seriam consideradas fatos mas normas jurídicas individualizadas. Passa-se à conceção de interpretação como mera subsunção".GRAU, Eros. Por que tenho medo dos juízes. Op.cit., p. 27-28.

${ }^{1282}$ VILANOVA, Lourival. Lógica Jurídica. Op.cit., p. 113-115.

1283 BANDEIRA DE MELLO, Celso Antônio. Teoria Geral do Direito. Op.cit., p. 04.

${ }^{1284}$ ATALIBA, Geraldo. Hipótese de Incidência Tributária. Op.cit., p. 43-45.

1285 MIRANDA, Francisco Cavalcanti Pontes de. Tratado de Direito Privado. Op.cit., p. 49.

1286 ATALIBA, Geraldo. Hipótese de Incidência Tributária. Op.cit., p. 32.
} 
tributária"1287, dissociando a hipótese abstrata (hipótese de incidência), do fato juridicamente realizado (fato gerador, fato jurídico tributário ou fato imponível).

A atenção com a estruturação normativa (e a localização de seus elementos material, pessoal, espacial, temporal e quantitativo - nessa estrutura) passa a ser objeto de preocupação fundamental da literatura tributária brasileira, ainda que essa não empreenda efetiva originalidade no trato da estrutura do tributo que já era estudado intensamente na literatura estrangeira, através do Tatbestand (e Sachverhalt) na literatura germânica, repercutindo-se nos países europeus e latino-americanos ${ }^{1288}$.

Assim, nesse panorama, a reconstrução contemporânea do tema (trazida pela teoria da norma tributária), pode ser observada em Alfredo Augusto Becker, Geraldo Ataliba e, mais notoriamente, em Paulo de Barros Carvalho e a sólida "Regra-matriz de incidência tributária" 1289 , indicando a compreensão geral pela elevação da norma tributária e sua aplicação aos temas fundamentais do Direito Tributário Brasileiro.

A preocupação com a determinação dos elementos da norma tributária (determinação do fato gerador) também leva à preferência pela adoção do princípio da “tipicidade fechada" no Direito Tributário Brasileiro, especialmente na interpretação disseminada por Alberto Xavier ${ }^{1290}$, e adotada pela maior parte da literatura tributária brasileira, argumentando que a lei tributária deve determinar com precisão todos os

${ }^{1287}$ CARVALHO, Paulo de Barros. Teoria da Norma Tributária. $2^{\circ}$ Edição. São Paulo: Editora Rt, 1981, p. 66-67.

${ }_{1288}$ Para a compreensão da importância fundamental do tema, conferir: JÈZE, Gastòn. O Fato Gerador do Imposto. Op.cit., p. 50-63. JARACH, Dino. O Fato Imponível. Teoria Geral do Direito Substantivo. Op.cit., p. 92 e seguintes. BUJANDA, Fernando Sainz de. Hacienda y Derecho. Estudios de Derecho Financiero. IV. Madrid: Instituto de Estudios Políticos, 1966, p. 25 e seguintes. LAPATZA, José Juan Ferreiro. Curso de Derecho Español. $18^{\circ}$ edición. Madrid: Marcial Pons, Ediciones Jurídicas y Sociales, S.Al, 1996, p.354. SCHOUERI, Luís Eduardo. O Fato Gerador da Obrigação Tributária. In: Direito Tributário. Estudos em Homenagem a Alcides Jorge Costa. Volume I. SCHOUERI, Luís Eduardo (coord.). São Paulo: Quartier Latin, 2003, p. 134 e seguintes. BECKER, Alfredo Augusto. Teoria Geral do Direito Tributário. São Paulo: Saraiva, 1963, p. 318; 328-332. FALCÃO, Amílcar de Araújo. O Fato Gerador da Obrigação Tributária. $3^{\circ}$ edição. Rio de Janeiro: Forense, 1997. p. 04-05. ATALIBA, Geraldo. Hipótese de Incidência Tributária. Op.cit., p. 65 e ss. VILANOVA, Lourival. As Estruturas Lógicas e o Sistema de Direito Positivo. Op.cit., p. 37. VILANOVA, Lourival. Lógica Jurídica. Op.cit., p. 17; CARVALHO, Paulo de Barros. Teoria da Norma Tributária. Op.cit., p. 66-67. COSTA, Alcides Jorge. Da Teoria do Fato Gerador. In: Curso de Teoria Geral do Direito Tributário. São Paulo: Secretaria da Fazenda do Estado de São Paulo. Coordenação da Administração Tributária, 1975, p. 113 e seguintes.

${ }_{1289}$ CARVALHO, Paulo de Barros. Direito Tributário: Fundamentos Jurídicos da Incidência Tributária. Op.cit.,p.69. CARVALHO, Paulo de Barros. Curso de Direito Tributário. Op.cit., p. 249.

${ }^{1290}$ XAVIER, Alberto Pinheiro. Conceito e Natureza do Acto Tributario. Coimbra: Almedina, 1972, p. 263-264. Também em: XAVIER, Alberto. Os princípios da legalidade e da tipicidade da tributação. São Paulo: RT, 1978, p. 12-18; 36-39; 57-58. XAVIER, Alberto. Tipicidade da Tributação, Simulação e Norma Antielisiva. São Paulo: Dialética, 2002, p. 22. 
elementos da norma tributária, a exemplo de Yonne Dolácio de Oliveira ${ }^{1291}$. Somente nos últimos anos é que o tema tem encontrado ponderações, conforme se observa em Misabel Derzi $^{1292}$ e, especificamente, Ricardo Lobo Torres ${ }^{1293}$, Fernando Aurelio Zilveti ${ }^{1294}$, Luís Eduardo Schoueri ${ }^{1295}$, Sérgio André Rocha ${ }^{1296}$ e Humberto Ávila ${ }^{1297}$, o que não afasta, ainda, a sólida preferência pela determinação conceitual na literatura tributária nacional ${ }^{1298}$.

Logo, as construções pautadas no dogmatismo normativo kelseniano aplicados à estrutura dos tributos no Brasil não afastam a conclusão de que a literatura tributária brasileira, historicamente, preocupou-se em demasia com o estudo do fato gerador (ou da hipótese de incidência) buscando determinar-lhe os contornos. Mas também o estudo do direito tributário a partir do dogmatismo normativo de inspiração kelseniana leva também à preferência pela análise das normas jurídicas e suas relações de coordenação e hierarquia. Por outro lado, favorece também ao afastamento de temas que apresentam conexões com outros campos do conhecimento, como a economia, por exemplo.

É o caso de temas como a vontade na consolidação do fato gerador, objeto de estudo analisado por Blumenstein ${ }^{1299}$, Hensel $^{1300}$, Antonio Berliri ${ }^{1301}$ e Fernando Sainz de

${ }^{1291}$ OLIVEIRA, Yonne Dolácio de. A tipicidade no direito tributário brasileiro. São Paulo: Saraiva, 1980, p. 180 e seguintes.

${ }_{1292}$ DERZI, Misabel. Direito Tributário, Direito Penal e Tipo. Op.cit., p. 248-286.

1293 TORRES, Ricardo Lobo. Curso de Direito Financeiro e Tributário. 16 ${ }^{\text {a }}$ Ed. Rio de Janeiro: Renovar, 2009, p. 110. TORRES, Ricardo Lobo. O princípio da tipicidade no direito tributário brasileiro. In: Revista eletrônica de Direito Administrativo Econômico. Número 5. Salvador: IBDP, Janeiro/Fevereiro/março de 2006, p. 01-02.

${ }_{1294}$ ZILVETI, Fernando Aurelio. Obrigação Tributária. Fato Gerador e Tipo. Op.cit., p. 212-249.

1295 SCHOUERI, Luís Eduardo. Normas Tributárias Indutoras e Intervenção Econômica. São Paulo: Forense, 2005, p. 243-256. Também: SCHOUERI, Luís Eduardo. Fato Gerador da Obrigação Tributária. Op.cit., p. 168-173.

${ }^{1296}$ ROCHA, Sérgio André. Existe um princípio da tipicidade no direito tributário?In: Revista Direito Tributário Atual. N.26. São Paulo: Dialética-IBDT, 2011, p. 341 e seguintes.

${ }^{1297}$ AVILA, Humberto. Sistema Constitucional Tributário. Op.cit., p. 231-260.

${ }^{1298}$ Sobre o assunto, conferir: LARENZ, Karl. Metodologia do Direito. Op.cit., p. 623-667. NOGUEIRA, Ruy Barbosa. Da Interpretação e da Aplicação das Leis Tributárias. Op.cit., p.89-93. FALCÃO, Amílcar de Araújo. O Fato Gerador da Obrigação Tributária. Op.cit., p. 26-28. XAVIER, Alberto Pinheiro. Conceito e Natureza do Acto Tributario. Op.cit., p. 263-264. Também em: XAVIER, Alberto. Os princípios da legalidade e da tipicidade da tributação. Op.cit., p. 12-18; 36-39; 57-58. XAVIER, Alberto. Tipicidade da Tributação, Simulação e Norma Antielisiva. Op.cit., 2002, p. 22. OLIVEIRA, Yonne Dolacio. Legislação tributária, tipo legal tributário (Arts.96 e 97 do C.T.N.). In: Direito Tributário 4, vol.2, São Paulo, 1976, p. 09-13. MARTINS, Ives Gandra da Silva. Os princípios da legalidade e da tipicidade. In: Curso de Direito Tributário. Org: MARTINS, Ives Gandra da Silva. São Paulo, 1982, p. 49 e seguintes; COÊLHO, Sacha Calmon Navarro. Princípios da tributação: legalidade e tipicidade. RDT n.33, São Paulo, 1985, p. 198 e seguintes.

${ }^{1299}$ BLUMENSTEIN, Ernst. Op.cit., p. 25-29

${ }^{1300}$ HENSEL, Albert. Op.cit., p. 144-145.

${ }^{1301}$ BERLIRI, Antonio. Principii di Diritto Tributario. I. Op.cit., p.116-117. 
Bujanda $^{1302}$, e outros estudiosos na América Latina, como Dino Jarach ${ }^{1303}$ e Amílcar de Araújo Falcão ${ }^{1304}$, mas que, por apresentar clara inspiração extrajurídica, acabou perdendo espaço para o dogmatismo normativo, muito embora seja importante componente para os debates contemporâneos referentes ao business purpose, conforme expôs Schoueri, que se liga invariavelmente à consideração econômica e ao "fato gerador supletivo ou subrogatório" $" 1305$.

Em outras palavras, uma das principais consequências do dogmatismo normativo de matriz kelseniana trazida ao Direito Tributário caminha para o afastamento gradual de outras perspectivas de estudo que não se alinhem ao estudo puramente ou prioritariamente dogmático-jurídico.

\subsection{A refração à consideração econômica na perspectiva normativista}

A esta altura, certas alternativas teóricas levantadas pelos tributaristas brasileiros tornam-se óbvias pelo contexto histórico instaurado. A influência de Alfredo Augusto Becker (normativista, também por influência de Pontes de Miranda ${ }^{1306}$ ), e profundamente dedicado a aplicar a Teoria Geral do Direito ao Direito Tributário, cumulado com a influência kelseniana (e sua "Teoria Pura do Direito") que permeou os estudos jurídicos brasileiros especialmente a partir da década de sessenta, forneceram suportes teóricojurídicos para que muitos estudiosos passassem a afastar peremptoriamente qualquer mecanismo interpretativo que não se fundasse em processos puramente jurídicos de interpretação.

Naturalmente, para estudos alinhados a essas perspectivas, a interpretação econômica foi rapidamente afastada, especialmente em momento que a literatura tributária

\footnotetext{
1302 BUJANDA, Fernando Sainz de. Hacienda y Derecho. IV. Op.cit., p. 604-605.

1303 JARACH, Dino. O Fato Imponível. Op.cit., p. 27-29.

${ }^{1304}$ FALCÃO, Amílcar. Introdução ao direito tributário. Rio de Janeiro: Editora Rio, 1976, p. 89-91.

1305 SCHOUERI, Luís Eduardo. O Fato Gerador da Obrigação Tributária. Op.cit., p. 134 e seguintes.

${ }^{1306}$ É nesse sentido o raciocínio de Pontes de Miranda, para quem a atividade de interpretar leis refere-se ao seguinte procedimento: (...) Interpretar leis é lê-las, entender-lhes e criticar-lhes o texto e revelar o conteúdo. Pode ela chocar-se com outras leis, ou consigo mesma. Tais choques tem de ser reduzidos, eliminados; nenhuma contradição há de conter a lei. O sistema jurídico, que é sistema lógico, há de ser entendido em toda a sua pureza". MIRANDA, Francisco Cavalcanti Pontes de. Tratado de Direito Privado. Op.cit, p. 16-20.
} 
passa a estudar com maior profundidade os estudos dogmático-normativos alicerçados na Teoria Geral do Direito, na Lógica Jurídica e na Filosofia da Linguagem.

Tal tendência pode ser visualizada, a partir da década de setenta em diante, em Paulo de Barros Carvalho. O insigne professor, partindo da premissa da unidade e indivisibilidade do ordenamento jurídico, seguiu a tendência maciça da doutrina jurídica da época, ao defender que, recorrer a elementos econômicos na interpretação do Direito Tributário configuraria verdadeiro "absurdo"1307. E na mesma linha ponderou outros importantes estudiosos, como Geraldo Ataliba.

Semelhante repercussão dessas doutrinas - favoráveis e contrárias - à interpretação econômica repercutiram-se na coletânea organizada a partir dos debates promovidos entre alguns dos principais tributaristas da época, ocorridos em evento promovido no II Curso de Especialização em Direito Tributário, da PUC-SP, no segundo semestre de 1971, sob a coordenação do Prof. Geraldo Ataliba ${ }^{1308}$. Nesse Curso, destacaram-se as posições de Dino Jarach, que se posicionou favoravelmente à interpretação econômica, ao contrário de Paulo de Barros Carvalho, que a refutou veementemente. ${ }^{1309}$

Nesse mesmo caminho ponderou Misabel Derzi, para quem o Código Tributário Nacional rejeitaria a interpretação econômica ${ }^{1310}{ }^{1311}$, assim como Sacha Calmôn Navarro Coêlho, sobre o art.118 ${ }^{1312}$ do CTN: "Este artigo é, para os fins a que se propõe, algo imprestável. Com ele, ao tempo em que se fez o CT, pretendeu-se dar escoras à chamada "interpretação econômica do fato gerador". A evolução doutrinária e jurisprudencial, contudo, estiolou quase que por completo o seu conteúdo. Ficou solto dentro do sistema do

1307 CARVAlHO, Paulo de Barros. O Absurdo da Interpretação Econômica do "Fato Gerador" Direito e sua Autonomia - O Paradoxo da Interdisciplinariedade. Cadernos da Escola de Direito e Relações Internacionais da Unibrasil. n. 07. Jan/Dez 2007. Curitiba: Publicação Oficial do Curso de Mestrado em Direito da Unibrasil, 2007, p. 448 e ss. Sobre o tema da interpretação no Direito Tributário, também se recomenda a proposição do autor sobre a interpretação enquanto sistema de linguagem. CARVAlho, Paulo de Barros. Curso de Direito Tributário. Saraiva: São Paulo, 2011, p. 131-169.

${ }^{1308}$ CARV ALHO, Paulo de Barros. Hermenêutica no Direito Tributário. Op.cit, p. 233.

${ }^{1309}$ CARVALHO, Paulo de Barros. Hermenêutica no Direito Tributário. Op.cit, p. 233.

${ }^{1310}$ DERZI, Misabel. Notas. In: BALEEIRO, Aliomar. Direito Tributário Brasileiro. Op.cit., p. 689 e seguintes.

${ }^{1311}$ Sobre o assunto, também conferir: TÔRRES, Heleno Taveira. Direito Tributário e Direito Privado Autonomia Privada: simulação e elusão tributária. Op.cit., p. 87 e seguintes. Para uma crítica ao conteúdo dos artigos 109 e 110 do CTN, conferir: TORRES, Ricardo Lobo. Normas de Interpretação e Integração do Direito Tributário. Op.cit., p.136 e seguintes.

1312 “Art.118. A definição legal do fato gerador é interpretada abstraindo-se: I - da validade jurídica dos atos efetivamente praticados pelos contribuintes, responsáveis ou terceiros, bem como da natureza do seu objeto ou dos seus efeitos; II - dos efeitos dos fatos efetivamente ocorridos". 
Código. Deve desaparecer na primeira revisão sistemática do CTN, já que em estado de dessuetude". ${ }^{1313}$

José Souto Maior Borges, ainda em seu primeiro estudo sobre Isenções Fiscais, reconheceu a divergência existente “(...) no tocante à admissibilidade de métodos de interpretações particulares do direito tributário - p.ex., a interpretação econômica - e quanto às resalvas com que se poderá utilizar a interpretação extensiva ou a analogia neste setor do conhecimento científico". Apesar de não expressamente opor-se ao mecanismo, sugeriu, naquela ocasião, a leitura da crítica de Alfredo Augusto Becker sobre o tema ${ }^{1314}$.

Não foi diferente a posição de Brandão Machado sobre a questão, mas sob outros fundamentos. No Direito Tributário Brasileiro, esse autor entendeu que não seria possível a utilização do critério econômico e do abuso de formas no Direito Tributário Brasileiro por existir a vedação da utilização do instituto da analogia no Direito Tributário, criticando, inclusive, a posição de Amílcar de Araújo Falcão de trazer as ideias do Direito Tributário Alemão, sem fazer as necessárias ressalvas de sua aplicabilidade ou não na realidade jurídico-tributária Brasileira ${ }^{1315}$.

Em estudos posteriores, Paulo de Barros Carvalho concebeu a interpretação no Direito Tributário a partir do fenômeno linguístico ${ }^{1316}$ que, naturalmente, refutou a interpretação econômica. Nesse sentido, reinterpreta os métodos tradicionais de interpretação (literal, lógico, histórico, teleológico, e sistemático) a partir dos planos da linguagem (sintática, semântica e pragmática) ${ }^{1317}{ }^{1318}$.

${ }^{1313}$ COÊLHO, Sacha Calmon Navarro. Curso de Direito Tributário Brasileiro. Op.cit., p. 702-704.

${ }^{1314} \mathrm{O}$ autor fez a remissão na nota de rodapé n.5, na página 129. BORGES, José Souto Maior. Isenções Tributárias. Op.cit., p. 129-147.

1315 MACHADO, Brandão. Prefácio do Tradutor. In: HARTZ, Wilhelm. Op.cit., p.7-8. Também: FALCÃO, Amílcar de Araújo. Introdução ao Direito Tributário. Op.cit. ,p. 69-93. NOGUEIRA, Ruy Barbosa. Da interpretação e da Aplicação das Leis Tributárias. Op.cit., p. 42-47.

1316 Parte do pressuposto de que se o Direito Positivo (...) é uma camada linguística, vazada em termos prescritivos, com um vetor dirigido ao comportamento social, nas relações de intersubjetividade, nada mais natural que apresentarmos a proposta de interpretação do direito como um sistema de linguagem. E o conhecimento de toda e qualquer manifestação de linguagem pede a investigação de seus três planos fundamentais: a sintaxe, a semântica e a pragmática. CARVALHO, Paulo de Barros. Curso de Direito Tributário. 2011, Op.cit., p. 99.

1317 Basicamente, o autor estabelece que o conhecimento de qualquer manifestação linguística requer a análise dos três planos supracitados. Primeiramente, temos o plano da sintaxe, que é formado "(...) pelo relacionamento que os símbolos linguísticos mantêm entre si, sem qualquer alusão ao sistema”. Ex. É sintática a relação entre norma da Constituição e a norma da Lei ordinária, bem como sintática também é “ (...) o vínculo entre a regra que estipula o dever e a outra que veicula a sanção”. Já o plano semântico diz respeito “ (...) à ligação dos símbolos com os objetos significados”. A “ (...) semântica jurídica é o campo das 
Assim, no plano sintático, estariam inseridos os critérios que se detêm nos arranjos dos signos jurídicos (método literal e lógico). Já o método histórico e o teleológico influem tanto no plano pragmático como semântico, pois tratam tanto das significações, como também nos problemas relativos à aplicação e interpretação das normas jurídicas, que pertence ao plano pragmático. Finalmente, o método sistemático está inserido nos três planos de linguagem. E isso é possível porque esse critério antessupõe os anteriores, que é considerado pelo autor o "(...) método por excelência"1319.

Deve-se dizer que, no período (especialmente entre a década de setenta e noventa), a posição de autores defensores da interpretação econômica foi restringida, justamente por influência dos fatores supramencionados, prevalecendo maior tendência à refração da interpretação econômica, por não se coadunar com os métodos propriamente jurídicos de interpretação, em importante literatura que buscava incessantemente a dignidade científica (e jurídica) do Direito Tributário, separando-a da influência de outros ramos do conhecimento (e notadamente, da Economia).

\subsection{A atividade interpretativa sob a perspectiva do dogmatismo normativo}

$\mathrm{Na}$ busca pela objetividade na interpretação, a literatura passa a aduzir funções a serem exercidas pelo intérprete, de forma a diminuir o máximo possível o subjetivismo e aumentar a qualidade "científica" de suas interpretações. A interpretação da Ciência do Direito passa a compreender uma atividade descritiva, descrevendo o objeto de estudo, tal qual ocorre em outros ramos do conhecimento científico, em contraposição à estrutura

significações do direito. É o meio de referência que as normas guardam com relação aos fatos e comportamentos tipificados. Essa relação é justamente a ponte que liga a linguagem normativa à conduta do mundo social que ela regula". Exemplificando, integra o plano semântico, o âmbito das acepções dos vocábulos jurídicos, tais como direito, obrigação, relação jurídica, dever, etc. Ainda, Paulo de Barros Carvalho ainda acrescenta que: (...) Mas, para além do estudo da arrumação dos termos jurídicos dentro da fraseologia da lei (sintaxe) e da pesquisa dos seus significados (semântica), o conhecimento da linguagem do direito supõe a indagação da maneira como os sujeitos a utilizam dentro da comunidade em que vivem (pragmática)". Há, portanto, o plano pragmático, que tem como preocupações determinadas questões tais como motivar a conduta, realizando os valores da ordem jurídica. Exemplificando, no campo pragmático, temos questões referentes à própria eficácia, vigência, aplicação, e até mesmo relativas à interpretação e integração das normas. CARVALHO, Paulo de Barros. Curso de Direito Tributário. 2011. Op.cit., p. 100 e seguintes.

${ }^{1318}$ Idem.

${ }^{1319}$ Ibidem, p. 102. 
jurídico-lógica da norma jurídica, que apresenta notável função prescritiva (prescrever condutas).

Por outro lado, a dualidade descrição/prescrição não foi unanimemente aceita na literatura jurídica, especialmente no estudo da hermenêutica jurídica, como se pode observar no clássico estudo de Carlos Maximiliano que, atento às influências europeias no campo da hermenêutica jurídica (anteriores à Kelsen), atribuiu à função do intérprete a de "explicar” o direito. Em outras palavras: “(...) interpretar é explicar, dar significado ao vocábulo, atitude ou gesto. É reproduzir por palavras o pensamento exteriorizado, ou mesmo, mostrar o sentido verdadeiro de uma expressão. Pode-se também entender como a atividade de extrair de frase, sentença ou norma, tudo o que nela se contém"1320.

Outros autores como Miguel Reale apresentavam sentido diferenciado para a atividade interpretativa: “(...) Interpretar uma lei importa, previamente, em compreendê-la na plenitude de seus fins sociais, a fim de poder-se, desse modo, determinar o sentido de cada um de seus dispositivos. Somente assim ela é aplicável a todos os casos que correspondam àqueles objetivos" ${ }^{1321}$.

A visão do jusfilósofo não afasta a atividade interpretativa da influência de outros elementos (fora do direito), concebendo a interpretação do direito, além de ser lógicoformal, mas também valorativa e axiológica. E, nesse sentido, fala em atividade construtiva: "Pois bem, dessa compreensão estrutural do problema resulta, em primeiro lugar, que o trabalho do intérprete, longe de reduzir-se a uma passiva adaptação a um texto, representa um trabalho construtivo de natureza axiológica, não só por se ter de captar o significado do preceito, correlacionando-o com outros da lei, mas também porque se deve ter presentes os da mesma espécie existentes em outras leis: a sistemática jurídica, além de ser lógico-formal, como se sustentava antes, é também axiológica ou valorativa". ${ }^{322}$

Para Eros Grau a atividade de interpretar é essencialmente, compreensiva (compreender em sentido amplo) ${ }^{1323}{ }^{1324}$, sendo relação entre duas expressões (objeto de interpretação e a função do interpretante) ${ }^{1325}$.

\footnotetext{
${ }^{1320}$ MAXIMILIANO, Carlos. Hermenêutica e Aplicação do Direito. Op.cit., p. 09-45.

1321 REALE, Miguel. Lições Preliminares de Direito. Op.cit., p. 272-276.

1322 Idem

${ }^{1323}$ GRAU, Eros Roberto. O Direito Posto e o Direito Pressuposto. Op.cit., p. 207.
} 
$\mathrm{Na}$ interpretação do direito opera-se processo intelectivo onde, a partir de fórmulas linguísticas inseridas em textos, enunciados, preceitos, disposições, é possível determinar conteúdo normativo. Para Grau, o intérprete "produz a norma", ou seja, a atividade interpretativa é também construtiva ${ }^{1326}$, onde se transformam disposições em normas (texto é sinal linguístico, ao passo que a norma é o que se revela dela) ${ }^{1327}$.

Mas de fato, a sistemática interpretativa prevalecente na literatura dogmática normativa, especialmente a partir da compreensão de que a Ciência do Direito e o Direito Positivo estariam estruturados a partir de dois corpos (diferentes) de linguagens. Tendo a Ciência do Direito e o Direito Positivo estruturas linguísticas diferenciadas, apresentariam dois discursos distintos: um discurso descritivo (Ciência do Direito) e outro prescritivo (Direito Positivo).

O discurso da Ciência do Direito, exemplificativamente para Paulo de Barros Carvalho (em primeira manifestação, que posteriormente seria ponderada), seria eminentemente descritivo, “(...) fala de seu objeto - o direito objetivo - que, por sua vez, também se apresenta como um estrato de linguagem, porém de cunho prescritivo (...)". Reside exatamente aqui uma diferença substancial: o direito posto é uma linguagem prescritiva (prescreve comportamentos), enquanto a Ciência do Direito é um discurso descritivo (descreve normas jurídicas) ${ }^{1328}$, compreensão que se coaduna com a teoria kelseniana de interpretação do direito, embora já amplamente mergulhada e aperfeiçoada através dos avanços teóricos da Filosofia da Linguagem, premissa de estudo que passou a ser desenvolvida por parcela doutrinária no Brasil a partir da década de oitenta.

\footnotetext{
${ }^{1324}$ GRAU, Eros Roberto. Por que tenho medo dos juízes (a interpretação/aplicação do direito e os princípios). Op.cit., p. 29.

1325 “A interpretação aporta à primeira expressão (objeto da interpretação) uma nova forma de expressão, que não é necessariamente verbal - como ocorre no caso das artes alográficas (música e teatro). Assim, interpretar é compreender + reformular ou reexprimir sob forma nova”. Para o autor: “(...) o texto, preceito enunciado normativo é alográfico. A "completude" do texto somente é realizada quando o sentido por ele expressado é produzido, como nova forma de expressão, pelo intérprete. Mas o "sentido expressado pelo texto" já é algo novo, distinto do texto. É a norma". GRAU, Eros. A interpretação do Direito e a Interpretação do Direito Tributário. In: Estudo de Direito Tributário em Homenagem à memória de Gilberto de Ulhôa Canto. Maria Augusta Machado de Carvalho (Coord). Rio de Janeiro: Forense, 1998, p. 123.

1326 Idem, p. 124.

1327 Ibidem, p. 125.

${ }^{1328}$ CARVALHO, Paulo de Barros. Curso de Direito Tributário. Op.cit., p. 34-35.
} 
Mas, na verdade, a evolução dos estudos jurídico-tributários direcionados à Lógica Jurídica e à Teoria Geral do Direito realmente caminhou nesse sentido, de sopesar, ponderar, relativizar, a função descritiva da interpretação do direito.

Essa evolução pode ser notada na reflexão de José Roberto Vieira, assinalando que outrora a atividade interpretativa tenha sido concebida como a atividade de descrever, explicar $^{1329}$, revelar o que já estava implícito na Lei, ou mesmo concebida a interpretação como atividade tendente a retirar “(...) a norma jurídica das dobras do direito positivo como implicando afirmar que ela já ali estava pronta e acabada, apenas escondida em suas pregas". Com o tempo (e o aperfeiçoamento doutrinário), a interpretação passa a constituir atividade construtiva. Em outras palavras, deve-se construir a norma através da interpretação $^{1330}$.

De forma análoga, manifestou-se Paulo de Barros Carvalho que, no desenvolvimento histórico de seus estudos, defendeu, em primeiro momento que “ (...) interpretar o direito é declarar o verdadeiro conteúdo, sentido e alcance das expressões do direito, dos comandos jurídicos (...)". ${ }^{1331}$ Portanto, em primeiro posicionamento, a interpretação apresentaria feição declaratória.

Por outro lado, em momento posterior, Paulo de Barros Carvalho assume posição aperfeiçoada, ao reconhecer que “(...) a aplicação do direito pressupõe a interpretação, e esse vocábulo há de ser entendido como a atividade intelectual que se desenvolve à luz de princípios hermenêuticos, com a finalidade de construir o conteúdo, o sentido e o alcance das regras jurídicas" ${ }^{\prime 332}$. Assim, Paulo de Barros Carvalho passa a reconhecer a atividade do intérprete como construtiva, isto é, constrói a norma (e o sistema normativo) através da interpretação jurídica.

\footnotetext{
${ }^{1329}$ BORGES, José Souto Maior. O Direito como Fenômeno Lingüístico, o Problema de Demarcação da Ciência Jurídica, sua Base Empírica e Método Hipotético-Dedutivo, in Anuário do Mestrado em Direito, Recife, Universidade Federal de Pernambuco, n. 4, jan/dez, 1988, p. 11-16.

${ }^{1330}$ José Roberto Vieira explica que: “(...) O Direito Positivo constitui uma linguagem que se direciona à conduta humana intersubjetiva, com intuito prescritivo. A Ciência do Direito, a seu turno, voltada para o conjunto das normas postas, tem índole cognoscitiva e descritiva. Pensamos, pois, que a reflexão científica se faz por uma linguagem de sobrenível que elege o discurso normativo como seu objeto". VIEIRA, José Roberto. A Semestralidade do PIS: Favos de Abelha ou Favos de Vespa? Revista Dialética de Direito Tributário. n. 83, agosto. São Paulo: Dialética, 2002, p. 89-91.

${ }^{1331}$ CARVALHO, Paulo de Barros. Hermenêutica do Direito Tributário. Op.cit., p. 223.

${ }^{1332}$ CARVALHO, Paulo de Barros. Curso de Direito Tributário. 2011. Op.cit., p. 96.
} 
Em semelhante sentido posicionou-se José Souto Maior Borges que, compreendendo o direito como fenômeno linguístico, mostrou expressas reservas à compreensão de que a atividade interpretativa do jurista seria tão somente a descrição, optando por uma "descrição aberta" ou ponderada, que se remeteria à atividade do intérprete como explicação ${ }^{1333}$.

14. A formação das estratégias de estudo e ensino entre a década de oitenta e a década de noventa.

\subsection{A influência de fatores históricos na consolidação dos estudos na década de noventa}

O perfil contemporâneo da literatura tributária nacional é também reflexo direto dessas inconstâncias jurídicas próprias do sistema tributário brasileiro, sedimentando-se, em parte, como verdadeira lei da "ação e reação" na construção (ou desconstrução) desse sistema.

Conforme observado no capítulo 2, importantes fatores históricos como o neoconstitucionalismo absorvido com o final do regime ditatorial e entrada em vigor da Constituição de 1988, favorecem posteriores reflexões (e ponderações) sobre os rumos do direito tributário no final do século XX.

Do ponto de vista teórico, o pós-positivismo passa a receber maior atenção na doutrina pátria, viabilizando flexibilizações positivistas, especialmente na consideração da segurança jurídica e legalidade frente à ética e justiça nas relações tributárias.

Porém, se de um lado, o positivismo dogmático normativo kelseniano começa a sofrer maiores reservas expressas (também motivada por variadas tendências póspositivistas), a recém-nascida (e imatura) constituição democrática, e as dificuldades enfrentadas para mantê-la protegida de sucessivas emendas constitucionais brasileira favorecem novos impulsos destinados à elevação da segurança jurídica, bem como à rigidez constitucional.

\footnotetext{
${ }^{1333}$ BORGES, José Souto Maior. O Direito como Fenômeno Lingüístico, o Problema de Demarcação da Ciência jurídica, sua Base Empírica e o Método Hipotético-Dedutivo. Op.cit., p. 11-16.
} 
Por outro lado, a elevação dos direitos fundamentais (sobretudo pautados na dignidade da pessoa humana) favorece o maior diálogo a novas tendências principiológicas, conforme visto no capítulo 2 .

Não obstante, a recepção de diferenciados fatores históricos que influenciam o processo disciplinar do Direito Tributário Brasileiro no Estado Constitucional Democrático Brasileiro deve ser considerada, pois peculiares a esse processo, e não necessariamente ligados a contextos históricos anteriores ou à realidade estrangeira.

As seguintes circunstâncias podem ser consideradas essenciais nesse contexto: a atuação desenfreada do poder executivo frente ao poder legislativo (tributário), através de inúmeras Medidas Provisórias; o surgimento acelerado de "contribuições sociais" como estratégia governamental para elevar a arrecadação, escapando das Limitações Constitucionais ao Poder de Tributar, assim como do dever de distribuição das receitas públicas aos demais entes federados; a "massificação" das lides tributárias, fornecidas pelos sucessivos equívocos trazidos pela complexidade e irracionalidade da legislação tributária infraconstitucional e infralegal no sistema tributário brasileiro; a "flexibilização involuntária” da Constituição através de sucessivas Emendas Constitucionais, fragilizandoa, e afastando-a de seu papel inicial; em face das ineficiências próprias do papel do poder legislativo a atender com eficiência os problemas estruturais do sistema tributário brasileiro, cresce em importância o papel da jurisprudência (administrativa e judicial) no direito tributário brasileiro, exercendo, em determinadas situações, verdadeira "função legislativa" e; consequentemente, na literatura jurídica tributária eleva-se o reforço formalista do Direito Tributário brasileiro, como tentativa de reação direta aos abusos frente à segurança jurídica.

As circunstâncias supracitadas proeminentes na década de noventa do século XX trazem importantes repercussões na literatura tributária especializada, já espalhada por diversas regiões do Brasil, constituindo-se como produto direto das linhas de pesquisa e ensino supracitadas, mas acrescentando novas tendências diretamente influenciadas pelos fenômenos históricos supramencionados.

Nesse sentido as principais tendências teóricas vislumbradas nesse período na produção literária brasileira convergem aos seguintes pontos doutrinários levantados no período: a) a dedicação extensa ao estudo dos aspectos constitucionais do direito tributário 
positivo brasileiro (Constituição de 1988), especialmente no intuito de protegê-la contra sucessivas alterações (proporcionadas pelas Emendas Constitucionais); b) a preocupação com o uso excessivo de medidas provisórias em substituição às leis tributárias ${ }^{1334}$; c) a busca pela melhor compreensão da natureza jurídica das contribuições sociais e dos empréstimos compulsórios ${ }^{1335}$; c) ampliação de estudos voltados ao desenvolvimento principiológico do Direito Tributário brasileiro (e das limitações constitucionais tributárias previstas na Constituição de 1988) ${ }^{1336}$; d) tendência ao estudo das espécies tributárias a partir das teorias normativas do tributo ${ }^{1337}$; e) o reforço do interesse por sub-ramos do Direito Tributário, como é o caso do Direito Processual Tributário ${ }^{1338}$, do Direito Tributário Administrativo ${ }^{1339}$, do Direito Tributário Penal e do Direito Tributário Internacional $^{1340}$; f) os primeiros passos para a consolidação de "novos" sub-ramos do Direito Tributário, a exemplo do "Direito Tributário Ambiental"1341; h) fortalecimento da vinculação entre "Direitos Humanos" e o Direito Tributário Brasileiro ${ }^{1342}$; g) a maior preocupação com as funções do tributo ${ }^{1343}$; h) naturalmente, a continuação e o aperfeiçoamento das contribuições das linhas de pesquisa e ensino supramencionadas na investigação dos aspectos teóricos (ou científicos) do Direito Tributário Brasileiro e seus institutos, seja através de seus líderes, se ainda remanescentes, seja através de seus discípulos.

Assim, a década de noventa passa por importantes mudanças, a começar pelo novo panorama constitucional, trazido pela Constituição de 1988. Naturalmente, como consequência natural de todo novo objeto de estudo, a literatura tributária especializada

\footnotetext{
${ }^{1334}$ AVILA, Humberto Bérgmann. Medida Provisória na Constituição de 1988. Porto Alegre: Sergio Antonio Fabris Editor, 1997, p. 109 e seguintes. BARRETO, Paulo Ayres; BARRETO, Aires Fernandino. Imunidades Tributárias: Limitações Constitucionais ao Poder de Tributar. $1^{\text {a }}$ ed. São Paulo: Dialética, 1999, p. 12 e seguintes.

${ }^{1335}$ FERRAZ, Roberto. Contribuições Especiais e Empréstimos Compulsórios: Natureza e Regime Jurídico. 1. ed. São Paulo: Resenha Tributária, 1992, p. 11-157.

${ }^{1336}$ Conforme visto no capítulo 2 .

${ }^{1337} \mathrm{Na}$ década de noventa, exemplificativamente, foram publicadas as seguintes obras com esse perfil: VIEIRA, José Roberto. A Regra-Matriz de Incidência do IPI: Texto e Contexto. Curitiba: Juruá, 1993, p. 15 e seguintes; MOSQUERA, Roberto Quiroga. Renda e Proventos de Qualquer Natureza. O Imposto e o Conceito Constitucional. 1 $^{a}$. ed. São Paulo - SP: Dialética, 1996, 16 e seguintes.

${ }^{1338}$ Sobre o assunto, mais específicamente, ver capítulo 4.

${ }^{1339} \mathrm{Na}$ década de noventa, exemplificativamente, foram publicadas as seguintes obras com esse perfil: SANTI, Eurico Marcos Diniz de. Lançamento Tributário. 1. ed. São Paulo: Max Limonad, 1996, p. 15-68. HORVATH, Estevão. Lançamento Tributário e Autolançamento. São Paulo: Dialética, 1997. QUEIROZ, Mary Elbe. Do lançamento tributário - execução e controle. São Paulo: Dialética, 1999, p. 27 e seguintes.

${ }^{1340}$ Sobre o assunto, ver capítulo 4.

${ }^{1341}$ Sobre o assunto, ver capítulo 4.

${ }^{1342}$ Sobre o assunto, ver capítulo 4.

1343 Sobre o assunto, ver capítulo 4.
} 
rapidamente busca adaptar-se à nova realidade, nunca antes tão constitucional, do direito tributário positivo.

Tanto para aqueles estudiosos que, à época, identificavam-se com os estudos da PUC-SP ou com os da USP, ou com nenhum deles, o aparecimento da Constituição significou nova oportunidade para intensificar e aperfeiçoar os estudos tributários a partir de premissas teóricas já consolidadas (e quem sabe viabilizar a construção de outras novas propostas). Tanto na USP como na PUC-SP, o que se viu foi a continuação (e atualização) das tradições, agora alicerçadas por objeto de estudo renovado e ampliado em matéria tributária.

Contudo, com o aparecimento da nova Constituição, (e a influência tardia do neoconstitucionalismo e do pós-positivismo europeu), as mudanças políticas, sociais e econômicas ocorridas no período, e o já amadurecido estágio de desenvolvimento da literatura tributária brasileira, consolidam-se diferentes tendências ao Direito Tributário, catapultadas por diferentes linhas de pesquisa e ensino posteriores às propostas identificadas nas décadas anteriores, que passaram a conviver com as já produzidas - e ainda ativas - no período.

Nesse sentido, embora reconhecendo que a riqueza doutrinária verificada contemporaneamente impeça a eleição redutora de apenas duas grandes possíveis linhas de pesquisa (ou de ensino) desenvolvidas atualmente no Brasil, opta-se por mencionar apenas algumas posições expressas que, de certa forma, refletem (ainda que pela refutação) com maior intensidade a produção jurídica-tributária brasileira atual. Além disso, será mencionada também a proposta complementar apresentada no âmbito da Hermenêutica Histórica, de José Souto Maior Borges.

\subsection{O Construtivismo Lógico-semântico aplicado ao Direito Tributário: a contribuição de Paulo de Barros Carvalho}

O Professor Paulo de Barros Carvalho, integrante da Escola da PUC-SP, discípulo de Geraldo Ataliba, passou, desde seus primeiros anos de formação, partindo das premissas 
epistemológicas e metodológicas seguidas pela PUC-SP, ao estudo do direito tributário a partir da Teoria Geral do Direito e da Lógica Jurídica.

Sua Tese de Doutorado, intitulada na época “A Estrutura Lógica da Norma Jurídica Tributária", defendida em 1973, e publicada em 1974, sob a denominação "Teoria de Norma Jurídica Tributária"1344, demonstrava alinhamento ao normativismo kelseniano, continuando também o aperfeiçoamento de estudos versados sobre o viés normativo de Alfredo Augusto Becker e Geraldo Ataliba sobre o assunto.

A partir desse trabalho, Paulo de Barros começa aperfeiçoar seus métodos de investigação, orientando-se principalmente à lógica jurídica, recebendo sólida influência de Lourival Vilanova e Hans Kelsen, assim como de Tércio Sampaio Ferraz Júnior no campo da Filosofia da Linguagem.

Na década de oitenta publica a primeira edição de seu celebrado Curso de Direito Tributário $(1985)^{1345}$, reeditado até os dias de hoje (com notável reformulação), e, na época (1981), defende sua Tese de Livre Docência, com o trabalho “A Regra-Matriz do ICM"1346, consolidando seus estudos sobre a teoria da norma tributária, e aperfeiçoando ainda mais a teoria que o iria consagrar no Direito Tributário: a Teoria da Regra-Matriz de Incidência Tributária.

A partir das décadas de setenta ${ }^{1347}$ e oitenta, Paulo de Barros passa a reunir alunos que, com ele, dedicam-se a estudar o direito tributário a partir dos pressupostos metodológicos e epistemológicos da Lógica Jurídica e da Filosofia da Linguagem por sua vez aplicados à Ciência do Direito Tributário.

\footnotetext{
${ }^{1344}$ CARVALHO, Paulo de Barros. Teoria da Norma Jurídica Tributária. $1^{\text {a }}$ Ed. São Paulo: Saraiva, 1974, p. 11 e seguintes.

1345 A primeira edição da celebrada obra do autor foi publicada em 1985: CARVALHO, Paulo de Barros. Curso de Direito Tributário. $1^{\text {a }}$ Ed. São Paulo: Saraiva, 1985. In; CARVALHO, Paulo de Barros. Curso de Direito Tributário. 2011. Op.cit., s/p.

${ }^{1346}$ CARVALHO, Paulo de Barros. A Regra-Matriz do ICM. Tese de Livre Docência defendida como requisito parcial para obtenção do grau de Livre Docente pela Pontifícia Universidade Católica de São Paulo. São Paulo, 1981, p. 01 e seguintes.

${ }^{1347}$ Ressalte-se que o autor também produziu diversos estudos em coautoria com estudiosos do período, a exemplo de CARVALHO, Paulo de Barros. SOUSA, Rubens Gomes de. CANTO, Gilberto Ulhôa. JARACH, Dino. ATALIBA, Geraldo. Interpretação do Direito Tributário. São Paulo: Saraiva e EDUC, 1975. CARVALHO, Paulo de Barros. SOUSA, Rubens Gomes de. ATALIBA, Geraldo. Comentários ao Código Tributário Nacional. 2. ed. São Paulo: Editora Revista dos Tribunais, 1975, entre outros.
} 
A Semiótica e a Filosofia da Linguagem ganham ainda maior atenção na obra de Paulo de Barros, a partir da década de oitenta e noventa ${ }^{1348}$.

Assumindo, em 1977, a presidência do IBET (criado originalmente por Antonio Roberto Sampaio Dória, Fábio Fanucci e Rubens Gomes de Sousa, em 1972), passou a ensinar e reunir estudiosos sobre as premissas por ele adotadas para estudar o direito tributário positivo, geralmente dedicados, em maior ou menor grau, a aplicar a Teoria da Regra-Matriz de Incidência (ou seus desdobramentos) ao Direito Tributário, além de divulgar a importância dos estudos de Lógica Jurídica e de Filosofia da Linguagem ao Direito Tributário. Os cursos de aperfeiçoamento promovidos no quadro deste celebrado Instituto (extensão, pós-graduação lato sensu, entre outros) caminham sempre sob essa perspectiva, isto é, ensinar a aplicar a metodologia desenvolvida e aperfeiçoada por Paulo de Barros Carvalho e seus alunos.

Aspecto de grande interesse refere-se à profícua relação entre Paulo de Barros e seus alunos. Dentro dos quadros da PUC-SP, e posteriormente ao IBET, Paulo de Barros criou, em meados da década de oitenta, grupo de estudos, formado por alunos, orientandos, professores, colegas, todos dedicados a refletir sobre as premissas epistemológicas e metodológicas aplicadas por ele, que passou a ser conhecido como "Grupo de Estudos" ou mesmo "Grupo de Estudos de Paulo de Barros Carvalho".

Dedicados ao estudo de textos filosóficos e jurídicos fundamentais para suas premissas de estudo, esse grupo de estudos consolidou, com estudos dirigidos, sob textos escolhidos e sob a orientação do Prof. Paulo de Barros Carvalho, conectando-se com a Teoria Geral do Direito, com a Lógica Jurídica e a Filosofia da Linguagem, e destas com o movimento filosófico denominado "Giro Linguístico"1349, a aplicação dessas premissas ao estudo do Direito Tributário. Dentre as principais influências desse grupo de estudos,

\footnotetext{
1348 Alguns dos principais estudos publicados na década de noventa: CARVALHO, Paulo de Barros. Medidas Provisórias. Revista de Direito Público, São Paulo, v. 97, 1991, p. 37-42. CARVALHO, Paulo de Barros. Princípio da legalidade e da Igualdade. Revista de Direito Tributário, São Paulo, v. 58, 1991, p. 217-223, entre outros.

1349 As referências ao Giro Linguístico, Wittgeinstein e suas influências nos estudos de Paulo de Barros Carvalho no âmbito da Filosofia da Linguagem são reconhecidas pelo próprio autor em: CARVALHO, Paulo de Barros. Direito Tributário: Linguagem e Método. São Paulo: Noeses, 2008, p. 23 e seguintes.
} 
destaca-se Lourival Vilanova (do qual deriva o termo "Constructivismo LógicoSemântico") ${ }^{1350}$.

Não é por acaso a grande influência exercida pelo movimento filosófico denominado "Neopositivismo Lógico" nos estudos de Paulo de Barros (e seu Grupo de Estudos). Os representantes deste movimento passaram a se reunir a partir de 1907 (Hans Hahn, Phillipp Frank, Otto Neuratt, Moritz Schlick), gerando um manifesto intitulado "O ponto de vista científico do Círculo de Viena”, apresentando uma concepção científica do mundo, que deveria ser conquistada através de uma série de medidas: “a) colocar a linguagem do saber contemporâneo sob rigorosas bases intersubjetivas; b) assumir uma orientação absolutamente humanista, reafirmando o velho princípio dos sofistas: o homem é a medida de todas as coisas; e c) deixar assentado que tanto a Teologia quanto a Filosofia não poderiam ostentar foros de genuína validade cognoscitiva, formando, no fundo, um aglomerado de pseudoproblemas. De tal concepção emergem dois atributos essenciais: 1) todo o conhecimento fica circunscrito ao domínio do conhecimento empírico; e 2) a reivindicação do método e da análise lógica da linguagem, como instrumento sistemático da reflexão filosófica. Este último aspecto dá originalidade ao movimento, em contraste com a tradição psicologizante da própria gnosiologia empírico-positivista"1351.

Entre os precursores apontados pelo movimento estariam David Hume, Gottlob Frege e Ernst Mach. Ressalta-se que Ludwig Wittgenstein não chegou a pertencer ao grupo, ainda que o clássico "Tractatus logico-philosophicus" tenha influenciado diretamente os integrantes do movimento, em $1922^{1352}$.

Paulo de Barros Carvalho consolida, através dessas influências, a chamada "Escola Analítica de Direito Tributário", aperfeiçoada também através dos debates promovidos pelo seu Grupo de Estudos, que constitui o núcleo-base para fervilhar concepções, ideias e construções teóricas, assim como para reunir alunos, ex-alunos, colegas e professores, ensinando os fundamentos da concepção filosófica jurídica denominada de “constructivismo lógico-semântico”, onde, segundo o próprio autor, “(...) a postura

\footnotetext{
${ }^{1350}$ Dentre obras mais recentes (além das já citadas) do Prof. Paulo de Barros, cita-se CARVALHO, Paulo de Barros. Derivação e Positivação no Direito Tributário. 1. ed. São Paulo: Noeses, 2011, p. 25 e seguintes. ${ }^{1351}$ CARVALHO, Paulo de Barros. Direito Tributário. Linguagem e método. Op.cit., p. 22-25.

${ }^{1352}$ Idem, p. 25-27.
} 
analítica faz concessões à corrente hermenêutica (...)"1353 e suas aplicações ao Direito Tributário.

Para Paulo de Barros, no Construtivismo Lógico-Semântico, abre-se espaço a “(...) visão cultural do fenômeno jurídico". ${ }^{1354}$ Assim, a incursão da visão analítica através da hermenêutica sairia reforçada, recebendo a colaboração de “(...) o tom de historicidade, a consideração dos valores, a interdiscursividade entre textos afins, o imergir em segmentos culturais bem concebidos (...)" ${ }^{\text {1355 }}$.

O Construtivismo Lógico-Semântico trabalha com a organização do campo empírico, realizada por três caminhos: “(i) no âmbito filosófico, mediante análise epistemológica; ii) no âmbito conceitual, tendo como ponto de partida a Teoria Geral do Direito; e iii) no âmbito factual, por cortes metodológicos das multiplicidades dos fenômenos concretos. Somente por meio desse aperfeiçoamento teórico que se alcançará o aprofundamento do conhecimento do direito positivo"1356.

Aspecto de grande importância na trajetória acadêmica de Paulo de Barros Carvalho, é que, na década de noventa (1997), já Professor Titular da PUC-SP, concorre e conquista a cátedra de titularidade na Universidade de São Paulo, com a aposentadoria compulsória por idade de Alcides Jorge Costa, através da Tese "Fundamentos Jurídicos da Incidência Tributária"1357, trabalho que reflete estágio mais amadurecido de sua doutrina, refletindo-se inclusive sobre seu tradicional "Curso de Direito Tributário", que passa a adotar as premissas daquele trabalho a partir de então. Conquistando a titularidade nas duas

${ }^{1353}$ CARVALHO, Paulo de Barros. Prólogo. In: Direito Tributário. Linguagem e método. Op.cit., p. xxvi.

${ }^{1354}$ Sobre a importância do Grupo de Estudos na formação do pensamento da Escola de Paulo de Barros Carvalho, sugere-se a leitura de: HARET, Florence; CARNEIRO, Jerson. A título de apresentação. In: Vilém Flusser e Juristas. Comemoração dos 25 anos do grupo de estudos de Paulo de Barros Carvalho. Coord. Florence Haret e Jerson Carneiro. São Paulo: Noeses, 2009, p. ix-xi.

${ }^{1355}$ CARVALHO, Paulo de Barros. Prólogo. In: Direito Tributário. Linguagem e método. Op.cit., p. xxvi.

1356 "O construtivismo lógico-semântico configura método de trabalho hermenêutico orientado a cercar os termos do dircurso do direito positivo e da Ciência do Direito para outorgar-lhes firmeza, reduzindo as ambiguidades e vaguidades, tendo em vista a coerência e o rigor da mensagem comunicativa. No Brasil, esse método foi desenvolvido e aplicado, pioneiramente, por Lourival Vilanova, que se dedicou ao aprofundado estudo do discurso normativo". TOMÉ, Fabiana Del Padre. Vilém Flusser e o Constructivismo LógicoSemântico. In: Vilém Flusser e Juristas, p.321 e seguintes.

${ }^{1357}$ A partir dessas premissas, os pressupostos teóricos consolidados pelo Grupo de Estudos sob a orientação de Paulo de Barros Carvalho passam a constituir o plano e estrutura de ensino do mais difundido instituto de pesquisa e ensino do direto tributário no Brasil atualmente, o IBET, que adota, como conteúdo programático de ensino, em todos os seus cursos, o método e os pressupostos filosóficos jurídicos desenvolvidos por Paulo de Barros. Pelo fato de que o IBET conta hoje com centros de estudos situados em diversas regiões do Brasil, a metodologia de ensino e pesquisa acabou se tornando uma das mais divulgadas, senão a mais, atualmente, influenciando doutrina, legislação e jurisprudência. CARVALHO, Paulo de Barros. Direito Tributário: Fundamentos Jurídicos da Incidência. Op.cit., p. 09 e seguintes. 
principais Escolas de Direito Tributário no período, passa a exercer influência em ambas, assimilando assim, sua própria Escola entre os quadrantes daquelas tradicionais instituições.

Em síntese, as premissas adotadas pela Escola Analítica são as seguintes: a) a elevação da lógica jurídica ao estudo do direito tributário; b) a observação do fenômeno jurídico a partir da filosofia da linguagem; c) o apoio e o incentivo ao estudo das conquistas filosóficas recentes do "giro linguístico"; d) a aplicação da "Regra-Matriz de Incidência" (com os aprimoramentos recentes identificados no "Fundamentos Jurídicos da Incidência Tributária") aos estudos dos tributos; e) incentivo à construção do Direito Tributário "Analítico", isto é, a Ciência do Direito Tributário a partir das premissas construídas por esta Escola (constructivismo lógico-semântico), em substituição às propostas hermenêuticas de outras Escolas.

Ao mesmo tempo, não guardou desarmonia com os pressupostos teóricos e metodológicos básicos consolidados na Escola da PUC-SP, quais sejam: a) o estudo elevado do Direito Constitucional Tributário; b) o normativismo kelseniano; c) a missão do intérprete é descrever, reflexiva e criticamente o sistema jurídico tributário, em consonância com os ensinamentos de Alfredo Augusto Becker e Geraldo Ataliba.

Assim, a Escola Analítica de Direito Tributário, formada por Paulo de Barros Carvalho nos quadrantes do IBET, e seu Grupo de Estudos, passa a deter grande difusão na literatura tributária brasileira, pelos motivos acima expostos.

\subsection{0 pós-positivismo neoconstitucional aplicado ao Direito Tributário: a contribuição de Ricardo Lobo Torres no Rio de Janeiro}

Ricardo Lobo Torres, Professor Titular de Direito Financeiro na UERJ, filósofo de formação, doutor em filosofia e livre-docente em direito tributário, passou a estudar o direito tributário entre os anos setenta, ganhando gradativamente mais prestígio na medida em que seus trabalhos foram publicados. Um dos primeiros trabalhos publicados pelo autor 
foi parte da coletânea "Tratado de Direito Tributário", sob o título "Sistema Constitucional Tributário Brasileiro", em $1986^{1358}$.

Nesse notável trabalho, já apresenta linha diametralmente distinta dos pressupostos advogados pela Escola de Direito da PUC-SP, defendendo, a partir de sólida pesquisa filosófica jurídica, o sistema jurídico tributário aberto, plural e passível de diálogo com outros sistemas. Sucessivamente, defende, dois anos depois, em tese de livre-docência o trabalho "Normas de Interpretação e Integração no Direito Tributário", na UERJ, em 1988, mas somente dois anos mais tarde, em 1990, publicou a Tese que the valeu o grau de Doutor em Filosofia pela UFG (Universidade Gama Filho): “A Ideia de Liberdade no Estado Patrimonial e no Estado Fiscal" ${ }^{\text {1359 }}$, além de seu Curso de Direito Financeiro e Tributário (1993) ${ }^{1360}$, sendo constantemente reeditado.

Afeiçoado à língua de Goethe ${ }^{1361}$, e atento às tendências doutrinárias estrangeiras, assim como seu antecessor na cátedra, Amílcar de Araújo Falcão, passa a tecer importantes estudos voltados à Constituição Tributária de 1988, a partir de perspectivas de estudo diferenciadas frente às tradicionais tendências teóricas já manifestadas na literatura tributária brasileira, especialmente aquelas aproximadas às linhas de estudo da Escola da PUC-SP.

Com o tempo, os trabalhos de Ricardo Lobo Torres passam a destacar-se pela concentração constante em temas específicos de estudo, como os direitos fundamentais relacionados ao Direito Tributário e ao Direito Financeiro ${ }^{1362}$, a ética na relação tributária, a justiça fiscal $^{1363}$, a solidariedade no Direito Tributário, e naturalmente atento também à

\footnotetext{
${ }^{1358}$ TORRES, Ricardo Lobo. Sistemas Constitucionais Tributários. Rio de Janeiro: Forense, 1986, p. 15 e seguintes.

${ }^{1359}$ TORRES, Ricardo Lobo. A Idéia de Liberdade no Estado Patrimonial e no Estado Fiscal. Rio de Janeiro: Renovar, 1991, p. 27 e seguintes.

1360 TORRES, Ricardo Lobo. Curso de Direito Financeiro e Tributário. Op.cit., s/p.

1361 TORRES, Ricardo Lobo. As Influências Germânicas no Direito Financeiro e Tributário Brasileiro. Revista Forense, v. 327, 1994, p. 109-115. TORRES, Ricardo Lobo. As Influências Italianas no Direito Tributário Brasileiro. Revista de Direito Renovar, Rio de Janeiro, n.4, 1996 p. 45-60. TORRES, Ricardo Lobo. $O$ Princípio da Tipicidade no Direito Tributário. Revista de Direito Administrativo, Rio de Janeiro, v. 235, 2004, p. 193-232, entre muitos outros.

${ }^{1362}$ TORRES, Ricardo Lobo. Os Direitos Fundamentais e o Tribunal de Contas. Revista do Tribunal de Contas do Estado do Rio de Janeiro, Rio de Janeiro, v. 23, 1992, p. 54-63. TORRES, Ricardo Lobo. Tratado de Direito Constitucional Financeiro e Tributário. O Orçamento na Constituição. 2a . ed. Rio de Janeiro: Renovar, 2000, p. 05 e seguintes.

1363 TORRES, Ricardo Lobo. Justiça Distributiva: Social, Política y Fiscal. Informativo Tributário Internacional, v. 3, 1998, p. 33-41; TORRES, Ricardo Lobo. A Jusfundamentalidade dos Direitos Sociais.
} 
interdisciplinaridade, isto é, nas relações entre o Direito Tributário e outros ramos do conhecimento.

A temática dos direitos humanos ${ }^{1364}$, incluindo-se os direitos sociais ${ }^{1365}$, nesse quadro, ganha especial atenção do tributarista. Gradativamente, os estudos de Ricardo Lobo Torres vão atraindo estudiosos em torno dos temas de interesse divulgados através do trabalho do autor.

A linha de estudo deste autor, apoiado em perspectiva teórica que favorece a consideração de valores inerentes ao sistema jurídico, tais como a liberdade, a justiça e a segurança, passa a enxergar, especialmente a partir de Immanuel Kant ${ }^{1366}$, Rudolf Stammler ${ }^{1367}$, John Rawls ${ }^{1368}$, Claus Canaris ${ }^{1369}$, Larenz ${ }^{1370}$ e, no campo tributário, Klaus Tipke ${ }^{1371}$, a elevação de diferenciadas perspectivas teóricas aplicáveis aos estudos tributários contemporâneos.

Não é por outro motivo a filiação de Ricardo Lobo Torres à denominada "Virada Kantiana" (favorecendo a reaproximação entre direito e ética) ${ }^{1372}{ }_{-}^{1373}$, cuja certidão de renascimento teórico seria visualizada nos estudos de John Rawls (sobre a justiça) ${ }^{1374}$.

Perspectiva essa que é, no campo da Filosofia do Direito, compartilhada por Radbruch, que enxergava o Direito como a realidade que possui o sentido de estar a

In: Revista de Direito da Associação dos Procuradores do Novo Estado do Rio de Janeiro, Rio de Janeiro, v. 12, 2003, p. 349-374.

${ }^{1364}$ TORRES, Ricardo Lobo. Os Direitos Humanos e a Tributação. Renovar: Rio de Janeiro, 1995, p. 03 e seguintes. TORRES, Ricardo Lobo. Tratado de Direito Constitucional Financeiro e Tributário. Os Direitos Humanos e a Tributação: Imunidades e Isonomia. 3. ed. Rio de Janeiro: Renovar, 2005, p. 12 e seguintes.

${ }^{1365}$ TORRES, Ricardo Lobo. Legalidade Tributária e Riscos Sociais. Revista Dialética de Direito Tributário, v. 59, 2000, p. 95-112.

${ }^{1366}$ KANT, Immanuel. À Paz Perpétua. Série Filosofia Política. São Paulo: L \& PM editores, 1989, p. 25 e seguintes.

${ }^{1367}$ STAMMLER, Rudolf. Tratado de Filosofia del Derecho. Trad. W.Roces. Primera Edición. s/l: Editora Nacional, s/d, p. 240 e seguintes.

${ }^{1368}$ RAWLS, John. Uma Teoria da Justiça. São Paulo: Martins Fontes, 2002, p. 03.

${ }^{1369}$ CANARIS, Claus Wilhelm. Op.cit., p. 25-45.

${ }^{1370}$ LARENZ, Karl. Op.cit., p. 621-701.

${ }^{1371}$ TIPKE, Klaus. Moral Tributaria del Estado y del Contribuyintes. Madrid: Marcial Pons, 2002, p. 09 e seguintes.

${ }_{1372}^{1373}$ KANT, Immanuel. A Metafísica dos Costumes.Op.cit., p.257 e seguintes.

${ }^{1373}$ Idem.

${ }^{1374}$ RAWLS, John. Op.cit., p.64 e seguintes. 
serviço do valor jurídico, da ideia de direito, essa que não poderia ser diferente da justiça (em seus diferentes sentidos) ${ }^{1375}$.

Curiosamente, os estudos de Ricardo Lobo Torres, retomam, em alguns aspectos, o trabalho iniciado por Amílcar de Araújo Falcão na mesma instituição (UERJ), guardando com ele muitos pontos em comum (como a predileção à literatura estrangeira e a familiaridade com a língua alemã e sua literatura), e o diálogo entre ramos do conhecimento. Também sucedeu Tito Rezende, Gilberto Ulhôa Canto e Agostinho Tavolaro na presidência da ABDF - Associação Brasileira de Direito Financeiro (antigo IBDF).

Considerando tais peculiaridades pode-se acrescentar que a disseminação da linha de pesquisa de Ricardo Lobo Torres, ainda é recente, em comparação às acima analisadas, e assemelha-se em alguns aspectos a autores da Faculdade de Direito do Largo São Francisco da USP, como Ruy Barbosa Nogueira, especialmente pela abertura investigativa e pela atenção às investigações de cunho histórico e atenção à literatura estrangeira (notadamente germânica).

Mas o critério diferenciador deste Professor foi a construção de linha própria de pesquisa (com temas de interesse distintos das demais), voltada à promoção dos direitos fundamentais relacionados à tributação, através de um sistema constitucional tributário aberto, plural e pautado em princípios e valores, e particularmente atento às transformações vivenciadas pelas configurações contemporâneas na ordem econômica, social, filosófica e política, e suas respectivas influências no campo do fenômeno financeiro e tributário atual.

Exemplificativamente, é indiscutível sua contribuição à reflexão crítica dos efeitos que a sociedade de risco (expressão cunhada por Ulrich Beck, para designar a sociedade contemporânea pós-industrial, agora sob a iminência de riscos e perigos globais à sociedade, decorrentes do desenvolvimento tecnológico e industrial desenfreado, da flexibilização da soberania estatal trazida pela globalização, e da destruição do meio ambiente) traz à tributação na realidade tributária brasileira ${ }^{1376}$.

\footnotetext{
${ }^{1375}$ RADBRUCH, Gustav. Op.cit. p. 85 e seguintes.

${ }^{1376}$ BECK, Ulrich. Sociedade de Risco: Rumo a outra modernidade. Op.cit., p. 01 e ss.
} 
Mas note-se que, diferentemente das linhas de pesquisa e ensino da PUC-SP (Geraldo Ataliba) e da Escola Analítica de Paulo de Barros, Ricardo Lobo Torres não apresenta esforço tão intenso na divulgação ampla de uma metodologia de ensino própria, focando-se, em maior intensidade, na busca de seu aperfeiçoamento investigativo (teórico).

Não há qualquer embaraço a denominar tal linha como "Escola", mas deve-se reconhecer que a propagação ou divulgação do método de "ensino" (método de aprendizagem) não é prioridade facilmente identificada na obra de Ricardo Lobo Torres (comparando-se com as linhas de pesquisa e ensino da PUC-SP, cuja divulgação é elemento de grande importância), embora seu Curso de Direito Financeiro e Tributário" apresente inequívoco teor didático.

Também na linha de pesquisa desenvolvida por Ricardo Lobo Torres existe maior liberdade investigativa e metodológica, diferentemente do que ocorria na Escola da PUCSP, sob a regência de Geraldo Ataliba, e, posteriormente, na Escola Analítica do Direito Tributário, e nesse aspecto, aproxima-se mais da tradição de Ruy Barbosa Nogueira (o que não signfica necessariamente existir qualquer vinculação acadêmica entre os citados autores).

As principais contribuições dos interlocutores de Ricardo Lobo Torres, em sua Escola de Direto Tributário, datam do século XXI, sendo considerada a Escola de início de produtividade mais recente no Brasil. Em síntese, as características essenciais da linha de pesquisa de Ricardo Lobo Torres são as seguintes: a) maior liberdade de método e pressupostos epistemológicos; d) temas de interesse voltados aos direitos fundamentais, à justiça, à ética e à solidariedade (virada kantiana); c) sistema constitucional tributário aberto, plural, permeado de princípios e valores; d) diálogo entre ramos do conhecimento (aceitação da interdisciplinaridade, incluindo-se o diálogo entre Direito Tributário e Ciência das Finanças); e) afinidade com os avanços da literatura estrangeira (inclusive de língua alemã) e com aspectos históricos de estudo; f) fundamentos filosóficos contrários ao positivismo praticado na literatura tributária (notadamente o kelseniano); g) reflexões pioneiras na consideração das transformações do Estado em face da Tributação; h) reflexões críticas pioneiras sobre os desafios que a sociedade de risco traz ao sistema tributário contemporâneo. 


\subsection{A construção da Hermenêutica Histórica enquanto estratégia complementar}

ao Dogmatismo Normativo no Direito Tributário: a contribuição de José Souto Maior Borges.

É claro que as tendências aplicadas ao ensino e à pesquisa no Direito Tributário Brasileiro na década de noventa podem ser reconhecidas como produtos diretos dos debates vivenciados nas décadas anteriores.

Em ambiente de reforço teórico, mas ao mesmo tempo, de reflexão e ponderação sobre premissas (metodológicas e epistemológicas) adotadas no ensino e pesquisa desenvolvidos nas décadas anteriores, é possível também observar a construção de teorias ou propostas individuais de estudos aplicáveis ao Direito Tributário, mesmo que complementares às propostas anteriormente sedimentadas. Talvez seja dificultoso atribuir a tais vertentes o status de "Escolas de Direito", nos termos apresentados no presente trabalho (ainda que sob a perspectiva teórica, algumas posições possam se identificar como verdadeiras correntes teóricas), o que não impede, no entanto, a profundidade e o sucesso do empreendimento disciplinar empreendido por esses autores.

Nesse rol pode-se mencionar a celebrada obra de José Souto Maior Borges. Esse notável jurista, desde seus primeiros estudos versados sobre direito financeiro e tributário, caminhou adiante das premissas de estudo e ensino consolidadas nas décadas anteriores, sobre elas tecendo importantes considerações, reflexões e até refutações. Não por acaso é a elevação e o interesse pelo conjunto de obra do autor manifestado em estudo de escol. ${ }^{1377}$ 1378

Entre as influências teóricas, pode-se mencionar Lourival Vilanova, Alfredo Augusto Becker, entre outros. Entre as profícuas parcerias acadêmicas, pode-se lembrar de Geraldo Ataliba e Paulo de Barros Carvalho ${ }^{1379}$.

${ }^{1377}$ Sobre a vida e obra de José Souto Maior Borges, conferir: FOLLONI, André Parmo. Ciência do Direito Tributário no Brasil. Crítica e Perspectiva a partir de José Souto Maior Borges. São Paulo: Saraiva, 2013, p. 35 e ss.

1378 BORGES, José Souto Maior. Ciência Feliz. São Paulo: Max Limonad, 2000, p. 01 e ss.

${ }^{1379}$ BORGES, José Souto Maior. Ciência Feliz. São Paulo: Max Limonad, 2000, p. 145 e ss. 
Por isso, Souto Maior Borges, na Faculdade de Direito de Recife, onde também lecionava Lourival Vilanova, apresentou fortes conexões à estratégia de estudo e ensino da Escola da PUC-SP, sobretudo sob a perspectiva da lógica jurídica e da teoria geral do direito, favorecendo o aperfeiçoamento das premissas construídas naquela Escola, e contribuindo para o aperfeiçoamento do referencial filosófico jurídico para os estudos tributários praticados na Faculdade de Direito da PUC-SP ${ }^{1380}$.

A proximidade de premissas metodológicas adotadas na Faculdade de Direito da PUC-SP é facilmente identificável na obra do autor, especialmente nos estudos elaborados no limiar da década de sessenta e noventa do século XX. Nesse período, o autor, que opta pelo dualismo formalista praticado por Giannini, em sua primeira obra ${ }^{1381}$, ainda que tenha traçado reflexões interessantes sobre Griziotti ${ }^{1382}$ e a teoria complexa do fenômeno financeiro ${ }^{1383}$, tende à elevação do direito constitucional enquanto ponto de partida para investigações tributárias, conforme se observa nos estudos voltados à determinação do Lançamento Tributário ${ }^{1384}$, da Isenção Tributária ${ }^{1385}$. Nessas obras já é observável a elevação do dogmatismo jurídico constitucionalista, bem como a busca incessante pela aplicação rigorosa do método jurídico, perspectiva que o mantém em maior harmonia com as premissas da PUC-SP perante outras estratégias de ensino e estudo desenvolvidas no Brasil a partir da década de sessenta.

Conforme o progresso nos estudos dogmáticos (tendência que já se verificava em estudos anteriores $)^{1386}$ sobre a teoria geral do direito, o renomado autor passa a empreender esforços em busca de afastar o chamado "sincretismo metodológico" “(...) que mescla o

\footnotetext{
${ }^{1380}$ A proximidade acadêmica e pessoal de Souto Maior Borges especialmente com Lourival Vilanova, Geraldo Ataliba e Alfredo Augusto Becker pode ser observada em BORGES, José Souto Maior. Ciência Feliz, $2^{\circ}$ Edição. São Paulo: Max Limonad, 2000, p. 151 e seguintes.

${ }^{1381}$ BORGES, José Souto Maior. Introdução ao Direito Financeiro. Op.cit., p. 80.

1382 BORGES, José Souto Maior. Isenções Tributárias. Op.cit., p. 129-130.

${ }^{1383}$ BORGES, José Souto Maior. Introdução ao Direito Financeiro. São Paulo: Max Limonad, 1998, p. 80 e ss.

${ }^{1384}$ BORGES, José Souto Maior. Lançamento Tributário. Tratado de Direito Tributário Brasileiro. Volume IV. Rio de Janeiro: Forense, 1981, p.05-06.

1385 BORGES, José Souto Maior. Isenções Tributárias. 1ª Ed. São Paulo: Sugestões Literárias S.A., 1969, p. 18 e ss.

${ }^{1386}$ Idem, p. 45 e ss.
} 
método jurídico, com investigações extrajurídicas, a dogmática e as investigações extradogmáticas". 1387

Essa perspectiva também foi abordada em seu celebrado estudo "Obrigação Tributária: uma introdução metodológica”, onde a necessidade da unidade metodológica deveria ser considerada elemento fulcral aos estudos do Direito Tributário ${ }^{1388}$.

No mesmo passo, transparece no autor o convite à filosofia, conforme se observa na publicação do livro de reflexões (semibiográficas) intitulado "Ciência Feliz", onde mostra, já com a inspiração de um mestre que percorreu toda a vida em busca do conhecimento científico ao Direito, importantes reflexões sobre os aspectos positivos e negativos da construção de conhecimento científico, bem como reflexos acadêmicos (e suas críticas), na Ciência do Direito. Alguns ensaios em particular, como "Apologia do Erro"1389, "A Satelitização da Inteligência"1390 "Ciência e Poder"1391 "Ciência Feliz" 1392 e a "Educação para o Brilho" ${ }^{1393}$, entre outros, demonstram claramente esse viés ${ }^{1394}$.

Entre o final do século XX e o início do século XXI Souto Maior Borges lança-se a novos desafios, que passam pela aplicação do rigor metodológico a outros ramos do Direito, conforme se observa no notável trabalho sobre "Direito Comunitário" "1395, ou pela elaboração de uma proposta investigativa aplicável (mas complementar à Ciência do Direito em sentido estrito - Dogmática Jurídica), denominada Hermenêutica Histórica.

\footnotetext{
${ }^{1387}$ Para o autor, mantendo convergência com os ensinamentos da PUCSP, “(...) O sincretismo é um atentado contra a pureza metodológica e ao mesmo tempo contra o monismo que deve caracterizar as ciências modernas, como o seu critério de demarcação. Misturam-se por essa via, antes um desvio epistemológico, saberes regidos por campos científicos diversos. A matéria-prima do direito é convertida numa colcha de retalhos (...)”. BORGES, José Souto Maior. Curso de Direito Comunitário. Op.cit., p. 09 e seguintes.

${ }^{1388}$ Sobre a vinculação das premissas da teoria geral do direito na obra do autor, conferir: BORGES, José Souto Maior. Obrigação Tributária (uma introdução metodológica). ${ }^{a}$ Ed. São Paulo: Malheiros, 1999, p. 19-46.

${ }^{1389}$ BORGES, José Souto Maior. Ciência Feliz. São Paulo: Max Limonad, 2000, p. 19-25.

${ }^{1390}$ Idem, p.25-35.

${ }^{1391}$ Ibidem, p. 45-51.

1392 Ibidem, p. 51-59.

1393 Ibidem, p. 73-85.

${ }^{1394}$ Note-se que nessa obra o autor também apresenta importantíssimas anotações históricas sobre alguns dos principais autores do direito tributário brasileiro, entre os quais Aliomar Baleeiro, Gilberto Ulhôa Canto, Lourival Vilanova, Alfredo Augusto Becker e Geraldo Ataliba. Ibidem, p. 145 e ss.

${ }^{1395}$ BORGES, José Souto Maior. Curso de Direito Comunitário. Op.cit., p.XXXVII; p. 106-108.
} 
A "Hermenêutica Histórica", sem identificar-se com a análise histórico-evolutiva, busca compreender as origens históricas de um instituto jurídico no âmbito de seu próprio contexto histórico em que foi elaborado ${ }^{1396}$.

Trata-se, na lição de Souto Maior Borges, de “(...) uma escavação conceitual; ir ao fundo dos fundamentos das categorias científicas (...)", mas que constitui-se como proposta metodológica diferenciada e complementar (mas não substitutiva), ao estudo dogmático do Direito Tributário. ${ }^{1397}{ }_{-}^{1398}$

Em síntese, diferenciando a hermenêutica histórica da análise histórico-evolutiva, defende que a primeira “(...) Preconiza a atitude retrospectiva, o passo atrás, a volta à origem, ao momento histórico em que uma teoria nova eclodiu o conserto da ciência jurídica. Trata-se de uma metodologia histórica. Empreender uma "escavação" conceitual da origem é instaurar, no campo jurídico, a hermenêutica histórica. Intenta-se revisitar as circunstâncias em que a teoria jurídica foi originariamente concebida. Localizá-la no seu tempo próprio - eis o desafio. E nele estancar a análise - eis a inovação. Por isso, a hermenêutica histórica não é histórico-evolutiva: esta procura surpreender prospectivamente o fenômeno na sua evolução ao longo do tempo. A hermenêutica histórica deve ousar o passo atrás, o retorno à origem". 1399

Deve-se ressaltar que a proposta investigativa apresentada pelo autor não apresenta vinculação expressamente assumida nas construções contemporâneas da História do Direito.

Por outro lado, a perspectiva instrumental da Hermenêutica Histórica era expressamente levantada. Assim: "Não aspira, a hermenêutica histórica, substituir os outros exegéticos, mas pretende conviver com eles como um instrumental valioso para o progresso da ciência do Direito Tributário". ${ }^{1400}$

\footnotetext{
${ }^{1396}$ As razões que levam o autor à elaboração de sua "hermenêutica histórica" são apontadas por Folloni. Conferir: FOLLONI, André Parmo. Ciência do Direito Tributário no Brasil. Crítica e Perspectiva a partir de José Souto Maior Borges. São Paulo: Saraiva, 2013, p. 36 e ss.

${ }^{1397}$ BORGES, José Souto Maior. Teoria Geral da Isenção Tributária. Op.cit. p.138.

1398 Idem, p. 133-136.

${ }^{1399}$ BORGES, José Souto Maior. Hermenêutica Histórica no Direito Tributário. In: Revista Tributária e de Finanças Públicas. n. 31, São Paulo: Rt, 2000, p. 112 e seguintes.

${ }^{1400}$ Idem, p. 112-113.
} 
Dessa forma, José Souto Maior Borges, ao lançar-se sobre novas perspectivas de estudo no limiar do século XX para o século XXI, apresenta posicionamentos que flertam com outros ramos do conhecimento (ainda que de forma meramente complementar à Ciência do Direito em sentido estrito).

Contudo, a visão do autor sobre o diálogo com outros ramos do conhecimento, receberia importante reformulação ulterior, a ser investigada no capítulo seguinte.

\section{Balanço do período: a impossibilidade de se conceber o processo disciplinar do Direito Tributário Brasileiro por uma rota única.}

A construção de linhas de estudo e ensino provenientes das principais faculdades de Direito no Brasil (e primeiramente em São Paulo) não deve deixar de transparecer a evidente característica de que uma Escola seja efetivamente "sucessora" de outra, como se o processo disciplinar do Direito Tributário Brasileiro caminhasse por estrada linear.

A realidade é que ambas as estratégias de estudo e ensino praticadas nas Faculdades de Direito da USP e da PUC-SP (assim como os estudiosos não alinhados a elas) partiam de pressupostos epistemológicos e metodológicos diferenciados.

Ao mesmo tempo, não deixaram de prosseguir e aperfeiçoar suas próprias linhas de estudo, caminhando paralelamente (mas nem por isso fora) no processo disciplinar do Direito Tributário. O que demonstra que o processo disciplinar do Direito Tributário brasileiro, na consolidação do ensino e do estudo do Direito Tributário segue por estradas vertidas em ramificações, por vezes convergentes ou divergentes em determinados temas de estudo.

Com sistemas de referências distintos, ${ }^{1401}$ é natural que os resultados investigativos sejam eventualmente distanciados, pois partindo de pressupostos epistemológicos e metodológicos divergentes.

De qualquer forma, deve-se reconhecer que, com a progressiva influência da Escola da PUC-SP, que apresentava maior disseminação no ensino jurídico-tributário no Brasil na

${ }^{1401}$ CARVALHO, Paulo de Barros. Direito Tributário. Linguagem e Método. Op.cit., p. 03. 
década de setenta e, sobretudo, oitenta, com a forte liderança de Geraldo Ataliba, estudos realizados por outros autores que apresentassem linhas epistemológicas distintas daquela renomada escola acabavam sentindo os mesmos efeitos, algo absolutamente compreensível no âmbito do processo disciplinar na teoria do conhecimento.

Em verdade, para o processo disciplinar do direito tributário no Brasil tais divergências foram positivas, pois se permitiu a construção de duas linhas de estudo em muitos aspectos divergentes na análise do fenômeno jurídico-tributário, atuantes em semelhante período histórico.

Tanto os esforços empreendidos nas duas Faculdades de Direito continuam ativos e aperfeiçoados - até os dias atuais, mas se fosse possível denominar as tendências doutrinárias diferenciadoras entre as duas escolas paulistanas, poder-se-ia atribuir à linha de pesquisa e ensino tradicionalmente adotada na USP como uma linha que não desprezava as contribuições históricas, do Direito Comparado, e, com ponderações, à Ciência das Finanças, em prol do ensino e da pesquisa do Direito Tributário Brasileiro, ao passo que a PUC-SP priorizaria o positivismo dogmático-normativo aplicado ao estudo do Direito Tributário, com substanciais aproximações à Teoria Geral do Direito e à Lógica Jurídica, na busca do raciocínio jurídico de excelência, afastando-se do diálogo entre Direito Tributário e Ciência das Finanças.

Não obstante, ainda que as citadas linhas de estudo continuem ativas (através de interlocutores dos mestres citados), a realidade jurídico-tributária posterior leva também à construção de diferentes linhas de estudo, além das linhas já existentes no Direito Tributário Brasileiro, algumas delas decorrentes das primeiras, como é o caso de Paulo de Barros Carvalho, ou como complementares, como é o caso de José Souto Maior Borges, e outras consolidadas à independência dessas, como ocorre com Ricardo Lobo Torres, mas fortemente influenciadas por fenômenos posteriores (como o neoconstitucionalismo e o pós-positivismo europeu), o que ainda não afasta outras linhas de estudos aplicáveis aos aspectos jurídico-tribuários no Brasil.

Portanto, do ponto de vista epistemológico, não há como assumir a prevalência absoluta (frente ao eventual esgotamento de outras) de uma linha de pesquisa e ensino, já que todas elas, em intensidades diferentes, seguem estudadas e aperfeiçoadas nos dias atuais. A grande diferença é que cada uma delas, por circunstâncias variadas, como o 
contexto histórico, o ambiente acadêmico, as possibilidades de difusão e divulgação, entre outros, tiveram maior ou menor difusão entre estudos do Direito Tributário em determinado período.

No próximo capítulo serão analisados fatores externos recentes e suas respectivas influências ao processo disciplinar do Direito Tributário Brasileiro. Do ponto de vista histórico, o período analisado pode ser considerado a partir de meados da década de noventa até o início do século XXI. Portanto, trata-se de uma breve análise do passado recente, com reflexões sobre a doutrina contemporânea, objetivando também lançar olhares ao futuro da disciplina no Brasil, sobretudo sobre a perspectiva de fenômeno epistemológico (e pedagógico) denominado "interdisciplinaridade" que, embora considerado e reconhecido na literatura pátria (ainda que sem vinculações expressas às peculiaridades epistemológicas e pedagógicas do fenômeno), tem apresentado poucos progressos em relação às principais construções teóricas sobre o tema. A análise dessas peculiaridades será apresentada no próximo capítulo.

\section{CAPÍTULO IV - DESDOBRAMENTOS RECENTES E A QUESTÃO DA “INTERDISCIPLINARIDADE" NO PROCESSO DISCIPLINAR DO DIREITO TRIBUTÁRIO BRASILEIRO CONTEMPORÂNEO}
1. O Processo histórico-disciplinar do Direito Tributário Brasileiro contemporâneo e as recentes "mudanças paradigmáticas".


Conforme visto no capítulo 1 , foi possível observar que o processo disciplinar do Direito Tributário Brasileiro não aparece desinteressado ou desatento em relação a influencias externas (extrajurídicas). $\mathrm{Na}$ realidade, fatores extrajurídicos catapultaram o progressivo reconhecimento da autonomia teórica, legislativa e de ensino no Direito Tributário Brasileiro. Assim, esses fatores forneceram o suporte para a superação do período pré-disciplinar para o período disciplinar, que se inicia na década de quarenta e mantém-se, sob diferentes premissas históricas, no processo disciplinar contemporâneo.

É preciso, não obstante, igualmente verificar quais fatores externos de influência são capazes de alterarem a configuração do processo disciplinar contemporâneo. O processo disciplinar, naturalmente, consolida-se e se estrutura, sobretudo sobre temas de interesse vinculados a esses fatores.

Talvez seja exagerado falar em "mudança paradigmática", no processo disciplinar do Direito Tributário. Aliás, muito se tem falado, entre representantes contemporâneos do Direito Tributário Brasileiro, que haveria uma mudança paradigmática completa no modo de pensar e raciocinar o Direito Tributário no Brasil.

Por isso é preciso lançar mão de algumas ideias sobre o sentido da mudança paradigmática e se ela de fato ela colabora para a identificação de um "novo processo disciplinar" substitutivo (ou complementar) ao processo disciplinar contemporâneo.

Nesse contexto, historicamente, a ideia de mudança de paradigma (que também é relativamente recente na epistemologia) foi exposta por Thomas Kuhn, para quem, quando determinado paradigma teórico entra em crise (epistemológica), sua substituição por outro paradigma, ainda que lentamente, é inevitável ${ }^{1402}$.

Assumindo como base o paradigma dominante, a ciência desenvolve-se selecionando problemas (objetos de estudo) em conformidade com os pressupostos daquele paradigma geralmente aceito. A "ciência normal" baseia-se em realizações científicas passadas, reconhecidas por determinado período enquanto capazes de proporcionar os fundamentos para sua prática científica posterior ${ }^{1403}$.

\footnotetext{
${ }^{1402}$ KUHN, Thomas. Op.cit., p. 13 e seguintes.

${ }^{1403}$ KUHN, Thomas. Op.cit., p. 29.
} 
Entretanto, muitas vezes, as perspectivas alternativas (anomalias) ao paradigma dominante são propostas no momento histórico em que o paradigma dominante prevalece, e são, naturalmente, excluídas ou desacreditadas ${ }^{1404}$. Porém, com o passar do tempo, eventualmente o paradigma dominante pode entrar em crise, ou ruptura, na terminologia de Bachelard $^{1405}$, e aquelas propostas que antes eram demonizadas, ridicularizadas teoricamente, começam a se fortalecer, até chegar ao momento em que formarão novo paradigma dominante, substituindo o anterior, já exaurido, por não ser mais capaz de atender com plenitude às demandas surgidas naquele campo do conhecimento. Surge a ideia de "ciência em crise", que é aquela ciência que já não consegue afastar os novos problemas (e que incorrem na inevitabilidade da alteração do paradigma que o suporta).

Da superação da crise científica (e alteração do paradigma dominante), emana-se a ideia da revolução científica ${ }^{1406}$, surgindo novo paradigma, e, consequentemente, nova ciência, agora aprimorada. Para Bachelard, a história da ciência não avança linearmente (continuamente), mas através de saltos e fraturas (revoluções teóricas), que anulariam ou retificariam totalmente os quadros conceituais anteriores. Daí a ideia de ruptura epistemológica enquanto fenômeno essencial para o surgimento de nova ciência ${ }^{1407}$.

Essa ruptura estaria ligada, segundo Boaventura de Sousa Santos, ao esfacelamento do paradigma sócio-cultural predominante, que surge entre o século XVI e o século XVIII, mas avança até meados do século XX. Este, denominado pelo autor como paradigma da

\footnotetext{
${ }^{1404}$ Alerta Kuhn: "Por exemplo, a ciência normal frequentemente suprime novidades fundamentais, porque estas subvertem necessariamente seus compromissos básicos. Não obstante, na medida em que esses compromissos retém um elemento de arbitrariedade, a própria natureza da pesquisa normal assegura que a novidade não será suprimida por muito tempo. Algumas vezes um problema comum, que deveria ser resolvido por meio de regras e procedimentos conhecidos, resiste ao ataque violento e reiterado dos membros mais hábeis do grupo em cuja área de competência ele ocorre. Em outras ocasiões, uma peça de equipamento, projetada e construída para fins de pesquisa normal, não funciona segundo a maneira antecipada, revelando uma anomalia que não pode ser ajustada às expectativas profissionais, não obstante esforços repetidos. Desta e de outras maneiras, a ciência normal desorienta-se seguidamente. E quando isto ocorre - isto é, quando os membros da profissão não podem mais esquivar-se das anomalias que subvertem a tradição existente da prática cientifica - então começam as investigações extraordinárias que finalmente conduzem a profissão a um novo conjunto de compromissos, a uma nova base para a prática da ciência. Neste ensaio, são denominados de revoluções científicas os episódios extraordinários nos quais ocorre essa alteração de compromissos profissionais. As revoluções científicas são os complementos desintegradores da tradição a qual a atividade da ciência normal está ligada". Idem, p. 24-25.

${ }^{1405}$ BACHELARD, Gaston. A Epistemologia. São Paulo: Martins Fontes, s/d, p. 27 e seguintes.

${ }^{1406}$ KUHN, Thomas. Op.cit., p. 107 e seguintes.

${ }^{1407}$ ABB AGNANO, Nicola. Dicionário de Filosofia. 2a Edição. São Paulo: Mestre Jou, 1998, p. 394-395.
} 
Modernidade, também pressupõe o cientificismo, elevado pela objetividade e neutralidade científica, onde a própria ordem social seria assente na ciência ${ }^{1408}$.

O paradigma dominante gera a ideia de que o modelo de racionalidade (do qual decorre a objetividade, cientificidade e redução do objeto de estudo) estende-se às ciências sociais. Mas esse modelo, que é global, é também totalitário, negando o caráter de científico a qualquer proposta que não se paute em seus próprios pressupostos epistemológicos e metodológicos ${ }^{1409}$.

Para Santos, a crise do paradigma dominante torna-se inevitável a partir da verificação dos seguintes sinais: “(...) primeiro, que essa crise é não só profunda como irreversível; segundo, que estamos a viver um período de revolução científica que se iniciou com Einstein e a mecânica quântica e não se sabe ainda quando acabará; terceiro, que os sinais nos permitem tão-só especular acerca do paradigma que emergirá deste período revolucionário, mas que, desde já, pode afirmar-se com segurança que colapsarão as distinções básicas em que assenta o paradigma dominante a que atrás aludi”.

Mas ressalta o próprio autor que, ironicamente, as insuficiências do paradigma dominante são visualizadas com maior clareza graças ao avanço do conhecimento científico que se estruturou sob esse próprio paradigma ${ }^{1410}$. Trata-se, portanto, de epistemologia pós-moderna que surge como resposta ao reducionismo epistemológico (do qual emana a especialização disciplinar) ${ }^{1411}$.

Contudo, a dúvida maior recai se realmente haveria uma mudança paradigmática no processo disciplinar do Direito Tributário contemporâneo apto a reformular totalmente a

${ }^{1408}$ SANTOS, Boaventura de Sousa. A Crítica da Razão Indolente: Contra o desperdício da experiência. São Paulo: Editora Cortez, 2007, p. 49.

${ }^{1409}$ Idem, p. 61.

${ }^{1410}$ Idem, p. 72-74.

${ }^{1411}$ As linhas de estudo epistemológicas pós-positivistas (ou neo-pós-positivistas) caracterizam-se pelos seguintes aspectos: “1) consciência do caráter humano e histórico temporal da ciência; 2) atenção aos aspectos concretos (e não simplesmente lógico-abstratos) do saber científico; e 3) ideia segundo a qual a filosofia da ciência sem a história da ciência é "vazia"; 4) tendência a enraizar as teorias nas estruturas conceituais mais amplas, que são os "paradigmas" ou os "programas de pesquisa"; 5) mentalidade holística e rejeição às dicotomias entre ciência e metafísica, contexto de justificação e contexto de justificação e contexto de descoberta, linguagem teórica e linguagem observacional; 6) negação de um suposto "método" (fixo) do saber e de qualquer "demarcação (rígida) entre a ciência e as outras atividades humanas; 7) interpretação "forte" do caráter teórico e da exclusão de uma base empírica neutra capaz de funcionar como critério de "verificabilidade" ou "falsificabilidade" das teorias; 8) propensão a considerar as teorias não em termos de "verdade" mas de "consenso"; 9) tendências a insistir na incomensurabilidade dos paradigmas; 10) rejeição à tradicional ideia de progresso científico, seja na forma positivista de acúmulo de certezas, seja na forma popperiana de aproximação gradual da verdade.”ABBAGNANO, Nicola. Op.cit., p. 393-394. 
Ciência do Direito Tributário Brasileiro, ou se apenas novas perspectivas de estudo (que parece também ser exagerado denominá-las de "anomalias"), ou se o processo disciplinar apenas estaria em momento de adaptação aos recentes fatores extrajurídicos reconhecidos progressivamente pela literatura especializada e por sua vez investigados.

Por esse motivo, acredita-se que seja conveniente, ao falar do processo disciplinar do Direito Tributário Brasileiro, seja do passado (que foi analisado nos capítulos anteriores) ou do passado recente, objeto deste capítulo, verificar se não seria mais adequado falar em adaptação ou mesmo absorção, pelo processo disciplinar do Direito Tributário Brasileiro da complexa (e diferenciada) realidade que suporta a tributação contemporânea.

Por outro lado, é evidentemente que o paradigma dominante no estudo do Direito Tributário vincula-se à perspectiva cartesiana (especialização e redução do objeto), e tal perspectiva de estudo favoreceu de fato ao processo disciplinar do Direito Tributário brasileiro, assim como qualquer outro processo disciplinar de qualquer ramo do direito. Mas não se pode afirmar seguramente, conforme se sustenta na presente tese, de que esse processo se desenrolou sem ser permeado por ponderações, mesmo em linhas de estudo supostamente impermeáveis ao diálogo entre Direito Tributário e outros ramos do conhecimento.

É verdade, porém, que gradualmente aparecem novos problemas (“anomalias", na terminologia de Kuhn) para os estudiosos do Direito Tributário no Brasil, e que geram certas dificuldades cujas soluções não podem ser encontradas na metodologia jurídicotributária tradicional. Mas isso também é resultado natural de atualização do processo disciplinar do Direito Tributário Brasileiro, que deve manter-se atento a novas demandas.

Porém, contemporaneamente, tem-se defendido a necessidade de consolidação de novas facetas aos estudos tributários contemporâneos. Em todas essas, aparece gradativamente a percepção de que o estudo dogmático-normativo tradicional aplicado ao fenômeno jurídico tributário possa talvez não ser capaz de resolver esses novos problemas. Daí o surgimento de novas tendências hermenêuticas e novos esforços a aprofundar a pragmática da norma tributária. Mas também não significa reformulação completa dos estudos tributários, mas complementação, daquilo que as tendências anteriores não foram capazes, ou simplesmente optaram por conceder menor atenção. O que há, portanto, diante 
do ambiente crítico perante tentativas anteriores lançadas aos estudos tributários, é a percepção de que determinadas lacunas devem ser preenchidas. É, portanto, aperfeiçoamento do processo disciplinar, mas não completa reformulação.

Ademais, os fatores externos influenciam severamente o processo disciplinar contemporâneo, como a globalização e o reforço dos direitos fundamentais, e as diferenciadas dinâmicas construídas hodiernamente entre o Estado (em sua perspectiva fiscal) e a sociedade contemporânea, pode-se visualizar determinadas tendências não tão bem desenvolvidas no contexto histórico anterior, mas que a partir desse diferenciado contexto histórico, passa a ser impulsionada. Mas também se entende como natural e necessário ao processo histórico disciplinar, que se impulsiona através de respostas destinadas a atender essas demandas.

É verdade que o contexto histórico contemporâneo, naturalmente, fornece importantes influências às configurações do processo disciplinar do Direito Tributário Brasileiro. Assim como o alicerce econômico, político, científico, social e estatal foi essencial para o início do período disciplinar do Direito Tributário Brasileiro, é preciso averiguar em qual medida esses recentes fenômenos contribuem para diferenciadas formatações ao estudo do Direito Tributário Brasileiro.

Nesse sentido, a influência das novas gerações de direitos fundamentais trazidas pelo século XXI e as transformações causadas pelo fenômeno da globalização no processo disciplinar do Direito Tributário brasileiro, promovem, a seu turno, novas tendências ao processo disciplinar, levando também a novas reflexões a respeito da interdisciplinaridade frente aos estudos tributários contemporâneos, impulsionando o tributarista à reconsideração do diálogo entre o Direito Tributário e outros ramos do conhecimento.

Mas torna-se necessário, naturalmente, verificar em que contexto histórico o processo disciplinar se corporifica, sobretudo na averiguação das diferentes configurações históricas do Estado Fiscal e da própria sociedade que o suporta. Nesse sentido, pode-se dizer que as recentes estruturações estatais e sociais contemporâneas influenciam fortemente o surgimento de novas tendências aplicáveis ao estudo do direito tributário brasileiro atual. 


\section{Os fatores externos recentes que impulsionam a consolidação (e atualização)}

disciplinar do Direito Tributário contemporâneo (o limiar do século XX para o século XXI)

\subsection{O Estado Fiscal contemporâneo e a tributação}

A consolidação da autonomia teórica do Direito Tributário Brasileiro, ocorrida a partir da década de quarenta do século $\mathrm{XX}$, conforme demonstrado no capítulo 1, não surgiu impulsionada puramente por motivos acadêmicos, mas foi influenciado por um contexto histórico plenamente justificado, e motivado por aspectos legislativos, científicos, econômicos, sociais, políticos, e que criaram o ambiente propício para a elevação disciplinar do direito tributário. Veja-se que, como já explorou pioneiramente Ricardo Lobo Torres, as diferentes configurações do Estado Fiscal surgem permeadas por diferenciados contextos históricos ${ }^{1412}{ }^{1413}$.

Se o Estado Fiscal Minimalista aparece entre os finais do século XVIII até o início do século XX, o Estado Social Fiscal manifesta-se principalmente no decurso do século XX (entre 1919 até 1989, aproximadamente), correspondendo ao aspecto financeiro do Estado Social de Direito, portanto ${ }^{1414}$.

A realidade brasileira, naturalmente, segue esse fluxo, ainda que com ponderações. Note-se que o ambiente oitocentista, seja no âmbito do direito público, seja no âmbito da economia pública (ou ciência das finanças), seguia essa tendência minimalista do Estado Fiscal (guarda-noturno ${ }^{1415}$ ), com poucas contribuições efetivas à elevação dos estudos tributários, e quando eram feitos, não escapavam da pecha de estudos econômicos ou técnicos (período pré-disciplinar), tendência que se manifestará com prevalência absoluta até meados da década de trinta na realidade brasileira.

A influência do pensamento político e econômico liberal foi sobressaliente, garantindo, nesse sentido, certa refração à evolução dos estudos tributários, sobretudo jurídicos. Com a Primeira Guerra Mundial, o Crack da Bolsa de 1929, e a revolução

1412 TORRES, Ricardo Lobo. A ideia de liberdade no Estado Patrimonial e no Estado Fiscal. Op.cit., p.01-09.

${ }_{1413}$ TORRES, Ricardo Lobo. Curso de Direito Financeiro e Tributário. 19 Ed. Rio de Janeiro: Renovar, 2013, p. 07-10.

${ }^{1414}$ No Brasil, a configuração do Estado Fiscal, segundo Ricardo Lobo Torres, aparece a partir da Constituição de 1824, mantendo, no entanto, certas características do Estado Patrimonial. De qualquer forma, com ponderações, a realidade estatal brasileira (e suas configurações fiscais) seguiu mais ou menos a tendência estrangeira. TORRES, Ricardo Lobo. A Ideia de Liberdade no Estado Patrimonial e no Estado Fiscal. Op.cit., p. 149 e ss. TORRES, Ricardo Lobo. Curso de Direito Financeiro e Tributário. Op.cit., p. 09.

${ }^{1415}$ SCHOUERI, Luís Eduardo. Direito Tributário. $3^{\text {a }}$ Ed. São Paulo: Saraiva, p. 25-26. 
keynesiana, na década de trinta, o Estado Fiscal Minimalista é gradualmente substituído pelo Estado Social Fiscal ${ }^{1416}$.

Nesse quadro, conforme já observado, a atividade financeira, fundada na receita de tributos, passa também a observar a intervenção, através de tributos, na economia e na própria sociedade, com finalidades extrafiscais, seja para desenvolver setores estratégicos da economia ou mesmo inibir determinadas condutas nocivas à sociedade.

Não é preciso ressaltar que o processo disciplinar do Direito Tributário no Brasil, não por acaso, floresce justamente no contexto do Estado Social Fiscal, e, portanto, reflete características próprias desse ambiente histórico (ainda que muitos tributaristas tenham tradicionalmente apresentado alguns reflexos ideológicos liberais na análise dos tributos). Contudo, conforme já observado, essa formação estatal-fiscal passa por sucessivas transformações.

Nesse contexto, a tributação expande-se (assim como o orçamento público), e o Estado Social Fiscal entra em crise financeira e orçamentária a partir do final da década de setenta, período em que a autonomia do ensino e a consolidação de diferentes pontos de vista sobre o estudo do direito tributário passam a se difundir na realidade brasileira, criando o pano de fundo necessário para o progresso dos estudos teóricos no âmbito do Direito Tributário, o que é impulsionado pelo processo de democratização (1985-1988) que se instaura no Brasil, tendo como ápice a Constituição de $1988^{1417}$.

Sob o ponto de vista do Estado Fiscal, a queda do muro de Berlim (1989) marca, simbolicamente, o surgimento de uma nova etapa, marcada pela globalização, pela crise do socialismo e do intervencionismo estatal, a mudança de determinados paradigmas políticos e jurídicos, passando-se a fortalecer o Estado Democrático e Social Fiscal (correspondente ao Estado Democrático e Social de Direito, ou Estado Subsidiário, ou Estado da Sociedade de Risco ou Estado de Segurança), especialmente na virada do século XX para o século $\mathrm{XXI}^{1418}{ }^{1419}$.

\footnotetext{
${ }^{1416}$ TORRES, Ricardo Lobo. Curso de Direito Financeiro e Tributário. Op.cit., p. 09-10.

1417 TORRES, Ricardo Lobo. Legalidade Tributária e Riscos Sociais. Op.cit., p. 178-185.

${ }^{1418}$ A última formação do Estado Fiscal tem como características, as seguintes: "Mantém características do Estado Social, mas passa por modificações importantes, como a diminuição do seu tamanho e a restrição ao seu intervencionismo no domínio social e econômico. Vive precipuamente de ingressos tributários, reduzindo, pela privatização de suas empresas e pela desregulação do social, o aporte das receitas patrimoniais e parafiscais. Procura, na via da despesa pública, reduzir as desigualdades sociais e garantir as condições necessárias à entrega de prestações públicas nas áreas da saúde e da educação, abandonando a utopia da inesgotabilidade dos recursos públicos. Nele se equilibram a justiça e a segurança jurídica, a legalidade e a capacidade contributiva, a legalidade e a responsabilidade". TORRES, Ricardo Lobo. Curso de Direito Financeiro e Tributário. Op.cit., p. 08-10.

${ }^{1419}$ SCHOUERI, Luís Eduardo. Direito Tributário. $3^{\text {a }}$ Ed. Op.cit., p. 30 e ss.
} 
Para Schoueri, essa transformação ocorreu porque o agigantamento do Estado (próprio do Estado Social Fiscal) não era garantia de melhor distribuição de renda ou de eficiência econômica. Assim, passa-se a observar espaço maior para a iniciativa privada. Não por acaso, a recente formatação estatal é marcada por uma “(...) diminuição de tamanho e restrição a seu intervencionismo. É Estado Fiscal, ainda de maneira mais marcante, uma vez que as privatizações diminuem os recursos provenientes de seus esforços" ${ }^{1420}$. A compreensão das funções do tributo nesse contexto fortalecesse (assim como o próprio reconhecimento da função indutora desses recursos financeiros).

É interessante notar que, embora o processo disciplinar do Direito Tributário tenha iniciado consolidação em meados da década de quarenta, o surgimento da autonomia de ensino, e a posterior consolidação das Escolas de Direito Tributário, a partir de meados da década de oitenta e noventa, efetivamente aparecem e se consolidam em diferente contexto estatal-fiscal, já no declínio do Estado Social e na progressiva construção do Estado Democrático Social. Na realidade brasileira, esse processo pode ser simbolizado inicialmente pela democratização constitucional, que se enraíza pela Constituição de 1988, consolidando-se na década de noventa do século XX.

Mas não se pode dizer que esse processo disciplinar não apareça permeado de características construídas no período estatal anterior. Certas preocupações consolidadas no ambiente político de grande instabilidade (período ditatorial) ainda guardam suas marcas, e a constitucionalização democrática (1988) não afasta, mas intensifica esses esforços.

A segurança jurídica, portanto, mantém-se como elemento-chave na configuração disciplinar do Direito Tributário nesse ambiente, sobretudo no período de instauração constitucional, e pelo enfrentamento de problemas antigos e ainda não superados pela imatura configuração constitucional (e seus efeitos tributários). O processo disciplinar do Direito Tributário aparece, naturalmente, permeado por essas características, que seguem reforçadas no intuito de afastar definitivamente problemas conjunturais identificados e combatidos nas décadas anteriores.

Mas, efetivamente, sob o ponto de vista disciplinar, novos desafios gradualmente aparecem aos estudos tributários, influenciados pelo particular ambiente históricocontemporâneo, sobretudo sob a perspectiva social e estatal, que, no âmbito tributário, hodiernamente, caracteriza-se pela formação do Estado Fiscal da sociedade pós-industrial globalizada, que segue influenciada pelo ambiente social e epistemológico contemporâneo. 
Essa diferente conjuntura, sob a perspectiva social, ganha outras expressões que exploram as grandes transformações contemporâneas vivenciadas na sociedade, que corporifica a "sociedade de consumo" ou a "sociedade de informação" (que seriam um novo tipo de sistema social, diferente dos sistemas sociais historicamente anteriores) ${ }^{1421}$.

No campo da epistemologia, essas transformações levariam ao encerramento da modernidade e a inauguração da "pós-modernidade" ou "pós-modernismo" ou ainda "sociedade pós-moderna". Nesse contexto, as discussões mais incessantes pautam-se no campo da epistemologia e da filosofia, conforme acertadamente expõe Anthony Giddens $^{1422}$, que se esforçam a compreender a contemporânea e complexa conjuntura social.

Note-se, portanto, que não é tarefa fácil compreender o caráter do Estado e da Sociedade contemporânea, uma vez que diferentes pontos de vista sobrepostos ao fenômeno estatal e social contemporâneos são capazes de aduzir distintas características, que se sobressaem dependendo da perspectiva adotada.

Reconhece-se, portanto, o surgimento gradual de diferenciado contexto estatalfiscal (seja pela atual configuração de um Estado Democrático Social Fiscal), social (seja pelo reconhecimento de uma sociedade globalizada pautada no consumismo desenfreado, e tendente, institucionalmente, à transição de uma sociedade de manufatura baseada em bens materiais para uma sociedade mais centrada na informação) e epistemológico contemporâneo, e que esse contexto (ou contextos) influencia o processo disciplinar do Direito Tributário Brasileiro Contemporâneo, de forma inequívoca.

Uma vez reconhecido que os diferentes perfis estatais (e das diferentes configurações da própria sociedade) interferem diretamente na configuração da própria atividade tributária, é evidente que o mesmo se procede com o direito tributário (positivado) e a ciência jurídica que o estuda. Assim, o processo disciplinar do Direito Tributário contemporâneo consolida-se em ambiente pautado por diferentes características e influenciado, ainda que indiretamente, por incessantes debates sobre os rumos presentes (e futuros) das configurações da sociedade e do próprio Estado em ambiente globalizado.

Independentemente dos particulares pontos de vistas ou perspectivas aplicadas a esse particular contexto contemporâneo, seja na consideração de uma "sociedade de consumo", "pós-moderna", "de informação", "globalizada”, ou "de riscos”, a sensação

${ }^{1421}$ GIDDENS, Anthony. As Consequências da Modernidade. Tradução de Raul Fiker. São Paulo: Editora UNESP, 1991, p. 08-09.

${ }^{1422}$ GIDDENS, Anthony. As Consequências da Modernidade. Op.cit., p. 08-09. 
geral é a de que se mostra cada vez mais clara a percepção de que o ambiente contemporâneo demanda respostas diferenciadas daquelas produzidas no ambiente histórico anterior e, sobretudo, no período em que se consolida disciplinarmente o Direito Tributário.

Mas desse diferenciado contexto contemporâneo emanam novas demandas que precisam ser respondidas, e com elas, novos problemas que necessitam de solução.

Esses problemas, próprios do consumo desenfreado, da troca incessante de informações, da globalização (que, embora geralmente identificado como processo econômico e tecnológico, vai muito além desses dois aspectos), e da evolução tecnológica galopante, trazem fortes consequências positivas, mas também negativas à sociedade contemporânea.

Noutro sentido, a perspectiva pós-moderna refere-se, segundo Anthony Giddens, a um deslocamento das tentativas de fundamentar a epistemologia, e da fé no progresso planejado da humanidade, caracterizando-se pela visão pluralista tendente ao reconhecimento de reivindicações heterogêneas do conhecimento, onde a ciência não teria lugar privilegiado ${ }^{1423}$.

O ambiente pós-moderno, portanto, apresenta consideráveis diferenciações perante a consagração modernista, e que de certa forma, influenciou fortemente a consolidação disciplinar do direito tributário brasileiro, a partir da década de quarenta do século XX. Mas, com o passar dos anos, e especialmente nos anos finais do século XX, novas demandas são gradualmente trazidas aos debates tributários (ou pelo menos gradualmente reconhecidas), enquanto frutos desse próprio diferenciado, heterogêneo e plural contexto.

\subsection{Globalização, sociedade de riscos e seus reflexos na tributação.}

Se antes determinadas tendências metodológicas aplicáveis ao estudo do direito tributário apareceriam enquanto pedra de toque para o progresso disciplinar, por sua vez emanadas do campo das ciências sociais, talvez as demandas motivacionais para o aperfeiçoamento contemporâneo do direito tributário sejam diferentes. E contextos diferentes emanam problemas diferentes, denotando, por outro lado, respostas (ou a busca por respostas) diferentes. Nesse sentido, é preciso compreender, ainda que sucintamente, o sentido de globalização e sua importância na sociedade contemporânea.

${ }^{1423}$ GIDDENS, Anthony. As Consequências da Modernidade. Op.cit., p. 08-09. 
A busca pela definição da expressão "globalização" sempre manifestou grande dificuldade terminológica. Não obstante, pode-se afirmar que, se é verdade que essa expressão encontre ligações históricas à Paz Perpétua, de $\mathrm{Kant}^{1424}$, nas relações entre Estados Soberanos, hodiernamente, porém, a globalização tem sido identificada comumente como "globalização da economia". Pelo menos esse é um dos sentidos mais desenvolvidos por seus estudiosos, muitas vezes ligado a importantes reflexos desta nas legislações nacionais, assim como na própria regionalização (formação de blocos econômicos) e internacionalização da economia. ${ }^{1425}$

A globalização prima pelo aperfeiçoamento técnico e tecnológico, mas, ao mesmo tempo, é também fenômeno imperceptível, e daí a dificuldade de sua precisa definição, identificação ou completa apreensão. ${ }^{1426}$ Sabe-se que a globalização está profundamente ligada à expansão dos meios de comunicação eletrônica, e é efeito irreversível da revolução tecnológica, marcado pelo crescimento da circulação e universalização da economia, e acelerada pela transferência eletrônica de capitais e informações entre diferentes locais, muitas vezes distantes no planeta $^{1427}$.

Para Souto Maior Borges, a globalização poderia ser identificada enquanto processo de integração espacial e social em nível planetário, ao mesmo tempo em que, em grande parte, pode ser entendida como a globalização da economia ${ }^{1428}$. Através dessa, o mundo passa a ser visto como “(...) uma comunidade de informação”. 1429

${ }^{1424}$ KANT, À Paz Perpétua. Op.cit., p. 25 e seguintes.

${ }^{1425}$ AMARAL, Antonio Carlos Rodrigues do. Visão Global da Fiscalidade no MERCOSUL. Tributação do Consumo e da Renda. In: MARTINS, Ives Gandra. Direito Tributário no Mercosul. Rio de Janeiro: Forense, 2000, p. 17.

${ }^{1426}$ BORGES, José Souto Maior. Curso de Direito Comunitário. Op.cit., p. 65

${ }^{1427}$ CINTRA, Marcos. Globalização, Modernização e Inovação Fiscal. In: Direito Tributário. Política Fiscal. VASCONCELLOS, Roberto França. Série GVLaw, São Paulo: Saraiva, 2009, p. 47 e seguintes.

${ }^{1428}$ BORGES, José Souto Maior. Curso de Direito Comunitário. Op.cit., p. 66.

${ }^{1429}$ Face à multiplicidade dos sentidos de globalização, “(...) ora percebidos pelo modo como são afetados os subsistemas sociais (globalização econômica, política, jurídica, religiosa e cultural), ora pelos instrumentos de sua atuação (globalização tecnológica, organizacional, comunicacional), ora pela alteração das formas de apreensão da realidade, em que espaço e tempo parecem sobrepor-se (globalização territorial, de simultaneidade dos eventos em qualquer espaço)". Tércio Sampaio Ferraz Júnior, igualmente, reconhece a dificuldade de identificar denominador comum frente à tal multiplicidade, embora busque enxergá-lo na "(...) ascensão da informação como centro organizador de suas diferentes manifestações. A informação é vista, assim, como um meio de interconexão de quaisquer atividades humanas, capaz de gerar uma nova concepção antropológica: o homo "informaticus". Na sua base estaria, na visão do autor, o ser humano “(...) como um ser que se comunica, sendo este o sentido de sua existência". JÚNIOR, Tércio Sampaio Ferraz. Estado de Direito, Desenvolvimento e Globalização. In: Estudos de Filosofia do Direito. Reflexões sobre o Poder, a Liberdade, a Justiça e o Direito. 2 Ed. São Paulo: Atlas, 2003, p. 285-286. 
De qualquer forma, os reflexos trazidos pela globalização emanam-se como intrincada teia de aranha, permeando-se sobre diferentes campos do conhecimento, que passam a refleti-la. Mesmo na Teoria do Estado a globalização se faz presente, onde o próprio conceito tradicional de soberania passa por revisão substancial, pois não há como defendê-la em sua plenitude original (Estado-Nação) à luz da globalização e da regionalização internacional. ${ }^{1430}{ }^{1431}$ Da mesma forma a própria configuração do Estado, e dos papéis exercidos no âmbito interno e internacional, sofrem mudanças (nem sempre positivas), conforme expõe Campilongo: "No mundo globalizado, o esvaziamento do Estado significa, para a democracia, o enfraquecimento da capacidade do sistema político para: a) regular o trabalho (daí a flexibilização dos direitos trabalhistas, a volatividade do capital em busca de trabalhadores menos onerosos e o surgimento de formas novas e fragmentárias de prestação de serviços domésticos, terceirizado e informatizado; b) promover o bem-estar social (daí a expansão dos serviços privados de saúde e educação, a "guerra fiscal" internacional pela atração de capitais e o declínio da arrecadação de tributos e de implementação de políticas sociais); c) garantir a segurança pública e controlar a violência (daí o crescimento da impunidade, da violação dos direitos humanos e do

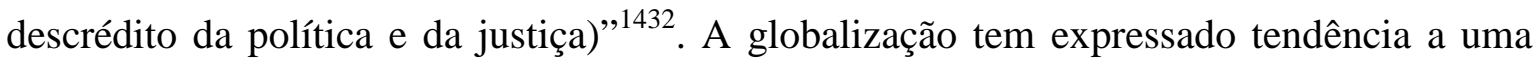
forma mais avançada e complexa de internacionalização, cuja precisão ou delimitação conceitual é ainda difícil (assim como a precisa percepção de suas consequências) ${ }^{1433}$, embora tendencialmente aplicada ao fenômeno de produção, distribuição, consumo de bens e serviços, estruturados dentro de uma estratégia mundial direcionada ao mercado global. $^{1434}$

Engloba também o aperfeiçoamento tecnológico mundial, aproximando países, culturas, economias e, ao mesmo tempo, a flexibilização de fronteiras nacionais.

\footnotetext{
${ }^{1430}$ Idem.

${ }^{1431}$ No mesmo sentido aponta Campilongo, a globalização abre campo para “(...) redescrição, em novas bases conceituais, das estruturas e processos sociais contemporâneos. Assim, soberania, democracia, direito, Estado, ordem internacional...ganham novos contornos teóricos”. CAMPILONGO, Celso Fernandes. O Direito na Sociedade Complexa. São Paulo: Max Limonad, 2000, p. 115 e ss.

1432 Idem, p. 118.

${ }^{1433}$ NOGUEIRA, Alberto. Globalização, Regionalizações e Tributação. A Nova Matriz Mundial. Rio de Janeiro: Renovar, 2000, p. 06.

${ }^{1434}$ OLIVEIRA, Odete Maria de. União Européia: Processos de Integração e Mutação. Curitiba: Juruá, 2001, p. 23-24.
} 
Naturalmente, no substrato tributário, a globalização também apresenta suas próprias peculiaridades ${ }^{1435}{ }_{-}^{1436}$, que incursionam renovadas reflexões na literatura ${ }^{1437}{ }^{1438}$.

Note-se, contudo, que a globalização nada mais é do que aspecto inerentemente ligado ao perfil característico da sociedade de riscos, e, portanto, analisá-la também importa em considerar os aspectos negativos inerentes à globalização, seja no aspecto social, econômico, ambiental, tecnológico, de acesso à informação, etc.

Assim, é necessário também assumir a profunda influência da globalização em recentes tendências temáticas aplicadas aos estudos tributários contemporâneos, seja na promoção de estudos voltados à consideração dos riscos sociais e o papel da atividade tributária em remediá-los, seja na consideração dos riscos ambientais, sociais ou econômicos inerentemente intensificados pela globalização.

Nesse contexto, pode-se aduzir que a configuração da sociedade globalizada não traz, naturalmente, apenas efeitos positivos, mas aprofunda e globaliza aspectos profundamente negativos.

Essa percepção, que já aparecia gradualmente na década de oitenta do século XX, ganha força com a expressão "sociedade de riscos"1439, cunhada pelo sociólogo alemão Ulrich Beck para designar a sociedade contemporânea, especialmente a partir do final da década de oitenta: "A sociedade de risco designa uma época em que os aspectos negativos do progresso determinam cada vez mais a natureza das controvérsias que animam a sociedade. O que inicialmente ninguém via e, sobretudo, desejava, a saber, colocar a si mesmo em perigo e a destruição da natureza, está cada vez mais se tornando o motor da história. Não se trata, pois, de analisar os perigos enquanto tais, mas de demonstrar que, diante da pressão do perigo industrial que nos ameaça e o consequente desaparecimento

${ }^{1435}$ Sobre o tema também conferir: CINTRA, Marcos. Globalização, Modernização e Inovação Fiscal. Op.cit., p. 47 e seguintes.

${ }^{1436}$ Sobre o assunto: ROSEMBUJ, Tulio. Principios Globales de Fiscalidad Internacional. Barcelona: Graficas Rey, 2012, p. 61 e seguintes.

${ }^{1437}$ ZILVETI, Fernando Aurelio. A Evolução da Teoria da Incidência - Análise Histórica das Estruturas Socioeconômicas na Formação do Sistema Tributário. Op.cit., s/np (cap.V, item 8).

${ }^{1438}$ AVI-YONAH, Reuven S. Os três objetivos da Tributação. In:Revista Direito Tributário Atual n. 22. Alcides Jorge Costa, Luís Eduardo Schoueri e Paulo Celso Bergstrom Bonilha (Coord.). São Paulo: IBDTDialética, 2008, p. 07 e seguintes.

${ }^{1439}$ BECK, Ulrich. Sociedade de Risco: Rumo a uma outra modernidade. São Paulo: Editora 34, 2011, p. 23 e ss. 
das questões tradicionais no conflito de classe e de interesses, aparecem chances de novas configurações" 1440 .

Segundo Beck, na modernidade tardia, a produção da riqueza em uma sociedade associa-se à produção (e distribuição, nem sempre equânime) de riscos (sociais, econômicos e ambientais, por exemplo). Assim, problemas e conflitos relativos à distribuição na sociedade da escassez acabam gradualmente se sobrepondo a problemas e eventuais conflitos próprios da produção, da definição e de distribuição de riscos cientificamente (e tecnologicamente) $\operatorname{produzidos}^{1441}{ }_{-}^{1442}$. Há, nesse contexto, o gradual transcurso da lógica da distribuição de riqueza na sociedade de escassez para a lógica da distribuição do risco na modernidade tardia. Essa transição estaria, segundo Beck, associada a duas condições: "Ela consuma-se, em primeiro lugar - como se pode reconhecer atualmente -, quando e na medida em que, através do nível alcançado pelas forças produtivas humanas e tecnológicas, assim como pelas garantias e regras jurídicas e do Estado Social, é objetivamente reduzida e socialmente isolada a autêntica carência material. Em segundo lugar, essa mudança categorial deve-se simultaneamente ao fato de que, a reboque das forças produtivas exponencialmente crescentes no processo de modernização, são desencadeados riscos e potenciais de autoameaça numa medida até

${ }^{1440}$ BECK, Ulrich. A Política da Sociedade de Risco. Traduzido da versão francesa: BECK, Ulrich. La politique dans la société du risque. In Revue du MAUSS. 1/2001 (no 17), p. 376-392. Disponível em: http://www.academia.edu.com (último acesso em 11/05/2015. Sobre o assunto também: BECK, Ulrich. Sociedade de Riscos: rumo a uma outra modernidade. Op.cit., p. 61-105.

1441 Analisando a questão politicamente, Beck traz as seguintes considerações: "Para a análise política, o mais importante é primeiro distinguir entre riscos e perigos. É o confronto da sociedade com o próprio potencial de autodestruição, criado artificialmente, que, de meu ponto de vista, marca a ruptura. Os perigos do átomo, os perigos químicos e ecológicos e os da manipulação genética constituem riscos que, em oposição ao primeiro período industrial, 1) não são limitáveis nem no espaço nem no tempo e tampouco no plano social, 2) não podem ser atribuídos a pessoas com base nas regras da causalidade, da culpabilidade e da responsabilidade em vigor, e 3) não podem ser objeto de compensação ou de alguma fiança. Onde as seguradoras privadas se recusam a cobrir riscos - tal é o caso para o desenvolvimento tecnológico que evocamos -, transpassamos o limiar entre riscos calculáveis e perigos incalculáveis. Dito de outra forma: à luz dos riscos incorridos, o sistema regulador que controla "racionalmente" as destruições industriais, se assemelha aos freios de uma bicicleta montados em um avião supersônico. Se os efeitos secundários nãopensados da produção industrial se tornaram o berço de uma crise ecológica global, não se deve ainda assim concluir que teríamos diante de nós simples problemas ambientais. Trata-se, antes, de uma crise profunda das instituições da sociedade industrial, cujas questões políticas em jogo são consideráveis. Perigos são fabricados de forma industrial, exteriorizados economicamente, individualizados no plano jurídico, legitimados no plano das ciências exatas, e minimizados no plano político. A questão decisiva que resta então saber é a seguinte: como uma política ecológica da auto-limitação ganha poder e poderia impor-se?” BECK, Ulrich. A Política da Sociedade de Risco. Op.cit., p. 376-392. Sobre o assunto também: BECK, Ulrich. Sociedade de Riscos: rumo a uma outra modernidade. Op.cit., p. 61-105.

${ }^{1442} \mathrm{Em}$ outras palavras: "Na modernidade tardia, a produção social de riqueza é acompanhada sistematicamente pela produção social dos riscos. Consequentemente, aos problemas e conflitos distributivos da sociedade da escassez sobrepõem-se os problemas e conflitos surgidos a partir da produção, definição e distribuição de riscos científico-tecnologicamente produzidos”. BECK, Ulrich. Sociedade de Riscos: rumo a uma outra modernidade. Op.cit., p. 23. 
então desconhecida" ${ }^{" 1443}$. A sociedade industrial ou de classes, permanece permeada pelo novo paradigma da sociedade de risco, que traz novas configurações sociais e novas preocupações. Por isso talvez se possa falar em sociedade pós-industrial ou da sociedade de risco.

Assim, os riscos e perigos sociais e ambientais, agora globalizados, a progressiva desigualdade e injustiça social, que leva a uma cada vez mais implacável e desigual distribuição de renda global, o terrorismo (em suas variadas vertentes), a constante ameaça nuclear, crises econômicas globais, o progresso tecnológico, o consumo e acesso à tecnologia e à informação desenfreadas, os perigos e riscos de danos irreversíveis ao meio ambiente (e suas consequências cada vez mais globalizadas) são apenas alguns desses fatores a serem considerados para compreender a complexa sociedade contemporânea, e a formação estatal que a suporta. A configuração da sociedade de risco, portanto, estrutura e fundamenta o Estado Subsidiário, ou Estado Social e Democrático de Direito.

É claro que essas novas configurações interferem e influenciam o contexto tributário contemporâneo. Não há como considerar o Estado Fiscal contemporâneo sob as mesmas lentes que o Estado Fiscal apresentava no período inicial de consolidação disciplinar do Direito Tributário no Brasil. É razoável supor também que o próprio estudo do Direito Tributário apareça, contemporaneamente, permeado por essas configurações. A sociedade de risco demanda novas reflexões sob o papel dos tributos (e suas configurações) nesse contexto. Mas como essa intrincada e complexa rede de influências (estatais, econômicas, sociais, políticas, culturais, epistemológicas, etc.) poderia influenciar positivamente o processo disciplinar do Direito Tributário Brasileiro contemporâneo?

A literatura tributária brasileira recente (também por influência estrangeira), especialmente no limiar do século XX para o século XXI, tem, gradualmente, manifestado sensibilidade maior em relação a determinadas questões inerentes à essa diferenciada configuração social (sociedade de risco).

Nesse quadro emana-se a contribuição de Ricardo Lobo Torres que, entre a doutrina nacional, mostrou-se particularmente atento a essa configuração ${ }^{1444}$ entre Estado e Sociedade, e sociedade de riscos ${ }^{1445}$, que, para o autor, seria característica do Estado

\footnotetext{
${ }^{1443}$ BECK, Ulrich. A Sociedade de Riscos. Rumo a uma outra modernidade. Op.cit., p. 23.

${ }^{1444}$ Sobre o tema, recomenda-se vivamente a leitura da seguinte obra: TORRES, Ricardo Lobo. Legalidade Tributária e Riscos Sociais. In: Revista de Direito Proc. Geral. (n.53). Rio de Janeiro, 2000, p. 178 e ss.

1445 "Na sociedade de riscos há uma cadeia de subsidiariedades, que se caracteriza pela responsabilidade primeira do indivíduo pela sua própria sobrevivência, secundada pela da comunidade se houver impossibilidade de cumprimento pelo cidadão, e complementada, em última instância, pelo Estado. Observou
} 
Subsidiário ou Democrático e Social de Direito, em contraste com a sociedade industrial, que sustentava o Estado Social de Direito (entre 1919 e 1989). Para Torres: "a sociedade de riscos se caracteriza por algumas notas relevantes: a ambivalência ${ }^{1446}$, a insegurança e o redesenho do relacionamento entre as atribuições das instituições do Estado e da própria sociedade".

Dessa configuração contemporânea, conforme expõe o celebrado autor, a própria noção de segurança jurídica acaba recebendo nova configuração: “(...) da ambivalência e do caráter paradoxal da sociedade de risco decorre a modificação do próprio conceito de segurança. A ideia de segurança jurídica, prevalecente no Estado Liberal Clássico, que tinha por objetivo a proteção dos direitos individuais do cidadão, começa a ser contrabalanceada no Estado de Bem-Estar Social com a de segurança social (rectius: seguridade social) e culmina no Estado riscos existenciais e ecológicos o custo da manutenção das agências"1447.

Se a segurança jurídica, fundamento basilar para a construção do sistema tributário contemporâneo, e elemento-chave para a consolidação disciplinar do direito tributário no Estado Social Fiscal (e anteriormente, no próprio Estado Fiscal minimalista), aparece contemporaneamente permeada por esses reflexos, não é por acaso que recentes estudos sobre a legalidade tributária (e sua eventual flexibilização trazida pelo pós-positivismo

K. Tipke que o Estado não possui dinheiro originalmente (Der Staat selbst hat kein Geld) eque sua missão se reduz a tirar parcimoniosamente recursos da camada mais rica da população para repassá-la à mais pobre, observados os postulados de justiça”. Idem, p. 183-184.

1446 "A ambivalência aparece diante da impossibilidade que da execução de políticas públicas surja sempre o consenso por parte dos cidadãos. Há uma distribuição não só de benefícios, como se pretendia ao tempo do Estado de Bem-estar Social, mas também de malefícios, como ser dá, por exemplo, na construção de vias expressas ou de instalações nucleares”. TORRES, Ricardo Lobo. Legalidade Tributária e Riscos Sociais. Op.cit., 185-186.

1447 "Por isso, mesmo aqui e no estrangeiro, a legislação vem criando "taxas de fiscalização" ou "contribuições especiais", para cobertura dos riscos, cabendo o seu pagamento às pessoas envolvidas na equação financeira dos respectivos contratos (v.g. seguro-saúde) ou na prática de atividades potencialmente arriscadas". "Os riscos da segurança nacional e da segurança pública devem necessariamente ser assumidos pelo Estado, que se financiará através de impostos extraídos da sociedade com base nos princípios da legalidade e da capacidade contributiva. Mas os riscos da existência (doença, velhice, desemprego, etc) e os riscos ambientais deverão ser suportados financeiramente pela própria parcela da sociedade que transferir ao Estado o ônus da proteção. No Brasil, a profunda reforma do Estado operada nos últimos anos, com o objetivo precípuo de adaptá-lo à sociedade de risco, tem levado à recente criação de inúmeros ingressos financeiros que devem ser examinados sob a ótica que repulsa a ideia de legalidade "estrita", pois incidem sobre atividades extremamente complexas e cambiantes tecnologicamente, que tornaram impossível o fechamento dos conceitos indeterminados em que se expressam os respectivos fatos geradores, tudo o que conduz à atividade regulamentar da Administração e à judicialização da política. Tal acontece, entre outras exações, com a contribuição de acidentes do trabalho, com a taxa ambiental do IBAMA e com a contribuição de saúde, como passamos a ver". Idem. 
ambientado na sociedade de risco) diante das configurações tributárias contemporâneas ligadas à sociedade de risco, sejam igualmente influenciados pelas lições de Beck ${ }^{1448}$.

Nesse sentido, parcela da doutrina aparece, gradualmente, a elevar a preocupação sob a influência dessa formação social contemporânea, também impulsionada pelos estudos de Ricardo Lobo Torres, e suas consequências à tributação, sobretudo sob a consideração da legalidade (e sua eventual flexibilização), e consequências ínsitas ao póspositivismo contemporâneo aplicado ao direito tributário ${ }^{1449}{ }_{-}^{1450}$.

Os direitos e garantias fundamentais historicamente reconhecidos ao cidadão também aparecem permeados por esse novo contexto, e, assim como a globalização, influenciam fortemente novas tendências aos estudos tributários.

O processo disciplinar do Direito Tributário contemporâneo volta-se à melhor compreensão desses fenômenos e suas consequências ao direito tributário brasileiro (e eventuais soluções a problemas trazidos por esse diferenciado contexto).

E a própria disciplina do Direito Tributário no Brasil é reconfigurada (ou reforçada) por essas demandas, que não eram facilmente identificáveis nos períodos disciplinares anteriores à consolidação da democratização (anteriores à década de noventa do século XX, sobretudo).

Portanto, algumas consequências são elementares no ambiente disciplinar contemporâneo do direito tributário: a) a influência da configuração atual do Estado Social e Democrático Fiscal e da sua configuração social contemporânea (sociedade de riscos); b) a globalização (social, de riscos, econômica, tecnológica, de informação); c) novos reflexos trazidos pela elevação de novos direitos fundamentais destinados a proteger o indivíduo e a coletividade das consequências negativas trazidas pela nova configuração do Estado Fiscal (e da sociedade de riscos que a suporta); d) a própria estrutura básica de institutos, conceitos ou princípios tributários basilares ao direito tributário (como a legalidade e a segurança jurídica) é revista sob a óptica dessas tendências contemporâneas.

\subsection{As novas Gerações de Direitos Fundamentais e os reflexos no Direito Tributário Contemporâneo.}

\footnotetext{
${ }^{1448}$ Ibidem, p. 185 .

1449 ZILVETI, Fernando Aurelio. Obrigação Tributária - Fato Gerador e Tipo. Op.cit., p. 118 e ss.

${ }^{1450}$ Sobre o assunto também: SCHOUERI, Luís Eduardo. Direito Tributário. 3 Ed. Op.cit., p. 30-32.
} 
É natural que, a partir de contexto diferenciado do Estado Fiscal, da influência esmagadora da globalização e do perfil da sociedade contemporânea atual (sociedade de riscos), o próprio reconhecimento de direitos individuais e coletivos acabe sofrendo forte influência. Não por acaso, contemporaneamente, são progressivamente elevados determinados "novos direitos fundamentais", enquanto reflexos diretos desses diferenciados contextos históricos ${ }^{1451}$.

Surgem, portanto, como freios, escudos protetores ao indivíduo (e a própria coletividade) frente aos indiscutíveis aspectos negativos das configurações estatais, econômicas e sociais contemporâneas ${ }^{1452}$. E, naturalmente, tais "direitos ou garantias fundamentais" repercutem diretamente na construção disciplinar do Direito Tributário contemporâneo.

Historicamente, contudo, embora a consagração dos Direitos Humanos seja fenômeno identificável desde o processo de democratização, que culmina com a Constituição de 1988, de fato, as consequências mais efetivas à construção disciplinar do Direito Tributário mostram-se já salientes desde o século XIX.

Ligam-se às Gerações de Direitos que, conforme ensina Bobbio, voltam-se como produto de um contexto histórico destinado ao aperfeiçoamento histórico de uma sociedade. Verificando o nível de atendimento a esses direitos, é possível observar o nível do progresso alcançado. ${ }^{1453}$ Com a ideia de desenvolvimento ligado ao tema, os Direitos Humanos ou Fundamentais ganham renovada atenção. ${ }^{1454}$

As Gerações de Direitos, isto é, os de Primeira (direitos individuais) e de Segunda Geração (direitos econômicos e sociais) na Constituição Brasileira (artigos $6^{\mathrm{a}}$ a $8^{\mathrm{a}}, 215$ e 216, exemplificativamente), construídos lentamente no século XX, favorecem a esse quadro diferenciado. ${ }^{1455}$

\footnotetext{
${ }^{1451}$ Para os propósitos do presente trabalho, adota-se aqui uma abordagem flexível e superficial da noção de direitos fundamentais, sem avançar na eventual diferenciação entre direitos fundamentais e normas de direitos fundamentais (normas jurídicas que outorgam direitos fundamentais), ainda que Robert Alexy considere acertadamente as últimas mais amplas que as primeiras. Sobre o assunto: ALEXY, Robert. Teoria dos Direitos Fundamentais. Op.cit., p. 50 e ss.

${ }^{1452}$ HESSE, Konrad. O significado dos Direitos Fundamentais. Op.cit., p. 26 e ss.

${ }^{1453}$ BOBBIO, Norberto. A Era dos Direitos. Rio de Janeiro: Elsevier, 2004, p.35. LAFER, Celso. Apresentação. In: BOBBIO, Norberto. A Era dos Direitos. Rio de Janeiro: Elsevier, 2004, p.10.

${ }^{1454}$ ALEXY, Robert. Teoria dos Direitos Fundamentais. Op.cit., p. 65 e seguintes.

${ }^{1455}$ BONAVIDES, Paulo. Curso de Direito Constitucional. Op.cit., p 500-517.
} 
Por outro lado, esse mesmo ambiente ganha o reforço dos Direitos de Terceira Geração que, consagrados no constitucionalismo democrático brasileiro, retratam os direitos difusos, coletivos e homogêneos. São os chamados Direitos de Fraternidade ou Solidariedade (seja no âmbito das relações internas ou internacionais), inseridos nos movimentos constitucionais a partir da década de sessenta ${ }^{1456}$, e permeando expressamente os dispositivos da Constituição de $1988^{1457}$.

A consagração dessa nova realidade traz ao bojo do constitucionalismo inerente carga axiológica. Nesse sentido, a relação entre democracia e direitos fundamentais se aprofunda, e torna-se marca registrada desse novo contexto o princípio da dignidade da pessoa humana, que, afinal, aproxima expressamente a ética e o direito ${ }^{1458}$.

As Gerações de Direitos reforçadas pelo constitucionalismo democrático elevam o reencontro ao pensamento kantiano, voltando-se à moralidade, à dignidade, ao direito cosmopolita e à paz perpétua de Kant ${ }^{1459}$, conforme reforça Flávia Piovesan. ${ }^{1460}$

É o que se conclui também da leitura de Sainz de Bujanda que, verificando a evolução histórica do Direito Financeiro, enxerga como processo contemporâneo a “(...) humanização do direito tributário"1461.

Nesse panorama, na década de noventa, consagra-se a contribuição de Ricardo Lobo Torres, já naquele período dedicando-se à elevação dos Direitos Humanos na Tributação, e fornecendo importantes bases para e defesa dos valores (axiológicos) no Direito Tributário, incluindo-os aos Direitos Fundamentais ${ }^{1462}$ e vinculando-os

\footnotetext{
${ }^{1456}$ FILHO, Manoel Gonçalves Ferreira. Direitos Humanos Fundamentais. 11 Ed. São Paulo: Saraiva, 2009 , p. 06

${ }^{1457}$ Sobre o assunto também: BONAVIDES, Paulo. Curso de Direito Constitucional. Op.cit., p. 563.

${ }^{1458}$ PIOVESAN, Flávia. Direitos Humanos e Direito Constitucional Internacional. $7^{\mathrm{a}}$ Ed. São Paulo: Saraiva, 2006, p.26-27.

${ }^{1459}$ KANT, Immanuel. À Paz Perpétua. Op.cit., p. 33.

${ }^{1460}$ Idem, p.29.

${ }^{1461} \mathrm{E}$ avança ao afirmar que, para que seja possível alcançar esse ideal, Sainz de Bujanda assinala que “(...) somente será possível se o direito não for um mero arsenal de técnicas, mas um refúgio dos supremos valores humanos". BUJANDA, Fernando Sainz de. Hacienda y Derecho. I. Op.cit., p. 462-463. Nota-se, portanto, a profunda conexão axiológica (ligada a valores) na visão do autor espanhol, também identificável em Bonavides: BONAVIDES, Paulo. Curso de Direito Constitucional. Op.cit., p. 571.

${ }_{1462}$ TORRES, Ricardo Lobo. Os Direitos Humanos e a Tributação. Renovar: Rio de Janeiro, 1995, p. 17 e seguintes.
} 
perenemente à ideia de liberdade fiscal ${ }^{1463}$. Para Ricardo Lobo Torres, o tributo é visto como "preço da liberdade". ${ }^{1464 \_} 1465$

Semelhante caminho segue Alberto Nogueira no mesmo período, que vê a necessidade da reconstrução do Direito Tributário a partir dos Direitos Humanos, apontando alguns caminhos para essa reconstrução ${ }^{1466}$. Para o autor, os Direitos de $3^{\text {a }}$ Geração (ou de $4^{\mathrm{a}}$ Geração, dependendo da opinião doutrinária), vinculam-se com maior clareza aos direitos ecológicos, ou ao meio ambiente sustentável ${ }^{1467}$.

A própria estrutura disciplinar do Direito Tributário é influenciada por esse contexto histórico peculiar, que, originalmente influenciada pela estrutura legislativa do Código Tributário Alemão (e aos manuais didáticos da época) ${ }^{1468}{ }_{-}^{1469}{ }_{-}^{1470}$, passa a exigir, especialmente por esse contexto, diferenciados contornos, repercutidos no próprio Código Tributário Nacional. Mas de fato, o constitucionalismo democrático, naturalmente, ofereceu novas perspectivas de reflexão ${ }^{1471}$, e o consequente amadurecimento (ou mesmo "releitura") sobre diferentes sub-ramos, conforme se observa no Direito Penal

1463 "Há uma relação profunda e essencial entre liberdade e tributo, que vem se ampliando no decurso da evolução do Estado Financeiro, pelo qual se pode cogitar de uma liberdade físcal (...)", pois na visão de Torres, o tributo pode ser visto como "preço da liberdade", especialmente no Estado Fiscal de Direito. Idem, p. $1-3$.

1464 TORRES, Ricardo Lobo. A ideia de liberdade no Estado Patrimonial e no Estado Fiscal. Op.cit., p. 138 e seguintes.

1465 TORRES, Ricardo Lobo. Os Direitos Humanos e a Tributação. Op.cit., p. 411 e seguintes

${ }^{1466}$ O primeiro estaria na participação ativa (de todos os segmentos da sociedade) no Estado Democrático de Direito. Já o segundo caminho passaria pelo Poder judiciário, que deve se configurar como efetivo instrumento democrático para os próprios cidadãos (perante os direitos humanos), inclusive para corrigir "desvios" cometidos pelo Poder Legislativo. Já o terceiro caminho apontado passa pela elevação constitucional dos direitos humanos em matéria tributária. NOGUEIRA, Alberto. A (Re)construção dos direitos humanos da Tributação. Rio de Janeiro: Renovar, 1997, p. 405-425.

${ }^{1467}$ NOGUEIRA, Alberto. A (Re)construção dos direitos humanos da Tributação. Op.cit., p. 173 e seguintes.

${ }^{1468}$ DINIZ, Souza. Códigos Tributários. Alemão. Mexicano. Op.cit., p. 01 e seguintes.

1469 Conforme já observado, tais sub-ramos já apareciam mencionados nos estudos de João Martins de Oliveira, refletindo a doutrina italiana (essa inspirada na doutrina germânica): OLIVEIRA, João Martins de. Op.cit., p. 08 e seguintes.

${ }^{1470}$ Cita-se, exemplificativamente, Albert Hensel, que, observando a RAO, elencou os seguintes sub-ramos: direito tributário material; direito tributário formal; direito tributário processual; direito tributário penal; direito tributário internacional e direito tributário constitucional. HENSEL, Albert. Op.cit., p. 10 e ss. Em semelhante sentido: BLUMENSTEIN, Ernst. Op.cit., p. 11 e seguintes. Note-se que mesmo em MyrbachRheinfeld já havia esboço das subdivisões do direito tributário, posteriormente consolidadas na doutrina alemã pós-RAO: MYRBACH-RHEINFELD, Franz Von. Op.cit., p. 01 e seguintes.

${ }^{1471}$ Exemplo pode ser visto em: BECHO, Renato Lopes. Tributação das Cooperativas. São Paulo: Dialética, 1998 , p.28 e seguintes. 
Tributário $^{1472}$, no Direito Tributário Administrativo ${ }^{1473}$, e no Direito Processual Tributário ${ }^{1474}{ }^{1475}{ }^{1476}$, que ganham, hodiernamente, crescente importância.

Nesse contexto histórico, tem sido crescente a menção doutrinária sobre novas "Gerações", "Dimensões" ou "Fases" dos Direitos Fundamentais, especialmente no que tange ao meio ambiente, à globalização, à internet, à tecnologia e o acesso à informação. São os Direitos Fundamentais de Quarta Geração ou Dimensão ${ }^{1477}$, abrindo-se, mais uma vez, a oportunidade de renovados estudos progressivos ao Direito Tributário, e que buscam responder a questões trazidas pelo contexto histórico contemporâneo (sociedade de riscos, globalizada, pautada no Estado Social Fiscal e Democrático).

Mas não se incorra no erro de considerar que esses novos diálogos promovidos ao Direito Tributário tornariam supérfluos os estudos oriundos das relações entre o Direito Tributário e as Gerações anteriores.

Na realidade, esses só poderiam ser viabilizados com efetividade em uma sociedade aberta do futuro (que dela depende), onde os Direitos de Primeira e Segunda Geração reforçam-se, e os Direitos de Quarta Geração são a chave (mais precisamente suas

${ }^{1472}$ A década de noventa, especialmente motivada pela criação dos "crimes contra a ordem tributária" na Lei 8.137 de 1990 favorece também o surgimento de novas imersões a determinados campos já tocados pela doutrina, mas ainda não adequadamente amadurecidos, como é o caso dos diálogos entre o Direito Penal e o Direito Tributário, como se pode observar nos seguintes estudos: SILVA, Juary C. Elementos de Direito Penal Tributário. São Paulo: Saraiva, 1998, p. 11-19. STOCO, Rui. Dos crimes contra a ordem tributária. In: Leis penais especiais e sua interpretação jurisprudencial. São Paulo: RT 1995, p. 12 e seguintes. CARVALHO, Aurora Tomazini de. Direito Penal Tributário: uma análise lógica, semântica e jurisprudencial. São Paulo: Quartier Latin, 2013, p. 29-80.

${ }_{1473}$ FILHO, Aurélio Pitanga Seixas. Princípios Fundamentais do Direito Administrativo Tributário. Rio de Janeiro: Forense, 1996, p. 21 e seguintes. BOTALLO, Eduardo Domingos. Op.cit., p. 13 e seguintes.

${ }^{1474}$ Sobre o amadurecimento histórico disciplinar do Direito Processual Tributário, conferir: MARINS, James. Direito Processual Tributário Brasileiro. Op.cit., p. 37 e seguintes; 81-87.

${ }^{1475}$ BONILHA, Paulo Celso Bergstrom. Da Prova no Processo Administrativo Tributário. Op.cit., p. 15 e seguintes. SEGUNDO, Hugo de Brito Machado. Processo Tributário. São Paulo: Atlas, 2009, p. 17 e seguintes. PISCITELLI, Thatiane (Coord). Direito Processual Tributário: Aspectos Fundamentais. In: Direito Tributário. Série GVlaw. São Paulo: Saraiva, 2012, p. 12 e seguintes.

${ }^{1476} \mathrm{O}$ mais claro exemplo da "reconstrução disciplinar" posterior à Constituição de 1988 pode ser observado no direito processual tributário, com a contribuição de James Marins, estudioso dedicado à construção disciplinar do Direito Processual Tributário (reconhecendo, no entanto, a autonomia didática perante os demais ramos do direito) a partir da década de noventa, tendo o mérito de estudar e sistematizar o Processo Tributário Brasileiro, ao reconhecê-lo como "território limite" entre o Direito Tributário e o Direito Processual. MARINS, James. Princípios Fundamentais do Direito Processual Tributário. Op.cit., p. 19 e seguintes.

${ }^{1477}$ Os Direitos Fundamentais, historicamente consolidados, hoje caminham para o realce da chamada Quarta Geração, que, na leitura de Paulo Bonavides, consagraria a derradeira institucionalização dos "Direitos Sociais", especialmente a partir da globalização política (fenômeno decorrente da globalização que viabilizaria a necessidade da consagração global ou universal dos direitos fundamentais). Para Bonavides, tais direitos seriam: a) direito à democracia; b) direito à informação; c) direito ao pluralismo. BONAVIDES, Paulo. Curso de Direito Constitucional. Op.cit., p. 570-572. 
respectivas concretizações) para o futuro da sociedade política ${ }^{1478}{ }_{-}^{1479}$. Não é por outro motivo que, entre os Direitos Fundamentais de Primeira Geração ${ }^{1480}$, a igualdade tributária ganhe severo reforço na literatura contemporânea ${ }^{1481}$.

Portanto, a literatura do Direito Tributário, influenciada por essa riquíssima realidade contemporânea, passa também a analisar diferentes perspectivas relacionadas ao Direito Tributário. Não é por acaso o progressivo diálogo com outros ramos do Direito, como o Direito Econômico, o Direito Ambiental, e não apenas aqueles ramos historicamente conectados com a atividade tributária (Direito Constitucional, Administrativo, Financeiro).

Note-se que a própria elevação de "novos direitos fundamentais" aparece como reflexo inerente ao novo perfil estatal-fiscal e social construído na sociedade contemporânea, cada vez mais atento à existência de riscos (econômicos, sociais, ambientais, inerentes ao acesso à informação e à tecnologia, por exemplo) que precisam ser compensados e minimizados pela elevação e reforço desses "novos" direitos fundamentais gradualmente reconhecidos pela literatura contemporânea, que por sua vez tende a refleti-los no próprio processo disciplinar do Direito Tributário Brasileiro (a tributação como instrumento apto a remediar ou combater esses efeitos nocivos).

Veja-se, portanto, nos itens seguintes, alguns reflexos das gerações de direitos fundamentais e da própria globalização (e consequentemente, do Estado Democrático e Social Fiscal contemporâneo, e da sociedade de riscos que o suporta) no desenvolvimento recente dos estudos jurídico-tributários no Brasil (e na legislação brasileira).

\section{Desdobramentos recentes no processo disciplinar do Direito Tributário Brasileiro contemporâneo}

\footnotetext{
1478 BONAVIDES, Paulo. Curso de Direito Constitucional. Op.cit., p. 570-572.

${ }^{1479}$ BOBBIO, Norberto. A Era dos Direitos. Op.cit., p. 29.

${ }^{1480}$ Exemplo também pode ser lembrado na obra conjunta coordenada por Melissa Folmann: FOLLMAN, Melissa (Coord.). Tributação e Direitos Fundamentais. Propostas de Efetividade. Curitiba: Juruá, 2006 , p. 16 e seguintes.

${ }^{1481}$ MARTINS, Ives Gandra da Silva. Teoria da Imposição Tributária. Op.cit., p. 27-48. DERZI, Misabel. O princípio da igualdade e o direito tributário. In: Revista da Faculdade de Direito Milton Campos, volume 1, número 1, 1994, p. 185 e seguintes. MELLO, Celso Antonio Bandeira de. O conteúdo jurídico do princípio da igualdade. São Paulo: Malheiros, 2001, p. 16 e seguintes. ÁVILA, Humberto. Teoria da Igualdade Tributária. $2^{a}$ Ed. São Paulo: Malheiros, 2009, p. 12 e seguintes.
} 
As transformações contemporâneas, seja do ponto de vista do Estado, ou da própria sociedade, ou da própria globalização, interferem diretamente no reconhecimento de novos direitos fundamentais. Enquanto reflexo desse diferenciado panorama, o progressivo reconhecimento de novos direitos aparece como tentativas claras de reunir ao lado do indivíduo e da coletividade o maior número de direitos possíveis diante dos perigos da sociedade de risco, da globalização, e da configuração estatal contemporânea, seja em seus efeitos econômicos, ambientais ou sociais.

Nesse contexto, embora já se manifestassem tendências claras no âmbito do processo disciplinar do Direito Tributário Brasileiro, reforça-se a necessidade de maior aproximação com outros ramos jurídicos, no intuito de reforçar a análise desses problemas, e dos direitos que buscam freá-los. Não é por acaso que sob a égide do século XXI, intensifique-se a atenção à Ordem Econômica, sobretudo pela E.C. 43 de 2002. O direito tributário e o direito econômico nunca estiveram tão próximos, o que justifica também a necessidade de ponderar os princípios da Ordem Econômica em suas relações com as Limitações Constitucionais ao Poder de Tributar.

Ao mesmo tempo, emana-se, enquanto fruto da maior atenção à determinados direitos sociais garantidos pela Constituição, maior apelo à solidariedade, sobretudo em sua ligação com a ideia de justiça (fiscal social), o que, na realidade, não deixa também de ser fruto desse próprio contexto, que tende a conceder maior atenção à justiça e à segurança jurídica.

Por outro lado, na sociedade de risco, elevam-se problemas globais, e o próprio meio ambiente torna-se objeto de proteção. Não é surpresa que a doutrina tributária, a partir dos anos noventa, tenha elevado progressivamente a atenção ao Direito Tributário frente ao ambientalismo (que leva ao necessário diálogo frente ao Direito Ambiental).

Assim, se a globalização traz tantas consequências ao direito tributário, é necessário ponderá-las, no processo disciplinar do direito tributário brasileiro. É claro que a internacionalização da economia, da informação e dos fatores tecnológicos leva à maior atenção, pela doutrina tributária, desses elementos no próprio direito tributário brasileiro.

A internacionalização da economia leva à internacionalização da tributação. Essa, já existente desde a década de sessenta na realidade tributária brasileira, fortalece-se com a adoção de tratados internacionais em matéria tributária, buscando evitar e combater a dupla tributação internacional e a evasão fiscal, tendência que se fortalece gradativamente, mas que se impulsiona efetivamente pelo reconhecimento inevitável da globalização. Não é a 
toa que entre os anos noventa e 2000, os estudos sobre o direito tributário nacional tenham progredido rapidamente, sobretudo para atender as novas demandas do capital e as perspectivas de investimentos no país.

Por outro lado, o panorama anterior leva também à questão do acesso à informação, que ganha especial importância na sociedade contemporânea, sobretudo pela pecha de "sociedade de informação". A facilidade do acesso à informação, e as consequências dessa, favorecem maior amadurecimento sob a secular questão que tangencia o debate entre a ilusão fiscal e a transparência fiscal, e as consequências, negativas ou positivas que possam resultar de tais reflexões.

Problemática que se intensifica na questão tecnológica. Afinal, globalização também é a quebra de barreiras tecnológicas. Frente a um crescimento tecnológico desenfreado, é preciso também repensar a dinâmica da relação tributária sob a perspectiva dos avanços tecnológicos contemporâneos, sobretudo para sopesar as vantagens e desvantagens que essas transformações possam trazer ao contribuinte e ao Estado. A própria realidade tributária segue tendência (nem sempre tranquila) de adaptar o direito tributário às facilidades da tecnologia. Repensar a relação tributária a partir dessa nova dinâmica é missão dos tributaristas contemporâneos.

Nesse quadro também, que é igualmente resultado da globalização, aumentam exponencialmente as perspectivas de diálogo entre o Direto Tributário e o Direito Contábil, sobretudo nas transformações contábeis nacionais promovidas pela "Nova Contabilidade", resultado da internacionalização dos padrões contábeis, e que concede profundas modificações para a tributação das empresas, que impulsiona, por princípios próprios e a própria realidade econômica dos fatos. Não é por acaso o surgimento, nos últimos anos, de obras dedicadas à promoção do diálogo entre Direito Tributário e Direito Contábil, buscando lançar luzes a essa pedregosa realidade jurídico-contábil contemporânea. Não há, nesse contexto, como fugir do diálogo interdisciplinar.

Mas o processo de especialização disciplinar do Direito Tributário Brasileiro leva também à peculiar consequência. Especializou-se tanto o direito tributário centrando-se na dinâmica relação tributária (criação do tributo à extinção do crédito tributário), que outras investigações conexas à tributação (mas não necessariamente insertas nesse espectro) foram deixadas de lado, como é o caso da origem e da destinação dos tributos. Por certo esses temas são propriamente estudados na órbita do Direito Financeiro. Porém, cresce entre os tributaristas a percepção de que interessa também aos tributaristas promover maior 
diálogo entre o Direito Tributário e o Direito Financeiro, sobretudo no que tange à origem e à destinação dos tributos. E essa necessidade não se faz apenas por razões acadêmicas.

Trata-se de questão cívica, que também não se afasta da política. Em face da própria realidade brasileira, caracterizada por vultuosos resultados de arrecadação anual, e pela notória incompetência na distribuição, destinação e fiscalização dessas receitas aos objetivos constitucionalmente vinculados, cresce, por pressão popular e cívica, a atenção dos tributaristas sobre tais aspectos do fenômeno jurídico-financeiro. O resultado é uma gradual aproximação entre o Direito Tributário e o Direito Financeiro. Algo aguardado por muitos.

Assim, o que se percebe, no âmbito da configuração material recente do Direito Tributário Contemporâneo, é a adaptação e a absorção da realidade (complexa, global, de riscos, e fortemente arrecadatória), que se manifesta na profusão de recentes diálogos destinados à melhor compreender os reflexos trazidos por esses fatores.

O processo disciplinar do Direito Tributário Brasileiro gradualmente assume-se como resultado das modulações contemporâneas da globalização, da sociedade de riscos, da configuração atual do Estado Fiscal, e dos próprios direitos fundamentais que surgem para combater os malefícios trazidos por esses novos contextos.

É claro que a configuração do direito tributário segue buscando a elevação e reforço de princípios fundamentais do direito tributário, como é o caso da segurança jurídica e da legalidade. Mas mesmo eles acabam sofrendo influências dessas novas formatações sociais, econômicas ou estatais contemporâneas. Não há como fugir dessa realidade.

Nas linhas abaixo, procurar-se-á apresentar, apenas brevemente e panoramicamente, e sem qualquer pretensão de aprofundar tais temas (pois cada tópico mereceria uma obra individual), algumas linhas gerais sobre os fatores recentes que influenciam a produção teórica contemporânea e as consequências dessa influência.

\subsection{O processo disciplinar do Direito Tributário Brasileiro contemporâneo e o diálogo com a Ordem Econômica.}

Embora historicamente os estudos de Direito Tributário tenham consagrado pouco ou nenhum espaço ao diálogo com a Ordem Econômica ${ }^{1482}$, a verdade é que fatores jurídicos favoreceram, no início do século XXI, maior aproximação. Os princípios da

1482 Sobre a ambiguidade da expressão "Ordem Econômica", conferir: GRAU, Eros Roberto. A Ordem Econômica na Constituição. Op.cit., pp.49-52; 58-59. 
Ordem Econômica consagrados no artigo 170 da Constituição ganham a atenção dos tributaristas, especialmente em decorrência da inclusão do artigo 146-A da Constituição (no Capítulo Tributário). Este artigo, trazido pela EC n.42/2003, dispôs que lei complementar poderá fixar critérios especiais de tributação visando prevenir desequilíbrios concorrenciais, sem prejuízo da competência da União estabelecer, por lei, normas que tenham o mesmo objetivo, isto é, de combater tais desequilíbrios de concorrência.

Ao incutir, especialmente a partir da EC n.42, maior atenção à Ordem Econômica no próprio Capítulo do direito constitucional tributário, a Constituição forneceu subsídios para que tributaristas passassem a prestar maior atenção à questão, especialmente no tocante ao diálogo (e eventuais conflitos) entre as limitações constitucionais ao poder de tributar e os princípios da Ordem Econômica, a exemplo da livre concorrência, da proteção do mercado, entre outros. Como compatibilizar o Direito Tributário e o Direito Econômico?

Conforme reconhece Ricardo Lobo Torres, a Constituição Tributária está em permanente contato e interação com a Constituição Econômica, pois são ambas subconstituições do mesmo sistema constitucional brasileiro, e da mesma forma ocorre com seus princípios: estão em constante e permanente interação ${ }^{1483}$, reconhecendo também estatura de princípio constitucional tributário à livre concorrência, fundamentados nos artigos 146-A e 170 da CF/88, com as alterações trazidas pela EC 43/2002, e considerando que o Estado Fiscal deve não apenas se manter neuro perante a concorrência, mas promover também ambiente propício ao desenvolvimento das forças de mercado ${ }^{1484}$.

Nesse sentido, importante coletânea foi organizada, nos últimos anos, dedicada a aprofundar as reflexões que esses princípios da Ordem Econômica detêm na tributação, intitulada, "Princípios e Limites da Tributação. Princípios da Ordem Econômica e Tributação", e organizada por Roberto Ferraz ${ }^{1485}$, praticamente contando com a maioria dos principais estudiosos interessados no tema (brasileiros e estrangeiros) na época.

\footnotetext{
1483 TORRES, Ricardo Lobo. Interação entre Princípios Constitucionais Tributários e Princípios da Ordem Econômica. In: FERRAZ, Roberto (Coord.). Princípios e Limites da Tributação. Os Princípios da Ordem Econômica e a Tributação. Vol.2. São Paulo: Quartier Latin, 2009, p. 493.

1484 TORRES, Ricardo Lobo. Interação entre Princípios Constitucionais Tributários e Princípios da Ordem Econômica. Op.cit., p.494.

${ }^{1485}$ FERRAZ, Roberto. Apresentação. In: Princípios e Limites da Tributação. Os Princípios da Ordem Econômica e a Tributação. Vol.2. São Paulo: Quartier Latin, 2009, s/p.
} 
Os diálogos entre o Direito Tributário e o Direito Econômico, assim como frente ao Direito Concorrencial, fazem parte dessa promoção entre o Direito Tributário e os Direitos Fundamentais de $2^{\mathrm{a}}$ Geração, e já começam a elevar muitos estudos brasileiros, especialmente nos primeiros anos do século XXI conforme é possível observar em Luís Eduardo Schoueri ${ }^{1486}$, Ives Gandra Martins ${ }^{1487}$, Tércio Sampaio Ferraz Júnior e José Luis Ribeiro Brazuna ${ }^{1488}$, e a defesa da livre iniciativa e da livre concorrência, assim como da competitividade das empresas protegidas contra abusiva carga de obrigações tributárias (mesmo acessórias), começa a aparecer em estudos de Ives Gandra Martins e Tércio Sampaio Ferraz Júnior ${ }^{1489}{ }^{1490}$.

Em muitos aspectos esses estudos passam a investigar em qual medida devem ser impostas obrigações tributárias acessórias, e os limites a elas, para que não se configurem como verdadeira restrição (indevida) à livre iniciativa e à livre concorrência.

Ora, conforme ensina Gerd Willi Rothmann, no Brasil (mas também em outros países), a relação entre sonegação, tributação e livre concorrência vincula-se a fenômenos fiscais lesivos: a) carga fiscal excessiva e distribuição injusta entre agentes econômicos; b) tributação e incentivos fiscais discriminatórios, privilegiando uns em detrimento de outros; c) sonegação e pirataria, viabilizando preços predatórios ${ }^{1491}$. Parcela doutrinária chega, inclusive, a considerar os efeitos econômicos de um tributo, como faz Schoueri, afastando por absoluto o "mito da neutralidade tributária" $1492 \_$_ ${ }^{1493}{ }^{1494}$.

\footnotetext{
${ }^{1486}$ SCHOUERI, Luís Eduardo. Livre Concorrência e Tributação. In: Grandes Questões atuais do direito tributário. 11 $1^{\mathrm{a}}$ volume. ROCHA, Valdir de Oliveira (Coord.). São Paulo: Dialética, 2007, p. 241 e seguintes.

${ }^{1487}$ MARTINS, Ives Gandra da Silva. O desequilíbrio da concorrência por distorções tributárias e a Emenda Constitucional n.42/2003. Repertório de Jurisprudência IOB, n.24, São Paulo: IOB, 2005, p. 971 e ss; MARTINS, Ives Gandra da Silva. Obrigações Acessórias Tributárias e a Disciplina Jurídica da Concorrência. In: FERRAZ, Roberto. Princípios e Limites da Tributação. Vol.1. Op.cit., p. 669 e seguintes. ${ }^{1488}$ BRAZUNA, José Luis Ribeiro. Defesa da Concorrência e Tributação à Luz do Artigo 146-A da Constituição. Série Doutrina Tributária Volume 2. São Paulo: Quartier Latin - IBDT, 2009, p. 17 e seguintes.

${ }^{1489}$ MARTINS, Ives Gandra da Silva. Obrigações Acessórias Tributárias e a Disciplina Jurídica da Concorrência. Op.cit., p. 669 e seguintes.

${ }_{1490}$ JÚNIOR, Tércio Sampaio Ferraz. Obrigação Tributária Acessória e Limites de Imposiçãa: razoabilidade e neutralidade concorrencial do Estado. In: FERRAZ, Roberto. Princípios e Limites da Tributação. Vol.1. Op.cit., p. 726 e seguintes.

${ }^{1491}$ ROTHMANN, Gerd Willi. Tributação, Sonegação e Livre Concorrência. In: FERRAZ, Roberto. Princípios e Limites da Tributação. Os Princípios da Ordem Econômica e Tributação. Vol.2. Op.cit., p. 333.

${ }^{1492}$ SCHOUERI, Luís Eduardo. Tributação e Indução Econômica: os efeitos econômicos de um tributo como critério para sua constitucionalidade. Op.cit., p. 142-143.

${ }^{1493}$ Idem, p. 141 e seguintes.

${ }^{1494}$ Em outro sentido: ROTHMANN, Gerd Willi. Tributação, Sonegação e Livre Concorrência. Op.cit., p. 341.
} 
Afinal, agora não apenas a tributação deve respeitar as Limitações Constitucionais ao Poder de Tributar, mas também os Princípios da Ordem Econômica, ou pelo menos, compatibilizá-los.

Dessa verificação surgem diferentes exemplos levantados pela doutrina tributária brasileira contemporânea e que devem ser resolvidos pela compatibilização, ou ponderação entre os princípios das duas ordens jurídicas. Surgem, assim, diversos casos em que emana a necessidade da ponderação entre os princípios da Ordem Tributária e da Ordem Econômica, onde os exemplos mais lembrados são: a) a técnica da não-cumulatividade das contribuições PIS/COFINS (Lei $10.637 / 2002$ e Lei 10.833/2003) ${ }^{1495}$; b) a Medida Provisória 232 e a rejeição da $\mathrm{CPMF}^{1496}$; c) a possibilidade e limitação da utilização de contribuições para a intervenção econômica e regulação do mercado, a exemplo da CIDE Petróleo ${ }^{1497}$; d) a expressa vedação das sanções políticas praticadas contra os contribuintes (e atentatórias à livre concorrência) ${ }^{1498}$.

${ }^{1495}$ ROTHMANN, Gerd Willi. Tributação, Sonegação e Livre Concorrência. Op.cit., p. 341.
${ }^{1496}$ Nesse ambiente, o bom tributo não apenas aquele que arrecada mais, mas aquele que constitui menos
óbices à sociedade de "exercer seu papel na construção da liberdade coletiva", como é o caso da Medida
Provisória 232 e a rejeição da CPMF (Proposta de Emenda Constitucional n.87/07, ampliando o prazo para
sua cobrança, rejeitado pelo Senado Federal), e a própria consideração do efeito confisco passa a ser
analisada sob outra perspectiva (de índole econômica), no que tange ao chamado "imposto sufocante", que
praticamente oblitera o surgimento de fato gerador, que também mereceu críticas de Hamilton Dias de Souza,
especialmente por sua "substituição" pela elevação de alíquotas do IOF (Decreto n.6339/08, e 6345/08),
tributo com função distinta no direito tributário brasileiro. SCHOUERI, Luís Eduardo. Tributação e
Indução Econômica: os efeitos econômicos de um tributo como critério para sua constitucionalidade.
Op.cit., p. 149-150. SOUZA, Hamilton Dias de. Ainda a racionalidade como limitação ao poder de
tributar: Impossibilidade de Utilização do IOF como sucedâneo da CPMF. In: FERRAZ, Roberto.
Princípios e Limites da Tributação. Os Princípios da Ordem Econômica e Tributação. Vol.2. Op.cit., p. 655 e
seguintes. ${ }^{1497}$ A tributação vincula-se também às funções estatais de intervenção e regulação da economia, conforme é possível observar nas contribuições de intervenção no domínio econômico (CIDE) que buscam, em muitos aspectos, regular o mercado (e, afinal, a livre concorrência), a exemplo da CIDE Petróleo (Art.177, §4 $4^{\mathrm{a}}, \mathrm{I}, \mathrm{b}$ ). ROTHMANN, Gerd Willi. Tributação, Sonegação e Livre Concorrência. Op.cit., p. 347.

${ }^{1498}$ A literatura tem reprovado terminantemente as chamadas "sanções políticas" aplicadas pelo Estado para forçar o pagamento do tributo com fundamento na Ordem Econômica, conforme se observa em Hugo de Brito Machado e Hugo de Brito Machado Segundo. MACHADO, Hugo de Brito. Ordem Econômica e Tributação. In: FERRAZ, Roberto. Princípios e Limites da Tributação. Os Princípios da Ordem Econômica e Tributação. Vol.2. Op.cit., p. 375. SEGUNDO, Hugo de Brito Machado. Tributação e Livre Concorrência. In: FERRAZ, Roberto. Princípios e Limites da Tributação. Os Princípios da Ordem Econômica e Tributação. Vol.2. Op.cit., p. 399. Aliás, o comportamento anticoncorrencial adotado através das chamadas sanções políticas foi sintetizado por Ávila (considerando a jurisprudência global do STF) da seguinte forma: “(...) o uso de meio coercitivo pelo Poder Público que, adotado como o propósito direto ou indireto de forçar o contribuinte a pagar tributo, cause restrição excessiva ou desproporcional ao direito fundamental de livre exercício de atividade lícita, já objeto de limitação intrínseca por outras liberdades". ÁVILA, Humberto. Comportamento Anticoncorrencial e Direito Tributário. In: FERRAZ, Roberto. Princípios e Limites da Tributação. Os Princípios da Ordem Econômica e Tributação. Vol.2. Op.cit., p. 435. Por outro lado, o próprio STF, como também registra Ricardo Lobo Torres, deixou de lado súmulas que consagram a proibição das sanções políticas (Medida Cautelar em Ação Cautelar n.1657/RJ, Ac do Rel. 
Até mesmo o estabelecimento, no art.151,V, de autorização da União para estabelecer diferenciação tributária para corrigir desigualdades econômicas e sociais entre regiões do Brasil também se mostra de necessária reflexão, já que a concessão de incentivos e benefícios fiscais a regiões desfavorecidas deve vincular-se também não somente às limitações constitucionais tributárias (art.145 e seguintes), mas também aos princípios da Ordem Econômica (art.170 e seguintes). ${ }^{1499}$

Enfim, a síntese da possibilidade de novas perspectivas de diálogo entre o Direito Tributário e o Direito Econômico pode ser simbolizada através das reflexões de Hugo de Brito Machado Segundo que, defendendo a livre concorrência como direito fundamental, reconhece igualmente a importância do diálogo entre Direito e Economia, “(...) decorrente do abandono de um ultrapassado positivismo reducionista que só admitia o estudo das normas (divorciado dos fatos e dos valores aos quais as normas servem de suporte)", e agora, em novo ambiente acadêmico, “(...) tem sido frequente, em estudos de Direito Tributário, a referência à livre concorrência, e aos reflexos que sobre ela pode ter a tributação" 1500 .

\subsection{O processo disciplinar do Direito Tributário Brasileiro e o diálogo com a Ordem Social (Solidariedade)}

O Direito Tributário aparece também permeado pela maior atenção a assuntos de destacada repercussão social, como é o caso da solidariedade, tema repercutido com cada vez maior intensidade no Direito Tributário Brasileiro. A maior atenção dedicada ao tema pode ser observada com clareza em estudo de relevo organizado por Marciano Seabra de Godoi e Marco Aurélio Greco ${ }^{1501}$, contando com contribuições acadêmicas de escol, a

Min.Cezar Peluzo, DJ de 27.06.2007). TORRES, Ricardo Lobo. Interação entre Princípios Constitucionais Tributários e Princípios da Ordem Econômica. Op.cit., p.495-496.

${ }_{1499}$ ROTHMANN, Gerd. Willi. Tributação, Sonegação e Livre Concorrência. Op.cit., p. 341.

${ }^{1500}$ SEGUNDO, Hugo de Brito Machado. Tributação e Livre Concorrência. Op.cit., p. 399.

${ }^{1501}$ Para Marco Aurélio Greco e Marciano Seabra de Godoi, “(...) A impressão é de que - neste tema já teria sido encontrada a "última resposta", que os tributos ou se justificariam quase automaticamente com base no poder atribuído ao Estado dentro das balizas constitucionais, ou buscariam a sua razão de ser nas ideias de benefício e contraprestação pelos serviços estatais". Embora não refratando as indiscutíveis contribuições da doutrina tributária brasileira (em suas linhas de pesquisa e ensino tradicionais), “(...) pouco dizem do ser humano que dá sentido ao ordenamento jurídico e para o qual suas normas se voltam em última instância". GRECO, Marco Aurélio; GODOI, Marciano Seabra de (Coord.) Solidariedade Social e Tributação. São Paulo: Dialética, 2005, s/p. 
exemplo de Humberto Ávila ${ }^{1502}$, Ricardo Lobo Torres ${ }^{1503}$, Tércio Sampaio Ferraz Júnior $^{1504}$, entre outros renomados estudiosos, brasileiros e estrangeiros ${ }^{1505}$.

A apresentação dos organizadores desta coletânea permeia-se finalidade clara àqueles estudiosos: superar ou avançar sobre outros temas que não haviam sido bem delimitados pela literatura na época, especialmente nos últimos quarenta anos, onde a tendência doutrinária, jurisprudencial e legislativa voltou-se às técnicas e formas de instituição e cobrança de tributos. Contudo, os organizadores criticam a falta de discussões a respeito dos fundamentos da tributação, dos valores que a justificam, do papel a ser exercido por ela na sociedade contemporânea, assim como das finalidades desta.

Por esse motivo, e claramente dedicados à elaboração de estudos que considerem o tributo focado na própria “(...) sociedade em si mesma, e não no Estado como aparato burocrático (...)", levam a um novo perfil de estudos tributários, a exemplo, segundo relatam, do regime tributário das cooperativas e do papel das contribuições.

Em ambos, o papel da solidariedade social seria ponto de partida para novos estudos tributários, já que “(...) estudar as relações entre tributação e solidariedade social é investigar o "modo de ser" da tributação contemporânea, inquirindo igualmente a sua justificação (o seu "por quê") e a sua finalidade (o seu "para quê") (...)", o que se coaduna perfeitamente com o Estado Democrático de Direito ${ }^{1506}$, já que como a própria Constituição brasileira de 1988 estabelece, em seu artigo $3^{\text {a }}$, I, um dos objetivos fundamentais da República Democrática é “(...) constituir uma sociedade livre, justa e solidária (...)", reforçando-se, seja pelos artigos $6^{\circ}$ e $7^{\circ}$ da mesma Carta (Direitos Sociais),

\footnotetext{
1502 ÁVILA, Humberto. Limites à Tributação com Base na Solidariedade Social. In: Solidariedade Social e Tributação. Op.cit., p.68-88.

${ }^{1503}$ TORRES, Ricardo Lobo. Existe um Princípio Estrutural da Solidariedade? In: Solidariedade Social e Tributação. Op.cit., p. 198-208.

${ }^{1504}$ JUNIOR, Tércio Sampaio Ferraz. Notas sobre Contribuições Sociais e Solidariedade no Contexto do Estado Democrático de Direito. In: Solidariedade Social e Tributação. Op.cit., p. 208-221.

${ }^{1505}$ GRECO, Marco Aurélio. Solidariedade Social e Tributação. In: Solidariedade Social e Tributação. Op.cit., p. 168-197; GODOI, Marciano Seabra de. Solidariedade Social e Tributação. In: Solidariedade Social e Tributação. Op.cit., p. 141-167.

${ }_{1506}$ GRECO, Marco Aurélio; GODOI, Marciano Seabra de. Apresentação. In: Solidariedade Social e Tributação. Op.cit., p. 05-07.
} 
seja pelos princípios da Ordem Social previstos no Título VIII. Esta última, na visão de Tércio Sampaio Ferraz Júnior, tem por finalidade alcançar a justiça social ${ }^{1507}$.

A solidariedade liga-se à ideia de justiça social, intrinsecamente vinculada também à ideia de fraternidade ${ }^{1508}$. Logo, na tributação, não há como negar a importância da solidariedade social ${ }^{1509}$.

Alguns estudiosos, dentre os quais Ricardo Lobo Torres, observam a Solidariedade sob duas perspectivas: enquanto valor básico do Direito; enquanto princípio jurídico constitucional. Nesta última perspectiva, vincula-se aos princípios orientados à justiça tributária, como a capacidade contributiva e o custo/benefício (que justifica a cobrança de contribuições sociais e econômicas) ${ }^{1510}{ }^{1511}$.

Mas os estudos sobre o tema devem se concentrar também a evitar distorções na utilização da solidariedade, como é o caso do chamado "princípio estrutural da solidariedade", que fundamentou a chamada criação dos "tributos exóticos", com o objetivo de camuflar novas incidências e de aliviar a União da obrigação de repasse aos Estados e Municípios de parcelas da arrecadação, dentre os quais se mencionam as contribuições sociais sobre o faturamento, (Cofins), sobre o lucro líquido (CSL), sobre a movimentação financeira (CPMF), e as aposentadorias dos servidores públicos.

Esse princípio chegou a ser defendido inclusive pelo $\mathrm{STF}^{1512}$, ampliando a compreensão do art.195 da Constituição, e "consolidando" fundamento para as

\footnotetext{
${ }^{1507}$ JUNIOR, Tércio Sampaio Ferraz. Notas sobre Contribuições Sociais e Solidariedade no Contexto do Estado Democrático de Direito. Op.cit., p. 208-221.

${ }^{1508}$ GODOI, Marciano Seabra de. Solidariedade Social e Tributação. Op.cit., p. 141-167.

${ }^{1509}$ GRECO, Marco Aurélio. Solidariedade Social e Tributação.Op.cit., p. 168-197;

1510 TORRES, Ricardo Lobo. Existe um Princípio Estrutural da Solidariedade? Op.cit., p. 198-208.

1511 É interessante notar como o Estado Democrático de Direito permeia-se pela óptica da solidariedade, consistindo, na leitura de Douglas Yamashita, em: a) justiça social, com fundamento nos artigos $3^{\mathrm{a}}$, I, 170, caput e 193 da Constituição, pautados na redistribuição de renda e igualdade de chances; b) segurança social, que se consubstancia em b.1) bem-estar social (arts. 186, VI e 193); b.2) assistência social. A solidariedade poderia ser dividida também em solidariedade genérica (quando se considera a sociedade como um todo), e a solidariedade de grupos sociais homogêneos (quando se refere a grupos específicos), onde o primeiro se concretizaria através do princípio da generalidade e da capacidade contributiva, da extrafiscalidade, progressividade e os princípios da necessidade e mérito, ao passo que na solidariedade de grupo seria possível vinculá-la às contribuições sociais destinadas a determinado grupo, atendendo a determinados requisitos. YAMASHITA, Douglas. Princípio da Solidariedade em Direito Tributário. In: Solidariedade Social e Tributação. Op.cit., p. 53-67.

${ }^{1512}$ RE 150.764-1, Acórdão do Plano, Relator: Ministro Marco Aurélio, RTJ 147:1.062, 16.12.1992; ADI 3.105/DF ADI 3.128/DF, Plenário, Rel. Orig. Ministra Ellen Gracie, Rel. p./acórdão Min. Joaquim Barbosa, 18.08.2004, Informativo n.357, 25.08.2004.
} 
“contribuições exóticas”, bem como para a contribuição previdenciária dos inativos (Lei 9.783/99), “(...) fazendo-as incidir genericamente sobre pessoas dotadas de capacidade contributiva e desatando os laços da solidariedade e da responsabilidade dentro do grupo de beneficiários" ${ }^{\prime 1513}$.

Por isso é oportuno também considerar o alerta de Humberto Ávila, para quem o Estado não poderia justificar a tributação com base direta e exclusiva no princípio da solidariedade social, já que o poder de tributar estabelecido constitucionalmente foi delimitado por regras de competência “(...) que já pré-excluem a escolha de outros meios de tributar diversos daquele já previsto (...)", aduzindo que, a partir da teoria jurídica da argumentação, o argumento baseado na solidariedade social teria importância restrita, “(...) não sendo possível aceitar o argumento pautado na solidariedade social para repercutir sobre esse núcleo competencial, alterando-o"1514.

De fato, é uma importante reflexão que se coaduna também com a exigência da segurança jurídica na consideração da solidariedade, não sendo possível, por exemplo, alegar falta de receita para o financiamento da seguridade social para justificar a tributação ${ }^{1515}$. Aliás, essa interpretação não se afasta da consideração de Marco Aurélio Greco, para quem o grande desafio dos estudiosos do Direito Tributário é justamente “(...) encontrar o ponto de equilíbrio entre os valores constitucionalmente consagrados" ${ }^{\Perp 1516}{ }^{1517}$.

\subsection{O processo disciplinar do Direito Tributário Brasileiro contemporâneo e o diálogo com o "Meio Ambiente".}

O chamado "ambientalismo", fruto da percepção da importância da proteção do meio ambiente, favoreceu, nos últimos anos, a construção da expressão "desenvolvimento sustentável", também conhecida como "sustentabilidade" que, em outras palavras, limita o desenvolvimento pelo desenvolvimento, vinculando-o a limites éticos, sociais e

\footnotetext{
1513 TORRES, Ricardo Lobo. Existe um Princípio Estrutural da Solidariedade? Op.cit., p. 198-208.

1514 ÁVILA, Humberto. Limites à Tributação com Base na Solidariedade Social. In: Solidariedade Social e Tributação. Op.cit., p.68-88.

1515 ÁVILA, Humberto. Limites à Tributação com Base na Solidariedade Social. In: Solidariedade Social e Tributação. Op.cit., p.68-88.

${ }^{1516}$ GRECO, Marco Aurélio. Solidariedade Social e Tributação. Op.cit., p. 168-197.

${ }^{1517}$ ZILVETI, Fernando Aurelio. A Evolução da Teoria da Incidência - Análise Histórica das Estruturas Socioeconômicas na Formação do Sistema Tributário. Op.cit., s/np (cap. V, item 7).
} 
ambientais ${ }^{1518}{ }_{-}^{1519}$, vislumbrando o desenvolvimento voltado para a vida digna das gerações futuras ${ }^{1520} \mathrm{e}$, naturalmente, à promoção dos Direitos Humanos ${ }^{1521}$.

No art. $170^{1522}$, inciso VI, inclui-se expressamente a temática ambiental (inc. VI), que, vincula-se ao princípio da cooperação, necessitando de uma operação conjunta entre Estado e Sociedade, assim como ao princípio do poluidor-pagador, visando a internalização dos custos relativos externos de deterioração ambiental e da precaução (evitando perigos ambientais e procurando uma qualidade ambiental favorável) ${ }^{1523}$.

Naturalmente, os próprios Direitos Fundamentais passam a consagrar a necessidade de ambiente ecologicamente correto ${ }^{1524}$, e a tributação passa a ser vista como instrumento apto a concretizá-la.

As políticas tributárias acabam vinculadas ao ambientalismo ${ }^{1525}$, já que o direito ao meio ambiente saudável é incluído no rol dos Direitos Humanos ${ }^{1526}$, e a tributação, entre os instrumentos aptos a alcançá-la. ${ }^{1527}$.

Nesse sentido, surge nos Estados Unidos e na Europa o fenômeno conhecido como Green Tax Reform (Reforma Fiscal Verde), favorecendo a instrumentação tributária à proteção do meio ambiente. A própria realidade tributária brasileira passa a repercutir tais

${ }^{1518}$ PERRONE-MOISÉS, Claudia. Direitos Humanos e Desenvolvimento: A Contribuição das Nações Unidas. In: AMARAL JR., Alberto; PERRONE-MOISÉS, Cláudia. O cinqüentenário da Declaração Universal dos Direitos do Homem. São Paulo: Edusp, 1999, p.180 e seguintes.

${ }^{1519}$ Agenda 21 da Conferência da ONU sobre Meio Ambiente e Desenvolvimento. Disponível em: www.mma.gov.br (último acesso em 12.10.2014).

${ }^{1520}$ NABAIS, José Casalta. Política Fiscal, Desenvolvimento Sustentável e Luta contra a Pobreza. Cadernos da Escola de Direito e Relações Internacionais da UniBrasil. n.07. Jan/Dez 2007, p. 369 e seguintes.

${ }^{1521}$ TRINDADE, Antônio Augusto Cançado. Direitos Humanos e Meio Ambiente. Paralelos dos Sistemas de Proteção Internacional. Porto Alegre: Sergio Antonio Fabris Editor, 1993, p. 23-54.

${ }^{1522}$ Art. 170 da CF/1988. "A ordem econômica, fundada na valorização do trabalho humano e na livre iniciativa, tem por fim assegurar a todos existência digna, conforme os ditames da justiça social, observados os seguintes princípios: (...) VI - defesa do meio ambiente, inclusive mediante tratamento diferenciado conforme o impacto ambiental dos produtos e serviços e de seus processos de elaboração e prestação."

${ }^{1523}$ DERANI, Cristiane. Aplicação do Direito Ambiental para o Desenvolvimento sustentável. In: Direito Tributário Ambiental. TôRRES, Heleno Taveira (org.). São Paulo: Malheiros, 2005, p. 642 e seguintes.

${ }^{1524}$ ALTAMIRANO, Alejandro C. El Derecho Tributario ante La Constitucionalización del derecho a un medio ambiente sano. In: TÔRRES, Heleno Taveira (org.). Direito tributário ambiental. Op.cit., p. 445 e seguintes.

${ }^{1525}$ YOSHIDA, Consuelo Yatsuda Moromizato. A Efetividade e a eficiência ambiental dos instrumentos econômico-financeiros e tributários. Ênfase na prevenção. A utilização econômica dos bens ambientais e suas implicações. In: TôRRES, Heleno Taveira (org.). Direito tributário ambiental. Op.cit., p. 531.

${ }^{1526}$ TRINDADE, Antonio Augusto Cançado. Op.cit., p. 23 e seguintes.

${ }^{1527}$ ALTAMIRANO, Alejandro C. El Derecho Constitucional a un ambiente sano, derechos humanos y su vinculación con el derecho tributário. In: Tributação e Meio Ambiente. James Marins (Coord). Livro 2. Curitiba: Juruá, p.11-93. 
fenômenos, como é possível observar através do "ICMS verde" (ou "ICMS Ecológico",1528) já aplicado em alguns Estados brasileiros (surgido no Paraná em 1991, e depois reproduzido em outros Estados) ${ }^{1529}$.

Com a indução de comportamentos ambientalmente orientados através da tributação ${ }^{1530}$, surge a ideia de "tributo ecológico", que, na concepção de Pedro Manuel Herrera Molina e Domingo Carbajo Vasco, pode ser compreendido como todo tributo cuja principal finalidade seja a de servir à proteção do meio ambiente ${ }^{1531}$. Este, na visão de Roberto Ferraz, serve a influenciar a decisão econômica de maneira a tornar mais interessante a opção ecologicamente mais adequada ${ }^{1532}{ }_{-}^{1533}{ }_{-}^{1534}$.

Não é surpresa que a proteção ambiental gere novas possibilidades ao estudo interdisciplinar nos estudos tributários brasileiros, aproximando a tributação da proteção ambiental $^{1535}$. A implementação de tributos ambientais pode ser caminho adotado inclusive para a tributação municipal, a exemplo da vinculação da progressividade extrafiscal do IPTU para imóveis urbanos que favoreçam (ou não) a proteção do meio ambiente, ${ }^{1536}{ }_{-}^{1537}$ -

${ }^{1528}$ SCAFF, Fernando Facury; TUPIASSU, Lise Vieira da Costa. Tributação e Políticas Públicas: o ICMS Ecológico. In: Direito tributário ambiental. TôRRES, Heleno Taveira (org.). Op.cit, p. 735.

${ }^{1529}$ Idem, p. 738 e seguintes.

${ }^{1530}$ SCHOUERI, Luís Eduardo. Normas tributárias indutoras e intervenção econômica. Op.cit., p. 32-34.

${ }^{1531}$ MOLINA, Pedro Manuel Herrera; VASCO, Domingo Carbajo. Marco Conceptual, Constitucional e Comunitario de La fiscalidad Ecológica. In: Direito tributário ambiental. Op.cit., p. 163 e seguintes.

${ }^{1532}$ FERRAZ, Roberto. Tributação ambientalmente orientada e as espécies tributárias no Brasil In: Direito tributário ambiental. TôRRES, Heleno Taveira (org.). Op.cit., p. 341.

${ }^{1533}$ CALIENDO, Paulo. Tributação e Mercado de Carbono. In: Direito tributário ambiental. TôRRES, Heleno Taveira (org.). Op.cit., p. 874 e ss.

${ }^{1534}$ Salienta-se, contudo, que não devem os tributos ecológicos ser encarados como sanção, pois não deve a green tax constituir qualquer exceção ao princípio da capacidade contributiva. A tributação ecológica não se vincula a desestimular atividades (contrárias ambientalmente) mediante sanção imprópria, mas “(...) refletir a realidade dos custos da atividade ecologicamente nociva (ou desorientada)". Busca arrecadar recursos para a correção dos efeitos nocivos ambientalmente da atividade tributada. FERRAZ, Roberto. O Princípio da Capacidade Contributiva na Tributação Ambientalmente Orientada. In: FERRAZ, Roberto. Princípios e Limites da Tributação. Os Princípios da Ordem Econômica e Tributação. Vol.2. Op.cit., p. 547.

${ }^{1535}$ Exemplo dessa promoção entre Direito Tributário e outros ramos do conhecimento jurídico para a proteção ambiental pode ser identificada na seguinte obra coletiva dedicada à promover o diálogo entre Direito Tributário e Direito Econômico aplicados ao meio ambiente e à mineração: SCAFF, Fernando Facury; ATHIAS, Jorge Alex (Cood.) Direito Tributário e Econômico aplicado ao Meio Ambiente e à Mineração. São Paulo: Quartier Latin, 2009, p. 09 e seguintes.

${ }^{1536}$ COSTA, Regina Helena. Apontamentos sobre a Tributação Ambiental no Brasil. In: Direito tributário ambiental. TôRRES, Heleno Taveira (org.). Op.cit., p. 312-325. FIORILLO, Celso Antonio Pacheco. Direito às Cidades Sustentáveis no âmbito da Tutela Constitucional do Meio Ambiente Artificial e o IPTU Progressivo no tempo como instrumento da Política Urbana em face do Direito Ambiental Tributário. In: Direito tributário ambiental. TôRRES, Heleno Taveira (org.). Op.cit., p. 783 e seguintes.

${ }_{1537}$ Outros exemplos são lembrados por: COSTA, Regina Helena. Apontamentos sobre a Tributação Ambiental no Brasil. In: Direito tributário ambiental. TôRRES, Heleno Taveira (org.). Op.cit., p. 323-325. 

ambiental, nos artigos 170 e 225 da Constituição, fornecendo impulso para a aplicação das Green Taxes, ${ }^{1539}$ que passam a agregar diversos exemplos na realidade brasileira. ${ }^{1540}$

Nesse contexto, em meados da década de 90, já se registram as primeiras contribuições brasileiras ao tema, como se pode observar no estudo de José Marcos Domingues de Oliveira, sobre Direito Tributário e Meio Ambiente ${ }^{1541}$, já defendendo que “(...) é preciso avançar no sentido da tributação ambiental, especialmente na sua vertente extrafiscal indutora de comportamentos não degradadores da Ordem Natural" ${ }^{, 1542}$.

Mas as aspirações doutrinárias supracitadas ganham força no Brasil especialmente na virada do século XXI, quando se identifica mais claramente essa importância ambiental aos estudos tributários, como é possível observar na coletânea organizada por Heleno Taveira Tôrres sob o título "Direito Tributário Ambiental”. O autor também denominou o

${ }^{1538}$ Recorda-se também a Contribuição de Intervenção Econômica criada pela EC 33/2001 (\$4ª , art.177, inc.I e II), que vincula a arrecadação desta CIDE voltada ao financiamento de projetos ambientais, à proteção do meio ambiente brasileiro de importação de combustíveis e derivados de petróleo, e a diferenciação de alíquotas em razão do uso ou do produto, revelando inequívoca política de proteção ambiental veiculada por esta contribuição. FERRAZ, Roberto. Tributação e Meio Ambiente: O Green Tax no Brasil (A Contribuição de Intervenção da Emenda 33/2001). In: Tributação e Meio Ambiente. James Marins (Coord). Livro 2. Curiiba: Juruá, p.96 e seguintes.

${ }^{1539}$ Schoueri, analisando as normas tributárias indutoras em matéria ambiental, considerou as externalidades (positivas e negativas) frente aos tributos ambientais (princípio do poluidor-pagador), o que, no campo da tributação, relaciona-se ao princípio da equivalência, onde aquela empresa que polui apresenta vantagem estratégica frente àquela empresa que não polui, e, portanto a primeira deve compensar as vantagens em relação àqueles que agem de acordo com exigências ambientais (tendo por isso maiores custos). SCHOUERI, Luís Eduardo. Normas Tributárias Indutoras em Matéria Ambiental. In: TôRRES, Heleno Taveira (org.). Direito tributário ambiental. Op.cit., p. 235-238. ROTHMANN, Gerd Willi. Tributação, Sonegação e Livre Concorrência. Op.cit., p. 357 e seguintes.

1540 Além da CIDE Combustíveis, dedicada a favorecer a política nacional energética, com previsão constitucional de destinação que deveria se remeter às questões ambientais (art.177, par.4 $4^{\mathrm{a}}, \mathrm{CF} / 88$ ), recordese também a Taxa de Fiscalização Ambiental do IBAMA (art.8 da Lei 9.960/2000, posteriormente alterada pela Lei 10.165/2000). MARTINS, Ives Gandra da Silva. A Taxa de Controle e Fiscalização Ambiental TCFA. In: Direito tributário ambiental. TôRRES, Heleno Taveira (org.). Op.cit., p. 749 e seguintes. LEIRIA, Maria Lúcia Luz. Breves considerações sobre a Taxa de Controle e Fiscalização Ambiental - TCFA, instituída pela Lei n.10.165/2000. In: Direito tributário ambiental. TÔRRES, Heleno Taveira (org.). Op.cit., p. 773 e seguintes. TORRES, Ricardo Lobo. Interação entre Princípios Constitucionais Tributários e Princípios da Ordem Econômica. Op.cit., p.515 e seguintes. TORRES, Ricardo Lobo. Valores e Princípios no Direito Tributário Ambiental. In: TÔRRES, Heleno Taveira (org.). Direito tributário ambiental. Op.cit.,p. 40-45; FERRAZ, Roberto. Tributação ambientalmente orientada e as espécies tributárias no Brasil. Op.cit., p. 349-350.

${ }^{1541}$ OLIVEIRA, José Marcos Domingues de. Direito Tributário e Meio Ambiente. Proporcionalidade. Tipicidade Aberta. Afetação de Receita. Rio de Janeiro: Renovar, 1995, p. 08-09. Recorde-se que o interesse do autor sobre o tema já podia ser observado em estudos anteriores: OLIVEIRA, José Marcos Domingues de. Meio Ambiente, Tributação e Vinculação de Impostos. Revista de Direito Tributário, n.56, 1991, p. 84-91.

${ }^{1542}$ OLIVEIRA, José Marcos Domingues de. Direito Tributário e Meio Ambiente. Proporcionalidade. Tipicidade Aberta. Afetação de Receita. Op.cit., p. 100 e seguintes. 
Direto Tributário Ambiental enquanto o conjunto de normas jurídicas tributárias elaboradas em concurso com o exercício de competências ambientais, para determinar o uso de tributos na função instrumental de garantia, promoção ou preservação de bens ambientais $^{1543}$.

Passa-se a construir o Direito Tributário Ambiental, sub-ramo do Direito Tributário dedicado a delinear a intersecção entre o Direito Tributário e o Direito Ambiental, corporificando conjunto de princípios comuns. ${ }^{1544}{ }^{1545}$.

Na visão de Ricardo Lobo Torres, o Direito Tributário Ambiental “(...) deixa-se imantar pelos valores e princípios jurídicos, que cresceram de importância com a reaproximação entre ética e direito e a superação das posições positivistas, assim formalistas que historicistas" 1546 . Mas isso não significa prevalência de um sobre outro.

Conforme pondera Hugo de Brito Machado, a tributação ambiental não deve implicar adicional à carga tributária que já existe, onde os princípios (tributários e ambientais) devem ser harmonizados, devendo a defesa do meio ambiente ser conciliada com a propriedade privada e a livre iniciativa ${ }^{1547}$.

Posições mais cautelosas frente à tributação ambiental (e seus limites) podem ser observadas, a exemplo de Heleno Taveira Tôrres ${ }^{1548}$, já que, em não raros casos, é necessário “(...) resguardar a sociedade de investidas legislativas do poder de tributar, a

${ }^{1543}$ TORRES, Heleno Taveira. Da Relação entre Competências Tributárias Constitucionais Tributária e Ambiental - Os limites dos chamados "Tributos Ambientais". In: Direito tributário ambiental. TÔRRES, Heleno Taveira (org.). São Paulo: Malheiros, 2005, p. 101-102.

${ }^{1544}$ Ricardo Lobo Torres, nesse sentido, liga os princípios do direito tributário ambiental a valores jurídicos (ideias absolutamente abstratas, supraconstitucionais e insuscetíveis de se traduzirem em linguagem constitucional), onde os princípios estariam situados entre os valores e as regras: a) liberdade (valor): relaciona-se ao princípio da imunidade do mínimo ecológico; b) justiça (valor): relaciona-se aos princípios do poluidor-pagador, do usuário-pagador, da capacidade contributiva e do custo/benefício; c) segurança: relaciona-se aos princípios da prevenção, da precaução, da legalidade tributária e da tipicidade tributária; d) solidariedade: relaciona-se aos princípios da capacidade contributiva solidária e da solidariedade de grupo. TORRES, Ricardo Lobo. Valores e Princípios no Direito Tributário Ambiental. Op.cit., p. 22 e seguintes. Sobre o assunto, também: TORRES, Ricardo Lobo. Interação entre Princípios Constitucionais e Princípios da Ordem Econômica. Op.cit., p.493 e seguintes.

${ }^{1545}$ Outros autores, como Lídia Maria Lopes Rodrigues Ribas, incluem entre os princípios ambientais no direito tributário o princípio do poluidor pagador (PPP) e o princípio da proporcionalidade, assim como da não-vinculação dos impostos. RIBAS, Lídia Maria Lopes Rodrigues. Defesa ambiental: utilização de instrumentos tributários. In: TÔRRES, Heleno Taveira (org.). Direito tributário ambiental. Op.cit., p. 675 e seguintes.

${ }^{1546}$ Idem, p. 49.

${ }^{1547}$ MACHADO, Hugo de Brito. Ordem Econômica e Tributação. Op.cit., p. 384 e seguintes.

${ }^{1548}$ TORRES, Heleno Taveira. Da Relação entre Competências Tributárias Constitucionais Tributária e Ambiental - Os limites dos chamados "Tributos Ambientais". Op.cit., p. 97 e seguintes. 
pretexto de medidas preservacionistas, para criar tributo que, ao fim e ao cabo, mais não permitam do que ampliar a carga tributária geral, desprovido de qualquer vínculo com a atividade estatal de proteção ao meio ambiente"1549.

Naturalmente, é razoável fixar balizas para a tributação ambiental, conforme reconhece Schoueri, ao apontar a necessidade de que a tributação ambiental (mais especificamente, as normas tributárias indutoras em matéria ambiental) deva se vincular às limitações constitucionais, a exemplo da legalidade, da igualdade, da proibição do efeito confisco, da delimitação da competência tributária e da competência regulatória, pois a tributação ambiental somente poderia ser exercida confirmando-se a competência tributária (art.153 a 156) e a competência material (em regra, concorrente, conforme o art.24, VI, $\mathrm{CF}$ ), o que não impede a vasta gama de oportunidades de emprego de normas tributárias indutoras em matéria ambiental. ${ }^{1550}$

\subsection{O processo disciplinar do Direito Tributário Brasileiro contemporâneo e o diálogo com o Direito Financeiro}

O Direito Financeiro, sinteticamente, pode ser definido como o ramo do Direito Público dedicado à disciplinar o fenômeno financeiro (atividade financeira) do Estado.

É a disciplina, no entendimento de Celso Ribeiro Bastos, da atividade financeira, e tem por objeto o estudo das normas que fazem parte da organização e da estrutura financeira estatal (direito financeiro positivo, por assim dizer) ${ }^{1551}$.

O Direito Financeiro, na visão de Ruy Barbosa Nogueira (enquanto disciplina jurídica) deve compreender o estudo jurídico não apenas da receita derivada (direito tributário) e originária. Deve também estudar a despesa, o orçamento e o crédito público $^{1552}$, ou, em outras palavras, foca em três momentos distintos: na receita; na gestão,

\footnotetext{
${ }^{1549}$ TORRES, Heleno Taveira. Da Relação entre Competências Tributárias Constitucionais Tributária e Ambiental - Os limites dos chamados “Tributos Ambientais". Op.cit., p. 101 e seguintes.

${ }^{1550}$ SCHOUERI, Luís Eduardo. Normas Tributárias Indutoras em matéria ambiental. Op.cit., p. 252 e seguintes.

${ }^{1551}$ BASTOS, Celso Ribeiro. Curso de Direito Financeiro e Tributário. São Paulo: Saraiva, 1994, p. 14 e seguintes.

${ }^{1552}$ NOGUEIRA, Ruy Barbosa. Curso de Direito Financeiro (Direito Tributário). Op.cit., p. xvi.
} 
e na despesa pública. ${ }^{1553}$ Vincula-se, portanto, ao estudo das relações jurídicas do exercício da atividade financeira estatal. ${ }^{1554}$

O Direito Financeiro, que abarca o Direito Tributário, apresenta importantes conexões com esse último, como é o caso do Direito Orçamentário ${ }^{1555}$, e o Direito das Prestações Financeiras ${ }^{1556}$, anteriores e posteriores ao trâmite da relação tributária, respectivamente. Assumindo como referência a tributação, a primeira dedica-se ao estudo do planejamento estatal para a arrecadação, gerência e aplicação de recursos financeiros, e a segunda é aquela que vai estudar a etapa posterior à arrecadação do tributo, isto é, o processo de administração e distribuição desse recurso financeiro (despesa) depois de ter sido arrecadado, viabilizando a chamada "destinação do tributo".

Contudo, a delimitação dos contornos da relação tributária constrói-se como tendência histórica de desvinculação da origem e do destino de seus encargos, como se observa em Otto Mayer ${ }^{1557}$, e, posteriormente, na órbita do Estado de Direito, em Ernst Blumenstein $^{1558}$, Myrbach-Rheinfeld ${ }^{1559}$, Nawiasky (e sua teoria das relações concêntricas) $^{1560 \_}{ }^{1561}$, Albert Hensel ${ }^{1562}$, Giannini (relação jurídica tributária complexa) ${ }^{1563}$, entre outros autores ${ }^{1564}$, chegando também à realidade doutrinária brasileira, conforme

${ }^{1553}$ GARZA, Sérgio F. de la. Derecho financiero mexicano. México: Porrúa, 1975, p. 13.

${ }^{1554}$ BALEEIRO, Aliomar. Uma Introdução à Ciência das Finanças. Op.cit., p. 04. GRIZIOTTI, Benvenuto. Princípios de Política, Derecho y Ciência de la Hacienda. Op.cit., p. 15. Em análogo sentido, ARAÚJO FALCÃO, Amílcar de. Introdução ao Direito Tributário. Op.cit., p. 18. BALEEIRO, Aliomar. Cinco Aulas de Ciência das Finanças e Política Fiscal. Op.cit., p. 32. Em semelhante sentido: BUJANDA, Fernando Sainz de. Hacienda y Derecho. I. Op.cit., p. 07. TORRES, Ricardo Lobo. Curso de Direito Financeiro e Tributário. Op.cit., p. 11 e seguintes.

1555 TORRES, Ricardo Lobo. Curso de Direito Financeiro e Tributário. Op.cit., p. 13 e seguintes.

${ }^{1556}$ Idem, p. 11 e seguintes.

${ }^{1557}$ MAYER, Otto. Op.cit, p.196 e seguintes.

${ }^{1558}$ BLUMENSTEIN, Ernst. Op.cit, p. 09.

${ }^{1559}$ MYRBACH-RHEINFELD, Franz Von. Op.cit., p. 115-129.

${ }^{1560}$ NAWIASKY, Hans. Op.cit., p. 68-71.

${ }^{1561}$ VOGEL, Klaus. Introducción a La Edición Española. In: NAWIASKY, Hans. Op.cit., p. XIV-XV.

${ }^{1562}$ HENSEL, Albert. Op.cit., p. 71-72.

${ }^{1563}$ GIANNINI, A.D. I Concetti fondamentali del Diritto Tributario. Op.cit., p. 125 e ss. Mas a construção originária acerca da "relação jurídica do tributo" encontra-se na seguinte obra: GIANNINI, A.D. Il Rapporto Giuridico D'Imposta. Op.cit., p.25-30.

${ }^{1564}$ BUJANDA, Fernando Sainz de. Sistema de Derecho Financiero Tomo I. Volumen Segundo. Análisis Estructural del Derecho Financiero. Ramos del Derecho público con sectores proyectados sobre la materia financiera. Madrid. Facultad de Derecho de La Universidad Complutense, 1985, p. 33 e seguintes. 
aponta Alcides Jorge Costa, em notável estudo ${ }^{1565}$, tendência que se elevou ainda mais com a influência do dogmatismo normativo kelseniano no Brasil.

É claro que não se ignora aqueles autores que tradicionalmente transitam entre o Direito Tributário e o Financeiro, como é possível observar em Ricardo Lobo Torres ${ }^{1566}$, Carlos Valder do Nascimento ${ }^{1567}$, Ives Gandra Martins ${ }^{1568}$, Kiyoshi Harada ${ }^{1569}$, José Maurício Conti ${ }^{1570}$, Estevão Horvath, Régis Fernandes de Oliveira ${ }^{1571}$, Fernando Facury Scaff $^{1572}$, Heleno Taveira Tôrres ${ }^{1573}$, José Maria Arruda de Andrade ${ }^{1574}$, Eduardo Marcial Ferreira Jardim ${ }^{1575}$, e muitos outros estudiosos contemporâneos. ${ }^{1576}$ Não é por acaso que Fernando Aurelio Zilveti trate da "reintegração" entre Direito Tributário e Direito Financeiro, portanto ${ }^{1577}$.

${ }^{1565}$ COSTA, Alcides Jorge. Algumas Notas sobre a Relação Jurídico Tributária. Op.cit., p. 21-35. Sobre o assunto, também: COSTA, Alcides Jorge. Contribuição ao Estudo da Obrigação Tributária. Op.cit., p. 07-10.

${ }^{1566}$ A constante preocupação com temas de Direito Financeiro (e, naturalmente, a consideração desses temas sob o prisma dos valores e princípios constitucionais aplicáveis) é marca registrada da obra de Ricardo Lobo Torres: TORRES, Ricardo Lobo. O Orçamento na Constituição. Rio de Janeiro: Renovar, 1995, p. 85 e seguintes, mantendo sempre a abertura ao diálogo entre direito tributário, ciência das finanças e direito financeiro: TORRES, Ricardo Lobo. Curso de Direito Financeiro e Tributário. Op.cit., p. 11 e seguintes.

${ }^{1567}$ NASCIMENTO, Carlos Valder do. Curso de Direito Financeiro. ${ }^{\text {a }}$. ed. Rio de Janeiro: Forense, 1999, p. 20 e seguintes.

1568 MARTINS, Ives Gandra da Silva; NASCIMENTO, Carlos Valder do. Comentários à Lei de Responsabilidade Fiscal. São Paulo: Saraiva, 2007, p. 12 e seguintes.

${ }^{1569}$ HARADA, Kiyoshi. Direito Financeiro e Tributário. São Paulo: Atlas, 2009, p. 06 e seguintes.

${ }^{1570}$ CONTI, José Maurício. Orçamentos Públicos - A Lei 4.320/1964 comentada. São Paulo: Revista dos Tribunais, 2008, p. 16 e seguintes.

1571 OLIVEIRA, Regis Fernandes de; HORVATH, Estevão. TAMBASCO, Teresa Cristina Castrucci. Manual de direito Financeiro. São Paulo: Rt, 1990, p. 14-15. A partir da segunda edição, registram apenas a colaboração dos dois primeiros autores: OLIVEIRA, Régis Fernandes de; HORVATH, Estevão. Manual de Direito Financeiro. $2^{a}$ ed. São Paulo: RT, 1997, p. 18-19.

${ }^{1572}$ SCAFF, Fernando Facury. República, tributação e finanças. RDE. Revista de Direito do Estado, v. 21, São Paulo, p 649 e seguintes.

${ }^{1573}$ TORRES, Heleno Taveira. Direito Constitucional Financeiro - Teoria da Constituição Financeira. $1^{\mathrm{a}}$. ed. São Paulo: Revista dos Tribunais, 2014, p. 14 e seguintes.

${ }^{1574}$ ANDRADE, José Maria Arruda de. Normas Gerais, Nacionais, Competência Legislativa e o Federalismo Fiscal. Revista Brasileira de Estudos Constitucionais, v. 6, 2008, p. 67 e seguintes.

${ }^{1575}$ JARDIM, Eduardo Marcial Ferreira. Manual de Direito Financeiro e Tributário. 3 ed. São Paulo: Saraiva, 1996, p. 10-11.

${ }^{1576}$ Embora exista certa prevalência, especialmente na década de noventa, pelo dualismo separatista, é possível visualizar certo grau de abertura ao diálogo já naquele período, como se verifica em Eduardo Marcial Ferreira Jardim: “(...) no plano das relações interdisciplinares, todas as disciplinas retrocitadas (direito financeiro, direito tributário, direito econômico e ciência das finanças) comportam o mesmo objeto, vale dizer, a atividade financeira do Estado, (...)”. Porém, “(...) de outro lado, as diferenças despontam com incontendível nitidez, pois a ciência das finanças "estuda" a atividade financeira do Estado, enquanto os direitos financeiro, tributário e econômico, normatizam a mencionada atividade (...)”. Idem, p. 12-13.

${ }^{1577}$ ZILVETI, Fernando Aurelio. A Evolução da Teoria da Incidência - Análise Histórica das Estruturas Socioeconômicas na Formação do Sistema Tributário. Op.cit., s/np (item I.9). 
Porém, não se afasta ainda a pouca atenção concedida à generalidade dos tributaristas ao diálogo com o Direito Financeiro e, mais precisamente, à origem e à destinação do tributo, afastamento favorecido tanto pelo Direito Constitucional Tributário, ao promover a gradual dissociação entre princípio da anualidade e o Direito Tributário, como a tendência legislativa, no âmbito da autorização para a elaboração de normas gerais em matéria financeira na Constituição de 1946 e, seguindo o exemplo estrangeiro, contemplar tão somente o Direito Tributário.

Felizmente, novos objetos de estudo dentro do próprio Direito Financeiro contemporâneo no Brasil atraem renovados diálogos entre as disciplinas, como é possível observar, por exemplo, na Lei de Responsabilidade Fiscal (LC n.101/2000, com as modificações trazidas pela Lei Complementar n.131/2009), que estabelece normas relativas às finanças públicas para intensificar a responsabilidade na gestão fiscal, na administração pública, oferecendo novo campo de estudos ao Direito Financeiro ${ }^{1578}$, viabilizando também reaproximação com o Direito Tributário. ${ }^{1579}$

Não é por outro motivo que dois recentes estudos simbolizam os esforços a essa reaproximação disciplinar.

O primeiro, publicado por Roberto Ferraz, demonstra preocupação quanto à tradicional tendência doutrinária brasileira de centrar-se na construção do "fato gerador", esquecendo-se de outros temas relevantes. Mais precisamente, para o autor, a doutrina tributária brasileira “(...) precisamente ao ganhar um trato propriamente jurídico, a discussão do tema tributário deixou a questão da destinação do produto da arrecadação à margem. Aliás, esse ponto quase ficou excluído das discussões jurídicas em geral, ficando circunscrito a um âmbito exclusivamente político”. Mas complementa: “(...) é de verificarse que a destinação do produto da arrecadação tem alta relevância jurídica, pois igualmente

\footnotetext{
1578 “Art. 48. São instrumentos de transparência da gestão fiscal, aos quais será dada ampla divulgação, inclusive em meios eletrônicos de acesso público: os planos, orçamentos e leis de diretrizes orçamentárias; as prestações de contas e o respectivo parecer prévio; o Relatório Resumido da Execução Orçamentária e o Relatório de Gestão Fiscal; e as versões simplificadas desses documentos".

1579، "Art. 11. Constituem requisitos essenciais da responsabilidade na gestão fiscal a instituição, previsão e efetiva arrecadação de todos os tributos da competência constitucional do ente da Federação. Parágrafo único. É vedada a realização de transferências voluntárias para o ente que não observe o disposto no caput, no que se refere aos impostos".
} 
pode determinar, ao lado das hipóteses de incidência, a validade ou não da exigência, contribuindo decisivamente na permanente busca pela tributação justa" ${ }^{2580}$.

O segundo, da autoria de Eurico Marcos Diniz de Santi e Vanessa Rahal Canado, igualmente dedica-se a estreitar as relações entre Direito Tributário e Direito Financeiro no âmbito da conceituação do tributo (e, sobretudo, no que diz respeito à sua destinação) ${ }^{1581}$, criticando a já mencionada tendência da Ciência do Direito Tributário brasileiro que “(...) delimitou seu objeto em torno do estudo das normas jurídicas que dizem respeito à instituição, arrecadação e extinção da relação jurídico-tributária (...)", recortando-a das relações com a destinação do tributo (cujo recorte foi favorecido pelo próprio Código Tributário Nacional, quando dispõe sobre a incidência tributária, a definição do fato gerador, os elementos da obrigação tributária, as formas de constituição e os prazos para cobrança do crédito tributário), acabou por gerar consequências negativas ao estudo do Direito Tributário Brasileiro, que basicamente passou a despreocupar-se com a destinação do valor arrecadado ${ }^{1582}$.

Contudo, nos últimos anos, ressaltam os autores, ganha atenção a despesa pública, especialmente sobre a discussão da pesada carga tributária, agora refletida em consonância com o gasto público. Por isso ressaltam os autores: “(...) é sob esse novo foco que se propõe a aproximação do estudo do direito tributário com o direito financeiro, no contínuo

\footnotetext{
${ }^{1580}$ Este trabalho, além de defender a importância da destinação do tributo para os estudos jurídico-tributários, também busca elencar os chamados "pressupostos de incidência", compreendidos pelo autor como "(...) as condições de legitimidade da imposição tributária, além de uma simples correspondência à hipótese constitucionalmente e legalmente configurada (...)", na busca por um tributo justo. Note-se, portanto, que as reflexões do autor não se limitam apenas à destinação do tributo (momento posterior à extinção da relação tributária), mas também ao conceito de tributo que, historicamente centrado na "cobrança", deve ser revisado, já que "(...) a lei que torna exigível o tributo somente será realmente lei se estabelecer a exigência em favor de despesas públicas na promoção do bem comum; caso contrário, não será lei nem estará criando tributo". Para o autor: "Pressupostos de incidência tributária é o conjunto de condições estabelecidas expressa ou implicitamente pela Constituição para a imposição de tributos", tanto no tocante à cobrança, quanto à destinação do produto da arrecadação. FERRAZ, Roberto. Da Hipótese ao Pressuposto de Incidência - em Busca do Tributo Justo. In: Direito Tributário. Homenagem a Alcides Jorge Costa. Volume I. SCHOUERI, Luís Eduardo (Coord.) São Paulo: Quartier Latin, 2003, p. 176-235.

${ }^{1581}$ SANTI, Eurico Marcos Diniz de; CANADO, Vanessa Rahal. Direito Tributário e Direito Financeiro: reconstruindo o conceito de tributo e resgatando o controle da destinação. In: Política Fiscal. VASCONCELLOS, Roberto França de. (Coord.) Série GVLaw. São Paulo: Saraiva, 2009, p.255-276.

${ }^{1582}$ SANTI, Eurico Marcos Diniz de; CANADO, Vanessa Rahal. Direito Tributário e Direito Financeiro: reconstruindo o conceito de tributo e resgatando o controle da destinação. Op.cit., p.255-276.
} 
processo de causalidade jurídica, favorecendo o desenvolvimento de formas de controle das despesas do Estado". ${ }^{1583}$

Portanto, os dois estudos supracitados demonstram inequívoca tendência contemporânea voltada à progressiva reaproximação entre o Direito Tributário e o Direito Financeiro, seja no estabelecimento dos pressupostos da tributação, seja nos aspectos ulteriores à arrecadação do tributo (destinação), peculiaridades que devem ser observáveis tanto pelo sujeito passivo como pelo sujeito ativo da relação tributária.

\subsection{0 processo disciplinar do Direito Tributário Brasileiro contemporâneo e o progressivo reforço da tributação internacional}

A consolidação dos estudos sobre Direito Tributário Internacional na realidade brasileira não ocorreu rapidamente. Somente a partir da década de sessenta, e profundamente influenciada pelas primeiras convenções internacionais celebradas no Brasil, é que o interesse pelo tema começa a ganhar apelo na literatura especializada. $\mathrm{O}$ Direito Tributário Internacional (ou Direito Internacional Tributário) passa a ser estudado lentamente no Brasil, especialmente a partir da década de sessenta, quando as primeiras Convenções Internacionais em matéria tributária foram assinadas. ${ }^{1584}$

Em verdade, a estratégia de celebração de convenções internacionais tributárias assumidas pelo governo brasileiro no período refletia também o ambiente internacional,

\footnotetext{
${ }^{1583}$ Adicionalmente, o estudo citado busca investigar critério de classificação de espécies tributárias aplicável à luz do diálogo entre direito tributário e direito financeiro (como objeto de análise as contribuições sociais CIDE), propondo os seguintes critérios de identificação:” i) presença da atuação estatal na hipótese normativa (Taxas, Contribuições de Melhoria, que possuem atuação estatal, impostos e empréstimos compulsórios, que não possuem); ii) previsão de restituição do valor arrecadado (Empréstimos Compulsórios); iii) destinação do produto da arrecadação (contribuições). Demonstram, ainda, que a conceituação do tributo ( $\operatorname{art} .3^{\mathrm{a}}$ ) deve ser repaginada por tais considerações, onde a contribuição deve ser conceituada tendo controle do momento posterior (destinação), propondo o seguinte conceito: “(...) tributo é toda prestação pecuniária compulsória, em moeda ou cujo valor nela se possa exprimir, cobrada e destinada mediante atividade administrativa plenamente vinculada". SANTI, Eurico Marcos Diniz de; CANADO, Vanessa Rahal. Op.cit., p.255-276.

${ }^{1584}$ Cabe lembrar, com Schoueri que, o primeiro acordo de bitributação assinado pelo Brasil foi protagonizado com a Suécia (em 17 de setembro de 1965), sendo concluído poucos meses antes da assinatura do Acordo de bitributação do Japão, em 24 de janeiro de 1967. Contudo, o Acordo firmado entre Brasil e Japão foi primeiramente aprovado no Congresso, sendo este o primeiro acordo de bitributação brasileiro em vigor. SCHOUERI, Luís Eduardo. Contribuição à História dos Acordos de Bitributação: a Experiência Brasileira. In: Revista Direito Tributário Atual. Coord. Alcides Jorge Costa; Fernando Aurelio Zilveti; Paulo Celso Bergstrom Bonilha. N.22. São Paulo: Dialética, 2008, p. 265 e seguintes.
} 
onde o desenvolvimento da temática já apresentava importantes avanços, graças aos esforços da Liga das Nações (posteriormente substituída pela ONU) e OCDE (Organização para Cooperação e Desenvolvimento Econômico) ${ }^{1585}$, influenciando, no campo teórico, o interesse brasileiro por temas ligados à tributação internacional. ${ }^{1586}$

Enquanto reflexo dessas tendências, a temática internacional no direito tributário positivo já podia ser observada em alguns dispositivos esparsos, a exemplo do artigo 98 do CTN, incorporado ao direito brasileiro na década de sessenta, que até hoje mantém polêmicas em sua interpretação.

Mas papel de destaque foi exercido por Francisco Dornelles ${ }^{1587}$, responsável por boa parte da negociação dos tratados celebrados pelo Brasil na década de setenta, e que apresentou preocupação constante com a problemática da bitributação (ou dupla tributação), e os desafios da política tributária internacional brasileira para combater a prática frente a potenciais parceiros econômicos (assim como seus prós e contras). ${ }^{1588}$

\footnotetext{
${ }^{1585}$ Nesse período, mantinha grande influência a Convenção Modelo da OCDE de 1963 nas celebrações desses acordos. Curiosamente, conforme avalia Schoueri, no primeiro Acordo (Suécia) não se adotou a estrutura-base da CM-OCDE, ao passo que o Acordo com o Japão já seguia o Modelo da OCDE (1963). Posteriormente, foram celebrados os Acordos com os seguintes países: Noruega (1967), Finlândia (1972), Bélgica (1972), Dinamarca (1974), Dinamarca (1974), Espanha (1974), Suécia (1975), Áustria (1975), Alemanha (1975), Itália (1978), Luxemburgo (1978), e tentou sem resultados favoráveis firmar acordos de semelhante natureza com Estados Unidos, Suíça e Reino Unido. Idem, p.267 e seguintes.

${ }^{1586}$ Embora a consideração dos aspectos internacionais da tributação nunca tenha escapado da reflexão do Direito Tributário no Brasil, como se pode observar em Pontes de Miranda, em seus Comentários à Constituição de 1946 (especialmente na consideração dos efeitos da lei tributária - ou da soberania fiscal - no espaço), e Ruy Barbosa Nogueira, no reconhecimento das relações entre Direito Tributário e Direito Internacional Público, deve-se reconhecer que os primeiros estudos publicados especificamente sobre o tema foram reflexo direto da intensificação do interesse governamental brasileiro para a assinatura dos acordos de bitributação. MIRANDA, Francisco Cavalcanti Pontes de. Comentários à Constituição de 1946. Vol. I (arts 1-36). Op.cit., p. 296 e seguintes. NOGUEIRA, Ruy Barbosa. Direito Financeiro (Direito Tributário). Op.cit., p. 42-43.

${ }^{1587}$ DORNELLES, Francisco. Acordos para eliminar a dupla tributação da renda. Revista de Direito Público, São Paulo, n.28, mar./abr. 1974, p. 278- 281. Este estudo, dentre vários outros, foi disponibilizado livremente pelo próprio autor em sua página eletrônica: http://www.dornelles.com.br/inicio/index.php?option=com_content\&task=view\&id=411\&Itemid=85.

(Ultimo acesso em 13 de setembro de 2014).

${ }^{1588}$ A própria definição de Dupla Tributação Internacional, exposta por Dornelles, em 1974, demonstra conhecimento do autor sobre as estruturas do Direito Internacional Tributário: "A dupla tributação jurídica da renda das relações internacionais ocorre quando a renda de uma pessoa, física ou jurídica, é tributada em dois Estados diferentes. Difere ela da dupla tributação econômica que ocorre quando uma mesma renda é tributada duas vezes em poder de pessoas diferentes. A dupla tributação jurídica decorre do fato de os Estados adotarem diferentes princípios para a fixação da sua competência tributária. No campo internacional exige basicamente três princípios para definir tal competência: residência ou domicílio, nacionalidade e fonte". DORNELLES, Francisco. Acordos para eliminar a dupla tributação da renda. Op.cit., p. 268 e seguintes.
} 
Na época também já apareciam os primeiros estudos de Gerd Willi Rothmann sobre bitributação internacional, voltados à tributação do mesmo contribuinte, sob o mesmo fato e em período idêntico, por dois ou mais Estados ${ }^{1589}{ }^{1590}$.

Mas, de fato, foi a partir da década de setenta que os estudos começam a aflorar, especialmente também impulsionados pela contribuição original de Alberto Xavier, em 1977, denominada "Direito Tributário Internacional do Brasil". Tributação dos Investimentos Estrangeiros". A partir desse estudo é possível dizer que no Brasil foi publicado o primeiro "curso" de direito tributário internacional em âmbito brasileiro (ainda que escrito por autor português) ${ }^{1591}$.

Na época, Alberto Xavier partiu do princípio da aplicação da lei tributária no espaço (territorialidade), distinguindo três critérios de estudo da territorialidade: a) em sentido positivo e negativo; b) em sentido real e pessoal; c) em sentido material e formal $^{1592}$. Assim, o estudo de Xavier favorece a difusão da temática internacional no âmbito da tributação em momento estratégico para o desenvolvimento nacional brasileiro, ${ }^{1593}$ e a doutrina tributária dedicada aos aspectos internacionais da tributação segue acompanhando o fluxo da política tributária brasileira de acordos internacionais ${ }^{1594}$.

${ }^{1589}$ ROTHMANN, Gerd Willi. Bitributação Internacional. In: DÓRIA, Antonio Roberto Sampaio; ROTHMANN, Gerd Willi. Temas Fundamentais de Direito Tributário Atual. Belém: CEJUP, p. 123 e seguintes.

${ }^{1590}$ Sobre a bitributação, dupla tributação ou pluritributação (econômica e jurídica), conferir: ROTHMANN, Gerd Willi. Inconstitucionalidade Múltipla na Tributação da Importação de Serviços - Requiém ou catarse do sistema tributário nacional? Tese de Livre-Docência. São Paulo: Biblioteca de Direito Econômico e Financeiro da Faculdade de Direito do Largo São Francisco, USP, 2010, p.26-27; SCHOUERI, Luís Eduardo. Planejamento Fiscal através de Acordos de Bitributação: Treaty Shopping. São Paulo: Rt, 1995, p. 19. TÔRRES, Heleno Taveira. Pluritributação Internacional sobre a Renda das Empresas. 2

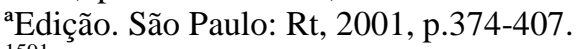

${ }^{1591}$ Nesta obra, conforme expõe Aliomar Baleeiro, a tônica prevalecente volta-se à perspectiva de que o Direito Tributário Internacional deveria ser analisado sob o “(...) ângulo do Direito Nacional de determinado país (...)", já que “(...) a legislação positiva deste ou seus tratados e convenções internacionais marcam os limites e a posição das normas de Direito Internacional realmente em vigor”. BALEEIRO, Aliomar. Prefácio. In: XAVIER, Alberto. Direito Tributário Internacional do Brasil. Tributação dos investimentos estrangeiros. São Paulo: Resenha Tributária, 1977, p. X-XI.

1592 XAVIER, Alberto. Direito Tributário Internacional do Brasil. Tributação dos investimentos estrangeiros. São Paulo: Resenha Tributária, 1977, p. 04 e seguintes.

${ }^{1593}$ Conforme expõe Baleeiro: "A obra de Alberto Xavier é de alto quilate, preencheu um vácuo em nossa literatura fiscal e chega em momento oportuno, porque, embora riquíssima em bibliografia e em base científica, fornece subsídios à solução de inúmeros problemas práticos suscitados pelo desenvolvimento do país nos últimos quinze anos com inevitáveis fricções de caráter internacional ou multinacional". BALEEIRO, Aliomar. Prefácio. In: XAVIER, Alberto. Direito Tributário Internacional do Brasil. Tributação dos investimentos estrangeiros. Op.cit., p. XI-XII.

${ }^{1594}$ Note-se que a maioria dos acordos foram assinados entre a década de 1970 e 1990 , ainda que na década de 90 apenas três foram assinados: Países Baixos (1990), China (1991), Finlândia (1996), além da 
Mas não se pode negar que a noção tradicional de territorialidade ${ }^{1595}$ foi princípio aplicável ao Direito Tributário brasileiro em suas relações internacionais naquele período, contribuindo para o desestímulo na consolidação de convenções internacionais.

Porém, na década de noventa, o Brasil passa a refletir com maior força as tendências à internacionalização do direito tributário, especialmente, quando a Lei n. 9249/1995 introduz o princípio da universalidade ${ }^{1596}$, ou, em melhores termos, introduziu a sistemática da tributação da renda de pessoas jurídicas sobre bases universais, além de adicionar sistemática de créditos para impostos pagos no exterior.

Outra alteração relevante na legislação tributária brasileira ocorreu com a Medida Provisória n. 2518-35/2001, que adotou o princípio da transparência total, “(...) obstacularizando qualquer diferimento: os lucros das filiais, controladas e coligadas no exterior são imediatamente imputados às empresas brasileiras (e, portanto, sujeitos à tributação no Brasil)",1597.

Ainda que algumas modificações na sistemática de tributação dos lucros empresariais sejam condenáveis pela literatura tributária brasileira e, em alguns aspectos, a velocidade desses progressos deixem a desejar, não se pode negar que o direito tributário brasileiro positivo tem guardado maior coerência com a tendência mundial, impulsionando a elaboração de novos estudos sobre a problemática em meados da década de noventa,

renegociação do Acordo com Portugal (2000). SCHOUERI, Luís Eduardo. Contribuição à História dos Acordos de Bitributação: a Experiência Brasileira. Op.cit., p.277.

${ }^{1595}$ Não é o caso de aprofundar as reflexões sobre o princípio da territorialidade, embora se reconheça que a territorialidade relaciona-se ao aspecto espacial do fato gerador do tributo, guardando conexão com a soberania fiscal do Estado. Em outras palavras, segundo a territorialidade o Estado pode tributar fatos que possuem elemento de conexão em seu território. Sobre os desdobramentos (ou acepções) do princípio da territorialidade, recomenda-se a leitura de: SCHOUERI, Luís Eduardo. Princípios no direito tributário internacional: territorialidade, fonte e universalidade. In FERRAZ, Roberto (Coord.). Princípios e limites da tributação. Volume 2. Op.cit., p. 326 e seguintes.

${ }^{1596}$ O princípio da universalidade possibilita, na lição de Schoueri, o alcance da norma tributária a situações que ultrapassem o território nacional do Estado. Para o autor, na realidade, com o parágrafo $4^{\mathrm{a}}$, do art. $3^{\mathrm{a}}$ da Lei n. 7713/1988, o princípio já havia sido adotado na legislação do imposto de renda de pessoas físicas, antecipando-se à posterior LC n. 104/2001, que acrescentou dois parágrafos ao art.43 do CTN, versando sobre a universalidade, notadamente no parágrafo $2^{\mathrm{a}}$. Sobre os desdobramentos (inclusive históricos no Brasil) do princípio, conferir: SCHOUERI, Luís Eduardo. Princípios no direito tributário internacional: territorialidade, fonte e universalidade. Op.cit., p. 354 e seguintes.

${ }^{1597}$ SCHOUERI, Luís Eduardo. Contribuição à História dos Acordos de Bitributação: a Experiência Brasileira. Op.cit., p. 279 e seguintes. 
como é o caso, no período, dos primeiros trabalhos de Luís Eduardo Schoueri ${ }^{1598}$ e Heleno Taveira Tôrres ${ }^{1599}$.

Assim, a partir da década de noventa, estudos estrangeiros na área passam a ser repercutidos em estudos brasileiros, como é o caso dos clássicos Klaus Vogel ${ }^{1600}$, Ottmar Bühler ${ }^{1601}$ e Philip Baker ${ }^{1602}$ e, consequentemente, os temas tributários internacionais passam a receber maior influxo na literatura tributária brasileira, a exemplo do treaty shopping; do planejamento tributário internacional; do tratamento dos preços de transferência $^{1603}$, dos estudos de bitributação (pluri ou dupla tributação) e da evasão fiscal internacional; do tratamento dos paraísos fiscais; da transparência fiscal internacional ${ }^{1604}$; do estabelecimento permanente ${ }^{1605}$, além de diversos outros vinculados à experiência internacional $^{1606}$, como é o caso dos artigos constantes nas Convenções Modelos para evitar a dupla tributação e a evasão fiscal internacional ${ }^{1607}$. A hierarquia do direito tributário internacional frente ao direito interno (art.98 $\mathrm{CTN}^{1608}{ }_{-}^{1609}$ e art. $5^{\mathrm{a}}, \S 2^{\mathrm{a}}$, $\mathrm{CF} / 88)^{1610}$, também é constantemente invocada, especialmente sob a perspectiva do

${ }^{1598}$ SCHOUERI, Luís Eduardo. Planejamento Fiscal através de Acordos de Bitributação: Treaty Shopping. Op.cit., p. 19-20.

${ }^{1599}$ TÔRRES, Heleno Taveira. Pluritributação Internacional sobre as Rendas de Empresas. 1 ed. São Paulo: RT 1995, p. 25 e seguintes; TÔRRES, Heleno Taveira. Direto Tributário Internacional. Planejamento Tributário e Operações Transnacionais. São Paulo: RT, 2001, p.16 e seguintes.

${ }^{1600}$ VOGEL, Klaus. On Double Taxation Conventions. A commentary to the OECD,UN and US Model Conventions for the Avoidance of Double Taxation on Income and Capital With Particular Reference to German Treaty Practice. Third Edition. 1997, p. 280.

${ }^{1601}$ BÜHLER, Ottmar. Principios de Derecho Internacional Tributario. Versión Castellana de Fernando Cervera Torrejon. Madrid: Editorial de Derecho Financiero, 1968, p.232-233.

${ }^{1602}$ BAKER, Philip. Double Taxation Conventions. A Manual on the OECD Model Tax Convention on Income and On Capital. Q.C. of ]gray' Inn, Barrister., Visiting Professional Fellow, Queen Mary, University of London. London: Sweet \& Maxwell; Thomson Reuters, 2012, p. 5-2.

${ }^{1603}$ BARRETO, Paulo Ayres. Imposto de renda e preços de transferência. São Paulo: Dialética, 2001, p. 61 e seguintes.

${ }^{1604}$ BIANCO, João Francisco. Transparência Fiscal Internacional. São Paulo: Dialética, 2007, p. 15 e seguintes.

${ }^{1605}$ SILVEIRA, Paulo Caliendo V da. Estabelecimentos permanentes em direito tributário internacional. Rt: São Paulo, Revista dos Tribunais, 2005, p. 12 e seguintes.

${ }^{1606}$ RAAD, Kees van. Cinco regras fundamentais para a aplicação de tratados para evitar a dupla tributação. Revista de direito tributário internacional. n.1. São Paulo: Quartier Latin, outubro de 2005, p.195-207.

${ }^{1607}$ TÔRRES, Heleno Taveira. Convenções Internacionais em Matéria Tributária sobre a Renda e o Capital - a Abrangência de Tributos Incidentes sobre as Empresas. Grandes Questões Atuais de Direito Tributário. Coordenador: Valdir de Oliveira Rocha. Volume 1. São Paulo: Editora Dialética, 1997, p. 65.

${ }^{1608}$ Sobre o assunto: CANTO, Gilberto de Ulhôa. Legislação Tributária, sua Vigência, sua Eficácia, sua Aplicação, Interpretação e Integração, RF, v. 267, p. 27.

${ }^{1609}$ COELHO, Sacha Calmon Navarro. Tratados Internacionais em Matéria Tributária (perante a Constituição Federal de 1988), Revista de Direito Tributário - 59, Ed. Malheiros, São Paulo, p.180-194.

${ }^{1610}$ XAVIER, Alberto. Direito Tributário Internacional do Brasil. Tributação das Operações Internacionais. Op.cit., p. 122. Também: XAVIER, Alberto. Tratados e Superioridade Hierárquica em relação à Lei face à Constituição Federal de 1988. Revista de Direito Tributário - 66, p. 33. ROCHA, 
chamado "treaty override" (não observância unilateral do teor de acordo internacional tributário em vigor por determinado país por legislação interna posterior) ${ }^{1611}$, ou mesmo das "isenções heterônomas"1612.

Essa renovação doutrinária segue impulsionada nos primeiros anos do século XXI, seja pela elaboração de diversos artigos e livros sobre a matéria, seja pela organização de periódicos e coletâneas de estudos dedicados a difundi-la. ${ }^{1613}{ }_{-}^{1614}{ }_{-} 1615$

Portanto, o panorama tributário voltado à internacionalização guarda cada vez maior harmonia com a prática tributária internacional, e é reflexo da própria globalização, conforme expõe Schoueri: “(...) nos últimos anos as mudanças na economia global - e, especialmente, quanto à importância de empresas brasileiras no cenário internacional - é refletida na nova política de negociação do País. De fato, algumas empresas brasileiras são agora global players e, embora não seja correto incluir o Brasil entre os exportadores de capital, é notório o aumento substancial no número dessas empresas”"1616_ ${ }^{1617}$.

Ainda que o número de Convenções Internacionais fixadas pelo Brasil não seja considerado elevado em comparação a outros países, não há dúvida que a tributação

Sérgio André. Treaty Override no Ordenamento Jurídico Brasileiro. São Paulo: Quartier Latin, 2007, p.25-54.

${ }^{1611}$ SCHOUERI, Luís Eduardo. Prefácio. In: ROCHA, Sérgio André. Treaty Override no Ordenamento Jurídico Brasileiro. São Paulo: Quartier Latin, 2007, p.12.

1612 BORGES, José Souto Maior. Isenções em Tratados Internacionais de Impostos dos Estadosmembros e Municípios. In: MELLO, Celso Antônio Bandeira de (Org). Direito Tributário. Estudos em homenagem a Geraldo Ataliba, São Paulo: Malheiros, 1997, p. 166-78. ROTHMANN, Gerd Willi. Inconstitucionalidade Múltipla na Tributação da Importação de Serviços - Requiém ou catarse do sistema tributário nacional? Op.cit., p. 54.

${ }^{1613}$ TORRES, Heleno Taveira (Coord.). Direito Tributário Internacional Aplicado. Volume 01. São Paulo: Quartier Latin, 2003.

${ }^{1614}$ Embora a temática internacional não seja objeto exclusivo de publicação na Revista Direito Tributário Atual, não se pode deixar de reconhecer nela importante espaço para a publicação de estudos brasileiros e estrangeiros sobre o tema. Instituto Brasileiro de Direito Tributário. Revista Direito Tributário Atual. Número 32. ZILVETI, Fernando (Coord.) São Paulo: Dialética, 2014.

${ }^{1615}$ FILHO, Clóvis Panzarini; TONANINI, Fernando Revista de Direito Tributário Internacional vol.16. São Paulo: Quartier Latin, 2005; Revista Internacional de Direito Econômico e Tributário. Universidade Católica de Brasília. Vol.1, (publicação eletrônica), 2006.

${ }^{1616}$ SCHOUERI, Luís Eduardo. Contribuição à História dos Acordos de Bitributação: a Experiência Brasileira, p. 277.

${ }^{1617}$ Tal mudança de estratégia política nos acordos de bitributação favoreceram, a partir de 2002, novos acordos de bitributação e, mais precisamente, com países que não são “(...) nem investidores tradicionais no Brasil nem têm um relacionamento regional”, a exemplo de Ucrânia (2002), Israel (2002), México (2003), África do Sul (2003), Rússia (2004), Venezuela (2005), Peru (2006). Ressalte-se, contudo, que, nos acordos posteriores ao ano de 2002 não houve a manutenção de cláusulas de "tax sparing" ou "matching credit", pois conforme relata Schoueri, os negociadores agora passariam a reconhecer que os investimentos não se dariam em sentido único (da Venezuela para o Brasil, por exemplo), mas poderia simbolizar nova percepção acerca do papel da empresa brasileira que aumentou sua participação na economia mundial. Idem, p. 279 e seguintes. 
internacional, especialmente em ambiente globalizado caracterizado pelas facilidades tecnológicas (e, naturalmente, da internet) contemporâneas favorece o desenvolvimento do Direito Tributário Internacional. Não é surpresa, portanto, que a doutrina tributária brasileira, já no século XXI, intensifique atenção a esse tema ${ }^{1618}$.

\subsection{O processo disciplinar do Direito Tributário Brasileiro contemporâneo e o progressivo desenvolvimento tecnológico (tecnologia e internet)}

O terceiro desdobramento da globalização nos estudos tributários brasileiros vincula-se ao rápido desenvolvimento tecnológico e, sobretudo, às facilidades de comunicação virtual (internet). Esse desdobramento, embora já manifestado com força nas últimas décadas do século XX (mas, sobretudo, na década de 90), ocasiona profundas transformações na relação tributária, agora cada vez mais dependente dos progressos tecnológicos obtidos através do uso da internet.

O Poder Tributário, juridicamente constituído, recebe novo aliado para facilitar a fiscalização, cobrança e arrecadação de tributos. Por outro lado, o contribuinte recebe

\footnotetext{
${ }^{1618}$ Por fim, adicionalmente, também se menciona a produção literária do Direito Tributário brasileiro a propósito do processo de integração regional latino-americana. A primeira obra sobre o tema foi escrita por Henry Tilbery, em 1971 (TILBERY, Henry. Tributação e Integração da América Latina. São Paulo: Editor José Bushantsky, 1971). Porém, deve-se reconhecer que, de lá para cá, hodiernamente, o processo capitaneado pelo Mercosul está paralisado, ainda que busque, no exemplo histórico de sucesso da União Europeia, a construção de estudos comparativos, a exemplo do Programa Conjunto de Tributação (da Associação Latino-americana de Livre Comércio), e, no âmbito do Mercosul, do "Relatório sobre a Harmonização dos impostos gerais sobre o consumo no Mercosul" (1993), este último buscando verificar as possibilidades da criação de um imposto sobre o valor agregado comunitário apto a impulsionar o Mercosul. Com repentino impulso na década de noventa, graças às perspectivas de reforma tributária da tributação no consumo na realidade brasileira, a literatura começa refletir melhor o assunto, mas, infelizmente, em face da instabilidade das políticas tributárias integrativas no Mercosul, o tema segue tendo menor atenção que outras temáticas internacionais na realidade brasileira. Sobre o assunto: COMISSÃO DE ASPECTOS TRIBUTÁRIOS. Informe sobre la Armonización de los Impuestos Generales al Consumo en el MERCOSUR. Anexo. In: AMARAL, Antonio Carlos Rodrigues do. Imposto sobre o Valor Agregado - IVA - Value Added Tax - VAT. Brasil - Mercosul - União Europeia. São Paulo: Academia Brasileira de Direito Tributário; Editora Rumo, 1995, p. 217 e seguintes. AMARAL, Antonio Carlos Rodrigues. Imposto sobre o Valor Agregado - IVA - Value Added Tax - VAT. Brasil - Mercosul - União Européia. Op.cit., p. 29. BALTHAZAR, Ubaldo César. Reforma Tributária e Mercosul. Belo Horizonte-MG: Editora Del Rey, 1999, p. 12 e seguintes. MARTINS, Ives Gandra da Silva. Tributação no Mercosul. Pesquisas Tributárias. Nova Série - 3. Centro de Extensão Universitária. Editora RT, São Paulo - SP, 1997, p. 34 e seguintes. FERNANDES, Edison Carlos. Sistema Tributário do Mercosul: o processo de harmonização das legislações tributárias. $2^{\circ}$ edição, São Paulo: Editora RT, 2001, p. 25 e seguintes FILHO, Osvaldo Othon de Pontes Saraiva, VASQUES, Sérgio, GUIMARÃES, Vasco Branco (Org.). IVA para o Brasil. Contributos para a Reforma da Tributação sobre o Consumo. Belo Horizonte - MG: Fórum, 2007, 15 e seguintes.
} 
facilidades para o pagamento, acesso à informações de seu interesse, e maior transparência (e controle) de informações tributárias oferecidas pelo poder público.

A internet capitaneia as conquistas tecnológicas aproximando países, fronteiras e pessoas, contribuindo diretamente para a ampliação da circulação de informações, das mais variadas naturezas, proporcionando livre acesso a essas, geradas e transmitidas com a velocidade do pensamento. Por outro lado, a ampla gama de informações também gera efeitos indiscutíveis nas relações econômicas, favorecendo a aproximação dos negócios internacionais, mas também interligando com maior intensidade as conquistas e fracassos da economia internacional.

A influência do desenvolvimento tecnológico não escapa ao Direito Tributário e, conforme assevera Victor Uckmar, vem “(...) redefinindo, em particular, as relações entre fisco e contribuinte não só na modalidade mas também nos conteúdos através dos quais a relação se desenvolve". ${ }^{1619}$

O Comércio Eletrônico espalha-se pelos Estados Unidos e Europa, passando a inaugurar novas reflexões sobre institutos e conceitos tradicionais ao Direito Tributário e ao próprio Direito Tributário Internacional (como é o caso da "definição" de estabelecimento permanente, tradicionalmente prevista no artigo $5^{\mathrm{a}}$ das Convenções Modelos, e que, diante do fenômeno mundial do e-commerce, começa a ser repensado) ${ }^{1620}$, implicando em novos dimensionamentos relacionados à tributação ${ }^{1621}$.

Evidentemente que tal contexto de grandes modificações, especialmente consolidadas entre a última década do século XX e o início do século XXI, impulsiona a realização de novos estudos tributários no Brasil, especialmente refletidos por importantes obras coletivas destinadas a esclarecer assunto ainda novo (e de grandes repercussões) para a doutrina tributária brasileira. Nesse sentido, recorde-se que Marco Aurélio Greco e Ives Gandra da Silva Martins organizaram coletânea destinada à divulgação do tema,

1619 UCKMAR, Victor. Tributação e Tecnologia. In: Tributação e Tecnologia. James Marins (Coord.) Coleção Tributação e Debate. Curitiba: Juruá, 2002, p. 12.

${ }^{1620}$ Sobre o assunto, conferir: HOFFART, Benjamin, Permanent Establishment in the Digital Age: Improving and Stimulating Debate Through an Access to Markets Proxy Approach, 6 Nw. J. Tech. \& Intell. Prop. 106 (2007), http://scholarlycommons.law.northwestern.edu/njtip/vol6/iss1/6; HOLMES, Kevin. International Tax Policy and Double Tax Treaties. An Introduction to Principles and Application. IBFD. SKAAR, Arvid A. Permanent Establishment. Erosion of Tax Principle. Series on International Taxation. Kluwer Law and International Publishers: Deventer - Boston, 1991, p. 09 e seguintes.

${ }^{1621}$ UCKMAR, Victor. Tributação e Tecnologia. Op.cit., p. 13 e seguintes. 
especialmente voltada à análise do comércio eletrônico, bem como suas implicações no direito tributário brasileiro. ${ }^{1622}$ James Marins, seguindo a mesma tendência, organizou estudo coletivo dedicado à investigação das relações entre tecnologia e tributação. No mesmo passo, outros estudos individuais passam a se consolidar, a exemplo dos trabalhos de Marco Aurélio Greco ${ }^{1623}$ e Júlio Maria de Oliveira ${ }^{1624}$.

No Brasil, hodiernamente, destacam-se estudos relacionados à incidência de ICMS sobre provedores de acesso à internet (sob eventual risco de o fisco equipará-lo ao chamado "serviço de comunicação", e, portanto, tributável pelo ICMS), ou sob a interpretação de que o serviço de provedores de internet deveria ser enquadrado no serviço não comunicacional. ${ }^{1625}{ }^{1626}$ Nesse contexto, é natural que o comércio eletrônico passe rapidamente a ganhar atenção de estudiosos brasileiros, especialmente sobre os termos em que se dará a tributação do consumo (no destino ou na origem) ${ }^{1627}$.

Evidentemente que a tecnologia também oferece novas perspectivas para a elisão e a evasão fiscal. Não é por outro motivo que cada vez mais o Fisco passa a depender de elementos tecnológicos, submetendo-os também ao contribuinte. A fiscalização, cada vez mais amparada nesses elementos, intensifica e eleva a eficiência fiscalizadora a níveis antes desconhecidos ${ }^{1628}{ }_{-}{ }^{1629}$.

A própria construção de tributos passa a ser considerada à luz desses novos fatores,

1622 GRECO, Marco Aurélio; MARTINS, Ives Gandra da Silva (Org). Direito e Internet: Relações Jurídicas na Sociedade Informatizada. São Paulo: Rt, 2001, p. 12 e seguintes.

${ }_{1623}$ GRECO, Marco Aurélio. Internet e Direito. 2 Ed. São Paulo: Dialética, 2000, p. 35 a 56.

1624 OLIVEIRA, Júlio Maria de. Internet e Competência Tributária. São Paulo: Dialética, 2000, p. 17 a 72.

1625 CARVALHO, Paulo de Barros. Não Incidência do ICMS na atividade dos provedores de acesso à internet. In: Tributação e Tecnologia. James Marins (Coord.) Coleção Tributação e Debate. Curitiba: Juruá, 2002, p. 53 e seguintes; CELLA, José Renato Gaziero. Tributação dos Provedores de Acesso à Internet. In Tributação e Tecnologia. Op.cit., p. 67 e seguintes.

${ }^{1626}$ OLIVEIRA, Júlio Maria de. Internet e Competência Tributária. São Paulo: Dialética, 2000, p. 145151.

${ }^{1627}$ ISQUIERDO, Renato Scalco. Tecnologia e Direito: A Tributação do Comércio Eletrônico na Internet. In: Tributação e Tecnologia. Op.cit., p. 85 e seguintes.

${ }^{1628}$ Exemplos dessas medidas podem ser observados na realidade tributária brasileira contemporânea, como a nota fiscal eletrônica (NF-e), assim como o SPED (Sistema Público de Escrituração Digital). MARINS, James. Defesa e Vulnerabilidade do Contribuinte. São Paulo: Dialética, 2009, 41-44.

${ }^{1629}$ Percebendo a necessidade e a conveniência estratégica que a tecnologia e a internet fornecem à fiscalização, o Estado impulsiona a aquisição de supercomputadores que chegam a ser dotados de programas de "inteligência artificial" (a exemplo do Programa Harpia, que foi construído em parceria com a Unicamp e o ITA - Instituto Tecnológico da Aeronáutica). Sobre o "Supercomputador" da Receita Federal, veja-se notícia publicada na Folha de São Paulo sobre o "T-Rex", com o título "Supercomputador da Receita vai caçar sonegador”, publicado em 2005. Folha de São Paulo, Por Fátima Fernandes, Claudia Rolli, 16 de outubro de 2005. Sobre o assunto, também: MARINS, James. Defesa e Vulnerabilidade do Contribuinte. Op.cit., p. 41-44. 
como foi o caso da CPMF, que viabilizaria pleno controle da movimentação financeira dos contribuintes, em processo que liga os sistemas de informática do Fisco e de instituições financeiras. Assim, a troca de informações mediante as recentes conquistas tecnológicas é elemento essencial para a eficiência da fiscalização, cobrança e arrecadação de tributos ${ }^{1630}$.

Ao mesmo tempo, é imperioso que estudos tributários busquem compreender adequadamente essa nova realidade, no intuito de "equilibrar a balança" (na medida do possível entre fisco e contribuinte), sempre resguardando os direitos fundamentais do contribuinte.

Naturalmente, ao lado das facilidades da tecnologia recente, não há dúvida de que o elevado poder trazido pela revolução tecnológica também gera aberturas para novas formas de abusos no exercício do poder tributário, assim como a novas formas de evasão tributária. De outro lado, a doutrina começa a demonstrar preocupação com a problemática, especialmente no que tange ao poder trazido pela tecnologia (e internet) atribuído ao Estado, na fiscalização, cobrança e arrecadação ${ }^{1631}$.

Assim, a ampliação do potencial tecnológico viabilizado pela internet gera indiscutíveis questões sobre os limites aplicáveis ao Poder Público no exercício do Poder Tributário, ainda não suficientemente regulados, por dois motivos: a) a uma, pois o fenômeno e sua amplitude apresentam-se recentes; b) a duas, pois mesmo o exercício e os limites legais e éticos da internet apresentam-se ainda em fase de regulação, mas ainda não adequadamente definidos ou compreendidos ${ }^{1632}$. Se no próprio campo da legalização e

${ }^{1630}$ ABRÃO, Carlos Henrique. Cobrança Compulsória da CPMF, In: Revista Tributária e de Finanças Públicas, ano 9, n.37, Editora Rt, São Paulo, março-abril de 2001, p. 79 e seguintes.

${ }^{1631}$ James Marins, nesse sentido, fala em "vulnerabilidade tecnológica" do contribuinte, em que o fisco eleva sua capacidade de controle das atividades do contribuinte a níveis inimagináveis. Por isso, pugnou pela fragilidade do "falso axioma da debilidade fazendária", nas relações com o contribuinte, submetendo-o ao “(...) respeito às garantias constitucionais e sobretudo à própria tutela jurisdicional, imprescindível para o desenvolvimento da relação jurídico-tributária, em todos os seus aspectos - material, formal, processual - e, assim, favorecendo o equilíbrio entre as partes que compõem a naturalmente delicada relação jurídicotributária". Não é por outro motivo que a penhora online, introduzida pela LC 118/2005, autorizando o juiz à indisponibilidade automática do contribuinte em execução fiscal, caso não apresente bens à penhora ou não seja encontrado para citação, enseja preocupação da literatura especializada, devendo ser considerada como medida extrema, e, naturalmente, à luz dos direitos fundamentais. MARINS, James. Defesa e Vulnerabilidade do contribuinte. Op.cit., p. 41-44.

${ }^{1632}$ Exemplo paradigmático pode ser identificado na Lei $\mathrm{n}^{\circ} 12.965$, de 23 de abril de 2014, que regula o chamado "Marco Civil da Internet", e basicamente disciplina os princípios, garantias, direitos e deveres do uso da internet no Brasil, apresentando os seguintes princípios (art. $3^{\mathrm{a}}$ ): "I - garantia da liberdade de expressão, comunicação e manifestação de pensamento, nos termos da Constituição Federal; II - proteção da privacidade; III - proteção dos dados pessoais, na forma da lei; IV - preservação e garantia da neutralidade de rede; V - preservação da estabilidade, segurança e funcionalidade da rede, por meio de medidas técnicas 
regulação do fenômeno da internet essa se reconhece como fenômeno em amadurecimento e rápida expansão, o mesmo pode-se dizer de seus reflexos no campo da tributação.

Exemplo paradigmático dessa dificuldade (mas que mostra o descompasso do STF frente às transformações da realidade tecnológica no ambiente tributário) refere-se à interpretação do dispositivo da alínea "d" do inciso VI do art. 150, que consagra a imunidade dos livros, jornais e periódicos e o papel destinado à sua impressão. A dúvida recaiu se os livros eletrônicos (e-books) estariam abarcados pela imunidade. O tema chegou a receber repercussão geral no STF (RE 330817), recebendo duas distintas interpretações: a) restritiva: baseada na interpretação literal do dispositivo, restringindo a imunidade ao material (físico) destinado à impressão dos livros, jornais e periódicos (e, portanto, e-books não seriam abarcados pela imunidade); b) extensiva: que considera que a imunidade visa proteger veículos transmissores de cultura, e, portanto, não se limitaria apenas a materiais "impressos", abarcando também, por extensão, os e-books.

Embora sejam identificáveis decisões favoráveis à extensão da imunidade (AMS 200061040052814, Juíza Consuelo Yoshida, TRF3 - Sexta Turma, 03/11/2008, que concedeu a imunidade, a partir de uma interpretação "evolutiva" do dispositivo), o STF manifestou entendimento também fundamentado pela interpretação da Súmula 657: “A imunidade prevista no artigo 150, VI, “d”, da CF abrange os filmes e papéis fotográficos necessários à publicação de jornais e periódicos"), reforçando a não extensão da imunidade aos e-books, por considerá-lo software (ou "programa"), e não livro "impresso".

Sem dúvida, o próprio Poder Judiciário deve adaptar-se paulatinamente aos novos desafios proporcionados pela internet, tecnologia e tributação, se quiser dar respostas eficazes e harmônicas com o rápido amadurecimento tecnológico que recai sobre a sociedade contemporânea (e respectivas relações econômicas). Assim, a revolução tecnológica proporcionada pela internet favorece novas perspectivas aos estudos tributários, apresentando elementos outrora ignorados e até desconhecidos aos olhos dos

compatíveis com os padrões internacionais e pelo estímulo ao uso de boas práticas; VI - responsabilização dos agentes de acordo com suas atividades, nos termos da lei; VII - preservação da natureza participativa da rede; VIII - liberdade dos modelos de negócios promovidos na internet, desde que não conflitem com os demais princípios estabelecidos nesta Lei”. 
$\operatorname{tributaristas}^{1633}$.

Aos poucos, começa-se a vislumbrar a perspectiva de que a relação tributária ganhe nova dimensão, antes facilmente observada sob a perspectiva jurídica ou econômica, e agora adicionalmente observável pela perspectiva tecnológica (informática). Ambos os sujeitos da relação tributária devem aceitar e se adaptar aos efeitos (éticos, inclusive) da revolução tecnológica na tributação.

\subsection{0 processo disciplinar do Direito Tributário Brasileiro contemporâneo e o "Direito Contábil" (reflexos da "nova contabilidade").}

Intensa relação possui o Direito Tributário com a Ciência Contábil. Esta tem sido compreendida como o ramo do conhecimento que estuda o patrimônio de determinada entidade, verificando e registrando eventuais variações nele sofridas, apurando resultados e prestando informações a usuários da informação contábil. ${ }^{1634} 1635$

Naturalmente, a Contabilidade sempre manteve inequívoca vinculação ao Direito Comercial e ao Direito Tributário. Os "guarda-livros" (contabilistas), como eram popularmente chamados, especialmente no período pré-disciplinar do Direito Tributário Brasileiro, sempre apresentaram importantes contribuições ao estudo do Direito Tributário, cujos reflexos foram intensificados pela ausência da consolidação disciplinar do Direito Tributário no Brasil ${ }^{1636}$.

\footnotetext{
${ }^{1633}$ Note-se que, em 2013, com a Emenda Constituição n.75/2013 incluiu-se no artigo 150, inc.III, e), a seguinte proibição aos entes políticos de tributar (imunidade): "e) fonogramas e videofonogramas musicais produzidos no Brasil contendo obras musicais ou literomusicais de autores brasileiros e/ou obras em geral interpretadas por artistas brasileiros bem como os suportes materiais ou arquivos digitais que os contenham, salvo na etapa de replicação industrial de mídias ópticas de leitura a laser". Logo, a própria realidade constitucional tributária reforça os sinais relativos ao reconhecimento e proteção de arquivos digitais, não se limitando à proteção do "material físico".

${ }^{1634}$ Equipe de Professores da FEA-USP. Contabilidade Introdutória. São Paulo: Editora Atlas, 2000, p. 02 e seguintes.

${ }^{1635}$ SCHMIDT, Paulo; SANTOS, José Luiz dos. História do Pensamento Contábil. São Paulo: Atlas, 2008, p. 148 e seguintes.

${ }^{1636}$ Nomes como Paul Hugon, Francisco D’Auria, De Plácido e Silva, figuraram entre os Professores de Ciências Contábeis que lançavam aportes sobre o na época famigerado "Direito Fiscal". HUGON, Paul. Op.cit., p. 05 e seguintes. D'AURIA, Francisco. Ciência das Finanças (Teoria e Prática). $2^{\circ}$ Edição. São Paulo: Companhia Editora Nacional, 1946, p.16-17. DE PLÁCIDO E SILVA. Op.cit., p. 151-153.
} 
Existia inclusive certa visão geral de que o próprio Direito Fiscal era matéria de "guarda-livros", e não dos juristas, o que de certa forma fortalecia o afastamento de estudos jurídicos sob a perspectiva da tributação. Especialmente nos estudos de Direito Comercial e de Direito Tributário, a Contabilidade exercia enorme importância, influenciando severamente esses dois campos do Direito.

A partir da década de quarenta, com a maior impulsão aos estudos propriamente jurídicos ao Direito Tributário, os tributaristas, ou pelo menos parte deles, mantiveram-se distanciados das contribuições trazidas por esse campo do conhecimento.

Mas deve-se reconhecer, hodiernamente, que as relações entre a Contabilidade e o Direito Tributário nunca se conservaram verdadeiramente afastadas, especialmente entre estudiosos dos tributos incidentes sobre pessoas jurídicas (cujas noções contábeis são essenciais), como é o caso do Imposto de Renda (IRPJ). Seus estudiosos nunca ignoraram a importância e a utilidade de o jurista entender (ainda que basicamente) os processos contábeis.

Essa visão é facilmente observada em estudiosos do porte de Bulhões Pedreira ${ }^{1637}$, Tullio Ascarelli, Rubens Gomes de Sousa ${ }^{1638}{ }_{-}{ }^{1639}$, Hércules Boucher ${ }^{1640}$, Walter Barbosa Corrêa ${ }^{1641}$, Henry Tilbery ${ }^{1642}$, Alcides Jorge Costa $^{1643}$, Brandão Machado ${ }^{1644}$, Ricardo

${ }^{1637}$ BULHÕES PEDREIRA, José Luiz. Imposto de Renda. Rio de Janeiro: Apec Editora, 1969, p. 02-06.

${ }^{1638}$ ASCARELLI, Tulio; SOUSA, Rubens Gomes de; João Batista Pereira de Almeida Filho. Op.cit., p. 104105.

${ }^{1639}$ SOUSA, Rubens Gomes de. Pareceres - 1 - Imposto de Renda. Edição Póstuma. Coord. IBET. São Paulo: Resenha Tributária, 1975, p.66-67. SOUSA, Rubens Gomes de. Imposto de Renda. Suplemento à $2^{\text {a }}$ Ed. do Compêndio de legislação tributária. Rio de Janeiro: Edições Financeira, S.A.,1955, p. 12 e seguintes. SOUSA, Rubens Gomes de. Estudos de Direito Tributário. Op.cit., p. 117 e seguintes.

${ }^{1640}$ BOUCHER, Hércules. Imposto sobre a Renda e Lucros Imobiliários. São Paulo: Freitas Bastos, 1953, p. $158-159$.

${ }^{1641}$ CORRÊA, Walter Barbosa. Subsídios para a o estudo da História Legislativa do Imposto de Renda no Brasil. In: Estudos sobre o Imposto de Renda (em memória de Henry Tilbery). MARTINS, Ives Gandra da Silva. (Coord) São Paulo: Resenha Tributária, 1994, p. 249 e seguintes.

1642 TILBERY, Henry. A tributação dos Ganhos de Capital. São Paulo: Co-Edição - IBDT - Resenha Tributária, 1977, p.19 e seguintes. TILBERY, Henry. A Tributação dos Ganhos de Capital das Pessoas Jurídicas. Comentário ao Decreto-lei n.1598/77. São Paulo: Co-Edição - IBDT - Resenha Tributária, 1978, p.33-34.

${ }^{1643}$ COSTA, Alcides Jorge. Conceito de Renda Tributável. In: Estudos sobre o Imposto de Renda (Em memória de Henry Tilbery). Ives Gandra Martins (Coord). São Paulo: Resenha Tributária, 1994, p. 20-21.

${ }^{1644}$ MACHADO, Brandão. Imposto de Renda. Ganhos de Capital. Promessa de Venda de Ações. Decreto-lei n.1510 de 1976. In: Direito Tributário Atual. Vol. 11/12. São Paulo: Co-edição: IBDT Resenha Tributária, 1992, p. 3188 e seguintes. MACHADO, Brandão. Breve Exame Crítico do art.43 do CTN. In: Estudos sobre o Imposto de Renda. Em memória de Henry Tilbery. Ives Gandra da Silva Martins (Org.). São Paulo: Resenha Tributária, 1994, p. 123 e seguintes. 
Mariz de Oliveira ${ }^{1645}$, Hiromi Higuchi e Marco Aurélio Greco ${ }^{1646}$, em período onde rapidamente (especialmente a partir da década de setenta) emergiu esforço dedicado à progressiva separação dos estudos jurídico-tributários perante outros ramos do conhecimento, ou seja, tendente à exclusiva juridicidade do conceito de renda, conforme é possível observar nos relevantes contributos de Gilberto Ulhôa Canto, Roque Antônio Carrazza e Roberto Quiroga Mosquera ${ }^{1647}$, caminhando inclusive pela aplicação estrutural da Teoria da Regra-Matriz de Incidência Tributária ao citado tributo, como pode-se observar em Paulo de Barros Carvalho, Mary Elbe Queiroz ${ }^{1648}$, e Paulo Ayres Barreto ${ }^{1649}$, por exemplo $^{1650}$.

Mas a natural tendência disciplinar no trato prevalecentemente jurídico do Direito Tributário não afasta a conveniência e oportunidade do diálogo necessário entre Contabilidade, Economia e Direito Tributário, que ganha novo capítulo, já no século XXI, quando emerge a chamada "Nova Contabilidade".

A "Nova Contabilidade" foi introduzida pela Lei n.11.638/07, visando harmonizar a legislação contábil nacional com os padrões internacionais (globais), trazendo inovações aos mecanismos de cálculo do lucro contábil e do lucro real. Em verdade, com a Lei n.11.638, a legislação societária teve modificação substancial, reestruturando a anterior contemplação preocupada prioritariamente com a perspectiva privatista do fenômeno empresarial, para alterar a forma de registro e demonstração contábil das sociedades.

Entretanto, as alterações trazidas por essa lei procuraram evitar mudanças substanciais no lucro real, incluindo-se o $§ 7^{\mathrm{a}}$, do art.177 na Lei das Sociedades Anônimas,

1645 OLIVEIRA, Ricardo Mariz de. Fundamentos do Imposto de Renda. São Paulo: Quartier Latin, 2008, p. 385 e seguintes.

${ }^{1646}$ GRECO, Marco Aurélio. Crise do Imposto de Renda na sua feição tradicional. In: Internet e o Direito. Marco Aurélio Greco (Coord.). São Paulo: Dialética, 2000, p. 179 e seguintes.

${ }^{1647}$ MOSQUERA, Roberto Quiroga. Renda e proventos de qualquer natureza: o imposto e o conceito constitucional. São Paulo: Dialética, 1996. p. 71-119.

1648 QUEIROZ, Mary Elbe. Imposto sobre a Renda e Proventos de Qualquer Natureza. São Paulo: Manole, 2002, p. 22 e seguintes.

${ }^{1649}$ BARRETO, Paulo Ayres. Imposto de Renda e Preços de Transferência. São Paulo: Dialética, 2001, p. 65 e seguintes.

1650 CANTO, Gilberto Ulhôa. A Aquisição de Disponibilidade e o Acréscimo Patrimonial no Imposto sobre a Renda". Estudos sobre o Imposto de Renda. (Em Memória de Henry Tilbery). Coord. Ives Gandra da Silva Martins. São Paulo: Resenha Tributária, 1994, p. 33 e seguintes. CARRAZZA, Roque Antonio. Imposto sobre a Renda (Perfil Constitucional e Temas Específicos). S.Paulo: Malheiros. 2005, p. 34-37. CARVAlHO, Paulo de Barros. O Princípio da Territorialidade no Regime da Tributação da Renda Mundial. In: Justiça Tributária: direitos do fisco e garantias do contribuinte nos atos da administração e no processo tributário. I Congresso Internacional de Direito Tributário. IBET, Vitória, 1998, p.669 e seguintes. 
prevendo genericamente que os lançamentos feitos para harmonizar as normas contábeis do modelo anterior ao atual não teriam efeitos tributários. ${ }^{1651}$

Interessante mencionar que, através dessa nova perspectiva contábil, não foram raros os casos em que se discutiu a possibilidade de que conceitos de Direito Privado poderiam chocar-se com as respectivas apreciações contábeis, a exemplo da própria noção de disponibilidade (jurídica ou econômica?) frente ao art.43 do CTN, ${ }^{1652}$ perspectiva que flerta com as relações interdisciplinares entre o Direito Tributário e a Contabilidade ${ }^{1653}$.

As novas regras contábeis da Lei $\mathrm{n}^{0}$ 11.638, de 2007, que tencionam aferir o acréscimo patrimonial priorizando uma perspectiva econômica, em detrimento de uma perspectiva jurídica (do Direito Privado) tradicional, na opinião de Schoueri, não trairiam o enunciado do art.43 do CTN, mas, pelo contrário, representaria importante utilidade no reconhecimento dos efeitos econômicos reproduzidos na contabilidade, permitindo a determinação do lucro contábil com maior confiança para os investidores e usuários externos, sem causar alterações substanciais na base de cálculo do IR (art.16 Lei n.11.941/2009). ${ }^{1654}{ }_{-}^{1655}$

\footnotetext{
${ }^{1651}$ Posteriormente, esse dispositivo foi substituído pelo Regime Tributário de Transição (RTT), previsto nos artigos 15 a 24 da lei n.11.941/09, no qual deverão ser mantidos, para fins fiscais, os critérios de reconhecimento de receitas, despesas e custos na apuração do lucro líquido do exercício vigentes em 31 de dezembro de 2007 (antes da entrada em vigor da Lei n.11.638/2007), e, portanto, o lucro líquido base para apuração do lucro real continua sendo aquele anterior à lei n.11.638. Visava o legislador evitar que as alterações promovidas pela Lei n.11.638 causassem efeitos fiscais. Nesse contexto, as pessoas jurídicas passaram a ter duas contabilidades paralelas: uma elaborada a partir das regras da Lei n.11.638/07, e outra feita a partir de ajustes sobre a primeira, adaptando-a perante as antigas regras de apuração do lucro líquido vigentes em 31 de dezembro de 2007, sendo sobre essa contabilidade ajustada sobre padrões antigos o ajuste das adições e exclusões do lucro real. Para aquelas empresas optantes do RTT, o lucro real não é o lucro líquido contábil, da forma vigente nos dias de hoje, mas o lucro líquido apurado pelas normas vigentes no período anterior de 31 de dezembro de 2007, ou seja, antes da lei n.11.638.

${ }^{1652}$ SCHOUERI, Luís Eduardo. O mito do lucro real na Passagem da Disponibilidade Jurídica para a Disponibilidade Econômica. In: Controvérsias Jurídico-Contábeis (Aproximações e Distanciamentos). MOSQUERA, Roberto Quiroga; LOPES, Alexsandro Broedel. 1ª Volume. São Paulo: Dialética, 2010, p.250 e seguintes.

${ }^{1653}$ ZILVETI, Fernando Aurelio. O Princípio da Realização da Renda. Direito Tributário: Volume I. Estudos em Homenagem a Alcides Jorge Costa. Coord. Luís Eduardo Schoueri. São Paulo: Quartier Latin, 2003, p. 316 e seguintes.

${ }^{1654}$ SCHOUERI, Luís Eduardo. O mito do lucro real na Passagem da Disponibilidade Jurídica para a Disponibilidade Econômica. Op.cit., p.250 e seguintes.

${ }^{1655}$ O Parecer de Orientação n.37/2011 da Comissão de Valores Mobiliários (CVM) expõe claramente o contexto da mudança de mentalidade trazida pela Nova Contabilidade, esclarecendo a nova concepção de consideração econômica dos fatos. Parecer de Orientação n.37/2011 da CVM.
} 
Evidentemente, a Nova Contabilidade insurgiu a novos questionamentos perante os estudiosos brasileiros, sobretudo quanto aos reflexos dessa nova orientação contábil perante a legislação societária e tributária ${ }^{1656}$.

Além disso, renovou-se a polêmica da consideração econômica dos fatos e sua aplicação ao Direito Tributário ${ }^{1657}$, tema que agora inevitavelmente deve ser avaliado na análise do Direito Tributário e suas relações com a Nova Contabilidade (e com o Direito Contábil). ${ }^{1658}{ }_{-} 1659$

O ambiente favorável à discussão do tema desencadeou também importante coletânea, expressamente dedicada à promoção do diálogo entre o Direito e a Contabilidade (e do Direito Contábil), coordenada por Roberto Quiroga Mosquera e Alexsandro Broedel Lopes ${ }^{1660}$, contando com alguns dos mais destacados estudiosos dedicados aos diálogos entre esses dois ramos do conhecimento.

${ }^{1656}$ Sobre o assunto, conferir: LOPES, Alexsandro Broedel. A Política Contábil e o Novo Ordenamento Contábil Brasileiro das Companhias Abertas. In: Controvérsias Jurídico-Contábeis (Aproximações e Distanciamentos). MOSQUERA, Roberto Quiroga; LOPES, Alexsandro Broedel. 2 ${ }^{\text {a }}$ Volume. São Paulo: Dialética, 2011. p.14 e seguintes.

${ }^{1657}$ Sobre a compatibilidade (ou incompatibilidade) do referido instituto com o Direito Tributário, conferir: BIANCO, João Francisco. Aparência Econômica e Natureza Jurídica. In: Controvérsias JurídicoContábeis (Aproximações e Distanciamentos). 1 ${ }^{a}$ Volume. Op.cit., p.175-184. OLIVEIRA, Ricardo Mariz de. A tributação da Renda e sua Relação com os Princípios Contábeis Geralmente Aceitos. In: Controvérsias Jurídico-Contábeis (Aproximações e Distanciamentos). In: Controvérsias Jurídico-Contábeis (Aproximações e Distanciamentos). $1^{\text {a }}$ Volume. Op.cit., p.401 e seguintes. TAKATA, Marcos Shigueo. A Conexão da Contabilidade com o Direito Tributário: Direito Contábil e Direito Tributário. In: Controvérsias Jurídico-Contábeis (Aproximações e Distanciamentos). $1^{\text {a }}$ Volume. Op.cit., p.290 e seguintes.

${ }^{1658}$ Nesse sentido, há também questionamentos sobre o grau de influência desses novos preceitos nos institutos de Direito Tributário e, naturalmente, eventuais conflitos, problemas, divergências ou mesmo compatibilidades ou conexões na intersecção onde atuam o Direito Tributário e a Nova Contabilidade. É nesse caminho que parece também apontar Ricardo Mariz de Oliveira. OLIVEIRA, Ricardo Mariz de. A tributação da Renda e sua Relação com os Princípios Contábeis Geralmente Aceitos. In: Controvérsias Jurídico-Contábeis (Aproximações e Distanciamentos). $1^{\text {a }}$ Volume. Op.cit., p, 401 e seguintes.

${ }^{1659}$ Sobre as divergências (convergências ou conexões) de interpretação entre o Direito Tributário e a Nova Contabilidade, conferir: BIFANO, Elidie Palma. Contabilidade e Direito: A Nova Relação. In: Controvérsias Jurídico-Contábeis (Aproximações e Distanciamentos). $1^{\text {a }}$ Volume. Op.cit., p.123 e seguintes. Sobre os problemas da inter-relação entre Direito Tributário e Nova Contabilidade, sobretudo no que diz respeito à dependência da tributação sobre a renda e receitas em relação às informações fornecidas pela Nova Contabilidade, conferir: SCHOUERI, Luís Eduardo; TERSI, Vinicius. As Inter-Relações entre a Contabilidade e o Direito: atender ao RTT significa obter a Neutralidade Tributária? In: Controvérsias Jurídico-Contábeis (Aproximações e Distanciamentos). $2^{a}$ Volume. Op.cit., p.113 e seguintes. POLIZELLI, Victor. Balanço Comercial e Balanço Fiscal: Relações entre o Direito Tributário e o Direito Contábil e o Modelo Adotado pelo Brasil In: Revista Direito Tributário Atual n.24. SCHOUERI, Luís Eduardo: ZILVETI, Fernando Aurelio; BONILHA, Paulo Celso Bergstrom (Coord.). São Paulo: Dialética-IBDT, 2010, p. 592 e seguintes. TAKATA, Marcos Shigueo. Op.cit., p.290 e seguintes.

1660 MOSQUERA, Roberto Quiroga; LOPES, Alexsandro Broedel (Coord).Controvérsias JurídicoContábeis (Aproximações e Distanciamentos). $1^{\text {a }}$ Volume. São Paulo: Dialética, 2010. MOSQUERA, Roberto Quiroga; LOPES, Alexsandro Broedel.(Coord). Controvérsias Jurídico-Contábeis (Aproximações 
Naturalmente, assevera-se que a Nova Contabilidade e o RTT não estão ilesos a críticas, chegando-se a questionar a própria efetividade da chamada "neutralidade" trazida no art.16 da Lei n.11.941/09, que criou o RTT, visando salvaguardar o Direito Tributário das influências da Nova Contabilidade.

Sem ignorar os relevantes questionamentos supramencionados, deve-se considerar que buscou o legislador uma forma de neutralizar os efeitos da Nova Contabilidade a fim de evitar aumento de impostos sem observância do princípio constitucional da estrita legalidade, lembrando, contudo, que a Nova Contabilidade tem alcance e objetivos diversos frente à contabilidade fiscal ${ }^{1661}$, que passam agora a ser objeto de análise de estudiosos brasileiros em análises interdisciplinares com o Direito Tributário. ${ }^{1662}{ }_{-}^{1663}{ }^{1664}$

e Distanciamentos). 2 ${ }^{\mathrm{a}}$ Volume. São Paulo: Dialética, 2011. MOSQUERA, Roberto Quiroga; LOPES, Alexsandro Broedel.(Coord). Controvérsias Jurídico-Contábeis (Aproximações e Distanciamentos). $3^{\mathrm{a}}$ Volume. São Paulo: Dialética, 2015.

${ }^{1661}$ SCHOUERI, Luís Eduardo; TERSI, Vinicius. As Inter-Relações entre a Contabilidade e o Direito: atender ao RTT significa obter a Neutralidade Tributária? Op.cit.. p.113 e seguintes. BIANCO, João Francisco. Aparência Econômica e Natureza Jurídica. Op.cit., p.175-184.

${ }^{1662}$ BIANCO, João Francisco. Aparência Econômica e Natureza Jurídica. Op.cit., p.175-184. OLIVEIRA, Ricardo Mariz de. A tributação da Renda e sua Relação com os Princípios Contábeis Geralmente Aceitos. Op.cit., p.401 e seguintes. ROCHA, Sérgio André. As Normas de Convergências Contábeis e seus Reflexos para os Contribuintes. In: Controvérsias Jurídico-Contábeis (Aproximações e Distanciamentos). MOSQUERA, Roberto Quiroga; LOPES, Alexsandro Broedel. 2a Volume. São Paulo: Dialética, 2011. p.283 e seguintes.

${ }^{1663}$ Sobre o assunto, confira-se: SCHOUERI, Luís Eduardo. Juros sobre o Capital Próprio: Natureza Jurídica e forma de apreciação diante da "Nova Contabilidade". Op.cit., p.187 e seguintes. Sobre a relação da Nova Contabilidade, do RTT e a noção de patrimônio para fins tributários, conferir: SCHOUERI, Luís Eduardo. O mito do lucro real na Passagem da Disponibilidade Jurídica para a Disponibilidade Econômica. Op.cit., p. 249 e seguintes; Sobre as noções de balanço contábil e balanço fisscal, conferir também: POLIZELLI, Victor. Balanço Comercial e Balanço Fiscal: Relações entre o Direito Tributário e o Direito Contábil e o Modelo Adotado pelo Brasil. Op.cit., p.589-591. POLIZELLI, Victor Borges. O Princípio da Realização da Renda. Série Doutrina Tributária. Vol.II. Reconhecimento de Receitas e Despesas para Fins do IRPJ. São Paulo: Quartier Latin - IBDT, 2012, p.66-82.

${ }^{1664}$ A Nova Contabilidade traz ainda importantes efeitos para a apuração da noção de patrimônio, que, para Schoueri, restaria prejudicada em seus contornos civis, não fazendo sentido falar em patrimônio apurado segundo a definição dada pelo Direito Civil, já que a universalidade de direitos e obrigações (civis) não constaria mais nos livros contábeis das sociedades. Essa situação decorre da diferenciação entre a noção de balanço contábil e balanço fiscal, que não existiria, face à ausência de previsão legal no Brasil, e suas repercussões para a legislação tributária em face da Nova Contabilidade. Na opinião do autor, os cálculos efetuados no FCONT, já que previstos apenas em normativa infralegal (art. $8^{a}$ da IN 949/2009), e sem amparo legal na Lei 11.941/09, servem de mero suporte para lançamento efetuado no Lalur, mas não configuram de forma alguma verdadeiro balanço fiscal. Sobre o assunto, conferir: SCHOUERI, Luís Eduardo; TERSI, Vinicius. As Inter-Relações entre a Contabilidade e o Direito: atender ao RTT significa obter a Neutralidade Tributária? Op.cit.. p.113 e seguintes. BIANCO, João Francisco. Aparência Econômica e Natureza Jurídica. Op.cit., p.175-184. 


\subsection{O processo disciplinar do Direito Tributário Brasileiro contemporâneo e o acesso à informação: a questão da transparência fiscal.}

A realidade contemporânea favorece novas perspectivas ao acesso à informação e reais consequências à relação tributária, que devem ser ponderadas pelos teóricos do Direito Tributário. Se antes, nos tempos heroicos ${ }^{1665}$ da disciplina, era preciso diariamente adquirir o jornal para verificar os diários oficiais e manter-se atualizado frente às novidades legislativas e jurisprudenciais tributárias, hoje, em pleno século XXI, a informação eletrônica chega imediatamente à análise dos estudiosos, através da internet, que favorece e amplifica em grau inigualável o acesso à informação pelo contribuinte em questões tributárias.

Vive-se, conforme já observado, em verdadeira "sociedade de informação". Os reflexos dessa configuração social, naturalmente, são sentidos e devem ser refletidos pela literatura tributária nacional.

É claro que o acesso à informação é uma via de mão dupla, e favorece também ao Fisco a obtenção de informações sobre o contribuinte. ${ }^{1666}$ Mas o tema do acesso à informação não é novo ${ }^{1667}$, e vincula-se ao que se consignou na teoria financeira como "transparência fiscal", já notoriamente reconhecida pela Economia, sobretudo, devido à sua inclusão nos princípios da tributação expostos por Adam Smith. ${ }^{1668}{ }_{-} 1669$

\footnotetext{
${ }^{1665}$ SOUSA, Rubens Gomes de. Prefácio à Primeira Edição. In: FANUCCHI, Fábio. Op.cit., p. xix.

${ }^{1666}$ GALLO, Franco. Alcune Riflessioni sulla Crisi del Sistema Tributario, In: UCKMAR, Victor. L'Evoluzione dell'Ordinamento Tributario Italiano, Il Diritto Tributario, Atti del Convegno "I Settanta Anni di “Diritto e Pratica Tributaria”, Serie I, Volume LXXXIX. Padova: CEDAM, 2000, p. 03-07.

${ }^{1667}$ Vanoni mostra que as primeiras lides fiscais no Império Romano já manifestavam insatisfação quanto às obscuridades da relação tributária e a sua solução. VANONI, Ezio. Natureza e Interpretação das Leis Tributárias. Op.cit., p. 20 e seguintes. Na realidade, essa noção antiga, etimologicamente, tem sido identificável à ideia de abertura, de cristalinidade, visibilidade em seus extremos. Aduzida aos estudos tributários, poderia indicar, em primeira aproximação, à ideia de relação tributária cristalina, transparente, visível em seus contornos, na relação entre o fisco e o contribuinte, e que tenha por objeto o tributo (em todas as suas etapas).

${ }^{1668}$ SMITH, Adam. Ob.cit., p. 281-282.

${ }^{1669}$ Mas realmente foi com Adam Smith que a ideia se impulsionou, pois pelo menos dois dos postulados regras ou princípios - da tributação do célebre economista político apresentam conexão direta com a transparência fiscal necessária entre súditos e governantes: "II. O imposto que cada indivíduo é obrigado a pagar deve ser fixo e não arbitrário. A data do recolhimento, a forma de recolhimento, a soma a pagar, devem ser claras e evidentes para o contribuinte e para qualquer outra pessoa (...)". "(...) III. Todo imposto deve ser recolhido no momento e da maneira que, com maior probabilidade, forem mais convenientes para o contribuinte". SMITH, Adam. Op.cit., p. 281-284.
} 
A teorização smithiana influenciou importantes contribuições no campo das Finanças Públicas, conforme é possível observar no celebrado estudo de Fritz Neumark, que também incluiu a transparência tributária no rol dos seus princípios da tributação (mais especificamente, no quadro dos princípios jurídico-tributários ou técnico-tributários). ${ }^{1670}$ 1671

É claro que há diferença entre o acesso à informação e à eficiência na interpretação e no uso dessa informação. A plena liberdade de acesso à informações fiscais (legislativas, infralegislativas, jurisprudenciais ou doutrinárias) só serve àquele que tiver capacidade para interpretá-las. As dificuldades que se impõem ao cidadão comum diante da complexidade e do excesso de novidades tributárias (diariamente) manifestam-se também como obstáculos para a compreensão dessas informações.

Desse panorama emerge a técnica de ilusão financeira, tão intensamente aplicada por políticos tributários, e que sempre foi o principal obstáculo ao acesso às informações fiscais (e à transparência fiscal). Mas mesmo essa técnica passa a ser adequada à necessidade de maior transparência fiscal, que não se limita apenas ao pleno acesso das informações, mas à sua intelecção eficiente.

Originalmente, a ilusão financeira foi objeto de análise do financista italiano Amilcare Puviani no século XIX, para quem a ilusão (tomada em sua acepção geral), poderia ser sintetizada da seguinte maneira: "Por ilusão entende-se uma representação errônea de fenômenos que vem em nossa mente em decorrência de circunstâncias das mais variadas naturezas."1672_ ${ }^{1673}$ Traduzindo essa noção para o fenômeno financeiro, Puviani

\footnotetext{
${ }^{1670}$ Neumark afirmou que a expressão "transparência tributária" foi utilizada expressamente pela primeira vez no Relatório sobre Harmonização Tributária redigida para a Comissão da Comunidade Econômica Europeia (o "Relatório Neumark"). Nesse sentido, Newmark formulou oportuna aproximação conceitual do princípio: "O princípio da transparência tributária exige que as leis tributárias em sentido lato, ou seja, com inclusão dos regulamentos, ordens, circulares, diretrizes, etc., estruturem-se de maneira que apresentem técnica e juridicamente o máximo possível de inteligibilidade e suas disposições sejam tão claras e precisas que excluam toda dúvida sobre os direitos e deveres dos contribuintes, tanto destes mesmos como dos funcionários da administração tributárias, e com eles a arbitrariedade na liquidação e arrecadação dos impostos". NEUMARK, Fritz. Op.cit., p. 406 e seguintes.

${ }^{1671}$ Idem, p. 407.

1672 PUVIANI, Amilcare. Teoria de la ilusión financeira. Madrid: Instituto de Estúdios Fiscales, Ministério de Hacienda, s/d, p. 11 e seguintes.

${ }^{1673}$ Partindo desse esboço teórico preliminar, o autor passou a especificar considerações políticas e sociais à aplicação do fenômeno na Política Financeira, identificando também a ilusão financeira como instrumento de dominação política de classes econômicas dominantes frente às classes dominadas, apresentando evidente teor político à teoria. Por exemplo, a ilusão financeira pode ser visualizada também na técnica adotada em
} 
acrescenta: “Assim, pois, podemos dizer que por ilusão financeira se entende uma representação errônea das riquezas pagas ou que devam ser pagas a título de imposto ou de alguma de suas espécies tributárias". ${ }^{1674}{ }^{1675}$.

O Brasil, nesse aspecto, passou por numerosas reformas fiscais nas duas últimas décadas, aumentando cada vez mais a chamada "tributação invisível”, cuja aplicação é mais facilitada, graças à ilusão financeira posta ao contribuinte ${ }^{1676}$. Não é sequer preciso ressaltar as diversas circunstâncias trazidas para dificultar ao cidadão a real percepção do quanto este paga a título de tributos. ${ }^{1677}{ }_{-} 1678$

A aplicação da técnica de ilusão financeira também leva ao problema da destinação dos tributos, já que o cidadão geralmente não sabe para onde exatamente são destinados os tributos, tampouco como são empregados, a duração dos gastos, bem como o verdadeiro destino da despesa pública, o que dá margem a milhares de circunstâncias que - na realidade brasileira - impulsionam sério desconforto entre a administração pública e a coletividade $^{1679}$.

Existem várias situações em que a aplicação da teoria da ilusão financeira se revela em sistemas tributários contemporâneos, geralmente atrelados a maneiras de dissuadir o contribuinte da real percepção dos tributos ao qual é submetido. Essas circunstâncias convergem também na manifestação da "vulnerabilidade cognoscitiva do contribuinte"1680, expressão cunhada em trabalho de James Marins para se referir à dificuldade compreensiva

política fiscal, que mascara a real percepção dos contribuintes acerca da carga tributária imposta, já que existem tributos cuja percepção é mais facilitada que outros. PUVIANI, Amilcare. Op.cit., p. 11-12

${ }_{1674}^{16}$ PUVIANI, Amilcare. Op.cit., p. 12.

${ }^{1675}$ Para Puviani, a ilusão financeira influenciaria também no juízo equívoco da real percepção sobre o montante pago de receitas públicas, ocultando-se certas despesas, e revelando-se outras. Assim, através da manipulação da percepção sobre as verdadeiras despesas públicas, seria possível convenientemente exigir mais receitas do que o Estado realmente necessitaria. Idem.

${ }^{1676} \mathrm{~A}$ técnica de aplicação dos tributos no Brasil baseia-se fortemente na ilusão financeira para camuflar a percepção do contribuinte frente aos tributos que lhe são imputados, cujo alicerce foca-se na forte tributação sobre o consumo, em detrimento da tributação sobre o patrimônio e a renda (ainda que essas também sejam elevadas). GONDIM, Fátima; LETTIERI, Marcelo. Tributação e desigualdade. In: Le monde diplomatique. Brasil. Ano 4. Número 39. Outubro 2010. p. 08.

${ }^{1677}$ Idem, p. 09.

${ }^{1678}$ Outro aspecto relevante da aplicação da técnica de ilusão financeira na realidade brasileira relaciona-se às peculiaridades do pagamento de determinados tributos pelo contribuinte. Em verdade, o uso da técnica da ilusão financeira é alarmante no que tange à "tributação indireta", através da adoção dos denominados "tributos invisíveis". Ibidem.

${ }_{1679}^{160}$ PUVIANI, Almicare. Op.cit., p. 25.

${ }^{1680}$ MARINS, James. Defesa e Vulnerabilidade do Contribuinte. Op.cit., p. 40-41. 
do contribuinte sobre a complexa e intrincada estrutura financeira estatal, o que, naturalmente, torna-se elemento importantíssimo à ilusão financeira estatal.

Mas, diante dessa técnica de ilusão financeira tão intensamente executada na política fiscal, o seu antídoto é o aperfeiçoamento de estudos destinados à promoção da transparência fiscal que deve prevalecer nas relações tributárias. O acesso à informação de natureza tributária pode ser viabilizado através da promoção da transparência fiscal, princípio que gradativamente tem ganhado espaço entre teóricos da tributação.

No século XXI já não é mais possível ignorar os efeitos que tal questão provoca no sistema tributário, especialmente porque a transparência das relações tributárias é também uma exigência para se alcançar a segurança jurídica em matéria tributária, tão arduamente defendida pelos juristas do direito tributário, em todas as "fases" da relação tributária.

No Brasil, poucos exemplos se dedicaram ao assunto, exceções nos quais se encontram Roberto Ferraz ${ }^{1681}{ }^{1682}$, Ricardo Lobo Torres ${ }^{1683}$, Eurico Diniz de Santi ${ }^{1684}$, James Marins ${ }^{1685}$, João Francisco Bianco (em sua perspectiva internacional) ${ }^{1686}$, entre outros.

Reforça a percepção da necessidade da elevação de temas destinados a promover o acesso à informação frente ao direito tributário positivo a elaboração de coletânea de estudos para chamar a atenção dos tributaristas à temática da transparência fiscal, coordenada por Eurico Marcos Diniz de Santi, Basile Georges Christopoulos, Daniel Leib

\footnotetext{
${ }^{1681}$ FERRAZ, Roberto. Limitações ao Poder Impositivo e Segurança Jurídica - O Princípio da Transparência Tributária, In: Ives Gandra Martins, Limitações ao Poder Impositivo e Segurança Jurídica, Pesquisas Tributárias, Nova Série, n. 11, Centro de Extensão Universitária. São Paulo: Editora Rt, 2005, p. 442 e ss.

${ }^{1682}$ Roberto Ferraz incluiu a transparência enquanto pressuposto para uma tributação sustentável. FERRAZ, Roberto. A "Doce Ilusão" da Tributação, dos Outros. In: Revista Direito Tributário Atual n.23. Alcides Jorge Costa, Luís Eduardo Schoueri e Paulo Celso Bergstrom Bonilha (Coord). São Paulo: Dialética - IBDT, 2009, p. 511-512.

${ }^{1683}$ TORRES, Ricardo Lobo. O Princípio da Transparência no Direito Financeiro. In: BuscaLegis.ccj.ufsc.br.2007.Disponível

em:<http://www.mundojuridico.adv.br/sis_artigos/artigos.asp?codigo=162 >. (último acesso em: 13/11/2014).

${ }^{1684}$ SANTI, Eurico Marcos Diniz de. O sigilo e a Lei Tributária: Transparência, Controle da Legalidade, Direito à Prova e a Transparência do Sigilo Bancário para Administração Tributária na Constituição e na Lei Complementar $\mathbf{n}^{\mathbf{0}}$ 105/2001. In: Piscitelli, Tathiane. (Org.). Direito Tributário - o Direito Tributário na Prática Dos Tribunais Superiores - Série Gvlaw Direito Tributário - o Direito Tributário na Prática Dos Tribunais Superiores - Série Gvlaw. 1ed. São Paulo: Saraiva, 2013, v. 1, p. 125-199.

${ }^{1685}$ MARINS, James. Defesa e Vulnerabilidade do Contribuinte. Op.cit., p. 40-41.

${ }^{1686}$ BIANCO, João Francisco. Transparência Fiscal Internacional. São Paulo: Dialética, 2007, p. 13 e seguintes.
} 
Zugman e Frederico Silva Bastos, e intitulada "Transparência Fiscal e Desenvolvimento" 1687 .

Por outro lado, a par dos conhecidos exemplos de ilusão financeira na realidade brasileira contemporânea, recorda-se que a realidade jurídico-positiva também fornece importante elemento no reconhecimento da transparência fiscal, mesmo diante de uma política financeira pautada na larga utilização da ilusão financeira. É o caso do expresso dispositivo revelador da transparência fiscal nas operações mercantis, nos termos do artigo 150, §5º da Constituição Federal de 1988, ao incutir entre as "Limitações Constitucionais ao Poder de Tributar" a necessidade de lei para instaurar medidas de informação aos consumidores sobre os impostos que incidam sobre mercadorias e serviços consumidos ${ }^{1688}$.

Assim, se até mesmo constitucionalmente demonstra-se maior alinhamento a essa necessidade, conforme é possível observar no preceito constitucional que vincula o esclarecimento dos consumidores sobre a carga fiscal incidente sobre os produtos e serviços, maior ainda a necessidade de compreender tais institutos.

Além disso, as políticas públicas estatais episodicamente apresentam genuínos esforços destinados a favorecê-la, como é o caso da Lei de Responsabilidade Fiscal (nos seus artigos 48 e 49), que atualmente já foi objeto de modificações, sobretudo viabilizadas pela Lei Complementar n.131/2009, que aparentemente busca dar maior objetividade (e aplicabilidade) ao princípio ${ }^{1689}$, seja atribuindo nova roupagem ao artigo 48 , seja pelo acréscimo do art.48-A, que claramente busca especificar as medidas adequadas à

${ }^{1687}$ SANTI, Eurico Marcos Diniz de; CHRISTOPOULOS, Basile Georges; ZUGMAN, Daniel Leib; BASTOS, Frederico Silva. Transparência Fiscal e Desenvolvimento - Homenagem ao Professor Isaias Coelho. $1^{\text {a }}$. ed. São Paulo: Fiscosoft Editora Ltda, 2013, p. 27 e seguintes.

1688 Art.150, § $5^{\circ}$, da CF/88. Art. 150, CF-1988. "Sem prejuízo de outras garantias asseguradas ao contribuinte, é vedado à União, aos Estados, ao Distrito Federal e aos Municípios: (...) $\S 5^{\circ}-$ A lei determinará medidas para que os consumidores sejam esclarecidos acerca dos impostos que incidam sobre mercadorias e serviços". Note-se também que nos últimos anos foi publicada a Lei n.12.741/2012, destinada a regulamentar o citado dispositivo constitucional, isto é, dispondo sobre as medidas de esclarecimento ao consumidor, de que trata $\mathrm{o} \S 5^{\circ}$ do artigo 150 da Constituição Federal, referindo-se especialmente à discriminação expressa dos tributos pagos em notas fiscais ao consumidor.

${ }^{1689}$ Dentre as medidas previstas no Artigo 48 (parágrafo único) encontram-se: "I - incentivo à participação popular e realização de audiências públicas, durante os processos de elaboração e discussão dos planos, lei de diretrizes orçamentárias e orçamentos"; "II - liberação ao pleno conhecimento e acompanhamento da sociedade, em tempo real, de informações pormenorizadas sobre a execução orçamentária e financeira, em meios eletrônicos de acesso público; III - adoção de sistema integrado de administração financeira e controle, que atenda a padrão mínimo de qualidade estabelecido pelo Poder Executivo da União e ao disposto no art. 48-A". 
transparência fiscal ${ }^{1690}$, ao passo que o art.49 obriga a disponibilização de contas do Chefe do Poder executivo (sobre o exercício financeiro), ao cidadão e instituições sociais, viabilizando sua análise e consulta. Além disso, os artigos 48, 48-A e 49 da Lei de Responsabilidade Fiscal, além de elevar a transparência fiscal como princípio do Direito Financeiro, impulsionam medidas que buscam concretizá-las, como é o caso da Lei de Acesso à Informação ${ }^{1691}$. Trata-se, portanto, de novo ambiente teórico fértil para reflexões dos tributaristas contemporâneos.

\section{Direito Tributário Brasileiro contemporâneo, legalidade tributária, a segurança jurídica.}

Ainda que a concepção sistemática do Direito Tributário caminhe pela busca de valores indiscutivelmente caros à disciplina, o processo histórico disciplinar do Direito Tributário apresenta inerente vinculação com a necessidade de segurança ${ }^{1692}$ nas relações tributárias. Essa, naturalmente, não deixa de ser o centro das atenções da literatura tributária, seja do passado ou do presente.

Por isso, não é surpresa que essa necessidade repercute-se com perenidade e refletese em importantes contribuições teóricas recentes no campo do Direito Tributário Brasileiro, a exemplo dos recentes estudos de Humberto Ávila ${ }^{1693}$, Paulo de Barros Carvalho $^{1694}$, Misabel Derzi ${ }^{1695}$, Roque Carrazza ${ }^{1696}$ e Heleno Taveira Tôrres ${ }^{1697}$.

\footnotetext{
1690 “Art. 48-A. Para os fins a que se refere o inciso II do parágrafo único do art. 48, os entes da Federação disponibilizarão a qualquer pessoa física ou jurídica o acesso a informações referentes a: I - quanto à despesa: todos os atos praticados pelas unidades gestoras no decorrer da execução da despesa, no momento de sua realização, com a disponibilização mínima dos dados referentes ao número do correspondente processo, ao bem fornecido ou ao serviço prestado, à pessoa física ou jurídica beneficiária do pagamento e, quando for o caso, ao procedimento licitatório realizado; II - quanto à receita: o lançamento e o recebimento de toda a receita das unidades gestoras, inclusive referente a recursos extraordinários".

${ }^{1691}$ Com a Lei n.12.527 de 2011 (Lei de Acesso à Informação), é possível obter informações de natureza tributária que antes não estavam facilmente à disposição do contribuinte (ou mesmo do cidadão interessado), favorecendo a elevação da transparência fiscal na relação entre Estado e contribuinte.

${ }^{1692}$ ÁVILA, Humberto. Segurança Jurídica: Entre permanência, mudança e realização no Direito Tributário. São Paulo: Malheiros, 2011, p. 103-105.

${ }^{1693}$ Idem.

${ }^{1694}$ CARVALHO, Paulo de Barros. Curso de Direito Tributário. 23 ${ }^{\text {a }}$ Ed. Op.cit., p.198-200.

${ }^{1695}$ DERZI, Misabel. Modificações da jurisprudência no Direito Tributário. São Paulo: Noeses, 2009, p. 159.

${ }^{1696}$ CARRAZZA, Roque Antonio. Curso de Direito Constitucional Tributário. Op.cit., p. 463-464.
} 
Evidentemente, a literatura jurídico-tributária nacional não destoa da importância da segurança jurídica, conforme é possível observar em Humberto Ávila que, considerando as variadas acepções doutrinárias que buscam explicar o sentido jurídico da expressão "segurança jurídica", demonstra, em profunda análise doutrinária, que a noção de segurança jurídica tem sido adotada pela doutrina de formas distintas. ${ }^{1698}{ }_{-} 1699$

Para Ávila, é possível referir-se à segurança jurídica, descrevendo-a (há segurança jurídica no Brasil), valorando-a (a segurança jurídica é uma exigência fundamental) separada ou conjuntamente, ou seja, descrevê-la enquanto fato, valor ou norma-princípio, preferindo, no entanto, investigar o princípio da segurança jurídica enquanto norma jurídica da espécie "princípio", ou seja, prescrição dirigida aos Poderes legislativo, judiciário e executivo, que determina a busca de um estado de confiabilidade e de calculabilidade do ordenamento jurídico com base na sua cognoscibilidade ${ }^{1700}{ }^{1701}$.

Já Paulo de Barros Carvalho, em outro retrospecto, apresentando concepção distinta acerca dos princípios jurídicos, inclui entre seus princípios gerais, o princípio da certeza do direito (ou sobreprincípio), diferenciando-o do princípio da segurança jurídica. ${ }^{1702}$

Evidentemente que a segurança jurídica tem por fundamento o próprio Estado de Direito, de forma que os direitos e garantias fundamentais nada mais servem do que

1697 TORRES, Heleno Taveira. Direito constitucional tributário e segurança jurídica: metódica da segurança jurídica do Sistema Constitucional Tributário. $1^{\mathrm{a}}$ ed. São Paulo: Revista dos Tribunais, 2011. p. 15 e ss .

${ }_{1698}$ ÁVILA, Humberto. Segurança Jurídica: Entre permanência, mudança e realização no Direito Tributário. Op.cit., p.113.

${ }^{1699}$ Idem, p. 113 e seguintes.

${ }^{1700}$ Ibidem.

${ }^{1701}$ Considerando diversas acepções e sentidos possíveis que a segurança jurídica implica, prefere Humberto Ávila conceituá-la como “(...) uma norma princípio que exige, dos Poderes Legislativo, Executivo e Judiciário, a adoção de comportamentos que contribuam mais para a existência, em benefício dos cidadãos e na sua perspectiva, de um estado de confiabilidade e de calculabilidade jurídicas, com base na sua conoscibilidade, por meio da controlabilidade jurídico-racional das estruturas argumentativas reconstrutivas de normas gerais e individuais, como instrumento garantidor do respeito à sua capacidade de - sem engano, frustração, surpresa e arbitrariedade - plasmar digna e responsavelmente o seu presente e fazer um planejamento estratégico juridicamente informado do seu futuro". Ibidem, p.682.

${ }_{1702}$ Para o autor, a certeza do direito é “(...) atributo essencial, sem o que não se produz enunciado normativo com sentido deôntico; este último é decorrência de fatores sistêmicos que utilizam o primeiro de modo racional e objetivo, mas dirigido à implementação de um valor específico, qual seja o de coordenar o fluxo das interações inter-humanas, no sentido de propagar no seio da comunidade social o sentimento de previsibilidade quanto aos efeitos jurídicos da regulação da conduta". CARVALHO, Paulo de Barros. Curso de Direito Tributário. 23 Ed. Op.cit., p.198-200. 
instrumentos para viabilizá-la ${ }^{1703 \_}{ }^{1704}$. Como alerta Misabel Derzi, no Direito Tributário, a segurança é fortalecida em sua máxima intensidade ${ }^{1705}$.

Tal preocupação, naturalmente, não é exclusiva da literatura jurídico-tributária, e já aparecia em estudiosos da Economia Política e das Finanças Públicas, e segue como principal norte dos tributaristas no século XX, conforme é possível observar nas leituras de Antonio Berliri ${ }^{1706}$, Ezio Vanoni ${ }^{1707}$ e, com antecedência, Adam Smith que, no desenvolvimento dos princípios da tributação, elevou pelo menos dois, dos quatro princípios da tributação, com relação direta com a segurança necessária às relações tributárias. ${ }^{1708 \_}{ }^{1709}$ Seguem esse caminho John Stuart Mill ${ }^{1710}$, assim como os financistas Benvenuto Griziotti ${ }^{1711}$ e Fritz Neumark ${ }^{1712}$, assim como na literatura jurídica de Otto

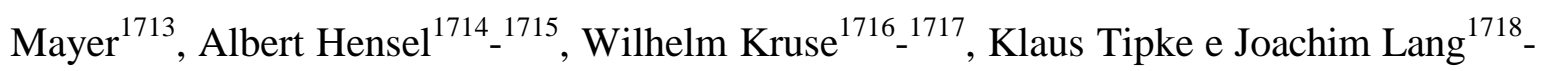
1719

\footnotetext{
${ }^{1703}$ Nesse diapasão, na realidade jurídico-constitucional brasileira, a doutrina de Humberto Ávila assevera que o princípio da segurança jurídica é construído através de duas formas. Em primeiro lugar, o princípio da segurança jurídica é construído através da interpretação dedutiva do princípio maior do Estado de Direito $\left(\operatorname{art} .1^{a}\right)$, que é seu sobreprincípio fundante, e em segundo lugar, pela interpretação indutiva de outras regras constitucionais, nomeadamente as de proteção do direito adquirido, do ato jurídico perfeito e da coisa julgada (art. $5^{\mathrm{a}}$, XXXVI) e das regras da legalidade (art. $5^{\circ}$, II, e art.150, I), da irretroatividade (art.150, III, "a") e da anterioridade (art.150,II, "b"). ÁVILA, Humberto Bérgmann. Sistema Constitucional Tributário. 4 Edição. São Paulo: Saraiva, 2010, p. 308-309.

${ }^{1704}$ Idem, p. 308-309.

${ }^{1705}$ DERZI, Misabel. Modificações da jurisprudência no Direito Tributário. Idem, p. 159.

${ }^{1706}$ BERLIRI, Antonio. Principi di Diritto Tributario. Volume 1. Op.cit., p. 206 e seguintes.

${ }^{1707}$ VANONI, Ezio. Natureza e Interpretação da Legislação Tributária. Op.cit., p. 16 e seguintes.

${ }^{1708}$ SMITH, Adam. A Riqueza das Nações. Investigação Sobre sua Natureza e suas Causas. Livro Quarto. Volume II. Tradução de Luis João Baraúna. Os Economistas. São Paulo: Nova Cultural, p. 282-284.

${ }^{1709}$ FONROUGE, Giuliani. Derecho Financiero. Volumen I. $2^{\circ}$ Ed. Buenos Aires: Depalma, 1970, p. 314315; COSTA, Ramón Valdés. Instituciones de Derecho Tributario. Buenos Aires: Depalma, p. 125-126. VILLEGAS, Hector. Curso de Finanzas, Derecho Financiero y Tributario. Tomo único. $5^{\circ}$ Ed. Buenos Aires: Depalma, 1993, p.190 e seguintes. NEUMARK, Fritz. Princípios de La Imposición. Obras Basicas de Hacienda Pública. Madrid: Instituto de Estudios Fiscales. Ministerio de Hacienda, 1974, p.71-72. ZAVALA, Ernesto Flores. Elementos de Finanzas Publicas Mexicanas. Los Impuestos. Décima Edición. México: Porrua, 1968, 138 e seguintes.

${ }^{1710}$ MILL, Stuart. Princípios de Economia Política. Com Algumas de suas Aplicações à Filosofia Social. Volume II. Trad. Luiz João Baraúna. Os Economistas. São Paulo: Nova Cultural, 1996, p. 375 e seguintes.

${ }^{1711}$ GRIZIOTTI, Benvenuto. Princípios de Política, Derecho y Ciência de La Hacienda. Trad. Enrique R.

Mata. Segunda Edicion. Madrid: Instituto Editorial Réus, 1958, p. 132-139.

${ }_{1712}^{12}$ NEUMARK, Fritz. Op.cit., p. 399-448.

${ }^{1713}$ MAYER, Otto. Op.cit., p.196 e seguintes.

${ }^{1714}$ Idem, p. 50.

${ }^{1715}$ Ibidem, p. 50 e seguintes.

${ }^{1716}$ KRUSE, Heinrich Wilhelm. Derecho Tributario. Op.cit., p. 190-211; TIPKE, Klaus; LANG, Joachim. Op.cit.,, p.179 e seguintes.

${ }^{1717}$ MARTUL-ORTEGA, Perfecto Yebra. Op.cit., Op.cit., p. 15

${ }^{1718}$ Idem.

1719 TIPKE, Klaus; LANG, Joachim. Op.cit.,p. 245-256.
} 
Se a construção histórica do Direito Tributário Brasileiro permeia-se pela necessidade de estabelecer limites ao exercício da tributação, é natural que a literatura especializada busque elevar a segurança jurídica em sua máxima intensidade, seja na Ciência do Direito Tributário ou em outros ramos do conhecimento conexos à tributação.

Porém, as dificuldades econômicas enfrentadas no período de democratização refletem a busca por mecanismos destinados à diminuição do déficit público, incluindo a elevação da carga tributária. Mas com a previsão mais extensiva de limitações ao exercício da tributação na Constituição, aliado ao esforço constituinte em proceder ao maior equilíbrio (e descentralização) financeiro entre os entes tributantes, o poder público federal logo caminhou para alcançar alternativas que viabilizem a maximização de receitas públicas.

Assim, a União Federal logo verifica que, entre a criação de novos impostos que necessariamente deveriam atentar ao extensivo rol de limitações, e para evitar a distribuição de receitas públicas entre os demais entes da federação, encontra nas chamadas "contribuições sociais" (previstas no artigo 149 e 195 da Constituição), e, sobretudo, através da competência residual prevista no art.154, I, o "cano de escape", para escapar das "amarras" constitucionais tributárias, já que o artigo 195 fixou a possibilidade da criação de novas contribuições sociais, desde que atendidas as condições do art.154, I, da Constituição Federal.

O crescimento do aparelho estatal reflete-se diretamente na carga tributária que, no início dos anos noventa, que já representava 25\% do PIB (1991), alcança no ano de 1999, o percentual de $30,32 \%$ do PIB, alcançando, no ano $2000,33,18 \%$ do PIB. ${ }^{1720}$

Não é difícil perceber que a atuação estatal, na medida em que se elevam as necessidades públicas, passa a procurar cada vez mais outros instrumentos para a majoração da carga tributária. E a necessidade de segurança e continuidade das relações

\footnotetext{
${ }^{1720}$ Dados extraídos de tabela publicada no web-site da Receita Federal do Brasil, que mostra o crescimento da carga tributária brasileira na década de noventa: http://www.receita.fazenda.gov.br/Historico/Arrecadacao/Carga_Fiscal/1999/tabela1.htm (último acesso em 29.11.2014)
} 
tributárias cada vez mais passa pela consideração da necessidade de dinamicidade que o papel da tributação deve manter enquanto instrumento de fiscal policy ${ }^{1721}$.

Por outro lado, note-se que parcela da doutrina nacional passa a criticar determinados posicionamentos considerados "positivistas", sobretudo na elevação de uma legalidade tributária fechada, e que levaria à conceitos fechados ou cerrados, concepção largamente predominante na literatura tributária brasileira, conforme já observado, optando por assimilar, em face das diferenciadas peculiaridades históricas que impulsionam o direito tributário contemporâneo, adotar premissas positivistas "diferenciadas". Fala-se em pós-positivismo, onde diferentes doutrinas assumem premissas positivistas fundamentais, mas com ponderações perante a complexidade e as necessidades contemporâneas que o direito tributário busca instrumentalizar.

Para alguns autores brasileiros como Ricardo Lobo Torres ${ }^{1722}$ e Fernando Aurelio Zilveti $^{1723}$, ancorados na literatura estrangeira (e notadamente alemã) maior razão atualmente seria tratar de um "positivismo flexível", mais atento às peculiaridades da realidade social contemporânea, "flexibilizando" determinadas concepções "radicais" defendidas pelo positivismo jurídico na construção do sistema tributário brasileiro, a exemplo da própria legalidade tributária, afastando ou flexibilizando determinados institutos jurídicos prevalecentes na construção disciplinar do Direito Tributário Brasileiro, como é o caso da tipicidade cerrada ou fechada.

Assim, não causa surpresa que a própria legalidade tributária, consubstanciada na necessidade de aprovação prévia ou consentimento prévio popular para a criação ou majoração de tributos, conforme prevê o artigo 150, I da Constituição, vai de encontro a mecanismos "alternativos" e mais dinâmicos ao processo legislativo, como é o caso da Medida Provisória, que repagina o antigo Decreto-lei, sob o argumento da necessidade e urgência da medida. Mas o que não é urgente no aparelho público estatal?

Os atos "normativos" do executivo substitutivos aos atos legislativos sempre estiveram presentes no desenvolvimento histórico da legalidade tributária, já observáveis

\footnotetext{
${ }^{1721}$ BUJANDA, Fernando Fernando. Hacienda Y Derecho. Estudios de Derecho Financiero. II. Madrid: Instituto de Estudios Políticos, 1967, p. 154-176.

1722 TORRES, Ricardo Lobo. Legalidade Tributária e Riscos Sociais. Op.cit., p. 178-185.

${ }^{1723}$ ZILVETI, Fernando Aurelio. Obrigação Tributária. Fato Gerador e Tipo. Op.cit., p. 112 e ss.
} 
em Otto Mayer ${ }^{1724}$, que os aceitava excepcionalmente, assim como Blumenstein ${ }^{1725}$, e em Hensel, que os refutava ${ }^{1726}$.

Na Itália também existia expressa utilização (no período fascista) dos decreto-legge (verdadeira inspiração para os Decretos-lei no Brasil), recebendo a crítica expressa de Tesoro $^{1727}$, ainda que reconhecesse, assim como Puglièse ${ }^{1728}$, Giannini ${ }^{1729}$ e Vanoni ${ }^{1730}$ a sólida tendência fascista da substituição do decreto legge à lei formal.

Chega-se até mesmo, para alguns estudiosos como Micheli, a defender-se uma legalidade "relativa""1731. Por outro lado, tais esforços se coadunam com as reflexões de Neumark, que registrou a maior ocorrência de debates sobre os contornos (e limites) da legalidade em democracias ainda imaturas, ${ }^{1732}$ ao passo que Sainz de Bujanda, sob outros fundamentos, chega a considerar a suposta "crise" da legalidade tributária ${ }^{1733}{ }_{-}{ }^{1734}$.

Por outro lado, na realidade brasileira, o afluxo de sucessivas emendas constitucionais destinadas a alterar o capítulo tributário da Constituição parecia atingir diretamente os objetivos mais caros do constituinte, elevando a preocupação com a necessidade de se estabelecer limites às alterações constitucionais. Não é surpresa que Geraldo Ataliba eleve a repartição de competências tributárias à categoria das cláusulas pétreas (artigo 60, par. $4^{\mathrm{a}}$ da Constituição), buscando alcançar um conteúdo mínimo e imutável a esses excessos ${ }^{1735}$.

\footnotetext{
${ }^{1724}$ MAYER, Otto. Op.cit., p.196 e seguintes.

${ }^{1725}$ Blumenstein reconhecia, por outro lado, que em alguns casos extraordinários a criação ou cobrança de certos tributos poderia ser feita através do Executivo, ainda que em caráter excepcional. BLUMENSTEIN, Ernst. Op.cit., p. 09.

${ }^{1726}$ HENSEL, Albert. Op.cit., p. 50.

${ }^{1727}$ TESORO, Giorgio. Principii di Diritto Tributário. Bari: Dott Luigi Macri Editore, 1938, p. 05-10.

1728 PUGLIĖSE, Mario. Instituciones de Derecho Financeiro. Derecho Tributário. Version Espanôla de José Silva. Fondo de Cultura Econômica: México, 1938, p. 114-128.

${ }^{1729}$ GIANNINI, A.D. Il Rapporto Giuridico D'Imposta. Milano: Dott.A. Giuffrè Editore, 1937, p. 02.

1730 VANONI, Ezio. Opere Giuridiche. II. Op.cit., p. 37-49. Também em VANONI, Ezio. Natureza e Interpretação das Leis Tributárias. Op.cit., p. 110 e seguintes.

${ }^{1731}$ MICHELI, Gian Antonio. Curso de Derecho Tributario. Trad. Julio Balacloche. Madrid: Reunidas, 1975, p. 87-89. Também em: MICHELI, Gian Antonio. Curso de Direito Tributário. Trad. Marco Aurélio Greco e Pedro Luciano Marrey Jr. São Paulo: RT, 1978, p. 17 e seguintes.

1732 NEUMARK, Fritz. Op.cit., p. 71-72.

${ }^{1733}$ BUJANDA, Fernando Sainz de. Hacienda Y Derecho. Estudios de Derecho Financiero. II. Op.cit.,, p. 151-161.

${ }^{1734}$ Sobre o assunto, sob uma perspectiva crítica: CAMPILONGO, Celso Fernandes. O Direito na Sociedade Complexa. São Paulo: Max Limonad, 2000, p. 73 e ss.

${ }^{1735}$ ATALIBA, Geraldo. República e Constituição. Op.cit., p. 40-47.
} 
Com as sucessivas alterações constitucionais e infraconstitucionais na tributação brasileira fortalece-se a sensação de complexidade, irracionalidade e ineficiência do Sistema Constitucional Tributário, pelo menos a atender os requisitos essenciais almejados pela doutrina tributária: segurança e justiça.

Por outro lado, o poder judiciário, paralelamente a esse fenômeno, cresce em importância, especialmente na consideração de que, diante de uma legislação ineficiente, complexa, mal compreendida e constantemente deturpada, é o poder judiciário o órgão competente para reaproximar o Direito Tributário da segurança jurídica. É a judicialização da política, conforme bem considerou Ricardo Lobo Torres. ${ }^{1736}$

O controle de constitucionalidade repressivo exercido pelo poder judiciário passa a ser gradativamente fortalecido (artigos 102 e 103 da Constituição Federal de 1988), trazendo importantes instrumentos (como a Ação Direta de Inconstitucionalidade, Ação Direta de Inconstitucionalidade por Omissão, Ação Declaratória de Constitucionalidade, Mandado de Injunção e a Arguição de Descumprimento de Preceito Fundamental) ${ }^{1737}$.

Eleva-se a importância das súmulas, e o caráter eventualmente vinculante lhes é agregado, fortalecendo ainda mais o poder das decisões naquela instância superior. Chegase a repercutir características contemporâneas dos tribunais superiores ao próprio contencioso administrativo, com súmulas administrativas e súmulas com efeito vinculante ${ }^{1738}$.

Ainda, no contencioso judicial, agrega-se a possibilidade da modulação de efeitos (artigos 27 e 11 das Leis n. 9.868/99 e n. 9882/99) em decisões do STF, possibilitando ao

\footnotetext{
${ }^{1736}$ TORRES, Ricardo Lobo. Legalidade Tributária e Riscos sociais. Op.cit., p. 178 e ss.

1737 BASTOS, Celso Ribeiro. Curso de Direito Constitucional. São Paulo: Saraiva, 2000, p. 390 e seguintess. CAMPOS, Francisco. Direito Constitucional, Volume I. São Paulo: Freitas Bastos, 1956, p. 430 e seguintes. MIRANDA, Francisco Cavalcanti Pontes de. Comentários à Constituição de 1967, com a emenda n. 1 de 1969. Tomo I. $3^{\mathrm{a}}$ ed. Rio de Janeiro: Forense, 1987, p. 376 e seguintes. KELSEN, Hans. Teoria Pura do Direito. Op.cit., p. 304 e seguintes. FERRARI, Regina Maria Macedo Nery. Efeitos da declaração de Inconstitucionalidade, São Paulo: Rt, 1999, p. 116 e seguintes. MENDES, Gilmar Ferreira. Jurisdição Constitucional, Saraiva: São Paulo,1998, p. 191-193. MENDES, Gilmar Ferreira; MARTINS, Ives Gandra da Silva. Controle concentrado de constitucionalidade. 2. ed. São Paulo: Saraiva, 2005, p. 465 e seguintes.

${ }^{1738}$ Recurso Extraordinário n. 105.789-MG (Segunda Turma), e Recurso extraordinário n.122.202-6-MG. MARINS, James. Curso de Direito Processual Tributário (Administrativo e Judicial). Op.cit., p.455 e seguintes.
} 
Tribunal restringir os efeitos da inconstitucionalidade da lei ou do ato normativo ${ }^{1739}$ e, mesmo em determinadas situações, em alteração de jurisprudência dominante ${ }^{1740}$.

Ao mesmo tempo, em processo onde os poderes legislativo, executivo e judiciário buscam maior harmonia (mas adaptados ao contexto histórico contemporâneo), não é surpresa que a literatura especializada aponte os riscos da insegurança jurídica nesse processo.

Mas os efeitos das modificações de jurisprudência, igualmente, também devem ser refletidos, e obsevados conforme o princípio da segurança jurídica. Não por acaso, assinala Misabel Derzi: “(...) As modificações da jurisprudência não podem configurar surpreendentes reviravoltas judiciais, sem que o juiz atenue os efeitos da mudança, protegendo a confiança e a boa-fé daqueles que tinham pautado seu comportamento de acordo com os comandos judiciais superados (...)"1741.

A segurança jurídica (princípio ou sobreprincípio, para parte da doutrina), da qual decorrem os princípios ético-jurídicos da confiança e boa-fé, ou mesmo da irretroatividade e a anterioridade, deve ser norte seguro a condicionar a oscilação de manifestações jurisprudenciais, ou mesmo a própria modulação de seus efeitos, para causar o mínimo de transtorno possível aos interessados.

Em qualquer caso, seja na elevação da jurisprudência ou na proteção da legalidade diante dos avanços do poder executivo, a busca pela segurança jurídica é caminho pelo qual o tributarista não pode se afastar.

Porém, contemporaneamente, a própria ideia de segurança jurídica aparece permeada pelos notáveis efeitos trazidos pelos fenômenos reconhecidos recentemente.

\footnotetext{
${ }^{1739}$ BARROSO, Luís Roberto. O controle de constitucionalidade no direito brasileiro. São Paulo: Saraiva, 2006, p. 187 e seguintes. MARINS, James. Curso de Direito Processual Tributário (Administrativo e Judicial). Op.cit., p742 e seguintes.

${ }^{1740}$ MARINS, James. Curso de Direito Processual Tributário (Administrativo e Judicial). Op.cit., p.742 e seguintes. PIMENTA, Paulo Roberto Lírio. O Princípio da Segurança Jurídica em face de Mudança da Jurisprudência Tributária. In: Grandes Questões Atuais do Direito Tributário. 10 Volume. Coordenador: Valdir de Oliveira Rocha. São Paulo: Dialética, 2006, p.358-372. MARTINS, Ives Gandra da Silva. Efeitos Prospectivos de Decisões Judiciais em Matéria Tributária. In: Revista Dialética de Direito Tributário. Valdir de Oliveira Rocha (Coord.). São Paulo: Dialética, junho de 2010, p. 48-58.

${ }^{1741}$ DERZI, Misabel. Modificações da Jurisprudência no Direito Tributário Brasileiro. Op.cit., p. 25 e seguintes.
} 
A configuração contemporânea do Estado Social e Democrático Fiscal, e os reflexos da sociedade de riscos trazem efeitos indiscutíveis à discussão da segurança jurídica (e conceitos jurídicos fundamentais) e, afinal, da própria legalidade, que gradativamente vê-se ponderada, seja pela elevação de um positivismo flexível, como sustentou Fernando Aurelio Zilveti ${ }^{1742}$, seja pela consideração da judicialização do Direito Tributário, conforme expôs Ricardo Lobo Torres, abrindo-se gradativamente maior espaço para o poder judiciário, na própria criação de normas jurídicas ${ }^{1743}$.

Segue o mesmo entendimento Fernando Aurelio Zilveti, para quem o positivismo (pós-positivismo da Sociedade de Riscos), considera que o princípio da legalidade não estaria previsto isoladamente, e nem reinaria sozinho na Constituição Federal do Brasil. Devendo manter harmonia com outros princípios do Estado de Direito (sobretudo o da capacidade contributiva), acaba recebendo inevitável ponderação. Cabe ao poder judiciário, ponderando princípios e afastar o confronto da legalidade tributária com outros princípios constitucionais ${ }^{1744}$.

Para Ricardo Lobo Torres, a legalidade tributária contemporânea aparece progressivamente flexibilizada pela ponderação da legalidade tributária perante outros princípios tributários (como a capacidade contributiva, ou do custo/benefício), pelo progressivo reconhecimento de conceitos indeterminados (superando a "ingênua" visão, segundo autor, na possibilidade de conceitos fechados no direito tributário); pelas novas configurações das relações harmônicas entre os poderes do Estado (a exemplo do poder regulamentar da administração) e; pela judicialização da política (interferência do judiciário nas questões políticas ínsitas à elaboração legislativa, sobretudo referente ao controle de constitucionalidade das leis). Assim, na visão de Ricardo Lobo Torres, a legalidade no ambiente do pós-positivismo (sob diferentes matizes), deve ser considerada no contexto em que a segurança jurídica deva ser ponderada com a justiça ${ }^{1745}$.

\subsection{A questão da rediscussão dos tipos no Direito Tributário Brasileiro}

Naturalmente, a influência do dogmatismo normativo kelseniano, também por influência da literatura jurídica ibérica, favoreceu tendência conceitualista abstrata na

\footnotetext{
1742 ZILVETI, Fernando Aurelio. Obrigação Tributária - Fato Gerador e Tipo. Op.cit., p. 113 e ss. 1743 TORRES, Ricardo Lobo. Legalidade Tributária e os Riscos Sociais. Op.cit., p. 178-185.

${ }_{1744}^{175}$ ZILVETI, Fernando Aurelio. Obrigação Tributária - Fato Gerador e Tipo. Op.cit., p. 118 e ss. ${ }^{1745}$ Idem.
} 
consideração de que a tipicidade seria compreendida como adequação ou determinação do fato gerador (e, portanto, vinculada à subsunção entre hipótese abstrata e fato concreto ${ }^{1746}$ ), confundindo Tatbestand (fato gerador) e Typus (tipo) ${ }^{1747}$.

Os estudos sobre a teoria dos tipos no direito tributário brasileiro podem ser identificados na literatura estrangeira, a exemplo de Karl Larenz ${ }^{1748}$, Heinrich Henkel ${ }^{1749}$, Arthur Kaufmann ${ }^{1750}$, Karl Engisch ${ }^{1751}$, na filosofia do direito e, no campo do Direito Tributário Alemão ${ }^{1752}$, entre outros, por Hensel, e, posteriormente, Kruse ${ }^{1753}{ }^{1754}$, Tipke e Lang $^{1755}$, assim como visão do espanhol José Juan Ferreiro Lapatza ${ }^{1756}$.

No Brasil, a questão da tipicidade já podia ser identificada na década de sessenta, com Ruy Barbosa Nogueira (tipicidade como apuração do fato gerador) ${ }^{1757}$ e Amílcar de Araújo Falcão (tipicidade como postulado da adequação do fato gerador) ${ }^{1758}$, mas teve impulso efetivo com os estudos de Alberto Xavier, ao defender que o princípio da tipicidade envolveria necessariamente tipos fechados no direito tributário, e vincular-se-ia à determinação exaustiva do fato gerador em lei. Segundo Alberto Xavier, o princípio da tipicidade ou reserva absoluta da lei possui os seguintes corolários: a) princípio da seleção;

1746 CARVALHO, Paulo de Barros. Direito Tributário: Fundamentos Jurídicos da Incidência Tributária. Op.cit.,p.69. CARVALHO, Paulo de Barros. Curso de Direito Tributário. Op.cit., p. 249.

1747 TORRES, Ricardo Lobo. O princípio da tipicidade no direito tributário brasileiro. In: Revista eletrônica de Direito Administrativo Econômico. Número 5. Salvador: IBDP, Janeiro/Fevereiro/março de 2006, p. 01-02.

${ }^{1748}$ LARENZ, P. 623-667.

1749 HENKEL, Heinrich. Introducción a la Filosofia del Derecho. Fundamentos del Derecho. Trad. Enrique Gimbernat Ordeig. Madrid: Taurus, 1968, p. 571-583.

${ }^{1750}$ KAUFMANN, Arthur. Filosofia do Direito. Fundação Calouste Gulbenkian, 1997, p.140-157.

${ }^{1751}$ ENGISCH, p. 205-208; 307-308.

1752 "A chamada teoria dos tipos que fora introduzida no Direito Tributário por Enno Becker, e na própria Alemanha é combatida pelo Prof. Dr. Ottmar Bühler e tantos outros, pode levar à interpretação e à aplicação da lei tributária por analogia porque, apreciando os fatos, e generalizando-os ou categorizando-os, acaba por aplicar o dispositivo que prevê um certo fato a fatos semelhantes e portanto analogicamente, o que sem dúvida sacrifica o princípio da segurança jurídica e da certeza do direito. A aplicação da lei tributária por analogia, em nosso sistema, fere o princípio da estrita legalidade do crédito fiscal e portanto é inconstitucional". NOGUEIRA, Ruy Barbosa. P. 89-93.

${ }^{1753}$ MARTUL-ORTEGA, Perfecto Yebra. Op.cit., p. 15

${ }^{1754} \mathrm{Na}$ literatura, Heinrich Wilhelm Kruse, principal artífice do renascimento germânico da doutrina tributária constitucional pós-guerra, reconhecia o papel original de Hensel na renovação constitucional tributária da doutrina tedesca, e defendia a tipicidade como “(...) uma forma especial do princípio da legalidade da administração”. KRUSE, Heinrich Wilhelm. Derecho Tributario. Op.cit., p. 92-94.

${ }^{1755}$ A tipicidade tem importância igualmente reconhecida por Klaus Tipke e Joachim Lang, para quem: “(...) a fixação e a determinação de um tributo, pressupõem o preenchimento de um tipo legal, que a lei concebe o tributo como consequência (tipicidade tributária). Essa consequência jurídica precisa também necessitar de lei’'TIPKE, Klaus; LANG, Joachim. Op.cit., p. 165 e ss.

${ }^{1756}$ LAPATZA, José Juan Ferreiro. Direito Tributário - Teoria Geral do Tributo. Trad. Roberto Barbosa Alves. Barueri-SP: Marcial Pons - Manole, 2007, p. 08-09; LAPATZA, José Juan Ferreiro. Curso de Derecho Financiero Español. $18^{\circ}$ Edición. Madrid: Marcial Pons, 1996, p. 37 e p. 52-60.

${ }_{1757}$ NOGUEIRA, Ruy Barbosa. Da Interpretação e da Aplicação das Leis Tributárias. Op.cit., p.89-93.

${ }^{1758}$ FALCÃO, Amílcar de Araújo. O Fato Gerador da Obrigação Tributária. Op.cit., p. 26-28. 
b) princípio do numerus clausus; c) o princípio do exclusivismo; d) e o princípio da determinação ou da tipicidade fechada ${ }^{1759}$.

Esse raciocínio, seguido por muitos estudiosos brasileiros, a exemplo de Yonne Dolácio de Oliveira ${ }^{1760}$, Ives Gandra da Silva Martins ${ }^{1761}$, Sacha Calmôn Navarro Coelho ${ }^{1762}$, Geraldo Ataliba ${ }^{1763}$ e Roque Antonio Carrazza ${ }^{1764}$, mantém-se de certa forma prevalecente na literatura brasileira.

A distinção entre tipos (abertos) e tipos fechados (conceitos classificatórios) apareceu com maior clareza em Misabel Derzi, ainda que tenha afastado os tipos do direito tributário, com fundamento na segurança jurídica (cuja preferência pelas estruturas conceituais decorreria da predominância do princípio da legalidade estrita, da segurança jurídica, da uniformidade e praticabilidade) ${ }^{1765}$. Análogo caminho já trilhava Ruy Barbosa Nogueira (já que abriria margem para a analogia e a extensão no direito tributário), para quem somente o legislador poderia categorizar fatos no direito tributário ${ }^{1766}$.

Note-se que, para maior parcela da literatura jurídico-tributária brasileira no século XX a utilização de conceitos determinados no direito tributário favoreceria a segurança jurídica, e seguia o caminho de boa parte da literatura tributária especializada, especialmente na elevação abstrata da lógica jurídica. Sendo o conceito abstrato, menores as chances de interferências exteriores (realidade concreta) ao direito tributário, e maior o campo de atuação da lógica jurídica, abstrata por excelência.

Por outro lado, conforme já observado, recentes tendências provenientes do ambiente teórico contemporâneo tendem a elevar a utilização de tipos no direito tributário,

\footnotetext{
${ }^{1759}$ XAVIER, Alberto Pinheiro. Conceito e Natureza do Acto Tributario. Coimbra: Almedina, 1972, p. 263-264. Também em: XAVIER, Alberto. Os princípios da legalidade e da tipicidade da tributação. São Paulo: RT, 1978, p. 12-18; 36-39; 57-58. XAVIER, Alberto. Tipicidade da Tributação, Simulação e Norma Antielisiva. São Paulo: Dialética, 2002, p. 22.

${ }^{1760}$ OLIVEIRA, Yonne Dolacio. Legislação tributária, tipo legal tributário (Arts.96 e 97 do C.T.N.). In: Direito Tributário 4, vol.2, São Paulo, 1976, p. 09-13 OLIVEIRA, Yonne Dolacio. Princípios da legalidade e da tipicidade. In: MARTINS, Ives Gandra da Silva. (Org). Curso de Direito Tributário, Vol. I, Belém, 1993, p.141; 186.

${ }^{1761}$ MARTINS, Ives Gandra da Silva. Os princípios da legalidade e da tipicidade. In: Curso de Direito Tributário. Org: MARTINS, Ives Gandra da Silva. São Paulo, 1982, p. 49 e ss; MARTINS, Ives Gandra da Silva. Princípio da reserva absoluta, In: Direito Constitucional Tributário. Belém, 1984, p. 81; MARTINS, Ives Gandra da Silva. Princípios da legalidade e tipicidade da tributação. In: Direito Constitucional Tributário. Belém, 1984, p.15.

${ }^{1762}$ COÊLHO, Sacha Calmon Navarro. Princípios da tributação: legalidade e tipicidade. RDT n.33, São Paulo, 1985, p. 198 e ss.

${ }_{1763}$ ATALIBA, Geraldo. Hipótese de Incidência Tributária. Op.cit., p. 70.

${ }^{1764}$ CARRAZZA, Roque Antonio. ICMS. Op.cit., p. 30-31. CARRAZZA, Roque Antonio. Curso de Direito Constitucional Tributário. $21^{\text {a }}$ Ed. São Paulo: Malheiros, 2005, p. 478-481.

${ }_{1765}$ DERZI, Misabel. Direito Tributário, Direito Penal e Tipo. Op.cit., p. 248-286.

${ }^{1766}$ NOGUEIRA, Ruy Barbosa. Da Interpretação e da aplicação da Lei Tributária. Op.cit., p. 93.
} 
sobretudo baseados no "pós-positivismo", que levaria a um "positivismo flexível"1767, permeável às peculiaridades da realidade econômica, social e política contemporânea (sociedade de riscos).

Nesse contexto, o tema só começa a ganhar renovação nos estudos de Ricardo Lobo Torres, que, diferenciando expressamente os tipos (abertos, elásticos e apenas descritos em lei, apresentando elementos de abstração e concretude) dos conceitos classificatórios (abstratos e definidos em lei). Diferenciando também o tipo (Typus) da tipicidade (Typizität) e da tipificação (Typisierung), admite-os no direito tributário ${ }^{1768}{ }_{-}^{1769}$. Reforça a argumentação do autor a verificação de debates jurisprudenciais sobre o tema observados contemporaneamente, fortalecendo o surgimento de estudos destinados à análise dos tipos (abertos) e "tipos cerrados" em matéria tributária, como é o caso do Seguro de Acidente de Trabalho (SAT) ${ }^{1770}$, assim como da taxa ambiental ao IBAMA ${ }^{1771}{ }_{-}^{1772}$.

Nesse contexto, no início do século XXI aparecem novos estudos sobre o tema, favoráveis ou contrários à utilização de tipos (já superadas as polêmicas acima citadas) no direito tributário, conforme se observa em Fernando Aurélio Zilveti ${ }^{1773}$, Luís Eduardo Schoueri ${ }^{1774}$ e Sérgio André Rocha ${ }^{1775}$, seja reinterpretando-os no direito tributário, conforme se observa em Humberto Ávila.

Fernando Zilveti, defendendo o uso de tipos no direito tributário (e baseado em positivismo flexível, mais apropriado ao contexto contemporâneo, da sociedade de riscos, na visão do autor), aduziu a "renda" enquanto tipo exemplar no direito tributário. Para Zilveti a doutrina precisa reconhecer a característica determinada da renda na doutrina,

\footnotetext{
${ }^{1767}$ ZILVETI, Fernando Aurelio. Obrigação Tributária - Fato Gerador e Tipo. Op.cit., p. 113 e ss.

1768 TORRES, Ricardo Lobo. Curso de Direito Financeiro e Tributário. 16 ${ }^{\text {a }}$ Ed. Rio de Janeiro: Renovar, 2009,p. 110.

${ }^{1769}$ Conforme explica o autor, a tipicidade, na expressão alemã Typizität, significa a "qualidade do tipo tributário, que é uma das configurações lógicas do pensamento jurídico, quando existe a escolha de formas abrangentes”. Por outro lado, a tipificação (Typisierung) seria a “(...) conformação normativa do tipo”. O tipo é apenas descrito pelo legislador, possuindo aspectos gerais e concretos, absorvendo características da realidade social, ao passo que o conceito jurídico é objeto de definição legal possuindo caráter abstrato. Para Torres, “(...) Os tipos jurídicos são sempre elásticos e abertos (ex: empresa, empresário, indústria (...)”. TORRES, Ricardo Lobo. O princípio da tipicidade no direito tributário brasileiro. Op.cit., p.01 e ss. ${ }^{1770}$ RE 343.446-SC, Ac. Do Plano. 20.03.03. Min. Carlos Velloso. Informativo 30.02.2003.

${ }^{1771}$ ADIN 2178, Ac. Do Pleno, 29.03.2000. Rel. Min.Ilmar Galvão. DJ 12.05.2000.

1772 TORRES, Ricardo Lobo. O princípio da tipicidade no direito tributário brasileiro. Op.cit., p.30 e ss.

1773 ZILVETI, Fernando Aurelio. Obrigação Tributária. Fato Gerador e Tipo. Op.cit., p. 212-249.

${ }^{1774}$ SCHOUERI, Luís Eduardo. Normas Tributárias Indutoras e Intervenção Econômica. São Paulo: Forense, 2005, p. 243-256. Também: SCHOUERI, Luís Eduardo. Fato Gerador da Obrigação Tributária. Op.cit., p. 168-173.

${ }^{1775}$ ROCHA, Sérgio André. Existe um princípio da tipicidade no direito tributário? In: Direito Tributário Atual. N.26. Ricardo Mariz de Oliveira, Luís Eduardo Schoueri e Fernando Aurelio Zilveti (Coord). São Paulo: Dialética-IBDT, 2011, p. 341-352.
} 
legislação e jurisprudência no Brasil, conforme deve ser no tipo, fluído, “(...) a ser determinado pelas cortes"

Já Sérgio André Rocha, com base nas lições de Ricardo Lobo Torres, que apontou a já citada confusão formulada pela doutrina entre tipo e conceito, assim como entre tipicidade com determinação e adequação típica, entende não haver um princípio da tipicidade no Direito Tributário, mas apenas princípios (segundo as teorias de Alexy), da determinação e da vedação à tributação por analogia ${ }^{1777}$.

$\mathrm{Na}$ leitura de Schoueri, analisando os conceitos indeterminados e cláusulas gerais $^{1778}$, e igualmente considerando a opinião de Ricardo Lobo Torres, entende não ser possível o emprego do tipo em matéria tributária, pois para o autor, o Código Tributário Nacional exige a definição do fato gerador, e, portanto, “(...) versa o legislador complementar sobre um conceito, não um tipo (...), pois “(...) tipos não se definem, descrevem-se (...)", não se satisfazendo o legislador com a mera descrição do fato gerador.

Para o autor, quando "(...) o doutrinador exemplificou como "tipos" hão de se entender, quando figurarem na definição do fato gerador da obrigação tributária, como meros conceitos indeterminados. Estes, não é demais repisar, são definidos em cada caso concreto" 1779 .

Para Ávila o tipo jurídico seria, na realidade, um conceito pouco nítido de classe. Assim, o debate "tipos X conceitos" perderia o sentido na concepção normativa contemporânea. A construção desse debate teria ocorrido sob a égide de uma concepção normativa hoje já superada por concepção contemporânea ("como nexo entre o texto da norma genérico e abstrato ou complexo de normas, por um lado, e o conjunto de fatos, cuja assimilação ao caso concreto, primeiramente produz o significado normativo completo - a

\footnotetext{
1776 ZILVETI, Fernando Aurelio. Obrigação Tributária - Fato Gerador e Tipo. Op.cit., p. 243-244.

1777 "Nessa linha de entendimentos, a tipicidade tributária, que não seria um princípio jurídico, seria, de um lado, um instrumento à disposição do legislador no momento da criação do texto legal físcal; e, de ouro lado, uma exigência de remissão do fato concreto ao tipo previsto na norma (isso apenas e tão somente quando a norma for constituída por um tipo jurídico)". ROCHA, Sérgio André. Existe um princípio da tipicidade no direito tributário?Op.cit., p. 352.

${ }^{1778}$ Conceitos indeterminados seriam aqueles conceitos impossíveis de se precisar com maior exatidão. Na verdade, os conceitos sempre terão um núcleo determinado e uma borda duvidosa. Não se afasta das críticas de Eros Grau, lembradas pelo autor, pela impropriedade da expressão conceito indeterminado (que prefere a "expressão termos indeterminados de conceitos"). Na leitura do autor, cláusulas gerais seriam aquelas formulações gerais da hipótese de incidência que, por sua generalidade, alcançam amplo campo. Para o autor, ainda que o legislador defina o fato gerador da obrigação tributária, “(...) não há como afastar o emprego de conceitos indeterminados e cláusulas gerais”. SCHOUERI, Luís Eduardo. Normas Tributárias Indutoras e Intervenção Econômica. Op.cit., p. 249-252. O autor retomou e atualizou reflexões sobre o tema, à luz dos conceitos indeterminados e cláusulas gerais em matéria tributária. Sobre o assunto, conferir: SCHOUERI, Luís Eduardo. Direito Tributário. 3 Ed. São Paulo: Saraiva, 2013, p. 295 e ss.

${ }^{1779}$ SCHOUERI, Luís Eduardo. Normas Tributárias Indutoras e Intervenção Econômica. Op.cit., p. 257.
} 
normatividade"). Porém, ao mesmo tempo questiona a possibilidade efetiva da determinação conceitual atribuída ao conceito classificatório. ${ }^{1780}$

Note-se que o tema, ligado ao grau de determinação exigível ao fato gerador definido em lei, envolve a discussão relativa à segurança jurídica voltada à impossibilidade ou possibilidade de certo grau de indeterminação nos elementos ligados ao fato gerador. Sejam eles tidos como tipos fluídos, conceitos indeterminados, ou conceitos de pouca nitidez, considera a vinculação do intérprete da norma a observação da realidade concreta dos fatos, caminhando, de certa forma, para alcançar caminho paralelo ao entendimento prevalecente no processo disciplinar do direito tributário brasileiro, caracterizado por elevar intensamente a redução, abstração e determinação, pelos motivos históricos supracitados, o que, de certa forma, guarda harmonia com o positivismo formal conceitualista característico da especialização disciplinar das ciências sociais contemporâneas, especialmente porque incentiva o afastamento da consideração da realidade concreta.

Conquanto a tendência brasileira manifeste-se majoritariamente pela tipicidade "cerrada", a existência de novos posicionamentos (inclusive jurisprudenciais) sobre a questão "tipológica" no direito tributário devem ser refletidos na literatura tributária contemporânea.

É perceptível, portanto, que mesmo institutos ou princípios basilares ao direito tributário contemporâneo não escapam dos efeitos trazidos pela mais recente realidade econômica, social e política contemporânea, sendo novamente retomados, seja pela crítica e elevação de propostas substitutivas, seja pela renovação dos argumentos destinados a defender os citados institutos.

Mas se a própria legalidade tributária (assim como a própria questão da tipicidade) e a segurança jurídica encontram atualizações ou novas reflexões na doutrina nacional, é preciso também considerar que determinadas tendências ou opções interpretativas no ambiente teórico contemporâneo também assumam diferentes posicionamentos (abrindo portas para novas perspectivas), sejam no sentido de aperfeiçoar compreensões

\footnotetext{
1780“Em outras palavras: se a hipótese de incidência contém ou não um conceito classificatório, isso não pode ser representado genericamente pela Teoria do Direito por um sistema de conceitos (Begriffslehre) - seja ela de orientação normativa, seja sem generalização - , mas apenas num certo caso de determinado âmbito material, inclusive porque o número de elementos distintivos de um fato de vida concreto é sempre ilimitado e sempre restarão dúvidas que são incompatíveis com conceitos classificatórios e com o consequente número reduzido de elementos distintivos isolantes". AVILA, Humberto. Sistema Constitucional Tributário. Op.cit., p. 231-260.
} 
anteriormente sedimentadas, reforçá-las ou ponderá-las, sob premissas metodológicas posteriores.

\section{Recentes ponderações (hermenêuticas) sobre as funções da Ciência do Direito Tributário frente ao Direito Tributário Positivo}

Embora os temas seguintes não estejam diretamente e expressamente conectados com as problemáticas antes analisadas no presente capítulo, opta-se por trazer breves considerações sob determinadas tendências hermenêuticas atribuídas à literatura tributária recente, que se mostram aparentemente contrárias ou pelo menos alternativas ou complementares às tendências hermenêuticas consolidadas pela dogmática normativa difundida no século XX.

Algumas tendências, no entanto, aproximam-se de críticas pontuais dogmatismo normativo que parte do pressuposto do dualismo (descrição/prescrição) para explicar o Direito Tributário (em sua dimensão normativa). Outras priorizam o dogma interpretativo pautado na dualidade (sujeito/objeto), questionando a ausência de investigações sobre a faceta subjetiva da interpretação. Por outro lado, fortalece-se também a tendência a estudos voltados ao reconhecimento da inerente vagueza da legislação, e técnicas destinadas a afastá-la, ou pelo menos remediá-la. Novas estratégias interpretativas tendem a aparecer, pautadas nas deficiências apontadas na literatura contemporânea.

Outro aspecto geralmente levantado refere-se ao questionamento fundamental dos planos prescritivo e descritivo (e que leva à compreensão fundamental de que a atividade interpretativa do jurista seria fundamentalmente descritiva), por sua vez atribuídos ao direito tributário positivo e à Ciência do Direito. A crítica à função descritiva, por sua vez, leva a aperfeiçoamentos ponderados sobre o perfil descritivo da Ciência do Direito, compreendendo a atividade interpretativa do jurista como descritiva, mas reflexiva, crítica, por vezes explicativa ou compreensiva, como já observado. Contudo, em posições mais enérgicas, chega-se a apontar eventual limitação estrutural na composição da atividade interpretativa vinculada à mera descrição.

Exemplificativamente, centra-se nesses aspectos o recente debate acadêmico entre Humberto Ávila e Paulo de Barros Carvalho sobre a função da Ciência do Direito (e do intérprete do direito). 
Para Humberto, pautado no estruturalismo argumentativo ${ }^{1781}$, a função da interpretação não se limitaria à mera descrição ${ }^{1782}{ }_{-}^{1783}$, que limita e reduz a função do

${ }^{1781}$ Humberto Ávila argumenta que a linha de estudos que defende tão somente a descrição enquanto atividade da Ciência do Direito é insuficiente, buscando demonstrar que a interpretação jurídica envolve sempre a escolha entre alternativas de significado e a reconstrução de significados, e concluindo que a Ciência do Direito embasada tão somente em uma perspectiva hermenêutica descritiva apresenta como pressuposto escolha limitada entre diferentes tipos de interpretação. Para o autor, há a escolha pressuposta de um tipo de interpretação descritiva, assim como de teorias da interpretação (interpretação cognitiva) e de tipos de conhecimento (conhecimento como juízo abstrato de captação de uma realidade). Essa premissa interpretativa, segundo Ávila, foi construída a partir do Círculo de Viena, visando elevar a Ciência do Direito à categoria de Ciência (e assim como as demais ciências deveria apenas conhecer o Direito, descrevê-la, com objetividade e exatidão). Em outras palavras, Humberto Ávila defende que a escolha pressuposta de determinado tipo e teoria da interpretação (assim como de determinado tipo de conhecimento) comprometeriam a atividade interpretativa, pré-direcionando-a antes mesmo da realização da atividade, e comprometendo, por isso, a eficácia da atividade interpretativa, tornando-a "falsa e obsoleta", nas palavras do autor. Na realidade, Humberto Ávila sugere a utilização de outros pressupostos, mais propriamente através da fusão entre proposições descritivas e normativas (tipo de interpretação), definidos por uma teoria da interpretação que combine uma teoria dos sistemas, uma teoria das normas e uma teoria jurídica da argumentação, que Ávila denominou "Estruturalismo Argumentativo". ÁVILA, Humberto. Função da Ciência do Direito Tributário: do Formalismo Epistemológico ao Estruturalismo Argumentativo. In: Revista Direito Tributário Atual. N.29. Ricardo Mariz de Oliveira, Luís Eduardo Schoueri e Fernando Aurelio Zilveti. São Paulo: Dialética, 2013, p.182.

${ }^{1782} \mathrm{O}$ Estruturalismo Argumentativo é uma proposta hermenêutica que busca superar a redução descritivista na atividade do intérprete da Ciência do Direito. Para Ávila, a mera função do intérprete de descrever (de forma neutra e avalorativa) o conteúdo das normas jurídicas (sem nele interferir) é insuficiente. Assim, a Ciência do Direito não apenas “(...) descreve, mas também adscreve e cria significados; de outro, que a sua função não é fundamentalmente descritiva, mas adscritiva e criativa, embora sempre limitada e suscetível de controle intersubjetivo". Criticando e apresentando obstáculos à tese descritivista da Ciência do Direito, justifica que esta seria "produto de um paradigma de Ciência do Direito criado à revelia do próprio Direito e, por essa razão, inapropriado para compreendê-lo em toda a sua extensão e em todas as suas manifestações". Nesse contexto, se a Ciência do Direito pode, além de descrever, adscrever e criar significados, sem perder a base empírica, mas alterando substancialmente os critérios para o reconhecimento científico do discurso (sério, racional e controlável), um dos caminhos, segundo Ávila, é a própria substituição dos critérios da objetividade semântica e da verdade por correspondência, considerados pelo autor como inadequados para o labor do jurista, pelos "(...) critérios da objetividade discursiva e de verdade por coerência, a serem conjugados com outros, na luta contra o obscurantismo interpretativo". Ávila, baseado em Ricardo Guastini, admite a existência de três espécies centrais de interpretação: a) Interpretação cognitiva: "é aquela por meio da qual o intérprete identifica os significados (S) dos textos legais (D), seja apontando qual é o significado de determinado dispositivo, na hipótese de só haver um $(\mathrm{D}=\mathrm{S} 1)$, seja indicando quais são os seus vários significados, no caso de existirem mais de um (S1 e S2), mas sem escolher nenhum. (...) A interpretação cognitiva envolve uma atividade meramente descritiva de significados; b) interpretação decisória: é a interpretação mediante a qual o intérprete escolhe um significado, dentre os vários existentes, descartando os demais ( $\mathrm{D}=\mathrm{S} 1$; não S2). A interpretação decisória “(...) não envolve uma atividade simplesmente descritiva, mas adscritiva de significados; c) interpretação criativa: “(...) é a interpretação por meio da qual o intérprete, diante de um dispositivo que admite, em razão da sua ambiguidade, mais de um significado (S1 e S2), introduz um novo significado (S3) e atribui esse significado ao dispositivo ( $\mathrm{D}=\mathrm{S} 3$ ). Assim, (...) desse modo, a interpretação não envolve uma atividade descritiva ou adscritiva, mas introdutora de conhecimentos". Idem, p. 184

${ }^{1783} \mathrm{O}$ estruturalismo argumentativo, proposta hermenêutica apresentada por Ávila, funciona a partir de três alicerces: $1^{\mathrm{a}}$ ) na teria dos sistemas: propõe mudança no critério fundamental de sistematização (de hierarquia formal para a coerência substancial), “(...) bem como um alargamento do seu objeto (não apenas elementos linguísticos, como função gramatical e lógica dos vocábulos e estrutura sintática das disposições, mas também elementos extratextuais pressupostos pelas normas, como fatos, atos, costumes, finalidades e efeitos)"; $2^{\mathrm{a}}$ ) na teoria das normas: Ávila propõe uma alteração dos critérios fundamentais de distinção entre as espécies normativas “(...) do caráter fundante ou do modo de aplicação e colisão para a natureza da descrição normativa, da justificação e da contribuição para a decisão, assim como uma ampliação das próprias espécies (não apenas regras e princípios, mas também postulados hermenêuticos e aplicativos)"; $3^{\mathrm{a}}$ ) 
intérprete, mas se vincularia a outras possibilidades. Assim, a função (e a interpretação) do jurista envolveria a descrição, mas também a criação e a decisão jurídica.

Por outro lado, Paulo de Barros Carvalho ${ }^{1784}$, manifestando-se diretamente sobre a posição de Humberto Ávila, critica, sob as premissas da construtivismo lógico-semântico, as funções atribuídas por Ávila à Ciência do Direito e, sobretudo, critica as premissas adotadas pelo autor para referir-se à própria obra de Paulo de Barros, acusando-o de interpretá-lo equivocadamente (na vinculação à função descritiva da Ciência do Direito), e arguindo que a função descritiva defendida em sua obra vincula-se à função descritiva crítica-reflexiva, e portanto, uma ponderação crítica à descrição, e não somente mera descrição pura e simplesmente ${ }^{1785}$.

A posição de Ávila foi mantida e aperfeiçoada em texto posterior, que intensificou a crítica no sentido de que o construtivismo lógico-semântico favoreceria a redução indevida da função da Ciência do Direito e do próprio intérprete da norma jurídica

através da teoria jurídica da argumentação: Ávila defende que deve ocorrer uma alteração dos critérios fundamentais de controle argumentativo, mais especificamente, de critérios racionais ou retóricos, para critérios fundados no ordenamento jurídico, e “(...) uma alteração da sua própria funcionalidade (não apenas demonstrar que a interpretação envolve decisões de sentido baseadas em argumentos, mas propor uma classificação dos argumentos e um conjunto de parâmetros discursivos destinados a relacioná-los e valorá-los com base em princípios democráticos e republicanos)". ÁVILA, Humberto. Função da Ciência do Direito Tributário: do Formalismo Epistemológico ao Estruturalismo Argumentativo. Op.cit., p. 184-202

1784 “(...) Foi publicado texto, recentemente, a respeito da função da Ciência do Direito Tributário, em que o autor conclui pela adoção do assim chamado Estruturalismo Argumentativo. Para chegar a esse resultado, firma premissas que envolvem a crítica do caráter descritivo da atividade científica nos domínios do direito, consignando, a meu ver, referências isoladas, apressadas, que distam de corresponder ao pensamento dos autores citados, sobre transmitir visão superficial e incorreta de tema tão relevante para a Epistemologia Jurídica”. CARVALHO, Paulo de Barros. Breves Considerações Sobre A Função Descritiva Da Ciência Do Direito Tributário. In: Revista Consultor Jurídico, 01 de outubro de 2013, 07:00-h (último acesso em 31.07.2014: http://www.conjur.com.br/2013-out-01/paulo-barros-breves-consideracoes-funcao-descritivaciencia-direito-tributario), p. 01 e seguintes.

${ }^{1785}$ Assim, a proposta apresentada por Ávila sofreu crítica de Paulo de Barros Carvalho, fundamentado nos pressupostos do "Construtivismo lógico-semântico", posicionando-se no sentido de que Humberto Ávila teria interpretado equivocadamente o sentido da "descrição" trabalhado por Paulo de Barros em seus estudos anteriores, assim como apresentou outras objeções ao trabalho de Ávila. Paulo de Barros defende que o sentido da descrição propagada por ele seria no caminho "descritivo-crítico explicativo", e não tão somente descritivo, objetivo e desprovido de valor. $\mathrm{Na}$ verdade, a evolução dos estudos jurídico-tributários direcionados à Lógica Jurídica e à Teoria Geral do Direito realmente caminhou nesse sentido, de sopesar, de ponderar a função descritiva da interpretação do direito, e Paulo de Barros Carvalho, no caminhar dos estudos desenvolvidos no âmbito do Construtivismo Lógico-Semântico de fato ponderou a função descritiva do intérprete do direito. Bem, passemos para a conclusão, onde se demora a proposta do Estruturalismo Argumentativo, assentado em três fundamentos: uma teoria dos sistemas, uma teoria das normas e uma teoria jurídica da argumentação. As perguntas são curtas, mas objetivas: 1) como são várias, qual delas é a referida entre as teorias dos sistemas? 2) igualmente, entre as teorias das normas, será, por exemplo, a de Kelsen, a de Hart ou a de Cossio? 3) e o mesmo se diga das teorias da argumentação, posto que todas elas defendem "uma alteração dos critérios fundamentais de controle argumentativo"? Ora, como todo o discurso é argumentativo, fica o espaço nebuloso da imprecisão, pedindo, implorando mesmo especificações mais sérias e profundas. A proposta fica solta, adejando sobre a cabeça do leitor, que permanecerá indeciso diante da multiplicidade de caminhos e de combinações de caminhos a respeito do itinerário do projeto". CARVALHO, Paulo de Barros. Breves Considerações Sobre A Função Descritiva Da Ciência Do Direito Tributário. Op.cit., p. 01 e seguintes. 
tributária ${ }^{1786}$. Embora, as críticas à posição de Paulo de Barros Carvalho, já fossem apresentadas com certa anterioridade por Eros Grau ${ }^{1787}$, sobretudo, deve-se reconhecer que o forte embate entre Humberto Ávila e Paulo de Barros Carvalho, contribui e impulsiona novas reflexões sobre as premissas da Ciência do Direito e do Estruturalismo Argumentativo.

Além da pândega acadêmica registrada entre os dois autores, é possível observar, no âmbito da própria dualidade (descrição/prescrição), críticas destinadas à maior ponderação ou flexibilização dessa estrutura dualista entre Direito Tributário Positivo e Ciência do Direito Tributário.

Nesse contexto, é interessante notar que, sob outras premissas do que as discutidas entre Ávila e Paulo de Barros Carvalho, o dualismo das proposições jurídicas (descritivas ou prescritivas) foi também criticado por André Folloni, que questionou, inspirado em Souto Maior Borges, o caráter absoluto dessa "verdade dualista"1788. Note-se que se trata de uma crítica diferente da formulada por Ávila à feição descritiva da Ciência do Direito,

${ }^{1786}$ O Construtivismo Lógico-Semântico, adotando posição normativista do direito, realiza seus estudos sobre o direito através de sucessivos cortes metodológicos, e que levam à indiscutível redução do seu objeto de conhecimento. Porém, essa Escola centra-se na premissa de Lourival Vilanova sobre a própria complexidade do conhecimento, e sua inviabilidade de conhecê-lo em plenitude (e por isso o recorte). CARVALHO, Paulo de Barros. Direito Tributário: Linguagem e método. Op.cit., p. 156-173.

A estratégia de estudo foca-se em cortes sucessivos. Nesse sentido, o primeiro corte refere-se à própria noção de direito como complexo de normas válidas em determinado país. O segundo recorte refere-se à consideração do direito enquanto manifestação linguística (onde há normas, há sempre uma linguagem). $\mathrm{O}$ terceiro recorte é procedido pela consideração de que o “(...) direito é um instrumento, constituído pelo homem com a finalidade de regular condutas intersubjetivas, canalizando-as em direção a certos valores que a sociedade deseja ver realizados". É, portanto, um "produto cultural" (o objeto cultural "é aquele produzido pelo homem para obter determinada finalidade”). VILANOVA, Lourival. Lógica Jurídica. Op.cit., p. 10. CARVAlHO, Paulo de Barros. Curso de Direito Tributário. 2011. Op.cit., p. 02 e ss. Como bem salienta Aurora Tomazini de Carvalho, no construtivismo lógico-semântico, não se pode falar em descrição "neutra" do intérprete, já que "analítica e hermenêutica se completam, consubstanciando-se no método próprio da Ciência jurídica, a qual nos propomos. A construção analítico-hermenêutica, no entanto, ocorre dentro de um processo dialético de contraposição de sentidos, próprio ao plano dos objetos culturais". Mostra a autora influência expressa de Miguel Reale e Tércio Sampaio Ferraz Júnior nessa ponderação. CARVALHO, Aurora Tomazini de. Curso de Teoria Geral do Direito. O Construtivismo Lógico-semântico. $2^{\mathrm{a}}$ Ed. São Paulo: Noeses, 2010, p. 82-83; p.88. Não é por outro motivo que Aurora Tomazini de Carvalho sintetiza com clareza expressiva o teor construtivo da Escola do Prof. Paulo de Barros: "Condizentes com a proposição adotada de que o conhecimento jurídico-científico é construtivo de seu objeto em razão do sistema de referência indicado pelo cientista e dos recortes efetuados, em algum momento é necessário que se estabeleça um corte restritivo, ponto de partida para elaboração descritiva, fundamentado no conjunto de premissas, as quais espera-se que se mantenha fiel do começo ao fim das investigações. As proposições delineadoras desse recorte são tomadas como "dogmáticas" e dela partem todas as outras ponderações. Não questionamos tais proposições, as aceitamos como verdadeiras e com base nelas vamos amarrando todas as outras para, em nome de uma descrição, construir nosso objeto (formal). E, neste sentido, o método dogmático encontra-se sempre aparente". CARVALHO, Aurora Tomazini de. Curso de Teoria Geral do Direito. O Construtivismo Lógico-semântico. Op.cit., p. 88-89.

${ }^{1787}$ GRAU, Eros. Por que tenho medo dos juízes (a interpretação/aplicação do direito e os princípios). 6 Ed. Op.cit., p. 41 e ss.

${ }^{1788}$ FOLLONI, André. Ciência do Direito Tributário. Op.cit., p. 183-184. 
mas também mostra com clareza a defesa de certa relativização à feição descritiva na interpretação do Direito Tributário.

Para Folloni, aí também se encontraria o paradigma redutor ao se dizer que a proposição é tão somente descritiva ou prescritiva, pois o reducionismo epistemológico, que prega a redução da realidade complexa, tenta simplificar "um objeto complexo como as proposições jurídicas". A escolha prévia por essa redução significa o abandono de outras possíveis, mutilando a realidade. ${ }^{1789}$

A compreensão (e não a redução) da realidade complexa só pode ser viabilizada através do pensamento que aceite a possibilidade de que determinado objeto de conhecimento possua características antagônicas complementares, buscando, assim, melhor trabalhar com elas. Para o autor, a descritividade e a prescritividade devem ser encaradas como características complementares, mas não excludentes. Para alcançar esse intento, deve-se superar o pensamento redutor, tradicionalmente consubstanciado nos planos sintáticos e semânticos da linguagem, para focar atenções no plano pragmático, este praticamente inexplorado $^{1790}$.

Assim, é possível observar a existência de linguagens descritivas com forte carga prescritiva (dedicada à influência de comportamentos), como é o exemplo de uma tese de doutorado, que, a princípio, situada no plano descritivo, apresenta a função prescritiva ao tentar convencer ou persuadir a banca de que merece aprovação ${ }^{1791}$.

Naturalmente, não se pode também ignorar os reflexos trazidos pelos recentes progressos da Hermenêutica Jurídica na doutrina tributária brasileira contemporânea na temática da interpretação da norma tributária. A literatura, gradualmente impulsiona novas reflexões sobre a carga subjetiva da interpretação normativa ${ }^{1792}$, assim como do próprio reconhecimento tradicional sobre a existência de vaguezas e ambiguidades (textura aberta) na interpretação da norma tributária, conforme se observa na leitura de José Maria Arruda

\footnotetext{
1789 Para uma crítica ao modelo dualista "presctividade x descritividade", recomenda-se a leitura de: FOLLONI, André. Ciência do Direito Tributário. Op.cit., p. 183-188.

${ }^{1790}$ FOLLONI, André. Ciência do Direito Tributário. Op.cit., p. 184-185.

${ }^{1791}$ Idem, p. 188.

1792 José Maria Arruda de Andrade censura a "a mera citação da "carga subjetiva" como um elemento existente, porém marginal. "Ora, tal "carga subjetiva", ou a "humanização do direito", é simplesmente a interpretação/aplicação/concreção do direito (texto normatizado). Não é uma mera adaptação, uma mera atualização, é a realização, o funcionamento, é, em termos müllerianos, a própria metódica jurídica". ANDRADE, José Maria Arruda. Interpretação da Norma Tributária. Op.cit., p. 77 e ss.
} 
de Andrade: "o estudo da hermenêutica jurídica mais recente demonstra certo afastamento de algumas características identificadas como tradicionais da hermenêutica jurídica, sobretudo o caráter absoluto da possibilidade de descoberta de um sentido e alcance preexistente do dispositivo normativo interpretado. Em outros termos, encontra-se com certa facilidade certa flexibilização da afirmação da capacidade de se achar a resposta correta e única ao significado de um texto objeto de análise" ${ }^{, 1793}$.

Naturalmente, não se pretende avançar nas considerações sobre as tendências hermenêuticas contemporâneas frente à doutrina tributária nacional. De qualquer forma, toma-se como exemplo a obra de Arruda de Andrade que, adotando posturas críticas a tais flexibilizações, demonstra claramente que a temática da interpretação jurídica (e suas atualizações) gera atualmente novas perspectivas de investigação e renovação do tema na doutrina tributária nacional, que, em grande parte, estruturou-se, conforme visto, nas perspectivas hermenêuticas tradicionais e, tendencialmente, à influência de determinadas tendências epistemológicas (e metodológicas) aplicadas à interpretação do direito tributário.

\section{A dimensão pragmática da norma tributária, a indução normativa e a consideração econômica.}

A dimensão normativa do direito tributário, por outro lado, teria galgado maior atenção histórica às dimensões sintática e semântica da norma tributária, desprestigiando historicamente a dimensão pragmática. Essa, na realidade, viabilizaria maior atenção aos efeitos da norma tributária na conduta humana, embora estudos voltados à interpretação (e naturalmente na consideração econômica), e na indução normativa (aspecto da extrafiscalidade) já apresentem poucas, mas importantes contribuições na doutrina nacional.

Porém, como já exposto, o processo disciplinar do Direito Tributário não caminha por uma linha reta, mas por ramificações, que se corporificam na construção de diferentes Escolas, cada qual com diferentes premissas epistemológicas, e com respectivos temas de afinidade, muitas vezes diferentes entre si.

${ }^{1793}$ ANDRADE, José Maria Arruda. Interpretação da Norma Tributária. Op.cit., p. 77 e ss. 
Evidentemente, não se pode negar que o estudo do Direito Tributário Brasileiro recebeu poucas contribuições relacionadas à perspectiva pragmática (isto é dos efeitos da norma tributária sobre a conduta do indivíduo), que passa pela própria função desempenhada pela norma tributária.

Porém, com o tempo, passa-se também a elevar a função da norma tributária, assim como a função promocional do Direito ${ }^{1794}$, com Norberto Bobbio, não a limitando, na estrutura lógica, à tradicional função repressiva, mas abrindo espaço para o estudo de normas de encorajamento e desencorajamento de condutas ${ }^{1795}$. Abre-se espaço para a análise funcional do Direito, que passa a elevar a possibilidade de teorias que não se vinculem apenas à estrutura da norma jurídica, mas também à sua função ${ }^{1796}$.

A própria dogmática jurídica tradicional acaba objeto de reflexões críticas, especialmente sob a perspectiva de sua tendência à desvinculação frente à realidade social (em prol do estudo abstrato e formal). Não é por acaso que Tércio Sampaio Ferraz Júnior eleve investigação à função social da dogmática jurídica. ${ }^{1797}$

É claro que, nesse contexto, no âmbito das funções dos tributos, o tratamento ao tema já recebia forte contribuição da Ciência das Finanças, especialmente na construção da dicotomia fiscalidade (tributo com finalidade arrecadatória) e extrafiscalidade (tributo com outras finalidades que não meramente a arrecadatória), ${ }^{1798}$ concepção que repercutiu na

\footnotetext{
${ }_{1794}$ BOBBIO, Norberto. Da Estrutura à Função. Novos Estudos de Teoria do Direito. Op.cit., p. 01-07.

1795 "Tenho razão em considerar que o escasso interesse pelo problema da função social do direito na teoria geral do direito dominante até os nossos dias seja associado, precisamente, ao destaque que os grandes teóricos do direito, de Ihering a Kelsen, deram ao direito como instrumento específico, cuja especificidade não deriva dos fins a que serve, mas do modo pelos quais os fins, quaisquer que sejam, são perseguidos e alcançados". Idem, p. 18-19; p.81-113.

1796“"Enfim, se quisermos deduzir uma consideração final, tal seria que a análise estrutural, atenta às modificações da estrutura, e a análise funcional, atenta às modificações da função, devem ser continuamente alimentadas e avançar lado a lado, sem que a primeira, como ocorreu no passado, eclipse a segunda, e sem que a segunda eclipse a primeira como poderia ocorrer em uma inversão de perspectivas a que os hábitos, as modas, o prazer do novo pelo novo, são particularmente favoráveis". BOBBIO, Norberto. Da Estrutura à Função. Novos Estudos de Teoria do Direito. Op.cit., p. 113.

${ }^{1797}$ Para Tércio Sampaio Ferraz Júnior, através de sólida reflexão sobre os fundamentos históricos das teorias jurídicas que levam ao dogmatismo jurídico, o elevado grau de abstração (que leva a um extremo formalismo) adotado na dogmática jurídica para enfrentar a complexidade sócio-política vigente, leva a determinados problemas, e, nesse sentido, o próprio conceito de Estado de Direito perde sua funcionalidade, “(...) na medida em que a sua conceituação formal deixa em aberto inúmeros problemas que apenas ampliam o papel do arbítrio, sem que a Dogmática forneça os parâmetros de controle. Diante de dificuldades deste gênero, é que se entreabre dúvidas a respeito do futuro da dogmática”. JÚNIOR, Tércio Sampaio Ferraz. Função Social da Dogmática Jurídica. São Paulo: Max Limonad, 1998, p.14-15; p. 194-195.

${ }^{1798}$ DEODATO, Alberto. As funções extrafiscais do imposto. Belo Horizonte: Imprensa Oficial, 1949, p. 2021. Newmark, Fritz. Princípios de la imposición. Op.cit., p. 46 e seguintes.
} 
literatura do Direito Tributário ${ }^{1799}$ (inclusive no Brasil). A extrafiscalidade passa a vincular o tributo a finalidades econômicas e sociais.

Assim, a função dos tributos recebeu, historicamente, poucos estudos exclusivamente dedicados a esclarecê-lo no Direito Tributário Brasileiro, mas não se pode dizer que foi totalmente ignorada ${ }^{1800}$.

No século XXI, Luís Eduardo Schoueri, a propósito do concurso de Titular da Cadeira de Legislação Tributária da Universidade de São Paulo, formulou a Tese intitulada: "Contribuição ao Estudo das Normas Tributárias Indutoras".

Inspirado na lição de Tércio Sampaio Ferraz Júnior (para quem o estudo da norma jurídica pode ocorrer através de critérios sintáticos (relevância, subordinação e estrutura), semânticos (destinatário, matéria, espaço e tempo) e pragmáticos ("força de incidência, finalidade e funtor) ${ }^{" 1801}{ }_{-}^{1802}$, reconhece que sua análise se perfilha na última perspectiva, buscando a "interação”: “(...) no lugar de buscar a estrutura da norma tributária indutora (o que se fará apenas de modo superficial) ou sua relação com outras normas do ordenamento, busca-se sua interação com o destinatário. A análise pragmática é especialmente útil quando se terá em conta que o objeto do estudo, normas tributárias indutoras, pressupõe, como se verá, a busca de uma reação da parte de seu destinatário (...)", que exige o conhecimento dos efeitos da norma tributária sobre o contribuinte.

\footnotetext{
${ }^{1799}$ Myrbach-Rheinfeld, Franz Von. Op.cit., p. 107-108. Blumenstein, Ernst. Op.cit., p. 164. HenSEL, Albert. Op.cit., p. 344. GIANNINI, A. D. I concetti fondamentali del diritto tributario. Op.cit., p. 59; 357. BIELSA, Rafael. Estudios de derecho público. II. Direito fiscal. Buenos Aires: Depalma, 1951, p. 357-364. PUGLIÈSE, Mario. Instituciones de derecho financiero. Op.cit., p. 62-63; 102. GRIZIOTTI, Benvenuto. Princípios de política, derecho y ciência de la hacienda. Trad. Enrique R. Mata. Madrid: Instituto Editorial Reus, 1958, p. 5-6. SAINZ DE BUJANDA, Fernando. Derecho financiero y politica fiscal. In: Hacienda y derecho. T. II, Op.cit., p. 37-39.

${ }^{1800} \mathrm{O}$ reconhecimento da extrafiscalidade na literatura tributária brasileira pode ser observado em: BALEEIRO, Aliomar. Uma introdução à Ciência das Finanças. Op.cit., p. 30-31. BECKER, Alfredo Augusto. Teoria geral do direito tributário. Op.cit., p. 541-545. NOGUEIRA, Ruy Barbosa. Curso de direito tributário. Op.cit., p. 184-187. TORRES, Ricardo Lobo. Curso de direito financeiro e tributário. 12. ed. Rio de Janeiro: Renovar, 2005, p. 6. MARTINS, Ives Gandra da Silva. Teoria da imposição tributária. 2. ed. São Paulo: LTr, 1998, p. 163 e ss. FALCÃO, Raimundo Bezerra. Op.cit., p. 20. DEODATO, Alberto. As Funções Extrafiscais do Imposto. Op.cit. p. 49. Note-se, contudo, que, à exceção de Raimundo Bezerra Falcão e Alberto Deodato (no âmbito da Ciência das Finanças), nenhum outro autor concedeu atenção exclusiva ao tema, tratando-o incidentalmente em objetos de pesquisa mais amplos ou em manuais didáticos. ${ }^{1801}$ SCHOUERI, Luís Eduardo. Normas tributárias indutoras e intervenção econômica. Rio de Janeiro: Forense, 2005, p. 04 e seguintes.

${ }^{1802} \mathrm{O}$ raciocínio de Schoueri sob as perspectivas sintática, semântica e pragmática, para fins didáticos, pode ser observado também em: JÚNIOR, Tércio Sampaio Ferraz. Introdução ao Estudo do Direito. Op.cit., p. 123 e seguintes.
} 
Note-se, contudo, que, no âmbito do enfoque pragmático, ecoa a abertura do diálogo com outros ramos do conhecimento: "Por tal razão, propõe-se a presente pesquisa a não deixar de lado descobertas efetuadas por outras ciências especialmente as da economia e das finanças públicas. Tendo este estudo o caráter jurídico, não se pretende discutir a metodologia ou o acerto dos trabalhos realizados naquelas áreas do conhecimento; seus resultados serão tomados, como dados táticos, os quais cabe ao jurista valorar juridicamente". Em outras palavras, reconhecendo a complexidade do fenômeno financeiro, eleva os avanços das Finanças Públicas (Ciência das Finanças) “(...) como forma de compreensão do fenômeno regulado pelo ordenamento jurídico contemporâneo (...)", ainda que não deixe de lado os avanços proporcionados pela literatura jurídica entre o final do século XX e o início do século XXI. ${ }^{1803}$

Para Schoueri, no estudo das funções da norma tributária, essas podem se enquadrar em distribuidoras da carga tributárias, indutoras de comportamentos ou simplificadoras da tributação $^{1804}$, o que leva o autor, na análise da função extrafiscal (gênero) a dividi-la em duas perspectivas normativas: a) normas tributárias de indução de comportamentos (normas extrafiscais em sentido estrito, vinculadas à intervenção econômica); b) normas de política social $^{1805}$.

A indução de comportamentos trazida pela norma tributária, evidentemente, traz em seu âmago a própria perspectiva pragmática defendida no plano linguístico-normativo.

Contudo, não se pode negar que, embora os estudos voltados à função da norma jurídica (e tributária) agreguem considerável atenção à função pragmática da norma, a tendência histórica da literatura tributária caminhou pelas investigações pautadas nas dimensões sintáticas e semânticas da norma tributária.

Essa tendência, caminhando à pragmática, não obstante, centra-se na crítica fundamental de que a maior parte da doutrina tributária (sobretudo no século XX) esteve

\footnotetext{
${ }^{1803}$ Assim, por exemplo, para Schoueri, na análise de determinado incentivo fiscal, não se deixa de lado eventual descoberta de que essa ferramenta (o incentivo fiscal) seja usada para beneficiar contribuintes de maior capacidade contributiva. A partir dessa verificação, Schoueri defende a averiguação desses dados fáticos a partir da valoração jurídica com vistas a averiguar se o incentivo afeta o princípio da isonomia no âmbito do ordenamento jurídico. SCHOUERI, Luís Eduardo. Normas tributárias indutoras e intervenção econômica. Op.cit., p. 40.

1804 Idem.

${ }^{1805}$ Nesse sentido, buscando investigar as normas tributárias indutoras, especificamente, enquanto instrumentos a serviço do Estado na intervenção por indução, são, ao mesmo tempo, “(...) relativos a tributos e portanto sujeitas a princípios e regras próprias do campo tributário”. Ibidem, p. 32-34.
} 
concentrada tão somente nas investigações com enfoque exclusivo ou prioritário das perspectivas semânticas e sintáticas da norma tributária, em detrimento da pragmática da norma tributária, que restaria pouco explorada na literatura nacional.

Essa crítica tem sido observada por autores do porte de Marco Aurélio Greco ${ }^{1806}$, não somente como enfoque que não se limite à perspectiva sintática e semântica dos estudos tributários, mas também na elevação do pragmatismo normativo como instrumento apto à superação do formalismo jurídico (vislumbrando maior atenção ao diálogo entre disciplinas conexas ao Direito Tributário) disseminado a partir da Escola da PUC-SP (e que se concentrou, historicamente, na perspectiva sintática e semântica da norma tributária), assim como do próprio Construtivismo lógico-semântico.

Da mesma forma, mas pautando-se em premissas epistemológicas distintas (sobretudo por fundamento na epistemologia da complexidade) a defesa de novos estudos sob a perspectiva pragmática da norma tributária tem sido defendida por André Folloni e José Souto Maior Borges ${ }^{1807}$, que denunciam a expressa preferência por estudos tributários focados na Semântica (teoria do significado normativo), na Sintaxe (teoria das relações hierárquicas internomativas), em detrimento da Pragmática (teoria da conduta normada, que considera a preocupação com os efeitos da linguagem na comunidade de usuários). Nesses dois campos, segundo Souto Maior Borges, os estudos tributários estariam praticamente esgotados.

Para os autores, no intuito de superar o impasse dogmático, caminhando para o delineamento do plano pragmático (mas sem considerá-lo isoladamente, o que causaria nova redução), é preciso pensar em complexidade, sugerindo, portanto, outro paradigma epistemológico substitutivo daquele caracteristicamente redutor, o paradigma da complexidade $^{1808}$ e sua aplicação ao estudo do Direito Tributário no Brasil ${ }^{1809}{ }^{1810}$.

\footnotetext{
${ }^{1806}$ GRECO, Marco Aurélio. Crise do Formalismo no Direito Tributário Brasileiro. n.1. Revista da PGFN. Brasília: PGFN, 2011, p. 09-19.

${ }^{1807}$ BORGES, José Souto Maior. Um ensaio interdisciplinar do Direito Tributário: Superação da Dogmática. In: Revista Dialética de Direito Tributário. n.211. Valdir de Oliveira Rocha (Coord.). São Paulo: Dialética, 2013, p. 106-107.

${ }^{1808}$ FOLLONI, André. Ciência do Direito Tributário no Brasil. Op.cit., p. 383.

${ }^{1809}$ Criticando as características do reducionismo epistemológico decorrente do paradigma da Modernidade, que se caracterizariam por quatro princípios (princípio de ordem, princípio de separação; princípio da redução e princípio de validade da lógica-dedutivo-indutiva-identitária), e que estariam presentes na ciência do direito tributário no Brasil, a superação epistemológica pelo paradigma da complexidade incutiria a necessidade de se reorganizar a compreensão do fenômeno normativo “(...) além da unidimensionalidade da
} 
Não se pode negar que reside aí campo amplíssimo para novos estudos voltados ao delineamento do plano pragmático do direito tributário, destinado a compreender os efeitos que a norma jurídica causa em seus receptores.

Tal abertura epistemológica leva também ao reconhecimento de José Souto Maior Borges da importância da consideração econômica, e como ela foi gradativamente excluída, sob o pretexto de confundir o jurista, e o risco de misturar direito e economia. Nesse ponto, Souto, reconhece que a consideração econômica, no método de ampliação de complexidades, não deve ser, a priori, excluída ${ }^{1811}$.

Mas, ainda que procedentes as críticas levantadas pelos autores, deve-se reconhecer que a perspectiva pragmática, embora pouco estudada sob as premissas do dogmatismo normativo contemporâneo, e notadamente na Escola da PUC-SP, estudos direcionados a essa perspectiva já podiam ser verificados, seja considerando expressamente a feição pragmática da norma tributária, seja simplesmente aplicando estudos atentos aos efeitos normativos que recaem sobre a conduta individual, que foi fortemente estudada no âmbito da extrafiscalidade.

De qualquer forma esse redirecionamento da literatura tributária no plano pragmático da norma tributária permite também, teoricamente, que se reapresente o tema da consideração econômica, motivado também pela inclusão legislativa, na virada do

norma (...)", fazendo-os respeitar outras dimensões do Direito Tributário, que seriam organizadas em seis categorias (ou níveis de complexidade): $1^{\mathrm{a}}$ ) primeiro nível: neles encontram-se estudos que tratam dos diversos institutos do Direito Tributário sob a perspectiva estrita ou tradicional (normas relativas à instituição e arrecadação de tributos, restrita ao direito tributário, mas já visto com grau de complexidade); $2^{\mathrm{a}}$ ) segundo nível: supera o âmbito estrito do Direito Tributário, mantendo ainda o sentido normativista, mas inclui outras proposições jurídico-normativas que se relacionam às normas tributárias (Direito Administrativo, Financeiro, Constitucional) e demais ramos dogmáticos do Direito (intertextualidade interna); $3^{\mathrm{a}}$ ) terceiro nível: ultrapassa os limites de um ordenamento jurídico, ainda que permaneça no âmbito do direito positivo (estudos de Direito Tributário Internacional, Comunitário ou Comparado); 4 ${ }^{a}$ ) quarto nível: caracteriza-se pela abertura do Direito Tributário à outras ciências (Economia, Sociologia, Pedagogia, História do Direito, Teoria Geral do Direito, etc), mas mantendo-se no plano científico; $5^{\mathrm{a}}$ ) quinto nível: congrega o Direito Tributário “(...) a partir de informações desenvolvidas no âmbito do saber racional não científico (Filosofia, Ética e Filosofia do Direito), saindo do plano jurídico e do plano científico); $6^{a}$ ) sexto nível: busca elementos não apenas racionais mas também estéticos (literário, senso comum, a arte), superando o dualismo entre Arte e Direito. FOLLONI, André. Ciência do Direito Tributário no Brasil. Op.cit., p. 385-387.

${ }^{1810}$ Em síntese: "Para a boa compreensão, é necessário complexificar o estudo. Considerar a proposição como um proferimento, não apenas como uma simples frase, à parte de todas essas contingências. Uma vez que todo ato linguístico pode produzir efeitos no ouvinte, mesmo que à revelia das intenções de seu autor, a compreensão das dimensões perlocucionárias desse ato depende de considerar, amplamente, seus efeitos nos sujeitos". Idem, p. 188.

${ }_{1811}$ BORGES, José Souto Maior. Um ensaio interdisciplinar do Direito Tributário: Superação da Dogmática. Op.cit., p. 113. 
século XX para o XXI, do artigo 116, parágrafo único do Código Tributário Nacional (a chamada "norma antielisão"). Não obstante a ausência de regulação normativa posterior, esse dispositivo impulsiona recentes estudos no século XXI - contrários ou favoráveis - ao dispositivo, gerando para muitos estudiosos a necessidade de reconsiderar (ainda que criticamente) o dispositivo à luz das construções históricas sobre o tema.

Assim, sobrevindo a expressa previsão legislativa trazida pela lei complementar n.104/2001 (parágrafo único, artigo 116, CTN), que trouxe a chamada "norma antielisão", permitindo à autoridade administrativa desconsiderar atos ou negócios jurídicos, conforme as circunstâncias, atentando apenas à natureza econômica camuflada naquelas operações $^{1812}$, bem como pelo reimpulso da literatura sob a perspectiva pragmática do estudo da norma tributária, e pela própria renovação do diálogo sobre a influência dos conceitos de direito privado sobre o direito tributário, pode-se dizer que tais fatores impulsionam a publicação de estudos destinados à refletir sobre essa nova realidade legislativa.

Ao mesmo tempo, recentes posições podem ser observadas na literatura tributária contemporânea $^{1813}$ (ainda que muitas delas repercutam e atualizem tendências tradicionalmente refratárias à questão, como Heleno Taveira Tôrres ${ }^{1814}$, James Marins ${ }^{1815}$, Paulo de Barros Carvalho ${ }^{1816}$ e Alberto Xavier ${ }^{1817}$ ).

Nesse quadro, seria a consideração econômica caminho óbvio para alcançar determinado resultado visado pelo Direito Tributário ou apenas flexibilização desnecessária e um desserviço à segurança jurídica?

Os debates sobre a utilização do mecanismo, no Direito Tributário, ainda passam pelos mesmos argumentos, seja defendida como mecanismo apto a ser utilizado, especialmente no âmbito de conceitos autônomos de Direito Tributário ${ }^{1818}$, seja refutado

1812 TEODOROVICZ, Jeferson. Autonomia do Direito Tributário: Revisitando os conceitos de direito privado em direito tributário. Revista Direito Tributário Atual n.30. IBDT. São Paulo: Dialética, 2014, p. 180 e seguintes.

1813 GRECO, Marco Aurelio. Planejamento Tributário. São Paulo: Dialética, 2011, p. 30 e ss.

${ }^{1814}$ TÔRRES, Heleno Taveira. Direito Tributário e Direito Privado - Autonomia Privada: simulação e elusão tributária. Op.cit., p. 78 e seguintes.

${ }^{1815}$ MARINS, James. Elisão Tributaria e sua Regulação. São Paulo: Dialética, 2002, p. 10 e seguintes.

${ }_{1816}$ CARVALHO, Paulo de Barros. Direito Tributário: Linguagem e método. Op.,cit., p.202-205.

1817 XAVIER, Alberto. Tipicidade da Tributação, Simulação e Norma Antielisiva. Op.cit., 2002, p.39 e seguintes.

${ }^{1818}$ NOGUEIRA, Liz Loli Cabral. Op.cit., p. 362-363. 
por violar a proibição da analogia no direito tributário ${ }^{1819}$, ou por supostamente promover o raciocínio tipológico no Direito Tributário ${ }^{1820}$, ou pela consideração de que a interpretação do Direito Tributário dever-se-ia dar por mecanismos propriamente jurídicos ${ }^{1821}$.

Por outro lado, já aparece parcela doutrinária, especialmente aquela familiarizada com as contribuições germânicas ao tema, que enxerga a possibilidade da consideração econômica ponderada pelas limitações contemporâneas dos princípios, regras e valores fundamentais ao ordenamento jurídico. ${ }^{1822}{ }_{-}{ }^{1823}$

Entre a doutrina tributária contemporânea, Fernando Aurelio Zilveti aduz que “(...) o conteúdo econômico da norma tem relevante importância para o Direito Tributário”. Para o autor, o critério econômico aplica-se ao método teleológico, no sentido de “(...) apanhar a função de cada dispositivo legal dentro da estrutura da ordem jurídico-tributária e em seu relacionamento com as demais partes da ordem jurídica”. Assim, o critério econômico, existindo legalmente, torna-se útil critério para o aplicador da norma tributária ${ }^{1824}$.

Mas, naturalmente, existindo eventuais divergências entre conceitos de Direito Civil e Direito Tributário, para Zilveti, existiria a necessidade de integração entre os dois ramos do direito conforme o princípio da igualdade na tributação, que, por sua vez, se vincularia ao escopo (da interpretação segundo a consideração econômica) “(...) da apuração efetiva da capacidade contributiva através da hermenêutica"1825.

${ }^{1819}$ XAVIER, Alberto. Tipicidade da Tributação, Simulação e Norma Antielisiva. Op.cit., p. 42-43.

${ }^{1820}$ TORRES, Heleno Taveira. Direito Tributário e Direito Privado. Autonomia Privada. Simulação. Elusão Tributária. Op.cit., p.205-213.

${ }^{1821}$ GRAU, Eros Roberto. Interpretação do Direito e Interpretação do Direito Tributário. Op.cit., p. 129-130.

${ }^{1822}$ TORRES, Ricardo Lobo. Curso de Direito Financeiro e Tributário. Op.cit., p. 154-155. Para uma contextualização histórica da interpretação econômica também conferir: TORRES, Ricardo Lobo. Normas de Interpretação e Integração do Direito Tributário. Op.cit., p. 143 e seguintes.

${ }^{1823}$ ZILVETI, Fernando Aurelio. Obrigação Tributária: Fato Gerador e Tipo. Op.cit., p. 181 e seguintes. ${ }^{1824}$ Refletindo sobre o debate na óptica da Sociedade de Riscos, onde o Direito Público e o Direito Privado “(...) se fundem e refundem em Direito Público-Privado, em que não há espaço para separações estanques que prejudiquem o interesse tutelado (...)" vincula diretamente a norma à interpretação justa. E a justiça pode revelar a necessidade de prescindir da forma do Direito Privado em determinada situação econômica, acaso se revele a finalidade de resultado "atípico ao escopo da tributação". Em outras palavras: "O critério da consideração econômica significa, portanto, interpretação mais livre de conceitos jurídicos, mormente daqueles com significado flexível, com o objetivo de abranger estruturações iguais, o que não importa na sobreposição do Direito Tributário sobre outros ramos do Direito, como o Direito Civil”. ZILVETI, Fernando Aurelio. Obrigação Tributária - Fato Gerador e Tipo. Op.cit., p. 188-189.

${ }^{1825}$ Idem, p. 190. 
É justamente nesse contexto que Luís Eduardo Schoueri, a propósito da consideração econômica em matéria tributária, assevera que hoje é consenso na doutrina que o Direito Tributário e o Direito Civil ${ }^{1826}$ são partes de uma única ordem jurídica, o que implica que os princípios fundamentais do Direito Civil sejam respeitados pelo Direito Tributário, ao mesmo tempo em que não se admite que o Direito Civil se sobreponha aos princípios fundamentais do Direito Tributário. Em outras palavras: "Em caso de concorrência entre os princípios, adota-se a ponderação entre uns e outros, sem que se tenha prevalência a priori"'. 1827

Assim, a consideração econômica, remanejada através da perspectiva pragmática da norma tributária e, por outro lado, pela própria previsão legislativa (parágrafo único do artigo 116, CTN, mas que ainda pende de regulamentação legislativa), e pelas novas reflexões oferecidas frente ao diálogo entre conceitos de direito privado e de direito tributário, oferece reaproximação à literatura tributária contemporânea, seja pela sua defesa (ainda que ponderada) ou sua crítica, fundamentada na própria segurança jurídica, que, naturalmente, aparece contemporaneamente permeada por diferentes fatores externos.

Por outro lado, a consolidação disciplinar do Direito Tributário Brasileiro contemporâneo também merece ser analisada a respeito da importante questão da interdisciplinaridade frente aos estudos de direito tributário.

Acredita-se que o debate contribui fortemente para o aperfeiçoamento disciplinar do Direito Tributário Brasileiro e, por esse motivo, as próximas linhas serão dedicadas à questão da interdisciplinaridade no processo disciplinar do Direito Tributário Brasileiro contemporâneo.

\footnotetext{
${ }^{1826}$ Sobre as relações entre o Direito Civil e o Direito Tributário brasileiro, recomenda-se também a leitura da seguinte obra coletiva: GRUPENMACHER, Betina Treiger (Coord). Direito Tributário e o Novo Código Civil. São Paulo: Quartier Latin, 2004.

${ }^{1827}$ Contextualiza Schoueri que: "A esse resultado, entretanto, não se chegou de imediato: por muito tempo, o Direito Tributário foi visto como um "Direito de Sobreposição", o que implicaria que a tributação incidiria sobre situações jurídicas, estas entendidas como aquelas reguladas por outro ramo do direito. Assim, havia uma espécie de subordinação ao Direito Privado, já que se acreditava que as leis tributárias fariam referência a fenômenos do Direito Privado (reenvio) e apenas na ocorrência destes é que seria possível que aquelas fossem aplicadas. Noutras palavras: na hipótese tributária haveria, necessariamente, um fato jurídico de natureza privada e, na inexistência (ou invalidade) deste, não haveria que cogitar de tributação". Depois de décadas de amadurecimento, os estudos do Direito Tributário, no que tange à consideração econômica, manifestam maior consonância no sentido de “(...) que o legislador tributário é livre para valer-se ou não, das estruturas de direito privado. É a partir do contexto que se concluirá acerca da decisão do legislador, descabendo qualquer conclusão a priori”. SCHOUERI, Luís Eduardo. Direito Tributário. $2^{\mathrm{a}}$ Ed. São Paulo: Saraiva, 2012, p.648 e seguintes.
} 


\section{7 - O processo disciplinar do direito tributário brasileiro diante do desafio interdisciplinar}

\subsection{Considerações iniciais sobre a "interdisciplinaridade" praticada no processo histórico-disciplinar do Direito Tributário Brasileiro no século XX.}

O recurso a elementos extrajurídicos para a consideração do raciocínio jurídicotributário nunca foi novidade no processo disciplinar do Direito Tributário Brasileiro. Se antes da consolidação disciplinar, o que se via, até a década de quarenta, era verdadeiro sincretismo disciplinar, sem sequer a consideração do direito tributário enquanto disciplina jurídica autônoma da Ciência das Finanças, o processo disciplinar, quando se inicia a difusão da autonomia (teórica) do direito tributário, mantém, em muitos aspectos graduais e tendenciais experiências com conhecimentos obtidos em outras ciências.

Além da evidente consideração econômica dos fatos, que denota especial atenção dos tributaristas brasileiros aos elementos econômicos (e, sobretudo fáticos) da tributação, não se pode deixar de considerar que a atenção a conhecimentos reunidos ou consolidados em outro ramo do conhecimento também era elemento a ser reconhecido mesmo em linhas de estudo que buscavam a emancipação jurídica plena do Direito Tributário em face da perniciosa influência da Ciência das Finanças.

Preliminarmente, a interdisciplinaridade objeto de estudo neste tópico não é a "interdisciplinaridade jurídica"1828, que já vem sendo desenvolvida no âmbito do diálogo entr direito tributário e outra disciplinas jurídicas afins. A interdisciplinaridade jurídica atua no interior da Ciência Jurídica. Seja entre o direito privado, o direito administrativo, constitucional, financeiro, econômico, processual, penal, etc., sempre hovue atenção dos estudiosos brasileiros sobre as relações jurídicas entre ramos de um mesmo ordenamento.

A interdisciplinaridade, evidentemente, no presente estudo, orienta-se pela análise do diálogo (recíproco) entre o Direito Tributário e outros ramos do conhecimento (extrajurídicos), que também, de certa forma, já podiam ser visualizados na literatura.

\footnotetext{
${ }^{1828}$ Exemplo onde a interdisciplinaridade jurídica é expressamente aplicada através do diálogo entre direito tributário e outros ramos jurídicos pode ser observado na coletânea de pareceres publicada por Sacha Calmon Navarro Coêlho. COÊLHO, Sacha Calmon Navarro. Direito Tributário Interdisciplinar. Rio de Janeiro: Forense, 1999, p. 01 e ss.
} 
Se Ruy Barbosa Nogueira, por vezes, levantava lições de Miguel Reale no âmbito da Filosofia do Direito ${ }^{1829}$, não é diferente também a atenção que Geraldo Ataliba mantivesse com o positivismo jurídico e, naturalmente, com a lógica jurídica (substrato formal da teoria do conhecimento), sobretudo pela influência de Hans Kelsen, Pontes de Miranda e Lourival Vilanova ${ }^{1830}$.

Paulo de Barros Carvalho, José Souto Maior Borges, Ricardo Lobo Torres e Ives Gandra Martins igualmente, mas cada qual com suas devidas ponderações, caminhavam e ainda caminham - fortemente embasados na consideração (e no diálogo) com conhecimentos obtidos no campo da filosofia e na epistemologia aplicados ao estudo do direito tributário brasileiro.

Quando Paulo de Barros Carvalho analisa o direito tributário a partir das conquistas filosóficas e epistemológicas construídas no Círculo de Viena, está trazendo para o Direito Tributário inequívocas considerações extrajurídicas, com importantíssimas consequências para o amadurecimento da disciplina no Brasil. Da mesma forma, quando o celebrado autor adota técnicas linguísticas para a interpretação do Direito, também promove aproximação a outro campo do conhecimento (sintática e semântica) aplicada ao Direito Tributário $^{1831}$.

Quando Ricardo Lobo Torres invoca o Círculo Kantiano para celebrar o póspositivismo axiológico pautado em valores no estudo do Direito Tributário Contemporâneo, igualmente promove aproximação com a Filosofia, sobretudo a Filosofia dos Valores, e os estudos no Direito Tributário ${ }^{1832}$, ou mesmo quando considera, à luz da Sociologia, os reflexos da sociedade de riscos no Direito Tributário Contemporâneo, está considerando elementos exteriores (e contribuições teóricas externas) ao estudo jurídico do direito tributário brasileiro ${ }^{1833}$.

\footnotetext{
${ }^{1829}$ NOGUEIRA, Ruy Barbosa. Curso de Direito Tributário. Op.cit., p. 04-05. NOGUEIRA, Ruy Barbosa. Miguel Reale e o Direito Tributário. In: Imunidades. Contra Impostos na Constituição Anterior e sua disciplina mais completa na Constituição de 1988. $2^{\text {a }}$ Ed. São Paulo: Saraiva, 1992, p.191 e seguintes.

${ }^{1830}$ ATALIBA, Geraldo. Sistema Constitucional Tributário Brasileiro. $2^{\circ}$ Edição. São Paulo: Editora Revista dos Tribunais, 1968, p. 01 e seguintes.

${ }^{1831}$ CARVALHO, Paulo de Barros. Direito Tributário: Linguagem e Método. São Paulo: Noeses, 2008, p. 23 e seguintes.

${ }^{1832}$ TORRES, Ricardo Lobo. Os Direitos Humanos e a Tributação. In: Tratado de Direito Constitucional Financeiro e Tributário, V. 3 Rio de Janeiro: Renovar, 1998, p. 27 e ss.

${ }^{1833}$ TORRES, Ricardo Lobo. Legalidade Tributária e Riscos Sociais. Revista Dialética de Direito Tributário, v. 59, 2000, p. 95-112.
} 
Quando José Souto Maior Borges constrói a "Hermenêutica Histórica" ao estudo do Direito Tributário, igualmente busca em recursos consolidados na história a aplicação desses (ainda que com ponderações) ao estudo do Direito Tributário ${ }^{1834}$.

Quando Ives Gandra da Silva Martins invoca o jusnaturalismo e o diálogo entre Direito Tributário e Economia como elementos necessários ao progresso da disciplina também se pode observar a aproximação entre o Direito Tributário e outros campos do conhecimento $^{1835}{ }^{1836}$.

E mesmo na consideração ética nas relações tributárias pode ser identificada na própria defesa da segurança jurídica nas relações tributárias. O discurso da proteção da capacidade contributiva, nesse contexto, apresenta inerente discurso de natureza econômica. Mas nem por isso também afasta o discurso ético (mínimo existencial, por exemplo). E praticamente nenhum tributarista brasileiro ousou afastar-se da elevação da capacidade contributiva, mesmo os mais afastados ao diálogo com a Ciência das Finanças.

Por isso, de certa forma, defender um direito constitucional tributário permeado por princípios orientadores da atividade tributária, ou decorrentes de direitos fundamentais, que parece ser praticamente uníssono na literatura tributária nacional, também caminha inevitavelmente pela consideração ética na tributação, o que não obsta ainda os rasos estudos dedicados expressamente à promoção da ética na relação tributária, que ainda precisa de urgentes aperfeiçoamentos.

Em outras palavras, o processo disciplinar do Direito Tributário brasileiro jamais renegou (pelo menos totalmente) a consideração de outros ramos do conhecimento. O verdadeiro dilema vivenciado no âmbito do diálogo entre disciplinas, por motivos históricos compreensíveis, deveu-se ao debate entre o Direito Tributário e a Ciência das Finanças.

É claro que o formalismo e o positivismo jurídico, em todas as suas vertentes, prezam pelo afastamento da consideração (ainda que com ponderações) do direito perante outros ramos do conhecimento.

Sempre foi assim, desde o século XIX, e permanecem, ainda que com gradações, no século XX. É claro que, diante das peculiaridades históricas do processo disciplinar do

\footnotetext{
${ }^{1834}$ BORGES, José Souto Maior. Hermenêutica Histórica no Direito Tributário. In: Revista Tributária e de Finanças Públicas. n. 31, São Paulo: Rt, 2000, p. 112 e seguintes.

${ }^{1835}$ MARTINS, Ives Gandra da Silva. A missão do jurista e o Direito Natural. In: Direito Econômico e Tributário. Comentários e Pareceres. Co-Edição - FIEO - Fundação Instituto de Ensino para Osasco. São Paulo: Resenha Tributária, 1982, p. xv-xx.

${ }^{1836}$ MARTINS, Ives Gandra. Uma Teoria do Tributo. São Paulo: Quartier Latin, 2005, p.436.
} 
Direito Tributário e, notadamente, no Direito Tributário Brasileiro, o foco das atenções foi sem dúvida alguma a influência da Ciência das Finanças, ou dos aspectos econômicos da tributação.

Nesse quadro, o progressivo afastamento do Direito Tributário perante a Ciência das Finanças, hodiernamente, identifica-se com o afastamento do diálogo entre Direito Tributário e os efeitos econômicos do tributo. Esse sim, ainda guarda fortes restrições, para forte parcela doutrinária.

Porém, uma importante ressalva deve ser tomada como pressuposta no desenvolvimento do presente tópico. O processo histórico-disciplinar do Direito Tributário mantém, com ponderações, a consideração a elementos extrajurídicos (seja a filosofia, a lógica, a linguística, a ética, a consideração econômica, etc.).

Contudo, seriam esses estudos propriamente designados como interdisciplinares, conforme poderia supor a literatura tributária contemporânea?

A verdade, como se observará nas linhas seguintes, é que a interdisciplinaridade, embora eventualmente mencionada por estudiosos contemporâneos na literatura tributária nacional, por outro lado, no âmbito da epistemologia e da pedagogia (onde a interdisciplinaridade é efetivamente estudada e aplicada) somente se consolida na década de setenta do século XX, e influencia específicas técnicas de estudos que apresentam poucas conexões com as experiências jurídico-tributárias nacionais alinhadas a aqueles contextos históricos analisados nos capítulos anteriores.

Os fatores supramencionados, oriundos da nova realidade contemporânea prevalecente no século XXI, incursionam novas reflexões sobre o debate interdisciplinar, ganhando apoio de crescente massa de estudiosos, que passam a elevá-la, ainda que sem apresentar com clareza, muitas vezes, as premissas epistemológicas e metodológicas fundamentais a serem aplicadas (e os obstáculos a serem ponderados) no empreendimento interdisciplinar à luz das recentes contribuições teóricas ao tema construídas na epistemologia e na pedagogia interdisciplinar.

De qualquer forma, feitas as ressalvas acima, passa-se a perceber que, sem avançar para novas perspectivas de estudo, sem permitir-se a abertura ao considerar as possíveis contribuições de outros ramos do conhecimento, os estudiosos do fenômeno tributário não conseguirão responder com eficiência determinados problemas que surgem na realidade contemporânea. 


\subsection{Recentes esforços pela elevação da interdisciplinaridade no Direito Tributário Brasileiro}

Nos itens anteriores foram identificados alguns fatores fundamentais emanados por esse contexto: a repercussão de "novos direitos fundamentais", os reflexos da "globalização", do Estado Social Democrático Fiscal, da sociedade de risco. Todos trazem indiscutíveis reflexos aos estudos tributários contemporâneos e, sem dúvida alguma, apontam o caminho da abertura disciplinar, favorecendo o desenvolvimento de novos "subramos do direito tributário", seja impulsionando a apresentação de novos problemas que não poderiam ser solucionados pela tradição disciplinar consolidada no século XX.

Como já informado, a consideração de elementos extrajurídicos ao raciocínio jurídico do tributarista não é novidade, e podia ser observado claramente mesmo em linhas de pesquisa que se assumiam como "kelsenianas".

A verdadeira novidade, contudo, que serve para distinguir as aproximações multidisciplinares ou pluridisciplinares ao Direito Tributário no decorrer do processo histórico disciplinar do século XX é referente ao contexto histórico em que foram consolidadas. E é justamente em ambiente histórico posterior e rico de novas circunstâncias (por vezes problemáticas), e não necessariamente identificáveis com os fatores históricos antecedentes, é que a elevação da promoção da "interdisciplinaridade" deve ser compreendida.

A “interdisciplinaridade" levantada por leva crescente de juristas busca responder a novos problemas verificados nos últimos anos. É consequência direta desses fenômenos, onde se permeia a busca de soluções para novos problemas não claramente identificados (ou mesmo existentes) nos períodos históricos anteriores.

Assim, gradativamente, parcela da literatura tributária brasileira começa sinalizar abertura expressa aos estudos interdisciplinares. Mas o sentido de interdisciplinaridade trazido por autores contemporâneos, contudo, aproxima-se mais das teorias sobre o tema construídas na epistemologia e pedagogia, ainda que sem fazer o devido reconhecimento, na maior parte dos casos. 
Nesse contexto, no século XXI, alguns esforços de estudiosos abertos ao diálogo com outros ramos do conhecimento podem ser identificados nas obras de Roberto Ferraz $^{1837}$, seja na consideração na origem e na destinação dos tributos ${ }^{1838}$ e James Marins ${ }^{1839}$, seja na defesa de uma conduta ponderada aos valores voltados à diminuição da vulnerabilidade do contribuinte nas relações tributárias (complexas por excelência), seja na promoção da justiça tributária e na consolidação da Política Jurídico-Tributária. ${ }^{1840 \_}{ }^{1841}$

E mais do que isso, as novas tendências epistemológicas manifestadas pela doutrina tributária contemporânea começam a fazer surtir efeitos contrários ao reducionismo epistemológico prevalecente no século XX, conforme atesta Humberto Ávila, que também parece caminhar para essa perspectiva ao prefaciar a obra de André Folloni ${ }^{1842}$.

Da mesma forma pode-se observar na obra de Renato Lopes Becho, ao apontar a existência de uma Filosofia do Direito Tributário, enquanto atitude filosófica para o direito tributário, identificando as diferentes premissas filosófico-jurídicas que inspiram a produção doutrinária (e jurisprudencial) no direito tributário brasileiro ${ }^{1843}$.

1837 FERRAZ, Roberto. Apresentação. Princípios e Limites da Tributação. FERRAZ, Roberto.(Coord).1. São Paulo: Quartier Latin, p. 19 e seguintes.

${ }^{1838}$ A investigação que não despreza elementos filosóficos, históricos, políticos e sociológicos para a compreensão do tributo (seja no âmbito de seu pressuposto ou de sua destinação) pode ser observada com clareza no estudo de Roberto Ferraz: FERRAZ, Roberto. Da Hipótese ao Pressuposto da Incidência: em busca do tributo justo. Op.cit., p. 176-235.

${ }^{1839}$ MARINS, James. Defesa e Vulnerabilidade do Contribuinte. Op.cit., p. 21 e seguintes.

1840 Marins nesse sentido tratou expressamente do reducionismo epistemológico frente ao "direito arrecadatório", que favoreceu o isolamento do Direito Tributário frente a outras disciplinas (como o Direito Financeiro). Ainda: "O reducionismo epistemológico, defendido por brilhantes teóricos positivistas de meados do século passado, estava justificado pelo objetivo de conferir segurança jurídica à obrigação tributária que se encontrava severamente exposta a razões de ordem puramente política ou preponderantemente econômicas. Ainda assim, apesar do objeto restritíssimo que lhe foi destinado, o Direito Tributário reduzido não foi concebido para servir como instrumento de poder do Estado ao contrário, sua gênese intelectual e cultural repousou sobre o objeto restritíssimo que lhe foi destinado, o Direito Tributário reduzido não foi concebido para servir como instrumento de poder do Estado, ao contrário, sua gênese intelectual e cultural repousou sobre o objetivo de limitar a ação política e econômica no âmbito de suas pretensões sobre a propriedade e a liberdade do cidadão no que concerne exatamente à função arrecadatória do Estado". E mais precisamente, sobre o reducionismo epistemológico ao fenômeno financeiro, sugere-se a leitura da nota de rodapé n.12, em que o autor retrata historicamente o embate na doutrina europeia e latinoamericana. Idem, p. 20-21.

${ }^{1841}$ MARINS, James. O Desafio da Política Jurídico-Fiscal. In: Tributação \& Política. James Marins (Coord.) Livro 6. Curitiba: Juruá Editora, 2005, p. 49 e seguintes.

${ }^{1842}$ AVILA, Humberto. Prefácio. In: FOLLONI, André. Ciência do Direito Tributário no Brasil: Crítica e perspectivas a partir de José Souto Maior Borges. Op.cit., p. 15-22.

${ }^{1843}$ BECHO, Renado Lopes. Filosofia do Direito Tributário. São Paulo: Saraiva, 2009, p. 267 e ss. 
Essa sensação também é reforçada pela leitura de Marco Aurélio Greco, ao enfatizar a "Crise do Formalismo no Direito Tributário Brasileiro"1844, elevando a função pragmática da norma tributária (por inspiração de Tércio Sampaio Ferraz Júnior), assim como a doutrina de Cristiano Carvalho que, à semelhança de Marco Aurélio Greco, e apresentando fortes críticas à mesma doutrina tributária de tradição positivista analisada por Greco, reforça a conveniência da interdisciplinaridade nos estudos de Direito Tributário (para que a doutrina transponha seus próprios limites, ampliando seu escopo, mas sem fundi-la com outras disciplinas) no Brasil ${ }^{1845}$.

Da mesma forma, a interdisciplinaridade pode ser observada no trabalho de Paulo Caliendo, a respeito da Análise Econômica do Direito no Direito Tributário (sobretudo sob uma perspectiva crítica) ${ }^{1846}$.

A relevância do diálogo interdisciplinar entre as matérias apontadas pode ser simbolizada por obra coletiva coordenada por Eurico Diniz de Santi, denominada "Curso de Direito Tributário e Finanças Públicas. Do Fato à Norma, da Realidade ao Conceito Jurídico" ${ }^{1847}$, cujo objetivo expresso, nas palavras de seu coordenador, foi inspirada em ensaio de Marcelo Neves (cujas ideias serão sucintamente analisadas no presente estudo). ${ }^{1848}{ }_{-} 1849$

${ }^{1844}$ GRECO, Marco Aurélio. Crise do Formalismo no Direito Tributário Brasileiro. n.1. Revista da PGFN. Brasília: PGFN, 2011, p. 09-19.

${ }^{1845}$ CARVALHO, Cristiano. Tributação, Ciência e Desenvolvimento: como poderia ser a Doutrina do Direito Tributário no Brasil? In:Tributação e Desenvolvimento. SANTI, Eurico Marcos Diniz de (Coord.) Op.cit., p. 127-141.

${ }^{1846}$ CALIENDO, Paulo. Direito Tributário e Análise Econômica do Direito. Uma Visão Crítica. Rio de Janeiro, Elsevier, 2009, p. 12 e ss.

${ }^{1847}$ Dividindo o curso em três partes (perspectiva histórica, perfil da Constituição de 1988 e percussão da tributação nos setores de serviços, industrial e comercial) o curso promove indiscutíveis avanços aos estudos interdisciplinares no Direito Tributário. A coletânea patrocinada pela FGV demonstra clara tendência de que o século XXI apresenta inevitável abertura à interdisciplinaridade nos estudos tributários. SANTI, Eurico Diniz de. Apresentação. In: Curso de Direito Tributário e Finanças Públicas. Do Fato à Norma, da Realidade ao Conceito Jurídico. Série Metodologia \& Ensino - Direito Desenvolvimento e Justiça. São Paulo: Saraiva, Direito GV, 2008, s/p.

${ }^{1848}$ Santi refere-se ao seguinte artigo: NEVES, Marcelo. Pesquisa interdisciplinar no Brasil: O Paradoxo da Interdisciplinaridade", In: Revista do Instituto de Hermenêutica Jurídica, Porto Alegre: Instituto de Hermenêutica Jurídica, pp. 207-214. Idem.

${ }^{1849}$ Adotando a proposta de Marcelo Neves como de interdisciplinaridade (como o espaço de comutação discursiva entre os diversos campos do saber jurídico), Eurico Diniz de Santi realça a pretensão da obra: “A proposta deste livro está ligada à esta última acepção de interdisciplinaridade, ou seja, oferecemos uma Dogmática Jurídica desprovida de pretensões de certeza e aberta aos influxos e pressões advindas de análises econômicas, históricas, políticas e sociológicas, - sempre empreendidas por reconhecidos experts destas diversas áreas do saber - e dirigidas, topicamente, aos casos concretos relativos ao fenômeno tributário e financeiro do Estado brasileiro que se encontram dispostos em toda extensão desse volume. Obtém-se, assim, 
Essa tendência de abertura disciplinar aparece expressamente também nas reflexões contemporâneas de Paulo de Barros Carvalho, que, não obstante já tecer históricas contribuições à filosofia da linguagem aplicada ao Direito Tributário, passa, no século XXI, diante desse novo contexto, a referir a interdisciplinaridade expressamente, mas, revelando a necessidade de ponderações (e cuidados) a serem adotadas por aqueles estudiosos que busquem enfrentar o desafio interdisciplinar ${ }^{1850}$, vinculando esse diálogo à necessidade de respeito aos limites de sua disciplina. ${ }^{1851}$

Nota-se que o autor, atento às perspectivas interdisciplinares, considera a necessidade da existência de disciplinas bem consolidadas como pressuposto da interdisciplinaridade. Não obstante, revela que “(...) o disciplinar leva ao interdisciplinar e este último faz retornar ao primeiro". ${ }^{1852}$

A interdisciplinaridade, na análise de Paulo de Barros Carvalho vincula-se à intertextualidade (diálogo entre textos científicos) ${ }^{1853}$, e, nesse sentido, o diálogo

o almejado material interdisciplinar como resultado prático dessa convergência de olhares de disciplinas epistemologicamente autônomas, mas acopladas pela força unificadora e pela riqueza material de cada caso concreto". Ibidem.

${ }^{1850}$ Para o autor, a construção da especialização disciplinar do direito “(...) constitui uma realidade propriamente sua". Porém, transportadas essas noções ao campo das ciências descritivas da disciplina do direito, "como metalinguagens da linguagem jurídica, iremos nos deparar com os limites sistêmicos de cada uma dessas "línguas científicas" e a possibilidade de elas "conversarem" entre si. A escolha do caráter disciplinar ou interdisciplinar, como estratégia para a construção do discurso científico, além de opção incontornável, continua sendo tema discutido nos círculos epistemológicos, juntamente com a própria amplitude da inter-relação das disciplinas, conteúdo de outra decisão a ser tomada pelo cientista. Tudo para perseguir aquele quantum de objetividade que pretende ter contraparte na carga mínima de subjetividade no agente do conhecimento". CARVALHO, Paulo de Barros. Curso de Direito Tributário. 2011, p. 166-167. CARVAlHO, Paulo de Barros Carvalho. Direito Tributário. Fundamentos Jurídicos da Incidência. OP.cit., p. 129-130.

${ }^{1851}$ Em outras palavras, Paulo de Barros reconhece, na própria consideração do fato social sua inerente complexidade: "Ele, o fato social, na sua congênita e inesgotável plurilateralidade de aspectos, reivindica, enquanto objeto, uma sequência de incisões que lhe modelem o formato para a adequada apreensão do espírito humano. (...) Não acredito ser possível, por isso mesmo, isolar-se, dentro do social, o fato jurídico, sem uma série de cortes e recortes que representem, numa ascese temporária, o despojamento daquele fato cultural maior de suas colorações políticas, econômicas, éticas, históricas, etc., bem como dos resquícios de envolvimento do observador, no fluxo inquieto de sua estrutura emocional". CARVALHO, Paulo de Barros. Curso de Direito Tributário. 2011. Op.cit., p. 166-167. CARVALHO, Paulo de Barros Carvalho. Direito Tributário. Fundamentos Jurídicos da Incidência. 2012. Op.cit., p. 129-130.

1852 "Sem disciplinas, é claro, não teremos as interdisciplinas, mas o próprio saber disciplinar, em função do princípio da intertextualidade, avança na direção de outros setores do conhecimento, buscando a indispensável complementaridade. O paradoxo é inevitável: o disciplinar leva ao interdisciplinar e este último faz retornar ao primeiro. A relação de implicação e polaridade, tão presente no pensamento de Miguel Reale, manifesta-se também aqui, uma vez que o perfil metódico que venha a ser adotado sê-lo-á, certamente, para demarcar uma porção da cultura”. CARVALHO, Paulo de Barros. Curso de Direito Tributário. 2011. Op.cit., p.168. CARVALHO, Paulo de Barros Carvalho. Direito Tributário. Fundamentos Jurídicos da Incidência. 2012, p. 129-130.

${ }^{1853}$ Analisando a ciência do ponto de vista da linguagem, que se constitui na forma e no sentido de texto, reafirma mais uma vez a ausência de sentido no argumento do isolamento disciplinar "(...) sem ferir de 
intertextual é viável ainda que existam severas dificuldades ao empreendimento, seja no âmbito da intertextualidade interna (diálogo entre Direito Tributário e Direito Econômico, por exemplo) seja no âmbito da intertextualidade externa (no âmbito do diálogo entre Ciência do Direito e História do Direito, por exemplo).

Mas Paulo de Barros ainda assim impõe reservas ao empreendimento interdisciplinar: "Aquilo que podemos esperar de quem empreenda a aventura do conhecimento, no campo do social, a esta altura, é uma atitude de reflexão de prudência, em respeito mesmo às intrínsecas limitações e à própria finitude do ser humano. Esta tomada de consciência, contudo, não pode representar a renúncia de seguir adiante, expressa nas decisões que lhe parecerem mais sustentáveis ao seu projeto descritivo". ${ }^{1854}$ 1855 _ $1856 \_1857$

Assim, a conclusão do autor pontua pela abertura à interdisciplinaridade, ainda que o tenha colocado sobre as peculiaridades da intertextualidade, aceitando a possibilidade do diálogo interdisciplinar, a propósito do mesmo evento. "Cada qual a recortaria, com os recursos de sua linguagem, e os desvios, as não coincidências, as dissonâncias entre os

maneira frontal o axioma da intertexualidade". CARVALHO, Paulo de Barros. Direito Tributário: Linguagem e Método. Op.cit., p. 200.

${ }^{1854}$ CARVALHO, Paulo de Barros. Curso de Direito Tributário. 2011. Op.cit., p. 168. CARVALHO, Paulo de Barros Carvalho. Direito Tributário. Fundamentos Jurídicos da Incidência. Op.cit., p. 129-130.

1855،'Simultaneamente, porém, não haveria cabimento falar-se numa interdisciplinaridade prescindindo-se do valor individual das disciplinas postas em relação, o que significa reconhecer a bi-implicação desses conceitos. Consignada a resalva, é preciso dizer que a intertextualidade no direito se apresenta em dois níveis bem característicos: (i) o estritamente jurídico, que se estabelece entre os vários ramos do ordenamento (intertextualidade, interna ou intrajurídica); e (ii) o chamado jurídico em acepção lata, abrangendo todos os setores que tem o direito como objeto, mas com outras propostas cognoscentes, assim como a Sociologia do Direito, a História do Direito, a Antropologia Cultural do Direito (intertextualidade externa ou extrajurídica). Quanto ao "direito comparado" tanto cabe na primeira classe quanto na segunda, dependendo da perspectiva em que se coloca o sujeito do conhecimento". CARVALHO, Paulo de Barros. Direito Tributário: Linguagem e Método. Op.cit., p. 198.

1856 "A intertextualidade intrajurídica já era defendida por Kelsen, ao proclamar a unidade do sistema de normas como necessária para a construção de uma ciência do direito jurídica. Naturalmente, nesse processo ocorre a demarcação do objeto científico (continuum heterogêneo), com o corte inicial da realidade para viabilizar a investigação científica (descontinuum homogêneo)". É justamente o recorte do objeto a ser investigado a que Paulo de Barros acrescenta os obstáculos à interdisciplinaridade: "Dois outros obstáculos, na forma de desafios, estarão no caminho do estudioso, mesmo que se admita superada aquela situação paradoxal: (i) quais as proporções do corte e (ii) que critérios utilizar para a condução do raciocínio no trato com o objeto já constituído (digamos, recortado)". Idem, Op.cit., p. 200.

${ }^{1857}$ Note-se também que em recente estudo coletivo organizado pelo Grupo de Estudos de Paulo de Barros, e destinado a homenagear Vilém Flusser, mais uma vez o autor posicionou-se sobre o assunto, adotando posicionamento mais restrito, ao tratar do diálogo entre textos (que se mostra semelhante ao diálogo entre as ciências, vertidas em linguagem). CARVALHO, Paulo de Barros. Poesia e Direito - o legislador como poeta: Anotações ao pensamento de Flusser. In: Vilém Flusser e os Juristas. Comemoração dos 25 anos do Grupo de Estudos de Paulo de Barros Carvalho. HARET, Florence (Coord); CARNEIRO, Jerson (Coord.). São Paulo: Noeses, 2009, p.71-76. 
relatos formariam a fonte de interesse e a matéria-prima fundamental da conversação entre eles (...)" ainda que finalize o trabalho elevando o pensamento de Alfredo Augusto Becker sobre o tratamento equivocado do fato jurídico tributário “(...) por doutrinas estranhas como a economia, a ciência das finanças, e outras mais" ${ }^{\text {81858 }}$.

Por outro lado, representantes contemporâneos de linhas de estudo tradicionalmente simpáticas ao diálogo com outros ramos do conhecimento (e, sobretudo, com a economia) encontram agora ambiente propício para reflexões dessa natureza, conforme se observa em Luís Eduardo Schoueri, representante da Escola da USP, que reconhece expressamente a complexidade da tributação (fenômeno tributário), e a sua possibilidade de ser estudada por diversos pontos de vista, seja do ponto de vista histórico, seja do ponto de vista econômico, seja do ponto de vista da ciência política, da sociologia, da psicologia, entre outros. $^{1859}$

Embora mantenha ao papel do jurista a função primordial de sistematizar o ordenamento jurídico tributário (sob a perspectiva jurídica), e que devem por isso ser resolvidas no plano da Teoria Geral do Direito, ressalta que: "Entretanto, a análise jurídica não deve deixar de lado o fenômeno sobre o qual se debruça. Sendo a tributação um fenômeno histórico, político, econômico e social, as contribuições oferecidas por essas aproximações não podem ser deixadas de lado na busca da construção de um sentido ao todo tributário (...)" ${ }^{\text {1860 }}$, embora o mesmo autor tenha advertido não fazer apologia ao uso acrítico pelo jurista das ferramentas construídas em outros campos do conhecimento (a exemplo da economia), mas, pelo contrário, deve-se atentar para eventuais riscos a que o jurista esteja submetido nesse procedimento ${ }^{1861}$, não podendo deixar de lado critérios

${ }^{1858}$ CARVALHO, Paulo de Barros. Poesia e Direito - o legislador como poeta: Anotações ao pensamento de Flusser. Op.cit., p.71-76.

${ }^{1859}$ Em verdade, conforme já visto no capítulo anterior o autor já havia assumido perspectiva eminentemente interdisciplinar no estudo das normas tributárias indutoras relacionadas à intervenção econômica: "Em virtude do próprio escopo, terá caráter interdisciplinar, já que as conclusões se formularão a partir da combinação de informações que se extrairão do Direito Tributário e do Direito Econômico, com as respectivas ramificações". E acrescenta: "Conforme já esclarecido, não se desprezarão as conclusões extraídas de outros ramos do conhecimento, como a economia e, em especial, as finanças públicas, quando dali surjam efeitos que não possam passar descurados pela análise jurídica”. SCHOUERI, Luís Eduardo. Normas Tributárias Indutores e Intervenção Econômica. Op.cit., p.15.

${ }^{1860}$ SCHOUERI, Luís Eduardo. Direito Tributário. $1^{\text {a }}$ Edição. Op.cit., p. 10-12.

1861 "Embora se relatem experiências interessantes nesse sentido - a análise econômica do direito é exemplo eloquente dessa prática -, não se pode deixar de apontar para os riscos de que os aplicadores do direito deixem de lado os critérios jurídicos para a solução dos conflitos. Assim como não seria tolerável que o uso da terapia - próprio da análise psicanalítica - servisse de ferramenta para investigar a legitimidade da economia de tributos, tampouco devem ser aplaudidas as análises de custo de oportunidade ou de transação para a investigação da licitude/ilicitude de um comportamento do contribuinte.”. Idem. 
jurídicos para solução de conflitos. Para o autor, existem mecanismos próprios construídos pela Ciência do Direito - que devem ser priorizados na interpretação e aplicação do direito ${ }^{1862}$.

Conforme já se observou, José Souto Maior Borges, através da elaboração do método de estudo denominado "Hermenêutica Histórica", também apresentou importantes considerações perante a estratégica de investigação histórica ao instituto jurídico no âmbito de seu próprio contexto histórico em que foi elaborado. Trata-se, conforme já observado, de “(...) uma escavação conceitual; ir ao fundo dos fundamentos das categorias científicas (...)" ${ }^{1863}{ }^{1864}$. Reforce-se, mais uma vez, que essa proposta tenciona ser complementar, mas não substitutiva, ao estudo dogmático do Direito Tributário. ${ }^{1865 \_1866 \_1867}$

Assim, nesse panorama, no processo disciplinar do Direito Tributário Brasileiro, ainda que estruturado pela tendência natural da especialização, pautou-se sempre com inequívocas ponderações, seja pela atenção à consideração econômica, aos aspectos históricos, à consideração das lições da filosofia e da epistemologia, enfim, sempre houve, em algum momento, considerações extrajurídicas aplicadas ao Direito Tributário, ainda que não expressamente assumidas.

Contudo, sobretudo no século XXI, já seria possível assumir a existência de uma verdadeira "interdisciplinaridade" aplicada ao Direito Tributário?

Acredita-se que a resposta mais razoável, nesse momento, é negativa.

1862 “A norma não é, portanto, o único aspecto do direito, já que ao lado convivem também fato e valor. A compreensão destes permitirá a extração do sentido da primeira. Assim é que ao jurista cabe estudar e refletir sobre as conclusões a que chegam os economistas, os historiadores, os filósofos e todos os outros pensadores que, com metodologias próprias, contribuem para a correta compreensão dos fatos e dos valores que informa, ao lado da norma, propriamente dita, o direito”. SCHOUERI, Luís Eduardo. Direito Tributário.1ª Edição. Op.cit., p. 12.

${ }^{1863}$ Diferenciando a hermenêutica histórica da análise histórico-evolutiva, defende que a primeira “(...) Preconiza a atitude retrospectiva, o passo atrás, a volta à origem, ao momento histórico em que uma teoria nova eclodiu o conserto da ciência jurídica. Trata-se de uma metodologia histórica. Empreender uma "escavação" conceitual da origem é instaurar, no campo jurídico, a hermenêutica histórica. Intenta-se revisitar as circunstâncias em que a teoria jurídica foi originariamente concebida. Localizá-la no seu tempo próprio - eis o desafio. E nele estancar a análise - eis a inovação. Por isso, a hermenêutica histórica não é histórico-evolutiva: esta procura surpreender prospectivamente o fenômeno na sua evolução ao longo do tempo. A hermenêutica histórica deve ousar o passo atrás, o retorno à origem. Trata-se de uma escavação conceitual; ir ao fundo dos fundamentos das categorias científicas". BORGES, José Souto Maior. Hermenêutica Histórica no Direito Tributário. In: Revista Tributária e de Finanças Públicas. n. 31, São Paulo: Rt, 2000, p. 112 e seguintes.

${ }^{1864}$ Idem, p. 112-113.

1865 Mas salienta: "Não aspira, a hermenêutica histórica, substituir os outros exegéticos, mas pretende conviver com eles como um instrumental valioso para o progresso da ciência do Direito Tributário". BORGES, José Souto Maior. Teoria Geral da Isenção Tributária. Op.cit. p.138.

${ }^{1866}$ Idem, p. 133-136.

${ }^{1867}$ BORGES, José Souto Maior. Hermenêutica Histórica no Direito Tributário. Op.cit., p. 112. 
Uma coisa é trazer "de fora” lições construídas em outros ramos do conhecimento e aplicá-las ao Direito Tributário. Isso sempre foi feito, e com êxito, no processo disciplinar do Direito Tributário, que não trilha, obviamente, o caminho da especialização disciplinar plena, logicamente. Outra questão, completamente diferente, é a interdisciplinaridade propriamente dita (a verdadeira interdisciplinaridade), construída na epistemologia, como decorrência da complexidade pós-moderna, e refletida na pedagogia (como decorrência da chamada "transdisciplinaridade").

Em outras palavras, a verdadeira interdisciplinaridade deve ser observada sobre premissas particulares que quase nunca foram identificadas com segurança na literatura tributária brasileira, ainda que lampejos históricos tencionados à consideração de elementos extrajurídicos aplicados ao direito tributário sempre tenham sido observáveis, com resultados muito interessantes e até mesmo essenciais para o progresso disciplinar do Direito Tributário Brasileiro.

Os motivos para apontar tal posicionamento serão compreendidos nas linhas subsequentes.

\subsection{As premissas epistemológicas (e pedagógicas) para a delimitação do tema: especialização disciplinar, complexidade e transdisciplinaridade.}

Para que se possa compreender adequadamente em que sentido deve ser adotado a expressão "interdisciplinaridade", urge-se apresentar alguns breves elementos sobre o contexto em que esse "diálogo entre disciplinas" surge, e quais os fundamentos para sua construção no âmbito da epistemologia (que a estuda) e da pedagogia (que a aplica).

Qualquer raciocínio que desconsidere essas premissas fundamentais inevitavelmente incorrerá no erro de supor que a interdisciplinaridade levantada na literatura tributária no século XX seria tão somente a consideração e aplicação de lições construídas em outros campos do conhecimento, com eventuais aplicações ao direito tributário. A teoria (ou teorias) da interdisciplinaridade demonstra que esse exercício não é, seguramente, a interdisciplinaridade construída na epistemologia e aplicada na pedagogia.

Historicamente, sabe-se que o século XX foi caracterizado pela elevação predominante da especialização disciplinar (ainda que com ponderações, como foi o caso do Direito Tributário). Essa tendência, decorrente do Paradigma ${ }^{1868}$ da Modernidade ${ }^{1869}$,

1868“Paradigmas são as realizações científicas universalmente reconhecidas que, durante algum tempo, fornece problemas e soluções modelares para uma comunidade de praticantes de uma ciência". KUHN, 
caracteriza-se pela predominância do cientificismo acadêmico, por sua vez fundada na verticalização/redução do objeto de estudo a partir da determinação metodológica cartesiana, e que leva à compreensão dos ramos do conhecimento através de estruturas científicas (com o conhecimento do objeto investigado através de estruturas formais préestabelecidas, onde o próprio objeto se amolda à forma pressuposta naqueles processos investigativos daquela estrutura) ${ }^{1870}$.

É o princípio da fragmentação do conhecimento ${ }^{1871}$, consolidado por René Descartes, que também favoreceu a tradição do conhecimento obtido na consideração de modo de pensar dicotômico de dualidades (sujeito/objeto, verdadeiro/falso, totalidade/unidade, objetividade/subjetividade, razão/emoção, bem/mal, certeza/incerteza, etc., ${ }^{1872}$, por sua vez fundada nos pilares da ordem, separabilidade e razão ${ }^{1873}$, e contribuindo para conceber a construção cognitiva do conhecimento enquanto pautado unicamente na relação entre sujeito e objeto, mas concedendo favorecimento expresso ao objeto (em detrimento do sujeito) através da objetividade investigativa alcançada idealmente nas ciências exatas, repercutindo no próprio processo de construção disciplinar das ciências sociais (e, por extensão, das ciências jurídicas).

Esse processo refletiu inevitavelmente sobre os rumos da disciplina jurídica tributária, que se dissociou do Direito Financeiro (e este do Direito Administrativo), e separou-se, no campo do ensino, da cátedra da Ciência das Finanças (e Legislação Financeira) e, após, do próprio Direito Financeiro.

Thomas. A estrutura das Revoluções Científicas. 5ª Ed. São Paulo: Editora Perspectiva, 1998, p. 13 e seguintes.

${ }^{1869}$ Segundo Anthony Giddens, em aproximação preliminar, a expressão "modernidade" “(...) refere-se a estilo, costume de vida ou organização social que emergiram na Europa a partir do século XVII e que ulteriormente se tornaram mais ou menos mundiais em sua influência. Isto associa a modernidade a um período de tempo e a uma localização geográfica inicial, mas por enquanto deixa suas características principais guardadas em segurança numa caixa preta." GIDDENS, Anthony. As Consequências da Modernidade. Tradução de Raul Fiker. São Paulo: Editora UNESP, 1991, p. 08.

1870 "Em uma primeira aproximação, uma estrutura é um sistema de transformações que comporta leis enquanto sistema (por oposição às propriedades dos elementos) e que conserva ou se enriquece pelo próprio jogo de suas transformações, sem que estas conduzam para fora de suas fronteiras ou façam apelo a elementos exteriores. Em resumo uma estrutura compreende os caracteres de totalidade, de transformações e de auto-regulação. Em uma segunda aproximação, mas pode tratar-se de uma fase bem ulterior e também sucedendo imediatamente à descoberta da estrutura, esta deve poder dar lugar a uma formalização". PIAGET, Jean. O Estruturalismo. Rio de Janeiro: Difel, 2003, p. 07-19.

${ }^{1871}$ DESCARTES, René. Op.cit., p. 46 e seguintes.

${ }^{1872}$ SANTOS, Akiko. Complexidade e transdisciplinaridade em educação: cinco princípios para resgatar o elo perdido. In: Revista Brasileira de Educação v. 13 n. 37 jan./abr. 2008. Disponível em: www.scielo.br/pdf/rbedu/v13n37/07. (último acesso em 05.12.2014).

${ }^{1873}$ MORIN, Edgar. O Paradigma da Complexidade. In: MORIN, Edgar; LE MOIGNE, Jean-Louis. A Inteligência da Complexidade. São Paulo: Petrópolis, 2000, p. 199 e seguintes. 
A formação disciplinar do Direito Tributário Brasileiro, portanto, seguiu essa tendência, que não é exclusiva dessa, mas remonta à escolha epistemológica geral prevalecente no aperfeiçoamento das ciências desde Descartes, alcançando o apogeu epistemológico durante todo o século XX. Dessa escolha epistemológica geral, seus reflexos foram sentidos em todo conhecimento jurídico, e emana-se o positivismo jurídico (em suas distintas vertentes), cujas premissas foram abraçadas pela doutrina tributária brasileira, em momento histórico altamente propício e conveniente (década de sessenta em diante do século $\mathrm{XX}$ ). $\mathrm{O}$ que não quer dizer que passou sem ponderações, próprias das peculiaridades ínsitas do Direito Tributário Brasileiro, como já foi observado.

Contudo, recentes circunstâncias tem favorecido a reestruturação de discussão epistemológica aos estudos de Direito Tributário, sobretudo no que diz respeito à possibilidade/viabilidade do diálogo entre o Direito Tributário e outros campos do conhecimento (e, portanto, “extrajurídicos”), mas agora sob a perspectiva da interdisciplinaridade (construída na epistemologia e na pedagogia), e não apenas como observação pontual de aspectos de outros ramos do conhecimento para aplicação ao direito tributário, como se defendia outrora.

Para estudiosos contemporâneos, essa progressiva retomada de fôlego ao diálogo (interdisciplinar) com outros ramos do conhecimento se justificaria porque a especialização disciplinar (ligada à redução epistemológica) estaria aos poucos sendo reformulada por outro paradigma teórico, mais especificamente, o Paradigma da Complexidade ${ }^{1874}$. Este último, que não somente aceita o diálogo interdisciplinar, mas o apoia, estaria por detrás dessas mudanças paradigmáticas ${ }^{1875}$.

Na realidade, a teoria da complexidade, sistematizada por Edgar Morin ${ }^{1876}$, vinculase, no âmbito da pedagogia disciplinar, à teoria da transdisciplinaridade, expressão

1874 BORGES, José Souto Maior. Um ensaio interdisciplinar do Direito Tributário: Superação da Dogmática. Op.cit., p. 106-107. FOLLONI, André. Ciência do Direito Tributário no Brasil. Op.cit., p. 383 e seguintes.

${ }^{1875}$ MORIN, Edgar. Ciência com consciência. Rio de Janeiro: Bertrand Brasil, 2010, p. 173 e ss. MORIN, Edgar. O Paradigma da Complexidade. Op.cit., p. 199 e seguintes.

1876 "O pensamento da complexidade se apresenta, pois, como um edifício de muitos andares. A base está formada a partir das três teorias (informação, cibernética e sistema) e comporta as ferramentas necessárias para uma teoria da organização. Em seguida, vem o segundo andar, com as idéias de Von Neumann, Von Foerster e Prigogine sobre a auto-organização. A esse edifício, pretendi trazer os elementos suplementares, notadamente três princípios, que são o princípio dialógico, o princípio de recursão e o princípio hologramático.” O primeiro princípio (dialógico), para Morin, busca unir noções antagônicas “(...) para pensar os processos organizadores, produtivos e criadores no mundo complexo da vida e da história 
originalmente criada por Jean Piaget (concebida originalmente como uma etapa superior de interação entre disciplinas), e posteriormente sistematizada e aperfeiçoada por Nicolescu $^{1877}$. A complexidade ${ }^{1878}$ e a transdisciplinaridade buscam confrontar o dualismo e reducionismo epistemológico tradicionalmente aplicado nos processos de construção disciplinar.

Em 1994, por ocasião do Primeiro Congresso Mundial de Transdisciplinaridade, realizado no Convento de Arrábida, em Portugal, entre os dias 02 a 06 de novembro daquele ano, foi redigida por Lima de Freitas, Edgar Morin e Basarab Nicolescu uma carta de intenções e princípios inerentes à transdisciplinaridade, buscando diferencia-la de outros níveis de interações disciplinares, ao mesmo tempo em que definia seus traços fundamentais para as disciplinas do futuro. Foi denominada de "Carta da Transdisciplinaridade".

Essa Carta foi adotada como protocolo de princípios básicos ao novo fenômeno na literatura especializada ${ }^{1879}$, que, embora originalmente cunhada por Piaget e desenvolvida

humana." Por outro lado o princípio da recursão organizacional, caminhando além da retroação (feedback), pode ser entendido como "círculo gerador no qual os produtos e os efeitos são eles próprios produtores e causadores daquilo que os produz". Já o terceiro princípio (hologramático) põe em evidência o aparente paradoxo de sistemas onde não apenas a parte está no todo mas “(...) o todo está na parte”, interagindo mutuamente. Exemplificativamente, o indivíduo é parte da sociedade, ao mesmo tempo que a sociedade está no indivíduo (através da linguagem, cultura, normas, etc.). Porém, deve-se ressaltar que o pensamento complexo de Morin não “(...) expulsa a certeza para colocar a incerteza, que expulsa a separação para colocála no lugar da inseparabilidade, que expulsa a lógica para autorizar todas as transgressões.” Dito de outra forma, o pensamento complexo não renega as conquistas trazidas pela ciência clássica, mas busca complementá-la no que é ineficiente. MORIN, Edgar. O Paradigma da Complexidade. Op.cit., p.204-206.

${ }^{1877}$ Basarab Nicolescu sistematizou a definição de transdisciplinaridade fundada em três postulados: “(...) transdisciplinaridade é o novo conhecimento "in vivo", e baseia-se nos três seguintes postulados: 1. Existem, na natureza e em nosso conhecimento da natureza, diferentes níveis de realidade e, correspondentemente, diferentes níveis de percepção; 2. A passagem de um nível de realidade para outra é segurada pela lógica do terceiro incluído; 3. A estrutura da totalidade dos níveis de Realidade e percepção é uma estrutura complexa: cada nível é o que é porque existem todos os níveis ao mesmo tempo". A lógica do terceiro incluído seria substituta da lógica do terceiro excluído, fundamental para a lógica tradicional (e para a compreensão do conhecimento em dualidades - verdade/falsidade, certeza/incerteza, sujeito/objeto, etc). Essa substituição simbolizaria a possibilidade da contrução de conhecimentos com graus variados de certeza ou incerteza, por exemplo, assim como a superação da percepção de que o conhecimento obtido não pode ser linear, mas advém de um particular ponto de vista que não necessariamente exclui outros sobre o mesmo objeto. NICOLESCU, Basarab. Definition of Transdisciplinarity. 2003. Disponível em: http://www.interdisciplines.org/interdisciplinarity/papers/5/ (último acesso em 05.12.2014). Também: NICOLESCU, Basarab. O manifesto da transdisciplinaridade. Trad. Lúcia Pereira de Souza. São Paulo: Trion, 1999, p. 29 e seguintes.

1878 "O pensamento complexo é, pois, essencialmente o pensamento que trata com a incerteza e que é capaz de conceber a organização. É o pensamento capaz de reunir (complexus: aquilo que é tecido conjuntamente), de contextualizar, de globalizar, mas, ao mesmo tempo, capaz de reconhecer o singular, o individual, o concreto". MORIN, Edgar. O Paradigma da Complexidade. Op.cit., p. 206 e seguintes.

1879 Nesse sentido, as principais motivações para a construção da teoria da transdisciplinaridade foram consolidadas da seguinte forma: "Considerando que a proliferação atual das disciplinas acadêmicas conduz 
como nível máximo de interação interdisciplinar (Jantsch), passa a apresentar características próprias que não necessariamente a vinculariam aos processos anteriores ${ }^{1880}$.

Assim, a transdisciplinaridade e a complexidade articulam-se nesse processo, que não rejeita a consolidação (e especialização) disciplinar, mas reforça-a, buscando atingir os "espaços vazios" entre as disciplinas. Note-se que, nesse ambiente, o paradigma da Modernidade (ou "Paradigma Dominante"), que leva ao reducionismo epistemológico, acaba sofrendo profundas críticas no limiar do século XX, cujas respostas aparecem na consolidação de diversas teorias ${ }^{1881}$, cada qual buscando contrastar, à sua própria maneira,

a um crescimento exponencial do saber que torna impossível qualquer olhar global do ser humano; Considerando que somente uma inteligência que se dá conta da dimensão planetária dos conflitos atuais poderá fazer frente à complexidade de nosso mundo e ao desafio contemporâneo de autodestruição material e espiritual de nossa espécie; Considerando que a vida está fortemente ameaçada por uma tecnociência triunfante que obedece apenas à lógica assustadora da eficácia pela eficácia; Considerando que a ruptura contemporânea entre um saber cada vez mais acumulativo e um ser interior cada vez mais empobrecido leva à ascensão de um novo obscurantismo, cujas conseqüências sobre o plano individual e social são incalculáveis; Considerando que o crescimento do saber, sem precedentes na história, aumenta a desigualdade entre seus detentores e os que são desprovidos dele, engedrando assim as desigualdades crescentes no seio dos povos e entre as nações do planeta; Considerando simultaneamente que todos os desafios enunciados possuem sua contrapartida de esperança e que o crescimento extraordinário do saber pode conduzir a uma mutação comparável à evolução dos humanóides à espécie humana; Considerando o que precede, os participantes do Primeiro Congresso Mundial de Transdisciplinaridade (Convento de Arrábida, Portugal, 2-6 de novembro de 1994) adotaram o presente Protocolo entendido como um conjunto de princípios fundamentais da comunidade de espíritos transdisciplinares, constituindo um contrato moral que todo signatário deste Protocolo faz consigo mesmo, sem qualquer pressão jurídica e institucional". FREITAS, Lima de; MORIN, Edgar; NICOLESCU, Basarab. Carta da Transdisciplinaridade. Adotada no Primeiro Congresso Mundial de Transdisciplinaridade Convento de Arrábida, Portugal, 2-6 novembro, 1994, p. 01-02.

${ }^{1880}$ Entre os princípios ou metas incorporados ao ideal de transdisciplinaridade, e trazidos na Carta da Transdisciplinaridade, citam-se: a) rejeição da redução do ser humano às meras definições ou tentativas de dissolução em estruturas formais, pois seria incompatível com a ideia de transdisciplinaridade (artigo 1); b) o reconhecimento de diferentes níveis de realidade que por sua vez seriam regidos por lógicas diferenciadas. Por outro lado, qualquer tentativa de reduzir a realidade a um único nível regido por uma única lógica não se enquadraria na transdisciplinaridade (artigo 2); c) a complementaridade à aproximação disciplinar, no sentido de que a transdisciplinaridade oferece uma visão da natureza e da realidade, não procurando domínio sobre as disciplinas, mas “(...) a abertura de todas elas àquilo que as atravessa e as ultrapassa” (artigo 3); d) a sustentação da transdisciplinaridade residiria na unificação semântica e operativa das acepções através e além das disciplinas, pressupondo uma racionalidade aberta sob novo olhar (relativizando as noções de definição e objetividade). Nesse sentido, a transdisciplinaridade combate o "(...) formalismo excessivo, a rigidez das definições e o absolutismo da objetividade, comportando a exclusão do sujeito levam ao empobrecimento" (artigo 4); e) a visão transdisciplinar é aberta, ultrapassando o domínio das ciências exatas por seu diálogo com as ciências humanas e com a arte, a literatura e a experiência espiritual (artigo 5); f) frente à interdisciplinaridade, e à multidisciplinaridade, a transdisciplinaridade é "multidimensional", e leva em conta concepções de tempo e da história, não excluindo “(...) a existência de um horizonte trans-histórico (artigo 6); g) a transdisciplinaridade não é religião nova, filosofia, metafísica ou ciência das ciências (artigo 7); h) é essencialmente humanista, compreendendo a dignidade da pessoa humana através da ordem cósmica e planetária (e compreende o indivíduo não apenas como cidadão de uma pátria mas como cidadão do planeta terra, é o ser humano transnacional). FREITAS, Lima de; MORIN, Edgar; NICOLESCU, Basarab. Carta da Transdisciplinaridade. Op.cit., p. 02-03.

${ }^{1881}$ Não é o caso de apresentar os percursos teóricos das correntes pedagógicas refratárias ao paradigma da Modernidade. Em todo caso, citam-se algumas delas para demonstrar a riqueza teórica desse processo, da qual emanam diversas correntes pedagógicas contemporâneas e respectivas linhas de pesquisa contrárias ao 
a superação do Paradigma da Modernidade. É nesse sentido também que se passa a falar em Pós-Modernidade, especialmente no substrato sociológico desse processo.

Nesse ambiente epistemológico pós-moderno, emana-se a interdisciplinaridade como alternativa (mas não necessariamente substitutiva) ao processo de especialização disciplinar, estruturando-se a partir do próprio Paradigma da Complexidade.

\subsubsection{O verdadeiro sentido da interdisciplinaridade na epistemologia e pedagogia: a alternativa ao processo desenfreado de especialização disciplinar.}

A interdisciplinaridade aparece como resposta epistemológica ao problema da especialização desenfreada do conhecimento, numa busca de combatê-la e reorganizá-la, ou pelo menos compensá-la, na tentativa de resgatar a totalidade das disciplinas. ${ }^{1882} \mathrm{Em}$ outras palavras, sugere aos cientistas a saída de suas próprias zonas de conforto, já que o “(...) progresso das ciências abre-se cada vez mais a exigências sempre novas”. ${ }^{1883}$

A interdisciplinaridade liga-se à epistemologia pós-positivista, vinculando-se às teorias da complexidade e da transdisciplinaridade. Para os estudiosos da interdisciplinaridade, dentre os quais se eleva Edgar Morin, o processo de especialização disciplinar vincula-se a uma particular "fratura" epistemológica na organização do conhecimento. Para Morin, a especialização racha o fenômeno multidimensional e

paradigma dominante cartesiano: Correntes Racional-tecnológicas (Ensino de excelência; Ensino tecnológico); Neocognitivistas (Construtivismo pós-piagetiano; Ciências cognitivas); Sociocríticas (Sociologia crítica do currículo; Teoria histórico-cultural; Teoria sociocultural; Teoria sociocognitiva; Teoria da ação comunicativa); "Holísticas" (Holismo; Teoria da complexidade; Teoria naturalista do conhecimento; Ecopedagogia; Conhecimento em rede); Pós-modernas (Pós-estrutruralismo; Neopragmatismo). Cada qual, sob seus próprios fundamentos e premissas, busca alternativas para a Modernidade, onde as correntes holísticas acabam fortalecendo a investigação sobre a teoria da complexidade e transdisciplinaridade. LIBÂNEO, José Carlos. As teorias pedagógicas modernas revisitadas pelo debate contemporâneo na educação. In: LIBÃNEO, José Carlos; SANTOS, Akiko (Coord). Educação na era do conhecimento em rede e transdisciplinaridade. Campinas: Alínea, 2005. p. 30 e seguintes.

${ }^{1882}$ Nesse contexto, para Japiassú, vários fatores servem de fundamento para defender a interdisciplinaridade, ainda que cientes de tais dificuldades: "a apreciação do estudo e da pesquisa como fundamentos de uma ação inteligente, racional ou "informada"; a complexidade do objeto da pesquisa; o imperativo de encontrar respostas para problemas novos; a necessidade de superação dos esquemas tradicionais de ensino; a necessidade de adequação das atividades universitárias ao mesmo tempo às urgências de uma crítica interna do saber e às urgências de uma crítica interna do saber às exigências sócio-profissionais; certos temas de investigação que exigem a colaboração de vários especialistas para serem solucionados, etc". JAPIASSÚ, Hilton. Interdisciplinaridade e Patologia do Saber. Serie Logoteca. Rio de Janeiro: Imago Editora, 1976, p. 64.

${ }^{1883}$ Idem. 
inseparável, prejudicando a obtenção deste, já que os saberes que permitiriam o conhecimento acabam separados e esfacelados, mas antes de tudo, ignorando “(...) a vista global da qual faz parte”. Essa (os efeitos provocados pela especialização disciplinar) seria, na opinião de Morin, a "patologia do saber", mencionada por Georges Gusdorf, ${ }^{1884}$ que leva à mutilação do conhecimento e, ainda que traga benefícios, traz também males modernos que são inseparáveis do progresso do conhecimento científico, levados por novo "obscurantismo",1885.

Morin chama de "Torre de Babel" o edifício do saber contemporâneo ${ }^{1886}$, já que os cientistas são incapazes de controlar os poderes escravizadores ou destrutores gerados pelo saber (um poder não controlado). ${ }^{1887 \_}{ }^{1888}{ }_{-} 1889$

Nesse sentido, os verdadeiros objetivos da interdisciplinaridade, segundo Clark Abt, seriam os seguintes: a) despertar entre os estudantes e os professores um interesse pessoal pela aplicação de sua própria disciplina a uma outra; b) estabelecer um vínculo sempre mais estreito entre as matérias estudadas; c) abolir o trabalho maçante e por vezes "bitolante" que constitui a especialização em determinada disciplina; d) reorganizar o saber; e) estabelecer comunicações entre os especialistas; f) criar disciplinas e domínios novos de conhecimento, mais bem adaptados à realidade social; g) aperfeiçoar e reciclar os professores, reorientando-os, de sua formação especializada, a um estudo que vise à

\footnotetext{
${ }^{1884}$ MORIN, Edgar. O Método. 3. São Paulo: Editora Sulina, 1999, p.18-19.

${ }^{1885}$ Conforme leciona George Gusdorf, citando G.K. Chesterton, o especialista “(...) é aquele que possui um conhecimento cada vez mais extenso relativo a um domínio cada vez mais restrito". Em tom ainda mais enérgico: "o triunfo da especialização consiste em saber tudo sobre nada". E vai além: "Os verdadeiros problemas de nosso tempo escapam à competência dos experts que, via de regra, são testemunhas do nada. A parcela do saber exato e preciso detida pelo especialista perde-se no meio de um oceano de não-saber e de incompetência". GUSDORF, Georges. Prefácio. In: JAPIASSÚ, Hilton. Interdisciplinaridade e Patologia do Saber. Op.cit., p. 8-9.

${ }^{1886}$ Idem, p. 20.

${ }^{1887}$ Idem, p. 20-21.

${ }^{1888}$ Para Morin, “(...) A especialização abstrai, isto é, retira um objeto do seu contexto e da sua totalidade, rejeitando suas ligações e intercomunicações com o seu ambiente, o insere no compartimento da disciplina, cujas fronteiras destroem arbitrariamente a sistematicidade (a relação de uma parte com o todo) e a multidisciplinaridade dos fenômenos: ela conduz à abstração matemática que, ao privilegiar tudo que é calculável e formulável, executa, a partir dela própria, uma cisão com o concreto". MORIN, Edgar. A Necessidade de um Pensamento Complexo. In: Representação e Complexidade. Candido Mendes (Org). Rio de Janeiro: Garamond, 2003, p. 69 e seguintes.

${ }^{1889}$ Não é demais lembrar que a interdisciplinaridade mostra-se com efetivo viés prático, como uma "atitude epistemológica", uma atitude diferente tomada pelo cientista, ao olhar sua disciplina em relação com outras. Não é, portanto, apenas conceito teórico (ou uma "disciplina"), mas cada vez mais se impõe como verdadeira prática. JAPIASSÚ, Hilton. Op.cit., p. 82-87.
} 
solução de problemas comuns a duas ou mais disciplinas; h) reconhecer o caráter comum de certos problemas estruturais, etc, ${ }^{1890}$

Com o aumento progressivo do interesse sobre o tema, surgem as primeiras propostas teóricas, como a de Guy Michaud, que buscou alcançar uma distinção terminológica em quatro níveis progressivos de interação disciplinar ${ }^{1891}$ : multidisciplinar; b) pluridisciplinar; c) interdisciplinar; d) transdisciplinar ${ }^{1892}$.

A interdisciplinaridade passa a ser identificada nesses primeiros estudos pela “(...) intensidade das trocas entre os especialistas e pelo grau de integração real das disciplinas, no interior de um projeto específico de pesquisa" ${ }^{1893}{ }_{-}^{1894}$.

${ }^{1890}$ A delimitação do campo de atuação da interdisciplinaridade foi preocupação que não escapou aos olhos da UNESCO que, entre outros institutos acadêmicos (como o CERI - Centre pour La Recherche et l'Innovation dans l'Enseignement, e a própria OCDE, Organização para Cooperação Econômica e Desenvolvimento), passaram a elaborar relatórios destinados a aclarar a questão e, eventualmente, viabilizar a construção de uma "disciplina" (ou "teoria geral”) da interdisciplinaridade. JAPIASSÚ, Hilton. Op.cit, p. 56.

${ }^{1891}$ Tome-se como referência a visão disciplinar no seguinte sentido: Na visão de Japiassú, disciplina teria o mesmo significado de "ciência", ao passo que "disciplinaridade" significaria a “(...) exploração científica especializada de determinado domínio homogêneo de estudo, isto é, o conjunto sistemático e organizado de conhecimentos que apresentam características próprias nos planos de ensino, da formação, dos métodos e das matérias (...)". JAPIASSÚ, Hilton. Interdisciplinaridade e Patologia do Saber. Serie Logoteca. Rio de Janeiro: Imago Editora, 1976, p. 51. Para Heckhausen, a disciplina seria ciência, e disciplinaridade seria: "exploração científica especializada de um domínio determinado e homogêneo de estudos, exploração que consiste em fazer surgir novos conhecimentos que se substituem a outros mais antigos". HECKHAUSEN, Heinz. Discipline et interdisciplinarité. In: L'interdisciplinarité. Problèmes d'enseignement et de recherche dans les Universités. Ceri (Eds). Paris: UNESCO/OCDE, 1972, p. 83-90. Também: FAZENDA, Ivani Catarina Arantes Fazenda. Integração e Interdisciplinaridade no ensino Brasileiro: Efetividade ou Ideologia?. São Paulo: Edições Loyola, 1992, p. 29 e seguintes.

${ }^{1892}$ Depois de muitos estudos realizados com o objetivo de esclarecer melhor tais distinções terminológicas (e variadas propostas), em 1970, formou-se grupo de especialistas (C.C. Abt; E. Jantsch), buscando mais uma vez aprimorar as conclusões trazidas anteriormente, partindo da proposta original de Guy Michaud, e melhor delimitar as variáveis terminológicas eventualmente aplicáveis ao estudo da interdisciplinaridade. Nesse estudo, dividiram as categorias disciplinares em significados distintos que poderiam ser remetidos à interdisciplinaridade: a) Disciplina: "Conjunto específico de conhecimentos com sua própria formação dos mecanismos, dos métodos, das matérias"; b) Multidisciplina: "justaposição de disciplinas diversas, desprovida de relação aparente entre elas”. Ex: Direito + Física + Química; c) Pluridisciplina: “justaposição de disciplinas mais ou menos vizinhas nos domínios do conhecimento": Ex: domínio científico: matemática + física; d) interdisciplina: "o nível em que a colaboração entre as diversas disciplinas ou entre os setores heterogêneos de uma mesma ciência conduz a interações propriamente ditas, isto é a uma certa reciprocidade nos intercâmbios, de tal forma que, no final do processo interativo, cada disciplina saia enriquecida"; e) Transdisciplina: Resultado de uma axiomática comum a um conjunto de disciplinas (Ex. Antropologia considerada como " a ciência do homem e de suas obras", segundo a definição de Linton). JAPIASSÚ, Hilton. Op.cit., p.74-75.

${ }^{1893}$ Idem.

${ }^{1894}$ No mesmo ano, em Nice, realizou-se seminário com países membros da OCDE por sua vez denominado "Seminaire sur La Pluridisciplinarité et l'Interdisciplinarité dans lês Universités", buscando aprimorar os referidos conceitos (participaram da conferência H.Heckhausen, J.Piaget, E.Jantsch, M.Boisot e A.Lichnerowicz). Ibidem. 
Posteriormente, em Relatório organizado a partir do Seminário sobre Interdisciplinaridade organizado pela CERI, e publicado pela OCDE em 1972 sob o título "L'interdisciplinarité: problèmes d'enseignement et de recherche dans lês universités", refletiu-se novamente as principais tendências dos pesquisadores na época (entre eles, G.Michaud, da França, H. Heckhausen, da Alemanha, J.Piaget, da Suíça, e E. Jantsch, da Áustria), apresentando nomenclatura aprimorada sobre as modalidades de interdisciplinaridade, que, por outro lado, denunciou as variantes terminológicas sobre o tema, ${ }^{1895 \_}{ }^{1896}{ }_{-}^{1897}$ demonstrando clara tendência às grandes variações terminológicas no âmbito dos estudos interdisciplinares, chegando ao Brasil, através de Hilton Japiassú ${ }^{1898}$, na década de setenta e, posteriormente, com Ivani Fazenda ${ }^{1899}$, assim como novos trabalhos nos anos seguintes ${ }^{1900}$.

${ }^{1895}$ GUSDORF, Georges. Réflexions sur l'interdisciplinarité. In: Bulletin de Psychologie, XLIII, 397, 1990, p. 847-868. JANSTCH, Erich. Vers l'interdisplinarité et la transdisciplinarité dans l'enseignement et l'innovation. In: L'interdisciplinarité. Problèmes d'enseignement et de recherche dans les Universités, Ceri (Eds). Paris: UNESCO/OCDE, 1972, p. 98-125. PIAGET, Jean. Epistemologie des rélations interdisciplinaires. In: L'interdisciplinarité. Problèmes d'enseignement et de recherche dans les Universités, Ceri (Eds.). Paris: UNESCO/OCDE, 1972, p. 131-143. HECKHAUSEN, Heinz. Op.cit., p. 83 e seguintes.

${ }^{1896}$ Segundo Japiassú, foi Piaget que criou a expressão "transdisciplinaridade". JAPIASSÚ, Hilton. Op.cit. p. 75.

${ }^{1897}$ Idem, p. 78 e seguintes.

${ }^{1898}$ No Brasil, o primeiro autor a publicar estudo especificamente sobre a interdisciplinaridade foi Hilton Japiassú, no trabalho "Interdisciplinaridade e Patologia do Saber", em 1976. Essa obra teve o mérito de inaugurar os estudos interdisciplinares (ou sua possibilidade) no Brasil, e inspirou outros importantes estudos nacionais, demonstrando claramente a rede de influências teóricas que giravam sobre o tema, sobretudo através de autores de língua francesa, como Georges Gusdorf. Partindo da crítica às estruturas atuais do conhecimento, e da formação científica das disciplinas, claramente construídas por uma forma de pensamento especializador e fragmentário, Japiassú busca, através da interdisciplinaridade, alcançar o reconhecimento de que o conhecimento deve observar a complexidade e a totalidade. Ibidem.

${ }^{1899}$ Outros trabalhos de relevo sobre o tema da interdisciplinaridade foram produzidos no início da década de noventa por Ivani Catarina Arantes Fazenda, que atualizou e contextualizou os progressos da interdisciplinaridade no ensino brasileiro e na epistemologia, com o trabalho "Integração e Interdisciplinaridade no Ensino Brasileiro: Efetividade ou Ideologia?", publicado em 1992 (e baseado em dissertação de mestrado apresentada em 1979), além de "Interdisciplinaridade: Um Projeto em Parceria" (1991). FAZENDA, Ivani Catarina Arantes Fazenda. Integração e Interdisciplinaridade no ensino Brasileiro: Efetividade ou Ideologia? Op.cit., p. 30 e seguintes.

${ }^{1900}$ Sobre o assunto, também: WEIL, Pierre; D'AMBROSIO, Ubiratan; CREMA, Roberto. Rumo à Nova Transdisciplinaridade. São Paulo: Summus, 1993, p. 33-41; NETO, Alfredo José da Veiga. Crise dos paradigmas e interdisciplinaridade. In: Interdisciplinaridade na sala de aula: uma experiência pedagógica nas $3^{\mathrm{a}}$ e $4^{\mathrm{a}}$ séries do primeiro grau. SILVA, Dinorá Fraga da; SOUZA, Nádia Geisa Oliveira de (Org).Porto Alegre: Editora da Universidade/UFGRS, 1995, p. 17-25; SCHÄFFER, Margareth. Interdisciplinaridade: um novo "paradigma" para a educação e as ciências humanas? In: Interdisciplinaridade na sala de aula: uma experiência pedagógica nas $3^{\mathrm{a}}$ e $4^{\mathrm{a}}$ séries do primeiro grau. Op.cit., p. 35 e seguintes; PETRAGLIA, Cristina Izabel. Interdisciplinaridade: o cultivo do professor. São Paulo: Pioneira, Universidade São Francisco, 1993, p.24 e seguintes. 
Para Jean Piaget, a interdisciplinaridade pode ser caracterizada pelo intercâmbio mútuo e integração recíproca entre diferentes ciências (disciplinas), causando enriquecimento recíproco entre elas ${ }^{1901}{ }_{-}^{1902}{ }_{-} 1903$.

Trata-se, portanto, de uma atitude de abertura epistemológica ou "abertura de pensamento". O diálogo (recíproco) entre disciplinas é essencial para a efetivação da

${ }^{1901}$ De fato, a visão de Piaget não se afasta das demais, e apesar de aparentar maior generalidade, não escapa da ideia de que o conhecimento interdisciplinar pressupõe interação recíproca entre disciplinas, onde ambas sairiam ganhando. Piaget não aponta como necessidade uma "intensidade mínima" de interação para a configuração da interdisciplinaridade, bastando que exista esse diálogo com enriquecimento recíproco. PIAGET, Jean. Epistemologie des rélations interdisciplinaires. Op.cit., p. 131-143.

${ }^{1902}$ Para Gusdorf, a interdisciplinaridade pode ser compreendida como “(...) atitude epistemológica que ultrapassa os hábitos intelectuais estabelecidos ou mesmo os programas de ensino”. Mas, existem, na realidade, vários sentidos para a atribuição do vocábulo "interdisciplinaridade". Já houve indicações de que a interdisciplinaridade seria caracterizada pela interação entre duas ou mais disciplinas, simplesmente. Outras preferem situar a interação como "condição de efetivação da interdisciplinaridade". Mas mesmo Hilton Japiassú reconheceu a dificuldade de precisão terminológica do termo "interdisciplinaridade", ao qual não conseguiu vincular sequer um sentido epistemológico único e estável, já que se trataria de neologismo, “(...) cuja significação nem sempre é a mesma e cujo papel nem sempre é compreendido da mesma forma". Percebe-se, portanto, não haver unidade terminológica a respeito da interdisciplinaridade. O prefixo "inter" não indica apenas uma pluralidade, uma eventual justaposição de saberes, mas clama por um espaço comum onde há coesão entre saberes, uma zona de intersecção a ser explorada por saberes distintos. Mas, como o próprio prefixo acima já expressa, a interdisciplinaridade é via de mão dupla, exigindo, para muitos estudiosos, reciprocidade. GUSDORF, Georges. Carta de 10.10.1977 endereçada a Ivani Fazenda. In: FAZENDA, Ivani Catarina Arantes. Integração e Interdisciplinaridade no Ensino Brasileiro: Efetividade ou Ideologia? Op.cit., p. 09-24.

${ }^{1903}$ Segundo Berger, um grupo interdisciplinar é formado por pessoas que possuem formações acadêmicas pautadas em diferentes conhecimentos especializados (disciplinas), que, por sua vez, possuem conceitos, termos, e métodos próprios. Esta é, evidentemente, uma noção insuficiente, que não explora as interações comuns entre estudiosos. Mas, por outro lado, Palmade entende a interdisciplinaridade como uma integração interna e conceitual apta a romper com a estrutura original de cada disciplina, visando alcançar eventual construção de uma "nova axiomática" que seja comum a todas elas, alcançando uma visão unitária do conhecimento. Já para Jantsch, a interdisciplinaridade pode ser vislumbrada como um princípio de organização tendente à coordenação de temas, conceitos e configurações disciplinares. Porém, alguns autores chegam a caracterizar a interdisciplinaridade como uma transferência de problemas, conceitos e métodos de uma disciplina para outra. Mais avançada é a proposta daqueles que identificam a interdisciplinaridade na construção de uma única linguagem, conceitos, preocupações e contribuições de várias disciplinas, como Delattre (o que, em verdade, não afasta as evidentes dificuldades para sua concretização). A cooperação (ou interação) pode exigir ainda escalas progressivas, desde a simples troca de informações úteis (quando, por exemplo, o direito tributário busca em dados econômicos para construção de determinada fundamentação para questionar determinada exigência de tributo), até mesmo a construção de conceitos, termos, procedimentos de pesquisa e organizações investigativas comuns (que, no direito tributário ainda não se manifesta, mas em outros campos do conhecimento, pode-se observar na construção da bioquímica, da bioengenharia). BERGER, Guy, Conditions d'une problématique de l'interdisciplinarité. In: L'interdisciplinarité. Problèmes d'enseignement et de recherche dans les Université. Ceri (eds.) Paris: UNESCO/OCDE, 1972, p.21-24. PALMADE, Guy. Interdisciplinaridad y ideologias. Madrid: Narcea, 1979, p. 05 e seguintes. JANSTCH, Erich. Vers l'interdisplinarité et la transdisciplinarité dans l'enseignement et l'innovation. Op.cit., p. 98-125. THOM, René. Vertus et Dan gers de l'interdisciplinarité. In: Apologie du Logos. Paris: Hachette, 1990, p. 636-643. DELATTRE, Pierre. Recherches interdisciplinaires. In Encyclopedia Universalis. Paris: Organum, 1973, p.387-393. 
interdisciplinaridade $^{1904}$. O cientista avança sobre campo de interesse comum de outros ramos do conhecimento, permitindo-se receber contribuições de outras áreas ${ }^{1905}$.

\subsubsection{Interdisciplinaridade como proposta substitutiva ou complementar ao processo disciplinar?}

Curiosamente, deve-se reconhecer que não é uníssona a terminologia afeita à interdisciplinaridade. E nem poderia haver o estabelecimento de um conceito geral sem identificar etapas ou gradações entre a cooperação de estudiosos de disciplinas distintas.

De todas as variantes terminológicas e estruturais sugeridas ao estudo interdisciplinar, a distinção apresentada por E. Jantsch foi a mais difundida (usando a terminologia de Michaud). Esse autor distinguiu expressamente os termos multidisciplinaridade, pluridisciplinaridade e interdisciplinaridade, por sua vez pautadas em uma escala crescente de coordenação de disciplinas ${ }^{1906}$.

Assim, Jantsch dividiu-as da seguinte forma: a) multidisciplinaridade: conjunto de disciplinas que aparecem simultaneamente, mas sem fazer aparecer qualquer relação entre elas, configurando-se sistema de um nível apenas e de objetivos variados, mas nenhuma cooperação. Nos estudos tributários poderia ser identificada quando o Direito Tributário e a Contabilidade aparecem simultaneamente, mas não parece haver qualquer relação entre eles (seja de síntese ou diálogo). Cada pesquisador pesquisa a tributação em sua respectiva área, com métodos próprios e seus próprios objetivos, mas sem haver qualquer cooperação. Não há nível superior (interdisciplina) para coordenar os trabalhos entre jurídico-tributaristas e contabilistas; b) pluridisciplinaridade: que poderia ser entendida como a justaposição de diversas disciplinas situadas geralmente no mesmo nível hierárquico e agrupadas de modo a fazer aparecer eventuais relações existentes entre elas, formando sistema de um só nível e com objetivos múltiplos (à semelhança da multi), mas com cooperação (embora sem coordenação). Nos estudos tributários ocorreria a

1904 FAZENDA, Ivani Catarina Arantes. Integração e Interdisciplinaridade no Ensino Brasileiro: Efetividade ou Ideologia? Op.cit., p.. 08.

${ }^{1905}$ GUSDORF, Georges. Réflexions sur l'interdisciplinarité. In: Bulletin de Psychologie, XLIII, 397, 1990, p. 847-868.

1906 JANSTCH, Erich. Vers l'interdisplinarité et la transdisciplinarité dans l'enseignement et l'innovation. Op.cit., p. 98-125. Também: JAPIASSÚ, Hilton. Op.cit., p. 51-76 e seguintes. 
justaposição entre o Direito (Tributário) e a Economia, por sua vez mantendo mesma hierarquia (mesmo nível), investigando o mesmo objeto, sob enfoques diferentes, e eventualmente mantendo relações entre Direito e Economia, mas sob objetivos diferenciados de acordo com a disciplina. Pode haver cooperação entre eles (troca de dados), mas não coordenação (que necessitaria de um grau superior que orientaria a pesquisa, de cima para baixo); c) interdisciplinaridade: “(...) axiomática comum a um grupo de disciplinas conexas e definida no nível hierárquico imediatamente superior, o que introduz a noção de finalidade (...)", e tendo sistema de dois níveis, objetivos múltiplos, assim como coordenação advinda do nível superior. Nessa fase, o Direito Tributário e, por exemplo, a "Ciência das Finanças" apresentam-se com um grupo de disciplinas, pesquisando determinado assunto em conjunto, em cooperação, mas também sob coordenação de um sistema de nível superior (que o coordenaria, a chamada “interdisciplina”), ainda que com objetivos diferentes, mas com uma finalidade comum; d) transdisciplinaridade: "coordenação de todas as disciplinas e interdisciplinas do sistema de ensino inovado, sobre a base de uma axiomática geral", com sistemas de níveis múltiplos e coordenação com vistas a uma finalidade comum de sistemas (...)"1907. Nessa fase, o Direito Tributário e, por exemplo, a Política Jurídico-Fiscal (interdisciplina), se uniriam de tal forma, que viabilizariam uma coordenação sob uma nova "axiomática geral”, com sistema de níveis múltiplos. Seria o passo adiante, coordenando disciplinas e "interdisciplinas" de modo a alcançar uma finalidade comum de sistemas tributários (econômico, jurídico, político, etc) ${ }^{1908 \_1909 \_1910}$.

Deve-se reconhecer que a pluralidade de propostas tipológicas sobre os grau de interação entre disciplinas varia intensamente na doutrina, recebendo contribuições adicionais de Jantsch (que inclui a interdisciplinaridade cruzada) ${ }^{1911}$, assim como

\footnotetext{
${ }^{1907}$ MORIN, Edgar. Ciência com Consciência. Op.cit, p. 277 e seguintes.

1908 JAPIASSÚ, Hilton. Op.cit., p. 74-75.

1909 JANSTCH, Erich. Vers l'interdisplinarité et la transdisciplinarité dans l'enseignement et l'innovation. Op.cit., p. 98-125.

${ }^{1910}$ Note-se que a expressão "transdisciplinaridade" usada por Jantsch é historicamente mais aproximada à noção de Piaget (enquanto grau superior de interação interdisciplinar), e guarda poucas semelhanças com a noção de Nicolescu e Morin, apresentada anteriormente.

${ }^{1911}$ JANTSCH, E. Vers l'interdisplinarité et la transdisciplinarité dans l'enseignement et l'innovation. Op.cit., p. 108 e seguintes.
} 
diferenciadas propostas tipológicas dos graus de interação interdisciplinares em Heckhausen ${ }^{1912}{ }^{1913}$, M. Boisot ${ }^{1914}$ e Japiassú ${ }^{1915}{ }^{1916}$.

Também não há unanimidade nas propostas tipológicas da interdisciplinaridade, e nem há separação clara entre as propostas "interdisciplinares" (Heckhausen, Boisot e Japiassú) e as propostas que distinguem a interdisciplinaridade de outras formas de interação (Jantsch). Muitas características parecem assemelhar-se umas as outras, de forma que não é possível atribuí-las plena harmonia (como se fossem necessariamente etapas “evolutivas" da interdisciplinaridade) ${ }^{1917}$.

Assim, o estudo da interdisciplinaridade, na Teoria do Conhecimento, mostra-se voltado ao diálogo recíproco entre disciplinas, gerando a perspectiva de reaproximação interdisciplinar através do estudo das zonas de intersecção do conhecimento.

${ }^{1912}$ Heckhausen, por exemplo, fala em interdisciplinaridade heterogênea (programa de ensino heterogêneo onde disciplinas distintas encontram-se incluídas), pseudo-interdisciplinaridade (quando diferentes disciplinas usam métodos comuns de estudo), interdisciplinaridade auxiliar (semelhante à interdisciplinaridade cruzada de Jantsch), interdisciplinaridade compósita (destinada à reunião de disciplinas para combater determinado problema estrutural), a interdisciplinaridade complementar (reunião de disciplinas para estudar semelhante objeto comum, como a psicopedagogia) e a interdisciplinaridade estrutural (onde há união de disciplinas com a construção de mesmo método e construção teórica de estudo, a exemplo da biofísica). HECKHAUSEN, Heinz. Op.cit., p. 83-90. Também: JAPIASSÚ, Hilton. Op.cit., p. 80. Também conferir: FAZENDA, Ivani. Integração e Interdisciplinaridade no Ensino Brasileiro: Ideologia ou Efetividade? Op.cit. p.30.

1913 HECKHAUSEN, Heinz. Op.cit., p. 83-87. FAZENDA, Ivani. FAZENDA, Ivani. Integração e Interdisciplinaridade no Ensino Brasileiro: Ideologia ou Efetividade? Op.cit. p.30

${ }^{1914} \mathrm{M}$. Boisot fala em interdisciplinaridade linear (semelhante à auxiliar de Jantsch), interdisciplinaridade estrutural (equivalente à proposta de Heckhausen) e interdisciplinaridade restritiva (equivalente à pseudointerdisciplinaridade de Heckhausen). BOISOT, M. Op.cit., p. 90 e seguintes. Também: FAZENDA, Ivani. Integração e Interdisciplinaridade no Ensino Brasileiro: Ideologia ou Efetividade? Op.cit. p.3334.

${ }^{1915}$ A classificação de Japiassú, mais simples divide-as em interdisciplinaridade auxiliar (que seria uma forma mais elaborada de pluridisciplinaridade, onde as disciplinas trocam informações, mas não há reciprocidade, não se identificando praticamente trocas metodológicas. Fazem-na a título de disciplinas auxiliares) e interdisciplinaridade estrutural (ocorreria quando duas disciplinas entram em processo interativo, simultaneamente, e dialogam em pé de igualdade, não existindo supremacia entre uma e outra e, logo, as trocas de informações seriam recíprocas, assim como o enriquecimento das disciplinas a partir dessas trocas). JAPIASSÚ, Hilton. Op.cit., p. 81.

${ }^{1916}$ Idem.

${ }^{1917}$ Conforme já informado, apesar de mais difundida, a classificação de Heckhausen não é a mais didática, e, muitas vezes, perde-se na clarificação da necessidade de existência de um "nível superior" (como se observa em Jantsch). Aparentemente, as classificações de Heckhausen e Jantsch não são harmônicas e por isso a comparação torna-se dificultada. O que é pseudointerdisciplinaridade para Heckhausen pode ser classificado como pluridisciplinaridade para Jantsch, e para Boisot, a chamada "interdisciplinaridade restritiva", e assim por diante. A classificação de Japiassú, mais simplificada, não afasta as dúvidas atinentes às classificações anteriores. BOISOT, M. Op.cit., p. 90 e ss. Também: FAZENDA, Ivani. Integração e Interdisciplinaridade no Ensino Brasileiro: Ideologia ou Efetividade? Op.cit. p.33-34. 
Contudo, a variedade terminológica e tipológica apresentada na literatura especializada inviabiliza a construção de uma “Teoria Geral da Interdisciplinaridade".

Ao mesmo tempo, a interdisciplinaridade pressupõe disciplinas já em estado avançado de amadurecimento. Sem disciplinas bem consolidadas a interdisciplinaridade perde terreno para o sincretismo epistemológico. $\mathrm{Na}$ interdisciplinaridade as disciplinas não perdem sua identidade, mas fornecem contribuições para serem pensadas em "um nível acima”, e aptas a resolverem problemas que sozinhas não conseguiriam. Assim, a reciprocidade é pressuposta na análise interdisciplinar.

Note-se que, ainda que a interdisciplinaridade se desenvolva através de uma visão holística, vinculada à complexidade, o próprio Morin assinala que não seria uma proposta substitutiva às disciplinas, mas complementar, buscando alcançar o que não seria alcançado no âmbito de atuação de uma única disciplina ${ }^{1918}$. O que há, portanto, é a complementação, para alcançar o que os limites epistemológicos disciplinares não poderiam visualizar com êxito.

\subsection{Os riscos e desafios da verdadeira interdisciplinaridade na Ciência Jurídica Brasileira.}

A problemática da interdisciplinaridade na Ciência do Direito recebeu contribuição recente no trabalho de Marcelo Neves que, por sua vez, apresenta determinadas reservas aos estudos interdisciplinares, especialmente vinculados ao conhecimento jurídico.

Primeiramente, Neves busca afastar a verdadeira interdisciplinaridade do enciclopedismo jurídico, que, por sua vez, seria compreendido como a mera justaposição de diversos conhecimentos sobre o direito.

Por outro lado, ataca eventuais discursos interdisciplinares que poderiam levar a um imperialismo disciplinar, isto é, a imposição de métodos científicos unilateralmente de uma disciplina a outra, sem haver trocas recíprocas. Nesses casos, lembra que muitas vezes, a superestimação dos conhecimentos de Law and Economics aplicados ao Direito, ao invés de simbolizar trocas recíprocas (verdadeira interdisciplinaridade), significaria tão somente, "subordinar os critérios do direito a uma racionalidade puramente econômica", onde se pleitearia uma "economic jurisprudence", desconhecendo-se qualquer racionalidade

${ }^{1918}$ MORIN, Edgar. O Paradigma da Complexidade. Op.cit., p. 205-206. 
jurídica específica e, logo, ao invés de uma prática jurídica mais adequada economicamente, ocorreria um "imperialismo econômico" ou "colonização econômica do direito" 1919 .

Esse risco poderia ser identificável também nos ensinamentos da Política do Direito, sobretudo, por existir tendência na consideração do direito como fenômeno do poder ou ideologia política, e assim, pleiteando-se uma "political jurisprudence", afastando-se, outra vez, da racionalidade jurídica (para o autor, alguns sintomas dessa tendência poderiam se ligar ao movimento "Critical legal Studies"), onde não se intermediaria a lógica do poder e a lógica do direito - buscando alcançar uma prática jurídica politicamente satisfatória, mas tão somente o "imperialismo político" ou a “colonização política do direito".

As mesmas preocupações poderiam ser observadas em modernas tendências da sociologia jurídica, ao buscar transformar o conhecimento sociológico do direito em "sociological jurisprudence", ao invés de um diálogo interdisciplinar, aplicando-se uma "Law and Society" e conduzindo-se ao "imperialismo sociológico ou colonização social do direito" ${ }^{\prime 1920}$.

Outro risco apontado pelo autor incorreria na eventual confusão entre interdisciplinaridade e metadisciplinaridade, que, sinteticamente, seria um “(...) metadiscurso ou uma metanarrativa capaz de impor, de cima, limites e formas de intercâmbio, entre áreas do saber referentes ao direito (...)", que busca simplificar, mas não considera as diversidades e conflituosidades que podem advir dessas relações, e geralmente é camuflado por discursos "filosóficos (...)" buscando impor limites e condições a essas relações (autoritariamente), sem respeitar as peculiaridades do direito em relação a outros campos do conhecimento ${ }^{1921}$.

Naturalmente, para Neves, confirmando as mais avançadas teorias interdisciplinares, a verdadeira interdisciplinaridade envolve trocas recíprocas, onde a autonomia entre as disciplinas é reforçada, nunca mitigada. Nesse contexto, na

${ }^{1919}$ NEVES, Marcelo. Pesquisa Interdisciplinar no Brasil: o paradoxo da interdisciplinaridade. In: Revista do Instituto de Hermenêutica Jurídica - RIHJ. Belo Horizonte: Editora Fórum, ano 1, n. 3, jan. / dez. 2005, p. 02-03.

${ }^{1920}$ Idem, p. 05.

${ }^{1921}$ Idem. 
interdisciplinaridade, a linguagem de um campo do conhecimento acaba traduzida na linguagem de outro campo, e essa tradução é feita segundo critérios do próprio campo do conhecimento onde a linguagem advinda de outro campo pretende ter relevância. ${ }^{1922}$. Com o diálogo entre discursos diversos sobre o direito, o conhecimento jurídico enriquece-se conceitualmente, e tende a elevar a sua própria capacidade de solução dos problemas que surgem em seu ambiente teórico ${ }^{1923}$. Através da interdisciplinaridade, possibilita-se que a linguagem econômica seja traduzida, e compreendida, no âmbito da linguagem jurídica.

É interessante notar que a reflexão de Neves, no entanto, transparece mais temerosa quanto ao debate interdisciplinar aplicável à realidade jurídica brasileira, sobretudo, porque, segundo o autor, haveria maior fragilidade nas fronteiras do conhecimento jurídico, sobretudo proporcionadas por suposta deficiência na autonomia do Direito ${ }^{1924}$.

Ainda que remetidas à generalidade da ciência jurídica no Brasil, sem considerar sub-ramo específico para aplicação de suas reflexões, as ponderações do autor sobre os riscos do empreendimento interdisciplinar na ciência jurídica brasileira merecem ser refletidas perante o processo histórico de especialização disciplinar do Direito Tributário Brasileiro, que como visto, guardou evidentes ponderações.

\footnotetext{
${ }^{1922}$ Para Neves, a interdisciplinaridade “(...) é um espaço fluido e instável de comutação discursiva. Nela, o sentido originário de um discurso atravessa um transformador para ser compreendido e ganhar sentido no âmbito de um outro discurso. Nesse sentido, a interdisciplinaridade permite que a linguagem econômica, política ou sociológica seja compreendida e ganhe sentido no âmbito da dogmática jurídica e vice-versa. Isso fortifica a adequação recíproca e uma certa cooperação num ambiente de conflituosidade disciplinar, sem que as respectivas pretensões de autonomia sejam negadas". NEVES, Marcelo. Op.cit., p. 06-07.

${ }^{1923}$ Em outras palavras: "Uma dogmática jurídica disposta a abrir-se interdisciplinarmente aos influxos e às pressões advindas da análise econômica, política ou sociológica do direito, e mesmo àquelas decorrentes da reflexão filosófica do direito, tende a ter uma maior capacidade teórica e prática de enfrentar os problemas que se lhe apresentam e oferecer soluções mais apropriadas dos mesmos do que um modelo formalista, insensível à interdisciplinaridade. $\mathrm{O}$ mesmo vale no sentido oposto: a análise econômica, política e sociológica e mesmo a reflexão filosófica do direito serão tanto mais ricas conceitualmente e mais influentes na prática jurídica, quanto mais elas forem capazes de traduzir ou comutar nas suas linguagens, mediante o transformador da interdisciplinaridade, a linguagem da dogmática jurídica". Idem.

${ }^{1924}$ Para Neves, o processo deficiente da autonomia do Direito dificultaria a distinção, "(...) entre autoobservação jurídico-dogmática e hetero-observação econômica, sociológica ou política do direito", gerando uma sobrecarga para a dogmática jurídica para definir suas fronteiras e afirmar sua identidade. Diferentemente da realidade europeia e norte-americana, no Brasil, segundo Neves, o problema “(...) não se resumiria à diferenciação no campo jurídico na fronteira de output (adequação social), mas também e, sobretudo, de diferenciá-lo na fronteira de input (consistência jurídica), ou seja, de afirmá-lo diante das pressões imediatas e particularistas que forças sociais exercem nesta fronteira (...)", gerando o risco de se aplicar o imperialismo disciplinar no dogmatismo jurídico que, na avaliação do autor, ainda não conseguiu, no Brasil, delimitar com clareza suas fronteiras disciplinares. Ibidem, p. 08-09.
} 
Por isso é importante analisar o retrospecto histórico do debate, especialmente para verificar se as ressalvas de Neves merecem ser acolhidas no processo disciplinar do Direito Tributário Brasileiro, ou se essas devem ser relativizadas.

\section{O progressivo reflexo da epistemologia da complexidade e a elevação da interdisciplinaridade na doutrina do Direito Tributário Brasileiro contemporâneo.}

É interessante notar que, embora como visto, Morin tenha construído sólida contribuição à epistemologia, sistematizando a complexidade, ao mesmo tempo, eleva também a necessidade do diálogo crescente entre disciplinas, buscando afastar-se da "torre de babel" que é o conhecimento científico contemporâneo.

O obra de Morin, e da própria epistemologia da complexidade, assim como os estudos interdisciplinares construídos na pedagogia francesa, a partir da década de setenta do século XX, tem recepção tardia nos estudos tributários contemporâneos, e, por esse motivo, somente agora parcela da doutrina passa a considerar a importância das contribuições desse ramo do conhecimento para os estudos tributários.

Nesse plantel se pode incluir as recentes contribuições de José Souto Maior Borges, que publicou recentemente estudo denominado "Um Ensaio Interdisciplinar em Direito Tributário: Superação da Dogmática”, no qual revisa sua posição epistemológica original, assumindo como pressuposto desse estudo paradigma teórico diferenciado de seus estudos anteriores, ou seja, o Paradigma da Complexidade, em substituição ao paradigma "redutor restritivo do conhecimento" em matéria tributária, muito embora reconheça que a aceitação desse novo paradigma incorre em assumir risco de “(...) elevado grau de indeterminação conceitual”. Não por acaso, para José Souto Maior Borges, neste ensaio, a interdisciplinaridade seria “(...) um outro nome da complexidade”. 1925

\footnotetext{
${ }^{1925}$ Aspecto importante deste trabalho é que o autor assume a noção de complexidade no fenômeno tributário “(...) no fundamental, ao caráter interdisciplinar da abordagem teórica”. E prossegue: "Trata-se da opção por uma perspectiva de estudo que supera, ao mesmo tempo, a) o isolamento disciplinar em nome da autonomia do Direito Tributário, como tradicionalmente concebida ("autonomia didática"); e b) a circunscrição estrita
} 
Criticando as tendências da doutrina brasileira (que atingiu uma saturação epistemológica), busca encontrar soluções para “(...) lograr um progresso efetivo nos estudos jurídicos sobre o tributo". ${ }^{1926}$ Para alcançar tal objetivo, inspirado em Morin, assume como paradigma epistemológico o modelo do enfrentamento das complexidades, induzindo a necessidade de uma "revolução copernicana" (ou "revolução metacopernicana") ${ }^{1927}$, sem necessariamente afastar a simplificação das hipóteses científicas. Em outras palavras, busca combater o estancamento da análise da estrutura do tributo, sem atenção às suas funções (à teleologia das categorias e institutos da dogmática do direito tributário) ${ }^{1928}$.

É interessante mencionar que o autor eleva a obra de Ives Gandra Martins, como feliz exceção doutrinária à tendência redutora no Brasil. "A justiça que não lhe fiz, desde sempre, faço-a agora.”, assim como reconhece a influência da obra de André Folloni ${ }^{1929}$. ${ }^{1930}$, para alterar substancialmente a forma de enfrentamento à temática tributária. ${ }^{1931}$

da dogmática jurídico-tributária em torno da obrigação tributária e respectivo fato gerador, bem como ao lançamento tributário". BORGES, José Souto Maior. Um Ensaio Interdisciplinar em Direito Tributário: Superação da Dogmática. In: Revista Dialética de Direito Tributário. n.211. Valdir de Oliveira Rocha (Coord.). São Paulo: Dialética, 2013, p.106-121.

${ }^{1926}$ Idem.

${ }^{1927}$ Essa atitude científica heterodoxa acarretará, se efetivamente adotada, uma "revolução copernicana" no âmbito dos estudos do Direito Tributário. Assim: “(...) Sob esse aspecto, relações interdisciplinares se assemelham ao modelo do universo de Hubbles: assim como o universo não tem centro, mas dispersão e expansão, o mundo jurídico junta (o sistema) aquilo que está disjunto (as especializações jurídicas descentralizadas). É dizê-las, numa palavra: excêntricas. A questão da complexidade é, como se verá, problema da organização do conhecimento no âmbito tributário. A revolução está na inversão de perspectiva (a) da norma de conduta para (b) a conduta normada (pragmática) e (c) da estrutura à (d) função tributária, como preconizava Bobbio". BORGES, José Souto Maior. Um Ensaio Interdisciplinar em Direito Tributário: Superação da Dogmática. Op.cit., p. 108-109.

${ }^{1928}$ E elenca o principal inconveniente da opção metodológica redutora, qual seja a alienação, que implica nos seguintes problemas: 1) o estudo da utilização dos recursos oriundos do cumprimento das obrigações tributárias seria vedada ao jurista especializado em tributo. Em outras palavras, o tributarista não entende de direito financeiro e o jus-financista não entende de direito tributário; 2) deixa de investigar criticamente a aplicação dos recursos públicos (destinação); 3) a conversão "em letra morta" do princípio da moralidade da administração (pela sua acentuada carga ética, ou seja, interdisciplinar a ser aplicada ao direito tributário) e a falta de diálogo entre Direito Tributário e Ética Administrativa; 4) os problemas da alienação que ignora as relações intersistêmicas do direito tributário e da moral positiva, cujo enfrentamento teórico não seria apenas uma questão acadêmica mas até de cidadania, dentre outros. Idem, p. 119-121.

${ }^{1929}$ Refere-se à obra: "Ciência do Direito Tributário no Brasil. São Paulo: Saraiva, 2012”. Ibidem, p.113 e seguintes.

${ }^{1930}$ FOLLONI, André. O Direito Tributário diante da Complexidade Econômica e Socioambiental ou: para além de Souto sem sair de Souto nos 50 anos da Teoria Geral de Becker. In: Revista Tributária e de Finanças Públicas. n.111. São Paulo RT, 2013, p.15 e seguintes.

1931 José Souto Maior Borges, além de defender ao estudo da pragmática no campo tributário, sinaliza também necessidade de reflexões às perspectivas funcionais relacionadas ao fim do direito tributário, vinculando inevitavelmente o jurista à justiça tributária, considerando as implicações da jurisdicização da moral pela CF, e sinalizando a abertura para a Política-Jurídica no Direito Tributário. BORGES, José Souto 
Assim, sob o paradigma da complexidade, José Souto Maior Borges reformula sua posição original $^{1932}$, aceitando a procedência da opinião sobre a complexidade como novo paradigma epistemológico, e elevando a interdisciplinaridade como campo necessário para os próximos estágios evolutivos do estudo do direito tributário.

Mas, gradualmente, os estudiosos passam a defender necessidade de maior abertura epistemológica, especialmente considerando a possibilidade da consideração do fato tributário em sua própria complexidade, e passam inclusive a iniciar reflexões sobre os fundamentos teóricos da interdisciplinaridade na teoria do conhecimento.

Abaixo, ressalta-se a publicação (exemplificativa) de alguns estudos recentes publicados sobre o tema, e que mantém as seguintes características comuns: a) a defesa da interdisciplinaridade como mecanismo apto ao aperfeiçoamento disciplinar; b) a substituição do paradigma tradicional (reducionismo epistemológico) pelo paradigma da complexidade; c) a elevação da necessidade de estudos conjuntos sobre o fenômeno tributário, especialmente no diálogo entre Economia, Contabilidade e Direito.

Os estudos de André Folloni realizados sob a perspectiva pragmática da norma jurídica, cumulados com a defesa do paradigma da complexidade, apresentam importante contribuição ao tema, inspirada na hermenêutica histórica de José Souto Maior Borges, e, especialmente, ao defender a superação do tradicional procedimento redutor de complexidades praticado pela literatura tributária brasileira, pautada na construção de teorias prévias à observação, condicionando-a, mas “(...) não cedendo caso a realidade objeto de estudo a contrarie (...)", ${ }^{1933}$ o que, em muitos aspectos, reflete a busca exacerbada pela segurança, e a consequente redução do objeto de estudo. ${ }^{1934}$

A crítica do autor às tendências tradicionais aplicadas na doutrina tributária brasileira, especialmente aquela construída na Escola da PUC-SP, ${ }^{1935}{ }_{-}^{1936}$ apresenta forte

Maior. Um Ensaio Interdisciplinar em Direito Tributário: Superação da Dogmática. Op.cit., p.118 e seguintes.

1932 Idem, p. 120.

${ }^{1933}$ FOLLONI, André. Ciência do Direito Tributário no Brasil. Crítica e Perspectiva a partir de José Souto Maior Borges. Op.cit., p.35 e seguintes.

${ }^{1934}$ Idem, p.1-75.

1935“'Os tributaristas costumam tratar do conteúdo jurídico-positivo sem trazer, à presença, a realidade social subjacente. Essa realidade, determinante para a boa interpretação e aplicação do direito, fica velada, no discurso que se volta exclusivamente para a forma estrutural do direito positivo e seu conteúdo semântico definido, este, em um método sistemático fechado, no sistema normativo, idealizado, em isolamento perante seu meio. A universalidade que reclama a torna vazia diante da realidade. Se é precioso o trabalho kelseniano 
carga teórica, que, relembrando os ensinamentos da hermenêutica histórica (extraída da trajetória teórica de José Souto Maior Borges), usa-a como subterfúgio para questionar a produção teórica brasileira (notadamente a tradição dogmático-normativa) ${ }^{1937}$, ao apontar que, para a efetiva evolução da Ciência do Direito Tributário, esta deve ser capaz de enfrentar a complexidade econômica e socioambiental contemporânea, superando, gradualmente, os seguintes obstáculos: a) hermenêutica kelseniana, que segundo Folloni, impede ao cientista de se manifestar “(...) com racionalidade científica, a respeito do que pode vir a ser”, restringindo “(...) qualquer manifestação pragmática sobre os efeitos que determinada norma ou teoria ou conduta podem gerar, isolando-a no campo da irracionalidade" ${ }^{1938}$; b) o reducionismo epistemológico, já que a doutrina admitiu que a redução de complexidades seria o pressuposto para viabilizar o estudo "científico" do Direito Tributário ${ }^{1939}$.

Evidentemente, o caminho apontado pelo autor também caminha à interdisciplinaridade ${ }^{1940}$, promovendo o diálogo com outros ramos jurídicos (Direito Financeiro, Constitucional, Administrativo, etc), assim como à Economia, à Política e à Ética, enfrentando a complexidade e incentivando a pragmática, sempre refletindo sobre o caminho apontado por José Souto Maior Borges. ${ }^{1941}$

ou vilanoviano no âmbito da teoria geral do direito, é inadequado, como metodologia exclusiva, buscar transformar o direito tributário em teoria geral. Essa exclusividade faz com que o direito tributário se esvazie de matéria, convertendo-o em uma fórmula simbólica. Subjaz, a isso, a exclusividade de uma razão incapaz de lidar com conteúdos materiais cambiáveis e permeáveis, sujeitos aos mais diversos condicionamentos, externos e internos". FOLLONI, André. Ciência do Direito Tributário no Brasil. Crítica e Perspectiva a partir de José Souto Maior Borges. Op.cit., p. 133-204

${ }^{1936}$ FOLLONI, André. O Direito Tributário diante da Complexidade Econômica e Socioambiental ou: para além de Souto sem sair de Souto nos 50 anos da Teoria Geral de Becker. Op.cit., p.23-24.

${ }_{1937}$ Idem, p.26.

${ }^{1938}$ FOLLONI, André. O Direito Tributário diante da Complexidade Econômica e Socioambiental ou: para além de Souto sem sair de Souto nos 50 anos da Teoria Geral de Becker. Op.cit., p. p.27 e seguintes. Também: FOLLONI, André. Ciência do Direito Tributário no Brasil. Op.ct., p. 207 e seguintes. ${ }_{1939}$ FOLLONI, André. Ciência do Direito Tributário no Brasil. Op.cit., p.333 e seguintes; p. 365-383.

1940 “Assim, não separar o tributário do Direito, e este do meio em que se insere, mas reintegrá-los; não cindir o jurista e o Direito, mas uni-los; não afastar a realidade mutante, individual, transitória, diferente, complexa, mas enfrentá-la. Não enxergar exclusividades onde existe coexistência. Não ver direção única onde existem paradoxos. Não impor uniformidades onde há complexidade. É o que se exige, epistemologicamente, do cientista contemporâneo, inclusive do jurista e do tributarista. O Direito Tributário do século XXI precisa se relacionar com as demais disciplinas jurídicas - como, aliás, vem fazendo diante do Direito Constitucional, do Direito Processual, do Direito Penal, do Direito Internacional e do Direito Privado, por exemplo - e avançar rumo ao relacionamento interdisciplinar com a Economia, a Política, a Ciência das Finanças e as Ciências Sociais que, diante da rigorosa delimitação disciplinar, ficou nas fronteiras entre o Direito Tributário, Direito Financeiro, Direito Constitucional, Economia, Política, etc”. FOLLONI, André. O Direito Tributário diante da Complexidade Econômica e Socioambiental ou: para além de Souto sem sair de Souto nos 50 anos da Teoria Geral de Becker. Op.cit., p.39-40.

${ }^{1941}$ FOLLONI, André. Ciência do Direito Tributário no Brasil. Op.cit., p. 283 e seguintes; p. 386-387. 
Nesse caminho seguiu também Elidie Palma Bifano, ${ }^{1942}$ analisando questões relacionadas ao Direito Tributário perante a Economia, a Informática, a Mecânica e a Contabilidade. Reconhecendo os complexos desafios da informação na relação tributária $^{1943}$, ao defender o reconhecimento da complexidade ínsita ao fenômeno tributário e o afastamento da tendência kelseniana (que leva ao reducionismo epistemológico) ${ }^{1944}$, chega até mesmo a investigar a estrutura teórica da interdisciplinaridade na teoria do conhecimento (Ivani Fazenda). Para Elidie, no Direito Tributário, essa atitude interdisciplinar é essencial, desde a elaboração da norma até sua aplicação e interpretação $^{1945}$.

O mérito apresentado no estudo da autora foi buscar defini-la e compreendê-la a partir de teóricos nacionais da interdisciplinaridade no campo da pedagogia interdisciplinar (Ivani Fazenda), que, evidentemente, pressupõe o reconhecimento da chamada “epistemologia da complexidade", reforçando a necessidade de que o sistema jurídico não seja concebido como monolítico, lembrando as importantes lições de Miguel Reale (teoria tridimensional), e elevando a complexidade ${ }^{1946}$.

${ }^{1942}$ BIFANO, Elidie Palma. O Direito Tributário e a Interdisciplinaridade com Outros Ramos do Saber. In: Direito Tributário Atual. ZILVETI, Fernando Aurelio (Coord.). n.30. São Paulo: Dialética-IBDT, 2014, p.158-171.

${ }^{1943} \mathrm{O}$ maior desafio do mundo moderno, certamente, é a informação sob diversos aspectos: i) necessidade do cidadão, o homem que vive em sociedade, de comunicar-se e conhecer-compreender o que os demais cidadãos pensam, fazem e produzem, sob pena de isolar-se; iii) necessidade do cidadão de elucidar dúvidas de seu cotidiano; e (iii) necessidade do cidadão de crescer, intelectualmente, inclusive no que respeita ao exercício de suas atividades profissionais". Idem, p. 159-160.

${ }^{1944}$ Nesse contexto, a autora repercute as recentes críticas epistemológicas sobre o paradigma redutor do conhecimento, na esteira dos defensores da interdisciplinaridade: "Essa segregação de ciências em decorrência de seus objetos e métodos de pesquisa consolidou a figura da disciplinaridade científica, em que cada suposto ramo do saber tem conteúdo e método próprios não se confundindo com quaisquer outros. $\mathrm{O}$ progresso de certos estudos evidenciou que, muitas vezes, é necessário envolver e trabalhar com mais de uma ciência, ao mesmo tempo, o que conformou a multipliscinaridade, ou seja, o recurso a duas diferentes disciplinas sem que elas sejam alteradas em seus objetos e métodos. Por essa razão, atualmente, considera-se que a divisão entre as ciências é apenas um instrumento prático, uma vez que os progressos científicos, observados decorrem de problemas nascidos nos limites de setores que, até então, eram tratados isoladamente" BIFANO, Elidie Palma. O Direito Tributário e a Interdisciplinaridade com Outros Ramos do Saber. Op.cit., p. 161.

${ }_{1945}^{19}$ Idem.

1946 “A complexidade das relações sociais, nos dias de hoje, não permite que o Direito deixe de interconectarse com outros setores do saber, tidos como jurídicos ou não. Esses elementos e aspectos têm, individual ou coletivamente considerados, relevante importância na matéria que adiante se examina: a eleição do valor social que se sujeitará à incidência tributária e o processo para se fazer essa eleição e inseri-la no ordenamento jurídico". Ibidem, p. 162. 
Para a autora, portanto, é injustificável o divórcio entre Direito Tributário, Contabilidade e Economia ${ }^{1947}$, que acaba determinando o “(...) afastamento do fato econômico, hoje privilegiado pela Ciência Contábil. Olvidar o fato econômico é olvidar que o tributo é, de per si, fato econômico, por excelência, criado e justificado pelas relações econômicas desenvolvidas pela sociedade". ${ }^{1948}$

Assim, na elevação da epistemologia da complexidade, por parcela da literatura tributária nacional contemporânea, há forte tendência de que novos estudos forneçam elementos para a superação das deficiências próprias do processo disciplinar. Contudo, esse empreendimento não é imune a inerentes dificuldades, e precisa necessariamente adaptar-se às peculiaridades do fenômeno tributário, assim como também arregimenta a necessidade de se alcançar finalidades próprias ao empreendimento. A literatura nesse campo ainda é muito recente, e precisa, como qualquer outra perspectiva de estudo e ensino, sedimentar progressivamente suas bases teóricas e metodológicas na aplicação dessas premissas ao fenômeno tributário.

\section{Interdisciplinaridade e a função prospectiva (normativa) do tributarista.}

O processo interdisciplinar, caracterizado pela troca de conhecimentos entre disciplinas afetas ao mesmo objeto de conhecimento, não pode ser encarado como a necessária "fusão" entre o Direito Tributário e outras disciplinas, como se o primeiro lentamente perdesse suas características historicamente consolidadas no processo de especialização disciplinar.

Complementar ao processo disciplinar, a interdisciplinaridade aparece como veículo fundamental para o reconhecimento da complexidade epistemológica e da

\footnotetext{
${ }^{1947}$ De forma mais incisiva, oferece reflexões sobre a interdisciplinaridade do direito tributário com a Economia e com a Contabilidade. Na interação entre Economia e Direito Tributário, aponta diversas utilidades no diálogo entre os dois ramos do conhecimento: "O uso do fenômeno econômico como indicador de riqueza não é privilégio do Direito Tributário, utilizado que é pelo Direito Societário para remunerar os sócios de empresas (dividendos ou lucro) sendo também irrelevante, para tanto, o recebimento dos correspondentes recursos. Como exemplo, a tributação pelo imposto sobre a renda alcança o acréscimo patrimonial, representado por fatos econômicos, o que exige que tais fatos sejam interpretados, necessariamente, à luz dos correspondentes fenômenos econômicos que gerara". Ibidem.

${ }^{1948}$ Em outras palavras: "Esses fatos dentre muitos outros que se podem apresentar e comentar demonstram que urge se promova a reconciliação entre o Direito Tributário, a Contabilidade e, por consequência, a Economia, cuja interação e interdisciplinaridade são incontroversas”. Ibidem, p.170-171.
} 
transdisciplinaridade e, portanto, ao invés do inevitável recorte metodológico caracteristicamente disciplinar, na interdisciplinaridade, assume-se a complexidade e busca-se enfrentá-la, adotando estratégias de aproximação de disciplinas que favoreçam o exame da "zona de intersecção" e, portanto, não incorrendo em uma suposta "destruição" das disciplinas já consolidadas.

Afinal, não é possível resolver os problemas contemporâneos que desafiam os estudos tributários sem buscar alternativas ao estudo disciplinar e, nesse sentido, a interdisciplinaridade oferece o caminho para que o raciocínio jurídico tributário seja reforçado, através da troca de informações e experiências úteis ao empreendimento do tributarista.

Reconhecendo a possibilidade do estudo interdisciplinar perante o fenômeno tributário como importante aliado ao empreendimento disciplinar, como esse deve ser realizado? E quais disciplinas afetas à tributação poderiam oferecer conhecimentos úteis ao empreendimento?

Em realidade, notar-se-á, em todos os esforços adiante lembrados, uma tônica comum: a perspectiva de que o direito tributário brasileiro positivo pode e deve ser aperfeiçoado, e não apenas descrito, como é próprio da função tradicional do intérprete do direito (com as ponderações formuladas pela literatura). A função prospectiva ou normativa aparece como instrumento pra que o direito tributário seja aperfeiçoado, direcionando-o a valores fundamentais caros ao próprio ordenamento jurídico ${ }^{1949}$.

A interdisciplinaridade deve ser empreendimento do qual participe a própria Ciência do Direito Tributário, valorizando-a. Esta, dialogando com disciplinas afins, viabiliza a construção conjunta de temas favoráveis ao reforço do raciocínio jurídicotributário.

\footnotetext{
${ }^{1949}$ A ideia de função normativa exposta neste trabalho é uma adaptação livre das ideias identificadas em estudos interdisciplinares. Nesse sentido, preliminarmente, sobre a função normativa no campo da Política Tributária: MARINS, James. O Desafio da Política Jurídico-Fiscal. In: Tributação \& Política. James Marins (Coord.) Livro 6. Curitiba: Juruá Editora, 2005, p. 49 e seguintes. FERREIRO LAPATZA, José Juan. Direito Tributário - Teoria Geral do Tributo. Barueri - SP: Marcial Pons - Manole, 2007, p. 130-132. Sobre a função normativa na Análise Econômica do Direito: CARVALHO, Cristiano. Análise Econômica da Tributação. In: Direito e Economia no Brasil. TIMM, Luciano Benetti (Org). São Paulo: Atlas, p. 158 e seguintes.
} 
A função prospectiva ou normativa permite abordagens investigativas centradas em objetivos semelhantes, que passam, naturalmente, a ser observados em decorrência dos valores mais importantes da tributação, que não se limitam à segurança no Direito Tributário, mas avançam às perspectivas de justiça tributária.

Nesse contexto, três possibilidades efetivamente interdisciplinares são apontadas para o diálogo recíproco com a Ciência do Direito Tributário na busca de seu aperfeiçoamento disciplinar no século XXI: a) o diálogo recíproco entre Ciência do Direito Tributário e a Filosofia da Tributação; b) o diálogo recíproco entre Ciência do Direito Tributário e a Análise Econômica do Direito e; c) o diálogo recíproco entre a Ciência do Direito Tributário e a Política Tributária.

Contudo, os três campos interdisciplinares do conhecimento afetos à tributação ainda mantém-se, de certa forma, em processos iniciais de aperfeiçoamento, em muitos aspectos decorrentes da própria tendência à especialização disciplinar do Direito Tributário e a exclusão do diálogo com outros ramos do conhecimento (sobretudo da Ciência das Finanças). De qualquer forma, tais dificuldades teóricas não devem impedir o enfrentamento de reflexões nesses campos do conhecimento, especialmente pelas valiosas contribuições ao aperfeiçoamento do Direito Tributário.

\subsection{Perspectivas de Diálogo Recíproco entre Filosofia e Tributação: a Filosofia Tributária e a Ciência do Direito Tributário Brasileiro contemporâneo}

O diálogo entre Direito Tributário e a Filosofia sempre esteve presente no processo disciplinar do Direito Tributário Brasileiro, que traz entre suas características, o de ser profundamente permeado por diferentes "linhas" da Filosofia do Direito (e muitas vezes ligadas a temas fundamentais da Filosofia Geral). ${ }^{1950 \_}{ }^{1951}{ }_{-}^{1952}$ Se a interdisciplinaridade é

\footnotetext{
${ }^{1950}$ KAUFMANN, Arthur. Filosofia do Direito. Lisboa: Fundação Calouste Gulbenkian, 2004, p. 01 e seguintes. Sobre o assunto também (notadamente sobre as relações entre Positivismo Jurídico e Direito Natural) consultar: BOBBIO, Norberto. O Positivismo Jurídico. Lições de Filosofia do Direito. Op.cit., p. 131 e seguintes.

${ }^{1951}$ CARVALHO, Paulo de Barros. Vilém Flusser e os Juristas. Op.cit., p. 20 e seguintes.

${ }^{1952}$ ZILVETI, Fernando Aurelio. A Evolução da Teoria da Incidência - Análise Histórica das Estruturas Socioeconômicas na Formação do Sistema Tributário. Op.cit., s/np (item i.9).
} 
diálogo entre conhecimentos, não há como negar a existência da interdisciplinaridade (jurídica) em todas essas construções teóricas.

Mas existe uma "Filosofia do Direito Tributário"? Essa pergunta foi formulada por Renato Lopes Becho, a propósito de seu trabalho homônimo à pergunta. A resposta foi a seguinte: "Partimos do pressuposto que filosofar é acima de tudo uma postura, uma forma de se colocar diante de um objeto. Esse é o ânimo interno de quem pratica ou realiza a filosofia. (...)" E conclui: “(...) Nos termos em que expusemos a respeito da postura filosófica, consideramos possível a existência da Filosofia do Direito Tributário, vista como atitude filosófica direcionada para o ramo do direito que se dedica aos tributos. Quem pretende fazer filosofia no campo da tributação procura refletir sobre o direito tributário no mundo jurídico. A exeteriorização de tais dúvidas compõe o resultado que pode advir dessa prática" ${ }^{1953}$.

Nesse contexto, o autor, além de apresentar rol de autores dedicados aos aspectos filosóficos da tributação, sobretudo franceses, busca considerar a filosofia do direito tributário estruturada em três frentes (epistemologia, axiologia e metafísica). ${ }^{1954}$ Contudo, diante da crise do positivismo jurídico, passa-se a reconhecer, cada vez mais, os direitos humanos aplicados à tributação", funcionando, de certa forma, como um retorno ao "direito natural",1955.

1953 Sobre a filosofia do direito tributário, confira-se: BECHO, Renato Lopes. Filosofia do Direito Tributário. Op.cit., p. 268.

${ }^{1954} \mathrm{Na}$ primeira, o autor cita Paulo de Barros Carvalho, sobretudo sobre a aplicação da teoria do conhecimento aplicada ao direito tributário (sobretudo na perspectiva da linguagem jurídica). Também considera a aplicação da teoria dos valores frente ao direito tributário, especificamente em dois campos distintos (normativo e subjetivo). Particularmente interessante refere-se ao argumento do autor no sentido de que correntes filosóficas podem explicar posturas dogmáticas e interpretativas ao direito tributário ou, pelo contrário, podem levar à diferentes compreensões do direito tributário (dependendo das premissas filosóficojurídicas assumidas), lembrando também de Sacha Calmôn Navarro Coêlho. Em primeiro lugar levanta o direito natural e o direito tributário, sobretudo, ligando-o a Ives Gandra Martins, assm como o direito positivo e o direito tributário, fortalecido pela codificação tributária brasileira; o Realismo Jurídico e o Direito Tributário (conhecimento do direio a partir de decisões judiciais), lembrando de José Cretella Júnior, Ricardo Lobo Torres, Eduardo Bottallo e José Eduardo Soares de Melo. Chega a considerar também a crise do positivismo jurídico frente ao direito tributário (ligando-o à impossibilidade de o direito resolver conflitos intersubjetivos exclusivamente pautados na legislação - juspositivismo - ou exclusivamente pautados em decisões judiciais - como aponta o realismo jurídico). BECHO, Renato Lopes. Filosofia do Direito Tributário. Op.cit., p. 275-306.

1955 "Entretanto, o direito natural não volta com a mesma configuração, pois a normatividade desenvolvida a partir do juspositivismo é aproveitada enquanto instrumento de identificação do fenômeno jurídico. $\mathrm{O}$ positivismo funciona como análise técnica, metodológica, enquanto a ética funciona verificando o conteúdo das normas jurídicas". Ainda, "(...) com os direitos humanos, a exigência feita de universalidade do direito natural passa a tomar nova dimensão”. Não por acaso, “(...) os princípios jurídico-tributários determinam a aplicação dos valores normatizados ao sistema tributário. Partindo da máxima kantiana da liberdade, 
Da mesma forma, deve-se reconhecer que, entre essas construções e a chamada "Filosofia dos Tributos", emana-se certa diferenciação. Enquanto na primeira se busca o conhecimento jusfilosófico sobre questões fundamentais do Direito (e aplicável, por extensão, à generalidade do conhecimento jurídico) para aplicá-los (os tributaristas, não os jusfilósofos) ao conhecimento jus-tributário, a Filosofia da Tributação, busca, através da Filosofia, resolver problemas tributários fundamentais. É substancialmente diferente da busca por uma questão jurídica fundamental que possui repercussões tributárias, da busca por uma questão tributária fundamental.

Gradativamente, a chamada "Filosofia da Tributação", que indica o direcionamento da Filosofia a temas de interesses tributários, começa a alcançar a Ciência do Direito Tributário. Assim, a Filosofia Tributária (investigada no campo da Filosofia Geral) diferencia-se da Filosofia do Direito Tributário, esta, por sua vez, investigada na perspectiva da Filosofia do Direito.

Mas deve-se reconhecer que, historicamente, a inclinação a temas filosóficos voltados à tributação sempre foi mais simpática aos estudiosos da Economia Política e da Filosofia Política, conforme é possível observar, exemplificativamente, na obra "Tax Philosophers", de Harold Groves ${ }^{1956}$, assim como na coletânea de estudos tributários editada por Robert W. Mcgee, denominada “The Ethics of Tax Evasion”, buscando compreender o papel da ética (ou a falta dela), através de argumentos filosóficos, psicológicos, políticos e até religiosos, na prática da evasão fiscal ${ }^{1957}$.

podemos separar os princípios constitucionais tributários em dois grupos: os pricnípios por natureza e os princípios por decisão. Os primeiros são uma decorrência natural dos valores maiores do ordenamento jurídico, os do segundo grupo decorrem das decisões fundamentais tomadas pela Assembleia Nacional Constituinte. Dentre os princípios constitucionais tributários por natureza localizamos, v.g., o da justiça tributária, o do devido processo legal tributário, da igualdade tributária, da vedação à tributação com efeito de confisco e da capacidade contributiva. Dentre os princípios constitucionais tributários por decisão encontramos, por exemplo, o princípio federativo fiscal, o da autonomia tributária municipal, o da não cumulatividade e o da seletividade do imposto sobre produtos industrializados. BECHO, Renato Lopes. Filosofia do Direito Tributário. Op.cit., p.294-331.

${ }^{1956} \mathrm{O}$ estudo de Harold M. Groves buscou apresentar as principais teorias fiscais (algumas delas relacionadas à ideia de justiça fiscal) de autores clássicos da língua inglesa, como Adam Smith, John Stuart Mill, E.R. Seligman, Henry Simons, Arthur Pigou, J.K. Galbraith, I. Fischer e J.M. Keynes, entre outros. Salienta-se, contudo, que embora a obra refira-se à ideia de filosofia tributária, em muitos aspectos, aproxima-se mais de compilado sobre as principais teorias econômicas aplicáveis à tributação. GROVES, Harold. Tax Philosophers. Two Hundred Years of Thought in Great Britain and United States. Edited by Donald J. Curan. The University of Wisconsin Press, 1974, p. 3-155.

${ }^{1957}$ MCGEE, Robert. W. (Editor). The Ethics of Tax Evasion. The Dumont Institute for Public Policy Research. South Orange, USA, 1998, p. 05 e seguintes. 
Talvez por isso a Filosofia da Tributação se desenvolveu com maior facilidade naqueles campos do conhecimento, em detrimento da Filosofia Jurídico-Tributária. Temas como a justiça tributária, a ética tributária, transparência tributária e o "direito tributário correto" ou "ideal" nunca escaparam da atenção da Ciência das Finanças e da Economia Política, conforme é possível observar na constante elevação de princípios aplicáveis ao aprimoramento da tributação observados em Adam Smith ${ }^{1958}$, John Stuart Mill ${ }^{1959}$, Fritz Neumark ${ }^{1960}$, Benvenuto Griziotti ${ }^{1961}$, Adolph Wagner ${ }^{1962}$ e Luigi Einaudi ${ }^{1963}$.

Contudo, tal aproximação à Economia Política e à Filosofia Política não afasta a constatação de que a falta de atenção a temas tributários é uma constante na Filosofia do Direito. Duas condições concorrem para prejudicar historicamente o estudo de temas filosóficos jurídico-tributários: a) a preferência expressa dos filósofos por temas transcendentais ao Direito (a justiça fiscal e a ética fiscal seriam temas de importância específica a um ramo do direito apenas e, portanto, escaparia à importância filosófica geral); b) a consideração, pelo cientista (dogmático) do Direito de que os temas da justiça e da ética fiscais deveriam ser considerados pela Filosofia do Direito (e não pelo Direito Tributário).

Frente a essa dupla refração, não é surpresa que os diálogos entre a Filosofia Tributária e o Direito Tributário tenham evoluído timidamente, revelando poucos ensaios atinentes ao tema, conforme se observa em Klaus Tipke, em relevante estudo sobre a moral (ou ética) tributária. Ainda que reconheça a atenção quase exclusiva aos filósofos políticos e aos economistas ${ }^{1964}$, Tipke assinala a grande necessidade de que os estudiosos do Direito Tributário aproximem-se da filosofia da tributação, pois o Direito Tributário não prescinde nem da moral nem da ética na tributação ${ }^{1965}$.

\footnotetext{
1958 SMITH, Adam. Op.cit., p. 419-420.

1959 STUART MILL, John. Op.cit., p. 375 e seguintes.

${ }^{1960}$ NEUMARK, Fritz. Op.cit., p.71-72.

${ }^{1961}$ GRIZIOTTI, Benvennuto. Principios de Política, Derecho y Ciência de La Hacienda. Op.cit., p. 185 e seguintes.

${ }_{1962}$ WAGNER, Adolph. Op.cit., p. 150 e 155-157.

${ }^{1963}$ EINAUDI, Luigi. Corso di Scienza della Finanza. Quarta Edizione. Torino: Edizione della Rivista "La Riforma Sociale”, 1926, p.03 e seguintes.

1964 TIPKE, Klaus. Moral Tributaria del Estado y del Contribuyintes. Madrid: Marcial Pons, 2002, p. 2526.

${ }^{1965}$ De fato, conforme acentua Tipke, até o presente momento os estudiosos da filosofia moral e economistas são aqueles que têm buscado a noção de justiça fiscal, lidando com a ideia de "imposto justo" ou "racional", o que poderia explicar o desinteresse do assunto por filósofos e juristas, o que também desautorizaria as críticas formuladas por juristas pelo fato de que economistas avançariam sobre os limites da análise
} 
Confirmando as preocupações de Tipke, Daniel Gutman, no estudo denominado "Do Direito à Filosofia da Tributação", reconheceu ser este campo ainda inexplorado pelos tributaristas, cujas dificuldades não deveriam constituir óbice para sua promoção ${ }^{1966}$, sobretudo na busca da justiça tributária substancial ${ }^{1967}$, preocupação que é compartilhada também por Luigi Vittorio Berliri, que reclamou da falta de atenção de economistas e juristas, políticos e experts da tributação ao tema da justiça tributária, preocupando-se muito mais com o labor técnico especializado do que a temas fundamentais (como a própria justiça na tributação) ${ }^{1968}$.

Reforce-se que a Filosofia da Tributação não se esgota na justiça (isonomia, por exemplo) ou na ética ${ }^{1969}$, mas também avança para esmiuçar possíveis contornos do "bom tributo" (pautado em determinados princípios da tributação, como a segurança, a transparência, a não surpresa, o sufrágio universal), conforme lembra Gutman. ${ }^{1970}$ Assim, abarcam o campo de atuação da Filosofia da Tributação temas de apelo transcendental que buscam encontrar elementos úteis à reflexão do tributarista na análise do Direito Tributário.

Na Ciência do Direito Tributário Brasileiro a Filosofia do Direito sempre manteve influência, especialmente através do positivismo jurídico, favorecendo a preocupação do direito tributário para sua análise formal, sobretudo através da Lógica Jurídica e da Teoria Geral do Direito, assim como da Filosofia da Linguagem ${ }^{1971}$, mas também no âmbito do

“jurídica” do conceito, já que eles mesmos não se interessariam historicamente pelo tema. TIPKE, Klaus. Moral Tributaria del Estado y del Contribuyintes. Op.cit., p. 25-26.

1966 Contudo, acentua Gutman, é a resistência contemporânea à fiscalidade o maior convite à reflexão, ressurgindo a necessidade de justiça que, por sua vez, chama a Filosofia. Embora a Filosofia do Tributo seja considerada um "tabu do direito tributário", deve-se reconhecer campo fértil de reflexões filosóficas sobre o tributo, especialmente no que tange à justiça fiscal. Mas, ressalte-se, o autor diferencia o tributo, enquanto objeto de estudo investigado do ponto de vista filosófico (filosofia do tributo), e o tributo investigado no seu sentido jurídico. Note-se que, Gutman, extraindo a filosofia do tributo do âmbito do Direito, reconhece o ainda "novo" campo, ainda praticamente inexplorado pelos juristas, mas que tem vastas possibilidades de atuação entre os filósofos. GUTMAN, Daniel. Do Direito à Filosofia do Tributo. In: FERRAZ, Roberto (Coord.). Princípios e Limites da Tributação. Vol.1. Op.cit., p. 29-39.

${ }^{1967}$ Assim, avaliar a justiça do imposto não significa avaliar a justiça de uma regra de direito ordinário, pois a filosofia do tributo preocupar-se-ia com a justiça (substancial), que seria apreendida em dois "prismas": a) o dos fins (objetivos perseguidos pelo tributo) e dos meios (modalidades que definem a divisão e o lançamento). Idem.

1968 BERLIRI, Luigi Vittorio. La Giusta Imposta. Milano: Dott.A. Giuffrè Editore, 1975, p. 09.

1969 TIPKE, Klaus. Moral Tributaria del Estado y del Contribuyintes. Op.cit., p. 27-83.

1970 GUTMAN, Daniel. Op.cit., p. 29-39.

${ }^{1971}$ FOLLONI, André. Ciência do Direito Tributário no Brasil. Crítica e Perspectivas a partir de José Souto Maior Borges. Op.cit., p. 73 e seguintes. 
jusnaturalismo, da teoria dos valores e do realismo jurídico ${ }^{1972}$. Contudo, ainda assim, as primeiras tendências seguiram com maior força perante as últimas. Por isso, não é surpresa que defesa expressa da justiça e a ética ${ }^{1973 \_}{ }_{-}^{1974}{ }_{-}{ }^{1975}$ nas relações tributárias acabem historicamente afastadas das considerações do cientista do Direito Tributário, por razões facilmente compreensíveis, ainda que a consideração ética possa ser inequivocamente identificada em todas as linhas de pesquisa dedicadas ao direito tributário.

Porém, para linha jusfilosófica contrária ao positivismo jurídico, a Filosofia do Direito representa a teoria do direito justo ${ }^{1976}{ }_{-}^{1977}$, da vinculação do direito aos valores ${ }^{1978}$, do direito correto ${ }^{1979}$, da ética, e passa a elevar influência a partir da segunda metade do século XX ${ }^{1980}{ }^{1981}$, como a busca pelo "direito correto", ou como alcançar a "justiça tributária" ou "ética tributária" (no âmbito do direito). Afinal, qual desses temas não seria de interesse geral para o Direito Tributário?

No Brasil, as perspectivas de diálogo entre as diferentes perspectivas da Filosofia da Tributação e Ciência do Direito Tributário, embora identificáveis (na perspectiva

\footnotetext{
1972 BECHO, Renato Lopes. Filosofia do Direito Tributário no Brasil. Op.cit., p.279-294.
}

1973 Johannes Messner, em estudo dedicado à ética social, analisa diversas teorias da justiça, classificando-as principalmente a partir de duas "espécies gerais: "justiça do bem-comum" ou toda a sociedade (composta pela justiça legal - a justiça "do Estado, dependendo por isso do direito legal, pela justiça social, referida ao bem-estar econômico e social da sociedade, e pela justiça internacional - que visaria o bem-comum da comunidade das nações) e a justiça particular (por sua vez dividida em justiça distributiva - onde há distribuição justa dos ônus e privilégios - e justiça comutativa - que é "aquela que obriga as pessoas individuais a dar a cada um o que lhe pertence, conforme uma medida de estrita igualdade"). MESSNER, Johannes. Ética Social. Trad. Alípio Maia de Castro. São Paulo: Editora Quadrante, 1987, p. 412-424.

${ }^{1974}$ Por outro lado, interessante mencionar o ensaio de Kelsen, refletindo sobre a ideia de justiça: "De fato, não sei e não posso dizer o que seja justiça, a justiça absoluta, esse belo sonho da humanidade. Devo satisfazer-me com uma justiça relativa, e só posso declarar o que significa justiça sob cuja proteção a ciência pode prosperar e, ao lado dela, a verdade e a sinceridade. É a justiça da liberdade, da paz, da democracia, da tolerância". Considerações críticas à ideia de justiça (assim como ao jusnaturalismo) perante o "tribunal da ciência” podem ser encontradas em KELSEN, Hans. O que é Justiça? Trad. Luís Carlos Borges. São Paulo: Martins Fontes, 1997, p. 1-25; p.137 e seguintes.

${ }^{1975}$ Em semelhante sentido, Gustav Radbruch, para quem a ideia de direito não pode ser diferente da ideia de justiça. RADBRUCH, Gustav. Filosofia do Direito. Op.cit., p. 86 e ss. Sobre o assunto, também: LARENZ, Karl. Op.cit., p. 113 e seguintes.

${ }^{1976}$ RADBRUCH, Gustav. Op.cit., p. 46.

1977 REALE, Miguel. Lições Preliminares de Direito. Op.cit., p. 312.

1978 MAYNES, Eduardo Garcia. Filosofia del Derecho. 17 Ed. Mexico: Porrua, 2009, p. 16.

${ }^{1979}$ A ideia de direito correto, segundo Henkel, passaria a ser atribuída ao jusnaturalismo, e não ao positivismo jurídico. Contudo, assinala Henkel que essa visão deve ser afastada, pois, o direito correto não viria previamente dado em uma ordem suprapositiva de validade geral, e nem prefixados em um direito concreto-mutável da natureza das coisas. HENKEL, Heinrich. Introducción a La Filosofia del Derecho. Trad. Enrique Gimbernat Ordeig. Madri: Taurus Ediciones, 1986, p. 673-696.

${ }^{1980}$ LARENZ, Karl. Op.cit., p. 113-115.

${ }^{1981}$ REALE, Miguel. Filosofia do Direito. 19 Ed. São Paulo: Saraiva, 2000, p. 285. 
jurídico-filosófica) na obra de Renato Lopes Becho ${ }^{1982}$, ainda necessitam de aperfeiçoamentos, pelo menos para impulsionar determinadas premissas (como a teoria dos valores aplicada ao direito tributário), embora já se mostrem importantes considerações de natureza filosófico-tributária, como é o caso da justiça tributária. Tal tendência pode ser remetida ao que Ricardo Lobo Torres chamou de "Virada Kantiana" (favorecendo a reaproximação entre direito e ética) ${ }^{1983}{ }^{1984}$, por sua vez também influenciado por John Rawls ${ }^{1985}$.

A reaproximação aos chamados "Direitos Fundamentais" também é elemento que favorece ao diálogo entre Ciência do Direito Tributário e Filosofia da Tributação, perspectiva que pode ser observada em interessantes contribuições teóricas voltadas ao estudo da justiça no direito tributário, conforme é possível observar em James Marins ${ }^{1986}$, Fernando Aurelio Zilveti ${ }^{1987}{ }^{1988}$, Marciano Seabra de Godoi ${ }^{1989}$, Douglas Yamashita e Klaus Tipke ${ }^{1990}$, Paulo Caliendo ${ }^{1991}$ e Renato Lopes Becho ${ }^{1992}$.

Para Becho, a literatura do Direito Tributário brasileiro, em ambiente permeado pelo pós-positivismo, caminha para as seguintes tendências (passando pela teoria dos valores, mas não se afastando do dogmatismo): a) a liberdade como pressuposto do Direito Tributário e; b) a metodologia da teoria dos valores no Direito Tributário ${ }^{1993}{ }^{1994}$. Viabiliza,

\footnotetext{
1982 BECHO, Renato Lopes. Filosofia do Direito Tributário. Op.cit., p. 279 e ss.

${ }^{1983}$ KANT, Immanuel. A Metafísica dos Costumes. Op.cit., p. 257 e seguintes.

${ }^{1984}$ Idem.

${ }^{1985}$ RAWLS, John. Uma Teoria da Justiça. Op.cit., p.64 e seguintes.

${ }^{1986}$ MARINS, James. Justiça Tributária e Processo Tributário (Ensaios). Coleção Ponto de Partida. 3. Curitiba, Editora Universitária Champagnat, 1998, p. 09-36, p. 09-37.

${ }^{1987}$ ZILVETI, Fernando Aurelio. Princípios de Direito Tributário e a Capacidade Contributiva. São Paulo: Quartier Latin, 2004, p. 49-68. Também: ZILVETI, Fernando Aurelio. A Evolução da Teoria da Incidência. Análise Histórica da estrutura sócio-econômica na formação do Sistema Tributário. Op.cit., Cap.1, item 8 e Cap.II, item 4.

1988 "Para haver justiça na tributação é necessário que o operador do direito se utilize de métodos particulares e critérios de delimitação a partir de aproximações e de seleções, que permitam definir um sistema igualitário. Assim, o cidadão poderá limitar o poder de tributar do Estado e, por seu turno, o Estado poderá alcançar a riqueza sujeita à tributação". Idem, p. 386-391.

${ }^{1989}$ GODOI, Marciano Seabra de. Justiça, Igualdade e Direito Tributário. São Paulo: Dialética, 1999, p. 173-261; p.248 e seguintes.

${ }^{1990}$ YAMASHITA, Douglas; TIPKE, Klaus. Justiça Fiscal e Princípio da Capacidade Contributiva. São Paulo: Malheiros, 2002, p. 19 e seguintes.

${ }^{1991}$ CALIENDO, Paulo. Direito Tributário. Três modos de pensar a tributação. Elementos para uma teoria sistemática do Direito Tributário. Porto Alegre: Livraria do Advogado Editora, 2009, p. 193-243.

${ }^{1992}$ CANARIS, Claus Wilhelm. Op.cit., p. 280-281.

${ }^{1993}$ BECHO, Renato Lopes. Filosofia do Direito Tributário. São Paulo: Saraiva, 2009, p. 281-282.

${ }^{1994}$ Idem, p. 336-339.
} 
assim, novas tendências hermenêuticas ao Direito Tributário, elevando o contribuinte como centro do Direito Tributário ${ }^{1995}{ }^{1996}$.

Porém, note-se que a Filosofia do Direito apresenta grande variedade temática, e diferentes linhas jusfilosóficas que, naturalmente, proporcionam diferenciadas ópticas sobre o papel e o conteúdo da Filosofia do Direito. O "pensar filosoficamente" sobre os rumos do Direito Tributário enquanto disciplina, buscando seu aperfeiçoamento (epistemológico), também revela autêntica tonalidade filosófica ao estudo do Direito Tributário brasileiro, conforme se observa em André Folloni, ao refletir sobre as "bases irreais" da Ciência do Direito Tributário no Brasil ${ }^{1997}$, assim como em Renato Lopes Becho, ao refletir sobre a aplicação das tendências filosóficas na doutrina tributária brasileira, considerando a existência de uma "Filosofia do Direito Tributário"1998.

Se a Filosofia vislumbra os problemas fundamentais da existência humana, como ressaltou Kaufmann, e a Filosofia do Direito busca responder questões jurídicas essenciais, sobre problemas jurídicos fundamentais, ${ }^{1999}$ a questão é: em que medida a justiça e a ética devem ser consideradas enquanto temas de interesses transcendentais?

A resposta dependerá dos pressupostos epistemológicos e metodológicos adotados pelo filósofo do direito, conforme a respectiva linha jusfilosófica adotada. Em todo caso, mesmo nas diferenciações entre o dogmático do direito e o filósofo do direito, para Kaufmann, “(...) entre a filosofia e a dogmática não existe uma relação de "mais ou menos", de mais importante ou menos importante, mas uma relação de diferentes formas de ser. Por isso, uma não se substitui à outra" ${ }^{2000}$.

Assim, o estudioso empreende esforço pautado na "Filosofia Tributária", unindo temas transcendentais tributários, mas inerentemente ligados ao Direito Tributário e, nesse caminho, eleva-se o potencial perspectiva interdisciplinar para o aperfeiçoamento do perfil

\footnotetext{
${ }^{1995}$ Ibidem, p. 341.

${ }^{1996}$ É evidente que a interdisciplinaridade pode ser claramente observada nessas reflexões, especialmente, quando o autor, categoricamente, reconhece: "É um erro pensar que a tributação seja tema exclusivamente jurídico. A tributação é um tema econômico, político, sociológico, psicológico, ético. E, como ciência primeira, há a filosofia aplicada à tributação". Ibidem, p. 282-285.

${ }^{1997}$ FOLLONI, André. Ciência do Direito Tributário. Op.cit., p. 23.

1998 BECHO, Renato Lopes. Filosofia do Direito Tributário. Op.cit., p. 267 e ss.

${ }^{1999}$ KAUFMANN, Arthur. Filosofia do Direito, teoria do Direito, dogmática jurídica. In:Introdução à filosofia do Direito e à teoria do direito contemporâneas. KAUFMANN, Arthur; HASSEMER, W. (Org.) Trad. Marcos Keel; Manuel Seca de Oliveira. Lisboa: Fundação calouste Gulbenkian, s/d, p. 25 e seguintes. ${ }^{2000}$ KAUFMANN, Arthur. Filosofia do Direito, teoria do Direito, dogmática jurídica. Op.cit., p. 26-27.
} 
prospectivo do tributarista, revelando como o direito tributário deve (idealmente) ser, em busca do "direito tributário correto" ou "direito tributário ideal" e, assim, oferecendo ao tributarista amplas possibilidades para o exercício da função prospectiva ou normativa no Direito Tributário.

\subsection{Perspectivas do diálogo recíproco entre Análise Econômica do Direito e Ciência do Direito Tributário contemporânea}

Recentemente, a literatura jurídica brasileira começa a refletir sobre a viabilidade das contribuições trazidas pela Análise Econômica do Direito (AED), que, basicamente, tem por objeto “(...) empregar os variados ferramentais teóricos e empíricos econômicos e das ciências afins para expandir a compreensão e o alcance do direito e aperfeiçoar o desenvolvimento, a aplicação e a avaliação de normas jurídicas, principalmente em relação às suas consequências"2001.

A análise econômica é, portanto, um método de pesquisa diferenciado dos métodos tradicionalmente jurídicos aplicados ao estudo do ordenamento jurídico.

Conforme contextualiza Paulo Caliendo, “(...) o movimento denominado análise econômica do Direito (Law and Economics) se constitui em uma alternativa à filosofia moral e política do utilitarismo que era dominante no contexto teórico norte-americano até a década de 1960 (...)”. Em outras palavras, “(...) trata-se de uma reação ao entendimento predominante no ambiente jurídico norte-americano de que o direito deve ser entendido como uma realidade e disciplina autônoma”.

Segundo Caliendo, a Análise Econômica do Direito possui as seguintes características: "i) rejeição da autonomia do Direito perante a realidade social e econômica; ii) utilização de métodos de outras áreas do conhecimento, tais como economia e filosofia;

\footnotetext{
${ }^{2001}$ Pode ser entendida como a aplicação “(...) do instrumental analítico e empírico da economia, em especial da microeconomia e da economia do bem-estar social, para se tentar compreender, explicar e prever as implicações fáticas do ordenamento jurídico, bem como da lógica (racionalidade) do próprio ordenamento jurídico". "É a instrumentação da abordagem econômica para tentar compreender o direito". Curiosamente, muitos juristas (muitas vezes de formação dúplice) tem aplicado esse método de estudo, ganhando a denominação "juseconomistas". JR, Ivo Gico. Introdução ao Direito e Economia. In: Direito e Economia no Brasil. TIMM, Luciano Benetti (org.) São Paulo: Atlas, 2012, p. 01.
} 
iii) crítica à interpretação jurídica como interpretação conforme precedentes ou o direito, sem referência ao contexto econômico e social"2002.

As considerações sobre as possibilidades investigativas trazidas pela AED são relativamente recentes, e talvez isso justifique a imersão ainda inicial de estudiosos brasileiros ao tema. Ronald Coase, por exemplo, em “O Problema do Custo Social” (1960), expôs as relações entre Direito e Economia ao tratar do custo social das transações e as chamadas "externalidades", demonstrando que as instituições legais condicionam o comportamento de agentes no mercado ${ }^{2003}$. Não é por acaso que essa perspectiva, portanto, oferece interessantes possibilidades para os juristas e economistas ${ }^{2004}$, conforme expõe Oliver Williamson. ${ }^{2005}$

Mas de fato, sem pretender enveredar sobre as querelas teóricas das diferentes linhas contemporâneas da $\mathrm{AED}^{2006}$, seus estudiosos concentram as atenções em dois aspectos (ou perspectivas) fundamentais: AED positiva (o que é no Direito, ligada à descrição, à verdade ou falsidade do fato); AED normativa (o que deve ser no Direito, ligada à prescrição, a valores, e verificando o que é bom e o que é ruim no Direito). As perspectivas da AED no Direito viabilizam a discussão entre eficiência e justiça no direito, e trazem a tônica do diálogo entre os estudiosos do Direito e as modernas teorias e instrumentais econômicos, sobretudo para auxiliar “(...) o jurista a identificar, prever e

2002 Naturalmente, não é o objetivo deste trabalho aprofundar a temática da Análise Econômica do Direito frente ao Direito Tributário, mas apenas levantar esse caminho, ainda que sujeito a críticas. Para uma investigação sistemática e aprofundada, recomenda-se a obra de CALIENDO, Paulo. Direito Tributário e Análise Econômica do Direito. Uma visão Crítica. Rio de Janeiro: Elsevier, 2009, p. 12 e ss.

${ }^{2003}$ COASE, Ronald H.. O Problema do Custo Social. (The Problem of Social Coast. Journal of Law and Economics, Outubro, 1960), 37 páginas. Tradução por Francisco Kümmel F. Alves e Renato Vieira Caovilla, bacharéis em Direito na PUC/RS e membros do Grupo de Pesquisa em Direito e Economia da PUC/RS, coordenado pelo Prof. Dr. Luciano Benetti Timm. Revisão técnica de Antônio José Maristrello Porto (FGV DIREITO RIO) e Marcelo Lennertz (FGV DIREITO RIO). Acesso em: http://www.google.com.br/url?sa=t\&rct=j\&q=\&esrc=s\&source=web\&cd=2\&ved=0CCkQFjAB\&url=http\%3 A\%2F\%2Fwww3.nccu.edu.tw\%2F jsfeng\%2FCPEC11.pdf\&ei=AuYiVPG MMLPggSwmoLYAw\&usg=A FQjCNFnubyRO2U7XQH4uY3aOxMXuzdkIg (último acesso em 12.11.2014).

${ }^{2004} \mathrm{Da}$ variedade de estudos relacionados ao tema (e das diferentes bases teóricas econômicas para aplicação da AED) surgem diferentes propostas, com pressupostos metodológicos diferenciados, para compreender a ligação entre Direito e Economia. ZYLBERSZTAJN, Decio; SZTAJN, Rachel. Análise Econômica do Direito e das Organizações. In: Direito e Economia. Análise Econômica do Direito e das Organizações. Rio de Janeiro: Elsevier, 2005, p. 01-15.

${ }^{2005}$ WILlIAMSON, Oliver. Por que Direito, Economia e Organizações? In: In: Direito e Economia. Análise Econômica do Direito e das Organizações. Rio de Janeiro: Elsevier, 2005, p. 16-60.

${ }^{2006}$ Sobre o assunto, conferir: SZTAJN, Rachel. Law and Economics. In: Direito e Economia. Análise Econômica do Direito e das Organizações. Rio de Janeiro: Elsevier, 2005, p 74 e seguintes. 
explicar as consequências sociais de escolhas políticas imbuídas em legislações (ex ante) e decisões judiciais $(\text { ex post })^{2007}$.

A preocupação crescente quanto à função da norma jurídica, conforme já exposto, aparece em Bobbio, ao expor que, antes da forma da norma jurídica, deve-se atentar à sua função ${ }^{2008}$. Mas tal fator não obscurece as dificuldades teóricas enfrentadas pelos estudiosos defensores da AED. ${ }^{2009}{ }^{2010}$

Embora a AED seja correntemente aplicada às relações entre Direitos Patrimoniais (propriedade), Direito Acidentário, Direito dos Contratos, Direito da Responsabilidade Civil (Direito Privado), e Direito Processual Civil, gradativamente essa proposta de estudo vai se disseminando por outros campos do conhecimento jurídico, inclusive para o Direito Penal $^{2011}$.

Nos últimos anos, é possível identificar também na doutrina tributária brasileira os primeiros posicionamentos favoráveis à aplicação da AED ao Direito Tributário.

\footnotetext{
${ }^{2007}$ Menciona-se a interessante crítica da autora à oposição do diálogo entre Direito e Economia: "A verdade é que ambos os grupos ainda são resistentes ao diálogo. Do ponto de vista jurídico, tenho a profunda crença de que os dias de hermetismo e xenofobia no direito estão chegando ao fim. Já passou da hora de os juristas descerem de suas torres de marfim, de suas faculdades distantes, e começarem a estudar a realidade. Do lado dos economistas, está na hora de olhar um pouco menos para suas fórmulas matemáticas esteticamente estonteantes e um pouco mais para a realidade brasileira. Estudam-se demais modelos estrangeiros e pouca coisa é feita para nossa realidade local. A solução para questões brasileiras requer conhecimento local e criatividade. Estaremos melhores se trabalharmos juntos". SZTAJN, Rachel. Law and Economics. Op.cit., p. 30 .

${ }^{2008}$ Sobre a crescente importância da análise funcional do direito, e seus problemas, também: BOBBIO, Norberto. Da Estrutura à Função. Novos Estudos de Teoria do Direito. Op.cit., p. 81-115.

${ }^{2009}$ Conforme bem expõe Rachel Sztajn, o positivismo jurídico (prevalecente na Ciência do Direito, sobretudo a filosofia analítica), partindo do "esquema teórico abstrato", abandona o empirismo próprio dos economistas, dificultando o diálogo: "As críticas ao avanço da Análise Econômica do Direito ou da combinação de Direito e Economia não desapareceram e vêm perdendo terreno pela demonstração de que a contribuição é positiva. Torna-se mais equivocado e enganoso a cada dia afirmar que a Economia busca eficiências enquanto o Direito se prende à promoção da questão ser/dever ser, com o objetivo de dizer que as posições são irreconciliáveis". E conclui: “(...) se nenhum outro argumento existisse, bastaria este, do economista, para estimular a pesquisa e o diálogo conjunto entre economistas e juristas. A importância do desbravamento da interdisciplinaridade e os benefícios que dela podem resultar para o aperfeiçoamento do estudo do Direito são inegáveis". SZTAJN, Rachel. Law and economics. Op.cit., p. 82.

${ }^{2010}$ Reproduz-se importante reflexão da autora: "Fato é que as objeções engendradas pelos críticos da aproximação (ou reaproximação) entre Direito e Economia partem, em geral, das formulações da Escola de Chicago. Esta, em várias situações, tenta quantificar os efeitos das normas positivadas aplicando não apenas conceitos econômicos, como, muitas vezes, a econometria, a área nas quais os efeitos patrimoniais das relações pessoais tendem a ser encarados como secundários, tal como ocorre nas relações de família. Seria impossível aceitar a ideia da precificação do afeto entre familiares? Poder-se-ia considerar que existe um preço que causa ou impulsiona as ações de membros da família a ponto de ser determinante na tomada de decisões? Isso seria inadmissível, dizem os críticos, e, por isso, não aceitam qualquer discussão ou relação que aproxime Direito e Economia. Idem, p. 79-80.

${ }^{2011}$ SHAVELL, Steven. Foundations of Economic Analysis of Law. Harvard, 2004, p. 07 e seguintes.
} 
Naturalmente, conforme já adiantado, a primeira obra de corpo dedicada inteiramente à temática no Brasil refere-se ao notável estudo de Paulo Caliendo, denominado "Direito Tributário e Análise Econômica do Direito"2012, que, atualmente, figura como a mais completa obra sobre a temática publicada no Brasil.

Mas, gradualmente, surgem recentes estudos dedicados a melhor compreender o fenômeno. Nesse sentido caminha o recente estudo de Cristiano Carvalho, denominado "Análise Econômica da Tributação"2013.

Nesse estudo, a função prospectiva ou normativa do tributarista pode ser identificada através da eleição de cinco requisitos para a configuração do "tributo ótimo": a) grande base de contribuintes (quando maior a base, mais viável é o estabelecimento de alíquotas menores), b) regras simples e objetivas (visando evitar ou diminuir os "custos de conformidade", que implicam em "custos de transação"), c) incidência sobre produtos e serviços de demanda inelástica (de baixa sensibilidade dos consumidores à alteração de preços, favorecendo equilíbrio entre oferta e demanda e evitando o chamado "peso morto" ou ineficiência alocativa), d) ser justo (não violando a isonomia), e) ter baixo custo administrativo (onde o Estado ou administração gastem o mínimo possível para administrar o tributo) $)^{2014}$.

Para o autor, a intervenção estatal através de tributos deve considerar que esses são instrumentos de distorção no sistema de preços do mercado, gerando custo social negativo (peso morto). Em muitos casos a tributação é nociva do ponto de vista econômico,

${ }^{2012}$ CALIENDO, Paulo. Direito Tributário e Análise Econômica do Direito. Uma visão crítica. Op.cit., p. 12 e ss.

${ }^{2013}$ Inicialmente, o autor já diferencia a análise econômica aplicada ao direito tributário da chamada "interpretação econômica do direito tributário", que, seria apenas forma de interpretação que beneficia os interesses financeiros do Estado. A AED, nesse sentido, não se preocupa com os interesses financeiros do Estado, mas "sim em analisar os incentivos criados pelas normas". O analista econômico do direito, segundo o autor, formularia as seguintes questões: "como reagirá o contribuinte em face dessas imposições normativas? Diminuirão elas a evasão e elisão fiscal, ou terão potencialmente o efeito de uma deserção ainda maior do cumprimento das obrigações tributárias?". Nota-se, portanto, clara diferença entre a interpretação econômica e a análise econômica do direito. Cristiano Oliveira ainda acrescenta as possíveis aplicações (a exemplo da teoria dos jogos para questões de elisões e evasões fiscais) da AED ao Direito Tributário, passando pela verificação do motivo pelo qual paga-se tributos, o tributo ótimo (e seus requisitos), o tributo ineficiente (distorsivo) e breve análise sobre a visão dos economistas acerca do direito tributário. CARVAlHO, Cristiano. Análise Econômica da Tributação. In: Direito e Economia no Brasil. TIMM, Luciano Benetti (Org). São Paulo: Atlas, p. 158 e seguintes.

${ }^{2014}$ Particularmente interessante é a reflexão do autor sobre a CPMF, que entende cumprir os cinco requisitos de tributação "ótima", do ponto de vista da AED, mas que foi rechaçado por muitos juristas, sob distintos argumentos. Para o autor, tal resistência à CPMF denunciaria o desconhecimento generalizado dos tributaristas contemporâneos sobre as regras básicas da economia aplicada aos tributos. CARVALHO, Cristiano. Op.cit., p. 257-258. 
podendo gerar a ineficiência alocativa. Deve-se, contudo, considerá-lo sob a perspectiva de que o tributo, sendo obrigatório, é necessário para a sociedade e, portanto, deve-se alcançar, do ponto de vista da eficiência econômica, a “(...) limitação da tributação em um ponto que não inviabilize a atividade econômica".

Em suma, deve-se buscar o equilíbrio entre justiça distributiva e eficiência econômica da tributação, perspectiva que pode ser analisada através da conjunção de estudos entre o Direito Tributário e a Economia. ${ }^{2015}{ }_{-}^{2016}$.

Assim, a perspectiva de que outros estudos com a mesma premissa (AED e Direito Tributário) gere maior interesse dos tributaristas brasileiros, é visível, especialmente em linhas doutrinárias familiarizadas com a consideração econômica no direito tributário.

Contudo, ainda que a Análise Econômica do Direito esteja sujeita a determinadas críticas, bem pontuadas por Caliendo, que aponta ser a mesma mais uma abordagem diferenciada do direito tributário do que uma teoria, propriamente dita. ${ }^{2017}$

Já é possível também observar a profusão desses estudos interdisciplinares em relevantes trabalhos nacionais, a exemplo do celebrado Curso de Direito Tributário de Luís Eduardo Schoueri, que, com as necessárias reservas, inclui pontuais considerações complementares versadas em Ciência das Finanças e Economia, promovendo a maturação no debate entre Direito Tributário e Economia Tributária. Na realidade, para o autor, o estudioso do direito deve descrever e sistematizar o ordenamento jurídico tributário, mas sem perder de vista o fato de que o fenômeno tributário (complexo) é permeado por outros aspectos (econômico, social, político, etc) e, por isso, as contribuições teóricas oferecidas por esses campos (...) não devem ser desprezadas na busca de um sentido ao todo tributário"2018.

\footnotetext{
${ }^{2015}$ CARVALHO, Cristiano. Op.cit., p. 259 e seguintes.

2016 Importante também mencionar que o autor, a partir de sua análise sobre os deveres instrumentais (obrigações acessórias), entende serem custos de conformidade, pois para seu cumprimento, o contribuinte deve realizar obrigações de fazer que importam em custos muitas vezes consideráveis. CARVALHO, Cristiano. Op.cit., p. 262-264.

${ }^{2017}$ CALIENDO, Paulo. Direito Tributário e Análise Econômica do Direito. Uma Visão Crítica. Op.cit., p. 16e ss.

${ }^{2018}$ Essa perspectiva não deve erroneamente parecer que o autor defende o uso acrítico de tais ferramentais pelo jurista: "Embora se relatem experiências interessantes nesse sentido - a análise econômica do direito é exemplo eloquente dessa prática -, não se pode deixar de apontar para os riscos de que os aplicadores do direito deixem de lado os critérios jurídicos para a solução dos conflitos”. Por outro lado, “(...) o jurista não
} 
Não obstante, deve-se mencionar que há ainda preferência doutrinária (ligada aos receios de Alfredo Augusto Becker) de afastar a possibilidade de utilização da AED ao Direito Tributário, conforme se observa em Heleno Taveira Tôrres ${ }^{2019}$.

Veja-se que, se utilizado ponderadamente, o diálogo entre a AED e o Direito Tributário não ataca o processo disciplinar tradicional de estudos tributários consolidados no Brasil, e muito menos avança sobre essas perspectivas. Trata-se apenas de uma nova possibilidade interdisciplinar de estudo, focada na intersecção entre Economia e Direito (Tributário), com ilimitadas possibilidades de investigação, e, possivelmente, gerando também novo perfil auxiliar ao tributarista. A intersecção entre o Direito Tributário e a "Economia Tributária" é campo onde a AED pode trazer importantes retrospectos à compreensão e ao aprimoramento do fenômeno jurídico tributário em direção ao "tributo ótimo", seja para reforçar argumentações jurídicas, seja para viabilizar novas propostas de políticas tributárias, destinadas ao aprimoramento do sistema tributário brasileiro ${ }^{2020}$.

É acertada, por isso, a conclusão de Caliendo: "O estudo das contribuições da análise econômica do Direito e, especialmente, do Direito Tributário ainda é um tema recente para a literatura jurídica. Entendemos, contudo, que podemos afirmar que existe uma importância real para a compreensão do fenômeno jurídico da tributaão e que existem aplicações práticas para o desenvolvimento do Direito Tributário e da Política Fiscal. Apesar dos grandes avanços desde os trabalhos seminais de Ronald Coase até os estudos de Richard Posner, James Buchanan, Mises e Douglass North, não podemos afirmar ainda que existam trabalhos específicos sobre a sua aplicação ao fenômeno tributário. Com certeza existem limites a essa aplicação, bem como muitos elementos a avançar nesta

deve isolar seu conhecimento, sob a pretensão de laborar sobre campo infenso a influências externas". Mas pondera: "Em síntese: ao mesmo tempo que não merece acolhida, na análise dogmática, o emprego de ferramentas econômicas para a análise jurídica (Law and Economics), quando o aplicador do direito raciocina com base em conveniência, no lugar da licitude do comportamento, também deve ser rejeitada a análise jurídica que se pretende destacada do contexto econômico, político e social no qual se insere". SCHOUERI, Luís Eduardo. Direito Tributário. 3 Ed. São Paulo: Saraiva, 2013, p. 15-16.

${ }^{2019}$ TÔRRES, Heleno Taveira. Direito Tributário e Direito Privado. Op.cit., p. 213-214.

${ }^{2020}$ Veja-se, como importante exemplo da contribuição interdisciplinar - e da AED - ao Direito Tributário, as interessantes passagens da obra de Schoueri, onde o autor considera a contribuição da Ciência das Finanças Públicas, assim como também trata de temas tradicionalmente analisados no campo da Ciência das Finanças, mas que nem por isso escapam à reflexão do autor, como é o caso das funções fiscais, a problemática da tributação, da eficiência e da equidade, dos objetivos da tributação e da questão da incidência econômica dos tributos. SCHOUERI, Luís Eduardo. Normas Tributárias Indutoras e Intervenção Econômica. Op.cit., p. 33-66. 
agenda de trabalho, contudo, cremos na importância significativa deste estudo para a construção de um modelo de tributação mais justo e eficiente"2021.

Logo, a função prospectiva ou normativa também aparece nas possibilidades do diálogo entre AED e o Direito Tributário.

\subsection{Perspectivas de diálogo recíproco entre Política Tributária e Ciência do Direito Tributário contemporâneo}

São muitas as perspectivas de diálogo entre a Política Tributária e o Direito Tributário. Se a disciplina do Direito Tributário (jurídica) tem como premissa metodológica a função do jurista, no intuito de, através da interpretação, construir o sistema jurídico tributário, a Política Tributária indica, através de um perfil essencialmente normativo (novamente, a função normativa ou prospectiva), o aprimoramento do sistema existente, tornando-o mais adequado segundo determinadas referências ou valores.

Se fosse possível indicar um perfil diferenciador entre o jurista e o político que estuda o Direito Tributário é que, enquanto o jurista busca construir o Direito Tributário a partir dos dispositivos legais positivados, o político do direito analisa o direito posto no intuito de melhorá-lo, sempre observando determinadas referências ou valores (geralmente integrados ao próprio sistema jurídico, como justiça, ética, segurança, etc).

Infelizmente, os diálogos entre o Direito Tributário e a Política Tributária ainda são escassos, mesmo na literatura estrangeira. Os motivos para que tal diálogo ainda seja incipiente podem ser compreendidos nas linhas abaixo.

Em verdade, a Política Tributária, em seus debates tributários, tem sido vinculada ao aspecto normativo da Ciência das Finanças, enquanto essa se preocuparia a enunciar princípios gerais sobre os aspectos econômicos da tributação (ontologicamente) ${ }^{2022}$.

Mas é também tradicional a distinção entre Ciência das Finanças, enquanto teoria econômica da tributação, e Política Fiscal, enquanto prática (como "arte"), em que os

\footnotetext{
${ }^{2021}$ CALIENDO, Paulo. Op.cit. p. 64.

${ }^{2022}$ BALEEIRO, Aliomar. Uma Introdução à Ciência das Finanças. Op.cit., p. 28-29.
} 
conhecimentos obtidos na Ciência das Finanças seriam aplicados em observância a determinado fim ou valor caro a aquele ambiente ${ }^{2023}$.

Contudo, dentro da própria Ciência das Finanças emergiu parcela de teóricos que consideraram a necessidade de afastar-se dessas premissas (avalorativas, por assim dizer), focando a Ciência das Finanças enquanto atividade normativa, isto é, estudando os fenômenos econômicos relativos à tributação tendo em vista seu aprimoramento ou aproximação à determinada finalidade pré-determinada. A essa concepção "normativa" da Ciência das Finanças, chamou-se também de Política Fiscal (enquanto teoria normativa das Finanças Públicas). É justamente essa concepção que assume a finalidade da Política Financeira enquanto busca do "dever ser", comportando a técnica (ou arte) de como fazer, ou “(...) saber como fazer (know how) (...)"2024.

Para Bielsa, a Ciência das Finanças corresponderia ao estudo dos princípios de repartição de gastos públicos (e condições de sua aplicação), ao passo que a Política Financeira conceberia e estimaria as finalidades a serem alcançadas pela utilização dos conhecimentos obtidos na Ciência das Finanças ${ }^{2025}{ }_{-}^{2026}$

Naturalmente, o perfil econômico da Política Tributária representa apenas uma parcela de seu campo de atuação, já que a Política Legislativa Tributária também pode ser considerada fração da Política Tributária.

Não é por outro motivo que Sainz de Bujanda diferencia as características (e diferenças) entre ambas: a Economia Financeira investiga a atividade financeira enquanto objeto descritivo; a Política Financeira investiga a atividade financeira enquanto objeto

\footnotetext{
${ }^{2023}$ Não se pretende avançar na polêmica, mas revela-se pertinente fazer, dentro dessa concepção, a rápida diferenciação da Política Financeira em seu sentido teórico, e a Política Financeira em seu sentido prático. A Política Financeira em seu sentido teórico, volta-se à investigação direcionada à otimização de atividades financeiras, por sua vez orientadas por finalidade pré-estabelecida, e geralmente identifica-se com a ideia de "Ciência das Finanças aplicada", motivando parcela doutrinária a incluí-la como parte da Ciência das Finanças destinada à resolução de problemas práticos. Já a Política Financeira, em seu sentido prático, vincula-se justamente à execução das atividades previamente construídas pela Ciência das Finanças, visando atingir um fim pré-determinado. Sobre o assunto: LAURÉ, Maurice. Traité de Politique Fiscale. Paris, Presses Universitaire de France, 1957, p. 07. BALEEIRO, Aliomar. Uma Introdução à Ciência das Finanças. Op.cit., p. 28-29. BIELSA, Rafael. Op.cit., p. 07-28. SOUSA, Rubens Gomes de. Compêndio de Legislação Tributária. Op.cit., p. 31.

${ }^{2024}$ BALEEIRO, Aliomar. Uma Introdução à Ciência das Finanças. Op.cit., p. 29.

${ }^{2025}$ BIELSA, Rafael. Op.cit., p. 09.

${ }^{2026}$ HICKS, Ursula K. Finanças Públicas. Manuais de Economia Cambridge. Traduzido por Leopoldo Fontenele. Rio de Janeiro: Zahar Editores, 1961, p. 133.
} 
normativo. $^{2027}$ Não obstante, é importante mencionar que o mestre espanhol também reconhece a tendência de se atribuir uma "teoria da política fiscal", no objetivo de “(...) mostrar cientificamente as possibilidades que a Política Fiscal oferece para assegurar uma ocupação plena dos fatores" 2028 .

Mas é interessante notar que o autor, sobre as relações entre Direito Fiscal e Política Fiscal, especialmente no elemento teleológico da primeira, identifica relações mais aprofundadas, onde ambas sairiam mutuamente ganhando através do diálogo. Para Sainz de Bujanda, a precisão de conceitos jurídicos, a segurança doutrinária que deve servir de base ao ordenamento positivo e o rigor necessário para aplicação das normas constituiriam um dos mais valiosos auxílios que a política fiscal pode encontrar em seu desenvolvimento. Outro reforço pode ser encontrado através das diretrizes da Economia Financeira. $^{2029}$ Naturalmente, o planejador da política fiscal deverá tributar e tomar empréstimos dentro do que for possível juridicamente, atuando em consonância com o ordenamento jurídico. ${ }^{2030 \_}{ }^{2031}$.

A Política Fiscal não prescinde de finalidade que fundamente sua veiculação, seja ela determinada ou não e, naturalmente, é variável conforme o ideal planejado por cada Estado, em determinado lugar e em determinado contexto histórico. ${ }^{2032}$

A Política Fiscal (em sua especialização tributária) envolve a utilização de tributos para alcançar determinadas finalidades ${ }^{2033}$.

Nesse contexto, Reuven S. Avi-Yonah menciona três funções (ou objetivos) exercidas pela tributação: arrecadação (no intuito de obter receitas necessárias para atender às funções estatais); redistribuição (visando redistribuir riquezas e diminuir as

\footnotetext{
${ }^{2027}$ BUJANDA, Fernando Sainz de. Hacienda y Derecho. Estudios de Derecho Financiero.V. Madrid: Instituto de Estudios Políticos, 1967, p. 22-26

${ }^{2028}$ BUJANDA, Fernando Sainz de. Hacienda y Derecho. Estudios de Derecho Financiero.II. Op.cit., p. 32.

${ }^{2029}$ Idem, p. 43.

${ }^{2030}$ BALEEIRO, Aliomar. Cinco Aulas de Finanças e Política Fiscal. Op.cit., p. 41.

${ }^{2031}$ SOARES MARTÍNES, Pedro Mário. Direito Fiscal. $7^{\circ}$ edição. Revista e Actualizada. Coimbra: Livraria Almedina, 1993, p. 03-05.

2032 DALTON, Hugh. Princípios de Finanças Públicas. $4^{\circ}$ edição. Traduzido por Maria de Lourdes Modiano. Rio de Janeiro: Fundação Getúlio Vargas, 1980, p. 59.

${ }^{2033}$ CASALTA NABAIS, José. Op.cit., p. 362. SOARES MARTÍNES, Pedro Mário. Op.cit., p. 22 e seguintes.
} 
desigualdades sociais) e regulação (tributação utilizada para orientar a atividade econômica do setor privado conforme os interesses do Estado) ${ }^{2034}{ }^{2035}$.

Em outro passo, tende-se também a elencar quadro ligeiramente diferenciado de funções delineáveis à tributação, segundo sua função alocativa (tendo em vista o fornecimento de bens públicos à sociedade), distributiva (buscando ajustar a distribuição de renda segundo as necessidades sociais), ou estabilizadora (enquanto instrumento de política econômica tendente a viabilizar crescimento econômico, pleno emprego, etc) ${ }^{2036}$, identificando-se com a Política dos gastos públicos. ${ }^{2037}$

Sejam elas prioritariamente arrecadatórias, redistributivas, ou regulatórias, ou estabilizadoras, os instrumentos tributários podem intervir na ordem econômica, social, ambiental, etc., e, por esse motivo, entra no rol da Política Tributária o direcionamento econômico, social ou ambiental da função dos tributos (extrafiscalidade), ou mesmo a busca pela aproximação do sistema tributário frente a determinados ideais, como a justiça fiscal $^{2038}$, a integração econômica regional, ou o próprio desenvolvimento econômico ${ }^{2039}$.

Não é por outro motivo que, do ponto de vista da Política Tributária, a noção de "bom sistema tributário", ou "sistema tributário ideal”, leva à necessária consideração dos ideais buscados pela Ciência das Finanças ${ }^{2040}$, ainda que a máxima da justiça fiscal (ideal) seja elemento primordial nas relações entre Estado e contribuinte ${ }^{2041}$.

José Juan Ferreiro Lapatza, analisando o perfil da Política Fiscal frente ao Direito Tributário, observa que a primeira orienta-se como "ciência normativa" dedicada ao aprimoramento da tributação, segundo certas finalidades. Nesse sentido, enxerga que o Direito Tributário deveria dialogar mais com a Política Tributária, no sentido de que a

\footnotetext{
${ }^{2034}$ AVI-YONAH, Reuven S. Os três objetivos da Tributação. Op.cit., p. 07-30.

2035 Sobre os objetivos da tributação, conferir também: ZILVETI, Fernando Aurelio. A Evolução da Teoria da Incidência - Análise Histórica das Estruturas Socioeconômicas na Formação do Sistema Tributário. Op.cit., s/np (cap.V, itens n.2 a 8).

${ }^{2036}$ MORI, Rogério. Política Fiscal e Desempenho Macroeconômico. In: Direito Tributário. Política Fiscal. Série GVlaw. Roberto França Vasconcellos (Coord.). São Paulo: Saraiva - FGV, 2009, p. 03-05.

${ }^{2037}$ FERNANDES, Edison Carlos. Adaptação da Política Fiscal em tempo de economia internacional integrada. In: Direito Tributário. Política Fiscal. Série GVlaw. Roberto França Vasconcellos. São Paulo: Saraiva - FGV, 2009, p. 129-131.

${ }^{2038}$ DALTON, Hugh. Op.cit., p. 126-127.

${ }^{2039}$ DUE, John F. Tributação Indireta nas Economias em Desenvolvimento. Traduzido por Camila Perret. São Paulo: Editora Perspectiva, 1974, p. 83-85.

${ }^{2040}$ SMITH, Adam. Op.cit., p. 282-283. NEUMARK, Fritz. Op.cit., p. 101 e seguintes.

${ }^{2041}$ ZILVETI, Fernando Aurelio. A Evolução da Teoria da Incidência - Análise Histórica das Estruturas Socioeconômicas na Formação do Sistema Tributário. Op.cit., s/np (cap.V, item n.10).
} 
Política Tributária, considerada em sua faceta normativa, favoreceria a construção de medidas tendentes ao aprimoramento do sistema ${ }^{2042}$.

\subsubsection{O desafio interdisciplinar da Política Jurídico-Tributária perante o processo disciplinar do Direito Tributário Brasileiro contemporâneo}

As considerações sobre a Política Fiscal (sob a perspectiva normativa aplicada ao aperfeiçoamento do sistema tributário brasileiro) em seu diálogo com o Direito Tributário já aparecem em estudos brasileiros recentes, conforme é possível observar na coletânea organizada pela Fundação Getúlio Vargas, e coordenada por Roberto França de Vasconcellos, por sua vez dedicada ao diálogo entre Direito Tributário e Política Fiscal ${ }^{2043}$ na doutrina tributária brasileira.

Ademais, recentemente, no âmbito das relações interdisicplinares entre Direito Tributário e "Política-Jurídica Tributária", já aparecem importantes reflexões contemporâneas, a exemplo de José Souto Maior Borges ${ }^{2044}$, ligando-as à zetética jurídica (questionamento do direito posto) e, consequentemente, à pragmática do Direito Tributário.

Contudo, no Brasil, a relação entre Direito Tributário e Política Tributária foi explorada com maior extensão por James Marins ${ }^{2045}$, cujas opiniões se harmonizam com as reflexões de Ferreiro Lapatza ${ }^{2046}$. Marins chega a elevar a construção pioneira de autêntica interdisciplina, denominada "Política Jurídico-Fiscal".

Marins, objetivando traduzir a dualidade existente nas relações entre Ciência das Finanças e Política Fiscal para a realidade jurídico-tributária, caminha para a construção de verdadeira interdisciplina, que denominou por Política Jurídico-Fiscal, formada por uma síntese entre o Direito Tributário e a Política Tributária. Utiliza, nesse sentido, as reflexões

${ }^{2042}$ FERREIRO LAPATZA, José Juan. Direito Tributário - Teoria Geral do Tributo. Barueri - SP: Marcial Pons - Manole, 2007, p. 130-132. MARINS, James. O Desafio da Política Jurídico-Fiscal. Op.cit., p. 49-52.

${ }^{2043}$ VASCONCELlOS, Roberto França de. Prefácio. In: Direito Tributário. Política Fiscal. Série GVlaw. Roberto França Vasconcellos. São Paulo: Saraiva - FGV, 2009, p. ix-X.

2044 BORGES, José Souto Maior. Um ensaio interdisciplinar em Direito Tributário: superação da dogmática. Op.cit., p. 118-120.

${ }^{2045}$ MARINS, James. O Desafio da Política Jurídico-Fiscal. Op.cit., p. 52.

${ }^{2046}$ FERREIRO LAPAZTA, José Juan. Op.cit., p. 130. 
de jusfilósofos contemporâneos atentos ao tema como Karl Larenz ${ }^{2047}$ e Gustav Radbruch, ${ }^{2048}$ assim como, igualmente, Miguel Reale ${ }^{2049}$ e Alf Ross, que consideram haver importante vinculação entre o estudo da Ciência do Direito e a Política do Direito. Ross, sobretudo, apresenta um dos mais extensos estudos dedicados à defesa da Política do Direito enquanto caminho hábil para o aprimoramento da dogmática jurídica ${ }^{2050}$.

Mas se a Ciência do Direito tradicionalmente tem como objeto a construção do ordenamento jurídico positivo, descrevendo o sistema normativo, estruturando as relações de coordenação e hierarquia entre normas e proposições não normativas previstas no ordenamento, ordenando-a como um todo estruturado e coerente, conforme a lição de Paulo de Barros Carvalho ${ }^{2051}$, como vinculá-la à Política do Direito?

Para Marins, a função da Ciência do Direito Tributário estaria vinculada à descrição do direito tributário (com o objeto de descrever - em sentido amplo - o sistema jurídico normativo) ${ }^{2052-2053-2054}$, ao passo que a Política Jurídico-Tributária estaria vinculada ao aprimoramento do sistema (analogamente às funções da Ciência das Finanças e da Política Fiscal). Confere, portanto, atribuição normativa ao estudo do Direito Tributário (no âmbito da Política Jurídico-Fiscal), em busca do “optimum jurídico fiscal” $2055 \_2056$.

\footnotetext{
${ }^{2047}$ LARENZ, Karl. Op.cit., p. 227 e seguintes.

${ }^{2048}$ RADBRUCH, Gustav. Op.cit., p. 228 e seguintes.

2049 Para Reale, a Política do Direito (ainda que alguns estudiosos a releguem ao campo da Sociologia Jurídica), tenderá a compor-se como estudo global da “(...) nomogênese jurídica, isto é, das valorações e estruturas sociais que condicionam o aparecimento de uma norma jurídica, como obra de síntese superadora de possíveis antagonismos fáticos e valorativos”. REALE, Miguel. Lições Preliminares de Direito. Op.cit., p. 311.

${ }^{2050}$ Para Ross: “(...) a política jurídica é sociologia jurídica paliçada ou técnica jurídica”. Na prática, a Política Jurídica abrange os seguintes elementos: “1) os problemas especificamente técnico-jurídicos de natureza sociológico-jurídica (política jurídica em sentido próprio); 2) os outros problemas políticos estreitamente ligados àqueles na prática que, por sua índole, pertencem, na realidade, ao campo profissional de outros especialistas, e a respeito dos quais o jurista aparece, portanto, como um "especialista de segunda mão"; 3) a atividade de pesar considerações e decidir como árbitro de especialistas; 4) a formulação linguística da decisão (a qual, que se diga de passagem, dificilmente pode ser separada da própria decisão), numa linguagem jurídica aceitável e que se harmoniza com o corpo de normas existente". Note-se que Ross não limita a Política Jurídica à Política Legislativa, já que a Política Jurídica apareceria na contribuição do administrador e do juiz. ROSS, Alf. Direito e Justiça. $1^{a}$ Ed. Bauru-SP: Edipro, 2000, p. 376 e seguintes.

${ }^{2051}$ CARVALHO, Paulo de Barros. Curso de Direito Tributário, Op.cit., p. 01-02.

2052 KELSEN, Hans. Teoria Pura do Direito. Op.cit., p. 50-51

${ }^{2053}$ CARVALHO, Paulo de Barros. Curso de Direito Tributário. Op.cit, p. 01-04.

${ }^{2054}$ MARINS, James. O Desafio da Política Jurídico-fiscal. Op.cit., p. 70.

2055 “(...) Desse modo, nosso pólo de magnetismo é claramente o jurídico, a partir de seu referencial contemporâneo, marco cultural que servirá de baliza para as demais fatias da realidade tributária”. Idem, p. 53-54.

${ }^{2056}$ Idem.
} 
Nesse contexto, consequentemente, em primeira aproximação terminológica, a Política Jurídica pode ser desmembrada em duas vertentes, ou dois aspectos: a) Política Jurídica Endógena (quando o próprio jurista, sem recursos extrajurídicos, passa a servir de inspiração ao aperfeiçoamento do direito tributário positivo); b) a Política Jurídica Exógena (quando o jurista serve-se do diálogo com outros ramos do conhecimento jurídico para viabilizar o aperfeiçoamento do direito tributário positivo). Ambos seriam necessários para o aperfeiçoamento da Política Jurídico-Fiscal, e se desdobrariam em Política JurídicoFiscal Endógena e Política Jurídico-Fiscal Exógena. ${ }^{2057}{ }_{-}^{2058} 2059$

Naturalmente, a Política Jurídico-Fiscal Exógena apresenta estreitas conexões com a interdisciplinaridade, já que se viabiliza entre o diálogo desta com outros ramos do conhecimento (ainda que conectados pela análise do fenômeno jurídico sob diferentes pontos de vista). ${ }^{2060}$

Nesse caso, a Política Jurídico-Tributária Endógena, no direito tributário brasileiro, poderia ser viabilizada no âmbito da própria Ciência do Direito, como por exemplo, na substituição paulatina da expressão "fato gerador", pelas expressões "hipótese de incidência" e "fato jurídico tributário", talvez expressões que melhor representem as perspectivas (abstrata e fática) do fenômeno normativo tributário na legislação nacional.

Por outro lado, a Política Jurídico-Tributária Exógena voltar-se-ia ao diálogo interdisciplinar com outras disciplinas conexas com a tributação na busca pelo aperfeiçoamento do direito tributário. Nesse caso, por exemplo, poder-se-ia verificar concepções filosóficas de justiça (na Filosofia do Direito) como pressuposto para a criação de determinadas leis que interfiram no princípio da isonomia tributária, de forma a harmonizá-las com os preceitos filosóficos jurídicos atinentes ao tema. Por outro lado, na busca pelo aperfeiçoamento tributário, seria possível, no âmbito da Política do Direito Tributário, o recurso aos ensinamentos econômicos (AED), por exemplo, na busca pelo tributo ótimo e, assim, favorecer o aperfeiçoamento legislativo (e consequentemente, jurídico) que se aproxime desse ideal.

\footnotetext{
${ }^{2057}$ ENGISCH, Karl. Introdução ao Pensamento Jurídico. Op.cit., p. 34-35.

${ }^{2058}$ REALE, Miguel. Lições Preliminares de Direito. Op.cit., p. 302-322.

2059 JÚNIOR, Tércio Sampaio Ferraz. Função Social da Dogmática Jurídica. Op.cit., p. 07-08.

${ }^{2060}$ MARINS, James. O Desafio da Política Jurídico-Fiscal. Op.cit., p. 43.
} 
Portanto, a Política do Direito Tributário se pauta na busca pelo aperfeiçoamento do sistema jurídico, seja em sua perspectiva endógena (fruto do trabalho do próprio cientista do direito em sua própria disciplina), seja na perspectiva exógena (fruto do diálogo entre o cientista do direito e outros campos do conhecimento), perspectiva que se alinha às reflexões de Ferreiro Lapatza, na consideração de que o Direito Tributário por vezes deve ser considerado também como ciência normativa e não apenas descritiva ${ }^{2061}$, ainda que tais diálogos devam ser feitos assegurando as ressalvas disciplinares necessárias.

Mais uma vez, portanto, intensifica-se a importância da função normativa ou prospectiva ao tributarista, na busca pelo aperfeiçoamento do Direito Tributário através do diálogo entre Direito Tributário e Política Tributária.

\section{O nível de cooperação "interdisciplinar" no processo disciplinar do Direito Tributário Brasileiro no século XXI}

Ainda que se reconheça como acertadas as ressalvas apresentadas à interdisciplinaridade na ciência jurídica, conforme expõe Marcelo Neves ${ }^{2062}$, especialmente no que tange aos riscos do imperialismo ou colonialismo disciplinar e da metadisciplinaridade, as linhas acima impulsionam posicionamento ligeiramente distinto do manifestado pelo autor. Isso porque as ressalvas à interdisciplinaridade na ciência jurídica não consideram as peculiaridades históricas atribuíveis ao processo disciplinar de cada "ramo" do conhecimento jurídico. De fato, tem razão Neves no sentido de que a interdisciplinaridade deve ser permeada através do diálogo recíproco entre disciplinas consolidadas, onde ambas teriam oportunidade de obter benefícios.

Porém, o processo histórico disciplinar do Direito Tributário Brasileiro, talvez mais do que outros ramos do Direito, conviveu com a discussão sobre o grau de cooperação

\footnotetext{
${ }^{2061}$ Segundo Ferreiro Lapatza:“(...) Queremos dizer, com tudo isso, que o Direito Tributário deveria, talvez, acentuar sua vertente de ciência social "normativa”, propondo medidas de política fiscal - de política jurídico fiscal - que podem ser tão necessárias e significativas quanto às propostas econômicas para alcançar os fins de um sistema tributário que cumpra as quatro regras smithianas da imposição, economia, certeza, comodidade e justiça. E, quando nos referimos a uma ciência jurídica normativa, obviamente não falamos do "dever ser" "na" norma ou "no" Ordenamento, mas da norma ou do Ordenamento que "devem ser". FERREIRO LAPAZTA, José Juan. Op.cit., p.132.

${ }^{2062}$ NEVES, Marcelo. Op.cit, p. 02-03.
} 
entre o Direito Tributário e outros ramos do conhecimento desde seus primeiros esforços disciplinares.

Por isso, há razões para considerar que a verdadeira interdisciplinaridade pode receber contribuições do Direito Tributário, desde que observadas certas premissas.

Em primeiro lugar, para o empreendimento interdisciplinar, é preciso haver uma finalidade norteadora. Nenhum empreendimento interdisciplinar é viabilizado sem ter uma finalidade comum que interesse às disciplinas envolvidas. Essa finalidade, na órbita da tributação, deve permear-se pela função prospectiva ou normativa aliada ao tributarista, no sentido de favorecer o aperfeiçoamento do direito tributário vigente.

Em segundo lugar, é preciso reunir disciplinas bem amadurecidas. Não há, em qualquer proposta da interdisciplinaridade, a substituição de uma disciplina por outra, formada pela colisão de várias próximas. A proposta interdisciplinar aparece como reforço aos estudos disciplinares, viabilizando resultados que não seriam permitidos no interior de uma disciplina isolada. Por isso, a interdisciplinaridade depende da atitude de abertura de pensamento, invocada tantas vezes por seus estudiosos ${ }^{2063}$.

Em terceiro lugar, é preciso buscar respostas para perguntas que não seriam respondidas no âmbito dos limites disciplinares, sem o qual não haveria razão para o empreendimento interdisciplinar.

Particularmente, no campo do fenômeno tributário, o processo disciplinar do Direito Tributário, hoje já amadurecido, possibilita, com menores restrições, o diálogo recíproco com outros campos do conhecimento conexos à tributação, como é o caso da Filosofia Tributária, da Política Tributária e da Análise Econômica do Direito. Essas se aproximam do Direito Tributário para alcançar finalidade não atingível àquela disciplina jurídica, isto é, a busca pelo aperfeiçoamento do direito tributário positivo (seja pela busca do direito tributário correto, ou do direito tributário ótimo), agregando (mas nunca substituindo a função "tradicional" do jurista) a função prospectiva ou normativa ao tributarista, que se torna viável a partir da consideração dos estudos produzidos naqueles campos do conhecimento.

${ }^{2063}$ FAZENDA, Ivani Catarina Arantes. Integração e Interdisciplinaridade no Ensino Brasileiro: Efetividade ou Ideologia? Op.cit., p. 09. 
Esses conhecimentos, uma vez obtidos, fornecem importante ferramenta para o aperfeiçoamento do próprio sistema tributário, seja para viabilizar o sistema tributário mais adequado aos ideais de transparência fiscal, seja para compreender melhor a tecnologia envolvida na tributação, seja para buscar adaptar o Direito Tributário à sua melhor intelecção com os conhecimentos contábeis ou até mesmo para adequar com maior clareza o direito tributário brasileiro às premissas decorrentes da globalização da economia.

Mas tal panorama consideravelmente favorável à interdisciplinaridade não afasta as dificuldades epistemológicas inerentes, e que impõe consideráveis cautelas ${ }^{2064}$.

Por isso entende-se conveniente, a partir das construções tipológicas elaboradas na teoria do conhecimento, compreender em que graus interdisciplinares (ou, em melhores termos, estratégias interdisciplinares de estudo) pode haver o diálogo recíproco entre o Direito Tributário, no presente momento, sem comprometer seu processo disciplinar. Notese, contudo, que a simples absorção de conhecimentos obtidos de outros ramos do conhecimento não significa necessariamente "interdisciplinaridade", que pressupõe o diálogo recíproco. Tal ressalva, não obstante, não afasta a utilidade dessa natureza de empreendimento, que tende a colaborar positivamente para o progresso disciplinar do Direito Tributário.

Em primeiro lugar, o Direito Tributário atua no nível disciplinar quando trabalha no âmbito de seu próprio feixe do conhecimento jurídico ${ }^{2065}$ (já especializado ou a caminho da especialização), com seu(s) próprio(s) método(s), historicamente restringindo interação com outros campos do conhecimento (embora essa restrição seja questionável).

Por outro lado, quando o Direito Tributário obtém informações, por exemplo, com a Contabilidade, para proceder a estudos que priorizem o enfoque do próprio Direito Tributário, mas sem que esses dados interfiram no modus operandi do estudioso do Direito Tributário, pode-se dizer que ocorre a interdisciplinaridade cruzada ou linear frente ao direito tributário. Essa estratégia, porém, historicamete, já é utilizada largamente no processo disciplinar do Direito Tributário Brasileiro (por exemplo, na adoção de dados

\footnotetext{
${ }^{2064}$ MARINS, James. O Desafio da Política Jurídico-Fiscal. Op.cit., p. 43.

${ }^{2065}$ Essa classificação foi inspirada nas propostas de JANTSCH, E. Op.cit., p. 108 e seguintes. JAPIASSÚ, Hilton. Op.cit., p. 80-81. FAZENDA, Ivani. Integração e Interdisciplinaridade no Ensino Brasileiro: Ideologia ou Efetividade? Op.cit. p.30-34. HECKHAUSEN, Heinz. Op.cit., p. 83-87. BOISOT, M. Op.cit., p. 90 e seguintes.
} 
contábeis para a investigação na órbita do direito tributário posto). Nada tem de novo ao Direito Tributário Brasileiro, portanto, embora não possa ser reconhecida como "verdadeira interdisicplinaridade".

Já quando o Direito Tributário empresta de outros campos do conhecimento métodos ou técnicas para auxiliar seu próprio estudo, ocasionando alteração do modus operandi do próprio estudioso do Direito Tributário, diz-se ocorrer a interdisciplinaridade auxiliar ou complementar ao direito tributário ${ }^{2066}$. Essa estratégia também não é novidade no processo disciplinar do Direito Tributário Brasileiro, uma vez que a adoção, exemplificativamente, de construções jurídico-filosóficas aos estudos jurídico-tributários tem feito parte constante do processo disciplinar do Direito Tributário Brasileiro, especialmente a partir da década de sessenta do século XX.

Contudo, aqui também não se pode falar em "verdadeira interdisciplinaridade", pois não se trata de diálogo recíproco entre disciplinas conexas buscando resolver zonas de intersecção interdisciplinar. Trata-se apenas de um reforço jurídico-filosófico para embasar construções teóricas aplicadas ao estudo (jurídico) do Direito Tributário, mas sem causar qualquer repercussão na disciplina originária (filosofia do direito). Veja-se que até aqui não há diálogo recíproco, mas mera utilização de conhecimentos externos obtidos em um campo do conhecimento e aplicados em outro campo do conhecimento. Não se poderia afirmá-lo, tecnicamente, enquanto técnica interdisciplinar, portanto. A mesma ressalva vale para o a interdisciplinaridade cruzada ou linear.

Evidentemente que, na busca pela função prospectiva ou normativa do tributarista, o diálogo interdisciplinar, seja entre Direito Tributário e qualquer outro campo do conhecimento afeto à tributação supra-analisado, ocorre reforço no modus operadi do tributarista, que passa a possuir, não apenas os mecanismos tradicionais, mas complementarmente, a possibilidade de avançar sobre sua disciplina para alcançar respostas que interessam ao aperfeiçoamento da própria disciplina ou de seu objeto de estudo. Portanto, o empreendimento que considere conhecimentos obtidos de outra ciência (extrajurídica), mas tendente a alcançar a função prospectiva ou normativa do tributarista insere-se na "interdisciplinaridade auxiliar ou complementar” ao Direito Tributário.

${ }^{2066}$ Utiliza-se da terminologia de Heckhausen, equivalente à interdisciplinaridade linear ou cruzada, de Boisot e Japiassú, também conhecida como disciplinaridade cruzada em Jantsch. JANTSCH, E. Op.cit., p. 108 e seguintes. JAPIASSÚ, Hilton. Op.cit., p. 80-81. HECKHAUSEN, Heinz. Op.cit., p. 83-87. 
Porém, no momento em que o Direito Tributário e a Política Tributária busquem compreender uma nova axiomática comum, proporcionando a criação de uma verdadeira interdisciplina, como é o caso da Política Jurídico-Fiscal, ocorre a interdisciplinaridade tributária propriamente dita (unificadora ou estrutural). Essa, de fato, é a verdadeira interdisciplinaridade, consolidada na epistemologia e na pedagogia contemporâneas. Notese o diálogo recíproco entre duas disciplinas aptas a formarem zona de intersecção entre ambas, e tendentes à investigação de problemas comuns, que sozinhas, não conseguiriam resolver.

Porém, esta, naturalmente, não é "aplicável" ao Direito Tributário, mas pode ser produto da fusão deste com outro ramo destinado a investigar determinado campo de intersecção comum a ambas as disciplinas. De todo modo, a interdisciplina propriamente dita não substitui o Direito Tributário, enquanto disciplina, apenas preenche o espaço epistemológico aberto que o Direito Tributário não pode alcançar com suficiente eficiência, com premissas, métodos e objetivos próprios.

A epistemologia contemporânea tem também levantado a possibilidade da "transdisciplinaridade" (como grau máximo de interação entre disciplinas) ${ }^{2067}$ enquanto produto do diálogo entre várias disciplinas e interdisciplinas voltadas a objetivo comum.

Essa também poderia agregar ao Direito Tributário, muito embora seja ainda de difícil aplicação, pois se situaria em um nível de interação acima da interdisciplinaridade propriamente dita (estrutural ou unificadora). Quando maior a abertura, maiores os riscos epistemológicos, naturalmente.

Em tese, a transdisciplinaridade ocorreria, hipoteticamente, quando o Direito Tributário (disciplina), a Filosofia Tributária (Interdisciplina), a Economia (Disciplina) e a Política Jurídico-Fiscal (interdisciplina) reunissem esforços recíprocos para buscar delimitar o problema da fome global através do redirecionamento de tributos pagos por países ricos às regiões mais afetadas pela fome mundial. O Direito Tributário e as disciplinas e interdisciplinas atuariam conjuntamente para o interesse comum.

\footnotetext{
${ }^{2067}$ Mais uma vez, convém destacar a diferença da composição de Jantsch, que fundamenta a classificação acima, frente à noção de transdisciplinaridade trazida por Nicolescu e Morin, que possui sentido mais amplo (e engloba os próprios processos interdisciplinares) do que a transdisciplinaridade entendida como grau máximo de interações disciplinares dentro da interdisciplinaridade. Para Morin, a transdisciplinaridade é decorrência da complexidade. MORIN, Edgar. Ciência com consciência. Op.cit., p. 173 e seguintes. Sobre o assunto também: NICOLESCU, Basarab. Definition of Transdisciplinarity. 2003. Op.cit., p. 01 e seguintes.
} 
Tanto a interdisciplinaridade propriamente dita como a transdisciplinaridade exigiriam um grau superior hierárquico acima das disciplinas (ou interdisciplinas) envolvidas. Seria esse grau superior responsável pela coordenação dos estudos buscando atingir determinada finalidade comum pré-determinada.

Nesse ponto reside maior dificuldade para aplicação ao Direito Tributário que, atualmente, encontra contemporaneamente melhores perspectivas nas duas primeiras etapas de interação "interdisciplinar" (que não são verdadeiramente interdisciplinares), o que não obsta, por exemplo, a colaboração da política jurídico-fiscal (formada pela interdisciplinaridade propriamente dita) ao aperfeiçoamento do Direito Tributário no intuito de agregar-lhe função normativa, em níveis de interdisciplinaridade auxiliar ou complementar, o que, como visto, não seria verdadeira interdisciplinaridade. 


\section{CONCLUSÕES}

O processo histórico disciplinar do Direito Tributário no Brasil envolve a incessante busca pela própria autoafirmação perante outros ramos do conhecimento, jurídicos ou não. Essa informação é confirmada pela análise exposta nos capítulos anteriores, que expõe o perene esforço da literatura tributária brasileira em ver emancipado esse objeto de estudos (e a disciplina a ele conexa). Mas essa busca não ocorre rapidamente, e nem linearmente. No processo histórico disciplinar do Direito Tributário, muitas variantes interferem nesse percurso, sejam oriundos de fatores internos ou externos ao Direito Tributário. Além disso, não há um único caminho ou rota disciplinar seguida pelo Direito Tributário.

Ademais, o processo histórico de especialização disciplinar do Direito Tributário Brasileiro difere-se de outros processos em virtude de suas próprias particularidades decorrentes do processo histórico de positivação do Direito Tributário Brasileiro.

A formação de diferentes estratégias de estudo e ensino desenvolvidas na realidade brasileira comprova que o mesmo objeto pode ser analisado a partir de diferentes premissas, métodos e objetivos, ainda que o ponto central seja o mesmo: elevar o direito tributário como disciplina jurídica.

Após o transcurso histórico apresentado nos capítulos anteriores, torna-se possível apresentar versão aprimorada daquela primeira classificação exposta na introdução: i) período pré-disciplinar: quando não há qualquer referência à separação dos estudos econômicos, sociais, legislativos, políticos no estudo do Direito Tributário (século XIX, no período monárquico, até década de trinta do século XX), e comporta aproximadamente os cem primeiros anos dos estudos tributários no Brasil; ii) período de transição disciplinar: Entre o final do período pré-disciplinar e o início do período disciplinar aparecem estudos que identificam as dificuldades para emancipação do Direito Tributário. Nesse mesmo contexto, surgem fatores que impulsionam o reconhecimento da necessidade de autonomia disciplinar, encontrando-se na zona limítrofe entre os dois períodos, a exemplo da elevação da carga tributária e da política fiscal keynesiana. Por outro lado, há aqueles fatores que já se movimentam em decorrência da própria consideração da autonomia teórica, como é o 
caso da criação de tribunais fiscais, a contribuição da Constituição de 1946 para a criação de normas gerais sobre direito financeiro pela União, entre outros (década de trinta e década de quarenta); iii) período disciplinar: quando os primeiros fatores que impulsionam o reconhecimento da necessidade de autonomia disciplinar, viabilizando, no campo teórico, a percepção da autonomia disciplinar (década de quarenta até os anos finais da década de sessenta e início da década de setenta, quando o direito tributário passa a ser reconhecimento institucionalmente e ensinado como cátedra universitária), recebendo ulteriores etapas nos anos seguintes. Note-se, contudo, que as "etapas" não apresentam divisão rigorosa, pois perfeitamente permeáveis entre si. Trata-se muito mais de uma classificação de índole didática, construída para facilitar a compreensão dos diferentes contextos históricos em que o processo disciplinar do Direito Tributário Brasileiro se constrói (ou reconstrói).

Ademais, o período disciplinar, que prevalece até os dias atuais, subdivide-se em: 1) período inicial da elevação da autonomia teórica (década de quarenta e cinquenta); 2) período em que se registram os antecedentes que levariam à consolidação da autonomia do ensino do Direito Tributário no Brasil (década de cinquenta e sessenta); 3) período de reconhecimento institucional da disciplina do Direito Tributário no ensino jurídico no Brasil (final da década de sessenta e início da década de setenta); 4) período de consolidação das estratégias de estudo e ensino no Direito Tributário Brasileiro: 4.1.) período não-democrático: USP (década de sessenta em diante), PUCSP (década de setenta em diante) e linhas de estudos não convergentes; 4.2) período democrático no século XX (especialmente a partir da década de noventa): situado em ambiente de democratização, trazido pela Constituição de 1988, quando são desenvolvidas (ou reforçadas) determinadas propostas de estudo e ensino ao Direito Tributário; 4.3) período disciplinar democrático contemporâneo (limiar entre os séculos XX e XXI): período em que novos fatores, como o reconhecimento progressivo das Gerações de Direitos, da Globalização, da configuração atual do Estado Fiscal (Estado Social Fiscal Democrático) e da própria concepção sociológica da sociedade de riscos influenciam na consolidação disciplinar, ampliando os horizontes do Direito Tributário brasileiro, viabilizando inclusive a perspectiva de novos "sub-ramos" do Direito Tributário. Ao mesmo tempo, velhas necessidades continuam aprimoradas no estudo do Direito Tributário, como a segurança jurídica, e também, surgem novas perspectivas de estudo críticas, alternativas ou complementares às propostas anteriores, a exemplo do aprimoramento do instrumental 
hermenêutico do tributarista, da defesa da complexidade e da maior aproximação da pragmática do Direito Tributário.

Mas reforce-se que a escolha epistemológica predominante na construção histórica disciplinar do Direito Tributário Brasileiro é, sem dúvida alguma, a especialização disciplinar, conforme se comprovou no presente trabalho. Esse fenômeno, nada mais é do que a tendência prevalecente na teoria do conhecimento, por sua vez amplamente influenciada pelo chamado "Paradigma da Modernidade", que vê na verticalização e redução do objeto de pesquisa os caminhos mais seguros para alcançar a dignidade científica que deve caracterizar uma verdadeira ciência.

Contudo, o processo de especialização disciplinar do Direito Tributário Brasileiro caracteriza-se pela progressiva elevação do Direito Tributário como disciplina jurídica autônoma, apta a consagrar-se como cadeira própria no ensino universitário, mas, ao mesmo tempo, confirma-se que o processo de especialização disciplinar do Direito Tributário Brasileiro guardou peculiaridades não necessariamente identificáveis em outros ramos do Direito.

Esse processo histórico, igualmente, também não foi completamente subsumido ao processo geral de especialização disciplinar identificado na epistemologia e pedagogia.

A realidade teórica brasileira, amplamente influenciada pelo exemplo europeu (notadamente francês e italiano), que tradicionalmente possuíam importante vinculação histórica com os estudos econômico-financeiros, caminhou considerando a influência econômica sem maiores reservas, e até com bons olhos, para firmar esse diálogo como demonstração da particularidade do Direito Tributário perante outros ramos do conhecimento. Na maioria esmagadora da literatura tributária da década de quarenta e cinquenta pode-se identificar o tratamento de temas econômicos sem maiores reservas ao Direito Tributário.

Ainda que tendências positivistas já fossem registradas no período inicial do processo disciplinar do Direito Tributário, herança da própria tradição europeia do Direito Público, a guinada epistemológica ao dualismo (ou separatismo) frente à Ciência das Finanças só aparece com força em Alfredo Augusto Becker, repercutindo as tendências dogmático-normativas da época, assim como a tendência ao dualismo do fenômeno 
financeiro registrado, por exemplo, na doutrina italiana de Giannini (e da Escola de Nápoles).

De fato, o processo de especialização disciplinar, já iniciado na década de quarenta, registra guinada ao dualismo radical, relativa ao diálogo entre Direito Tributário e Ciência das Finanças, especialmente a partir da década de sessenta, tendência também influenciada pelo dogmatismo kelseniano que, desembarcado no Brasil, passa a exercer forte influência na ciência jurídica da época, e cuja linha mestra focava-se na abstração de qualquer elemento econômico ao estudo do direito. Somente o raciocínio jurídico conteria dignidade científica.

Nesse contexto histórico, no Direito Tributário, consolidam-se duas perspectivas de estudo diferenciadas: a) a primeira, que apresentaria estudos jurídico-tributários sem desconsiderar radicalmente a possibilidade de contribuições históricas, econômicas, financeiras à investigação do jurista; b) a segunda, que buscaria afastar dos estudos jurídico-tributários toda e qualquer influência oriunda dos aspectos econômicos da tributação.

Naturalmente, ainda que se registrem posições ponderadas entre ambas, pode-se dizer que a segunda linha, ligeiramente posterior à primeira, empenhada na divulgação de seu método de ensino e pesquisa na realidade jurídica brasileira como o "método jurídico" por excelência, passa a prevalecer, favorecendo a difusão de tendência de estudos voltados ao raciocínio puramente jurídico, na medida do possível.

Notadamente, a construção das linhas adotadas pelas também se forma em ambiente histórico sedimentado. A primeira, construída em ambiente no qual inexistia a perspectiva do ensino institucionalizado do Direito Tributário Brasileiro e a segunda, já configurada no momento ligeiramente ulterior a essa institucionalização, mas que não concordava com a proposta anterior, elegendo e difundindo seu próprio método, sempre tendo como referência a consideração (ponderada) ou a refutação da influência da Ciência das Finanças no raciocínio jurídico. São dois caminhos, portanto, que aparecem para apresentar suas respectivas visões sobre o estudo do Direito Tributário, e que acabam repercutindo-se na produção doutrinaria brasileira, ainda que, com o passar do tempo, apresente-se maior difusão da segunda, pelos motivos acima expostos. 
Tais caminhos são novamente reforçados com a redemocratização, impulsionada pela Constituição de 1988, e pelo papel fundamental do movimento constitucional democrático europeu aliado aos Direitos Fundamentais consagrados na Declaração dos Direitos Humanos.

O neoconstitucionalismo passa gradativamente a exercer influência na literatura publicista brasileira. $\mathrm{O}$ constitucionalismo democrático centrado na dignidade da pessoa humana também favorece a emanação de tendências alternativas ao positivismo dogmático normativo kelseniano (doravante denominadas "pós-positivismo"), que passam a refletir influência na construção jurídico-tributária brasileira.

Por outro lado, a segurança jurídica, mais uma vez, é a pedra de toque da literatura tributária, agora reforçada por extensão inédita da matéria tributária. Ainda que a década de noventa seja caracterizada por diferentes problemas tributários, e sucessivas violações à segurança jurídica, emergem diferentes linhas de pesquisa com suas próprias visões sobre esse contexto jurídico-tributário.

Naturalmente, as linhas de pesquisa e ensino construídas nesse período não representam as únicas posições possíveis na literatura tributária brasileira, mas foram escolhidas por representar as grandes tendências epistemológicas (e metodológicas) nos estudos tributários, pelo menos até o século XX. Em todas elas, há sempre grande importância na consideração de fenômenos "extrajurídicos" (notadamente relacionadas à Ciência das Finanças), seja pela sua aceitação (ponderada ou não), complementação ou refutação peremptória.

Assim, o processo de especialização disciplinar do Direito Tributário Brasileiro não caminha por uma linha reta, mas por ramificações, justificadas por seus respectivos ambientes históricos, cada qual manifestando suas próprias propostas de estudo e ensino, e demonstrando posições distintas sobre o diálogo com outros campos do conhecimento. $\mathrm{O}$ processo disciplinar do Direito Tributário Brasileiro é muito mais identificável como uma árvore, e seus sucessivos ramos, ainda em crescimento, mas jamais uma linha reta, onde a disciplina supostamente caminharia pelo prevalecimento absoluto de uma opção teórica em exclusão ou superação absoluta das demais. 
O limiar do século XX frente aos primeiros anos do século XXI registra, em ambiente histórico diferenciado dos contextos anteriores, importantes acréscimos que fornecem, por outro lado, a oportunidade para a reanálise do diálogo do Direito Tributário perante outros ramos do conhecimento.

O vasto campo de possibilidades trazido pelo século XXI impulsiona a elevação da interdisciplinaridade no Direito Tributário brasileiro. Mas, como visto, segundo as teorias recentes sobre a interdisciplinaridade, esta pressupõe o diálogo recíproco entre disciplinas amadurecidas, e ainda que a consideração de conhecimentos ou fatores "extrajurídicos" seja facilmente identificada na literatura pátria (a exemplo da filosofia ou da filosofia do direito no Direito Tributário), entre essa consideração e a interdisciplinaridade, conforme visto no trabalho, emana grande diferença.

As teorias da interdisciplinaridade, surgidas como contrapropostas epistemológicas à especialização disciplinar, esta decorrente do Paradigma da Modernidade, levam em consideração a necessidade de estudos que promovam a aproximação entre campos distintos do conhecimento, de forma que ambos possam reforçar seus resultados investigativos. Surgida na segunda metade do século XX os estudos interdisciplinares passam a refletir a gradual abertura das ciências, e, para muitos estudiosos, a elevação de novo Paradigma, o Paradigma da Complexidade, assim como, no campo pedagógico, a teoria da Transdisciplinaridade.

Contudo, deve-se reconhecer que os estudos interdisciplinares ainda são relativamente recentes e, por isso, há sérias divergências terminológicas e tipológicas em suas propostas, e até mesmo insuficiente amadurecimento teórico sob os graus ou etapas de cooperação interdisciplinares.

Porém, detalhe importante que não pode ser deixado de lado é a perspectiva de que todos os esforços interdisciplinares almejam alcançar finalidade comum de interesse de ambas as disciplinas. São as "vantagens recíprocas" que mencionou Piaget. Nesse contexto emana-se a oportunidade da elevação da função prospectiva ou normativa aplicada ao Direito Tributário, que pode aproximar disciplinas no exame das zonas de intersecção interdisciplinares. 
Nesses casos pode ser reconhecida a verdadeira interdisciplinaridade, o que não obsta a grande utilidade de graus inferiores na cooperação entre disciplinas, conforme já tem sido praticado no próprio Direito Tributário no Brasil.

Portanto, a resposta à pergunta elementar apresentada na Introdução desse trabalho é no seguinte sentido: no percurso histórico disciplinar do Direito Tributário Brasileiro prevalece a especialização disciplinar, enquanto reflexo do Paradigma da Modernidade, ainda que com notáveis ponderações inerentes às peculiaridades históricas da disciplina.

Naturalmente, a afirmação histórica da disciplina, no sentido de sua constante absorção de fenômenos internos e externos ao Direito Tributário, e sua consequente construção - ou reconstrução - autônoma, no ambiente histórico contemporâneo, oferece também vislumbre de outros caminhos (a exemplo da verdadeira interdisciplinaridade), a serem postos à pauta de discussão na Ciência do Direito Tributário, enquanto estratégias válidas ao progressivo aprimoramento do direito tributário enquanto objeto de estudo e, consequentemente, da própria disciplina hoje denominada Direito Tributário. 


\section{REFERÊNCIAS BIBLIOGRÁFICAS}

$\underline{\mathbf{A}}$

ABBAGNANO, Nicola. Dicionário de Filosofia. 2a Edição. São Paulo: Mestre Jou, 1998.

ABRÃO, Carlos Henrique. Cobrança Compulsória da CPMF. In: Revista Tributária e de Finanças Públicas, ano 9, n.37, Editora Rt, São Paulo, março-abril de 2001.

Agenda 21 da Conferência da ONU sobre Meio Ambiente e Desenvolvimento. Disponível em: www.mma.gov.br (último acesso em 12.10.2014).

ALEXY, Robert. Teoria dos Direitos Fundamentais. Trad. Virgílio Afonso da Silva. São Paulo: Malheiros, s/d.

ALLIX, Edgard. Traité Élémentaire de Science des Finances et de Législation Financière Française. Quatrième Édition. Paris: Rousseau et Cie Éditeurs, 1921.

ALMODOVAR, António. José Ferreira Borges. In: CARDOSO, José Luís (coordenador). Dicionário Histórico de Economistas Portugueses. Lisboa: Temas e Debates, 2001.

ALLORIO, Enrico. Diritto Processuale Tributario, $1^{\text {a }}$ ed., Torino, Unione Tipografico, 1942

AltamiRAnO, Alejandro C. El Derecho Tributario ante La Constitucionalización del derecho a un medio ambiente sano. In: TôRRES, Heleno Taveira (org.). Direito tributário ambiental. São Paulo: Malheiros, 2005.

El Derecho Constitucional a un ambiente sano, derechos humanos y

su vinculación con el derecho tributário. In: Tributação e Meio Ambiente. James Marins (Coord). Livro 2. Curitiba: Juruá, s/d.

AMARAL JÚNIOR, José Levi Mello do. Memória jurisprudencial: Ministro Aliomar Baleeiro. Brasília: Supremo Tribunal Federal, 2006. - (Série memória jurisprudencial).

AMATUCCI, Andrea. Las Raíces de la Concepción Sustancial del Derecho Financiero Público en Nápoles y en la Italia Meridional. In: D’AMATI, Nicola. AMATUCCI, Andrea (Organiz). Historia del Derecho de la Hacienda Pública y del Derecho Tributario en Italia. E aporte del pensamento jurídico financiero de la Italia Meridional. Derecho de la Hacienda Pública. Obras Fundamentales 1. Bogotá-Colombia: Temis, 2004.

. Historia de La Enseñanza del Derecho Financiero Público en Italia. In: In: D’AMATI, Nicola. AMATUCCI, Andrea (Organiz). Historia del Derecho de la Hacienda Pública y del Derecho Tributario en Italia. E aporte del pensamento jurídico financiero de la Italia Meridional. Derecho de la Hacienda Pública. Obras Fundamentales 1. Bogotá-Colombia: Temis, 2004.

L'Insegnamento del Diritto Finanziario. In: L'Evoluzione dell'Ordinamento Tributário Italiano. Atti del Convegno "I settanta anni di "Diritto e Pratica Tributaria". Il Diritto Tributário. Antonio e Victor Uckmar (Coords.) Serie I. Volume LXXXIX. Padova: CEDAM, 2000.

AMARO, Luciano. Direito Tributário Brasileiro. 11 Ed. São Paulo: Saraiva, 2005. 
AMED, Fernando José; NEGREIROS, Plínio José Labriola de Campos. História dos Tributos no Brasil. $2^{a}$ Ed. São Paulo: Sindicato dos Agentes Fiscais de Rendas do Estado de São Paulo Sinafresp.

ANDRADE, José Maria Arruda de. Normas Gerais, Nacionais, Competência Legislativa e o Federalismo Fiscal. Revista Brasileira de Estudos Constitucionais, v. 6, 2008.

ANDRADE, José Maria Arruda de. Interpretação da Norma Tributária. São Paulo: MP Editora, 2006.

“Anistia Fiscal”. Ação Rescisória n.7. são Paulo. Autora: Alonso, Calcerrada \& Cia. Ltda. Ré: Fazenda Nacional; Relator: Exmo. Snr. Ministro Afrânio Antônio da Costa. Revisor: Exmo. Snr. Ministro Edmundo de Macedo Ludolf. Rio de Janeiro: Tribunal Federal de Recursos, 1948.

Anteprojeto Constitucional, elaborado pela Comissão Provisória de Estudos Constitucionais, instituída pelo Decreto n ${ }^{\circ}$ 91.450, de 18 de julho de 1985. Diário Oficial. Suplemento Especial ao n.185. Sexta-Feira, 26 de setembro de 1986, Brasília - DF.

ARANHA, Osvaldo. Exposição de Motivos do Ministro da Fazenda (Exposição n.1250, de 217-1954. Projeto de Código Tributário Nacional). In: Trabalhos da Comissão Especial do Código Tributário Nacional. Ministério da Fazenda, Rio de Janeiro, 1954.

ASCARELLI, Tullio; SOUSA, Rubens Gomes de; FILHO, João Batista Pereira de Almeida. Lucros Extraordinários e Imposto de Renda. Comentários ao Decreto n.15028 de 13 de março de 1944, em relação com a doutrina e a legislação do imposto de renda. São Paulo: Livraria Martins Editora, 1944.

Assembleia Nacional Constituinte. ATA DA 6 ${ }^{\text {a }}$ REUNIÃO, REALIZADA EM 29-4-87 E PUBLICADA NO SUPLEMENTO AO DANC $\mathrm{N}^{\circ}$ 53, DE 19-5-87. In: ANAIS DO SENADO FEDERAL (ATAS DE COMISSÕES). Subcomissão de Tributos, participação e distribuições de receitas. Disponível em: www.senado.gov.br. (último acesso em 28.11.2014)

Assembleia Nacional Constituinte. ANEXO A ATA DA $8^{\text {a }}$ REUNIÃO REALIZADA EM 5-5-87, ÀS $10 \mathrm{~h} 20 \mathrm{~m}$ E PUBLICADA NO SUPLEMENTO AO DANC $\mathrm{N}^{\circ} 56$, de 8-5-87. In: ANAIS DO SENADO FEDERAL (ATAS DE COMISSÕES). Subcomissão de Tributos, participação e distribuições de receitas. Disponível em: www.senado.gov.br. (último acesso em 28.11.2014)

Assembleia Nacional Constituinte. ATA DA TERCEIRA REUNIÃO, ORDINÁRIA, COM AUDIÊNCIA PÚBLICA, REALIZADA EM 22-4-87. In: ANAIS DO SENADO FEDERAL (ATAS DE COMISSÕES). Subcomissão de Tributos, participação e distribuições de receitas. Disponível em: www.senado.gov.br. (último acesso em 28.11.2014)

ATAliBA, Geraldo. Prefácio. In: BALEEIRO, Aliomar. Limitações Constitucionais ao Poder de Tributar. Atualizada por Mizabel Derzi. Rio de Janeiro: Forense, 1999.

ATALIBA, Geraldo. Natureza Jurídica das Contribuições de Melhoria. Revista dos Tribunais, São Paulo, 1964.

Editora Revista dos Tribunais, 1968.

Sistema Constitucional Tributário Brasileiro. $2^{\circ}$ Edição. São Paulo:

Dispositivos Constitucionais Pertinentes aos Tribunais de Contas Proposta para Discussão do Tribunal de Contas - Proposta para Discussão do Tribunal de Contas do Estado de São Paulo. In: Assembleia Nacional Constituinte. Ata da Quarta Reunião, 
ordinária, com audiência pública, realizada em 24-4-87. In: ANAIS DO SENADO FEDERAL (ATAS DE COMISSÕES). Subcomissão de Tributos, participação e distribuições de receitas. Disponível em: www.senado.gov.br. (último acesso em 28.11.2014)

. República e Constituição. São Paulo: Rt, 1985.

República e Constituição. São Paulo: Malheiros, 2001.

Prefácio para esta Edição. In: MICHELI, Gian Antonio. Curso de Direito Tributário. Trad. Marco Aurélio Greco; Pedro Luciano Marrey Jr. São Paulo: RT, 1978.

.; CARVAlHO, Paulo de Barros. Apresentação. In: VI Curso de Especialização em Direito Tributário (Aulas e Debates). Volume I. São Paulo: Editora Resenha Tributária, 1978.

Prefácio. In: DERZI, Misabel Abreu Machado. Direito Penal, Direito Tributário e Tipo. 1. ed. São Paulo: Revista dos Tribunais, 1988.

Editores, 1973.

Hipótese de Incidência Tributária. $1^{\circ}$ Edição. São Paulo: Malheiros

. Princípios de Procedimento Tributário. In: Novo Processo Tributário. São Paulo: Resenha Tributária, 1975.

Hipótese de Incidência Tributária. São Paulo: Malheiros, 2007.

Prefácio. In: VILLEGAS, Héctor B. Curso de Direito Tributário. São

Paulo: RT, 1980.

. Prefácio. In: JARACH, Dino. O Fato Imponível. $2^{\mathrm{a} E d . ~ T r a d . ~ D e j a l m a ~ d e ~}$ Campos. São Paulo: Rt, 2004.

Editores, 2006.

Hipótese de Incidência Tributária. $6^{\circ}$ Edição. São Paulo: Malheiros

Atas da Congregação da Faculdade de Direito da Universidade de São Paulo.

AYALA, José Luiz Perez de; GONZALEZ, Eusébio. Curso de Derecho Tributário. Madrid: EDERSA, 1975.

AVI-YONAH, Reuven S. Os três objetivos da Tributação. In:Revista Direito Tributário Atual n. 22. Alcides Jorge Costa, Luís Eduardo Schoueri e Paulo Celso Bergstrom Bonilha (Coord.). São Paulo: IBDT-Dialética, 2008.

ÁVILA, Humberto. Teoria dos Princípios. Da definição à aplicação dos princípios jurídicos, 14 ed, São Paulo, Malheiros, 2013, p. 64-85.

Teoria dos Princípios. Da Definição à aplicação dos Princípios Jurídicos. $2^{\circ}$ Edição. Editora Malheiros. São Paulo -SP. 2004.

A Distinção entre Princípios e Regras e a Redefinição do Dever de Proporcionalidade. Revista de Direito Administrativo 215 -1999. 
Segurança Jurídica: Entre permanência, mudança e realização no Direito Tributário. São Paulo: Malheiros, 2011.

Antonio Fabris Editor, 1997.

Medida Provisória na Constituição de 1988. Porto Alegre: Sergio

Função da Ciência do Direito Tributário: do Formalismo Epistemológico ao Estruturalismo Argumentativo. In: Revista Direito Tributário Atual. n.29. Ricardo Mariz de Oliveira, Luís Eduardo Schoueri e Fernando Aurelio Zilveti. São Paulo: Dialética, 2013.

Teoria da Igualdade Tributária. $2^{\text {a }}$ Ed. São Paulo: Malheiros, 2009.

. Comportamento Anticoncorrencial e Direito Tributário. In: FERRAZ, Roberto. Princípios e Limites da Tributação. Os Princípios da Ordem Econômica e Tributação. Vol.2. Op.cit.

Ciência do Direito Tributário e Discussão Crítica. In: Revista Direito Tributário Atual. n. 32. Fernando Aurelio Zilveti (Coord.) São Paulo: Dialética, 2014.

Limites à Tributação com Base na Solidariedade Social. In: Solidariedade Social e Tributação. GRECO, Marco Aurélio; GODOI, Marciano Seabra de (Coord). São Paulo: Dialética, 2005.

Neoconstitucionalismo: entre a ciência do Direito e o Direito da ciência. In: NETO, Cláudio Pereira de Souza; BINENBOJM, Gustavo (Coordenação). Vinte anos da Constituição Federal de 1988. São Paulo: 2009.

AZEVEDO, Luiz Carlos de. História do Direito, Ciência e Disciplina. OPVSCVLA IV. Osasco: FIEO, 1998.

BACHELARD, Gaston. A Epistemologia. São Paulo: Martins Fontes, s/d.

BAKER, Philip. Double Taxation Conventions. A Manual on the OECD Model Tax Convention on Income and On Capital. Q.C. of ]gray' Inn, Barrister., Visiting Professional Fellow, Queen Mary, University of London. London: Sweet \& Maxwell; Thomson Reuters, 2012.

BALEEIRO, Aliomar Uma Introdução à Ciência das Finanças. $15^{\circ}$ Edição. Atualizador: CAMPOS, Dejalma Rio de Janeiro: Forense, 2000.

Imposto sobre a Renda. Bahia: Editora Bahiana, 1938.

Baiana, 1939.

A Tributação e a Imunidade da Dívida Pública. Baía: Livraria Editora

Bushatsky, 1975.

Cinco aulas de finanças e política fiscal. $2^{\circ}$ edição. São Paulo: José

Clínica Fiscal. Prefácio. Bahia: Editora Progresso, 1958, s/np. 
Prefácio. In: FALCÃO, Amílcar de Araújo. Introdução ao Direito Tributário. Rio de Janeiro: Editora Rio - Faculdades Integradas Estácio de Sá, 1976.

. Nota Prévia.In: BALEEIRO, Aliomar. Direito Tributário Brasileiro. $11^{\circ}$ edição. Atualizada e com notas de Mizabel Derzi. Forense: Rio de Janeiro, 2000.

Janeiro: Forense, 1959.

Limitações Constitucionais ao Poder de Tributar. $2^{\text {a }}$ Edição, Rio de

Prefácio. In: XAVIER, Alberto. Direito Tributário Internacional do Brasil. Tributação dos investimentos estrangeiros. São Paulo: Resenha Tributária, 1977.

Rio de Janeiro: Forense, 2000.

Direito tributário brasileiro. 11. ed. rev. e atual. por Misabel Derzi.

Direito Tributário Brasileiro, Rio de Janeiro: Forense, 1987.

Parecer sobre o Projeto do C.T.N. In: BALEEIRO, Direito Tributário Brasileiro. Rio de Janeiro: Forense, 1973.

Limitações Constitucionais ao Poder de Tributar. Atualizada por Mizabel Derzi. Rio de Janeiro: Forense, 1999.

Discriminação de Rendas. Rio de Janeiro: IBDF, s/d.

BALTHAZAR, Ubaldo César. Reforma Tributária e Mercosul. Belo Horizonte-MG: Editora Del Rey, 1999.

História do tributo no Brasil. Florianópolis: Ed. Boiteux, 2005.

BANDEIRA, Antonio Herculano de Souza. Novo Manual do Procurador dos Feitos da Fazenda. Rio de Janeiro: Lemmert \& C - Livreiros Editores, 1888.

BARBOSA, Rui. Trabalhos Jurídicos. Vol. XXVL. 1891. Tomo I. In: Obras Completas de Rui Barbosa. Ministério da Educação e Saúde. Rio de Janeiro, 1949.

Relatório do Ministro da Fazenda. In: Obras Completas de Rui

Barbosa. Vol. XVIII 1891. Tomo III. Ministério da Educação e Saúde. Rio de Janeiro: Imprensa Nacional, 1949.

BARRETO, Aires Fernandino. Base de Cálculo, Alíquota e Princípios Constitucionais. Coleção Textos de Direito Tributário. 12. São Paulo: RT, 1987.

BARRETO, Paulo Ayres; BARRETO, Aires Fernandino. Imunidades Tributárias: Limitações Constitucionais ao Poder de Tributar. 01. ed. São Paulo: Dialética, 1999.

BARRETO, Paulo Ayres. Imposto de renda e preços de transferência. São Paulo: Dialética, 2001.

2001.

Imposto de Renda e Preços de Transferência. São Paulo: Dialética, 
Considerações sobre a Situação Financeira do Brasil acompanhadas da Indicação dos Meios para Occorrer ao Deficit do Thesouro. Rio de Janeiro: Typographia Universal de Laemmert, 1867.

BARROS, José Eduardo Monteiro de. Momento Histórico. Tit - 70 anos de Justiça Fiscal. In: Repertório Histórico - 1935-2005. Edição Comemorativa 70 anos de Justiça Fiscal, Secretaria da Fazenda do Estado de São Paulo, 2005, p. 23.

Notas sobre a História Externa do Código Tributário Nacional. In: Revista AFRESP de Tributação. Ano II. n.4. Outubro/Dezembro de 1998. São Paulo: Afresp, 1998.

BARROSO, Luís Roberto. O controle de constitucionalidade no direito brasileiro. São Paulo: Saraiva, 2006.

Curso de Direito Constitucional Contemporâneo. Os conceitos fundamentais e a Construção do Novo Modelo. 3 Ed. São Paulo: Saraiva, 2012.

BASTOS, Celso Ribeiro. Curso de Direito Constitucional. São Paulo: Saraiva, 2000.

BECHO, Renato Lopes. Tributação das cooperativas. 1. ed. São Paulo: Dialética, 1997.

Dialética, 2000.

Sujeição passiva e responsabilidade tributária. 1. ed. São Paulo: Filosofia do Direito Tributário. São Paulo: Saraiva, 2009.

BECK, Ulrich. Sociedade de Risco: Rumo a outra modernidade. São Paulo: Editora 34, 2011

BECK, Ulrich. A Política da Sociedade de Risco. Traduzido por Estevão Bosco da versão francesa:

BECK, Ulrich. La politique dans la société du risque. In Revue du MAUSS. 1/2001 (no 17). Disponível em: http://www.academia.edu.com (último acesso em 11/05/2015.

BECKER, Alfredo Augusto. Teoria Geral do Direito Tributário. $1^{\circ}$ edição. São Paulo: Saraiva, 1963.

Carnaval Tributário. 2. ed. São Paulo, Lejus, 1999.

BEISSE, Heinrich. O critério econômico na interpretação das leis tributárias segundo a mais recente jurisprudência alemã. In: Direito Tributário: Estudos em Homenagem à Ruy Barbosa Nogueira. Coord: Brandão Machado. São Paulo: Saraiva, 1984.

BERGER, Guy, Conditions d'une problématique de l'interdisciplinarité. In: L'interdisciplinarité. Problèmes d'enseignement et de recherche dans les Université. Ceri (eds.) Paris: UNESCO/OCDE, 1972.

BERLIRI, Antonio. Principi di Diritto Tributario. Volume 1. Milano: Dott.A.Giuffrè - Editore, 1952.

Giuffrè - Editore, 1957.

Principi di Diritto Tributario. Tomo I. Volume II. Milano: Dott. A. 
BERLIRI, Luigi Vittorio. La Giusta Imposta. Milano: Dott.A. Giuffrè Editore, 1975.

BIANCO, João Francisco. Transparência Fiscal Internacional. São Paulo: Dialética, 2007.

Aparência Econômica e Natureza Jurídica. In: Controvérsias Jurídico-Contábeis (Aproximações e Distanciamentos). MOSQUERA, Roberto Quiroga; LOPES, Alexsandro Broedel. $1^{\text {a }}$ Volume. São Paulo: Dialética, 2010.

BIELSA, Rafael. Estudios de Derecho Público. II. Derecho Fiscal. Buenos Aires: Depalma, 1951.

BIFANO, Elidie Palma. Contabilidade e Direito: A Nova Relação. In: Controvérsias JurídicoContábeis (Aproximações e Distanciamentos). MOSQUERA, Roberto Quiroga; LOPES, Alexsandro Broedel. $1^{\mathrm{a}}$ Volume. São Paulo: Dialética, 2010.

O Direito Tributário e a Interdisciplinaridade com Outros Ramos do Saber. In: Direito Tributário Atual. ZILVETI, Fernando Aurelio (Coord.). n.30. São Paulo: Dialética-IBDT, 2014.

BOBBIO, Norberto. Teoria da Norma Jurídica. Tradução: BAPTISTA, Fernando Pavan; SAUDATTI, Ariani. Bueno. São Paulo: EDIPRO, 2001.

1999.

Teoria do Ordenamento Jurídico. $10^{\mathrm{a}}$ Ed. Brasília: Editora UNB,

O positivismo jurídico. Lições de filosofia do direito. São Paulo:

Ícone, 1995.

A Era dos Direitos. Rio de Janeiro: Elsevier, 2004.

Da Estrutura à Função. Novos Estudos de Teoria do Direito. São

Paulo: Manole, 2007.

BONAVIDES, Paulo. Curso de Direito Constitucional. 19a Edição, São Paulo: Editora Malheiros, 2006.

BONILHA, Paulo Celso Bergstrom. Da Prova no Processo Administrativo Tributário. São Paulo: Dialética, 1997.

Editora Resenha Tributária Ltda., 1979.

IPI e ICM Fundamentos da Técnica Não-Cumulativa. São Paulo:

. Da Educação Tributária como fator de desenvolvimento econômico e social. $2^{\text {a }}$ Congresso Interamericano de Direito Tributário - 1975. São Paulo: Co-edição Sociedade Brasileira de Instrução - CEAD, Associación Interamericana de Estudos de extensão Universitária, Editora Resenha Tributária, 1975.

BORGES, José Ferreira. Princípios de Syntelologia: coprehendendo em geral a Theoria do Tributo, e em particular Observaçoens sobre a Administração, e Despezas de Portugal, em grande parte applicaveis ao Brazil. Londres: Impresso por Bingham, 1831.

BORGES, José Souto Maior. Isenções Tributárias. $1^{a}$ Edição. São Paulo: Sugestões Literárias S.A., 1969. 
Lei complementar tributária. SP: RT/EDUC, 1975.

Teoria geral da isenção tributária. $3^{\mathrm{a}}$ ed., SP: Malheiros, 2001.

. Obrigação Tributária (uma introdução metodológica). $2^{\mathrm{a} E d}$. São

Paulo: Malheiros, 2002.

Introdução ao Direito Financeiro. São Paulo: Max Limonad, 1998.

BORGES, José Souto Maior. Ciência Feliz, 2º Edição. São Paulo: Max Limonad, 2000.

Lançamento Tributário. Tratado de Direito Tributário Brasileiro.

Volume IV. Rio de Janeiro: Forense, 1981.

O Direito como Fenômeno Lingüístico, o Problema de Demarcação da Ciência Jurídica, sua Base Empírica e Método Hipotético-Dedutivo, in Anuário do Mestrado em Direito, Recife, Universidade Federal de Pernambuco, n. 4, jan/dez, 1988.

Curso de Direito Comunitário. São Paulo: Saraiva, 2005.

Isenções em Tratados Internacionais de Impostos dos Estadosmembros e Municípios. In: MELLO, Celso Antônio Bandeira de (Org). Direito Tributário. Estudos em homenagem a Geraldo Ataliba, São Paulo: Malheiros, 1997.

Hermenêutica Histórica no Direito Tributário. In: Revista Tributária e de Finanças Públicas. n. 31, São Paulo: Rt, 2000.

Um Ensaio Interdisciplinar em Direito Tributário: Superação da Dogmática. In: Revista Dialética de Direito Tributário. n.211. Valdir de Oliveira Rocha (Coord.). São Paulo: Dialética, 2013.

BOTALlO, Eduardo Domingos. Curso de Processo Administrativo Tributário. São Paulo: Malheiros, 2009.

BRAZUNA, José Luis Ribeiro. Defesa da Concorrência e Tributação à Luz do Artigo 146-A da Constituição. Série Doutrina Tributária Volume 2. São Paulo: Quartier Latin - IBDT, 2009.

BRITO, Edvaldo Pereira de. IPI: Fato Gerador da Importação. Revista Tributaria e de Finanças Públicas, v. 45.

BOUCHER, Hércules. Imposto sobre a Renda e Lucros Imobiliários. São Paulo: Freitas Bastos, 1953.

BuChanan, James. La Hacienda Publica en un Proceso Democrático. Trad. Jose R. Alvarez Rendueles. Madrid: Aguilar.

BUENO, José Antonio Pimenta. Direito Publico Brazileiro e Analyse da Constituição do Imperio. Parte 1 e 2. Rio de Janeiro : Typographia Imp. e Const. de J. Villeneuve \& C., 1857.

BÜHLER, Ottmar. La Importanza di Enno Becker per Lo Sviluppo del Diritto Tributario Tedesco dal 1918. In: Rivista di Diritto Finanziario e Scienza della Finanze.Volume IV. XVIII, Parte I. Padova: Cedam - Casa Editrice Dott. Antonio milani, 1940. 
Principios de Derecho Internacional Tributario. Versión Castellana de Fernando Cervera Torrejon. Madrid: Editorial de Derecho Financiero, 1968.

BUJANDA, Fernando Sainz de. Hacienda y Derecho. Introducion al derecho financiero de nostro tiempo. I. Madrid: Instituto de Estudios Politicos. Madrid, 1975

Hacienda y Derecho. Estudios de Derecho Financiero.I. Madrid: Instituto de Estudios Políticos, 1967.

Hacienda y Derecho. I. Madrid: Instituto de Estudios Políticos, 1967.

Hacienda y Derecho. I. Estudios de derecho financiero. Estudios de administración. Madrid: Instituto de Estudios Politicos, 1975.

Instituto de Estudios Políticos, 1966.

Hacienda y Derecho. IV. Estudios de Derecho Financiero. Madrid: de Estudios Políticos, 1962.

Hacienda y Derecho. II. Estudios de administración. Madrid: Instituto

Hacienda y Derecho. V. Estudios de Derecho Financiero. Madrid: Instituto de Estudios Políticos, 1967.

Hacienda y Derecho. II. Estudios de Derecho Financiero. Madrid: Instituto de Estudios Políticos, 1967.

Sistema de Derecho Financiero Tomo I. Volumen Segundo. Análisis Estructural del Derecho Financiero. Ramos del Derecho público con sectores proyectados sobre la materia financiera. Madrid. Facultad de Derecho de La Universidad Complutense, 1985.

BULHÕES PEDREIRA, José Luiz. Imposto de Renda. Rio de Janeiro: Apec Editora, 1969.

\section{$\underline{\mathbf{C}}$}

CALIENDO, Paulo. Tributação e Mercado de Carbono. In: Direito tributário ambiental. TôRRES, Heleno Taveira (org.). São Paulo: Malheiros, 2005.

CALIENDO, Paulo. Três modos de pensar a tributação. Elementos para uma teoria sistemática do Direito Tributário. Porto Alegre: Livraria do Advogado, 2009.

CALIENDO, Paulo. Direito Tributário e Análise Econômica do Direito. Uma visão Crítica. Rio de Janeiro: Elsevier, 2009.

CAMPOS, Dejalma de. Direito Processual Tributário. 4. ed. São Paulo, Editora Atlas, 1996.

CAMPOS, Francisco. Direito Constitucional, Volume I. São Paulo: Freitas Bastos, 1956.

CANARIS, Claus Wilhelm. Pensamento Sistemático e Conceito de Sistema na Ciência do Direito. $2^{\circ}$ Ed. Trad. A. Menezes Cordeiro. Lisboa: Serviço de Educação Fundação Calouste Gulbenkian, 1996.

CARNELUTTI, Francesco. Metodologia do Direito. Traduzido por Frederico A. Pascoal. $3^{\circ}$ Edição. Campinas - SP: Bookseller, 2005. 
CANOtIllo, J.J. Gomes. Direito Constitucional e Teoria da Constituição. $3^{\circ}$ Edição. Almedina: Coimbra, 2003.

CANTO, Gilberto Ulhôa. Obrigação Tributária, seus pressupostos e elementos. In: Instituto Brasileiro de Direito Financeiro (Filiado à I.F.A.). Publicação n.6. Curso de Direito Financeiro. 1958. Rio de Janeiro - 1958.

Legislação Tributária, sua Vigência, sua Eficácia, sua Aplicação, Interpretação e Integração, RF, v. 267, s/l, s/d.

A Aquisição de Disponibilidade e o Acréscimo Patrimonial no Imposto sobre a Renda. Estudos sobre o Imposto de Renda. (Em Memória de Henry Tilbery). Coord. Ives Gandra da Silva Martins. São Paulo: Resenha Tributária, 1994.

Temas de direito tributário. s/l: Ed. Alba, 1964.

Estudos e Pareceres de Direito Tributário. São Paulo, Ed. Revista dos

Tribunais, 1975.

. A Causa da Obrigação Tributária. Temas de Direito Tributário.

Pareceres e Estudos. Rio de Janeiro: Edições Financeiras S.A, 1955.

CARNELUTTI, Francesco. Introduzione al Diritto Processuale Tributario. In Rivista di Diritto Processuale Civile. Direttori: Chiovenda; Carnelutti. Cooeditori: Calamandrei. Volume IV - Parte 1 - X. Padova: CEDAM, 1932.

CARRAZZA, Roque Antônio. Curso de Direito Constitucional Tributário. $21^{\text {a }}$ edição, São Paulo: Malheiros, 2005.

$\overline{\text { São Paulo: Saraiva, } 1986 .}$

Princípios Constitucionais Tributários e Competência Tributária. São Paulo: Malheiros. 2005.

Imposto sobre a Renda (Perfil Constitucional e Temas Específicos).

Tributária, 1977.

O Sujeito Ativo da Obrigação Tributária. São Paulo: Resenha O regulamento no direito tributário brasileiro. Revista dos Tribunais,

1972.

ICMS. São Paulo: Malheiros Editores, 1994.

CARRAZZA, Elizabeth Nazar. Progressividade e IPTU. Curitiba: Editora Jurua, 1992.

CARVAlHO PINTO, Carlos Alberto A. Discriminação de Rendas. Prefeitura de São Paulo, 1941.

CARVAlHo, Aurora Tomazini de. Curso de Teoria Geral do Direito. O Construtivismo Lógico-semântico. $2^{\mathrm{a}}$ Ed. São Paulo: Noeses, 2010.

Direito Penal Tributário: uma análise lógica, semântica e jurisprudencial. São Paulo: Quartier Latin, 2013. 
CARVAlHO, Cristiano. Análise Econômica da Tributação. In: Direito e Economia no Brasil. TIMM, Luciano Benetti (Org). São Paulo: Atlas, s/d.

Tributação, Ciência e Desenvolvimento: como poderia ser a Doutrina do Direito Tributário no Brasil? In: Tributação e Desenvolvimento. SANTI, Eurico Marcos Diniz de (Coord.). São Paulo: Quartier Latin, 2011.

CARVAlHO, Paulo de Barros. Curso de Direito Tributário. $17^{\circ}$ Edição. São Paulo: Saraiva, 2006.

Curso de Direito Tributário. São Paulo: Saraiva, 2011.

Paulo: Saraiva, 2012.

Direito Tributário. Fundamentos Jurídicos da Incidência. $9^{a}$ Ed. São

Hermenêutica do Direito Tributário. Elementos de Direito Tributário. III Curso de Especialização em Direito Tributário realizado na PUC-SP. Coordenação: ATALIBA, Geraldo. São Paulo: Revista dos Tribunais, 1978.

1974.

Teoria da Norma Jurídica Tributária. $1^{\text {a }}$ Ed. São Paulo: Saraiva,

Teoria da Norma Tributária. $2^{\circ}$ Edição. São Paulo: Editora Rt, 1981.

Teoria da Norma Tributária. São Paulo: .Max Limonad, 1998.

Direito tributário: fundamentos jurídicos da incidência. $2^{\mathrm{a}}$ ed., SP:

Saraiva, 1999.

O Absurdo da Interpretação Econômica do "Fato Gerador" Direito e sua Autonomia - O Paradoxo da Interdisciplinariedade. Cadernos da Escola de Direito e Relações Internacionais da Unibrasil. n. 07. Jan/Dez 2007. Curitiba: Publicação Oficial do Curso de Mestrado em Direito da Unibrasil, 2007.

A Regra-Matriz do ICM. Tese de Livre Docência defendida como requisito parcial para obtenção do grau de Livre Docente pela Pontifícia Universidade Católica de São Paulo. São Paulo, 1986.

; SOUSA, Rubens Gomes de. ATALIBA, Geraldo. Comentários ao Código Tributário Nacional. 2. ed. São Paulo: Editora Revista dos Tribunais, 1975.

$37-42,1991$.

Medidas Provisórias. Revista de Direito Público, São Paulo, v. 97, p.

São Paulo, v. 58, 1991.

Princípio da legalidade e da Igualdade. Revista de Direito Tributário,

- Anotações e memórias de leituras jurídicas e filosóficas (Edição Limitada). São Paulo: Editora Noeses, 2008.

Noeses, 2011.

Derivação e Positivação no Direito Tributário. 1. ed. São Paulo: 
Direito Tributário. In: Revista Consultor Jurídico, 01 de outubro de 2013, 07:00h (último acesso em 31.07.2014: http://www.conjur.com.br/2013-out-01/paulo-barros-breves-consideracoes-funcaodescritiva-ciencia-direito-tributario).

O Princípio da Territorialidade no Regime da Tributação da Renda Mundial. In: Justiça Tributária: direitos do fisco e garantias do contribuinte nos atos da administração e no processo tributário. I Congresso Internacional de Direito Tributário. IBET, Vitória, 1998.

Poesia e Direito - o legislador como poeta: Anotações ao pensamento de Flusser. In: Vilém Flusser e os Juristas. Comemoração dos 25 anos do Grupo de Estudos de Paulo de Barros Carvalho. HARET, Florence (Coord); CARNEIRO, Jerson (Coord.). São Paulo: Noeses, 2009.

Não Incidência do ICMS na atividade dos provedores de acesso à internet. In: Tributação e Tecnologia. James Marins (Coord.) Coleção Tributação e Debate. Curitiba: Juruá, 2002.

CASTRO, Augusto Olympio Viveiros de. Prefácio à Primeira Edição. In: Tratado dos Impostos (Estudo Theorico e Pratico). Segunda Edição. Rio de Janeiro: Industria Nacional, 1910.

CELLA, José Renato Gaziero. Tributação dos Provedores de Acesso à Internet. Tributação e Tecnologia. James Marins (Coord.) Coleção Tributação e Debate. Curitiba: Juruá, 2002.

CINTRA, Marcos. Globalização, Modernização e Inovação Fiscal. In: Direito Tributário. Política Fiscal. In: VASCONCELLOS, Roberto França. Série GVLaw, São Paulo: Saraiva, 2009.

COASE, Ronald H. O Problema do Custo Social. (The Problem of Social Coast. Journal of Law and Economics, Outubro, 1960), 37 páginas. Tradução por Francisco Kümmel F. Alves e Renato Vieira Caovilla, bacharéis em Direito na PUC/RS e membros do Grupo de Pesquisa em Direito e Economia da PUC/RS, coordenado pelo Prof. Dr. Luciano Benetti Timm. Revisão técnica de Antônio José Maristrello Porto (FGV DIREITO RIO) e Marcelo Lennertz (FGV DIREITO RIO). Acesso

em: http://www.google.com.br/url?sa=t\&rct=j\&q=\&esrc=s\&source=web\&cd=2\&ved=0CCkQFjAB\&u $\mathrm{rl}=\mathrm{http} \% 3 \mathrm{~A} \% 2 \mathrm{~F} \% 2 \mathrm{Fwww3}$.nccu.edu.tw\%2F jsfeng\%2FCPEC11.pdf\&ei=AuYiVPG_MMLPggS wmoLYAw\&usg=AFQjCNFnubyRO2U7XQH4uY3aOxMXuzdkIg

COCIVERA, Benedetto. Principî di Diritto Tributário. Volume I. Milano: Dott. A. Giuffrè Editore, 1959.

COELHO. Luiz Fernando. Lógica Jurídica e Interpretação das Leis. $2^{\circ}$ Edição. Rio de Janeiro: Forense, 1981.

Teoria da Ciência do Direito. São Paulo: Saraiva, 1974.

COÊLHO, Sacha Calmon Navarro. Convênios competência isencional. 1. ed. Belo Horizonte: Instituto de Técnica Tributária, 1974.

Companhia Editora Forense, 1999.

Curso de Direito Tributário Brasileiro. $3^{\text {a }}$. ed. Rio de Janeiro: 
Tratados Internacionais em Matéria Tributária (perante a Constituição Federal de 1988). In: Revista de Direito Tributário - 59, Ed. Malheiros, São Paulo, s/d.

Paulo, 1985.

Princípios da tributação: legalidade e tipicidade. RDT n.33, São . Direito Tributário Interdisciplinar. Rio de Janeiro: Forense, 1999.

COMISSÃO DE ASPECTOS TRIBUTÁRIOS. Informe sobre la Armonización de los Impuestos Generales al Consumo en el MERCOSUR. In: AMARAL, Antonio Carlos Rodrigues do. Imposto sobre o Valor Agregado - IVA - Value Added Tax - VAT. Brasil - Mercosul - União Europeia. São Paulo: Academia Brasileira de Direito Tributário; Editora Rumo, 1995.

COMPARATO, Fabio Konder. A Afirmação Histórica dos Direitos Humanos. São Paulo: Saraiva, 2015.

Conselho Administrativo de Recursos Fiscais. Origens do Conselho Administrativo de Recursos Fiscais: Histórico dos Conselhos de Contribuintes do Ministério da Fazenda. Disponível em: http://carf.fazenda.gov.br/sincon/public/pages/ConsultarInstitucional/Historico/HistoricoPopup.jsf (último acesso em 06/12/2004).

CONTADOR, Cláudio R. A Importância da Teoria Geral do Emprego, do Juro e da Moeda. Apresentação da Edição Brasileira. In: KEYNES, John Maynard. A Teoria Geral do Emprego, do Juro e da Moeda. Tradução de Mário R. da Cruz. São Paulo: Editora Atlas S.A., 1992.

CONTI, José Maurício. Orçamentos Públicos - A Lei 4.320/1964 comentada. São Paulo: Revista dos Tribunais, 2008.

CORDEIRO, Antonio Menezes. Introdução à Edição Portuguesa. In: CANARIS, Claus Wilhelm. Pensamento Sistemático e Conceito de Sistema na Ciência do Direito. $2^{\circ}$ Ed. Trad. A. Menezes Cordeiro. Lisboa: Serviço de Educação Fundação Calouste Gulbenkian, 1996.

CORREAA, Walter Barbosa. Subsídios para a o estudo da História Legislativa do Imposto de Renda no Brasil. In: Estudos sobre o Imposto de Renda (em memória de Henry Tilbery). MARTINS, Ives Gandra da Silva. (Coord) São Paulo: Resenha Tributária, 1994.

COSSIO, Carlos. La Valoración Jurídica y La Ciência Del Derecho, Ed. Arayú, B.Ayres, 1954.

Madrid, s/d.

La Norma y el Imperativo. In: Anuario de Filosofia Del Derecho de

COSTA, Alcides Jorge. História da Tributação no Brasil. In: FERRAZ, Roberto (Coord.). Princípios e Limites da Tributação. Volume 1. Quartier Latin: São Paulo, 2005.

Direito Tributário e Direito Privado. In: Direito Tributário. Estudos em Homenagem ao Prof. Ruy Barbosa Nogueira. MACHADO, Brandão (Coord). São Paulo: Saraiva, 1984.

A doutrina italiana e sua influência no Direito Tributário Brasileiro. In: Princípios do Direito Tributário Comparado. Homenagem a Gilberto Ulhôa Canto. Org: Agostinho Toffoli Tavolaro, Brandão Machado e Ives Gandra Martins. Forense: Rio de Janeiro, 1998. 
Algumas Notas sobre a Relação Jurídico Tributária. In: Direito Tributário. Estudos em Homenagem a Brandão Machado. Coordenadores: Luís Eduardo Shoueri; Fernando Aurelio Zilveti. São Paulo: Dialética, 1998.

Da Teoria do Fato Gerador. In: Curso de Teoria Geral do Direito Tributário. São Paulo: Secretaria da Fazenda do Estado de São Paulo. Coordenação da Administração Tributária, 1975.

In: ATA DA TERCEIRA REUNIÃO, ORDINÁRIA, COM AUDIÊNCIA PÚBLICA, REALIZADA EM 22-4-87. In: ANAIS DO SENADO FEDERAL (ATAS DE COMISSÕES). Subcomissão de Tributos, participação e distribuições de receitas. Disponível em: www.senado.gov.br. (último acesso em 28.11.2014)

Tributária, 1978.

ICM na Constituição e na Lei Complementar. São Paulo: Resenha

Contribuição ao Estudo da Obrigação Tributária. 1972. Instituto Brasileiro de Direito Tributário. Edição especial para a Jornada de Direito Tributário. São Paulo: IBDT, 2003.

Conceito de Renda Tributável. In: Estudos sobre o Imposto de Renda (Em memória de Henry Tilbery). Ives Gandra Martins (Coord). São Paulo: Resenha Tributária, 1994.

COSTA, Regina Helena. Apontamentos sobre a Tributação Ambiental no Brasil. In: Direito tributário ambiental. TôRRES, Heleno Taveira (org.). São Paulo: Malheiros, 2005.

\section{$\underline{\mathbf{D}}$}

DALTON, Hugh. Princípios de Finanças Públicas. $4^{\circ}$ edição. Traduzido por Maria de Lourdes Modiano. Rio de Janeiro: Fundação Getúlio Vargas, 1980.

D'AMATI, Nicola. AMATUCCI, Andrea (Organiz). Historia del Derecho de la Hacienda Pública y del Derecho Tributario en Italia. E aporte del pensamento jurídico financiero de la Italia Meridional. Derecho de la Hacienda Pública. Obras Fundamentales 1. Bogotá-Colombia: Temis, 2004.

D’AMATI, Nicola. La Formación del Derecho Tributário en Itália. In: D’AMATI, Nicola. AMATUCCI, Andrea (Organiz). Historia del Derecho de la Hacienda Pública y del Derecho Tributario en Italia. E aporte del pensamento jurídico financiero de la Italia Meridional. Derecho de la Hacienda Pública. Obras Fundamentales 1. Bogotá-Colombia: Temis, 2004.

Historia de La Enseñanza del Derecho Financiero Público en Italia. In: In: D'AMATI, Nicola. AMATUCCI, Andrea (Organiz). Historia del Derecho de la Hacienda Pública y del Derecho Tributario en Italia. E aporte del pensamento jurídico financiero de la Italia Meridional. Derecho de la Hacienda Pública. Obras Fundamentales 1. Bogotá-Colombia: Temis, 2004.

D’AURIA, Francisco. Ciência das Finanças (Teoria e Prática). $2^{\circ}$ Edição.São Paulo: Companhia Editora Nacional, 1946.

DECARTES, René. Discurso do Método. Meditações. Tradução. Roberto Leal Ferreira. São Paulo: Martin Monet, 2008. 
DELATTRE, Pierre. Recherches interdisciplinaires. In Encyclopedia Universalis. Paris: Organum, 1973.

DERANI, Cristiane. Aplicação do Direito Ambiental para o Desenvolvimento sustentável. In: Direito Tributário Ambiental. TôRRES, Heleno Taveira (org.). São Paulo: Malheiros, 2005.

DE PLÁCIDO E SILVA. Noções de Finanças e Direito Fiscal. $2^{\circ}$ Ed. São Paulo: Guairá Editora, $\mathrm{n} / \mathrm{d}$.

DEL BRIO, Francisco Dominguez. Estudio Preliminar. In: La Politica Fiscal em Accion. In: DEL BRIO, Francisco Dominguez. Madrid: Instituto de Estudios Fiscales, 1971.

DEL VECCHIO, Giorgio. Filosofia del Derecho. Novena Edición Española Corregida y Aumentada. Barcelona: Bosch, Casa Editorial.

DEODATO, Alberto. As funções extrafiscais do imposto. Belo Horizonte: Imprensa Oficial, 1949.

DERZI, Misabel. Modificações da jurisprudência no Direito Tributário. São Paulo: Noeses, 2009.

Tribunais, 1988.

Direito Tributário, Direito Penal e Tipo. 1. ed. São Paulo: Revista dos

Rio de Janeiro: Forense, 2000.

Notas. In: BALEEIRO, Aliomar. Direito Tributário Brasileiro. $11^{\mathrm{a}} \mathrm{Ed}$.

DINIZ, Souza. Códigos Tributários. Alemão. Mexicano. Brasileiro. $1^{\circ}$ edição. Tradução de Souza Diniz. São Paulo: Edições Financeiras S.A., 1965.

DINIZ, Maria Helena. Compêndio de Introdução à Ciência do Direito. $12^{\circ}$ edição. São Paulo: Saraiva, 2000.

DÓRIA, Antonio Roberto Sampaio. Discriminação de Competência Impositiva (Sua evolução na federação brasileira). Tese de Concurso à Cátedra de Direito Financeiro da Faculdade de Direito da Universidade de São Paulo: USP, São Paulo, 1972.

Law. São Paulo, 1964.

Princípios Constitucionais Tributários e a Cláusula Due Process of Da lei tributária no tempo. São Paulo, Ed. Obelisco, 1968.

. Elisão e Evasão Fiscal. 2. ed. São Paulo, Bushatsky, 1977.

São Paulo: Ed. RT, 1964.

Princípios constitucionais tributários e a cláusula due process of law.

DORNELLES, Francisco. In: ATA DA TERCEIRA REUNIÃO, ORDINÁRIA, COM AUDIÊNCIA PÚBLICA, REALIZADA EM 22-4-87. In: ANAIS DO SENADO FEDERAL (ATAS DE COMISSÕES). Subcomissão de Tributos, participação e distribuições de receitas. Disponível em: www.senado.gov.br. (último acesso em 28.11.2014) 
O Sistema Tributário da Constituição de 1988. Disponível em: www.dornelles.com.br (último acesso em 22/10/2014)

Ata das Comissões. In: Anais da Assembleia Nacional Constituinte de 1987. Disponível em: www.senado.gov.br (último acesso em 02.12.2014)

Acordos para eliminar a dupla tributação da renda. In: Revista de Direito Público, São Paulo, n.28, mar./abr. 1974, p. 278- 281. Este estudo, dentre vários outros, foi disponibilizado livremente pelo próprio autor em sua página eletrônica: $\mathrm{http} / / / \mathrm{www}$. dornelles.com.br/inicio/index.php?option=com_content\&task=view\&id=411\&Itemid= 85. (Ultimo acesso em 13 de setembro de 2014).

DUE, John $F$. Tributação Indireta nas Economias em Desenvolvimento. Traduzido por Camila Perret. São Paulo: Editora Perspectiva, 1974.

DWORKIN, Ronald. Levando os direitos a sério. Trad. Nelson Boeira. São Paulo: Martins Fontes, 2002.

$\underline{\mathbf{E}}$

EINAUDI, Luigi. Corso di Scienza della Finanza. Quarta Edizione. Torino: Edizione della Rivista "La Riforma Sociale", 1926, p.03 e ss.

$\underline{\mathbf{F}}$

FAGUNDES, M. Seabra. O Controle dos Atos Administrativos pelo Poder Judiciário, $4^{\circ}$ Ed., Rio, 1967.

FALCÃO, Amílcar de Araújo. Sistema Tributário Brasileiro. Discriminação de Rendas. Rio de Janeiro: Edições Financeiras, 1965.

Forense, 1997.

O Fato Gerador da Obrigação Tributária. $3^{\circ}$ edição. Rio de Janeiro:

Introdução ao direito tributário. Rio de Janeiro: Editora Rio, 1976.

Janeiro: Estácio de Sá, 1998.

Introdução ao Direito Tributário. Faculdades Estácio de Sá. Rio de

FALCÃO, Raimundo Bezerra. Tributação e Mudança Social. Rio de Janeiro: Forense, 1981.

FALSITTA, Gaspare. Osservazioni sulla nascita e lo sviluppo scientifico dei Diritto Tributário in Itália. In: L'Evoluzione dell' Ordinamento Tributário Italiano. Atti del Convegno "I settanta anni di "Diritto e Pratica Tributaria". Il Diritto Tributário. Antonio e Victor Uckmar (Coords.) Serie I. Volume LXXXIX. Padova: CEDAM, 2000.

FANNO, Marco. Elementi di Scienza delle Finanze. Anno VII. E.F. Torino: S.Lattes\& C.,Editori, 1929.

FANUCCHI, Fabio. Curso de Direito Tributário. Curso de Direito Tributário Brasileiro.

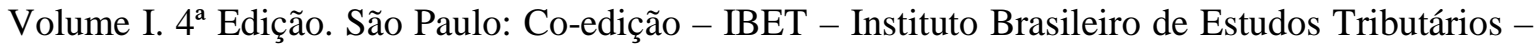
Editora Resenha Tributária, 1976. 
. A decadência e a prescrição no direito tributário. Resenha Tributária,

1976.

FANTOZZI, Augusto. Diritto Tributário, Torino: UTET, 1991.

FAZENDA, Ivani Catarina Arantes Fazenda. Integração e Interdisciplinaridade no ensino Brasileiro: Efetividade ou Ideologia?. São Paulo: Edições Loyola, 1992.

FERNANDES, Edison Carlos. Sistema Tributário do Mercosul: o processo de harmonização das legislações tributárias. $2^{\circ}$ edição, São Paulo: Editora RT, 1999.

Sistema Tributário do Mercosul: o processo de harmonização das legislações tributárias. São Paulo: Rt, 2001.

Adaptação da Política Fiscal em tempo de economia internacional integrada. In: Direito Tributário. Política Fiscal. Série GVlaw. Roberto França Vasconcellos. São Paulo: Saraiva - FGV, 2009.

FERREIRA, Benedito. A História da Tributação no Brasil. Causas e Efeitos. Brasília, 1986.

Federal, Brasília: Centro Gráfico,1986

Legislação Tributária (História da Tributação no Brasil). Senado

FERREIRA, Ademar. Direito Fiscal. Aspectos Doutrinários e Práticos. São Paulo: Saraiva, 1961.

FERRARI, Regina Maria Macedo Nery. Efeitos da declaração de Inconstitucionalidade, São Paulo: Rt, 1999.

FERRAZ, Roberto. Princípios são Universais e não comportam Exceções. $10^{\circ}$ Volume. Grandes questões do direito tributário. Valdir de Oliveira Rocha. São Paulo: Dialética.

. Contribuições Especiais e Empréstimos Compulsórios: Natureza e Regime Jurídico. 1. ed. São Paulo: Resenha Tributária, 1992.

. Apresentação. In: Princípios e Limites da Tributação. Os Princípios da Ordem Econômica e a Tributação. Vol.2. São Paulo: Quartier Latin, 2009.

Princípios e Limites da Tributação. Os Princípios da Ordem Econômica e a Tributação. Vol.2. São Paulo: Quartier Latin, 2009.

Tributação ambientalmente orientada e as espécies tributárias no Brasil, In: Direito tributário ambiental. TôRRES, Heleno Taveira (org.). São Paulo: Malheiros, 2005.

O Princípio da Capacidade Contributiva na Tributação Ambientalmente Orientada. In: FERRAZ, Roberto. Princípios e Limites da Tributação. Os Princípios da Ordem Econômica e Tributação. Vol.2. São Paulo: Quartier Latin, 2009.

Da Hipótese ao Pressuposto de Incidência - em Busca do Tributo Justo. In: Direito Tributário. Homenagem a Alcides Jorge Costa. Volume I. SCHOUERI, Luís Eduardo (Coord.) São Paulo: Quartier Latin, 2003. 
Limitações ao Poder Impositivo e Segurança Jurídica - O Princípio da Transparência Tributária, In: Ives Gandra Martins, Limitações ao Poder Impositivo e Segurança Jurídica, Pesquisas Tributárias, Nova Série, n. 11, Centro de Extensão Universitária. São Paulo: Editora Rt, 2005.

Quartier Latin: São Paulo, 2005.

Apresentação. Princípios e Limites da Tributação. 1. São Paulo:

A “Doce Ilusão" da Tributação, dos Outros. In: Revista Direito Tributário Atual n.23. Alcides Jorge Costa, Luís Eduardo Schoueri e Paulo Celso Bergstrom Bonilha (Coord). São Paulo: Dialética - IBDT, 2009.

FILHO, João Pedro da Veiga. Manual da Sciencia das Finanças. Quarta Edição. São Paulo: Monteiro Lobato \& C, 1923.

obras do Estado, 1917, p. 82-83.

Manual da Sciencia das Finanças. Terc. Ed. São Paulo: Secção de

FILHO, Paulo Barbosa de Campos. Codificação do Direito Tributário Brasileiro. In: Revista de Direito Administrativo, Vol.III. Rio de Janeiro: Seção II da Revista do Serviço Público Departamento Administrativo do Serviço Público - Fundação Getúlio Vargas, janeiro de 1946.

FILHO, F. Sá. Estudos de Direito Fiscal. Rio de Janeiro: Imprensa Nacional, 1942.

FILHO, Marçal Justen. Sujeição Passiva Tributária. Belém: CEJUP, 1986.

FILHO, Manoel Gonçalves Ferreira. Direitos Humanos Fundamentais. 11 Ed. São Paulo: Saraiva, 2009.

FILHO, Clóvis Panzarini; TONANINI, Fernando. Revista de Direito Tributário Internacional VOL.16. São Paulo: Quartier Latin, 2005.

FILHO, Osvaldo Othon de Pontes Saraiva, VASQUES, Sérgio, GUIMARÃES, Vasco Branco (Org.). IVA para o Brasil. Contributos para a Reforma da Tributação sobre o Consumo. Belo Horizonte - MG: Fórum, 2007.

FILHO, Paulo Barbosa de Campos. Crédito Fiscal. I - Dívida Ativa; II - Prescrição; III Preferência. São Paulo: Prefeitura do Município de São Paulo, s/d.

FILHO, Teotônio Monteiro de Barros. As Taxas e seus Principais Problemas Teóricos. São Paulo: Editora Revista dos Tribunais, 1941.

FIORAVANTI, Maurizio. Stato e Costituzione. In: Lo Stato Moderno in Europa. Istiuzioni e Diritto. A cura di Maurizio Fioravanti. Roma-Bari: Laterza, 2010.

FIORAVANTI, Maurizio. La Scienza del Diritto Publico. Dotrinne dello Stato e della Costituzione tra Otto e Novecento. Per La storia del pensiero giuridico moderno. 58/59 Tomo II. Milano: Giuffrè Editore Milano, 2001.

FIORILLO, Celso Antonio Pacheco. Direito às Cidades Sustentáveis no âmbito da Tutela Constitucional do Meio Ambiente Artificial e o IPTU Progressivo no tempo como instrumento da Política Urbana em face do Direito Ambiental Tributário. In: Direito tributário ambiental. TôRRES, Heleno Taveira (org.). São Paulo: Malheiros, 2005. 
FLEINER, Fritz. Les Principes Généraux Du Droit Administratif Allemand. Traduction de Ch. Eisemann. Paris: Libraire Delagrave, 1933.

FOLLONI, André. Ciência do Direito Tributário no Brasil: Críticas e Perspectivas a partir de José Souto Maior Borges. São Paulo: Saraiva, 2013.

O Direito Tributário diante da Complexidade Econômica e Socioambiental ou: para além de Souto sem sair de Souto nos 50 anos da Teoria Geral de Becker. In: Revista Tributária e de Finanças Públicas. N.111. São Paulo RT, 2013.

FOLLMAN, Melissa (Coord.). Tributação e Direitos Fundamentais. Propostas de Efetividade. Curitiba: Juruá, 2006.

FONROUGE, Giuliani. Derecho Financiero. Volumen I. $2^{\circ}$ Ed. Buenos Aires: Depalma, 1970.

Anteproyecto de Código Fiscal. Facultad del Derecho y Ciências Sociales. Investigaciones del Seminário de Ciências Jurídicas y Sociales. XXXVIII. Buenos Aires: Seccion publicaciones del seminário de ciências jurídicas y sociales, 1942.

Conceitos de Direito Tributário. São Paulo: LAEL, 1973.

FONSECA, Ricardo Marcelo. Introdução Teórica à História do Direito. Biblioteca de História do Direito. FONSECA, Ricardo Marcelo (Coord.). Instituto Brasileiro de História do Direito. Curitiba: Juruá, 2011, p. 32 e seguintes.

FONSECA, Ricardo Marcelo. O deserto e o vulcão: reflexões e avaliações sobre a história do direito no Brasil. In: História do Direito Brasileiro. BITTAR, Eduardo C.B. (Organizador). São Paulo: Atlas, 2012.

FRANÇA, Limongi. Hermenêutica Jurídica. 7º Edição. São Paulo: Saraiva, 1999.

\section{$\underline{\mathbf{G}}$}

GALLO, Franco, Alcune Riflessioni sulla Crisi del Sistema Tributario, In: Victor Uckmar, L'Evoluzione dell'Ordinamento Tributario Italiano, Il Diritto Tributario, Atti del Convegno "I Settanta Anni di "Diritto e Pratica Tributaria", Serie I, Volume LXXXIX. Padova: CEDAM, 2000.

GAMA, Mozart da. Direito Tributário e Justiça Fiscal - Único Livro que contém a mais moderna jurisprudência em vigor sobre: imposto de consumo, imposto de renda, vendas e mercadorias, selo e tarifas de alfândega. São Paulo: Livraria Freitas Bastos, 1941.

GARZA, Sérgio F La. de. Derecho financiero mexicano. México: Porrúa, 1975.

GASTALDI, J.Petrelli. Apresentação. In: Iniciação ao Curso de Direito Tributário. São Paulo: Edições Saraiva, 1965.

GENY, François. Le Particularisme du Droit Fiscal. Revue Trimestrielle de Droit Civil, 30 Vol., Recueil Sirey: Paris, 1931.

GERBER, Carl Friedrich Von. Grundzüge des Deutschen Staatsrechts. Leipzig: Verlag Von Bernhard. Tauchnitz, 1880. 
GERBER, Carl Friedrich Von. System des Deutschen Privatenrechts. G. Fischer, 1895.

GIANNINI, Achille Donato. Il Rapporto Giuridico D'Imposta. Milano: Giuffrè Edittore, 1937.

I Concetti Fondamentali del Diritto Tributario. Torino: Unione Tipografico - Editrice Torinese, 1956.

GIDDENS, Anthony. As Consequências da Modernidade. Tradução de Raul Fiker. São Paulo: Editora UNESP, 1991.

GIL, Antonio Hernández. Problemas Epistemológicos de la Ciencia Jurídica. Madrid: Civitas, 1981.

GIL, Otto; GIL, Vizeu. Direito Fiscal. Pareceres e Memoriais. Rio de Janeiro: Associação Comercial do Rio de Janeiro e Associação Bancaria do Rio de Janeiro, s/d.

GILLISSEN, John. Introdução Histórica ao Direito. Lisboa: Fundação Calouste Gulbenkian, p. 1986.

GODOI, Marciano Seabra de. Justiça, Igualdade e Direito Tributário. São Paulo: Dialética, 1999.

In: Solidariedade Social e Tributação. GRECO, Marco Aurélio; GODOI, Marciano Seabra de (Coord). São Paulo: Dialética, 2005.

GONDIM, Fátima; LETTIERI, Marcelo. Tributação e desigualdade. In: Le monde diplomatique. Brasil. Ano 4. Número 39. Outubro 2010. p. 08.

GONZALEZ, Eusebio. La Enseñanza del derecho Tributario. In: L'Evoluzione dell'Ordinamento Tributario Italiano. UCKMAR, Victor (Coord.) CEDAM: Milani, 2000.

GRAU, Eros Roberto. A Ordem Econômica na Constituição de 1988 - Interpretação e Crítica. Malheiros: São Paulo, 2012.

O Direito Posto e o Direito Pressuposto. São Paulo: Malheiros, 2002.

Por que tenho medo dos juízes (a interpretação/ aplicação do direito e os princípios). 6 Edição, São Paulo: Malheiros, 2013.

A interpretação do Direito e a Interpretação do Direito Tributário. In: Estudo de Direito Tributário em Homenagem à memória de Gilberto de Ulhôa Canto. Maria Augusta Machado de Carvalho (Coord). Rio de Janeiro: Forense, 1998.

GRECO, Marco Aurélio. Dinâmica da tributação e procedimento. 1. ed. São Paulo: Revista dos Tribunais, 1979.

Do Poder à Função Tributária. In: FERRAZ, Roberto. Limites e Princípios da Tributação 2. São Paulo: Quartier Latin, 2009.

Tributação. São Paulo: Dialética, 2005. 
; Solidariedade Social e Tributação. In: Solidariedade Social e Tributação. GRECO, Marco Aurélio; GODOI, Marciano Seabra de (Coord). São Paulo: Dialética, 2005.

; GODOI, Marciano Seabra de. Apresentação. In: Solidariedade Social e Tributação. São Paulo: Dialética, 2005.

; MARTINS, Ives Gandra da Silva (Org). Direito e Internet: Relações Jurídicas na Sociedade Informatizada. São Paulo: Rt, 2001.

. Internet e Direito. 2 Ed. São Paulo: Dialética, 2000.

Crise do Imposto de Renda na sua feição tradicional. In: Internet e o Direito. Marco Aurélio Greco (Coord.). São Paulo: Dialética, 2000.

da PGFN. Brasília: PGFN, 2011.

Crise do Formalismo no Direito Tributário Brasileiro. n.1. Revista

Planejamento Tributário. São Paulo: Dialética, 2011.

GRIZIOTTI, Benvenuto. Princípios de Política, Derecho y Ciência de la Hacienda. Trad: Enrique R. Mata. Segunda Edición. Madrid: Instituto Editorial Réus, 1958.

1956, t. II.

Studi di Scienza delle Finanze e Diritto Finanziario. Milano: Giuffrè,

GROSSI, Paolo. Mitologias Jurídicas da Modernidade. $2^{\circ}$ Ed. Florianópolis: Editora Fundação Boiteux, 2007.

GROVES, Harold. Tax Philosophers. Two Hundred Years of Thought in Great Britain and United States. Edited by Donald J. Curan. The University of Wisconsin Press, 1974.

GUIMARÃES, Carlos da Rocha. Introdução ao Direito Fiscal. In: Elementos de Direito Tributário. Curso proferido em 1953 na Fundação Getúlio Vargas. Rio de Janeiro: Edições Financeiras S.A., s/d.

GRUPENMACHER, Betina Treiger. Tratados Internacionais em Matéria Tributária e a Ordem Interna. 1. ed. São Paulo: Dialética, 1999.

GRUPENMACHER, Betina Treiger (Coord). Direito Tributário e o Novo Código Civil. São Paulo: Quartier Latin, 2004.

GUSDORF, Georges. Prefácio. In: JAPIASSÚ, Hilton. Interdisciplinaridade e Patologia do Saber. Serie Logoteca. Rio de Janeiro: Imago Editora, 1976.

$397,1990$.

Réflexions sur l'interdisciplinarité. In: Bulletin de Psychologie, XLIII,

Carta de 10.10.1977 endereçada a Ivani Fazenda. In: FAZENDA, Ivani Catarina Arantes. Integração e Interdisciplinaridade no Ensino Brasileiro: Efetividade ou Ideologia?São Paulo: Edições Loyola, 1992.

GUTMAN, Daniel. Do Direito à Filosofia do Tributo. In: FERRAZ, Roberto (Coord.). Princípios e Limites da Tributação. Vol.1. São Paulo: Quartier Latin, 2005. 
HABERMAS, Jünger. Direito e Democracia. Entre facticidade e validade. Volume II. $2{ }^{a} \mathrm{Ed}$. Trad. Flávio Beno Siebeneichler - UGF. Rio de Janeiro: Tempo Brasileiro, 2003.

Direito e Moral. Lisboa: Instituto Piaget, 1992.

HARADA, Kiyoshi. Direito Financeiro e Tributário. São Paulo, Ed. Atlas, 1995.

. Direito Financeiro e Tributário. São Paulo: Atlas, 2009.

HAURIOU, André. A Utilização em Direito Privado das Regras e Princípios do Direito Privado. Vol.I. Fasc. II. In: Revista de Direito Administrativo, Rio de Janeiro: Seção II da Revista do Serviço Público - Departamento Administrativo do Serviço Público - Fundação Getúlio Vargas, abril de 1945.

HART, Herbert. O conceito de direito. Lisboa: Fundação Calouste Gulbekian, s/d.

HARTZ, Hilhelm. Interpretação da Lei Tributária. Conteúdo e Limites do Critério Econômico. Trad. Brandão Machado. São Paulo: Resenha Tributária, 1993.

HARET, Florence; CARNEIRO, Jerson. A título de apresentação. VILÉM FLUSSER E JURISTAS. Comemoração dos 25 anos do grupo de estudos de Paulo de Barros Carvalho. Coord. Florence Haret e Jerson Carneiro. São Paulo: Noeses, 2009.

HECKHAUSEN, Heinz. Discipline et interdisciplinarité. In: L'interdisciplinarité. Problèmes d'enseignement et de recherche dans les Universités. Ceri (Eds). Paris: UNESCO/OCDE, 1972.

HENKEL, Heinrich. Introduccion a La Filosofia del Derecho. Trad. Enrique Gimbernat Ordeig. Madri: Taurus Ediciones, 1986.

HENSEL, Albert. Diritto Tributario. Traduzione di Dino Jarach. Milano: Dott. A. Giufrrè Editore, 1956.

HESPANHA, António Manuel. A história do direito na história social. Lisboa: Livros Horizonte, 1978.

HESSE, Konrad. Constituição e Direito Constitucional. In: HESSE, Konrad. Temas Fundamentais do Direito Constitucional. Textos selecionados e traduzidos por Carlos de Santos Almeida, Gilmar Ferreira Mendes e Inocêncio Mártires Coelho. São Paulo: Saraiva, 2009.

Conceito e peculiaridade da Constituição. In: HESSE, Konrad. Temas Fundamentais do Direito Constitucional. Textos selecionados e traduzidos por Carlos de Santos Almeida, Gilmar Ferreira Mendes e Inocêncio Mártires Coelho. São Paulo: Saraiva, 2009.

Significado dos Direitos Fundamentais. In: HESSE, Konrad. Temas Fundamentais do Direito Constitucional. Textos selecionados e traduzidos por Carlos de Santos Almeida, Gilmar Ferreira Mendes e Inocêncio Mártires Coelho. São Paulo: Saraiva, 2009.

A força normativa da Constituição. In: HESSE, Konrad. Temas Fundamentais do Direito Constitucional. Textos selecionados e traduzidos por Carlos de Santos Almeida, Gilmar Ferreira Mendes e Inocêncio Mártires Coelho. São Paulo: Saraiva, 2009. 
HICKS, Ursula K. Finanças Públicas. Manuais de Economia Cambridge. Traduzido por Leopoldo Fontenele. Rio de Janeiro: Zahar Editores, 1961.

HOFFART, Benjamin. Permanent Establishment in the Digital Age: Improving and Stimulating Debate Through an Access to Markets Proxy Approach, 6 Nw. J. Tech. \& Intell. Prop. 106 (2007), http://scholarlycommons.law.northwestern.edu/njtip/vol6/iss1/6;

HOLMES, Kevin. International Tax Policy and Double Tax Treaties. An Introduction to Principles and Application. IBFD.

HORVATH, Estevão. Lançamento Tributário e Autolançamento. São Paulo: Dialética, 1997.

HUCK, Hermes Marcelo. Evasão e elisão: rotas nacionais e internacionais do planejamento tributário. São Paulo: Saraiva, 1997.

HUGON, Paul. O Imposto. Teoria Moderna e Principais Sistemas. São Paulo: Editora Renascença, 1945.

IHERING, Rudolf Von. A Luta pelo Direito. $2^{\mathrm{a}}$ Ed. Trad. Ricardo Rodrigues Gama. São Paulo: Russel, 2005.

ICHIHARA, Yoshiaki. Direito Tributário. São Paulo, Editora Atlas, 1990.

INGROSSO, Gustavo. Istituzioni di Diritto Finanziario. Volume II. Le entrate dello Stato. Imposte e Tasse. Ed altri entrate patrimoniali. Napoli: Dott. Eugenio Jovene Editore, 1937.

ISQUIERDO, Renato Scalco. Tecnologia e Direito: A Tributação do Comércio Eletrônico na Internet. In: Tributação e Tecnologia. James Marins (Coord.) Coleção Tributação e Debate. Curitiba: Juruá, 2002.

JANSTCH, Erich. Vers l'interdisplinarité et la transdisciplinarité dans l'enseignement et l'innovation. In: L'interdisciplinarité. Problèmes d'enseignement et de recherche dans les Universités, Ceri (Eds). Paris: UNESCO/OCDE, 1972.

JAPIASSÚ, Hilton. Interdisciplinaridade e Patologia do Saber. Serie Logoteca. Rio de Janeiro: Imago Editora, 1976.

JARACH, Dino. O Fato Imponível. 2ªEd. Trad. Dejalma Campos. São Paulo: Rt, 2004.

Hermenêutica no Direito Tributário. In: Interpretação no Direito Tributário. Coord. Geraldo Ataliba. São Paulo: EDUC, 1975.

1980.

Curso de Derecho Tributario. Tercera Edición. Buenos Aires: Cima, 
JARDIM, Eduardo Marcial Ferreira. Curso de Direito Tributário. São Paulo: Editora Saraiva e Fundação do Instituto de Ensino de Osasco, 1982.

Saraiva, 1993.

Manual de Direito Financeiro e Tributário. $1^{\text {a }}$. ed. São Paulo: Editora

JÈZE, Gastón. Cours de Science des Finanzes et de Legislatión Financière Française. Sixième Editión. Paris: Marcel Giárd, 1922

Avertissement au Lecteur Français. In: MYRBACH-RHEINFELD,

Franz Von. Précis de Droit Financier. Traductión Française par É. Bouché-Leclercq. Paris: V. Giard \& Briere, 1910.

O Fato Gerador do Imposto (Contribuição à Teoria do Crédito do Imposto). Trad. Paulo da Mata Machado. Revista de Direito Administrativo. Vol. II - Fase I. Julho -1945 .

Natureza e Regime Jurídico do Crédito Fiscal, Revista de Direito Administrativo, Vol.III. Rio de Janeiro: Seção II da Revista do Serviço Público - Departamento Administrativo do Serviço Público - Fundação Getúlio Vargas, janeiro de 1946.

JUANO, Manuel de. Curso de Finanzas y Derecho Tributario, $2^{\mathrm{a}}$ ed., Rosario, Ediciones Molachino, 1969.

JR, Ivo Gico. Introdução ao Direito e Economia. In: Direito e Economia no Brasil. TIMM, Luciano Benetti (org.) São Paulo: Atlas, 2012.

JÚNIOR, Goffredo Telles. O Sistema Brasileiro de Discriminação de Rendas. Tese de Livre Docência defendida na Faculdade de Direito de São Paulo. São Paulo: Imprensa Nacional, 1946.

JÚNIOR, Tércio Sampaio Ferraz. A Ciência do Direito. São Paulo: Atlas, 1977.

Ed. São Paulo: Atlas, 2003.

Introdução ao Estudo do Direito. Técnica, Decisão e Dominação. $4^{\mathrm{a}}$

Notas sobre Contribuições Sociais e Solidariedade no Contexto do Estado Democrático de Direito. In: Solidariedade Social e Tributação. GRECO, Marco Aurélio; GODOI, Marciano Seabra de (Coord). São Paulo: Dialética, 2005.

Estado de Direito, Desenvolvimento e Globalização. In: Estudos de Filosofia do Direito. Reflexões sobre o Poder, a Liberdade, a Justiça e o Direito. 2 Ed. São Paulo: Atlas, 2003.

1998.

Função Social da Dogmática Jurídica. São Paulo: Max Limonad, . A Ciência do Direito. São Paulo: Editora Atlas S.A., 1977.

$\underline{K}$

KANT, Immanuel. À Paz Perpétua. Série Filosofia Política. São Paulo: L \& PM editores, 1989. 
2008.

A Metafísica dos Costumes. Trad. Edson Bini. São Paulo: Edipro,

KAUFMANN, Arthur. Filosofia do Direito. Lisboa: Fundação Calouste Gulbenkian, 1997.

Filosofia do Direito, teoria do Direito, dogmática jurídica. In: Introdução à filosofia do Direito e à teoria do direito contemporâneas. KAUFMANN, Arthur; HASSEMER, W. (Org.) Trad. Marcos Keel; Manuel Seca de Oliveira. Lisboa: Fundação calouste Gulbenkian, s/d.

KELSEN, Hans. Teoria Pura do Direito. São Paulo: Matin Fontes, 1999.

Teoria Geral do Direito e do Estado. São Paulo: Martins Fontes, 2000.

O que é Justiça? Trad. Luís Carlos Borges. São Paulo: Martins Fontes,

1997.

.CAMPAGNOLO. Umberto Direito Internacional e Estado

Soberano. Organ. Mario G. Losano. São Paulo: Martin Fontes, 2002

KEYNES, John Maynard. El camino hacia La prosperidad. In: La Politica Fiscal em Accion. In: DEL BRIO, Francisco Dominguez. Madrid: Instituto de Estudios Fiscales, 1971.

. A Teoria Geral do Emprego, do Juro e da Moeda. Tradução de Mário

R. da Cruz. São Paulo: Editora Atlas S.A., 1992.

. A Teoria Geral do Emprego (1937). John Maynard Keynes. Economia.

Organizador: Tamás Szmrecsányi. $2^{\circ}$ edição. São Paulo: Editora Ética, 1984.

KRUSE, Heinrich Wilhelm. Derecho Tributario. Parte General. $3^{\circ}$ edición.Editorial de Derecho Financiero. Editorial de Derecho Reunidas. Madrid, 1978.

KUHN, Thomas. A estrutura das Revoluções Científicas. $5^{\text {a }}$ Ed. São Paulo: Editora Perspectiva, 1998.

$\underline{\mathbf{L}}$

LABAND, Paul. Le Droit Publique de l' Empire Allemand. Tome V. La force armée de l'Empire Allemand.. Traduction de Savinien Souissy. Paris: V. Giard \& Briere, 1903.

LABAND, Paul. Staatsrecht des Deutschen Reiches. Freiburg: Mör, 1895.

LACERDA, Antonio Correia de. et al. Economia Brasileira. 3.ed. - São Paulo: Saraiva, 2006.

LACERDA, Româo Côrtes de. Observações sobre a Tributação Municipal. In: Revista de Direito Administrativo, Vol. IV, Rio de Janeiro: Seção II da Revista do Serviço Público Departamento Administrativo do Serviço Público - Fundação Getúlio Vargas, julho de 1946.

LACOMBE, Américo Masset. Obrigação tributária. São Paulo, Revista dos Tribunais, 1977.

Noções de Direito Tributário. São Paulo: Ltr, 1973. 
LAFER, Celso. Apresentação. In: BOBBIO, Norberto. A Era dos Direitos. Rio de Janeiro: Elsevier, 2004.

LAPATZA, José Juan Ferreiro. Curso de Derecho Español. 18º edición. Madrid: Marcial Pons, Ediciones Jurídicas y Sociales, S.Al, 1996.

Direito Tributário - Teoria Geral do Tributo. Trad. Roberto Barbosa Alves. Barueri-SP: Marcial Pons - Manole, 2007.

LARENZ, Karl. Metodologia da Ciência do Direito. $3^{\circ}$ Edição. Tradução de José Lamego. Lisboa - Portugal: Editora Fundação Calouste Gulbenkian, 1997.

LAURÉ, Maurice. Traité de Politique Fiscale. Paris, Presses Universitaire de France, 1957

Lei de Adaptação Fiscal (1934). In: Souza Diniz. Códigos Tributários. Alemão. Mexicano. Brasileiro. $1^{\text {o }}$ edição. Tradução de Souza Diniz. São Paulo: Edições Financeiras S.A., 1965.

LEIRIA, Maria Lúcia Luz. Breves considerações sobre a Taxa de Controle e Fiscalização Ambiental - TCFA, instituída pela Lei n.10.165/2000. In: Direito tributário ambiental. TôRRES, Heleno Taveira (org.). São Paulo: Malheiros, 2005.

LIBÂNEO, José Carlos. As teorias pedagógicas modernas revisitadas pelo debate contemporâneo na educação. In: LIBÃNEO, José Carlos; SANTOS, Akiko (Coord). Educação na era do conhecimento em rede e transdisciplinaridade. Campinas: Alínea, 2005.

LIMA, Ruy Cirne. Princípios de Direito Administrativo Brasileiro. 3 Ed. Porto Alegre: Livraria Sulina, s/d.

LOPES, Luiz Simões. Apresentação. In: Revista de Direito Administrativo. Seção II da Revista do Serviço Público. Carlos Medeiros Silva (Diretor).

LOPES, José Reinaldo de Lima. O Direito na História. Lições Introdutórias. $3^{\circ}$ Ed. São Paulo: Atlas, 2011.

LOSANO, Mario G. Sistema e Estrutura no Direito. Volume 1. Das origens à Escola Histórica. Trad. Carlo Alberto Dastoli. São Paulo: Martins Fontes, 2008.

LUHMANN, Niklas. Introdução à Teoria dos Sistemas. Petrópolis: Editora Vozes, 2010.

MACHADO JR, Armando Marcondes. "Cátedras e Catedráticos". Curso de Bacharelado. Faculdade de Direito. Universidade de São Paulo. 1827-2009. Associação dos Antigos Alunos da Faculdade de Direito de São Paulo (1931)

MACHADO, Brandão. Prefácio do Tradutor. In: HARTZ, Wilhelm. Interpretação da Lei Tributária. Conteúdo e Limites do Critério Econômico. Tradução, Prefácio e Notas de Brandão Machado. Rio de Janeiro: Resenha Tributária, 1993.

Breve Exame Crítico do art.43 do CTN. In: Estudos sobre o Imposto de Renda. Em memória de Henry Tilbery. Organ. Ives Gandra da Silva Martins. São Paulo: Resenha Tributária, 1994. 
. "Ruy Barbosa Nogueira". Direito Tributário. Estudos em Homenagem ao Prof. Ruy Barbosa Nogueira. São Paulo: Saraiva, 1984.

Apresentação. In: MORAES, Oswaldo de. Curso de Legislação Tributária. São Paulo: Saraiva, 1974.

São Tributos as Contribuições Sociais? Revista Direito Tributário Atual, São Paulo: Resenha Tributária, v.7/8, 1987-1988.

Fato gerador complexivo - uma questão terminológica. In: Suplemento Tributário, LTr, 73:82, entre outros.

MACHADO, Hugo de Brito. Curso de Direito Tributário. 34 Ed. São Paulo: Malheiros, 2013.

Curso de Direito Tributário. 27 Ed. São Paulo: Malheiros, 2006.

Ordem Econômica e Tributação. In: FERRAZ, Roberto. Princípios e Limites da Tributação. Os Princípios da Ordem Econômica e Tributação. Vol.2. São Paulo: Quartier Latin, 2009.

MAFFEZZONI, Frederico. Profili di una Teoria Giuridica Generale Dell'Imposta. Milano: Giuffrè, 1969.

MALERBI, Diva Preste Marcondes. Elisão Tributária. São Paulo: Revista dos Tribunais, 1984.

MARINS, James. Justiça Tributária e Processo Tributário: Ensaios. 1. ed. Curitiba: Champagnat, 1997.

Paulo: Dialética, 1998.

Princípios Fundamentais do Direito Processual Tributário. 1. ed. São

Elisão Tributaria e sua Regulação. São Paulo: Dialética, 2002.

Dialética, 2001.

Direito Processual Tributário Brasileiro. 1. ed. São Paulo: Editora 2012.

Direito Processual Tributário Brasileiro. $6^{\circ}$ Ed. São Paulo: Dialética,

Direito Processual Tributário Brasileiro. $7^{\circ}$ Ed. São Paulo: Dialética,

2014.

2009.

Defesa e Vulnerabilidade do Contribuinte. São Paulo: Dialética,

O Desafio da Política Jurídico-Fiscal. In: Tributação \& Política. James Marins (Coord.) Livro 6. Curitiba: Juruá Editora, 2005.

MARONGIU, Gianni. L'Ordinamento Tributário Italiano Tra La Prima Guerra Mondiale e II Consolidamento del Regime Fascista. In: L'Evoluzione dell'Ordinamento Tributário Italiano. Atti del Convegno "I settanta anni di "Diritto e Pratica Tributaria". Il Diritto Tributário. Antonio e Victor Uckmar (Coords.) Serie I. Volume LXXXIX. Padova: CEDAM, 2000. 
MARTINS, Ives Gandra da Silva. Efeitos Prospectivos de Decisões Judiciais em Matéria Tributária. In: Revista Dialética de Direito Tributário. Valdir de Oliveira Rocha (Coord.). São Paulo: Dialética, junho de 2010.

Belém, 1984.

Princípio da reserva absoluta, In: Direito Constitucional Tributário.

Do Direito Tributário. Excerto da Seção Imposto sobre a Renda Comentário - n.31/84. São Paulo: Resenha Tributária, s/d.

. Apresentação (da $1^{\text {a }}$ Edição) In: MACHADO, Hugo de Brito. Curso de Direito Tributário. 27 Ed. São Paulo: Malheiros, 2006.

Apresentação. In: BONILHA, Paulo Celso Bergstrom. Da Educação Tributária como fator de desenvolvimento econômico e social. $2^{\mathrm{a}}$ Congresso Interamericano de Direito Tributário - 1975. São Paulo: Co-edição - Sociedade Brasileira de Instrução - CEAD, Associación Interamericana de Estudos de extensão Universitária, Editora Resenha Tributária, $1975, \mathrm{~s} / \mathrm{p}$.

Bushatsky, 1975

Apropriação indébita no direito tributário brasileiro. São Paulo:

Teoria da Imposição Tributária. São Paulo: Saraiva, 1983.

Direito Constitucional Tributário. Pareceres. BELÉM: CEJUP, 1985.

Sistema Tributário na Constituição de 1988. São Paulo, Editora

Saraiva, 1989.

Uma Teoria do Tributo. São Paulo: Quartier Latin, 2005.

Direito Constitucional Tributário. Pareceres. BELÉM: CEJUP, 1985.

Saraiva, 1989.

Sistema Tributário na Constituição de 1988. São Paulo, Editora

Prefácio. In: MORAES, Bernardo Ribeiro de. Compêndio de Direito Tributário. Volume I. Rio de Janeiro: Forense, 1993, s/p.

Os princípios da legalidade e da tipicidade. In: Curso de Direito Tributário. Org: MARTINS, Ives Gandra da Silva. São Paulo, 1982.

O desequilíbrio da concorrência por distorções tributárias e a Emenda Constitucional n.42/2003. Repertório de Jurisprudência IOB, n.24, São Paulo: IOB, 2005 .

Obrigações Acessórias Tributárias e a Disciplina Jurídica da Concorrência. In: FERRAZ, Roberto. Princípios e Limites da Tributação. Vol.1. São Paulo: Quartier Latin, 2005.

A Taxa de Controle e Fiscalização Ambiental - TCFA. In: Direito tributário ambiental. TôRRES, Heleno Taveira (org.). São Paulo: Malheiros, 2005. 
Tributação no Mercosul. Pesquisas Tributárias. Nova Série - 3. Centro de Extensão Universitária. Editora RT, São Paulo - SP, 1997.

A missão do jurista e o Direito Natural. In: Direito Econômico e Tributário. Comentários e Pareceres. Co-Edição - FIEO - Fundação Instituto de Ensino para Osasco. São Paulo: Resenha Tributária, 1982.

Direito Econômico e Tributário. Comentários e Pareceres. Co-Edição - FIEO - Fundação Instituto de Ensino para Osasco. São Paulo: Resenha Tributária, 1982.

Tributos, Justiça Social e Desenvolvimento. In: Direito Econômico e Tributário. Comentários e Pareceres. Co-Edição - FIEO - Fundação Instituto de Ensino para Osasco. São Paulo: Resenha Tributária, 1982.

O Comércio Internacional e o Retorno às Teorias Protecionistas. In: Direito Econômico e Tributário. Comentários e Pareceres. Co-Edição - FIEO Fundação Instituto de Ensino para Osasco. São Paulo: Resenha Tributária, 1982.

Inflação e Política Tributária. In: Direito Econômico e Tributário. Comentários e Pareceres. Co-Edição - FIEO - Fundação Instituto de Ensino para Osasco. São Paulo: Resenha Tributária, 1982.

MARTUL-ORTEGA, Perfecto Yebra. Prólogo. In: KRUSE, Heinrich Wilhelm. Derecho Tributario. Parte General. $3^{\circ}$ edición. Editorial de Derecho Financiero. Editorial de Derecho Reunidas. Madrid, 1978,

MAYER, Otto. Derecho Administrativo Alemán. Tomo II. Parte Especial. Poder de Policía y Poder Tributário. Buenos Aires: Depalma, 1950.

MAXIMILIANO, Carlos. Comentários à Constituição Brasileira. Quarta edição. Volume II. Rio de Janeiro: Livraria Freitas Bastos, 1948.

MAYNEZ, Eduardo Garcia. Introducción al estudio del Derecho. 53 Edición. Mexico: Porrua, 2002.

. Filosofia del Derecho. 17 Ed. Mexico: Porrua, 2009

MCGEE, Robert. W. (Editor). The Ethics of Tax Evasion. The Dumont Institute for Public Policy Research. South Orange, USA, 1998.

MELLO, Celso Antônio Bandeira de. Elementos do Direito Administrativo. Editora RT, São Paulo. 1981.

MELO, José Eduardo Soares de. O Imposto sobre Produtos Industrializados (IPI) na Constituição de 1.988. São Paulo: Editora Revista dos Tribunais, 1991.

ICMS: Teoria e Prática. São Paulo, Dialética, 1995.

O ICMS e a Lei Complementar 87/96. São Paulo, Dialética.

Curso de Direito Tributário. São Paulo, Dialética, 2006. 
Interpretação e Integração da Legislação Tributária. Curso de Direito Tributário. Volume 1. Coordenador: MARTINS, Ives Gandra. $4^{\circ}$ Edição. São Paulo: CEJUP, 1995.

MENDES, Gilmar Ferreira. Jurisdição Constitucional, Saraiva: São Paulo,1998.

; MARTINS, Ives Gandra da Silva. Controle concentrado de constitucionalidade. 2. ed. São Paulo: Saraiva, 2005.

MESSNER, Johannes. Ética Social. Trad. Alípio Maia de Castro. São Paulo: Editora Quadrante, 1987.

MICHELI, Gian Antonio. Curso de Derecho Tributario. Trad. Julio Balacloche. Madrid: Reunidas, 1975.

Curso de Direito Tributário. Trad. Marco Aurélio Greco e Pedro Luciano Marrey Jr. São Paulo: RT, 1978.

Corso di Diritto Tributário, $4^{\circ}$ ed. Ver. Aum. Torino, Utet, 1978.

MIRANDA, Francisco Cavalcanti Pontes de. Comentários à Constituição de 1946. Vol. II (arts 37-48), Rio de Janeiro: Livraria Boffoni, 1946.

Livraria Boffoni, 1946.

Comentários à Constituição de 1946. Vol. I (arts 1-36). Rio de Janeiro:

Comentários à Constituição de 1967, com a emenda n. 1 de 1969.

Tomo I. $3^{\text {a }}$ ed. Rio de Janeiro: Forense, 1987.

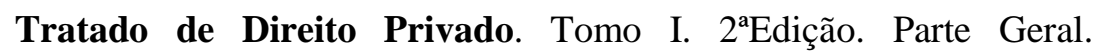
Introdução. Pessoas Físicas e Jurídicas. Campinas-SP:Bookseller, 2000.

MIRANDA, Jorge. Teoria do Estado e da Constituição. Rio de Janeiro: Forense, 2007.

MOLINA, Pedro Manuel Herrera; VASCO, Domingo Carbajo. Marco Conceptual, Constitucional e Comunitario de La fiscalidad Ecológica. In: Direito tributário ambiental. TôRRES, Heleno Taveira (org.). São Paulo: Malheiros, 2005.

MORAES, Bernardo Ribeiro de. Sistema Tributário brasileiro na Constituição Federal de 1969. São Paulo: Rt, 1973.

Imposto de Indústrias e Profissões - da Legitimidade da Nova Sistemática, São Paulo, Prefeitura Municipal, 1963.

Forense: Rio de Janeiro, 1995.

Compêndio de Direito Tributário. Primeiro e Segundo Volumes. $3^{\text {a }}$ Ed.

MORIN, Edgar. Ciência com Consciência. São Paulo: Bertrand Brasil, 2010.

O Paradigma da Complexidade. In: MORIN, Edgar; LE MOIGNE, Jean-Louis. A Inteligência da Complexidade. São Paulo: Petrópolis, 2000, p. 199 e ss.

Ciência com consciência. Rio de Janeiro: Bertrand Brasil, 2010. 
O Método. 3. São Paulo: Editora Sulina, 1999.

A Necessidade de um Pensamento Complexo. In: Representação e Complexidade. Candido Mendes (Org). Rio de Janeiro: Garamond, 2003.

MOSQUERA, Roberto Quiroga. Renda e Proventos de Qualquer Natureza. O Imposto e o Conceito Constitucional. $1^{\text {a }}$. ed. São Paulo - SP: Dialética, 1996.

SP: Dialética, 1998.

Tributação no Mercado Financeiro e de Capitais. $1^{\text {a }}$. ed. São Paulo -

; LOPES, Alexsandro Broedel.(Coord).Controvérsias

Jurídico-

Contábeis (Aproximações e Distanciamentos). $2^{\mathrm{a}}$ Volume. São Paulo: Dialética, 2011.

MYRBACH-RHEINFELD, Franz Von. Précis de Droit Financier. Traductión Française par É. Bouché-Leclercq. Paris: V. Giard \& Briere, 1910.

\section{$\underline{\mathbf{N}}$}

NABAIS, José Casalta. O Dever Fundamental de Pagar Impostos. Coimbra: Livraria Almedina, 1998.

NASCIMENTO, Carlos Valder do. Curso de Direito Financeiro. $1^{\mathrm{a}}$. ed. Rio de Janeiro: Forense, 1999.

NASCIMENTO, Walter Vieira do. Lições de História do Direito. Rio de Janeiro: Forense, 2006.

NAWIASKY, Hans. Cuestiones Fundamentales de Derecho Tributário. Obras Básicas de Hacienda Pública. Madrid: Instituto de Estúdios Fiscales, 1982.

NETO, Alfredo José da Veiga. Crise dos paradigmas e interdisciplinaridade. In: Interdisciplinaridade na sala de aula: uma experiência pedagógica nas $3^{\mathrm{a}}$ e $4^{\mathrm{a}}$ séries do primeiro grau. SILVA, Dinorá Fraga da; SOUZA, Nádia Geisa Oliveira de (Org).Porto Alegre: Editora da Universidade/UFGRS, 1995.

NEVES, Marcelo. Pesquisa Interdisciplinar no Brasil: o paradoxo da interdisciplinaridade. In: Revista do Instituto de Hermenêutica Jurídica - RIHJ. Belo Horizonte: Editora Fórum, ano 1, n. 3, jan. / dez. 2005.

NEUMARK, Fritz. Princípios de La Imposición. Obras Basicas de Hacienda Pública. Madrid: Instituto de Estudios Fiscales. Ministerio de Hacienda, 1974.

NICOLESCU, Basarab. Definition of Transdisciplinarity. 2003. Disponível em: http://www.interdisciplines.org/interdisciplinarity/papers/5/ (último acesso em 05.12.2014).

São Paulo: Trion, 1999.

O manifesto da transdisciplinaridade. Trad. Lúcia Pereira de Souza.

NITTI, Francesco. Princípios da Ciência das Finanças. 2 Volumes. Rio de Janeiro: Atena Editora, 1937.

NOGUEIRA, Alberto. Os limites da legalidade tributária no estado democrático de direito. RJ, Renovar, 1999. 
1997.

A reconstrução dos direitos humanos da tributação. RJ, Renovar,

NOGUEIRA, Lis Loli Cabral. A consideração econômica no direito tributário. In: Estudos Tributários. Ruy Barbosa Nogueira (Edição e Colaboração). São Paulo: Resenha Tributaria, s/d.

NOGUEIRA, Ruy Barbosa. Prefácio. In: Souza Diniz. Códigos Tributários. Alemão. Mexicano. Brasileiro. $1^{\circ}$ edição. Tradução de Souza Diniz. São Paulo: Edições Financeiras S.A., 1965

José Bushatsky, 1964.

Direito Financeiro (Curso de Direito Tributário). 1 Ed. São Paulo:

A Contribuição de Tullio Ascarelli para a formação da doutrina jurídico-tributária no Brasil. Direito Tributário Atual. Vol.10. São Paulo: Co-edição. Instituto Brasileiro de Direito Tributário. Resenha Tributária, 1990.

Curso de Direito Tributário. 15º edição. São Paulo: Saraiva, 1999.

. Ensino Pesquisas e Serviços à Comunidade. Direito Tributário Atual. Volumes 7/8. São Paulo: Resenha Tributária- IBDT, 1987-1988.

Rubens Gomes de Sousa, 30 anos amigo e companheiro. Estudos Tributários. São Paulo; Resenha Tributária, s/d.

Tribunais, vol.305, 1960.

A Problemática do Direito Tributário no Brasil. In: Revista dos

O Direito Tributário. Monografia publicada na Revista Jurídica LEMI n.06 - Dezembro de 1977.

Estudos Tributários. In: Debates Tributários. Ruy Barbosa Nogueira e Colegas. Co-edição. Instituto Brasileiro de Direito Tributário. Editora Resenha Tributária. São Paulo, 1975.

Rubens Gomes de Sousa, trinta anos amigo e companheiro. In: Estudos Tributários. Direção e Colaboração. Prof. Ruy Barbosa Nogueira. São Paulo: Resenha Tributária, s/d

Prefácio. In: DINIZ, Souza. Códigos Tributários. Alemão, Mexicano, Brasileiro. Rio de Janeiro: Edições Financeiras S.A., 1965.

Programas e Compêndios de Direito Tributário. Excerto da Seção Imposto de Renda - Comentário, n.34/85. São Paulo: Resenha Tributária, 1985.

Estudos Tributários. In: Debates Tributários. Ruy Barbosa Nogueira e Colegas. São Paulo: IBDT - Resenha Tributária, 1975.

Curso de Direito Tributário. 15º edição. São Paulo: Saraiva, 1999.

O Estudo Teórico e Prático do Direito Tributário. São Paulo:

Resenha Tributária, 1975. 
Direito Tributário e Direito Tributário Comparado. Cursos de Graduação, Mestrado, Doutorado, Extensão Universitária e Mesa de Debates. Plano de Trabalho e Pesquisas para 1972 (apresentado à Faculdade de Direito e Reitoria da Universidade de São Paulo).

Ensino, Pesquisas e Serviços à Comunidade. Separata do Vol.7 da Coleção Direito Tributário Atual. São Paulo: IBDT/Resenha Tributária, 1987.

Apresentação do Dicionário Expositivo do Direito Tributário e das Ciências Fiscais. Publicação da Cadeira de Direito Tributário Comparado. São Paulo: Faculdade de Direito do Largo São Francisco, 1972.

Panorama do Direito Tributário Brasileiro e as Elaborações Germânicas. Separata da Revista dos Tribunais. Volume 303. Janeiro de 1961. São Paulo: RT, 1961.

São Paulo, LTr, Sup.Trib.n96, s/d.

O Novo Código Tributário da Alemanha: como se deve legislar.

Miguel Reale e o Direito Tributário. In: Imunidades. Contra Impostos na Constituição Anterior e sua disciplina mais completa na Constituição de 1988. $2^{\mathrm{a}}$ Ed. São Paulo: Saraiva, 1992.

Teoria, Experiência e Trabalho a Serviço do Ensino e do Desenvolvimento. Melhoria da Legislação Tributária. In: Direito Tributário Atual. Vol.1. São Paulo: IBDT - Resenha Tributária, 1982.

; NOGUEIRA, Paulo Roberto Cabral. Prefácio à $2^{\mathbf{a}}$ Edição. In: Direito Tributário Aplicado e Comparado. Volumes I e II. Forense: Rio de Janeiro, 1977.

Novo Código Tributário Alemão (AO - 1977). Tradução de Alfred J. Schimid, Brandão Machado, Eduardo Frederico de A.Carvalho, Gerd W. Rothmann, Henry Tilvery, Ruy Barbosa Nogueira. São Paulo: Co-edição: Companhia Editora Forense \& Instituto Brasileiro de Direito Tributário, 1978.

NUNES, Castro. Problemas de Partilha Tributária. In: Revista de Direito Administrativo, Vol.I. Fasc. I, Rio de Janeiro: Seção II da Revista do Serviço Público - Departamento Administrativo do Serviço Público - Fundação Getúlio Vargas, abril de 1945.

OLIVEIRA, Candido Baptista de. Sistema Financial do Brasil. São Petersburgo: Typographia Privilegiada de Fischer, 1842.

OLIVEIRA, Fabrício Augusto de. A evolução da estrutura tributária e do fisco brasileiro: 1889-2009. Texto para discussão n. 1469 Brasília: IPEA, 2010.

OLIVEIRA, João Martins. Direito Fiscal (Estudos doutrinários e anotações ao decreto-lei n.960, de 17 de dezembro de 1938). Rio de Janeiro: Livraria Jacinto, 1943.

OLIVEIRA, José Marcos Domingues de. Direito Tributário e Meio Ambiente. Proporcionalidade. Tipicidade Aberta. Afetação de Receita. Rio de Janeiro: Renovar, 1995. 
Direito Tributário, n.56, 1991.

Meio Ambiente, Tributação e Vinculação de Impostos. Revista de

OLIVEIRA, Regis Fernandes de; HORVATH, Estevão. TAMBASCO, Teresa Cristina Castrucci. Manual de direito Financeiro. São Paulo: Rt, 1990

; HORVATH, Estevão. Manual de Direito Financeiro. 2ªed. São

Paulo: RT, 1997.

OLIVEIRA, Ricardo Mariz de. Fundamentos do Imposto de Renda. São Paulo: Quartier Latin, 2008.

A tributação da Renda e sua Relação com os Princípios Contábeis

Geralmente Aceitos. In: Controvérsias Jurídico-Contábeis (Aproximações e Distanciamentos). MOSQUERA, Roberto Quiroga; LOPES, Alexsandro Broedel. $1^{\text {a }}$ Volume. São Paulo: Dialética, 2010.

OLIVEIRA, Yonne Dolacio. A tipicidade no direito tributário brasileiro. São Paulo, Saraiva,1980.

Legislação tributária, tipo legal tributário (Arts.96 e 97 do C.T.N.). In: Direito Tributário 4, vol.2, São Paulo, 1976.

PAULSEN, Leandro. Direito Tributário: Constituição e Código Tributário à Luz da Doutrina e da Jurisprudência. 1. ed. Porto Alegre: Livraria do Advogado Editora, 1998.

PALMADE, Guy. Interdisciplinaridad y ideologias. Madrid: Narcea, 1979.

Parecer da Comissão Especial, composta por Tito Rezende (Presidente), Carlos da Rocha Guimarães, Eduardo Lopes Rodrigues, Jayme Péricles e Gilberto Ulhôa Canto, sobre o AnteProjeto de Código Tributário Nacional. In: Instituto Brasileiro de Direito Financeiro. A Codificação do Direito Tributário. Publicação n.4. Rio de Janeiro: s/e, 1954.

Parecer de Orientação n.37/2001 do Comitê de Pronunciamentos Contábeis.

Parecer de Orientação $\mathrm{n}^{\mathrm{o}}$ 37, de 22 de setembro de 2011, do Comitê de Pronunciamentos Contábeis, aprovado pela Deliberação Comissão de Valores Mobiliários n.539/2008.

PERRONE-MOISÉS, Claudia. Direitos Humanos e Desenvolvimento: A Contribuição das Nações Unidas. In: AMARAL JR., Alberto; PERRONE-MOISÉS, Cláudia. O cinqüentenário da Declaração Universal dos Direitos do Homem. São Paulo: Edusp, 1999.

PESSOA, Epitácio. Pareceres Jurídicos. Tomo I. Rio de Janeiro: INL, 1959.

Elementos de Direito Fiscal. Segunda Edição. Volume I. Rio de Janeiro: Livraria Freitas Bastos, 1943.

PETRAGLIA, Cristina Izabel. Interdisciplinaridade: o cultivo do professor. São Paulo: Pioneira, Universidade São Francisco, 1993. 
PIAGET, Jean. O Estruturalismo. Rio de Janeiro: Difel, 2003.

Epistemologie des rélations interdisciplinaires. In: L'interdisciplinarité. Problèmes d'enseignement et de recherche dans les Universités, Ceri (Eds.). Paris: UNESCO/OCDE, 1972.

PISCITELLI, Thatiane (Coord). Direito Processual Tributário: Aspectos Fundamentais. In: Direito Tributário. Série GVlaw. São Paulo: Saraiva, 2012.

PIMENTA, Paulo Roberto Lírio. O Princípio da Segurança Jurídica em face de Mudança da Jurisprudência Tributária. In: Grandes Questões Atuais do Direito Tributário. $10^{\circ}$ Volume. Coordenador: Valdir de Oliveira Rocha. São Paulo: Dialética, 2006.

PINTO, Bilac. Estudos de Direito Público. Edição comemorativa do cinquentenário da fundação da "Revista Forense". Rio de Janeiro: Revista Forense, 1953.

POLIZELLI, Victor. Balanço Comercial e Balanço Fiscal: Relações entre o Direito Tributário e o Direito Contábil e o Modelo Adotado pelo Brasil In: Revista Direito Tributário Atual n.24. Organizadores: SCHOUERI, Luís Eduardo: ZILVETI, Fernando Aurelio; BONILHA, Paulo Celso Bergstrom. São Paulo: Dialética-IBDT, 2010.

O Princípio da Realização da Renda. Série Doutrina Tributária. Vol.II. Reconhecimento de Receitas e Despesas para Fins do IRPJ. São Paulo: Quartier Latin IBDT, 2012.

POMBO, Olga. Texto apresentado no Congresso Luso-Brasileiro sobre Epistemologia e Interdisciplinaridade na Pós-Graduação, realizado em Porto Alegre, Brasil, na Pontifícia Universidade Católica do Rio Grande do Sul, nos dias 21, 22 e 23 de Junho de 2004. Disponível em: http://revista.ibict.br/liinc/index.php/liinc/article/view/186/103 (último acesso em 17.11.2014)

PONTES, Helenilson Cunha. Princípio da proporcionalidade e o Direito Tributário. São Paulo: Dialética, 2000.

PORTO, José Luiz de Almeida Nogueira Porto. Lucros Extraordinários. Teoria e Prática. São Paulo: Editora Comercial, 1944.

com Marcello Ulysses Rodrigues) - São Paulo - 1942.

Primeiro Relatório da Comissão do Ministério da Fazenda. In: Reforma Tributária Nacional. Rio de Janeiro: FGV, 1965.

Projeto de Código Tributário Brasileiro. In: Souza Diniz. Códigos Tributários. Alemão. Mexicano. Brasileiro. $1^{\circ}$ edição. Tradução de Souza Diniz. São Paulo: Edições Financeiras S.A., 1965.

PUGLIĖSE, Mario. La prueba en el Processo Tributario. Jus: México, 1949.

$\overline{1939 .}$

Instituciones de Derecho Financiero. Alfonso Cortina.México, 
PUVIANI, Amilcare. Teoria de la ilusión financeira. Madrid: Instituto de Estúdios Fiscales, Ministério de Hacienda, sem data.

\section{$\underline{\mathbf{Q}}$}

QUEIROZ, Mary Elbe. Do lançamento tributário - execução e controle. São Paulo: Dialética, 1999.

Paulo: Manole, 2002.

Imposto sobre a Renda e Proventos de Qualquer Natureza. São

$\underline{\mathbf{R}}$

RADBRUCH, Gustav. Filosofia do Direito. Arménio Amado - editor, sucessor - Coimbra, 1979.

RAMOS, José Nabaltino; CORRÊA, Walter Barbosa; COSTA, Alcides Jorge. Sesquicentenário Onze de Agosto, 1976. In: NOGUEIRA, Ruy Barbosa. Curso de Direito Tributário. São Paulo: Instituto Brasileiro de Direito Tributário - Saraiva, 1999.

RAWLS, John. Uma Teoria da Justiça. São Paulo: Martins Fontes, 2002.

REALE, Miguel. Lições Preliminares de Direito. 27ª Ed. São Paulo: Saraiva, 2002.

Filosofia do Direito. 19 Ed. São Paulo: Saraiva, 2000.

Jurídica). São Paulo: Saraiva, 1968.

O Direito Como Experiência (Introdução à Epistemologia Teoria Tridimensional do Direito. Situação Atual. 5a Ed. São

Paulo: Saraiva, 1994.

Entrevista concedida ao programa Roda Viva. Disponível em: http://www.rodaviva.fapesp.br/materia/727/entrevistados/miguel_reale_2000.htm (último acesso em 11/05/2015.

REZENDE, Tito. Manual Pratico do Imposto de Renda $2^{\text {a }}$ Ed Rio De Janeiro: Sfreddo \& Gravina Ltda, s/d.

Revista de Direito. Civil Commercial e Criminal. Doutrina, Jurisprudencia e Legislação. Antonio Bento de Faria (Dir.). Volume I. Julho. Fasc.I. Rio de Janeiro: s/e, 1906.

Revista de Direito. Civil Commercial e Criminal. Doutrina, Jurisprudencia e Legislação. Antonio Bento de Faria (Dir.). Volume II. Outubro. Fasc.I. Rio de Janeiro: s/e, 1906.

Revista Forense. Doutrina, Legislação e Jurisprudência. Volume I; Fascículo 1ª Bello Horizonte: Imprensa Official do Estado de Minas Geraes, 1904.

Revista Forense. Doutrina, Legislação e Jurisprudência. Volume II; Fascículo 1 ${ }^{\text {a }}$. Bello Horizonte: Imprensa Official do Estado de Minas Geraes, 1904. 
Revista dos Tribunais (Publicação Official dos trabalhos do Tribunal de Justiça de São Paulo). Anno I. Fasciculo n.1. Volume I. São Paulo: s/e, 1912

Revista dos Tribunais. Anno I. Fasciculo n.7, São Paulo: s/e, 1912.

Revista dos Tribunais. Anno I. Fasciculo n. 9. Volume II, s/e, 1912

Revista de Critica Judiciária. Ano II. Rio de Janeiro: s/e, 1925.

Revista fiscal. Imposto de Consumo - Assuntos Aduaneiros - Outros Assuntos. REZENDE, Tito. (Coord). Número 1. Rio de Janeiro: s/e, 1930.

Revista fiscal. "Imposto da Renda. Selo. Despesas. Contribuições Públicas. Vendas Mercantis e Pequenos Impostos". REZENDE, Tito. (Coord). Rio de Janeiro: RBN, 1931.

Revista fiscal. “Consumo. Assuntos Aduaneiros. Outros Assuntos”. REZENDE, Tito. Rio de Janeiro: RBN, 1931.

Revista fiscal. “Consumo. Vendas Mercantis. Outros Assuntos Aduaneiros”. REZENDE, Tito. Rio de Janeiro: RBN, 1932.

RIBAS, Lídia Maria Lopes Rodrigues. Defesa ambiental: utilização de instrumentos tributários. In: TôRRES, Heleno Taveira (org.). Direito tributário ambiental. São Paulo: Malheiros, 2005.

RODRIGUES DO AMARAL, Antonio Carlos. Visão Global da Fiscalidade no MERCOSUL. In: Tributação do Consumo e da Renda. In: MARTINS, Ives Gandra. Direito Tributário no Mercosul. Rio de Janeiro: Forense, 2000.

ROCHA, Sérgio André. As Normas de Convergências Contábeis e seus Reflexos para os Contribuintes. In: Controvérsias Jurídico-Contábeis (Aproximações e Distanciamentos). MOSQUERA, Roberto Quiroga; LOPES, Alexsandro Broedel. $2^{\text {a }}$ Volume. São Paulo: Dialética, 2011.

Quartier Latin, 2007.

.Treaty Override no Ordenamento Jurídico Brasileiro. São Paulo:

.Existe um princípio da tipicidade no direito tributário?In: Revista Direito Tributário Atual. N.26. São Paulo: Dialética-IBDT, 2011.

ROTHMANN, Gerd Willi. O princípio da legalidade tributária. Revista de Direito Administrativo, São Paulo, v. 109, 1972.

; NOGUEIRA, Ruy Barbosa. Tradução do verbete Auslegung (Interpretação, de Heinrich Beisse, do Handwörterbuch des Steuerrechts und der Steuerwissenschaften). In: Resenha Tributária. (Org.). Estudos Tributários. São Paulo: Resenha Tributária, 1974.

Enciclopédia Saraiva do Direito. São Paulo: Saraiva, 1977.

Bitributação Internacional. In: FRANÇA, Rubens Limongi. (Org.). 
Tributação, Sonegação e Livre Concorrência. In: FERRAZ, Roberto. Princípios e Limites da Tributação. Os Princípios da Ordem Econômica e Tributação. Vol.2. São Paulo: Quartier Latin, 2009.

Bitributação Internacional. In: FRANÇA, Rubens Limongi.. (Org.). Enciclopédia Saraiva do Direito. São Paulo: Saraiva, 1977.

Inconstitucionalidade Múltipla na Tributação da Importação de Serviços - Requiém ou catarse do sistema tributário nacional? Tese de Livre-Docência. São Paulo: Biblioteca de Direito Econômico e Financeiro da Faculdade de Direito do Largo São Francisco, USP, 2010.

ROSEMBUJ, Tulio. Principios Globales de Fiscalidad Internacional. Barcelona: Graficas Rey, 2012.

ROSS, Alf. Direito e Justiça. $1^{\text {a }}$ Ed. Bauru-SP: Edipro, 2000.

SALDANHA, Nelson. Teoria do Direito e Crítica Histórica. Rio de Janeiro: Freitas Bastos, 1987.

Filosofia do Direito. Rio de Janeiro: Renovar, 1998

SANTI, Eurico Marcos Diniz de. Lançamento Tributário. 1. ed. São Paulo: Max Limonad, 1996.

Limonad, 2000. Decadência Prescrição no Direito Tributário. 1. ed. São Paulo: Max

Direito tributário em rede e desenvolvimento: Prefácio em Homenagem ao Prof. Aires Barreto. In: Transparência Fiscal e Desenvolvimento. Homenagem ao Professor Isaias Coelho. Coordenação: Eurico Marcos Diniz de Santi, Basile Georges Christopoulos, Daniel Leib Zugman, Frederico Silva Bastos. São Paulo: Fiscosoft, 2013.

; CANADO, Vanessa Rahal. Direito Tributário e Direito Financeiro: reconstruindo o conceito de tributo e resgatando o controle da destinação. In: Política Fiscal. VASCONCELLOS, Roberto França de. (Coord.) Série GVLaw. São Paulo: Saraiva, 2009.

O sigilo e a Lei Tributária: Transparência, Controle da Legalidade, Direito à Prova e a Transparência do Sigilo Bancário para Administração Tributária na Constituição e na Lei Complementar no 105/2001. In: Piscitelli, Tathiane. (Org.). Direito Tributário - o Direito Tributário na Prática Dos Tribunais Superiores - Série Gvlaw Direito Tributário - o Direito Tributário na Prática Dos Tribunais Superiores - Série Gvlaw. 1ed. São Paulo: Saraiva, 2013.

; CHRISTOPOULOS, Basile Georges; ZUGMAN, Daniel Leib; BASTOS, Frederico Silva. Transparência Fiscal e Desenvolvimento - Homenagem ao Professor Isaias Coelho. 1 ${ }^{\text {a }}$. ed. São Paulo: Fiscosoft Editora Ltda, 2013. 
Apresentação. In: Curso de Direito Tributário e Finanças Públicas.

Do Fato à Norma, da Realidade ao Conceito Jurídico. Série Metodologia \& Ensino - Direito Desenvolvimento e Justiça. São Paulo: Saraiva, Direito GV, 2008.

SANTOS, Akiko. Complexidade e transdisciplinaridade em educação: cinco princípios para resgatar o elo perdido. In: Revista Brasileira de Educação v. 13 n. 37 jan./abr. 2008. Disponível em: www.scielo.br/pdf/rbedu/v13n37/07. (último acesso em 05.12.2014).

SANTOS, Boaventura de Sousa. A Crítica da Razão Indolente: Contra o desperdício da experiência. São Paulo: Editora Cortez, 2007.

SAVIGNY, Friedrich Karl Von. Metodologia Jurídica. Traducción de J.J. Santa-Pinter. Buenos Aires: Depalma, 1994.

SCAFF, Fernando Facury. República, tributação e finanças. RDE. Revista de Direito do Estado, v. 21, São Paulo.

; TUPIASSU, Lise Vieira da Costa. Tributação e Políticas Públicas: o ICMS Ecológico. In: Direito tributário ambiental. TÔRRES, Heleno Taveira (org.). São Paulo: Malheiros, 2005.

; ATHIAS, Jorge Alex (Cood.) Direito Tributário e Econômico aplicado ao Meio Ambiente e à Mineração. São Paulo: Quartier Latin, 2009.

SCHÄFFER, Margareth. Interdisciplinaridade: um novo "paradigma" para a educação e as ciências humanas? In: Interdisciplinaridade na sala de aula: uma experiência pedagógica nas $3^{\mathrm{a}} \mathrm{e}$ $4^{a}$ séries do primeiro grau. SILVA, Dinorá Fraga da; SOUZA, Nádia Geisa Oliveira de (Org).Porto Alegre: Editora da Universidade/UFGRS, 1995.

SCHMIDT, Paulo; SANTOS, José Luiz dos. História do Pensamento Contábil. São Paulo: Atlas, 2008.

SCHNAID, David. Filosofia do Direito e Interpretação. $2^{\circ}$ Edição. São Paulo: Revista dos Tribunais, 2004.

SCHOUERI, Luís Eduardo. Planejamento Fiscal através dos Acordos de Bitributação: Treaty Shopping. 1. ed. São Paulo: Revista dos Tribunais, 1995.

1996.

Distribuição Disfarçada de Lucros. 1. ed. São Paulo: Dialética, São Paulo: Dialética, 1999;

Preços de Transferência no Direito Tributário Brasileiro. 1. ed.

Paulo: Forense, 2005.

Normas Tributárias Indutoras e Intervenção Econômica. São

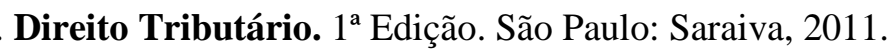

Direito Tributário. 2a Edição. São Paulo: Saraiva, 2012.

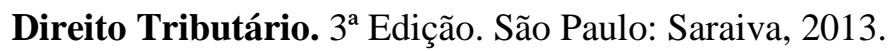


Princípios no direito tributário internacional: territorialidade, fonte e universalidade. In FERRAZ, Roberto (Coord.). Princípios e limites da tributação. Volume II. São Paulo: Quartier Latin, 2005.

In: ROCHA, Sérgio André. Treaty Override no Ordenamento Jurídico Brasileiro. São Paulo: Quartier Latin, 2007.

Livre Concorrência e Tributação. In: Grandes Questões atuais do direito tributário. 11 ${ }^{\text {a }}$ volume. ROCHA, Valdir de Oliveira (Coord.). São Paulo: Dialética, 2007.

Tributação e Indução Econômica: os efeitos econômicos de um tributo como critério para sua constitucionalidade. In: FERRAZ, Roberto. Princípios e Limites da Tributação. Os Princípios da Ordem Econômica e Tributação. Vol.2. São Paulo: Quartier Latin, 2009.

O mito do lucro real na Passagem da Disponibilidade Jurídica para a Disponibilidade Econômica. In: Controvérsias Jurídico-Contábeis (Aproximações e Distanciamentos). MOSQUERA, Roberto Quiroga; LOPES, Alexsandro Broedel. $1^{\text {a }}$ Volume. São Paulo: Dialética, 2010.

; TERSI, Vinicius. As Inter-Relações entre a Contabilidade e o Direito: atender ao RTT significa obter a Neutralidade Tributária? In: Controvérsias JurídicoContábeis (Aproximações e Distanciamentos). MOSQUERA, Roberto Quiroga; LOPES, Alexsandro Broedel. $2^{\mathrm{a}}$ Volume. São Paulo: Dialética, 2011.

Brandão Machado - Uma Amizade. In: Estudos em Homenagem a Brandão Machado. SCHOUERI, Luís Eduardo; ZILVETI, Fernando Aurelio; COSTA, Alcides Jorge. São Paulo: Dialética, 1998.

Segundo Relatório da Comissão. In: Reforma Tributária Nacional. Rio de Janeiro: FGV, 1965.

SEGUNDO, Hugo de Brito Machado. Processo Tributário. São Paulo: Atlas, 2009.

Tributação e Livre Concorrência. In: FERRAZ, Roberto. Princípios e Limites da Tributação. Os Princípios da Ordem Econômica e Tributação. Vol.2. Op.cit.

SELIGMAN, Edwin R. A. Essais sur L'Impôt. Traductión française d'après de 1' $8^{\circ}$ edictión américaine par Louis Suret. Tome Second. Paris: V. Girard \& E.Brière, 1914.

SHAVELL, Steven. Foundations of Economic Analysis of Law. Harvard, 2004.

SICHES, Luis Recasens. Nueva Filosofia de La Interpretación del Derecho. Mexico: Editorial Porrúa, 1980.

SILVA, José Afonso da. Curso de Direito Constitucional Positivo. Malheiros: São Paulo, 2006.

$\overline{2015 .}$

Curso de Direito Constitucional Positivo. São Paulo: Malheiros,

SILVA, Virgílio Afonso da. Princípios e Regras: Mitos e Equívocos acerca de uma Distinção. Revista Latino-Americana de Estudos Constitucionais 1. 2003. 
SILVA, Gerson Augusto da. Sistema Tributário Brasileiro. 2 2 Edição. Prefácio de Valentim F. Bouças. Rio de Janeiro: Ministério da Fazenda, 1948.

SILVA, Juary C. Elementos de Direito Penal Tributário. São Paulo: Saraiva, 1998.

SKAAR, Arvid A. Permanent Establishment. Erosion of Tax Principle. Series on International Taxation. Kluwer Law and International Publishers: Deventer - Boston, 1991.

SMITH, Adam. A Riqueza das Nações. Investigação Sobre sua Natureza e suas Causas. Livro Quarto. Volume II. Tradução de Luis João Baraúna. Os Economistas. São Paulo: Nova Cultural.

SOARES MARTÍNES, Pedro Mário. Direito Fiscal. $7^{\circ}$ edição. Revista e Actualizada. Coimbra: Livraria Almedina, 1993.

SOUZA, Hamilton Dias de. Ainda a racionalidade como limitação ao poder de tributar: Impossibilidade de Utilização do IOF como sucedâneo da CPMF. In: FERRAZ, Roberto. Princípios e Limites da Tributação. Os Princípios da Ordem Econômica e Tributação. Vol.2. Op.cit.

SOUSA, Rubens Gomes de. A Distribuição da Justiça em Matéria Fiscal no Brasil. São Paulo: Livraria Martins Editora, 1943.

A coisa Julgada no Direito Tributário. In: Revista de Direito Administrativo, Vol. 5, Rio de Janeiro: Seção II da Revista do Serviço Público - Departamento Administrativo do Serviço Público - Fundação Getúlio Vargas, julho de 1946.

Resenha Tributária, 1975.

Compêndio de Legislação Tributária. Edição Póstuma. IBET -

Introdução ao Direito Tributário. Parte Especial, 1947.

Estudos de Direito Tributário. São Paulo: Ed. Saraiva, 1950.

São Paulo: Resenha Tributária, 1975.

Pareceres - 1 - Imposto de Renda. Edição Póstuma. Coord. IBET.

Imposto de Renda. Suplemento à $2^{\mathrm{a}}$ Ed. Do Compêndio de legislação tributária. Rio de Janeiro: Edições Financeira, S.A.,1955.

Relatório. In: Trabalhos da Comissão Especial do Código Tributário Nacional. Ministério da Fazenda, Rio de Janeiro, 1954.

A Codificação do Direito Financeiro. In: Carvalho Santos, Repertório Enciclopédico do Direito Brasileiro, 9/103. In: Trabalhos da Comissão Especial do Código Tributário Nacional. Ministério da Fazenda, Rio de Janeiro, 1954.

Anteprojeto de Código Tributário Nacional. 1953. In: Trabalhos da Comissão Especial do Código Tributário Nacional. Ministério da Fazenda, Rio de Janeiro, 1954.

volume 72 .

O sistema tributário federal. In: Revista de Direito Administrativo,

Apresentação. In: FANUCCHI, Fabio. Curso de Direito Tributário.

4.ed. Resenha Tributária, 1976. 
Prefácio da $1^{a}$ Edição. In: FANUCCHI, Fabio. Curso de Direito Tributário.Volume I. $4^{\text {a }}$ Ed. São Paulo: IBET- Resenha Tributária, 1976.

Normas de Interpretação no Código Tributário Nacional. In: Interpretação no Direito Tributário. MORAES, Bernardo Ribeiro de (Org). São Paulo: EDUC/Saraiva, 1975.

São Paulo: RT, 1978.

Do Procedimento Tributário. In: Elementos de Direito Tributário.

STAMMLER, Rudolf. Tratado de Filosofia del Derecho. Trad. W.Roces. Primera Edición. s/l: Editora Nacional, s/d.

STOCO, Rui. Dos crimes contra a ordem tributária. In: Leis penais especiais e sua interpretação jurisprudencial. São Paulo: RT 1995.

STOLLEIS, Michael. Storia Del Diritto Pubblico in Germania. Per La storia Del Pensiero giuridico moderno. n.79. Milano: Giuffrè Editore, 2008.

STOLLEIS, Michael. The History of Public Law in Germany. 1914-1945. Oxford.

STRECK, Lenio Luiz. Hermenêutica Jurídica e(m) Crise. Uma exploração hermenêutica da Construção do Direito. $2^{\circ}$ Edição. Porto Alegre: Livraria do Advogado, 2000.

STUART MILL, John. Princípios de Economia Política. Com algumas de suas Aplicações à Filosofia Social. Vol. II, Os economistas. Trad. Luiz João Baraúna. São Paulo: Nova Cultural, 1996.

SUNDFELD, Carlos Ari. Os Publicistas da Geração de 60, a Turma de Perdizes e o Direito Tributário. In: Curso de Direito Tributário e Finanças Públicas. Do fato à norma, da realidade ao conceito jurídico. SANTI, Eurico Diniz de (Coord.). São Paulo: Saraiva-FGV, 2008.

SZTAJN, Rachel. Law and Economics. In: Direito e Economia. Análise Econômica do Direito e das Organizações. Rio de Janeiro: Elsevier, 2005.

TAKATA, Marcos Shigueo. A Conexão da Contabilidade com o Direito Tributário: Direito Contábil e Direito Tributário. In: Controvérsias Jurídico-Contábeis (Aproximações e Distanciamentos). MOSQUERA, Roberto Quiroga; LOPES, Alexsandro Broedel. $1^{\text {a }}$ Volume. São Paulo: Dialética, 2010.

TAVARES, André Ramos. Curso de Direito Constitucional. São Paulo: Saraiva, 2007.

TEODOROVICZ, Jeferson. Autonomia do Direito Tributário: Revisitando os conceitos de direito privado em direito tributário. Revista Direito Tributário Atual n.30. IBDT. São Paulo: Dialética, 2014.

TESORO, Giorgio. Pricipii di diritto tributario, Bari: Dott. Luigi Macri Editore, XVI, 1938. 
TEUBNER, Gunter. O direito como sistema autopoiético. Trad. José Engrácia Antunes. Lisboa: Fundação Calouste Gulbenkian, 1996.

THOM, René. Vertus et Dan gers de l'interdisciplinarité. In: Apologie du Logos. Paris: Hachette, 1990.

TILBERY, Henry. Tributação e Integração da América Latina. São Paulo: José Bushatshky, 1971.

- Resenha Tributária, 1977.

A tributação dos Ganhos de Capital. São Paulo: Co-Edição - IBDT

A Tributação dos Ganhos de Capital das Pessoas Jurídicas. Comentário ao Decreto-lei n.1598/77. São Paulo: Co-Edição - IBDT - Resenha Tributária, 1978.

TIPKE, Klaus; LANG, Joachim. Direito Tributário. Tradução da $18^{\circ}$ edição alemã. Tradutor Luiz Dória Furquim. Volume 1. Porto Alegre: Sergio Antonio Fabris Editor, 2008.

TIPKE, Klaus. Steuerrecht. Ein Systematischer Grundriß. 4. Völlig überarbeitete Auflage. Verlag Dr. Otto Schmidt KG. Köln, 1977.

Pons, 2002.

Moral Tributaria del Estado y del Contribuyintes. Madrid: Marcial

TOMÉ, Fabiana Del Padre. Vilém Flusser e o Constructivismo Lógico-Semântico. In: Vilém Flusser e Juristas. Comemoração dos 25 anos do grupo de estudos de Paulo de Barros Carvalho. Coord. Florence Haret e Jerson Carneiro. São Paulo: Noeses, 2009.

TORRES, David. Revelando o sistema tributário brasileiro. Sinafresp: São Paulo, 2003.

TORRES, Heleno Taveira. Contribuições da Doutrina Italiana para a Formação do Direito Tributário Brasileiro. Direito Tributário. Vol. II. Homenagem a Alcides Jorge Costa. Coordenação: SCHOUERI, Luís Eduardo. São Paulo: Quartier Latin.

Financeira. $1^{\text {a }}$. ed. São Paulo: Revista dos Tribunais, 2014.

Direito Constitucional Financeiro - Teoria da Constituição (org.). Direito tributário ambiental. São Paulo: Malheiros, 2005.

Da Relação entre Competências Tributárias Constitucionais Tributária e Ambiental - Os limites dos chamados "Tributos Ambientais. In: Direito tributário ambiental. TôRRES, Heleno Taveira (org.). São Paulo: Malheiros, 2005.

Convenções Internacionais em Matéria Tributária sobre a Renda e o Capital - a Abrangência de Tributos Incidentes sobre as Empresas. In: Grandes Questões Atuais de Direito Tributário. Coordenador: Valdir de Oliveira Rocha. Volume 1. Editora Dialética. São Paulo. 1997.

São Paulo: Quartier Latin, 2003.

(Coord.). Direito Tributário Internacional Aplicado. Volume 01.

Pluritributação internacional sobre as rendas de empresas. 1. ed.

São Paulo: Revista dos Tribunais, 1997. 
Direito tributário internacional: planejamento tributário e operações transnacionais. São Paulo: Revista dos Tribunais, 2001.

Direito Tributário e Direito Privado - Autonomia Privada: simulação e elusão tributária. São Paulo: Rt, 2003.

Direito constitucional tributário e segurança jurídica: metódica da segurança jurídica do Sistema Constitucional Tributário. 1. ed. São Paulo: Revista dos Tribunais, 2011.

$\overline{1995 .}$

Os Direitos Humanos e a Tributação. Renovar: Rio de Janeiro,

de Janeiro: Renovar, 1991.

A ideia de liberdade no Estado Patrimonial e no Estado Fiscal. Rio

1986. v. II.

Sistemas Constitucionais Tributários. Rio de Janeiro: Forense,

Renovar, 2005.

Curso de direito financeiro e tributário. 12. ed. Rio de Janeiro:

Curso de Direito Financeiro e Tributário. $16^{\mathrm{a}}$ Ed. Rio de Janeiro:

Renovar, 2009.

Curso de Direito Financeiro e Tributário. Rio de Janeiro: Renovar,

2013.

O princípio da tipicidade no direito tributário brasileiro. In: Revista eletrônica de Direito Administrativo Econômico. Número 5. Salvador: IBDP, Janeiro/Fevereiro/março de 2006.

As Influências Germânicas no Direito Financeiro e Tributário Brasileiro. Revista Forense, v. 327, 1994.

As Influências Italianas no Direito Tributário Brasileiro. Revista de Direito Renovar, Rio de Janeiro, n.4, 1996.

O Princípio da Tipicidade no Direito Tributário. Revista de Direito Administrativo, Rio de Janeiro, v. 235, p. 193-232, 2004.

Os Direitos Fundamentais e o Tribunal de Contas. Revista do Tribunal de Contas do Estado do Rio de Janeiro, Rio de Janeiro, v. 23, p. 54-63, 1992.

Tratado de Direito Constitucional Financeiro e Tributário. O Orçamento na Constituição. 2a . ed. Rio de Janeiro: Renovar, 2000.

A Jusfundamentalidade dos Direitos Sociais. Revista de Direito da Associação dos Procuradores do Novo Estado do Rio de Janeiro, Rio de Janeiro, v. 12, 2003.

Rio de Janeiro: Renovar, 2006.

Normas de Interpretação e Integração do Direito Tributário. 4. ed. 
Interação entre Princípios Constitucionais Tributários e Princípios da Ordem Econômica. In: FERRAZ, Roberto. Princípios e Limites da Tributação. Os Princípios da Ordem Econômica e Tributação. Vol.2. São Paulo: Quartier Latin, 2003.

Tratado de Direito Constitucional Financeiro e Tributário. Os

Direitos Humanos e a Tributação: Imunidades e Isonomia. 3. ed. Rio de Janeiro: Renovar, 2005.

TORRES, Ricardo Lobo. O Direito ao Mínimo Existencial. Rio de Janeiro: Renovar, 2009.

Existe um Princípio Estrutural da Solidariedade? In: Solidariedade Social e Tributação. GRECO, Marco Aurélio; GODOI, Marciano Seabra de (Coord). São Paulo: Dialética, 2005.

Legalidade Tributária e Riscos Sociais. In: Revista de Direito Proc. Geral. (n.53). Rio de Janeiro, 2000.

TROTABAS, Louis. Ensaio sobre o Direito Fiscal. Revista Forense. Doutrina. 145/53-68.

Interpretação das Leis Fiscais. Vol.I. Fasc. I. In: Revista de Direito Administrativo, Rio de Janeiro: Seção II da Revista do Serviço Público - Departamento Administrativo do Serviço Público - Fundação Getúlio Vargas, abril de 1945.

UCKMAR, Victor. Princípios Comuns de Direito Constitucional Tributário. Trad. Marco Aurélio Greco. São Paulo: Malheiros, 2001.

WAGNER, Adolph. Traité des Science des Finances. Théorie de l'Impositión, Théorie des Taxes et Théorie Générale des Impôts. Traduction par Jules Ronjat. Deuxième Editión. Paris: V. Giard \& E. Brière, 1909.

WEIL, Pierre; D'AMBROSIO, Ubiratan; CREMA, Roberto. Rumo à Nova Transdisciplinaridade. São Paulo: Summus, 1993.

WILLIAMSON, Oliver. Por que Direito, Economia e Organizações? In: In: Direito e Economia. Análise Econômica do Direito e das Organizações. Rio de Janeiro: Elsevier, 2005.

WOLKNER, Antonio Carlos. Prefácio. In: História do Direito Brasileiro. BITTAR, Eduardo C.B. (Organizador). São Paulo: Atlas, 2012.

Síntese de uma História das Ideias Jurídicas. Da Antiguidade

Clássica à Modernidade. Florianópolis: Boiteux, 2006.

Ideologia, Estado e Direito. $2^{\text {a }}$ Ed. São Paulo: RT, 1989. 
VALDÉS COSTA, Ramón. A Codificação Tributária na América Latina. Direito Tributário: estudos em homenagem ao Prof. Ruy Barbosa Nogueira. COORDENADOR: MACHADO, Brandão. São Paulo: Saraiva, 1984.

VALDÉS COSTA, Ramón. Interpretación de las Normas Tributarias. In: Estudios de Derecho Tributario Latinoamericano.Montevideu, 1982.

VALDÉS COSTA, Ramón. Curso de Derecho Tributário. Nueva Edición. Buenos Aires-BototáMadrid: Depalma, 1996.

VALDÉS COSTA, Ramón. Instituciones de Derecho Tributario. Buenos Aires: Depalma.

VANONI, Ezio. Opere Giuridiche. A cura di Francesco Forte e Cesare Longobardi. II. Elementi di Diritto tributario. Altri saggi di diritto finanziario. Milano - Dott.A. Giuffrè Editore, 1962.

L'Esperienza della Codificazione Tributaria In Germania. In: Opere Giuridiche. A cura di Francesco Forte e Cesare Longobardi. II. Elementi di Diritto tributario. Altri saggi di diritto finanziario. Milano - Dott.A. Giuffrè Editore, 1962.

Natureza e interpretação da legislação tributária. Trad. Rubens Gomes de Sousa. Rio de Janeiro: Edições Financeiras S.A., 1952.

VARSANO, Ricardo; PESSOA, Elisa de Paula; SILVA, Napoleão Luiz Costa da; AFONSO, José Roberto Rodrigues. ARAUJO, Erika Amorim; RAMUNDO, Julio Cesar Maciel. Uma Análise da Carga Tributária do Brasil.Texto para Discussão n. ${ }^{\circ}$ 583, Rio de janeiro: IPEA, 1998.

VEIGA, Dídimo Agapito da. Ensaios de Sciencia das Finanças e de Economia Publica. Rio de Janeiro: Jacintho Ribeiro dos Santos, 1927.

VIEIRA, Enilton. Fisco versus Fisco, Rio de Janeiro: 1950.

VIEIRA, José Roberto. A Semestralidade do PIS: Favos de Abelha ou Favos de Vespa? Revista Dialética de Direito Tributário. n. 83, agosto. São Paulo: Dialética, 2002.

Juruá, 1993.

A Regra-Matriz de Incidência do IPI: Texto e Contexto. Curitiba:

VILANOVA, Lourival. Lógica Jurídica. São Paulo: José Bshatsky, 1976.

RT, 1977 As Estruturas Lógicas e o Sistema de Direito Positivo. São Paulo:

VILLEGAS, Héctor. Curso de Direito Tributário. São Paulo: Rt, 1981.

Curso de Finanzas, Derecho financiero y tributario. Autor: $5^{\circ}$ Edición. Tomo único. Buenos Aires: Depalma Ediciones, 1993.

VOGEL, Klaus. Introducción a La Edición Española. In: NAWIASKY, Hans. Cuestiones Fundamentales de Derecho Tributário.Obras Básicas de Hacienda Pública. Madrid: Instituto de Estúdios Fiscales, 1982. 
On Double Taxation Conventions. A commentary to the OECD,UN and US Model Conventions for the Avoidance of Double Taxation on Income and Capital With Particular Reference to German Treaty Practice. Third Edition. 1997.

\section{$\underline{\mathbf{X}}$}

XAVIER, Alberto. Conceito e natureza do acto tributario. Coimbra, Livr. Almedina, 1972.

Do procedimento administrativo, São Paulo, 1976.

Do lançamento no Direito Tributário Brasileiro, São Paulo, 1977.

Direito Tributário Internacional do Brasil, São Paulo, 1978.

Paulo: Editora RT, 1978.

Os Princípios da Legalidade e da Tipicidade da Tributação. São

Direito Tributário Internacional do Brasil. Tributação das Operações Internacionais. $5^{\text {a }}$ Ed. Forense: Rio de Janeiro, 2000.

Tratados e Superioridade Hierárquica em relação à Lei face à Constituição Federal de 1988. Revista de Direito Tributário - 66. São Paulo: Malheiros, s/d.

Paulo, Dialética, 2001.

Tipicidade da Tributação, Simulação e Norma Antielisiva. São Tipicidade da Tributação, Simulação e Norma Antielisiva. São

Paulo: Dialética, 2002.

\section{$\underline{\mathbf{Y}}$}

YAMASHITA, Douglas. Princípio da Solidariedade em Direito Tributário. In: Solidariedade Social e Tributação. GRECO, Marco Aurélio; GODOI, Marciano Seabra de (Coord). São Paulo: Dialética, 2005.

Contributiva. São Paulo: Malheiros, 2002.

; TIPKE, Klaus. Justiça Fiscal e Princípio da Capacidade

YOSHIDA, Consuelo Yatsuda Moromizato. A Efetividade e a eficiência ambiental dos instrumentos econômico-financeiros e tributários. Ênfase na prevenção. A utilização econômica dos bens ambientais e suas implicações. In: TÔRRES, Heleno Taveira (org.). Direito tributário ambiental. São Paulo: Malheiros, 2005.

ZAVALA, Ernesto Flores. Elementos de Finanzas Publicas Mexicanas. Los Impuestos. Décima Edición. México: Porrua, 1968.

ZILVETI, Fernando Aurelio. Obrigação Tributária. Fato Gerador e Tipo. São Paulo: Quartier Latin, 2009. 
O Princípio da Realização da Renda. Direito Tributário: Volume I. Estudos em Homenagem a Alcides Jorge Costa. Coord. Luís Eduardo Schoueri. São Paulo: Quartier Latin, 2003.

A Evolução da Teoria da Incidência - Análise Histórica das Estruturas Socioeconômicas na Formação do Sistema Tributário. Tese de Livre Docência. São Paulo: USP, 2010.

Paulo: Quartier Latin, 2004.

Princípios de Direito Tributário e a Capacidade Contributiva. São

Um Perfil de Brandão Machado. In: Estudos em Homenagem a Brandão Machado. SCHOUERI, Luís Eduardo; ZILVETI, Fernando Aurelio; COSTA, Alcides Jorge. São Paulo: Dialética, 1998. 